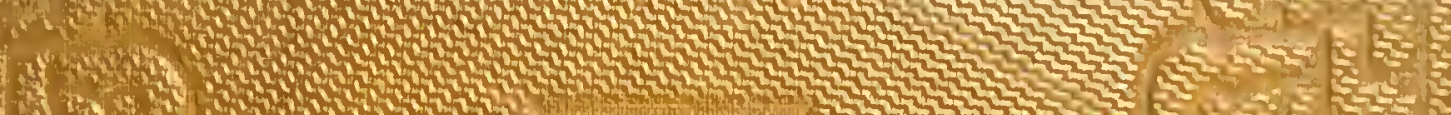

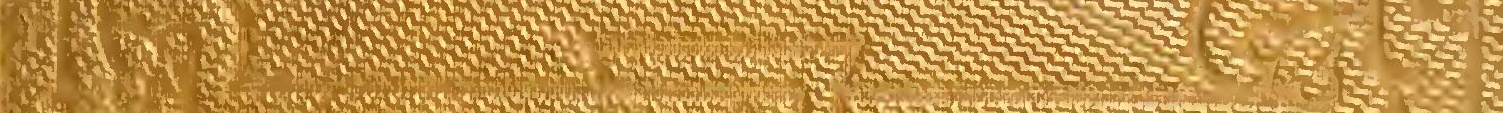

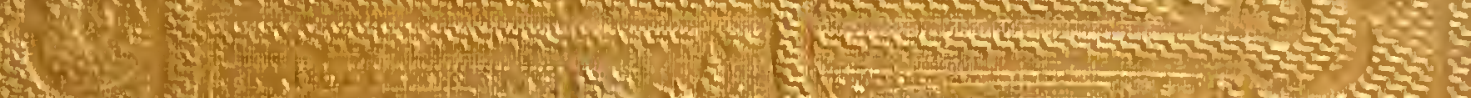
A. 


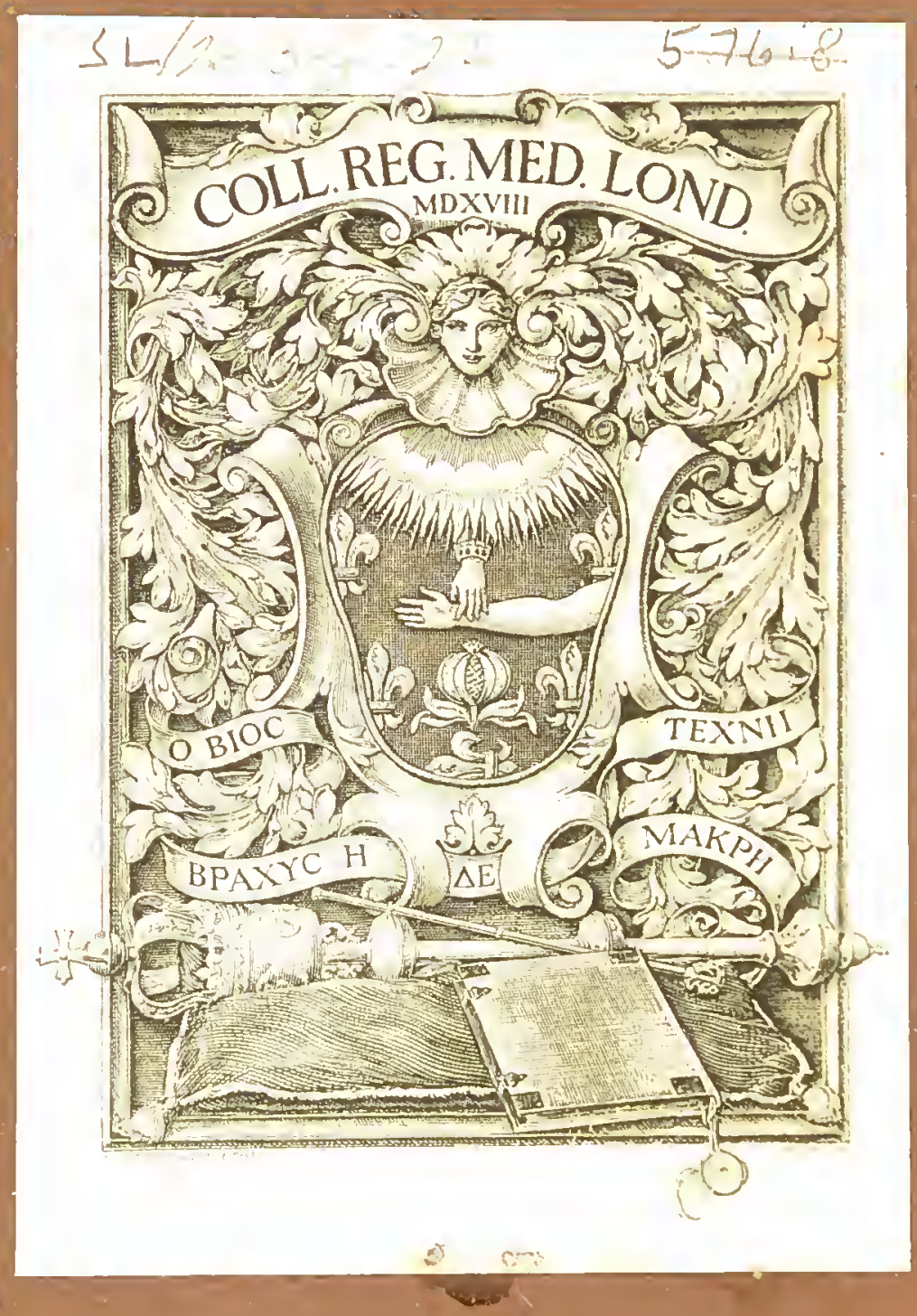



Digitized by the Internet Archive in 2015

https://archive.org/details/b22650805 


\section{THE NEW SYDENHAM SOCIETY.}

Instituted MDGCCLVIII.

VOLUME CXXXII. 



\section{MICR0-0RGANISMS}

WITH SPECIAL REFERENCE TO THE

ETIOLOGY OF THE INFECTIVE DISEASES, sure

$\mathrm{BY}$

Dr. C. FLÜGGE,

o. O. Prnjessor and Director of the IIygienic Institute at Güttingen.

\section{Translated fiom the}

SECOND AND THOROUGHLY REVISED EDITION OF "FERMENTE UND MIKROPARASITEN."

B Y

W. WATSON CHEYNE, M.B., SURGEON TO KING'S COLLEGE HOSPITAL.

VITEI 144 DFAVINGS.

I0 croon :

THE NEW SYDENHAM SOCIETY. 


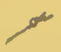

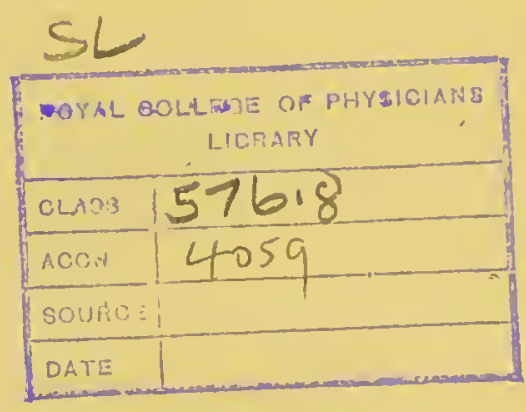


E్ the and antox?

OF

J. HENIE. 



\section{P R E F A E.}

The first edition of the present work formed a part of the Handbuch der Hygiene, edited by von Ziemssen and ron Pettenkofer; the deseription, however, there given was incomplete, because it was intended to supplement it by artieles by other authors on "Air," "Soil," and "Common Diseases." As, howerer, the apperanee of these supplementary artieles has been greatly delayed, and as also, on aceount of the great divergence of the riews on the subjeet of miero-organisms, uniformity of deseriptiou was scareely possible, I have preferred to publish the seeond edition of "Miero-organisms" in a separate form, and to add ehapters on the subjeets which rrere not treated of in the first edition.

Apart from these additions, the chapters of the previous edition liave been fully rerised and in great part re-written.

There are two leading ideas which lave guided me in the preparation of the present edition. In the first plaee, I desired to give a praetieally useful classifieation of baeteria. For this purpose I have deseribed as fully as possible the culture charaeteristics of the individual forms, and have provided a liey for the diagnostic separation of the different species of bacteria in eaeh of the three ehief groups.

I lave not made any attempt to give a scientific elassification of the bacteria, and the charaeteristics deseribed are only of use praetieally in enabling the reader to obtain a general idea as regards the species already known, and to recognise new species should he meet with them, \&e. In this way material will be eolleeted, which may, perhaps, at a future period be of use in leading us to a truly seientifie elassification. 
Our linowleclge of micro-organisms is as jet so imperfect that for the present we absolutely require some such rough method of making ourselves mutually intelligible. The attempts to classify bacteria according to other principles, and with reference to their ontogenetic and phylogenetic development are doubtless justified, but in view of the small number of definite observations are premature, and at any rate for practical purposes are in the meantime completely useless.

Nor can we form a practical classification on the basis of spore formation, because in the case of most species it is very difficult to decide whether, under what conditions, and how they fructify.

On the other hand, by careful attention to the characteristics of growth on certain soils, it is comparatively easy, as the experience of several years has taught us, for the beginner to find his way in the labyrinth of the forms of bacteria, and we are certainly justified in the meantime in joyfully trusting ourselves to this Ariadne thread, always bearing in mind that the indications so obtained are provisional and only pave the way for more thorough linowledge.

For the diagnostic summary attempted here it was necessary to give names as far as possible to the individual species of bacteria. The culture characteristics have for the most part formed the bases for these names, and hence they have, like the classification itself, only a provisional importance, and are only justified in so far as they render mutual understanding easier for the present. Should some authors be dissntisfied with the names which hare here been chosen for the bacteria first described by them, they may excuse my action when they remember the necessity for a terminology, the provisional character of the names, and the possibility of altering them at any time.

Some of the more common forms of saprophytes collected in this Hygienic Institute are only described incompletely, and with almost exclusire reference to the characters which are of use in differentiating them. A more complete study of these forms is proposed at a later time. I am decply indebted to the workers at the Institute, Drs. Oberdiek, Henrijenn, Gunneri, Kreibohm, 
Sc., but in particular to my assistants, Dr. Deneke and Dr. Praussnitz, for the help which they have given me in this arduous work.

The second idea which guided me in altering the former edition has reference to the etiology of the infective diseases.

As to the mode of spread of these diseases we have as yet received explanations almost entirely from the experiences of medical practice, and from statistical observations. The number of definite results obtained in this way has, however, been extremely small, and where a law such as the peculiar local and seasonal distribution of typhoid and cholera epidemics is recognised we are, with regard to the significance and explawation of the phenomena, thrown back on a series of more or less probable hypotheses.

The bacteriological investigations of the last few years have produced a complete change in this respect. By the discovery of numerous disease germs, and of the methods of their pure cultivation, it has become possible to study experimentally the conditions of life of the infective organisms, their mode of life, their relation to their surrounding, their transportability, and the mode of their entrance into man, and thus to obtain information as to the canses of the peculiar mode of spread of epidemic diseases, in a manner incomparably quicker and more trustworthy than by empirical and statistical methods.

I have as far as possible in the present work made use of these advances of the most recent scientific investigations, the bearing of which is decidedly underrated, and have attempted to explain the mode of spread of infective diseases, more especially of cholera, by reference to the facts ascertained by experiment as to the characteristics of the causal agents.

It must be evident that we lave already gained in this way, iu the case of a number of infective discases, a deeper insight into their mode of spread and the prophylactic measures necessary in combating them. In the case of mauy disenses re do not as yet fully understand their mode of spread; nerertheless by the aid of the results of bacteriological investigntions we cau 
at least understand what are the points which will eventually lead to the elucidation of the peculiarities in this respect; and wo can recognise most clearly that it is not correct to regard in a one-sided manner the soil or the water as the only important factor. In every case we may hope that a continued experimental investigation carried on with a definite aim will lead us most quickly to an increase of our knowledge, and to a rational method of prophylaxis against the epidemic diseases.

Many other duties have prevented me from finishing the publication of this book as quickly as I could have wished. I hare not been able to utilise completely the literature of 1885 , and only the most important of the works which have appeared in the present year have been added while the book was passing through the press. The yearly report of micro-organisms lately published by Baumgarten, and written with as much care as knowledge, relieves me, however, of the necessity of giving in an appendix a notice of the more recent works.

\section{FL $\ddot{U} G G E$.}

\section{GötTIxgex,}

August 24th, 1886. 


\section{LITERATURE,}

'TEX'T-BOOKS, HAND-BOOKS, REVIEWS, \&e.

L'Hrexbert, die Infusionsthierehen als vollkommene Organismen. Leipzig, 1838.

Dudardn, Histoire naturclle des zoophytes. Paris, 1841 .

Hexte, Pathologisehe Untersnchnngen, 1840. Handbuch der rationellen Pathologie, 2 Band. 2 Abth., 1853.

Bovornen, Handbuch der allgemeinen Mykologie, 1851.

BaIL, Die wichtigsten Sätze der neneren Mykologie. Jena, 1361.

Halder, Dic pflanzlichen Parasiten. Leipzig, 1836. Paraitologische Untersuchungen, Lcipzig, 1868. Phytopathologie, ib. 1868 .

De Bart, Morphologie und Physiologie der Pilze fc. 2 B . I $\lambda$ bth. von Hofmeister's Handbnch der physiologise'en Botanik. Lei]rig, 1866.

Lìnı. Der gegenwärtige Standpunkt der Mykologie, 2 Anfl. Berlin, 1872.

Sachs, Lehrbuch der Botanik, 4 Aufl. Leipzig, 1874.

Pfeffrir, Pflanzenphysiologie, cin Handbuch, \&e., 2 Bde. I siprig. 1881.

Lausis, Symopsis der Pflanzenknnde; 3 Abth., Kryptogamen, bearb. von Frank. Hannover, 1877. 3 Aufl, 1883 (in the precss).

Raberiorst's Kryptogamenflorn, $1 \mathrm{Bd}$. Pilze, ron Winter. Leipzig, 1881.

Ronin, Histoires des végétaux parasites.

Van Timanem, Traité de botanique, 1883.

Grove. A Synopsis of the bacteria and yenst-fungi and allicd species.

Mhoixix, Les bactéries. Paris, 1878.

Refercnees by Richter and Birch-Hirschfeld in Schmidt's . Tahrbüchern der ges. Mediein especially, Bd. 159, S. 169; 1875, Bd. 166, S. 169 ; Bd. 168 , S. 57.

Lex, in Roth und I.ex, Militärgesundheitspflege, I., S. 167, and 480.

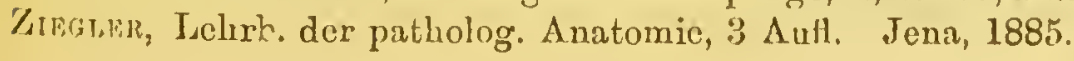


KLEBS, Beiträge zur Anatomie der Sehusswunden. Leipzig, 1872 -1873.-Artiele "Ansteekende Krankheiten" in Eulenburg's Realeneylopädie.

Duclaux, Ferments et Maladies. Paris, 1882.

Perroncto, Parassiti dell' nomo e degli animali utili: delle qui eomuni malatti da essi prodotté : profilasi e eura relativa. Milano, 1882.

ROCHAS, Les sehizophytes parasites de l'homme. Bâle, Lyon, Génève, 1884.

Fou, Les mierobes. Génève, 1885.

WoodieAd and Hare, Pathologieal Myeology, 1 Seetion. Edinburgh, 1885.

Cornil et Babés, Les Baetéries. Paris, 1885.

Zopf, Die Spalt-pilze, 3 Auf. Breslau, 1885.

De Bary, Vergleiehende Morphologie, u. Biologie der Pilze. Myeetozoen 1. Baeterien. Leipzig, 1884.

Fisch, Die systematisehe Stellung der Balzterien. Biolog. Centralbl., Bd. 5, 1885.

Tommasi-Crudeut, Institnzioni di Anatomia patologiea. Torino, 1884.

(See also under. "Production of Disease.")

\section{GENERAL LITERATURE.}

Coirs, Untersueh. über d. Entwiekelungsgeseh, d. mieroseop. Algen

u. Pilze, Nov. Aet. Leop., Vol. 24, 1853.

—, Beiträge zur Biologie der Pflanzen, I. Band 1875; II. Band 1877 ; III. Band 1879-1880.

1) E Bary u. Woronin, Beiträge z. Morphol. u. Physiologie der

Pilze. Frankfurt-a-M. 1864, 1866, 1870.

Horfmann, Mykologisehe Beriehte. Giessen, 1870-1872.

N̈̈GEL, Beiträge z. wissensehaftliehen Botanik, Heft. II. (1860).

-, Die niederen Pilze in ihren Beziehungen zu den Infeetionskrankheiten. Münehen, 1877.

-, Untersuchungen über niedere Pilze. Münehen, 1882.

Renne U. Kertuor D Die Zersetzung der Kartoffel dureh Pilze. Berlin, 187?

Cienkowsti, Zar Morphologie der Bakterien. Petersburg, 1876.

Zopk, Zur Morphologie der Spaltpflanzen. Leipzig, 1882.

_, Zur Kenı, tniss des Phykomyeeten I. Halle, 1884.

_, Zur Morphologie u. Biologie der niederen Pilzthiere (Monadinen). Leipzig, 1885 . 
1/OPF, Dic Pilzthicre odcr Schleimpilze. Breslan, 1835.

Davaine, Recherches sur les Vibrioniens. Compt. rend., 1884, T. 59, p. 629.

Pasteur, Animalcules infusoires, \&c. Compt. r'end., LiT., 1861.

Joubert ét Chamberdand, La théorie des germes et ses applications

ì la médicine et chirurgie. Compt. rend. 1878, Vol. 86, p. 1037 -1043 .

K Lebs, Bciträge zur Anatomie der Schusswunden. Leipzig, 1872.

Biliroth, Untersuchungen über die Vegetationsformen d. Coecobacteria septica. Berlin, 1874.

Ijoner, Beale, Disease germs, their nature and origin, 1872.

KrEIN, Experimental Contribution to the Etiology of Infectious

Diseases, with special reference to the Doctrine of Contagium vivum. Proceed. of the Roy. Soc. of London, Febr., 1878, Vol. 27.

A ufrecht, Pathologische Mittheilungen., I. Heft. Magdebnrg, 1881, bci Faber.

Baumgarten, Ueber pathogene pflanzliche Organismen, II. Die pathogenen Schizomyceten. Berlin, 1884.

Hitreneilungen des kaiscrlichen Gesundheitsamts, Bd. I., 1881, Bd. II., 1884.

Arbetrox aus dem kaiscrl. Gesnndheitsamt., Bd. I., 1885.

\section{Spontaneots Generation.}

(See also "Fermentation.")

Sumurze, Gilbert's Annalen der Physik u. Chcmic, 1836, Bd. 39, S. 487.

Eitrenber:, Abhdl. der Königl. Akad. d. Wissench. zu Bcrlin, Jahrg. 18:30, 1832, 1834-1835. Uebersicht der scit, 1847, fortgcsetzten Untcrsuchungen über das von der Atmosphärc unsichtbar getragene reiche organische Leben. Aus den Abhdl. d. Kgl. Akad. d. Wissensch. z. Berlin, 1871, C. Vogt.

Scuwaxy, Gilbert's Annalen der Chemie n. Physit, 1.837, Bd. 41, S. 18.4.

Schröder u. v. Dusch, Annalen der Chemie u. Pharm., 1854, Bd. 89, S. $232-243$; 1859, Bd. 109, S. 35-52; 1861, Bd. 117, S. $273-294$.

F. Scirulze, Ann. d. Phys. u. Chem., 1836, Bd. 39.

Poucher, Hétérogénic ou traité de la génération spontanée. Paris, 1859.

Pouchur fer Houzeau, Compt. rend. de l'Acad. des sc., 1858, Bd. 47. Pasteur, Compt. rend. de l'Acad. des 'sc., 1860, Bd. 50 u. 51.

Hulzinia, Arch. f. d. ges. Physiologie, 1873, 1874, 1875. 
Bastian, Centralbl. f. d. med. Wissenschaften, 1876, S. 521.

-, Compt. rend., Bd. 83 , No. 8.

-, On Fermentation and the appearance of Bacilli, Micrococci, and Torulæ in Boiled Fluids. London, 1877.

Cherne, Antiseptic Surgery, 1882.

Gscheiduen u. Putzers, Pflüger's Aich., 1874, Bd. 9, S. 163-17t.

Samuleson, Pfïger's Arch., Bd. 8, S. 277, 288

Burdon-Sanderson, Nature, Bd. 8, S. 478.

Nü esch, Die Nekrobiose in morphologischcr Beziclung. Schafhausen, 1875.

Arndt, Untersuchungen über die Entstehung von Coccen u. Bacterien in organischen Substanzen. Virch. Arch., 1880, Bd. 82, S. 119-146.

Thaschenberg, Lehre ron der Urzengung sonst und jetzt. Halle. 1883.

Bе́снамт, Les Microzymes dans lcurs rapports arcc l'hétérogenié, \&c. Paris, 1883.

Wiann, Entstehung und Fermentwirkung der Bacterien. Marburg, 1884.

On the Existence of Goms in Living Tissues.

Van den Brock, Ann. f. Chemie u. Pharm., 1860, S. $115,175$.

Pasteur, Compt. rend., 56, S. 738, 1194, 1863, Bull. de l'acad. de méd., 1875. Etudes sur la bière, 1876, p. 46.

Gayon, Recherches sur les altérations spontanécs des œufs. Paris, 1875, p. 45.

-, Compt. rend., 1873, Jan.

LüDERS, Arch. f. mikr. Anat., \&, S. 317, 1867.

Samuel, Arch.f. cxp. Pathol., 1873, Bd. 1.

Sternberg, John Hopkin's Univ, stud. biol. Baltimore, Vol. ?.

Lewis, Quart. Journ. of Microsp. sc., 1879, Vol. 19.

Hensen, Ibid., p. 342.

Rindfleisch, Virch. Arch., 54, S. 39, 1872.

Chauveau, Compt. rend., 76, p. 1092, 1873.

Pascriutin, Virch. Arch., 59, S. 490, 1874.

Kolaczer, Centralbl. f. Chirurgic, 1875, S. 197.

'T'reger, Virch. Arch., 60, S. 453, 1874.

Koukot-Yasnoporski, P'flüger's Arch., 12, S. 80, 1876.

Servel, Compt. rend., 79, p. 1270, 1874.

Burdon-Sanderson, 'Thirtcenth report of the Medical Office of the

Priv. Counc., p. 63; Quarterly Journ. of Microscop. sc., 1871;

The British Mcdical Journ., 1878, p. 119.

Nenckr v. Gracosı, Journ. für pract. Chemie., N. F., Bd. 19 u. 20. 
Roвerts, Philosophical 'Transactions, 1874, p. 457.

Cazeneuve et Livon, Compt. rend., 45, p. 571, 1877.

Bılroth, Arch. f. klin. Chir', 20, S. 432, 1877. Coccobaeteria septiea, p. $59 \mathrm{ff}$.

Weissgerber u. Perls, Areh. f. exp. Pathol., Bd. 6.

Lister, Journ. of Mierosp. se., 1878, p. 179.

Watson Cheyne, Path. Soc. Transaetions, 1879, and Antiseptic Surgery, 1882.

Chiene and Cossar Ewart, Journ. of Anat. and Phys., 1878, April. p. 448.

Rosisвach, Ueber einige fundamentale Fragen in der Lehre von den chirurgisehen Infectionskiankeiten; Deutsche Zeitschr. f. Chirurgie, Bd. 13, S. 334, 1880. There also detailed reference to Meissner's experiments.

Zahn, Virchow's Archiv, Bd. 95.

Leube, Zeitschr. f. klin. Med., 1881, Bd. 3.

Firket, Annal. de la soc. méd. chir. de Liège, 1879, Vol. 18.

Horsley and Mott, Journ. of Physiolog., 1880, Vol. 3.

Hauser, Arch. f. ges. Physiol., Bd. 33.

v. Hoffuarn, Untersuchungen über Spaltpilze im menchslichen Blute. Berlin, 1884.

Marchand, Sitzungsber. d. Ges. zur Beförderung d. ges. Naturwissenchaftcn zu.Marburg 1885, März.

\section{GENERAL LITERATURE ON MOULD FUNGI.}

Leunis, Rabenhorst, de Bart, p. 1.

Brefetd, Botan. Untersuehungen über Schimmelpilze, I.-IV.

Sizbenmann, Die Fadenpilze. Wiesbaden, 1883.

vas Tieghes, Sur le développement de quelques Ascomycètcs

(Aspergillus). Bull. soc. bot. de France, 1877.

-, Reeherches sur les Mueorinées. Ann. sc. nat., 1873, 1875, 1878.

'/imarmans, Das Genus Mueor. Chemnitz, 1871.

BREFELD, Landw. Jahrb. V. 1876 (Mucor racemosus).

F'or further facts see Leunis und de Bary.

\section{Diseases of Prants due to Mould Fungf.}

'T'viasxe, Mémoirc sur les Ustilagin. compar. aux Urédin. Annil] des se. natur., 3 sér., T. 7, 1847; T. 2, 1854. Mém. sur. l'lirgot. Ibid., 'l', 20.

1): BakY, Untersuchungen über die Brandpilze, 1853. Untcrsuchnngen über Uredineen. Monatsber. d. Königl, Aead. d. Wiss. zu Berlin, 1864-66.

-, Annal. de Landwirthscluft., 23 Jahrg., 1865. 
or BARr, Recherches sur le développemcnt de quelques champignons parasites. Ann. des. sc. nat. 4 sér. 11., 1865.

de Bary u. Woronin, Beiträge zur Morph. u. Phys. der Pilze, III.

Frankfurt, 1870.

KüHN, Die Krankheiten dex Culturgewächse. Berlin, 1858.

WiLiкомм, Die mikroskopischen Feinde des Waldes. Dresden,

1866.

Horfmann, Botanische Untersuehungen, herausgeg. von Karsten, 1866.

Fischer u. Waldheim, Jahrb. f. wiss. Botanik ron Pringsheim, Bd. 7, 1869.

Rees, Die Rostpilzformen der deutsehen Coniferen. Halle, 1869. Hartig, Wichtige Krankheiten der Waldäuıne.

-, Untersuchungen aus dem forstbotan. 1nst. zu München, I.-III.

—, Ueber die durch Pilze bedingten Pflanzenkrankhciten. Vorträge im ärztlichen Verein zu München, 1881:

—, Die Zerstörung des Bauholzes durch Pilze, 1. Berlin, 1885. Sorauer, Landwirthsch. Versuchsstationen, Bd. 25, 1880. Botan. Zeitung, 1882.

WoLfF, Thiel's Landw. Jahresber, 1872.

\section{Moutd Fungi as Animal Parasites.}

\section{In Caterpillar's.}

Robin, Histoire naturelle des végétaux, qui croissent sur l'homme et les animaux vivans. Paris, 1848, 1853.

De Bary, Zur Kenntniss insectentödtender Pilze, Botan. Zeit., 1867, 1869.

Bart, Ueber Pilzepizootien der forstverherecnden Raupen. Danzig, 1869.

\section{Ii F'lies.}

Gürrre, Hefte zur Morphologie, I. 292.

Nees y. Esenbeck, Nov. Act. Acad. Caes. Leop. Car. Niat. Cur.,

Bd. 15, 1831.

Corr, Empusa muscae u. die Krankheit der Stubenfliege. Breslau, 1865.

LEBRit', Abli. der naturfor'sch. Ges. in Zürich, 1856.

Frisenius, Abh. d. Senckendorff'sehen. naturf. Ges., Bd. 2, S. 201. Brafkld, Unters. über die Entwickl. der Empusa muscae and Emp. radicans. Halle, 1871.

Peyritsch, Sitzungsber der k. k. Akad. der Wiss. in Wien., Bd. 64, 1871. 
In Man and Higher Animals.

RoBIN, 1. c.

Friedreich, Virch. Archiv, Bd. II.

Сонмнегі, Ibid., Bd. 33.

Fürbringer, Ibid., Bd. 76.

Rosenstein, Berl. klin., Wochenschr., 1867.

WAGNER, Jahrb. f. Kinderheilkunde, 1868.

Zenker, Jahresb. der Ges. für Natur'- n. Heilk. in Dresden, 186162.

Groнe, Berl. klin. Woch., 1871.

BLOCK, Ueber Pilzbildung in thierischen Geweben. Diss. Stettin, 1871.

Leber, Aerztl. Intelligenzbl., 28 Jahrg., Nr. 7.

BEZOLD, In den Vorträgen im ärztlichen Verein zu München, 1881.

Kistr, Deutsche Zeitschr. f. Thiermedicin., Bd. 7.

Grawitz, Virchow's Archiv, Bd. 70, 1877 ; Bd. 81, 1880.

—, Berl. klin. Woch., 1881, Nr. 45 u. 46.

Krannhals, St. Petersb. med. Woch., 1881.

Siebermanx, Die Fadenpilze. Wiesbaden, 1883 (See there the oldcr literature).

GAFFKY, Mittheilungen des Kais. Ges.-Amts., 1 Bd., S. 80.

LÖFFLER, Ibid., S. 134.

KocI, Berl. klin. Woch., 1881, Nr. 52.

Leber, Berl. klin. Woch., 1882, Nr. 2.

Liснтнеiм, Berl, klin. Woch., 1882, Nr. 9 u. 10.

-, Ueber pathogene Mucorineen. Zeitschr. f. klin. Medicin., Bd. 7, H. 2.

SснÜтz, Ueber das Eindringen von Pilzsporen in die Athmungswege. Mittlı. a. d. Kais. Ges.-Amt., Bd. II.

-, Ueber den Pilz des Hühnergrinds, Ibid., Bd. II.

Hückel, Zur Kenntniss der Biologie ron Mucor corymbifer.

Beitr. zur path. Anat. u. Phys. von Zicgler u. Nauwerck., Heft.

I. Jena, 1884 .

Klenninns, Dic parasitären Hautaffectionen. Erlangen, 1864.

PIck, Unters. über die pflanzlichen Hautparasiten. Verhandl. d. zoolog. botan. Ges. in Wicn., Bd. 15, 1865.

Perritscer, Beitrag. zur Kenntniss des Favus. Wien. ıedicin. Jahrb., Bd. 17, 1869.

Bız.ozero, Ueber dic Mikrophyten der normalen (Oherhaut des Menschen. Virch. Areh., 98.

Baniss (Ö̈dium subtile entis) Biolog. Centralbl., Bd. 2.

Frivireich, Virchow's Arch., Bd. 30, 1864. 
Excisisch, Centralbl. f. Chirurgie, Bd. 15, 1883 (Schimmelpilye at dem Praeputium.von Diabetikern).

Behrend, Herpes tonsurans u. Farus. Viertelj. f. Dermatol u. Syphilis, 1884.

Kundrat, Ueber Gastro-enteritis favosa. Wien. medie., Bl., Nr. 4!! Baugartey, Die pathogenen Hyphomyceten. Deutsche MedicinalZeitung, 1874.-Berl. klin. Woeh., 1882.

Batzer, Contribution à l'étude de l'érythème tricophyticyur. (Herpes circinnatus), Areh. de Phys., 1883, Bd. 1.

Roecki, Ueher Pneumonomykosen. Deutsche Zeitschr. f. Thicr'med. X., S. 122 .

\section{ACTINOMYCES.}

Boldinaer, Centralbl. f. d. Med. Wissenseh., 1877.

Ponfick, Die Aetinomyliose. Berlin, 1881 (See there the older. literature).

IFRAëL, Virchow's Areh., Bd. 74.-Bd. 78.-Bd. 95 1. 96. Klinische Beiträge $\%$ Kenutuiss der Actinomykose des Menschen. Berlin, 1885.

Joпxe, Jeutsche Zcitschr. f. Thiermed., 1881.

Tisk, Centralbl. f. d. med. Wiss., 1881, 1882.

Pficti, Centralbl. f. d. med. Wiss., 188:2.

Gaxyer, Boston Med. and Surg. Journ., 1882.

L'Leming, Actinomycosis, Loudon, 1883.

'T'reves, Lancet, 1884, p. 107.

l'inkít, Rev. de Méd., Paris, 1884.

Pusch, Arch. f. wiss. u. gr. 'Thierheilk, 1883.

BANG, Tidskrift far Veterinaerer, 1883. Ref. in Fortsehr. d. Modicin, 1I., Heft 6.

ZJemaxn, Wien. Med. Jahnb., 1883, S. 477.

Vinchow, Virehow's Archiv, Bd. 95.

Mij'teldorpf, Deutsche Medie. Woch., 1884.

KaRSTEX, Ibid., 1884.

Chrari, Prager mecl. Wocli., 188t, Nr. 10.

Boströм, Verh. d. Congr. f. imere Merd. Wiesbaden, 1885.

Maguusex, Beiträge mur Dingnostikn. Casuistik der Actinomykose.

Disscrtation. Kiel, 1885.

\section{BUDDING FUNGI-.. YEAST.}

(For Fermentation, see p. 4.5.)

Cagiardo-Latolr, Mémoire sur la fermentation vineuse. Ann. de. chim. et de pliys., 2 sér., T. 68, p. 206.

Scurwax, Annal. d. Phys. u. Chemic., 1837, 'T. t], p. 18.4. 
Kïtzisi, Jousn. f. prakt. Chemie., Band 11, S. 385.

ReEs, Botan. Unter's. üb. d. Alkoholgährungspilze. Leipzig, 1870.

.., Ucber den Soorpilz. Sitz-ber. der phys. med. Ges.zu Erlangen. Juli, 1877, u. Januar., 1878.

Boxokdex, Abl. der naturf. Ges. zu Halle, 1864.

Cirxkowsk, Die Pilze der Kahmhaut. Mélang. biolog. Acad. Impl. de St. Petersbourg, T. 8.

Grawl'z, Virchow's Arch., Bu. 70, 1877, and Bd. 73, 1878.

Pasteur, Mémoirc sur la fermentation alcöolique. Ann. Chim. Phys., T. 5̇.

- Etudes sur la bière. Paris, 1876.

Schützenberger, Unters. über die Bierhefe. Ber d. Chem. Ges., 27,

S. 192. Compt. rend., 1879, p. 383.

Fritz, Ber d. Chem. Ges., Bd. 6, 1873.

Brefetid, Mucor racemosus und Hefe. Flora, 1873.

-, Thiel's Landw. Jahrb., 1875-1878.

—, Botanische Untcrs. über Hefepilze (Leipzig, 1883).

Hischer, Die systematische Stellung der Hefepilze. Biolog. Centralb., Bd. 4, 1884.

Huxsex, Medcledelser fra Carlsberg-Laboratoriet, Band I.

-, Botan. Centralb., Bcl. 17.

- Nene Untersuchungen über Alkoholgährungspilze. Ber. d. deutsch. botan. Gesellsch., 1884, Bd. II.-Zeitschr. f. d. ges. Brauwesen, 1884.

Bors, Article "Soor" in Gerhardt's Handb. d. Kinderkrankheiten. 'Tübingen, 1880 .

Kunrer, Ueber den Soorpilz. Heidclberg, 1883 (See there the older literature).

Mantry, Soor beim Truthahn. Jahrb. d. k. Theierarzneisch. \%u München, 1882 -18S3.

Pldur, Beitrag zm systematischen Stellung des Soorpilmes. Leiprig, 1885.

I'FerfFer, Ueber Sprosspilze in der Kälberlymplic. Weimar, 18r.'.

\section{(FNERAL LITERATURE ON BACTKRIA NN1)} INFECIIVE DISHASFS OH WOUNDS.

Kucн, WVundinfectionskrankhciten. Leiprig, 1878.-Mitthuil. d.

Kais. Ges.-Amts., Bd. I.

Wor.'p, Vireliow's Areh., Bd. 81, B31. 92.

Pвни: De la Septicémic. Paris, 1880.

Sнмивг, Virchow's Aichiv, 130. 8:3.

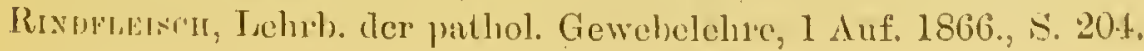


von Rechlinghadsen, Verl. der Würzb. pliys.-med. Ges., 1871. Birch-Hirsohferd, Untersuehungen über Pyämie. Leipzig, 1873. KLEBS, Beitr. zur. pathol. Anat. der Schusswunden. Iseipzig, 1872. -, Areh. f. exper. Pathol. u. Pharmakol. Leipsig, Band I., 1873.

IIl. 1875, 1V. 1875, V. 1876, X. 1879.

-, Centralb. f. d. med. Wissensel. Berlin, Bd. 6, 1863.

Birch-Hirschfetd, Referenees in Sehmidt's Jahrbüchern, Bd. 166,

S. 169, as to the literature during the years 1872-1874.

Virchow, Embolie u. Infection. Gesamm. Abhdl. 1857, S. 656.

WALDEYER, Zur pathol. Anatomie der Wundinfeetionskrankheiten,

Virehow's Areh., Bd. 40, 1867.

-, Mikrokokkeneolonien in den parenehymatisehen Organen.

Vortrag. i. d. med. Ges. zu Breslau, 4 Ang., 1871.

Stricr, Charité-Annal., 1852.

Wéer, Deutsehe Klinik., 1864-65.

Biliroth, Arch. f. klin. Chir., Bd. 6, 265.

Birliroth und Eirrlich, lbid., Band 20, 1876.

Billroth, Coeeobaeteria sept. Berlin, 1874.

Fischer, Centralblatt f. d. med. Wissench., 1868.

'T'I gake, Ueber den fiebererregenden Eigensehaften des Mierosporon septieum. Bern. 1871, Diss.

一, Vireliow's Arehiv, Bd. 60, 1874.

Zahr, Znr Lehre von den Entzündıngen, \&c. Heidelberg, 1872.

Heiberg, Die puerpalen u. pyämisehen Proeesse. Leipzig, 1873.

Олтн, Virehow's Areh., Bd. 59, 1874.

-, Areh. d. Heilk. Leipzig, Bd. 13, 1872.

—, Virehow's Areh., Bd. 58, 1873.

- Areh. f. wissenseh. u. prakt. Thierheilk. Bd. 3, 1877.

-, Berliner klin. Woehensehr., Bd. 9, 1872.

Coze et Feltz, Reeherehes expérimentales. Strassburg, 1866.

Lacassagme, De la putridité morbide et de la septieémie. Paris, 1872.

Davaine, Bouley, Behier, Vujpian, Colin, Hayem, Bull. d. l'Aead. de méd., 1872-1873.-1bid., 1862, 1879, 1881.

-, Compt. rend. Soe. de biol. Paris, 1874.

Nassijoff, Virehow's Areh., Bd. 57, '1873.

Ėberti, Zur Kenntniss der bakterisehen Mykosen. Tueipzig, 1872.

-, Med. centralblatt. 11, S. 8, 32. 1873.

-, Virehow's Arch., Bd. 57, 1873.

-, 1hid., Bd. 77, 1879.

-, 1bid., Bd. 80, 1880.

Lever, Med. Centrlbl., Bd. 11, 1873.

Hetbers, Med. Centrlbl., Bd. 12, 1874. 
Clementi, Med. Centrlbl., 1873, 45.

Hunter, Allgem. Chirurgie. Leipzig, 1873.

—, Deutschc Zeitschr. f. Chirg., 1872.

Huber, Deutsches Archiv f. klin. Med. Leipzig, Bd. 25.

Lixdau, Arch. f. klin. Chir. Berlin, 27, 1874.

—, Verhandl. d. dentschen Gesell. f. Chirurgie, Band 2, 1878.

Schüller, Deutsche Zeitschr. f. Chir. Leipzig, Bd. 6, 1875.

Nepveu, Ueber die Bedeutung der niederen Organismen bei chirurgischen Affectionen. Gaz. de Paris, 1875.

FELTz, Compt. reud. Acad. d. sc. Paris, T. 76, 1873.-Ibid., T. 79, 1874.

Letzerich, Arch. f. exper. Path. u. Pharmakol. Leipzig, Band 7, 1877.

—, Virchow's Arch., Bd. 68, 1876.

Chauvenu, Compt. rend. Acad. d. sc. Paris, T. 76, 1873.-Ibid., T. $92,1881$.

—, Gaz. hebd. de méd. Paris, T. 12, 1875.

-, Gaz. d. hôp. Paris, 1881.

Colin, Bull. Acad. de Méd. Paris, T. II., 1873.-Ibid., T. 4, 1875.

—, Ibid., T. 7, 1878.—Ibid., T. 8, 1879.—Ibid., T. 10, 1881.

Bert, Compt. rend. Soc. de biol. Paris, T. 2, 1875.-Ibid., T.

5, 1878.-Ibid., T. 7, 1880.

Balfour, Edinburgh Med. Journ., Vol. 23, 1877.

Pasteur, Bull. Acad. de méd., Paris, T. 9, 1880.

—, Compt. rend. Acad. d. sc. Paris, T. 85, 1877.-Ibid., T. 87, 1878.

PuкY, Virchow's Arch., Bd. 69.

Beck, Rep. Med. Off. Local Gov. Board, 1879.

Isräes, Virchow's Archiv, Bd. 74, 1878.

—, Berl. klin. Wochenschr., Bd. 15, 1878.

LrTten, Bcrl. klin. Wochenschr., 1878.

—, Zeitschr. f. klin. Mcd., 1880.

Drysdale, Pyrexia. London, 1880.

'Tillyanss, Verhal. d. deutschon Gescllsch. f. Chirurgic, Band 7, 1878.

Toussaint, Compt. rend. Acad. de sc. Paris, T. 91, 1880.

'Trndele, Essays on the Floating Matter of the Air in relation to Putrefaction and Infcetion. London, 1881.

Zwaifer, Zeitschr'. f. physiol. Chemic. Strassburg, Band 6, 1882.

Mlrubıcz, Areh. für klin. Chir. Berlin, Band 22, 1878.

Lister, Lancet, Vol. 2, 1867.

—, Med. 'limes and Gazctte, Vol. 2, 1877. 
Lister, Quart. Jourm. Micr. Sc. London, Vol. 13, 1873.-Ihid., Vw. 18, 1878.-Ibid., Vol. 21, 1881.

K IEIN, Rep. Med. Off. Local Boardd (1881) London, 1882.

Braidwood and Vacuer, Brit. Med. Journ., Vol. I., 1881.

Oerter, Zur Aetiologie der Infectionskrankheiten, 1881.

Ogstox, Brit. Mcd. Joum., Vol. I., 1881. -, Journ. of Anat. aud phys., Vol. 17, 1882.

Ratwaud, Bull. Acad. de méd. Paris, T. 10, 1881. Rószahegri, Practitioner, London, Vol. 38, 1882.

Rosexberger, Verhdl. der phys. med. Ges. zu. Würtzburg; 188?. Sternbert, Am. Journ. Mcd. sc. Philad., Vol. 84, 1882.

-, Johu Hopkins Univ. stud. biol. lab. Baltimore, Vol. 2, 188:.

NAUnr, Bcrl. klin. Wochenschr., Bd. 20, 1883.

Ewak'T, Proc. Roy. Soc. London, Vol. 32, 1881.

Gussenbauer, Sephthämie, Pyolämie, und Pyosephthämie. Dentsche

Chirurgie von Lücke und Billroth. Stuttgart, 1882.

Dowdesweli, Proc. Roy. Soc. London, Vol. 34, 1883.

-, Quart, Joum. Micr. Sc. London, Vol. 18, 1878.

Connil et Babès, Arch. de physiol. norm. et path., T. 2, $188: 3$.

Babìs, Compt. rend. Acad. de sc. Paris, T. 97, 1883.

Arlolng, Compt. rend. Acad. de sc. Paris, T. 98, 1884.

Cheyxe, Trans. path. Soc. Isondon, Vol. 30, 1879.-Ibid., Vol. 33,

1884. Brit. Med. Journal, 1884, 1886, 1888, \&c.

Sutton, T'rans. Path. Soc. London, Vol. 34, 1813.

Strange, Brit. Med. Journ., Vol. 2, 1883.

Stevexs, Glasgow Med. Journ., Vol. 22, 1884.

Rosenbach, Mikioorganismen bei den Wundinfektionskrankheiten des Menschen. Wiesbaden, 1884.

Passet, Fortschritte d. Medicin, Bd. 3, 1885.

Arı.org, Recherches sur les scpticémies, Lyons, 1884.

\section{SUPPURATIVE INFLAMMATION OF THE CELLULAK TISSUE.}

Pasteve, Le furoncle. Bull. de l'Acad. de Méd., Sér. 2., 'T. 9. 1880.

l öwenbera, Le furoncle de l'oreille. Paris, 1881.

ROSENBACH, Mikroorganismen bei den Wundinfectionskrankheiten des Menschen. Wiesbaden, 1884.

PAsse'T, Ueber Mikroorganismen der eitrigen Zellgewebsent \%ündung des Menschen. Fortschritte d. Med., 1885, No. 2.

GArrf, Yur Aetologie acut eitriger Entzündungen. Fortschritic de Med., 1885, 165. 
1) celaux (Bouton d'Alep. et de Biskra), Bull. de l'Acad. do médecinc, 1884, 10th Junc.

Currwe, Brit. Med. Journal, 1884, 1886, 1888.

\section{OSTEOMYELITIS.}

Cullinas, Bakterien im Organismus eines an einer Verletzung am Oberschenkel verstorbenen Mädchens. Göttingen, 1873.

ËBERTH, Virchow's Arch., Bd. 65, 1875.

Friedranx, Fall von primärer infectiöscr Osteomyelitis. Berl. klin. Wochenschr., XII. 4, 5, 6, 1876.

T́CHÜLLer, Zur Kenntniss der Mikrokokken bci acnter infectiöser Osteomyclitis. Mikrokokkenherde im Gelenkknorpcl, Centralbl. f. Chir., 1881., No. 12.

BHC'kgr, Voll. Mitth. über den die acute infectiöse Osteomyelitis erzengenden Mikroor"ganismus., D. Med. Wochenschir., Nov., 1883.

Kralise, Ueber einen bei der acuten infcctiösen Osteomyelitis vorkommenden Mikrokokkus, Fortschr. d. Mcd., Bd. 2, 1884.

Rosexbach, Vorl. Mitth. über dic acutc Osteomyelitis beim Menschen erzeugenden Mikroorganismen. Centralbl.f. Chir., 1884, No. 5.

Priroud, Compt. rend., 1884, October.

Ropet, Etude expérimentale sur l'osteomyélite infectieuse. Compt. 1'end., T. 99, p. 569.

\section{ERYSIPELAS.}

Rechlinghausen U. Lankowski, Ucber Erysipelas. Virchow's Archiv, B. 60, 1874.

Lunousky, Virchow's Archiv, Bd. 60, 1874.

HüTer, Med. Centralbl., No. 34, 1868.

Ortu, Archiv f. expcr. Pathol. n. Pharmacol., Bd. 1, $187 \%$.

Raynaud, Union Méd., Paris, 1873.

'T'roster, Bull. Soc. anat. de Paris, 1875.

Bandri, Zur Aetiologie des Erysipels. Schweiz. naturf. Gesellsch. Bascl, 1875.

Krebs, Archiv f. exper. Pathol ur. Pharmakol, Bd. 4, 1875.

Eirkifir, Langenbeck's Archiv, Bd. 20.

'T'illiasis, Verhandl. d. deutsch. Ges: f. Chirurgie, 1878.

-, Expcrimentclle a. anatomische Unters, \&c., Archiv f. klin. Chirurgic. Band 23, 1879.

Wor,Fr, Virchow's Archiv, Bd. 81. 
Dopeyrat, Reserehes eliniques et experimentales sur la pathogŕnic d. l'ćrysipèlc. Paris, 1881.

Fenteisen, Die Aetiologie des Erysipels. Bcrlin, 1883.

-, Deutsche Zeitschr. f. Chirurgie. Band 16, 1882.

--, Ueber den Erysipelaspilz. Würzburger pliys. med. Ges. Ang., 1881.

Janicke U. Neisser, Exitus lethalis nach Erysipelas. Centralbl.

f. Chir., 1884, No. 25.

Rheiner, Beitr z. path. Anat. des Erysipels bei Gelegenhcit der Typhusepid. in Zürich, 1884. Virchow's Arch., Bd. 100, Heft 2.

\section{EMBOLI AND METASTASES.}

Burkart, Ein Fall von Pilzembolie. Berl. klin. Wochenschr., XI., 1874.

Martini, Deutsche Ges. f. Chirurgie, 19 April, 1873.

Orth, Mitth. ü. d. Mikrokokkenembolieen in den Capillaren.

Sitzung der Niederrh. Ges. f. Natur- n. Heilkunde. Bonn, März., 1879.

Perles u. Weissgerber, Archiv f. exper. Pathol. n. Pharmakol., Bd.6. Recklinghausen und Lankowski, Verhandl, der physik. med. Ges. Würzburg, Bd. II., 1871.

Wassiliefr, Beitr. zur Fräge über die Bedingungen zur Entwicklung von Mikrokokken in den Blutgcfässen. Centralbl. f. d. med. Wissensch., Nr. 52, 1881.

Parenski, Ueber embolische Darmsgeschwüre. Med. Jahrbüchcr, III. Heft, 1876.

RıввеRт, Eine mikroparasitäre Invasion der ganzen Gehirmrinde.

Virchow's Arch., Bd. 80.

LETZERICH, Eneephalitis bacteritica. Virehow's Arch., Bd. 65.

Fos, Mycose d. Pancreas. Giorn. Intcrnat. della scient. medica, III., 1841.

Letzerich, Ucber Mycosis oesophagi. Arch. f. cxper. Pathol., Bd. 7, 1877.

LrTres, Einige Fülle von mycotischer Nicrenerkiankung. Zeitschr. f. klin. Med., 6.

Krause, Ueber dic acutc katarrhal. Gelenksentzündung bei kleinen Kinder'n und den dabei vorkommenden Kettenkokkus. Berl. klin. Wochenschr., 1884, Nr. 43.

Heubner u. Bahrdt, Zur Kenntniss der Gelenkeiterungen bei Seharlach. Berl. klin. Wochensehr., 1884, Nr. 44.

Fleiscinauer, Acriter Gelenkrheumatismus mit. miliaren Abseessen. Virehow's Arch., Bd. $62,1875$. 


\section{PUERPERAL FEVER.}

Marrhofer, Vibrionen als Krankheitsursache des Puerperalfiebers. Monatsschr. f. Geburtsk. u. Frauenkrankheitcn. Bd. 25, 1865. WALDEYER, Ueber Vorkommen ron Bakterien bei der diphthcritischen Form des Pucrperalfiebers. Arch. für Gynäkologie, 1872, III.

Heibera, Die puerperaleu und pyämischen Processe. Leipzig, 1873.

-, Om pyaemia og puerperalficbcr. Norsk. Magaz. for Lägevelsk, Bd. 11.

Orth, Virchow's Arch., Bd. 58, 1873.

LAFWer, Gchirnerweichungsherde durch Mikrokokkenembolieen bei puerperaler Pyämie. Bresl. ärtztl. Ztg., 1879.

Karewskr, Exper. Unters. über die Einwirkung puerperaler Secrete auf den thierischen Organismus. Zeitschr. f. Geburtsh. u. Gynäkologie, Bd. 7, 1881 .

Doleris, La fièvrc puerpérale et les organismes infect. Paris, 1880.

Pasteur, Bull. de l'Acad. de méd., 1880, T. 9.

Aufrecht, Die cxper. Erzcugung der Endometritis diphtherica puerperalis. Naturforsch. Versamml., 1884.

\section{ENDOCARDITIS.}

Mater, Virchow's Arch., Bd. 62.

ISBERTH, Virchow's Aich., Bd. 57, 62, 65.

Koes'Jer, Virchow's Alch., Bi. 72.

Brrch-Hirschento u. Grrber, Archiv d. Heilkunde, 1876.

Litrenen, Zeitschr. für klin. Med., Bd. 2.

Weiceirt, Virchow's Arch., Bd. 84.

O. Rosexich, Ueber artificielle Hcrzklappenfehler. Archir für exper. Pathol., Bd. 9, 1878.

Henima-HJalmar, Virchow's Arch., Bd. 56.

Wever, Berl. klin. Wochensclir., 1877.

KLeBs, Archiv f. exper. Pathol., Bd. 9.

Hambura, Ucber acutc Endocarditis, Berlin, Inaug.-Diss., 1880.

LEYDN, Z/scitschr. f. klin. Medicin., 1881.

Branwel, Discases of the Henrt. Edinburgh, 1884.

OnRrвeck, Casuistische Bciträgc zur Lchre von der Endocarditis ulccrosa. Inaug.-Diss. Göttingen, 1881.

Kundrat, Sitz.-Bcr. d. Kais. Acat. d. Wisscnsch. zu Wien, 1883.

Wysokowrtsch, Ccntralb]. f. d. med. Wissensch., 1885, Nr. 33. 


\section{MALIGNANT GEDEMA AND TETANLS.}

Dataine, Bull. de l'Acad. de Méd., 1862, Scpt.

Pasteur, Ueber d. Vibr. septique. Bull de l'Acal. de Mérl. 1877, 1881.

Koch, Mittl. aus denı Ges.-Amt, I., S. 54.

GrFFkY, Ibid., S. 88.

Brieger, u. Ehrlich, Berl. klin. Wochenschr., Ni. t4, 1882.

Lebedefr, Versüche uber Desinfection bei malignen Oedembacillen.

Arch. de phys. norm. et path., 1882, 6.

Trriraud, De la gangrène gazeusc foudroyante. Rer. de chir., III.

Cimuveat et Arloing, Bull. de l'Acad. de Méd., 1884, 6 May-19

August.

Lustla, Zur Kenntniss bakteriämischer Erkrankungen bei Pferden

(Malignes Oedem). Jahresber. d. K. Thierärzncischulc zu Hannover, 1883-4.

KrTr, Unters. übcr maligncs Oedem und Rauschbrand bei Haust-

hieren Jahresbcr. der K. Thierärzneischule zu Münchcu, 1883-4.

Hesse, W. and R., Ucber Züchtung der Bacillen des Malignen

Oedems. Deutsche mod. Wochenschr., N1. 14, 1885.

Carle: \& Ratrone, Studio spcrimentale sull' etiologia del tetano.

Gior'n. della R. Acad. di Medicina di Torino, März, 1884.

Nicoldier, Deutsche med. Wochenschr., 1884, Nr. 52.

Vogel, Drei Fälle von infectiösem Tctanus. Deutsche med. Wochenschr., 1885, Nr. 31.

\section{PUTRID INTOXICATION, PTOMAINES.}

Hexmer, Exper. Studien. uber d. Wirkung faulender Stoffu. München, 1866.

S'CHWeninger, Ueber d. Wirkung faulender org. Substanzen, \& München, 1866.

v. Raison, Zur Kenntniss der putriden Intoxication, $\mathbb{d e}$. 1)iss. Dorpat, 1866.

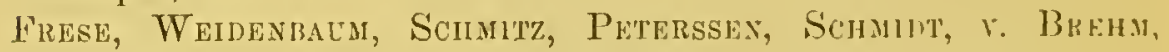

Dissertationen über d. putride Gift, \&c. Durpat, 1866-7:.

Brirgmann, Das putride Gift, \&c. Bd. I. Dorpat, 1866.

-, Deutsche Zeitschr. f. Chirurgie, 13d. 1., 1.87:2.

Bergmaxn u. Schmedebera, Med. Centralbl., 1868, s. 397.

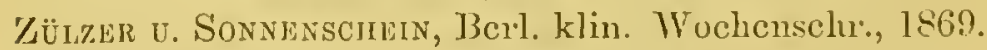

Panum, Virchow's Aieh., Bd. 60, 1874.

Frascr, Exper. Studien, üb. d. Verbreitungd. Faulnissorganismen, \&c. Jilangen, 1874. 
Ruvissch, Zur Lehre von der putriden Infection, \&c. Berlin, 1872. Hituek, Centralbl. f. Chirurgie, 1876.

-, Die Lehre von der Fänlniss. Berlin, 1879.

Nexcki, Ueber die Zersetzung der Gelatine, \&c. Bern, 1876 Journ. f. prakt. Chem., Bd. 26, 1882.

Clementi \& Thin, Unters. üb. d. putride Infection. Wien. med. Jahrb., 1873, S. 292.

Keyrer, Archiv f. exper. Pathol., Bd. I:, 1874.

Budmberg, Experimenteller Beitrag zur Kenntniss der putriden Intoxication. Virch. Arch., Bd. 100, S. 377.

Selyi, Chemische Bcr., Bd. 6, 7, 12.-Sulle ptomäine ad alcaloide eadaverici. Bologna, 1878.

Bouchard, Compt. rend. de Biol., 1882, Aug.

Gautier, C. R. de l'A.cad. d. sc., T. 94, 2.

-, Journal de l'anat. et de la phys., T. 17.

Gaupter et Etard, C. R. de l'Acad. de sc., T. 94.

Brovardel et Bouthy, C. R. de l'Acad. de sc., T. 92, p. 1056.

-, Annal. d'hyg. publ.. 3 sér., T. I.

Tanret, Ibid., 92 T., publ. 1163.

Schiffer, Arch. f. Anat. u. Physiol. Abtheil., 1882.

Bocci, Ctrlbl., f. d. med. Wiss, 1882.

Groenner, Beiträge z. Kcnntniss Der Ptomäine. Dorpat, 1882.

Guareschi et Mosso, Arch. ital. de Biolog., 1883.

S.thowski E. \& A., Ber. d. Chem. Ges., Bd. 16.

SAlomorson, Nordisk. Archiv, Bd. 13.

M.ıs, Ueber Faülnissalkaloide des gekochten Fleisches und des Fischfleisches. Fortschr. d. Med., II. 729.

Vayingede, Les ptomäines. Arch. d. Biol. par van Beneden. Gent, 1884.

WiLLGERODT, Ucber Ptomäine. Freiburg, 1834.

Husemann, Arch. d. Pharmac, 1880, 1882, 1883.

Kö.vig, Massenerkrankung von Menschen nach dem Genuss von Fleisch einer an putrider Metritis vcrendeten Kuh (Putride Intoxication). Ber. üb. d. Veterinä1-Wesen in Königreich Sachsen, 1881.

Bergmann \& Axgrrer, Das Verhältniss der Fermentintoxication zur Septicämie. Wurtzbürgcr Jubil Festschr., 1882.

Schmenebirg v. Harvack, Arch. f. exp. Pathol., Bd. 16.

Brieger, Zur Kenntniss der Faülnissalkaloide. Zeitschr. f. physiol. Chemie., Bd. 7, 1883.-Bcr. d. Deutseh. Chem. Ges., 1884, Bd. 17.

-, Ucber Spaltungsproducte der Bakterien, '/citschr. f. physiol. Chemie, 1884, Band 8, Heft 4.-Bd. 9, Heft 1. 
Brieger, Ueber giftige Producte der Fäulnissbakterien. Berl. klin. Wochensehr., 1884, No. 4.

-, Ueber Ptomäine. Berlin, 1885.

-, Weitere Untersuchungen über Ptomäine. Bcrlin, 1885.

BACKLISCH, Ber. d. deutseh. chem. Gesellsch, Bd. I8, 1885.

CAPpola, Areh. ital. de biolog., Bd. 4.

FOA \& Pellacani, Arch. ital. de biolog., Bl. 4.

Offinger, Die Ptomäine. Wiesbaden, 1885.

Orro, Anleitung zur Ausmittelung der Gifte. Braunschweig, 1884.

\section{DIPHTHERIA.}

Oerter, Deutseh. Arch. f. klin. Med., Bd. 8, 1871.

一, von. Ziemssen's Handb. dcr spec. Pathologie u. Therapic, Band II.

—, Zur Aetiologie der Infectionskrankheiten. München, 1881.

Hueter \& Tomassi, Centralbl. f. d. med. Wissensch., 1868.

Trendelenburg, Areh. f. klin. Chirurgie, Bd. 10.

NASsiloff, Virch. Arch., Bd. 50.

Z ZAHN, Beiträge zur Pathol. u. Histol. der Diphtherie. Leipzig. 1878.

Corvil, Arch. de physiol., 1881.

Kuens, Arch. f. exp. Pathol., Bd. 4, 1875.

LeTZerich, Virchow's Arch., Bd. 52, 55, 61, 68.

-, Mikrochemische Erseheinungen des Diphtheritispilzes. Berl.

klin. Wochenschrift, XI., 1874.

Ëвеrth, Jer diphtheritische Process. Med. Ctrlbl., XI., No. 8 , 1873.

Everetr, Med. and Surg. Reporter. Philadelphia, 1881.

Wood axd Formad, Nat. board of health Bull. Wash., 1882.

Talamox, Bull. de la soc. anat. de Paris, T. 56, 1881.

Salisbury, Gaillard's Med. Journ. New Tork, 1882.

Friedberger, Ueber Croup u. Diphtheritis beim Hausgeflügel.

Deutsche Zcitschr. für Thiermed. n. vergl. Pathol., 1879.

Nica't, Compt. rend., 1879, Bd. 88.

Nuvmayer, Nene Thesen zur Diphtheritisfrage. Freising, 1880.

Fürbringer, Virch. Arch., Bd, 91, 1883.

Heunner, Die cxperimentelle Diphtherie. Lciprig, 1883.

Gerhardt u. Klebs, Verhandl. d. Congresses f. inn. Mred. Wiesbaden, 1883.

Loevpler, Mittlicil. a. d. Kais. Ges.-Amt., Bd. II.

Francotte, La Diphthérie. Jiège, 1883. 
Eum вricu, Ueber die Ursachen der Diphtherie des Menschen und der Tauben. Deutsehe med. Woeh., 1884, S. 614.

-, Compt. Rendus et Mémoircs du V. Congrès internat. d'Hygèine. la Hayc, 1884, p. 247.

Rrvolta, Die Diphtherie der Hühner im Vergleich zu der des Menschen. Giornale de Anat. Fisiol. e Patol. delli anim., 1884.

\section{GONORRHCEA, OPHTHALMOBLENNORRHCEA, AND SYPHILIS.}

\section{BLENNORRHEA.}

Neisser, Centrllbl. f. d. medicin. Wiss., 1879, Nr. 28.

Bokal, Ueber das Contagium der acuten Blennerrhoe. Allgem. med. Centralzeitung, 1880, Nr. 74.

Bofai and Finkelstein, Prager med. chir., Presse, 1880.

BÜcker, Ueber Polyarthritis gonorrhoica Diss. Berlin, 1880.

A virecht, Pathologische Mittheilungen, 1881.

Weiss, Le microbe du pus blennorhagique. Thèse de Nancy, 1880. Ann. de Dermatol., I., 1881.

HaAB, Corresp. f. Sehweizer Aerzte, 1881.

-, Der Mikrokokkus 'der Blennorrhoea neonator. Weisbaden, 1881. Hirschibrt U. Krause, zur Pathologie der ansteckenden Augenkrankheiten. Centralblatt f. pract. Augenheilk, 1881.

KraUse, Die Mikrokokken der Blenorrhoea neonator. Ibid., 1882. Leistikow, Uober Baktere in bei den venerischen Krankheiten. Charité-annalen, 7 Jahrg., S. 750, 1882.

EkLund, Sur les microbes de la blennorrhagie. Haarlem, 1882 Ref. in Schmidt's Jahrbiichern, Bd. 197, S. 139.

Bockinlir, Beitrag z. Aetiologic und Pathol. des Harmröhrentrippers. Viertelj. f. Dermatol und Syph., 1883. Sitzungsbericht d. phys. med. Ges. zu. Würzburg. Sept., 1882.

M.ntix, Rech. sur les inflamm. métast. à la suite de la gonorrłéc. Geuève, 1882.

Arsinc, Gonokokken bei Bartolinitis. Vierteljschr. f. Dermatol. u. Syph. 1883, S. 371.

Wschisum, Beitr. zur Aetiologie der gonorrh. Seerete. Deutsche med. Woch., 1883, S. 187.

Newiberny, Maryland Med. Jourı. Febr., 1883.

Gampona, Italia Medica., 1883.

AUfreci'r, Mikrokokken i. d. inneren Organen bei Nabelvenenentzündung Nengeborener. Centralbl. f. d. med. Wiss., 1883, Nr. 16. 
PETRONe; Snlla natura dell' artrite blcnnorragica Rivista clin. 1883, No. 2.

ZWErEEL, Zur aetiol. der Ophthalmoblcnnorrhoea neonator. Arch. f. Gyn. XX11., S. 318.

Bимм., Gonorrhoe d. weibl. Genitalien. Ibid. XXlll., S. 328.

Wefander, Sur les microbes pathogènes de la blcnnorrbagie. Gaz. médicale, 1884, u. Nord. med. Arkiv. Bd. 16., Nr. 2.

Leopold U. Wesser, Beitr. z. Aetoil. u. Prophylaxe der Ophthalmoblennorhoca neonat. Arch. f. Gyn. XXIV., S. 92.

Chameron, Progrès médical., 1884, 43.

Sternberg, Med. news., Bd. 45, 1884, Nr. 16.

Kammerer, Ucber gonorrh. Gelcnkentzündung. Centralbl. f. Chirurgie, 1884, $\mathrm{Nr} .4$.

Kroner, Zur Aetiol. der Ophthalmoblennorrhoea neonator. Natur-

fosschervcrs. in Magdcberg, 1884, Arch. f. Gyn. XXV., S. 109.

SäNGER, Ueber gonorrh. Erkrankung der Utcrasadncxe. Ibid., S. 126.

Oppeniemer, lbid., XXV., S. 5l,

Fränk Fi, Deutsch. med. Wochenschr., 1885, S. 22.

Búm, Der Mikroorganismus der gonorrhoischen Schleimhantẹkrankungen. Weisbaden, 1,885.

Lunnströs, Studien übcr Gonococcus. Dissert. Helsingfors, 1885. E. Fränkel, Mikrokokken bei Colpitis. Deutsche med. Wochenschr., 1885, No. 2.

\section{Srphilis.}

Lostorfer, Arch. f. Dermat. u. Syph., 1872.

KLEBS, Arch. f. exp. Pathol., Bd. 10, 1879.

Aurrecht, Centralbl. f. d. med. Wissensch., Bd. 19, 1881.

Martineau ET Hamonic, De la bactéridic syphilitiquc. Compt. rend., 1882 , p. 443.

Morison, Maryland Med. Journ. Baltimore, 1882.-Ibid., 1883.Weiner Mcd. Wochenschr., 1883.

Birch-HrrschetLn, Baktericn in syphilitischen Ncubildungen. Centrälbl. f. d. med. Wisscnsch., 1882, Nr. 33, n. 34.

Pescirel, Centralbl. f. Augenheilk, 1882.

LET'NIK, Wien. mod. Wochenschr., 1883.

Petrone, Gaz. medica Ital. Lomb., 1884.

'Tornery et Marcus, C. R. de l'Acad. d. sc., 1854, p. 472.

Lustgarten, Wcin. med. Wochenschr., 1884, N1: 47.

Königer, Dentsche med. Wochenschr., 1884, S. 816.

Lö́stcarten, Dio Syphitisbacillen. Wien, 1885.

Doutrelepont U. Scrütz, Deutsche mod. Wochenschr., 1885, No..19. 
de Gracomi, Neue Färbungsmethode der Syphilisbacillen. ' Correspondenzbl. f. Schweizer Acrtze, Bd. 15.

Götrstern, Fortschr. d. med., Bd. 3, S. 543.

Alvarez et Tavel, Bull. d, l'Acad. de méd., 1885, August.

\section{Tuberculosis.}

Villemin, Etude sur la Tuberculose. Paris, 1868.

Сонмнеiм, Uebertragbarkeit der Tuberculose. Berlin, 1877.

Kı,EBS, Arch. f. exp. Pathol. u. Pharmakol., Bd. 1., 1873.--Ibid., Bd. 17, 1883.

-, Virchow's Arch.; Bd. 44, 1868.

'Toussaint, Compt. rend. Acad. de sc., Paris, T. 93, 1881.

Kосr, Die Actiologie der Tuberculose. Berl. klin. Wochćnschr., 1882.

-, Mittheilungen aus dem Kais Ges.-Amt, Bd. II., 1884.

-, Kritische Besprechung der gegen die Bedeutung der Tuberkelbacillen gerichteten Publicationen. Dentsche med. Wochenschr., 1883, No. 10.

Baumgarten, Berl. Klin. Wochenschr., Bd. 17, 1879.

-, Centralbl. f. d. med. Wissensch. Berlin, Bd. 19, 1881.--Ibid., Bd. 20, 1882.-Ibid., Bd. 21, 1883.-Ibid., Bd. 22, 1884.

- Deutsche med. Wochenschr, Bd. 8, 1882.

-, Zeitschr f. klin. Med., Bd. 6, 1883.

Aurrecht, Centralbl. f. d. med. Wissensch., Bd. 21, 1883.

Bollinger, Ibid., Bd. 21, S. 600, 1883.

Cheyne, Brit. Med. Journ., Vol. 1, 1883 and 1885.

-, Nature, Vol. 27, 1883.

-, Practitioner, London, Vol. 30, 1883.

Bоск, Virchow's Archiv, Bd. 91, 1883.

BALOGH, Wien. med. Wochenschr., 1882.

Küssner, Beitr. z. Impftuberculose, Dcutsche med. Wochcuschr., 1883, Nr. 36.

A.NDREw, Lancet, Vol. 1, 1884.

Biedent, Virchow's Archiv, Bd. 98.

A Arirecirt, Arch. f. Kinderheilk, Bd. 5, 1884.

Schorreuros, Zur Kritik d. Tuberculoscfrage. Virchow's Archiv, Bd. 91, 1883.

'L'scheraing, Inoculationstubereulose beim Menschen. Fortschr d. Mied., III., 65.

WAII, Zur Tuberenlosefrage, Deutsch. med. Wochenschr., 1882 , Nr. 46.

Van Eirmengem, Le microbe de la tuberculose. Ann. de la Soc. belge de Microscopie, 1882. 
HrLler, Dcutsche med. Wochenschr., Bd. 8, 1882.

RAymond, Arch. gén. de méd. Paris, Bd. 11, 1883.

BOULEY, La nature vivante de la contagion, contagiosité de la Tubcreulose. Paris, 1884.

Babìs et Cornir, Note sur les bacilles de la Tuberculose. Journ. de l'Anat. et de la Physiol. norm. ct pathol., 1884.

DetTWeiler, Berl. klin. Wochenschr., Bd. 21, 1883.

Formad, The bacillus tuberculosis. The Philad. Medical Timus, 1882, Nov.

SprNa, Studien über Tuberculose. Wien, 1883.

CräMer, Sitzungsber. d. phys. med. Soc. zu .Erlangen, 188:3.

Marchand, Deutsche med. Wochenschr., 1883, Nr. 15.

Heron, Lancet, Vol. 1, 1883.

Green, Brit. Med. Journ., Vol. 1, 1883.

—, Lancet, Vol. 1, 1882.--Ibid., Vol. 2, 1882.

Kundrat, Wien. med. Presse, 1883.

Landouzy et Martin, Rev. de méd., T. ., 1883.

Ciriari, Wien. Med. Presse, 1883.

Cocher, Compt. Rend. Soc. de biol., Paris, T. 5, 1883.

Premfrer, Berlin klin. Wochenschr., Bd. 21, 1883.

Doutrele pont, Die Actiologie des Iapus vulgaris. Vierteljahr'schr' $\mathrm{f}$.

Dermatologie u. Syphilis, 1884.

Connil \& LeLorr, Recherches etc. sur la nature du lupus. Arch. de physiol. norm. ct pathol., 1884.

Leube, Sitzungsber. der phys.-med. Soc. zu Erlangen, 188:3.

Creighton, Brit. Med. Journ., Vol. 1, 1885.

-, Lancet, Vol. 1, 1885.

-, Trans. Path. Soc. London, Vol. 33, 1882.

Déderine, Rev. de Méd. Paris, T. 4, 1884.

Gaffky, Verhalten der Tuberkclbacillen im Sputum. Mittlı. ‘. d.

Kaiserl. Gesund-heitsamt, Bd. 2.

NEGRI, Colorations des spores dans les bacilles de la tubereulose.

Journ. de Microsc., T. 8, 1884.

Rindfletscri, Phys. med. Ges. zu Wü̈zburg, 1882, Nr. 8.

LEYDEN, Klinisches ïber Tuberkclbacillon Zscitschr. f. klin. Med., 1884, VIII.

ZIEHL, Bedeutung der T'uberkelbacillen für Diaguose und Prognose. Deutsche med. Wochenschir., 1883, Nr. 5.

Dieulafoy et Krishaber, Arel. de physiol. norm. et path., T. 1., 1883.

Malassez et Vignat, 1bid., T. 1I., 1883.-Compt. rend., T. 97, 1883. - Sur le mieroorg. de la tuberculose zooglocïque. Compt. rend., T. 99, p. 200. 
Vignat, Compt. rend. Soe. de biol. Paris, T. 5, 1883.

Grbies, Lancet, Vol. 1, 1883.

Ewart, Brit. Med. Jour'1., Vol. 1, 1882.

一, Lancet, Vol. 1, 1882.

EHrutr, Deutschemed. Wochenschr., Bd. 8, 1882.-Ibid., Bd.9, 1883.

Lustre, Ueber Tnberkelbacillen im Blut bei an allg. acutcr.

Miliartnb. Erkinankten. Wien. Med. Wochenschr., 1884, Nr. 48. Levinskr, Deutsche med. Wochenschr., Bd. 9, 1883.

Lichtherm, Fortschr. d. Med., Bd. 1, 1883.

WEst, Lancet, Vol. 1, 1883.

—, Trans. Path. Soc. London, Vol. 34, 1883.

Dansch, Die Impfbarkeit der Tubereulose als diagnostisches

Hülfsmittel bei Urogenitalerkrankungen. Deutsches Areh. f. klin. Med., Bd. 31.

_-, Deutsche Med. Wochensehr., 1883, Nr. 17.

Babès, Der erste Nachweis des Tuberkelbacillus im Harn. Centralbl. f. d. med. Wissensch, 1883.

Rosensteris, Centralbl. f. d. med. Wissensch, 1883.

Johne, Ein zweifelh. Fall ron congenitaler Tuberculose. Fotschr.

d. Med. III., 198.

WEIGERT, Deutsche med. Wochenschr., 1883. Nr. 24, ff.

NAUWERCK, lbid., 1883.

SChäFfer, 1bid., $\mathrm{N}_{1}$. 21, ff.

Celti \& Guranert, Arch. pour les sciences médie. 1883.

Fräntzeis u. Palmers, Berl. klin. Woehenschr., 1882, $188: 3$.

De Giacour, Fortschr. d. Med. I., 1883, S. 1.45.

Schuchardt U. Kracse, Ibid., I., 277.

MüLler, Ueber den Befund ron Tuberkelbaeillen bei fungösen

Knochen u. Gelenk-affectionen. Centralbl. f. Chir., 1884, 3.

Broviluy, Note sur le présence des bacilles dans les lésions chirurgieales trberculeuses. Rev. de chir., T. 3, 1883.

Schlegtexda, Fortsehı: d. Med., I., 1883.

S'Chill U. Fischer, Mitth. a. d. Kaiserl. Ges.-Amt., Bd. 11.

Sмгтн, Bristol Med. Chir. Journ., Vol. I., 1883.

Vilianis, Lancet, Vol. 2, 1883.

Veragutr, Arch. f. exp. Patl. u. Pharmakol. Leipzig, Bd. 16, 188:3.

Vor'rorn, Ueber Tuberkelbacillen im Ohr. Dentsehc med.

Woehenschr., 1884, Nr. 31.

Strrassmann, Virchow's Archiv, Bd. 96, 1884.

Fürterin, Ucber das Vorkommen u. die Vertheilung der 'luberkelbacillen in den Organen. Virch. Arch., Bd. 100, 11 Ieft 2.

Pürz, Ueber die Bezichnngen der T'ubereulose des Mensehen zu der der 'Thiere. Stuttgart, 1883. 
Esser U. Schürz, Zur Casuistik der Tubereulose bei Thiere Arch. f. wiss. u. prakt. Thicrhcilk, XI.

Bollinger, Münch. ärztl. Intelligenzbl., 1883, Nr. 16.

Johne, Die Geschichte der Tuberculose. Leipzig, 1883.

—, Zur Aetiologie der Hühnertuberculosc. Deutsche Zcitschr. f.

Thiermed. u. vergl. Pathol., Bd. X., S. 155.

-, Ber. üb. d. Veterinär'wesen im Königr. Sachsen, 1883.

Zippelius, Wochenschr. f. Thierheilk., Bd. 20.

Demme, 20 Jahresber d. Jenner'schen Kinder'spitals. Bern. 1883.

Lydrin, Badische thierärztl. Mittheil, 1883.

Ribber'T, Ueber d. Verbreitungsweise der Tuberkelbacillen bei

Hühnern. Deutsche med. Wochensclır., 1883, nr. 28.

BANG, Ueber Eutertuberenlose der Milchkühe. Deutsche Zeitschr.

f. Thiermed. u. vergl. Pathol., Bd. XI.

Surron, Trans. Path. Soc. London, Vol. 35, 1884.

Weichselbaum, Wien. med. Jahrb. 1883 (Tuberkelbacillen im Blut.).

Meisels, Wien med. Wochenschr., 1884, Nr. 39 u. 40.

Dotrrelepont, Fall von Meningitis tuberculosa nach Lupus, Tuberkelbacillen im Blut. Dentsche med. Wochenschr., 1885, Nr. 7.

Spina, Casopis lekaru ceskych, 1885, Nr. 4.

Obrzut, Prof. Spina's neue Färbungsmethode der Fäulnissmikroorganismen und ihre Bezichung zu den Tuberkelbacillen. Deutsche med. Woch., 1885, Nr. 12.

\section{LEPROSY.}

Neisser, Breslauer ärztl. Zeitschrי, 1879.

—, Jahresber. d. schles. Ges. für vaterl. Cultnr., 1879.

-, Virchow's Archiv, 1881, Bd. 84.

KöBner, Virchow's Arch., 1882.

Hansen, Armaucr, Virchow's Arch., Bd. 79.-Ibid., Bd. 90.

Cornil et Suchard, Ann. de dermat. et syph. Paris, 1881.

Gaucher et Hiclatret, Progrès méd. Paris, 1880, 'I'. 8 . Société de biolog., 1881.

John Hrits, On leprosy in British Guiana. London, 1881.

Kaposi, Wiener med. Woehenschr., 1883.

Hillis, Trans. Patll. Soc. London, 1883, Vol. 34.

BABìs, Etude comparative des bactéries de la lèpre et de la tuberculose. Compt. rend., 1883, T'. 96.

VIDAL, La lèpre et son traitement. Paris, ISS4.

Armiva, Ueber das Vorkommen der bacillus leprac bei Lepra anaesthetica s. nerrorum. Virchow's Arehiv, Bd. 97. 
Mülurn, Dcatsches Archiv f. klin. Med., Bd. 34, 1884.

DAMsch, Uebertragungsversuche von Lepra auf Thiere. Virch. Aich., Bd. 92, 1883.

_, Centralbl. f. d. mcd. Wissensch., Bd. 21, 1883.

KöBNER, Uebertragungsvelsuchc von Lepra auf Thiere. Virchow's Aich., 1882.

Campana, Sur la transmissibilité de la lèpre aux animaux. Arch. ital. de biolog., T. 5. fasc. '2.

Vossius, Uebertragungsversuche von Lepra auf Kaninchen. Ber. über d. Ophtalmologencongress in Heidelberg, 1881.

Virchow, Berl. klin. Wochenschr., 1885, Nr. 12.

Unsa, Ueber: Leprabacillen. Deutsche med. Wochenschr., 1885, Ni. 32 .

\section{GIAANDERS.}

Lömpler u. Schütz, Ueber den Rotzpilz. Deutsche med. Wochenschr., 1882, Nr. 52.

Israte, Berl. klin. Wochenschr., 1883, Nr. 11.

Bouchard, Capitan et Charrin, Bull de l'Acad d. sc. 1882, Nr. 51 (27 Decbr.).

Wassiliefr, Deutsche med. Wochenschr., 1883, $\mathrm{Nr} .11$.

Molkentr, Zur Sichcistellung der Diagnose von Rotz. Inaug.Diss. Dorpat, 1883.

Grüvirald, Zur Differentialdiagnose des Rotzes. Oesterl. Monatsschr. für Thierheilk, 1884, Nr. 4.

Weichsicibaum, Zur Aetiologie der Rotzkrankheit des Menschen. Wicner med. Wochenschr., 1885, 21-24.

Fröhner, Rotzige Elephantiasis des Kopfes beim Pferde. Rep.d. Thierlieilk, 1883-4.

KIrT, Versuche ïbcr d. Züchtung des Rotzpilzes. Jahresber d. München Thiel-arzneisch., 1883-84.

\section{ANTHRAX.}

(Compare also p. 53, "Immunity and Protective Inoculation.")

Poll,exder, Vierteljahrschr. f. ger. Med., Bd. 8, 1855.

Brauela, Virchow's Arch., Bd. 11, 1857.-Ibid., Bd. 14, 1858.

1) Avaine, Compt. rend Acad. de sc. Paris, 'I'. 57, 1863.-Ibid., 'T. 59,1863 ; T'. 60, 1865; 'T. 61,$1866 ;$ T. 77, 1873.

-, Rec. de méd. vét., T. 4, 1877.

-, Compt. lend. 1877 (Reviow of Davaine's Publications in Cosmil ut, Babès' Handbuch, p. 493). 
Pasteur, Bull. Acal. de méd. Paris, 1877, 1879, 1880 (Wanth Worms).

-- Compt. rend. Aead. de sc. Paris, T. 84, 1877; T. 90, 1880 ; Ibid., T. 91, 1880; T. 92, 1881; Ibid., T. 95, 1882.

Colis, Bull. Acad. de mćd. Paris, T. 2, 1873; Ibid., 'T. 7, 1878. Ibid., T. 8, 1879 ; Ibid., T. 9, 1880 ; Ibid., T. 10, 1881.

FELTz, Sur la rôle des vers de terre dans la propagation du charbon. Compt. rend., 1882, T. 95.

Bert, Compt. rend. Soe. de biol., T. 4, 1877 ; 1bil.. 'T' 5, 1878: Ibid., T. 6, 1879.

Bolinger, . Ziemssen's Handbueh der spec. Pathol. u. Therapie. Bd. III.

—, Centralbl. f. d. med. Wissensch., 1872, Bd. 10.

Toussaint, Recherches expérimentales sur la maladie charbonneusc. Paris, 1879.

-, Compt. rend. Acad. de sc., T. 85, 1877, 1878, 1880.

Cinauveat, Compt. rend. Acad. de se., T. 90, 1880; T. 91, 1880 ; T. 92, 1881; T. 94, 1882; T. 96, 1883.

Bouler, Bull. Acad. de Méd. Paris, T. 9, 1880; Ibid., T. 10, 1881. —, Compt. rend. Acad. de sc., T. 92, 1881. Tbid., T. 93, 1881.

Kocr, Beitrag zur Biologie der Pflanzen. Breslau, 1876, Bd. •., Heft 2.

-, Wundinfectionskrankheiten. Leipzig, 1878.

-, Mitth. aus d. Ges.-Amt., Bd. I., 1881.

Oemrer, Arehiv f. wissenseh. u. pract. Thierheilk., Bd. 4, 1878. -Ibid., Bd. 5, 1879 ;-Bd. 6, 1880.

Scrimit, Milzbrand bei Wildsehweinen. Deutsche Zeitselır. f. Thiermed. u. vergl. Pathol., 1879.

WWart, Quart. Journ. of Microse. Se., April, 1878.

Roder, Compt. rend., T. 94, 1882.

- Contribution à l'étude expérimentelle du Charbon Bacteridicn. Lyon, 1881.

Wachenien, Etude expérimentelle sur la septicité et la virulence du sang charbonneux. Nancy, 1880.

Sternaerg, Am. Monthly Micr. Journ., Vol. 2, 1881.

Huber, Deutsehe med. Wochensehr., Bd. 7, 1881.

Gremantis, Proe. Roy. Soe. London, Vol. 30, 1880.

-, Quart. Journ. Micr. S'c. London, Vol. 20, 1879.

Krefre, On the relation of Pathogenie to Septic Bacteria, as illustrated by Anthrax Cultivations. Rep. of the Medieal Officer of the Isoeal Government Board for 1881, ff.

-, On a Morploological Variety of Bacillus Anthracis. Quart. Journ. Micr. Sc. n. s., Vol. 23, 1883. 
FohKer, Virchow's Archiv, Bd. 88, 1882.

—, Centralbl. f. d. med. Wissensclı., Bd. 18, 1880.-1bid., Bd. 19, 1881.

Semmer, Centralbl. f. d. med. Wissensch., Bd. 18, 1880.--1bid., Bd. 22,1884 .

—, Der Milzbrand und das Milzbrandcontagium. Jena, 1882.

RolofF, Ueber dic Milzbrandimpfung und d. Entwicklung d. Milzbrandbakterien. Archiv $\mathfrak{t}^{\prime}$. wisscnsch. u. pract. Thierheilk., Bd. 9, 1883.

-, Der Milzbrand. Berlin, 1883.

Archangelski, Centralbl. f. d. med. Wissensch., 1882, 1883.

Dowdesweli, Rep. Med. Off. Local Gov. Board, 1883.

Toepper, Die neueren Erfahrungen über d. Aetiologie d. Milzbrands.

Jena, 1883.

Buchner, Ueber dic expcr. Erzengung des Milzbrandcontagiums aus den Hcupilzen, München, 1880.

-, Versuche ïber die Entstehung des Milzbrands durch Einathmung. Sitzungsber. d. K. bayer, Akad. d. Wissensch., 1880.

-, Vorträge in ärztl. Vercin zu München, 1881.

-, Die Umwandlung der Milzbrandbakterien in nnschädliche

Bakterien. Virchow's Arch., Bd. 91, 1883.

Prazmowski, Acad. d. wissensch. in Krakau, 1884 (polish).

—, Biol. Centralbl., Bd. 4, 1884.

Szpilman, Zeitschr. f. physiol. Chemie. Strassburg, Bd. 4, 1880.

Friedrich, Zur Aetiologie des Milzbrands. München. Inaug-Diss. Leipzig, 1885.

Esser \& Schürz, Zur Casuistik des Milzbrands. Mitth. a. d. K. prcuss. amtl. Vet. Sanitätsbcricht, 1882-1883.

Bollinger, Zur Aetiologie des Milabrands. Sitzungsber. 1. Ges. f.

Morphol u. Physiol. zn München, 1885, 10 Febr.

Kitr, lbid., 1885, Febr.

Bleuler, Milzbrand beim Menschen. Correspondenzbl. d. Schwoi\%. Aerzte, 1884.

Sichrakamp, Zur. Aetiologie des Milzbrandes. Archir. f. Hygienc, Bd. 2, 1884 .

V. Chelciowstr, Zur Charakteristik des Milzbrandvirus. Ier. Thierarat, 1884.

\section{'TYPHOID HEVER.}

KLiBs, Arch. f. exper. Pathol. u Pharmakol., Bd. 12, 13, 15. 1880 81.

Bircie-Hirscheren, Unters. zur Pathologie des Typhus abdominalis, Zeitschr f. Epidemiologic, T., 1874. 
Kuein, Med. Centralbl., X1I., 1874.

Sokoloff, Virchow's Arehiv, Bd. 66.

Feltz, Compt. rend., 1877, T. 85.

Eppinger, Beitr. zur pathol. Anatomie ans d. patholog. Institut. Prag., 1880.

Letzerich, Virehow's Arehiv, Bd. 68.

-, Archiv f. exper. Pathol., Bd. 9, 1878; Bd. 10, 1881.

-, Expcrimentel!c Untersuchungen über die Actiologie des

Typhus abdominalis. Leipzig, 1883.

Wernich, Zeitschr. f. klin. Med., Bd. 6, 1882.

Fischel, Ueber das Vorkommen von Mikrokokken in einigen

Organen bei Typhus abdominalis. Beitr. zur Pathol. Anat. aus

d. pathol-anat. Inst. Prag., 1880.

Tizzoni, Stadi. di pat. sperim. sulla gen. d. tifo. Milano, 1880.

Rapprn, Contrib. ál'étude des bact., de la bouche, à l'état normal et dans la fièvre typhoïde. Paris, 1881.

Maraghano, Centralbl. f. d. med. Wissensch., Bd. 15, 1882.

Braltegcht, Pathogene Bakterion im Trinkwasser bei Epidemieen.

Virehow's Arelı., Bd. 84, 1881.

AluquUst, Typhoïdfeberus-Baktcric. Stockholm, 1882.

Crooke, Brit. Med. Journ., Juli, 1882.

Boens, Acad. roy. de Méd. de Belgique. Bull, 1883. 3. Ser., T. 17.

Enerth, Der 'Typhus-Bacillus und die intestinelle Infection.

Volkmann, klin. Vorträge, 1883.

-, Arch. f. pathol. Anat., Bd. 81, 1880.-Ibid., Bd. 83, 1881.

Meyer, Unters. über den Bacillns des Abdominaltyphus. Inaug.Diss. Berlin, 1881.

Gafткr, Zur Actiologie des Abdominaltyphns. Mitth. a. d. Ges.Amt., Bd. 2, 1884.

Conts, Ebcrth's Typhoïdbacillus. Brit. med. Journ., Mäı’z, 1882.

I'AYon, Le mierobe de la fièvre typhoüde de l'homme. Compt. rend., T. 99, p. 331 ; 'T. 101, No. 6.

Preiffer, Ueber den Nachweis der Typhusbacillen im Darminhalt u. Stuhlgang. Deutsehe med. Wochensehr., 1885, Nr. 29.

\section{RELAPSING FEVER.}

Obанмегел, Vorkommen feinster, cigene Bewegung zeigender Fäden im Blute von Recurrenskranken. Med. Centralbl., 1873.-Berl. med. Ges., März, 1873. Berl. klin. Wochenschr., 1873.

WNGEI, Ueber die Oberneicr'sehen Recurrensspirillen. Berl. Klin. Woch., 1873.

Wregert, Deutsche med. Wochensehr., 1876. 
Moczurowsky, Dcutsch. Arehiv f. klin. Med., Bd. 24.

Birch-Hirschfeld, Ibid., Bd. 13, 1874.

I.Ap'Tschinshy, Centralbl. f. d. med. Wissensel., Bd. 13, 1875.

A LBReснт, St. Petersb. med. Woehcnsehr., 1879, Nr. 1.

Conn, Deutsehe med. Wochensehr., 1879.

Herdenreich, Der Parasit des Rückfalltyphus. Berlin, 1877.

一, St. Petersb. med. Woehenschr., 1876.

Kосн, Deutsehe med. Woehenschr., 1879.

Gutrmans, Virehow's Arch., 1880.

MüHLhäuser, Virchow's Arch., Bd. 97, 1884.

V. JAksch, Wieu. med. Wochenschr., 1884, Juli.

\section{CHOLERA.}

Косн, Ueber die Cholerabaktericn. Deutsche med. Wochensehr., 1884.

Verhandiungen der Conferenz zur Erörterung der Cholerafrage. Berliner klin. Woehensehr., 1884, Nr. 31, ff. Deutsche med. Wochenschr., 1884, S. 504 ff.-2: serie : 4. May, 1885, and the following days. Deutsche med. Wochenschr., 1885, Nr. 19, 20; $37 \mathrm{a}, 38,39$.

Vin Ermengen, Reeherches sur le microbe du choléra asiatique.

Paris-Bruxelles, 1885.

-, Conelusions prés à la Soc. Belge de Microsp. dans la séance din 26 Oct., 1884.

-, Note sur l'imoculation des produits de culture du bacillevirgule. Bull de l'Aead. roy. de méd. de Belgique. 3 Sér., XVIII.

Gibier et van Ermexgem, Rech. expér. sur le Choléra. Compt. rend., T. 101, 1885.

Preiffer, Ueber die Cholcra in Paris. Deutsche med. Wochenschr., $1885, \mathrm{Nr} \cdot 2$.

Jonne, Einiges über die sogen. Choleracurse in K. Ges.-Amt. Deutsche Zeitsehr. f. Thicrmed., Bd. XI.-published scparately by Vogel, Leipzig.

Bianchi, Laneet, Vol. 2, 1884.

Macnamara, Brit. Med. Journ., Vol. 1, 1884.

Hunter, Ibicl., Vol. 1, 1884.

CArTur, Lanect, Vol. 2, 1884.

Cameron, Brit. Med. Journ., Vol. 1, 1884.

Strauss, Roux, Thumbiler at Nocard, Compt. rend. Soc. de biol. Paris, T. 4, 1883.

Doren, Mikroorganismen in Leber und Niere ron Choleraleichen. Soe. de Biol. de Paris, 13 Dec., 1884. 
Bucinver, Ueber Cholerabacillcn. Münchn. äıtl. Intelligenzb., 1884, S. 549.

KLEBS, Ueber Cholcra asiatica. Bascl, 188. .

Sснот'telius, Zum mikiosk. Nachw. v. Cholcrabacillen in Dejectionen. Deutsche med. Wochenschr., 1885, Nr. 14

Bocinefontaine, Expér. pour servir à l'étude des phénomènes déterminćs chez l'homme par l'ingestion stomacale du liquide diarrhéique dn cholćra, Compt. rend., T. 99, p. 845; and T. 100, p.
1148 .

KLEIN, Brit. Med. Journ., Vol. 1, 1885.

-, Lancet, Vol. 2, 1884. Ibid., Vol. 1, 1885.

-, Proc. Roy. Soc. London, Vol. 38, 1885.

Finkler U. Prior, Unters. über Cholera nostras, Deut. med. Woch., 1884, Nr. 36.

-, Ueber den Bacillus der Cholera nostras und seine Cultur. Naturforscherversammlung Magdeburg, 1881.

-, Ueber dic Kommabacillen. Kölnische Zeit. (!), 1884, 11 Novbr:

-, Forschungen über Cholerabakterien. Ergänzungshefte zum Ccntrabl. f. allg. Gesundheitspflege, Bd. 1, Heft 5 u. 6.

Denere, Ueber eine nenc den Choleraspirillen ähnliche Spaltpilzart. Dentsche med. Wochenschi1., Nr. 3, 1885.

Mruler, Kommaförmiger Bacillus aus der Mundhöhle. Deut.med. Woch., 1885, Nr. 9.

Enmerich, Die Cholera in Neapel. Deutsche med. Wochenschr.. Nr. 50, 1884.

FLÜGGE, Kritik der Emmcrich'schen Unter'suchnungen über Cholera.

Dentsche med. Wochenschr., Nr. 2, 1885.

Cheyne, Brit. Med. Jonunal, 1885.

Drasche, Allg. Wien. med. Zeit., 1885.

Bruxerti, Fatti Considerazioni Conclusioni sul coléra Padua, 1885.

NiCA't et RIETSCh, Alch. de physiol., 1885. Compt. rend., T. 99. p. 928.

-, Revue d'hygiènc, 1885.

-, Revue de médccin, 'T'. 5, 1885.

Transact. of the Royal Medical and Chirurgical Socicty of London, March-April, 1885.

Vifirises, Sur la formation des ptomaïnes dans le choléra. Compt. rend., 'T. 100, p. 91.

PFerrekr, Der bisherige Verlauf der Cholera in Tlüuringen etc. Corresp. Bl. des allgem. ärztl. Vcr. in 'Thüringen, 1884, $\mathrm{N}_{r}$. 9. Ferran, Sur l'action pathogènc et proplyylactique du bacillus. virgule. Compt. rend., 'T. 100 , p. 959. 
Héricovrt, Sur la nature inlifférente des bacilles-virgules. Ibid., p. 1027.

Van Erangem, Die Forran'schen Impfungen. Deutsche med. Wochenschr., 1885, Nr. 29. Compare. Bull. de l'Acad de méd. Sćance du 13 Juillet, 1885.

\section{PNEUMONIA.}

Küнx, Die Uebertragbarkeit endemischer Pneumonieformen auf Kaninchen. Berl. klin. Wochensehr., 1881, Nr. 38.

-, Die contagiöse Pneumonie. Deutsch. Arch. f. klin. Med., 1878.

Friediäyder, Virehow's Areh., Bd. 87, 1882.

-, Fortsehr d. Med., Bd. 1, 1833, S. 715. Ibid., Bd. 2, 1884, S. 333 u. 652

-, Beste Färbung zur Darstellung der Kapseln der Pnenmoniekokken. Fortschritt, III., 92.

Matrat, Wien. med. Presse, 1883, Nr. 23.

'ZieHL, Ueber das Vorkommen der Pneumonickokken im pneumonischen Sputum. Centralbl. f. d. med. Wissensch., 1883, 1884. Jürgensen, Berl. klin. Wochenschr., 1884, Bd. 22.

Mendelssohn, Zeitschr, f. klin. Med., 1884, Bd. 7.

Exmerich, Pncumoniekokken in der 'Zwischendeckenfüllung.

Archiv f. Hygiene, Bd. 2, Heft 1.

German-Sée, Compt. rend. Acad. de se. Paris, 1884.

—, Des maladies specifiques du poumon. Paris, 1885.

Sahyioli U. Zäslein, Ueber don Miorococeus und die Pathogenese der croupösen Pneumonie. Centralbl. f. d. med. Wissench., 1883 .

-, Arch. pour les sc. méd., Bd. 8, 1884.

Puatonow, Ueber die diagnostische Bedeutung d. Pneumoniekokken. Inaug.-Diss. Würzburg, 1884.

Maguire, Blit. Med. Journ., Vol. 2, 1884.

Grues, Ibid., Vol. 2, 1883.

'Talamon, Progr. médic., 1883.

Aranassiew, Compt. rend. Soc de biol. Paris, T. 5, 188t.

Korínyi u. Babès, Pester med. chirnrg. Presse, 1884.

A. Fränkel, Verhandl. d. Congr, f. innere. Med., 1884.-Fortsehr. d. Med., 1884, Nov.

Bringer, Zeitsehr. f. physiol. Chemic., Bd. 8.

Kuarn, Centralbl. f. d. med. Wissensch., 1884.

NAuwercr, Ueber morbus Brightii bei croupöser l'neumonie. Beitr. zur pathol. Anat. von Ziegler. Jena, 1884. 
Ribbert, Zur Färbung d. Pneumoniekokken. 'Deut. med. Wochensehr., 1885, Nr. 9.

Dreschfeld, Ueber Wanderpneumonie u. ihre Beziehung zur epidemisehen Pneumonie. Fortsehr. d. Med., I1I., 389, 1885.

ScHou, Untersuehungen über Vaguspneumonie. Fortschr. der Mediein., Bd. 3, Nr. 15, 1885.

\section{MALARIA.}

Ku.ens u. Tommasi-Crudent, Areh. f. exp. Pathol., Bd. 2, 1879.

Tommasi-Crudeli, Der Baeillus Malariae im Erdboden von Selinunte u. Campobello. Arel. f. exp. Pathol., Bd. 12.

- La production naturelle de la malaria. Conférenee faite à la 8 sess. du eongrés intern. méd. à Copenhague, 1884.

-, Die Malaria von Rom. Dentseh von Sehuster. Münehen, 1882.

Laveran, Les parasites du sang dans l'impaludisme. Compt. rend., No. 17, 1882.

- Traité des fièvres palustres. Paris, 1884.

Richard, Compt. rend., No. 8, 1882.

Marchand, Zur Aetiologie der Maleria. Virehow's Arehiv, Bd. \&\&: 1882.

ZienL, Deutseh. med Woeh., Nr. 48, 1882.

Roszahegy, Von der Ursaehe des Weehselfiebers. Biol. Ctrlbl, Bd. 2, 1882.

Kotelmann, Der Bacilhts Malariae in Alterthum. Virehow's Areh., Bd. 97, 1884.

Stennberg, Nat. Board of Health. . Bull. Suppl., Washington, 1881.

Cuboni und Marchiafava, Atti della, R. Acad. dei Lincei., 1881.

-, Neue Studien uib. d. Natur der Malaria. Arch. f. exp. Pnthol.. Bd. 13.

CECI, Ueber die in den malarisehen und gewöhnliehen Bodenarten enthaltenen Keime nnd niederen Organismen. Arch. f. exp. Pathol., Bd. 15 u. 16.

Marchiafava U. Cahli, Nene Untersuehungen über dic Malariainfeetion. Fortselı. d. Med., III., 339.

- Blntverïnderung bei Malaria. Areh. ital. de biologie, Bd. 5, fase. 2 .

-, Atti della R. Aendemia dei Lineei, 1884.

v. Sehlew, Fortsehr. d. Med., Bd. 1I., 1884.

Leoni, Gazetta mediea di Roma, 1884, Dee.

GerhardT, Zeitsehr. f. klin. Med., Bd. 7, 1884. 
Marriotai \& Ciabroceni, Lo sperimentale, Bd. $\check{4} 4,1884$.

ToRELli, La malaria in Italia. Roma, 1883.

Mavrel, L'étiologie et la nature du paludisme. Am. d'lyygiènc, 1883.

Bardels, Gaz. des hôpit., 1882.

\section{EYE AFFECTIONS.}

Ererth, Ueber Entzündung der Hornhaut nach 'TrigeminusDurchsneidung. Med. Centralbl., XI., I873.

Frisch, Die Milzbrandbaktericn und ihre Vegetationen in d. lebenden Hornhant. Acad. d. Wiss., Bd. III., 1876.

Schmidt-RImpler, Ueber Hornhautimpfungen mit Berücksichtigung eiteriger Keratitis beim Mensclıcn. Marburger' Sitzungsber., 1876, III.

LeBER, Ueber Entzündung der Hornhaut durch septische Infection. Med. Centralblatt., XI., 1873.

BaLOGH, Sphaerobakterien in der cntzïndeten Hornhant. Merl. Centralbl., XIV., 1879.

Dolschenkoff, Impfung faulender Substanzen anf die Kaninclienhornhaut. Med. Centralbl., 1873.

Horner, Keratitis mycotica. Monatsbl. f. d. Augenheilk, XIII. Röтн, Retinitis septica. Virchow's Archiv, Bd. 55.

KaHLer, Ueber septische Retinitis. Prager Zcitschr. f. prakt. Heilk., Bd. I., 1882.

Förster, Pilzmasse im unteren Tlüänenkanülchen. Arch. $f$. Ophthalm., XV., 1.

GRäFE, Ibid., Bd. XV., l.

Cons, Ibid., Bd. 15.

ง. Reuss, Pilzconcretionen i. d. 'Whränenröhrchen. Wien. merl. Presse, 1884.

Goldziener, Streptothrix Focrsteri im unteren Thräncuröhrehen. Centralblatt f. prakt. Angenlıcilk, 1884, Febr.

Herzog von Bareri, Zur Kenntniss der beim Menschen rorkoummenden Bacillen. Tbid., 1880, Oetober.

Satther, Unters. ̈̈ber das Trachom. Ber. üb. d. OphithinlmologenCongress zu Heidelberg, 188:.

Kroner, Zur Actiologie der Oplithalmoblemnorrlioe. Verh. d. Naturforscher" Vers. Magdelung, 1884 (for the rest of the literature see under" "(ionormhora").

Kuschanrt L. Nelsser, \%ml Pathologie und Aetiologic der Xirosis conjunctivae. Bresl. är\%tl. Zeitschr., 1883, Nr.4.

Kuschibrt, Dentsch. med. Woch., 1934, N1,21. 
Leber, Ueber die Xerosis der Bindehaut. 'v. Graefe's Arch. f. Ophthalmologie 29, 3.

Scirfirir, Verh. des Ophthahmologen-Congr., zu Heidelberg, 1883.

Bock, Ueber die miliare Tubcrkulose der Uvea. Virchow's Arch., 1883, Bd. 91.

MicheL, Graefe's Ar'chiv f. Augenheilkunde, Bd. 1, 1882.

Deutschmann, Zur Pathogenese der sympathischen Ophthalmie. r. Graefe's Arch., 30, 2 Abthl.

A brailam, Dublin Jomrn., 73. Febr., 1882.

De Wecker; Die Jequirity'sche Ophthalmie. Klin. Monatsbl. f. Augenheilkunde Jahrg., 20 n. 21.

Satrler, Ueber d. Natur der Jequirity-Ophthalmie. Zehender's klin. Monatsblatt, Juni, 1883.

-, Wien. med. Woch., 1883. Nr. 17.

Satther ET de Wecker, L'Ophthalmie jequiritiqne. Paris, 1883.

Cornil ét Berlioz, Sur l'empoisonnement par le Jéquirity.

Compt. rend. de l'Acad. d. sc., 1883, Sept.

NeIsser, Fortschr. d. Med., Bd. 1I., S. 73.

Salomonson, Ibid., Bd. 11., S, 78.

Kuein, Centralbl. f. d. med. Wiss., 1884, Nr. 8.

Vennemann et Bruyrants, Le jéquirity et son principe pathogène.

Braxelles, 1884.

SATtLer, 1bid., 1I., S. 501.

Vossius, Berl. klin. Woehenschr., 1884, Nr. 17.

DE WeCKer, v. Graefe's Areh., Bd. 30, Abtl. 1.

- Archiv. f. Augenheilkunde., Bd. 14.

Kxapp, Klinisehe Beob. über die Anwendung von Jequirity bei

Trachom. Arch. f. Augenheilk., XIV.

\section{OTHER INFECTIVE DISEASES OF MAN.}

VARIOLA, Vaccinia.

Kaber, Virchow's Arch., Bd. 42.

Cinuvgeau, Compt. rendus., 1868, Februar.

Colis, Virchow's Archiv, Bd. 55, 1872.

Lúginume, Der Microcoecus der Variola. Verhdl. d. phys.-med.

Ges. in Würzburg, 1873.

Z/ÜLZBR, Berl. klin. Wochenschr., 1872.

Weigert, Anat. Beitr. z. Lehre v. d. Pocken., 1874.

Pissin, Berl. klin. Wochenschr., 1874.

KunBs, Areh. f. exp. Path. u. Pharmakol. Leipzig, Bd. 10, 187s.

Pont-Pincus, Vaccination. Berlin, 1882. 
T'Apere, Actiologie u. Histologie der Schafpocken. Berlin, 1881. Plaut, Das organis. Contagium der Schafpocken. Leipzig, 1883. Cornit et Babìs, Soc. médicale des hôpitaux, 1883, 10 August. Quist, St. Petcrsburg medic. Woch., 1883, Nr. 46.

Fërst, Corresp.-Blatt. d. ärztl. Kreis- u. Bez.-Vereins. in Sachscn. Leipzig, Bd. 33.

Hityertir, Ueber die sog. Vaccination u. Variola. Prag., 1884. PFEIFFER, Ueber die Rückimpfung auf Kühe und Kälber. Jahrb.

f. Kinderheilk, 1882, Bd. 19.

-, Ucber Sprosspilze in der Kälberlymphe.

M. Wolr, Zur Impffrage. Berl. klin. Wochenschr., 1883, Nr. 4.

\section{Scarlatina.}

COZE ET Frutz, Les Maladies infectieuses, 1872.

Pонд-Practs, Centralbl. f. d. med. Wiss., 1883.

HeUbarer U: BahrdT, Zur Kenntniss der Gelenkeiterungen bei

Schạrlach. Berl. klin. Woch., 1884, Nr. 44.

Crooḱ, The Lancet, 1888, March.

Rотн, Nünchener ärztl. Intelligenzbl., 1883.

Bokal, Orrosi hetilap. 1882 u. 1885. (Arthritis scarlatinosa; s. Cornil ı. Babès' Handbuch, S. 537.)

\section{YELLOW F'EVER.}

Domingos Freire, Recherches sur la cause, \&c., de la fièvre jaunc. Rio de Janeiro, 1884.

Doningos Freire et Rebourcieon, Compt. rend., T. 99, p. 804, 1884.

BABÈs, Sur les microbes trouvés dans le foie et dans le rein d'individns morts de la fièvre jaune. Compt. rend. 1883. 17 Sept.

Bouley, L'inoculation préventive de la fièvre jaune. Compt. rend., Bd. 100; p. 1276.

\section{Cerebrospinal-Meningitis.}

IAYYen, Dic Mikrokokken der Cerebrospinal-Meningitis. Centralbl. f. klin. Med., 1883, Nr. 10.

Lieicitenstirn, Deutsche Mcdic. Woch., 1885, N1. 23 u. 31.

\section{INFLUENZA.}

Sfirert, Ueler Tnfluenza. Volkmann's Sammlung klin. Vorträge,
Nl. 2 to. 


\section{ACUTE YaLlow Atrophy of THE haver.}

UPrintien, Prag. Viertelj., 187i.

Hu,ava, Prag. med. Wochenschr., 1882.

\section{HéMOPHLLA NEOMTORLM.}

Kuris 1 . EPpinger, In Klebs' Beitr: zur pathologischen Anat., 1878.

\section{RABIES.}

Colıs, Bull. Acad. de méd. Paris, T. 10, 1881.

Dot.rists, Gaz. méd. de Paris, T. 3, 1881.

-, Tribune méd. Paris, 'T. 14, 1881.

Pasteur, Compt. rend. Acad. de sc., 1881-83.

- Nouvclle communication sur la rage. Ann. de méd. vétérin, 1884, Part 5.

Pasteur, Chamberland, Roux et Thullier, Noureaux faits pour servir à la connaissance de la rage. Compt. rend., 1882, T'. 95.

Brirt, Contribution à l'étude de la rage. Compt. rend., 1882.

Grbifr, Ibid., T. 96, 1883.

\section{Rhivoscleroma.}

Culixil, B. de la soc. anatom., 1885, 15 Febr.

Corvil et Alvarez, Sur les micro-organismes du Rhinoscleroms. Acad. de Mćd., 1885, March.

\section{OzaENa.}

li. Frïxket, Virchow's Areh., Bd. 90, 1882.

föwhingert, Deutsche med. Woch., 1855, Nr. 1.

\section{Luxg Affectioss (Pnemmonia, sce p. 31 ).}

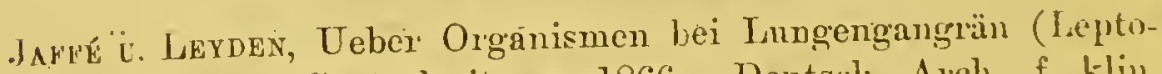
thrix). Med. Centralzeitung 1866. Deutsch. Arch. f. hlin. Med., II.

'T'raubi, Leptothrix im Sputum. Deutsche Klinik., $185 \%$.

Hermer, Ueber Pneumonomycosis sareiniea. Deutches Arch.f. klin. Med., 1877 (vgl. Sarcina, S. 29).

Burgki, Der Kenchhustenpilz. Berl. klin. Wochensehr., 188:3, $\mathrm{N} \cdot 1$.

\section{Gorrre.}

Kı̈̌ıs, Studien über Kretinismus. Prag, 1877.

Burcine, Der endemische Kropf. Basel, 1883. 
Skin Affections.

Rindeleiscu, Mycosis fungoides. Deutsehe med. Woch., 1885.

Acspitz, Granuloma fungoides. Viertlj. f. Dermat. u. Syph., 1885.

v. Sentex, Mikrokokken bei Arca Celsi. Fortschr. de Med., Bi. " 1, i 883.-Virch. Areh.', Bd. 99, S. 327.-Bd. 100, S. 361.

Michersox, 1bid., Bd. 99, S. 572.-Bd. 100, S. 576.

'Tнг, British Medie. Journ., 1882, S. 304.

\section{UISEASES OF THE MOUTH AND TEETH.}

(As to Leptothrix see also p. 24, Fürster, ffi., S. 26, Jaffé.u. Leyden. $\mathfrak{H}^{\circ}$; as to Thrush,.s., S. 9.)

L_EBER, Berl. klin. Wochenschr., 1867, Nr. 16.

Leber U. Rotrexstern, Unters. über Caries der Zähne. Berlin, 1867. Satterthwate and Cursis, Rep. of the New York Board of Health, 1877.

MrLer, Der Linfluss der Mikro-organismen auf die Caries der Zähne. Arch. f. exp. Path., XVI., 1882.

-, Deutsche med. Woch., 1884, Nr. 25 u. 36.

-, Correspdzbl. f. Zahnärzte., Bd. 13, 1884.

- Ueber einen Zahnspaltpilz Leptothrix gigantea. Ber de deutsch. bot. Ges., 1883, Heft 5.

v. Uвisch, Leptothrixbildung im Munde. Berl. klin. Woehenschr., 1875, Nr. 52.

Arvot, Bcob. an Spiroehacta denticola. Arch. f. pathol. Anat., Physiol. u. klin. Med., 1880, Bd. 79.

Pasteur, Bull. de l'Ae. de méd., 1881, Jamuar.

Rayaud et Jannelongue, Bull. de l'Aead. de méd., 1881, Febr.

Vurpiax, Ibid., 1881, März.

Küıx, Rerl. klin. Woeh., 1881.

A. Fränks, Dentsehe med. Wochenselir., 1884, Nr. 25.

Rapprix, Des bactéries de bouche á l'état normale et dans la fièvic iyphoide. Paris, 1881.

R.sucssex, Om Drykning af Microorganismer fra slyst of sundo menneske1: Kopenliagen, 1883.

Кь⿻上, Centralbl. f. d. med. Wiss., 1884, Nr. 30.

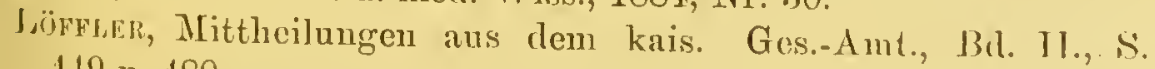
149 n. 480.

Rosismach, Mieroorganismen dei den Wundinfeetiouskranklieiten. Wiesbaden, 1884, S. 77 (Jahnearies). 


\section{DISEASES OF ANIMALS.}

Geverali Literature.

RöLL, Die Thierseuehen. Wien, 1881.

Zürn, Parasiten in und auf dem Körper der Haussäugethiere, 1874. Pürz, Die Seuchen- und Herdekrankheiten, der Hausthicre. Stuttgart, 1882.

HYDROPHOBIA, sec p. 36.

RAUSCHBRAND.

(Symptomatic Anthrax, Black leg, \&c.)

Bolirger u. Feser, Wochenschr. f. Thierheilkunde., 1878.

Arlonga, Cornevin et Thomas, Compt. rend. de l'Acad de se. $1880-83$.

-, Revue de méd., 1881, 1883, 1884.

-, Du eharbon bactérien. Paris, 1883.

—, Bull. de l'Acad. de Méd., 1881.

BABìs, Journ. de l'anatomie, 1884, Janvier.

Neelsen U. Ehleus, Ucber den Rauschbrand. Ber. d. Naturforsch. Ges. zu Rostock., Januar, 1884.

- EnLers, Unters. ïb. d. Rausehbrandpilz. Inaug.-Diss. Rostock, 1884.

Kiтt, Unters. über malignes Oedem und. Rauschbrand bei Hansthieren. Jahresber der K. Thierarzneiseh. in München, 1883-84.

\section{RINDERPEST.}

Semmer U. Archangelski, Ueber das Rinderpesteontagim und dessen Mitigation. Centralbl. f. d. med. Wiss., 1883.

Semmer, Rinderpestähnliche Erkraukungen und die Mikioorganismen bei denselben. Deutsehe Zeitsehr. f. Thiermed. XI., S. 77 .

\section{Pleuro-Preumoxia.}

Sussdorff, Ueber d. Lungenseuche des Rindes. Dentsehe 'Zeitsehr. f. Thicrmed. u. vergl. Pathol., 1879.

Marrwieser, Ueber infectiösen Bronehialcroup bei Rindern. Wochenschr. f. Thierheilk u. Vichzueht., 1884, 19.

Pasteur, Note sur la péripnemnonic contagiense des bêtes à cornes. Recueil de méd. vét., 1882.

Corall et Babis, Arch. de physiol. norm. et path., 1883, T. 2.

Pöls u. Nolen, Centralbl. f. d. medic. Wissenseh., 1884, Nr. 9. 
Swint ERysiperas.

Pasteur, Sur le rouget, ou mal rougc des pores. Compt. rend., T. $95,1882$.

Cornil ex Babis, Arch. de physiol., 1883, Anguist.

K Lein, Rep. of the Med. Offic. of the Privy Council, 1877-78.

-, 'Die Bakterien der' Schwèncsenche. Virchow's Archir, Bd. 95.

Eggeling, Reference in Fortschr. d. Med. I., 793.

Pasteur et Thullier, Bull. de l'Acad. de méd. de Paris, 1883. Compt. rend., Bd. 97, 1883.

LÖFFLER, Experimentelle Untersuchungen über Schweinerothlauf. Arbeiten aus dem kaiserl. Gesundheitsamt, Bd. 1, 1885.

Schüтz, Ueber den Rothlauf der Schweine und die Impfung desselben. Ibid., S. 56.

Jimpin U. Schottelius, Der Rothlauf der Schweine. Wiesbaden, 1885.

\section{Chicken Cholera.}

ZÜRN, Die Krankheiten des Hausgeflügels. . Weimar', 1882.

Mégnin, Maladies des oiseaux.

IoANnès ET MÉgnix, Joum. d'acclimatation, 1877.

Semmer, Hühnerpest. Dentsche Zeitschr. f. 'Thiermed. u. vergl. Path., 1878.

Pasteur, Sur la cholćra des poules. Compt. rend., T. 90, 1880.

-, Hühnercholera. Uebersetzt von A. Schuster. Arch. f. exp. Pathol., Bd. 12.

Perroncito, Uebcr das cpizootische Typhoïd der Hübner. Aich.

f. wiss. u. prakt. Thierheilk, 1879.

Cornil, Arch. de physiol., 1882, Bd. 10.

BABE's, Compt. rend. de l'Acad. d. se., 1883, Scpt.

- Arch. de physiol., 1883, Juli.

KITT, Mittheilungen über dic Typhoïdseuche des Geflügels. Allg. deutsche Gcflügcl-zeitung, 1885, 15 Febr.

Petri, Centralbl. f. d. med. Wissensch., 1884.

Parthétemy, De l'incubation des oeufs d'une poule atteinte du choléra des poules. Compt. reud., 1883, '1. 96, No. 18.

\section{Discase of Parrots.}

EBerti, Virchow's Archiv, Bd. 80.

Wolfe, Ibid., Bd. 92, 1883. 


\section{Disease of Silkworms.-Pebrine.}

Cornalia, Rapp. della Comissione per le studio della mallattia dei briochi. Milano, 1877.

-, Ueber Pebrine. Monographia del Bombice del Gelso. Milano, 1856:

Lebert, Verein zur Beförderung d. Seidenbaues d. Prov. Brandenb., 1856-57.

Frey u. Lebert, Ueber Panhistophyton. Vierteljahrsehr. d. naturwissensch. Ges.-Zürich, 1856.

Osimo \& Vitradini, Giomi. Instit. Lombard, Bd. 3.

—, Recherches sur les maladies des vers à soie. Paduà, 1859.

NÄGELI, Ueber Nosema bombycis. Bot. Zeitg., 1857.

Pasteur, Etudes snr les maladies des vers à soie. Paris, 1870.

Fitherierie.

Leydig, Ueber Gattine. Du Bois-Reymond's u. Reichert's Archir, 1863.

BÉchaMr, Ueber Mierococcus bombyeis. Compt. rend., 1867, Bd. 64.

Pasteur, Ibid., Bd. 64. .

Verson et Vlacovitsch, Recherches sur la gattine et la flacherie. Publ. de la station séricicole de Montpellier, 1874.

Ferry de la Billone, Compt. rend. du congrès internat. séricicole, 1878.

\section{SAPROPHY'TES.}

(See also References in the Text.)

Bacteria which produce Pigment.

Tihrenberg. Micr. prodigiosus. Verhandl. d. Berl. Acad., 1839.

Schrörer, Ueber cinige von Bakterien gebildete Pigmente.

Cohn, Beitr. z. Biol. der Pflanzen, Bd. I., Heft 2.

Erdunan, Bildung von Anilinfarben aus Proteïnkörpern. Jour'r.

f. pract. Chemie., Bd. 99, 1866.

Lankester, On a Pcach-colourcd Bactcriûm. Quart. Journ. of mic1. se., Vol. 13, 1873; Ibid., Vol. 16, 1876.

,$- \Lambda \mathrm{n}$ experiment on the destructive effeet of heat upon life of Bacteria and their germs. Natme, 1874, IX.

KLEIN, Quart. Journ. of mier. sc., Vol. 15, 1875.

Wernich, Cohn's Beitrïge zur Biol. d. Pflanzon, IlI., Heft 1.

Grakd, Revue des se., 'T. 5, 1877.

Fraxk (Bacillus ruber), Cohn's Beitr. z. Biol. d. Pflunzen, Bd. I.. Heft 3. 
Cohn u. Mifleit (Bact. crythrosporns), Ibid., Bd. III., Heft 1.

Van Tieghem, Bull. de la Soc. bot. de France, 1880.

Lücke, Arch. f. klin. Chir., 1862 (blue pus).

Girard, Untcr's. über blauen Eiter. Chirurg. Centralbl. II., 1975.

Éвеrтн, Centralb1. f. d. med. Wissensch., 1863 (Idem).

-, Virchow's Archiv, Bd. 72, 1875 (Idem).

Fordos, Compt. rend. de l'Acad. de sc., T. 51 (Idem).

Gessarn, De.la pyocyaninc et de son microbe. Thèse de Parris, 1882.

Charrix, Communication faitc ì la Socićtć anatomique, 1884, December (Blaucr Eitcr).... . :

BaBes, Vom rothen Schweiss. Biolog. Centralbl., Bd. 2, 1882.

\section{Phosphorescence.}

Bancen et Husson, Sur la phosphorescence de la viande de homard.

Compt. rend., 1879, T. 88.

NüEsch, Ueber das lcuchtende Fleisch gestorbener T'hiere.

Cosmos les Mondes, Revuc hebdom. des sciences, 1878.

Tassar, Pflüger's Atrchiv, Bd. 21, 1880.

Ludwig, Micrococcus Pflüger・i. Hedwigia, 1884, Nr. 3.

- Uebcr die spectroscopische Untersuchung pathog. Pilze.

Zcitschr. f. Mikiosk., Bd. 1, 1884.

\section{SARCINA.}

Goonsir, Edinb. Med. and Surg. Journ., 1842.

Oerşted, Naturhist. Tidsskrift., Bd. III., 1840.

WELCKER, Ucber Sarcina. Henle's Zcitschr. f. ration. Med., 3 Ser., Bd. 5.

liserth, Virchow's Archir, 1858, Bd. 13.

Cous, Beitr. z. Biol. d. Pflanzen, Bd. 1, Heft 2.

ITzirsohs, Virchow's Archiv, Bd. 13.

C.ssrary, Schriften der physik. ökon. Ges. zu. Königsberg, Bd. 15, 1874.

Virchow U. Colinhera, Virchow's Aleh., Bd. 10 u. 33.

Sumpasr, Areli. Necrland, 1866.

-, Ueber den Zellenbau der Sareina. Bot. '/seit., 1866.

HĔLER, Heller's A.ch. f. Chemie, 1847 (Harnsarcine).

Whicker, Zeitschl. f. ration Med., 1859 (Idem).

Muxk, Virch. Arch., Bd. 22, 1861.-Med. Centralbl., 186t (Tdem).

Pasteuli, Ann. de chim. et de phys., T. 6 t, 1862.

Losnonirr, Merl. Jahıb, 1871, Heft 3. 
Fritederch, Beiträge zux Kenntuiss der Sputa، Virch. Areh., Bd. 30.

Heimer, Ueber Pneumonomycosis sareiniea. Deutsch Alel. f. klin. Med., 1877.

Fatikenhinim; Areh. f. exp. Patholog. u. Pliarmakol, Bd. 19.

\section{Other Saprophitus.}

Lüners, Ueber Abstammung n. Entwicklung des Bacterium termo. Bonn, 1867.

EWART, Proeeedings of the Roy. Soc. of London, 1874.

Daldinger, Journ. of the Roy. Mieroseop. Soe., London, 1878.

Daluivger and Driydale, The Monthly Mierosc. Journ., 1875.

Eidasr, Coln's Beitr. zur Biol. d. Pflanzen, Bd. 1, Heft 3.

VAN Treghem, Sur les prétendns eils des baetéries. Bull. de la

Soc. bot. de Franee, 1879.

EXGELANA, Baeterium photometrieum. Unters.aus d. phys. Laborat. zu Utreeht, 1882.-PAlüger's Areh. f. d. ges. Physiol., Bd. 30, S. $95,1882$.

Kurtu, Bacterinm Zopf. Ber. d. dentsch.. bot. Ges. Botanisehe: Zeitg., 1883.

Zopf, Baeterium merismopediö̈les. Sitz.-Ber. d. Botan. rer. d. Prov. Brandenb., Juni., 1882.

Breferd, Baeillus subtilis. Ges. nat. Freunde, Berlin, 1878, u. in Sehimmelpilze, Heft 4.

VAndevelde, Studien zur Chemie des Baeillus subtilis. Zeitschr. f. phys. Chemie, Bd. 8, 1884.

As to Leptothrix s.,pp. 24, 37, 53.

Gemdes and Ewart, On the Lifc-History of Spirillum. Proceed. of the Roy. Soe. of London, 1878.

MühlhäUser, Ueber Spirillen. Vireh. Arch., Bd. 97, 1884.

KÜ'TZING, Sphaerotilus natans. Linnaen 8, 1883.

Eidam, Schles. Ges. f. vaterl. Cultur., 1876.

Wersse, Monas Okenii. Bull. phys.-mathemat. de St. Pétersbourg, III., 1845 .

Conn, Ueber d. Bı'mmenfaden. Beitr. z. Biol. d.-Pflanzen, Bd. I., Heft 1 .

1/30rr, Ueber Crenothirix polyspora. Berlin, 1879.

LANkester, Quarterly Journal of Microseop. Sc., 1873 and 1876.

Ginger, Pilzvegetat. des weissen oder todten Grundes in der Kieler.

Jueht. Ber. d. Comm. zur Erforsehung deutseher Meere, 1881.

Bubif, Sur la formation des spores chez le Cladothrix dichotoma. Compt. rend., T. 100, p. 1251. 
Giard, Sur le Crenothrix-Kühniana. Compt, r’end., 1882. Zopf, Zur Morphologie der Spaltpflanzen. Leipzig, 1882. Coнn, Ueber zwei neue Beggiatoen. Hedwigia, 1865, p. 81-83. Cienkowski, Zur Morpliologie der Bakterien. St. Petersburg, 1876. RichteR, Ibid., 1884.

\section{'BIOLOGY OF THE BACTERIA.}

\section{Generat.}

Corv, Beitr. z. Biol. d. Pflanzen. Breslau, 1875, and following Jears. Nägeli, Die niederen Pilze. München, 1877.

—, Unters. über niedere Pilze. München, 1882.

Nencki, Beitr. z. Biologie d. Spaltpilze. Journ. f. prakt. Chemic., N. F., Bd. 19, 20, 23.

-, Virchow's Archiv, 1879.

Wiesner, Sitz.-Ber. d. Kaiserl. Akad. d. Wissensch. zu Wien. I. Abthlg., 1873, April.

Erdar, Cohn's Beitr. zur. Biol. d. Pflanzen, Bd. I., Heft 3.

\section{Analyses.}

Raulis, Compt. rend., T. 56.

Gayon, Bull. de la Soc. Chim., T. 35.

Sieber, Journ. f. prakt. Chemie. (2) 23, p. 412.

Nägetr, Sitz.-Ber. d. K. bayer. Akad. d. Wissensch., 1878, Mai.

Martin U. Löw, Journ. f. prakt. Chemie., Bd. 17.

Nencki, Beiträge zur Biol. der Spaltpilze. Leipzig, 1880.

- Ueber das Eiweiss der Milzbrandbacillen. Ber d. deutschen chem. Gescllsch., 1884, p. 2605.

\section{Nutrient Materiats.}

Raulin, Compt. rend., T. 56.

Buchelut, Arch. f. exp. Pathol., Bd. 7.

Mayer U. Knierim, Landwirthsch. Versuchsstat., Bd. 16.

Cонn, 1. с.

NäGELI, Untersuchnngen ïber niedcre Pilzc. München, 188?.

v. JАкsсн, Zcitsclı. f. physiol. Chemie., Bd. 5, 1881.

See under Fermentation, page 45; Pasteur, Duclaux, Schütrcuberger, Maycr, Nägeli.

(Nutrient Materials of Yeast.)

\section{InHUENCE OF OXYGEN.}

Pasteur, Compt. rend. 52, p. 340, 1260, T. 56.-T. 75.-T. 80.

Istebig, Annal. d. Clicm. и. Pharm., 1870, T. 153. 
Schüryesberger et Qunquaud, Compt. rend., T. 77.

A. MAYER, Landwirthsch. versuehsstat., 1873, Bd. 16.-Ibid., 1880, Bd. 25.

$\therefore$ - Poggendorf's Annalen., 1871.

-, Zeitschr. f. Biol., Bd. 5.

Müstr, Ann. de Chim. et de Phys., 1876, Bd. 8.

Breveld, Landwirthsch. Jahrber., 1874, Bd. 3.--1bid., 1876, Bd. 5.

-, Verhandl. d. Würzburger physik.-med. Gcs., 1873.

HüFNER, Journ. f. prakt. Chemie., 1876, Bd. 13.

Paschutin, Virehow's Arch., Bd. 59.

Grossmain u. Mayerhausen, Arehiv f. phys., 1877, Bd: 15.

Guxvisg, Chem. Centralbl., 1878, P. 799-_1880, P. 9.-Ibid., 20, P. 418.

Traube, Ber d. ehem. Ges. 1874, P. 875.

N fiscki, Beiträge z. Biologie d. Spaltpilzc., 1880.

-, Journ. f. prakt. Chemie., 19, P. 337.

_, Ueber die Zersetzung der Gelatine. Bern, 1876.

Lechartier et Beliayy, De la fermentation des fruits. Compt. rend., T. $69,75,79,81$.

Popoff, Pflïger's Arch. f. Physiol., 10, P. 135.

Juanneret, Journ. f. prakt. Chemic., N.F. 15, P. 353.

Hoppe-Seyter, Ueber d. Einfluss des Sanerstoffs auf Gärungen. Strassburg, 1881.

-; Dic Einwirkung von Sauerstoff auf die Lebensthätigkeitniedcrer Organismen. Zeitschr. f. phys. Chemie., Bd. 8, 1884.

('rossmann u. Mayerhausen, Das Leben der Baktericu in Gasen. Pflüger's Areh., Bd. 15.

Sirtumans, Verh. d. Milzbrandbacillen in Gascn. Zeitschr. f. physiol. Chemie., Bd. 4.

PAuris, Reeh. sur la respiration de la lecure. Ref. Fortschr. d. Med., Bd. 2, p. 53.

Ixpluence of Light, Electricity and. Atmospleric Pressure.

Exghimann, Botan. Zcitg., 1882.-Arch. f. d. ges. Physiologic, Bd. 26. JAmieson, Transact. of the Roy. Soc. of Vietoria, Vol. 20.

sirrasburger, Wirkung des Liehts und der Wärme auf. Schwärmsporen, 1878.

Downes and Buent, Tbid., Bd. 20.

Cons U. Mendeisonn, Ucber Jinwirkung des clektrischen Stromes auf die vermelırung d. Bakterien. Beitr. z. Biol. d. Pflanzen., Bd. III., Heft 1.

buccaux, Influence de la lumière du soleil sur la ritalité des germes de nicrobes. Compt. rend., $\mathrm{N}_{1}$. 2, 1885. 
Cortes, De l'action des hautes préssions sür les phénomènes de: la putréfraction, ete. Compt. rend., T. 99, p. 385.

Regrard, Rech. sur l'intluenec de très hantes pressions sur lex. org. vivants. Compt. rend., 'I. 98, p. 744.

\section{Isfluence of Mofehest.}

Horvate, Arch. f. d. ges. Physiol., Bd. 17.

ReIYke, Ibid., Bd. 23.

Tusas, St. Petersb. med. Wochenschr', 1881.

\section{FERMENTATION.}

\section{(For Yeast, see p. 8.)}

Fermentation is Gexelual and the Alcohoric Fermextatron.

Braconrot, Ann. de Chim. et Phys., T. 47, 59.

Schubert, Poggendorf's Annalen., Bd. 69 и. 77.

Berzelius, Lehrbueh der Chemie, Bd. 8, P. 84.

-, Jahresberichte, 1839, 1840.

Schönвeis, Journ. f. prakt. Chemie, Bd. 63, P. 323.-Bd. 89, P. 323.

—, Verhandl. d. Baseler naturf. Ges., Bd. 4, P. 797.-Bd. 5, P. $1-5$.

-, Zeitschr. f. Biol., Bd. 1, P. 273.-Bd. 3, P. 140.-Bd. 4, P. 367. Mitscherlich, Monatsber d. Berl. Akad. d. Wiss., Dee., 1841.

-, Poggendorf's Annalen., 1842, Bd. 55.-Ibid., 1843, Bd. 59.

Líbig, Verhandl. der Münchener. Akad. d. Wiss. 9 Mai, 1861 и.

5) Nov., 1869.

- Annalen der Pharmacie, Bd. 30, P. 250.

-, Die Chemie in ihrer Anwendung auf Agrieultur u. Physiologie. Braunsehweig, 1846, P. 371-584.

-, Ueber Gährung, Quelle der Muskelkraft und Einälirung. I

Pistelr, Etudes sur le vin., 1866.

-- Etudes sur la bière, 1876 .

-, Annal. de chim. et de phys., 1860, III. six., 'T'. je, Ibid., 'T'. (i), 1862.

-, Compt. rend., 1857, 'T. 45-Ibid., 1861, '. 52.-Ibid.. 1863, 'T.'56.-Ibid., 1864, Jan._Ibid., 1871, Dce.—rbicl., 187.), 'T'. $7.5 \mathrm{ff}$.

'T'lidube, Chem. Ber., 8, P. 776.

-, Poggendorf's Annalen., 1858, 13d. I03, P. :3:31.

-, 'Theorie der Fermentwirkungen. Berlin, 1858. 
Dunas; Compt. rend., 1872, T. 75, Nr. 6.

-, Ann. de ehim. et de phys., 1874.

Helmholtz, Müller's Arehiv, 1843, P. 4.3.

-, Journal f. prakt Chemie, Bd. 31, P. 429.

Turpin, Compt. rend., T. T, 1838.

- Annal. d. Chemie u. Pharmacic, 1839, T. 23, P. 100.

LüderrsdorfF, Poggendorf's Annalen, Bd. 67, P. 4.08.

C. Schnidt, Annal. d. Chemie und Pharm., T. 61, P. 168.

Blondeau, Journ. de Pharm., 1846, T. 12, Pp. 244 u. 336.

WaGner, Journ. f. prakt. Chemic, Bd. 45, P. 241.

Berthelot, Compt. rend., 1857, T. 44.

Hofmanx, Aerzt]. Verein. zu Wien., Mai, 1873.

-, Allgem. med. Centralbl., 1873,.P. 605.

Duclaux, Thèses prèsentées à la faculté de Paris, 1865.

Dubrunfaut, Compt. rend., 1871, T. 73.

l.Ex, Centralbl. f. d. med. Wiss., 1872, P. 291.

Panum, Nord. med. Ark., 10, P. 4.

Moster, Mykologische Studien am Hühnerei. Vireh. Arch., Bd. 29, P. 510.

HÜFNER, Journ. f. prakt Chemie, N. F. 10, P. 148.

CoLts, Annal. d. Chim. et Phys., 28, p. 128; 30, p. 42.

Hope-Seyter, Arch. f. Phys., 12.

-, Medic. ehem. Untersuchungen, 1871, H. 4.

-, Zeitschr. f. physiolog. Chemie, Bd. 2.

Baumain, Ibid., Bd. 5, P: 244.

Fueck, Ber. d. ehem. Contralst. Dresden, 1876.

Karstex, Chemismus der Pflanzenzelle. Wien, 1869.

HALLiter, Gährungserscheimnngen. Leipzig, 1867.

Schützenberger, Die Gährungserscheinungen, 1874.

A. Mayer, Lehrbuch der Gährungschemic, 2 Aufl., 1876.

HARz, Grundziige der alkoholischen Gährungslchre. Munehen, 1877.

NäGEL, Theorie der Gäln’ung. Münehen, 1879.

BREFELD, Landwirthsch. Jahresber, 1874, Bd. 3.-Ibid., 1875, Bd. 4.-Tbid., 1876, Bd่. 5.

Firz, Berichte d. chem. Ges., 1873, Bd. 6, P. 48.-1878, Bd. 10, P. $276 .-1879$, Bd. 11 , P. 4.2 u. 498 ; Bd. 12, P. 474.-1880, Bd. 13, P. 1309.-1882, Вd. 15, P. 857.-1883, Вd. 16, Р. 8441884, Bd. 17, P. 1188.

Prazmowski, Unter'suelungen über die Entwicklungsgeschichte und Fermentwirkung einiger Bakterien. Leipzig, 1880.

TrNDALL, lissays on the floating matter of the air in relation to putrefaction aud infection. London, 1881.

Eursson, Unters. aus d. botan. Institut in Tübingen, 1881, Heft 1. 
Poroff, Botan. Jahiesber, 1875.

Kö.xIG, Berichte d. deutsch. chem. Gescllsch., B. 14.

\section{Lactic. Acid Fermentation.}

Boutron ex Frémy, Ann. de chim. et de phys. (3), T. 2.

PasteUr, 1bid. (3), T. 52.

LeBolt, Journ. f. prakt. Chemie, Bd. 77.

Provst, Ann. de chim. et de phys. (2), T. 10.

LisTer, The cause of the putrefaction and lactic fermentation.

The Pharmac. Journ. and Transact., 1877.

Boutroux, Sur la fermentation lactique. Compt. rend., T. 86, 1878.

RicHét, Compt. rend., T. 88, 1879.

Huepre, Mitth. a. d. Ges. Ant., Bd. 2.-Deutsche med. Woch., 1884, Nr. 4.8.

\section{Butrric Fermentation, Fermentation of Cellolose.}

Pasteur, Compt. rend., T. 52, 1861.

T'récul, Bacillus Amylobacter. Compt. rend., 1865, T. 61.-1867. T. 65.

一, Ann. des sc., sér. 5, T. 7, 1867.

Van Tieghem, Développement du Spirillum amyliférum. Bull. de la Sos. bot. de France, 1879.

-, Sur la fermentation de la cellulose. Ibid., 1879, p. 25-30.

-, Compt. rend., T. 89, 1879.

-, Sur le Bacillus Amylobacter. Compt. rend., 1879, T. 88.

-, Identité du Bacillus Amylobacter et du Vibrion butyrique de Pasteur.-1bid., Compt. rend., 1879, T. 89.

-, Sur le ferment butyrique à l'époque de la houille. Ibid., 1880.

-, Développement de l'Amylobacter dans les plantes à l'état et vie normale. Compt. rend., 1884, No. 6.

'TAPpeiner, Ccllulosevcrdaung. Fortschr. d. Med., I., 151; II., $377,416$.

Prazmowski, Unters. üb. d. Entwicklungsgeschichtc und Fermentwirkung einiger Baktericn. Leipzig, 1880.

\section{Ammoniacal Fermentation.}

Van 'limglem, Compt. rend., T. 58, 1864, p. 210. Fri,iz et Ritrer, Journ. de l'Anat. et Phys., 1874. P'ASTEur, Compt. 1'end., T. 50, 1860. 
Pasteur, Ann. de chim. et de Phys., T. 64, 1862.

-, Bull. de l'Acad. de méd., 1876, No. 27.

T'ridald, Compt. rend., T. 58, 1864.

MülLER, Journ. f. prakt. Chemie, Bd. 81.

Cojls, Bull. de l' Acad. de méd., 1875.

Mesculus, Ber. d. chem. Ges., 1874, P. 124.

- Archiv. f. Phys. 12, P. 214.

Hilier, Centralbl. f. d. med. Wiss, 1874, P. 53.

Béchasip, Compt. rend., 60, p. 445.

Debelit, Arch. f. exp. Pathol. 5, P. 195.

Pasteur et Joubert, Compt. rend. de l'Acad. d. sc., T. 83, 1876.

-, Ber. d. chem. Ges. 9, P. 1130.

V. Jacksch, Studien über den Harnstoffpil\%. Zeitsehr. f. phssiol. Chemie, Bd. 5, 1881.

Gurard, Thèse de Paris, 1883.

Tufinin: et Roux, Compt. rend., T. 101, 1885.

tafibe, Ueber die ammoniakalische Harngähı'ung. Vireh. Arch., Bd. 100, P. 540.

fandiead, Sur le ferment ammoniacal. Compt. rend., T. 99, p. 877.

li1.LY, Sur le bacterium urea. 1b., T. 100 , p. 1252 .

Mannite leranestation.

PAstitir, Bull. de. la soc. chim., 1861.

Movorer, Thèse de Strassbur'g, 186.2.

Ве́снам., Compt. rend., T. 93.

\section{Dextran Fermestation.}

Van Tieghem, Leuconostoc mesenterioides. Amm. d. sc. nat., 6 sér., T. 7.

-, Sur la gomme de sucrerie. Ibid.

S'Cheniser, Ueber die Natur des Frosehlaich. \%eits. f. Rübenzuckerindustrie, 1874.

('inkkuwski, Die Gallertbildungen d. Zuekerrübensaftes. Charkow, 1778.

Putreactore Fenmentastos.

(See "Putrid Intoxication, Ptomaines," P. 16).

Hoppr-SkYter, Zeitschr. f. phy̌s. Chennie, 13d. ?.

-, Atch. f. d. ges. Physiol., 13d. 12.

BaUмn.N, Ibid., Bd. 5-7.

Nucki, Uber den ehenisehen Mechanismus der Fäulniss. Journ.

i. maktische Chemic, Bd. 17. 
Nixck, Ueber die Zersetzang der Gelatine und des Eiweisses bei der Fänlniss mit Pancreas. Bern., 1876.

Sıккоwsкк, Zur Kenntniss der Eiweissfäulniss. Ber. d. deutsch. ehem. Ges., XII., 107, 648; XIII., 189.

-, Zeitschr. f. physiol. Chemie, V., 424. ; TX., 8, 491.

Brieger (see p. 17).

Shlomoxser, Die Fäulniss des Blntes. Kopenhagen, 1877 (Danish), Just, Jahresbericht für 1877, P. 222.

K.ufmax, Zersetzung des Blutes durel Baeillus subtilis. Journ. f. prakt. Chemie, Bd., 17, 1878.

Rosenibach, Giebt. es verschiedene Arten von Fäulniss? Deutsch $\theta$ Zeitschrift für Chirurgie, XVI., P. 342, 1882.

W'Ard ét Olivier, De la reduction des sulfates par les être vivants. Compt. rend., 1882 , p. 846.

Brastock, Ueber die Bakterien der Freces. 7eitsehr. f. klin. Med., Bd. 8.

Hscherich, Die Darmbakterien des Neugeborenen und Säuglings.

Fortschritte der Med., Bd. 3, P.

Haser, Ueber Fäulnissbakterien. Leipzig, 1885.

Tappeider, Medie. Centralbl., 1884.

\section{Decomposition of Milk (See p. 47).}

HüPPF, Unters. üb. die Zersetzungen der Mileh dureh Mikroorganismen. Mitth. a. d. Ges. Amt., Bd. 2, 1884.

-, Deutśche med. Wochensehr., 1884, Nr. $48 \mathrm{ff}$.

DuCr,adx, Ann. de l'Institut agronomique, 1882.

Fuchs, Zur Kenutniss der gesunden und fehlerluften Mileh der Hansthiere. Gurlt's u. Hertwig's Mag. f. d. ges. Thierheilk., Bd. $7,2$.

Hermstäd, Ueber die blaue und rothe Mileh. Iseiprig, 1833.

S'rusmoff, Ueber das Blauwerden der Milch. Nene Ann. d. meklenb. landw. Ges., 1838.

CHabert et Fromage; D'une altération du lait de vaclee, désignée sous le nom du lait bleu. Paris, 1850.

Gielun, Mag. f. ges. d. Thierheilkunde, Bd. 18, 1852.

Mostwr, Ueber blaue Milel und dureh deren Gemuss herheigeführte Krankheiten. Virelıow's Archir, Bd. 43, 1868.

Newhas, Cohn's Beitr. z. Biologic d. Pflamen., Bd. III. Hoft 2.

Hugurs, I la lat blea. Jieho vétérinaise. liège, 1884.

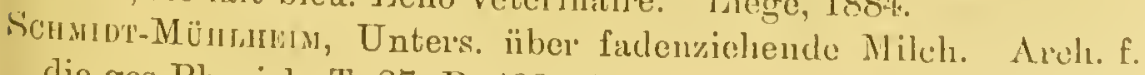
die ges Physiol., 'T. 27, P. 490-510.

Krrs, Ueber ein weues Milehferment aus dem Kaukasus. Bnll. (le. la Soe. Imp. des Natmralistes de Moskizu, 1.851, No. 3. 
Kern, Dispora caucasica, cinc neue Baktericnform. Biolog. Centralbl., Bd. 2, P. 137.

Mandowskr, Deutsche med. Woch., 1884.

Krannhals, Uebcr das kumysähnliche Getränk Kephir. Deutsches Arch. f. klin. Med., Bd. 35, 1884.

\section{Other Decompositions.}

GaYon, Sur les altérations des oeufs. Compt. rend., 1877, T. 85.

Béchamp et Eustache, Ibid., 1877, T. 85, p. 854-857; p. 1290 1292.

Marcano, Fermentation de la fécule. Présence d'un vibrion dans la graine de maïs qui germe et dans la tige de cette plante. Compt. rend., 1882, p. 345 .

Priblieux, Corrosion de grains de blé colorés en rose par des Bacteries. Bull. de la Soc. Bot. de France, 1879, p. 31. -, Ibid., p. 187-189.

JoLY, Etudes nouvelles tendant à établir la véritable nature de la glairine ou barćgine. Compt. rend., 1882, T. 95, No. 24.

\section{Unorganised Ferments.}

MAYER, Die Lehre von den chemischen Fermenten. Heidelberg, 1882.

Baranetzk, Die stärkeumbildenden Fermente, 1878.

KraUCH, Landwirthsch. Versuchsstation, 1879, Bd. 23.

Schü tzenberger, Die Gährungscrscheinungen, 1876.

MAYER, Landwirthsch. Versuchsstation, 1871, Bd. 14.

GaYon, Compt. rend., 1878, T. 86, p. 52.

一, Bull. soc. chim., 'T. 35.

Ducraux, Compt. rend., T. 91.

Donath, Ber. d. chem. Ges., 1875, p. 286.

BARTH, Ibid., 1878, p. 474.

NäGELI, Sitzber. d. Bayr. Akad. d. Wiss., 1878, H. 2, S. 177.

Berthelot, Compt. rend., 50, p. 890.

Hoppe-Seyler, Bei. d. chem. Ges., 4, p. 810.

-, Arch. f. Phys., Bd. 12.

v. Gorup-Besanez, Bcr. d. chem. Ges., 1874, Bd. 7.-1875, Bd. S.

A. Schmidr, Ueber Emulsic., \&c. J)iss. Tübingen, 1871.

v. D. Horst, Chem. Centralbl., 1878, P. 279.

KrUkinbrirg, Unter's. des physiologischen Instituts zu Heidelberg.

2, P. 273.

WurTz ET Bovciut, Compt. rend., 89, p. 42.5; 90, p. 1379.

Boucriut, Compt. rend., 91, p. 67. 
Ductacx, Compt. rend., T. 91, p. 731.

Küнуе, Unters. aus dem phys. Institut z. Heidelberg, Bd. 1.

-, Centralbl. f. d. med. Wiss., 1878, P. 357.

v. Nexcki, Ber. d. ehem. Ges., 9, P. 295.

Scrmaxski, Zur Kenntniss des Malzpeptons. Chem. Ber., Bd. 18.

Wortmann, Ueber das diastatisehe Ferment der Bakterien. Ztsehr.

f. physiol. Chemie, 1882, Bd. 6 .

-, Biol. Centralbl., Bd. 3.

\section{PRODUCTION OF DISEASE.}

Gexeral Literature.

NäGELI, Die niederen Pilze. Münehen, 1877.

Buchner, Die Nägeli'sehen Theorie der Infeetionskrankheiten. Leipzig, 1877.

KocH, Untersuchungen über Wundinfectionskrankheiten. Leipzig, 1878.

Biliroth, Coceobacteria septica. Berlin, 1874.

Kı,EBs, Beiträge zur Anatomic der Sehusswunden. Leipzig, 1872-73. - Areh. f. exp. Pathol. u. Pharm., Bd. 1-16.Artikle; "Ansteekende Krankheiten" in Eulenburg's "RealEneyclopädie.

Wersich, Die Entwieklung der organisirten Krankheitsgifte. Berlin, 1880.

Buchner, Bortinger, Soyka 11. A., Vorträge a. d. ärztl. Verein in München, 1881.

Virchoir, Krankheitswesen u. Krankheitsursachen. Virehow's Arehiv, Bd. 79.

Hudier, Berl. klin. Wohnsehr., 1877.

Frisch, Experimentelle Studien über Verbreitung der Fäulnissorganismen in den Geweben. Erlangen, 1874.

Bermetin, On the Relations of Miero-organisms to Disease. The Med. Ree., Vol. 23, 1883, No. 9-16.

RAs'm, On the Oecurrence of Bacteria in Living Plants. Transact. of Roy. Soe. of Victoria, T. 20, 1884.

'Traub: u. Gschrinu, Ueher Fäulniss a. den. Widerstand der lebenden Organismen gegen dieselbe. Sehles. Ges. f. vaterländisehe Cultur, 1874.

ReribrT, Dic Schicksale der Osteomyelitiskokken im Organismus. Deutschie med. Woch., I884, P. 682.

Cusix, Rech. expér. sur la conservation temporaire des virus dans lorganisme des animanx oil ils sont s.ms aetion. C'ompt. rend., T. 99, , . 759. 
v. Bergmann, Ueber eine Blutreränderung bci den aeuten Infectionskrankheiten. Verhandl. des Chirurgeneongresses, 1882. RossBacm, Mikrokokken nach Papayotin-Einspritzungen. Centralbl. f. die med. Wiss., 1882.

Salomonsen, Pseudoinfeetion bei Frösehen. Fortsehr.d. Med., II., 617. Schou, Untersuehungen über Vaguspneumonie. Fortschr. d. Med., III., Nr. 15, 1885.

Rosenberger, Centralbl. f. d. med. Wissenseh., 1882.

Mrtschnikorf, Ueber die Beziehung der Phagocyten zu den Milzbrandbaeillen. Virehow's Areh., Bd. 97, P. 502-526.Ibid., Bd. 96, P. 177.

Virchow, Der Kampf der Zellen und der Baktericn. Virch. Arch., Bd. 101, Heft 1.

RibBert, Ueber das Vorkommen von Spaltpilzen in der normalen Darmwand des Kaninchens. Deutsehe med. Wochensehr., 1885, $\mathrm{Nr} .13$.

-, Weitere Unter'suchungen über das Schicksal pathogener Pilze im Organismus. Deutsehe med. Woehensehr., 1885, Nr. 31. FAck, Verhalten vou Infectionsstoffen im Verdaungskanale. Areh. f. pathol. Anat. u. Phys, u. f. klin. Med., 93, 1883, Nr. 2.

Nipveu, Uebergang von Bakterien dureh die Darmwand bei Darmstrietur. Soc. de biol., 1883.

Fscherich, Bakteriolog. Unters. über Frauenmileh. Forts. d. Med.: III., 231, P. 93a.

\section{Transmission of Bacteria to the Fetes.}

Simrauss et Chamberraxd, Passage de la baetéridie charbonneuse de la mère au foetus. Compt. rend., 1882, T. 95, N1. 25.

Koubassofr, Compt. rend. de l'Acad.d. sc., 1855, Juli.

Koсk, Mitth. a. d. k. Ges.-Ant., Bd. II. Berl., 1884, P. 86.

Landouzy er Martin, Faits eliniques et expérimentaux pour servir à l'histoire de l'lérićdité de la tubereulose. Reruc de méd.. i883, Dee.

JoHse, Ein zweifelloser Fall ron congenitalcr Tuberkulose. Fortschr. d. Med., Bd. 3, P. 198.

Passage of Organishs into the Urive (Michoc. Urere, Sce p. 47). Grawit\%, Virchow's Arch., Bd. 70 (Schimmelpilzsporen).

KムNnimbra, Zeitsehr. f. klin. Mcd., Bd. 1, 1830.

Babis, Wicn. med. Woehensehr., 1884.

Pasieur, Compt. rend., Vol. 56, 1863.

Cazeneuve ét Livòn, Compt. rend., Vol. 85, 1877.

Meissner, Deutsche Zcitsehl. f. Chir., Bd. 13, P. 34.4.

Cinyer, Brit. Med. Jomrnal, 1883. 
Lister, Transactions of the Roy. Soc. of Edinb., 1875.

Nexcki u. Gracosa, Jonrn. f. pract. Chem., N. F., Bd. 20.

Leúbe, Zeitschr. f. klin. Med., Bd. 3, 1881.

Strauss et Chamberlaxp, quoted in Centralbl. f. Gynäkol, 1883

(Anthrax bacilli).

Duclatx, Bull. de l'Acad. de Méd., 1884, N12. 24, (Micrococci of clou de Biskra).

WatTER, Baycr. Intelligenzbl., 1884 (Cocci in Diphtheric).

BaLOGH, Wien. med Wochensehr., 1882 (Cocei in Scharlach).

Ekuuxd, Bayer. Intelligenzbl., 1884 (Cocei in Scharlach).

Marckwald, Inaug.-Diss. Königsberg, 1872 (Bacteria in Septicernia).

Sk_tetz, Petersb. med. Wochenselur., 1883 (The same).

Welcker, Zeitschr. f. ration. Med., 1859 (Sarcina).

Muxk, Virch. Arch., Bd. 22, 1861.-Med. Centralbl., 1864 (Sarcina).

Kuessner, Berl. klin. Wochenschr., 1876, P. 278 (Leptothrix).

Huber, Deutsch. Arch. f. klin. Med., 1879 (Leptothrix).

Wruson, Centralbl. f. klin. Med., 1885 (Bacilli in Chyluria).

BExdA, Deutsche med. Wochenschr., 1884, P. 154 (Tubercle bacilli in urine).

Dittel, Centralbl. f. Chir., 1883 (The same).

Damsch, Deutsch. Arch. f. klin. Med., 1882 (The same).

Badmgarten, Centralbl. f. d. med. Wissensch., 1883, P. 753 (The same).

Rosenstein, Ibid., P. 65 (The same).

Babis, Ibid., P. 9 (The same).

Phicipowicz, Ueber das Auftreten pathogener Mikroorganismen im Harn. Wien med. Bl., 1885, Nr. 22 u. 23.

Inaunity and Protective Iroculation.

Toussadxt, Bull. de l'Aead. de Méd., 18s0, Juli-Sept.

—, Gazettc Médicale de Paris, 1881, Nr. 32.

-, Compt. rend., 1880-81.

-, Pasteur, Schutzimpfung bei Hühnercholera, Bull. de l'Acad. de Méd., 1880.-Gaz. Méd. de Paris, 1850, N1. 18.

-, Sur la Vaccination charbouncusc. Compt. 1'end., 1883.

-, La Vaccination charbonncuse. Paris, 1883.

-, Réponsc au Doct. Koch. Revue Seientifique, 20 Jau., 188:3.

Ciauveau, De la prédisposition et de l'immunité patloologique. Compt. rend., 'T. 89, 1879.

-, Du rôlc de l'oxygène de l'air dans l'attenuation quasi instantanéc des cultures virulentes par l'action de la chalcur.

Ibid., 1883, T. 96, Nr. 11. 
Chauvgau, Ibid., 1883, T. 96, Nr. 10.

一, Ibid., 1883, T. 96, Nr. 9, p. 553-557.

-, De l'atteniation des cultures virulentes par l'oxigène comprimé. Gaz. hcbdom. de med. et de cliir., 1884, 22.

OLtive, Sur la résistance des moutons de la race berbcrine à l'inoculation du charbon. Compt. rend., 1879, T. 89.

Perroxcito, Sull'attenuazione del virus carbonchioso. Atti R. Acc. d. Lincei., Bd. 8, 1882-83.

Chamberland et Roux, Compt. rend., 1883, T. 96, Nr. IJ, p. $1088-1091$.

Chamberland, Le charbon ct la vaccination cliarbonncuse d'après les travaux récents de M. Pasteur. Paris, 1883.

Massé, Des inocnlations préventives dans les maladics virulentes. Paris, 1883.

Ommuer, Arch. f. Wissensch. u. pract. Thierheilk, 1876-1881.

Loefpler, Zur Immunitätsfrage. Mitth. a. d. Ges.-Amt., Bd. I.

Koch, Gaffix U. Loefruer, Exper. Studien über. d. künstl. Abschwächung der Milzbrandbacillen. Mittl. a. d. Ges.-Amt., Bd. II.

Косн, Ueber die Milzbrandimpfung. Cassel u. Berlin, 1882.

Roloff, Ueber die Milzbrandimpfung, \&c. Arch. f. wissensch. u. pract. Thierheilkunde, Bd. 9.

Eggeitita, Die Resultate der nach der Pasteur'schen Methode auf der Domäne Packisch angestellten Milzbrand-Impfrersuchc. Deutsche landwirthsch. Presse, Jahrg., 10.

Buazeikovic, Zur Präventiv-Inoculation Pasteur's. Oesterr. Monatschr. f. Thierheilk, 1884.

Rószahegri, Ueber die mit Pasteur'scher Schutrimpfung gegen Milzbrand in Ungarn ansgeführten Versuche. Pester. med., chir. Presse, 1882.

Frank, Jahresber. d. K. Thicrarzneischulc in München, 1882-83.

PÜr๘, Vorträgc f. Thierä1zte, Ser: 7, Heft. 1, 1884.

Hess, Vorl. Mitth. ï. die Schutrimpfung gegen Milzbrand im Kanton Bern nach der Methode Chauveau. Schweiz. Arch. f. Thicrheilk, Bd. 27.

Arrong, Cornevin el Thomas, Du charbon bactirien; Pathogínie ct inoculations prérentives. Paris, 1883.

Strezer, Znr Rauschbrandimpfung. Schweiz. Arch. f. Thicrheilk, $1885,1$.

Simmar, Virchow's Areh., Bd. S3.

Slimmed v. Krajkiwski, Centralbl. f. d. med. Wisscusch., 1880.

PASTrur, Vaccination des Schwcinerothlaufs. Bull. de l'Acad. de méd., 1883. 
Grawtez, Die Theorie der Schutzimpfung. Virchow's Areh., Bd. 84, 1881.

Buchner, Eine neue Theorie über Erzielung r. Immunität gegen Infeetionskrankheiten. Münehen, 1883.

Wolffberg, Unters. zur Theorie des Impfsehutzes, sowie über die Regeneration der Poekenanlage. Frgänz. Hefte z. Centralbl. f. allgem. Gesundheïtspflege I., Heft 4 ; lbid., I., Heft 1.

Feltz, De la durée de l'immunité vaceinale anticharbonneuse chez le lapin. Compt. rend., T. 99, p. 246, 1884.

Bovley, L'inoeulation préventive de la fièvre jaune. Compt. rend., T. 100 , p. 1276.

\section{DISTRIBUTION OF THE MICRO-ORGANISMS.}

V. Fodor, Hygienische Unters. über Luft, Boden, u. Wasser. Braunschweig, 1882.

Sirart, Germs, Dust, and Disease. Edinburgh, 1883.

Косн, Vortr. a. dem. 11 deutsehen Aerztetag, Juni, 1883.

NüGELI, Unter's. über niedere Pilze. München, 1882.

Buchner, Die Bedingungen des Uebergangs von Pilzen in die Luft. Zur Aetiologie der Infectionskrankheiten, Vorträge in ärztl. Verein zu Münehen, 1881.

Wernich, Cohn's Beiträge z. Biol. d. Pflanzen, Bd. 3, 1879, p. I05. SorkA, Sitz.-Ber. der K. bayr. Akad. d. Wiss. Math. Physik. Classe, 1881.

—, D. Vierteljsch f. öff. Ges., Bd. 14, 1882.

—, Vorträge im ärztl. Verein in Münehen. Müncheı, 1881.

Pasteur, Compt. rend. de l'Aead. d. sc., T. 50, 52, 56, 85.

-, Ann. de ehim. et de phys., 3 sér., T. 64.

Trivdal, Med. Tim. and Gaz., 1870.

-, Brit. Med. Journ., I877.

- Essays on the floating matter of the air. London, I881.

Poucher, Compt. rend., T. 47.

Lemaire, Ibid., T. 57.

Maddox, Monthly Mieroscop. Journ., Vol. 3.

Liecitenstein, Berl. klin. Woehensehr., Bd. 11.

Cunningham, Mieroscopical Lxamination of the air. Caleutta, 1874. Tissandere, Compt. rend., T. 78.

MifLET, Unter's. über die in der Luft suspendirten Baktericn. Cohn's Beitr. z. Biol. d. Pflanzen, Bd. III.

Eмmerich, Ueber die Bestimmung der entwicklungsfähigen Luftpilze. Arehiv f. Hygiene, Bd. 1, Heft 2.

Kinbs u. Tommast-Crudis, Unters. der Luft auf die Mikroorganismen der Malaria. Archiv f. exper. Path., Bd. 11, 1879. 
V. Sehlen, Fortsehr. d. Med., Bd. 2, P. 585.

Hesse, Ueber quantitative Best. der in der Luft enthaltenen Mikroorganismen. Mitth. a. d. Ges.-Amt., Bd. II.

-, Ueber Abscheidung d. Mikroorganismen aus d. Luft. Deutsche: med. Woehenschr., 1884, 2.

-, Weitere Mitth. über Luftfiltration. Dentsehemed. Wochenschr.. 1884, Nr. 51.

Miquis, Compt. rend., T. 86.

—, De la présence dans l'au du ferment de l'urée. Bull. de lit Soe. ehim., 1878.

-., Ann. d'hygiène, 1879.

-., Annuaire de l'Observat. de Montsouris, 1877-82.

-, Les organismes vivants de l'atmosphère. Paris, 1883.

Giacosa, Les corpusc. organ. de l'air des hautes montagnes. Arch. ital. de Biol., T. 3.

Miquel e'T Freudenreich, La semaine médieale, 1884.

Olivier, lies gel'mes de l'air. Thèse. Rev. scientif., 1883.

Moreau et Prantrmausion, La semaine Médieale, 1884.

Freddenreich, Les microbes de l'air des montagnes. Rer. scientif., II., p. 384.

Косн, Verhandl. der Choleraconferenz., 1884 u. 1885.

v. Pettenkofer, Verhandl. der Choleraconferenz., 1885.

Letzericin, Exp. Unters. üb. die Aetiologie des Typluus mit bes. Berücksichtigung der Trink- n. Gebrauchswässer, 1883.

Zander, Centralbl. f. allg. Ges., 1883, 2.

Angus Surth, On the examination of waters. Soc. Rep. to the Loeal Government Board. London, 1884.

-, Sanit. Record, 1883, Febr.

Gunning, Beitr. z. hygienisehen Unter'suehung des Wasser's. Areh. f. Hyg., 1883, 3.

Winnacker, Ucber die in Rinnsteinen beobaeht. nied. Organismen. Göttinger Inaug.-Diss. Frankfurt a. M., 1882.

Dre Wasserversorgung von Zürich, Zurieh, 1885. (Herein a repont by Cramer as to the presence of bacteria in various waters).

Becker, Reichsmedicinalkalender, 1885.

Fol at Dunant, Arel. des se. phys. et natur. Bibliothèque universelle de Genève, T. 13, 1885, Febr.

Chambertand, Sur un filtre domnant de l'eau pliysiologiquement. purc. Compt. rend., T. 99, 1. 247.

Hesse, Ueber Wasserfiltration. Deutsehe med. Woch., 1885, Nr. 5. Woldun, Ueber die Thätigkeit nioderer Organismen im Boden. Viert. f. öff. Ges., 1883, P. 705.

_, Deutsche landwirthschaftl. Presse, Bd. 9. 
Hoppe-Serler, Ucber d. chem. Vorgänge im Boden u. Grundwasser' n. ihre hygienisehe Bcdentung. 'Arch. f. öff. Gesdhtspfl. in Lothringen, 1883.

Soykd, Die Lebensthätigkeit niederer Organismen bei weehselnder Borlenfeuchtigkeit. Prager med. Woch., 1885, Nr. 4.

KocI, Milzbrandbacillen im Boden. Mitth a. d. Ges.-Amt., Bd. 1, P. $65 \mathrm{ff}$.

Schrakayp, Arehiv f. Hygiene, Bd. 2, 1884.

Cecr, Malariakeime im Boden. Arch. f. exp. Pathol., Bd. 15 u 16. Toreldi, La malaria in Italia. Roma, 1883.

Emserich, Die Verunreinigung der Zwischendecken mnsrer Wohnräume. Ztschr. f. Biol., Bd. 18.

-, Pneumoniekokken in der Zwisehendeckenfüllung. Arch. füı Hyg., Bd. 2, Heft 1.

Grassi, I malcfizi delle mosche (Distribution of bacteria by Flies). Gaz. degli Ospitali, 1883.

Marpman, Die Verbreitung von Spaltpilzen durch Fliegen. Areh. für Hygiene, Bd. 2, Heft 3.

Heller, Septisehe Infection durch Insekten. Inaug.-Diss. Tübingen, 1883.

Ducladx, Pasteur, Stoffwechsel bei Ausschluss von Mikroorganismen. Compt. rend., 1885, Nr. 1.

\section{Disinfection.}

\section{Gencral.}

Lex, Roth u. Lex, Militärgesundheitspflege. -, Vierteljahrschr. f. öffentl. Ges., Bd. 4.

Fischer, Article "Desinfection" in the Nenen Handworterbach der Chemie.

Wersich, Grundriss der Desinfeetionslehre. Wicn u. Leipzig, 183). Nä́gLi, Die niedcren Pilze. München, 1877.

Scrirörer, Cohn's Beitr. zur Biol. der Pflanzen, Bd. I., Heft 3. Kocr, Ibid., Bd. II., Heft 2.

-, Ueber desinfection. Mitth. a. d. Ges.-Amt., Bd. 1, P. 23 t.

Instructions for Distrfection, prepared for the National Board of Health, New York, 1879.

Plaut, Desinfection der Viehställe. Leipzig, 1884. Verl. v. H. Voigt.

S'Teinseyer, Ueber Desinfectionslehre. Braunschweig, 1884. W. Curysw, Antiseptic Surgery, its prineiples, practice, history,
and results. London, 1882 .

Forster, Wie soll der Arzt seine Häude reinigen? Centralbl. f. klin. Med., 1885, Nr. 18. 
Mitıkr, Die Anwendbarkeit einiger Antiseptica bei der Behandlung der Krankheiten der Mundhöhle u. d. Zälnnc. Deutsche med. Wochenschr., 1885, $\mathrm{N}_{1}$. 32.

Miquel, Antiseptiques et bactéries. Semaine médicale, 1883.

-, Annuaire de l'observatoire de Montsouris pro 1884.

Chauveau, Compt. rend., 1883, 1884.

Chamberland et Roux, Ibid., 1883.

Perroncito, Sur la tenacité de vie du virus charbonneux. Arch. ital. de biol., 1883.

VALLIN, 'Traité des désinfectants et de la désinfection. Paris, 188:3. Ratimoff, Revue Scientif. I., p. 797.

Buchol'z, Antiseptica u. Baktericn. Klebs' Arehiv f. exp. Path., Bd. 2 и. 4.

-, Ueber das Verhalten von Bakterien zu einigen Antisepticis. Dorpat, 1876.

-, Areh. f. exp. Pathol., Bd. 7, 1877.

Haberkors, Das Verhalten von Harnbakterien gegen einige Antiseptica. Dissert. Dorpat, 1879.

De la Crorx, Das Verhalten der Bakterien d. Fleischwassers gegen einige Antiseptica. Areh. f. exp. Pathol., Bd. 13, 1881.

Scnwartz, Sitzungsber. d. Dorpater Naturf.-Ges., 1879.

Weinicki, Diss. Dorpat, 1879.

MeYer, Ueb. d. Milchsäureferment u. sein Verhalten gegen Antiseptica. Dorpat, I880.

S̈'HotTe U. Gärtner, Vicrtelj. f. öff. Ges., 12, 337.

Salikowski, Viertelj. f. ger. Med., 23, 375.

Sorka, Ber. d. Bayr. Akad. d. Wissensch, 1879, Mai.

Toussaint, Bull. de l'Acad., 1880.

Scinlu v. Fischer, Ueber die Desinfection des Auswurfs der Phthisiker. Mitth a. d. Kaiscrl. Ges.-Amt., Bd. II.

Lebedeff, Desinfectionsversuche am malignen Ocdem. Arclı. de. physiol. norm. et pathol., 1882.

Coun, Desinf. versuche mit Blut v. Choléra des poules.-Thieren. Compt. rend., T. 99.

Cirarr, Action des agents climiques sur les bactéries du genre 'Tyrothrix., ib., p. 980.

\section{MODES OF DISINFECTION IN DETAIL. \\ HEAT aNd COLd.}

Frsen, Ueber den Ëinfluss nied. T'emp. auf. d. Lebensfähigkeit der. Bakterien. Sitzungsber. d. Wiencr. Akad., Bd. 75 1. 80.

Picter lat Youne, De l'action du froid sur les microbes. Compt. rend., T. 98,1884, p. 747. 
EIDAM, Einwirkung versch. Temperaturen a. d. Entwieklung ron

Bactcrium tërmo. Cohn's Beitr. zur Biol., Bd. 1, Heft 3.

LemederF, Arch. de phys. norm. et pathol., 1882, No. 6.

Herdenreich, Sur la stérilisation des Liquides au moyen de la marmite de papin. Compt. rend., 1884, 'T. 98.

Merke, Virchow's Archiv, 1880, Bd. 81.

—, Vicrtelj. f. ger. Med., Bd. 37.

Trndali, Philos. Transact. of the Roy. Soc., 1877.

Valdix, Ann. d'hyg., 1877.

IIornemanx, Hygiejnske Mededelser, Ny. Raekke., III., 1.

Mörscheru, Deutsche med. Wochenschr., 1880.

LASSAR, Ibicl.

Pasteur, Ann. d'hyg., 1880.

Arlong, Cornevin et Tromas, Lyon médical., 1883.

Kосн U. Wolffhüget, Unters. üb. die Desinfection mit heisser

Luft. Mitth. a. d. Kaiserl. Ges.-Amt., Bd. I., P. 301.

Hucppe, Ueber das Verhalten nngeformter Fermente gegen hole

Temperatur. Mitthcilg. a. d. Kaiserl. Ges.-Amt., Bd. I., P. 341

-, Ueber die Hitze als Desinfectionsmittel. Deutsche mili-

tärärztl. Zeitschr., 1882.

Koch, GAFFK, U. Tö̈FLER, Versuche über die Verwerthbarkeit heisser Wasserdämpfe zu Desinfectionszwecken. Mitth. a. d. Kaiserl. Ges.-Amt., Bd. I., P. 322.

VALLIN, Lues nouvelles étuves à desinfcetiou. Revuc d'hygiène, 1883.

-, Ann. d'hygiène, 1877, 1884.

Rochefort, Herscher, Revue d'lyygiène, 1884.

M. WolfF, Zur Desinfectionsfrage. Centralbl. f. d. med. Wissensch. 1885, Nr. 11.

\section{Sulphurous Acid.}

WoLffü̈Ger, Ueber den Werth der schwefligen Sïure als Desinfectionsmittel. Mittheilg a. d. Kais. Ges.-Amt., Bd. I., P. 188. LAildser, Du gaz acide sulfurenx. Ann. d'hygiène, 188:3.

Dumaruin-Beduntetz, Bull. de l'Acad. de méd. de Paris, 18st, September.

Leriothst, Ibid.

Marté-Davr, Revue d'liygiène, 1884.

\section{Cirtorine and Bromine.}

Fraxk, Bericht der 56 u. 57 Natuforscherversammlung.

- Ueber Desinfection von Abtrittsgruben. Berlin, 188, Verlag. der deutschen Medicinal-Zeitung.

Fiscrigr U. Proskaubr, Mitth. a. d. Kaiserl. Ges.-Amt., Bd. II. 
Wolfmïgit 0. Knorre, Zu der vcrschiedcnen Wirksamkeit rou

Carbolöl u. Carbolwasser. Mitth. a. d. Kaiserl. Ges.-Amt., Bd. I., P. 352.

WervicI, Die aromatischen Fäulnissproducte in ihrer Einwirkung auf Spalt. und Sprosspilze. Virchow's Archiv, Bd. 78, 1879.

Renaudot (Borphenyl acid), Rev. scient., II., p. 318.

Brexonn (Vapour of Turpentinc Oil), Amn. d. hygiènc, 1884, p. 344. Rossbach, Einfluss des innerl. Naphtalingebrauchs auf die Harnfäulniss. Bcrl. klin. Wochenschr., 1884.

-, Fortseher. d. Med. Beilage, 215.

Fiscuer, Unter's. üb. d. Wirkung des Naphtalins. Berl. klin. Wochenschr., 1883.

Repond (Salicylresorcinketon, \&c.), Corr. f. Schweizer Aerzte., $1883, \mathrm{Nr} .8$.

REnL, Zur Theoric der Heilwirkung des Franzensbader Moorcs. Prager med. Wochenschr., 1885, Nr. 10 u. 11.

Ronat (Sulphatc of Iron), Compt. rend., 1883.

Credé ( $2 \%$ Arg. nitr. against Blennorrhoea neonat.), Archlı. f. Gynäkol., Bd. 21.

Leivin, Die Bor'süure. Inaug. Diss., Bonn, 1883.

ScheDE, Die antiseptische Wundbehandlung mit Sublimat. Sammlung klin. Vortrügge, Nr. 251, 1885.

KöNı(i, Sublimatdämpfe. Chirurg. Centralbl., 1885.

Larrivé, L'ean oxygènée. Thèse de Paris, 1883, Jan.

Maty ฯ. EMch, Antisept. Wirkung der Gallensäuren. Sitzungsbcr.

d. kais. Akad. d. Wiss. zu Wien., 1883, Jan.

Schurtz, Die antiseptischcn Eigenschaften der Citronensäure.

Deutsche med. Wochenschr., 1883, Nr. 17.

Hoffuan, Experimentelle Untersuchungen über die Wirkung der Ameisensäure. Dissertat. Groifswald, 1884.

'Thol, Ueber d. Einfluss nicht aromat. organ. Säuren auf Fäulniss 11. Gährung. Disscrtat. Greifswald, 1885.

Scruviz, Die Amciscnsäure als Antisepticum. Dentsche med. Woch., 1885, N1. 24.

Schnerzler, Lies proprićtés antiseptiques de l'acide formique. Archiv de Génève, Jan., 1884.

\section{CONSTANCY AND VARIABILITY OF THE VARIOUS SPECIES OF BACTERIA.}

Bıllrotn, Unters. üb. d. Vegetationsformen der Cocobacteria scptica. Berlin, 1874. 
Kr, Es, Article "Ansteckende Krankheiten" in Eulenburg's ReatEncyclopädie, and numerous other articles in the Archiv f. exp. Pathol.

Nïgel, Die niederen Pilze, 1877.

—, Unters. über niedere Pilze. München, 1882.

Bucuser, Sitzungsber. d. Ges. f. Morphol, u. Physiol. zu München, 18.5., Heft I.

—, Virchow's Arch., Bd. 91.

-, Vorträge im ärztl. Verein. zu München, 1881.

-, Die Nägeli'sche Theorie der Infectionskrankheiten. Leipzig, 1877.

Grawtez, Virchow's Archiv, Bd. 81.

Zopf, Ueber den genetischen Zusammenhang von Spaltpilzformen.

Sitzungsber. d. Berl. Akad. d. Wissench., 1881.

-, Zur Morphologie der Spaltpflanzen. I Ieipzig, 1882.

-, Deutsche med. Wochenschr., 1885, Nr. 4.

Zopi U. Mrulur, Arch. f. exp. Pathol., 1882.

Miriter, Archiv f. exp. Pathol., Bd. 14.

-, Deutsche med. Wochenschr., 1884, Nr. 36.

Neecsen, Cohn's Bcitr. z. Biol. d. Pflanzen, Bd. 3.

-, Neuere Ansichten üb. d. Systematik d. Spaltpilzc. Biolog. Centralbl., III., Nr: 18.

VAXDEVelde, Zeitschr. f. physiol. Chemie, Bd. 8.

Roloff u. Archangelski, Centralbl. f. d. med. Wiss., 1882, 1883.

Fokker, Ibid., Bd. 18, 19.

V. JACksch, Zeitschr. f. phys. Chemie, Bd. 5.

Van Tieüed, Compt. rend., 1879.

Hauser, Ueber Fäulnissbakterien. Leipzig, 1881.

Koсн, Mitth. a. d. Kaiserl. Ges.-Amt., Bd. I., P. 49.

GaFfky, Ibid., Bd. I., P. 80.

FLüGGE, Deutsche med. Wochenschr., 1884, Nr. 46.

Hufppe, Fortschr. d. Med., 1883, Nr. 6.

Benfra, Virch. Arch., Bd, 100, P. 439.

\section{METHODS.}

(For further Literuture, see IIueppe's "Metholik:")

Microscopic Examination.

Kocir, Untersuchungen ïber Wnudinfectionskrankheiten. ' І ‘iprigr, 1878.

-, Verfahren zur Untersuchung, zum Conserviren und Photographiren der Bakterien. Cohn's Beitr. z. Biol. d. P'Aanz., B3. II., 3. Heft, 1877. 
Koch, Zur Untersuchung vorr path. Organismen. Mitth. a. d. K. Ges.-Amt., Bd. I., 1881.

Wergert, Schnittpräparatc. Virehow's Arch., Bd. 84, 1881.

--, Sitzung'sber. d. Schles. Ges. f. vaterl. Cultur., 10 Dec., 1875.

A въÉ, Ueber Stephenson's System der homogenen Immersion.

Sitzungsber. d. Jenaisehen Ges. f. Med. u. Naturw., 1879, 10 Jan.

Linzich, Zeitsehr. f. klin. Med., Bd. I., 1880, P. 553.-Bd. II., Heft 3.

—, Deutschc med. Woehensehr., 1882, Nr. 19.

Schwarze, Ueber eosinophile Zellen. Dissert., Berlin, 1880.

Westriat, Ueber Mastzellen. Dissert., Berlin, 1880.

Gram, Ueber die isolirte Färbung der Sehizomyceten. Forts. d.

Med., II., 1884, Nr. 6.

Fritediânder, Mikroskopisehe Teehnik, 2 Aufl., 1884.

Buchner, Ueber das Verhalten der Spaltpilzsporen zu den Aniliu-

farben. Aerztl. Intelligenzb]., 1884, N12.33.

Baumgarten, Beitr. zur Darstellungsmethode der Tuberkelbacillen.

Zeitsehr. f. wissenseh. Mikrosk., I., 18\$4, p. 51.

-, Ueber Untcrsuehungsmethoden zur Unterscheidung vour

Lepra und Tuberkelbaeillen. Zeitsehr. f. wissensch. Mikn'osk., Bd. I., Heft 3.

Fürterer, Ueber eine Modifieation der Ehrlich'schen Fürbemethode für. Tuberkelbacillen. Virch. Areh., Bd. 101, 1885.

PLAUT, Färbungsmethoden zum Nachweis der Mikroorganismen.

2 Aufl. Leiprig, 1884.

Bвнrexs, Hilfsbuch zur Ausführung mikroskopiseher Untersuchungen, 1883.

Hukppe, Die Methoden der Bakterienforschung. Wicsbaden, 1885. Brzzozero et Frrket, Manuel de Microscopie eliniquc. 2 éd., Paris"Br'uxelles, 188.5.

\section{Metiods of Cultivation.}

KI,EBS, Ueber fractionirte Cultur. Archiv f. exp. Pathol., Bd. T., 187:3.

Kocr, Zur Untersuchung von pathogenen Organismen. Mitth. a. d. Kaiserl., Ges.-Amt., Bd. I., 1881.

-, (Blood serum) Ber.l. klin. Wochenschr., 1882, Nr. 15.

-, Mitth. a. d. Kaiserl. Ges.-Amt, Bd. 2, 1884.

Briferid, Methoden \%. Unters. der Pilze. Verhandl. d. physik med. Ges. in Wür»bnrg. N. 1'., Bd. 8, 1874-75.

-, Kulturmethoden \%. Untersucliung der Pilze. Bot. Unters. ïbcr Schinmelpil\%e, Bd. IV., 1881. 
Brefeld, Die künstl. Kultur parasitischer Pilze. Bot. Unter's. über Hefepilze, Bd. 5, 1883.

Fehleisen, Ueber ncue Methoden der Untcrsuchung u. Cultur pathogener Bakterien. Physik. med. Ges. zu. Würzburg, 1882, p. $113-121$.

Pasteur, Etudes sur la bière, 1867.

Buchner, In Nägeli's Untersuchungen über niedere Pilze. München, 1882.

Salomonsen, Zur Isolation differenter Bakterien. Bot. Zcitg.. 1879, Nr. 39.

-, Eine einfache Methode z. Reincultur versch. Fäulnissbakterien. Ib., 1880, Nr. 28.

JoHNe, Ueber die Koch'schen Reinculturen und die Cholerabacillen. Leipzig, 1885.

As to Anäerobiosis see p. 4:3. For the investigation of air, water, and soil, see under "Distribution of the Micro-organisms," p. 55. 



\section{INTRODUCTION.}

Is the outer world with which mankind is in daily con- Significance tact, and which forms the subject of hygienic research, of microthe attentive observer finds micro-organisms widely distributed and only. just visible with the aid of the best optical means; these bodies, however, on account of their silent yet widespread and energetic activity, play an important part in the economy of nature and in the existence of mankind. They occasion the destruction of dead organic material, they cause the oxydation of substances otherwise very resistant, and constantly provide new nutriment for chlorophyllous plants; they set up the most varied fermentations, and are indispensable aids in the preparation of our ordinary nutritious and savoury food; on the other hand they attack our plants as parasites, bringing degeneration and death to their hosts; at times they cause the severest diseases in the lower and higher animals, and threaten even man with fatal epidemics. In no department of hygiene is their influence missed; in the air, in the water, in the soil, in our immediate surroundings, in our dwelling, and in our food, the same minute organisms are present as constant companions, and at times as dangerous foes.

The majority of these important yet minute bodies Synonym. are plants of the most clementary structure and with the most simple mode of propagation, but jet witl extraordinary powers of multiplication. They are grouped together under the headings "micro-orgnnisms" or "microbes"; at times they are designated 23 "lower fungi" or as "bacteria." Further, various terms are applied to particular groups of these organisms according to the particular mode of action to which attention is directed. Thus, from the plysio- 
logical chemical standpoint, they have been termed "organised ferments"; on the otler hand, from the special pathological point of riew, "parasitic plants" or " micro-parasites."

The object of the present work is to describe the form and vital characteristics of these micro-organisms in so fur as they have a direct or indirect interest from a hygienic point of viers.

The method of tescription.

The plan of this work embraces in the first place a short historical slietch of the development of our knowledge with regard to the ferments and parasites during the last few years. Then follows a description of the form and mode of development of those micro-organisms which are important from a hygienic standpoint, and also a short morphology and classification, a knowledge of which is indispensable for the comprehension and the further successful study of these bodies, so difficult to recognise and to distinguish one from the other. Nor is the biology of the micro-organisms less instructive; hence the third part deals with the general conditions of life of the lower fungi; in the fourth are described the results of their life, their tissue change, and energy, as well as their action as exciting agents of fermentation and of parasitic diseases; and the fifth chapter deals with the conditions of decay of the microorganisms and with the means which cause their cufecblement or reath.

In the sixth and seventh divisions the points which are of special interest in hygiene are referred to ; in the sixth the distribution of the varions micro-organisms in our surroundings, in air, soil, water, food, and dwelling; and in the seventh there is giren a digest of the conclusions to which we must come with regard to the etiology and proplyylaxis of the infectire diseases. The contents of this chapter include the discussion of the external sources of infection, of the local and sersonal predisposition to infective diseases, of the mode of entrance of the infectire agents into the organism and their fate in the body, of the means by which it is possible to obtain protection agninst the 
langer of infection and to orercome it, of immunity and protective inoculation, of the general prophylactic rules, and of the modes of disinfection suitable in practice.

Finally, in the last chapter there is added a sketch of those methods of investigation which are most useful in the study of this most difficult department of hygiene. 



\section{PART' I.}

THE PROGRESS OF KNOWLEDGE IVITH REGARD TO THE

FERMENTS AND MICRO-PARASITES DURING RECENT YEARS.

THE first undoubted observation as to the existence of The carlicst small microscopical living beings in our surrounding's was observationmade by Ehrenberg, who found numerous organisms to micro. in water and in clust, and designated them "Infusion animals (Infusionsthierchen, 1828)." Eight years later" the vegetable nature of yeast was discorcred by CaignardLatour and Schwann, although the cell form had becu seen much carlicr (first by Leenwonhock, 1680), and their organised and regetable character had been suspected by sereral investigators (Thénard, Persoon). Schwann also, in the year 1837, assorted as the result of experiments, that the atmospheric air was constantly laden with fermentative and putrefactive germs, and also that certain fermentative processes ricre dependent on the access of living organisms.

From that time dates the lasting and active interest in micro-organisms, and the development of the subject has chicfly taken two difierent directions: on the one liand, the problem inrestigated was the relation between the formentative germs and the processos of formentation and putrofaction; on the other liand, the attempt was made to demonstrate a carrsal connection between similar minute living bodies and infectire diseases in man and animals, a connection which various hypotheses and analogies rendered probable. It is only possible to follow the numerous controrersies with regard to the significance of the micro-organisms by tracing separutely the gradual development of knowledge, on the one hand witl regard to fermentation, and on the other witl regird to parasitic growth. 


\section{Micro-org.nishs as the Exciting Agents ol Ferientation axd Putrefaction.}

\section{Gradual Development of the Vitalistic or Germ Theory.}

Schwamn's discorery of the orgauic nature of yeast.
Beforc Schwann's discovery the essence of the formentative process-and especially of the alcoholic or vinous fermentation in which sugar is broken up into alcohol and carbonic acid-was by some not at all associated with the yeast, which was looked on as only an accidental accompaniment; by others the role of the yeast was regarded as an etiological one, but only in the sense that the mass of these cells acted as a porous body which easily condensed the oxygen, passed it over to the other substances, and thus occasioned the decomposition of the sugar (Bracomnot, 1831), or that the yeast possessed catalytic propertios, and thus had the power of splitting up the fermentescible substances in the same way as peroxide of hydrogen is decomposed by finely: divided platinum, \&c. (Berzelius, 1827). Up to this time no one had held the view that the process of fermentation was closely comnected with the living multiplying yeast cells, and was in fact the result of their life, and no one could hold such a view previously, because the organised nature of yeast was not yet known. Schwam was the founder of the vitalistic or germ theory. As the result of new experiments he asserted that the cause of the fermentation was the vegetation and multiplication of the living yeast in the fermentescible fluid, that the yeast cells took from it the materials necessary for their growth, and that the elements which were not taken up by the yeast becime grouped together principally in the form of alcoliol. Scliwnnn's experiments were repented sereral times in the course of the next few yenrs, and the results were confirmed and extended; among the more immediate advances it is only necessary to mention the proof furnished by Lüdersdorff that triturated ycast cclls are inoperative, and that only intact cells can produce fermentation, and also the obserration by Blondeau tlat 
different fermentations are causcd by different kinds of micro-organisms.

The strict proof that living yeast cells or minute Evidenee reoronisms cimiled to organisms similar to yeast are the only cause of every prove the defermentation, could however only be furnished by a pendenee of series of experimental investigations, which must have on living for their aim the following questions:yeast.

1. In the first place it was necessary to show that 1. Living eells germs are present in all fermenting and putrefying are present fluids. This was proved by all the investigators who ing fluids. busied themselves with the question of fermentation after Schwann, and in fact it was the constant presence of definite microscopical organisms which formed the starting point of the vitalistic theory. The fact itself was much less disputed by the adversaries of this theory, than its meaning. Not till later years were here and there observations published which asserted the existence of putrefying and fermenting media without microorganisms-observations which will be considered in detail later.

2. From the constant concurrence of putrefaction and 2. Fermenmicro-organisms the causal rôle of the latter did not teseible subof course directly follow; that must on the contrary ferment wher be proved by be proved by special experiments. The behaviour of of livingyest fermentescible substances without micro-oroanisms wo eclls is prethcrefore tested in the first instance; and for this purpose the attempt was made to kill any germs which might be present in the substances themselves, in the vessels, \&c., by a temperature of at least $100^{\circ} \mathrm{C}$., carc boing then taken to protect the materials against the entrance of fresh germs, either by suitable methods of closing the vessels, or by subjecting the cntering air to the action of means which could kill the germs.

These experiments also date back to an carly period. In $1836 \mathrm{~F}$. Schulze showed that no decomposition occurred in putrescible materials when ho boiled thern, thus killing any germs which might be present, and then prevented the access of air, as for example by interposing a layer of oil, or conducted the cntering air through sulphuric acid, which detained and destroyed 
the germs. Schwann also in 1837 made similar experiments; he freed the entering air from the organisms by heating it strongly. At a later period Schröder and von Dusch attempted to remove the putrefactive germs from the air by simple mechanical means, for example by filtering the air through cotton wool; this was completely successful, and no putrefaction occurred in vessels containing boiled putrescible materials and plugged with cotton wool. Hoffmann, and later Cherreuil, and in 1862 Pasteur obtained the same result by drawing out the neck of the flask used for the experiment, and bending it several times acutely.

The weight of all these experiments was much enhanced by the fact that control experiments were made in which the same fermentescible fluids were employed, and treated in the same way (by prolonged boiling, \&c.), only with this difference, that the air entered the vessels without being previously deprired of its germs by filtration or by destructive agents. In these control-experiments fermentation or putrefaction always occurred; and the same result was obtained if the pretective arrangements were subsequently remored from vessels which had been preserved free from germs for a long time, and the entrance of germ-laden air was permitted, or when germs were intentionally sorn from other putrefying fluids.

These experiments were repeated later on a gigantic scale in the preservation of articles of food; scarcely any biological experiment has been so extensively carried out, and has furnished such a uniform result. If fermentescible substances are treated by metlods which are able to destroy existing organised germs, and if the entering air, and everything that will eventually come in contact with these substances, is treated in such a way that no organised living germs can enter, neither fermentation nor putrefaction occurs; if any of these precautions are omitted, and the entrance of germs is allowed, then fermentation takes place. It is true, as may be remarked here in passing, that at a later period contradiction of these experiments and their results was not wanting. 
Some investigator's asserted that in spite of the most careful isolation of the fermentescible substances, and in spite of the most thorough destruction of existing germs, putrefaction and fermentation nevertheless occurred. These experiments will be discussed below, but I may here point out that a contradictory result must be obtained when even one of the many necessary precautions is omitted during the experiment, and that therefore a certain percentage of unsuccessful attempts at preservation is something quite intelligible.

The more experienced the experimenter, the more rarely do the experiments fail ; the more the methods of preserving food have been developed, so much the more successful are the results. The best experimenter must register a series of failures when he begins to busy himself with these questions, in which the sources of error are so numerous, and in which unusual precautions are required. But for this vcry reason a few of these contradictory experiments, in which putrefaction and fermentation occurred, in spite of the apparently complete exclusion of all germs, cannot be used as a proof against the vitalistic theory.

If we assume, for the present, that the result of the most numerous and carefully conducted of these experiments is that by the exclusion of organisms putrefaction and fermentation are prevented in fermentescible substances, there at once arises another old matter of dispute, namely, that with regard to abiogenesis (generatio cquivoca). Sceing that no development of organisms occurs in substances which under ordinary conditious offer a most admirable soil for their development, when the access of living organisms is rendered impossible, and seeing that the most active life at once appears as soon as eren the smallest number of living organisms cuters, the conclusion is justified that tho living cells cannot be formed from unorganised material, but that they always originate from another organised cell.

The experiments referred to admitted, however, of two valid objections, and hence they required to be further modificd if they were to prove absolutely the 
vitalistic theory of fermentation, or the improbability of abiogenesis. Thus a possible objection to some of the experiments was that the deficiency of oxygen in the boiled and hermetically sealed ressels hindered the development of organic life; but this objection was already met by the fact that the experiments with ail filtered through cotton wool permitted an undiminished supply of oxygen, and that nevertheless the development of organisms was prevented. It was much more difficult to answer the other objection; it was said that the heating of the fermentescible substances which were employed for the experiments altered them in such a way that so-called chemical ferments which were previously present, and were able to cause their decomposition without the intervention of organisms, were destroyed by the heat, and that it was for this reason that decomposition did not occur. Had the heating not taken place these substances would hare undergone fermentation under the influence of those ferments even without the entrance of organisms. The advocates of spontaneous generation also put formard a similar plea, assuming that as the result of the action of the heat an alteration of the material occurred, and that it thus became unsuitable for the generation of cells. These objections gave rise to a large number of new experiinents with unboiled and quite unaltered organic materials. Van der Broek, Pasteur, Rindfleisch, Lister, and many others, more recently Meissner, Leube, Hauser, Marchand, Cheyne, were able to preserre for year's a great variety of fermentescible substances without the occurrence of any fermentation or putrefaction if only they were not previously exposed to the danger of contamination by organisms, and were protected from the entrance of new germs and liept in absolutely pure vessels. In this way success was obtained with grape juice, yolk of egg, blood, milk, the most various animal organs, \&c. These experiments, which we must discuss more fully at a later period, and as compared with which a few experiments in which the attempt to preserve materials by the same method failed have of 
course no value, are of the greatest importance for the questions of abiogenosis, and of the rite of the organisms in fermentation and putrefaction. It was only as the result of these experiments that it could be absolutely maintained that spontaneous generation does not take place, and that fermentation and putrefaction do not occur without the aid of minute organisms.

3. If organisms are the constant cause of fermentation 3. Fermentaand putrefaction, one must, bearing in mind the fact occur cverythat decomposition of putrescible materials occurs at all where, and places and at all times (provided that no special means escible subare employed to prevent it), come to the conclusion that stances these lower putrefactive organisms are extremely widely undergo redistributed, and that thus there is always and every- provided that where opportunity for the infection of putrescible organisms are materials. The further efforts of the advocates of the not intentionritalistic theory were therefore directed to the demonstration of the presence of organised ferments in all our surroundings. Investigations which were begun by Ehrenberg, and then continued by Pouchet, Tyndall, Pasteur, Cohn, \&c., demonstrated with certainty that the air always contains the germs of fermentation and putrefaction, that dust consists in part of micro-organisms, and that water, soil, and in fact all our surroundings are always contaminated by these minute cells. In recent times the methods, more. especially of aëroscopy, have been perfected on the view that the air is the most frequent carrier of the germs, and is the medium which leads most frequently to the infection of fermentescible substances. Later investigations (Sanderson, Rindfleisch, Cohn, Hiller, Brefeld) have, however, shown that the air in most places contains relatively fow active germs, and that the activo agents of fermentation are conveyed by solid substances, water, \&c., which aro contaminated with germs, more frequently than through the medium of the air; but by this alteration in the views as to the part played by the different media in setting up fermentation there is no change in tho doctrine of Panspermism and of the universal distribution of germs in our surroundings. 
'The causal connection between micro-organisms and fermentation and putrefaction is definitely demonstrated by the investigations to which we have referred. It was found that organisms were present in all putrefying and fermenting substances; the same organisms were shown to be widely distributed in our surroundings; it was demonstrated that without these organisms no fermentation or putrefaction occurred even when the fermentescible substances were left otherwise unaltered, the entrance of the organisms being alone prevented, and that these changes only occurred when living germs had been introduced by contact with the impure surroundings.

Mode of action But there remained the further question, viz., in what of the ycast colls in the fermentative process. way the action of these organisms on the fermentescible substances was to be explained; and the further experiments and researches with reference to the etiology of the process of fermentation were made with the view of ascertaining whether fermentation and putrefaction were to be regarded as a vital process, as a manifestation of the life and activity of the causal organisms, and what were the intimate changes that took place.

Even shortly after Schwann's discorery definite riews were formed as to the mode of action of the organisms. Schwamn himself asserted that the fermentative process went on pari passu with the growth of the yeast, and that fermentation occurred by the jeast plant withdrawiug from the nutritive substratum ecrtain materials necessary for its growth, and at the same time inclucing the formation of alcohol from the elements which were of no use for nutrition. The contemporaries of Schwann expressed views which were similar but on the whole more speculative, and not sufficiently based on experiment. The vitalistic theory was in reality first elaborated by Pasteur. It is true that Pasteur did not succeed in finding at first a suitable cxplanation of the process of fermentation, or one which was permanently adopted; on the contrary, his teaching lias undergone most important modilieations in the conrse of time, and as the result of further experiments und better linow- 
ledge; but in such a complicated question, and one requiring the whole efforts of more than one investigator, a definite conclusion was not at first possible, and too rigid a deduction would only have impeded the development of knowledge.

In 1857 Pasteur demonstrated that fermentation was Pasteur's most intimately bound up with the life and the growth riews. of the yeast cells, and was thus a result of the action of these cells. The growth of the yeast takes place at the expense of the constituents of the fermentescible fluid, and therefore all the sugar cannot be broken up into alcohol and carbonic acid; on the contrary a portion (about 5 per cent.) is employed for building up the cell constituents and for the formation of bye-products. The fermentescible materials form the nutriment of the yeast, and these cells employ a portion for the formation of new cell substance, while the other and much larger portion is transformed in the yeast cell into alcoliol and carbonic acid. 'As the yeast cells consist also of nitrogenous material and mineral substances Pasteur assumed that traces of both these materials must be present in the fermentescible fluids if the yeast was to develop and break up the sugar. Pasteur found at a later period that yeast could develop in pure sugar solutions free from nitrogenous materials, and could there excite fermentation; but the further development in this case takes place at the expense of a reserve stock of nitrogenous material which fresh yeast cells usually contain. In like manner old dead yeast cells seem to be able to furnish new nutritive material for young cells; and under certain circumstances, namely, when yeast is mixed with fluid free from sugar, the non-nitrogenous substance (cellulose?) of the old yeast cells can talic the place of the sugar, produce alcohol and carbonic acid, and so give rise to a fermentation of the yeast itsclf.

In the year 1860 Pasteur showed that it was not essential that the nitrogenous nutriment of the yeast should consist of albuminous materials, but that salts of ammonia could take their place. Sucl salts along with mineral substruces (which are most easily added in 
the form of ashes of yeast) and sugar form the only necessary ingredients for a cultivating fluid for ycast, and in solutions of this simple composition fermentation goes on well. These experiments were completely confirmed by Cohn, Duclaux, \&c., and they render it quite impossible to ascribe to the albuminous materials in the fermenting fluids such an important roile in the fermentative process as Liebig, for example, has done. (See below.)

The following observations on its relation to oxygen were also very important for the lnnowledge of the tissue change of the yeast. Pasteur found that the fermentative organisms during their growth took up a large quantity of oxygen and gave off carbonic acid; this fact was confirmed by Schützenberger, who further ascertained that the more oxygen was used the more actire was the vegetation of the yeast cells. Several other investigations led to similar results (Traubc, Brefeld), and thereby the biological behaviour of the fermontative organisms seemed to have been made clearer and the direct dependence of fermentation on the nutritive processes of jeast rendered more certain.

But further investigations by Pasteur led to rery. different results. He found that if the access of air were hindered alcohol was formed in large amount, while if oxygen was admitted but little sugar was broken 11p. Pasteur made the same observation in the case of other fermentative processes, for example in butyric fcrmentation and in putrefaction: active fermentation only occurred where the amount of oxygen was deficicnt; the admission of oxygen. seemed in fact to be detrimental to the fermentative processes, although growith arid multiplication of the yeast cells could take place. Certain exciting agents of fermentation and putrefiction did not however seem to be able to cxist witlout free oxygen; Prsteur distinguished these organisms as aërobes from the anaërobes whicl are lilled by free oxygen, or at any rate are active only in the absence of oxygen.

Deficiency of axygen scemed to Pusteur to be the 
most necessary condition of fermentation; he loolicd on it as practically an indispensable condition for every fermentation, and formulated his views by saying that fermentation occurred as soon as any living cell was compelled to grow in the absence of oxygen, and that wherever fermentation was found there also the oxygen was deficient. More especially in the case of the alcoholic fermentation Pastcur assumed that the yeast cells, owing to the deficiency of oxygen, took it from the sugar molccule, and thus caused the latter to break up.

Numerous later investigations have shown that Pasteur's results arc only in part correct; the majority of fermentative organisms can, it is true, live and grow without free oxygen, and it is especially those organisms which can cxist without oxygen which possess the property of cxciting fermentation. But, and in this the morc recent vicws differ somewhat from Pastcur's, these organisms are as a rule also able to thrive when oxygen is admitted, destruction or hampering of their development by oxygen only rarely happens, and the regetative life and the fermentative action of the most typical fermentative organisms occurs most actirely in the presence of oxygen.

Pasteur's view as to the morc exact manner in which decomposition of the fermentescible materials by the micro-organisms takes place has not, thereforc, held its ground, and other investigators have only as yet becu able to suggest more or less probable hypotheses as to the nature of the physiological process of fermentation, and none of thesc views can be looked on as frec from oljection. (Compare the remarlis in the fourth part.) But the numerous experiments which have becn uudertaken as proof of the one or the other hypothesis have always shown that the most intimate relations exist between the living micro-organisms and the fermentations, and that fermentation must undoubtedly be looked on as a physiological act of the micro-organisms. In favour of this view we have, besides the numerous is a physioexperiments of Schwamn and lis followers, the fuct that iogical action the intensity of the fermentation runs parallel with the yeast cells. 
development of the micro-organisms in the fermenting mixture, that the fermentations go on best at that temperature which corresponds with the optimum of tcmperature for the growth and the other vital functions of the micro-organisms, and that the typical physiological poisons, such as chloroform, ether, and hydrocyanic acid, are able even in small doses to prevent the fermentation. It has also been demonstrated by accurate chemical analysis of the products of fermentation, that the breaking up of the fermenting material during fermentation implies such a profound transformation of the molecules, and such an intense displacement of the atoms, that an approximately similar alteration could only be obtained by our strongest chemical agents. And as such chemical means do not come into play, we arc thrown back on the physiological actions, the profound effects of which are everywhere evident.

Specific excit ing agents of fermentation.

Of greater importance for the further development of the vitalistic theory of fermentation was the demonstration of the fact that different sorts of micro-organisms gave rise to diverse and specific actions. At the time when the germ theory was founded, one only spolie of organised ferments in general. The course and the products of fermentation and putrefaction were studicd under varying conditions, without paying special attention to the species of fermentative agents present, and without ascertaining whether one definite species alone, or a mixture of different fungi, were concerned in the decomposition of the fermentescible materials. And yet rigid obserration of this kind was absolutely necessary in order to learn accurately the conditions of the life of the organisms, and the relation between their life and nutritive processes and the phenomena of fermentation. In this direction also Pasteur's researches formed the real foundation. He distinguished with striking perspicuity a definite form of micro-organism which set up lactic acid fermentation, another which furnished butrric acid, Sc., and he laid stress on the necessity for further differentiation. It was thus that the adrantages of 
experimenting with pure cultures of the fermentative organisms were understood, and by the help of the results so obtained a more accurate knowledge of the products of fermentation and of the equation according to which the material was broken up in the individual fermentations was gained. These questions even now form the subject of the most rctive discussion and work, and it seems as if, by the aid of the most recent and important improvements in the methods of pure cultivation of the micro-organisms, we may arrive at a precise linowledge of the different fermentative processes, such as Pasteur and numerous other supporters of the ger'm theory have striven for a long time to obtain.

\section{Objections to the Germ Theory.}

In what has gone before, the vitalistic theory has been represented $\Omega$ s a completed whole, of which the development seemed to be steady, and with scarcely a trace of fundamental objections and attacks. This, Objections to howerer, has by no means been the case; on the contrary, theory. from an early period adrersaries of the new teaching hare appeared, have laid"bare with much acuteness all its weak points, and have sought to upset the propositions of Pasteur and his followers by numerous experiments.

The following were the chief objections :-

1. Various observers found that fermentation and 1. Fermentaputrefaction occurred in numerous experiments, even tion in spite of when the entrance of micro-organisms was completely elnision of prevented. In the interior of dead bodies, in the contents orgmisms, of hatched but uninjured hens' eggs, in dead cmbryos of man and animals, intense putrefaction was often present. Under similar conditions lactic, acetic, and butyric fermentations were also repeatedly observed (Colin, Billroth, Hiller, Schröder, Hoppe-Seylcr, Kühne). Numerous experiments were also made by Hoppe-Seyler, Billroth, Tiegel, Servel, Paschutin, Sanderson, Nencki, and others, in which putrescible materials were kept for $\Omega$ long time with sucl precautions that entrance of orgnnisms apparently could not occur; neverthcless, in many cases, 
putrefaction was observed. In the same way in urine, kept with certrin precautions, an alkaline reaction and commencing putrefaction were observed after some time (Colin, Billroth, Hiller, \&c.). Attempts were also made to kill the organisms by the action of heat (Bastian, Huizinga, \&c.), or by the addition of a moderate amount of carbolic acid (e.g., urine 0.5 per cent.-Hoppe-Seyler). Nevertheless putrefaction sometimes occurred. Finally, attempts were made to remove the organisms from putrefying or fermenting fluids by filtration; but here, also, putrefaction or fermentation of the fluid thus filtered, and free from organisms, occurred in sereral cases (Helmholtz 1843, Fleck, and others).

In all these cases when the putrid fluids were ultimately examined the observers found either no trace of organisms, in which case the fermentation could only have occurred under the influence of chemical ferments, the existence and activity of which would lower the rote of the micro-organisms to a subordinate position; or in spite of all the precautions against the entrance of organisms, they were found in the putrid substrata, and then the supporters of abiogenesis saw therein a new proof of the accuracy of their views. Eren in quite recent times Béchamp and Wigand hare supported with the greatest energy, and after many experiments, the theory of the spontaneous generation of minute organisms from the dying cell-protoplasm of higher organic beings. They observed the origin of moring and multiplying micro-organisms from the minutest constituents of clead animal and regetable cells, and when all cxternal germs had apparently been completely excluded, putrefaction and fermentation occurred under the influence of these organisms.

Sources of error in theso experiment..

In spite of the large number of observers and experiments, the germ theory is however not in any way upset by these contradictory results. Suflicient weight cannot be laid on the fact stated abore, that in these observations and cxperiments the results which are unfavourable to the vitalistic theory always coincide with possible errors of experimentation, or witl want of 
accuracy in the observations. In view of the very wide distribution of the micro-organisms, and of their relatively great resisting power to noxious agents, it is not easy to devise faultless experiments in which the entrance of organisms into the fermentescible substances will be prevented with certainty. It is only recently that the degree of heat which will kill micro-organisms in all cases has been accurately determined; and we can now assert definitely that the earlier observer's admitted sources of error in that the ressels and utensils employed were not freed from germs adhering to them by exposure to a sufficiently high temperature. Those experiments are of course especially difficult in which exposure to high temperatures, and in fact any alteration of the fermentescible material, must be aroided, in order not to interfere with any possible aliogenesis, or with the power of the chemical ferments. It is only after great practice and many failures that one is able to carry out such a series of experiments with uniform results. If one is contented with a small number of experiments, and is not completely master of the methods, all or the majority of his preparations will without doubt contain organisms, and show putrefaction or fermentation; and if the sources of error are overlooked, and if it is believed that in every case the precautions were sufficient to exclude micro-organisms, every erroneous experiment will furnish proof of abiogenesis, or of the occurrence of putrefaction without organisms. It is clear that it is only possible to attach weight to such results when they are uniform in all cases and when we are justified in assuming that the experimenter possesses the necessary skill in mycological work. On the contrary, it is known that several investigators-for example, Marchand, Meissner, aud othershave obtained a large number of results which support the germ theory; substances of a putrescible nature have been preserved without alteration for year's, simply by absolute exclusion of organisms, and indeed an increase in the percentage of successes is distinctly evident in these experiments in proportion to the increasing skill of the experimenter. 
As the result of more accurate lnowledge of the conditions of the life and death of the lower fungi, it is at the prescnt time easy to repeat at will the same experiments with similar results, and only he who continues to hold completely false idcas as to the biological peculiarities of the micro-organisms, and who is not intimatcly acquainted with the more recent experimental methods, can at the present day obtain results which may be used in proof of the doctrine of abiogenesis. The experiments recently published by Wigand hare been made with complete disregard of our present knowledge. Wigand starts with the view that the distribution of the micro-organisms, and the danger of their entrance from without, is not particularly great, and he does not consider it necessary to test this assumption in the same precise manner as others hare done.

The striking result also at which many of the aborementioned observers arrived as the result of their fermentation experiments, viz., that in spite of the existence of putrefaction or fermentation no organisms could be found in the fluids in question, rests, as we can now assert with certainty, on an error. Under certain circumstances it is a difficult task to recognise micro-organisms-perhaps degcnerated and altered-in an albuminous fluid which has putrefied for a long time, and at all events it seems essential to employ in all cases the special methods which have been recently devised, such as drying, staining, \&c.; in former times these methods were unknown, and as a matter of fact micro-organisms were not found. But that by no means justifies us in saying that in reality no organisms were present at any poriod of the experiment; for in more recent experiments on this point they have nerer been missed, if care was taken to examine the fluid at a sufficiently carly stage of putrefaction.

2. Presenee of mieroorganisms in fermenteseible fluids without fermentation.

2. In contrast to the experiments in which putrefaction was found without micro-orgnuisms, it was observed on the other liand that numerous micro-orgnnisms could take up their abode in fermentescible substratn, without any resulting decomposition, fermentation, or putrefac- 
tion. Results of this lind were obtained by Hiller, for example, in his experiments with urine. Further, living micro-organisms were found by several observers in organs which had been taken from the freshly killed animal body, and their presence was therefore presumably unaccompanied by any alterative action.

These objections and experiments are, however, now only of historical interest. They date from a period at which little or nothing was known of the various species of micro-organisms, and of their very different conditions of life and mode of action. It is now self-evident that it is not every organism which is able to grow actively in every nutritive substratum, and further that the development of certain organisms is not necessarily accompanied by the formation of stinking gases, in short, by the ordinary symptoms of putrefaction. To find organisms without accompanying putrefaction or fermentation is therefore not surprising, and proves nothing against the vitalistic theory.

3. In several series of experiments it was observed 3. Difficulty in that albuminous solutions were only slowly or not at all the assimila. hyt allion of broken up by the micro-organisms sown in them, that the albuminous latter, in fact, like the higher plants, build up their mierials by protoplasm from the simplest organic compounds, and hence only grow and multiply with difficulty in the living animal tissue, and in cultivation experiments in eggs, for example. It was therefore concluded that it was impossible that they could take any important part in such intense decomposition of albuminous materials as is the characteristic of the putrefactive process. (Billroth, Hiller, Hoppe-Seyler, Paschutin, and others.)

These observations could only be puzzling at a time when the marked biological differences between the different species of fungi were as yet unknown or disregarded. Now we know with the most complete certainty that some micro-organisms occasion a profound decomposition of the albuminous molecules, and thus set up the putrefactive process, while on the other hand a large number of the lower fungi do not possess any such power, and therefore we cannot deduco from experi- 
4. Fermentution causcrl by so-called chemical ferments. ments with any unknown kind of miero-organism that no speeies is able to cause the putrefaetive deeomposition of albumen.

4. More weighty objections, whieh have held their ground up to the most recent times, were brought forward by those investigators who sought a more direetly ehemical explanation of the proecsses of fermentation, and did not regard the vitalistie theory as elearing up, but on the contrary as obseuring what it was desired to unravel. Liebig, more especially, and at a later date Hoppe-Seyler took part in this opposition; Colin, Billroth, Hiller, Fleek, and other's joined them.

Licbig's vicws. As early as the year 1839 Liebig had endeavoured to cxplain the phenomena of fermentation and putrefaction by assuming the existence in yeast of a soluble protëid substanee, which in breaking up exeited the decomposition of the sugar exaetly in the same way as numerous well-known ehemieal bodies when uniting or breaking up are able to excite a similar movement of the atoms in other bodies. This breaking up of the soluble protëid substanees is not an aet of the living yeast eells, but on the eontrary is a eorrelative phenomenon of their death. It is a peeuliarity whieh may be notieed in many ehemieal actions, that relatively small quantities of the body whieh is breaking up are able to set up the deeomposition of large quantities of the other body; thus Liebig instrneed the deeomposition of oxalie aeid, oxamid, and water in whieh a small quantity of oxalie aeid is suffieient for a large amount of oxamid; he also pointed ont the similar fact in the deeomposition of eyanogen by aldchydc in the presenee of watcr. The differenee between the aleoholie fermentation and the putrefnetive process ean be easily explained on Liebig's vicw. In putrefaetion the decomposition is transmitted by the deeomposing albuminous material itself, so tliat the proeess once begun eontinues by its own morement cven after the original enuse which set it going has beeome inactive; in fermentation, on the other hand, the sugar (the substance here undergoing decomposition) is unable to transmit its own movement, and henee a 
foreign cause, a ferment, is necessary, not only for thc commencement, but also for the continuance of the morement.

Liebig's view was, however, evidently a purely hypothetical one; the decomposing protëid substance which was supposed to be the cause of the fermentation was by no means demonstrated to be really present; the only experimental support of this supposition was the fact that in the so-called self-fermentation of yeast which takes place without the addition of sugar, and entirely at the cost of the yeast substance, much more alcohol is formed than could be derived from tho amount of cellulose in the yeast cells, and that thus some other complex substance contained in the cells must furnish the materials for the formation of the alcohol. This analytical proof was, however, shown to be erroneous by Nägeli (Theorie der Gährung, p. 3), but at a much earlier period Liebig had becn compelled to modify his theory considerably by the numerous experiments which absolutely proved the direct dependence of the fermentative process on the life of the ycast cells.

In 1870 he declared that the living yeast cells con- Later tained and produced the supposed ferment-like substance, modification and that therefore the formation of the fcrment depends view. on the life of the cell; the fermentative act, however, depends on an unorganised ferment, and the yeast cells in producing the ferment do nothing more than numerous other cells do. Just as man produces diastatic ferment, pepsin and trypsin, so all other animals and plants have their ferments; but the organisms are not identical with these ferments, and the fermentative action cannot bc looked on as the direct work of the cells. If it were possible to separate the ferments from the cells the latter would then be no longer necessary for the commencement and continuance of the fcrmentative process. Similar vicws were taught by Traube in 1858; and in 1876 they were defended by Hoppe-Seyler. Thoy rested in part on the analogy betwcen the fermentative and putrefactive process, and the splitting up and decomposition caused by unorganised ferments. 'The micro-organisms 
according to this view are not the primary and immediate cause of the decompositions of organic substances occurring in fermentation and putrefaction; on the contrary, it was assumed that a transformation of the fermentescible materials usually occurs at first from causes present in the substances themselves-by soluble chemical ferments, and that it is only when the material has undergone a certain amount of alteration that multiplication of those organisms occur's, which on account of the wide distribution of their germs always of course gain access to these substances; the nature and constitution of the fermentescible substrata, and especially the first changes that occur in it, determine what particular species of organism chiefly develop and flourish. From that point these organisms aid as a rule in the decomposition of the substance; but they are not absolutely necessary even for its further splitting up, and the decomposition does not go on by any means parallel with their development.

On this view accordingly by far the most important rôle is ascribed to the unorganised soluble ferments. Lately we have become acquainted with a large number of such ferments, and in accordance with this knowledge the probability of their great activity in the ordinary processes of fermentation and putrefaction seems to increase. The action of diastase, of emulsine, of myrosine, of the inverting ferment of yeast, of ptyalin and pepsin, the energetic action of the pancreas, and of the trypsin isolated from it, offered the most important analogies, and the support of the "chemical" theory of

Diffierences between the action of chemieal ferments and of the olganised exciting igents of fermentation fermentation. As a matter of fact the supporters of the germ theory have never disputed the influence and the action of chemical ferments, but an exact analysis of the decomposition caused by chemical ferments on the one hand, and of the marked alterations in fermentation and putrefaction on the other, lend us of necessity to the conviction that it is quite inadmissible to designate these tro processes as sufficiently analogous and similar to warrant the inference tlint both are due to a similar cause. The chemical ferments only set up bydrolytic decompositions; their place can be taken by so-called 
contact-substances, and also by dilute sulphuric acid and various other agents; the amount of the chemical ferments remains the same or becomes diminished during the process; the best temperature for their action is about $60^{\circ} \mathrm{C}$., and they are not affected by powerful physiological poisons. In fermentation and putrefaction, on the other hand, there is always a complex alteration in the grouping of the atoms, a separation of carbonic acid, and often of other atomic groups; the number of the causal organisms increases in proportion to the intensity of the fermentation; they are most active at a temperature between $25^{\circ}$ and $40^{\circ} \mathrm{C}$., and their action ccases under the influence of physiological poisons. 'I'hus the nature and action of the chemical ferments, and of the fermentative organisms, are sharply separated from one another, and a relation between them only cxists in so far as in the more complex fermentative processes, and especially in putrefaction, both agents are often at work in such a manner that chemical fcrments which are in part produced by the micro-organisms lcad to the solution of the fermentescible substance, and so prepare the soil for its subseguent profound alteration under the influence of the specific organised ferments.

If, however, we assume with Liebig that in the lattcr instance the transposition of the atoms in fermentation and putrefaction occurs as the result of the action of a ferment-like group of atoms which can only be produced by living micro-organisms, and are practically bound up with the life of the cells, we cannot regard this view as an essential objection to the vitalistic theory; it is, on the contrary, a recognition of it. This view corresponds entirely with the vitalistic theory in the immediate do- the vitalistic pendence of the fermontative process on the life of the jeast cells; it only seeks to dofino morc precisely the mode in which the living cells occusion the decomposition of the fermenting or putrefying substance. But the existence of such a ferment is a pure hypothesis, as is evidont from the fact that it has as yet been found impossible to isolate the supposed ferment from the yeast cells; this failure being excused on the idea that tho forment is at 
once destroyed when the yeast cells die, or even when their life is interfered witl.

As the result of the preceding historical sketch of the development of the views on fermentation and putrefaction, we may take it as absolutely certain that minute living organisms are the direct cause of the processes commonly grouped together under these terms, and that these processes are intimately dependent on the life of the organisms.

\section{Micro-organisuis as Parasitic Excitixg Agexts of Disease.}

Even at an early period of scientific obserration and research on the subject of the infective diseases, we meet with the belief that the immediate cause of these devastating affections is an entity endowed with vital

Earlier hypotheses as to the organised nature of contagia. properties, a contagium animatum. This view was clearly expressed by Hufeland; but at first all sorts of fantastic notions as to the more intimate nature and mode of action of this supposed entity, endowed with vital properties, were added to these leading ideas. Soon, however, there was evolved from this cloud of phantasies the definite view that the transmission of the infectire diserses depended on the growth of independent minute organisms (Kircher, Linné, Wichmamn, and others). In fact it was extremely tempting to refer the characteristic phenomena in the occurrence of the infective diseases to such organisms, and to draw a certain parallel between these diseases and the processes of fermentation and putrefaction, which are likewise caused by similar fungi. The sudden appearance of epidemics in various isolated places, their relatively slow spread, and the fact that they often remain localised to a particular locality, must exclude the idea of an evanescent, gaseous agent. The mode of their spread, the unlimited development of the infective material through a large series of individuals, the transport of the infective material over considerable distances, its adherence to the most heterogeneous objects, the stage of incubation, the typical cyclical conrse 
of the disease, and the subsequent immunity, pointed more or less distinctly to the organised nature of the causal agents, and could be explained by the mode of development of these supposititious beings. The anxiety to find a relation between the phenomena of infective diseases and those of fermentation and putrefaction, is shown by the fact that by some pathologists the whole group of infective diseases was designated by the term "Zymotic diseases."

These views, which have continuously gained ground during the last forty years, did not, it is true, at first rest on clear knowledge, and were wanting in an experimental basis. They were only based on speculations; but these speculations were made with such acuteness, and with such logic, that they led to almost the same results as were arrived at forty year's later by elaborate experimental investigations. It was more especially Henle's Henle who, in the year 1840, in his Pathologischen dednctions. Untersuchungen, and later, in 1853, in his Handbucl, der rationellen Pathologic, sketched with wonderful precision the relation of micro-organisms to the infective diseases, and defined the intimate nature, the vital properties, and the mode of action of the micro-organisms, as well as the dependence of the individual phases and symptoms of the diseases in question on the behaviour of the parasites, almost as accurately as has subsequently been done as the result of direct observations with optical aids, at that time unknown, and of numerous experiments. The great influence which Henle's views have exercised on the further development of knowledge on the subject of the parasitic exciting agents of disease renders it necessary for us to reproduce at this place some of the most important of these views in his own words:-

"If we trace the miasmatic contagia in their action on the animal organism, we find at once, although with many inrividual differenees, a gencral and eluracteristic property which can only be ascribed to living matter, uamely, that of inultiplying at the cost and by the assimilation of foreign organie material. 'Ihis conclusion is supported by the course of the great majority of miasmatic contagious diseases. 'They 
belong to the group of diseases which I have termed typicial, whose sharply defined stages indicate a development of the cause in accordance with definite laws, such as we only find imong living beings.

"That was stated above with regard to the propertics of the cause of miasmatic diseases in gencral holds good as regards the multiplication of contagia by assimilation. It can, however, only be absolutely proved in the casc of the inoculable diseases where we are able to define aceurately both the point of entrance and the quantity of material taken up, and the proof becomes the more insufficient the more in any given epidemic the number of the cases prodneed by miasma exceeds those arising by contagion. That the cause of the disease has multiplied in the region affected by the epidemic is probable whenevcr the latter spreads gradually from small begimmings and attains large dimensions.

"It is only when its development and reprodnction in the diseased body is demonstrated that we are justified in designating the material which occasions epidemic diseases as a contagium, and the analogy of these contagia with parasites: the analogy of the miasmatic contagions diseases with the results of the deposit of parasitic organisms in living bodies: previously referred to becomes at once crident. This analogy. as I have indicated above, has led to the discovery of parasites as the cause of many affections formerly termed contagious discrses. There are, howerer, a number of diseases in the eontagium of which nothing has been found which recalls the forms of known speeies of animals and plants. Nevertheless: this negative result is not so ccrtain that we can, therefore. absolutely refuse to reckon the contagia anong these microscopic parasites. It is not necessary to assume that the organisms which act as contagia are too small for onr optical means. Bnt the smallest animals can only be distinguisher from the cells, nuclei, and grammles which occur in so many tissues and excreta, especially in pus, by their movements, and the smallest plants only in certain stages of their derelopment by the arrangement of their elementary constituents. The granules of which the Botrytis bassiana consists behare exactly like pigment graules or the molccnles of pus. It is possible, therefore, that bodies of very various and of grent significance may be concealed among the molecules which occur in every microseopical oljject. It is senrcely necessary to add that these speculations are as yet only hypothetical, but they are not superfluous even in the eases where animal or vegetable parasites lave been, or will yet be discorered in the contaginm. The question will, howerer, still remain, whether the parasitc is an accidental inhabitant of the con- 
tagium and of the discased body, or whether it is the important active constituent. Much has already been gained by these views which, though they may only represent a transitional period in our knowledge, will prove a lasting gain. In place of the unintelligible view that the diseased body, or the diseasc itself, forms the contagious material, we have thc opinion that the formation of the contagium is a reproductire process, and that the disease is the result of the reproduction of this extraneous being in the organism and at its expense. From this point of view we must iuterpret the symptoms of the miasmatic contagious diseases.

"While we must hold that the cause of the miasmatic contagions diseases is a material cndowed with independeut lifc, which can reproduce itself after the mauner of animals and plants, can increase by assimilation of organic materials, and, growing parasitically on the infected body, can give rise to the s5mptoms of the special disease, yet the question arises of what the as yet unseen body of this parasite is composed, the result of whose life is so evident and so devastating. It is one of the laws of human phantasy that we must ascribe to the contagium, as soon as we reckon it to be something living, one of the forms which the known organic world presents to our senses; hence in the earlier childish times of research one thought of insects, and when the microscopic animals wcre discovered, the infusoria could, with still better grounds, he accused of being contagium and miasma. At the present time, since the conclusions that have bcen arrived at with regard to the fungus of muscardine and similar diseases, it seems more likely that the contagium belongs to the regetable world, because the extensive distribution, the rapid multiplication, and the tenacity of life of the lower microscopical regetable beings, as well as the mode of their action on the hodies which they have selected as the seat of their vegetation, present in fact the most remarkable analogics witl the infective material of the miasmatic contagious diseases. Muscardine also arises in stagnant marshes, apparently independently, as if it were due to miasma; under the influence of heat and drought it becomes epidemic and contagions. Towards the cessation of the epidemic its contagionsmess diminishes, and nltimately becomes lost. Currents of air carry the contaginm over long distances, so that the disensc appears again in another placc, uncler the aspect of a miasmatic affection. The contagium is an aëriform, and at the same time a fixed, body It retains its power for years in a dry statc. An impondernble and incommensurable quantity of it is sufficient to set up the disease, and even to produce devastating cpidemics." 
The enrliest liseovery of parasitie exviting agents of disenre.
Hullier: discoveries
Actual facts in support of the theory of the development of disease by micro-organisms were first obtained by the study of a number of diseases of plants and insects. As far back as 1835 Bassi demonstrated that a fungus was the cause of muscardine, a fatal disease of silkworms; other diseases of insects werc shortly afterwards demonstrated with certainty to be due to similar fungi ; in like manner Tulasne, de Bary, and Kühn explained a number of devastating diseases of various kinds of grain, of potatoes, \&c., by the entrance and parasitic derelopment of fungi. Also in the case of the ligher animals and man positive proof was soon obtained that minute vegetable bodies were the cause of certain diseases. Apart from numerous discoveries of fungi which could not with certainty be demonstrated to be the cause of the accompanying diseases, favus, thrush, and various affections of the skin were shown to be dependent on parasitic microscopic fungi. Of especial importance was the discovery that anthrax was characterised by the appearance in the blood of minute rod-shaped organisms, and that these organisms could be shown experimentally to be the cause of the disease (Pollender, 1855; Davaine, 1863).

On the one hand the constantly increasing frequency of severe pestilences which led to the earnest desire to solve the etiological questions, on the other hand the convincing deductions of Henle, the numerous analogics with diseases of plants and animals, and the discorcry of the contagium of anthrax, gave rise to a period of research which was charncterised by an excess of zeal and by a large number of imperfectly proved discoreries which were of no real advantage to the parasitic theory.

It was Hallier more particularly who became $\Omega$ ton enthusiastic apostle of the parasitic theory. As the result of numerous researches lie asserted that the varions micro-organisms only represented special regetative forms of known mould fungi, arising in conscquence of the external conditions of life; that these vegctative forms gave rise to all sorts of diseases, but that under suitable conditions one could always cultirate 
from them the corresponding mould, and could in this way demonstrate the true cause of the disease. By the investigation of and cultivation from a great variety of diseased organs and excreta Hallier obtained a series of different fungi which he proclaimed to be the causes of the diseases; and in a short time scarlet fever, measles, as well as cholera, typhoid fever, and all other diseases of this class, were referred to their supposed cause.

The reaction to this period of fantastical exaggeration Reaction was inevitable. Authorities on fungi like de Bary against these showed that Hallier's investigations were quite valueless, because they were conducted with totally insufficient precautions against the entrance of extraneous organisms. De Bary's objections could not be upset, the structure of Hallier's teaching on parasitic diseases fell, and at the same time a serious blow was given to the whole parasitic theory; even up to the present day there are those who, as the result of the overthrow of these errors, look on the development of disease by micro-organisms as an erroneous and exploded view.

Further positive discoveries with regard to parasites which have been made by numerous investigators in recent years tended, however, to restore the lost faitl. These discoveries had chiefly reference to the infective Microdiseases of wounds ; Rindfleisch, Waldeyer, and ron organisms in Recklinghausen $(1866,1870)$ were the first who directed diseases of attention to the micro-organisms which occurred in pyæmic processes; similar observations were made in erysipelas, in phlegmon, in diphtheria, and in puerperal fever (Hüter, Orth, Oerftel, and others). The pathogenic nature of the micro-organisms found was confirmed by numerous experiments on animals (Coze and Feltz, Davaine, Hüter, Eberth, Leber, Frisch, Klebs, and others).

The striking results of Lister's antiseptic treatment of Lister's wounds liad a most important influence on the recogni- antisentic tion of the parasitic theory; carried out with the definite wounds. aim of preventing or hindering the action of the infective organisms, and followed by astonishing results, it spread widely the knowledge and importance of the micro- 
parasites, and the number of seeptics and opponents have diminished from year to year.- - It is true that the difficulty of these investigations, which only permitted an extremely slow advanee, and one but little satisfying to the enrnest desire for rapid enlightenment, led some observers to overstep the limits of exact investigation, and to attach too far-reaching speeulations to the results of the experiments: it was natural and pardonable tlat at times conclusions as to the origin of the disenses rrere drawn from the mere presence of miero-organisms in the dead bodies or in pathological seeretions, and that these organisms were at times prematurely and crroneously proelaimed to be the exeiting agents of the disease. On the other hand many investigator's recognised that it was only by detailed study of the different forms of miero-organisms which eame under observation, by the investigation of the conditions and results of their life, by improvement of the methods of microseopical observation, and by faultless experiments on animals that a basis could be obtained on which an aecurate and sure insight into the rôle of the parasitic agents of disease could be founded. Based on the recognition of these facts the more recent methods of myeological investigations were built up. Before it ras possible to obtain exaet and unequirocal results it was necessary to have Pasteur's and Cohn's systematie eultivations, Koch's method of microscopical investigation and pure cultiration of the fungi, Weigert's and Ehrlich's raluable researehes on the employment of dyes for demonstrating the miero-organisms, Brefeld's eontributions to the methodical study of the lower fungi, and Nägeli's work as to the conditions of life and the tissue change of the lower fungi.

The objections which are raised against the parasitic theory are derived almost entirely from former times, and are now scarcely heard. Apart from the viers of some stubborn adversaries, who only believe the contradietory results of their own experiments, the doubts raised against the reeent work on tee parasitic theory hare to do ehiefly with individual eases and special disenses. 
Thus from time to time authors have denied that unicro-organisms act as exciting agents of the infective diseases of wounds, their views being based more especially on the statements made by several observers, that after mechanical removal of the organisms from infective fluids the filtrate, which is devoid of organisms, exerts pathogenic action. More accurate experiments have however shown that this action depended solely on an intoxication, on a poison in solution, and that therefore it could not be at all compared with an infective process (Panum, Hiller, Koch, and other's).-The Billroth's obresults of Billroth's investigations attracted special at- jections to the tention for a considerable time; he repeatedly found theory. micro-organisms in subcutaneous suppurations, where there was no external wound; he likewise found them in living organs; and he concluded, therefore, that living germs were always present in the body, but that they wero not able to develop in the healthy body, and could not utilise the tissues of the living body as nutritive material. It was not till a "phlogogenous ferment" (Phlogistisches zymoid) had been formed as the result of decomposition, which ferment could of itself cause inflammation, that the conditions were suitable for the development and multiplication of the micro-or'ganisms; and under favourable conditions these organisms can become carriers, and lead to the multiplication of this ferment. According to Billroth the micro-organisms originate from a single plant, the Coccobacteria septica, which is characterised by the multiplicity of its vegetative forms, and according to the external conditions appears now in one, now in another morphological form.

It is easy at the present time to refute Billroth's objections. In the first place, we know from numerous experiments that bacterial germs are not present in the normal living organism in recognisable numbers, and that the numerous organisms in the diseased living body can only bo referred to entrance from without-to an infection. An objection might, however, bo made that the facts made out, as to the absence of pre-existing germs 
in animal organs, do not of necessity apply to man, and it was therefore necessary, when possible, to bring forward experimental facts which would undoubtedly show that micro-organisms are the direct and only cause of certain diseases, and are not merely accidental companions of other noxious materials.

Definite proof Experiments were formerly performed with this aim

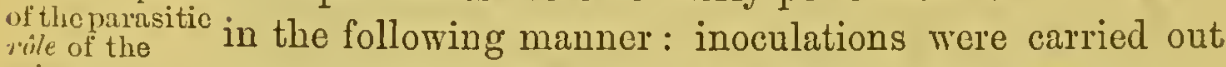
microorganisms by with infectivo substances, an effort being made at the and by them same time to free the organisms from other materials infective experiments.

Isolation by filtration. adhering to them, which might possibly cause the disease. In some cases an attempt was made to isolate the organisms by the addition of distilled water, in which the organisms would sink to the bottom, or by filtration; but in these attempts it was always questionable whether the noxious materials by possibility present in solution were really removed, and on the other hand whether the organisms were not injured by the washing and by the great osmosis. Filtration in the living body, obtained by studying the relation of the foetus to the infected maternal organism, did not lead to a definite result, as it was only in certain instances (anthrax) that the fotus remained free from infection, while in other cases it also became attacked by the disease.

By dilution of Experiments were then made by dilution of the the infective infective material, on the assumption-undoubtedly
matcrial. correct-that only a contagium dependent on a liring organism capable of multiplication could be diluted to an extreme degree without losing its activity. Such a dilution was in reality obtained when one animal was successfully inoculated from an infected one, a third from the second, and so on through a whole series of animals; nevertheless there was always the possible objection in this case that the cells of the body might take part in the regeneration of the poison.

On the other hand all doubt as to the pathogenic properties of certain micro-orgnnisms is remored in the face of the proof obtained during the last few years, that the infective material can be diluted outside the body to an extraordinary extent, without thereby losing its activity. Thus Koch was able to dilute infective blood 
to such a degree that one-millionth part of a cubic centimetre injected into the animal caused the same typical diseasc, fatal in eighteen hours, as was obtained by the injection of undiluted blood. The dilution can, horvever, be carried to a much greater extent by the aid of the methods of cultivation. Pasteur and Bycultivation Klebs were the first to show that micro-organisms, supposed to be pathogenic, could be cultivated outside the animal body in artificial nutritive material; that then after the growth of a cultivation a minimal quantity could be placed on a new nutrient material, that a trace of the colonies which then developed could be inoculated on a third soil, and that thus the micro-organism could be cultivated through a whole series of generations. Koch then gave us methods by which it is possible Koch's pure to prepare the cultivations of any given organism cultivations. in sucl a way that no other organism grows along with it, and that on further transplantations on new soil only the same organism appears. Thus we could for the first time stady witl certainty, and in an unaltered condition, the organism suspected as the cause of the parisitic disease, and that for a long time, and in spite of a large series of new transplantations. When an organism has in this way been cultivated through fifty or a hundred generations, it is self-evident that the last generation does not contain any of the materials which adhered to the original organisms; it is easy to see that the dilution must be reckoned by trillions, and must ultimately be incalculable; any poisonous material originally mixed with it, however intense its action may be, cannot be. present in the last cultivation in appreciable amount, and therefore when infection is obtained with the last cultivation it can only be becausc the micro-organisms themselves, which are constantly reproduced at the expense of the nutritive materials, are the real noxious agents.

As a matter of fact, inoculations with the minutest quantity of the hundredth pure cultivation succeed quite as well as with the original matcrial. In the case of anthrax, of various forms of septicemia, of glanders, of tuberculosis, sc., Koch was able to carry on pure 
cultivations through a long series; if he introduced a trace of the last cultivation into an animal, the diseasc in question appeared with all its characteristic sjrmptoms after the typical incubation period; death followed after a definite time. The results of the autopsy were always the same; organisms of the same form, and with the same characters as those introduced, were found in enormous numbers in the blood and tissues; and traces of the blood containing the organisms when inoculated in!o other animals, caused in them the same fatal disease.

In the case of these diseases the causal connection of the micro-organisms was therefore proved with completc certainty; and it was naturnl to draw similar conclusions with regard to the other numerous infective diseases which had the same characters. Nerertheless it is best, and will contribute more to the development of knowledgc with regard to the micro-parasites, if we proceed with the greatest caution, aroid generalisations, and only proclaim a disease as parasitic when we succeed in finding microorganisms with well-marked morphological characteristics, in demonstrating their presence in such numbers and with such a distribution that all the phenomena of the disease can thereby be explained, in transmitting them to other higher animals, or if possible in cultivating them for several generations on an artificial soil, and reproducing the characteristic disease by inoculation of animals with minute quantities of these cultivations.

That these minute organisms act as parasitic exciting agents of disease, is as much beyond question as is the function of similar minute bcings in exciting fermentation and putrefaction. And it is to this fact that the great and many-sided importance of micro-organisms in relation to hygiene and public health is due. It was the processes of fermontation and putrefaction of organic substances in our surroundings which first awakened uneasiness and distrust, and called the efforts of modern hygiene into being, and tho most important, and also the most difficult part of the hygienic investigntion of soil, water, air, and dwellings, lies in ascertaining those conditions which favour the derelopment and spread of the exciting agents of disease. 
PART II.

MORPHOLOGY AND CLASSIFICATION OF THE MICIO-

ORGANISHS.

The micro-organisms which have as yet been The microrecognised as exciting agents of fermentation and whichinterest putrefaction, or of disease, belong almost entirely nsherebelongr to the lower fungi. Certain preliminary observations fungi. render it probable that organisms which belong to other classes of plants or animals, for example the algæ, the flagellata, and the protozoa, may also occasionally act as parasites, and become of hygienic interest; but in the meantime the known facts are too few for a systematic review of this part of the subject, and it is therefore sufficient to include here only those micro-organisms which are of special importance for us, and which belong to the lower fungi.

In order to indicate the place of the lower fungi in the system of the plants the following short sketch is given, and the botanical handbooks, more especially the paper by Frank on the Cryptogams in Leunis's Botany, and de Bary's Comparative Morphology and Biology of the Fungi, will furnish further details.

The fungi, mycetes, belong to the cryptogams, that Place of the great division of the vegetable lingdom which is fungi in the characterised by propagation by means of spores, in kingdom. contrast to the other great division of the phanerogams. The plianerogams bear flowers and produce seeds, in which the various parts corresponding to the future structures of the plants are already distinguishable; the cryptogams are flowerless, and propagate by means of the spores just mentioned, that is to say, by small cells, which show no differentiation and, when present in lirge numbers, resemble one another. The cryptogams 
Former sub. division into fungi, algæe, and liclicus.

Untenability of this classifi eation. are divided into the stem-forming cryptogams, and the thalloplyytes, or leafy plants, in which only a leaf or thallus is formed, which does not in any way follow the lars of growth of the higher stem-forming plants.

The thallophytes were formerly divided into three sub-classes-fungi, algr, and lichens. The fungi trere defined as cells devoid of chlorophyll, which can only obtain nutriment from previously formed organic compounds, and hence can only live as saprophytes on organic substances undcrgoing decomposition, or as parasites in living plants and animals. Algæ were described as cells always containing chlorophyll, which obtained nutriment from inorganic materials, and for the most part lived in water. Lichens were defined as a mixture of cells, some containing chlorophyll and others without it, which could obtain nutriment from inorganic materials, and for the most part lived in the air.

At the present time very little value is attached to these distinctions, which are based chiefly on the presence or abscnce of chlorophyll. Eren among the phanerogams there are many plants which are deroid of chlorophyll (orchids, monotropacex), but which are not on that account struck out of the families or orders to which from their morphological characters they belong. If also in the case of the thallophytes the chief stress is laid on the mode of propagation, and on the morphological characters, the fungi and algre show a great deal that is common to both. And with regnicl to the lichens the latest investigations hare shown with considerable certrinty that they consist of a fungus and an alga, the first of which preys upon the second, so that they cannot be looked upon as an independent class. Hence it is best to gire up the former dirision into fungi, algre, and lichens, and to choose for the whole of the thallophytes a principle of classification in conformity with that employed for the other plants.

Opinions vary greatly as to the most suitable and natural mode of classifying the thallophytes, but we need only refer licre to de Bary's classification ( $\mathrm{T} \mathrm{C}$ gleichende Morphologie und Biologie der Pilze, page 
142), to Brefeld's subdivision (Untersuchungen ïber Schimmelpilze, Heft 4), and to Frank's elnssifieation in the third edition of Leunis's Botany, page 398. The present description will bo based chiefly on Frank's classification, because Leunis's Synopsis is an indispensable book of reference for anyone who studies the thallophytes minutely.

Among the thallophytes only the fungi are at present of hygienie interest, henee the algæ and lichens are not at all referred to in the following pages, and with regard to the forms of algre, morphologieally similar to the fungi, reference must be made to Leunis's Synopsis and to Coln's Beitrüge zur Biologie der Pflanzen, Bd. 1, H. 2.

From the hygienie standpoint it seems most praetieal Subdivision of to depart from the botanical arrangement and divide a practical the fungi into four ehief groups, of which the first $\begin{gathered}\text { hygienic } \\ \text { standpoint. }\end{gathered}$ comprises the true fungi, or mould fungi; the seeond the myeetozoa; the third the yeast fungi, or blastomyeetes; and the fourth the fission fungi, or sehizomyeetes.

\section{The Fungi Proper (Mould Fungi).}

\section{General Morphology.}

The fungi eonsist of small mieroseopieal eells, in Nature of the whieh we can distinguish a membrane and protoplasmie contents. The eell membrane is eomposed of a substance similar to ecllulose but not identieal with it, and does not show any violet colouration with iodine. In the protoplasm there are as a rule no nuelei, no stareh granules, and no chlorophyll ; on the other hand there are frequently vaeuoles, oil globules, various colouring materials, and at times erystals of oxalate of lime which re however deposited especially on the onter surface of the eoll wall in the form of small necdlos and prickles.

'The growth of the fungi takes placo by elongation of Hypbr. the cells. Thus a series of thronds or hyphro are formed. Usually the hyphro aro divided into segments 
Varieties of the mycelium.

by transverse divisions; and the threads are almost always branched, either by the formation of a branch at some part or other of a segment, or by the terminal cell becoming divided dichotomously during growth. The group of hyphr," whether they are prescnt in small numbers or quite single, or whether they are united in masses, is termed the thallus of the fungus.

In the thallus we have to distinguish mycelium, and later fruit-bearing hyphre. Before the development of the fruit-bearing hyphe the mycclium is identical with the thallus, which signifies the more or less diffuscd and branched hyphæ which have grown on an organic substratum. As a rule by uniform spsead of the threads in all directions and by continued branching a flocculent mycelium is produced. At times membranous parenchymatous layers or fibrous bands are formed by the close union of numerous hyphx. Under certain circumstances the mycelium of many fungi assumes the form of the so-called sclerotia, tuberous fleshy bodics which develop sccondarily from an ordinary mycelium. In the sclerotium we can distinguish a cortical and a medullary substance, the latter consisting of interworcu hyphæ, the former of the terminal cells of the hyph firmly bound together and surrounded by dark membranes. The sclerotium must be regarded as a resting form, from which a development of fluid-bearing hyph only occurs after a long time, and when the surroundings are constantly moist.

The hyphr of the mycelium penetrate with great cnergy into the nutritive substratum. In the case of dead portions of plants the hyphre can bore through the cell membrane, the molceulcs of the membrane in contact with them being brolien up. But even in the case of living plants the parasitic fungi not only sprend on the surface, but the hyphre grow in between the cells of the plants and send short projections, so-ealled haustoria, into the interior of the colls; or they penetrate through the coll walls, as in the ense of dend plants. In like manner animal membranes do not ofler any narked rosistance to the penctration of the growing 
hyphæ of many fungi, and even teeth and bones may become infiltrated with fungus threads.

The propagation of the fungi occurs usually by means Varietics of of spores, i.e., cells, which can give rise to one or several spore formagerminating tubes, and thus to a new regetative body similar to the original one. In rare cases some of the cells of the mycelium themselves form the spores; as a rule, however, certain hyphæ grow from the mycelium, take on another form and show other conditions of growth, and are termed fruit hyphæ, or fruit-bearers. If a large number of fruit hyphæ lie together, a so-called fruit body is formed, and this is more especially the case in the higher fungi. The modes in which the spores develop on the fruit-bearers, and the manner in which they are distributed after ripening, are very diverse, and these differences in fructification furnish in the main the principles on which the usual classification of the fungi is based.

With regard to the development and dissemination of the spores we distinguish-

a. Intercalary formation. Along the course of the growing hyphre certain cells are marked off, assume it somewhat distinct form, and become spores or sporebearing cells. These formations are frequently termed yemme.

b. Acrogenous segmentation. The terminal portions of the fruit hyphæ are separated by transverse division, and act as spores. The thin stalks or fruit-bearers are termed basidia. If from the ends of these hyphre thin stalk-like branches proceed, on which the spores are formed by strangulation, these spore-bearing stalks are termed sterigmata. As to the mode in which the transverse division of the terminal cells occur's only one spore may be formed; or a number of buds may arise at the sime time on the summit of the basidium; or several spores may be separated one after the other from onc busidium. The freeing of the spores takes place either by disappearance of the stalk, or by strangulation, where a zone disappears, or softens in the transverse division bctween spore and fruit-carrier, or by being lurled away. 
The last mode of separation of the spore, which is very peculiar, occurs in this way: the spore cell rests on the - apex of a tube-like basidium, which, in consequence of continued absorption of water, becomes more and more turgescent, while it possesses at the same time a rery clastic membrane; immediately beneath the transverse dirision the cohesion of this membrane is less than elsewhere, and here, therefore, as soon as the turgescence has reached a certain degree, a ringlike rupture occurs; at once the elastic wall contracts, and a large part of the contained fluid is forcibly driven out of the rent, and carries the spore with it.

The spores formed by acrogenous segmentation are termed basidiospores, or acrospores, or simply conidia. At times this mode of spore formation occurs in fruit bodies, the so-called spermogonia and pycnida. These fruit bodies contain a cavity, on the inner wall of which is a thick lajer of basidia which gire off numerous sporcs.

c. Endogenous spore formation. The spores arise in the interior of mother cells, the walls of which persist as sporangia till ripening has occurred. The sporangia are for the most part acrogenous cells; spore formation occurs in them by division of the plasma without the formation of walls. The sporangia hare often a clubshaped or tube-like form, and are then termed asci; in these eight ascospores are usually formed. The asci are often formed in small round or flask-like fruit bodies, the perithecia, which enclose a cavity, and the club-shapced tubes spring from the bottom of this carity.

The ripe spores escape either through an opening in the sporangium which is formed by sudden and great swclling of a small circumscribed portion of the rall; or the largest and upper portion of the wall of the sporangium becomes converted into a deliquescent substance; or, in the case of the asci, the aborementioned ejaculation of the spores is not uncommonly observed.

d. The spore formation is often preceded by a sort of sexual fructification. This may consist of the socalled copulation, in which two hyphe, each with a club- 
shaped protrusion, grow towards one another, unite after absorption of the opposing walls, and form a zygosporc. For the most part, however, well-marked male and female sexual organs are formed. The female is attached to a mycelium thread in the form of a globular swollen cell, and is termed oogonium; the male, anthoridium, is a long or elub-like swollen cell which attaehes itself to the oogonium and becomes separated from its hypha; at times the antheridium sends a so-called fertilising tube into the interior of the oogonium. After fertilisation, the oosporcs, whieh are globular eells provided with a cellulose membrane, are formed in the oogonium. Such anastomoses between hyphie do not, however, in all cases indieate a sexual copulation.

The ripe spores are for the most part simple, often, Structure of howerer, composite, eells of very varying forms; usually they are spherical or oval; at times, however, they have the form of long thin rods. The wall consists of an external, and often coloured sheath, the cpisporium, and an inner, more delicate, colourless layer, the cndosporium. The contents consist of protoplasm, and oil globules are frequently present. The general distinetive characteristic of the spores is that they either become converted into the mother cells of new spores, sporangia, or send out one or more germinating tubes from which the myeelium threads may again develop.

The swarming spores and the resting spores beliare somewhat differently. The former are round, naked protoplasmic bodies without a firm cellulose envelope, provided with two cilia, and thus capable of movement; they arise endogenonsly from the spores by division of the spore contents, and beeome free by swelling of the sheath of the sporangium. They are only formed and liberated under water. After the mobile, naked stage has lasted for a short time, the swarming spores come to rest, surround themsclves with a cell wall, and then, like other spores, send out a germinatiug tube. By resting spores wo understand those spores which are not able to germinate immediately after their formation, but require first a period of rest, c.g., a whole winter. Zygospores and 
Different modes of spore formation in the same fungus.

oospores are the forms which usually bchave as resting spores.

These different kinds of fructifying organs occur at times together or in succession on one and the same thallus; the same fungus can under certain conditions furnish basidiospores, and under other conditions ascospores; thus there is frequently a polymorphism of the fructifying organs. In addition an altermation of generation often occurs; the thallus of one fungus bears only one form of fructifying organ; the spores so developed grow to form a thallus which is different from the original thallus and gives rise to another fructification, often indeed not growing on the same host, but requiring another species of plant for its development. From the spores formed on the second thallus, the original mycolium with its characteristic fructification is again dercloped.

\section{Classifieation of the True Fungi. \\ (After Frank in Leunis's Synopsis).}

sketch of the classification of the fungi.
First order : Ascomycetes.-Highly developed form of fungus; at the height of vegetation ascospores are formed. A formation of protospores often precedes this fructification, these bodies appearing in the form of conidia-carriers and conidir or spermogonia. The protospore forms of the ascomycetes, such as Eurotium aspergillus, Erysiphe oïdium, \&c., which occur much oftener in nature than the higher forms of fructification, were formerly described as particular species of fungi, and have only recently been associated with the ascospore forms.

Families : Pcrisporiacer, Pyrenomycetes, Tuberacen, Discomycetes, Gymnoasci.

Sccond order: Basidiosporece.-In these the spore formation always occurs by acrogenous segmentation, even when the fungi have reached the acme of development. Almost all form fructifying bodies, which carry in their interior a hymonium layer of basidia. 
Families: Gasteromycetes, Hymenomycetes, Tremcilini, Ascidiaceæ or Urediner, Entomophtorere, Ustilaginer.

Thirl order: Zygomycetes.-These form zygospores, as the highest form of fructification; these spores arising by copulation. A non-sexual formation of spores by sporangia, or by separation of conidia, usually precedes this fructification.

Families: Mucorineæ, Chrtocladiacex, Piptocephalider.

Fourth order: Phycomycetes.-These are unicellular thallophytes. The cell is tubular, and forms the spores at the end of some of its branches. In the non-sexual fructification these spores are swarming spores or conidia; oospores are also often formed.

Families: Saprolegniacer, Peronosporer, Chytridiaceæ.

Of the various orders and families mentioned, I Description of have only selected for more detailed description those interesting which are of directly hygienic interest, in that they at fungi. times appear as parasitic exciting agents of diseasc in man and the higher animals; or those which demand attention on account of their wide distribution as ordinary mould fungi, and on account of their constant occurrence in all practical mycological work. In addition, some of the forms which attack lower animals and plants are describel shortly where the mode of appearance and distribution of the diseases excited by them furnisl analogies with human infective diseases. For all other details the botanical text-books mentioned above must be consulted.

A. The following forms, which are parasitic on plants or the lower animals, may be mentioned :-

1. Ustilaginex. The fungi of various forms of blight Blight fungi. (order: Basidiosporex). These aro parasitic on tho organs of plants, especially on various linds of grain. The fine mycelium threads grow between and transrorsely through the cells of the plants. At certain spots the 
hyphre multiply, become segmented, and break up into spores, which then occupy the place of the tissue destroyed, in the form of dark, dust-lilie masses. The short germinating tube (promycelium) branches in single segments (sporidia), which become detached from tho promycelium, and can again grow in the form of germinating tubes. Different species of these fungi attack different

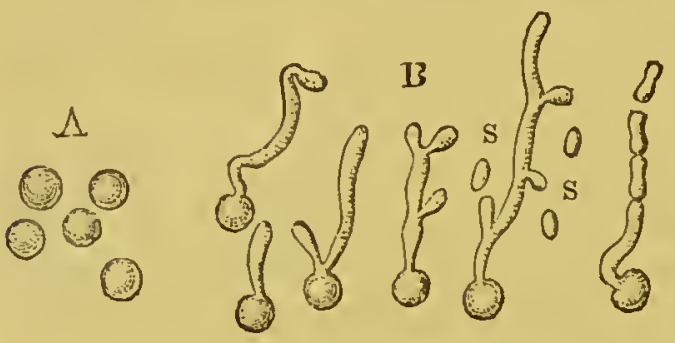
parts of the plant,

Fig. 1.-Ustilago carbo $\times 400$.

$A$, ripe spores.

$B$, germinating spor'cs, forming promycelium and sporidia $(s)$. now the flower, now the stalk and flower, and now the root. The detection of the disease depends chiefly on the presence of the dark masses of spores. Continued moisture is necessary for the germination of the spores, and for the penetration of the germinating tubes into the lost. The disease is prerented by diminution of the moisture, or by disinfection of the grain, e.g., by means of sulphate of copper.

Ustilago carbo (brand, smut). $-\mathrm{A}$ black powder on the ears and panicles of wheat, barley, and oats. At thetime of har'vest the brand mass, which rapidly breaks up, is removed by wind and rain, and hence there is no contamination of the meal. Spores brown, spherical (fig. 1); episporium smooth; sporidia composed of longish cells (fig. 1, B). About 30 varictics.

Titletic caries (smmt). -A blackish brown powder in the grains of

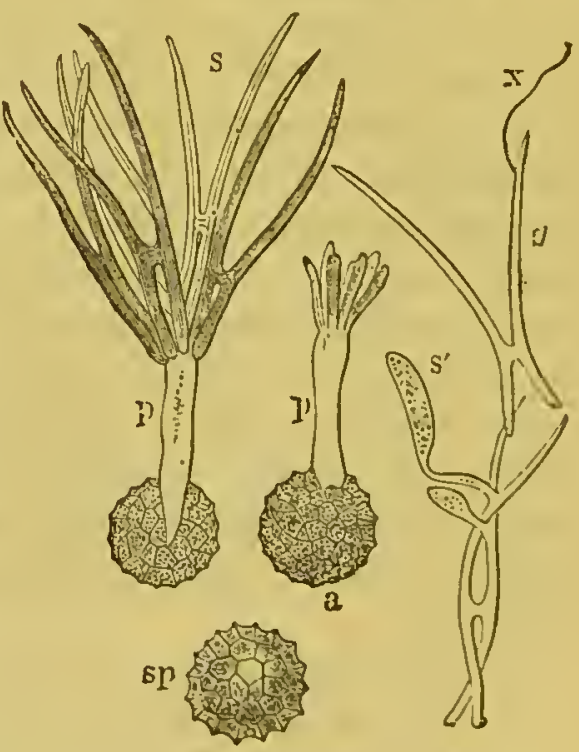

Fig. 2.-Tillctia carics $\times 400$. $s p$, ripo spores.

$p p$ sprouting spores, at a commencing development of the sporidin; at $s$ fully formed sporidin united in pairs.

$x$, germinating tube of a sporidium.

$s^{1}$, sccondary sporidia. 
wheat and spelt which smells of herring brine. The grains do not fall to pieces, but remain closed; hence the brand maiss contuminates the meal, and imparts to it a disagrecable sunell. Spores spherical, pale brown; episporium, with highly dcreloped reticular thickenings. When the spores sprout there is formed at the cud of the promycelium a whorl of thrcadlike sporidia, which at the lower half become united in pairs by a transverse branch, and drop off while thus united; these send out at some point or other a thread-like germinating tube, in which there is frequently a separation of secondary sporidia in the form of longish oval cells, which can again sprout (fig. 2).

When grown in saccharine solutions the Ustilnginex, according to Brefeld's recent investigations, form a continuous series of vegetative forms, the promycelium either continuing to develop in the form of buds, or the germinating tube of the resting spore growing to form a thread-like mycelium, which gires rise to spores by segmentation, either in the fluid or on branches rising into the air. 2. Entomophtoreæ (order: Basidiosporeæ). These Empusi or gan is ms grow parasitically on insects, and cause the death of their hosts; they are the curuse of certain cpidemic diseases of insects.

Empuscu muscre.Parasitic on house thics. The flies which are killed by this fungus hang on the walls with their legss extcnded; three white belts (the basidia) project betwcen the segments of the swollen posterior part of the body; the fly is surrounded by a broad white area of dust, which consists of spores which have becn thrown off. The

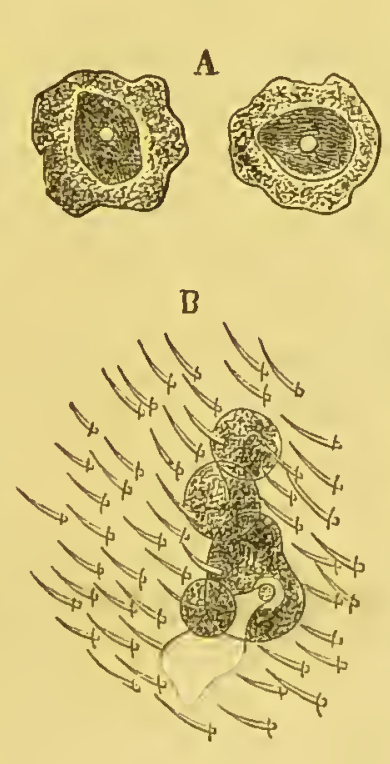

C

Fig. 3.-Enpusa musea $\times 300$. (After Brefild.)

$A$, ripe spores surrounder by pretoplasm. $B$, a portion of the slin of a fly with germi-
nating spores.

$C$, a hypha fermed in the interior of the body, tho swollen end of which is developing into a basidium.

$D$, portion of a similar thread with the spore already crident 
spores $(0.011 \mathrm{~mm}$. in diameter) sprout readily on the skin of the abdomen of healthy flies, send ont a germinating tube whieh penetrates under the skin and there forms, by budding, short round eells, whieh beeome detaehed and spread in the blood (the germinating tube possesses a very sensitive membrane which is at onee dissolved in water, but not in salt solution). These eells ultimately develop into tube-like hyphæ, of which one end projeets through the skin of the posterior part of the body, in the form of a elub-like basidium. The upper end of the basidium then forms spores by the produetion of a poeket, into which plasma flows; this poeket, the future spore grows, and finally beeomes eut off by segmentation from the basidium. Large vaeuoles are then formed in the latter, it takes up more and more moisture, and beeomes swollen; finally it bursts, and the eontents spouting out, hurl away the spore with eonsiderable foree. The empty tube slirinks, and in its plaee a new one appear's, in whieh the same proeess is repeated. In this way the dusty layer of spores aronnd the flies is formed; the round spores (fig. 3) are surrounded by a layer of plasma, which favours their adhesion to the body of other flies. To this group also belong Empusa radieans, observed in the eaterpillar's of the eommon white butterfly, and Fariehium megaspermum in the eaterpillars of Noctuce segetum (Wintersaateule).

Fungus of potato disease.
3. Peronosporeæ (order: Phycomycetes). Parasites on living plants; the mycelium present between the cells sometimes sends haustoria into their interior. All these fungi can fructify asexually, fruit hyphæ projecting from the surface of the plant, and giving rise to conidia by segmentation. The ripe conidia can at once germinate, either by the direct formation of a germinating tube, or by division of their contents into a number of portions, which grow into swarming spores; these ultimately sprout like the other spores. Many peronosporer, however, possess in addition a sexual fructification.

Speeies Peronospora; about 4.0 rarieties, attaeking a numher of phanerogans; mostly on green parts, the conidia hearers being situated by preferenee on the under surfaee of the leaves. The parts attaeked beeome prematurely yellow or brown, and die; the eonidia bearers form a fine, grey. mould-like eovering on the smrfiee. J'eronospora infestans: fungus of the potato disease; 11 yeelial tubes $0.005 \mathrm{~mm}$. thick. without haustoria; eonidia benrer's with $1-5$ branehes, thin towards the top, with ellipsoid or egg-shaped conidia (fig. 4).

This fungus has been known in Germany sinee 1830, and was very destruetive betwcen 184.5 and 1850 ; sinee then it 
has only becn present when there was a large amount of moisture. From the end of June brown spots appear on the lenres, the under surface of whieh shows the mould-like border of eonidia benrers; this is soon followed by the death of the plant. Deeomposition of the tubers then takes place; dirty brown patehes indieate the development of the mycelium. On the dead tubers two forms of mould fungi frequently derelop: Fusisporium solani and Acrostulagmus cinnabarinus, which howeverhave nothing to do with the disease. The infeetive fungus lires through the winter in the tubers, renches the field with the seed, and develops by preference during extreme moisture; it is only young parts with delieate membranes whieh permit the entrance of the germinating tubes. Disinfection experi-
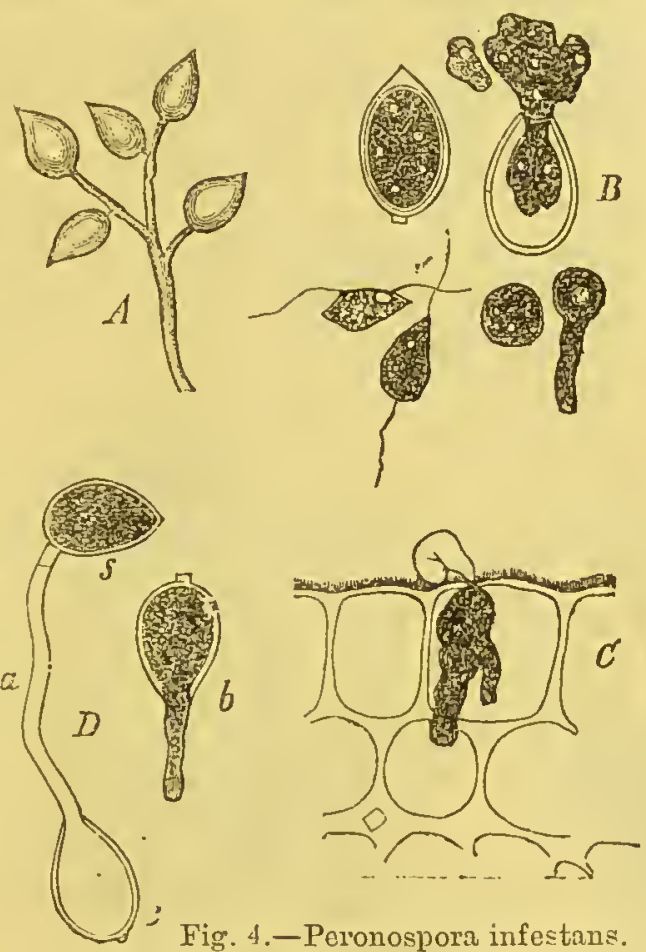

Fig. 4.-Peronospora infestans. (After de Bary.)

$A$, Young twig of the fungus.

$B$, Formation of swarming spores.

$C$, Swarming spores which have bored throngh the epidermis of a potato stalk.

$D, a$. The conidia $(c)$ forms a secondary onc (s). b. Sprouting of conidia.

ments have as yet been without result; but the loenl predisposition may be influenced by avoidanee of moisture, the indicidual predisposition by the seleetion of resistant, toughwalled kinds of potatoes, and the seasonal predisposition lyy 1)'eserving the seed in a dry state and sowing late, a slow derclopment of the fungus and a rapid growtl of the potato being obtrined in all these ways. Otler kinds of peronosporn occur. on leguminons plants-elorer, vines, lenres of beet-root, $d c$.

4. Pyrenomycetes (order: Ascomycetes). They Jire partly as saprophytes and partly as parasites, on plants or insects. There are usually two modes of fructification : conidia and ascospores, the latter formed in perithecia.

Claviceps purpurea, the fungus of elgot, occurs in the fruit 


\section{4}

Fungus of ergot.

of grasses. The fungus develops in the first place on the bloum, in the form of a conidia-bearing stroma, which looks like it dirty white, checse-like mass (sphacelia, sce below). The numerous conidia project from the bloom, and are covered with a saccharine sticky juice (honey-dew) secreted by the fungus. The fungus is spread directly by means of the conidia; the mycelium becomes gradually converted into a black sclerotium, which assumes a horn-like form $(1-3 \mathrm{~cm}$. long), projects from the bloom, and carries at first on its apex the dead and dried remains of the mycelium, like a cap of a dirty yellow colour. This sclerotium lasts during the winter, germinates in spring on moist soil, and derelops
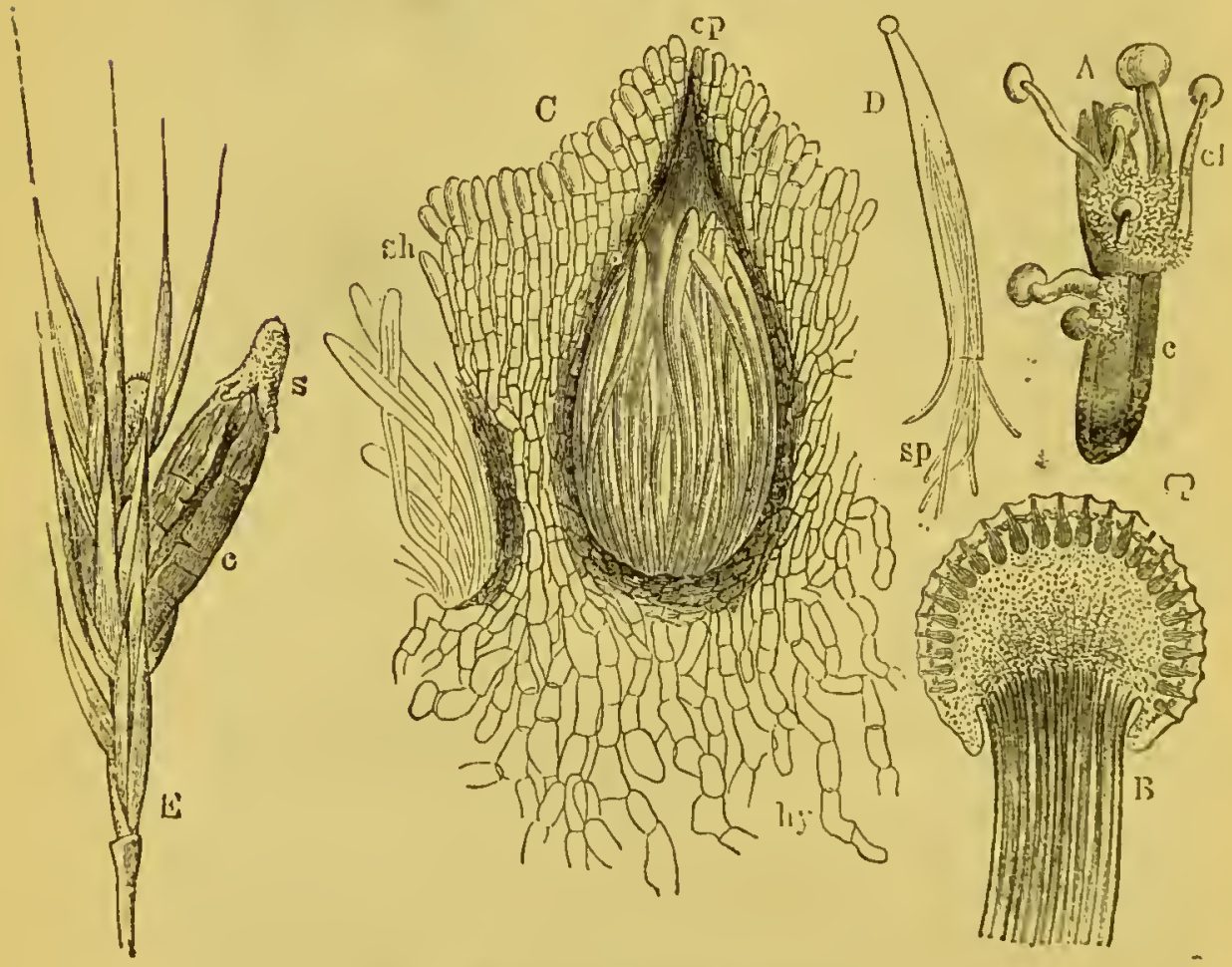

Fig. 5.-Clavicops purpurea.

$A$, sprouting selerotium $(c)$ with fruit-bearcrs $(c l)$.

$B$, Iongitudinal seotion of the upper part of a frut-bonring hypha;

$c p$, peritheoia more highly magnified.

$C$ scetion through a perithcoium; sh, oxtornal layer of tissuo:

$h y$, notwork of hyphe ; $p$, orifice of perithecium.

$n$, ascus torn and giving oxit to the thread-like spores sp.

$r$, ear of ryo with ergot $c$; $s$, romains of the sphacelia.

perithecial-bearing stromata in the form of small stalked recldish heads. The perithecin are embedded in the surface of the head; the spores are thrend-like, unicellular. The sclerotium which has the form of a cylindrical, dark violet body with long sulci, and is in its interior white or reddish, and 
lard and wax-like, is known as ergot (Secale cornutum). It oecurs most frequently in the bloom of rye, morc rarely in barley and wheat. Damp situations farour its appearanec.

To this group belong also Cordyceps isaria; fungi, whose conidia bearers (isaria) develop parasitically on living larva and caterpillars, while the perithecial fructification develops on the dead animals in the form of club-like stromata (cordyecps).-Also Fumago and pleospora, which are parasitic on plants, and laboulbenia on insects, but often without any scrious disturbanec of health.

Botrytis, grape monld.-Fruit hyphæ divided at the apex into littlc short closcly, aggregated branches, on which the uuicellular spores are seated. The proper fructification by ascospores is unknown in most of the varieties. Mould-likc fungi occurring ou putrcfying portions of plants, but also parasitic on iusects.

Botrytis Bassiana, the muscardiue fungus.-As was first Bassi's musrecognised by Bassi in the ycar 1835, this fuugus is the cause eardine of the fatal discase of silkworms, ealled muscardine or calcino.
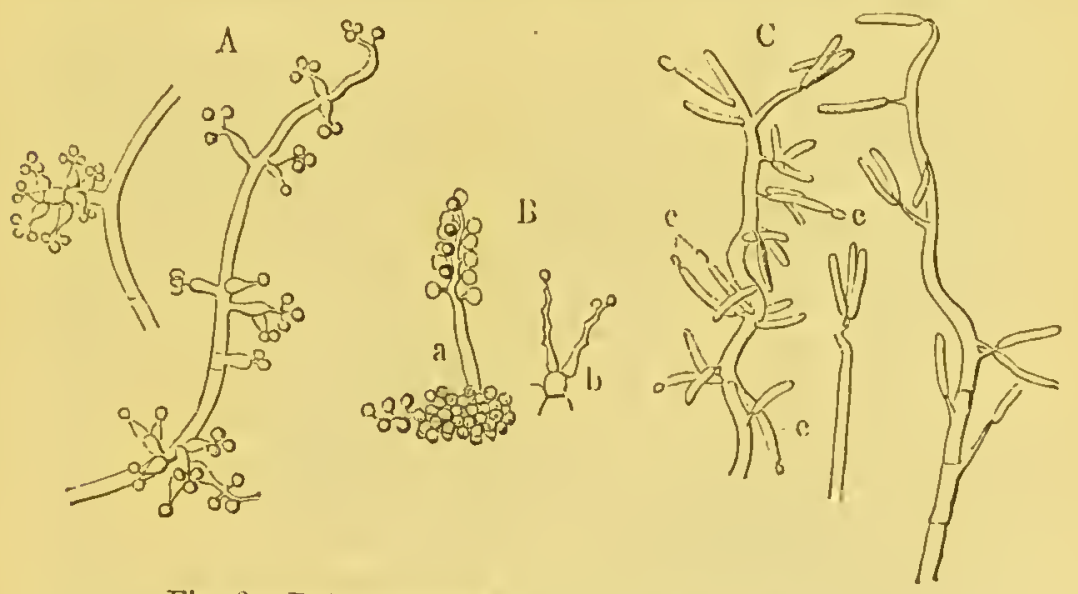

Fig. 6.-Botrytis Bassiana. (After de Bary.)

$A$, spore-bearing portions of the fruit hyphæ $\times 390$

$B$, spore-bearing twigs, at $b$ most of the eonidia have fallen off $\times 700$.

$C$, fungus threads from the inner part of tho skin of a caterpillar, at $c$ numerous eylindriform eonidia aro being given off by stran-
gulation $\times 300$.

This disease formerly caused great devastations, but for some ycars has almost entircly disappeared. This fungus also vecurs on varions indigenons butterfly catcrpillars and insects. It penetrates through the skin into the body, the germinating tubes pass decply among the muscular bundles and fat lobules, where they give off cylindrical conidia from their sides aud apices. These conidia multiply in the blood, and form a widely distributed mycelium by longitudinit growth and transverse segmentation. From this mycelium 
the numcrous fruit hypha grow, clothe the stiff mummylike corpse with a snow-white mould, and bear on their sides sereral spore capsules, with colourless spherical sporcs. The latter gcrminate in various nutricut solutions, and are thus capable of artificial eultivation.

list fungi.

5. Urediner, or Acidiacer (order: Basidiosporex). Parasites on plants. The thread-like mycelium grotrs between the cells of the plant which acts as host, and the organs of fructification which arise under the epidermis burst through it in the form of small, often reddish dust-like masses or patches, which consist of closely packed basidia. In most cases there is well-marked alteruation of generation; formerly the different fructifying forms were described as distinct species of fungiuredo, puccinia, rcidium-while at the present time these former specific names are only used for the particular spore form of these species of fungi.

As an example we may mention Puccinia graminis, the rust of grain, which occurs on many grasses. It forms on its inyeclium, which grows under the cpiclermis of the plant, clubshaped masses of basidia, which give rise to spores by segmentation, break throngh the epidermis, and set frec the spores in the form of oral cells, in whose protoplasm an orange recl oil is present, and whose episporium is colourless and rough. These spores, the so-ealled uredospores, or summer spores, sprout rapidly, and derelop always the same inycelium and the same fructification during the whole summcr. In the nutumn, howercr, club-shaped spore cells derelop on the basidin, which consist of two superimposed cells with thick, dark brown membranes, smooth on the outsidc; these so. called teleutospores, or, winter spores, germinate in the following spring, but the germinating tube docs not penctrate iuto a plant, but sends out only a fer thin branches, at the cnd of which ronndish, colourless cells are formed lyy segmentation. The sporidia so formed germinate quickly, not on grasses, but on the leares of the barberry bush, through the epidermis of which the germinating tubes of the sporidia penetrate. The thallus dereloped in the barberry is called Aॄcidium berberidis; from it short basidia are derelopec in flask-shaped organs (ecidium flasks, the corcring of which is called peridia), and burst through the epidermis on the under surface of the leaves. On the basidia long rows of simple roundish cells are formed, containing redilish-ycllow oil drops. The aceidium spores germinate as soon as they are 
ripe, but the germinating tubes only eontinue to grow when they carn penctrate into the stomata of the leaves of grisses. Here the original my. celium, witlı its uredospor'es, is then dereloped, and thus, the peculiar cycle of derelopment of this fungus is completed.

Along with the recidia another fructifying apparatus, the spermogonia, always oecurs; these are small jug-like eapsules, which project by prefercnce on the upper surface of the leares, and shed their spores eren before the secidia are ripe; the germination of these spores lias not yet been obscrved.

In some uredincæ all three generations oecur on the same host. In many rust fungi one or two of the chicf genera.

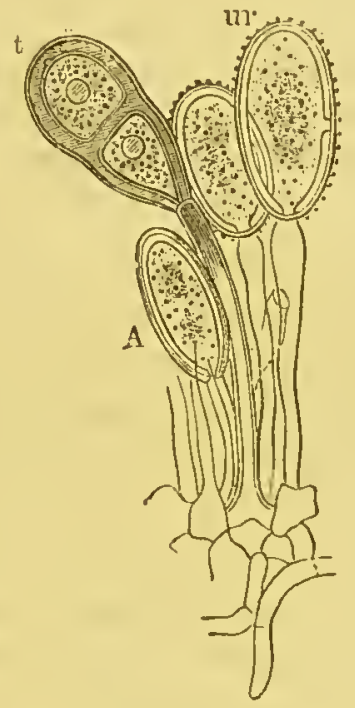

Fig. 7.-Rust of grain.

A, Puccinia graminis. A portion of the basidium with uredospores $\left(u v^{\circ}\right)$ and a telentospore $($ l $) \times 390$. tions are absent. When they only possess the telcutosporc stage these spores germinate as soon as they are ripe, and eom-

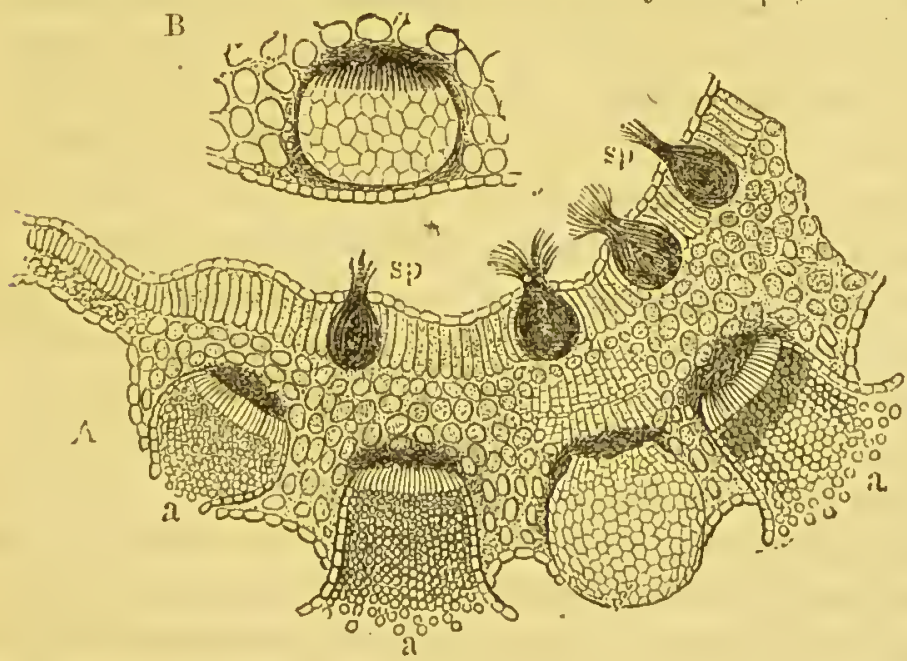

Fig. 8.

A, Fidinm borberidis. Section throngh a thickencil portion of the leaf contrining iecirlium flasks ( $(e)$ and spermogonia $\left(s p_{1}\right)$ At $a$ tho under surface of the leaf.

$B$, section throngh an acidium in a young condition. 
monee the development again; if only the acidia exist, the development begins likewise directly they are ripe, and the proeess of germination is similar to that of the telentospores. 'I'he speeies of the urediner are deseribed according to the teleutospores because these show distinet differenees, while the uredo. and acidium fruetifieation essentially eoineide in all the species. The rust fungi oeeur extensirely on the most various kinds of planerogams, on grasses, shrubs, and trees. Moisture of the ground and of the air favours their development. In the ease of many rust fungi the actual alternation of generation is not yet certain, and hence the independence of many forms as yet reckoned as particular species is doulstful. Where it is known it is often possible to prevent the infection by preventing the development of one of the stages of fruetifieation. Thus corn-fields may be protected against infeetion with rust by extirpating the barberry bushes in the neighbourhood on whieh the aeidium generation oecurs.

B. The following mould fungi, which are interesting either from their frequent occurrence, or from attacking at times higher animals, and even man, in the form of pathogenic parasites, are worthy of note :-

Perisporiacex. 1. Some forms of the Perisporiacex (order : Ascomycetes). In the fungi belonging to this family the spore tubes are formed in the interior of a capsule-like fruit body, the peritheciunı; the latter has no preformed opening, but tears open when ripe. The perithecia are very small round bodies, seldom more than $1 \mathrm{~mm}$. in size, and commonly immediately surround the mycelium in large numbers; their walls are for the most part coloured, and often covered with hairs or hair-like processes. In many cases the origin of the perithecium by sexual fecundation may be demonstrated. In eurotium, for example, short twigs derelop from single mycelium cells and become twisted like a screw $($ fig. $9, c)$; this screw represents the female organ, the ascogonium. From the lower part of this thread branches then grow ontwards along the side of the screw as far as its end. and one of the branches and the upper turn of the screw apply themselves to ench other and exchnnge their contents; after this fecundation the male branches, the lollinodia, divide and brauch frequently, and thus form " corering which becomes the wall of the perithecium. 
Some observers look on this supposed sexual copulation as only an unimportant anastomosis of hyphæ.

Besides the perithecia many perisporiacer present a second asexual fructification on the same mycelium; simple fruit hyph are formed which give rise to spores, or conidia, by fission. This asexual fructification is extremely widely spread, and very frequently it is the only form; it is only the presence of a large amount of nutriment which predisposes to the formation of perithecia. Thus the most common mould fungi usually form only the asexual fructification, and their connection with the perithecial forms is for the most part only recognised at a later period. Hence the conidia forms of these fungi were described as particular species, while from recent researches they can only be looked on as secondary fructifying forms of the ascomycetes. The conidia germinate readily immediately after they are ripe, form a mycelium, and again develop conidia bearers; on mycelium arising in this way from conidia, perithecia can also presumably derelop under suitable conditions, but this has not as yet been directly observed. The ascospores are as a rule only able to germinate after a period of rest; in the case of some of them it is certain that they develop to form a conidia-bearing mycelium. The most important species are-

\section{Eurotium-aspergillus.}

We distinguish (after Siebenmanu) the so-called true Aspergillus. aspergilli (Asp. clavatus, flarus, fumigatus, niger, ochraceus, albus), and the two eurotium forms proper (Eurotium aspergillus glauens and Eurotium repens). In the former the higher form of fructification is represented by a form of sclerotium, the formation of which is completed in two periods. In the first period a resting fruit (Danerfrucht) is formed consisting of the centrally placed ascogonium, which is for the time being inactive, and the store material originating from the carpogonium. This condition persists so long as the sclerotium is in a dry surrounding. On a moist 
substratum the sccond period at once begins; after absorption of the store material the ascogonium cularges and sends out branches which finally develop into asci containing spores. In the curotium forms, on the other hand, very delicate perithecia form in the placc of the tough sclerotia, and present the appcarance of refracting clear yellow or sulphur yellow transparent bodies of the size of a grain of sand with an enroloping membrane which is very easily crushed.

The sclerotia of the true aspergilli are found in old

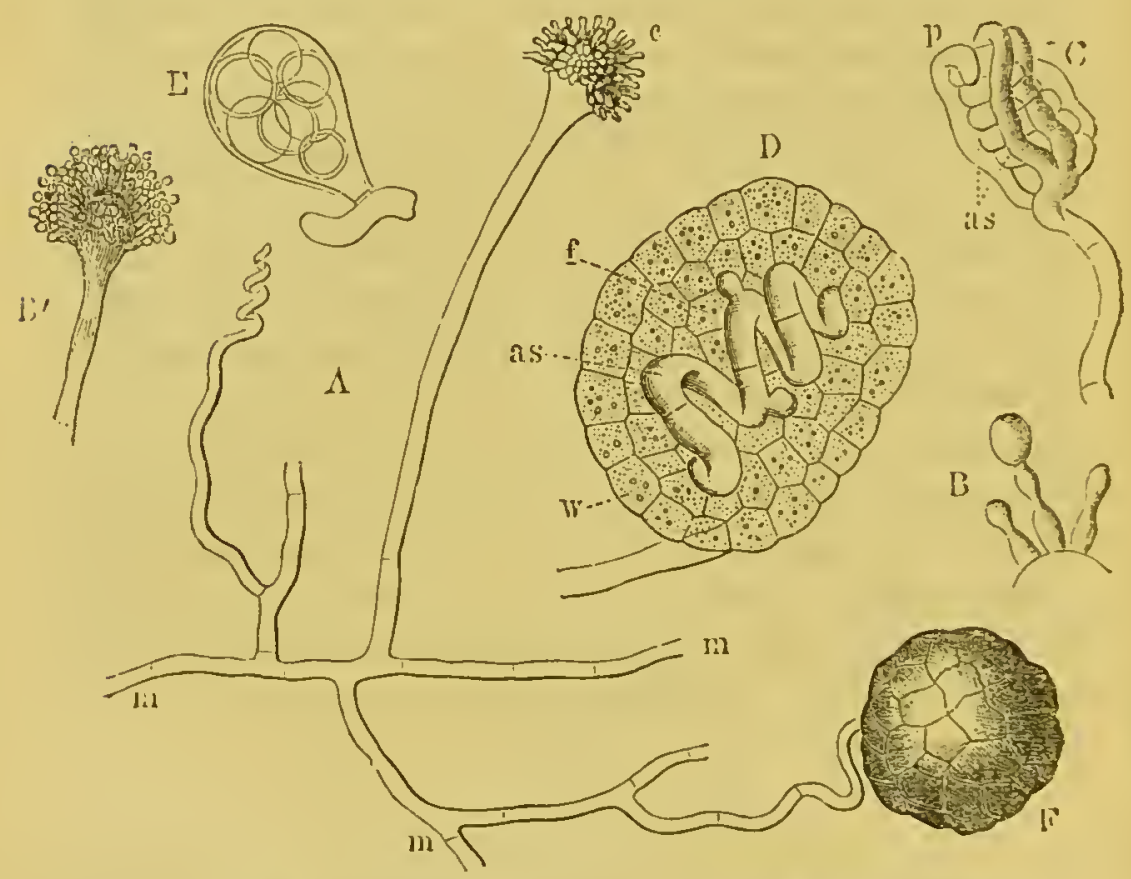

Fig. 9.-Aspergillns glaueus. (After de Bary.)

$A$, porticn of a myeelium thiread $(m)$ with a eonidia bearer $(c)$ :nd a young Eurotium perithecium $(F) \times 190$.

$B, B^{\prime}$, conidia bearer with basidin and conidin. $B$, some of the la-iclia. more highly magnified.

C', aseogon surrounded by the pollinodia.

$D$, young peritheeium ent longitndiunlly; $v$, the future wnll; $f$, the store matorial $\times 250$.

$E$, an ascus with spores from a perithecium $\times 600$

cultivations (for example on brown bread) arranged in nests in those places where there is incomplete access of air, and where therefore conidia benrers do not grow ; they form granules $0.5-1.5 \mathrm{~mm}$. in diameter, and of irregular form. Usually, howerer, only the conidial 
fructification is met with. Fruit-bearing hyplise, not branching and $0.3-10 \mathrm{~mm}$. in length, arise from a colourless mycelium consisting of delicate hyphr. 'These fruit hyphre are globular at their upper end, or dilated in the form of club-shaped bladders, on which thin projections or stcrigmata are arranged radially. It is only in the eurotium forms that the sterigmata are separated by septa from the bladders of the fruit-bearers. The stcrigmata give off at their apices a succession of conidia, consisting of round or somewhat oval cells $1-6 \mu$ in diameter. Some aspergilli (A. clavatus, flavus, fumigatus) have unbrauched sterigmata; in the other three on the contrary thcy are branched. The latter forms are also described as sterigmatocystis.

Asp. flarus or flarescens. - Yellow or greenish lrown masses of fungi. Conidia yellow or brown witl a fine warty surface; $5-7 \mu$ in diametcr. Sclerotia rery small, black. Grows best at about $+28^{\circ} \mathrm{C}$.

Asp. fumigatus.Greenish, often bluishgrey masses very likc penicillium. Short conidia bearers, curred forrwards to form a hemisphcrical bladder, $8-20 \mu$ in diameter. Closely packed awl-shaped sterigmata on

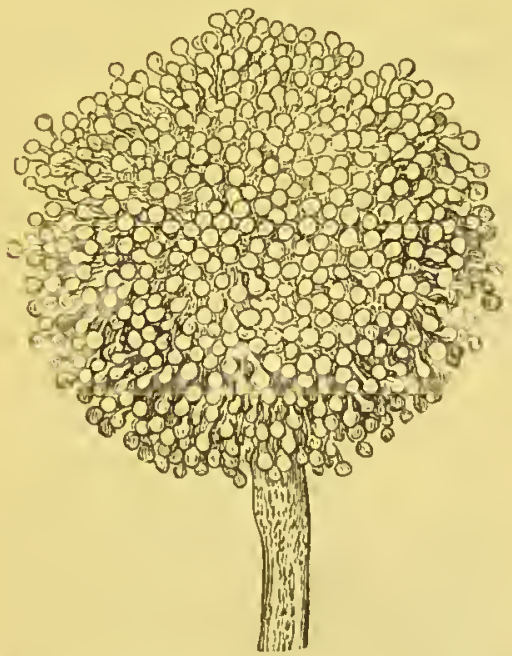

Fig. 10.-Aspergillus flarus $\times 300$. (After Sicbenmam.) the hemisplerical cup. Conidia round, smooth, with single contour, for the most part colourless, $25-3 \mu$ in diamcter. Sclerotia unknown. Thrives best at $37^{3}$ $-40^{\circ} \mathrm{C}$.

Asp. niger.-Dark brown masses. The knob of the fruit hypha completely spherical. Sterigmata 20-100 $\mu$ in lengtl, brauched like a hand. Conidia round, when ripe blackish-brown; diametcr $3 \cdot 5-5 \mu$ Selerotia 
brownish red, of the size of a rape seed. Best temperature $34^{\circ}-35^{\circ} \mathrm{C}$.
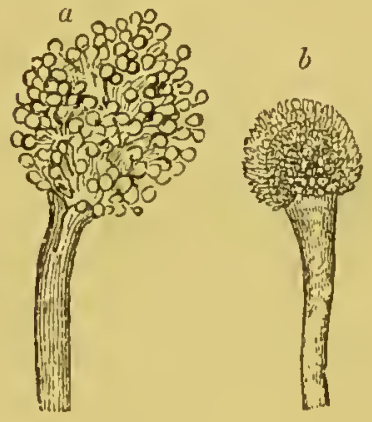

Fig. 11.-Aspergillus fumigatus $\times 300$.

(After Sicbeumann.)

Asp. ochraceus.At first of a flesh colour, later ochre yellow; spherical heads; branched sterigmata.

Asp. albus. - Pure white in all parts; branched sterigmata.

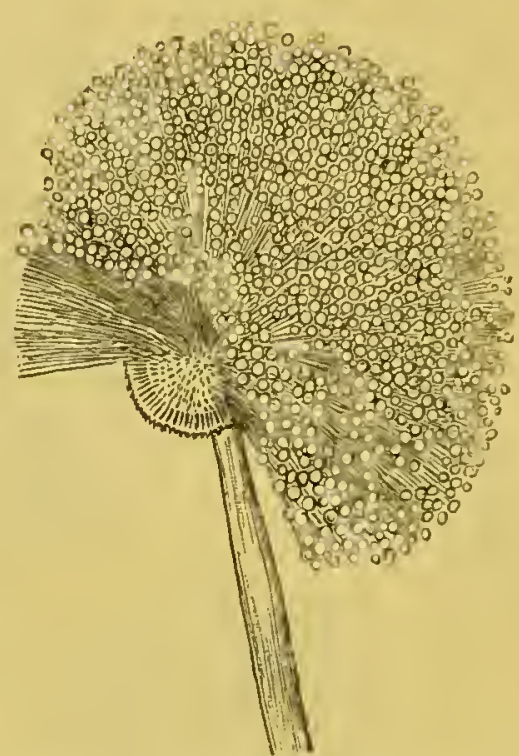

Fig. 12.-Aspergillus niger $\times 300$. (After Siebenmann.)

At the lower part on the left side the sterigmata hare been removed artifieially.

Asp. claratus.-Greenish; club-shaped bladders on rery long and strong fruit hyphæ; very small conidia.

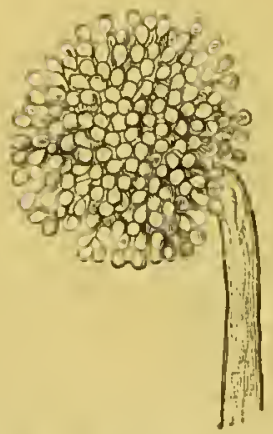

Fig. 13.-Eurotium aspergillns oflaueus $\times 300$. (After Siebenmam.)

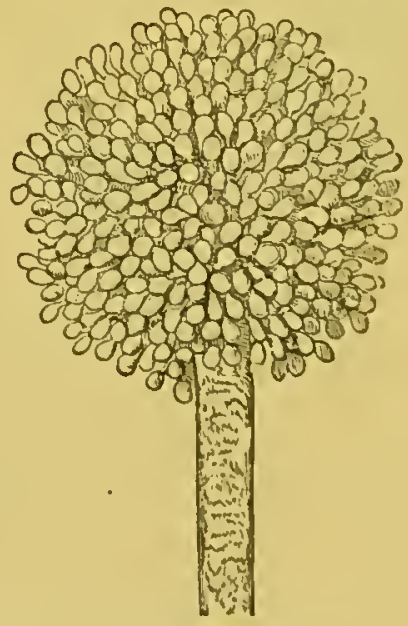

Fig. 14.-Eurotium repens $\times 3$ : 0 . (After Siebenmann.)

The curotium forms possess mycclium and conidia bearers like the true aspergilli. The peritlecia, the 
formation of which corresponds with the general description given abore, appear to the nalsed eyc as brightly refracting, very small, round granules $18-4 \mathrm{~mm}$. in diameter, arising from the aërial mycelium, which is of a sorrel colour in this stage of fructification.

Eurotium aspergillus glaucus. - Bluish-green or jellowish-green; heads regularly round. Conidia round, warty or knobby; $9-15 \mu$ in diameter. It occurs in fruit juice, moist wood, frequently on dimp walls, but only in very cool places-about $10^{\circ}-12^{\circ} \mathrm{C}$.

Eurotium repens.-At first white, ultimately dark green; heads often fringed; conidia oval, smootl, colourless or greyish-green, $5-8.5 \mu$ in largest diamcter. Occurs on preserved fruits, bread, \&c.; the best temperature is $10^{\circ}-15^{\circ} \mathrm{C}$.

The aspergilli have of late cxcited special interest Pathogenic because some of them (Asp. fumigatus, Asp. flarus, properties of and Asp. niger) are able to grow in the bodies of warmblooded animals.

This pathogenic property was first ascertained by Action of studying the result of the injection of mixtures contain- intravenou. ing spores into the blood stream of animals, especially of rabbits. When the number of spores injected was very large the animals died in a few days, and numeroussmall deposits of fungus mycelium which had developed from the sporcs werc found in the intcrnal organs. If smaller quantitics of spores were employed, the animals lived, but if they werc killed after two or three days a small number of mycelial deposits were

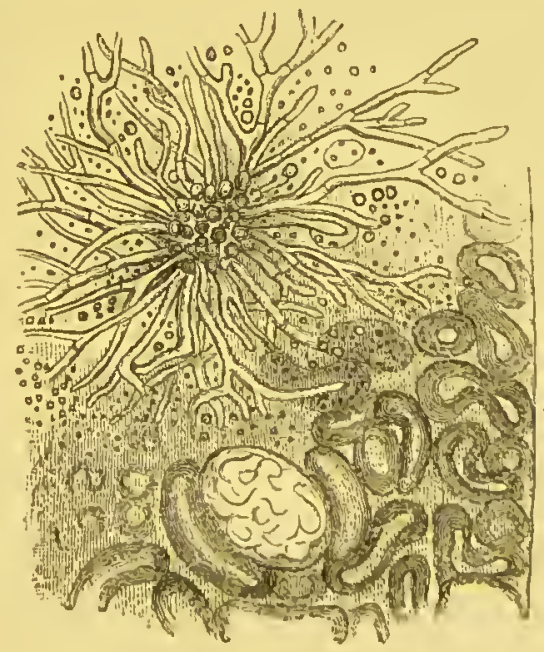

Fig. 15.-Microscopicnl scetion from the kidney of a rabbit killed 36 hours aftor the injection of spores. (After
Grawitz.) found; atlater periods these had disappeared, so that when 
in small numbers they were evidently quickly destroyed and were only able to oceasion the death of the animal when in enormous quantity. The myeelia formed from the spores are not equally distributed in all the organs. The kidneys are attacked by preferenee; then the cardiae and other muscles; at times numerous masses are found in the liver. After the injeetion of the spores of Asp. fnmigatus there are very peeuliar disturbances of equilibrinm, the animals lying on one side with the head placed obliquely, the one cheek looking upwards, the other downwards; the eyes are directed towards the same side. If one attempts to raise the animals from this position they resume it at onee; if one plaees them on the opposite side they remain at first in this position, but soon assume the old posture with violent rotatory movements around the long axis. Liehtheim found that the explanation of these spmptoms was the lucalisation of the fungi in the membranous labyrinth.

Iufectivity of the diffcrent species of aspergillus.

Natural occurrence of aspergillus infection.

In bircts.
The suecess of the infective experiments is most eertain with Asp. fumigatus, and then with Asp. flavus. The spores of Asp. niger do not appear to have by any means such an intensely malignant action; the other speeies of aspergillus and eurotium are on the other hand entirely without effeet, even when injected in large quantities.

It is not only by artifieial infection that gromth of these aspergillus forms is observed in the animal body, a natural infeetion seems to oecnr not uneommonly. Myeotic diseases liave been known for a long time to oceur in the ear passages of birds; in these eases we have to do with the growth of aspergilli. Schütz lias recently demonstrated by exret experiments that the spores of these mould fungi can as a matter of fact set up severe pnenmonie affections. If healthy pigeons, geese, and smaller birds were exposed for only a few luinutes to air eontrining numerous spores of Asp. fumigatus the nuimals died of pueumonia as late as the fifth day afterwards. Numerous mycelial threads were then found in the bronehi, and in the enses where the disease had lasted longest extensire necrosis was present. 
An affection of the air passages also occurred when masses contrining spores were swallowed. The pneumonomycosis aspergillina is caused most often by Asp. fumigatus, more rarely by Asp. niger ; the spores of the latter do not form a luxuriant mycelium, but only germinate imperfectly, while Asp. fumigatus can even fructify in the larger bronchi when there is a plentiful supply of free oxygen to the mycelium. In zoological gardens extensive epidemics of these mycoses hare also been observed. In the case of mammals also, for example in cows, In mammals. similar conditions have beell scen in the lungs, and aspergillus mycelium has been often observed in human sputum and in the bronchi of dead bodies. Hence it is not impossible that the inhalation of similar spores have also occasionally set up pneumonic affections in man.

Deposits of aspergilli have been found on two parts In man. of the surface of the human body. Leber observed, after abrasion of the cormea by an ear of corn, that an abundant development of aspergillus mycelium took place in the cornea accompanied by severe suppurative leratitis. On inoculation of the spores of the fungus cultivated pure in an artificial soil, on the cornea or into the anterior chamber of the eye of rabbits, growth of the fungus occurred. Further, the aspergilli develop not uncommonly in the external auditory meatus; nevertheless only when disensed condilious are already present, such as perforation of the tympanic membrane with degeneration of the wall of the tympanic cavity, and when there is a layer of serum which ean act as a suitable nutritive substratum. In that situation suppurative and putrefactive processes interfere with the derelopment of the aspergilli, while the use of astringent remedies as a rule favours it; the introduction of oil readily sets up eczema, and thus farours tho growth of the fungus, or at any rato of the mycelium, while the formation of conidia is hindered.

It is noteworthy that it is only those aspergilli whose Temperature temperature optimum is high and approaches the body optimum of the temperature, that can grow in the bodies of warm-blooded aspergilli. 
animals. Fränkel* was unable to diminish their pathogenic properties by the continued action of abnormally high temperatures. He cultivated Aspergillus fumigatus for half a year at $51^{\circ}$ C., numerous ro-inoculations being made; under these circumstances the fungus formed only a sterile mycelium, and it was necessary to continue the cultivations from this mycelium. When however it was placed at a temperature of $37^{\circ} \mathrm{C}$., the fungus at once began again to fructify, and the spores formed proved to be as virulent as others cultivated

Distribution of the aspergilli. in the ordinary manner.-All these fungi appear to be very widely distributed in our climate. According to Siebenmann, it is only necessary to expose freshly baked brown bread to the air for a short time, to place it then in a moist chamber and to regulate the temperature at various heights; according to the temperature, it is found that either on the surface or in the interior of the piece of bread one or other form of aspergillus has developed.

\section{Erysiphe ö̈dium.}

Erysiphe forms the mould-like covering on living plants which is known as mildew. Summer and winter spores are developed; the former have the appearance of oval unicellular conidia which are formed by segmentation on single upright fruit hyphr; the winter spores are formed in the peritlecia which arise at a late period on the same mycelium, and they are only able to germinate after a period of repose. The fructification by conidia was formerly described as a separate species of fungus under the name oidium. In the case of some forms of oïdium the corresponding perithecial fructification has not yet been found. Mildew attacks the most various kinds of plants, and the different species of plants have their particular forms of mildew. The plants which are attacked droop and die early. Damp weather in the latter part of summer and autumn and moist situations are favouring conditions.

Silprophytic varictics of ö̈litum.
Two important kinds of oïlium whose perithecia are as yet unknown belong to this group.

* Deutsche med. Hochenschrift, 1885, No. 31. 
Oidium Tuckeri, the fungus of vine disease.-A whitish mildewy layer appears on brownish patehes of the leaves and twigs of the vine, and also attacks the young berrics, whose epidcrmis dies and bursts. The longish round conidia are plaecl singly on the fruit hyphæ.

Oidium lactis.-Fruit hyphæ, single, upright, eolourless; form a terminal chain of spores; at times apparcut formation of branches, the fruit hyphæ growing upwards alongside the terminal chain of spores already formed. Spores short, cylindriform, 0.0077-0.0108 mm. long (fig. 16). Vory widely distributed, forming a whitish mouldy eoating on milk, brcad, dung, \&c. Flourishes lest between $19^{\circ}$ and $33^{\circ} \mathrm{C}$. (Hausen).

In some parasitic slin affections of man development of fungi has becn for a long time observed, and these fungi appear to have a ccrtain resemblance to the mycelium and fructification of oildium. Grawitz has in fact attempted to prove by cultivations that the favus fungus (Achorion Schönleinii), the fungus of Tinea tonsurans (Tricophyton tonsurans), and the fungus of Pityriasis rersicolor (Microsporon furfur) are identical with Oidium lactis. According to Grawitz the conidia of this fungus, when cultivated artificially, form one or several germinating tubes; these soon become segmented and send out lateral branches which clongate by apical growth. The growth ccases often after a very short, often again after a longer time, and segmentation of the threads into conidia begins; these conidir aro

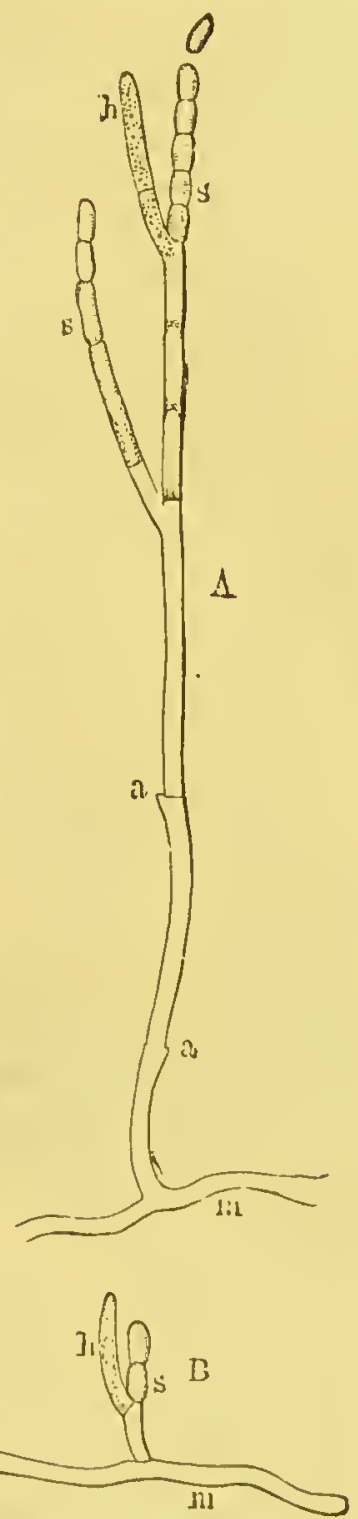

Fig. 16.-Oidium lnetis.

$A$ oldor, $B$ younger, fruit hyphæ. $m$, mycelium : $s$, chains of spores in the neighbourhood of which the fruit hyphe $(h)$ continuo to grow like a laterul branch. $\times 200$.
Oidium as the causo of Favi: and Tinea tonsurans. at first almost cubical cells, but later assumo a longish oval 
form by rounding off of the borders. Certain threads givo off lateral brauches almost at right angles; where the growlh is linxuriant, certain of the lateral branches become large refracting globes, which are cut off, aud are again capable of growth. The mycelium of the

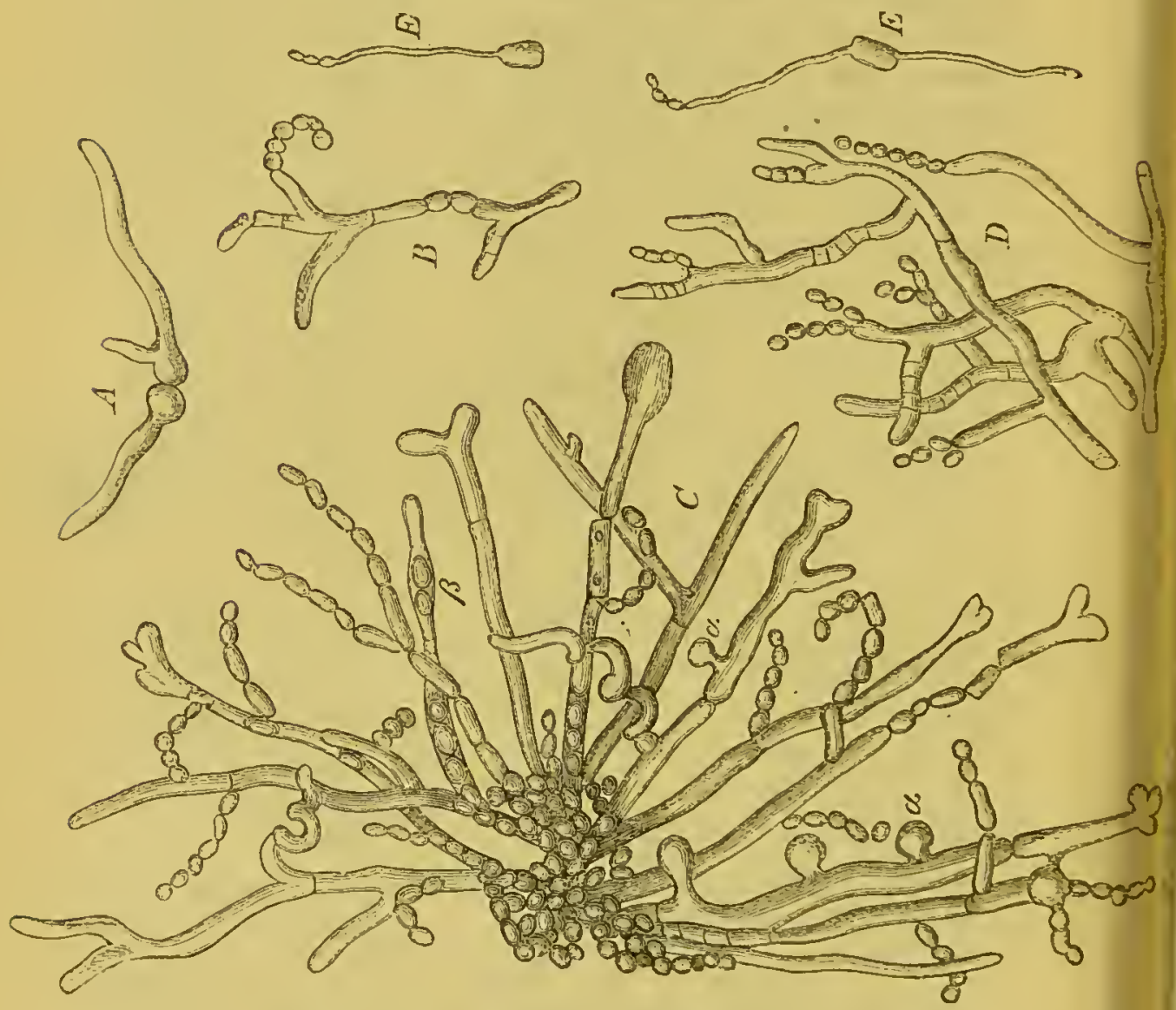

Fig. 17.-Favus and Tinca fungus. (Aftcr Grawitz.)

A. gr rminating tule cultivated in gelatine solıtion.

$b$, I realing up of a germinating tube into single conidia (in concentrated solution).

$C$. fcrmation of fruit; $a$ formation of buds ; $b$, formation of gcmux.

$J$, timen fungns: myeclial threads with fructification.

E: conirlia of Oidlium lactis (in dilute ncid untricnt solution, from which thin germinating tubes sre growing out) $\times 350$.

tinca fungus, sc., is very delicate in comparison with the much thicker conidia of the Oidium lactis growing on milk; but on alteration of the mutrient substratum Grawitz was able to obtain great raricties in this respect, so that, for example, a large conidia sent out a mucl 
more delicate thread, which then gave off a cell of onefourth of the diameter of the original one.

Grawitz's experiments were performed at a time when there were no trustworthy methods of isolating individual fungi from a mixture of organisms, sueh as are usually present on the affected skin, and henee they urgently require repetition with better methods, and the asserted identity is rendered very doubtful by the result of experiments made with other mould fungi. Oidium laetis flourishes only eomparatively imperfeetly at the body temperature, and therefore its parasitie existenee on the surfaee of the body is improbable.

In the lower animals affections occur very similar to Fungus of favus in man, and in these the causal agent has of late $($ fowl scal) been cultivated pure. Such are the fungus of tinea galli grind). and that of the so-called favus of mice. The first has been studied by Schütz; it leads to the formation of whitish grey round patches on the comb and wattles of fowls, which gradually merge together and spread on to the neck, breast, and trunk. By continued cultivation on nutrient jelly Schütz succeeded in obtaining pure from the scales on diseased combs a fungus which forms a white mycelium, gradually liquefies the gelatine and causes it to assume a reddish colour. It grows also on potatoes, bread paste, \&c., and best at a temperature of about $30^{\circ} \mathrm{C}$. Microscopicaliy the mycelium consists of segmented and often branched threads of very various dimensions; not uncommonly these threads show small warty or pedunculated projections; some of the segments are also globular, while others are lying free, and occasionally provided with processes. Again, in some cases fine shoots are seen on the sides of the mycelial threads, these shoots bearing one or two globular greyish coloured bodies. Whether these or the spherical bodies, or neither of them, are to be regarded as spores is as yet uncertain; the position of the fungus is therefore doubtful, and it is only the microscopical similarity of the mycelium and the simple separation of tho cells supposed to be spores that has led to its provisional inclusion among the forms of oidium. Inoculation of pure cultivations of the fungus gave rise to the charac- 
Fungus of mouse furus.

teristic morbid symptoms in fowls; mice, rabbits, and various other animals were not affected.

Mouse favus has been repeatedly studied, and quite recently in the author's laboratory. Nicolaier demonstrated that the disease could be transmitted by the application of scales to patches of the skin of healthy mice previously scraped with a knife and denuded of epidermis. After about eight days a crust is formed about the size of a lentil, whitish yellow, and pitted in the middle; this crust constantly enlarges till it finally comes to occupy the whole forehead and ears, spreads orer the eyes and covers the head of the animal with a
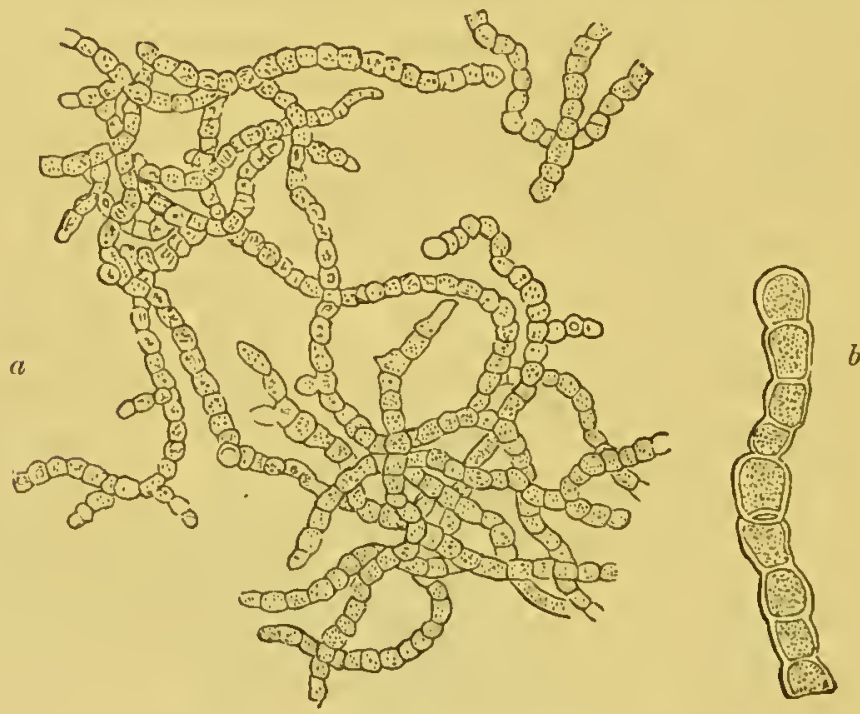

Fig. 18.-Cultivation of Mouse Favus.

$a$, mycelial threads $\times 300 ; b$, a thread more highly magnified $\times 700$.

whitish grey dry mass of a laminated character which forms a thick layer on the slin. Small crusts planted on acid nutrient agar, or on potatoes impregnated with tartaric acid, and kept at $30^{\circ}-35^{\circ} \mathrm{C}$, give rise after repeated recultivations to a pure cultivation of a fungus which forms a thick low mycelium, at first of a pure white colour, with very closely packed, delicate hyphe, so that the whole mass (particularly on potatoes) looks like : crist of sugar. At a later period the surface of the mycelium assumes a red or reddish-brown colour. In microscopical preparations of the farus crusts, or of cul- 
tivations, we see a maze of jointed threads which arc terminated by oval cells somewhat flask-shaped, or in some cases more spherical.

Special spore-bearing hyphæ or distinct spore formation have not as yet been observed. Inoculation of mice with small quantities of cultivations carried through a considerable number of tubes gave rise in all cases to the peculiar disease just described; inoculation of a cock was tried without result.

Cultivations made from human favus furnished appearances on the whole microscopically and macroscopically similar, but not identical; the investigations on this point are not yet concluded. All these three fungi probably belong to one species, and are in some respects closely allied to the oidium fungi, but they appear to differ among themselves as well as from the Oidium lactis, as shown, for example, by the differences in their temperature optima.

The fungus of thrush was formerly deseribed under the name of Oidium albicans, and placed among these fungi. Recent investigations render it, however, probable that the thrush fungus belongs to the yeast fungi.

2. Mucorinex (order: Zygomycetes). Very widely distributed; on putrefying substances they form white or brown patches of mould, which consist of delicate nyycelium and fruit hyphre given off at right angles. At the apex of the latter a globular sporangium is formed, the protoplasm of which breaks up into a large number of spores. The membrane of the sporangium is at first colourless, but later it usually becomes blackish, and when the sporangium is ripe it dissolves in water. Many mucorincre form zygospores by the copulation of two myeclium branches; there is often also a formation of gemma.-Among these we may mention: MIucor saprophytie mucedo. Fruit hyphe colourless, simple or branclied, forme of $1-13 \mathrm{~cm}$. long; sporangia yellowish-brown to black; 

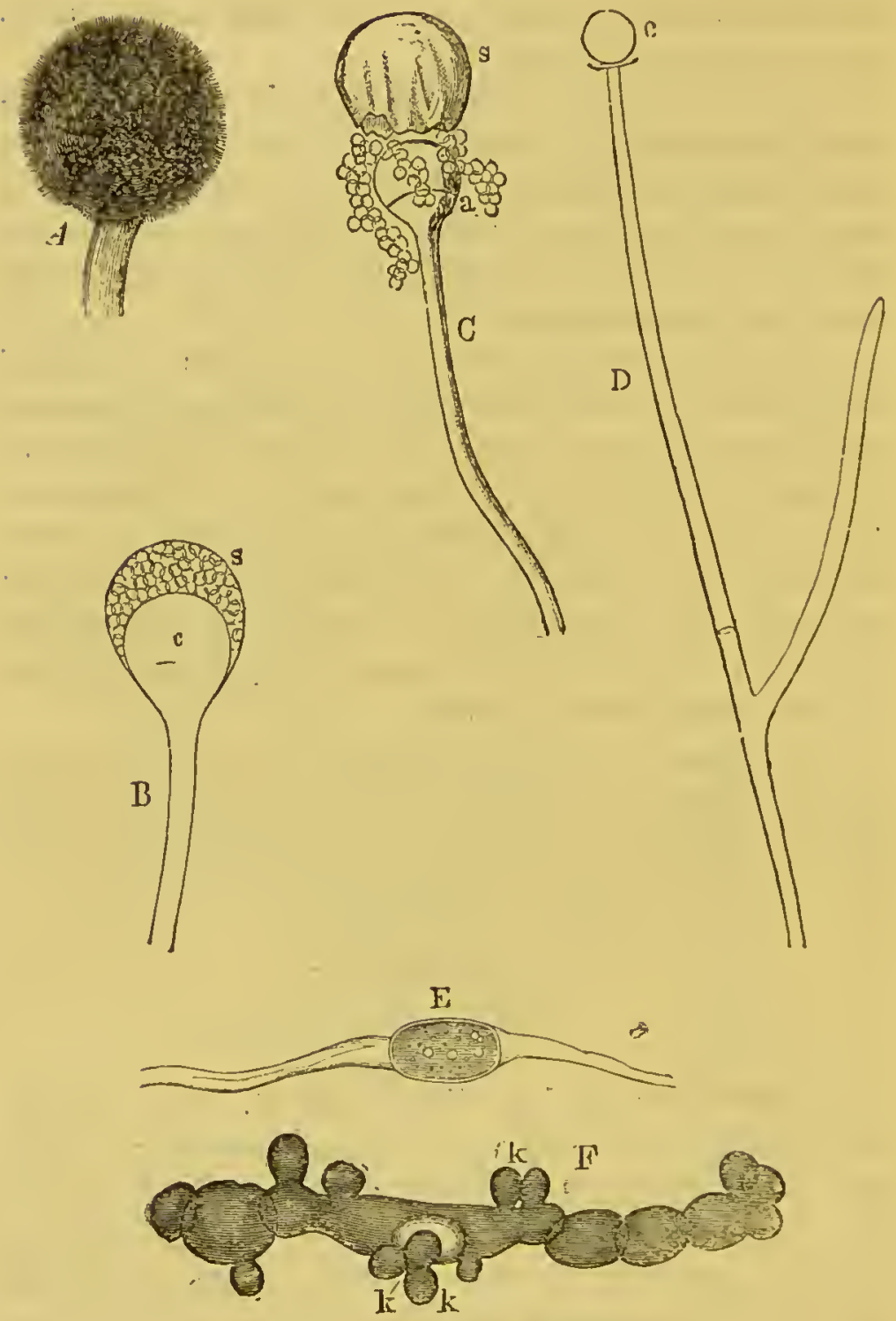

Fig. 19.-MIueor mueedo.

$A$, ripe sporangium.

$B$, the same, represented as transparent; $e$, columella; $s$, the space filled with spores.

- $C$, almost ripe sporangium, the membrano having been remored by artificial pressune.

$D$, fruit hyphn with naked colmmella $(c) \times$ ic.

$E$, an old myeelium thrend which has formed an end eell which lins become converted into a gemmia $\times 350$.

$F$, spore of Mueor rnecmosus which lias sprouted in a sugar sclution. to a gorminating tube, and has formod spherieal ycast-like cel's (li) $\times 350$. 
membrane smodth, or" closely covered witl acicular. cystals of oxalate of lime (fig. 19). Longish spores $(0.008 \mathrm{~mm}$. long, $0.0037 \mathrm{~mm}$. broad). Very widely distributed on all sorts of nitrogenous substances.Mucor racemosus, much more delicatc fruit hyphæ, at most $1.5 \mathrm{~cm}$. long; sporangia yellowish to light brown; spores roundish. Grows extensively on substances rich in carbo-hydrates. When the mycelium is old, or when the spores germinate under water, so-called gemmæ or brood cells (that is to say, pear-shaped swollen spots, which develop thick membranes and a protoplasm rich ill oil) are formed in the hyphæ. - On continued cultiration in saccharine fluids the germinating tubes become constantly shorter, and show yeast-like budding; the spherical segments are termed spherical or segmentation yeast (Kugel- or Gliclerhefe). These spherical yeast cells readily lead to deficiency of oxygen in the nutritive medium, and can then break up any sugar which is present into alcohol and carbonic acid-in other words, set up fermentation. The rising bubbles of carbonic acid usually however carry the yeast cells to the surface, where they again form normal mycelium, so that the setting up of fermentation, and the production of $\mathrm{CO}_{2}$, seem to be the means by which the fungus returns to its normal conditions of life.

Mucor stolonifer.-Mycclium, with branehes rising in arches and again sinking, and attached by root hairs; sporangia deep black and warty; spores brownish, almost spherical, 10-20 mikrom. in diameter; zygospores dark brown.

Further: ML. macrocarpus; M. fusiger ; M. aspergillus; $M$. phycomyces, rare.

M. Melittophtorus.-Found in the stomaeh of becs; eolourless hyphe, with cgg or pcar-shaped sporangia; colourless elliptical sporcs.

Lichtheim has recently discovered two new species of Pathogeni. mucor which exert a pathogenic action:

M. rhizopodiformis. Mycelium at first snow-white, then mousy grey; mycelial threads colourless; brownish mycclial branches rise and sink in an arched manner on the surface of the substratum, giving rise at the point of contact to short branclied rhizoids, with

species of mucor. 
straight pointed brancles which run downwards, and to sporangia benrers which pass upwards, very like M.

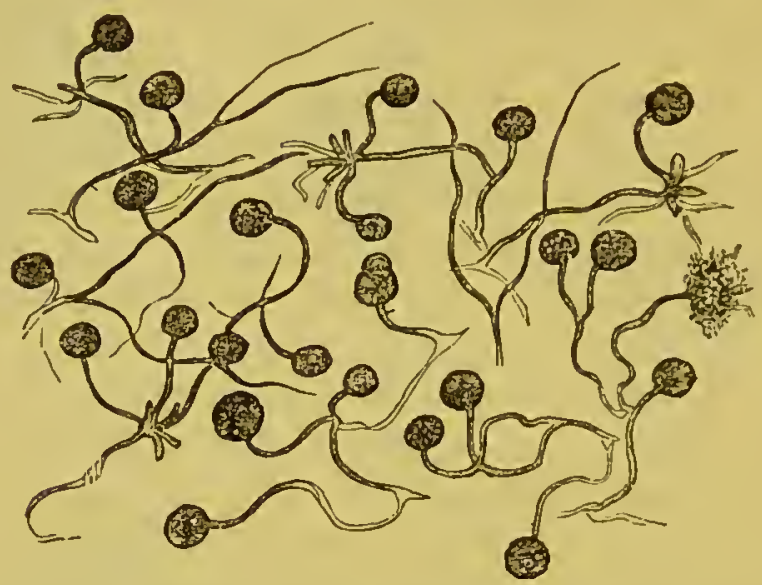

Fig. C01.-Nueor rhizopodiformis. (After Liehtheim.) Zeiss A, eye-pieee 5 .

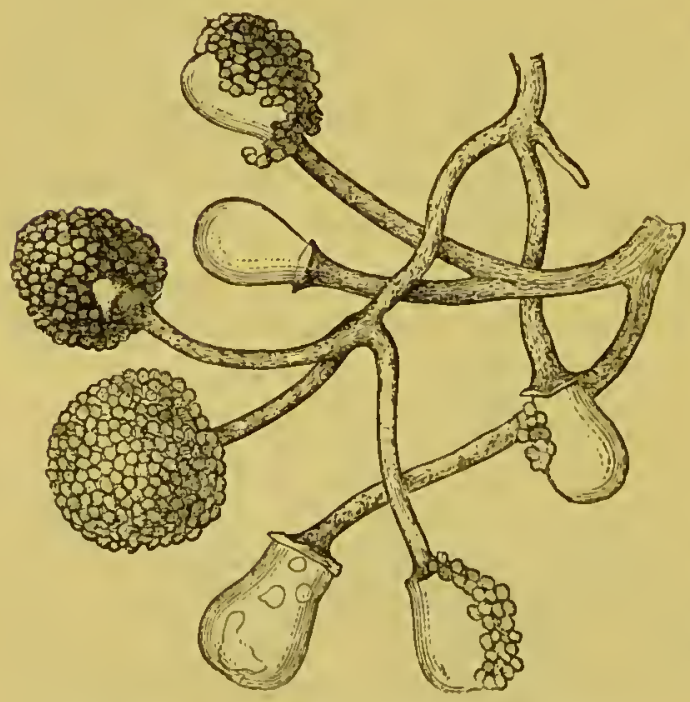

Fig. 20B.-Mueor rhizopodiformis after rupture of the membrane of the sporangium. (After Liehthein.)

Zeiss E, eye-piceo 2. stolonifer, but with shorter sporangial stalks; the egg-shaped columella is arched forwards in a dome-lilic manner, and diminishes in size torrards its base ; spores colourless, and only $5-6 \mu$ in diameter. M. corymbifer.Mycelium whitish grey ; sporangia bearers not passing upwards at right angles, but stretched lengthways, branehed in an umbelliferous manner, and forming at the end of the branclies a number of grape-like, umbelliferous, closely paeked sporangia; the litter are also colourless when ripe, rounded off at their apex, jointed, top-shaped and gradually uarrowing as they pess 
ERYSIPHE OÏDIUM.

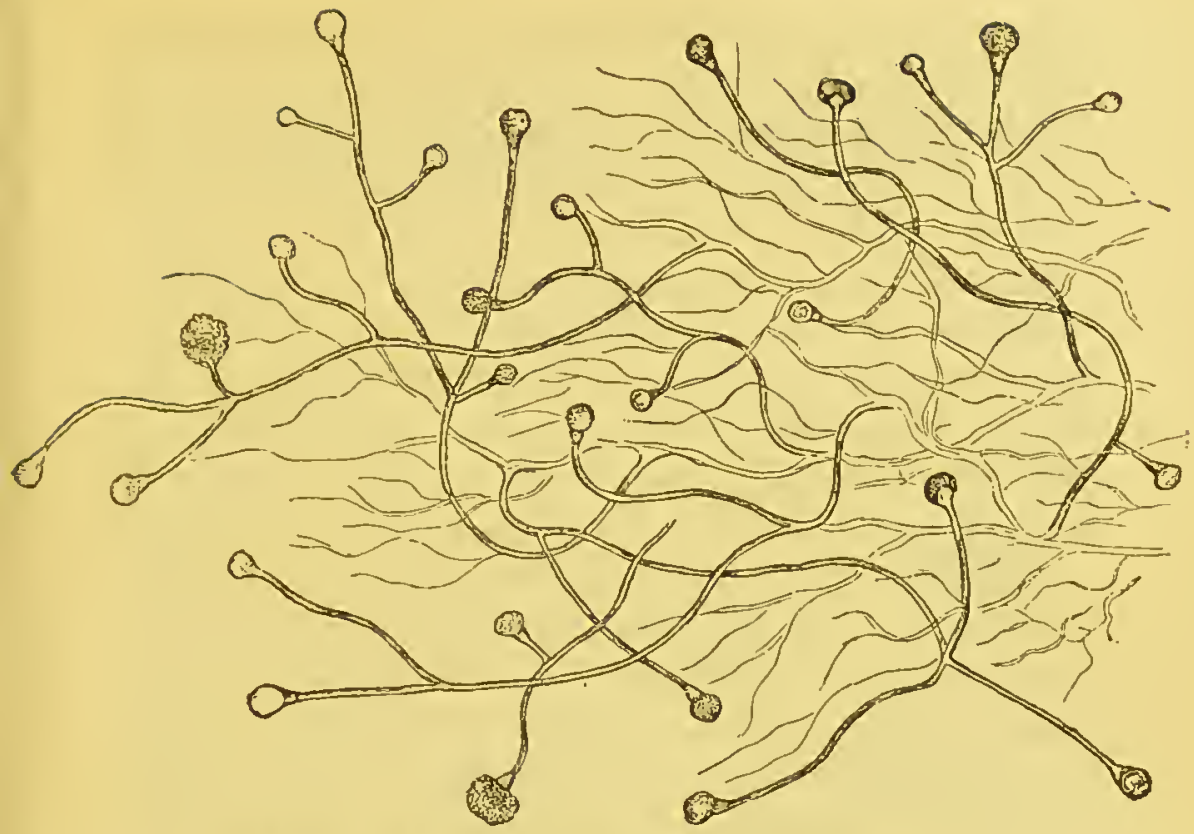

Fig. 21A.-Mucor corymbifer. (After Lichtheim.)

Zeiss C, eye-piece 4.

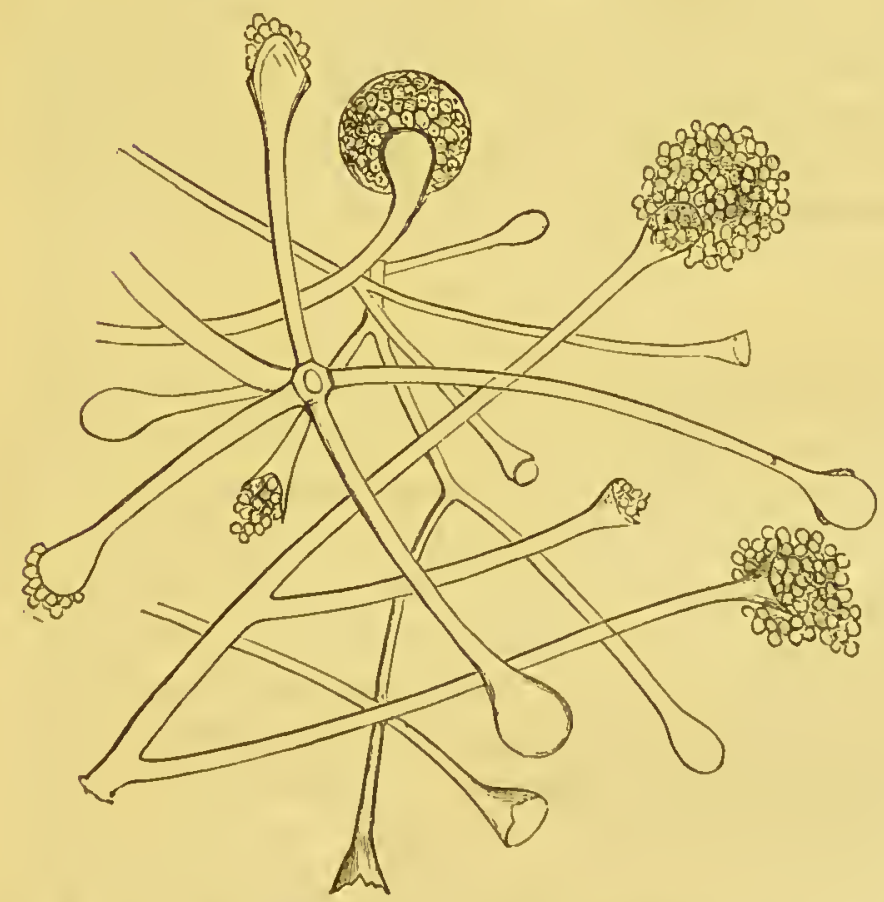

Fig. 21в.-Mncor corymbifer. After rupture of the wall of the sporangium. (After Lichthoim).

Zoiss E, oye-pioco 5. 
into the stalk; spores colourless, very small, longish, $3 \mu$ long, $2 \mu$ broad.

These two forms were obtained from ordinary white bread kept at the body temperature. M. corymbifer was also found by Huickel in a plug in the auditory meatus in man.-When the spores are injected into the blood stream in rabbits, both forms cause the death of these animals after $48-72$ hours, the incubation period lasting 24 hours. On post-mortem examination fungus mycelium is found chiefly in the kidneys, then in the mesenteric glands and in Peyer's patches, more especially in the lower part of the small intestine. The patches show marked swelling and ulceration.-Injections into the peritoneal cavity also give rise to the same symptoms. Dogs are entirely immune, while aspergillus spores produce disense, though only when present in large numbers. It is also noteworthy that of the mucor forms only those can exert a pathogenic action which grow well at the body temperature. On the other hand it is evident that this is not the only or a sufficient condition for the malignant action of mould spores on warm-blooded animals, for M. stolonifer also flourishes well at high temperatures, but the spores of this fungus cultivated at that temperature causc no effect when injected.

'I'lie common poncil mould, Penicillinm grlaneum.
In Aspergillus glaucus, Ö̈dium lactis, Mucor mucedo, and Mucor racemosus, we have four of the most widely spread mould fungi, witl which every one who works with pure cultivations of fission or mould fungi becomes unintentionally acquainted. There is only one fungus which excites even greater interest from this point of view, because it occurs extremely frequently, and is the most common mould fungus : this is the pencil mould, penicillium, which belongs to the tuberacer (order: Ascomycetes).

The higher form of fructification, a kind of truffle, is only observed very rarely, and under special conditions of cultivation. It presents the appearance of a small yellow, sand-like 
protubcrance, and behaves like a thiek-walled sclcrotium, and probably, like the peritheeia, owes its origin to a scxual act. On suitable cultivation an ascus-bcaring fungus grows out of this sclerotium, and the ordinary myeelium and fructifieation eall again be got from the ascospores thus obtaincd.

Otherwise it is only the conidia fructification of penicillium which is observed. The fruit hyphr are segmented and branched like atree, and a whorl of upright branches projects like a pencil from the uppermost cell, each branch bearing either a chain of spores or another whorl of branches, terminating in sporechains. Spores spherical, uni-。 cellular.-Penicilliumglaucum, the most common mould fungus (fig. 22), gives rise to a flocculent mould growth, at first white, but later bluish-green. It grows oll the most various nutritive substrata; it occurs everywhere, and hence its spores very often gain access to cultivations. It does not seem to flourish at high temperatures $\left(38^{\circ}-40^{\circ}\right.$ C. $)$. The diameter of the spores is $0.0035 \mathrm{~mm}$.; that of the liyphre varies according to the food between 0.004 and $0.00071 \mathrm{~mm}$. The very stunted forms are unbranched, and bear only a single chain of conidir; when the development is most luxuriant several fruit hyphi become united to form a thick stem (coremium), at the upper end of which they again separate

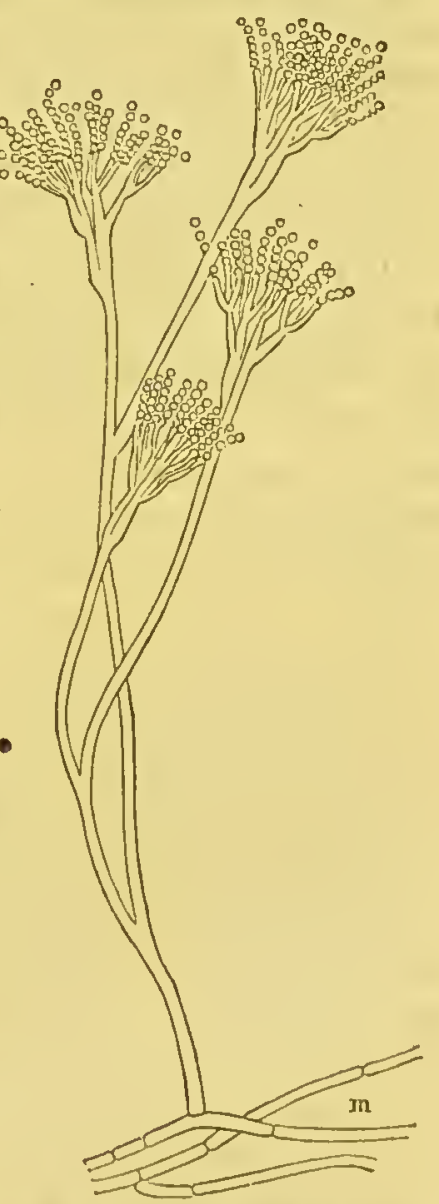

Fig. 22.-Penicillinm glanemu. $m$, mycelial hyplia with a fruit hypha passing mpwards. and form chains of conidia, in the manner described above.

Penicillium spores may be injected into rabbits amel other 
Derelopment animals in large numbers without causing any had effects. by cultivation Aceording to Giawitz, however, malignancy ean be produced properties in by gradual acclimatisation of the mould fungi on fluid alkatino mould fungi. substrata, and at the temperature of the animal body. 'This view rests on an error, for Grawitz evidently worked with a mixture of spores of Asp. flavescens and penicillium: when he cultirstad this mixture at a low temperature $\left(15^{\circ} \mathrm{C}\right.$.) only tho: penieillium, which was quite harmless, grew; when, howerer, ho employed temperatures of $35^{\circ}-37^{\circ} \mathrm{C}$., the luxuriantly growing aspergillus orerpowered the penicillium, which grows only. imperfectly at this temperature, and the aspergillus cultivition, which was quite similar in appearance to the penicillium eultiration grown in the cold, furnislied spores of a malignant nature.

\section{Addendum: Actinomyces, Ray Fungus.}

A Feculiar parasite, the relationship of which was till recently quite doubtful, may find a place here provisionally; I refer to the so-called ray fungus. The disease set up by this fungus is most frequently obserred Morphological in the jaws of cattle. It forms there a whitish tumour, chitracters of t'ie ray fungus. which springs from the alveoli of the molar teeth, or from the spongy tissue of the bone, expands the latter, erodes it, and finally bursts outwards, or in rare cases inwards. The substance of this new formation, which is in the main soft and juicy, shows on section a large number of yellowish, abscess-like foci, from which peculiar bodies are obtained on scraping, about the size of a hemp seed, of a sulphur yellow colour, and with a fatty feel. Similar deposits are found in the pharyns, in the larynx, in the corresponding lymphatic glands, \&c. On closer examination these yellow bodies are found to present a coarsely granular, often mulberry-like appearance, and consist of numerous closely interworeu threads. On slight pressure the round gland-like bodies break up into a number of fungus masses; these are groups of bifurcated threads, like hypha, which, gradually spreading out from the centre, end in club or flask-like swellings (Bollinger). The threads are usually straight, more seldom slightly wary, or even spiral, and they swell more and more towards the periphery. As 
they spread out in all directions from a central point, the resulting structure resembles that of a closely packed bunch of flowers, or of a druse of crystals.

Since more attention has been directed to this peculiar fungus it has been often found, chiefly in cattle and swine. In cattle it causes abscesses in the external soft parts of the head, in the tongue, and in the bones of the jaws. In swine it has been often found in the crypts of the tonsils, without any accompanying morbid appearances. Several cases of actinomycosis of the lung, and some of peritonitis, due to actinomyces, . have also been observed in cows and swine. In some instances indeed actinomycotic diseases have appearcdendemically; thus there was an endemic in Denmark, which attacked 30 cattle on one farm. In this case the only thing

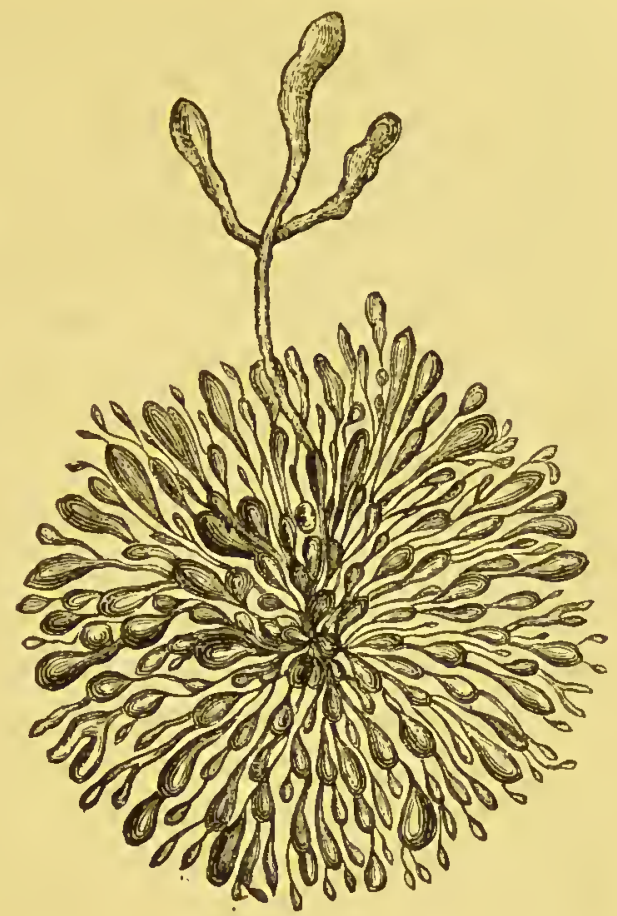

Oeenrence of the ray fungur:

Fig. 23.-Druse of actinomyces (ray fungus) with an isolated branched thread passing upwards. (After Ponfick.)

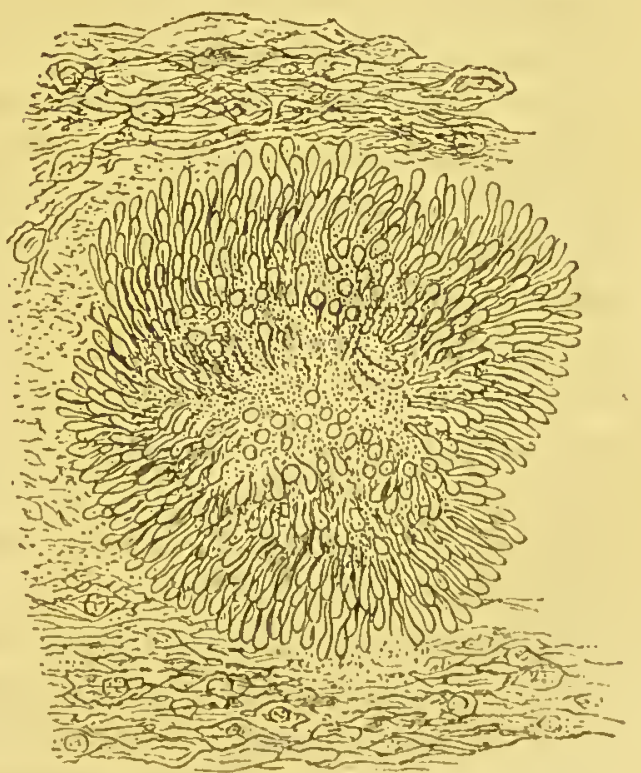

Fig. 24.-Actinomyces druse. Section from a tumour $\times 300$. 
that could be suspected as a common source of the disease was fodder obtained from a newly tilled field (Bang).Duncker has also found bodies in pork similar to the ray fungus, which however are not, according to Jolne, identical with actinomyces.

Occurrence in Masses of actinomyces have been at times observed $n$ man.

the crypts of the tonsils in man, but here also without any morbid symptoms. Also in various affections accompanied by suppuration, such as abscesses in the neighbourhood of the jaw, in concretions in the lachrymal duct, in severe suppurations which present the clinical picture of a prevertebral phlegmon, or of a peripleuritis with suppuration and metastasis, or of a chronic pyæmia. Lately also five cases of peritonitis of actinomycotic origin (per. chronica, parametritis, perityphlitis) have been described by Zemann. In the latter affections the usual point of entrance must be the intestine, in the wall of which fresh nodules and scars can be found, or at times also the Fallopian tubes and the genital apparatus; in the case of actinomycosis localised on the face and neck, carious tecth, injuries to the jaw, inflammatory processes in the pharynx and tonsils, \&c., predispose to the affection. In all the above mentioned cases, different as they were in their clinical picture, the same masses of actinomyces could always be demonstrated in the pus.

'Transmission to animals.

That the fungus is in reality the exciting agent of the disease is rendered much more certain by the inoculation experiments which have been pcrformed with isolated and carefully purified actinomyces masses. The disense has in several instances been reproduced in calves, by introduction of the graius into the subcutaneous tissue, but fecding the animals with them has had no result. Dogs appear to be insusceptible to the discase ; rabbits have recently becn successfully inoculated in the peritoneal cavity by Isracl.

Former cultivation expcriinents.

Repeated attempts have been made to cultivate the fungus, first by Harz, then by Johne, and then by Israel on solidified blood serum, whicll was intentionally made of soft cousistencc. The results of these cultivation experiments agree but little with each other, and 
these authors do not appear to have succeeded in cultivating the fungus on artificial substrata through a long serics of generations. Hence we wcre up till recently entirely without any guide as to the place occupied by the ray fungus in the regetable kingdom. Lichtheim observed in his investigations on aspergillus and mucor that a stunted mycelium, closely resembling the ray fungus, was at times formed in the animal body; and this was the only fact, though in truth a very feeble one, on which a relation of actinomyces with the mould fungi was provisionally based.

Lately Boström has made a preliminary communica- Boström's tion, from which we seem to be approaching an elucidation of the behaviour of the ray fungus in cultivations, and of its place in the vegetable world. Boström employed for his cultivation experiments not the refracting, club-like processes, which cannot be cultivated, but the central network. The grains were placed in gelatine, which was poured out on plates; the slow growth of the mass in the gelatine was not however awaited, but after a feir days the grains which had remained free from contamination were taken out of the gelatine, crushed between glass plates, and then employed for stroke inoculations on ox blood serum and agar. These strokes soon acquire a finely granular, whitish appearance, having become in the first two days broader and thicker; then there appear in the centre small yellowish red nodular patches, the border's of which are occupied by extremely delicate, branched processes, growing from the line of inoculation at definite distances. These yellowish red masses become gradually conflueut, and covered with a delicate downy white layer; at the periphery similar masses are subsequently formed. The cultures require seven to eight days for this stage. The temperature optimum is between $33^{\circ}$ and $37^{\circ} \mathrm{C}$. The gelatine is not liquefied by the actinomyces. The inoculation of such cultivations on various anima?s las been repentedly carried out with positive results by Boström.

Microscopically the cultivations show in the first tw days threads with true dichotomous brnnching. At 
first they are segmented at wide intervals, the scgments afterwards become shorter, and when the yellowish red masses appear in the cultivations numerous very short rods and some more coccus-lilie structnres are found lying free and mostly surrounded by a membrane. In the deeper layers, and on those places where the nutritive soil is exhausted, the well known club-shaped swellings appear in connection with the colonies.

According to these results the actinomyces does not belong to the mould fungi, but to the fission algæ, and must be looked on as a branched species of cladothrix. The place here assigned to the ray fungus is therefore a provisional one, and can only be maintained till the publication of more detailed and confirmatory communications.

\section{The Mycetozon.}

'The mycetozoa, which are as yet but little knomn, include the myxomycetes, or slimy fungi, the acrasia, and the monadina. It is very difficult to define with certainty the place of the mycetozoa in the vegetable lingdom on account of their morphological and biological peculiarities; they are classified among the fungi because they form reproductive orgaus, which resemble fungus spores; on the other hand the division of the monadina, more especially, is placed by some botanists in the animal world, usually among the rhizopoda, with which they show many resemblances.

Morphology and ilevelop. ment of the myxomycetes.

The myxomycetes have no mycelium; in the young state they form naked protoplasmic bodies, plasmodia, of a slimy consistence and of variable form. At the period of fructification they become converted into sporangia, in which spores are developed by the formation of cells. When germination occurs, movable swarming bodies are developed from the spores, and by the fusion of large numbers of these bodies a plasmodium is again formed. The plasmodin form for the most part brightly coloured voluminous masses, which derelop on putrefying vegctable substratr, on trunlis of trees, \&c.; they often 
flow upwards to higher levels, and send out and again witludraw simple or branched processes. Under favourable conditions of moisture groups of sporangia are formed from the plasmodia with considerable rapidity, presenting the appearance of large pedunculated or sessile bladders, only a few millimeters in size. The spores fill the interior of the ripe sporangium in the form of a dusty powder; they are simple roundish cells, with a coloured membrane; when they germinate they do not send out a germinating tube, but the protoplasm passes out of the spore membrane in the form of

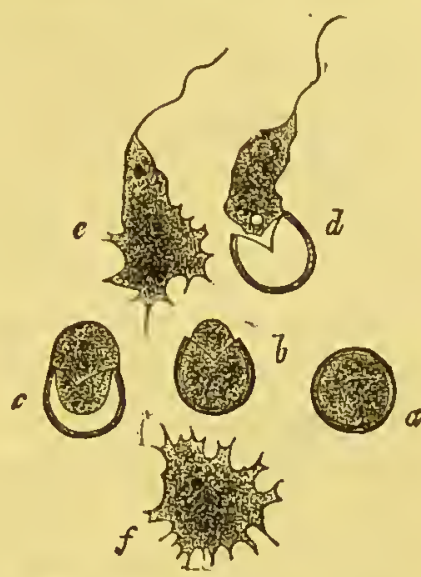

Fig. 25. - Spores of a myxomycetes (trichia varia). $a$, not as yet germinated. $a$ to $f$, gradual extrusion of the amoeboid swarming body. (After de Bary.)

swarming spores, which are round or egg-shaped bodies, with a swinging cilium at their anterior end; at this end of the swarming spore lies a cell nucleus, while the other part contains one or two vacuoles, which alternately contract and dilate, and contain watery fluid. The swarming spores sometimes swim freely, rotation round the axis and side to side movements being caused by the activity of the cilium; at other times they creep like amœbæ, protoplasmic processes being sent out and retracted. The swarming spores multiply by segmentation; they finally unite together in constantly increasing numbers, and thus form again a plasmodium.

The acrasia differ from the myxomycetes only in that The ncrasie. the swarming spores do not fuse together to form plasmodia, but become closely aggregated and then each forms a spore.

'The monadina, or the lower mycetozoa, form swarming The monndinit. spores, amœbx, plasmodia, and spores in the samo way as the higher mycetozoa; they are distinguished chiefly by the fact that the result of the differentiation of the plasma in the sporangia is the production of reproductive cells in the form of mobile swarming spores or amœbr; 
Parasitic mycetozoa. the monadina thus form so-called zoocysts in contrast to the'sporocysts in which resting spores develop (Zopf).

The more highly organised mycetozoa obtain their nourishment entirely from dead organic materials, chiefly vegetable, more rarely animal. A large amount of moisture is a necessary condition for their development.-The lower mycetozoa, on the other hand, play an important part as parasites. They chiefly attack aquatic 1lants, alga, fungi, \&c., and in consequence of their rapid development and the ease with which their germs can spread the diseases of the algr caused by them have often an epidemic character. But they seem also to be able to act as parasites on higher plants as well as in the animal body. Animals which seek their food in marsh water and in mud seem to be most readily affected. In the intestine of man also amoba have been found, but their characteristics are not accurately known. It is therefore very readily conceivable that the monadina, which it would be very difficult to recognise in the animal body, may deserve marked attention from a hygienic standpoint on account of their rôle as infective agents.

For the prescnt only 2 monadina need be specially mentioned.

1. Plasmiodophora brassicx.-This organism lires as a parasitc in the roots of cruciferæ, especially in certain rarieties of cabbage, and causes marked swelling at the part. Large cells with amoboid movements are found in the markedly cnlarged cells of the roots, thesc ultimately becomc motionless and divide into a large number of spores, without previously forning a special membranc. A ciliatcd swarming spore escapes from the spore into the water, and erchtually penctrates through the young epidermis of the root into i new host.

2. Haplococcus reticulatus.-This organism has been frequently found by Zopf in the muscles of swine. It forms zoocysts $16-22 \mu$ in diameter, almost spherical, with smooth nombranes. In these $6-15$ amobe are formed at the period of ripening, and these pass ont of thin and ultimately completely gelatinous places in the membranc. "Thie spores hare the form of spheres, or tetraliedra, with mnrkedly rounded surfaces and border's, and a diameter of $25-30 \mu$; on the surface there arc of ten band-like elevations. In the contents of the ripe spore there is a large drop of reserve plasma. The mode of sprout- 
ing of the sporcs and the further behaviour of the amoba have yet to be asccrtained.-Flesh, in which the parasites are present in large numbers, presents a perfectly healthy appearanee; the museular fibres seem only pressed together, or pushed out of their position here and there by the parnsitic deposits. Nor is anything abnormal observed in the living swine. The distribution of the fungus, which is probably taken up with the food, seems to be very widc; Zopf found that 25-72 per eent. of the swine examined were affected. For further details as to myeetozoa sce Zopf and dc Bary.*

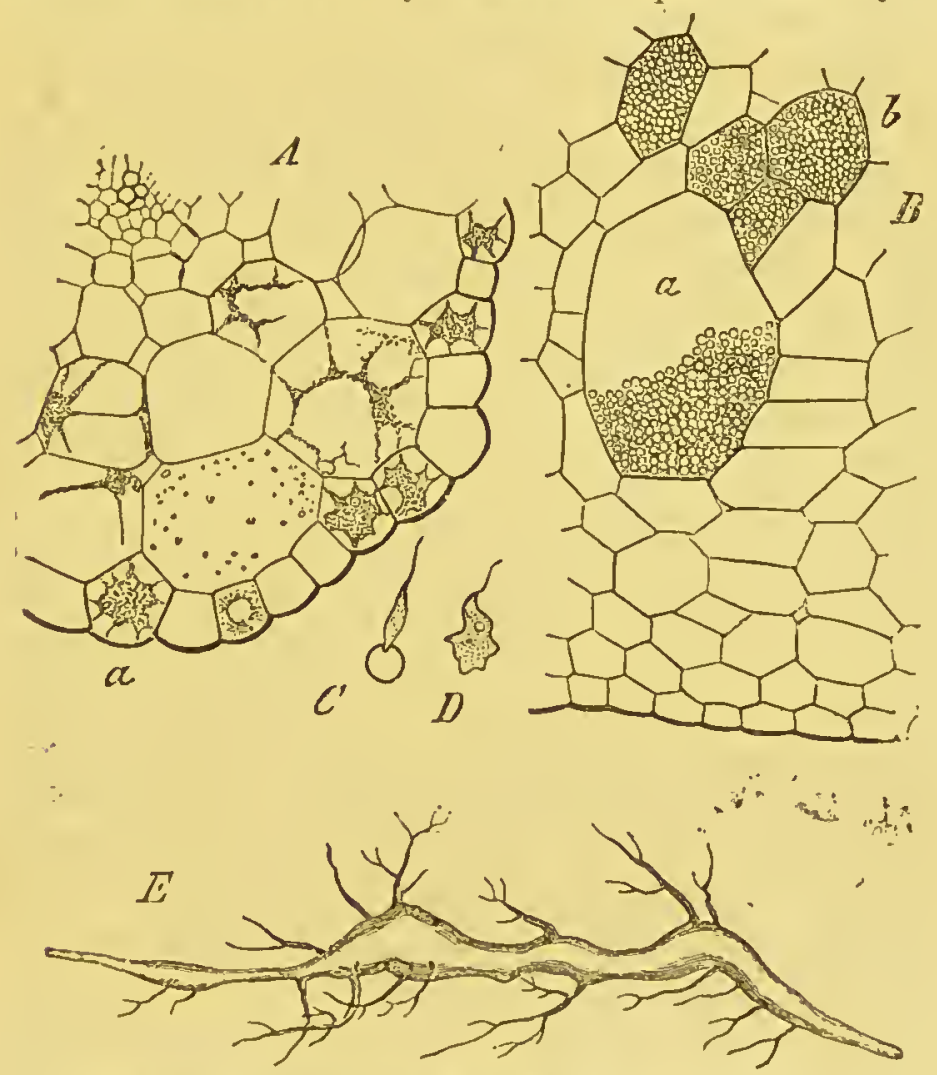

Fig. 26.-Plasmiodophora brassica. (Aftor Zopf.)

A. $\times 90$. Transverse section through a young root of a cabbage seedling. In the epidermic cells $(a)$ amoboid or plasmodia-like condition
of the parasito. $B$, $\times 90$. Section through the laminn of $\Omega$ eabbago leaf; cells $(a, b)$

is a sporo which is just emitting its swarming spore $\times 600$.

$n$, awarming spores becoming transformed in to amoba $\times 600$.

$E$, portion of the root of a young ennliflower whiel shows swellings
caused by the parasite. Natural sizo.

* Zopf, Die Pilzthiere oder Schleimpilze, Broslan, 1885. "Ucber Haplococeus reticulatus," Biolog. C'entralblatt, 1884, No. 22. "Ueber Plasmiodophora ": Woronin, Pringshoim's Jahrb., xi., p. 548. Soo nlso, de Bary, Sorph. u. Biologie der Pil:e; Mycelozoen u. Bakterien. Loipzig, 


\section{The Yeasti on Budding Fungi.}

A common characteristic of all forms of budding fungi is that they consist of microscopical cells which multiply by budding, the cell membrane bulging out like a bladder at one or both ends of the cell, this projection becoming filled with a part of the contents of the mother cell, gradually assuming the same size and form, and finally becoming separated from the mother cell by a transverse division at the point of attachment of the bud.

Torulagrowth in mould fungi.

Bulding fungi iroper.
A similar yeast-like mode of growth is seen in a number of fungi which under other conditions assume quite different developmental forms. This is the case in Exoascus taphrina, where as a rule asci, arranged side by side in a palisade-like manner, are formed from a thread-like mycelium; the ascospores expelled when ripe germinate in water or in nutritive solutions, and grow by typical and often repeated budding. This is also the case with Mucor racemosus when it is cultivated below the surface of saccharine fluids (see p. 133); also with Exobasidium, a family belonging to the hymenomycetes, in which the spores developed from basidia send out yeast-like buds when they germinate. According to Zopf fumago behaves similarly; and so, according to de Bary, does Dematium pullulans, which probably belongs to fumago or pleospora; and this also occur's, according to Brefeld's most recent investigations, in the tremellini and ustilagineæ (see p. 109).

This mode of growth by budding is specially developed in a class of fungi, which are termed, therefore, budding or yerst fungi. To this class belong the ordinary yeasts, the vinegar plant, and the fungus of thrush. It is probable that they must all be classed among the lower ascomycetes, and are most nearly allied to the species exoascus, mentioned above; at least in some typical yeast fungi a form of fructification has been found in which spores are formed witlin the cells corresponding cxactly to the process linown in connection with asci. In the cas s of other yeast fungi this higher form of 
fructification has not yet been observed; nevertlieless the position above indicated may be assigned to the whole class of the yeast fungi.*

Many of the yeast fungi excite fermentation, and are able to set up alcoholic fermentation in saccharine solutions. Nevertheless there are typical budding fungi, such as the pink torula, \&c., which are not able to set up fermentation; and on the other hand the yeast-like developmental forms of micor, and of other of the above mentioned higher fungi, have a certain though restricted power of exciting fermentation.

The peculial mode of multiplication of the yeast fungi Mrultiplicagroes on to an almost unlimited extent so long as all budding. the conditions of existence are favourable; the new formed cells which arise by budding derelop fresh daughter cells which either soon become separated and continue to grow as independent individuals, or lemain united to the mother cell for a time, and thus give rise to chains and masses. The cells have a spherical or oval form, are surrounded by a thin colourless membrane, and contain a granular protoplasm, in which are vacuoles filled with cell juice.

By a special mode of cultivation it is possible to By spore. furobtain multiplication by ascospores in various forms of mation. yeast (beer and wine yeast, mycoderma of wine). If the yeast is cultivated, after being washed and freed from adhering wort, on solid moist soil which provides little nourishment, e.g., on slices of potato or carrot, two or more round sells appear within the mother cell by free cell formation just as in spore tubes, these young cells being surrounded by a thick membrane and becoming free after some time by solution of the wall of the mother cell; in other cases the cell contents contract so as to form a single spherical body. The spores thus formed germinate in sugar solution, and develop in the form of ordinary yeast.

At times a tendency to form mycelial threads is Formntion of obscrved. If the jeast is cultivated on the surface of mycelinl

* De Bary l. c., p. 232. Compne the contrary views of Brefold in Botan. Untersuchungen über Herepilze. Leipzig, 1 38?. 
solid substances witl frec entrance of air the jeast-lik buds lose their distinctness, the strangulations become less deep, and the whole cliain takes on more the form of an elongated lyypha-like cell with thicker and thinncr places. The cellular chain then represents a mycelial hypha with the apical growth periodically interrupted, lut we never find the formation of a complete mycclium consisting of true hyplix, or of typical fruit-bearing hyphæ. A marked formation of threads was observed by Grawitz in the cells of mycoderma vini, and the less the amount of sugar present in the nutritive fluid the longer were the threads that were formed; but constriction of the apex or a subsequent segmentation were never noticed.

Pasteur': torule.

Pastenr and Hansen deseribe under the name of tornla a group of yeast fungi which do not form aseospores or myeelial threads even on the most various solid substrata. but multiply only by budding as in saceharine fluids. They also oeension very slight or 110 alcoholic fermentation in these fluids, nor do they lead to the formation of a seum on the surfaee. These torulx, of which Hansen deseribes fire different kinds, are in some places rery widely distributed. and ean easily be eonfused with true yeast, beeause a morphologieal distinetion between the two budding forms is not possible. With regard to these torula it is most probable that they are only derelopmeut stages of other fungi.

It has not as yet becn possible to distinguish in a satisfactory manner between the differcnt linds of yeast fungi by morphological and biological characters, because there was no method of cultiration by which we could isolate them, and thus obtain with certaintr a pure cultivation of the individual forms. It is only latcly that such a separation and classification has becn attempted by Hansen and other investigators, but up to the present these attempts lave not been sufficiently satisfactory to bo of use for a handbook. Of the species formerly distinguished from one another, the following may be mentioned here:-

The most im- Saccharomyces cererisice (Cryptococcus cer.), the portant kinds yeast of becr or brandy. Cells splerical or oral, $8-9$
of yeast. 
$\mu^{*}$ in length, single or witl branches composed of short chains. Three or four spores in the mother cell, $-1-5 \mu$ in diameter. Employed in the brewing of becr ; in the low fermentation which goes on slowly between $4^{\circ}$ and $10^{\circ} \mathrm{C}$., the yeast is deposited at the bottom of the vessel (unter-hefe), and the cells are for the most part single, or united in small numbers. In the high fermentation, which takes place between $14^{\circ}$ and $18^{\circ} \mathrm{C}$., the stream of carbonic acid carries up the yeast to the
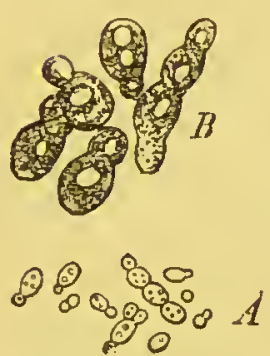

Fig. 27.-Saecharomyces ecrevisire (yeast).

A. slightly enlarged.

$B$, low yerst highly magnified.

c', upper ycast highly magnified.
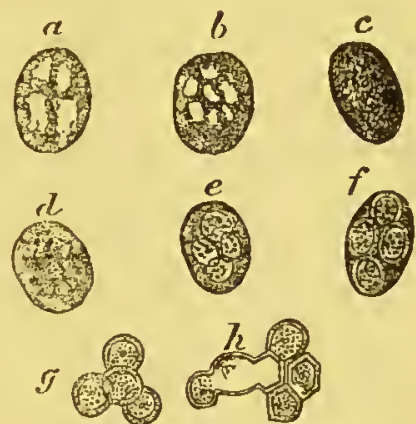

Fig. 28.-Sporc formation in saccharomyces cerevisix. (After Rees.)

$a, b$, eells with several vacuoles. c, cell with uniform granular contents.

d, four plasma portions.

$e$, young spores arising from these.

$i$, the same with double eontours.

\%, frec spores after solution of the membrane.

$h$, commencing sprouting of the spores.

surface of the fluid, and this upper yeast (ober-hefe) contrins branched bands composed of several buds. - The uppcr yeast is employed in haking to raise the dougly; it further serves for the formation of the compressed reast. - On plates of nutrient gelatine the colonies form after two days small white points, so long as they are beneath the surfacc; as soon as they reach the surface they for'm somewhat more cxtensive white drops, or dry masses. Under a low power the colonics appear yellowish-grey in colour, and with a rougl contour, like

\footnotetext{
* The mark $\mu$, which is much nsed in the following pages, significs
} n micromillimeter $=0.001$ of a millimeter. 
mulberries or bramble berries; here and there we see irregular processes which look like fine knotted strings. Under a somewhat higher power it is evident that these colonies are composed of a number of individual cells. In test tube cultivations they grow similarly and morc luxuriantly on the surface than in the substance of the jelly, and send out relatively thick processes.

Sacch. ellipsoideus, wine yeast. Cells elliptical, as a rulc $6 \mu$ in length, single or in short-branched chains; usually 2 to 4 spores in a mother cell, 3 to $3 \frac{1}{2} \mu$ in diameter.-This is the chief fungus of spontaneous fermentations, especially of the fermentation of wine juice, hence it is present crerywhere.-Sacch. conglomeratus. Cells round, bound together to form balls. It occurs on decomposing grapes, and at the commencement of the vinous fermentation.-S. cxiguus. Cells conical or circular, $5 \mu$ long, up to $2 \cdot 5 \mu$ thick. It appears in beer ycast during the after fermentation.S. pastorianus. Cells oval or club-shaped. The colonies consist of primary club-shaped joints 18 to $22 \mu$ in length, which form secondary lateral roundish or oval daughter cells 5 to $6 \mu$ in length. It forms 2 to 4 spores. It occurs in the after fermentation of winc and cider, and in the fermentation of beer.-S. apiculatus. Cells citron-shaped, with short points at each end, 6 to $8 \mu$ in length, 2 to $3 \mu$ in breadth; its buds are only at the pointed cnds. Seldom united in colonies. Spores unknown. Occurs along with other forms of yeast in various spontancous fermentations. -S. sphcericus. The basal cells of the colony are oblong or cylindrical, 10 to $15 \mu$ in length, $5 \mu$ in breadth; the other cells arc spherical, 5 to $6 \mu$ in diameter, unitcd in branched families. Spores unlinown.

Sacch. mycoderma (Mycoderma cercvisix et rini, Kahmpilz). Cells oral, clliptical, or cylindrical, 6 to $7 \mu$ long, 2 to $3 \mu$ thick; form chains with numerous branches. The sporc-forming cells may be as long as $20 \mu ; 1-4$ spores in every mother cell. Forms a scum on fermenting fluids, and grows on the surface without 
exciting fermentation; it is found especially on wine, then on beer, juice of firuits, sauerkraut, \&c.

Formerly it was supposed that this organism caused acetic fermentation in fermented fluids; but according to Nägeli the relation of the fungus to acetic fermentation is not a causal one. It is found especially on the surfacc of markedly acid fluids, e.g., wine poor in alcohol; in that case it occasions no formation of acetic acid, the latter is due rather to specific fission fungi, which, howerer, cannot regetate in markedly acid fluids. This fungus acts in the first place like a covering of mould, it lcads to the combustion of the acid, and diminution of the amount of acid in the fluid. Thus it prcpares the soil for the reception and multiplication of the fission fungus which produces acetic acid; the occurrence of this scum is therefore a necessary preparation for the acetic fermentation. Nägeli distinguishes the following scums on fermented fluids: 1. Acetic mother (Essigmutter), a rery thick, tough, glue-like scum, with a smooth surface; oxidises the alcohol to acctic acid, consists of bacteria= Mycoderma aceti. 2. Acetic skin (Essighäutchen), thin, slimy, smooth, or finely wrinkled, oxidises the alcohol to acetic acid, consists of bacteria = Mycoderma cerevisia. 3. Mesenteric skin (Kahmhcutt, Gekrösehaut), comparatively Composition strong and firm, folded like the mescntery, consists of yeast of the fungi (Saccharomyces mesentericus), which destroy the fruit acids. At a later period the acetic fungus (bactcrium) appcars in the matcrial, and oxidises the alcohol to acetic acid = Mycoderma vini. 4. Smooth skin (Fulsche Kahmhaut, Glatthaut), comparatively strong, but without folds, of a loosely grnular composition, consists of yeast fungi, docs not destroy the fruit acids to any marked extcnt, and docs not permit the rcetic fungus to settle in the fluid. 5. Acctic ether skin (Essigätherhautchen), thin, not folded. Composed of yeast fungi (Sacchrromyces sphæricus) and of bacteria (acetic fungus), the combined action of which converts a part: of the sugar into acetic ether.-The acetic mother and acctic skin are formed on alcoholic fluids, which contain few fruit acids, but on the other hand may contain a good deal of acctic acid; for example, on beer, on vincgar, to which winc or beer is added, seldom on slightly acid winc. 'The other' skins, on the other hand, appear constantly on fluids which contain a certain quantity of fruit acids, the mesenteric skin on fermented wine juice and other fruit juices, the smooth skin at times on similar fluids which are altered by the addition of sugar and other materials.-Nore reccit investigations by Hansen on the incmbrancs occurring on 
beer have giren the following results: if the surface is grey and dull, Saccl. mycoderma is cxclusivcly or chiefly prescnt. and numcrous air bubbles appear between the groups of cells; if the surface is glistening and slimy, the membranc consists of microbactcria, and the fluid is then muddy and discolour'ed. Under a membrane consisting exclusivcly of Mycoderma aceti, Mycoderma Pasteurianum (sce description of both among the bactcria), or Saccl. mycoderma, the fluid is always clcar and unaltercd in colour. A temperature between $30^{\circ}$ and $34^{\circ}$ C. is particularly farourable for Myc. aceti and Pastcurianum. Sacch. mycoderma grows best at $15^{\circ} \mathrm{C}$., at higher tempcratures it is difficult for it to hold its own against the bactcria; above $26^{\circ} \mathrm{C}$. this becomes practically impossiblc.

If this fungus is compelled to regetate beneath tho surface of fluids, a small quantity of alcohol is formed, but the fungus soon dies.

In watery, acid fluids, poor in sugar, the cells often form long tubes, which then send out further buds, become transversely divided, and finally break up into single cells. The latter again bud in a similar manner The furgus of (Cicnkowsky). - This structure is most pronounced in
tlrmsh. the case of Saccharomyces albicans, the fungus of thrush (formerly described as Oidium albicans). Accord. ing to Rees and Grawitz this fungus rescmbles rery closely the S. mycoderma, if, indeed, it is not identical with it, Cells partly spherical, partly oval or cylindrical, $3 \cdot 5-5 \mu$ in thickness; the cylindrical cells are 10-20 times as long as thick. The budding colonies consist for the most part of rows of cylindrical cells, from the ends of which rows of oval or spherical cells sprout out; spores single, formed in roundish cells. Occurs as thrush on the mucous membrane of the mouth, especially in suckling children, and forms greyish-white patches which contain also cpithelium, schizomycetes, ycast cells, and mycelin of different mould fungi. 'The thrush fungus is easily cultirated on solid or in fluid nutritive substrata, which contain, besides sugar, tartrate of ammonia and inorganic salts: according to the amount of sugar present, the cells either sprout out to form long threads, or, in strong saccharine solutions, $4-8$ daughter cells project from 
onc mother cell in rarious directions, these daughter

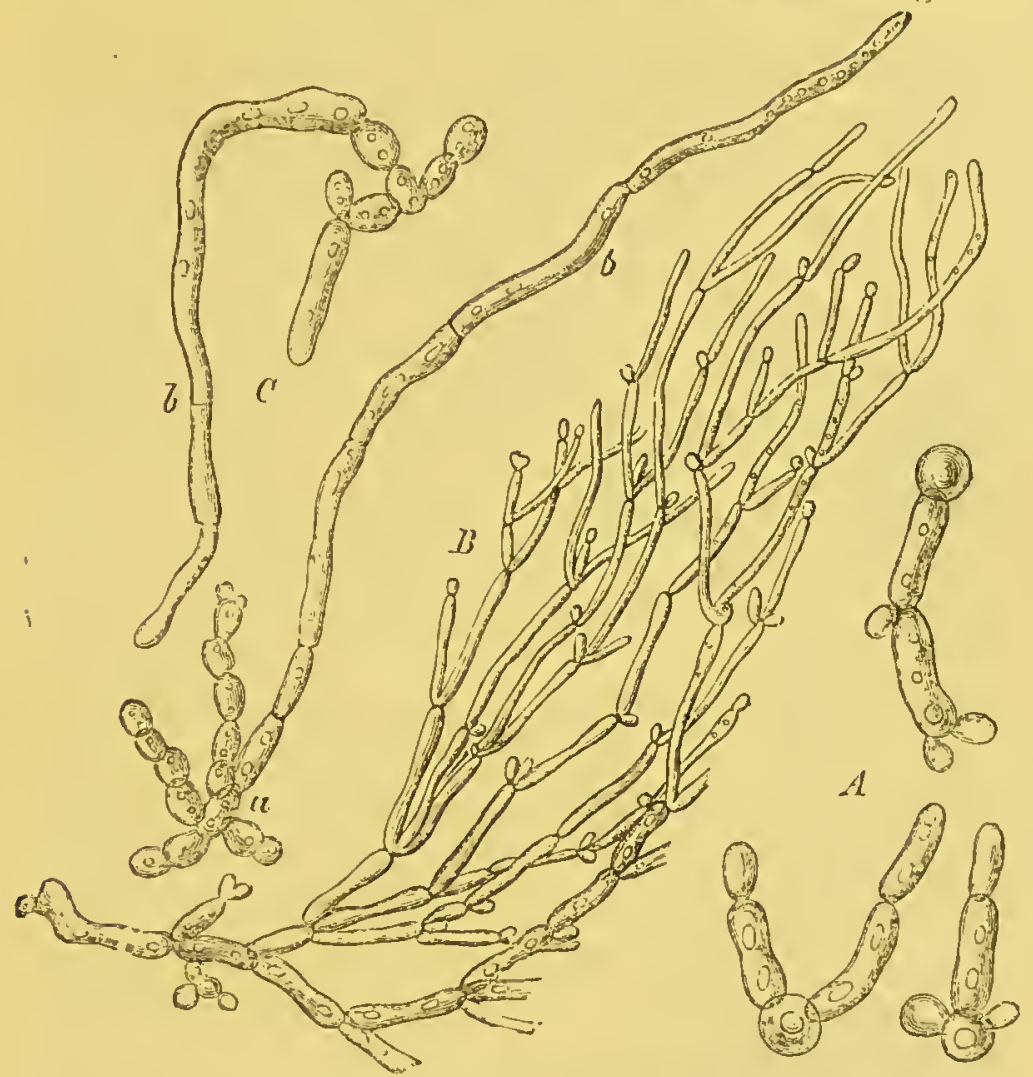

Fig. 29. - The thrush fungus, Saccharomyces mycoderma. (After Grawitz.)

A, sprouting spores highly magnified.

$B$, branched mycelium with a few lateral buds, eultivated in dilntc nutrient solntions.

$c$ at $a$ the ycast stage, at $b$ the mycclium stage of the thrush fungus. colls being for the most part round and arranged in roll-like rows.-The fing gus is able to set up a very mild alcoholic fermentation. Spore formation has not as yet been olsserved.

As the result of more recent inrestigations, Plaut does not regard S. mycoderina and the thrush fun-

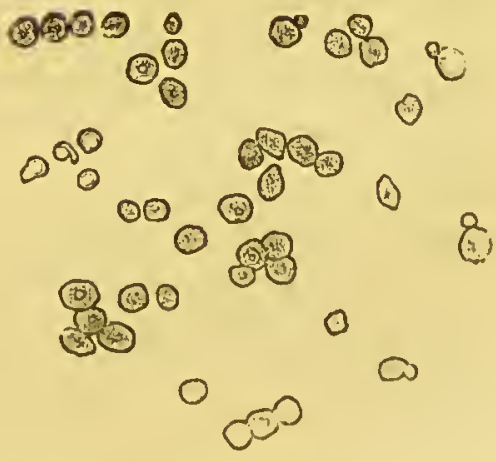

Fig. 30. Purc enltiration of the thrush fungus on a nutrient soil containing sugar. (Aftcr Plaut). orus as identical; the first sets up only minimal fermentation 
with simultaneous death of the cells; further, it readily forms spores, its cells approach more and more the form of spindles or ellipses, and are not able to cause thrush when inoculated on fowls. The thrush fungus, on the other hand, sets up marked fermentation with simultaneous luxuriant vegetation, forms no spores, the cells are more spherical, and it causes distinct thrush when pure cultivations are inoculated on the crop of fowls. The experiments on animals require to be extended and completed, in them more especially lies the decision of the question of identity.

Rose-colomred

Pigment-producing yeasts are also known :

Saccharomyces glutinis (Cryptococcus gl.) Cells spherical, oval or short cylinders, $5-11 \mu$ long, $4 \mu$ broad, isolated or united in pairs. Cell membrane and contents colourless in the fresh state, when dried and again moistened they show a faintly reddish nucleus in the centre. Spore formation unknown.-Forms rosecoloured slimy coatings on slices of potato, nutrient jelly, \&c. In the latter, when inoculated by pushing a needle into the substance of the gelatine (puncture cultivation), the growth beneath the surface has the appearance of white threads shooting out on all sides; marked growth and the production of colouring matter only take place on the surface. The colouring matter is not altered by acids and alkalies. The pink torula is apparently rery widely distributed; in our neighbourhood one or more colonies appear on every jelly plate exposed to the air for a short time. According to Hansen there are three different varieties of pink torula, of which one forms ascospores, while a second gives rise to germinating tubes of peculiar form when the nutriment is insufficient.

A brownish-black yeast is also at times present in water and air; a more detailed description cannot as yet be given. 


\section{The Fission Fungi, Schizomycetes.}

Under the fission fungi or bacteria* is included a large group of minute, unicellular, spherical, or threadlike organisms, which multiply by fission. As they are ordinarily devoid of chlorophyll, they are, like the fungi, compelled to lead a parasitic or saprophytic existence. Multiplication and assimilation of nutriment usually occur with such energy that intense alteration and destruction of the nutritive substratum is the result of their development; they are often able to increase this decomposition still more by setting up fermentation, and in the cases where they lead a parasitic existence they are wont to bring disease and death to their host.

\section{Gencral Morphological Character's.}

The fission fungi exhibit great varieties in external Genoral form. Some grow as spheres or oval cells ; this form of morphology of growth is termed micrococcus; if the spheres form fungi.
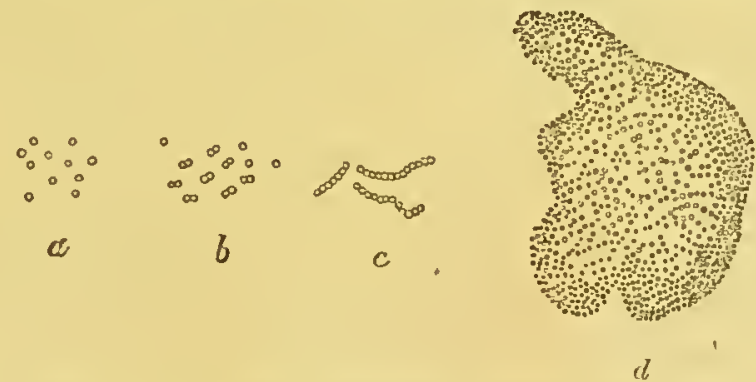

Fig. 31A. - Various vegetativo forms $\times 700$.

$\begin{array}{ll}a, \text { miorocoocus, isolated. } & b \text {, in the act of subdivision (diplocooons.) } \\ c \text {, streptocooous, torula. } & d \text {, zooglwa. }\end{array}$

chaplet-like chains the organism is termed strcptococcus or torula; if arranged in irregular masses it is dis-

* De Bary prefors the torm Bacteria bocause some varietios contain chlorophyll, and are thus not truo "fungi." The torm "Bactorium" was formerly omployed for a division of tho fission fungi; as, howovor, this division ean no longer bo maintained, thoro is no objoction to de Bary's suggestion. Other names for this class are: Microbes, Champignons, Torulaoées, Bacteriés (Pastour); Mikrozymas (Béchamp): Spalthofe (Nügeli); Mikrosporinen, and Monadinon (Klobs); Coccobacterin-with tho subdivisions Mikro- Meso-Meg-acocens, MikroMoso-Mcga-bactoria-Gliacooous, Potalococens, \&o. (Bill roth). 
Vurions.s regetative forms.

tinguished from the former as staphylococcus. Other fission fungi grow in the form of rods, the longitudinal diameter being markedly greater than the transverse; for this form the term bacillus is employed. (Formerly a distinction was made between the shorter rods, bacterium, and the longer rods, bacillus, in which the one diameter is more than two or three times greater

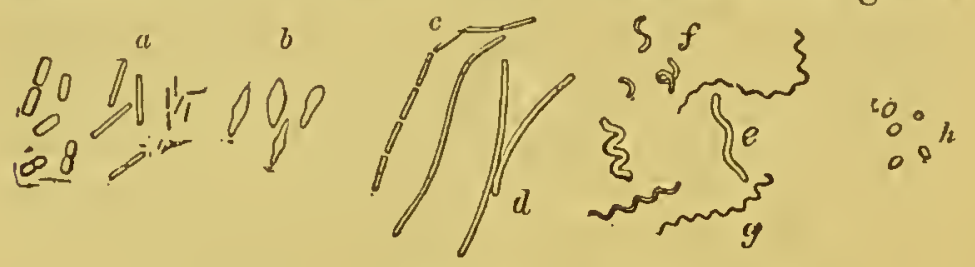

Fig. 31в. - Various vegetative forms $\times 700$.

$a$, baeilli ; $b$, clostridium ; $c$, threads, pseudo-threads ; $d$, apparent branching; $e$, vibrio; $f$, spirillum; $g$, spirochæte $h$, spores.

than the other.) Bacilli which are swollen in the middle or spindle-shaped have the special name clostridium. Where the bacilli are much elongated wo have true threads, or where several bacilli are arranged in a longitudinal direction so-called pseudo-threads; this thread form is sometimes termed leptothrix. The threads and pseudo-threads never show true branches like the hyphre of the mould fungi; at the most pseudo-branches are formed by the peculiar apposition of several threads (fig. $31, b$ ). In many forms the bacilli or threads are regularly wavy or corkscrew in form, and these represent the vegetative form termed spirillum or spirochetc. If the turns of the corkscrew are not markedly developed. and if the spirilla appear more elongated, the organism is termed vibrio. Loops of threads, the ends of which are wound around each other like a plait of hair, are termed spirulina.

Spore. Another form which the fission fungi not uncommonly assume is that of spores. These are spherical or oral cells which serve only for the diffusion and the maintenance of the species, and always sprout and form again or'ganisms similar to the nother forms from which they arose.

Involution forms.

Further, the fission fungi when grown in exhausted soil and under various other conditions present all sorts 
of abcrrant forms which are due to their involution and decay; flask-like swellings may be associated with stunted, shrunken, and broken up forms.

It is a characteristic of many fission fungi that they only occur under one form of growth, e.g., only in the form of micrococci. Other varieties of fission fungi present various forms of growth through which each individual passes in a

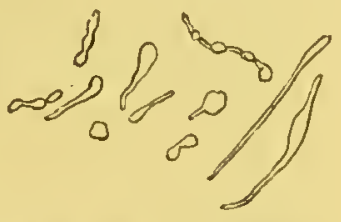

Fig. 32.-Involution forms. definite order during its development; thus many bacilli grow to threads; in the threads spores are formed, and from the spores bacilli are again developed. The bacillar thread and spore forms belong therefore to the cycle of development of this bacterium.

Besides the general characters of the regetative forms which have been described, some slighter morphological differences characteristic of the one or other species can be made out in spite of the small dimensions of the fission fungi. Either it is the size of the individuals Morphological which is of importance, the one form differenees in vero frowing only as the same very l ఇrge cocci (megacoccus), which have a diameter vegetatire

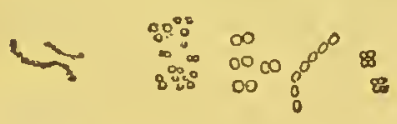

Fig. 334.-Morphologically different cocci $\times 700$.

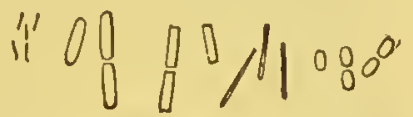

Fig. 33в.-Morphologically different bacilli $\times 700$.

of $1 \frac{1}{2}$ to $2 \mu$ or more; other kinds forming very small micrococci 0.1 to $0.2 \mu$ in diameter, \&c. Still more Morpholngimanifold and typical differences are found among the cally differert bacilli ; those of on among the species. these of another sank and thin;, those of another short and thick; the one very large, the other extremely fine and delicate; or the one may have the ends rounded off or almost pointed, while tlic other are sharply truncated or even somewlat concare.

Individual differences in form may also occur in one Individual and the same species of bacterium. In this respect the differcnees in age of the individual is of the greatest influence; young specics. bacilli appear shorter than older forms; cocci just formed. by fission are often smaller then those which 
are about to undergo fission. The nutriment has also a certain influence; according to the medium in which the spccies in question is cultivated, and according to the more or less favourable statc of all the conditions of life, slight differences in size and thickncss appear, and fully developed or stunted individuals are formed. As

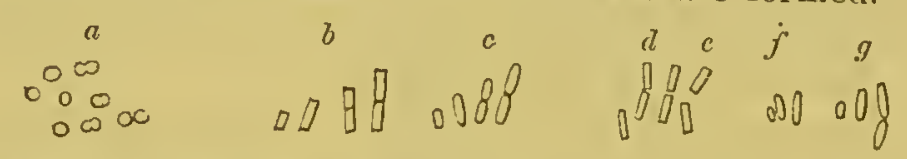

Fig. 34.-Individual morphological differenees depcndent on agc and nutriment $\times 700$.

", cocci. Various conditions of age and nutrition of the same species. b) $c$, varions conditions of age of two species of bacilli.

de, modifications of one specics of bacillns dependent on the nutritive conditions.

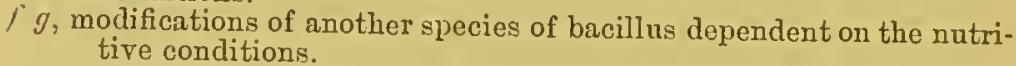

thesc factor's, however, arc of relatively slight intensity, none of them as a rule destroy the peculiar morphological character of the species; in spite of the modifications induced by age and food, ccrtain characteristics, as for example the relations between longitudinal and transverse diameter, the form of the ends of the rod, \&c., are so completely preserved in the majority of the individuals that they arc thereby sufficiently characterised morphologically.

Structure of the cells of the fission fungi.
All bacteric cells consist of cell membrane and cell contents. The latter have the appearance of ordinary protoplasm, are as a rulc colourless, except in some forms reccntly discoverod by van Ticghem, which contrin chlorophyll, as well as some putrefactive organisms stained red by the so-called bacterio-purpurin. Small oil globules are often obscrved in the cclls; at times also dark, highly refracting bodics, which consist of sulphur (beggiaton and red putrefuctive organisms). Some bacteria assume a bluc colour on the addition of iodine, and thus show the presence of granulose; this reaction is espccially marked in the stage preceding the formation of spores. Nuclei arc not found. When the cells degencrate and dio a marked turbidity and granular degeneration of the protoplasm occur's.

The cell membrane, which must be rery cxtensile in 
the robile forms, is in some species impregnated with colouring matter. On the outside a further gelatinous sheath may be recognised which is developed to a very variable degree in different species of bacteria. At times it is very distinct, especially after the use of staining materials, and surrounds the individual cells as a broad zone, the outer contour of which corresponds to the form of the cell; at times the existence of the sheath can only be suspected from the spaces left between the closely packed cells.

Some vegetative forms and species of bacteria are Independent always at rest; thus the spherical cells, and all those movement of species which only occur in the form of micrococci, bacterin. exhibit only a trembling movement with rery slight alteration of position which may be referred to unavoidable agitation and currents; they are never seen to travel over considerable distances. Other forms, bacteria, bacilli, and spirochrte are sometimes at rest, sometimes in active movement. This movement consists partly in rotation around their long axis and partly in bending and stretching; in many cases the action of flagella seems to be the cause of the commencement and maintenance of the movement. These flagella can be demonstrated with complete certainty in some spirilla and bacilli; but even in them they can only be seen with the best lenses, and after special treatment of the preparation (drying and staining with gentian violet, or better with concentrated watery solution of hæmatoxy-

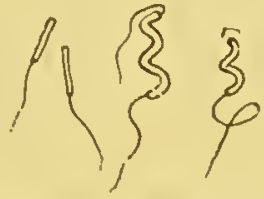

Fig. 35.--Baeilli and spirilla with flagella.

lin). At times their presence is only betrayed by the peculiar whirling movement of the fluid surrounding the ends of the cells. 'The movement of the swarming bacteria takes place forwards and backwards in the direction of the long axis; at times it is slow, oscillating and rolling, at times active and darting, so thint the field of the microscope is traversed in a moment. Various alterations of the external conditions, such as change of temperature, exclusion of oxygen, \&c., cause slowing and cessation of the movement. 
Different modes of urangenen

Ihe more intimate process of multiplieation by fission.
In the quiescent state the fission fungi cither remain isolated or are united in threads, or in extensive flat or massive colonics. In the latter cases the daughter colls which arise by fission do not become separated, but remain united by their gelatinous capsule; ultimately large conglomerations of cells are formed which are all united by gelatinous interccllular substance. This form is termed zooglæa; it is most frequent in the micrococei and bactcrin, but it is also observed in short bacilli and spirochætæ. 'The external form of the zooglæa masses is very various; sometimes they are spherical, sometimes tuberous, sometimes lobate; at times a rery peculiar tree-like branching occurs; in certain cases thick cartilaginous capsules are formed. As a whole the zooglaa formation is closely similar to the formation of gelatinous capsules in some families of alga (phycochromacer).

The multiplication of the bacteria by fission takes place as a rule continuously in the same direction, so that if the now formed cells remain attached to cach other, a chain (streptococcus) or a thread is formed. It is only in some micrococci (mikr. tetragonus, sarcina) that simultaneous or subsequent division in two or three different directions may be observed, leading to the formation of flat groups of four or packets of at least eight cells; the former are designated by Zopf by the special name merismopedia, the term sarcina being reserved for the latter. In the spherical bacteria the division may occur in any diameter, in the rod-shaped cells on the other hand only in the transverse diameter. Before division the cells increase in length; then as a rule a distinct constriction appears in the middle, and finally the two halves separate at this spot. T'liese tro independent individuals can either undergo further segmentation apart from cach other, or they remain united by delicate gelatinous material and form chains and pscudo-threads, the transverse division always oceurring in the same direction; or lastly, they take part in the formation of zooglæa masses, gelatinous material being produced in considerable quantities; in the interior of 
this zooglica mass the division of the individual cells can continue, leading to a denser accumulation in the zooglixa.-The fission is as a rule completed very rapidly; at $35^{\circ}$ C. complete division was observed in the bacilli at the end of 20 minutes; external and individual influences may cause variations as regards the time, but it is erident that the the fission fungi can multiply to an enormous extent in one or a few days. If we start with a single bacterium and assume that each individual requires an hour to grow and divide, we find tha ; in the course of a day about 16 million organisms have been formed, while by the end of the following day the number has reached several billions.

\section{Propagation by Spores.}

Besides multiplication by fission we find a true fructification, a spore formation, in many fission fungi under special circumstances, chiefly, but not exclusively, when the nutriment is becoming exhausted. Fructification Formation of by endospores and by arthrospores may be observed; of these the first is the most important and most definitely ascertained mode of spore formation. This occurs in various bacilli, and perhaps in some spirilla, but the process varies in different species. In many cases the bacilli grow to long threads before the formation of spores; under favourable conditions they may attain even

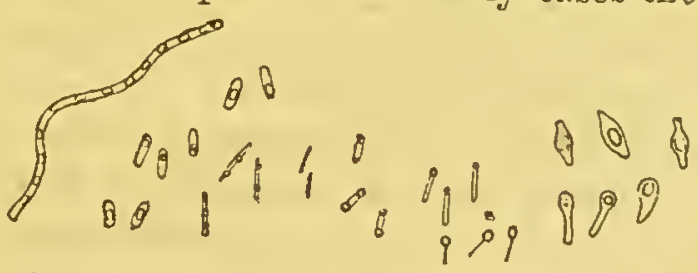
in 3-4 lour's 20 times the length of the original bacillus. The tlireads may be much twisted, united in bundles or interwoven to form a thick network, and they have pale homogeneous contents. After some hours the segmentation of these pseudo-threads begins and becomes more distinct; at the same time tho contents become turbid and less in amount, and highly refracting granules appear in the threads at regular intervals. After about: 
20 hours highly refracting spores with dark contour's, and for the most part egg-shaped, are formed from these granules, and the threads present a moniliform appear. ance; the latter become gradually dissolved, and the spores are liberated and sink to the bottom of the fluirl. In another mode of spore formation the bacilli do not grow out in the form of long pseudo-threads, but become broader; they thus assume spindle, elliptical, or tadpole forms, while at the same time the whole plasma becomes denser, and the membrane thickened. The contents then become turbid, and highly refracting largish drops are differentiated and transformed into the spores (spore formation in Clostridium butyricum according to Prazmowski). In other cases 2,3 , or more small spherical refracting points, which represent the spores, appear in the bacillus without the latter laving undergone any marked alteration; or a spherical or oval spore which often markedly exceeds in diameter the parent bacillus develops at one end of the rod. If a similar spore formation occurs at both ends of the bacillus, bodies are formed of a dumb-bell appearance. At times the spores bulge out the contour of the bacillus in a remarkable manner, so that the latter appears as if covered with small swellings.

Characters

The spores formed in this way within the cells appear rit the spores. when isolated as spherical, generally however longish egg-shaped cells of $1-2.5 \mu$ in longitudinal diameter, and $0.5-1 \mu$ in transverse diameter. Their marked refracting power is very striking; it gires the impression as if their contents consisted of a bright oil globule. At the same time the refraction is not altered by boiling with ether, so that the contents cannot be regarder as fat, but rather as condensed protoplasm. The thicliness of the wall is well-marked; at times tro layers, an exosporium and an endosporium, can be differentiated, and there is often a peculiar clear area around it, which is sometimes regarded as a spherical clear mass in which the cells are embedded, sometimes liowerer only as an optical appearance due to the high refracting power of the spore. 
The spores can germinate and form bacilli in suitable Germination nutrient solutions and at a proper temperature; but this seldom occurs in the same solution in which the spores were formed, nor till after a considerable period of rest. According to Koch, when the process of germination begins the clear spherical mass in which the spores are embedded becomes egg-shaped, and then elongated, while the spore becomes pale and finally disappears. According to Prazmowski and Brefeld the spores swell in the first place, become pale and lose their dark contour and the clear area around; then half-moon shaped dark shadows either appear at each end, and the spore, which is in a state of trembling, dancing movement, sends out a projection on one side like a papilla which subsequently grows out to form a rod; or in other cases the germinating tube passes out in the direction of the long axis of the spore, the spore membrane having - . 00 ? 000080

Fig 37.-Germination of spores become uniformly thickened in its whole circumference: The endosporium then becomes the cell wall of the young shoot, while the discarded exosporium usually remains for a consiclerable time near the newly formed. rod.

In the case of the bacteria which for'm arthrospores so-called the fructification simply occurs by individual members arthrospores. of a chain or of a mass of bacteric cells showing greater vitality than the rest; there is often no morphological difference to be noted between them and the other bacteria in the same chain, while at other times the cells destined for the maintenance of the species appear to lecome somewhat larger, thicker walled, and flled with. denser and moro highly refracting protoplasm. While the remaining cells of the group die, these segments form the commencement of new groups (de Bary).

Most spores, especially those formed endogenously, Resisting havo the character of resting cells, which are more re- power of the sistant than the vegetative cells of the same species. some are extraordinarily resistant, can even withstand boiling in fluids for several ininutes, and are only slowly 
and incompletely destroyed by the most various chemicul agents. It is clear that on account of theso properties the spores possess a special hygienic interest; for example, the possibility of exterminating a pathogenic fungus from the surroundings of man by disinfecting means depends chiefly on whether or not the fungus in question forms resistant resting spores.-All resting spores do not show the same high degree of resisting power; different spores have apparently rery different powers of resistance, but a certain increased power of resistance, notably the capability of retaining their vitality for a long time in a dry state, must be held to be a necessary characteristic of spores. Bearing this in mind, we require better reasons than have as jet been brought forward for assuming the existence of the so-called arthrospores.-The micrococci and most of the spirilla are probably characterised by complete absence of resisting spores; at any rate if we examine strongly heated mixtures of bacteria to see what forms have retained their vitality after exposure to a temperature of $80^{\circ}-100 \mathrm{C}$., we find only the bacilli which form resting spores, and none of the other regetative forms.

\section{Characteristics of the Cultivations of the Fission Fungi.}

Extermal characteristics of the cultivations the fiasion fungi.
When in considerable masses, whether these consist simply of apposed organisms and swarm formation, or of zooglæa, the bacteria become visible eren to the nalied eye. In fluids they cause either diffuse or cloudy muddiness, or they cover the surface in the form of thin or thick scums; or the zooglin masses form swimming flakes; or a powdery deposit of bacteria forms at the bottom, especially when the nutritive materials in the fluid are exhausted and are no longer able to supply food for a further multiplication of the organisms. Some species of bacteria can also undergo extensire multiplication in fluids or on solids without anything becoming noticeable to the nalied eye.-The appearance of the colonies of bacteria on solid substrata, 
containing much water, is especially characteristic. Solid substrata have of late been employed by preference Advantages of for the cultivation of the bacteria, and they are useful chiefly folidsubstrata becruse they permit a completely independent develop- nition of the ment of cach individual bacteric colony, while in fluids the individual species do not grow at a definite spot, but become mixed with any other species which may happon to be present. It is therefore only on solid substrata that the characteristic appearances of the colonies formed by any given species of bacteria can be observed, while it is just the external appearances of the isolated pure colonies which are of the greatest importance, because they differ in almost every species of bacteria, and because we can thus obtain much more important character's and better distinctive marks than we get with the help of the microscopical differences in form. For this reason the appearance of the isolated colonies is of special service in the diagnosis of the species of bacteria, a thing which is otherwise often very difficult.

As suitable solid substrata we employ either potatoes, bread-paste, \&c., on which the bacteric colonies appear, sometimes as slimy white, yellow, or reddish drops, sometimes as drier whitish films, sometimes as diffuse, gelatinous layers of various colours, and sometimes as delicate, scarcely noticeable skins; or we use the socalled nutrient jelly (see culture methods), which is prepared by adding so much gelatine to a good nutrient solution, that the mixture forms a transparent mass, which is solid below $25^{\circ} \mathrm{C}$. This nutrient jelly is employed for plate cultivations, in which a very small portion of the bacteric mixture to be investigated. is added to a quantity of the nutrient jelly, which is liquefied by placing it at $30^{\circ} \mathrm{C}$.: after tho admixture is complete it is then poured out on a horizontal gliss plate, so that the latter is covered by a layor a fow millimetres deep. The jelly solidifies quickly; cach Character of individual bacterium in the mixture is thus fixed at a the colonies lefinite spot, and grows thero to form a colony. If the plates. experiment is successful, i.e., if too many bacteria have not been mixed with the quantity of jolly, and if 
they are not sown too closely on the plate, each colony develops apart from the others, and then shows distinctive cliaracteristics, sometimes so marked that with some practice the species of bacteria present may be easily diagnosed in the development either of small golatinous

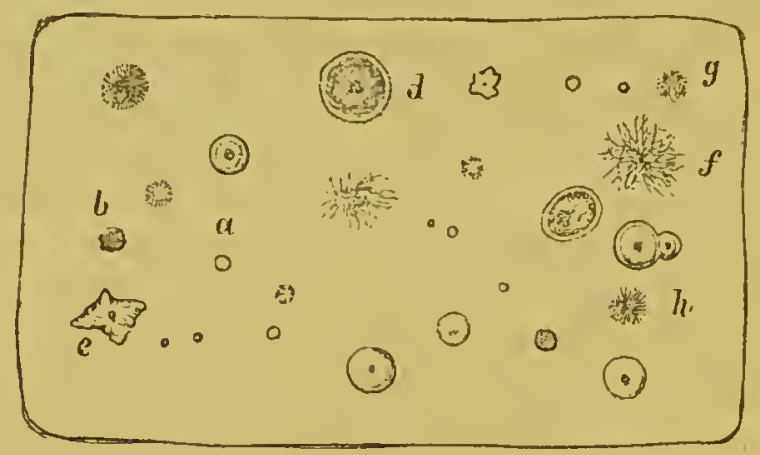

Fig. 38.-Various colonics on a gelatine plate.

coloured drops, white, yellow, rose-coloured, red, or violet (fig. 38, a); or of very small white or yellow circumscribed, almost point-like heaps; or of flat, mucous layers peculiarly bulged ont at their borders (fig. 38, l, e); or of branching and tristed threads of surprising fineness, which run out from a centre for a longer or sliorter distance into the jelly (fig. $38, f, g, h$ ). Or the organisms in the colony in question have the porrer of gradually liquefying the gelatine, in $\pi$ hich case a ditclilike depression is slowly formed around the colony, the periphery of which surrounds the colony in the form of a ring (fig. $38, d$ ) ; or a fumnel is quickly formed which is filled with fluid, at the bottom of which the original colony lies, and which often extends rapidly orer largo

stucly of the colonies with low powers. areas of the plate. Thus the contour, colour, size, mode of liquefaction, \&c., furnish special characteristics for each bacteric colony; and the sum of these distinguish-
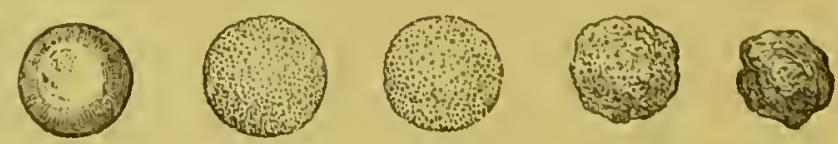

Fig. 39.- Youngest eolonies of bacteria in gelatine $\times$ S0.

ing features increases very considerably when the colonion are examined with a low power $(\times 80)$. It cau then 
be scen that one colony presents a completely smooth, sharp outline, another is bulged out or dentate at its margin, or is provided with small outgrowtls, or shows wary threads, which run out from the colony and back to it again. The surface of the former colonies appears smooth, that of the latter granular; one is dark, almost black, another brown, a third light yellow; some can scarcely be distinguished from the surrounding jelly by their colour.

If by this means of distinguishing and recognising the species of bacteria it nevertheless turns out that certain species do not differ in their growth on plates, the growth along strokes, or along a puncture, may show something characteristic. This is ascertained by Characterispouring the nutrient jelly into test tubes, and allowing puncture it to solidify in some of the tubes in an upright position, cultivations: and in others in an oblique or almost horizontal layer. Then a small quantity of the colony which has grown on the plate is picked up on the point of a piece
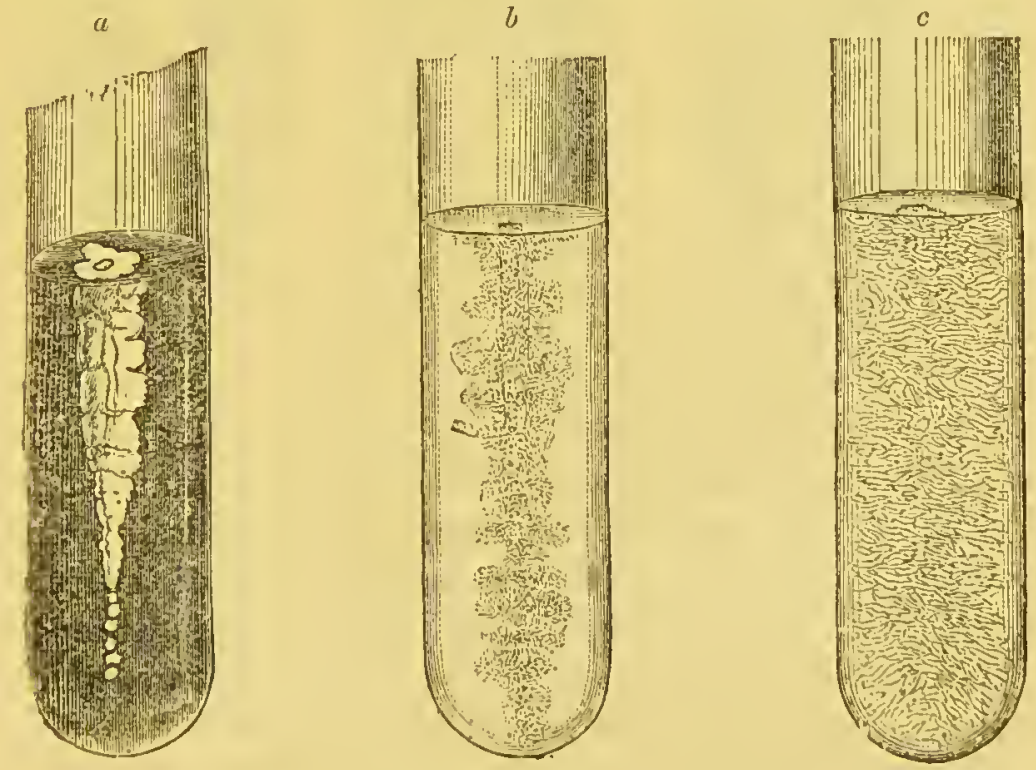

Fig, 40.-Puncture cultivations in gelatine.

of platinum wire, and long scratches are made on the surface of the oblique gelatine, while in the other tubes punctures aro made with the wire to the deptl of about $4 \mathrm{~cm}$. Along the punctures we cither find only small 
isolated punctiform colonies (provided that the quantity inoculated was minimal); or a thin confluent layer is formed along the course of the puncture, so that the line of puncture appears as a thread, while a delicate layer spreads out at its upper end towards the periphery of the jelly (fig $41, b$ ); or a thick opaque mass is formed, filling the channel completely and
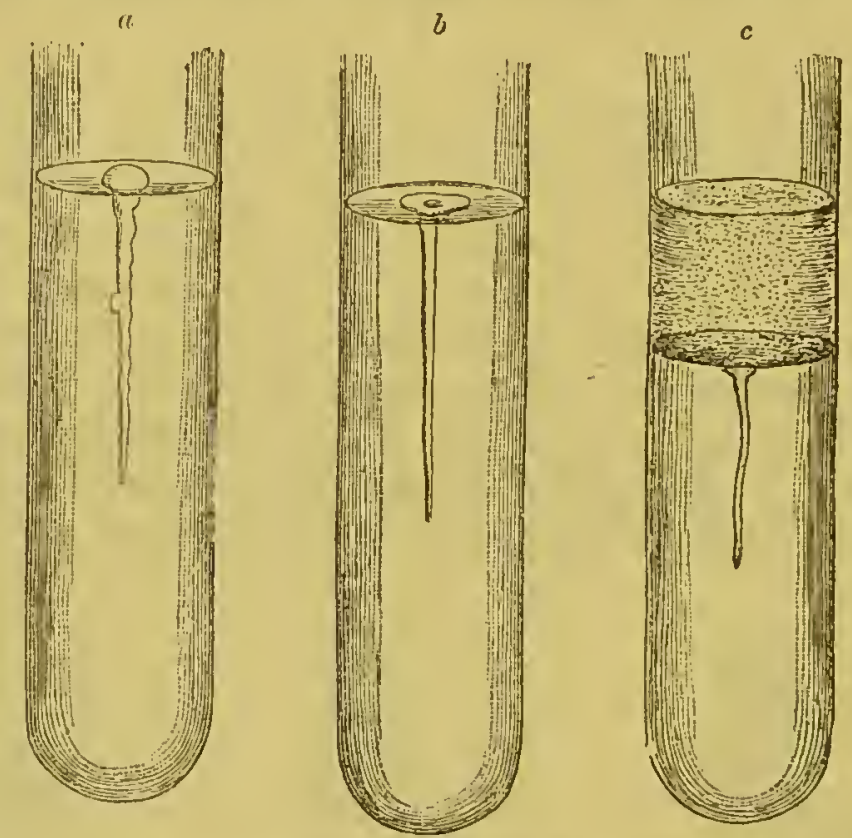

Fig. 41.-Puncture eultivations in gelatine.

forming a markedly prominent lnob at the orifice of the puncture (figs. $40, a$, and 41 , a) ; or liquefaction occurs, beginning slowly at the top and confined to the vicinity of the puncture, or energetically and from the first occupying the whole area of the tube (fig. 41, c). At times a turbidity spreads tbrough the gelatine, starting from the line of puncture, which however is not very distinct; in some cases the jelly appear's smoky, or cloudy, in others the growth is more in the form of rays, or of a network of threads

Characteristics of tho stroke cultivitions on Felntine. (fig. $40, b, c$ ). Where the stroke method is employed wo sec whether separate little drops form, whether these are glassy and transparent, or white and opaque; further, whether the growth remains limited to the 
line, or whether it spreads more or less rapidly from it towards the periphery; whether the spreading margin is straight or irregular, sinuous or jagged, \&c.

In the case of many organisms which liquefy gelatine energetically, we may now and then employ with advantage a mixture of the nutritive solution with agaragar, which remains solid at $37^{\circ} \mathrm{C}$; nevertheless this cultivating medium does not on the whole show such characteristic differences in growth. Some bacteria

a

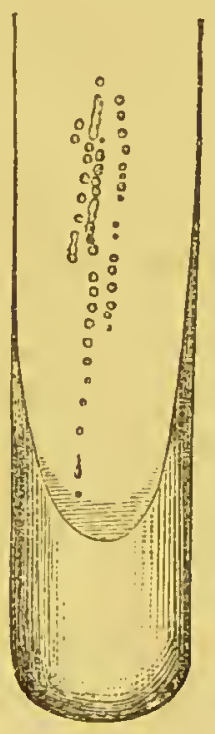

b

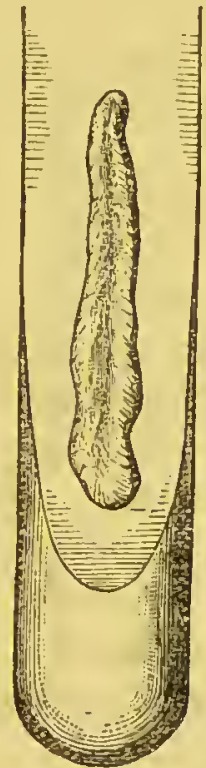

$c$

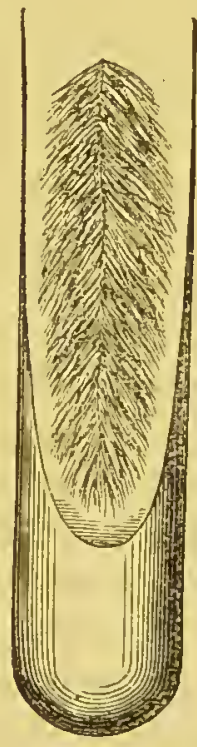

Fig. 42:-Stroke cultivations on gelatine.

grow only on solidified blood serum at the body temperature, and may form very characteristic colonies; finally, some only grow to visible colonies when free oxygen is excluded, and can therefore only be cultivated with special precautions, to be afterwards described.

\section{Classification and I)istinctive Characters of the Bacteria.}

A systematic classification of the bacteria is a matter of very great difficulty, because they are so minute that even by the use of the highest powers of the microscope only the external form, and not tho difier- 
Necessity for a provisional classification of bacteria. ences in the structure of the individual cclls, can be recognised; nor can any marked differences be madc out in the process of fructification, and yet it is that process which furnishes the most important principle of classification in other plants and in the higher fungi. In view of the extremely numerous species of bacteria which are already linown, and the number of which is rapidly increasing; an enumeration and classification of these organisms appcars to be indispensable, in order that we may at least be able to obtain a general view of the known species, to settle the identity of any species which may in future come under observation, and to include ncw species in the system of classification. This necessity for a definite classification, and for a $k \in y$ for the diagnosis of the bacteria, is so grcat, that in riew of the impossibility of forming a classification on the ordinary scientific principles, we must for the present put up with some kind of systematic division, although the principle of the classification may not be founded on the devclopmental history, nor have analogies in the other dcpartments of botany. Just as in the first beginnings of a botanical classification any striking extermal charactcrs which were of use for dinguosis were employed as aids for the distinction and classification of the plants, so we must in the present state of our knowledgc with regard to bacteria employ as means of distinction auy properties of the bacteria, their morphological and biological characters, their external form, their mede of growth on ccrtain mutrient substrata, thcir relation to oxygen, their behaviour with regard to stains, \&c., provided that these properties are constant and characteristic for the individual specics, and enable us to distinguish thom readily. We may hope that with the advances in our optical means, and with the further linowledge of the processes of fructification, we may gradually obtain for the bacteria a gronndwork on which is true classification can be built, and we must therefore thoroughly realise the provisional character of our present attcmpts at classification. But to abstain entirely from these attempts would be in the lighliest 
degree inpractical, and would retard for a long time, and practically prevent, the further progress of our knowledge with regard to the bacteria.

In the present state of our knowledge it is best to em-Morphological ploy both the morphological and the biological claracter's the fortur chicf of the bacteria for their classification and distinction. grouls. Four great divisions are in the first place made by selecting a single vegetative form or a definite and limited cycle of regetative forms which are common to a large number of species of bacteria. To the first belong all those bacteria which only occur in the regetative form, micrococcus. In the second we include the bacilli which occur in the form of rods, at times also in that of threads or spores. The third dirision is composed of the spirilla, which are only met with in the form of spirals, or of fraginents of. spirals. The fourth includes those bacteria in rhose cyele of development a variety of regetative forms occur. The chief characteristics of these four divisions are the following :-

\section{Division I.-Micrococci.}

Spherical or egg-shaped cells multiplying by fission, Morploogogieal and always forming spherical cells; they do not show characters of spontaneous movement. (The micrococci often exhibit, cocci. as above mentioned, a trembling molecular movement, and frequently also an alteration of situation due to imperceptible currents of fluid. On closer observation these can, however, be very easily distinguished from true spontaneous movement.) Further, in the micrococci endogenous spore formation does not occur; we cither observe no spore formation at all (in most cases), or else so-called arthrospores are present and are distinguished from the other cells by their size and refracting character. In some micrococci the cells are not accurately isodiametric, but the one diameter exceeds the other to such an extent that an oval or egg form results. Further, the spherical form is often 
Distinction between diplo cocci and short bacilli.

not distinctly marked when the act of fission has bcgun, and while the two cells still adhere to onc another and the constriction is incomplete (diplococcus). The cells which are undergoing division are under these circumstances elongated with a sharp and more or less deep constriction in the centre, so that they resemble a short rod. A comparison with neighbouring individuals not yet undergoing division, or with those in which the division has proceeded further and led to distinct formation of two spheres, is as a rule sufficient in such a case to enable the diagnosis to be made as against bacilli. After the division is complete, the micrococci either remain isolated or they assume the various arrangements mentioned on page 156, staphylococcus, streptococcus, merismopedia, sarcina, zooglæa. If in the zooglæa formation the intercellular substance is very tough, so that cartilaginous masses are formed enclosed in the general mass, the group is termed ascococcus; if the gelatinous masses of such groups become dissolved in the interior, so that only a thin extermal layer surrounds a hollow cavity filled with fluid, the arrangement is termed clathrocystis.

\section{Division 2.-Bacilli.}

Morpholog:cal Rods in which the longitudinal diameter is 2, 3, or characters of the bacilli.

many times in excess of the transverse: The organisms belonging to the class of the bacilli for the most part pass through a definite cycle of forms, so that they do not appear exclusively in the vegetative form, bacillus; many can form threads, and in thesc spores; in others there is only well-marked thread formation; others produce spores in their middle, at the end, or at screral places, according to the modes described ou p. 161 ; most of them form at times all sorts of inrolution forms. We may also meet with these bacteria under many different forms ; but it is characteristic for all the thread forms, and round or oval cells, occurring in connection with the bacilli, that they liave been developed from cells having the vegetative form of bacillus, and that if 
they are at all capable of development they again grow into bacilli under favourable conditions, either directly or after an intermediate stage. The bacilli occur either in a quiescent stage, in which case they are often arranged in threads, heaps or zoogliea, or in a swarming stage. In many forms, however, the latter stage has not yet been observed. Now and then a mistake may be made between rods and micrococci when the rods are in an upright position and present their circular transverse section to the observer's eje; a correct conclusion may usually be arrived at by careful examination with repeated alteration of the fine adjustment of the microscope, and by comparison with neighbouring individuals. It is at times uncertain Distinction whether an elongated cell constricted in the middle is $\begin{gathered}\text { between } \\ \text { mieroeocci }\end{gathered}$ a diplococcus or a rod. The sharp, acute-angled con-and young striction which is noticeable after the division of a which are uncoccils, and the round form of the two halves, may serve dergoing as a means of distinction when contrasted with the those whici less acute constriction of the rod, and the fact that the right angles single individuals are never isodiametric. Even here, to the field of however, it is only after comparison with other neighbouring cells, or after continued observation of the further development of the individual cell, that an absolute conclusion can be arrived at. Young bacilli, which have just been formed by fission, or by the sprouting of a spore, often show a very slight excess of one diameter over the other, and thus approach the vegetative form, micrococcus, but are easily distin. guished from it by their further development, and by the presence at the same time of older forms. Finally, in the spore form a confusion between bacilli Distinetion and micrococci could also occur, if it were not between that the higher refracting power of the spores, and the cocci. feeble manner in which they take up aniline colouring matters, formed good points for their recognition; the diagnosis is rendered certain by the study of the further behaviour of the two cells, the sprouting of the one to form a bacillus, and the multiplication of the other by division to form fresh spherical cells. 


\section{Division 3.-SPIRILLA.}

MLorphological characters of the spirilla.

The typical forms are spirally twisted threads, which produce new spirals by fission, and which are for the most part mobile and often united in swarms. As to the existence of a cycle of forms in the spirillis there is very little known, but they seem to have a special tendency to the formation of involution forms. In the case of some spirilla it can be distinctly seen that the spirals are composed of short, curved rods; mnder certain circumstances these rods form the prominent vegetative form, while under other conditions they become fused together, and spiral threads are developed. A precise differentiation of these rod-shaped spiral elements from true bacilli, which often show a slight curvature in microscopical preparations, is frequently very difficult; and it will probably be impossible, as our linowledge increases and transitional forms are discovered, to uphold the genus spirillum as an independent division. In the meantime, however, it appears desirable on practical grounds to group togethcr in the genus spirillum those curved bacilli in which 8 development of spiral threads and a multiplication in that vegetative form is observed.

\section{Diviston 4.-Fission Fungi with Variable Vegetative: Forms.}

Characters of the bacteria which show variable vegetative forms.
The aquatic fungi studied by Zopf (formerly describech as fission algæ)-cladothrix, beggiatoa, crenothrix-cannot be included in any of the foregoing divisions. In: these fungi, according to Zopf, a manifold cycle of forms occurs, so that one and the same fungus may appear in micrococcal, bacillar, and spirillar regetative forms. It is possible that in course of time other bacteria may become known in which an equally extcur sive serics of forms occur. 'The specics which can at vitepresent time be included with certainty in this group. are comparatively easily recognised and distinguished? 
lyy their great tendency to the formation of various regetative forms, as well as by a number of other characteristics.

The extcrnal form of a baeteric eell does not of itself afford Necessity for information as to the species to which the vegetative form under observation belongs, but at times admits of various coneeptions and interpretations. If, for example, we find a spherical cell, it may be a microcoeeus, a spore, or an inrolution product. The cell can only be designated as a micrococcus when it ean be proved that it arose by fission froin a similar spherieal eell, and that, under suitable cireum. stanees, it may again give rise by fission to another spherical cell. For it is characteristic of the vegetative form, micro. coceus, that the same spherical vegetative form repeats itself through a shorter or longer series of cells. If, on the other land, the round cell has arisen not by fission but by spore formation from another bacteric cell, and if it is not eapable of multiplying by direct fission, but must first sprout and form an individual similar to the mother cell, this spherical cell must be looked on as a spore. And, finally, if the spherical form of the cell has arisen from a cell of another shape only when it began to deeay, if this spherical remnant is no longer able to multiply or propagate itself in any way, then we have a dead involution structure before us, to which the term micrococeus cannot be applied.

To take another example: if a twisted or spiral thrend comes under obscrvation, the question arises whether it has developed by fission from a eell of the same form, and whether it can again give rise to a cell of a similar shape. It is not till this is demonstrated that we are justified in saying that we have to do with the regetative form spirillum or spirochæte. If this is not the case, it is possible that we have before us a portion of a thread aeeidentally twisted, or some phenomenon of deeay which has arisen under abnormal conditions. It is very important to be clear from the first as to the meaning and the proper designation of these varions vegetative forms, as otherwise confusion and mistakes readily oceur.

The subdivision of the four chief groups cannot be made exclusively according to the morphological characters; of tho ehathe various species of bacteria which occur in the micro- of growth for coccal form more especially show scarcely noticeable the further differences of shape under the highest powers, and even the bacteria. the arrangement of the cocci in chains. or masses prea eorrect con. ecption and designation of any given vegetative form.

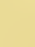


sents so many transitional appearances that they cannot be employed as decisive distinctive characters. Here it is evidently of importance to make use of the manifold and valuable distinctions described above, those, namely, which the bacteria show when growing on certain substrata, especially on nutrient jelly. When sub-classes have been successfully formed by the help of these differences, the further subdivision of the relatively small number of bacteria in any small group may be made by the belp of morphological characters, of behaviour with staining re-agents, of relation to oxygen, or of the power of exciting fermentation or disease, aud thus we are ultimately able to recognise a given species by the study of its various characters as compared witl other species. Of course the species thus formed cannot in the slightest degree be regarded as natural species or varieties; they hare an entirely prorisional character, and are only meant to serve as a means of rendering the further recognition of the bacteria easy, and of paving the way for a natural classification; they have only arisen from, and are only suitable for the

Practical method of diagnosing the bicteria . practical necessities. Hence the classification given here rests on that practical method which almost erery one now employs who wishes to ascertain what bacteria are present in any unknown mixture of fungi. The first step is always an attempt at isolation by means of gelatine plates; the colonies which have developed on the plates can then be easily investignted by making a microscopical preparation with a small quantity, and ascertaining whether the colony cousists of micrococci, bacilli, or spirilla. It is almost always easy to decide this point, because when we have a large number of similar individuals all at the same stage of development we have none of those uncertainties mentioned above which might render the diagnosis of an individual cell a matter of great difficulty. When the chief division to which the species in question belongs is thus ascertained, the appearance of the colonies, both macroscopically and under low powers of the microscope is investigated, and then with the help of a simple tablo (see p. 178) the relatiou of the species 
to a small group of similar species of bacteria is fixed. The distinction of these closely similar species is then easily made by the aid of some very characteristic reagent, $\mathrm{or}^{\circ}$ is a complicated study, and can only be rlone by observing the appearance of the growths in stroke or puncture cultivations, by studying the action of the cultivation on animals, \&c.

Formerly Cohn made the attempt to distinguish a large Coln's formex number of species of bacteria on the basis of their morpho- classification logical characters. But exactly similar morphological pecu- schizophytes. liarities occur in the lower algæ; and it is essentially only the absence of chlorophyll which separates the fungi from the algæ; on this point however, as has been said above, no special weight is now laid. And thus when special attcntion is paid to the morphological characters, the rcsulting classification of the "schizophytes," must include fission fungi and fission alga. Such a classification is certainly admirably adapted for placing in correct light ccrtain similarities and differences between the lower algæ and fungi, but it is not sufficient for the number of species now discovercd, and it no longer meets practical wants, more especially bccause a number of heterogeneous organisms of unequal value from a hygienic standpoint are mixed together. In the former edition of this handbook the author attempted by omitting the algæe to transform Cohn's classification in the following manner so as to bc useful for a circle of rcaders composed chiefly of medical men:- 

CLASSIFICATION OF THE MICRO-ORGANISHS.
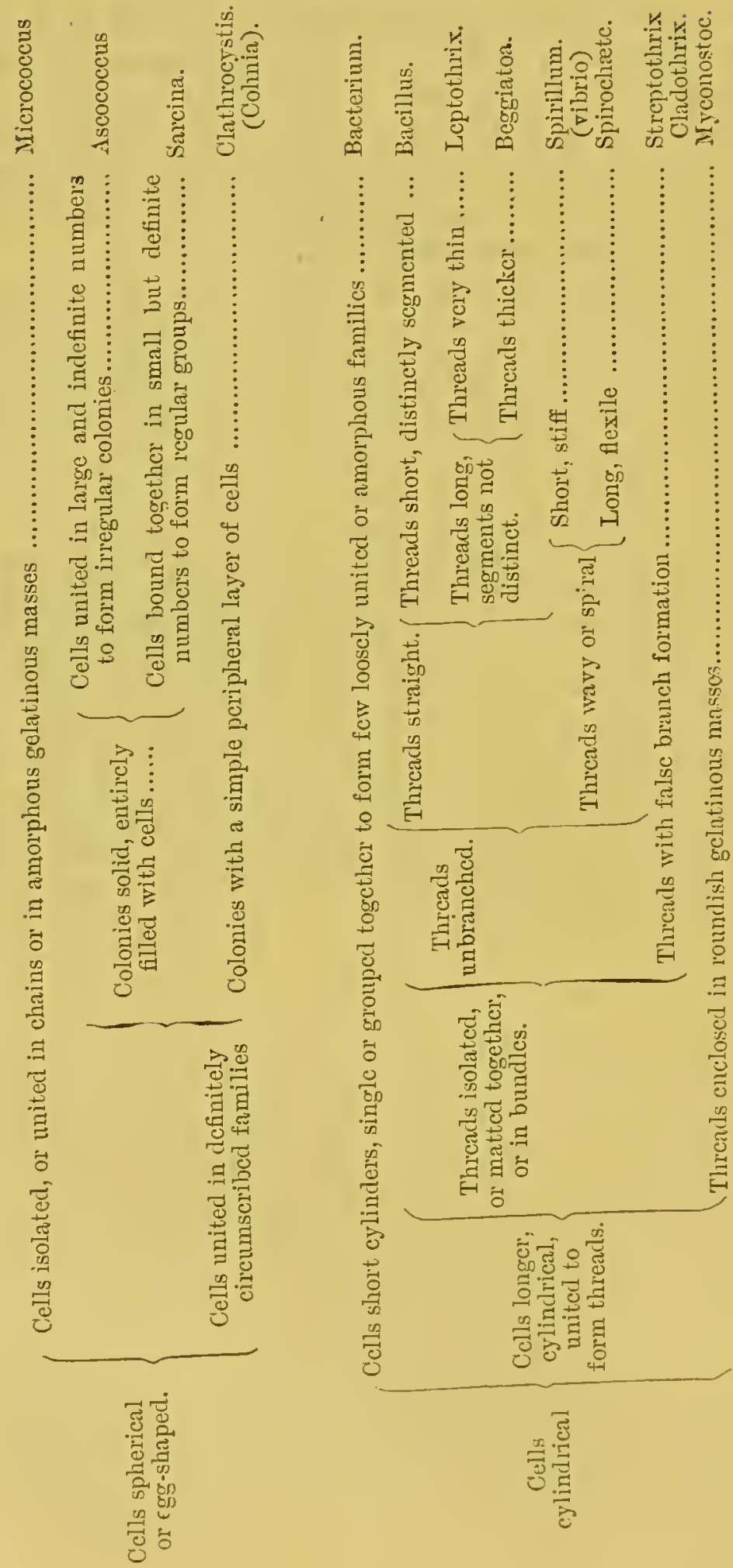

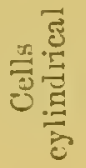


Bearing a doubtful relation to the fission fungi are: Crenothrix, spherotilus, spiromonas, rabdomonas; monas Okenii, Warmingii, vinosa.

It was frequently stated in the previous edition that this Nocessity for classification is in many points impracticable, that many of alteration of tlic genera cannot be upheld as indepcndent forms, and that classification. it would have to give place to one more in accordance with practical requirements. In fact is has become more and more evidcnt in the course of the last few ycars that certain of the genera up till recently reckoned as independent forms only represent vegetative and colony forms of various species bclonging to other groups, and that the presence of gradual transitional forms grcatly incrcases the difficulty of diagnosis. Thus a deposit within a tough gelatinous mass which was held to justify the classification under ascococcus occurs morc frequently than was formerly supposed, and in bacteria of different vegetative forms (leuconostoc, clostridium, polymym, \&c.) Again, sarcina cells are spherical micrococci before the characteristic division into 8 occurs, and of ten exist for a very long time as isodiametric cells bcfore the division into 4 or 8 is apparent; other micrococci usually occur as single cells or as diplococci, at times, however, in a merismopedia-like arrangement; hence this character can be employcd at the most only in a small group of micrococci. As regards the method of arrangement, clathrocystis closcly resembles the genus ascococcus. Further, a distinction betwecn bacterium and bacillus is impossible, because there are too many transition forms which may be placed with as much right in the one class as in the other. The genera leptothrix and streptothrix represcnt a regetative form which is seen in many bacilli as an occasional stage of devolopment. Similar difficultics attend the diagnosis between spirillum and spirochate as betwcen bacterium and bacillus. Finally, beggiatoa and cladothrix, on account of their great mutability of form as discovcred by Zopf, must be cntirely excluded from a classification based on the constancy of morphological characters.

Cohn, also, las always regarded his classification as a Do Bary's provisional onc, and one only intended as a gencral guide till classification. a suitable classification is obtained analogous to that of the higher plants, in which special regard is paid to the peculinritics of fructification, and to the natural process of devclopment. Attcmpts have alrendy been made from the botanical sidc to form such a classification. 'Thus Van Tieghem and do Bary make 2 great divisions-bacteria which form eurlosporcs, and those which form arthrospores; but this division is of little scrvicc for practical purposes, becausc it is just tle mode of spore formation which is most diflicult to 
ascertain in investigating a fungus, while on the other hand this subdivision only indieates the first begimings of :i scientifically eor'rect elassifiention.

Zopf's classifi- Another classification of the bacteria las been made by. cation of the Zopf. He extended the doetrine of plcomorphism which he
bacteria. had observed in the aquatic fungi mentioned above to the other bactcria, original obscrvations, and some made by other observers, having demonstrated in scrernl cases a ehange of form from coeci into baeilli, threads, and spirilla. Zopf is of opinion that variability of the regetatire forms oecurs in all baeteria, and that thongh in the case of many bacteria the eomplete ejele of forms appertaining to them is not jet known, we may expeet that eren in the organisms as yet known only in a mierococcal form. thread-forming stages, de., will yet be discorered.

Zopf divides the baeteria according to tlicse riews into 4 groups :-

1. Coecacca. These are as jet only known in the coeeus form. To these the following genera bclong: streptococcus (cocei arranged in threads like strings of beads); merismopedia, tablet eocei (division in two directions, leading to the formation of tablet-like flat layers of eclls); sarcina, paeket coeei (division in three dircetions, leading to the formation of bale-like colonies); micrococcus (division in one direction, the cocci bceoming aggregated together in irregular hoaps); and ascococcus (the heaps of eoeei aceompanied by marked formation of gelatinous matcrial).

2. Baeteriaccæ. These possess chiefly coecus, rod, and thread forms; the former may also be absent; in the latter there is no contrast betwecn base and apex. Threads straight or screw-like.

Gencra: Bacterium, forms eoeei and rods, or only rods which arc arranged in rows to form ordinary threads; spore formation absent or mknown. Spirillum, tlureads serem-like, formed only of rods, or of rods and coeci; spore formation absent or mnknown. Fibrio, threads screw-like, spore formation in the longer or shorter joints. Leuconostoc, forms coeci and rods, spore formation in eoeei. Bacillus, coeei and rods. or only the latter in the form of simple or twisted threads; spore formation prescnt, oceurring in rods or in eocci. Clostridium, resembles bacillus, but the spore formation oceurs in peculiar dilated rods.

3. Leptothrix. Coecal, rod, and thrcad forms ; the latter show a eontrast letween base and apex; threads straight or screw-like; spore formation not demonstrated.

Gencra: Crenothrix, threads enelosed in a sheatl, cells without granules of sulplur; inlabitants of watcr. Beggiatoa, 
threads without a shcath, cells with sulphur granules; inha. bitants of watel. Phragmiliothria, threads withont sheaths, snccessive divisions vely extensive; colls free from sulphmr; iuhabitants of water. Leptothrix, threads with or without sheaths, divisions not very extensive; cells devoid of sulphnr.

4. Cladothrix. Show coccus, rod, thread, and spirillar. forms. The thread form is provided with pseudo-branches. Spore formation not demonstrated. Genns: Cladothrix.

A priori the possibility of the mutability of form of the Disadvanhacteria asserted by Zopf, and to which expression is given in tages attendthe foregoing classification, must at any rate be admitted; adoption of but before we accept it as a matter of fact, and as so general, Zopf's hypowe must demand complete proof, and we must insist the more strenuously on a satisfactory proof, as we would be deprived, by the admission of extensive changeability of form, of an important diagnostic aid which is of great value to us in medical and hygienic practice. We know now a number of exciting agents of disease which occur, for example, in the form of characteristic bacilli; we are able to make a diagnosis of tuberculosis by the discovery of the tubercle bacillns, and of cholera by the demonstration of the cholera bacilli. If the characteristic bacilli are absent on careful and repeated investigation, and if we find only bacilli or cocci of other form, we consider oursclves justified in denying the existence of tuberculosis or of cholera. Further, we frequently undertake the investigation of some object, which is suspicious from a hygienic point of view, for the presence of typhoid bacilli, of inthrax bacilli, dc., and we can only hope for a result because we search in all cases for an organism of definite and characteristic form. If, howerer, Zopf's view is correct, and if these bacilli often occur in a coccal form, investigations of this. kind innst obviously be without result; it is impossible to recognise by the microscope organisms in the coccal form, and . hence any extrancous innocent coccus night lead us to the diagnosis of tuberculosis or typhoid fever just as well as the supposed coccal form of these pathogenic bacilli. We should also meet with great difficulties in isolating organisms by cultivation if the colonies of, for cxample, the typhoid bacillus could occasionally contain only coccus forms. We should then find it rery difficult to decide with regard to a group of cocei whether they slould be included in the genus spirillum, or beggiatoa, or micrococeus, or bacterium, and also to what species of these genera they belonged.

Complete proof of the accuracy of Zopf's views lias certainly Absence of not been furnished with regard to the great majority of the proof of the fission fungi. Our most skilled micloscopists mality of the universal gists bar. Our most skilled micloscopists and bacteriolo- applicability of '7opf's hypothesis. 
formation of micrococci into bacilli or vice versi. 'The positive observations which furnish support to Zopt's views proceed almost entirely from investigator's who have not liad a long and special instruction and experience in bacteriological 1.esearch. 'These, however, aje the investigators who are most liable to fall into errors which leud to a mistaken assumption of an alteration in form, and which are only avoidable by long practice and particularly careful observations. In the first place, it may easily happen that any roundish body which is like a coceus may be mistaken for a true coccus. Such a mistake is possible, for example, with spores and with involution forms (see p. 175); further, young bacilli just formed by fission show often only a very slight excess of the long diameter (see

Sourees of error in the proof.
Refutation of some state. ments made in support of Zopf's hypothesis. p. 173); bacilli standing upright and seen in transverse section resemble cocci; hy the use of staining materials-a method to which we owe the most beautiful facts, but which in unskilled hands is a dangerons means and often lcads to mistakes-a coccus form may be produced by staining very old bacilli which no longer take up the colouring matter in their whole extent, or by heating too strongly; or by employing differentiating matcrials for too long a time, so that again only a partial staining results. In investigating cultivations also, the possibility of contamination from without is never absolutely excluded, and abnormal forms must always in the first place be closely tested on the suspicion that they may be derived from contamination with other fungi; it is only when we repeatedly obtain similar results after employing all precautions for maintaining pure cultivations that we ean conclude that all the forms observed hare arisen from one and the same species.

These numerons sources of error certininly justify us in exercising a certain rescrve with regard to the statements as to an extensive alteration in form of the bacterin. Many of these statements have already been shown to be undoubtedly erroncous; thus Kurth has, in the case of the bacterium Zopfii which is according to Zopf a striking example of the great mutability of form of the fission fungi, seen, according to his own description, spores, but not cocci, originating from the bacilli ; for these "cocci" did not multiply by fission, but grew directly to rods in fresh nutritive solntions. and were less sensitive to external influences than the rods. In like minner the bodies which Hanser of late saw arising from bacilli, and which he erroneously termed cocci, do not produce now cocci by fission; while the spirnlina of the same anthor represent simplo bending and irrcgulnr intertwining of thrends snch as occurs in every long flexible thread. To mention another example, wo may refer to de Bary"s bacillns megaterinm, 
which is said to occur in coccus forms; this form was obscrved "when the cultivations were rendcred impure by the presence of othcr small bactcria, the species under discussion letaining, howercr, the upper hand; the torula-likc chain form can then by purcr cultivation be again transformed into that of the smooth rods." Undoubtedly such a trausformation in vcry impure cultivations is not frec from objection.-Thus a number of apparent proofs of the mutability of Constancy of form of the fission fungi have been refuted or recognised as uncertain, while on the other hand we convincc ourselves daily how extraordinarily constant the most various saprophytic bacteria. and pathogenic species of bacteria are when full attention is paid to all the sources of error. On the ground of these extensive and daily observations onc may now with justice assert that variation in form does not occur to any large extent in the majority of the bacteria; that on the contrary most bacteria pass through ouly the limited cycle of forms which are casily observed and permit a diagnosis of the individual varieties. Should, however, ncw and unobjectionable invcstigations demonstratc an cxtensive mutability of form in onc or othcr spccies, these spccics must then be classed with the fungi included in the last division of this provisional classification; we would, however, be compelled to regard such a state of matters rather as the exception than thc rule, and would not be warranted in deducing a law applicable to all Express recognition of the possibility other bacteria from such exceptional cases, sceing that manifold investigations havc always proved the contrary.

\section{MICROCOCCI.}

(For characteristics, see p. 171.)

A. Micrococci Pathogenic in Man.

Staphylococcus pyogenes aurcus.

First observed by Ogston; cultivated by Rosenbach, later by Krause and Passet. Small isodiametric cells about $0.87 \mu$ in diameter (Passet). Often grouped as diplococci, at timos in 4's, and also in short chains of 3 or 4 individuals, generally, however, in larger irregular masses. Retains the aniline stain after treatment with Gram's fluid (iodine and iodide of potassium solution and alcohol).-Grows on gelatine plates, * and forms in

* Where we speak of nutrient jolly in the following pages we always 
Growth on gelatine platos.

In puncture cultirations.

Growth on other nutritive media. two days at the temperature of the room punctiform colonies, which under a low power of the microscope present the appearauce of light brown circular balls, dark in the centre and with smooth borders. On the second or third day the colonies have generally increased to such an extent that they reach the surface of the gelatine; they then assume a characteristic appearance, presenting a yellow colour from this time forward, and also slowly liquefying the gelatine in their neighbourhood. The liquefaction becomes evident by the occurrence of a very shallow depression around the colony which is marked off from the rest of the gelatine by a sharp border. With suitable illumination a number of absolutely circular depressions, $5-10 \mathrm{~mm}$. in diameter, are seen on such a plate, and in the centre lie the yellow colonies of at the most $1 \mathrm{~mm}$. in diameter. At a later period the liquefaction extends further, the individual liquefying centres coalesce, and the colonies break up into fragments. - The puncture in nutrient jelly shows at first a white confluent layer along the track of the needle; liquefaction quickly occurs, beginning at the surface, and soon, as a rule, occupying the whole tube up to the glass; after a few days the yellow coloration appears, and increases somewhat in intensity up to the eighth day. The whole contents of the test-tube ultimately become liquid, and at the bottom lies the golden yellow mass of the deposited colonies.

If agar-agar is employed as the solidifying material instead of gelatine, no liquefaction occurs, and the growth of the colonies on the plates can be watched for a long time, but the very characteristic appearance due to the slnw liquefaction of the gelatine is absent. In strolies and puuctures the agar cultivations hare the appearance of whitish masses, which after a few days present at the surface a golden yellow colour. The

refer to the mixture eontaining $5-8$ per eent. of gelatine deseribed in letail in the ehapter on the methods; it is only in such a mixture that the eharaeters of growth of the various baeteria present the appear. inces deseribel here. Further, a temperature of $20^{\circ}-22^{\circ} \mathrm{C}$. is generally employecl for golatine eultivations. 
staphylococcus grows on potatoes in the form at first of a bright yellow, and later of a thick soft golden yellow layer.-When inoculated into milk, coagulation occurs after one to eight days in consequence of the production of one or several acids, among which lactic acid has the preponderance. A peculiar sour smell also becomes evident after some time in the cultivations on potatoes or agrr.

The yellow colouring matter is only formed where Products of the colony is in contact with free air ; under a layer of growth. oil the cultivations remain white. It is probable from the peculiar and energetic action of the fungus on the living tissue of warm-blooded animals that poisonous irritating materials are produced, and hence it would be very desirable to obtain a more accurate knowledge of the products of their growth. Brieger has recently (Weitere Untersuchungen über Ptomaine, p. 73) isolated an organic base from staphylococcus which had been grown in meat infusion. This base does not appear to be identical with any of the ptomaines as yet known, and thus seems to be a specific product of the growth of the staphylococcus; it did not however prove to be poisonous to the animals experimented on.

The staphylococcus is remarkable on account of its relatively great resisting power to external agents; the cultivations in gelatine or agar are active after more than a year.

The action of the staphylococcus on animals varies Action on greatly according to the mode of application. Subcu- animals. taneous inoculation is without result in mice, guinenpigs, and rabbits; when inoculated on the cornea of rabbits a small greyish white infiltration occurs, nccompanied by inflammation which subsides on the fourth day. After subcutancous injection the pyogenic properties of the fungus become evident. It is only in mice, and after the injection of relntively large quantities, that death occur's enrly; in guinea-pigs and rabbits, on the other hand, an abscess forms in the first instance, and this can cither heal and the animal recover, or a general infection may ultimately occur. Intraperitoncal and 
intravenous injections usually kill the animals after from two to nine days. On post-mortem examination the most characteristic alterations are found in the kidneys, which present the appearance of a septic embolic nephritis; whitish yellow masses from the size of pin points up to that of peas are present, and at times large wedges which infiltrate the lidney like pyramids. Many capillaries are completely blocked with thrombi consisting of cocci, as are also the smaller arteries in the cortex as well as a few straight tubules. Further, purulent metastases often occur in joints, in the muscles, and, where fractures have been recently made, in the medulla of the injured bones; frequently, however, the latter. situation escapes, although recent fractures are present. Small quantities of the fungus are at times without effect, even when injected into the veins; nevertheless in these cases also deposits appear to form in the kidneys, but remain limited and heal.

Renal deposits.

The deposits in the kidneys do not arise as the result of the excretion of the staphylococcus by the kidneys, nor does the localisation occur here in connection with any protective excretion; on the contrary, it has beell demonstrated by the experiments of Wysokowitsch that not a single coccus appears in the urine during the first six hours after the injection of large quantities of staphylococcus, and that when cocci can be cultivated from the urine deposits are always demonstrable in the

No physiological excretion throngh the urine.

Oecurrence in man.

kidneys. The cocei introduced into the blood are deposited in various organs, especially in the spleen, in the medulla of bone, \&c., and they either soon die or remain for a loug time capable of development.

Staphylococcus occurs very frequently in man ; it is the most common pyogenic organism. The experiments of Rosenbach and Passet, repeated recently with great care, have shown that materials mechanically and chemically

- irritating (turpentine and mercury) can only excite suppuration in extremely exceptional cases, when microorganisms are not present at the same time. In almost all the cases of suppuration which come nuder observa-

\footnotetext{
* Gottinger lyggion. Institut.
} 
tion in practice bacteria are the causal agents, and some forms of suppuration are more especially caused by staphylococcus aureus. This organism causes rapid suppurative destruction of the tissue, and it excites suppurative phlegmons which spread more in the tissue than in the lymphatic vessels. Hence it is found more especially in acute abscesses, in empyema, and in boils; further, in acute osteomyelitis, although the above mentioned experiments in animals have not demon-

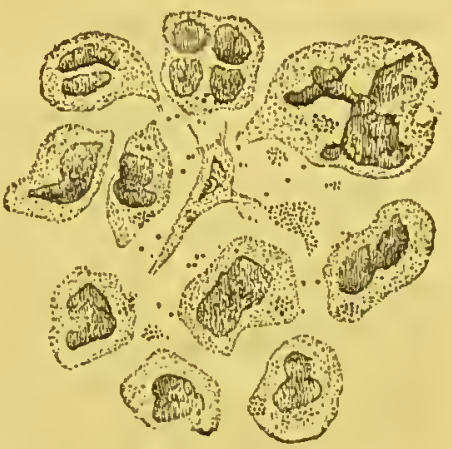

Fig. 43.-Pus containing staphylococcus $\times 800$. strated with absolute certainty the causal rôle of this fungus in that disease. Lastly, it occurs at times in some severe diseases, accompanied by metastases, in pyæmia, and in ulcerative endocarditis. According to the point of entrance of the fungus into the body, and according to the numbers which enter, affections of very differcnt severity may follow. That in reality the staphylococcus cultivated from pus from osteomyelitis is also the exciting cause of furuncular inflammation has been proved recently by an experiment made by Garré on limself, where a culture of staphylococcus, originating from the pus from osteomyelitis, was rubbed into the completely intact skin of the arm, and where the organisms penctrating through canals of the cutaneous glands, set up furuncles over a large extent of the surface.

\section{Staphylococcus pyogenes albus.}

Found frequently by Rosenbach in pus along with staphyl. aureus. Corresponds in microscopical appearance, in the characters of its cultivations, and in its relation to animals, with staphyl. aureus, the only difference being that its colonies remain white evell after a long time; in old gelatine cultivations a white deposit is seen at the bottom of tho liquefied mass. According to Passet, staphyl. albus occurs more fre- 
quently in man than aureus ; according to Rosenbach, on the contrary, less frequently, and usually mixed with aureus. In many animals (rabbits) the staphyl. albus seems to be decidedly the most frequent.

\section{Staphylococcus pyogencs citrcus.}

Found by Passet in a few cases (in 10 per cent. of the cases) in the pus of acute abscesses. Differs from the foregoing only in the bright citron yellow colour of its cultivations, the difference as contrasted with the dark yellow orange-coloured pigmentation of staphyl. aureus being distinctly evident, especially in old cultivations.

\section{Micrococcus of the "Clou de Biskra."}

By the term "Clon de Biskin, or Bouton d'Alep," is meant an endemie disease oecurring in Aleppo, Bagdad, Biskra, and Tunis, eharaeterised by tuberenlar swellings on the faee and extremities, which develop in the course of ¿year, burst, and finally eieatrise. Duelaux has found mierocoeei in the blood of these patients, whieh were less than $1 \mu$ in diameter, oecur in the form of diploeocei or zooglæa (thus belonging to the staphyloeoeei), and can be cultivated in neutralised veal infusion. Twenty drops of the cultivation injeeted subentaneously into rabbits exeite extensive gangrene, but the animals ultimately recorer. Large doses injected into the blood of rabbits kill them within 16 hours, and on post-mortem examination pericarditis, pleuritis, hamorrhagic infarcts in the lungs, \&c., are tound. After the intravenous injeetion of small doses, a chronie disease, which gradually gets well, begins after an incubation period of 10 days; this clisease is eharacterised by the oeenrrence of numerons small ulecrating nodules distributed over the skin of the whole body, and reealling exaetly the disease in man. A confirmation of this obserration by the investigation of other enses of Clou de Biskra must be "twaited.

Duclanx has made a striking olscrvation with regard to the cultivations of these mierococci. Old eultirations graslually lose their virulenee, so that after standing for two inonths the eultivations were inactire, eren in large doses. But if fresh infusion was inoenlated from these old inactive "ultivations, the new cultivation was as virulent in the first. lew days as the former young cultirations, and neeording to the dose emplnyed it set 11 the whole series of morbid symp- 
toms described above. As, howerer, the experinents were made only with fluid media there is no absolute certainty that in these experiments impurities in the cultivations did not lead to mistakes.

\section{Micrococcus pyogcnes tenuis.}

Found by Rosenbach in a few instances (in 10 per cent. of the cases examined) as the only micro-organism present in the pus of unopened abscesses. Irregular cocci, somewhat larger than staphylococci, showing in contrast to the latter, but little tendency to the formation of masses. Two dark poles with clear intermediate substance are frequently observed in the micrococci; the cultivations on agar have the appearance of thin deposits spreading out from the line of inoculation, almost as clear as glass; in puncture cultivations a somewhat thick and slightly opaque lajer is formed. No experiments on animals have as yet been made.

\section{Streptococcus pyogenes.}

First recognised by Ogston from its microscopical Pyogenic appearance; cultivated from pus by Rosenbach, then by streptococcus. Krause and Passet.-Spherical cocci, about $1 \mu$ in dinmeter, larger than the staphylococci. Retain the stain in Gram's method. What is very characteristic, and the origin of the name of this species, is the tendency of the cocci to divide continuously in the same direction and to form chains of 4,5 , or even 10 , or more cocci; these chains are frequently united in delicate loops to form larger heaps. Besides the chain form, the fungus often appears as a diplococcus. At times one or other cell in a chain is larger than the rest; it is not certain whether this indicates the formation of arthrospores. The stroptococcus grows on gelatine plates in tho form of very small punctiform colonies which spread out on the surface as rery

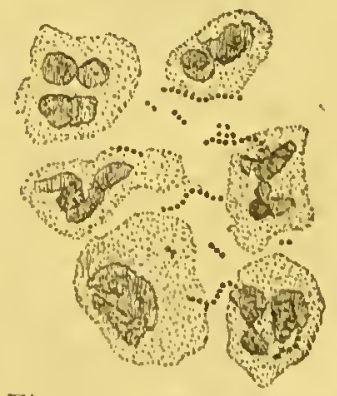

Fig. 44, - Pus containing streptococcus $\times 800$.

Growth on gelatine plates. 
In pumeture cultivations.

In stroke eultivations.

Effect on animals. small, slightly prominent transparent drops, about $\frac{1}{2} \mathrm{~mm}$. in diameter. Even after several days there is no extension of these colonies and no liquefaction of the gelatine. Under a low power the youngest colonies present the appearance of round, seldom oval, yellow spots, with regular contours and finely granular surface. Later they become somewhat darker, almost brown, and the border is here and there interrupted by projecting chains of cocci, which either terminate in a free end, or form loops; the growtl is somewhat more marked on agar plates, the colonies are rather broader and opaque.-Along the track of the puncture in gelatine a delicate layer appears, which consists, either entirely or in part, of isolated colonies; these are of a faintly whitish appearance, almost transparent, very small; only a few attain the size of a pin's head. In stroke cultivations the streptococcus seldom forms continuous lines, it usually occurs in discrete centres; on agar the growth is thickest in the middle, and becomes gradually thinner in a terrace-like form towards the periphery; at the periphery punctiform masses of the organisms can be seen here and there.-On solidified blood serrm the growth is similar to that on agar; it does not seem to grow on potatoes.

In mice in the majority of cases (about 80 per cent.) no effect follows the subcutineous inoculation of small quantities; at times slight suppuration occurs at the point of inoculation, at times the animals die without the presence of any marked pathological change or of micro-organisms in any of the organs. If rabbits are inoculated on the ears marked redness and swelling occurs on the following duy, but disappears on the second or third days; subcutaneous and even intravenous injection of considerable numbers of the streptococci cause as a rule no apparent offect in healthy rabbits. It is only when the animals are artificially weakened, as for example by the injection of toxic substances, that death occurs from marked growth of the micrococci; the animals also died after $2-5$ days from extensire endocarditis, with numerous deposits of streptococci, if the aortic ralves had been injured before the injection (Wysokowitsch). 
Streptococcus pyogenes is frequently found in pus Oconrrenoo in from man (in 40-60 per cent. of the kinds of pus ${ }^{\text {inan. }}$ cxamined). It occurs by preference in the inflammations which hare their chief seat in the lymph tracks; it does not as a rule cause such rapid suppuration and dcstruction of the tissue as the staphylococcus, but it can penetrate further into the tissice and infiltrate it before suppuration and destruction occurs. Also in serere affections, in spreading gangrene, in several cases of pyiemia, cultivations from the pus have yielded only the strept. pyogenes (compare the following streptococci).

\section{Streptoeoceus erysipelatosus.}

Proved by Fehleisen by cultivation and re-inoculation Streptococcus on man to be the causal exciting agent of erysipelas; of erysipclas. the streptococci had already been demonstrated microscopically by other observers. It can scarcely be distivguished from the preceding either microscopically (also by Gram's method) or by its behaviour in cultivations. It is only in the case of the stroke cultivations that Growth in a noticeable difference at times occurs in so far that oultivations. the colonies have a somerwhat greater tendency to run together, appear more whitish and opaque, and show at the periphery numerous out-growths which consist of projecting chains, and give to the cultivation the appearance of $a$ fern leaf. Nevertheless these characteristics are not sufficicntly constant to furnisli a trustworthy point of

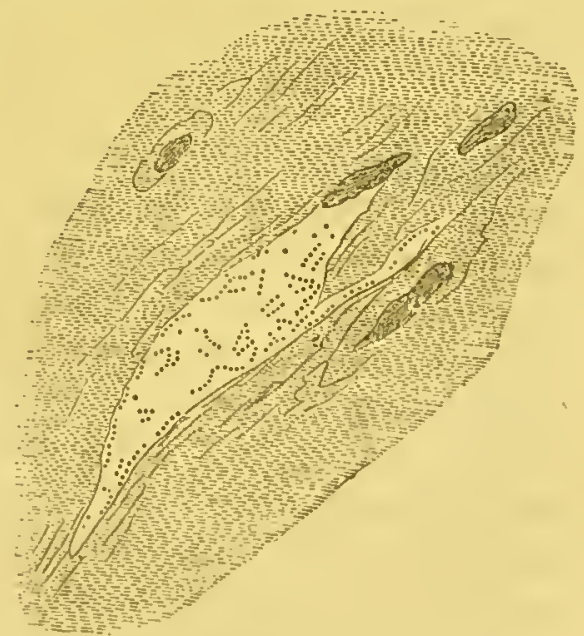

Fig. 45.-Erysipelns cocei $\times 700$. Section through $n$ lymphatic ressel of tho skin. distinction between the two cultivations.

Experiments on animals slow a slight difference 
Action on animals.

Occurrence in While thus only very slight differences can be made man.

between the two forms of streptococci. Subcutaneous inoculations in mice arc always without effect, the wounds almost always healing without suppuration. In rabbits inoculation on the cornen sets up keratitis, as in the case of streptococcus pyogenes; inoculations on the ear cause in the majority of cascs an erysipelas which is recognised by redness and elevation of temperature of the ear ; it appear's later, and is not accompanied by such intense redness as is the case with the inflammation due to the streptococcus pyogencs. A sharply limited redness appear's in the neighbourhood of the point of inoculation within 36 to 48 lours; and this cxtends in the direction of the reins as far as the root of the ear. In sections of the affecter eur the lymphatic vessels are filled with micrococci in numerous places. The animals recover completely after a few days ; intravenous injections of large quantities of the organisms are also borne without bad effect. out between these two streptococci as the result of cultivations and of cxperiments on animals, they apparently differ to a marlied degree in their action on man. Strept. pyogenes is prescnt in about the half of all kinds of suppuration, while the streptococci of erysipelas only occur in this relatively rare contagious disease, and arc able to set up this disease in healtlyy Cultivation of people. They can be best obtained, according to the cocci from Fehleisen, from erysipelas in man, by excising a small
man. piece of skin from the sharply defined border of an erysipelas marginatum (not from the earlier affected parts, in which, as a rule, no living cocci can be found), and introducing it into a tube contrining nutrient jelly; the tube is then liept for two hours at about $40^{\circ} \mathrm{C}$., so that the gelatine becomes liquid, and comes into intimate contact with the piece of slin; it is then liept at $20^{\circ} \mathrm{C}$., or better, the contents of the tube are poured out on a glass platc in the usual manner. After two or three days, numerous punctiform colonies can usually be found in the neighbourhood of the piece of slin.

Fehleisen has inoculated these cultirations on man after 
a number (17 and more) of successive cultivations on new Artificial nutrient jelly, and in these cases typical errsipelas has inoculation resultod. The exporim of the resulted. The experiments were carried out on patients cultivation. who were suffering from malignant tumours, which could not be operated on (lupus, carcinoma, sarcoma), and this was done because former experience has shown that these tumours often improve in a remarkable manner, or entirely disappear after recovery from an accidental attack of erysipelas. Such an "erysipèle salutaire" has several times during the last few years been induced by inoculation of pure cultivations, and often with good therapentical results. The incubation period in the cases observed by Fehleisen extended from 15 to 61 hours; the disease always commenced with an initial rigor, elevation of temperature, and disturbance of the general health. Individuals who had suffered from an attack of erysipelas a short time (up to some months) before the inoculation proved to be immune.

\section{Streptococcus pyogenes malignus.}

Cultivated by the author from necrotic masses in a leucremic spleen. Not distinguishable microscopically from the streptococci previonsly described, the cultivations are also very similar in appearance; the colonies on gelatine plates and in puncture cultivations appear somewhat smaller and grow more slowly, so that they do not begin to be visible till after about 48 hours. The stroke cultivations resemble most closely those of Strept. pyog.--Experiments animals yield results which differ in an important manner from those attained by the other streptococei; mice inoculated subeutaneously with small quantities of the cultivation die almost without exception after 3-5 days; a lurge collection of pus is found at the place of inoculation, a moderate number of diplococci and short chains of cocei in the blood and especially in the splecn, at times also deposits of micrococei in the internal organs. The disease may be transmitted to other mico by small 
quantities. Rabbits, after inoculation on the ear, show at first almost the same appenrances as after inoculation with Strept. pyog. and with Strept. erysip.; but after two or three days a general infection occurs, and death follows on the fourth day; the post-mortem appearances are similar to those found in mice; some of the joints are also frequently affected, and filled with pus containing numerous cocci. It is probable that the Strept. pyog. described by Krause, and which differed in its malignant effects on animals from the coccus isolated by Rosenbach and Passet, is identical with this organism.

\section{Streptococcus articulorum.}

Loeffler has observed chain-forming micrococci on and in the diseased mucous membrane in various forms of diphtheria; these organisms probably do not bear any causal relation to the diphtheria itself, but appear to be accidental accompaniments which may give rise to secondary complications either local or general. If these cocci are cultivated on nutrient jelly, small light greyish drops, as clear as water, are noticed in about three days, their border's showing with a low porrer small curly lines composed of chains of cocci. The chains may contain up to 100 individuals, some of which attract attention by their size, and at times the whole of the chain consists only of these large cocci; on closer examination indications of transverse division can be seen in these organisms.-On subcutaneous inoculation or injection of the cultivations into mice a considerable number, more than half, of the animals usually die; streptococci are found in the spleen and in other organs. After inoculation on the ear an erysipelatoid inflammation occur's in the case of rabbits; if, however, cultirations are injected into the veins, affections of the joints occur in 4-6 dnys, the joints becoming filled with pus containing streptococci, and the disease in most cases gradually ending in the death of the animals. Similar joint affections occur in connection with the streptococci already described, but here only as part of a general 
infection running a rapid course. Further, after injcetion of crysipelas cultivations Locffler obtrined joint affections in two cases, but the author was unable to confirm this result in a larger number of experiments.

Heubner and Bahrdt have recently found similar streptococci in the pus in a fatal case of scarlatina, accompanied by suppuration of joints. They werc able to show that the cocci entered the jugular vein through a purulent canal extending from the original diphtheritic affection of the tonsil, and then, just as in Loeffler's experiments, set up the suppurative inflammations of the joints.*

\section{Streptococcus septicus.}

Although this organism has not as yet been observed in man it may be mentioned here, because in its whole behaviour it shows a great resemblance with the other streptococci.-Strept. sept. was repeatedly found by Nicolaier, and afterwards by Guarneri, in impure earth. $\uparrow$ It cannot be distinguished microscopically from the other streptococci, but it has not such a marked tendency to form chains under all circumstances; it occurs especially in the tissues, and usually in the form of diplococci. Where, however, masses are present, which are composed of larger balls of the organisms, the chain-like arrangement becomes distinctly marked, especially at the borders, and it is also well developed in cultivations in hanging drops, on plates, \&c.-The colonies on gclatine grow cven more slowly than those of the other streptococci-not till after 3 or 4 days do they become cvident as fine points; in puncturc cultivations also. distinct colonies are first seen on the 5 th or 6 th day. Micc dic without exception in 48-72 hours after subcutancous inoculation of minimal quantitics of a cultivation. During the last 24 hours a distinct motor and scnsory paralysis of the hinder extremitios is present. On post-mortem cxamination large number's of diplococci are found in the blood and organs, at times in largo masses, which completcly fill the vessels. Inoculations

* Berl. klin. Woch., 1884, No. 44.

† Gijttinger hygien. Institut. 
on other mice succed with the minutest quantities of blood or splenic juice. In rabbits after inoculation on the ear there occurs in the first instance a local redness, then a general disease, and death after 2 or 3 dars. In the internal organs a marked accumulation of micrococci is found everywhere, at times leading to plugging of the vessels and the formation of necrotic foci. This tendency to the formation of foci leads in the case of rabbits to transmission of the coccus to the fotus, as shown by Oberdiek; * nevertheless in the latter there are always markedly fewcr micrococci, because the lesion of the placental tissue evidently occurs only towards the tormination of the life of the mother.

Lomparison and distine. tion of the various streptococci.
In connection with the species of streptococci just described we meet with the striking fact that fire organisms, scarcely distinguishable from each other microscopically or by cultivation, are so markedly different in their action on man and the lower animals. The resemblances on the one hand, and the differences in pathogenic effect on the other, have been accurately ascertained by Guarneri in a special series of experiments in which particular attention was paid to any possible deception or confusion. More especially any possible immunity of the animals as the cause of the inefficiency of the pyogenic and erysipelas streptococci was excluded, because the same animals which had resisted one or several inoculations with the Strept. pyog. without effect, at once died from inoculation with Strept. pyog. malignus.

From this result we may assume that streptococei of very different virulence occur in the various infective diseases of wounds in man, and that the symptoms and the result of the disease caused by streptococci are due not only to the mode of invasion, or the functions of the organs attacked, but also to the specific characters of the organism. In order to recognise the latter it is

* Götting ar hygicn. Institut. 
crident from what lias gone bcfore that the characteristics observable by the microscope or by cultivation are not sufficient, but that cxperiments on animals must also be made, and in many cases even these are not sufficient for a diagnosis.

Tn a series of diseases in man streptococci have been found, luut we have not been able to decide whether we have to do with specific organisms peculiar to the clisease in question, or' with one of the forms of streptococci previously mentioned. 'Thus in-

Endocarditis ulcerosa.--The masses of micrococci found in the ressels show for the most part a chain-Jike arrangement of the cocci; nevertheless stapliylococci may present similar appearances in the tissues, and in one cultivation experiment with the micrococci of endocarditis only staphylococci grew (Wysoliowitscll). Accord-

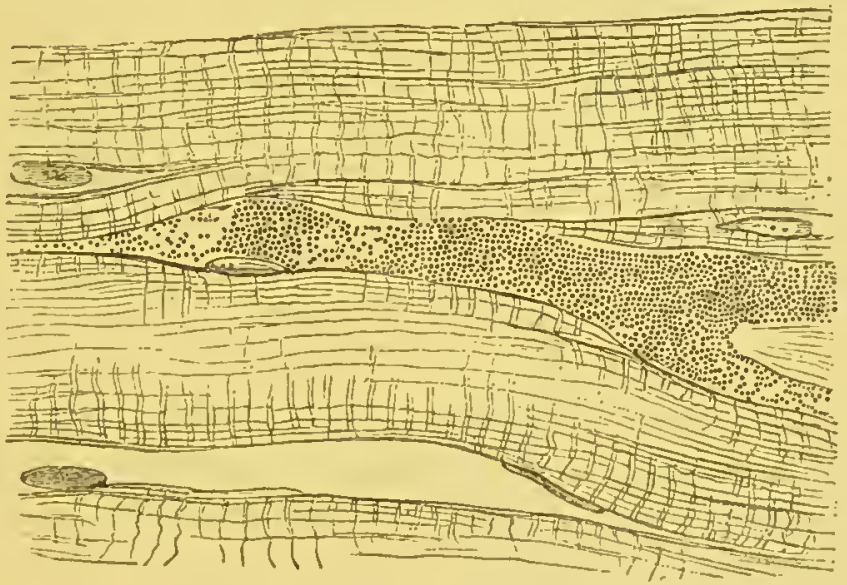

Fig. 46.-Endoearditis ulcerosa $\times 700$.

Section from the cardiac muscle. (After a photograph by Koch.)

ing to tho author's experiments refered to above, it is at all cvents unnecessary to assume the existence of a specific organism in order to explain the origin of an cndocarditis. Further, in many cases of pyrmia and pyamic metastasis, also in puerperal metritis as well as in ccrebrospinal meningitis, streptococci liave becn 
demonstrated microscopically, and have been assumed to be the causal agents of the disease (Lit., pp. 15 and 35).

\section{Micrococcus gonsmithoce.}

Gonorrhœa coccus.

Morphological peculiarities.

Observed by Neisser in 1879 in gonorrhœal secretions, and later termed gonococcus; cocci which almost always occur in the form of diplococci. The elongated body of the diplococcus in stained specimens shows in the middle a clear line (best seen in preparations stained with fuchsin), which with the highest powers appears as a distinct partition; this line divides the coccus into two halves, and gives it the roll (biscuit) form. As a rule the two halves are not true half circles; at times a. slight concavity is present on the opposed and flattened surfaces of the hemispheres. Cocci not undergoing division are only exceptionally seen. The average

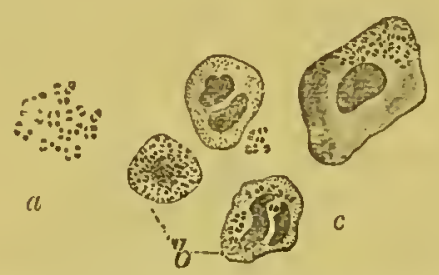

length of the diplococcus is about $1.25 \mu$. ; its long diameter varies between 0.8 and $1 \cdot 6 \mu$., its transverse diameter between 0.6 and $0.8 \mu$.-The cocci in the Fig. 47.-Micrococcus of gonorrhœa gonorrhœal secretion lie $\times 800$. (After Bumm.)

$a$, free cocci.

$b$, cocci in pus cells.

$c$, epithelial cell containing cocci. chiefly on or in the pus cells in small irregular heaps. They are not in contact with the cell nuclei, but that they really lie in the protoplasm of the cells appears certain from the fact that in carefully prepared specimens they do not extend beyond the margin of the protoplasm; a similar inclusion in the protoplasm is not observed in the cirse of the other nonspecific micrococci, which are also often present in considerable numbers in gonorrhœal secretion. Tle number of cells containing cocci is greatest not so much in the early period after infection, so long as the secretion still remains serous, as in the later suppurative stage of the gonorrhoa.-The cocci become decolourised in Gram's method.

('ultivation (:xperiments.
In cultivation experiments with the gonoryaal cocci, the saproplytic organisms present in the secretion hare 
often led to mistakes. By the elaborate reserrches of Bumm it seems to be definitely ascertained that no growth of the specific cocci occurs on nutrient jelly or on the other ordinary nutritive substrata, or at the temperature of the room. Positive results under these circumstances have always been due to saprophytes morphologically very similar to the gonorrucal cocci. According to Leistiliow and Loeffler blood serum gelatine is a very suitable soil for the gonorrhœal cocci; according to Krause and Bumm solidified blood serum is the best. Bumm obtained the best cultivations with moderately firm blood serum, the surface of which was protected from drying by placing the tubes in a moist chamber, and at about $32^{\circ} \mathrm{C}$. If he inoculated the secretion containing cocci on such blood serum, a fine layer spread over the surface from several spots along the inoculation stroke; this layer attained a breadth of 1-2 mm., ultimately presented the appearance of a very thin greyish yellow layer with moist smooth surface, and then ceased to grow, and was found to consist of closely packed masses of cocci. Further cultivations can be carried on through several generations when the reinoculations are made as early as possible. The growth is always very imperfect; the line of inoculation increases in breadth by scarcely $1 \mathrm{~mm}$. in the course of a day, and the organisms frequently die without any apparent reason.

Animals have proved completely immune to the Inoculation on gonorrhœal cocci. In dogs, rabbits, horses, monkeys, animals. \&c., neither the fresh secretion, nor cultivations inoculated on the conjunctival or urethral mucous membrane have caused inflammation. On the other hand, the on man. attempt has been made in two cases by inoculation of cultivations on healthy human beings to demonstrate the etiological róle of the cocci in gonorricea. In the first case Bockhart introduced a largo quantity of a cultivation in peptonised nutrient jelly into the urothra of a lunatic who died somo time afteriwards from an accidentally acquired pneumonia; during life typical gonorrhea had dereloped, the secretion being full of 
cocci, and in the sections through the urethral mucous membrane numerous cells filled with cocci were found. This case is not quite free from objection, because later experiments have shown that no growth of the cocci occurs on nutrient gelatine; perhaps, therefore, the positive result was obtained by cocei which had not grown in the cultivation but had been carried over in the inoculations, and had remained alive; this is not at all improbable, because large quantities were employed in the inoculation from the pus, and in the subsequent reinoculations, and also because the fourth generation was employed for the infection experiment. A second inoculation experiment was made by Bumm on the healthy urethral mucous membrane of a woman, and in like manner with a positive result; the second generation of a cultivation on blood serum was employed. Here also, in spite of the fact that pus cells could not be found in the cultivation on microscopical examination, the objection is possible that perhaps cocci were carried over from the secretion, especially as the first inoculation on the artificial soil was always made with relatively large quantities.*

Oecurienee of the gonorrhoa cocets.

The occurrence of the gonorrhœa coccus is, according to the opinion of all trustworthy observers who are acquainted with the saprophytic forms similar to the gonococcus, limited to gonorrhœal affections of the urethra or bladder, of the cervix uteri, sc., and to the specific blennorrhœa of the conjunctiva. The characteristic cocci were also found in the purulent effusion into a knee joint in a case of gonorrhœal inflammation of the joint (Petrone and Kammerer).

\section{Micrococcus sulffavus.}

\section{(Yellowish-white diplococcus of Bumm.)}

Mieloeocens similar to the gonorilioen cocets.
Similar to the foregoing, frequently observed in the lochia and in vaginal secretions, and perhaps also * Bumm has since obtrined a successful result by inoculation of a twenticth eultivation. 
pathogenic for man. A diplococcus $0.5-1.5 \mu$. in diameter; it shows a central division, and is composed of two hemispheres like the gonococcus; in contrast to that organism M. subflavus retains the aniline dye after treatment with Gram's iodine solution. Twenty-four hours after inoculation on nutrient jelly whitish points develop and grow to whitish-grey, later yellowish, and finally ochre-coloured confluent masses; after a few days nutrient jelly and blood serum become liquid in the neighbourhood of the cultivation.-Inoculation experiments on various mucous membranes susceptible to the gonorrhoal contagium was without result. On the other hand, according to Bumm, an abscess, varying from the size of a pigeon's egg to that of a man's fist, and containing numerous diplococci, follows the injection of these bacteria into the subcutaneous cellular tissue in man.

Besides the lochia this organism was also found in the urine in some cases of catarih of the bladder and also in the contents of the bullæ in pemphigus neonat., and in the pus of a mammary abscess. Further, Fräinkel has found the same diplococcus, along with another coccus to be mentioned under the saprophytes, in the raginal secretion in a large number of children suffering from colpitis, but not infected with gonorrhœa.

\section{Micrococci in Zoonotic Finger Erysipeloid.}

Cocci were found by Rosenbach* in a mild disease of the skin, not associated with general disturbance, which is characterised by a bluish brown red, sharply defined infiltration of the skin of some fingers and of the hand very similar to erysipelas. Those organisms formed, when inoculated on agar, very delicate and elegant colonies which wero scarcely visible without magnification. Inoculation of the cultivations on the upper arm of a healthy man reproduced the affection.

Corduat lias studied 127 casos of tho samo disease.

* Mikroorganismen bei den Wundinfectionskrankheiten. Wiesbuden, 1884, p. 117.

$\dagger$ Deutsehe medicin. Wochensehrift, 1885, No. 33. 
The individuals chiefly affected were those who had to do with animals and animal tissues, such as tanners butchers, \&c. Cordua was able to cultivate cocci from the affected portions of skin, and they formed in $21-36$ hours on agar at $36^{\circ} \mathrm{C}$. luxuriant chalk-white colonies, with slightly facetted margins. Inoculations on animals were without result, but here, also, he was successful in setting up the affection on his own arm from a cultivation. Probably Rosenbach and Cordua have been dealing with cultivations of the same organism which presented different appearances only in consequence of differences in the nutritive substrata. Further investigations must be awaited.

Imperfectly known pathicgenic micrococei.
Micrococci have also been described as causal exciting agents in numerous other diseases in man, but they have been demonstrated either by microscopical investigation alone, or the infective and cultivation experiments are not free from objection, and therefore further confirmation appears to be necessary. To these belong *-

Variola.-Cohn, Weigert, Koch, and others, found micrococci in the pustules and in various internal organs in persons who died of smallpox. Cultivations hare not yet been made.

Vaccinia.-In the lymph in the vesicles micrococci have been frequently observed; cultivations of coeci have also been repeatedly obtained from the lymph, but all the micro-organisms as yet cultirated are evidently only impurities for the most part of a saprophytic character, as a vaccino pustule has never been produced by inoculation of the cultivations. The recent cultiration experiments by Wolff do not seem to hare given a better result.

Scarlatina, Measles.-Micrococei found, but of 110 importance (see Lit., p. 35).

Diphtheria.-In tho former investigntions by Klebs, Oertel, and others, these authors evidently did not work

* As to the Micrococeus puetunonia sec under "breilli." 
with specific organisms. As to Loefler's streptococcus see above (p. 19t); as to bacilli in diphtheria seo below.

Cerebrospinal meningitis.-Leyden, and more recently Leichtenstern, have found cocci in the purulent exudation on the pir mater; these were sometimes enclosed in white blood cells, sometimes they lay outside them.

Influenza.-According to Seifert numerous micrococci $1.5-2 \mu$. in length and $1 \mu$. in breadth, are embedded in the tenacious mucus composing the greyish-white clumps present in the sputum and in the nasal secretion at the height of the fever. They are mostly arranged in long chains; their numbers markedly diminish as the number of cells in the secretion increases. In control examinations of the secretion in bronchitis, \&c., the cocci were not found.

Ozcenu.--Frïnkel found various micrococci in the secretion, Loewenberg chiefly only one kind. The cultivation and infection experiments do not sufficiently establish their significance.

Cocci have been demonstrated in Hemophilia neonatorium, and in acute yellow atrophy of tive liver.

In yellow ferer. Domingos Freire has found a microorganism which he terms Cryptococcus xanthogenicus and which he regards as the cause of that disease; the observation, however, is evidently based on gross errors. Cornil and Babes recently found in one case that the capillaries of various organs contained long chains of diplococci, but they could not find these organisms in five cases investigated subsequently. As to bacilli in yellow fever see below.

In trachoma of the conjunctiva Sattler has found coeci in the secretion and in the trachoma nodules; he was able to cultivate these organisms on nutrient jelly, and when inoculated on tho normal conjunctiva they set "1 vesicular-like granules without pathological secretion or subjective symptoms. We must await repetition of these experiments with more typical results before concluding that these cocci aro the causal agents.

In areu Celsi, Buchner, and later von Sehlen, have found micrococci somewhat less than $1 \mu$. in diameter, and 
lave cultivated them in nutrient jelly. Michelson has however asserted that von Sehlen's case was not one of true area Celsi (see Lit., p. 37).

Rindfleisch found numerous plugs of streptococci in the cutancous capillaries in a case of myeosis fungoides or granuloma fungoides (spongy nodular out-growths of the skin consisting of granulation tissue); these organisms stain well with Gram's method. Auspitz has also seen cocci in a similar case.

\section{B. Micrococci Pathogenic in the Lower Animals.}

Micrococci have been stated to be the cause of some important infective diseases of domestic animals (mammalia), nevertheless the proofs as yet brought forward are insufficient.

Rinderpest.-In Russia, and in some parts of Austria, a widespread epidemic contagious disease exists among cattle; it is characterised by general prostration, increased secretions, fluid, slimy, or bloody stools, and quickly terminates in death. On post-mortem cxamination the appearances are those of an intense gastrocnteritis with hypertrophy or ulceration of the solitary follicles, and of Peyer's patches. Semmer asserts that lic has cultivated micrococci from the dead body, and that he has crused the disease by inoculation of these organisms. These investigations are howerer open to the same objections as the other bacteriological work of the same author.

Plenropneumonia in cattle (péripneumonie contagicuse du gros bét(cil). An epidemic pleuropneumonia of cattle which causes death in a fourth of the cases. Poels and Nolen have isolated cocci from the pulmonary exuclation which resemble Friedlaender's pneumonia bacteria morplologically, and in their growth in cultivations. Cornil and Babes found a mixture of various bacteria in the exudation, as to the special etiological significance of which nothing has as yet been settled. The fluid flowing from 
the cut hepatised lung has been frequently employed for protective inoculations; it is injected subcutaneously into the tail, and causes at the most a local affection, and after this has passed off immunity is said to be attained.

Swine erysipclas (pig typhoid, \&c.). Pasteur and Thuillier have found micrococci in the blood and in the exudations, and have ascribed to them a causal significance. Loeffler and Schütz, Lydtin and Schottelius have, however, described bacilli as the true causal agents of this disease (see later).

A number of well characterised pathogenic micrococci have been observed in various of the animals ordinarily employed for experiment. To these belong, besides the above-mentioned staphylococcus, which can be inoculated on lower animals with success, streptococcus malignus and septicus.

\section{Micrococcus tetragenus.}

First described by Gaffky.* It is not uncommonly Microcoens.s found in human sputum, and is especially observed tetragenns. in the sputum and in the walls of the cavities in cases of pulmonary tuberculosis. Micrococci about $1 \mu$. or Mieroscopic more in diameter, dividing into four individuals which apporance. l'emain united by a gelatinous envelope. In cultivations we find some large spherical cells undergoing division, but the greatest number consist of cells in which the division has been completed. The round gelatinous envelopo stains faintly, the microccoci strongly with aniline dyes; the colour is retained in Gram's method; the appearance recalls that of sarcina, but the division in the third plano and the formation of many-celled packets is absent. $-O n$ gelatine plates M. tetragenus Cultirations. forms in $24-48$ hours small white points which undor a low power present the appenrance of circular or citronshaped yellow masses, with a graunlar, mulberry-like surface, and regular, but somowhat rougl, jagged

* "Klinische, exporimentelle u. botanischo Studien über dio Bc. deutung des 'Torfmulls als Vorbandmittol." Von Dr. Nenber, Dr. Gaftky, u. Dr. Prahl, r. Langenbeek's .4rch.f. Chir., vol. 28, Heft 3 , 
borders. When they have reached the surface they form white raised thick drops on the gelatine $1-2 \mathrm{~mm}$. in diameter. In the inoculation puncture the colonies

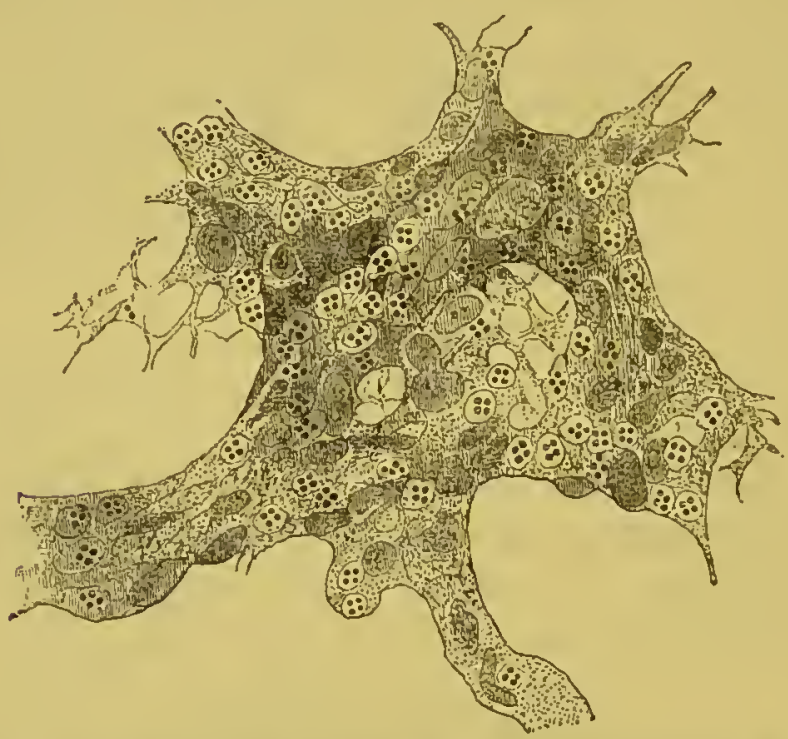

Fig. 48.-Micrococcus tetragenus. Section of lung $\times 800$.

become confluent, so that a thick white gelatinous mass is formed along the line of puncture, and fills any cracks or cavities in connection with it; on the surface a thick layer $4-5 \mathrm{~mm}$. in breadth is formed.

Fixperiments on animals.

The minutest quantity of the cnltivation inoculated subcutaneously into white mice causes in all cases a

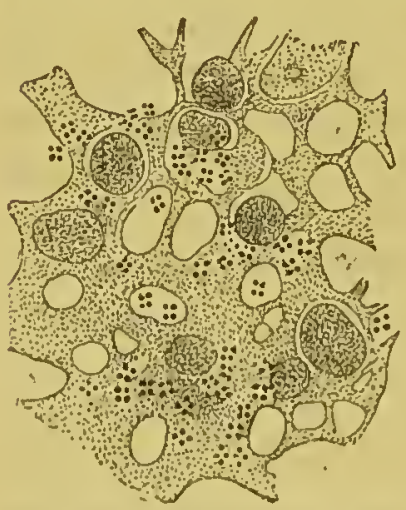

Fig. 49-Micrococcus tetragenus. Section of splecn $\times 600$. fatal disease. The first 2 days pass by without noticeable symptoms; then the animals become still and somnolent, and after 3-6 days death occurs. The cocci are only present in the interior of the blood vessels; in the blood of the heart they are relatively few in number, they are present in larger numbers in the splenic juice and in sections of the lungs, in the glomeruli of the kidneys, in the lirer, \&c. Grey house mice are almost without exception immune against $\mathrm{M}$. 
tetragenus; guinea-pigs show either local abscesses or septicremia; rabbits and dogs are unaffected by large quantities injected subcutaneously or into the veins. Whether in man the presence of $M$. tetragenus in the tuberculous lungs is accompanied by any secondary injurious results must be ascertained by further investirations. In the meantime M. tetragenus is of importance to us as it is a micro-organism admirably adapted for experiments on account of its morphological peculiarities and of the ease with which it can be cultivated.

The following are imperfectly known: Streptococcus Organism of a perniciosus psittacorum. According to Eberth and disease of Wolff parrots imported into Europe die in large numbers from a disease in which nodules are formed on the surface of the lungs, spleen, kidneys, \&c. Cocci of medium size with a tendency to the formation of chains are found in the vessels, in the nodules, and in the blood of the heart.

Streptococcus Charrin.-Found by Charrin* in the Charrin's bodies of rabbits which had died of anthrax. Oval micro- scpticimie cocci 1 to $2 \mu$. in diameter, with a tendency to form ausécutive chains composed of as many as twenty cocci. They are present in large numbers in the vessels of all the organs. The micrococcus kills rabbits within eighteen to fortyeight hours after subcutaneous inoculation. On postmortem examination we find great swelling of the spleen and cedema at the seat of injection. Besides rabbits, sparrows and cats are also susceptible, the latter, however, not always; dogs and fowls are immune. This septicamia is termed "septicémie consécutive au charbon." It is probably identical with Koch's coccal sepsis
(p. 211).

Streptococcus bombycis (Mikrozyma bombycis, Bé- Silkworm champ.) Oval cells at most $1.5 \mu$. in diameter, single or disense. united in pairs or cliains of $4-8$, or even longer straight or curved chains; causes the lethargy (flacherie, facci- Lethargs. dezza, maladic de morts-blancs) of the silkworms which appeared about 15 years ago, and since then has broken out with great violence from time to time.

\footnotetext{
* Socićté de biologio, Sérnce du 2 Août, 1884.
} 
The living animal shows diminisher appetitc, and becomes languid; soon after death the bodies become soft and almost fluid; after 24-48 hours they present a dark colour, anrl become filled with gases and blackish brown putrid fluid. The disease appears to develop "spontancously" under" unfarourable hygienic conditions-bad ventilation and food, \&c. ; it is also propagated by infection. The disense can lue set up in healthy animals by feeding them with dust from affected localities. In the digestive tube of the diseased and dead animals, especially in the juice of the stomach, these

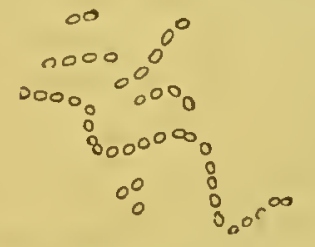

Fig. 50.-Micrococeus bombycis (afterCohn) $\times 600$. micrococei are constantly present in large numbers, and other bacteria also appear shortly before death. Nercrtheless there is no proof that all the morbid symptoms can be explained by the distribution of the micrococci in the body, or that the minutest number of the isolated organisms can induce the disease; there is, ther efore, a possibility that other bacteria more difficult to demonstrate are the truc cxciting agents of the diseasc.

Pebrine

Nosemabombycis (Micrococcus ovatus, Panlistopluyton oratum, corpuscules du ver it soie), the canse of the pebrine (Gattine, Fleckenkrankiteit, muladie des corpuscules) of the silkworms

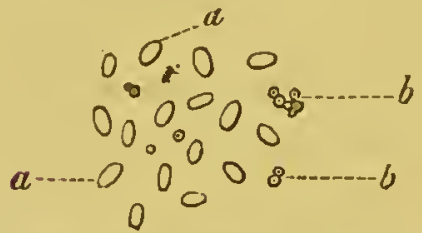

Fig. 51. -Nosema bombycis $\times 500$.

", Nosema cells.

$b$, urates which are usually present in the preparations. (After Duclaux.) may be included here, although from the sizc and form of the organisms, as well as from the imperfect knowledge of their developmental history, we are still doubtful as to their propor place. In the blood and in all the organs of the diseased worms we find highly refracting oral cells. $3-4 \mu$. long. $2 \mu$. broad; for the most part isolated, at times united in pairs or masses. They vere first discovered by Cornalia, and subsequently described by Lebert, Nägeli, and Pasteur. Rocently Metsclmikoff has supported the supposition fornerly cutertained, that the exciting agents of pebrine belong to the psorospermeec.

The disease is characterised by the appenrance of blackish patches on the skin of the caterpillars. At the same time the appetite diminishes and the wor'ms become moroslender and watery; the silk organ swells up in a garland form, becomes opaque, and the discased worms furnish no coccoons, or only rery weak ones; finally, they dic after a short time. The whole organs then appear to be infiltrated with the "micro- 
cocci"; the organisms are also found in the eggs of the butterflies, and by means of these infected eggs the hereditary transmission and the continuance of the disease is provided for'; for otherwise, on account of the slight resisting power of the micrococci, they would be in danger of disapporring. Pasteur has demonstrated experimentally that the discase may be transmitted by micrococci contained in the food, or by their penetration through injured parts of the skin, and that currents of air, handling by the brecder, \&c., may Icad to the spread of the infective germs.-As prophylactic means the plan introduced by Pasteur is now generally adopted; the butterflies which are laying eggs are separated in pairs, and after copulation and the laying of the cgos, are cxamined as to the presence of the characteristic "micrococci." If the latter" are found the eggs are destroyed, and not employed for breeding:

To this group also belong some infective wound dis-Koch's microeases in animals which were investigated as fully as infectire possible by Koch by microscopical observation at a time wound when no trustworthy methods of cultivation wele known. lowcranimals.

Micrococcus of Progressive Necrosis of tissuc in Micc.Round cells, $0 \cdot 5 \mu$. in diameter, usually arranged in beautiful and regular chains, at times massed together in thick groups (fig. 52), causes necrosis of the tissue; as far as the micrococci reach no blood or collnective tissue cells remain intact, and even the cartilage cells are destroyed. The gangrene ex- Fig. 52.--Micrococci of progressire tends from the point of necrosis of tissue in mice. (Aftcr inoculation, and sooncauses deatl (in about 3 days);

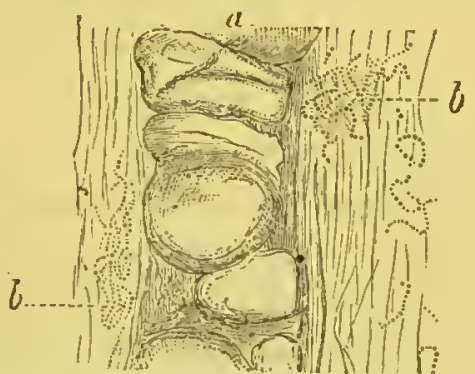

a, cells of the cartilage of the cax. $b$, chain forming micrococci. tho blood and internal organs remain free from micrococci. From their behaviour we must assume that a soluble noxious material is producal by the vegetation of the cocci. - The clisease was obtained by Koch by inoculation of putrid material on the car of mice; at the same time, however, bacilli which caused septicrmia were always inoculatecl, and led to the death of the animal; it was not till ficld mice, which aro immune against the 
bacillar septiciemia, were inoculated, that the course of the disease could be observed undisturbed by the presence of other bacteria.

Micrococcus of Progressive Abscess Formation in. Rabbits.-Minute cells, only about $0.15 \mu$. in diameter, generally in thick cloud-like zooglæa masses (fig. 53). It was obtained by injection of putrefying blood into

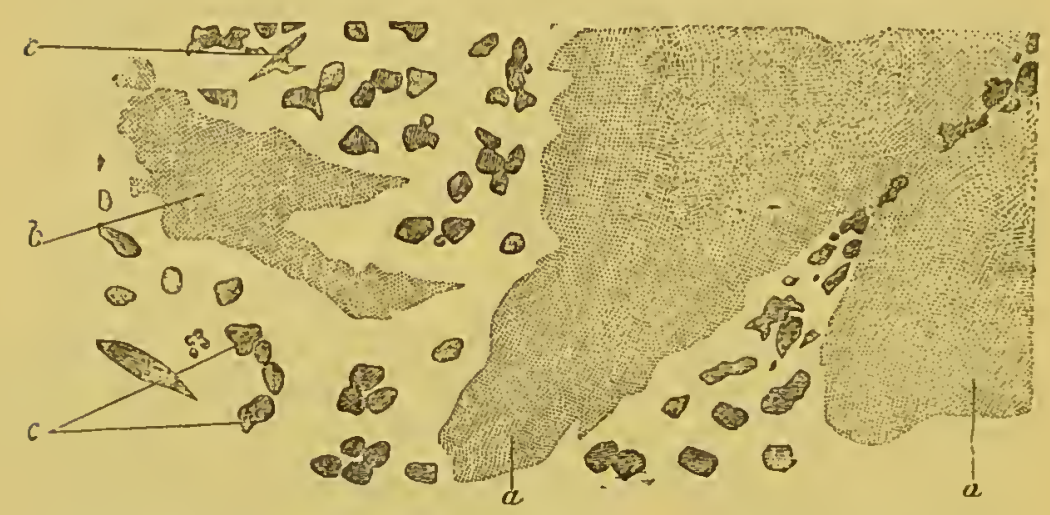

Fig. 23.-Micrococcus of progressive absoess formation in rabbits (after Koch) $\times 700$.

Border of a cheesy abscess :-

$a$, cloud-like masses of zooglxa.

$b$, smaller colonies of micrococci.

c, nuclei.

rabbits; an extensive abscess formed at the seat of injection, and caused the death of the animals in about 12 days. No bacteria are present in the blood; a finely granular mass is found in the cheesy contents of the abscess; the wall of the abscess is formed of a thin layer of micrococci united in dense zoogliea masses; towards the interior of the abscess the zoogliea appears to degenerate and dic. Nevertheless the contents of the abscess are infective, and set up the same disease in liealthy rabbits.

Micrococcus of Pycemia in Rabbits.--Round cells. $0.25 \mu$. in diameter, for the most part single or united in pairs; they tend to surround and enclose the blood corpuscles in a characteristic manner (fig. 54). The disease in question was obtained by injection of fluid used for maceration; on post-mortem examination there was great infiltration around the seat of injection, peri- 
tonitis, metastatic deposits in the lungs and liver-in slort the appenrances of pyæmia. In the capillarics of all the organs investigated dense micrococcal masses, with enclosed blood corpuscles, were found; likewise in the metastatic deposits, where they had passed out of the ressels and attacked the neighbouring tissues. In the blood of the heart and of the larger vessels numerous micrococci were likewise present, but, in consequence of the numerous thrombi, they were not so numerous as in other septicrmic diserses. Healthy rabbits were infected successfully by inoculation of blood from the heart, \&c., but larger doses (1-3 drops) caused death more rapidly (40 hours) than

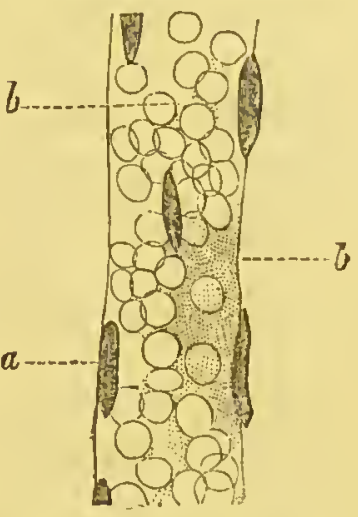

Fig. 54.-Micrococcus of pyæmia in rabbits (atter Koch) $\times 700$

Vesscl from the cortical part of the kidney:", nuclei of the vilscular. wall.

$b$, micrococci. small quantities ( $\left.\frac{1}{10}\right)$ drop), on account of the relatively small numbers of cocci in the circulating blood.

Micrococcus of Septicamia in Rabbits (compare above Streptococcus Charrin). - Oval cells, $0.8-1.0 \mu$. in greatest diameter. They do not cause coagulation in the blood, and never enclose the blood corpuscles, but

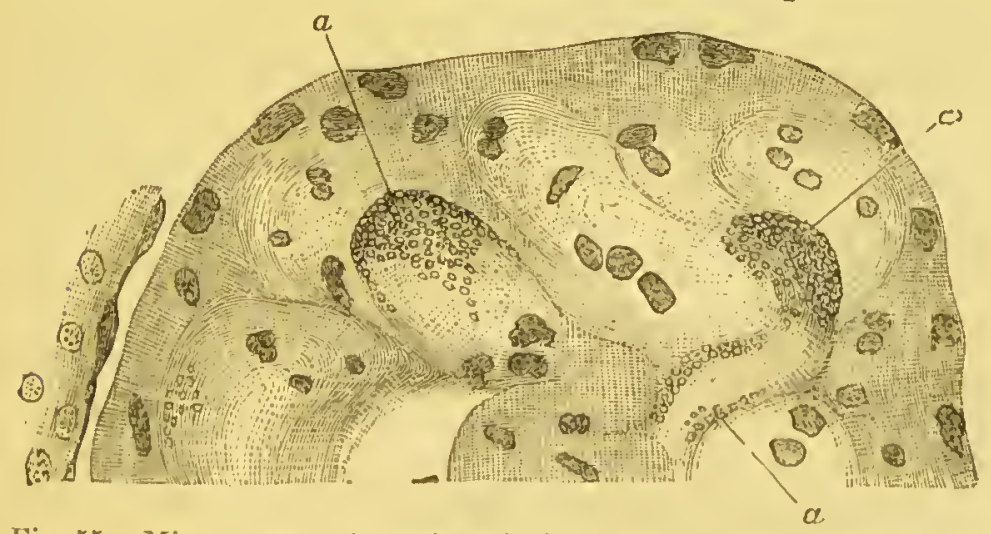

Fig. 55.-Micrococeus of septictomia in rabbits (after lioch) $\times 700$.

Part of a glomerulus:-

At $a$ tho capillary vessol with micrococci.

push them to ono side (fig. 55). The disense was obtained by Koch by injection of meat infusion; after 
death slight œdema was foumd at the seat of injection, small extravasations of blood, marked enlargement of the spleen; no embolic processes, no peritonitis. Masses of micrococci were found obstructing the capillaries of various organs, more particularly in the glomeruli of the lidneys. Inoculation of the blood of the heart transmitted the disease to rabbits and mice, but only when considerable quantities ( $2-10$ drops) were used.

\section{Saprophytic Micrococci.}

Some micrococci set up fermentations, or peculiar decomposition products, when growing in suitable media. To these belong :-

\section{Micrococcus Uirec.}

Leube's micrococens nice.
Micrococei $0.8-1.0 \mu$. in diameter, often grouped together in the form of diplococci and tetrads, frequently also in longer chains. In plate cultivations, according to Leube, white mother-of-pearl-like spots about the size of a hemp-seed, with smooth surfaces and sharply defined margins, are formed on the gelatine within 24 hours. In 10 days the colonies hare attained the size of about a 20 pfennig piece (about the size of a sixpenny piece). They project somerhat abore the surface, and resemble a drop of stearine which has fallen on the gelatine. The circular colony gradually breaks up into several portions divided by fissures, and each of these forms a zooglæa, which gradually increases in size.-

Under a low power the border of the colony

:

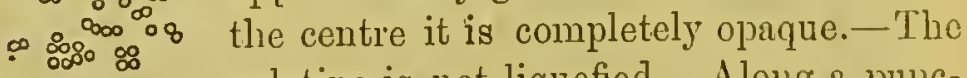
Fig. 56.-Micro- gelatine is not liquefied. Aloug a punccoccus ures $x$ ture in gelatine the cocci form a thim 700 .

tenacious thread. In old cultirations a heavy paste-like smell is dereloped.

If a small quantity of the cultiration is introducer into urine, or into a solution of urea, an energetic decomposition of urea into ammonium carbonate occurs. Pasteur and van Tieghem regarded micrococci as the 
active causes of this dehydration, and gave to this organism the name of M. urca; Leube has recently shown that a large number of bacteria (such as sarcinie from the lungs, and several bacilli which arc found in ammoniacal urine-see under "bacilli") can set up the same decomposition with, to some extent, the same energy. In the author's laboratory another coccus was isolated from decomposing urine, which, like the preceding, causes an energetic fermentation of urea, but shows certain differonces in the characters of growth; more especially it liquefies the gelatine.

\section{Micrococcus urece liquefucions.}

Spherical cells, 1.25-2 $\mu$. in diameter, singlo or A micrococcis forming chains of 3-10 individuals or irregular groups. urea which Oll gelatine plates they form in two days small white gelatine. points, which under a low power appear as darkgrey circular discs, with sharply defined borders. When they reach the surface the colonies become markedly larger; when magnified 80 times they have the appearance of dises of a yellowish-brown colour, which often contain in their middle a dark nucleusthe deeper portion of the colony; the surface of the dises is distinctly grauular; the border's gradually assume a wavy charactor, at the same time gradual liquefaction of the gelatine occurs. In the puncture cultivation a white confluent layer is at first formed along. the needle track, then liquefaction of the gelatine soou occurs, and extends to the wall of the glass; finally, the lialf or the greater portion of the tube becomes filled with a whitish turbid fluid, at the bottom of which a thick whitish-yellow deposit lies.

It might appear doulutful which of the two coeci deseribed ahore was the one reforred to in the observations published formerly at a time when a definite isolation of the individual species was not possible. Nevertheless, the eircumstanec that in Leulue's elaborate experiments the organism first descrilued was elicfly met with in the great majority of cases, Biological is in finvour of the view that former observers were working propertics of with it.-From the numerous entributions to the biology the miero- 
Museulus's ferment of urine.

of this organism which have been furnished by Pasteu. rin 'Tieghem, Mnsculus, v. Jaksch, and others, we lcarn that the alkaline reaction which occurs in no way interferes with the derelopment of the organism. The fermentation continues till about 13 per cent. of carbonate of ammonia has been formed. Artificially prepared solutions of urca, to which the necessary salts have been added, are rapidly decomposed in the same manner. According to r. Jaksch the best artificial cultivating fluid consists of 3 grammes of urea, 5 grms. of tartrate of potash and soda, 0.12 grins. of monophosphate of potash, $0.06 \mathrm{grms}$. of magnesium sulphate, dissolved in 1,000 ccm. of water. The best temperature for development lies between $30^{\circ}$ and $33^{\circ}$ C.-Musculus has attempted to show that the ferment of the ammoniacal fermentation can be separated from the micrococei which produce it, just as the inverting ferment can be separated from the yeast. By precipitation of urine containing much mucus from cases of catarrh of the bladder by means of absolute alcohol, and subsequently drying and pulverising the precipitate, Musculus obtained a substance soluble in water which converts urea very energetically into carbonate of immonia. Leube was able, nevertheless, to shorr that pure cultirations of Microc. urew filtered through plaster cells are inactive, that thus the ferment which was isolated is not produced by the organisms, but has perhaps some other. source of origin.

According to v. Jaksch and Billet the micrococcus shows a great variety of regetative forms in that it can also gire rise to rod-shaped forms, which again become changed inte chains of cocci. These observations wcre made on cultiviltions in which there was no gnarantec for their purity, and could not be confirmed either by Leube or in the anthor"s laboratory.

\section{Leuconostoc mesenterivides.}

Recognised by Cienliowski and van Tieghem as the cause of the so-called frog-spawn fermentation (Froschlaichgïhrung) of the beet juice and molasses in sugar factories. Forms chains of cocci, which are surrounded ly a thick tenacious gelatinous enrolope; large compact gelatinous masses ultimately arise by union of numerous chains. When the nutritire materials are becoming cxhausted, the majority of the cells dic; some howerer, which appear to be larger, with thicker walls and more 
highly refracting, remain as arthrospores, and derelop in fresh nutritive solutions to new coccus chains.

The organism grows on the surface of carrots or beetloot in the form of thick massive gelatinous cakes, of cartilaginous consistence. It also flourishes in solutions of grape and cane sugar, to which nitrates and phospliates hare been added. Cane sugar is in the first place converted into glucose, by a ferment formed by the

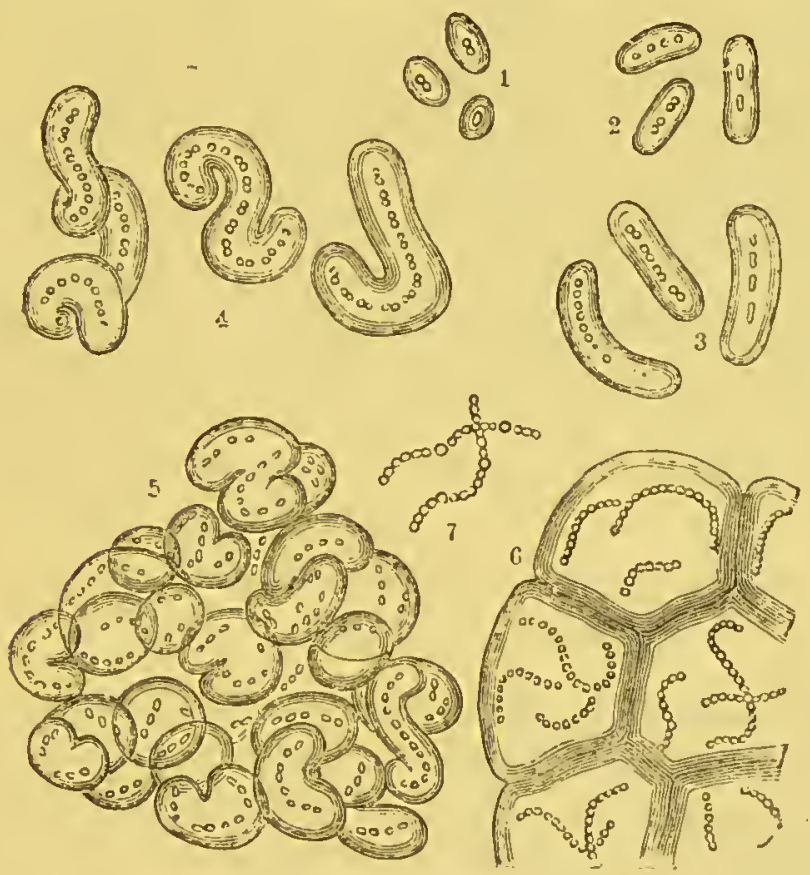

Fig. 57.

Leuconostoc mesenterioides. (After Zopf.)

$1,2,3,4$. Sncessive stages of division of the cocci and formation of the gclatinous material. 5. A collection of small zooglæa. 6. Scetion through an older zooglaa mass, containing fairly long torula-like threads. 7. Chain of cocci, showing spores herc and there, the spores being larger than the cocci.

organisms. When the organisms develop luxuriantly, enormous quantities of sugar can be assimilated in a relatively short time and converted into the sulustance of the organisms, cliefly into the gelatinous material. 'This material is described by Scheibler as "dextran," and the whole process, which may be very luretful to tho manufacturers of sugar, is included under the term "dextran fermentation." Nothing is as yet linown as to the growth of the organism on the ordinary solid nutritive medin. 


\section{Micrococcus viscosus.}

Pasteur* has found a micrococcus which seems to be the cause of viscosity in wine (vin flant); the diameter of this or.ganism is only $0.2 \mu$, and it is arranged chiefly in the form of chrins. It grows in the most various saccharine fluids, and converts them into a viscoid and tenacious mass; a form of gum is constantly developed, to which Béchampt has given the name of viscose. Nothing is definitely known as to the morphology and characteristics on cultivation of this organism. Cocci have been found by Schmidt-Mülheim $\ddagger$ in tenacious milk, which were possibly the cause of this abnormality. The cocci measure about $1 \mu$, and often lie in clains like strings of beads, containing 15 or more individuals. The decomposition does not appenr to be the same as in the case of the viscous wine, for no mannite and no carbonic acid are formed; the mucus is closely allied to that of plants. Cultivation experiments are wanting.

\section{Micrococcus Pflïgeri.}

(Bacterium Pflügeri, Ludwig.)

Nicrococci $\frac{1}{2}$ to $1 \mu$. in diameter, for the most part in zoogliea masses. They were first observed by Pflüger, later by Lassar, Ludwig, and Nüesch, on phosphorescent meat (from slaughtered animals, fish, \&c.), the surface of which was covered with a luminous slime. The cocci are also sard to grow on boiled white of egg and potatoes, on which they also develop their peculiar luminosity. Further statements as to the conditions of cultivation, \&c., are wanting.

\section{Micrococcus forticlus.}

Found by Rosenbach in carious teetl. Tery small oval somewhat irregular cocci which stain badly with aniline dyes. They could not be cultivated in stroke cultivations on agar jelly, but on the other hand grew

* Bull. de la Soc. Ch., 1S61, 30.

† Compt.rend., T. 93.

^ Pfliger's Archiv, 1852, vol. 27, p. 490. 
on exclusion of air at the bottom of nutrient agar, the growth being accompanied by the development of gas and foul smell.

\section{Micrococci of Putrefaction.}

Besides the forms already mentioned there are probably a number of micrococci which play some part in the ordinary processes of putrefaction. At the commencement of putrefaction more especially, and also when it occurs at a moderate temperature, micrococci of varying size and arrangement are always observed in enormous numbers in the substrata; they multiply actively for some time, and must exer't some preparatory or direct action. Isolation of these organisms, and the determination of their special action and the part they play in the process of putrefaction, must be the subject

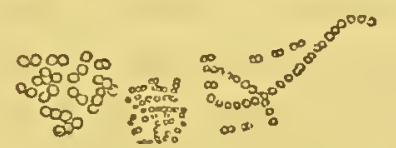

Fig. 584.-Micrococci of varions sizes from putrefying blood $\times 700$.

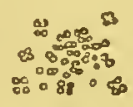

Fig. 58в.-Micrococci arranged in tetrads $\times 700$.

of subsequent investigntions. Fig. 58A shows some of these micrococcus forms from blood which had stoud for 4 days at about $10^{\circ} \mathrm{C}$; f fig. $58 \mathrm{~B}$ shows micrococci arranged in fours which had developed in wound secretions in man (both after Koch).

Some saprophytes are of interest to us becruse thoy, are frequently found as accidental colonists on the jelly plates and on other nutritive substances; they are evidently very widely distributed in our surroundings, and call enter the cultivations from the air or by contrct with a great rariety of substances. Hence the forms described here represent only a sinall selection from the micrococei which have been met with in the Laboratory at Göttingen. A more complete description will shortly be published in another place. 


\section{Micrococcus candicans.}

Moderately large micrococci, completely round; unite together to form irregular masses. In gelatine plates the colonies lying in the substance of the jelly present after two days the appenrance of white dises with a tendency to yellow $0.4-0.5 \mathrm{~mm}$. in diameter; those which lie on the surface form within the same time pure milk white flat colonies like drops of varnish, and with a diameter of $2 \mathrm{~mm}$. or more. Under a low power the deep colonies are quite circular, witl smooth margins, and of a dark blackish brown colour with indications of a granular surface; the superficial colonies present irregular contours, often indented and sinuous; the surfice is finely granular, and in correspondence with this shows under a somewhat higher power (100 diameters) a finely jagged border. In the middle the colonies are dark brown, but become clearer towards the border, which is quite transparent. In puncture cultivations there are confluent white masses and a linob-like eleration (nail cultivation) on the surface at the entrance of the canal.-An extremely frequent impurity on plates, Se.*

\section{Micrococcus cinnabarcas.}

Large spherical micrococci often in the form of diplococci, erch half however being completely round; often arranged in threes and fours.-Grows extremely slowly; after 4 days the colonies lying in the depth are punctiform and just recognisable, while those placed superficially have attrined a dirmeter of $0.5-1 \mathrm{~mm}$.; after about 8 days the latter are elevated abore the gelatine in a linob-like form. The colonies appear at first of a light wax-red colour, later cinnabar red. Under a low power the youngest deep colonies are egg or lentilshaped, with sharp contour, and of a dark reddish-brown colour. The superficinl colonies are light brown, transparent at the margins, round but with a somewhat irregular contour, due to projecting henps of cocci.-In

* Göttinger hygicnisclics Institut. 
the puncture cultivation white colonies, which remain isolated, form in the deeper parts after 4 or 5 days; on the surface there is a moderately large knob, at first rose-coloured, and later of a cinnabar tint. The gelatime is not in the least liquefied. The growth is somewhat slower on potatoes.-It occur's frequently as an impurity on old cultivations.

\section{Micrococcus flawus liquefaciens.*}

Comparatively large cocci, arranged for the most art in twos or threes, or also in masses. They form small yellow colonies on gelatine plates after two days, around these a shallow depressed zone can be seen (similar to the Staphyloc. aureus). The youngest colonies are (as seen under a low power) circular or oval, or also at some parts irregular; their surface is finely graunlar; their contour sharp but finely toothed; their colour yellowish brown. The superficial colonies, which are already causing liquefaction, and are distinctly yellow, still show the remains of the deep colony in the centre; the border forms a ring with a sharp outline which is here and there interrupted by heaps of cocci, and ultimately several neighbouring colonies coalesce. The ring is separated from the centre by a broad clear zone, in which we see isolated, radially arranged lines of cocci. The whole colony has in this stage a diameter of $4-6 \mathrm{~mm}$., and resembles microscopically the wheel of a waggon.-In test tubes spherical yellow rolonies appear in two days along the puncture track; these become confluent, and soon liquefy the jelly, so that after 8 days the tube contrins all upper zone filled with clear fluid with the yellow masses of organisms at the lower part.- It is comparatively common.

\section{Micrococcus farus tardigradus.}

Large spherical cocci, showing at times peculiar dark poles; for the most part arranged in masses. Grows extremely slowly. After 6 days the deep colonies in

* Güttinger hygienisches Institut.

+ lbir. 
gelatine plates have attained the size of $0.4-0.6 \mathrm{~mm}$., are of a dark chrome yellow colour, round or oval; the superficial ones have a smooth wax-lile surface, measure ultimately $\frac{1}{2}-1 \mathrm{~mm}$., and project at their middle somewhat above the gelatine. Under a low power the deep colonies present a sharp, smooth contour, and a uniform dark olive green colour; in the superficial ones the colour becomes lighter and more of a greyish yellow tinge towards the margin. - In the puncture it is not till fifter $6-8$ days that a row of minute yellow colonies, which form balls and remain isolated, can be noticed. The gelatine is not at all liquefied.-Less common than the forms mentioned before; often occurs along with M. cimnabareus.

\section{Micrococcus coronatus.*}

Cocci somewhat more than $1 \mu$. in diameter, single or arranged in short chains or masses.-On gelatine plates the colonies appear on the second day as whitish yellow points; those which lie superficially project somewhat above the gelatine, and are surrounded by a slightly depressed zone. The deep colonies appear, when magnified 80 times, as very dark opaque sharply defined plates. In the superficial ones the remains of the deep colonies ire altered in a peculiar manner; at two or three places of the dise, which was formerly circular, short pointed processes project at equal intervals from the periphery ; the remains of the deep colonies which have become broadened out in this peculiar manner are of a dark colour, but are now surrounded by a broad yellowishbrown border, the superficial extension of the cocci. On the following day the gelatine is liquefied in the neighbourhood of this border; a ring has formed at a certain distance from the dark centre, and surrounds the original colony like a crown or halo. At times the colony lies somewhat excentrically in the ring, which is then more of an oval form. Between the ring and the

* Güttinger hygienisches Iustitut. 
original colony there is clear fluid. A low power shows at this stage that the contour of the original colony is no longer quite sharply defined, the ring haring an irregular margin and granular surface.- In the puncture cultivation the growth and the liquefaction of the gelatine does not present much that is characteristic.-The organism was several times met with in examinations of air.

\section{Micrococcus radiatus.}

Micrococci under $1 \mu$. in diameter, at times arranged in short chains, more frequently in small masses. Even in 24 hours they form visible colonies; after tro days they are almost $1 \mathrm{~mm}$. in size. They have a white appearance with a yellowish green lustre; under a low power they are yellowish brown with sharply defined contour's, granular, round, or with somewhat irregular borders; at times they form a series of out-growths, so that they appear like stri-fish. In the middle a small remnant of the deeper part of the colony usually persists as a dark centre. At this stage the colonies sink a little into the gelatine, which has become gradually somewhat liquid, and after one or two days more a very delicate regularly arranged circle of rays has been formed from the out-growths; from the centre thickly packed delicate threads project with a radial arrangement, and these increase somewhat in breadtl towards the periphery, and thus almost run together to form a ring; a true sharply defined ring is however not formed, but the irregular ends of the rays lie more regularly near one another. After two or three days more a secondary circle of rays has dercloped from the periphery of the first, and eventually a third is formed; the radial rays are then however shorter, and the arrangement more irregular. The whole colony occupies at this stage a circle 1 to $1.5 \mathrm{~cm}$. in diameter.

This organism also grows in a characteristic manner in test tubes, and here also the formation of rays becomes noticeable. Along the course of the line of inoculation isolatod centres form from which projections 
extend in a holizontal direction, so that the line has a pinniform appearance. At the same time a funnelsliaped area of liquefaction forms at the upper part, but this is very pointed and spreads relatively slowly.

\section{Micrococcus flarus desidens.}

Yellow

liquefying micrococens.

Small cocci for the most part arranged as diplococci, but also in triangles and short chains.-After two days the colonies on nutrient jelly present the appearance of whitish yellow points, which, under a low power, appear as oval plates often projecting on one side, yellowish brown, finely granular ; those which lie superficially have a lighter zone towards the margin. After four days the deeply lying colonies have undergone but little alteration, they have only become more distinct. The superficial ones are now $5-10 \mathrm{~mm}$. in size, but present a round form with various projections and a dull yellow colour passing into brown; they form a smooth mucous layer on the gelatine, and they neither project abore it nor lie markedly below the surface. It is only on touching it that it becomes evident that the gelatine is softened and has become pulpy in the neighbourhood of the colony; after two days more this also becomes evident by a moderate sinking in of the colony, which is then surrounded by a very flat depressed ring $2-4 \mathrm{~mm}$. in breadth (hence the name dcsidcns = slowly sinking in).In tubes a confluent mass of porcellanous white appearance is formed in the depth of the puncture canal; on the surface a yellowish brown slimy deposit, which does not however reach to the walls of the glass. After eight days the gelatine below the deposit is so far softened that a cylinder filled with thick fluid has been formed $3-4 \mathrm{~mm}$. in height, and of the diameter of the superficial deposit, to the bottom of which the latter then gradually sinks down.- Repeatedly observed as an accidental contamination on plates.

\section{Micrococcus versicolor.}


form white points on gelatine plates after 24 hours; after two days, yellow colonies, spherical when lying deeply, up to $1 \mathrm{~mm}$. in size, circular under a low power, with sharp contours of yellowish green colour, opaque, finely granular. The colonies which lie superficially for'm flat deposits $2-6 \mathrm{~mm}$. in size, increasing even to $10 \mathrm{~mm}$. after four or five days, of irregular form, often almost quadrilateral, as a rule approaching this form very closely, and with an irregular outline. The deposit is gelatinous, glistening at the surface, and yellowisl green, but according to the illumination there is it greenish and bluish shimmer like mother of pearl. In the middle of the deposit there is often a somewliat projecting knob, the remains of the deeper part of the colony. Along an inoculation puncture small spherical colonies of a yellow colour are formed; on the surface a deposit with irregular margins as if eaten ont and changing colour like mother of pearl.-Common.

\section{Micrococcus viticulosus. *}

Micrococci with a very peculiar mode of growth Micrococcus. observed by Katz in the Hygienic Laboratory at Götin- forming cirri. gren. They are somewhat oval, and measure about $1.2 \mu$. in the largest and $1 \mu$. in the smallest diameters; they always form thick zooglæa musses, but without particularly marked development of gelatinous material. On velatine plates their growth is quite different according as the colonies develop in the substance of the material or on the surface. In the first case fine hair-like tendrils tevelop from a centre, which soon however becomes scarcely noticeable, and these form an extremely fine and delicate meshwork and extend widely. Under the microscope we see that these processes do not liave smooth contours, but are markedly bulged out; they consist of numerous spherical large or small zooglixa masses arranged in rows like a string of beads. - If the threads reach the surface, or if from the first the colonies lic near the surface, a thin deposit is formed of a muddy white appearance and gelatinous consistence, and spreads

$$
* \text { cirrous. }
$$


rery rapidly. 'T'his deposit often spreads along the threads which run in the deeper part of the gelatine, or sends here and there fine threads into the deeper layer's of the gelatine.-In the puncture and stroke cultirations the same appearance is repeated; in the deeper part a delicate network of threads is formed, but this is soon obscured by the more quickly growing superficial layer; this network spreads out from the inoculation track in the form of rays like the plume of a feather.This organism has as yet only been met with once, and then as an accidental impurity.

Pigmentforming mierococci.

Some rarer cocci which attract attention by the production of colouring material may also be mentioned here, although they are for the most part as yet insuffciently known, and do not perhaps all belong to the miorococci. (M. cinnabareus, flavus, \&c., see above; Micrococcus prodigiosus, see Bacillus prodigiosus.)

Micrococcus luteus.*-Cells abont $1 \mu$. in diameter, elliptical, highly refracting. Form yellow drops, $1-3 \mathrm{~mm}$. in diameter, on slices of cooked potato; on fluid substrata thcy form thick, ycllow, wrinkled skins. The pigment is insoluble in water.

Micrococcus aurantiacus.-Oval bodies, $1-5 \mu$. in diameter. occurring singly or united in pairs, in fours or in zooglan masses. Orange-yellow spots, which finally form an unintcrrupted layer, especially on boiled white of $\mathrm{cgg}$; a thick. golden-yellow layer on nutrient solutions. Colouring matter soluble in watcr.

Micrococcus chlorinus.-Oecur's in the form of a finely granular zooglæa; forms yellow or greenish layer's on nutrient solutions aud boilcd cggs. Colouring matter soluble in water, decolourised by acids.

Micrococcus cyancus.-Elliptical sphcres, giving to nutrient solutions and slices of potato an intense bluc colour. The colouring matter is very similar to that of litmus; it is soluble in watcr, becomcs red with acids, and again assumes the blue colour on ncutralisation of the acid by ammonin.

Micrococcus violaceus.-Elliptical cells, larger than Mic. prodigiosus, often united in cluins, form violet blue gela tinous clumps and patches on boiled potintoes.

* All described by Schrötor, Cohn's Beiträge zur Biologie der Pflanzen. Bd. 1, Hoft 2 . 
Micrococcus fulvus.-Sphcrical cells $1.5 \mu$. in diameter, Irequently united in pairs, with tough interccllular substance. Form rusty red drops of firm consistence and about $\frac{2}{3} \mathrm{~mm}$. in diameter on horse dung (Cohn, Beiträge, Bd. 1. Hitt. 3).

To the pigment-producing micrococci belong also-

\section{Micrococcus hematoides.}

Discorered by Babes as the cause of red sweat (sueur rouge). Micrococcus Micrococci $1 \mu$. in length and $0.6 \mu .-0.8 \mu$. in breadth, united of red sweat. by a gelatinous zooglæa mass of a uniform red colour. These zooglien masses surround the hairs on those parts of the body where the red sweat is formed, e.g., the axilla. The cocci can be stained by Gram's method; they grow on white of eggat $37^{\circ} \mathrm{C}$., and here also produce the red colouring matter, which has similar reactions to that formed by Bacillus prodigiosus.

\section{Sarcina lutca.*}

Round cells more than $1 \mu$. in size, which divide in Yellow three axes; the daughter cells remain united together, and thus packet-like colonies are formed resembling corded bales of goods; these again may be united together in larger packets. When sown on gelatine

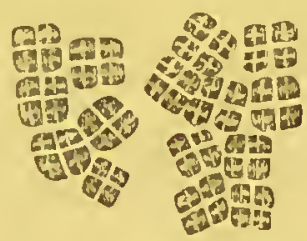

Fig. 59.--Sarcina $\times 600$. Drawn as if lying in one plane.

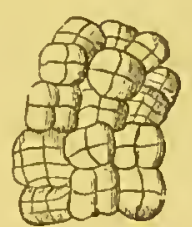

Fig. 60.-Sarcina $\times 650$.

Diagrammatic picture.

plates the colonies form in two days yellow points which are just visible, and which under a low power present the form of irregular plates in part lobate and furnished with projections grey in colour but transparent towards the margin. In punctures and strokes on gelatine, agar, and slices of potato, a slowly growing yellow confluent mass is formed. It is not uncommonly obtained from the air as an accidental impurity.

* Hygienic Laboratory nt Güttingen. sarcina. 


\section{Sarcina aurantiaca.}

Oringecoloured sarcina.

Sareina ventrieuli,

Cultivation experiments.
Observed in Koch's laboratory, and frequently employed in disinfection experiments. (Mitth. a. d. Kais. Ges. Amt, vol. 2). On nutrient jelly it forms slowly growing orange yellow colonies with gradual liquefaction of the gelatine. A more detailed description is wanting.

\section{Sarcina rentriculi.}

Discovered by Goodsir in 1842. Is found in the contents of the stomach in man and animals, and especially in the vomit; is most frequently observed in those cases where there are intense fermentative processes favoured by retention of the contents of the stomach; colourless or yellowish brown, round or slightly oval cells, with an average size of $2.5 \mu$., united in groups of eight forming small cubes rounded at the angles; these are bound together to form larger packets.

Falkenheim has recently obtained cultivations of this sarcina on gelatine plates; they formed after 36 to 48 hours roundish, for the most part prominent, colonies of a yellowish colour. On microscopical examination colourless spherical cocci $1.5 \mu$. in diameter. were found in these cultivations, as well as numerous diplococci and tetrads, but no cubical packets. Growth also occurred on other nutritive media, potatoes, blood serum, \&c., but the arrangement of the cocci characteristic of sarcina was not present. On the other hand, this arrangement was well marked in cultivations in neutralised hay infusion, which showed after 24 hours brownish flocculi and a scum consisting of small brownish scales. In the scum as well as in the flocculent deposit were numerous sarcina packets with a distinctly cubical arrangement. On the addition to the liay infusion of 2 per cent. of cane or grape sugar growth was very luxuriant.

If the hay infusion was decolourised with animal charcoal, and then a solution of litmus added, it berame 
evident that an acid reaction was produced by the regetation of the sarcinæ. Fallicnheim was also able Iodine to confirm the observation made by former writers, that reaction. the outer membrane of the sarcina cells gives a cellulose leaction with iodine and sulphuric acid, or with a solution of iodine and chloride of zinc. If a little fluid containing sarcinæ is placed on a slide, and a drop of Schultze's solution of iodine and chloride of zinc is added to and mixed with it, and if a cover glass is placed on the fluid, the outer membrane of the cells is seen after some time to present a distinctly reddish violet colour. Aniline dyes, which are as a rule very greedily taken up by the sarcinæ, and must therefore be employed in rery dilute solutions, stain the contents of the cells. Nuclei cannot be demonstrated in the cells.

For the present it is doubtful whether this Sarcina ventriculi is identical with the Sarcina lutea described abore, and which is everywhere present. Comparative cultivations and comparative measurements of the size of the individual cells are as yet wanting; the fact that in Sarcina lutea distinct cubical arrangement of the cells occurs in gelatine and potato cultivations, points for the present against any such identity.

There are many statements (varying somewhat with Occurrence of regard to the size of the cells and the composition of sarcina in the packets,) as to the occurrence of surcinæ in other parts of the human and animal body, in the sputum and pulmonary tissue, in the urine, in the blood, \&c., as well as outside the body on the most various nutritive substrata. In the first mentioned cases it is probable that micrococci arranged in fours, especially micrococcus tetragenus, liave been mistaken for sarcinæ. Whether in the other cascs other specics of sarcine than those described here liave been present cannot in the meantime be decided.-Zopf lias found in the crecum of Zopf's Sarcina domestic fowls a specios called by him Surcina in-intestinalis. testinalis, the colonies of which, howerer; do not form cubical packets, but plates composed of tetrads corresponding to the vegetative form merismopedia, but eventually arranged in several superimposed layers and 
Sarcina litoralis, \&c.

then representing a true sarcina.-The Sarcina litoralis Rcitenbachii hyalina, formerly reckoned here, has apparently only a merismopedia-like arrangement of the cells, and its other characters as well as its relationship to the algre or to the bacteria are as yet doubtful.

In pus, secretions, \&c., of the human body, the following micrococci have also been occasionally observed as saprophytic parasites; their characteristics must however be more fully worked out.

\section{Micrococcus cercus albus.}

Cocci $1 \cdot 16 \mu$. in diameter, single or in groups, at times also arranged in short chains. They form white points on gelatine plates during the first few days; these subsequently spread out on the surface and ultimately attrin a size of $1-2 \mathrm{~mm}$. In stroke inoculations a white, dull stearin or waxy-like layer is formed with somewhat thickened, irregular margins. On blood serum a greyish white dull line appears along the line of inoculation; on potatoes a greyish white layer of medium thickness.Found by Passet on pus, but probably without pyogenic properties, as injections and inoculations of the cultivations into animals produced no results.

\section{Micrococcus ccrcus flavus.}

Microscopical characters and growth in cultivations like the foregoing, only the colour of the colonies soon passes from the original white to a dark citron yellow:Also isolated by Passet from pus; without pyogenic action.

\section{Micrococcus citreus conglomeratus.}

Observed by Bumm in pus from blennorrhea, and also in dust from the air. Forms firmly agglomerated masses which resemble tuberculater linobs; if these are crushed and diluted with much water we sce djplococci, 
which have tho tendency to unite in fours, and which very much resemble the micrococcus of gonorrhœe. The average size is $1.5 \mu .-$ Forms citron yellow colonies on gelatine, which extend over the gelatine like a tongue, and are raised like a wall at the margins; the surface is at first moist and slimy, later cracked and scaly,--Inoculation on animals produces no effect.

\section{Micrococcus lacteus faviformis.}

Frequently found by Bumm and Bockhart in the vaginal secretion, also in the secretion from the cervix, in sputum, \&c. In these materials it usually forms isolated diplococci; preparations from cultivations, on the other hand, present a peculiar honeycomb appearance (hence the term faviformis), the individual diplococci lying side by side with their long diameter in the same direction. Each diplococcus measures on an average $1.25 \mu$. and consists of two hemispheres which are separated by a fissure; the latter is narrower than in the gonococcus, but otherwise there is a great morphological similarity between the two cocci.-It grows readily on the most various soils at the ordinary temperature, and forms small points in the stroke inoculation, which gradually develop to mille white confluent colonies.-Not infective.

\section{Micrococcus albicans amplus.}

Found at times by Bumm in vaginal secretion. Diplococci, which are similar in form to the gonococcus, but are distinctly larger. Before division the hemispheres may attain the size of $2 \cdot 28 \mu$. Grows on nutrient jelly at the temperature of the room in the form of greyish-wlite lines.

\section{Micrococcus roscits.}

Obtained accidentally on nutritive substrata from the dust of the air (Bumm). Diplococei like the gonococeus, but with a broader division between the hemispheres; size=1$1 \cdot 5 \mu$. Grows luxuriantly on nutrient jelly at the ordinary 
temperature without causing liquefaction; forms in stroke cultivations broad laised strijes, with a moist, shiny, granular surface, and wall-like raised nargins. The colour of the colonies is a distinct rosy l'ed.

\section{Diplococcus albicans tardissimus.}

Cocci which are morphologically eompletcly identical with the micrococci of gonorrhen; the concave form of the dirision in the diplococci is also present. They stick together somewhat more readily than the gonococci, and form small masses. They grow extremcly slowly on nutrient jelly, the iuoculated track only attaining the breadth of $1 \mathrm{~mm}$. after some weeks. On blood serum at the body temperature whitish points develop aftcr 2 or 3 days, which finally form thin greyishwhitc spots, with jagged contours and slightly moist surfaec. -Cultivated ou screral occasions by Bumm from pus from the urethra, but quite harmless.

A diplococcus has also been cultivated by E. Fränkel* from vaginal secretion which forms on nutrient agar a delicate layer consisting of bundles branching off at right angles from the line of inoculation; it nerer grows in the deeper parts. Morc detailed statements are as yet wanting.

Miller has isolated a coccus from carious tecth which occurs singly. or in ehnins, and forms in uutrient jelly luxuriant spherical colonies, in the ueighbourhood of which the gelatine becomes pulpy; also another which forms irregular masses. and very quickly liquefies the gelatine so that a fumuel-shaped depression appears in the tubes $4-6$ hours after the inoculation, and after 36 hours a broad canal filled with fluid reaches to the bottom of the glass. Sec below:

\section{We may also mention-}

\section{Ascococcus Billrothii.}

The small spherical cells (micrococci) are united to form peculiar colonies. On the surface of nutrieut solutions it. forms a creamy skin in which numerous bodies of sphcrical or oval shape can be distinguished even macroscopically. Under the microscope it is evident that ench of the bodics consists of an cxtremely lesistant envelope $10-15 \mu$. in thickness, jelly-like and cartilaginous; onc or sereral spherical

* Deutsche med. Woch., 1885, No. 2. 
or elliptical bodics arc cnclosed in it, 20-70 and more $\mu$. in diamcter, consisting of closely aggregated spherical bacteria, and an uncommonly firm scanty interccllular substance (fig. 61).

It was first observed by Billroth on putrid meat infusion, then by Cohn on ordinary nutritive solutions; in the latter it gives rise to a cheesy smell, converts the original acid reaction into a markedly alkaline one, and leads to the deve- Large tuberous cell families surrounded lopment of consi- by smaller ones, all of them being emderable quantities of

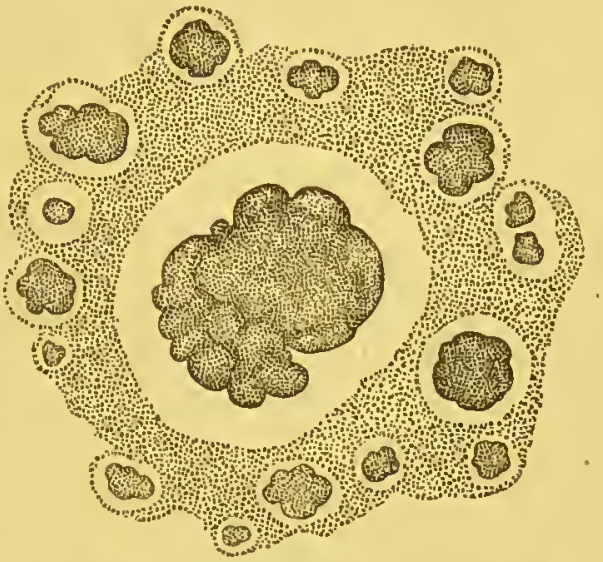

Fig. 61.-Ascococcus Billrothii $\times 65$. ammonia. It develops also on slices of turnip, in the form of a whitish-green slimy mass; in beetroot juice it sets up a viscous fermentation.

A development of the gelatinous enveloping substance to the degree as yet reckoned as characteristic of ascococcus has been also observed in various cocci and bacilli (as in Lenconostoc, in Mic. citreus conglom., Clostridium polymyxa, and in various otber bacteria not yet isolated pure). It is doubtful whether the production of this marlied gelatinous mass is constantly present in the species mentioned; at all events, on account of its extensive distribution, it does not appear sufficient of itself to serve as the distinguishing characteristic of an individual species or family. 


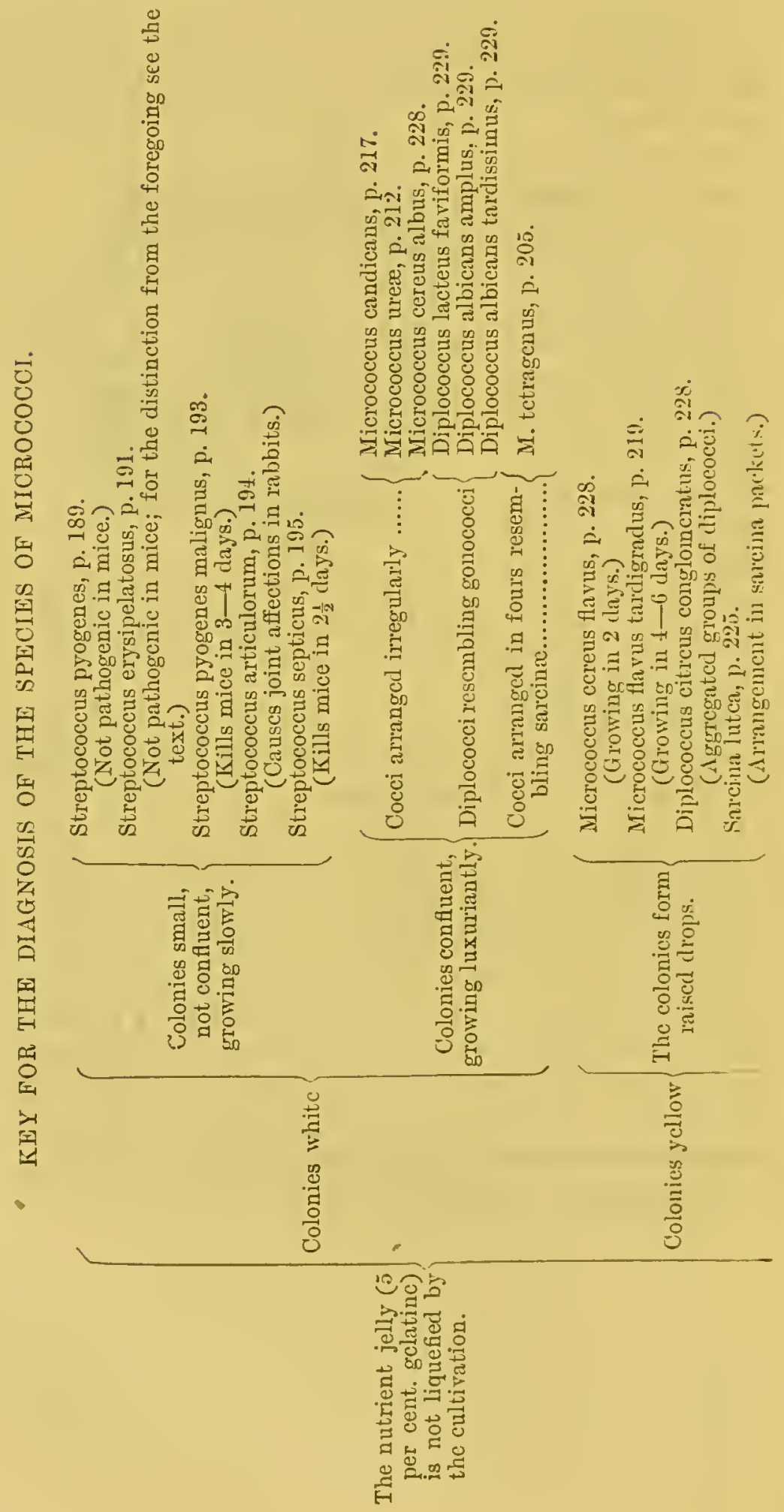




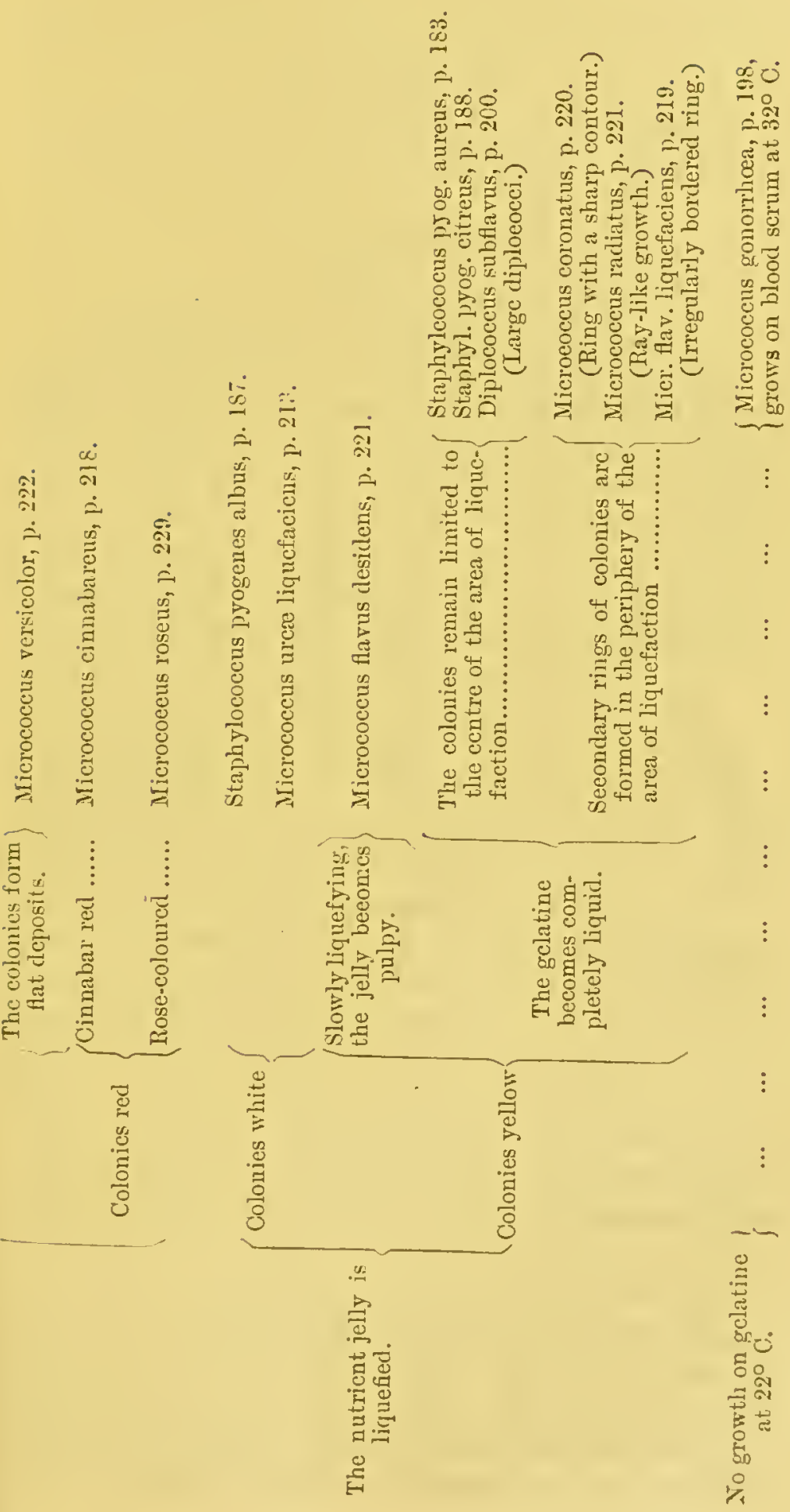




\section{BACILLI.}

(For the characters of the genus, see p. 172.)

A. Bacilli Pathogenic in Mas.

Bacillus anthracis.

(Bactéridic du charbon, Milzbrandbacillus.)

Morphological characters of anthrax bacilli.

Rods 5 to $20 \mu$. in length, and 1 to $1.25 \mu$. in breadth, which divide when they have grown to about double their length. Bacilli are frequently found with a commencing transverse division in the middle; many are bent at this place, or are loosely connected, the two segments forming an angle with each other.-The rods present somewhat different appearances in preparations which have been made by drying a thin layer of blood, of the pulp of the spleen, \&c., and subsequent staining. The chains of bacilli are then distinctly segmented; the individual bacilli do not show any difference in length and breadth, but are truncated at the ends, not rounded

Fig. 62.

off; the segments are not divided by a transverse line, but the clear line of division has a small swelling in its middle, and the point of union between the two segments presents a slightly knob-like thickening. Flagclla have not been obserred; the rods arc alrvays motionless. - On cultivation on diffcrent media the thickness of the rods may vary somewhat, without the characteristic form being otherwise altered. Manifold involution forms occur under unfurourable circumstances. (Sce page 157.)

On suitable soil, and at a temperature of about $36^{\circ}$ C., the bacilli form long threads, which may be much twisted, and often attain 100 times the lengtle of the original bacilli. After some time small, lighly refracting granules appear at regular intervals in the rod, and develop into roundish spores, while the threads 
become gradually dissolved. The spore has an eggshaped form, and is embedded in a spherical transparent mass. When the spores germinate this mass loses at first its spherical form, then the swollen external envelope splits at one pole, and the germinating tube

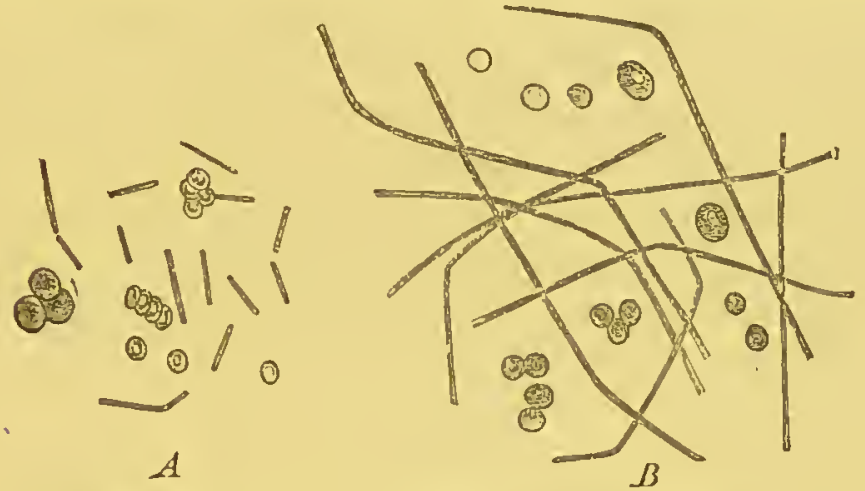

Fig. 63A.-Antlirax bacilli (after Koch) $\times 650$.

$A$, from the blood of a guinea-pig.

$B$, from the spleen of a mouse after being cultirated for three

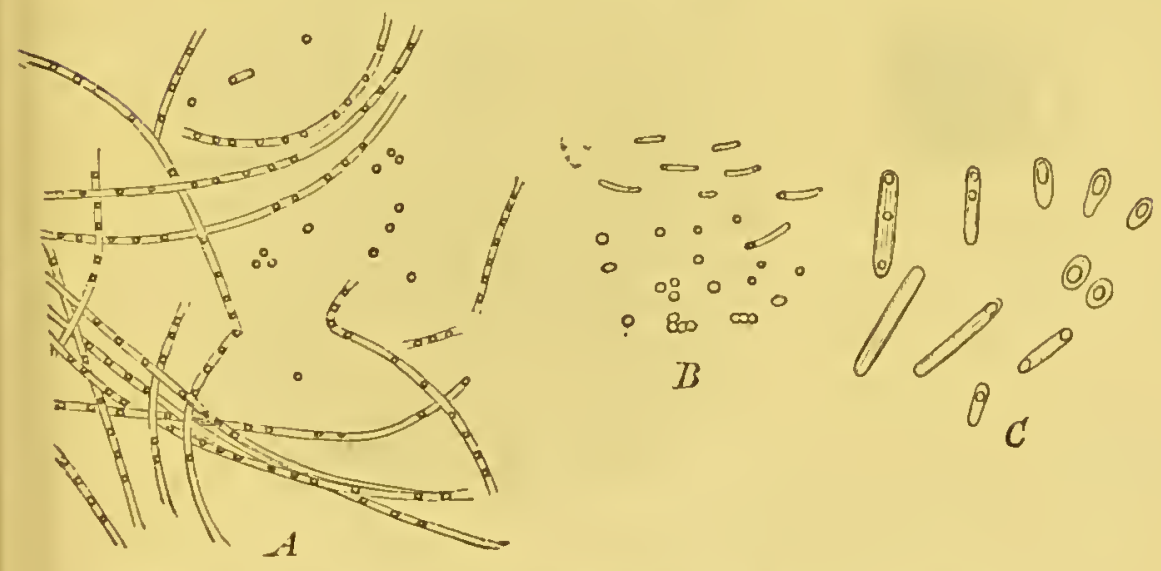

Fig. 63B.-Anthrax bacilli; spore formation and spore germination.

(After Kocl.)

$A$, from the spleen of a mouse after cultivation for twenty. four hours in aqueous humour. Spores arranged like strings of beads in the $B$, germination of the spores $\times 650$.

$C$, the same more highly magnified $\times 1650$.

shoots out in the direction of the long axis of the spore; tho latter at first remains attached to one end of the young rod.

The anthrax bacilli are easily cultivated on artificial nutritive substrata, on slices of potato, on gelatine, on 
Growth on grelatine plates. seeds of plants containing starch, on juicy roots; they may also be cultivated and form spores at a suitable temperature in alkaline urine, in neutralised hay infusion, in meat infusion. They belong to the aërobes, in so far that they only grow imperfectly when oxygen is excluded; attention must also be paid in cultivations to the great sensitiveness of the anthrax bacilli to an excess of acid in the nutrient substrata.-In plates of nutrient jelly they form after 24 to 36 hours small scarcely visible points; under a low power, however, a characteristic appearance can be seen at this stage; the round, dark, greenish-black colonies have an irregular wary contour.
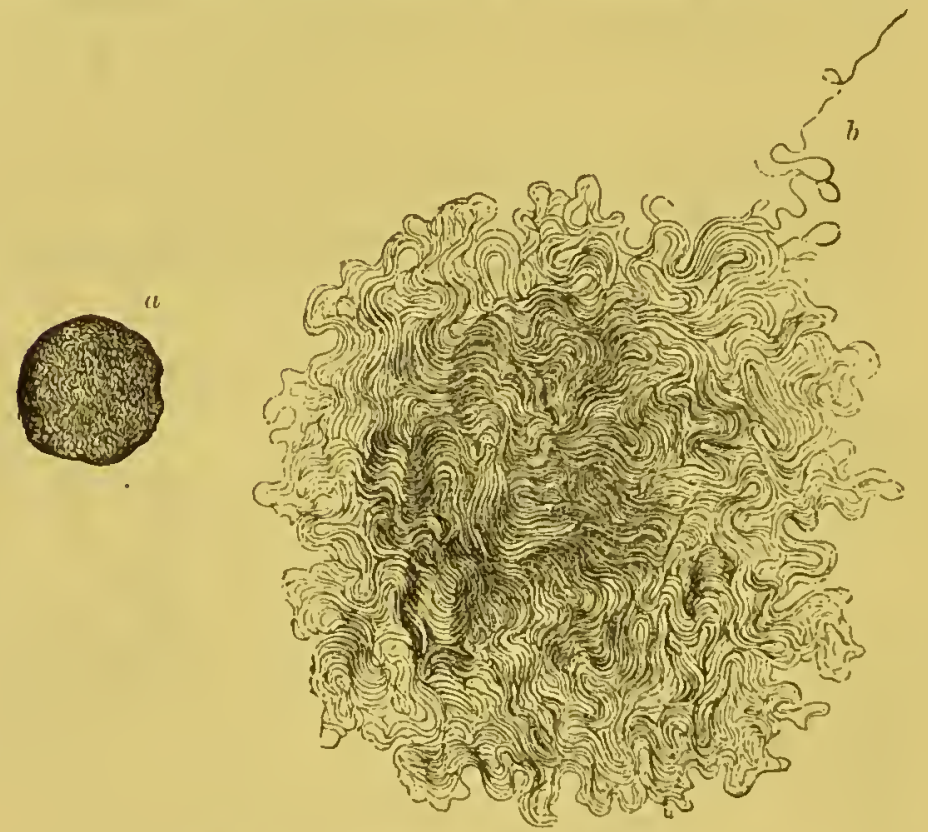

Fig. 64. - Anthrax colony in gelatine.

a, after 24 hours. $\quad b$, after 48 hours $\times 80$.

This wavy margin becomes more and more marked as the growth of the colony increases, and at once becomess much more distinct and spreads out more quickly on all sides when the colony has reached the surface of the gelntine. Under a low power the dark remnant of the deeply placed colony can only be seen in the middle; around this centre, however, there is a light-brown or light-grey shiny mass, which consists of numerous wary, curly bundles, recalling the appearance of the locks of hair on 
the head of a medusa. Ultimately individual threads, or bundles of threads, branch off from the irregular periphery, and grow over the gelatine in various directions. At the same time the gelatine is liquefied over a small area; the colonies, which have now a diameter of 2 to $4 \mathrm{~mm}$., begin to float and break down at their margins under the action of the fluid formed.-In punc- Puncture ture cultivations in gelatine a delicate whitish line is cultivations. formed along the needle track, from which fine threads run off at right angles, and grow in a ray-like form into the jelly, extending furthest on and near the surface, to a less extent at the deeper parts of the puncture; here also slow liquefaction begins after two or three days, in such a way that the radiating branches at first remain, and it is only in the course of eight days that the colonies sink to the bottom of the liquefied area, which is now more extensire.-On the addition of a small quantity of agar to the nutrient jelly, no liquefaction occurs. On Growth on slices of boiled potatoes the anthrax bacilli form greyish- $\frac{\text { other nutricnt }}{\text { medin. }}$ white elevated gelatinous deposits with a rough surface; these deposits do not extend over the whole surface of the potatoes, but only spread for 3 to $5 \mathrm{~mm}$. from the line of inoculation. On blood serum they form whitish layers; in meat infusion they cause a cloudy turbidity, which develops by preference at the bottom of the ressel.

When introduced even in minimal quantities into the Action on blood of living animals or man by intravenous injection animals and or' subcutaneously, the bacilli cause anthrax, which either takes the form of local symptoms, anthrax carbuncles, and then not uncommonly cnds in recovery, or appears as a septicrmia, and then usually rapidly ends in denth. Anthrax was the first case in which an infective disease occurring in man was proved with ccrtainty to be due to a vegetablo micro-parasite, the organism being at the same time inoculable on various animals, and being thus suitable for experimental study. The smallest trace of a cultivation of anthrax bacilli inoculated on mice, rabbits, guinea-pigs, hedgchogs, sparrows, sheep, and horses, causes the illness or deatl of the animals from 
anthrax, death occuring in the case of mice after about 20 hours, and in that of rabbits after 42 hours. After death the bacilli are found in largest numbers in the swollen spleen, and also in all the capillaries, especially in the lungs, liver, lidneys, and intestine; in the larger vessels, on the other hand, often only single bacilli are met with.-Certain races of sheep (Algerian), white rats, dogs (especially adults), and frogs, are entircly, or to a certain degree, immune against anthrax.

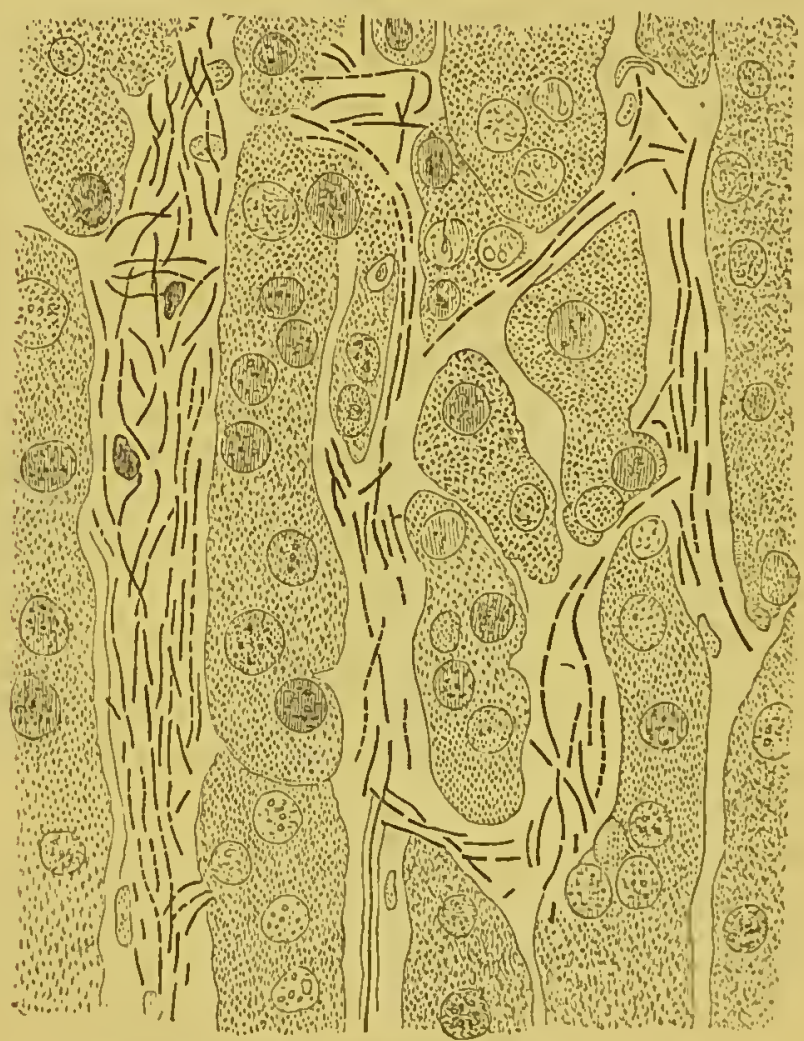

Fig. 65.-Anthrax, section from the liver $\times 700$.

Cattle are comparatively slightly susceptible to anthrar after inoculation, but on the other haud readily suecumb to the matural infection, which generally spreads in the ease of sheep and cattle from the intestine as the result of infection by the food. Non-sporc-bearing bacilli do not appear to be able to retain their vitality in the intestine; on the other hand, it has becu shown with regard to spores that they can sprout in the intestine of sheep, 
and penetrate through the uninjured mucous membrane.

In the body of living animals the bacilli multiply only Conditions of by fission, and nerer form spores. These arise on dead tiore formanutritive substrata, but only under definite conditions, among which a suitable temperature is the most important. The highest limit of temperature is about $43^{\circ}$ C. ; the lowest from $12^{\circ}$ to $18^{\circ} \mathrm{C}$.; below $12^{\circ} \mathrm{C}$. neither growth of threads nor spore formation seem to occur. Hence if the bodies of animals which have died of anthrax are buricd rery deeply in the soil, where in our climate there is a constant temperature below $12^{\circ} \mathrm{C}$., spore formation does not occur, and the bacilli themselves speedily die without having passed into a resting form. Pasteur's assertion that the bacilli or their spores are preserver in the buried bodies, and that they are then brought up to the surface of the soil by means of worms, is thus wholly improbable. On the contrary, we have to explain the occurrence of an epidemic of anthrax, according to Koch, in the following manner: the germs Mode of which are distributed since ancient times in marshy spread of regions, on banlis of rivers, \&c., can again develop on bacilli. suitable vegetable substrata, and there form new spores; these are carried to pasture lands by floods, and thus become mixed with the fodder.-This mode of spread also explains the infection from the intestine, which is mucl the most frequent mode observed. Recently Schrakamp and Friedrich have mentioned the possibility that the growth and development of the anthrax bacilli may also occur in the upper layers of the soil; while Kitt regards cattle dung as the chief nutritive substratum in which the development and spore formation of the bacilli occurs in the regions infected by this disease. (See the chapter on the exciting agents of disease.)

Of great scientific value is the discovery by Toussnint Artificinl and Pasteur that the antlurax bacilli can lose their patho- attemention of genic properties by the moderato action of abnormally bacilli. high temperatures, or of small doses of poisonous substances, while their morphological and biological characters remain otherwise unaltered. On the mode in 
which the means used for the attenuation are employed depends apparently the answer to the question whether and within what time the bacilli can regain their virulence on subsequent contiuned cultivation under farourable normal conditions. The degree of attenuation can be modified with precision to any desired extent by the method described by Koch.-The inoculation of sufficiently attenuated bacilli sets up in the case of sheep, cattle, \&c., a mild disease ending in recovery, after which the animals in question are immune for a considerable time against the virulent anthrax bacilli (Pasteur's protective vaccillation).

Buchner's experiments.

According to Buehner the anthrax hacilli are extremely variable in morphological and biological eharaeters, and ly. variations in the eultivations ean be transformed, after passing through a series of intermediate stages, into the elosely allied hay baeilli (Bacillus subtilis), and in like manner the latter can be converted by suitable cultivations into true anthrax baeilli. Buchner in the first plaee enltirated the anthrax bacilli for many generations in a nutritive solution eontaining extraet of meat, peptone and sugar; after a short time these eultivations were only virnlent in large doses, but the baeilli again regained their full virulenee in the animal body; ultimately they entirely lost their pathogenic properties, but grew and behaved exactly like hay baeilli. Koch has shown in the most convineing manner that this supposed transformation ean only have been due to contamination and the gradual displacement of the anthrax bacilli by the hay baeilli. Had it been a case of gradual loss of pathogenic properties, there must have been, in the first place. jnst as in the case of the anthrax bacilli cnltivated at high temperiatures, a lcss severe and no longer fatal clisease: in Buchner"s experiments there was no effect after small doses, while after large doses there was the complete fatal aetion; this eircumstance, as well as the increase of rirulenee after passage throngh the animal experimented ou, corresponds entirely. with the behaviour of impure nutritive sulstrata containing only a few infective organisms from which loy the eultivation in the body the pathogenie organism is again isolated and eultivated pure.-Buchner tried to carry out the transformation of the hny baeilli into inthrax bacilli by cultirating the formor in the first place in white of eggr with a lit tle meat infusion, and then in fresh rablbit's blood which was constantly shaken np with air lut not sterilised. From such blood eultivations further cultures were wade in meat in- 
fusion, and by the injection of large quantitics of the sporcs formed in this medium a fatal discase was obtained in somc cases which Buchner looked on as anthrax. Since it has, however, bcen demonstratcd that among the so-called hay bacilli various pathogenic organisms are present which resemble the anthrax bacilli and give rise to similar diseases (see page 242), and that in meat infusion and putrefying blood spores of these pathogenic bacilli often occur, Buchner's experiments cannot be regarded as convincing; the disease which was finally obtained was possibly not anthrax, but malignant œdema or some other affection. This possibility becomes a probability when we consider how extraordinarily constant anthrax bacilli and hay bacilli have proved to be under the most varied conditions of cultivation in the hands of those investigators who rightly estimate the magnitudc of the sources of error in cultivations in fluid substrata. - Further, Buchner states that he has been able to obtain a transformation of anthrax bacilli in the first place into an intermediate form, and then into true hay bacilli within a very short time (24 hours) by cultivating them at $36^{\circ} \mathrm{C}$, in nutrient solutions composed of meat infusion, yolk of egg (from old eggs preserved in lime water), and a little alkali. The yolk of egg was not sterilised, and the inoculation was made from the spleen of an animal which had died of anthrax; thus there were two possible modes of entrance of extraneous germs, and that such an unintentional contamination had in all probability taken place is likely from the totally different results obtained in numerous other cultivation experiments with anthrax.-Recently Prazmowski has in so far supported Buchner's views that he has also in cultivations made by Buchner's method obtained a scumforming non-pathogenic motile bacillus which he looks on as the result of the transformation of the anthrax bacilli. On the other hand he ascertained that this organism was not identical with Bacillus subtilis, which is totally different from the anthrax bacillus in the mode of the sprouting of its spores, and in its other constant characters. Experimcnts which the author has set a-going with regard to Buclncr's ricws have only led to the conviction that the devclopment of extraneons organisms is a very frequent and scarccly avoidal)le occurrence in the method of experimentation describcd, and that there was in no casc any guarnntcc that the bacilli ultimately obtained had been developed from the antlurax hacilli inoculated.-Kurth comes to a similar conclusion as the result of his own experiments in his work on "Bact. "zopfii."

$\Lambda$ great variability in morphological form has also becn wrongly attributed to the anthrax bacilli by various observers. 
Thus more especially Buchner, Zopf, Fokker, Arehangelski, and Roloff have observed cocci as a regetative form of the anthrax bacillus both in cultivations and in diseased animals. Numerous careful examinations by those observers who are thoroughly acquainted with microscopical technique, and who know how to nvoid the sources of error mentioned above (page 182), have demonstrated the inaccuracy of this assertion. -De Bary states that he has observed in certain eultivations (peptone solutions) a breaking up of the threads of the anthrax bacilli into round bodies which become aggregated in the form of grape-like or irregular groups, but which with doubtful exeeptions proved to be dead. It is evident that these degenerative forms, which are very various, have not the slightest claim to be designated as cocci.

\section{Bacillus oxdematis maligni.}

Discovered by Koch as the exciting agent of malignant œdema, a fatal disease of mice, guinea-pigs, and rabbits ; formerly termed by Pasteur vibrion septique. Malignant cdema has recently also been observed in domestic animals and in man.

Morphological The odema bacilli, which are morphologically similar character of the odema bacillus. to the anthrax bacilli, are rods $3-3 \cdot 5 \mu$. in length and $1-1 \cdot 1 \mu$. in breadth; usually two or three bacilli remain

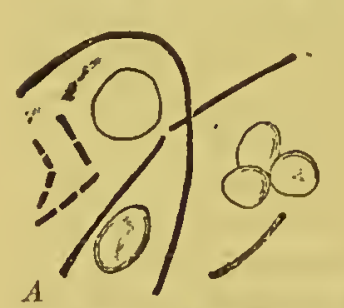

Fig. 66.-Bacillus of malignant coma (vibrion septique), after Koch, $\times 700$.

$A$, from the spleen of a guinea-pig.

$B$, from the lung of a motise. united together, and then the thread is two or threc times longer; indeed one may frequently find long pseudo-thrcads 15 to 40 $B \mu$. in length. The threads secm to be comparntively stiff, and are oftcn broken or bent; at times also they are looped and twistcd around each other [n strined proparations they frequently present a somewhat granular appearance, oriug to irregulne deposit of the colouring matter. Anthrnx bacilli differ from the edema bacilli by their somerhat greatcr breadth, their truncated ends, and their peculine segmentation in strined preparations. Further, onc does not find in fresh anthracic blood the numcrous 
long threads of the œèm $\Omega$ bacilli, and the œdema bacilli are sometimes, though not alrays, motile, while the nuthrnx bacilli are always motionless. The most marked morphological difference between the two is, however, the mode of spore formation. In the cdema bacilli this does not occur in the threads in the same way as in the anthrax bacilli, but the individual bacilli show before the spore formation a slight swelling in the middle or at one end, so that a spindle or tadpole form results, and in this swollen part the large oral spore, at first dull, but later highly refracting, is formed, and when its forma-

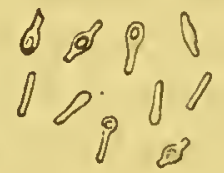

Fig. 67.-Spore formation in the bacilli of malig. nant cedema $x$ 700 . tion is complete the colourable remains of the bacilli gradually disappear.

There is considerable difficulty in cultirating the Cultivation of cedema bacilli, because they are marlsed anaërobes, so the cacilli. much so that they only form visible colonies when oxygen is pretty completely exciuded. They do not grow at all on gelatine plates, eren in the deeper lajers; nor do they grow along the inoculation track on gelatine, agrar, or blood serum. On the other hand they can grow when they are inoculated at a certain depth in tubes containing nutrient agar or blood serum, in such a manner that the canal of inoculation becomes tightly closed over the material introduced. As Hesse first observed, a diffuse muddiness of the nutritive material consisting of bacilli appears in the nutrient agar, with here and there more markedly muddy lines or clouds. At the same time gas bubbles are formed within the inoculation canal, which penetrate into the agar in rarious directions, often divide it transversely, and drivo up tire separated portion as high as the cotton wool plug, and at the same time so compress the agar that a muddy fluid is separated which collects at the bottom of the glass, and contains numerous bacilli. Tho escaping gas lias a slight, somewhat heavy smell.-Blood serum is quickly liquefied, by the bucilli, and there is at the same time marked development of gas; in a few days, when kept in an incubator at $37^{\circ} \mathrm{C}$, the whole mass 
of the blood serum is converted into a yellow fluid, at the bottom of which there still lie some pieces of the serum with eaten away, shreddy margins. - In nutrient gelatine a spherical layer, $5-10 \mathrm{~mm}$. in diameter, forms at the bottom of the inoculation puncture, around the material inoculated, the periphery of which shows fine radiating markings, and the contents consist of liquefied and somewhat turbid jelly. The œdema bacilli grow best in a nutrient jelly which contains 1-2 per cent. of grape sugar; and very characteristic cultivations are obtained in test tubes if the gelatine is fluid when inoculated, and the material well distributed through the whole jelly by shaking it before it is allowed to solidify. After two or three days a number of small spheres, $-\hat{1} \mathrm{~mm}$. in diameter, and filled with fluid, form in the lower part of the tube, and these show under a low power the radiating marking of the periphery. The colonies extend from the bottom of the vessel to about $2 \frac{1}{2} \mathrm{~cm}$. below the surface. The upper $2 \frac{1}{\mathrm{~cm}}$. of the gelatine remain completely unal-
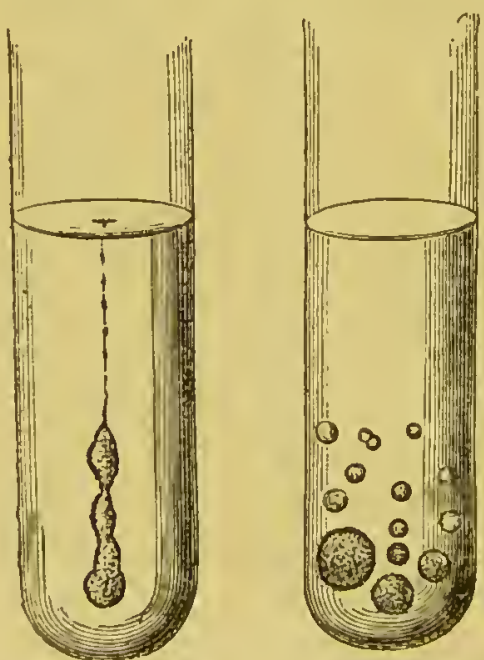

Fig. 68.-Cultivations of the bacilli of malignant œdema in golatino. tered. By pouring on oil, introduction of carbonic acid, \&c., one can artificially raise the upper limit within which risible colonies are formed.*

The best temperature for growth is about that of the human body; but luxuriant growth also occurs at $18^{\circ}-20^{\circ} \mathrm{C}$., especially in jelly containing sugar. Spore formation has alsobeen obserred at this temperature, but it occurs more readily and plentifully at the higher temperature. In the animal body only bacilli and threads aro found immediately after

* After observations by Dr. Liborius in the Hygionic Institute at Göttingen. 
death, but no spores; the latter are, however, observed when the body has lain for some time after death at a high temperature.

The œdema bacilli are apparently extremely widely Distribution distributed in our surroundings. They appear to be and sapropresent in almost all decomposing substances in greater the cedema or less numbers, and they perhaps also take a definite though limited part in the putrefactive process. As is shown by the behaviour of the pure cultivations, the œdema bacilli have the power of energetically peptonising albumen, and possibly also of further breaking up the albuminous molecule. A more accurate analysis of the nature of the decomposition is as yet wanting, at all events the cedema bacilli can pass through their characteristic cycle of development as saprophytes. In accordance with this we find them in the most various putrid substances, in the bodies of animals which have died of suffocation and have then been kept at a high temperature, in the freces, and in the intestinal contents; their spores are present in every specimen of earth which has been impregnated with putrid fluids, \&c.; they are also found in the dust of rooms, in the dust of rags, of hay, \&c.

At the same time, also, the œdema bacilli possess Pathogenic pathogenic properties, and by means of these their pre- properties of sence can be most easily demonstrated, and they can be bacilli. most readily isolated from the mixture of other saprophytes. If not too small an amount of garden earth or hay dust is introduced under the skin of a guinea-pig (this is best done by making a small cut with scissor's through a fold of skin over the abdomen, and then loosening the subcutaneous cellular tissue with the handle of the scalpel so that a small pocket is formed, which is then filled with earth and the wound closed with one or two stitches), the animal becomes ill very soon, and dies in 24 to 48 hours. On post-mortem examination the most striking appearance is an exteusive subcutaneous odema extending from the seat of inocution, the odematous fluid being clear and red, and containing numerous bacilli and a fow gas bubbles. The internal 
organs are but little altered, the sploen is for the most part enlarged and of a dark colour, and the lungs have a. pale greyish-red appearance. Immediately after death few or no bacilli are found in the blood of the heart; on the other hand they are plentiful in the juice from the various organs, and also more especially in and on tho serous conts of the organs. (In this point also this organism differs in an important manuer from anthrax.) If some timo has elapsed since the death of the animal the bacilli are found everywhere, even in the blood of the heart, in large numbers; thus they are apparently able to multiply actively in the dead body. In mice, however, the brcilli are not uncommonly found immcdiately after death in the blood of the heart and in the blood ressels of the organs; here therefore it is easily possible to mistake the disease for anthrax. As a rule, in mice the bacilli are only seen in the crushed spleen, on the pleural covering of the lungs, and most beautifully in preparations of the mesentery, obtained by spreading out a loop of intestine over a cover glass, loosening the mesentery at the margin of the cover glass, and subsequently treating it like the ordinary corer glass preparations (drying, heating, staining). In mice the œdema is for the most part not very marked; the animals die very quickly-on an average $16-20$ hours after inoculation.-Horses, sheep, and swime are liable to malignant wdema; on the contrary, according to the researches of Arloing and Chauveau, cattle are not affected.-The animals cannot be infected with such small quantities of bacilli as in the case of anthrax; to transmit the disease from one animal to another it is best to cmploy small pieces of spleen, or one or two drops of œdematous fluid, or a portion of the subcutaneous tissue; from cultivations it is best to impregnate a silk thread with a little of tho fluid contrining bacilli, and then place this under the slin. Tho wound also must not be too trivinl, it must really penetrate through the cutis; it is only then that tho conditions necessary for the existence of this anaërobic organism are obtained. Scarcely noticeablo symptoms follow tho intrarenous 
iujection of relatively large doses, $1,5,10$ drops. - In How to obtain orcler to obtain cultivations from the dead body of an from the animal the skin is washed as soon as possible after animal body. deatli with sublimate solution, and thon with sterilised water, or the hair is completely singod off at the part; then small portions of spleen, diaphragm, or of the cedematous dorsal muscles, are taken with heated instruments, and introduced into tubes of jelly containing sugar, and liept at the temperature of $30^{\circ} \mathrm{C}$; ; these are then allowed to solidify.

Recently several cases of malignant œdema have Malignant been observed in man. This disease has commonly œema in been designated by surgeons as progressive gangrenous emphysema (gangrène gazeuse); it seems to have been comparatively frequent before the introduction of antiseptic methods ; it is now chiefly observed after compound fractures or deep wounds, into which earth or other material containing œdema bacilli has passed. A crepitating emphysema of the skin spreads in these cases from the wound, accompanied with the development of a very putrid smell; the muscles are at the same time converted into a peculiar reddish-brown, loose, frothy mass, full of gas bubbles; and death generally occurs in a few days with comatose appearances and gradual spread of the cdema. Lately the identity of this gangrene with malignant œdema has been repeatedly ascertained by inoculation of animals and by cultivations (Chauveau, Arloing, * Brieger, and Ehrlich).

Chauveau and Arloing have observed that animals which Experiments recover from the discase are immune; injection into the on immunity. reins produces a similar immunity, which, howercr, cannot withstand repeated inoculations. Subcutaneous inoculations of small quantitics produce, according to Loeffler's experiments, no noticcable disease, but also no immunity (Mitth. a. d. Fais. Ges. Amt., Bd. I.).

* Bull. de l'Acad. de Med., May, 1884, and August, 1884. 


\section{Bacillus typhi abdominalis.}

Eberth, Klebs, and Koch were able to demonstrate in the spleen, lymphatic glands, and Peyer's patches of patients suffering from typhoid fever, peculiar short, plump bacilli which wore not met with in other discascs. According to Klebs, long threads develop from these bacilli, and in these rows of spores are formed; this statement was not confirmed by the other two authors, and probably rests on error owing to the accidental presence of putrefactive organisms. Meyer and Gafflky have subsequently confirmed Eberth and Koch's results. Occurrence of Gaffky found the characteristic bacilli 26 times in 28 the typhoid bacilli. cases of typhoid fever investigated; and recently similar

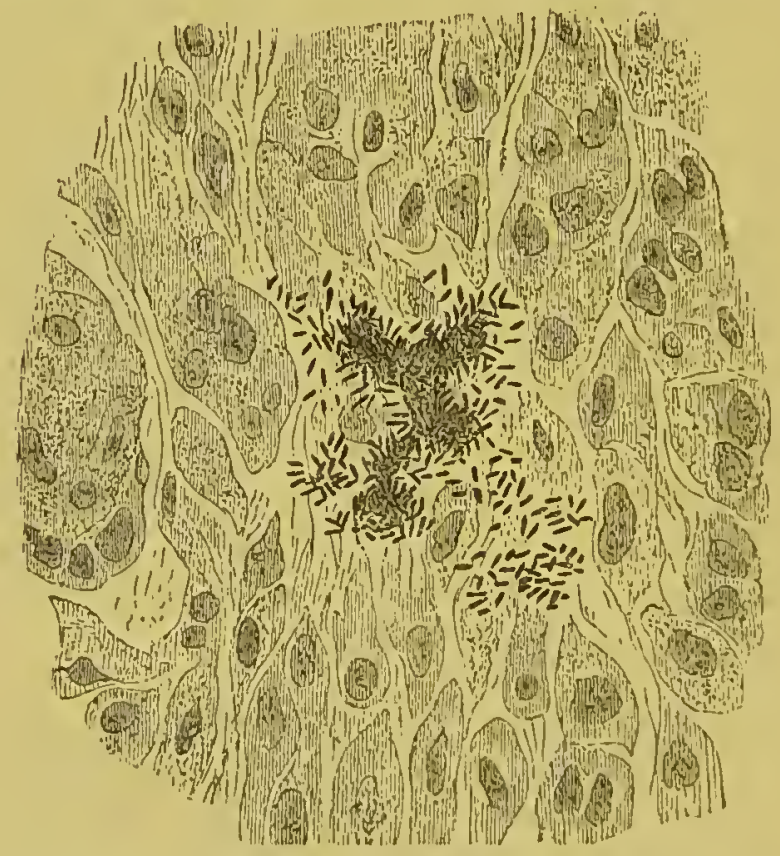

Fig. 69.-Typhoid bacilli; scetion from splecn $\times 800$.

observations have been made by a number of inrestigators. This constant occurrence of the bacilli, which are limited, as can bo shown, only to typhoid affections, renders it highly probable that they are causally connected with the disense.

The bacilli are present in the diseased parts of the intestine, in the mosenteric glands, in the splecn and 
liver, but not so numerous in the kidneys. They are not diffusely distributed in these organs, but always occur in the form of small isolated deposits. This renders the microscopical investigation especially difficult; it is often only after the examination of a large number of sections that one or a few of these deposits are found. The masses occur in the form of groups with irregular outlines lying usually in the capillaries or smallest blood vessels, these groups being resolved at their margins into individual bacilli (see fig. 69).

The latter appear as rods $2-3 \mu$. in length, and Morphological about three times less in breadth. Their ends are distinctly rounded off. In many cases undoubted spores are found in the bacilli, presenting the appearance of round unstained portions occupying the whole breadth of the rod.-Aniline dyes are slowly taken up, but quite sufficiently when the staining process is continued for a considerable time; the best stains are gentian violet, Bismark brown, and especially alkaline methylene blue. With Gram's method the typhoid bacilli are ver'y readily and completely decolourised.

Gaffky was the first to cultivate these bacilli on suitable soil from the organs of patients who had died from typhoid fever. Former attempts by other investigators did not lead to a pure culture of the typhoid bacilli. Gaffky succeeded in 13 cases in obtaining pure cultivations of the bacilli, by planting on nutrient jelly minute portions of tissue taken with all precautions from the interior of the spleen. These cultivation experiments showed that even in the cases where on microscopical examination it was only with difficulty and in a small proportion of the sections that bacilli could be demonstrated, every minutest portion of the juice of the organ gave rise to several colonies of bacilli, so that it was evident that the best idea of the number of bacilli present, and of their distribution, could be obtained by the cultivation method.-Cultivations of the typhoid bacilli have since been repeatedly made; they are invariably successful from the organs of fresh typhoid bodies. Pfeiffer has recently succeeded in isolating 
the characteristic bacilli by means of plate cultivationis from typhoid stools, and from the intestinal contents of typhoid bodies.

Characters of the cultivations of typhoid bicilli.
Growth ou potatoes.
When sown on gelatine plates the colonies of the typhoid bacilli form, after about 36 hours, minute white points; when magnified 80 times these appear as irregular, oval, and even whetstone or citron-shaped plates of a light yellow or yellowish-green colour, with sharp, smooth borders, and an indistinct granular character. In the course of 36 to 48 hours more the colonies have spread out to form a roundish greyish-white flat deposit 1 to $1 \frac{1}{2} \mathrm{~mm}$. in diameter; these do not form any knoblike elevation, and project very slightly above the gelatine. The contour of this layer is irregular, indented, and at times distinctly branched; under a low power the colony, with the exception of the central part, is colourless, and shows on the surface numerous lines and furrows. Liquefaction of the gelatine does not occur at any stage. - On agar plates at a higher temperature the characters are similar; after about 20 hours the young colonies have the appearance under a low power of pearor citron-shaped brownish plates with sharp borders.

In puncture cultivations in gelatine a thin whitish thread forms along the line of puncture; at the surface a greyish-white flat layer is constantly formed, at first small, but later reaching almost to the margin of the glass; the outline of the growth shows in the later stages numerous projections and irregularities. - In stroke cultivations a similar greyish-white lajer forms on the surface of the gelatine.

The typhoid bacilli can also grow on blood serum, fluid and solid, in meat infusion, and on other nutrient substrata. In milk the bacilli grow actirely but witlout causing any noticenble alteration of the milk.Their growth on boiled potatoes is extremely charneteristic, and of special importauce for the distinction of the typhoid bacilli from all other forms of bacterin as yet known. Slices of potato inoculated with small quantities of typhoid bacilli appear almost completely unaltered after two or three days; at the most 
the surface in the neighbourhood of the track of inoculation has acquired a somewhat moist, more shiny appearance. If this part of the potato is touched with a platinum wire it gives the impression as if the surface was covered with a resistant skin; and if we examine microscopically a minute portion from the surface we can easily see that this skin consists of masses of bacilli which have taken possession of the soil over a great extent, often over the whole surface. If the inoculated potato is kept at $35^{\circ} \mathrm{C}$. the development of the layer of bacilli occurs more rapidly, while otherwise the appearance of the potato remains the same.

In all these cultivations the bacilli appear under the Morphological microscope as short, thin rods similar to those observed characters of in the tissue. Nevertheless long pseudo-threads are bacilli. almost always formed in the cultivations, and there are also marked differences in length corresponding to the various stages of growth. It is also possible to stain culture preparations with aniline dyes, but it is more dificult than the staining of other bacilli (e.g., Bacillus anthracis).-Further, the bacilli taken from the cultivations show distinct and often fairly active movements. Spore formation can not be observed in cultivations liept at $15^{\circ}-$ $18^{\circ} \mathrm{C}$.; at $20^{\circ} \mathrm{C}$. a few spores are formed, and betrieen $30^{\circ}$ and $42^{\circ} \mathrm{C}$. the spore formation is plentiful. The spores are situated at the end of the rods, and only one spore is formed in each rod in the form of a highly refracting round body, occupying the

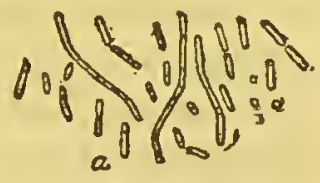

Fig. 70.-Typhoid bacilli from a cultivation $x$ 800.

Showing on the right hand sporebearing bacilli and free spores. whole breadth of the bacillus. Where two bacilli are joined together it. is always the two ends not in contact which bear the spores.

Inoculation experiments on animals have as yet been Expcriments without result, whother the material used was typhoid on aninals. stools or the pure cultivated brcilli. Thoso few experiments in which a typhoid disease was said to follow inoculation or feeding have evidently been mado witl impure material containing other active bacteria. It is 
known that a group of fairly widespread organisms, which, however, differ totally from the typhoid bacilli, have this property in common, that when introduced either by intravenous or subcutaneous injection, they kill animals with the symptoms of a gastro-enteritis, often with marked swelling and ulceration of Peyer's patches. It is probably to these organisms that we must ascribe the apparent positive results which certain authors think they have obtained by inoculation of the typhoid bacilli; this remark applies more especially to the typhoid cultivations isolated by Tayon, and tested with apparent success on animals and man, for these in no respect correspond to the characters of pure cultivations of the characteristic bacilli which constantly occur in typhoid fever.-Recently numerous experiments have been made by Gaffky (and also in the laboratory at Göttingen) with the view of setting up a corresponding disease in animals with pure cultivations of the typhoid bacilli. Besides rabbits, guinea-pigs, and rats, calres and monkeys have also been employed in these experiments; infection has been attempted by continued feeding, in some cases along with simultaneous employment of various medicinal substances, by subcutaneous and intravenous injections, and by inhalations, but as yet without any positive result. However, there is always the possibility that some preliminary preparation of the animals may render them susceptible to an infection. The success of such experiments would be of great importance in completing the proof that the bacilli described are really the causal exciting agents of typhoid fever, although the constancy of their occurrence and their exclusive presence in this disease leares scarcely any real doubt as to their significance.

Occurrence of typhoid bacilli in human surroundings.

Typhoid bacilli have never as yet been demonstrated with certainty outside the human body with the exception of Pfeiffer's demonstration of their presence in the dejecta of typhoid paticnts. It is true that there are statements by Brautlecht and Krlebs as to the successful demonstration of typhoid bacilli in suspected drinking water; but according to the description which 
theso anthors give of the bacilli found by them it is certain that neither of them were dealing with typhoid bacilli. Brautlecht's bacilli were very thin, slender bacilli ; those isolated by Klebs from the water supply of Zürich were not decolourised by Gram's method, they showed another mode of spore formation, were infective for rabbits, and were therefore certrinly not identical with the bacilli of Eberth and Gaffky.*

The most distinctive character of the typhoid bacilli is their peculiar mode of growth on potatoes; and when we have to diagnose these organisms the potato cultivations must be employed as the distinctive criterion. With the help of this aid to diagnosis it will now per- Modes of haps be possible to follow more closely the distribution of the typhoid of the typhoid bacilli in our surroundings and the modes bacilli. in which it causes infection. What has as yet been done in this direction rests only on deductions and on practical experience and statistical facts which are in many respects open to question, and are in part contradictory. The following views may be deduced from the knowledge which we have gained during recent years as to the specific exciting agents of typhoid fever.

We may perhaps conjecture that the seat of entrance of the infective agents is by preference the digestive tract; in favour of this'we have the observations as to the distribution of the typhoid bacilli in the body of the patient as well as the analogy with many other diseases which are chieffy localised in the intestine (swine erysipelas, cholera). Nevertheless, in spite of these observations and analogies, the possibility of some other seat of invasion is not excluded (see the chapter on the causation of disease).-Further, from the mode of spread of typhoid epidemics we may probably draw the conclusion that a certain preparation of the intestine for infection

* Kleb's article, "Bacillen," in Eulenburg's Realencyclopodia.Lec'ure on the drinking water supply of the town of Zurich and its suburbs. Ausscrsihl, 1885.-Compare the refutation by Cramer in Die H'asser. versorgung von Zürich, Zurich, 1885; and Die Wasserversorgung von Zürich und Ausgemeinder; Entgegnung der erveiterten Wasser.com. mission auf die Angrife von Herrn Prof. Klebs. Zürich, 1885. 
Transport by articles of foor.

must always take place, that a condition of irritation, a hyperæmia and detachment of epithelinm, such as occurs, for example, in animals after the injection of putrid mixtures, prepares a spot for the entrance of the true infective agents.

If the view as to the. important rôle played by the intestine in the production of infection is correct, it becomes probable that the transport of the typhoid bacilli to the seat of infection occurs most frequently through the food; and rery various articles of food are not less suitable as rehicles than the drinking water which is commonly blamed in a somewhat one-sided manner.

Articles of food and drinking water can evidently be impregnated with large quantities of typhoid bacilli or spores in the most various wajs; of great importance for the continued existence and development of the typhoid bacilli ontside the body is, on the one hand, the fact that many typhoid bacilli leave the body of the patient in the form of resistent spores, and on the other hand that their development can occur on the most various nutrient materials at the ordinary temperatme, and that without any alteration of the nutrient material noticeable to the naked eye. Thus the channels for the spread of the infective material from the dejecta of typhoid paticuts to articles of food are extremely $\mathrm{nm}$ morous, and are in a marked manner subject to chance, which at one time follows no apparent rule, at another time may present a deceptive appearance of law. It is necessary to refer in illustration of this to the fact that the dejecta containing spores are ultimately deposited on garden earth, on fields, or on meadows, that the nnaltered spores may be thence transported to the dwellings by fruit, man, \&c., and by unforeseen actions and accidents reach $a$ suitable nutrient medium where they can multiply plentifully, and from whence further infection may erentually occur.

It is necessary to bear in mind these numerous and complex ways in which an infection may possibly occur in order to some extent to meet the prevailing tendency to treat these etiological questions in a schematic manner. 
In numerous typhoid epidemics a local and seasonal pre-disposition can be recogniséd, and Pettenkofer has, as is well-known, observed that the moisture of the soil plays an important part in this pre-disposition. How far this view can be brought into harmony with the biological characters of the typhoid bacilli will be discussed more in detail in the chapter on the causation of disease.

\section{Bacillus pneumonice (Friedländer).}

The infectious, and at times cpidemic charncter of certain forms of pneumonia has been repeatedly pointed out by various observers, - for example by Kühn, Jurgensen, and others, - this character leading to the belief that micro-organisms may be the exciting agents of the diseasc. In 1883, Friedländer and Frobenius, as a matter of fact, found and isolated by cultivation bacteria in a large number of cases of pneumonia, the organisms presenting infective properties.

The bacteria were at first only found on post-mortem Oceurrence of examination, especially in the alveolar exudation, in the pneumonia cover glass preparations of the juice, and in sections; they were also present in the pleuritic and pericardial exudation. The same bacteria have also been found by Ribbert, Ziehl, and others in the rust-coloured sputum, and by Friedländer, in one of six cases examined, in the blood obtained by cupping.

These micro-organisms present, under the microscope, Morphological the form of oval cells; it is difficult to say whether these are to be regarded as ornl micrococci, or as very short rods with rounded ends. Friedlünder has doscribed them as micrococci, but in every preparation a relatively large proportion of the individuals shows such a preponderance of the longitudinal diameter that they cannot be reckoned among the cocci; further, isodiametric cells never occur, or only in so fur as they are seen in preparations, where the colls stand at right augles to their long diameter; and as also under ligh powers of the microscope, eren the shorter forms show distinctly parallel and longitudinal limiting lines, it seems more correct to designate thic organisms as bacilli. 
In this species we not uncommonly find that the youthful stages only appear as oval, egg-shaped cells, and that under certain conditions, where the multiplication is very

Staining of the capsule. rapid, these young cells prepon-
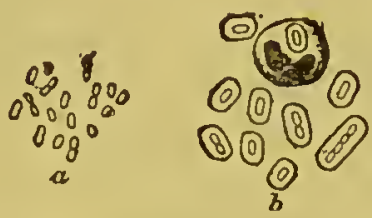

Fig. 71.-Pneumonia bacilli $\times 700$.

$a$, from cultivations.

$b$, from cxudation showing capsules. derate; but the simultaneous presence of older individuals showing a distinct rod shape, enables us to determine that all the cells are bacilli, for if we had to do with the forms which we are accustomed to designate as cocci, we should only find round, or at most very slightly oval cells.

The short bacilli grow very frequently in chains of two to four members; these forms are apparently the more numerous, the more rapid is the multiplication, and hence in these preparations the short forms show a marked preponderance.

In preparations which are obtained from the animal body, but not in those taken from cultivations of the bacilli, the organisms are surrounded by a sort of capsule. Each bacillus lies embedded in a gelatinous sheath which is evidently composed of a substance similar to mucine, as shown by its solubility in dilute alkalies, and its insolubility in acetic acid; the sheath stains faintly when treated in a certain manner with gentian violet or fuchsine, and is thus rendered rery distinct. In order to demonstrate the capsules distinctly in sections, Friedländer recommends the following method: place the sections for twenty-four hours in acid gentian violet solution (concentrated alcoholic solution of gentian violet 50 parts, distilled water 100 parts, acetic acid 10 parts), then decolomrise in - 1 per cent. of acetic acid for one to two minutes; then treat with alcohol, oil of cloves, \&c. Ribbert employs for cover glass preparations a staining fluid composed of 100 parts of water, 50 parts of alcohol, $12 \frac{1}{2}$ of glacial acetic acid, saturated, when warm, with dahlia; the preparations are immersed in this solution only for a very short time, then washed in water and examined. 
The sheath has exactly the form of the bacillus which it surrounds, and hence it usually presents the appearance of an elongated oroid; tro to four bacilli in chains are often present in one capsule; in other cases the division is complete, and each of the new bacilli has its owl capsule. The breadth of the sheath is at least as great as the transverse diameter of the bacilli; at times, however, it is two to three times greater. This capsule formation is not at all peculiar to the pneumonia bacilli, in which, however, the enveloping substance which is present in a very large number of bacteria is particularly well formed; this material is also quite as great in some other species.

Cultirations of Friedlünder's bacilli are readily obtained Cultirations. on rery rarious nutrient substrata. On gelatine plates white points appear after twenty-four hours, and under the microscope present the form of round, sharplydefined discs, with a dark granular centre, and a narrow olive-coloured border; at a later period a white porcellaneous deposit is formed on the surface of the gelatine, like a very prominent convex knob. In cultivations made by plunging the needle into the gelatine, a thick, white, confluent mass is formed along the track of the needle, and this mass extends into any fissures which may communicate with this track; here, also, we find a convex knob on the surface. In strolie cultivations a thick, white, creamy layel is formed.-The bacillus also grows well on agar, blood serum, and potatoes. On the latter whitish-yellow gelatinous masses are formed, which may extend over the whole surface of the potato, presenting a glistening surface and showing at times a development of gas and formation of bubbles. - The rod slape of the bacilli is particularly evident in microscopical preparations of cultures, especially when the frowth has occurred at a low temperature and the individual organisms have attained their full size beforo dividing. The formation of spores has not as yet been observed with certainty.

Friedlïnder and Frobenius havo performed inoculation experiments on animals witl pure cultivations of the animals. 
bacilli. If fluids containing the cultures were injected through the wall of the thorax into one lung of $x$ rabbit by means of a Prasaz syringe, no disease occurred, rabbits being completely refractory to the organisms. On the other hand, 32 mice treated in the same way died; on post-mortem examination reddish, turbid fluid was found in both pleural cavities, both lungs were very markedly reddened, almost completely devoid of air, and showed scattered and ill-defined patches of red infiltration. Of 11 guinea-pigs, 6 showed similar appearances; of 5 dogs, 1 . If the cultivation was exposed to a temperature of about $80^{\circ} \mathrm{C}$. for 15 to 20 minutes, ancl then injected into mice, the animals remained healthy, with the exception of a few, where the injury was unintentionally more severe. (This is a control experiment, which in view of the serious injury done by such injections into the lungs of mice was absolutely necessary, and still requires further repetition). - Fire mice were also successfully infected by inhalation of cultirations, and these, in like manner, presented typical appearances of pneumonia. The same organisms could be cultivated from the affected lungs of the animals experimented on.

Significance of Friedländer's bacilli for the etiology of pneumonia.
In judging of the significance of Friedlïnder's pneumonia bacilli, more especially for the purpose of clinical diagnosis, it is very important to note that they cannot be distinguished with certainty from a number of other organisms, either by their microscopical characters, or by their cultivations. The same morplological characterseven the capsules - are present in a number of bacteria; the character of the cultivations is extremely common, and shared by many species of bacteria; both the morphological and cultural characteristics were combined in bacilli studied by Passet, Krreibohm, and others. Hence a defnite diagnosis of these organisms is only possible by experiments on animals; and eren in this respect the distinction is difficult, because other organisms also show similar pathogenic action to that of Friedländer's bacilli (for example, the bacillus isolated by Schou). The allied pathogenic bacteria which have been as yet isolated in a similar manner show, howercr, differenecs 
with regard to their growth in gelatine and with regard to the species of animals susceptible to their action, and these differences enable us to distinguish them from Friedländer's bacilli. But the diagnosis of the latter can only be made by the aid of elaborate comparative cultivations and experiments on animals. And hence the establishment of a causal connection of these bacilli with pneumonia, based on their distribution in pneumonic processes, is very difficult, because it is not possible in erery case to employ all the methods which alone enable us to distinguish these organisms from others which are constantly present in the sputum and in the bronchi, and which are therefore frequently found in pneumonic exudation, although they are of no importance.

The answer to these questions is so much the more difficult because Friedlünder's bacilli are, without doubt, not the only cause of the pneumonic process. We are alleady acquainted with pneumonias which are caused by aspergillus and actinomyces; it is a priori not improbable that also among bacteria there are several other species which can set up pneumonia ; and the probability of this view is increased by Schou's observations. Further careful observations, combined with cultivations and experiments on animals, will thcrefore possibly discover a greater variety of causes of pneumonia.*

Emmerich has demonstrated the presence of Fried- Occurrence of lïnder's bacilli in the soil of a room in which there were the pneumonia $_{\text {bailli ontside }}$ many pneumonic patients; the diagnosis was rendered the human certain by inhalation experiments with cultirations on 18 mice, of which 8 died of pneumonia; hence the soil seems to be one of the places where the pneumonia bacilli can be preserved, and whence, in suitable cases, they may pass into human beings. Possibly also there are a number of other places in our surroundings which play a similar róle. But as the result of our present linowledge as to their occurrence and their properties, we cannot make any more definite statement with regard to the mode of spread of these pneumonia bacilli.

* Fränkel has isolated a bacillus which is much more often associated with pacnmonis than the above-mentioned orgnnism. 


\section{Bacillus tuberculosis.}

Demonstir. tion of the inoculability of tuberculosis.
Mcthod of demonstrnt. ing tlio tubercle bacilli microscopio.zly.
Klencke, and at a later period Villemin, were the first to show that the affected organs from tuberculous human beings, and from animals suffering from perlsucht, set up tuberculosis when inoculated on animals; they thereby proved the infective nature of tuberculosis, and provided a justifirble basis for the supposition that in this disease also the exciting agent was an organised living body. The infective experiments were subsequently repeated in a convincing manner, more especially by Cohnheim and Salomonsen, and later by Damsch, who employed the eyes of rabbits as the seat of inoculation, and were able to set up tuberculosis of the iris by inoculation of tuberculous material into the eye, the disease spreading from thence to other organs. In spite of these experiments the nature and the ultimate cause of tuberculosis was for a long time obscure, as the attempts to find, even with the most careful microscopical examination, any organised bodies in tuberculous organs, which could be looked on as the exciting agents of the disease were not successful, and as also expcriments on the cultivation of the supposed organised virus did not lead to any definite result. It was not till a few jenrs ago that by means of Koch's. classical investigations we obtained a complete insight into the etiology of this disease; a result which so much the more deserves our most complete admiration, because entirely new and special methods were necessary as well for the microscopical examiuation as also for the cultivation of the micro-organisms, and because the whole investigation was laid before us in such a complete form that in respect of this question the points as to tho etiology of tuberculosis aro scarcely capable of any further important expansion. The following description is consequently in the main based only on Kocli's rork on tuberculosis.

In the first place Foch succeded in demonstrating the presence of peculiar bacilli in the most rarious tuberculous affections by means of a special method of staining. While no micro-orgnnisms conld be demon- 
strated by the aniline stains as ordinarily employed, nor by the other nuclear stains; organisms at once became quite evident when a small quantity of alkali was added to the solutions of the aniline colouring matters. As later investigations showed, the substitution of anilin, toluidin, turpentine, carbolic acid, or ammonia, for the alkali acts in a similar mannner in enabling the staining material to penetrate into the tubercle bacilli; even without any such addition to the staining fluids, the bacilli may be successfully stained if only the action of the staining material is sufficiently intense to show quantitative differences with respect to the taking up of the colouring matter. It is also of special advantage that the staining material once it has penetrated into the bacilli is held very tenaciously; Koch found that on treatment of sections stained in the alkaline colouring material with strong nitric acid or hydrochloric acid the colouring matter is extracted from cells, nuclei, and all other bacteria, while the tubercle bacilli alone remain stained. In the tissue, which is now colourless, the individual bacilli are remarkably easily recognised on account of their stain; and the picture may be further improved by treating the section, after the employment of the decolourising means, with an ordinary nuclear aniline stain, the tone of which presents a good contrast to the solution first employed for the staining of the tubercle bacilli. The cell nuclei and also the other bacteria (not tubercle bacilli) take on this second stain, so that, for example, the tubercle bacilli appear red, the cell nuclei and other bacteria blue, or the former violet, and the latter brown. (As to the modifications and the technique of the method of staining tubercle bacilli, as well as with regard to the exceptions to the exclusive staining of the tubercle bacilli, see the chapter on "Methods."

The bacilli found in tuberculous organs by the aid Morphologieal of this extremely sliarp and sensitive method are rods chrracter's. $1.5-3.5 \mu$. in length; their breadth is constant wheu the same staining methods aro employed, and corresponds to that of the bacilli of mouso septicemia. For 
the most part the bacilli are slightly bent, or even more frequently curved. They are often spore-bearing, the number of the spores being usually $2-4$ or even 6 . By the ordinary method of treating the preparations the spores do not take up the colouring matter, and hence the spore-bearing bacillus when stained presents the appearance of a dark thread, interrupted by clear eggshaped spaces. At times it seems as if the spores pro-

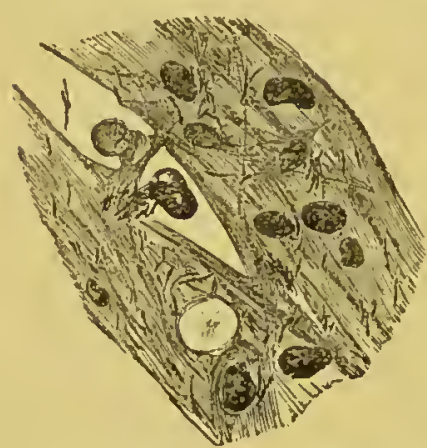

Fig. 72.-Sputum containing tubercle bacilli $\times 600$. jected laterally beyond the contour of the bacillus. If the specimen is examined with insufficient magnification one readily obtains the impression that such a spore-bearing thread is composed of a chain of cocci ; if the preparation is badly stained, too much heated, or too long treated with acid, this appearance is increased. Nevertheless it is always possible, in carefully prepared specimens and with the aid of good lenses (Zeiss $\frac{1}{18}$, Winkel $\frac{1}{24}$ ), to convince oneself that the supposed chain of cocci does not exist, but that the delicate contour of the bacillus can be for the most part traced through its whole length, and that it is only within this contour that the alternation of stained and unstained zones gives the deceptire appearance of stained cocci separated by narrow intermediate spaces. The assertion made by some obserrers that the tubercle bacilli also occur in the form of cocci can only be referred to this and other errors of observation. In all cases the tubercle bacilli appear to be non-motile.

Situation of the tubcrcle baeilli.

The bacilli are most readily found where the tubercular process is commencing or spreading.

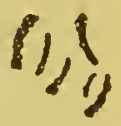
At first the bacilli are single, and then almost Fig 73.always lie in the immediate neighbourhood of a $\begin{gathered}\text { Tubercle } \\ \text { bacilli } x\end{gathered}$ nucleus and in the interior of the cell to which 1200 . this nucleus belongs; later they occur in closely packed small masses. The cheesy centre of the mass shows only broken down nuclear substance, which no longer 
takes on the nuclear stain, and in which there are very few or no tubercle bacilli; from the infectivity of the

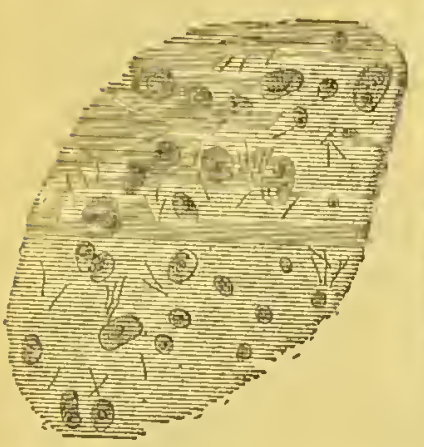

Fig 74.-Miliary tuberculosis of the lungs $\times 700$.

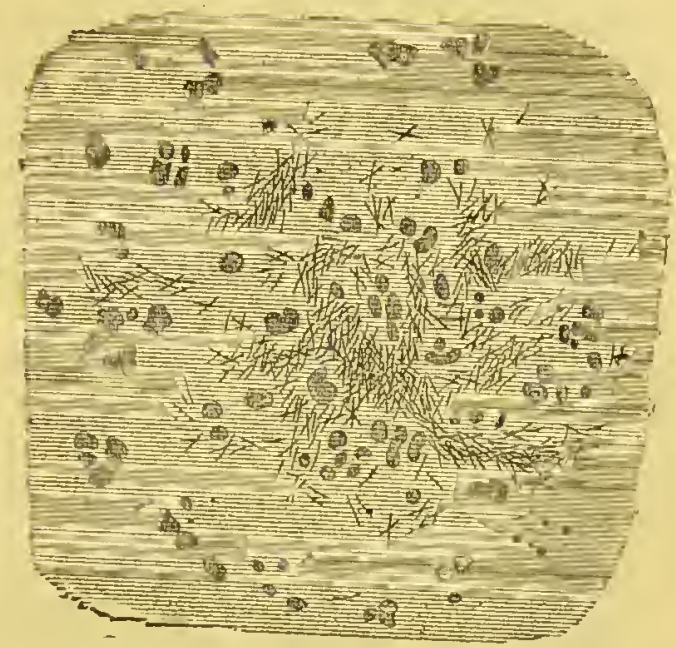

Fig. 75.-Tuberculosis of the intestine $\times 700$.

cheesy centre the conclusion may, however, be drawn that the bacilli have here passed into the spore stage, which cannot be demonstrated by staining.

As soon as giant cells appear in the tubercles, tubercle bacilliare almostalways found in them. They often contain only one bacillus, and then a peculiar antagonism is frequently evident between the nuclei of the giant cells and the enclosed bacillus. T'he latter takes up a position opposed to the nuclei, and lies as

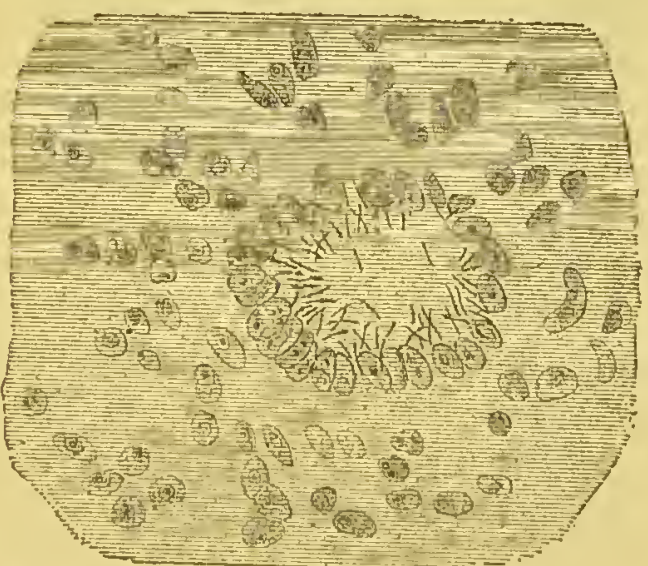

Fig. 76A.-Giant coll from a case of miliny tuberculosis $\times 700$. fin as possible in the part of the cell which is free from nuclei (fig. $76 \mathrm{~B}$ ). If the number of tubercle bacilli which develop in the giant cells increases markedly, they finally break through the wall of nuclei, and the giant cell then apparently dies. 
The bacilli are probably first introduced into the diseásed tissue by wandering cells which take up and transport the bacilli, which are not themselves capable of independent movement; it is possible that this transporting wandering cell becomes then transformed into an epithelioid cell and afterwards into a giant cell. In many infective experiments wandering cells containing tubercle bacilli can be directly demonstrated in the blood and tissues.

Distribution of the bacilli in the various tubercular affections.

Koch examined in man 19 cases of miliary tuberculosis, in none of which the bacilli were missing from the

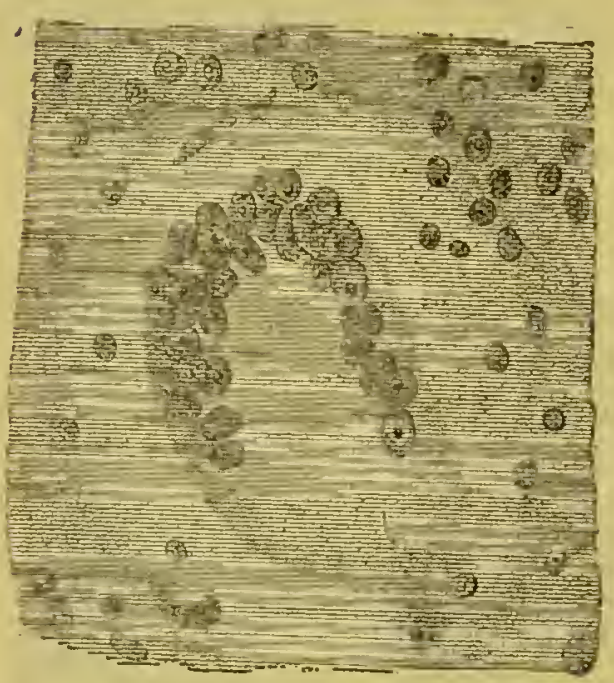

Fig. 76B.-Giant cell contrining a tubercle bacillus; section from lupus of the skin $\times 700$. tubercular nodules: 29 cases of phthisis of the lungs $(8 \mathrm{com}$ plicated with intestinal tuberculosis); here also the bacilli were constantly found, and apart from the sputum they were most numerous in fresh cheesy infiltrations and in the interior of carities where the walls were rapidly breaking down. In tuberculous ulcers of the tongue, in tubereulosis of the pelvis of the lidney, of the uterus, of the testicle, \&c., the bacilli were constantly found ; likewise in 21 cases of tuberculous glands. Further, they were present in 13 cases of tuberculosis of the joints and 10 cases of tuberculous affections of bones; in 4 cases of lupus, where the bacilli were only found in giant cells, and only one organism in ench: iu 7 cases of bovino tuberculosis ; finally, in various animals inoculated with tubercular material (273 guinea-pigs, 105 rabbits, 44 field mice, 28 white mice, 19 rats, 13 cats, as well as dogs, marmots, fowls, pigeons, sce.). Further, sputa and organs in a very large number of other non- 
tuberculous affections were examined; here, however, the clinrncteristic bacilli were invariably absent. .

From all these microscopical investigations it follows with certainty that the tubercle bacilli occur constantly. and exclusively in tuberculosis, that they precede the pathological alterations which are peculiar to tuberculosis both in place and time, and that their number, their appearance, and their disappearance, stand in direct relation to the course of the disease. These results evidently imply an etiological relation between the tubercle bacilli and the tubercular process.

The cultivation of the tubercle bacilli was also ac- Cultivation of companied, like their microscopical demonstration, the tubercle by special difficulties, and required new and special methods. No growth occurred on the ordinary nutrient media. The tubercle bacilli evidently lead a parasitic existence, and saprophytic growth can only occur when the conditions under which they flourish in the animal body are copied as accurately as possible; as also the whole development of the tubercular process only goes on very slowly we can only expect a difficult and slow growth of the bacilli, even under conditions which to some extent correspond with those which are present in the animal body. As a matter of fact Koch only succeecled in obtaining cultivations when he employed blood serum, gelatine, or solidified blood serum kept at the body temperature, and when also these nutritive media were so prepared that they could be liept for 14 days or longer at the body temperature without drying up, or becoming contaminatcd with other organisms. It was found that blood serum kept in test tubes, and sterilised, was the most suitablo material, ospecially when the tubes were kept in an oblique position while the blood serum was solidifying, and thus a large surface was presented for the growth of the cultivation. (More accurate details as to the preparation of this nutrient medium will be givon in the chapter on "Methods.") During solidification of the blood serum the condensed water collects in large drops at the lowest part of the oblique surfaco of the sorum, and this roser- 
voir of water is in so far of importance for the cultivation, as by means of it the surface of the serum is kept sufficiently moist, and preserved from drying during the long time that it is kept in the incubator.

If tubercular masses are placed on such nutrient

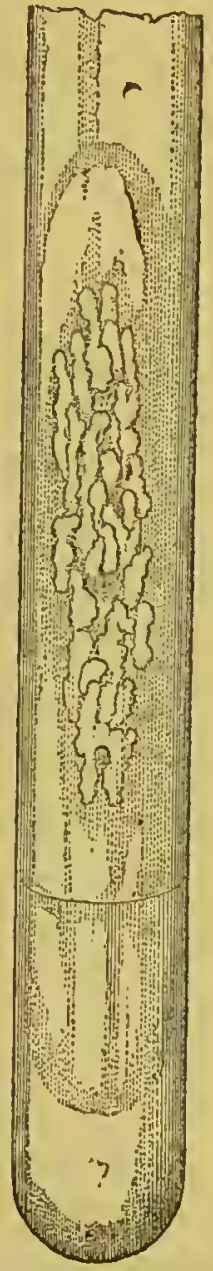

Fig. 77.-Cultivation substrata (care being taken completely to exclude other bacteria), and lept permanently at $37^{\circ} \mathrm{C}$, distinct multiplication of the tubercle bacilli can be seen after about 14 days. The greatest care must of course be employed to exclude other bacteria, more especially because the saprophytes as a rule grow much more rapidly at the body temperature, and, starting from a very small number of individuals, may completely occupy the surface of the soil before the tubercle bacilli have eren begun to multiply. According to Koch, it is best to commence the cultivations from the lymphatic glands of a guinea-pig which has been inoculated with tubercular sputum or tubercular organs; and has been killed after about three or four weeks. The skin is purified with corrosive sublimate, and one of the swollen lymphatic glands is exposed, a series of heated knives and scissors being employed for the purpose.

Finally, the gland is cut through and a portion of the interior is rubbed orer of tubercle bacilli the surface of the blood serum. In on blood sernm.

spite of these precautions, it is always well to inoculate a considerable number of tubes, for some always become contaminated and useless. In the incubator the tubes remain unaltered for 7 to 10 days; after this time, sometimes not till the fourteenth day, dull white points and small flnkes are formed on the surface of the serum, these flakes haring the appearance of dry scales with a dull surface. At times they unite 
to form a thin, dull covering over the surface of the serum. On further inoculation of these cultivations on new blood serum the growth takes place more readily; later cultivations give more luxuriant growths, which also spread over the surface of the drop of fluid present at the lower part of the tube. When examined under a low power of the microscope (80 diameters) the appearance of the colonies is seen to be very peculiar and characteristic. After five to six days very peculiar and delicate figures are seen on the surface of the blood serum, forming finely curved and S-shaped lines; these gradually spread and form masses which ultimately become united with one another. These

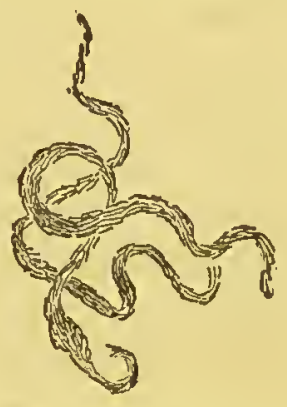

Fig. 78.-Colonies of tubercle bacilli from a cultivation, dried and stained on a cover glass $\times 700$. colonies can be obtained by pressing a cover glass on the surface of the serum, and they can then be stained and the individual bacilli recognised under high powers of the microscope.

Koch has made in all 43 cultivations from tubercular material; several of these bcing from bovine tuberculosis, scrofulous glands, fungous disease of joints, and lupus. Some of these cultivations have been now kept up through more than forty generations for over three year's; but the bacilli have in no way lost their virulence.-Another soil on which they can grow is a mixture of infusion of meat with agar, but the growth on this material is by no means so good. Koch was only able to obtain a cultivation in neutralised meat infusion under special conditions, and in this material the bacteria formed, after four or five weeks, a white, granular deposit at the bottom of the clcar fluid. No growth could be obtained on any vegetable substance. The development of the bacilli completely ceases below $28^{\circ}$ or $29^{\circ} \mathrm{C}$.; at $30^{\circ} \mathrm{C}$. it is very slow; it is best betwcen $37^{\circ}$ and $38^{\circ}$, and completely coases at $42^{\circ}$. The difficulty of cultivation and the narrow limits with-Cultivation in which growth occurs has been confirmed by other cxperiments 
observers, and this fact shows that the supposed pure cultivations of tubercle bacilli carried out by earlier nuthors, and not under the conditions mentioned above, were not pure cultivations, but were cultivations of somé accidental saprophyte.

Experiments From these cultivations Koch has infected numerous on animals. animals, and thus completed the necessary proof. In the first place he has in many cases repeated the former infective experiments with tubercular tissues. For example, 179 guinea-pigs, 35 rabbits, and numerous other animals were inoculated with nodules from miliary tuberculosis, with phthisical sputum, with pus from tubercular abscesses, with the material from fungous disease of joints, with scrofulous glands, with lupus, and with nodules from bovine tuberculosis, and in all the cases tuberculosis occurred.

Inoculation with tuberculir sputum.

Infection by pure cultivations of tuber cle bacilli.
The infection occurs most easily by introducing a little sputum into a pocket in the skin over the abdomen of guinea-pigs. The wound is closed with a stitch, soon heals, and usually shows no reaction. After two to three weeks, however, swelling.of the nearest lymphatic glands occurs; at the same time the seat of inoculation becomes hard, and a nodule is formed. This nodule subsequently ulcerates, and becomes covered with a dry crust, under which is a shallow ulcer with cheesy base. The animals become thin, they have difficulty of respiration, and generally die.in from the fourth to the eighth week.-In rabbits the course of the disense after such an inoculation is not so definite; it is best here to inoculate into the anterior chamber of the eye.

Koch has further made numerous inoculations with pure cultivations. For this purpose animals freshly bought were employed; they wore liept in a special cage, killed in the early strge of the disease, and in order to exclude, as far as possible, all suspicion of accidental tuberculosis, uninoculated control animals were always kept beside thom. Tho pure cultirations were inoculated in a variety of ways; in the first place subcutaneously. As a result, all tho guinea-pigs and 
field mice died, also ono marmot. Fowls were in part By subcutano. susceptible; white mice were almost altogether insus- ous inoculaceptible. A second mode of infection was the invcula- By inoculation tion of the pure cultivations into the anterior chamber of into the the eye in rabbits. An incision several millimetres anterior cham. length was made at the upper border of the cornea, and, by menns of a blunt hook, a minute fragment of a pure cultivation was pushed into the anterior chamber, or $a$ mixture of the cultivation in water was injected by means of a syringe which posisessed a fine, sharp callula. If by this mode of infection few bacilli were injected, tuberculosis of the iris occurred somewhat more quickly than after the introduction of tubercular tissue. This was followed by swelling and caseation of the nearest lymphatic glands, and subsequently by tubercular infection of other organs. Wliere large quantities of bacilli were injected; however, caseation of the bulb and general tuberculosis rapidly occurred, so that the lymphatic glands were, as it were, passed over
by the infection.

In a third series of experiments, a mixture of the By injection cultivations was injected in to the peritoneal cavity. By into the this mode of infection, animals which were otherwise cavity. very insusceptible to the disease-such as dogs, rats, and white mice-died with extensive eruption of tubercles in the abdominal organs. Fourthly, mixtures of the By intra. cultivations, which had been "filtered through fine venous gauze, were injected into the veins (the jugular or aural rein). By this mothod the most rapid and most complete infection was obtained, an enormous number. of tubercular nodules appearing in a much shorter time than is ever the case in spontaneous tuberculosis. In these experiments, thereforo, the possibility of spontaneous tuberculosis can be excluded most readily, and with the greatest certainty.

Lastly, Koch attempted to introduco tho cultivations of bacilli into the animals by inloglation. the cultivations By inhalation. the cultivations with water hand spray into the was sprayed by means of a open air, and in the interior of a box standing in tho open air, and in this box 20 to 30 rabbits, guinea-pigs, 
Control experiments.

rats, and white mice were placed. The animals were then kept in a special cage and well tended; after 28 days they were killed, and all showed extensive tuberculosis.

The inoculations were made on a total of 217 animals. The more susceptible animals-guinea-pigs, field mice, rabbits, and cats-died as the result of all the different modes of infection; and where large numbers of bacilli were employed, dogs, rats, and white mice were also unable to withstand their action.

It must also be mentioned that numerous control experiments were made with a great variety of cultirations and mixtures of other bacteria, and that the inhalation experiments were also controlled by Koch in a similar manner. Nevertheless, in no case was tubercular discase observed in these animals.

The proof that we must look on the tubercle bacillus as the only and all-sufficient cause of all kinds of tubercular diseases has thus been brought by Koch with a completeness and certainty which has scarcely erer been attained as regards the etiology of any other disease. The results of Koch's experiments have been subsequently confirmed completely by several observer's; thus the whole series of investigations has been repeated by Watson Cheyne, Rosenbach, the author, \&c. The constant and exclusive occurrence of the tubercle bacilli in tubercular diseases has been confirmed by numerous observers, more particularly their occurrence in phthisical sputum, and also in the surgical tubercular affections in lupus, bovine tuberculosis, \&c. The objections which have becn raised by Formad, Spina, and others, against the etiological significance of the tuberclo bacillus, or against certain parts of the proof furnished by Koch-for example, against the specific applicability of the methods of staining, against the $\mathrm{ex}$ periments on animals, \&c.-have been shoml to be badly founded in every respect, and have for the most part arisen only from imperfect employment of Koch's methods. 
From the knowledgo which we have obtained, as the Deductions as result of experiments, with regard to the biological to the mode of relations of the tubercle bacilli, important conclusions may tuberculosis. be drawn as to the mode of spread of these bacilli, and of the disease caused by them. In our ordinary surroundings the conditions necessary for the multiplication of the tubercle bacilli are, without doubt, never present; in other words, they do not possess a saprophytic stage of existence, but they always behave as true parasites under the conditions which are present in nature. Hence the spread of tuberculosis could only occur by infection from individual to individual, were it not that the bacilli can retain their vitality and all their virulent characters for a considerable time outside the body. This preservation of the organisms is aided to a great degree by the presence of spores, which have proved, as the result of direct experiments, to be very resisting. Sputum, containing spore-bearing tubercle bacilli, was Length of life still virulent after six weeks, although it was kept moist, of the tubercle and although putrefaction occurred in it; such sputum when dried retained its virulence up to 186 days, as was proved by the inoculation of guinea-pigs. Hence we may assume that our ordinary surroundings must be frequently much contaminated with virulent bacillus spores, and that infection can occur not only directly from the patient, but also by means of the most varions objects from his surroundings, often in a very indirect manner and after a relatively long time. The most Distribution important source of the contamination of our surround- of the bacilli ings with tabercle bacilli is undoubtedly phthisical phthisical sputum; as almost one-serenth of mankind die sputa. phthisis of the lungs, and as a large portion of the sputum is constantly dried in the clothes and on other objects, and thus is able to pass into the dust, the distribution of the virulent material must bo comparatively great.

Nevertheless numerous experimenters have failed to discover any tubercle bacilli in the air, even of places such as wards in which phthisical patients were constantly present (Celli and Guarneri, Bollinger), and only 
Futile at.

tompts to demonstrate tuberele bacilli in the air.

Reasons for the negative results.

Modos in which tle tuborcle breillus enters the inody. one observer (Williams) was able to demonstrate, by means of the microscope, tubercle bacilli in the air obtained from the ventilation shaft of a consumption hospital. These failures are, however, by no means sufficient to cause us to modify our convictions as to the wide distribution of virulent tubercle bacilli or spores; our methods are, on the contrary, much too imperfect to enable us to demonstrate with certainty bacilli in air, which, nevertheless, when inhaled, might introduce a number of these organisms into the body sufficient to produce infection. The examination of air with this view can be carried out by means of microscopical investigation, by cultivation, or by infection experiments. As regards the first method, we have already learned in the case of other fungi that by means of it we can only recognise a very small percentage of the bacteria which are really present, arid that a negative result is obtained even in those cases where we are able to demonstrate the prescnce of numerous individuals by means of cultivation. With regard to the tubercle bacilli also, the investigation by means of cultivation, which is otherwise very useful and much more sensitive, cannot be employed for these experiments, because, as the result of the slow and difficult growth of the tubercle bacilli, the soil is always completely occupied at an carlier period by other unavoidable bacteria, and also because for infective experiments we require larger numbers of bacilli, and more especially a more concentrated material than is obtained by these investigations of the air, and hence it is not correct to conclude that because infection has not occurred the air investigated has been free from tubercle bacilli. Where a longer time is spent in rooms contaminated by phthisical sputum, \&c., and where the air of these rooms is breathed for some time, the entrance of the respiratory tract comes into contact with many more bacilli than can as yet be demonstrated by means of any mode of acroscopic investigation.

The tabercular virus without doubt enters the body most frequently with the inspired air, and this is the mode in which lealthy persons are most commonly 
infected with tuberculosis; in rare cases the tubercle bacilli may also penetrate into the body through wounds of the skin. At times tubercular animals are the source of the infection; but the disease seems only to be carried by the milk of tubercular cows when the mammary glands are themselves affected with the disease.

In apparent contrast to the influence of the local spread of the tubercle bacilli, we have the experience that as the result of living in the neighbourhood of tubercular individuals by no means all the healthy persons are infected; indeed, the percentage of infections is only slightly greater than where there is, as far as we can judge, much less opportunity for infection. The Important predisposition evidently plays a very important vôle in part played luy the occurrence of tubercular infection; it practically predisposirontrols the mode of spread of the tuberculosis, and is more especially important because it has the greatest influence on the treatment of the disease. What this individual predisposition consists of is a question whicl has been as yet very little investigated as regards its relation to the infective agents which have as jet been recognised. We know that there are certain protective arrangements in the body which, along with the very limited conditions of life of the tubercle bacilli, render it difficult for the latter to obtain a foothold; in this respect we may point out the moist and sticky lining membrane at the entrance to the respiratory tract, the mode in which elements which have passed further are expelled by the ciliated opithelium and by coughing, and the resisting power of the normal cells, more especially of the epithelial cells (Veraguth), towards the individual parasites. It is only when, for example, as the result of chronic catarih, there are lesions of the epithelial corering, or when there is stagnation of the secretion in certain parts of the lung, or when the nutrition and the energy of the epithelial cells is defective, that the bacilli which have ontered can develop and multiply undisturbed; and these conditions again chiefly occur only in individuals in whom the thorax is abnormal or where the nutrition is bad, or in those who do not breathe sufficiently deeply, 
or again in those where, as the result of their employment, there is constantly irritation of the respiratory mucous membrane. In low far, however, these supposed predisposing causes can be experimentally proved, $\mathrm{or}^{*}$ can be brought into unison with clinical experience, must be for the present left in doubt.

\section{Bucillus lepre.}

In all forms of leprosy (Lepra tuberculosa, maculosa, and anrstletica), and quite apart from the country in which the disease has been acquired, whether in the East, in Norway, or in other places where it is endemic, we find in the affected organs numerous characteristic bacilli, which were first described by Armauer, Hansen, Occurrence of and Neisser. These bacilli have been demonstrated in
the leprosy bacilli. the leprous tumours of the skin, in the mucous membrane of the mouth, palate, and larynx; further, in the peculiar interstitial affections of the peripheral nerves, of the cornea, cartilage, and testicle; in the lymphatic glands, spleen, and liver; in the anæsthetic form of leprosy, for example, in the thickened ulnar nerve; and lastly, on several occasions, in the blood of lepers. On making sections through the cutaneous nodules we see that the tissue is infiltrated with numerous small round or oval cells, which are more or less completely filled with bacilli; the latter often lie in a thick mass in various directions, they often appear arranged in a more or less ray-like form radiating from the centre of the cell ; at times they form parallel bundles. In the older tumours the so-called true lepra cells are present in large number's, these cells being large, multi-nuclented, and similar to giant cells, and also containing very numerous bacilli in their interior. In part, howerer, the bacilli also lie outside the cells in the lymphatic spaces. Recently Unna states that lie has convinced limself, from the examination of dry sections, that the supposed cells contrining bacilli are only masses of bacilli which are held together by gelatinous material, and that the greater number of the bacilli are free, and 
lie usually in globular masses in the lymphatie ehaunels; but these statements require further proof in view of the unusual mode of inrestigation employed by Unna. -Tlie epidermie layer of the skin is always free from baeilli; Babes alone has pointed out the presence of bacilli in the hair follieles, and in the sebaceous glands of the hair, and has thus shown that it is possible that the organisms may

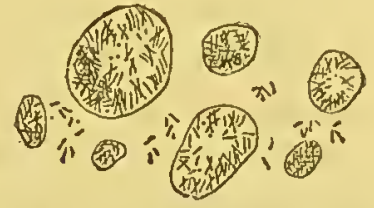

Fig. 79.-Lepra cells containing bacilli $\times 700$. in this way reach the surface of the skin.

The baeilli are 4 to $6 \mu$. in length, and less than Morphologica $1 \mu$. in breadth, resembling on the whole the tuberele characters. bacilli, but not so irregular as regards length as these, nor so often curved. Spores seem to be generally present, but they are not so distinct as in the ease of the tuberele bacilli. The leprosy bacilli can be distinguished from the latter by the fact that they take up the ordinary aniline stains and the nuclear stains mueh more readily than the tubercle bacilli. They can, however', be stained in the same manner as the tubercle bacilli; like these, the leprosy bacilli alone among all the bateria hold an alkaline aniline stain, or one eontaining aniline oil, so energetically that it is not removed on treatment with strong acids. Henee in the case of the leprosy baeilli we ean employ the same method of double staining as. in the case of the tuberele baeilli. The baeilli ean be stained red and the tissue blue, or violet and the tissue brown. This is the best method of staining seetions of leprosy, and it shows most distinetly the individual organisms. If we wish to distinguish between leprosy baeilli and tubercle bacilli we place a dried cover glass preparation for six to seven minutes in a dilute alcoholic solution of fuchsine, decolourise for a quarter of a minute in acid alcohol, wash in distilled water, and stain witl methylene blue. When treated in this way the leprosy baeilli appear red on a blue ground, while the tubercle baeilli have not taken up the red stain in this short time (Baumgarten).

All attempts at cultivation of the leprosy bacilli have 
C'ultivintion experiments ancl experi. ments on animals.

been as yet in vain. Even after being kept for fourteen day's on solidified blood serum at $37^{\circ} \mathrm{C}$. no growth can be observed.-In like manner, attempts to communicate the disease to animals have met with great difficulties, although on several occasions a slight spread of the leprous process from the particles introduced to the normal tissue has been seen. Thus Damsch observed, in the case of two rabbits after inoculation of a piece of a tumour into the anterior chamber of the eye, that after five weeks in both animals the iris and the ciliary body were infiltrated with dense lines of large cells contrining bacilli, and that deposits appeared on Descemet's membrane, and on the anterior capsule of the lens, which consisted of round cells containing bacilli. In like manner a successful attempt has been made to inoculate the leprous tumours into the peritoneal cavity, and under the skin of two cats. In the latter case the cats were killed after 120 days; on making an examination it was seen that the tumour had become flattened and shrunk in the subcutaneous tissue, and that it was surrounded and fixed to the skin by a brownish tissue of new formation, which contained numerous cells filled with leprosy bacilli. Vossius repeated the experiment of introducing pieces of tumour into the anterior chamber of the eje in rabbits, and likewise observed multiplication of the leprosy bacilli, and their penetration into the iris and cornea. But in none of the cases did the process sprend further, nor was the clinical picture of leprosy produced; and in many other experiments even the infection of the neighbouring tissue has failed. Thus attempts which were made by Dainsch to inoculate the disease subcutaneously in mice and rabbits, by Vidal in a pig, ly Köbner in frogs, eels, \&c., were entirely without result.In the case of man also, the spreal of the disease by infection is extremely rare, and is evidently only possib?e under very special predisposing circumstances.

En spite of the great blanks in our knowledge with regard to the leprosy bacilli, we must look on these organisms as undoubtedly the cause of the disease, becruse thiey occur constantly and exclusively in this 
affection, and because also they are present in enormous number's, and practically form the greater part of the affected tissue in the leprous organs.

\section{Bacillus mallei.}

\section{(Glanders, Rotz, Morte.)}

Although several observers have described the occur- Historical rence of micro-organisms in cases of glanders, nothing facts as to the cer of micro-organisms in casery certain was ascertained as to their etiological significance the glan till Loeffler and Schütr succeeded, three year's ago, in completely clearing up the etiology of this disease by the demonstration of characteristic bacilli in the glander's llodules, by the cultivation of these bacilli on artificial substrata, and by the inoculation of the caltivations on rarious animals with the production of the typical discase. Almost at the same time Bouchard, Capitan and Charrin made cultivations in broth from an abscess in a man suffering from glanders, and from the ulcer's of i horse, and, after several generations, inoculated these cultivations with success on asses, cats, and guinea-pigs ; but these observers found in their cultivations only round organisms, at times occurring in chains, and they looked on these as the active exciting agents of the risease. About the same time also Israel made cultivations on blood serum from the glanders nodules of three horses, and was able to set up glanders in rabbits by means of these cultivations; Israel obtained bacilli in lis cultivations corresponding with those isolated by Loeffler and Schütz. At a later period Kitt and Weichselbaum have made cultivations and inoculations of the glanders organisms, and both of these observers were able to confirm, in the main, the statements made by Iocftler and Schütr; Woichselbaum obtained the inaterial for his cultivations from a man suffering from icute glanders.

The bacilli which have been described by all the Morphological obscrvers - with the exception of the French investi-characters of gritors before mentioned-are thin rods, similar to the becilinders tubercle bacilli, but more uniform in size, and somewhat 
broader; like these they are often slightly'curved. One can almost always observe in stained preparations that the individual bacilli are composed of dark and clear zones, so that under a low power they may resemble a chain of cocci; but when higher powers are employed this impression is seen to be incorrect. The clear unstained spaces are probably spores. The bacilli lie in part singly, in part they are united in bundles of 4 to 8 parallel rods, in part they lie in confused masses. It is by no means easy to stain these organisms well in sections; the glanders bacilli take up the aniline stains
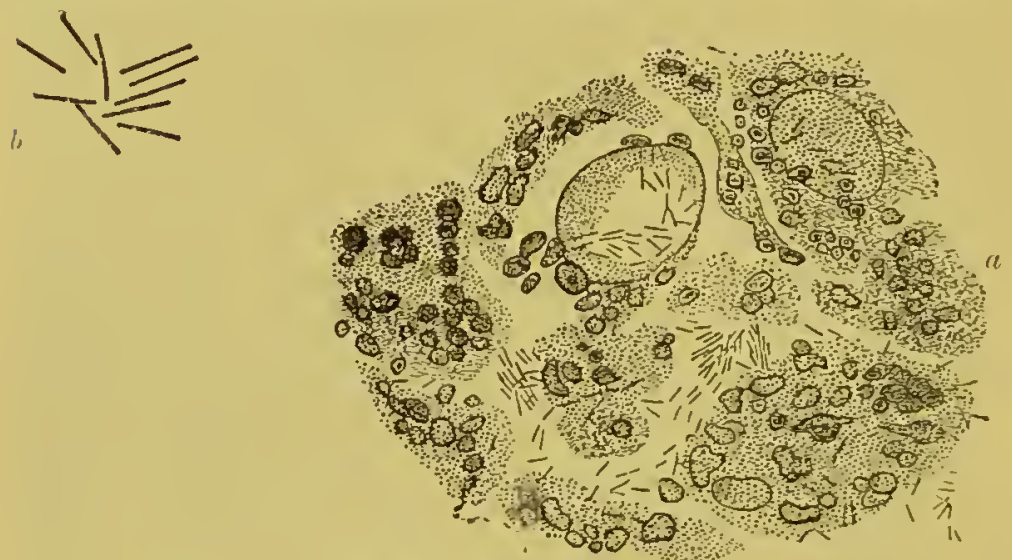

Fig. 80.-Glanders bacilli.

(1, section from a glanders nodule $\times 700$.

6 , bacilli of glanders stained with methylene blue $\times 1,500$.

with some difficulty, and further the dense accumulaticn of strongly staining nuclei in the glanders nodules rendors the discovery of the bacilli difficult. The best plan is to stain with alkaline methylene blue for 12 to 24 hours, then to treat the specimell cantiously witl very dilute acetic acid till the decolourisation has so fur advanced that the bacilli can be distinctly seen. After such treatment we find, here and there, clearer parts in the tissue where the masses of glanders bacilli can be seen particularly sharply defined.

The best situation for finding the bacilli are fresl nodules which have not yet ulcerated; in old ulcers, in pus, in the secretions of the nose, \&c., it is often impossible to demonstrate bacilli, possibly because they have passed into the spore stage. Weichselbaum has suc- 
ceeded in demonstrating the bacilli nicroscopically in the blood of a patient suffering from glanders, and Philipowicz was able to set up the disease in healthy animals by injection of the urime of a guinea-pig suffering from sinder's.

For the cultivation of the bacilli fresh nodules are most Criltivation. suitable; nerertheless, pure cultivations have been obtained from abscesses. - On slices of boiled potato liept at $35^{\circ}$ C., they form within 2 or 3 days a brownish, slimy, but not very thick layer. The cultivations can be best preserved by inoculating mashed boiled potatoes, liept in Erlenmeyer's flasks, in the form of a layer on the bottom 1 to $2 \mathrm{~cm}$. in thickness; in these circumstances a chocolate-brown layer is formed on the surface, which, if protectel from drying, contains for months living bacilli or spores. Potatoes are the best nutrient medium, and next to them comes solidified blood serum. On serum kept at $37^{\circ} \mathrm{C}$. we see, after three dass, small transparent discrete drops, which scarcely differ in colour from the surface of the serum, but which distinctly project above it. According to Weichselbaum and Kitt the glanders bacilli also grow at about $25^{\circ} \mathrm{C}$, although much more slowly. On mutrient agar they form drop-like, soft, greyish-white colonies; in liquid nutrient jelly a tenacious whitish mass is developed.

Under the microscope the cultivations show the same bacilli which we find in the glanders nodules; as the result of differences in age and development there are greater differences in the length of the bacilli; as a rule spore formation can be distinctly seen.

If the cultivations were inoculated into house-mice, no Experiment. result followed; rabbits were partially susceptible, but in on anina:ls. some only local ulcers formed, and these subsequently liealed up. On tlee other hand the inoculation was always successful in the case of ficld-mice, guinea-pigs, horses, asses, and also in one sheep.-Field-mice dio after subcutaneous inoculation with small quantities of the cultivation within 8 days, and show on post-morten examination numerous small greyish-yellow nodules full of bacilli in the spleen and liver. In the case of 
guinea-pigs an mlcer develops 3 or 4 days after inoculation, and this is followed by swelling of the nearest lymphatic glands. If small quantities are inoculated the process may remain for weeks in this stage, in other cases acute nodular swellings form in the testicles, the ovaries, the vulva, or the feet, and ulcerative processes occur in the nasal cavities. In the case of horses and asses the typical picture of glanders was obtained.-The most susceptible animals, and hence the animals best suited for the diagnosis of glanders, are, according to Molkentin and Grünwald, young dogs.

From these results we can no longer doulut that the bacilli deseribed above arc the truc causc of glanders. The obscrrations madc by Bouchard and Capitan, which differ as to the morphologieal characters of the causal micro-organisms. have evidently becn duc to their defective method of cultiration; for they madc thcir inoculations into fluid nutricnt mcdia from open ulcers, containing of course othcr bactcria. and thus they must always have had a great cxcess of the morc quickly growing saprophytes in their cultivations; the majority of these may, as Bouchardd describes, have consistch of cocci, and the few glanders bacilli which wcrc present, and to which the virnlence of the eultures was duc, may hare becu masked by them.

Bacillus diphtherie.

(Loeffler.)

D.fficulties in the e'sological investigation of diphtheria.
As to the etiology of diphtheria, more especially of the epidemic diphtheria of the throat, little that is trustworthy is as yet known, although recently Heubner lias made out some important fucts with regard to the more intimate process of the origin of the diphtheritic membrane, and with regard to the ultimate part played by the bacteria in the formation of the membrane. The difficulties which stand in the way of the knowledge of the ultimate causes of this disease are evidently particularly great and manifold. As the result of om recent investigations the possibility presents itself that in the case of diphtheria we have to do mith organised infective agents which cannot be rendered risible by our 
present means, and perhaps require entirely new methods for their recognition. Expert microscopists, such as Eberth, Weigert, Heubner, Fürbringer, Loeffler, have bcen unable to find any miero-organisms, either in the deeper parts of the affected portion of the throat, in scctions of the urula and tonsils, in the internal organs in cases where there has been rnarked general infection of the body (especially in the kidncys), or in the blood. When we take into account the great number of negative Negative reresults, we must conclude that in the few cases in which bacteria have been demonstrated in the kidncys, or in other organs, we have to do with bacteria which have sults of the of the internal c1rtered accidentally.-Unless we conclude from these negatirc results that we have not as yet been able to render the infective agents of diphtheria visible, there remains as a second cxplanation of the facts, the assumption that in the case of diphtheria, even in the cases where the morbid process is spread over parts of the body far remored from each other, we have only a local derelopment of the infective micro-organisms in the diphtheritic membrane, that some soluble noxious materiuls are produced in that situation by certain micro-organisms, and that these products eause the other symptoms of disease. Even on this assumption, however, we meet with great difficulties in our attempts t) discorcr the specific bacteria which furnish these noxious products. At the primaly seat of disease, and in diphtheritic membrancs, there is, it is true, no want of micro-organisms; but since we have begun not to see the cause of the disease in the presence of any sort of bacteria, but to require that for ench wellcharactcrised disease there must also be specific, wellcharacterised infective agents, we hare the further task of discovering which of these various species of bacteria is of importance etiologically. We lnow now that a Mrixture of number not only of saprophytic bacteria, but also of rarions kinds organisms which are very pathogenie in eertain also of of bacterin in inhabit the carity of the mouth of healthy individuals, itic membrane. and these find a good nutrient soil in the diphthcritiv nembrane; without doubt, also, one of these linds may 
Insusceptibility of the lower uniunals.

grow better there than the others, and hence, in all probability, we shall see one or other species in largest numbers in the great majority of cases, thus leading us to the crroueous conclusion that they have a specific etiological meaning. It is evident that here we can only attempt to isolate the true infective agent with extreme caution, and with care that full weight is attached to all the sources of error.

Further difficulties arise from the behaviour of the animals ordinarily employed for experiments. These are much less sensitive than man to the infective agents of cliphtheria; infective experiments with diphtheritic membrane have becn carried out very extensively in various linds of animals, but very often without any corresponding effect, although the membranes were placed directly on the mucous membrane of the open trachea (Trendelenburg, Francotte, and others). In some cases it is true that illness of the animals, formation of false membranes in the trachea, \&c., hare been obscred, but there has never been a derelopment of typical diphtheria, with all its various symptoms, and those morbid phenomena which were obserred could also be caused by inoculation with non-diphtheritic putrefying material (Huter, Marcuse, and others), and also with various species of bacteria evidently not in etiological connection with human cliphtheria, but nerertheless occurring at times in the normal secretions of the mouth. Such morbid conditions in animals rescmbling diphtheria cannot be of themselves utilised for the recognition of the infective agent of human diphtheria, and thus there is increased difficulty in cxperiments made for the purpose of clearing up the ctiology of this devastating disease.

Vurious kind. Finally, many clinical and epidemiological facts indiof diphtheria. cate that there are various forms of diphtheria caused by different infective agents. If this idea is confirmed it is evident that a further complication of the inrestigations is unavoidable.

Former investigators haie, without doubt, paid too little attention to these dangers and dificulties, and the 
repeated supposed discoveries of the diphtheritic bacteria rested on errors. - Of late Locfler' has attempted to clear Loefter's up the etiology of diphtheria by the employment of investigation: better methods, and by bearing carefully in mind the sources of error. He found in sections of diphtheritic membranes that, in addition to what were evidently accessory organisms, two kinds were present which were of special interest; on the one hand, cocci which were Streptococci. arranged in the form of chains, and chiefly occurred in the diphtheritic throats in cases of scarlet ferer. These had their starting point usually in a loss of substance of the diseased mucous membrane, and extended from that point into the tissue in the form of wedge-like or tonguelike masses, learing necrosis of the tissue behind them; they penetrate into the lymphatic vessels, and at times spread through the whole body. That these chains of cocci play a secondary rôle in diphtheria is probable from the fact that in other diseases accompanied by lesions of mucous membranes we can observe a similar growth of streptococci; and further, they were not so much characteristic of typical cases of diphtheria, with a definite membrane in the throat and with spread of the process to the air passages, as of cases of scarlet fever, in which the process remains limited to the throat. As to the characters of these cocci on cultivation, and in experiments on animals, see page 194.

The other bacteria found by Loeffler in the majority Locttler's of the cases of typical diphtheria are rods with peculiar. morphological and biological characteristics; they are probably identical with the form of bacillus which was also found by Klebs in diphtheria, and was looked on by him as the infective agent of the disease, although he did not succeed in obtaining pure cultivations of the organisms. Loeffler found these bacilli, which stain markedly with methylcne blue, in the false membranes at a deeper level than the masses of other bacteria which covered the surface, namely, at the inner margin of the layer of exudation; they also occupied the oldest Position of the portion of the membrane, and penetrated deeper than membrane. all the other bacteria. Cultivations could not be made 
on the ordinary gelatine plates, but Loeffler succeeder in growing them by diluting a small portion of the material taken from the diphtheritic membrane, and by inoculating drops of the dilnted material on solidified blood serum; in this way pure cultivations of the bacilli Mode of eom- were obtained. Wyssokowitsch recently succeeded in
mencing the viltivations.

Growth on igar plates.
Morpliological charactcrs of the bacilli. isolating the same rods from a piece of diphtheritic membrane which had been coughed up, employing agar plates for the purpose, and keeping the material at $35^{\circ} \mathrm{C}$. In order to render the isolation of the organisms certain one must always employ a large number of plates, as a large proportion of them are generally completely overgrown by the rapidly growing saprophytes.Loeffler found that the best medium was a solid material composed of three parts of calves' or sheep's blood serum, and one part of neutralised real broth, to which one per cent. of peptone, one per cent. of grape sugar, and a half per cent. of common salt were addled. On this soil the bacilli grew at $37^{\circ} \mathrm{C}$.in the form of whitish opaque drops, or of a thick white layer, which attained the acme of its derelopment within two days. Agar jelly for'ms an almost equally favourable soil ; on nutrient jelly growth also occurs at about $22^{\circ} \mathrm{C}$, but it is slow and imperfect; no growth appears to talic place on potatoes.

On agar plates the youngest colonies lying in the substance of the matcrial appear, when rangnified 80

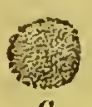

(6)

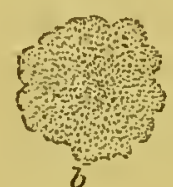

Iig. 81--Colonics of diphtheritic bacilli on agar plates $x$ 80.

", colonies lying in the substance of the almost net-like, surfaces, and witl

$b$, those situated on the a delicato wary border. surface.

The rods are immobile, the majority of them are slightly bent. They rary much in length, being on an arerage of much the same leugth as the tubercle bacilli, but they are considerably thicker than 
the latter. It is not uncommon to find one end, and often even both, swollen; here and there there arc distinct club-like forms. In an unstrined condition the polc, and often also other portions of the bacilli, present a highly refiacting appearance. When stained with methylene blue these portions of the rods take on the stain markedly, and thus there is not uncommonly an appearance as $b$, involution for

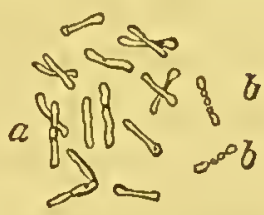

Fig. 82.-Diphtheritic bacilli $\times 1200$.

, bacilli from a fresh if the bacillus were composed of short pieces with irregular outlines. In the case of some bacilli, more especially when they are taken from cultivations on soil which was not very favourable for their growth, the ends appear very markedly enlarged, or the middle is distinctly thickoned, or the rod is divided into large roundish or oval bodies. These deviations from the normal form of the bacilli, the club-like swellings, and the fragments which arise by fission, evidently imply the occurrence of involution. In farour of this view we liave the fact that when they are grown on the best soil-in the living body-these abnormal swellings seldom appear, and are much less marked, so that there is only a slight thickening of individual portions, and more especially of the ends. On the other hand these appearances are the more numerous the worse the soil, and the more imperfect and slow the growth.-We might be inclined to look on the portions of the bacilli which are highly refracting as spores, or at least as the commencement of the formation of spores, but Loeffler was able to show that the rods, even when they showed large numbers of these bodies, died witlout exception after being exposed for half an hour to the temperature of $60^{\circ} \mathrm{C}$. Nor is there any better reason for looking on these bodies as the early stage of arthrospores at any rate not till we have some evidence that they possess a greater resisting power to noxious influences than bacilli in which this change has not occurred.-At tho temperature of the room the cultivations retain their
vitality for about three months. 
Eixperiments on animals.

thections to the otiological significance of

As the result of experiments on animals which were made with cultivations of Loeffler's bacilli, it was found that mice and rats were immune against their action; guinen-pigs and small birds died after subcutancous inoculation, with the occurrence of a whitish or liæmorrhagic exudation at the seat of inoculation, and extensive redemn of the subcutaneous cellular tissue. No microorganisins were found in the internal organs of these animals. If the cultivations were applied to the trachea of rabbits, fowls, and pigeons, characteristic and often very extensive false membranes appeared. These formed in like manner on the scrified conjunctiva of rabbits, and at the entrance of the vagina of guinea-pigs. Besides the false membranes, there also occurred a bloody œdema, hæmorrhages into the tissue of the lymphatic glands, and effusions into the pleurnl cavity. Young animals, as a rule, succumbed to the infection more readily and more quickly than older ones.

The symptoms caused by the bacilli are thus rery similar to the morbid phenomena which are set up in man by the diphtheritic virus. Nerertheless, Loeffler has hesitated to assume as a matter of certainty that these bacilli are the sole specific exciting agents of diphtheria, because they were not found in the falso membranes in a number of typical cases of diphtheria ; because they were not present in the false membranes developed in animals in the same typical arrangement as was observed in man, but were, on the contrary, cither entirely absent or only present in small numbers; and, thirdly, because they could not be inoculated on the lealthy mucous membrane of susceptible animals, but required the presence of small injuries before they could cause infection. Nevertheless, it is quite possible that the bacilli, whose great tendency to inrolution mas mentioned above, had already died in many of the membranes, or had been eliminated, and were hence no longer found; further, that even in the case of man trivial injuries of the mucous membrane may be necessary to enable them to enter, and that thus these objections do not exclude the possibility that these bacilli plas a 
causal part in the disense. - Of greater weight is another objection which also arises from an observation made by Loeffler. On examining the secretion of the mouth in 20 children and 10 adults by the aid of cultivation, Loeftler obtained in one case colonies, which consisted, as shown by the microscope, by cultivation experiments, and by experiments on animals, of these diplitheria bacilli. Nerertheless, it is not impossible that the pathogenic bacilli may at times be present in the secretions of the mouth without setting up symptoms of disease, either because there are no points at which it can enter the body, or because, for some other reason, the patient is immune, and this assumption hardly seems to be too unlikely when we remember the characteristic distribution of these bacilli, and the striking result of the experiments on animals, which seem distinctly to imply that at least for a certain group of diphtheritic diseases these bacilli are the causal agents.

As regards the bacteria of diphtheria in pigeons and calves see below.

Emmerich has assorted in a preliminary communication Emmerich's published in the procecdings of the Hygienic Congress, at diphtheria Hagmc, that the cxciting agents of diphtheria are short, thick rods, which are twice as long as broad, and which grow luxuriantly on nutrient jelly in the form of round, whitish colonics. about the size of the head of a pin, and on potatoes in the form of a thick, whitish-yellow laycr. The cultivations were successfully inoculated on pigcons, rabbits, and white mice; if a cultivation was applied to the mucous mombrane of the trachea of a rabbit, it was found after doath, which occurred about 60 hours later, that the mucous membrane was covered with a croupous, dirty greyish-yellow membrane; further, there was fibrinous inflammation of the pericardium and fibrinous deposits on the lungs. The bacilli were not only found in the false membrane and the mucous membrane, lut were more or less numcrous in the blood and internal organs, iu the liver and splecn, and more especially in the kidney. Emmerich obtaincd the same result from 8 cases of human diphtheria, and 6 eases of pigeon diphtheria, and he looks on luman and pigcou diphtheria as discases causcel
by the same infective agent.

Fmmerich's couclusions arc, howerer, by no monns sumicicntly satisfactory. According to the best obscrvations, NC 
cannot accept the identity of pigeon diphtheria with human diphtheria ; the almost eonstant presence of numerous bacilli in the internal organs, and more especially in the kidneys of the animals experimented on, when eontraster with the negative results obtained in man, seem to show that the disease caused by Emmerieh's baeilli differs in an inportant manncr from human diphtheria; as to the distribution of his bacilli in sections of human diphtheritie membrane, Emmericll makes no statements, although it must surprise the reader that Emmerich has obtained sueh markedly eontradictory results to those obtained by Loeffler in his careful invest: gation, and that he has assigned to other baeteria whieh wero not at all thought of importance by Loeffler, a greater rôle than Loeffler's streptoeoeei and baeilli.-It is possible that the method employed by Emmerieh, which is one by no means to be recommended, led to erroneous eonclusions. Emmerich introdueed pieces of mucous membrane and partieles of the false membiane into nutrient substrata, allowerl impure cultivations to grow, and then at once inoculater these on animals, with the view of separating the pathogenic from the non-pathogenic bacteria. By this mode of proeedure it was almost unavoidable that septie breteria which are almost always present in the seeretions of the mouth, and in diphtheritic membranes, should infect the animals, and thus obscure the true diphtheritie baeteria.

The following bacilli, which are pathogenic on man, are only imperfectly known, and require further inrestigation:-

\section{Syphilis.}

Lustgarten's syphilis bacilli.
During the course of the last few rear's numerous authors (Hallier, Lostorfer, Klcbs, Aufrecht, BirchHirschfeld, and others) have made statements which are evidently erroncous as to the discovery of the infectire agents of syphilis, but lately Lustgarten has succecded in demonstrating micro-organisms in the syphilitic new formations, by the aid of a special method of staining. These organisms may with considerable probability be looked on as the specific infective agents of syphilis, on account of their characteristic behaviour with regard to staining solutions, on account of their constant presence, and on 
account of the mode in which they are arranged in the diseased tissues.

The method of staining successfully employed by Lustgarten consists in staining the sections in aniline gentian violet solution, and subsequent decolourisation by means of a solution of permanganate of potash, the dioxyde of manganese-the product of the reduction process-being subsequently removed from the sections by sulphurous acid; after this treatment the sections appear quite colourless, with the sole exception of the syphilis bacilli.

Lustgarten's method may be shortly described as Method of follows :staining.

The sections remain in a mixture of 100 parts of aniline water, and 11 parts of eoncentrated alcoholic gentian violet solution for 12 to 24 hours at the ordinary temperature, or for 2 hours at the body temperature; they are then washed in aleohol, then for about 10 seeonds in a $7 \frac{1}{2}$ per cent. watery solution of permanganate of potash; in that fluid the preparations beeome eovered with brownish flakes of dioxyde of manganese. By plaeing thcin for a short time in a watery solution of sulphurous aeid, the dioxyde of manganese is redueed, dissolved, and washed away; the seetions are then washed in distilled water, and if they have not been suffieiently deeolourised, the process is repeated; as a rule it is only after repeating it three or four times that a good result is obtained. Finally the seetion is dehydrated in aleohol, and then placed in the usual manner in oil of cloves and Canada balsam. Cover glass preparations are treated in like manner, with the exeeption that, after the aetion of the violet, water, and not aleohol, is employed as the first decolourising agent. Not only is the tissue decolourised by this plan, but also all baeteria, with the exception of the syphilis baeilli, and the bacilli of leprosy and tuberele; the syphilis baeilli may, however, be distinguished from the latter by the fact that they are quiekly deeolourised by trcatmont with hydrochloric acid

The bacilli found in syphilitic new formations are Morphological usually bent, slightly S-shaped, and on an avernge $4 \frac{1}{2}$ characters. $\mu$. long; they often show a sliglit knob-like swelling at the ends; their contour is not quite uniform, but it is more or less wavy, or indented at parts. When highly magnified we can see, in the dark blue stained bacillus, clear oval refracting spots two to four in namber and 
placel at equal distances; these spots are, in all probability, spores.

The bacilli do not occur free in the tissue, but are for

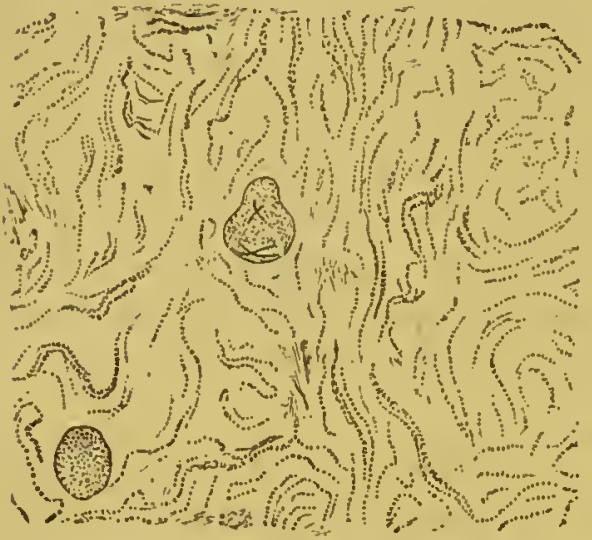

Fig. 83A.-Syphilis bacilli. Group from a chancre X 1050. (After Lustgarten.) the most part present only in large oval or. polygonal cells, in tlic interior of which they often lie in groups of two to eight, often crosscd or twisted round one another. As a rulc there are only relativcly few bacilli in the affected parts, so that at times severnl sections must be examined before a cell containing bacilli is found.

Lustgarten has been able to demonstrate these bacilli in each of 16 cases of syphilis cxamined by him. They were also found in a periosteal gumma in a case of congenital syphilis; on the other hand, they were absent in two cases of soft chancre, and in numerous specimens of normal and pathological organs which were examincd for purposes of control.

Othermethods De Giacomi, in demonstrating these bacilli, has of staining.

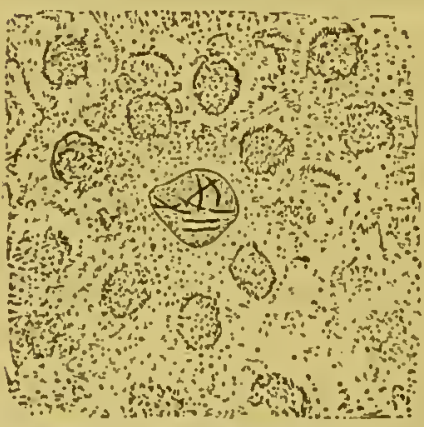

Tig. 831.-Wandering colls con. taining syphilis bacilli $\times 1050$. (After Lustgarten.)

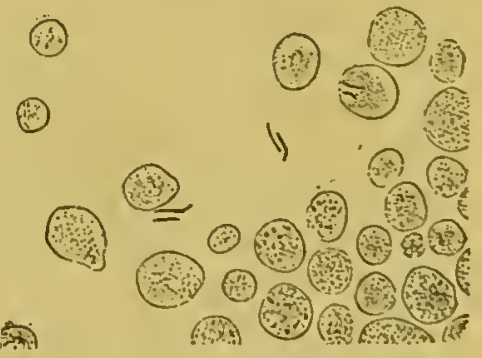

Fig. 83c.-Covor glass preparation from the pus from a chancre showing syphilis bacilli $\times 1050$. (After Lustgarten.)

employed a solution of chloride of iron to decolomrise the scctions and cover glass preparations; this method has been tested and recommended by Gottstein. In 
this method the sections are stained for 24 hours in fuclisine, washed in watcr, then placed for a few seconds in pure or diluted solution of chloride of iron, washer in alcohol, and then transferred to oil of cloves. The syphilis bacilli remain red or reddish-violet, the tissue and the other bacteria-with the exception of tubercle bacilli-remain unstaincd. Double staining can also be employed, both after this method and after Lustgarten's plan, but it does not add much to the distinctness of the picture.

Doutrelepont and Schütz were able to demonstrate Lustgarten's bacilli by placing thin sections for 24 , to 48 hours in a 1 per cent. watery solution of gentian violet, then for a fer seconds in dilute nitric acid ( 1 to $15)$, and then for about ten minutes in 60 per cent. alcohol; the tissues were afterwards stained in a dilute watery solution of safranin. After this treatment the tissues and nuclei had a bright-red appearance, while the syphilis bacilli were blue.

An investigation which has been recently made for Similar bacilli prurposes of control by Alvarez and Tavel in Cornil's in the smegma. lnboratory, throws doubt on the exclusive applicability of Lustgarten's method of staining to the syphilis bacilli. These authors found bacilli in the smegma of the prepuce and of the vulva, which presented the same characters, as regards staining, reaction, and morphological appearance, as Lustgarten's bacilli. Hence further inrestigations are required to demonstrate the causal conncction. of these bacilli with syphilis, although their distribution in the tissues is decidedly against the idea that they are. only accidental.

\section{Rhinoscteroma.}

In this disease, which has bcen observed in Austria, Bacilli of Italy, and Central America, and which is characterised shino-
lyy thiclicning of the skin and mucous membranc of the region of the nose and the formation of nodules, characteristic micro-organisms were first described by Fiscl, 
and later by Pellizari, Chiari, Alvarez, and Cornil.* On examining sections of the affected skin we find a small celled infiltration of the cutis, sclerosis of the small vessels, and a considerible number of large spherical cells, most of them containing several small nuclei ; the protoplasm of these cells contains very large numbers of bacilli, which are also present in the surrounding tissue and in the lymphatic vessels. The bacilli are short rods, 1.5 to $3 \mu$. in length, and 5 to $\cdot 8$ $\mu$. in breadth; their ends are rounded, and in their interior are three or more markedly stained granules. In order to render the bacilli visible, the sections are best. stained in methyl violet for 24 or 48 hours, and then placed in iodine water. If we employ a strong violet solution, and leave the specimens in it for 48 hours, and then decolourise for 48 hours in absolute alcohol, we often see that each bacillus is surrounded by an oval resistant capsule of a light bluish violet colour. Cultivations, and attempts at inoculation with these bacilli, have been, as yet, without result. For further details, see Cornil and Babès "Les bacteries.".

\section{Malaria.}

(Fièrre intermittente, Paludisme.)

For a long time it has been supposed that malaria is caused by an organised virus, and that it might be possible to obtain this virus by cultivation on artificial substratu. From the mode of spread of malaria it is evident that this disease is not contagious in the ordinnry sense, and does not require the presence of a person suffering from the disease for direct or indirect transmission; on the contrary, it seems to be chiefly connected with a certrin constitution of the local surroundings of man, and is not dangerous to man in other places. Hence we may issume that, in the case of malaria, we have not to do with a true parasite, which can only develop with difficulty, or not at all, outside the human body, but

- Frisch, Wien. medic. Wochenschr., 1882.-Pellizari, Il Rhinoscleromn, Florenz, 1883.-Chiari, Wien. medic. Jahrb., 1882, see ए. 26. 
with an organism which can live, and probably also Influence of multiply under certrin conditions, on the dead nutritive locality on th substrata in our ordinaly surroundings, and which only of the virus of at times takes on a temporary parasitic existence.

As to the substratum which is necessary for the Insufficiont development of the virus of malaria, we have as yet knowledge of rery few facts which are trustworthy or of use in disposition. connection with artificial cultivation experiments. As a rule in former times it was thought that a warm, very moist, or marshy soil, containing a large amount of organic, and more especially regetable materials, was a source of permanent danger in any particular region. As the result of the careful inrestigations of TommasiCrudeli, nuade within the last few years, which have shown that endemics of malaria may occur also in highlying and by no means marshy districts, and also in regions which liave been rendered dryer by planting eucalyptus trees, it is evilent that the amount of moisture of the soil which is necessary for the development of malaria is very much less than was formerly supposed; the other factors of importance have been so difficult to define inore precisely that we evidently require further elaborate investigations in this direction.

On the other hand, attempts at isolating and cultivating Inoenlability the virus of malaria are the more encouraging because, of malaria. as the result of recent experiments, the possibility of the existence of a true miasmatic virus has been distinctly disproved; because, therefore, we do not liave to do with an unorganised something not capable of multiplication but produced by a particular soil. Cuboni, Marchiafara, Dochmann, and quite recently Gerliardt; lave demonstrated that malaria is inoculable from mam to man. Gerhardt was alle to set up a distinct quotidian ague with temperatures up to $41 \cdot 1^{\circ} \mathrm{C}$. in two healthy men who had been under obserration for a long time, and in a locality quite free from malaria, by inoculating them with blood taken during the attack from patients suffering from malaria.

As the result of the assumption, justified by these 
Attcmpts to recognisc and isolate the virus of malaria.

Inlebs" bacilli. much influenced by preconceived ideas. Thus Klebs and Tommasi-Crudeli found bacilli in the marshy ground in a malarial region, and described these organisms as "malaria bacilli"; "rods 2 to $7 \mu$. in length, which grow and form convoluted threads; these either become segmented by the appearance of clear intervals in their protoplasm, more seldom by distinct divisious, and then ultimately form, when exposed to the air, bundles of threads composed of short segments, or they develop resting spores in their interior either before or only after fission lias commenced. In the rods these spores appear either at the centre, or at one end, or they may be both central and terminal." These bacilli were cultivated in isinglass jelly, in solutions of egg-albumen, in urine, \&c.; they only grew in the presence of the air, and when they were inoculated on rabbits they set up a febrile affcction which Klebs looked on as malaria. The statement with regard to their morphological characters, the results of the cultivations and the characters of the disease produced in animals do not, however, furnish any sort of guarantee that Klebs was dealing with pure cultivatious of specific bacilli, and not with other infective organisms of the

Bacilli in the blood of patients suffering from malaria. soil. Shortly after this communication as to malaria bacilli, Cuboni and Marchiafava announced that they had found in the blood of patients suffering from malaria, and at the period of commencement of the ferer, mobile, short bacilli, usually containing spores at each end, and on the whole corresponding with the bacilli obtained by Klebs from the soil. Cuboni and Marchiafava, howerer, also demonstrated the same bacilli in the blood of persous not suffering from malaria, although in smaller numbers. Then followed observations by Zichl, who found bacilli in the blood of three patients suffering from malaria, the organisms being hammer-shaped, $4 \mu$. in lengtl, and $7 \mu$. in breadth, and with spontaneous morement; the author looked on these as identical with the rods 
described by Klebs; he found them both during the paroxysms, and also in the afobrile period. Ziell examined the blood of 25 patients suffering from other discases without finding these bacilli; they were, howercr, obtained in the case of a patient suffering from diabetes.

About the same time Laveran stated that he had Laveran's found in the blood of patients suffering from malaria, of thination micro-organisms of a totally different appearance. According to him these organisms belong to the class of protozoa, and in the fully developed state they form transparent spheres of the size of red blood corpuscles, and shoot out fine mobile filaments; dark red pigment granules, in active movement, are enclosed in the interior of the spheres. Richard has confirmed these observations, which, however, were made without the aid of the microscopical means now employed.

Finally, in the year 1883, Marchiafava and Celli Marchiafura's observed in the blood of malarial patients, taken during and Celli's the period of fever, dried in a thin layer on the cover of blood. glass, and then stained with methylene blue, peculiar alterations of the red blood dises. Bluish stained bodies of various size and form wore present in a greater or less number of the blood corpuscles; at first these bodies resemble micrococi stained of an intense blue colour, and in addition to these there are larger round or oval bodies, in the interior of which are granules, or masses of black pigment. At times the whole bloor corpuscle is converted into a faintly blue stained round mass, which is filled with small clumps of pigment. On cxamining the fresh blood, without any addition to it, the larger bodies appear as colourless patches in the. red blood dises; these patches usually contain pigment granules, and gradnally increase in size, till nltimately the whole red blood corpuscle is composed of a colourless substance cnclosing a large number of pigmcut granules.

Von Sehlen confirmed these observations, funding in blood taken from malarinl patients during the febrile stage, and prepared with all ordinary precautions, 
round granules staining with methylene blue, 5 to $1 \mu$. in size, partly cnclosed in the red blood corpuseles, partly lying free between them; in addition to these granules, there were ring-shaped bodies of almost clouble the size. When this blood was inoculated on nutrient agar, he obtained a pure cultivation of a species of micrococcus, growing in the form of a white gelatinous mass; in addition, in one case he obtained yellowish growths of micrococci. No positive results were obtained by experiments on animals with either of these species; these experiments have, however, only as yet been made on rats, and are not concluded. The method employed by Von Sehlen for making the cultivittions affords no guarantee of the exclusion of accidental micro-organisms. Examinations of soil and air male loy Von Sehlen in malarial regions and in regions free from malaria led, in both cases, chiefly to the isolation of two species of bacilli and cocci, the latter of which grew in a similar manner to those cultivated from blood. and were likewise without any marked action on the animals experimented on.

Criticism of the investiga. tions which have been made up to the present time.
A consideration of these various facts leads us to t'ie conclusion that the cultivation experiments have not as yet yielded any trustworthy results as to the organisms which take part in the malarial infection. The observations as to the presence of large bacilli in the blood of patients suffering from malaria are undorbtedly erroneous, as shown by the control investigations which have been subsequently made. We cannot at once sily the same as regards the results obtained by Laverau, hy Marchiafara and Celli, and by Ton Sehlen, which agree with regard to the constant occurrence of peculiar bodies in the interior of the red blood corpuscles; we can only say that Laveran evidently obtained a number of forms, as the result of errors in preparation, and mistook these forms, as well as the altered blood corpuscles, for stages of the development of a micro-organism. As the result of the investigations made by Marchiafara aud Celli, the alteration of the red corpuscles secms to be, to some extent, a constant occurrence in malaria; it is, 
lowever, as yet doubtful whether the granules and bodies observed are to be looked on as parasitic forms, or only as secondary products of the breaking up of blood corpuscles arising under the influence of microorganisms as jet unkmown.

This last assumption, which is nevertheless equally justified, would open up the prospect that we must search for the true infective agents of malaria with other technical means than have as yet been tried; and it is probably advantageous to remember that these agents may not necessarily belong to the class of fission fungi, but to some other class of micro-organisms.

Iu the case of yellow fever Babès demonstrated in two cases short rods, similar to the typhoid bacilli, with. large spores, nsually at one end, and present in the nucous membrane of the small intestine. As regards the presence of cocci in this disease, see page 203.

In the case of whooping congh, Letzerich (Virchow's Archic, 1874) looks on the infective agents as cocci, and Burger (Berl. lilin. Woch., 1883) as short rods often constricted in the middle, and present in the sputum of the patient; nevertheless there is no sufficient support for either of these views.

In some cases of lichen ruber, Lassar observed, on staining with fuchsine, the tissue at the same time being stained brown, distinct and extremely fine bacilli, which are aggregated in thick masses, and can only be recognised as individual rods under very high powers. They lie chiefly in the lymphatic channels of the affecter I'trts in the form of tube-like masscs.

In the case of xerosis conjunctice, Leber, Kuschbert and Neisser, and Schleich found micro-organisms. Leber describes them as short rods, often resembling cocci, which grow readily on untrient gelatine, and when inoculated in large numbers on the conjunctiva of rabbits (the ejes of the animals being kept closed for forty-eight hours by means of superficial sutures) led to 
necrosis of the epitholium of the cornca, and to suppurative inflammation of the cornea. According to Kuschbert and Neisser, the bacilli are about as long as those of mouse septicremia, and are of rarying breadth, according as the sheath which surrounds the bacillus like a capsule is stained or unstained. If a small portion of the deposit on the surface of the conjunctiva is stroked over the surface of blood serum jelly, dry, fatty whitish strealss grow, at the temperatmre of $37^{\circ} \mathrm{C}$., these streaks consisting of bacilli similnr to those found on the conjunctiva. Neisser observed the production of spores, forming small spherical swellings at each end of the bacillus. At times the terminal joints break up into broad plates, or become swollen like a pear (formatiou of involution forms). Experiments on animsls with the cultirations gave entirely negative results. As, however, the methods of cultivation employed were not derised with sufficient care to exclude accidental bacterin, which were so apt to be present on account of the exposed seat of the clisease, the question as to the significance of the bacteria, which have as yet been found, for the etiology of rerosis cannot be regarded as completely settled.

In the case of caries of the teeth, which is probably due to the action of one or several species of specific bacteria, different bacilli have been isolated, which, howcver, scem chiefly to play a saproplyytic part, and at the most to prepare the tooth for the occurrence of caries. As regards these organisms, see below.

As regards leptothrix and other bacteria of the mouth, see later. As regards jequirity, see the following chapter. 


\section{B. Bacilli Pathogenic in Anmals.}

The following bacilli have been recognised as the exciting agents of infective diseases, partly in the case of domestic animals, and partly in animals used for experiments :-

\section{Bucillus of Rauschbrand.}

(Bactérie du Charbon symptomatique.)

In the case of Rauschbrand of cattle, Bollinger and Feser, and later Arloing, Cornevin, and Thomas, have found large rods, resembling anthrax bacilli, but nevertheless distinctly different, and have come to the conclusion that they are the exciting agents of the disease. This clisease, which chiefly attaclis young cattle, a half symptoms of to four years old, and lambs, and which often runs Rauschbrand. through herds in the form of rery fatal endemics, begins with loss of appetite, followed chiefly by the formation of an irregular swelling in the skin at some part or other of the body; this swelling rapidly increases in size, and distinct crepitation can be felt at its centre. Death occurs 36 to 48 hour's after the commencement of the symptoms, the temperature rising at first and then sinking to an abnormal degree. On making a Post-mortem post-mortem exumination we find, at the sent of the appearances. swelling in the subcutaneous cellular tissue a collection of gas, which chicfly consists of a mixture of cabornic acid and methane; the muscles and cellular tissue are soaked with a large quantity of sero-sanguincous fluid, and the surface of the muscles are of a black colour; the Jymphatic glands in the neighbourlood of the part affected are markedly hyperæmic. In the intcrnal organs there aro no characteristic or constant alterations. In the serous fluid between the fibrillic of the muscle, and in the subcutaneous collular tissue there are large numbers of bacilli; these may also be found in cover glass preparations made from the liver and splecn, and in the blood vessols and capillaries, though this is rare, and they arc only found in these situations in 
considerable numbers when the post-mortem examination is not made immediately after deatl. Inoculation with the organs or the serous fluid from the tumours causes the same or similar phenomena and a fatal result, in calves, sheep, goats, rabbits, and guineapigs; borses, asses, and white rats are but little 00 o 0 susceptible; swine, dogs, cats, ordinary 000 rats, and fowls are completely immune. Fig. 84.-Rausch- cutaneous injection of the serous fluid brand bacilli, at causes an extensive œdema of the sub-
$a$ spore bearing. cutaneous tissue; the animal dies after two or three days, and then it is found that the subcutaneous tissue is infiltrated with a large amount of sero-sanguineous fluid, and that the muscles are discoloured. If too small a quantity is injected, only a local tumour is formed in the animal inoculated, and this tumour heals and leaves the animal immune against larger doses.

Morphological The bacilli are 3 to $5 \mu$. in length, 5 to $6 \mu$. in characters of the bacilli.

breadth, with distinct spontaneous movement, and thus at once distingnished from the anthrax bacilli. They often show at one cnd a round swelling, so that their form resembles that of the clapper of a bell, and in this swelling an oval refracting spore, exceeding the rod in diameter, is gradually formed.

unltivations. Arloing, Cornevin, and Thomas were able to cultirate the bacilli, but only by the exclusion of oxygen. The organisms grow best in fowl-brotll, to which a littlc glycerine and sulplate of iron have becn added, the ressels employed being exhausted of air, or filled with carbonic acid. In cultivations in other mutrient media the virulence of the organisms diminishes very rapidly.

Artificial

The same observer's were also able to obtain an artificial intcnuation of attenuation of the rauschbrand bacilli by another method, brand bacilli, and protective inoculation.

and on inoculation of these attenuated bacilli they were able to produce immunity of the animals against the virulent bacilli. They found in the first place that locil affections, which left immunity behind, arose after subcutaneous inoculation of small quantities of the serous 
cedematous fluid containing the bacilli ; that immunity, however, was obtained witl still greater certainty when small quantities of the cdematous fluid (in the case of cattle, 3 to 5 drops) were injected into the veins, witl such precautions that none of the material passed into the subcutanoous tissue. At a later period another method proved to be more trustworthy and more practicable : the virulent colematous fluid was dricd quickly at $32^{\circ}$ to $35^{\circ} \mathrm{C}$.; the dried mass was rubbed up with water and heated to $100^{\circ} \mathrm{C}$., and this formed the first vaccine material; another portion heated to $85^{\circ} \mathrm{C}$. formed the second raccine. The dry vaccine, which call be sent where required, is rubbed up before use with 100 parts of water, filtered, and injected to the amount of 1 c.c. m. into the animals; the second raccine, which is less attennated, is injected from 9 to 14 days later than the first. The inoculation is made in the case of cattle at the tail, and in the case of sheep on the inner surface of the thigh. The animals so inoculated ought to be completely immune against artificial and natural infection with virulent rauschbrand bacilli. The accuracy of these statements has been confirmed by numerous experiments, and it is probable that the protective inoculation against rauschbrand may be practically and advantageously employed. Thus Strebel states that in the course of 1884 , in 7 cantons in Switzerland 2,200 cattle were vaccinated, of which only a few developed a local tumour, from which they recovered, and of which a much smaller percentage died of rauschbrand acquired in the natural manner tha:1 was the case with uninoculated cattle kept under the same conditions. The experiments which have been made with other protective inoculations seem, however, to indicate that we must maintain a certain reserve with regard to the first farourable reports of the results of rauschbrand inoculations.

Rauschbrand and the bacilli which cause it show great Differenoes resemblance with malignant cedema and its cause. botween these However, the chlema bacilli, as a rule, for cause. bacilli and threads, while the rauschbrand bacilli are, form longer thoso of form of isolated 
and epidemic oceurrence of rauschbrand we must assume that the distribution of the infoctive agents is different to that of the odema bacilli, which occur everywhere in our surroundings. Kitt has also observed that while rauschibrand is always fatal after inoculation, a calf inoculated with malignant œedema became very ill, but recovered. It is probible that cultivations on solid nutricnt substrata may show marked differences between the two organisms; but as yet we know nothing trustworthy with regard to the mode of growth of the colonies of the rauschbrand bacilli.

Neclsen and Ehlcr's found that the rauschbrand organisms formed in the animal body only bacilli and spores, but that, on the other hand, on enltivation on blood serum cocci derelopecl. 'They statcd also that on other nutrient substrata the cultiration of the bacilli taken from the affected animal did not in the first placc succecd, but that after they had become aceustomed to life outside the body by cultivation on blood scrum they then grew on nutrient jelly, \&c. These statements, which are opposed to the results obtained by all other authors, and which are quitc unlikely, arc probably due to errors in the methods employed.

\section{Bacilli of swine erysipelas.}

(Ronget du porc, Mal rouge, Hog choler, Pig typhoid.)

Within the last few years various investigators have directed their attention to the erysipelas which occurs cpidemically among swine, and which leads to great loss of life; and as the result of the investigations of Thuillier, Pastcur, Looffler, Schütz, Lydtin, and Schottelius, the cxciting agent of this disease has been discorered in the animals affected; it has been cultivated on artificial nntrient substrata, and the original disease has been agrin produced by inoculation of the cultivations on animals, and thus the chain of evidence nocessaly to demonstrate the etiological significance of the infectire agents has been completed.

Symptoms of

The symptoms of swine crysipelas as a rule commence the disease. very suddenly. The swine attacked become suddenly dull, they creep about, and cease to eat; the roice 
becomes hoarse, and there is often evacuation of blood and slimy freces. The temperature (which in normal young swine is between $39^{\circ}$ and $39.5^{\circ}$ C.) rises at times is high as $43^{\circ} \mathrm{C}$. Sometimes, eren in the commencement, but usually not till the height of the disease, red patches appear at the lower surface of the belly, breast, and neck, which gradually extend and run together and ultimately assume a dark red or brown colour; swelling of the reddened portions of slin is not noticed, nor does there scem to be pain, nor is the temperature of the part apparently above that of the surrounding skin. Death occurs with increase of the listlessness, at times with paralytic symptoms of the hinder extremitios, at times with convulsions. The duration of the disease, from its first appearance until death, varies from a few hours to four days. Wherc it ends in recorcry, 6 to 20 days pass before the animal is quitc well. Fifty-five to sixty-six per cent. of the animals attacked die; of those which survive the acute attack a considerable number ultimately die of chronic wasting. Older animals are nerer attacked, those which are affected are aged from thrce months up to at most three jears. Different races show great differences in their susccptibility; the ordinary swine arc almost withont exception insusceptible, while the more noble races-more especially the English Suffolk swine-show a very great susceptibility to the discase.

According to the observations of veterinary surgcons Mode of the infection occurs almost entirely from the digestive track, the freces of the diseased animal getting into the foclder, or infected mice being eaten. At Lydtin's suggestion it was on sercral occasions shown cxperimentally, during the inquiry as to the causes and the mode of protection from swino erysipelas, in the Duchy of Baden in April, 1885, that swine can be infected by cating the intestines of other animals which have died of swine erysipclas. In somo of the experiments which gave negative results, the above mentioned insusceptibility of certain races scems to haro come into play. In some cases also infection was caused by subcutaneous injection. According to the most trustworthy 
reterinary reports, the disease never recurs a second time.

Post-mortem On making a post-mortem examination of the swine appcarances. that die, the slin at the reddened parts is found to be infiltrated with odematous and bloody fluid; the muscular tissue is soft, and of a greasy pale red appearance ; the lymphatic glands, especially the glands of the mesentery, are swollen, of a dark-red colour, and show on the cut surfuce punctiform hæmorrhages. The peritoneum is of a dirty-red colour, or covered with ecchymoses; the same is the case with the serous membrane of the small intestine. The mucous membrane of the small intestine is much reddened and swollen, and the summits of the folds are deprived of their epithelium and covered with blood; the solitary follicles and Peyer's patches are very prominent, and here and there, especially in the neighbourhood of the ileo-crcal valve, their place is taken by ulcers of considerable size. Liver and spleen are moderately enlarged. The lungs contain air and a large amount of blood. There are small hæmorrhages in the serous layers of the pericardium, and constantly in the epicardium of the auricles of the heart.

Morphological In corer glass preparations of fresh blood, and also in characters of the bacilli. the juice of various organs, in the lymphatic glands, and in the muscles, we find large numbers of delicate bacilli. These resemble most closely the bacilli of Koch's mouse septicxmia, but they are somewhat larger and

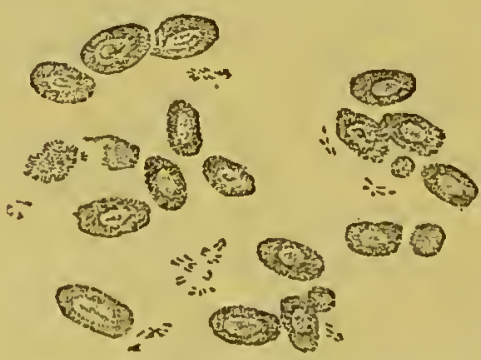

Fir. 85.-Pigeon blood contrining tho baoilli of swino erysipelas $\times 600$. (After Shütz.) thicker ( 6 to $1: 8 \mu$. in length), and they also resemble the latter in that they lie partly between the blood corpuscles, either singly or in pairs or groups of four, and partly in the swollen white colpuscles, leading evidently to degeneration of these cells. The bacilli stain well with the ordinary colouring materials; they also retain their colour on treatment by Gram's metlod. In sections the 
bacilli are found in largest numbers in the capillaries, especially of the spleen and kidneys; the walls of the capillaries are for the most part thickly covered with bacilli, while the ltimen remains more or less free. The most beautiful preparations are obtained by means of Gram's method, or by double strining, in the first place witl gentian riolet, which colours the bacilli violet, and afterwards with picrocarmine, which gires the tissue a r'osy-red hue.

These bacilli grow readily in alkaline meat juice, in Cultirations. blood serum, and in the ordinary nutrient jelly between $18^{\circ}$ and $40^{\circ} \mathrm{C}$; their growth is extremely like that of the bacilli of mouse septicæmia. On plate cultivations small round patches appear after two or three days, which have a cloud-like character, and are of a bluishgrey colour; these patches gradually increase in size, and under a low power of the microscope present the appearance of finely branching bundles of threads, not at all unlike the lacune and canaliculi of bone. The surface of the gelatine remains smooth, and the growth of the colonies only occurs in the deeper layers. A puncture cultivation in jelly shows, after three or four days, bluish-grey cloudy bundles, projecting into the gelatine on all sides at right angles to the line of inoculation, so that the cultivation resembles a glassbrush, such as is usually employed for cleaning test tubes. This cloudy appearance remains more or less limited to the neighbourhood of the line of inoculation, and is not so delicate as in the cultivations of the bacilli of mouse septicrmia. Growth does not occul on the surface. In meat infusion these organisms cause slight opacity of the fluid, and, at a later period, it whitish-grey deposit at the bottom of the ressel, which on very slight morement of the vessel rises in the for'm of very fine cloucls. There is never any scum formed at
the surface.

In the cultivations the bacilli occur singly or united Mobility of together in threads of various lengths. According to the bacilli. Schottelius the shorter bacilli show distinct, although not very actire, spontaneous morement; other observers 

Spore forma- have, lowever, failed to observe any movement. In
tion. cultivations in meat infusion which bave stood for three days at the temperature of the room, or for 24 hours at

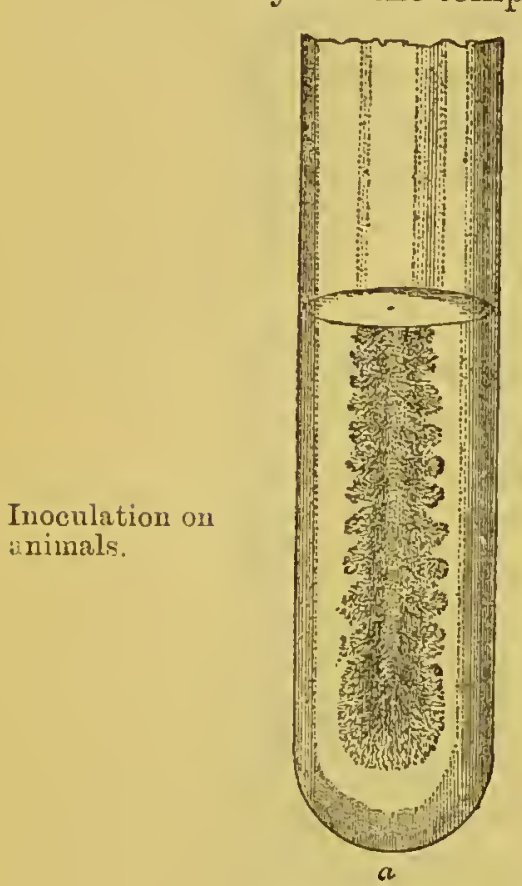

Fig. $86 \mathrm{~A}$-Cultivation of the bacilli of swine erysipelas in gelatine. $a$, puncture cultivation. $b$, colony on a plate $\times 80$. forms, \&c., appear. $40^{\circ}$ C., we can observe the formation of small spheres which probably represent spores, although, on account of the minute size of the object, no accurate observations have as yet been made as to the formation and sprouting of these bodies. In old cultivations the ordinary involution forms, such as club-shaped swellings of the threads, drum-stick

These cultivations, after being carried for a series of generations through

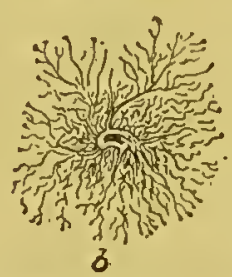
gelatine or meat infusion kill with great certainty the ordinary house mice in the course of two to four days, and on examination numerous fine bacilli are found in the blood and in the capil-

laries of all the organs. Pigeons are very susceptible, and die within three or four days. Rabbits are less susceptible; after inoculation on the ear of a rabbit an crysipclatous inflammation occurs in the first instance, just as after inoculation with the bacilli of mouse septicxmia. As a rule general infection follows and causes death in five to six days, nevertheless not uncommonly complete recovery takes place. Sheep, and pcrhaps also young cattle, are susceptible; on the other hand guineapigs and fowls are completely immune. The cultivations have also been repeatedly inoculated with success on swine belonging to susceptible races, and at a susceptible age.

Pasteur's protective inoculation.

Swine erysipelas has quite recently excited special interest because Pasteur has recommended a special mode of protective inoculation which has been experi- 
mentally tested in a large number of animals by Lydtin during April, 1885, in the Duchy of Baden.

Pasteur found that the virus of this disease was more virulent for swine when it had passed through the bodies of several pigeons in succession, and had attained the maximum of its virulence in the case of pigeons; that, on the other hand, the danger of the virus as regards swine was markedly diminished when it was inoculated through a series of rabbits. If Pasteur inoculated the erysipelas bacilli into the thoracic muscle of a pigeen, the latter died in from six to eight days, having previously exhibited the external symptoms of chicken cholera. If, now, the blood of the first pigeon was inoculated into a secoud, the blood of the second into a third, and so on, the latter animals died much more quickly than the first, and the blood of the last pigeon was much more virulent for the swine than was the most poisonous product from a swine which had died of spontaneous erysipelas. On the other hand, by reinoculation from rabbit to rabbit, an increase of the rirulence of the virus in these animals was observed, and ultimately the animals died without exception, and more quickly than after the first inoculation. If now Pasteur inoculated the bacilli thus acclimatised in rabbits. on swine the latter became ill, but did not die, and were protected, after recovery, against the most virulent erysipelas poison. (Pasteur always speaks in his paper's of a round microbe, which, when taken from the blood of rabbits, was larger than in swine, and which had the form of the figure 8.)

Acting on these principles Pasteur has prepared two Control cx. vaccines with which young swine-the age is from periments 8 to 11 weeks-are inoculated by subcutaneous injection waceine. on the inner surface of the thigh at an interval of twelve days. By this means an immunity is obtained which lasts about a jear-in other words, is sufficient to enable the animal to pass through the period of life when it is most liable to the erysipelas infection. These vaccines have been recently examined bacteriologically by Schütz and Schottelius, and their action on 
animals lias also been tested. Besides some indifferent bacteria mixed with them, both anthors found clicefly the characteristic erysipelas bacilli, and they were able to convince themselves by experiments that these organisms were as a matter of fact attenuated as regards the virulence of their action on swine; in like manner they were able to ascertain that the pigs inoculated with these vaccines, and which, after being ill, had again recovered, were immune against inoculation with virulent material. Thus the accuracy of Pasteur's experiments, and the possibility of attenuation and protectire inoculation for swine ergsipelas, is proved. This result was i priori not improbable, as Loeffler had formerly shown that the bacilli of mouse septicæmia, which so much resemble the erysipclas bacillus, cause a mild disease iu rabbits, as the result of which these animals are rendered completely immune; and as also it was known that swine erysipclas belongs to the class of diseases which do not recur, one attack protecting agrinst a later infection.

Practical value of the protective inoculation.
Nevertheless the result of the vaccination experiments carried out in large numbers in Baden cannot be regarded as being particularly farourable from a practical and economic standpoint. Of 119 animals inoculated, 6 , or 5 per cent., died of erysipelas as the result of the inoculation, while the average loss from the ordinary disease is at most only 2 per cent. ; howerer, the animals which died as the result of inoculation were, on account of their jouth, of much less ralue than the animals which died of erysipclas. It was also ascertained that the animals which were rendered ill by the inoculation were able to infect other animals with the fatal disense; and, finally, we do not as yet linow whether the inoculated swine are protected against the natural infection. From these considerations it is evident that the fiwal judgment as to the practical ralue of Pasteur's proteclive inoculation must be deferred till mere accurate experimental evidonce has been obtrined.

Klein has claimed the discorery of the erysipelas bacillus. but from his statements that these bacilli may be confomed 
with bacterium termo, that the transverse diameter of the erysipelas baeilli is the same as that of the hay and anthrax bacilli, further that a superficial seum, as well as a deposit at the bottom is formed in the fluid cultirations, and, finally, that the baeilli taken from the eultivations move as actively as bacteriun termo, wo may with ecrtainty assume that Klein lias not recognised the true crysipelas baeilli, and, at most, lats dealt with them in impure cultivations.

Pasteur also has at first probably not recognised the true infective agents, and has evidently worked with impure cultivations; and it is a matter of surprise that, nevertheless, lie has obtained these interesting results with regard to protective inoculation, now confirmed on all sides. Baillet and Jolyet (Revue Veter., 1884) also describe the erysipelas organisms incorrectly as mierobes of the form of the figure of 8 , at times arranged in chains, and-in opposition to all ot her obscrvations-virulent in guinea-pigs.

Locffler in a case of a pig, which had died of so-ealled swine erysipelas, but in which the discase was evidently different from the epidomic form, found other baeteria which carused in guinen-pigs sero-sanguincous infiltration of the subcutancous tissue and hrmorrhagie affections of the muscles. F'urther facts as to this diseovery will be mentioned lator.

Of special interest is the observation made by Schottelius, A second that in almost all cultivations made from animals whieh liad speeics of clied of this disease, the cultures being made in some eases bacilli in the a rery short time after death (within 20 minutes), other larger cultivations. bacilli also grew which formed light yellow spherical eolonies in the gelatine. This bacillus, which is described in detail below, breaks up the gelatine with the formation of a foul smoll, and is thus evidently one of the cxeiting agents of putrcfaction, and probably comes from the intestine, in the contents of which Schottelius was also able to demonstrate it. Henee it is probable that these bacilli are able to penetrate Entranee of into the body eren before the death of the animal, entering these bacilli through those parts of the intestinal mucous membrune through the which are denuded of epithclium and uleerated; this vicw is injestine directly supported by the observation that these bacilli are present in largest numbers in the orgaus in the neighbourhood of the intestine (not only in the intestinal wall itself, but in the mesenterie glands, and in the spleen), while, on the other hand, they gradually diminish in numbers in the organs further away from the intestine, and thus only oeeur rarely in the lungs and the musenlar tissue of the henrt. This disonvery enalles us to draw important eonelusions with regard to the cntranee of fungi secondarily in other diseases aeeonl. panied with injury of the intestinal epithelium. 


\section{Bacilíu; murisepticus (Koch).}

(Bacillus of Mouse Septicremia.)

Bicillus of mouse septicremia.

These organisms, first discovered by Koch, and rery closely resembling the bacilli of swine erysipelas, occur not uncommonly in all sorts of mixtures of bacteria. If small portions of putrefying fluids, which have been exposed to the entrance of all kinds of bacteria, are taken during the early stage of putrefaction and inoculated subcutaneously into, say, twenty mice, one or other of these animals generally dies of a septicæmia which is caused by the bacilli of which we are speaking.

The early symptoms of the disease are increased secretion from the conjunctiva and adhesion of the eyelids, lassitude, \&c. ; the animal sits quietly with the back arched, and death occurs in this position 40 to 60 hours after the inoculation, coming on almost imperceptibly and without any convulsive movement. Even after death the mouse generally remains in this position, while the mouse which has died of anthrax, for example, lies on its back or its side with its extremities stretched out. On making a post-mortem examination slight œdema is sometimes found at the seat of inoculation, and there is also considerable swelling of the spleen, but no further alterations. Delicate bacilli are present in the neighbourhood of the seat of inoculation, in all the blood ressels of the body, in the blood of the heart, and more especially in the capillaries of the kidneys and spleen.

Morphological charncters.

These bacilli are 8 to $1 \cdot \mu$. in length, and about $\cdot 2 \mu$. in thickness. They often occur in pairs or in fours, forming short threads ; they frequently form small groups; they have no spontaneous morement. They can be rendered distinctly visible by trentment with the aniline colours, which they readily take up ; corer-glass preparations of blood are best stained in alkaline methylene blue, and then decolourised by momentary immersion in rery dilute acetic acid; Gram's metlod also gives very distinct pictures. For sections the method 
of double staining used for demonstrating the bacilli of swine erysipelas can be employed.

In the preparations from the blood of the lieart the bicilli slow a very characteristic arrangement: they lie in part in the interior of the white blood corpuscles. When this is the case the latter are generally much swollen; in some of the cells the protoplasm takes on the stain only very feebly, and the outlines are indistinct; in other cases the whole body of the cell consists solely of thickly aggregated bacilli, which here and there project from the surface of the disintegrating cell mass. By examination of the various stages which can usually be recognised in the same specimen we obtain the impression that the cells are destroyed by the bacilli in their interior, and not that the bacilli undergo destruction in the cells.
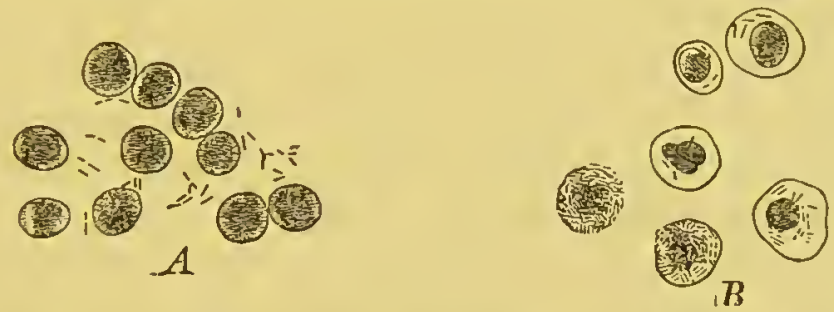

Fig. 87.-Bacilli of mousc septicæmia (after Koch) $\times 700$. $A$, blood of a septicæmic mouse, red corpuscles with bacilli between them.

$B$, white corpuscles containing bacilli.

The bacilli can be readily cultivated, and grow on the Cultirations. various nutrient substrata exactly in the same manner as the bacilli of swine erysipelas (except with the slight differences mentioned above). On gelatine plates they form bluish-grey cloudy flakes lying underneath the surface, which are resolved, under a low power of the nicroscope, into a network of delicate threads; in jelly puncture cultivations a very delicate bluish-grey cloud forms around the track of the needle, and this cloud gradually extends outwards from the line of puncture till it almost reaches the wall of the vessel (fig. 86).

'T'le minutest trace of blood containing bacilli or" of a Inoculation on cnltivation is suflicient to set up the disease in mice. Fireld mice and guinea-pigs are completely immune; 
sparrows and pigcons are, on the other hand, susceptible. Riabbits sometimes, but not always, die after inoculation; often they only show a local reaction, such as an erysipelatous formation on the ear, which can be traced over the ear to the parts beyond; after inoculation on the cornea an intense inflammatory process occurs in the eye. Loeffler has made out that rabbits which have ouce recovered from this inoculation on the ear, or on the colnea, are completely immune against any now attempt to introduce the bacilli, however large the dose employed.

Bucillus cuniculicida (Koch).

(Koch's Rabbit Septicæmia.)

B:teteria of r:ubit septicumia.
Slicroscopical rharacters.

Howth on plutes.
'This septicrmia was obtained by Koch* by inoculation of rabbits with impure river water (the water of the Panlic), and on another occasion with flesh that wis undergoing putrefaction. Numerous other attempts to obtain the same morbid agents from putrefying materials were unsuccessful, so that the distribution of this organism seems to be limited, both as regards place and time.

These organisms present the form of short rods somewhat pointed at their ends; whon stained the ends take up the dye, while the central portion of the rod remains mnstained; there is no constriction in the middle, but the peculiar distribution of the colouring matter readily leads to the erroneous idea that the organism consists of two micrococci lying side by side. They do not stain by Gram's method. Their length is $1: 4 \mu$ and their breadth 6 to $\cdot 7 \mu$. Two and more bacteria often remain uniter after division, and thus form apparently longish rods; under these circumstances they frequently prescnt the form of a figure of 8 , and are surrounded by a somewhat clear area. Spontineous movement has not been observed.

The bacilli grow readily in brotl, in blood serum, ant on nutriont jelly. On gelatine plates small white points

* Mittheil. a. d. Kais. Ges. A., vol. i., p. 9.1, ff. 
appear on the third day, and these under a low power present the form of circular dises, with a sharp, dark ontline not quite regular, and of a yellow colour, lighter towards the periphery. At a somewhat later stage the dark yellowish brown central zone and the clearer peripheral zoue are often sharply marked off from each other, so that the colony appear's to consist of concentric layers. When it spreads at the surface, which only occur's to a rery slight extent, and does not cxtend further than a millimetre, the outline remains sharp, dark,

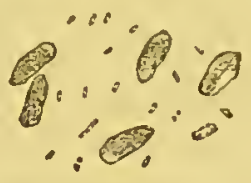

Fig. 88.-Baccillus of rabbit septicamia (after Koch) $\times 700$.

Blood of a sparrow showing the nuclci of the red blood corpuscles with numerous bactcria betwecn them. and for the most part fairly cireular, though often somewhat irregular. The colony presents a finely granular appearance at this stage. In the puncture In mucture cultivations a thin deposit forms along the line of cultivations. puncture, and this deposit does not become confluent in many places, but presents the appenrance of discrete spherical colonies of a somewhat transparent yellowish white colour. On the surface it spreads in the form of a flat and limited layer ; in strolie cultivations it forms a thin layer somervlat thickened at the borders, which are irregular and serrated; here and there the line is interrupted by isolated colonies. The cultivations only retain their vitality for 4 or 5 weeks.

If the minutest portion of a cultivation is inoculated Inoculation on into a rabbit (a prick in the cornea suffices) the body temperature becomes clevated after an incubation period of 10 to 12 hours, and the breathing becomes slow and Jilboured; ultimately the temperature falls below the normal, and after the occurrence of some convulsive attacks the animal dies 16 to 20 hours after the inoculntion. On post-mortem examination, the spleen and fymphatic glands aro found enlarged, and the lungs present a strikingly marbled appearnnce; there are $n 0$ extravasations of blood, and 170 peritonitis. The characteristic rods are equally distributed everywhere thronghont the blood; on sections of the various organs they 
are found in the blood resscls and eapillaries; the best appearances arc obtained from sections of lung, stained with gentian violet. Mice and birds (sparrows, pigeons, fowls) are as susceptible as rabbits; guinea-pigs and white rats are immune; dogs do not react on inoculation of small quantitics, but after subcutaneous injection of larger amounts an extensive codcma of the subcutaneous cellular tissue occurs, and the animals dic after two or three days. No experiments have as yct been made as to the attenuation of these bacilli; in successive cultivations even continued for a long time they retain their fu!l rirulence.

\section{Bacillus cholera gallinarum.}

(Bacteria of Chicken Cholera, or Fowl Typhoid;

Microbe du Cholera des Poules.)

Chicken cholera.

Clinieal symptoms.

In the epidemic disease which occurs in poultry yards, and which has been known and dreaded for a long time in France under the title of chicken cholera (although the symptoms show rery little resemblance to those of human cholera), bacilli were found in the first instrnce by Perroncito, then by Toussaint, and later by Pasteur, and these have proved to be the causal exciting agents of the disease. These observations bare been confirmed and cxtended by Rirolta, Marchiafara and Celli, and Kitt. Petri has also found bacteria in an epidemic in a poultry rard, which are probably identical with the bacilli of chicken cholera.

The discase begins by the fowls attacked becoming rery lielpless and tumbling about, the wings havg, and ultimately the animal sits quietly rolled up in a ball. with erected featlers. The animals are very somnolent; if they are compelled to open their eres they uppear as if they had aralied from a deep sleep: they soon close the cyelids again, and usually after a slight convulsive attack, die without having mored from the spot. Very frequently at the lieight of the disease there is a slimy diarthon, the stools 
containing very numarous bacilli. The whole course of the disease is o! u very rapid, lasting only a few lours.

On post-mortem examination the spleen and liver are Pust-nortem found to be enlarged, there is also intense inflammation apperisuce: of the intestinal mucous membrane, especially of the duodenum, with numerous hæmorrhages, and at times with ulcerations, hæmorrhagic infiltration in the peritoneum, hrmorrhagic pneumonia, and numerous ecchymoses in the pericardium, in the pleura, and in the brain.

Large numbers of short bacilli, very similar to those Microscopical described before in rabbit septicæmia, but somewhat characters of shorter and thicker, are found in the blood of the heart, and of all the other organs. They have been described by Pasteur as cocci, but when highly magnified there is no doubt as to their rod character. The fully-grown individuals attain a length of about 1 to $1.2 \mu$, and usually show, when stained, an aggregation of the colouring matter at the ends, as in the case of rabbit septicæmia, the dark poles being separated by an unstained central portion. The bacilli are usually in a state of active division, and thus many forms are found which are constricted in the middle, not unlike a diplococcus, and also numerous young individuals in which the length is only very slightly greater than the breadth. We can

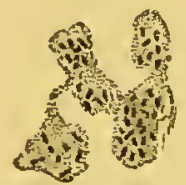

Fig. 89.-Bacilli of chicken cholcra $x$ 800 .

Cover glass preparation from a fresh cultivation.

always see, howerer, with good lenses that even the youngest individuals are not round, but more quadrilateral with parallel contours-in other words, that they are short bacilli. In sections of the organs the rod character is usually much more distinct; they are found there in varying numbers within the blood ressels. sumetimes only a few examples, sometimes in dense masses.

The bacilli of chicken cholera can be readily cul-Growth in tirated. On plates of nutrient gelatine they appear on cultirations. the second day as whitish-yellow points, which are seen 
under a low power to be dises of a yellowish-brown colour with shap outlines, finely granular, seldom circular, but as a rule with irregular boundarics. The centre is of a lightish-yellow colour, towards the periphery therc is a narrow brownish ring, and then a light border. The superficial colonios form small moderately prominent, transparent drops of a yellowish-whito

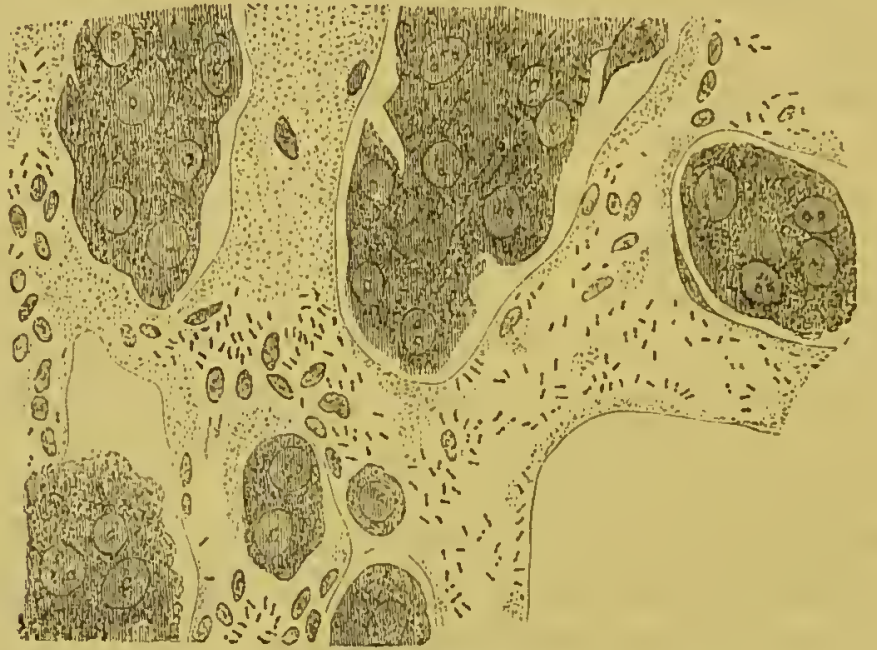

Fig. 90.-Chicken eloolera.

Scction from the liver of $\Omega$ hen $\times 700$.

colour, they show less of a circular form and are distinctly granular; but the zones above mentioned can still be recognised, and have only become correspondingly broader. In puncture cultivations they form partly discrete and partly confluent colonies along the necdle track; on the surface they spread out in a flat layer, which is somowhat more marked than in the case of the bacilli of rabbit septicrmia.-On blood serum the cultivations form a dull, white, thin layer. On potatoes a wax-like transparent greyish-white and only slightly promincht layer is formed, which grows slowly and only at a temperature of about $28^{\circ} \mathrm{C}$. Growth of the bacilli also occurs on hard-boiled white of egor. In nentralised brotl they grow luxuriantly, and cause sliglit turbidity of the fluid.-According to Pastcur they soon lose their vitality in neutralised mine; they do not grow at all in yeast water. 
Subcutancous inoculation of the smallest quantity of Insculation on a cultivation scts up iu healthy fowls the symptoms anim:als. described above, and death occurs in 24 to 36 hours. Pigeons, sparrows, pheasants, micc, and rabbits are likewise very susceptible to the discase; guinea-pirss, shcep, and horses do not as a rule die, but abscesses form at the seat of inoculation, the pus of which contains large numbers of bacilli. Mice, fowls, and rabbits can also be infected by feeding them with the cultivations; dogs remaiu healthy even when fed for a long time with the bacilli. It is probablc that the natural mode of infection iu the poultry yards is that the dejecta of the diseased animals which contain the bacilli contaminate the food, and are then swallowed by the healthy animals.

Pasteur failed to set up a fatal disease in fowls when Filtration of le filtered the cultivations in ncutralised chicken-broth the enitivithrough plaster or porcel:in, but after large doses of the filtrate there occurred in the first place a short period of excitement and then moderate somnolence, which after a few hours ended in recorery. This result is probably to be explained by the presence of toxic products of the bacilli in the filtcred cultivations. Marchiafura and Celli have found that the bacilli of chicken cholera can pass Transference to tile fortur. from the mother to the fotus; such a transference is in many cases à priori probable, because in chicken choler'a hæmorrhages and lesions of the ressels occur in all the organs, and in this way the orcanisms pass out of the blood vessels.

The bacilli of chickon cholera have excited special Attcnuationo interest because Pasteur carried out with them lis first the virulence experiments on attenuation and protective inoculation. and protective Pasteur observed that old cultivations which laad stood for several months in vessels plugged with cotton wool had diminished in their virulcnee, as he concluded, as the result of the influence of oxygen; at any rate this attenuation did not occur when he preserved the cultirations in sealed ressels containing only rery little air. The bacilli when attenuated retaincd the degree of virulence at which they lad arrived, even when further 
cultivations were made in broth, and carried through several generations. If Pasteur inoculated fowls in the subcutaneous cellular tissue over the muscles of the breast with these attenuated bacilli, only an inflammatory swelling of the cellular tissue, especially of the muscle, occurred; the affected portions of the muscle soon became separated from the healthy by an abscess wall, so that a sequestrum of the muscular tissue was formed. This was absorbed with greater or less rapidity, and usually had completely disappeared some weeks after inoculation. The forwls which had thus recovered were then found to be immune against inoculation with the most virulent bacilli.

Diserepunt re sults of other observels.

The results of Pasteur's experiments could not be confirmed by Kitt and others. Cultivations on potatoes and gelatine five or six months old, and alrays exposed to air, showed the same virulence as fresh cultivations. It is possible therefore that Pasteur's cultivations, which were always made in fluids, were gradually overgrown by other bacteria, and that thus the diminution in activity was produced.

\section{Bacillus septicus agrigenus.}

Septic earth

bacilli.

These bacilli were first obtained by Nicolaier in the author's laboratory, and at a later period on sereral occasions from the earth of manured fields. These bacilli agree, as regards their size, for the most part with the two forms before mentioned, but they are usually Micrcscopical somerwhat longer; the same peculiar distribution of the linticters. colouring matter is also at times secn, although not so frequently, nor so well marked. Rapid division occurs in cultivations, and hence, as a rule, there is only a trivial Cultivatione. excess of the longitudinal diameter.-On gelatine plates the colonies present the appearance under a low power of circular dises, with sharp ontlines and of a finely granular charncter; the centre is yellowish-brown, and the margin greyish-yellow, these two parts being separated from each other ly a dark ring. These differences in colour gradually disnppenr at a later period, so that 
ultimately there are no distinct zones to be secn; on the other hand, the granular appearance becomes more marked; the circular ontline for the most part remains. In puncture cultivations a thin and but slightly characteristic layer is formed.-Mice inoculated with small quautities of the cultivations die after 12 to 22 hours, as also to field mice; rabbits die after inoculation on the ear in from 24 to 36 hours. On post-mortem examina- Aotion on tion 110 special abnormalities are found; the bacilli above described are present in the blood of the heart and in the capillaries of all the organs, but always in decidedly smaller numbers than in the two diseases just described. Further, the bacilli show a special tendency to adhere to the blood corpuscles; the border of a blood corpuscle frequently has two, three, or four bacilli attached to it; but the bacteria do not seem to penetrate into the intcrior of the cells.

A number of short, fine bacteria, which are similar to Septic the three species of bacilli just observed by various authors in thescribed, have been sembling the the human sent in the tongue, in the secretions of the mouth, and in the secretion of sputum. In the Hygienic Institute in Gottingen, Kreibohm found two bacteria which were chiefly distinguished from the above mentioned forms by the fact that they could not be cultivated on any of the ordinary artificial substrata.

The first species was obtained on two occasions from First species. the deposit on the tongue by the inoculation of some mice with this deposit; the animals died after a few days, and large numbers of these bacilli were found in the blood. The rods resemble very closely those of rabbit septicæmia, but they are somewhat longer and more pointed at the cnds; they do not show any constriction in the middle, but take up the colouring matter only at the polcs, leaving a clear zone in the middle. In the blood they occur singly or in small groups, seldom in the form of threads composed of two 
Inoculation from animal to auimal.

inilure of cultivation caperiments.

Second sureicz. or three nembers.-The blood containing the bacilii when inoculated on mice in the quantity of about onc drop always produced the same discase in 30 inoculations continued in series: on the first day no alteration coulul be observed in the animals inoculated; on the second day they were lazy, they sat quietly with erected back, and the cyelids were stuck together; death occurred as it rule after two or three days, at times, howerer, not till after five days. On post-mortem examination nothing alonormal was found, except very marked enlargement of the spleen, and slight enlargement of the liver. In sections of the organs small groups of bacteria were found within the capillaries, but they were not particularly numerous; they were only present in rery large numbers in the lungs. Rabbits are relatively but little susceptible; after inoculation with small quantities of blood only a transitory illness resulted; after subcutaneous injection of larger quantities of blood the animals died after two or three days, and the bacilli showed the same distribution as in the case of mice. Field mice were very susceptible; inoculation on a fowl was without lesult. Cultivations were frequently attempted with tho most varied solid and fluid substrata, and at rarions temperatures; nevertheless they all failed, while control experiments with the bacteria of rabbit septiciemia were, without exception, successful.

'The second species was isolated in a similar manner by the animal body (mice) from a deposit on the human tongue. These organisms consisted of short rods rounded at the ends, and slightly constricted in the middle; when stained they resemble a figure of 8 , the stain being more intense at the poles; they are also surrounded by a ciear area, and on the whole they most closely resemble the bacilli of chicken cholern. The rods were present in large numbers in the blood of the henrt of mice; in sections of the organs they were found inside the capillaries, but as a rule in isolated masses, and not more numerous in the lungs than in the other organs. The imoculation of the disease on mice was carried on successfully throught 40 or 50 generations with minute quantities of blood; 
death occurred much more quickly than in the case of the first species, often even after 18 hours, at the latest after 40 hours. Rabbits were completely immune. Cultivation experiments showed at most a multiplication Cultivation of the bacteria in the blood inoculated on the first sub-experiments stratum; further attempts at inoculation were always unsuccessful. unsuccessful.

The following bacteria isolated from saliva by other author's are either identical with one or other of these species, or it may be different from them, but this cannot be decided on account of the absence of sufficient characteristic distinctive points.

Pasteur obtained a microbe from the saliva of a child Pasteur's which had died of hydrophobia. Raynaud and Lanne- mierobe of longue had discovered that the inoculation of such saliva on rabbits caused the illness and death of the animals; Pasteur confirmed these experiments, and cultivated a micro-organism from the blood of the rabbits in veal broth, this organism being rod-shaped and somewhat constricted in the middle in the form of a figure of " 8 "; the organism was only $1 \mu$. in diameter, and was surrounded by a gelatinous substance like an aureole. In the cultivations these rods were said to become converted into chains of cocci. Fowls and guineapigs were not susceptible to the action of the microbe.Although at first Pasteur supposed that he had obtained the infective agent of hydrophobia, he succeeded in setting up the same disease, and found the same organisms in rabbits inoculated with the saliva of healthy human beings. In like manner Vulpian was able to set other similar up, by inoculation of normal saliva on rabbits, a disease species. which ended fatally in two days, and which could be (Krain, transmitted from animal to animal by small quantities of blood.-Fraenkel also obtained a similar result by the inoculation of his own saliva. (See Literature, p. 37.)

Klein has set up infective diseases in rabbits and mice by the sputum of patients suffering from pneumonia, and he has described the infective agents of these diseases as belonging to various species of micro- 
coci. It is possible that in these cases also the bactcria belonged to the group here described.-In like manner the septicremia formerly described by Davaine, which is fatal to rabbits and guinea-pigs but not to pigcons, seems to have been duc to similar bacteria.

Group of septic bacteria resembling the pneumonia bacilli.

Another smaller group of bacteria is formed by short, thick cells, egg-shaped when young, and resemblingr the pneumonia bacilli; like these thcy are often surrounded by a sheath which can be stained, and in puncture cultivations in gelatine they give rise to nail-shaped growths, and on potatocs to thick gelatinous deposits. It is at times impossible to distinguish the species belonging to this group from each other either by the microscope, or by the appearance of the cultivations, and this can only be done by experiments on animals.

\section{Bacillus crassus sputigenus (Kreibohm).}

Kreibohm's thick sputum bacilli. Microseopical characters.

These organisms wcre obtained by Kreibohm on two occasions from sputum, and on onc occasion from the fur on the tonguc. They present the form of short, thick bacilli, or oblongs with rounded corners; ther are often bent like a sausage, or twisted. Immediately after division the longitudinal diameter is only about a half greater than the transserse, but later on the difference is more marked, so that before new dirision takes place the bacilli are three or four times as long as thick. The bacilli are often seen to be connected together, either while division is going on, or after division has occurred, but longer threads do not occur. The bacilli, both from blood and from cultirations, frequently present abnormal forms, often showing swollen ends or irregular contours, and here and there converted into shapeless masses. The bacilli strin readily, and retain the stain on treatment by Gram's method; at higher temperatures $\left(35^{\circ} \mathrm{C}\right.$.) they appear to Cultivations. form spores. - The bacilli can be cultirated on a number of different substrata. In gelatine plates they form distinct greyish-white points after about 36 hours, 
these points soon rising abore the surface and then spreading out in the for'm of greyish-whitc round gelatinous drops, which project considerably above the surface of the jelly. Under a low power the youngest colonies appear circular, of a greyish-brown dark colour with dark points, or with short dark lines over the whole surface. The superficial larger colonies appear distinctly lighter, irregular in outline, and the surfacemore especially at the border-is distinctly granular. In puncture cultivations the organisms grow very quickly, in about 24 hours, and show the typical nailshaped appearance. On potatoes they form a thick,

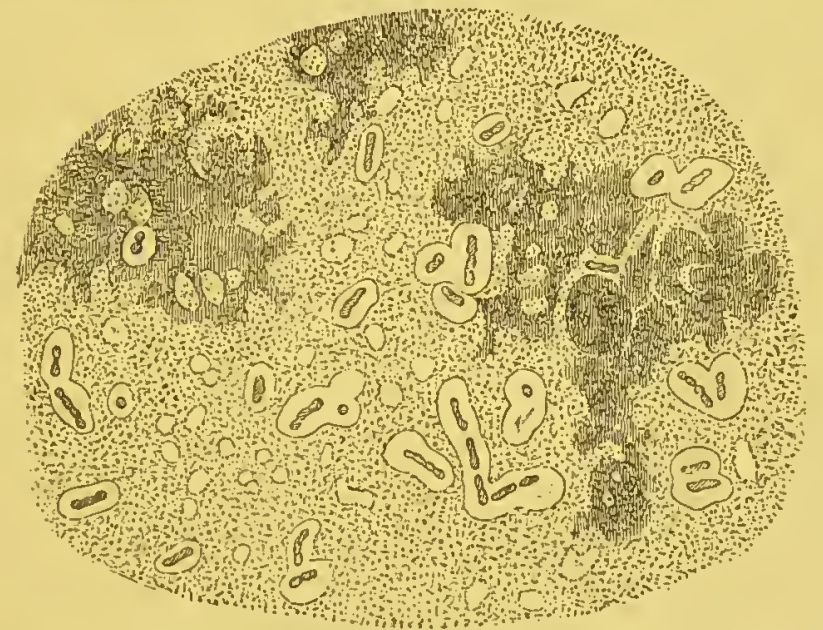

Fig. 91.-Bacillus crassus sputigenus (Kreibohm) $\times 700$.

Cover glass preparation from the blood of the heart of a mouse.

greyish-white moist and shining layer, similar to the cultivation of the pneumonia bacilli, but somewhat flatter and tougher, though as a rule scarcely distinguishable from the latter:-Mice die after inoculation with Experiment small quantities of the cultivation in about 48 hours; on animals. numerous bacilli are found in the blood of the heart, and in all the capillaries, in largest numbers in the liver. Rabbits are not markedly aflected by small doses, if introduced by illoculation, but after intra-venous injection of small doses they die within 48 lours, large masses of bacilli being found in the blood. Large $\Lambda$ etion of quantities of the cultivation injected into the veins larger doses. cause in rabbits, and to a still more marked degree in 
dogs, diarrhœa, with at times bloody stools, and death within 3 to 10 hours; on post-mortem examination all the appearances of an acute gastro-enteritis are found.

\section{Bacillus pseudopneumonicus (Passet).}

Psoudopncumonic bacteria.

These organisms havo been cultivated on trio occasions by Passet from the pus of abscesses in man.* They are oval or round, seldom elongated, cells resembling those of the pneumonia bacilli, but with a greater tendency to the formation of rounded forms. Their transverse diameter is $\cdot 87 \mu$., their longitudinal $1 \cdot 16$. Microscopical In preparations which have been taken from the animal characters. body, or from cultivations grown at the body temperature, the bacteria are seen to be surrounded by a sheath which takes up the colouring matter.

('nltivations. In gelatime plates white points appear after 24 hours, and under a low power present the form of round, finely granular, grey, and later often very dark discs, with regular sharp outlines. On the surface the colonies form greyish-white prominent nodules of about the size of half the head of a pin; the puemmonia colonies are somewhat thicker and whiter. In puncture cultivations the pseudo-pneumonia bacillus grows only on the surface, being a pure aërobe, and forms on the surface greyish-white hemi-spherical glistening nodules; it does not grow at all along the track of the needle. On blood serum it forms a thin greyish-rhite layer; on potatoes liept at $37^{\circ} \mathrm{C}$. a thick white shiny moist lajer appears in 24 hours, without any derelopment of gas,

Experiments in animials. or formation of bubbles.-In mice, rats, guinea-pigs, and rabbits the injection of Passet's bacteria into the plemra causes pleuritis, and into the abdomen, peritonitis; subcutaneous inoculation lills mice from septicxmin, but as a rule only causes the formation of abscesses in rats, guinea-pigs, and rabbits; 43 mice treated by inhalation of the cultivations remained well.

* They arc described by tho anthor as cocci, but on account of the analogy with the pneumonia bacteria, and for the reasons giren with regard to the latter, theso organisms have been included here under the bucilli. 


\section{Bacillus septicus sputigenus (Fraenkel).}

These organisms have been repeatedly obscrved by Fraenkel's A. Fraenkel* in the rust-coloured sputum of patients spacturia. suffering from pneumonia. These microbes have the appearance of cocci, resembling very much the pneumonia bacteria, and like these they are surrounded by a broad capsule. They do not grow on gelatine at the ordinary temperature, but they grow on agar and blood serum at the body temperature; in the latter they form a veil-like almost transparent layer, or a deposit like drops of dew. Rabbits die after subcutaneous inoculation in 24 to 48 hours, with the symptoms of acute septicæmia.-Fraenkel thinks it probable that these bacteria have a causal relation with human pneumonia and with the empyemata which develop after pneumonia. A more detailed description of these organisms has not as yet been furnished.

\section{Bacillus pneumonicus agilis (Schou).}

These organisms were cultivated by Schou on three Bacteria of occusions from the lungs of rabbits which had become vagus pneuaffected with pneumonia after section of the vagus nerve. They present the form of short thick rods, or more elliptical cells often occurring in pairs, or, seldom, in chains of three or four members. They do not stain by Gram's method. When examined in drop cultivations they show very active spontaneous movements; in gelatine plates the colonies of the bacilli appear under a low power as round, dark, granular discs, with a slightly rough surface and borders. After 20 to 24 hours liquefaction of the gelatine commences, and even under a low power we see very marlied movements in the middle of the colony. At this stage the borders appear as if surrounded by a small crown of rays, but soon afterwards the gelatine becomes entirely liquefied. On solidified blood scrum the bacillus grows very slowly, and leads to slight liquefaction of tho serum; in broth it forms a plentiful yellowish deposit at the bottom of the

$$
\text { * Ijit. p. } 37 .
$$


vessel; on potatoes it forms a reddish chamois-coloured flat layer, which extends very quickly.-Cultivations introduced into the lungs of rabbits through the wall of the chest, or by injection into the trachea, or by inhalation into the lungs, set up a violent pneumonia, which presents exactly the same appearance as the vagus pncumonia, in which the bacilli were originally found.

\section{Bacillus diphtheria columbarum (Loeffler).}

Bacilli of pigeon diphtheria.

Symptoms of the disease.
In fowls and pigcons we not uncommonly find epidemics of a disease resembling human diphtheria, which begins with hyperæmia of isolated spots of the mucous membrane; at a later period these spots become covered with a thick light yellow deposit. In the case of pigeons the base of the tongue, the mucous membrane of the throat, and the angle of the mouth, are more especially attacked; in forvls the usual seats are the tonguc, the palate, the nasal cavities, the conjunctive, and the cntrance of the larynx. The temperature of the affected animals is somewhat elevated. The disease runs its course as a rule within two or three weeks, and may at times last for some months with repeated exacerbations; 80 per cent. of the fowls affected die; of the pigeons, however, a smaller proportion. Young animals, and those belonging to pure breeds, are more especially predisposed to the disease.

Microscopical Loeffler* was able to isolate, from the cxudation of a characters of the bacilli.

pigcon which had died with these symptoms, bacilli which were only slightly longer and somewhat narrower than the bacilli of rabbit septicamia, and were rounded at the ends, and usually occurred in groups. In sections of the lungs, and more especially of the liver, the rods were found in the interior of the blood vessels, forming Cultivations. masses similar to those of the typhoid bacilli.-On nutrient golatine they form at the deepcr parts whitisl spheres, on the surface whitish layers; under a low power the colonies present a yellowish-brown appearance. On blood serum they form a grerish-white * Mitth. a. d. Kaiserl. Ges, Amt., rol. ii. 
semi-transparent lajer; on potatoes a deposit which is only distinguishable from the surface of the potato by having a somewhat greyer colour.-Pigeons inoculated Experiments subcutaneously with pure cultivations of these bacilli on animals. are attacked by inflammations ending in necrosis; after inoculation on the mucous membrane of the mouth i morbid process develops, which completely coincides with the natural infective disease. - Sparrows and rabbits are susceptible to the action of the bacilli; forls, guineapigs, rats, and dogs are immune, or only show a transitory local affection. Mice show very characteristic effects; they die as a consequence of subcutaneous inoculation in about five days, and the short bacilli, described above, are found in the blood, and in all the organs, most numerous in the liver; they lie everywhere in the interior of the blood vessels, and often also in the interior of colourless blood cells. To the naked eye the peculiar Characteristic character of the liver is most striking in the mice, as post-mortem also the marked swelling of the spleen, and the patchy in mice. redness of the lungs; the liver has a marbled white appearance, due to the fact that in the pale red livertissue uumerous white irregularly limited patches were present. Under the microscope no liver-tissue can be seen in the neighbourhood of these patches, and the nuclei do not stain at all; in the centre of the patches, however, there are dense masses of bacilli within the vessels, which have evidently led to the death of the surrounding tissue of the liver over a considerable area.As this post-mortem result is found in all the mice inoculated, we have in the inoculation of mice with these bacilli the best means of recognising them.

These bacilli must therefore be looked on as the exciting agents of pigeon diphtheria. As they were not found in human diphtheritic membranes, even after the most careful microscopical examination, we must conclude that the two forms of diphtheria are not etiologically the same. The view that human beings can become affected with diphtheria from infection from diseased pigeons and fowls has been repeatedly expressed, but has been objected to by a number of 
Relation of pigeon diphtheria to human diphtheria.

authors (for example, Magnin*). Recently Gerhardt and Stumpft have published cases of infection of man from pigeon diphtheria; but in none of these cases has it been shown that the disease in man was true contagious diplitheria; on the other hand, it is probable that milder affections of the mucous membrane were present. It is possible that these affections might be caused by the diphtheritic bacteria of pigeons or fowls, especially as. we know from the experiments on animals that many kinds of bacilli can set up diseases of the mucous membrane of the most various intensity, and even diseases accompanied by the formation of membrane, and yet these affections cannot be included under the term contagious diphtheria; and further, severe diphtheritic attacks would be of much more frequent occurrence in man, in association with epidemics in poultry yards and among pigeons, if the infective agents in the two cases were identical. - Further, according to Loeffler's experiments, the diphtheria of fowls is apparently different from that of pigeons, and the etiology of the former is, as yet, not at all made out.

\section{Bacillus diphtheria vitulorum (Loeffler).}

Bacilli of the diphtheria of calves.
The diphtheria which occurs in calves in an epidemic form is characterised by great lassitude of the animals, flow of saliva, ye!low exudation from the nose, imperfect Symptoms and attacks of coughing, and diarrhœa. On the mucous mempost-mortem brane of the cheeks, of the tongue, and of the hard palate, the diphtheria we find yellow deposits extending deeply into the tissue;
of calpes. the entrance to the larynx and the nasal cavities are often affected at the same time; and similar infiltrations have also been observed in the skin between the tocs of the fore-fect. Deatli sometimes occurs on the fourth or fifth day, usually, however, the disease lasts for sereral weeks. On post-mortem examination we find besides these deposits similar alterations in the mucous membrane of the large intestine, and deposits in the lungs

* Magnin, Gaz. des hipil., 1879.

† Gerhardt, Lit., p. 18.-Stumpf, Deulsch., Arch. f. klin. Med., rol. 36. 
varying in size from a pea to a nut, of a grcyish-yellow colour, and in part suppurating.-On microscopical examination of the deposits in the mucous membrane Loeffler* found, quito at the surface, numbers of all linds of bacteria, more especially of micrococci; then follows a broad, unstained zone, the structure of which is unrecognisable, and in which there are no bacteria, and it is only close to the tissue itself that we find at first single, and then as we go deeper numerous long bacilli, ultimately arranged in long wavy bundles and dense masses, separated from the tissue by a narrow unstained zone on the further side of which we see a dense nuclear infiltration of the tissue. The majority of these Microscopical bacilli wnited torcther to form longish threads; the characters of individual segments are about five or six times as long as broad; their thickness is about half that of the bacilli of malignant œdema. As Loeffler was able to demonstrate the presence of thesc bacilli with the same characteristic arrangement in seven cases of diphtheria in calves, we are justified in drawing a conclusion as to their causal connection with the disease from the constancy with which they occur.-Cultivation experi-Caltivation ments have as ret led to no result; nutrient jelly, experiments sheep's blood serum, \&c., have remained cntirely sterile result. after inoculation; in calves' blood serum a whitish rim is formed around the pieces of organs which are planted on it, this ring consisting exclusively of the long bacilli, but attempts to inoculate fresh serum from this rim failed.- On the other hand, the fresh diphtheritic deposit was inoculated with success on mice, while guinea-pigs and rabbits did not show any charactcristic discase. The mice died after 7 to 30 days; Inoculation on a grcyish-ycllow speckled infiltration extended from the animals. seat of inoculation, involved tho whole of the wall of the bclly or back, reached oftcn as far as the peritoneal cavity, and enveloped kidneys, liver, and intestine in yellow masses of cxudation. Other mico could be successfully inoculated from this infiltration. In all the affected animals it could be shown by the microscope

* Artth. a. d. Kaiserl. Ges. Amt., vol. 2. 
that, as in the case of the calves, the infiltration was occasioned by the long bacilli.-Further proof of the etiological róle of these bacilli must be furnished by more extensive cultivation experiments.

Group of bacteria which set ap gastroenteritis.
Another group of bacteria characterised by similarity in their pathogenic action is formed by those bacilli which set up a more or less severe gastro-enteritis in the animals ordinarily employed for experiments, such as dogs, rabbits, and guinea-pigs, the disease occurring when the bacteria are injected in relatively large numbers, either into the veins, or subcutaneously. Similar symptoms were formerly often obtained experimentally by the employment of mixtures of bacteria, and Virchow* observed, as long ago as 1847, vomiting and diarrhœa with ultimate collapse, in animals after injection of a Earlierexperi-fluid obtained from putrid fibrin. Among more recent ments with mixtures of bacteria.

Later experiments with pare caltiva. tions. cultivation of organisms, experiments hare been made writers we need only mention Popoff, $\dagger$ who obtained similar results by the injection of a mixture of yeast, and also of putrid Pasteur's solution; and Blumberg, $\ddagger$ who worked with putrefying dog's blood, and with the water employed for the maceration of dog's flesh, and set up violent romiting and rapid death after intravenous injection, and milder and less constant symptoms after injection subcutaneously. On post-mortem examination of the animals, the severe cases showed the appearances of a hæmorrhagic gastro-enteritis with marked swelling, and often deep ulceration of Pejer's patches. In milder cases there was only hyperæmin of the stomach and intestines, and swelling of the follicles.

After the elaboration of the methods for the pure with different species of bacterin, and cultirations of these bacteria have set up the same morbid symptoms and the same anatomical appearances after intravenous, and sometimes after subcutaneous injection, as was done by tho mixtures formerly employed.

* Handb. der spec. Pathol. $u$. Therapie, vol. i., p. 242.

+ Berl. klin. Woch., 1872, Nr. 43.

‡ Virch. Arch.. rol. 100, p. 37 . 
The effect obtained is, however, not, uniform, but raries according to the virulence of the individual species, as well as according to the number of bacteria introduced and the seat of their application. After the injection of large qunntitics into the reins the the animals. animals become collapsed in a very short time and die in from one to three hours. Where smaller quantities are employed romiting sometimes occurs, followed by profuse diarrhœa, the stools being often mixed with blood, and ultimately collapse, and death occurs after 12 to 24 hours. Some species of bacteria cause a passing diarhœe, without any further bad result, after intravenous injection of very small doses or after the subcutaneous introduction of medium doses. - We cannot as yet properly explain this action of the bacteria. Wo do not usually find, either in the acute or in the protracted cases, any sufficient multiplication of the bacteria injected to explain the phenomena, and it has also been observed on some occasions that the same results follow the injection of sterilised cultivations. These two facts seem to indicate that we do not have here to do with the immediate action of the bacteria, but with the toxic effect of a substance which has been produced by the bacterin. More elaborate investigations will probably give us information as to this point.

The organisms which act in this way cannot be looked on in all cases as specific pathogenic organisms; some of them are mainly saprophytes, or exciting agents of putrefaction, while many belong to the forms of bacteria previously described, which, when inoculated in small quantities, set up discases, mostly forms of septicæmia, which run a slower coursc, but, oil the other hand, when introduced in to the blood stream in large doses, lead to the sudden illness just described. 'Thus, for cxample, wo obtain these results with the Enumeration bacilli of rabbit septicamia, in a very marked manner of the with the bacillus crassus sputigenus, the bacillus of longing to this pneumonia, and, among the bacteria which are clicfly saprophytic, with the bacillus rubcr indicus. It must 
be mentioned that very many of the other kinds of bacteria, even the pathogenic lincls, when introduced even in very large quantities into the blood stream, do not produce this effect; thus the typhoid bacilli, bacillus tetragenus, the pyogenic cocci, the anthrax bacilli, and many others when introduced in enormous doses are either without effect, or set up specific diseases after they have gradually spread and multiplied in the body.

The following are some of the bacteria which set up these intestinal symptoms in the most marked manner :-

\section{Bacillus oxytocus perniciosus (Wyssolowitsch).}

Toxic lactic acid bacilli.

Experiments on animals.
These organisms were isolated by Wyssokowitsch in the author's laboratory from milk, which had stood there for a considerable time. They present the form of short bacilli with rounded ends, somewhat thicker and shorter than the ordinary lactic acid bacteria. They form on gelatine plates at the deeper parts small yellow colonies, which under a low power have a circular appearance, are sharply outlined, finely granular, and brownish-yellow in colour. On the surface the colonies spread to the extent of about $1 \frac{1}{2} \mathrm{~mm}$., they are greyishwhite in colour, round, raised, and show under a low power a sharp outline, and light brown colour. In puncture cultivations a nail-shaped growth is formed at first, at a later period the cultivation extends superficially over the whole surface of the gelatine. In stroke cultivations a rapidly increasing deposit is formed of a yellowish-white, or greenish colour.-A small quantity of the cultivation added to sterilised milk causes coagulation and acid reaction within 24 hours. Neither the milk nor the cultivations have any odour.-Small doses inoculated on mice or rabbits have no effect at all. Mixtures prepared from one or two test tubes, and injected into the aural vein of rabbits, caused in each of six cases death within three to twenty-two hours. Violent diarrhea set in about threc-quarters of an hour after 
the injection. On post-mortem examination there was found in all cases intense and often hrmorrhagic inflammation of the intestinal mucous membrane.

\section{Bacillus caricida (Brieger).}

These organisms present the for'm of rery small rods Brieger's about twice as long as broad; they were isolated by gainea-pig Brieger* from human freces. They form colonies on nutrient jelly composed of irregular concentric rings; the cultirations present an appearance resembling that of the scales on the back of a tortoise. On potatoes they form, pretty quickly, dirty yellow masses. Guineapigs are killed without exception within 72 hours by the subcutaneous inoculation of the most minute quantities of the cultivation; rabbits and mice are for the most part immune; if guinea-pigs are fed with the cultivation no bad result follows. Koch $\uparrow$ has stated that the guineapigs killed by subcutaneous injection show alterations in the small intestine, marked injection of the mucous membrane, and a large quantity of thin fluid con tents; in short, similar symptoms to those formerly obtained by the subcutaneous injection of mixtures of bacteria.

\section{Bacillus coprogenus parvus (Bienstock).}

This is an extremely small slowly-growing bacillus, Bienstock's obtained by Bienstock on several occasions from human small bacillus freces. They are only slightly longer than broad, so that it is only under high powers that the rod form can be distinctly seen; they grow very slowly on nutrient jelly; in the course of weels the cultivation extends from the line of inoculation to a distance of scarcely $1 \mathrm{~mm}$., and forms a scarcely visible layer on the nutrient soil.-If white mice are inoculated with a cultivation marked cdema occurs in the neighbourhood of the seat of innculation within 10 hours; the auimals die 24 hours later; after death the bacilli can be demon-

* Zeitschr.f.phlysiol. Chem., rol. viii., p. 308.

† Conferenz zur Erörterung der C'holcrafrage, 2 Jahr. 
strated in small numbers in the blood of the heart. A rabbit showed after inoeulation on the ear erysipelatous swelling, followed by profuse diarrhoca, and death oeeurred eight days after inoeulation. On post-mortem examination eatarrh of the intestinal mucous membrane was the only abnormal condition found.-Further experiments on animals with this baeillus are desirable.

\section{Bacterium coli commune (Escherich).}

Microscopical These baeilli were obtained by Escherich* from the characters. frees of ehildren nourished exclusively with their mothers' milk. They are short, slightly curved rods, their length varying from 1 to $5 \mu$., and their breadth from 3 to $4 \mu$. They stain intensely with aniline eolours, but do not retain the stain when Gram's method is employed. When examined in drop eultirations they Cultivations. show slight mobility. On mutrient jelly the deeply seated eolonies present the form of yellow granular dises ; the superficial ones show a white-lateral extension with a homogeneous granular appearance, or starshaped and wrinkled. On agar and blood serum they grow in the form of white deposits; on potatoes they form a soft layer of the eolour of maize or yellow peas. The bacilli slowly eoagulate milk with the formation of acid; in solutions of grape sugar they set up fermentaExperiments tion.-When a pieee of a eultivation on potato about the on animals. size of a lentil is mixed with sterilised water, and injected into the veins of the neck of rabbits and guimea-pigs, the animals die after a few hour's, or at latest after three clays, with symptoms of elevation of temperature and violent diarhœa. On post-mortem examination the duodenum and the upper eoils of the small intestine show a rose-eoloured hyperæmin, while the excum and eolon have usually a normal appearance; Peyer's patehes show alterations similar to those seen in the early stage of typhoid fever. In some cases we also find injeetion of the peritoneum and exudation into the peritoneal eavity. Subeutaneous injection of larger closes produce the same effect in guinea-pigs.

\footnotetext{
* Fortschritte der Meclicin, vol. iii., 1SE5, Nr. 16.
} 
Bacterium lactis aërogenes (Escherich).

This organism was found, along with the previous A second one, in the freces of infants. It consists of short bacillus from generally constricted rods with rounded ends, on an infants. average 1.4 to $2 \mu$. in length, and $5 \mu$. in breadth, as a rule occurring singly either as rods constricted in middle, or as pairs of rods; not motile. These organisms Cultivations. grow on nutrient jelly like the pneumonia bacteria; in plate cultivations they form round colonies, which spread on the surface and form raised points of a porcelain white colour. In puncture cultivations they grow luxuriantly along the track of the needle, the needle track being filled with a number of small white spheres arranged like a string of beads with, at the upper part, a knoblike swelling; at the surface the colonies show a limited growth, arched like the head of a pin, and of a soft consistence. On potatoes they form a whitish-yellow creamy layer full of gas bubbles. Milk coagulates with the for- Formation mation of lactic acid in the course of 36 to 48 hours, at lactic acid. the ordinary temperature; in solutions of milk sugar and grape sugar the organisms cause intense fermentative action. In sugar solutions they appear to form terminal spores. When sugar is present the bacteria are also able to grow when oxygen is excluded, and at the same time to cause fermentation, while without sugar they cannot live in the absence of oxygen.-Experiments Need for on animals gave the same result as with the species oxygcn. previously mentioned, but the action was somerwhat less intense.

\section{Bacillus Neapolitanus (Emmerich).}

A bacillus which appenrs to belong to this group of Bacillusfound bacteria was isolated by Emmerich* during the epidemic by Emmerich of cholera in Naples, in 1884, from the organs, and the bodics of later from the intestinal contents of patients who had had died of died of cholera. This organism presents the form of cholera. short rods, with rounded ends, about $9 \mu$. in breadth,

* Emmerich, Arch. f. Itygiene, vol. iii., 3 \& 4 Hcft.-Buchncr, ibid. 
Microscopical and at times forming egg-shaped or even more elongated cells, without or with very slight spontaneous morement. In certain nutrient solutions (cane sugar, cxtract of meat, and peptone) longer rods and threads are formed, according to Buchner; in glycerine jelly various involution forms appear, characterised by slight thickening of the rod, and by staining only at the ends.-Ou

Caltivations. gelatine plates the bacilli form colonics in the substance of the jelly, which present the appearance, under a low power, of round, and later irregular, alnost egg-shaped colonies with sharp outlines, of a brownish-yellow colour, highly refracting, and distinctly granular in the interior. On the surface of the gelatine the colonies spread to about ten times the diameter of the deeper ones, and lie on the surface like scales, of a cartilaginous or ground

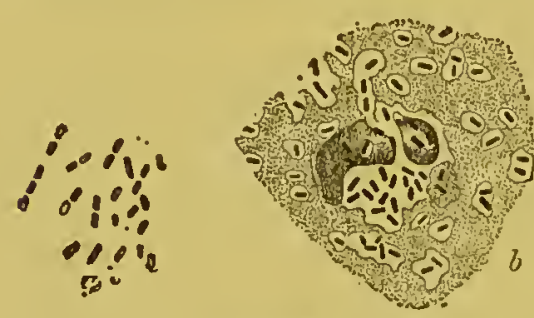

Fig 92.

a. Preparation from a piece of mucus from the rice water contents of the human intestine $\times 700$.

b. Preparation from the peritoneal exudation of a guinea-pig which had died after subcutaneous injection of the Naples bacteria (stained with aniline fuchsine) $x$ 700. (Both after Emmerich.) glass appearance, showing rainbow colours with transmitted light. Under a low power it can be seen that the limiting line is markedly irregular or lobular; the interior shors two zones, a peripheral one, clear, colourless, faintly granular; and a central one, rellowishbrown towards the middle, and equally granular. Where the colonies are mor'e markedly developed, we can also notice radially arranged, though but slightly marked furrors (Buchner*). -On potatoes the bacilli grow at $37^{\circ} \mathrm{C}$., in the form of a brownish-yellow gelatinous laycr.

Experiments on animals.
When Emmerich injected large quantitics of the pure cultivations of this organism under the skin, into the lungs, or into the peritoneal cavity of guinea-pigs, death occurred in from 30 to 42 hours, and, on examination, hyperæmia of the intestinal and gastric mucous membrane, and even hæmorrlingic crosions and supcrficial

* Arch. f. Ilygiene, rol. iii., 3 Heft. 
sloughs on Peyer's patches were found. Where the dose ras smaller the course of the disease was more protracted, and in these cases the ulcerations in the intestine were more extensive and deeper. If the cultivations were injected into the peritoneal cavity death generally occurred in 8 to 10 hours.-Cats were less susceptible, relatively larger quantities of the cultivation being required in order to cause infection; and still larger quantities were necessary in the case of dogs and rabbits. Of the dogs infected only one died on the third day, while the other's recovered after being ill for several days. A monkey died after 42 hours, and shorred similar alterations in the intestine; Peyer's patches were of a dark brownish-red colour, and distinctly swollen. The guinea-pigs as a rule passed pulpy motions during life; the cats suffered from vomiting and diarrhea; the monkeys had also romiting, with repeated watery stools. -From the results of the experiments on animals, and of the proof furnished by cultivation that the bacilli were present in the blood and in all the organs of nine patients who had died of cholera, and that they were also present in the blood of patients in the last stage of the disease, Emmerich has come to the conclusion that these organisms are the exciting agents of cholera. Nevertheless, the results of the experiments on animals did not differ in any important particular from those obtained by the numerous forms of bacteria mentioned above and the method employed by Emmerich to demonstrate the presence of bacilli in the organs was by no means free from error. In more recent investigations made on Occurrence of eight cholera bodies in Palermo, Emmerich and Buchner the bacilli in were unable to confirm the occurrence of these organ- of paticnts isms in the blood and in the internal organs, but found sufforing from them chiefly or only in the intestines and lungs.

It is evident that the presence of these organisms in the intestines of clolera patients can only be of significance if it is shown that the same bacillus is not present in the normal intestine, nor in intestines in which any other pathological process is going on. Such 
proof, however, does not appear to have been furnished; Occurrence of in Koch's laboratory, as well as in the author's, a brcilli in the bacillus has been repeatedly isolated from the intestinal normal in. testine. contents of man and animals which is absolutely identical with that described by Emmerich both as regards microscopical characters, growth in cultivations, and pathogenic action. (The bactcrium coli communc obtained by Escherich from the intestinal contents shows according to the description only very unimportant differences, due probably to differences in the nutrient substratum, and it is possibly identical with the bacillus of which we are speaking.) Hence there is no ground for the assumption that Emmerich's bacilli play any etiological rôle in the cholera process ; on the contrary, they represent a species of bacterium which occurs frequently in the intestine, and which corresponds in its pathogenic action on animals with other intestinal bacteria.

\section{Bacillus necrophorus (Lœffler).}

Locttier's hacteria which cause necrotic processes.

Cultivation experiments.

This organism was obtained by Loeffler,* by the inoculation of small particles of broad condylomata into the anterior chamber of the eye of rabbits. The bacilli are of varying length, but of uniform thickness, and they often form long thin threads, with a slightly wary outline. They do not grow on the ordinary nutrient media, only slightly in horses' serum and in chicken broth, and best in neutralised rabbit broth. A whitish down is formed after about 3 days around the pieces of the organs which are placed in the rabbit broth, so that the particles of tissue appear as if they were enveloped in cotton wool; after a few days numerous white flakes are seen floating in the fluid consisting exclusively of a dense network of these bacilli, which have grown in the form of long threads. Here and there swellings are found in the threads which may be looked on as inrolution forms, and there are in addition light stained spots, which, however, do not, on the whole, give the impresInoculation on sion of spores. - If rabbits are inoculated on the ear, or ribbits.

* Mitth. a. d. Kaiserl. Ges. Amt., vol. ii., p. 493. 
into tho anterior chamber of the eye, with a piece of the growth, or with a portion of an affected organ, they die on an average after about eight days; at the seat of inoculation necrotic caseous processes are found, and in the lungs there are deposits surrounded by hæmorrhagic pneumonia, or accompanied by necrosis of the whole of the affected portion of the lung; there are also deposits in the heart. Where these deposits have reached the surface of the organs they canse exudation on the serous membranes. The alterations are chiefly limited to the lungs and heart, and it is only seldom that nodules are also found in the abdominal organs. In all these morbid products the same thin bacilli were constantly present. - White mice die after inoculation in six days; on mice. at the seat of inoculation there are greenish-yellow masses infiltrating the muscular tissue of the back over a large area, extending deeply into the muscles of the thigh, and ultimately reaching the peritoneum. In sections of the tissues which are altered in this way, long bundles of these bacilli are seen.

\section{Bacillus parvus ovatus (Loeffler).}

In a pig which had died of a disease resembling Bacilli of erysipelas, Loeffler* found on microscopical examination pseudoof the cdematous skin, and also of the liver arysipelas of large numbers of sin, and also of the liver and lkidneys, swine. large numbers of small ovoid bacteria, sometimes recalling in form the bacilli of rabbit septicæmia, more especially in those forms which are undergoing division, Microscopical but distinguished from these organisms by the fact that characters. the latter are almost twice as large. In sections the organisms are best demonstrated by staining with alkaline methylene blue, and subsequent treatment with $1 \frac{1}{4}$ per cent. of acetic acid; in the skin they are arranged in rows following the bundles of the connective tissue. They grow readily in various nutrient Cultiration:. medin, in rabbit broth and blood serum; in nutrient jelly they develop somewhat better at the point of entrance of the puncture than along the needle track,

* Arbeiten a. d. Kaiserl. Ges. Amt., vol. i., 1885, p. 51. 
Fixperiments on animals.

and around the point of entrance they form a gresishwhite wall, presenting a dry appearance.-After subcutaneous inoculation, mice die in about 24 hours, and show on post-mortem examination œdema of the subcutaneous cellular tissue, swelling of the spleen, patchy redness in the lungs, and the same bacteria in all the organs. Rabbits also die quickly, and present the same post-mortem appearances as animals which have died of rabbit septicæmia. Guinea-pigs die after 1 to 3 days, and show extensive sero-sanguineous œdema of the subcutaneous tissue, and of the muscles. Fowls, pigeons, and rats proved insusceptible; on the other hand, in a pig the same disease, terminating fatally in 2 days, was produced as that which had formed the starting point of the investigation, the disease being characterised by enormous œdema of the skin, bluish-red colouration of the abdominal wall, and hyperæmia of the gastric mucous membrane, but without alteration in the rest of the intestine or the mesenteric glands, and being thus distinguished from true swine erysipelas.

\section{Bacillus tetani (?).}

Tetanns bacilli.

Distribution in the soil.
In the Göttingen Hygienic Laboratory, Nicolaier made the observation that when garden earth was introduced under the skin of mice and rabbits, these animals frequently dereloped a series of symptoms which may be shortly designated as tetanic. For the peculiar bacilli found in the pus in these animals the name "tetanus bacilli" may for the present be retained, although it is doubtful whether these organisms are to be looked on as the specific exciting agents of that disease.-In all, orer 30 different kinds of earth from fields, gardens, and streets were investigated; the animals frequently developed malignant œedema after inoculation, and died of this disease in from 24 to 36 hours; at times linds of earth were found, the inoculation of which caused sometimes malignant œdema and sometimes tetanus; some kinds of earth, particularly earth taken from the deeper layers, from the soil in forests, scc., had no hurt- 
ful action; a larger proportion, more than half of the specimens investigated, caused always, or almost always, tetanus. In the case of mice about as much as lay on the point of a pen-knife, in the case of rabbits four or five times this quantity, was introduced into a small pocket in the skin, made on the back or thigh; in rabbits the wound was closed by one or two stitches.

After an incubation period of $1 \frac{1}{2}$ to $2 \frac{1}{2}$ days the Course of the carliest symptoms of the disease appear, consisting in slight abduction and stretching of the hinder extremity which is nearest the seat of inoculation, the limb soon becoming completely stiff. In the course of a few hours the hinder extremity on the other side is similarly affected, and then follow the anterior extremities. Ultimately the animals become quite helpless, and generally lie on their backs, while intermittent spontaneous contractions of the extensor muscles of the neck and back occur, in which the head is bent backwards, and the posterior part of the body is raised from the surface on which it is resting, the body thus describing a convex line. These attacks can, however, be set up artificially, and may even be caused by knocking the table, or by a slight touch. Breathing is difficult in this stage, the pauses become constantly longer, and finally respiration ceases, and death occurs. In the case of rabbits well developed trismus can be obscrved. Mice die on an average at the end of 3 days; rabbits, in whom the incubation period usually lasts from 3 to 5 days, die from the 5 th to the 7 th day after inoculation; guineapigs are also susceptible; dogs, on the other hand, are completely immune.

On post-mortem examination of animals which have Post-mortem died witl these symptoms, a relatively small amount of appearances. pus of a peculiar musty disagreeable odour is found at the seat of inoculation. Besides this, however, no important or constant pathological alteration is noticeable in any organ, in the trunlis of the nerves, or in the spinal cord. Microscopical examination of the blood and internal organs was also almost entirely without result; but in the pus at the seat of inoculation fine 
bacilli were constantly present which were somewhat

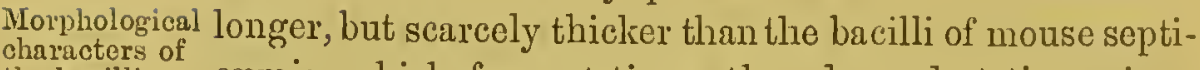
the bacilli.
Experiments with sterilised earth.

Inoculation from animal to animal. cxmia, which form at times threads, and at times irregular groups, and which show a characteristic mode of spore formation. In the first place they become more or less equally thickened, then one end swells more markedly, finally an oral refracting spore with sharp outlines is formed at this end, while the rest of the bacillus remains as a thin thread, three or four times thinner than the spores. Numerous free spores are also usually: present in the preparations. The same bacilli were found not only in the pus, where they were always mixed with other species, but also in the immediate neighbourhood of the seat of inoculation, and in the pyogenic membrane.

These bacilli could not be directly demonstrated in the earth. That, however, micro-organisms were the cause of the infective properties of the specimens of earth was evident from the fact that the same specimens when heated to $190^{\circ} \mathrm{C}$. were completely without effect, eren when introdnced in very large quantities. Further, the disease with all its characteristic symptoms could be transmitted from animal to animal. The pus proved to be the most virulent material; much smaller quantities of pus than of the original earth were required; a ver's minute loopful of pus introduced beneath the slin was sufficient to set up a more rapid and intense tetanus in mice after a shorter incubation period. Under these circumstances mice died in 24 to 36 hours, and rabbits in 3 to 4 days. - The disease could also be set up in healthy mice and rabbits by inoculation with the blood and organs (liver, spleen, spinal cord) of the animals which had died; but this was only successful when larger quantities of the material were employed, and even then the result was not constant, but only occurred in about a quarter of the cases. When it occurred, lowever, the whole group of symptoms were dereloped, and the case terminated fatally.

Cultivations. Nicolaier was able to cultivate the infective organisms in blood serum at the body temperature, without, however, obtaining a puro cultiration. The mixture of 
bacteria, which developed in tho deptle of the blood serum and not at the surface, proved, even when carried through nine cultivations, to be very virulent, and when introduced under the slin of mice and rabbits with a little wool or with a syringe, to the amount of $\frac{1}{2}$ to 1 drop, set up severe and fatal tetanus. He did not succeed in purifying these cultivations by the ordinary methods, but the growth obtained consisted chiefly of the fine bacilli above described with terminal spores; the virulent organisms were typical annerobes, and could not be cultivated at all on gelatine or agar plates. In order to obtain a pure cultivation of these bacilli it was necessary to employ entirely new methods, in some ways more complicated, and with regard to which a report will be shortly published in the Zeitschrift fiir Hygiene.

Carle and Rattone have recently excised the seat of Transmission infection shortly after death from a patient who had of human died of tetanus, and they injected an emulsion made animals, from the tissue into the dorsal muscles or into the spinal canal of rabbits; 11 out of 12 animals became affected with typical tetanus after two or three days' incubation, and this disease corresponded absolutely in its symptoms and course to that produced by Nicolaier, and could be transmitted from animal to animal by inoculation of portions of the sciatic nerve. Thus the assumption becomes more probable that even in many cases of traumatic tetanus in man the infective agents discovered by Nicolaier are concerned in the disease. We must, however, await further investigations on this point.

\section{Bacillus aliei (Watson Cheyne).}

The etiology of the so-called foul brood of bees, a Bacilli of diseaso in which an organism has been repeatedly sus- foul brool of pected to be the causal agent, has been recently cleared up in the manner which was to be expected by Watson Cheyne and Cheshire.* The infective agents wero iso-

\footnotetext{
* Frank R. Choshire and W. Watso Choyne Journ. of the Royal
} Microscop. Soc., 1885, 11, March. 
lated by first purifying the surface of a diseased comb containing in its interior affected larve with sublimate solution, and then opening the cells with heated instruments; small portions of the dead and almost fluid larve were then employed for microscopical examination and for cultivation; by both methods a very characteristic bacillus was found alone and in large numbers.

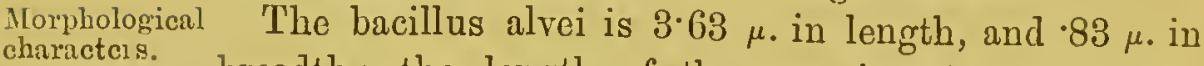
breadth; the length of the organism in cultivations varied between 2.54 and $5.08 \mu$. The ends of the bacilli are rounded or pointed. Slow spontaneous movement

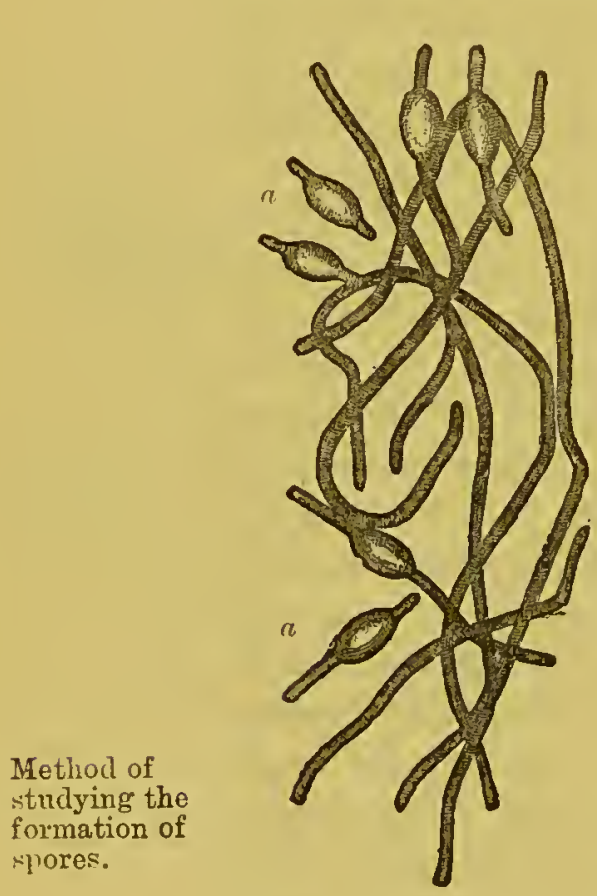

Fig. 93.-Bacillus alvei $\times 3000$. From a cul tivation in blood serum.

At $a$, we see spores (after Cheshiro and Watson Cheyno). can be noticed in many bacilli. They form very large spores, usually preceded by a swelling of the bacillus in a spindle-shaped form; these spores are $2 \cdot 12 \mu$. in length, and $1.07 \mu$. in breadth, and are thus broader than the bacillus and occupy more than half its length. The spores do not take up aniline colours, but the bacilli can be readily stained; when the spores are commencing to sprout, which occurs after they have become elongated at one pole, they again take up the colouring matter. Watson Cheyne has been able to study the formation of spores, and to follow accurately their mode of sprouting, by setting on foot numerous drop cultivations, some from material containing only bacilli, and some from material containing only spores, and after these cultivations have been kept at the body temperature for varying lengths of time $(10,20,40,60$ minutes, sc.), taking off the cover glass, drying and staining it. The series of permanent preparations so obtained, replaced in a more complete manner the continued observation of one and the same cultivation. 
The bacilli grew well at $20^{\circ} \mathrm{C}$, on various nutrient Cultirations. media; in gelatine plates they form at first small round or oval discs, in which, with a low power, peculiar markings, occasioned by the bundles of bacilli, is noticable. The colonies become gradually pear-shaped, and from the pointed end of the pear prolongations begin to shoot out into the gelatine. These prolongations can be still better studied in stroke cultivations on gelatine plates. In that case growth in the first place occurs
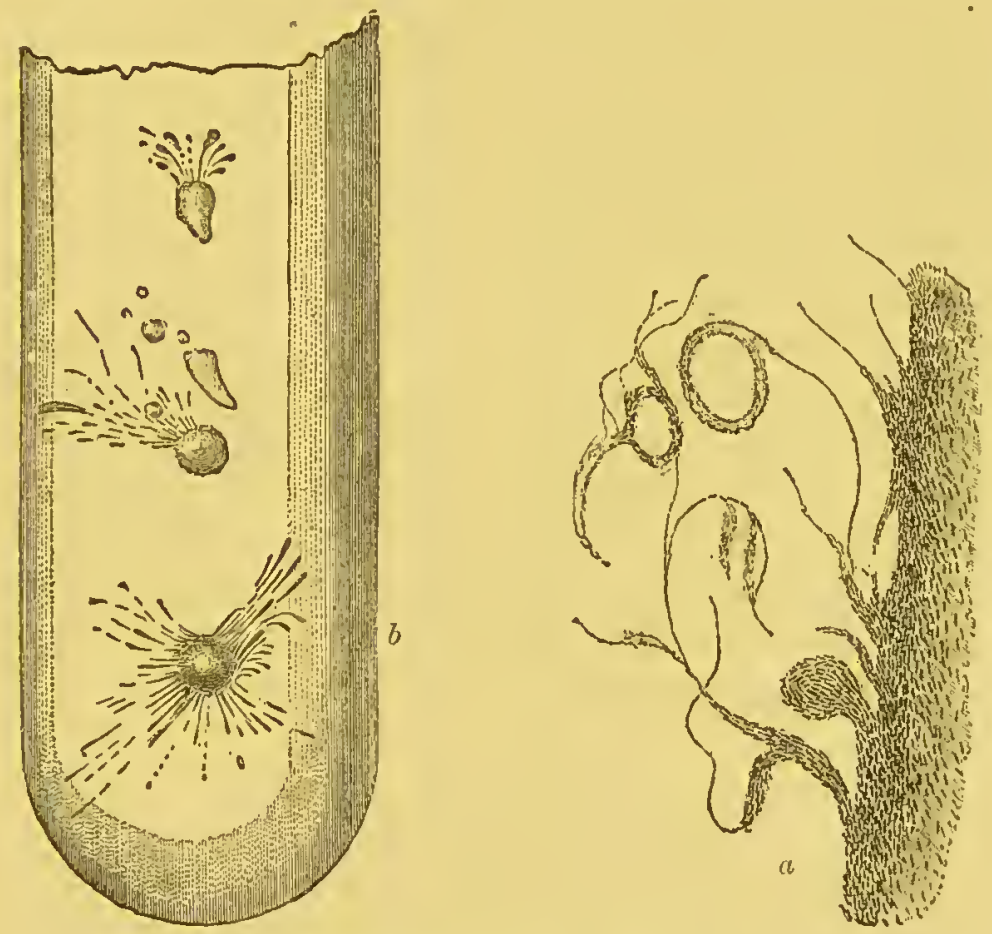

Fig. 94.-Cultivation of brcillus alvci.

$a$, growth on gelatine plates $\times 80$.

$b$, puncture cultivation in nutrient jelly $\times 4$.

along the track of the needle; but soon small lateral projections appear, and from these bands of bacilli grow out often in a single row, often two or three bacilli side by side; these projections gradually curve, and form well-marked circles; from these circles new projections proceed; the individual branches also anastomose with each other. In the immedinte neighbourhood of the bacilli the gelatine becomes at the same time fluid, so that ultimately there is a network of fine canals in the 
gelatine. In puncture cultivations the same growth appears at the surface, but along the track of the needle white irregular clumps are formed, from which fairly coarse branches radiate, often thickened and club-shaped at the end, and varying much in direction and length. In the older cultivations the fine branches disappear, so that the connection between the primary and secondary centres is apparently lost; ultimately, the gelatine becomes gradually liquefied all around the colony.

On nutrient agar the bacilli form a whitish layer, on potatoes they grow slowly in the form of a yellowish deposit. They cause coagulation of mill in a few days; later on this coagulum becomes gradually liquefied, while a very small amount of acid is formed. The various cultivations have a peculiar smell, like old but not yet ammoniacal urine.

Experiments on animals.

'Therapeutic employment of jequirity infusion.
Cheshire was able to demonstrate that foul brood could be set up by the introduction of a pure cultivation of these bacilli into healthy combs; adult bees could also be infected by feeding them with pure cultivations. Flies also seem to be susceptible; mice and rabbits show no marked symptoms after subcutaneous inoculation of small quantities; but the experiments as to the action of larger doses have not yet been concluded.

\section{Bacilli of jequirity ophthalmia.}

De Wecker recommended, in 18S2, the employment of an infusion of jequirity seeds (obtained from Abrus precatorius, a shrub which occurs in Southern Asia and in Africa, and which has been transplanted to America, and belongs to the family of the leguminosa) in order to set up inflammation and suppuration of the conjunctira in cases of granulations and pannus, these troubles being, as we know, frequently cured by these means. The views of practitioners are at present divided as to the therapeutic value of this substance; it has chiefly attracted attention from the fact that some obserrers hare referred the action of jequirity to specific bacilli.

The infusion employed is very dilute (1 to 1 per 
cent.), and is prepared by maceration of the pounded Preparation of seeds with cold water for 24 hours, and subsequent the infusion. filtration (at the temperature of the body the infusion obtained is much weaker). If a few drops of this infusion are introduced into the eye of man or rabbits symptoms of irritation commence even after 3 hours; after 16 hours all the appearances of a severe ophthalmia are present, the conjunctiva becomes covered with a thick, greyish-yellow, firmly adherent membrane, and it is not till 5 or 6 days that the symptoms subside and recovery takes place.

Sattler has found bacilli constantly present in the Sattler's jequirity infusion, these organisms being 2.5 to $4.5 \mu$. jequirity in length, and $58 \mu$. in thickness; they are partly at rest, partly in active movement; they form distinct spores, the spores in the shorter rods being formed at the poles, and in the longer also in one or two parts of the middle of the bacillus; at timos longer threads, containing rows of spores, are found. The bacilli at a later period become united together in the form of a scum ou the surface of the infusion; they are typical aerobes. The spores are relatively resistant, and withstand in the dry state heating to $110^{\circ} \mathrm{C}$. for five minutes. The bacilli can be cultivated on solidified blood serum and on nutrient jelly, as well as in a number of other media; they cause liquefaction of the gelatine. According to Sattler the cultivations set up conjunctivitis when inoculated on the eyes of rabbits, though to a markedly less degree than the jequirity infusion and without the formation of membrane observed when the latter is employed.

Cornil and Berlioz believe that they were able to Infection of demonstrate infective properties in the jequirity bacilli, frogs and these properties appearing after subcutancous injection animals by of infusion containing the bacilli into warm-blooded jequirity animals, and into frogs. In the case of frogs the injection of one drop of a 2 to 4 per cent. infusion into the dorsal lymph sac sets up a disease which ends fatally within a few days with symptoms of increasing muscular weakness; on post-mortem examination we find sub. 
cutaneous œdema, ecchymoses in tlie intestinal mucous membrane, and often large quantities of bloody fluid in the peritoneal eavity. The jequirity bacilli are present in the blood in large number's. If such blood is injected into another frog, the latter animal dies with the same symptoms. In the case of mice, rabbits, guinea-pigs, and fowls, extensive cdema occurs after subcutaneous injection of the infusion, and severe pleuritis or peritonitis, as well as infarets in the liver and lungs after injection into the pleural or peritoneal cavities. If the infusion is injected directly into the reins of rabbits, the animals die in a short time, often even after one hour. If the infusion containing the bacilli was filtered through a porcelain filter, the filtrate was found to be without effect.

Disprool of the reasons for assuming the existenco cf a parasitio action of the jequirity infusion.
In spite of these apparently convincing experiments, it has, nevertheless, been most definitely demonstrated by Neisser, Bordet, Widmark, Klein, Bruylants, and Venuemann, and especially by Salomonsen and DirckincliHolmfeld, , that no specific bacteria are concerned in the action of the jequirity, but that the effect is due to the presence of a soluble poisonous substance in the seeds. It was shown that infusions free from bacilli prepared with sterilised water and with the employment of the usual precautions exerted the same effect on the eye, and after subcutaneous injection on the body generally of frogs and warm-blooded animals; further, neither microscopically nor by cultivation could bacilli be demonstrated in the secretions of the affected eyes; and pure cultivations of the bacteria which occur in jequirity infusion either produced no effect on animals, or set up, when repeatedly applied to the eyes of rabbits, at most a mild inflammation which could also be produced by other bacteria not peculiar to the jequirity infusion. More accurate experiments also demonstrated that the

* Noisscr, Fortschr. de Med., Bd. 2, Nr. 3.-Bordet, Le Jéquirily. Lyon, 1883. Thise-Widmark, On Jequirity Oftalmien. Stockholm. 1843. -Klein, Centralbl.f. d. med. Wiss., 1884, Nr. 8.-Bruylants and Vennemann, Bull. de l'Acud. de d/éd, de Belg., 3 sér., Bd. 18.-Salomonscn und Christmas Dirckinek-Holmfeld, Fortschr. d. Iled., Bd. 2, Nr. 15 n. 19. 
jequirity ophthalmia could not be conveyed to healthy eyes by pus or pieces of the membranous exudation, that further the blood of frogs containing bacilli or the œclematous fluid of warm-blooded animals infected witl jequirity by no means always causes infection in other animals; on the contrary, it was only possible to transmit the disease in this way when the animals first infected were inoculated with such large doses of a concentrated infusion that in the second transmission a considerable portion of the original infusion was carried orer. Cornil and Berlioz, who were the first to observe the transmission of the jequirity disease from one animal to another, have worked with these great concentrations, and hence have obtained an apparent reproduction of the virus, which, however, does not take place if the first infection is caused by smaller doses and less concentrated material.

All these observations imply that the actire agent of The action the jequirity seeds is not a virulent micro-organism, depends or but a soluble poison, and, as a matter of fact, Salomonsen poison, and Dirckinck, and likewise Bruylants and Vennemann, succeeded in obtaining a poisonous material of this character in a concentrated form by extracting the pounded seeds with glycerine. The glycerine extract was precipitated with alcohol, the precipitate dried, extracted with water, again precipitated, and then dissolved in water or glycerine. These solutions of jequiritine had an extremely intense action, even the quantity contained in $\frac{1}{10}$ th millegramme of jequirity seeds being sufficient to set up marked conjunctivitis in rabbits, and the extract when injected subcutaneously rapidly causes the death of mice and frogs. Thus it is clear that the action of the jequirity sceds is only due to the presence in them of a poison soluble in water and glycerine, insoluble in alcohol, ether, benzine, and chloroform, and completely deprived of its power by keeping it for one lour at a temperature of $65^{\circ}$ to $70^{\circ} \mathrm{C}$.

Against the explanation of all the jequirity symptoms as the result of the action of an unorganised virus, we liave only the observation made by Cornil and Berlioz 
Length of life that numerous bacilli are constantly present in the of various

kinds of hacteria when injected into living frogs, ut the same time that jequiritine is introdaced.

blood of the infected frogs, as well as in the pathological secretions of warm-blooded animals. Salomonsen, however, was able to demonstrate that we had not here to do with the so-called jequirity bacilli, and that the species of bacteria found in the blood may be varied at will, according as one or other species is intentionally allowed to develop in the jequirity infusion. Salomonsen succeeded in obtaining multiplication of bacillus prodigiosus of the bacilli of blue milk, \&c., in the blood of frogs in the same manner as of the bacilli ordinarily present in jequirity infusion. The reason of this striking preservation and multiplication of bacteria in the interior of the body must be sought for in the action of the jequiritine, for it is only when this substance is at the same time introduced in sufficient amount into the animals that this multiplication of bacteria in the blood takes place.

Whether the so-called jequirity bacilli are a separate species of bacteria, or whether they are identical with some other well-known saprophyte, perhaps with one of the socalled hay bacilli, cannot as yet be determined from the statements which have been made with regard to their mode of growth and their morphological characters.

Bacilli causing erysipelas in the ear of rabbits.-In sections from an erysipelas of the ear which occurred in a rabbit after injection of softened fæces of mice, Koch found large numbers of thin bacilli, $3 \mu$. in length, and $3 \mu$. in thickness, they also formed thrcads up to $10 \mu$. in length. No experiments werc made at that time (1878) as to the infective character and mode of growth of the bacilli.

Bacillar necrosis of the liver (Ebcrth).-This discase was only met with on one ocension accidentally in a guinea-pig. In the liver and spleen small greyish-ycllow firm nodules were found; the lower portion of the liver was for the most part of a gelatinous appearance, and in a state of complete necrosis. In the ncerotic tissue there were imumerable bacilli whieh stained by Gram's method, were rounded at the ends, and of an clongated egg-shape; they often showed the prescnee of sporcs, either at their ends or in the middle. 
nsually one, but at times two in number, and the bacilli contrining the spores were swollen in the form of a spindle $01^{\text {. }}$ whetstonc. Experiments on vabbits wore unsuccessful.

\section{Bachit which have no known Specific Pathogenic Properties.}

In the course of the last few years a very large number of different kinds of saprophytic bacilli have been discovered, of which some have been shown to be without any pathogenic action on the higher animals, while witl regard to other's the absence of pathogenic properties has not yet been tested, or has not yet been demonstrated with certainty. Hence the possibility must be kept in mind that in future many of the bacteria grouped together under this heading will subsequently be included in one of the preceding groups when their characters have been subjected to more accurate study.

Among the saprophytic bacilli we know some which Classification attract attention at once by the fact that they produce of the sapropignent; others set up fermentes. pigment; others set up fermentation in mixtures containing carbo-hydrates; others are able to split up albumen, and thus take part in the process of putrefaction; with regard to others, again, no marked action on the substratum has as yet been observed. In the following description certain groups liave been formed in accordance with the above facts, but these are only temporary, and are employed to simplify their study. A number of bacilli belong to several of these divisions, on account of the multiplicity of their functions-procluction of pigment, along with simultaneous decomposition of albumen or sugar-and in the case of others a similar multiplicity of properties will probably be found. Hence this classification is more or less arbitrary, and it must be left to the judgment of the individual in which group such bacteria should be placed. 
To the bacilli which produce colouring matter belong :-

\section{Bacillus modigiosus.}

\section{(Micrococcus mrodigiosus, monas prodigiosa.)}

Microsecpical chiracter:

Cultivatio
These are elliptical cells, about $1 \mu$. in their greatest diameter, distinctly rod-shaped before division, and at times forming pseudo-threads. When the multiplication is rapid the short egg-shaped cells predominate; but their contour is seen under a high power to present the form of an oblong with rounded ends, and not that of a circle or ellipse. This circumstance, taken in conjunction with the observation that when they grow slowly, distinct rods and threads appear, renders the prerious designation of these organisms as micrococcus no longer tenable.

Bacillus prodigiosus grows very rapidly in nutrient jelly. In plates liept at $20^{\circ}$ to $22^{\circ} \mathrm{C}$., the deeply lying colonies are evident after 20 hours as light grey points, the superficial ones as light grey dises of about $1 \mathrm{~mm}$. in diameter, which are somewhat depressed and surrounded by an area of liquefied, but perfectly clear, gelatine, about $2 \mathrm{~mm}$. in diameter. Under a low porrer the deep colonies are seen to be round or oral with sharp outlines, of a light reddish-brown colour, clear and transparent at their margin. The superficial colonies present an irregular rough outline, $\Omega$ gramular surface, and a light greyish-brown colour in their middle, darker towards the periphery.-The liquefaction of the geiatine goes on so rapidly that after a few hours the whole inaterial on the plate is fluid ; this fluid, as well as filter paper impregnated with it, gradually assumes a bright red colour; before the gelatine is completely liquefied, the colonies themselves show only very little of the red coloration. As the gelatine plates of the bacillus prodigiosus require great attention in order that they may be examined before they have become completely liquid, it is on the whole better to employ agnr. The agar is not liquefied, and on this matcrial 
the colonies, which are at first white, may be allowed to grow till their surface presents a distinct red colour. In puncture cultivations in gelatine there is rapid liquefaction and formation of a reddish deposit; in puncture cultivations in agar, colourless colonies develop sparingly along the track of the needle, while on the surface the growth extends towards the margin of the material, and gradually assumes a deep red colour.

Bacillus prodigiosus grows very well on potatoes; on this material an intensely blood-red, moist layer is formed, growing with a luxuriance and a production of a bright colour not found in the case of any other bacterium. When the cultivation has been kept for some time, the surface of the red deposit presents a greenish shimmer, similar to the appearance of crystals of fuchsine.-Growth also occurs on a great variety of other vegetable substrata, it also takes place in milk, and in the latter material the oil globules contain the red colouring matter in solution.

The bacilli themselves are colourless. The pigment Characters of is insoluble in water, but soluble in alcohol; its solution shows a characteristic absorption band both in the green and in the blue portions of the spectrum. By the addition of acid the colour changes to a carmine red, and then to violet; when an alkali is added it becomes yellow. The colouring matter is only formed when the colonies of fungi are in contact with free oxygen. Hence the more deeply seated colonies, and those which develop along the track of the needle in puncture cultivations, are colourless. - Not only do these bacilli produce pigment, but they also set up marked decomposition of albuminous decomposition media, this change being characterised by the produc- stratum. tion of a smell resembling that of trimethylamine, as well as by the alkaline reaction of the gases which are formed; this change has not as yet, however, been accurately analysed.-Bacillus prodigiosus appears not Distribuinon. unconımonly as a spontaneous infection of articles of food; the phenomena which were formerly repeatedly observed of the so-called bleeding bread and the bleeding host were probably caused by it; in fact it occurs at 
times in an almost epidemic manner, as was the case in 1843 in Paris, where it grew more especially in the bread obtained from the military bakehouses. It does not set up any symptoms in the bodies of warm-blooded animals, even when it is injected into the blood in large quantities.

\section{Bacillus indicus ruber (Koch).}

This organism was isolated by Koch from the contents of the stomacl of a monkey in India; it produces a colouring matter similar to that of bacillus prodigiosus. The organism has the form of fine rery short bacilli, with rounded ends. In gelatine plates the deeply placed colonies show under a low power even after 20 hours a golden yellow colour and a wavy outline ; the superficial colonies liquefy the gelatine, and form a funnel-shaped depression, which very soon disappears on account of the rapidly spreading liquefaction. The liquefied gela-

Comparison with bacillus prodigiosus : Jigher optinıum of temperature.

Colour more like that of red wax.

'Ioxic aetion on animals. tine has a distinctly red colour. The optimum of temperature is higher in the case of bacillus indicus than in the case of bacillus prodigiosus; while the latter grows best at about $25^{\circ} \mathrm{C}$, aud as the temperature is increased gradually shows less growth, the bacillus indicus flourishes best at about $35^{\circ} \mathrm{C}$; hence luxuriant cultivations can be obtained on agar, on which it forms deposits at first of a white colour, but soon assuming a red hue. On potatoes an intensely red layer is formed, the colour of which is more of a wax-red colour, while the colour of the bacillus prodigiosus is darker, with a slight tendency to violet.

Another important distinction between these tro bacilli is that the bacillus indicus is not without effect on animals, but, on the contrary, rapidly kills them when it is injected directly into the blood in large quantities. Rabbits die within 3 to 20 hours, violent diarrhœa setting in a short time after the injection; on post-mortem examination we find the appearances of a severe gastro-enteritis, at times accompanied with extensive ulceration of the intestinal mucous membrane. 


\section{Bucillus raber (Frank).}

These are actively moving rods, occurring singly or united in twos or fours; in some of these rods there are two to four highly refracting granules (spores). The organisms produce, when grown on boiled rice, a red colour resembling that of red lead or sealing-rax. Nothing further is as yet known regarding this organism.

\section{Bacillus pyocyaneus.}

\section{(Buctcrium acruginosum, Organism of greenish-bluc pus.)}

It has been known for a long time that the greenishblue colour which sometimes appears in the dressings on suppurating wounds is occasioned by micro-organisms. More or less pure cultivations have also been made by numerous investigators, and most recently by Gessard and Charrin; but nevertheless the majority of observer's do not seem to have obtained the organism quite pure, for they have described it usually as a round or oval micrococcus. The organism can be readily isolated by the aid of gelatine plates. It is a thin fine bacillus, of varying length, the average length being about the same as

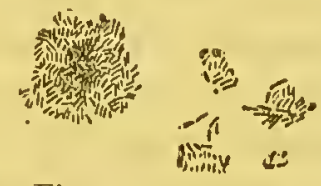

Fig. 95.-Bacilli if greenish-blue pus $\times 700$.
Mrorphological characters. that of bacillus murisepticus, the thickness somewhat greater. Chains of two or three bacilli are observed, but usually they form irregular masses, united together by a tenacious zooglæa; spore-bearing bacilli are also not uncommon, and in that case they are usually somewhat thickened.-On gelatine plates the colonies form, Cultivation: after 24 hours, whitish opaque patches, which under a low power show a round, but not sharp outline, of $a$ yellowish colour, and with radiating markings; the whole of the gelatine presents a greenish shiny appearance. 'Twenty-four hours later the deep colonies have a grey centre, with a dark brownish-yellow zone at the ontermost border, from which delicate radially arranged threacts 
pass out; the zones gradually spread, and the circle of fine ruys constantly becomes greater. In the superficial colonies the grey centre, and the surrounding narrow darker zone are enclosed in one which is much broader, finely granular, yellow, and highly refracting, and, towards the outer part, gradually more and more colourless, with indistinct outlines; and from the margin of this zone fine, radially arranged, and somewhat couvoluted lines run into the gelatine. The gelatine is at the same time liquefied, so that the original colonies soon sink below the surface of the material. - In puncture cultivations the growth is less characteristic; complete liquefaction of the gelatine soon occurs with the production of a greenish colour, which becomes more yellow as the cultivations get older. On agar material a whitish deposit is formed at the surface, and the substratum assumes a bright green colour. On potatoes the organisms form a yellowish-brown moist layer; if this layer is completely removed, and the exposed portion is acted on for a long lime by the air, or for a short time by the rapour of ammonia, the surface of the potato becomes greenish.-In sterilised milk the bacilli in the first place cause the formation of greenish-yellow flakes on the surface, they then lead to precipitation of the casein, which they peptonise gradually, with the simultaneous appearance of ammonia.

Colouring material.

The colouring matter produced by the bacilli has been investigated by Fordos and Gessard, and has been called pyocyanin. It is soluble in chloroform, and crystallises from the pure solution in the form of long blue needles; acids convert the blue into red, reducing substances into yellow. It is apparently closely related to the ptomaines because it is precipitated by chloride of platinum, phosphoric molybdic acid, Sc.This organism does not cause suppuration, and is apparently only a harmless iuhabitant of rounds. 


\section{Bacillus fluorescens putidus.}

This organism occurs frequently in putrefying Fluorcscing materials; it imparts to the latter a greenish hue, and bacillus. produces at the same time a smell resembling that of trimethylamine; it does not liguefy the gelatine.*-The organism presents the form of small, short, very actively moving bacilli, with rounded ends. They form in the deeper parts of the gelatine plates very small dark colonies (under a low power), which grow better at the surface, and then present the appearance of round discs, with sharp wary outlines; in the centre the remains of the deep-seated colonies appear as a dark speck; the surrounding mass is yellow, light grey, and finely granular towards the margin. On the third day the colonies have extended markedly on the surface, they present an irregular outline and have a greenish shimmer, in fact the whole plate has a greenish shimmer; at the same time there is a strong smell resembling that of herring brine. In puncture cultivations a faint grey or milky muddiness develops along the track of the needle, this muddiness extending much more markedly on the surface; from the third day onwards there appear's a greenish coloration of the gelatine gradually extending from above downwards. On potatoes the organisms grow rapidly in the form of a brownish, or at the surface more greyish, thin layer.

\section{Bacillus crythrosporus.}

This organism was formerly observed by Eidam, and Fluorescing afterwards by Cohn and Miflet, in ment infusion, in breillus with putrefying albuminous fluids, \&c., and was obtained spores. from the air.t Since that time it has been often observed in a great variety of putrefying fluids as well as in drinking water. I.t presents the form of thin mobile bacilli with abruptly rounded ends, often forming short threads. At the ordinary temperature two to eight

* Göttinger hygienisches Institut.

† Cohn's Beiträge zur Biologie der Pflunzen, vol. iii., part 1, p. 128. 
oval spores, arranged like a string of beads, appcar in caclı rod; these spores project in part beyond the contour of the bacillus, and, when brought into accurate focus, slow a distinct dirty red colour. Thic spores also retain the red colour after staining the rods, for cxample, with methylene blue.-The bacilli form whitish colonies on gelatine which are circular under a low power, witl irregular but sharp outlines. The opaque brownish centre is surrounded by a greenish-yellow lighter marginal zone; the surfacc shows faintly marked radiating lines. As the colonics spread on the surface of the gelatine their border becomes rery irregular and dentate, and from the dark centre radiating lines, now much more distinct, run in a wavy manner towards the periphery, implying wrinkling of the layer. At the same time a greenish-yellow fluorescing colour appears around each colony.-In puncture cultivations a somerhat plentiful growth occurs along the whole canal, chiefly, however, at the surface; the whole of the gelatine gradually assumes a greenish colour by transmitted light, and yellowish by reflected light, this colour spreading from above.-On potatoes a slight deposit is formed, at first of a reddish hue, and later of a brownish nut colour.

\section{Bacillus fuorescens liquefaciens.}

Liquefying fluorescing bacillus.
This organism occurs extrcmely frequently in a great rariety of putrefying substrata, in water, \&c.-It presents the form of short mobile bacilli arranged in pairs, and constricted in the middle; spore formation has not becn seen.-On gclatine plates it forms whitish points which spread at the surface in the form of fairly large colonics, attaining even as much as $3 \mathrm{~mm}$. in diamcter; at the samc time a ring-shaped liqueficd zone appears around cach colony. Under a low power irregularly circular, and latcr sinuate colonies with sharp outlines arc observed; the ccntre is dark brown, finely gramular, and surrounded by a ycllow fincly granular zone, which becomes whitish-grey and transparent tomards the 
margin. The whole gelatine gradually assumes a wreenish colour.--In puncture cultivations a whitisl layer is formed along the track of the needle, and at the point of entrance of the needle a small funnel-shaped lepression appears, containing at the lower part liquefied celatine, and at the upper part air. The liquefaction gradually spreads until it reaches the wall of the glass, and slowly extends downwards; at the bottom of this liquefied material, a thick, whitish deposit is formed. Beneatl the area of liquefaction the gelatine has a greenish-yellow fluorescing appearance; the liquefied mass does not show the play of colours so markedly.-Ou potatoes a brownish deposit is formed, which, however, is not characteristic.

A mong the baeilli which produee greenish eolouring matter Greenish should probably be placed the organism described by Engel- coloured mann as bacterium chlorinum, and by van Tieghem as bacterinm viride and bacillus virens, in which the substanee of the eell itself presents a greeuish eolour. The speeies investigated by Engelmann was an oval, very mobile rod, 2 to 3 $\mu$. in length; the bacilli investigated by van Tieghem were non-motile. It is, however, not impossible that in all three cases these authors had to do with fission algre; we must await a more aeeurate description.

\section{Bacillus lutcus.*}

This is a short bacillus of medium thickness, and Yellow apparently non-motile. It forms in gelatine plates deeply placed colonies, of a lentil or whetstone form (as seen under a low power), at times with irregular outlines, at times with sharp smooth contour, and of a brown colour. The superficial colonies are 10 to 20 times larger, they measure 2 to $3 \mathrm{~mm}$. in diameter, and appear round, often irregular in outline, of a light brown colour, and witls a whitish, clear, transparent margin. Macroscopically, the colonies are yellow and opaque; in puncture cultivations a yellow growth is formed botll along the track of the needle and also on the surfuce,

* Güttinger hyg. Institut. 
but without liquefaction and without staining of the gelatine.-It occurs very frequently as an impurity on plate cultivations, \&c.

\section{Bacillus fuscus.**}

\section{(Bacterium brunneum.)}

Brown bacillus.

This organism was obtained by Schröter from a putrefying infusion of maize in the form of mobile rods, which produced a brown colouring matter, and which he described under the name of bacterium brunneum. These organisms are probably identical with a bacillus which also furnishes a brown colour, and which occurred in some rare cases as accidental impurities in Göttingen. - These organisms present the form of long narrow rods with abrupt ends, and irregular and in parts slightly projecting outlines. They form on gelatine plates fairly quickly growing knob-like colonies of a brownish colour; under a low power we see in the centre irregular brownish-black balls which are surrounder by a highly refracting border. In puncture cultivations their growth is not very characteristic; on the surface they form a fairly thick, and at a later period a wrinkled brownish-red deposit around the point of entrance of the needle.

\section{Bacillus synxanthus.}

\section{(Bacterium synxanthum, Ehrenberg.)}

Bacillus of ycllow milk.
These are actively moving rods which were observed by Schröter $\dagger$ in milk which had accidentally become yellow; by inoculating the organism on normal boiled milk, its colour became citron-yellow. The colouring mattcr was soluble in water, insoluble in alcohol and ether ; acids decolourised it, alkalies again brought back the colour. Nothing further is known as regards the micro-organisms which produce these effects.

* Göttinger hyg. Institut.

+ Cohn's Beilr. zur Biol. d. Pfanzen, rol. i., part 2, p. 120. 


\section{Bacillus janthinus (Zopf).}

\section{(Bacterium janilinum, violet bacillus.)}

Zopf observed on pieces of swine's bladder, which violet were floating on water containing fungi, violet patches bacillus. consisting of longer and shorter mobile rods, ultimately breaking up into short segments.-These bacilli are perhaps the same as those found by Hueppe, and at a later period on several occasions in the laboratory at Göttingen, and which produce an intensely bluish-violet pigment. These bacilli when grown on gelatine form at first mill-white layers, which gradually assume a violet colour at the margins, and in the neighbourhood of which the gelatine acquires the same tint; it is not till after several days that the whole surface of the colonies acquires an intense violet hue. In puncture cultivations the violet growth only develops at the surface; on potatoes a deep violet layer is produced. In sterilised milk the bacilli produce patches on the cream, at first intense sky-blue in colour, but gradually becoming blackishblue; at the same time the casein is precipitated and then peptonised, the fluid acquiring an alkaline reaction, and ammonia being formed (Hueppe).

\section{Bacillus cyanogenus.}

\section{(Bacterium syncyanum, Bacillus of blue milk.)}

The occurrence of blue milk is frequently observed in Bacillas of many places; ats times its occurrence varies, like that of blue milk. epidemics, in accordance with local and seasonal influences. Great moisture of the atmosphere has generally becn regarded as a furouring factor, while temperature, light, \&c., do not apparently exercise any marlied influence.

Fuchs in 1841 asserted that a vibrio was the agent Former which produces the blue colour, and he demonstrated investigathat this production of colour could be set up in good mill; these investigations were confirmed and extended by Haubner, Hermbstädt, Mosler, and others, and recently more especially by Neelsen and Hueppe. Neelsen has 
described bacilli which undergo an extensive change of form, and which always ultimately break up into cocci; but these observations evidently depended on contamination of the cultivations with other forms of bacteria, sucl a contamination being almost unavoidable with the methods of cultivation employed at that time. It is now quite easy by the lielp of gelatine plates to isolate the characteristic bacteria from any specimen of blue milk.

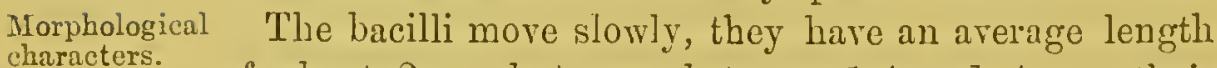
of about $2 \mu$., but vary between 1.4 and $4 \mu$.; their thicliness is about $4 \mu$., and in stained preparations it also shows slight variations. In preparations from milli their size is more uniform. At the ordinary temperature spore formation occurs in gelatine, in mill, \&c.; the spores are formed at one end, so that the spore and the remains of the bacillus often present a club form. In unsuitable

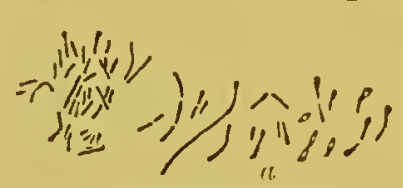

Fig. 96.- Bacilli of blue milk $\times 700$.

At $a$ we see spore-bearing bacilli, and others with unstained portions of plasma. nutrient solutions, for example in slightly acid solutions of tartrate of ammonia, or Cohn's nutrient solution to which nitrate of potash is added, involution forms often appear, the bacilli being club-shaped or spindleshaped, or presenting the form of long threads, with spherical dilatations at interrals.

Cultivations. In gelatine plates small greyish-white points appear after two days, and these spread out on the surface in the form of moist clrops, 1 to $2 \mathrm{~mm}$. in breadth. The whole plate assumes a steel greyish-blue colour, so tiat the white colonies become gradually more distinct. Under low powers the smallest deeply-lying colonies present the form of circular dises with black centre and brownish granular margin, and witl a sharp black outline. The superficial colonies show a blackishbrown centre, around this a greyisll-brown area, and further outwards a narrow, yellowish, finely granular zone with sharp outline.-In puncture cultivations a whitish deposit is formed especially on the surfice, and from this growth a dark stecl blue staining of the gelatine spreads downwards.-On jotatoes a jellowisl moist 
deposit is formed, and in the ncighbourlood the substance of the potato assumes a deep greyish-blue colour. At times the gelatine has a more greenish shade; distinct green colour is produced, for cxample, in solutions of tartrate of ammonia, of leucine, asparagine, \&c., but this green pigment only represents a lower stage of oxidation of the blue, and can be transformed into the blue by oxidising agents. - When inoculated in sterilised milk the bacilli cause no coagulation and no acidity, but gradually produce a slightly alkaline reaction; further, a slate-grey colour, which, however, on the addition of acid becomes an intense blue, appear's in the first instance in the layer of cream, and then spreads downwards through the whole fluid. In milk which has not been sterilised, and Charaeter of in which the lactic acid bacilli are growing at the same the pigment. time, the colour is sky-blue from the first.-In milk the colouring matter seems to be formed at the expense of the casein, while the milk sugar remains unaltered; the bacilli, however, are able to build up the colouring matter synthetically in fluids which only contain lactate of ammonia, or tartrate of ammonia without any albumen. The optimum of temperature for the production of the pigment is from $15^{\circ}$ to $18^{\circ} \mathrm{C}$; ; above $25^{\circ} \mathrm{C}$. the pigment production is delayed; at $37^{\circ} \mathrm{C}$. no colouration of the nutrient solution occurs. The pigment is not an aniline dye, but more accurate investigations as to its properties and its nature are still wanting.-The bacilli and the milk in which they are growing have proved to be quite harmless to animals, even when injected into the veins.

Among the bacilli which cause fermentation of carbohydrates, the following must be mentioned:-

\section{Bacillus acidi lactici.}

(Lactic acid bacteriu.)

The phenomenon which has been for a long time woll known, that when milk is kept for some time the milk sugni becones transformed into lactic acid, and, as a 
Formation of lactic acid by varions kinds of bacteria.
Lactic acid hacillus. кат $\mathfrak{\epsilon} \xi \circ \chi \hat{\eta} \nu$.

Morphological cliaracters. result, the casein coagulates, was first ascribed by Pasteur to the action of definite micro-organisms. Nevertheless, Lister secms to have been the first to obtain a pure cultivation of lactic acid bacteria by the employment of the so-called dilution method.-As the result of the investigations of the last few years the views adrocated by Pasteur and Lister have in so fur undergone an important modification in that, according to more recent experience, the power of forming lactic acid from carbohydrates, and more especially from the milk sugar of the milk, evidently appertains to a large number of species of bacteria, and differences among these species exist mainly as regards the quantitative production by each kind. For example, this property is possessed by all the pyogenic organisms, more especially by the staphylococci, then by the bacillus oxytocus perniciosus; the bacterium coli commune, and bacterium lactis aerogenes; further, by a species of bacteria isolated by Miller from carious teeth; lastly, according to Hueppe's experience, by bacillus prodigiosus, and by a species of coccus isolated from the secretion of the mouth, and growing in the form of flat white knobs. Undoubtedly the number of organisms which are capable of causing lactic acid fermentation is not exhausted by these 15 species.

Nevertheless, one definite organism seems to have the right to the designation "lactic acid bacterium," becruse it is evidently by far most frequently the cause of the spontaneous clotting of milk, and because also it is marked out from the other bacteria which have a similar action by its wide distribution, and by the intensity of its effect. This lactic acid brcillus has been accurately described by Hueppe, and is probably identical with that observed by Lister and Pasteur.

This bacillus forms short, thick cells, which are at least half as long again as broad, and are usually united in pairs, seldom in fours. Under too low a power the individual cells may present the appearance of oval cocci, but when moro highly mugnified we see distinctly that the outlines are parallel, and that the ends are slightly narrowed in the longitudinal direction. The arerage 
length of these rods is, according to Hueppe, 1 to $1.7 \mu_{\text {. }}$, their breadth 3 to $\cdot 4 \mu$, but rods as long as $2 \cdot 8 \mu$, also occur. The bacilli have no spontaneous movement. In solutions of sugar they show distinct spores, which are also formed in milk, but are much more difficult to recognise in that medium. The spores appear as refracting globules at the ends of the bacilli; if two bacilli are united together the spores often appear at the ends furthest removed from each other, but often also at the adjacent ends. Bacilli containing

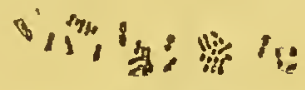

Fig. 97.-Lactic acid bacillus $\times 700$.

Cover glass preparation from a fresh cultiva. tion. these spores are not killed when boiled for a short time.The bacilli grow readily on various soils. In gelatine Cultirations. plates they form on the second day whitish colonies, which under a low power, and so long as they are deeply siturted, present the form of circular discs, miformly dark, and with sharp black outlines; those which occur on the surface are surrounded by a somewhat clearer marginal zone. In puncture cultivations a deposit, which is at first delicate, and later somewhat denser, and which forms at parts discrete spheres, appears along the whole track of the needle. In stroke cultivations the individual colonies, which are at first circular, run together and form a narrow white stripe, with irregular border's.

Lactic acid fermentation can be set up with pure cul- Conditions of tivations of these bacilli in solutions of milk sugar, cane factic acid sugar, mannite, and dextrose. In addition to lactic acid, carbonic acid is also always formed. When more than 8 per cent. of lactic acid is present in the fermenting mixture, the progress of the fermentation is interfered with, and hence when it is desired to carry the fermentation further it is necessary to add chalk in order. to neutralise the acid.

According to Hueppe, free oxygen is necessary for the Necessity for occurrence of the fermentation; nevertheless, very oxygen, small quantities are sufficient in order to pormit the formation of the amount of lactic acid necessary to cause coagulation of the casein; but larger quantities of acids appear to be formed only when there is a corre- 
spondingly larger amount of oxygen present. The optimum of temperature lies between $35^{\circ}$ and $42^{\circ} \mathrm{C}$.; Inoculation on at $45 \cdot 4^{\circ} \mathrm{C}$. fermentation censes.-If a small portion of a
milk.

pure cultivation is introduced into milk, previously sterilised at $100^{\circ} \mathrm{C}$, the latter becomes uniformly gelatinous in 15 to 24 hours at the body temperature. Here and there small spaces are visible in the coagulum, containing bubbles of carbonic acid. At a later period the coagulum contracts somewhat, and clear serum collects around it. The coagulum does not become peptonised subsequently.

Delydratiog. propertics of the bacilli.

Rennet-like precipitation of the casein by bateria.

It appears that the lactic acid bacilli dehydrate the milk and cane sugar before they cause their fermentation. They are also able to convert starch into sugar in the same manner as a diastatic ferment. (See under "Ferments.")

It must be borne in mind that the casein of mill is not only congulated by lastic acid, but also by remnetlike ferments, and that, as Duclaux first showed, a number of bacteria are able to furnish these ferments, and thus without the formation of lactic acid to coagulate the casein; the reaction of the material is amphoteric, that is to say, slightly acid, and slightly alkaline. This property occurs, for example, in the bacillus butyricus, in the so-called potato bacillus to be described below, in sarcina lutea, in a large coccus cultivated by Hueppe from water, and causing liquefaction of the gelatine, and probably also is many other bacteria. The same bacteria frequently exert a subsequent peptonising action on the coagulated casein.

\section{Bacillus butyricus.}

\section{(Clostridium butyricum, Bacillus amylnbactcr.)}

Butyric acid bacillus.
In the case of the butyric acid fermentation we must probably also come to the same conclusion as in that of the lactic acid fermentation, viz., that several kinds of bacteria can cause this fermentation of carbo-hydrates, and this without reckoning those bacteria which form butyric acid from other materials (for example, the 
bacilli of greenish-blne pus from glycerine, \&c.). Pasteur, Butyric acid Prazmorski, Fitz, and Hupe have each described formentation Prazmowski, Fitz, and Hueppe have each described caused by bacilli which cause butyric fermentation, but which various according to the descriptions as yet given are not the same species in each case, although some of them have not been sufficiently accurately studied to enable us to come to a conclusion as to their identity. According to investigations in the author's laboratory the number of butyric acid bacilli is probably very considerable; but the majority of these, on account of the fact that they are anaerobes and cannot be isolated and cultivated pure by the ordinary methods of cultivation, present such great difficulties in their diagnosis that we must await further investigations in order to obtain an accurate knowledge of these forms. In the following description we shall take as our basis the description of the butyric acid bacillus given by Prazmowski, which corresponds fairly well with that of Pasteur and van Tieghem, but which lias not been based on pure cultivations; secondly, we may describe for the present as a separate species an anaerobic bacterium, the characteristics of which have been studied by Liborius in the autlor's laboratory-with regard to its fermentative activity, accurate analyses are wanting, but it is possibly identical in its morphological and biological characters with Prazmowski's organism; and in the third place we must mention the bacillus isolated by Hueppe from milk, and which differs in an important manner from those previously mentioned on account of its aerobic properties.

\section{Bacillus butyricus (Prazuowsiri).}

This organism presents the form of rods 3 to $10 \mu$. 1. Prazmow. in length, and $1 \mu$, or somewhat less, in breadth. It ski's butyric frequently forms chains, or apparently threads, which have not undergone segmentation. It is usually actively mobile, but at times it is at rest and forms zooglœa. After some time the rods cease to grow in Morphological length and increase in thickness; the shorter rods characters increase in thickness chiefly in their middlo, and 
Anaerobic properties. assume a spindle form; the longer are often enlarged at onc cnd like a tadpole. The swollen rods may attain a breadth of from 1.8 to $2.6 \mu$. At the same time the plasma becomes more highly refracting, and the membrane markedly thickened. When this has taken place spore formation commences; the ovoid spores are 2 to $2.5 \mu$. in length, and $1 \mu$. in breadth, they become free by solution of the membrane of the mother cell. The spores sprout in the following manner :-At one of the pointed ends of the longish spore the double contour of the spore membrane disappears, and the germinating tube passes out; the longitudinal diameter of the latter is parallel to that of the spore. The dense spore membrane does not shrink, and often remains attached to the young rod for a long time.

This bacillus is a typical anaerobe; its whole rital
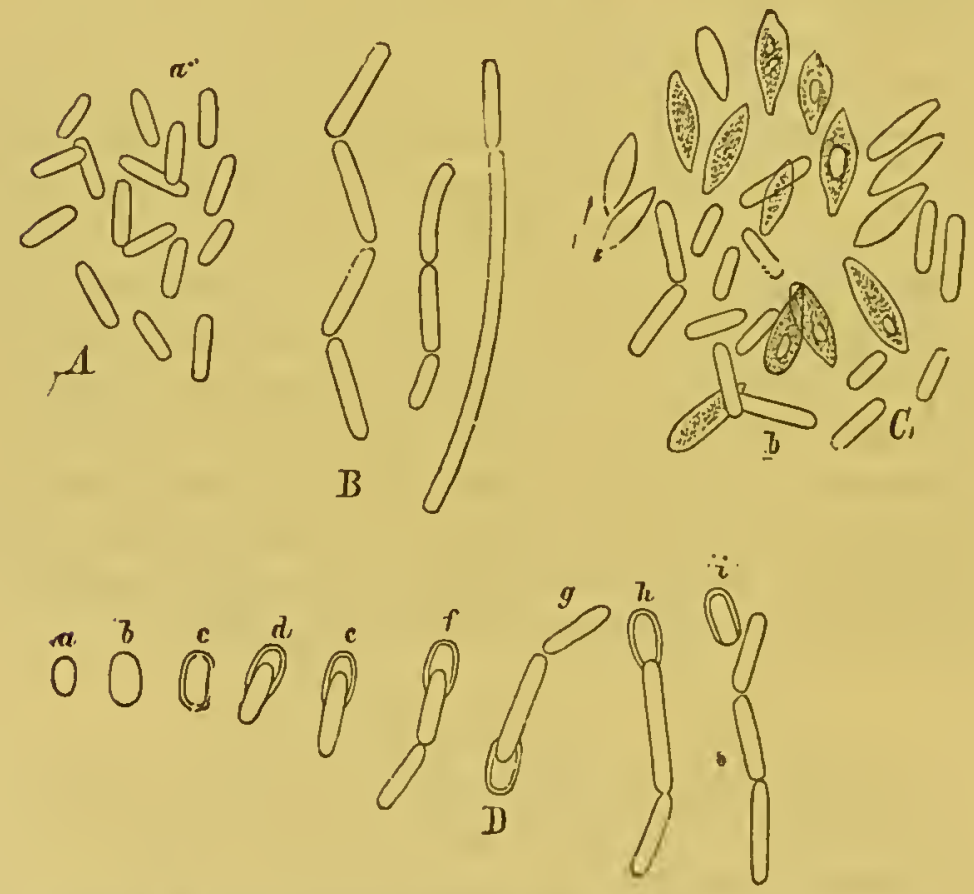

Fig. 98.-Bacillus butyricus (nfter Prazmowski) $\times 1020$. $A$ and $B$, colonies and chains of bncilli.

$C$, colonies with swollen, spindle-shaped, and spore-forming bacilli. $D$, germination of the spores; $a$ to $i$, successire stages.

functions secm to go on quite independently of the presence of free oxygen, and, in fact, they are inter- 
fered with when considerablo quantities of that gas are present. The spore formation and the sprouting of the spores appear's also to occur only when oxygen is ubsent. Hence it differs markedly in its physiological characters from the bacillus subtilis, which in other respects resembles it. Further, the spores of bacillus butyricus do not show the same resisting power as the spores of bacillus subtilis. The boiling temperature continued for five minutes is sufficient to kill them.

Intense fermentation can be readily set up by the Conditions of bacillus butyricus. In solutions containing starch, dexfermentation. trine, sugar, or lactates, a considerable quantity of butyric acid is formed in the course of a few days as the result of the action of the bacillus butyricus, carbonic acid and hydrogen being at the same time given off. The ressels containing the nutrient solutions in which these fermentation experiments are made should be kept hermetically sealed, and freed as far as possible from air before the bacilli are introduced; the high pressure which the accumulated gases exert after a short time does not at all interfere with the development of the bacillus and the progress of the fermentation. The same bacillus is the cause of the butyric acid fermentation which occurs in old milk, and in the ripening of cheese. In the case of milk this fermentation commences after the active growth of the lactic acid bacteria has converted a large portion of the milk sugar into lactic acid, either because the necessary removal of the oxygen is accomplished by the previous development of the aerobic lactic bacilli, or because the mill sugar is dehydrated by the lactic bacilli and thus converted into good fermentescible material. The best temperature for the fermentation is between $35^{\circ}$ and $40^{\circ} \mathrm{C}$. Just as in the lactic fermentation so here we must add chalk to the fermenting mixture in order to prevent the disturbing effect on the bacillus of the accumulation of acid.-According to Fitz the bacilli aro also able to dissolve casein slowly, but not to cause the direct fermentation of sterilised milk, or its coagulation, because they are not able to break up milk sugar. 
Ioline renetion.

Other fermentative action.

A property which occurs under certain circumstances, and which is peculiar to the butyric acid bacillus, is the power of forming a material (granulose) in the plasma, which assumes a blue or blackish-violet colour with iodine. This property can be most readily observed when the bacillus is cultivated in media containing starch; but the coloration also occurs in the absence of starch when, instead of it, cellulose, or lactate of lime, or glycerine is present; it seems to occur seldom in nutrient solutions containing dextrine and sugar. Young rods stain of a pure blue colour, older rods of a dark violet; in some only a few transverse zones are blue, in others the rods are continuously stained (compare also Leptothrix, page 392 ; bacillus polymyxa, page 374 ; bacillus Pasteurianus, page 390 ).

It is possible also that the bacillus butyricus has another fermentative action, in that it is able to cause fermentation of cellulose; according to Tappeiner, methane, carbonic acid, and sulphuretted hydrogen, or only hydrogen and carbonic acid are formed according to variations in the composition of the nutrient substrata. (See the chapter on "Fermentation.") This decomposition of cellulose has probably a certain technical importance, for example in the preparation of flax, and is perhaps also of physiological significance in the digestion of cellulose by herbivora. (Van Tieghem ascribes the property of destroying cellulose to a special bacterium called bacterium amylobacter, an organism, however, which this author stated at a later period to be identical with the butyric acid bacillus described by Pasteur).

Distribution. Bacillus butyricus seems to be extremely widely distributed in nature; it can be obtained from hay-dust, from a great variety of putrefying vegetable infusions, from sauerkiaut, from old cheese, from milk which has been kept for a long time; according to Déherain and Maquenne* it occur's also in the earth of fields. It has also been observed in the cells of plants which have a milky juice. Van Tieghem was able to recognise it

* Bull. soc. chim. (2), 39.-Compt. Rend., 37. 
from its morphological peculiaritics in fossil conifers of the coal formation.

\section{Bacillus butyricus (Liborius).}

Liborius' butyric acid bacillus presents scarcely any 2. Liborius' noticeable difference from the former in its morphological bacillus. characters, more especially in its mode of spore formation. Cultivations in solid nutrient media (nutrient agar, or nutrient gelatine, best when grape sugar is added) only succeed when a fairly thick lajer is emp'oyed, and in this case a superficial zone, about 3 $\mathrm{cm}$. in breadth, usually remains free from growth; the organism can also be cultivated in nutrient substrata from which the oxygen has previously been expelled by some other gas. Further, it is of importance not to inoculate the solid gelatine by the puncture method, and thus to form a canal for the air, but to mix the material with liquefied gelatine. In this case whitish, but not sharply defined colonies appear in the course of one or two days, and after 24 hours more become surrounded by a narrow line of liquefaction; the extent of the liquefaction gradually becomes greater, and the whitish mass of the colony sinks to the bottom; ultimately these globules coalesce, and at the same time gas bubbles usually penetrate into the upper part of the gelatine, drive out the oxygen from it, and thus the growth and the liquefaction gradually extend upwards. - In nutrient agar the form of the young colonies can be better recognised; and it is then seen that their outline is irregular, and even to the naked eye shows a fincly branched appearance; under a low power the delicate ramifying threacls around the margin of the colony form a very characteristic picture. In the test-tubes containing agar active development of gas also occurs, so that the upper portion appears as if it had been split. These gases have a disagreeable smell, often recalling that of pure butyric acid; other gases, which probably arise from the simultaneous decomposition of the albumen, are also often present. A more accurate analysis of the formentative products is still wanting. 
3. Hueppe's aerobic butyric acid bacillus.

Action on milk.

Organisuns of kephyr.

The course of the kephyr fermentation.

\section{Bacillus butyricus (Hueppe).}

Hueppe was able to isolate large bacilli from milk which was sterilised sufficiently to prevent the lactic fermentation, but in which the casein became precipitated later, the reaction of the medium being at first unaltered, and later slightly alkaline; these organisms resembled morphologically those described by Prazmowski, but were much less sensitive to oxygen. I'hey grew in nutrient jelly, and led to rapid liquefaction of it, and no precautions with regard to the removal of oxygen were necessary.These bacilli are unable to cause directly the fermentation of milk sugar, and only form butyric acid when the milk sugar has been either dehydrated by other bacteria or when lactates are present. They also cause coagulation of the casein like the rennet ferment, and then they split up the casein, and produce peptone, leucine, tyrosine, ammonia, and substances with a bitter taste. The coagulum of casein, which is at first precipitated from sterilised milk by the butyric acid bacilli, presents, after about 8 days, an appearance as if its edges were being eaten away, and it gradually disappears almost entirely.

\section{Bacillus caucasicus.}

\section{(Dispora caucasica, the ferment of licphyr.)}

Au intoxicating drink has been repeatedly obtained from milk by alcoholic fermentation, as for example in the preparation of koumis from the mill of mares by the inhabitants of the Kirghiz steppes, and also in the preparation of kephyr from the milk of cows, as has been done from ancient times in the Caucasian highlands. In these cases the alcoholic fermentation appears to be always occasioned by a torula; as, howerer, the milk sugar of mills cannot undergo the alcoholic fermentation directly, something must be added to it which is able to transform the milk sugar into fermentescible glucose. This transformation is carried out in an energetic mamner by the ordinary lactic acid bacterin, and thus an alcoholic fermentation of milk may be set up by the combined use of lactic acid bacteria and jeast cells. But the lactic 
acid bacteria always transform at the same time a portion of the milk sugar into lactic acid, and this leads to the coagulation of the casein, and thus ultimately a drink results which contains alcohol, but which also has a rery sour taste, and in which coagulated casein, usually in the form of finely divided flakes, is suspended. According to Hueppe, other bacteria are also present in the kephyr which are able to peptonise the casein, so that we have here a combined action of three micro-organisms.

The ferment of kephyr, which includes two or three Constituents active fermentative agents, can be dried, preserved for a of the kephyr long time, and sent from one place to another. In the milli the kephyr granules grow and form largish fungus masses which are composed of numerous microscopic globules. In these globules, according to Kern and Krannhals, three structures can be distinguished under a high power-yeast cells, fairly long rods, and smaller cells, which are looked on as free spores. The long rods have been accurately described by Kern, and called Dispora cancasica.

These bacilli are $3 \cdot 2$ to $8 \mu$. in length, and $8 \mu$. in Morphological breadth. At one end a flagellum can sometimes be seen, characters of and in fresh preparations the bacilli show spontaneous morement in the form of a slow, pendulous, and see-saw motion. The spore formation appears to be very characteristic; on each rod two terminal spherical cells are. formed, and threads containing rows of spores occur, the spore being always so arranged that each of the cells contained in the thread has two spores. The spores which lie in the cells are about $8 \mu$. in diameter, those which are free attain a size of $1 \mu$, and those which are sprouting may swell up to about $1 \cdot 6 \mu$. The usual mode of sprouting of the spores is that the thinner endosporium first projects out of the thicker exosporium like a small wart,

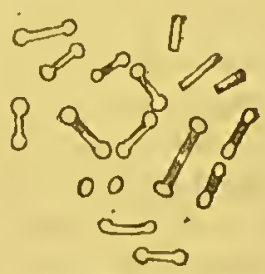

Fig. 99.-Disporn cancasica $\times 1000$.

(After Krannhals.) which gradually increases in size, and develops in the form of a cylindrical tube.-According Cultivation to Kern a suitable nutrient solution is formed by 5 experiments. 
parts of phosphate of potash, 5 parts of sulphate of magnesia, $\cdot 5$ parts of chloride of calcium, 9 parts of tartrate of ammonia, $44 \frac{1}{2}$ parts of milk sugar, and 1,000 parts of water; according to Krannlals they also grow in mixtures containing extract of meat, milk sugar, and gelatine. Investigators have, however, not as yet succeeded in making out any definite culture cliaracteristics.

The yeast cells which are also present in the kephyr are round or egg-shaped, 3.2 to $6.4 \mu$. in diameter, and occur singly and in various stages of budding; spherical and ovoid spores are also seen.- We must await further investigations of these organisms, and more especially pure cultivations, in order to obtain a clear understanding of the peculiar fermentative process which takes place in the preparation of kephyr. (See under "Fermentation.")

The culture characteristies and the fermentative products of the following bacilli which act on media rich in sugar are imperfectly known.

Bacillus polymyxa (Clostridium polymyxa), Prazmowski.This organism exactly resembles bacillus butyricus in size, shape, and mode of development, and occur's along with it. The ouly differenee between the two organisms is that in the case of the bacillus polymyxa we find here and there peculiar dilated and wary threads without any distiuct segmentation, and these break up at a later period into slorter segments; it is probable that these structures are inrolution forms. Further, these bacilli usually require free oxygen for their growth and spore formation, and do not exert ans fermentative action under normal conditions; but if the access of oxygen is prevented they set up intense fermentation, the exact nature of which is not known, in infusions of potato, lupin-seeds, \&c. 'The bacilli form a scum on the surface of nutrient solutions; on boiled beet-root they form gelatinous masses of large extent, and of cartilaginous consistence like those of lenconostoc and ascococeus.-In nutrient solutions containing stareh the bacilli show a faint blue colour when treated with iodine, but this reaction is not found when they are growing in solutions in which starch is not present.

Bacillus dysodes (Zopf).- These are rods forming threads which break up into short rods and cocci, and ench of these rods produces an elliptical sporc. They eanse peculiar fermen- 
tative ehanges in bread, forming there fluid substances with a disagreenbie smell (similar to that of a mixture of peppermint and turpentine oil), and the result of their growth is that the bread beeomes grensy in its interior and unfit for usc. If the yeast is washed with a half per cent. solution of hydroehloric acid, the hurtful action of the organism seems to be prevented.

As to the production of glnconie acid, acetic aeid, propionic acid, \&e., from carbo-hydrates as the result of the growth of bacteria, see the ehapter on "Fermentation."

Bacilli which are able to split up the albuminous Putrefactive molecule with the development of gaseous foul-smelling products, and thus set up putrefactive fermentation of a more or less intense character, are apparently very common. Among the bacteria already described, and which chiefly act in this manner, may be mentioned bacillus butyricus, bacillus prodigiosus, bacillus fluorescens putidus, bacillus fluorescens liquefaciens, and a bacillus isolated by Miller* from the intestines, but not as yet more accurately described, and which furnishes sulphuretted hydrogen and ammonia; also the bacillus ureæ, to be mentioned below; all these organisms are able to split up albumen or gelatine, with the formation of foul-smelling products. The following may also be mentioned as having considerable power in this respect.

Bacillus pyogencs fotidus (Passet).

This organism was obtained by Passet from the foul- Passet's putresmelling pus of an abscess. It consists of short rods, factive rounded at the ends, with slow movements, $1.45 \mu$. in pus. length, and $.58 \mu$. in breadth, and frequently arranged in pairs or in groups. One or two unstained spots can at times be seen in the interior of the rods; these are probably spores. In gelatine plates white points appear after 24 hours, which develop at the surface in the form of greyish-white patches, extending to about $1 \mathrm{~cm}$. in diameter, and becoming confluent, thicker, and whitish in the middle, thinner and greyish towards the margin. In puncture cultivations only fine points appear along the track of the needle, but on the surface a delicate

* Miller, Deutsche med. Woch., 1885, Nr. 49. 
greyish-white veil-like growth is formed, which is somewhat thicker, and irregular at the margin. On potatoes the bacillus forms luxuriant glistening, lightbrown cultivations; on blood serum, thick, whitish lines. In all these mutrient media a foul smell is de-

Fig. 100.-Bacillus pyogenes fœtidus (Passet) $\times 790$. veloped.-Animals are not affected by small doses administered subcutaneously, but when the quantity is larger a localised suppuration occurs.

Bienstock's patrefactive bacillns from freces.

Spore formation and germination.

\section{Bacillus putrificus coli (Bienstock).}

These are thin, actively moving rods, about $3 \mu$. in length, though often shorter, and often arranged in the form of long threads. When spore formation takes place a thickening of the rod occur's at one, or, more rarely, at both ends, and this thickened part becomes gradually isolated from the rod, and assumes a spherical form. This spore remains for some time in connection with the rod, giving it thus the form of a drum-stick, and the rod continues to move about with the spore attached to it, that end of the bacillus being in front. As the result of the gradual disappearance of the rod the spherical and very highly refracting spore becomes free; if this spore is introduced into suitable nutrient material it becomes narrower and gradually elongates to form a rod. From these freshly formed rods chains of very short rods arise, these shorter bodies gradually growing to form longer rods and threads.The growth of the bacilli on nutrient gelatine has at first a mother-of-pearl aspect, but as it becomes older it acquires a yellowish colour, and presents a homogeneous appearance without any striped arrangement. More accurate statements as to the characters of growth are as yet wanting. Bienstock was able to demonstrate by careful analytical fermentative experiments that the bacilli can split up albumen energetically; when small quantities of a cultiration of 
these bacilli aro introduced into Cohn's nutrient solu- Chemical tion containing fibrino in suspension, the following analysis of the substances are proluced, namely, peptone, ammonia, fermentation. amine bases, fatty acids, amido fatty acids, tyrosin, phenol, paraoxyphenylpropionic acid, paraoxybenzoic acid, indol, scatol ; further, when the bacilli act on these individual products the lower series of decomposition products

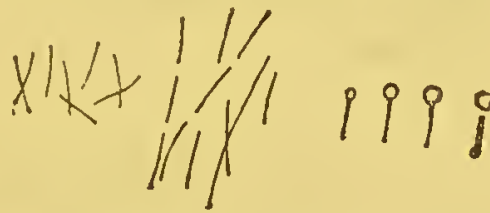

Fig. 101.-Bacillus putrificus coli (Bienstock) $\times$ about 1000 are produced; for example, tyrosin gave rise to paraoxybenzoic acid, the latter to phenol, \&c. Albuminates of the allialies are either not at all or only very gradually broken up. When air is excluded the whole process Necessity for runs its course somewhat more slowly, but otherwise oxygen. in a similar manner.-The bacillus appears, according to Bienstock, to be constantly present in freces, and is only absent in that obtained from infants fed exclusively on milk.

\section{Bacillus saprogenes, No. 1 (Rosenbach).}

These organisms have been repeatedly obtained by Rosenbach's Rosenbach from stinking secretions or as an accidental putrefactive contamination, \&c. They are fairly large bacilli, which produce a large spore at one end. Stroke cultivations on agar show a greyish-yellow, opaque line, which, however, is still transparent when viewed by strong transmitted light; it is about $1 \mathrm{~mm}$. in height, and of a tenacious, soupy consistence; at a later period a sort of wavy bloom is formed, so that the surface presents a shell-like appearance. The bacilli also grow on blood serum (nutrient jelly was not tried), and on both of these nutrient soils an intense putrefactive odour is produced.

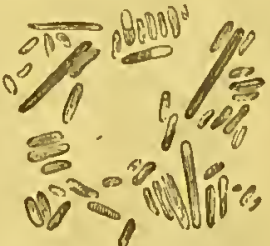

Fig. 102.-Bacillns saprogenos, No. 1 (Rosonbach) $\times 962$ Erg albumen and meat are rapidly decomposed by the 
bacilli when air is present, with the production of foul smell, while in the absence of air only a slight effect is produced.-Fluids containing these bacilli when injected into rabbits or dogs, either subcutaneously or into the joints, or into the pleura, caused no bad effects.

\section{Bacillus saprogenes, No. 2 (Rosenbach).}

This organism was isolated by Rosenbach from foul smelling sweaty feet. The organisms are bacilli, thinner and shorter than those just described. When inoculated on agar rapid superficial growth occurs; if a fine stroke has been made the whole surface appears on the next day as if sprinkled with minute drops, the growth gradually spreading over the surface in an equally thick layer, which at first has a watery appearance, but later is whitish-grey and of a tough, gelatinous consistence. The cultivations give off Fig. 103.-Bacillus albumen and meat are rapidly decomsaprogenes, No. 2 . posed in the presence of air with the
(Rosenbach) $\times 962$. formation of stinking gases; when oxygen is absent distinct, though delayed, putrefaction occurs.-When the cultivations were injected into the knee and pleural cavity of rabbits these animals died from suppurative inflammations.

Bacillus saprogenes, No. 3 (Rosenbach).

In two cases of suppuration of bone accompanied by septic symptoms Rosenbach obtained, among other

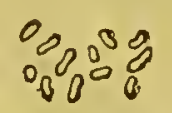
bacteria, a short, thick bacillus, with rounded ends. When stroked orer agar a layer about $3 \mathrm{~mm}$. in breadth is deFig. 104.-Bacillus veloped in about 8 days at the tempersaprogenes, No. 3 ature of the room, this layer being of
(Rosenbach) $\times 962$. ature an ashy grey colour, and almost fluid; at the same time the material gives off a foul putrefactive odour. Egg albumen is rapidly broken up and 
undergoes putrefaetion after infeetion with cultivations of the baeilli in the presenee of air; when air is absent there is at first violent decomposition, whieh, lowever, soon eeases.-Suppuration oeeurred in rabbits after injeetion of the bacilli into the knee joint.

\section{Bacillus coprogenes foetidus (Sehottelius).}

In the eourse of investigations on swine erysipelas Schottelius' Schottelius found that in all eases some of the puncture intestinal eultivations in nutrient jelly, where the infeetive material was taken from the organs, more especially from the mesenterie glands and the spleen, contained, besides the eharacteristie colonies of the erysipelas bacilli, also a few light yellow spherical eolonies, eomposed of larger baeilli. These rods are about as thick as the hay baeilli Morphological but shorter; but the length of the individual baeilli characters. differs markedly, aeeording to the nutritive eonditions. They are non-motile. The ends of the rods are rounded. In eultivations spore formation oecurs after 3 or 4 days at the temperature of the room; the spores are arranged in rows; when they germinate the long axis of the new rod is at right angles to the long axis of the spore, so that from a row of spores six or eight small rods may grow out, lying with the long diameter parallel to each other. The spores are only formed when air is present, and do not appear in the animal body. In the Cultivations. deeper parts of the nutrient jelly the bacilli form pale yellow closed eolonies which do not liquefy the jelly; on the surface they produee a fine, transparent, greyish layer. The eultivations give off an intense putrefactive odour. On potatoes a light grey dry layer, about $\cdot 5 \mathrm{~mm}$. in thicliness, is formed.-Sub-

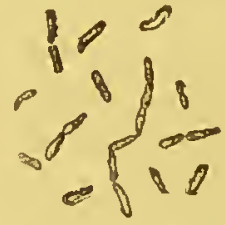

Fig. 105.-Bacillu coprogenes fotidus (Schottelius) $x$ about 600 . cutaneous injections of small quantities of the cultivation produeed no effeet on mice and rabbits; but very large quantities produeed a toxie effect in rabbits, but none on swine.

The samo organism eould be demonstrated by Sehot- 
l'enetration of the bacilli from the intestine into the internal organs in swine affected with erysipelas.

telius in the intestinal contents of the swine; and as in the cases investigated these bacilli were always most numerous in the organs lying in the immediate neighbourhood of the intestinal canal, while they became fewcr and fewer in the organs which were more remote from it, it is probable that they enter the body by the intestinal ulcerations which usually occur in this disease, and that they are purely secondary, and on the whole without any important significance.

\section{P'roteus vulgaris (Hauser).}

Hauser's putrefactive bacilla.

Hauser has shown that in putrefying animal substances, in all putrefying meat infusions, in the contents of putrid ulcers, \&c., three species of bacteria almost always occur which show many characters in common, Morphological but also some constant differences.-The most common characters. of these varieties-Proteus vulgaris-forms rods on an average $6 \mu$. in thickness, and of very varying length; according to the conditions of their life they are sometimes very short, forming almost spherical bodies, sometimes they have the appearance of bacilli 1.25 to $3.75 \mu$. in length, sometimes they appear as threads. These threads are sometimes twisted and convoluted, sometimes they present an appearance like plaited hair. Hauser designates these formations as spirilla and spirulina; they, however, give the impression of accidental twistings caused by a varicty of external conditions, and not of a characteristic type of growth recurring in successive generations (sce p. 175).-Many of the rods are in active movement; in some distinct

Involution forms.

Cultivations. long cilia can be seen. Involution forms are frequently observed, large, for the most part spherical bodies, on an average $1 \cdot 6 \mu$. in diameter.

The growth of these rods in 6 per cent. nutrient jelly is extremely characteristic. At the temperature of the room round depressions, containing liquefied gelatine and whitish-grey turbid masses of fungi, appear on gelatine plates, even after 6 to 8 hours. Under a low power we see that the gelatine around these depressions is corered by 
a narrow zone of bacteria two or three layer's in thickness, Superficial this zone being at the outer part surrounded by a single colonies. layer of bacteria. From the latter tongue-like branches and projections pass outwards, and these projections, which consist of groups of rods and threads, constantly vary their position, become separated, and pass with a slow gliding movement over the surface of the gelatine, forming isolated islands and anastomosing threads ; after some time and at a favourable temperature $\left(20^{\circ}\right.$ to $22^{\circ} \mathrm{C}$.)

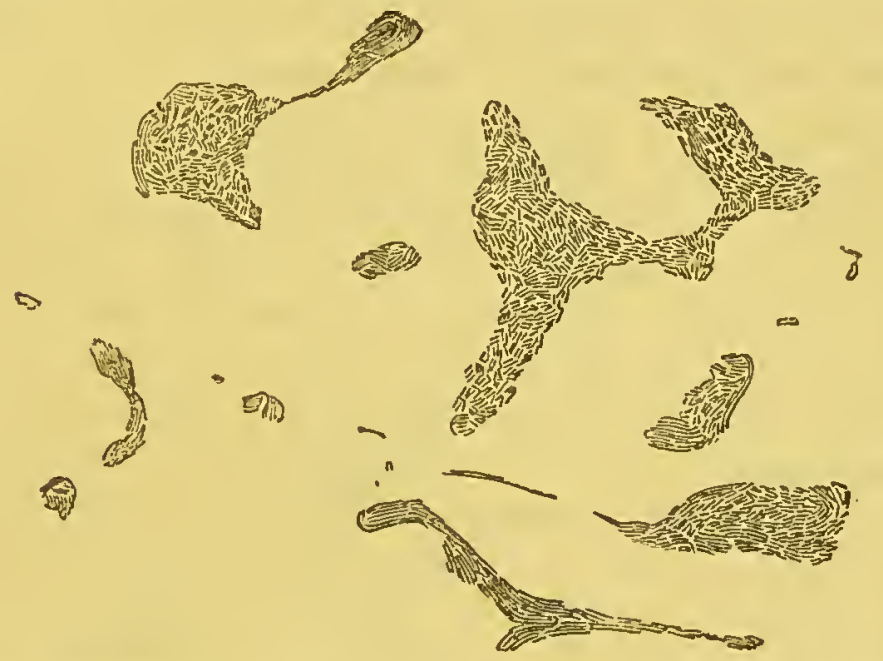

Fig. 106. Swarming islands of proteus vulgaris (Hauser) $\times 285$.

active changes of situation can be seen to be going on in all these islands and threads, and circular movements are more especially evident. Gradually the whole surface of the gelatine becomes covered with wandering: colonies; from that point rapidly progressing liquefaction occurs, which, after 24 to 48 hours, affects the whole surface to a depth of about $1 \mathrm{~mm}$. At the samo time there is a foul smell and a marked alkaline reaction.

While these phenomena are observed in the superficial Charucters of colonies, a ray-like arrangement, composed of chains of placed rods, is formed around the deepor zooglica masses; colonies. these chains as a rulo run outwards in a radiating manner, and show a peculiar movoment in that they often shoot out and thon again retract. They gradually bore more deeply into the gelatine, the ray arrangement becomes more markedly developed, and the aroa of the 
liquefaction of the gelatine extends further; in tho periphery of this area actively moving rods are found, and also some which show distinct cilia, as well as convoluted Zooglea threads which are called spirilla and spirulina. Peculiar formation. zooglæa formations often extend from the circle of rays in the form of clubs or screws, or of spirules twisted like corkscrews. - In 10 per cent. gelatire the migration of the colonies is no longer observed. In meat infusion there is active growth and the development of foul smell; on the other hand, in Nägeli's and Cohn's nutrient solutions there is only slight multiplication of the organisms.

Necessity for If the oxygen is expelled from the vessels employed for oxygen. cultivation and replaced by hydrogen, the growth takes place only very slowly, and the liquefaction of the gelatine is likewise very gradual, though ultimately complete.The temperature optimum is between $20^{\circ}$ and $24^{\circ} \mathrm{C}$. Spore formation is never observed; nevertheless, drying of the cultivations in a thin layer does not destroy the Production of organisms. The bacilli set up putrefactive decomposition putrefaction. in fresh meat, and also in boiled and sterilised meat; this, however, does not occur when the fluid added to the meat has been filtered through plaster cylinders.Experiments In animals small doses produce no pathogenic effect, on animals. somewhat larger doses often cause abscesses at the seat of injection, large doses injected into the veins or subcutaneously produce symptoms of poisoning in rabbits and guinea-pigs. As the same effect was brought about by cultivations which had been filtered through plaster of Paris, it was evident that liquid poisonous materials were the cause of the pathogenic action.*

\section{Proteus mirabilis (Hauser).}

Morphological characters.

Thesc are rods $6 \mu$. in breadth and of very various length; they are sometimes almost round, sometimes in the form of rods 2 to $3.75 \mu$. in length. This form is distinguished from the preceding variety more especially by the much more frequent occurrence of inrolution

* 'That this is not the whole truth is evident from Mr. Watson Cheyne's paper on "Some Conditions of Infeetion," Brit. Med. Journal, July, 1886. 
forms, large spherical or pear-shaped or spermatozoa- More frequent like structures 3.75 to $7 \mu$. in diameter. Further, the involntion liquefaction of the gelatine occurs much more slowly than in Proteus vulgaris. After 12 hours a roundish, Cultivations. whitish deposit 2 to $3 \mathrm{~mm}$. in diameter has formed on the jelly plates, and under a low power this presents a finely granular brownish appearance, diminishing in thickness towards the periphery in a stair-like manner, and showing an irregular or wavy outline. As in the case of Proteus vulgaris, projections pass out from the

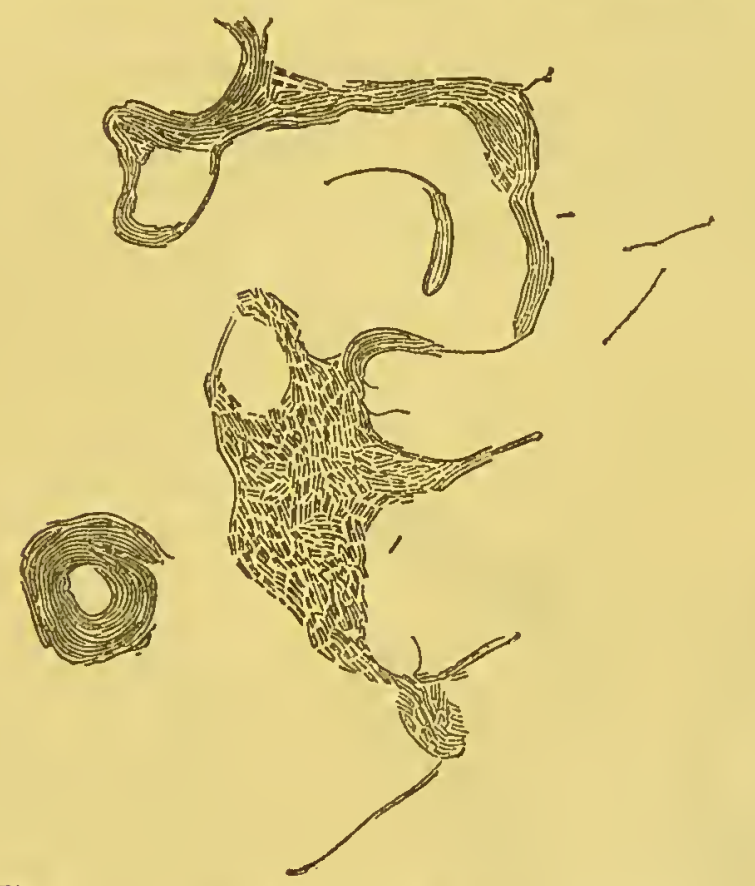
Fig. 107A.-Protens mirabilis (Hauser), swarming
islands, $\times 285$.

border, and these gradually become detached and move array; but in this case the movements are on the whole less active, and the network which is formed at the surface is characterised by the presence of threads of enormous length. In the moving islands we find the most marked involution forms. In the depth of the gelatine well-developed convoluted zooglia masses appear; the appearances thus produced recall those found by Klebs in the organism which he looked on as the contagium of syphilis, and which ho termed heli- 
Zooglaea formation.

comonas. At the outer margin of the puncture a ringlike zone appears which is filled with a network of

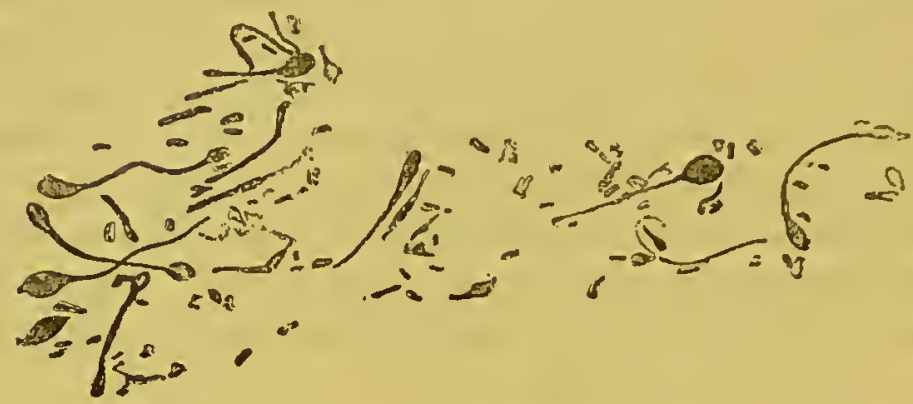

Fig. 107B, - Involution forms of Proteus mirabilis $\times 524$.

bacilli and"threads, and which shows numerous spirilla and spirulina forms. After about 48 hours the superficial colonies become confluent, and form a thick, moist,

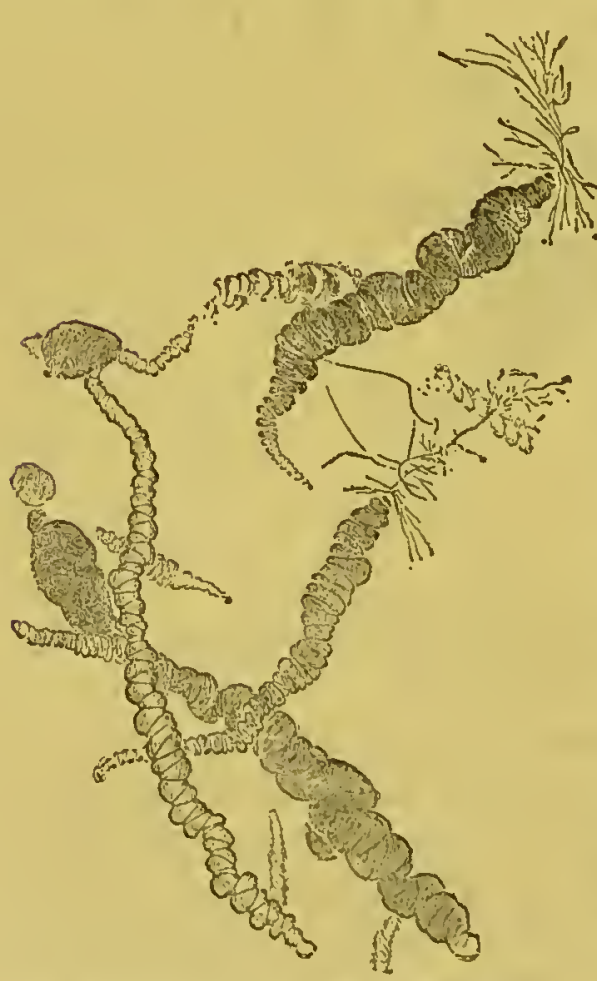

Fig. 108.-Zooglia forms from a cultiva: tion of Proteus mirnbilis $\times 95$. shining greyish larer, which presents a markedly sieve-like appearance. Total liquefaction of the gelatine does not begin till after 2 to 3 days.'The growth in stronger gelatine, and in the other nutrient materials, presents the same characters as in the case of Proteus vulgaris; but in cultivations in which oxygen is absent no liquefaction of the gelatine nccurs eren after a long time. Proteus mirabilis is also similar to the foregoing form in its fermentative action on egg albumen as well as in its pathogenic action. 


\section{Proteus Zenkeri (Hauser).}

These are bacilli $4 \mu$. in breadth, and of an average length of $1.65 \mu$; sometimes the forms are rounder, at other times longer. After inoculation on gelatine a layer, which towards the periphery becomes thinner like the steps of stairs, is formed around the point of inoculation, and from the margin of this layer numerous threads and rods begin to pass out; after 24 hours we find large numbers of moving islands, composed of rods and threads, presenting exactly the same appearance as in the case of Proteus mirabilis. The deposit becomes gradually thicker and opaque; but liquefaction of the gelatine does not occur (or only quite at the surface). The formation of spirilla and spirulina are seldom observed.-Cultivations in gelatine and blood serum do not show any marked development of smell; meat infusion, on the other hand, is decomposed with the production of a strong smell. In its other effects Proteus zenkeri resembles the species previously described.

\section{Anairobes which excite putrefaction.}

In a great variety of putrefying mixtures, as also in the intestinal contents, in the buccal secretions, \&c., a peculiar want of correspondence is observed between the numerous bacteria which are evident under the microscope, and the species which can be isolated by the ordinary methods of cultivation. As a rule, by the latter methods only a few colonies are obtained, or the nutrient soil remains completely sterile, even after several days, and in spite of all sorts of variations in the composition and temperature. This absence of bacteria Part played by which can be cultivated appears to be due to a consider- thin tho purobes able extent to the fact that many of the species of factive bacteria which usually take part in the putrefactive process are anaerobes, and hence do not grow under the ordinary conditions of cultivation. The spores of these bacilli are probably very widely distributed, and almost always enter putrefying mixtures. As soon as the 
oxygen which is present has, been used up by the preliminary development of the aerobes, and as soon as the nutrient medium has become loaded with the products of tissue change and of the fermentative action of these bacteria, with carbonic acid, hydrogen, and other gases, the most favourable conditions conceivable for the growth of the anaerobes are produced, ard from this point they multiply rapidly. If the access of air and the amount of oxygen in the nutrient substratum is from the first limited, as is the case in the interior of dead animals, and more especially in those which hare died of asphyxia, the anaerobes occupy the foremost place from the beginning. - $\mathrm{U}_{\mathrm{p}}$ till recently only the bacilli of malignant œdema of symptomatic anthrax, of tetanus, and of the butyric acid fermentation, hare been known as typical anaerobes. Some other anaerobic bacilli have been isolated in the course of the last fer years in the author's laboratory, and among these are some which break up egg albumen energetically, and

Methods of cultivation. which produce intensely foul-smelling gases. These can be obtained pure by the aid of the ordinary gelatine or. agar plates if kept permanently in an atmosphere of pure hydrogen. They also develop if a thick Inyer of a solid nutrient material is employed, in which case an upper portion, several centimetres in breadth, remains completely free from colonies.

The organisms which have been as yet isolated are for the most part large bacilli which form large, highly refracting spores in the threads, or after preliminary development of clostridium forms. At times they present the appearance of fine rods with large terminal spores. The majority do not produce dense and circumscribed colonies, but branched and linotted masses; gelatine and blood serum are liquefied, and the cultirations give off a foul smell varying in degree and character in different cases. An accurate description of some of the bacilli which belong to this group will be shortly published. 
The bacterium termo was formerly looked on as the truc Bacteriun exciting agent of putrefaction, and it was defined in the termo following manner :-

Colls short, cylindrical, oblong; $1.5 \mu$ in length, 5 to $\cdot 7 \mu$. 1 breadth; the contents either light or dark, according to the focussing; the membrane comparatively thick. It occurs in formerly looked on 1 'regular' dense masses, often ar'anged in rows, and forming clumps, or in denso grape-like spherical zoogliea. Flagclla were obser'ved in bacterium termo by Dallinger and Drysdalc. Its mode of movement does not differ in any important particular from that of any other bacteria; "the cells twist around their long axis, and swim forwards, and then again, without turning round, they go backwards, or else move in a curved direction through the water, as a rule not very quickly, with a trembling or oscillating motion, but sometimes making sudden forward movements, sometimes rotating

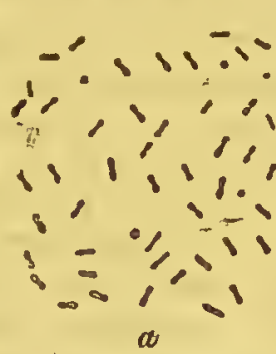

Fig. 109.-Bacterium termo $\times 650$.

$a$, isolated bacteria.

$b$, group of bacteria, around the transverse axis, and then again remaining quiet for a long time, and again suddenly moving backwards and forwards" (Cohn).

J. C. Ewart has made the following statement as to the mode of development of bacterium termo in the moist chamber. The rods (their size is not stated) grow to form threads shorter than those of anthrax, and without any tendency to form a network or mycelium; in the threads small, lefracting, round sporos soon appear. 'Two or thrce days aftor. their formation these spores escape from the threads, and lie cither free in the middle of the cultivation, o1 form zoogloa masses at its cdge. After some timo they sprout and form small, narrow rods, which then multiply by transverse division. The accompanying drawings, howover, show that Ewart was not studying the organism which Cohn had tor bacterium tormo, but some sor sort of spor*-bearing bacillus.Eidam, add a small quaterium termo, we should, according to stood for a long tim quantity of an infusion of peas, which has this is done lume, to Cohn's nutricnt solution, and when quickly occuxuriant development of bacterium termo rery crused, in Es. The bacteria so cultivated, however, never' checsy odour was produced.

'The precoding asoris

the exciting gent of putrefaction.

(


number of bactcria which are now known, and the name at that time cmployed camnot be limited to any one of thesc spccies. Hence it is bettcr to give up entircly the dcsignation "bactcrium termo," as it can only be regarded as a collcctive name for an inconstant mixture of different specics. According to Eidam's experiments, the bactcria which were formerly grouped under the term "bactcrium termo" have apparently no relation to the process of putrcfaction; hence it is probably about time that we should ceasc to designate the specics which are conccrncd in putrefaction as bactcrium termo, although this tcrm is still frequently employed in text-books and scicntific papcrs.

The same statements hold good as regards bacterium lineola, which was formerly characterised as follows :-

Bacterium lineola.-Cclls 3.8 to $5.2 \mu$. in length, $1.5 \mu$. in breadth; occurring singly, or in pairs, but never forming longer threads; at times arranged in

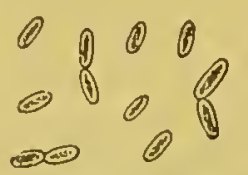

Fig. 110.-Bacterium limeola (after Cohn) $\times 650$. zooglæa form. The contents of the cells are highly refracting, and contain fatty particles. Their movements resemblc those of bacterium termo. They occur in water from wells, \&c., in slimy masses on the surface of potatoes, \&c.

The following are some bacteria which occasion other fermentative processes, or which dehydrate certain chemical substances:-

\section{Bacillus Fitzianus.}

Fitz's glycerine. aethyl bacteria.

Fitz has becn able to sct up fermentation in fermentcscible mixtures consisting chiefly of glycerine, the products of the fermentation being in the main aethylic alcohol; the organism present is a bacillus which he looks on as bacillus subtilis, aud which he obtained from How to obtain the dust of hay. Buchner constantly obtaincd these
this organism. bacilli when he allowed unboiled hay infusion to stand in a room for some days, and when he transferred a small portion of the scum which was then formed to a sterilised mixture contrining 2 per cent. of meat extract with 5 per cent. of glycerine, and about 10 per cent. of carbourte of lime. According to the same nuthor these bacilli have a breadth of $1 \mu$., but their length 
varies considerably from $1 \cdot 2 \mu$. upwards; where the Morphological rods are longer they are frequently bent at their ends. characters. Spore formation takes place in a similar manner to that in bacillus subtilis.-On nutrient jelly thcy form brownish-Cultivation. yellow colonies, with sharp ontlines and with dark, almost opaque, centres; the superficial colonics have the appearance of brownish-yellow, gelatinous drops lying on the surface of the gelatine.

\section{Bacillus aceticus.}

(Mycoderma aceti, Mycoderme du vinaigre, Essigpilz.)

According to Hansen's investigations the bactcria Bacteria of which have the specific property of transforming the fermentation. alcohol of fermented liquors into acetic acid can be obtained with the greatest certainty by placing lager beer (for example the Copenhagen Carlsberg beer, containing 4 per cent. of alcohol and 5 per cent. of extract) in open ressels at a temperaturc between $30^{\circ}$ and $34^{\circ} \mathrm{C}$, best at $33^{\circ} \mathrm{C}$. ; after two or three days a scum is formed which consists almost entirely of acetic bacteria, while the fluid has bccome muddy and strongly acid. The bacilli ale short rods, somewhat constricted in their middle, the ends of the rods being cut off at right angles to the long axis; their size is about the same as that of

$a$
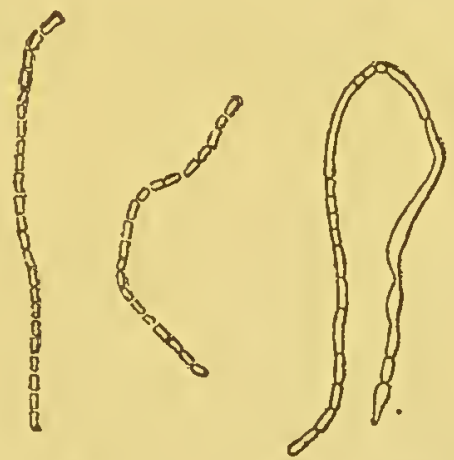

Fig. 111.-Mycoderma aceti. (After. Hanscn.)

$a$, two normal chains $\times 1180$.

$b$, chain with involution forms $\times 1180$. c, abnormal chain $x$ about 2000 . the lactic acid bacteria.

A charactcristic appcarance is their arrangement in long chains, which often extend through scveral fields of the microscope. Some of the members of these chains show more or less distinct variations; they assume cylindrical, hour-glass, 
or spherieal shapes, or form long thread-like and irregularly swollen cells. After treatment with iodine solution, all these forms take on the same yellow colour. It is not as yet possible to say with eertainty whether some of the eells with thieker walls and of rounder' shapes are to be looked on as arthrospores, and whether they are, as a matter of fact, much more resistant than the other growing cells, or whether all these variations from the ordinary form of the ehains are in reality involution stages. Nothing trustworthy is as yet known as regards the mode of growth of this organism on solid nutrient substrata.

\section{Bacillus Pasteurianus (Hauser).}

\section{(Mycoderma Pasteurianum.)}

This organism does not differ morphologically from the foregoing one; it forms similar ehains and involution forms, but on treatment with iodine all the eells take on a blue colour. It was first observed by Hansen in sweet Copenhagen double beer, and develops best in beer which contains a large amount of extract, and a small amount of aleohol, and also in beer wort.

\section{Bacillus urca (Leube).}

Bacilli of the ammoniacal fermentation of urine.
These are plump rods with rounded ends, usually $2 \mu$. in length, and $1 \mu$. in breadth. On gelatine plates a small, almost transparent, patch appears after 2 days, and extends in the course of 10 days to about the size of a farthing; the colonies have the appearance of $\Omega$ ground glass plate which has been breathed upon; the growth extends from the point of inoeulation in the form of eircular irregular zones, so that at a later period a number of eoncentrie rings are seen; the outermost zone shows a dentate outline. Growth occurs exclusirely at the surfaee; the gelatine is not liquefied. In puneture eultivations the track of the needle appenrs after 10 days as a very thin grey prolongation, and it is only 
rarely that, at its uppermost part, tho growth is somewhat broader. Older cultivations have $\Omega$ distinct smell of herring brine.-It was frequently found by Leube in old urine. The bacilli are able to convert urea into carbonate of ammonia, and they do this moro energetically than the micrococcus ureæ.

Leube was able to demonstrate a similar energetic Other bacilli dehydrating action on urea in the case of two other which have a bacilli, and also of a species of sarcina. The first bacilius formed thick oval rods, $1 \cdot 2$ to $1.5 \mu$. in length, and 7 to $\cdot 8 \mu$. in thickness; on gelatine they form superficial dull grey colonies with sharp margins, which descend rapidly to the level of the nutrient soil, their marginal zone being narrow, transparent, and finely granular. The second bacillus was $1 \cdot 2$ to $1.4 \mu$. in length, $\cdot 6 \mu$. in breadth, had sharply truncated ends, and formed circular, highly refracting, fairly high colonies, of a pale greyish-yellow colour, and tough consistence.

\section{Bacteria in Dental Caries.}

The numerous organisms which are constantly present in the secretions of the mouth and in the deposit on the tongue and teeth, set up in part very various fermentative and putrefactive processes, and in part they play a rôle in the etiology of dental caries. According to Miller Etiology of the first stage of dental caries consists in a decalcifica- dental caries. tion of the dental tissue by acids, these being chiefly formed in the mouth by a process of fermentation; and the second stage must be regarded as a simple destruction of the softened tissue of the tooth by microorganisms.

Formerly the most important rôle in these processes Leptothrix was ascribed to a particular genus-the leptothrixbuccalis. which were defined as long thin threads, 7 to $1 \mu$. in breadth, apparently without any segmentation and often united in dense bundles or felt-like masses; the forms which occur in the buccal cavity mixed with micrococci and other fission fungi, wero designated leptothrix buccalis. 

Morphological It was regarded as characteristic of the latter form that
huracters. the threads were mixed with dense masses of micro. cocci ; further, according to Leber, the threads of leptothrix buccalis show a special reaction: they assume a violet colour under the action of iodine and acids; Reaction with iodine alone does not cause this coloration, acids must
iodine. be added at the same time; but it is not necessary to employ sulphuric acid (if it were so the reaction would have a great resemblance to that of cellulose), very dilute hydrochloric acid, acetic acid, or lactic acid, act even better than sulphuric acid. If the medium is already acid the addition of iodine alone is sufficient to

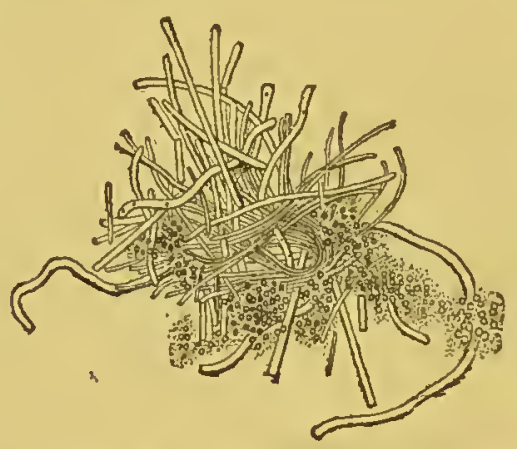

Other situations in which leptothrix is found.

Leptothrix giganter.

Rasmnssen's species of leptothrix. cocci, and spirilla. produce the colour. It is not the sheath which stains; on the contrary it remains colourless, and only the contents become violet; the septa of the threads remain unstained, and hence can be distinctly seen.

Leptothrix has also been found in the concretions in the tear-ducts, as well as in the sputum in cases of gangrene of the lungs (Traube, Leyden, and Jaffé); and Leber has recently demonstrated that Leptothrix buccalis, when inoculated on the cornea, causes serere suppuration, and that during the course of this process very fine, long, jointed threads and chains of rods are developed, which show the characteristic iodine reaction.*

Miller has described a form, under the name of Leptothrix gigantea, which occurs on the teeth of sheep, cattle, and other animals, and which forms very long and thick threads, and may also appear in the form of rods,

Rasmussen isolated from the human saliva by the aid of nutrient jelly and potato cultivations a number of bacteria, of which he reclions three as species of leptothrix, because they form in nutrient solutions (urine, meat 
infusion) long thrcads, which break up into short segments.

It is evident, however, that the designation "lepto- The oxistenee thrix" cannot be employed as a generic term, for the "leptothrix" most various kinds of bacilli may produce these thread- cannot be like formations, and the threads which occur in the buccal secretions and in the deposit on the teeth are probably nothing more than the thread form of various well known, or still unknown, and widely distributed bacilli. It is possible, for example, that bacillus butyricus not uncommonly takes part in the formation of leptothrix in the mouth; it is probable, however, that many other bacilli, more especially anaerobic bacilli, do the same. Since we have been able to work with better microscopes and with strining methods it is easy to convince ourselves, from the marked morphological differences, that the leptothrix threads of the mouth do not belong to one individual species; the threads show very great variations in thickness, at times they form spores (or the early stages of spore formation) arranged in a characteristic manner; some thrends are stiff and readily broken, others are flexile, \&c. The species of Fruitless bacteria which have as yet been isolated by cultivation attempts at from the buccal secretion do not appear to be identical bacilliforming with those bacilli which form the marked threads which forms.

have led to the designation leptothrix; as a matter of fact we ouly obtain by cultivation a small fraction of the numerous species which we find by the microscope in the secretions of the mouth. Miller also states, in his most recent commurication, that the leptothrix buccalis has not as yet been cultivated pure.

As regards the other organisms found in the mouth, Miller:s Miller has isolated, during the last few year's, $\dot{2} 5$ different bacteria from species, 12 cocci and 13 rod forms. Somo of these have teeth. been already mentioned; we may refer here to the organism described by Miller under the symbol $\epsilon$. 'This forms small curved bacilli, often S-shaped from the union of two individuals; it grows on gelatine, and causes its liqucfaction, and is probably identical with the spirillum of Finkler and Prior. The characteristics of the 
other species isolated by Miller have not as yet been. published in detail.

- With regard to the pathogenic bacteria present in the buccal secretions, see pages 319,322 and 325 ; as regards Spirochæte denticola, see bolow.

Bacilli which are not known to produce Specific Fermentations.

Bacillus subtilis.

(Hay bacillus.)

Hay bacillus. These are cylindrical rods, up to $6 \mu$. in length, and on an average about three times as long as they are thick. Morphological They grow and divide very rapidly; the length of time
charactere. $\quad$ between one fission and a second is, at $21^{\circ} \mathrm{C}$., about an hour and a quarter, and at $35^{\circ} \mathrm{C}$. about 20 minutes. Pseudo-threads frequently appear, which can be frequently seen to be made up of rods, by the fact that they soon become bent in a zig-zag manner; in other cases, however, they do not present this appearance. The individual members of a thread are as a rule in different stages of growth and subdivision, and are therefore of different lengths. Under various conditions, which have not as yet been accurately ascertained, the rods begin to swarm; the movements are active and snake-like. At each end of the rod a fairly long and twisted flagellum can be seen, especially after treatment with hrematoxylin (Koch). - When the substratum becomes poorer in nutrient material the continued multiplication of the rods by fission gradually ceases, Spore form: - and then as a rule spore formation commences. At one tion. part of the rod which has now ceased to more a dark, shaded part becomes evident, sometimes more in the middle, sometimes more towards one end, and ultimately this portion becomes converted into a highly refracting spore with dark outlines. The rods swell up at the same time in some cases in an almost umnoticenble manner. At the same time that the spores are formed the contour of the rods becomes dull and indistinct, and 
they soon disappear entirely, so that the spores become free, as a rule, during the course of one day. The spores are $1 \cdot 2 \mu$. in length, and $\cdot 6 \mu$. in breadth; when they are looked at from above they appoar round. Around their dark centre there is a distinct light area, which is also seen when several spores are lying together. The sprouting of the spores often does mot hegin at the Sprouting of ordinary temperature of the room till after 12 hours; it occurs most quickly when the spores are boiled for fire minutes in the uutrient solution, the material being then allowed to cool slowly; under these circumstances sprouting occurs even after two tothree hours. When this takes place the spores lose their dark appearance, the clear area disappear's at the same time, and a
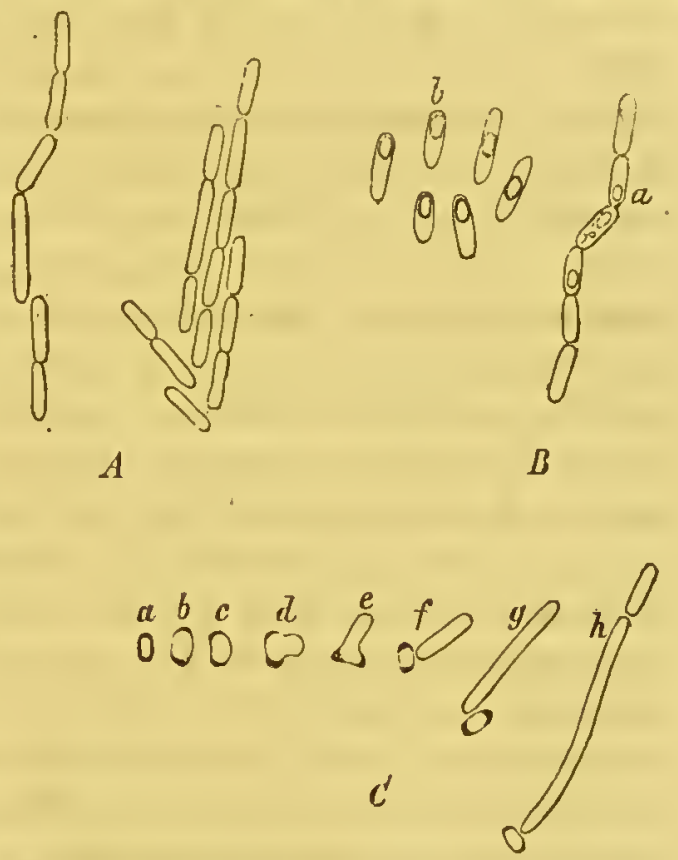

Fig. 113.-Bacillus subtilis (after Prazmowski) $\times 1020$.

$A$, colonies of bacillus subtilis.

$B$, spore formation$a$, in a pseudo-thread.

$b$, in individual rods.

$C$, germination of the spores. $a-h$, successive stages.

lighter zone appear's in the middle of the spore. This zone becomes larger, and then on one side a distinct projection is formed, at the apex of which the spore membrane is ultimatcly ruptured in order to permit the sprouting portion to pass out. The latter elongates and forms a rod, but for a time the end still remains sticking in the opening in the empty spore membrane as if a bladder wore attacher to it. The spore membrine can often be distinctly seen, even after repeated fission of the rods, and it accompanies the moving bacilli in their wanderings. 
The newly formed rod always stands at right angles to the long axis of the spore; but the long axis of the newly formed spore is the same as that of the rod in which it develops; hence, as the result of the spore formation, there is an alteration in the direction of growth of the bacilli.*

Distribution. Bacillus subtilis is very widely distributed; its spores are present in the air, in dust, on the surface of all kinds of articles, and they occur only too often as undesired impurities in cultivations of other organisms. It forms a white efflorescence on the dung of herbivorous animals; on liquid dung it forms thick wrinkled skins. This organism grows on a great variety of nutrient substrata, even when they only contain a little organic material; it grows in fluids just as well as on solid but moist substrata; a markedly acid reaction of the media interferes, however, markedly with its development. A cultivation of this bacillus, to some extent pure, is most easily obtained by infecting the ordinary nutrient solutions with a little dust from hay, or by employing an infusion of hay as a nutrient solution; in the latter case the fluid is boiled for about a quarter of an hour; as a result almost all the other fission fungi are killed, and only the extremely resistant spores of bacillus subtilis retain their vitality.

According to Buchner, in order to obtain bacillus subtilis with certainty, it is best to allow hay to stand at $36^{\circ} \mathrm{C}$. for four hours with extremely little water, then to pass it through a fine sieve, to dilute the water to a specific gravity of 1004, and then to raise about $500 \mathrm{~cm}$. of this mixture to the boiling point in a ressel closed with cotton-wool, the heat being continued for one lour, and only very little sterm being developed; after it has been boiled the fluid, if liept at $36^{\circ} \mathrm{C}$., shows a scum on the surface after 48 hours, collsisting of bacillus subtilis. It is only when the reaction is very markedly acid that it is necessary to neutralise the material before boiling it.

Botarionr on $\quad$ On gelatine plates bacillus subtilis forms small whitish
cultivation. * After Brefeld, Botan. Unters., Part 4, and Prazmowski, Lit., p. 47. 
colonies, which, under a low porver, have a yellowishbrown colour, and an irregular margin, with numerous hair-like processes projecting from it. At a later period a narrow clear zone appear's around the dark centre, and beyond this there is a greyish layer consisting of a circle of rays. At the same time the gelatine is energetically liquefied.-On agar a thick wrinkled skin is formed. On potatoes thick yellowish-white deposits appear, which, on the second day, have a moist satinlike appearance, with dry, whitish spots at parts of the surface, soon extending over the whole extent of the layer; ultimately the cultivation appears as if powdered with a white granular mass.

These bacilli require plenty of oxygen, and growth, Necessity for multiplication, and spore formation only go on in a oxygen. normal manner when there is no hindrance to the access of air; in vessels devoid of air no development visible to the naked eye takes place.-Under unfavourable conditions of life the bacillus subtilis forms the most various kinds of involution forms, flasklike swellings, \&c., which, under the microscope, show a peculiar fatty appearance. According to Buchner Involution these involution forms appear especially when the amount of sugar in the nutrient solutions is markedly greater than the amount of nitrogen. The same author found that even slight variations in the composition of the nutrient substratum occasion certain alterations in form, and more especially alterations in thickness of the bacilli.

Bacillus subtilis does not appear to exercise any Action on the special fermentative action, more especially with reference nutrient subto the carbo-hydrates; the reason why such properties were formerly ascribed to bacillus subtilis was evidently because it was confounded with bacillus butyricus and other bacteria. Vandervelde has recently asserted that bacillus subtilis can set up fermentation when it is compelled to exist witlout oxygen. Vandervelde tried to show this by careful analysis of the nutrient substratum in which a pure cultivation of bacillus subtilis had grown for a considerable time; he found that glycerine or grapo 
sugar werc used up, and that lactic acid, volatile futty No fermenta- acids, carbonic acid, and hydrogen, were produced; but
tion. these substances wero formed in such small quantitics, and after such a length of time ( 1 to 2 months) that we cannot speak of a true fermentation; on the contrary, these products only indicate the result of the assimilation and tissuc change of the growing bacilli within ordinary limits. Further, in Vandervelde's experiments the absolute quantity of gases produced was not determined, and there was no certainty as to the purity of the cultivation, and for this reason the cxperiments, which are nevertheless interesting as regards the tissue change of bacteria, cannot be regarded as definite proof of the fermentative activity of bacillus subtilis. -

Peptonising As the only energetic transformation of the substratum
aotion. caused by the bacillus we have its peptonising porrer on albumen (also on blood serum) and on gelatine, as indicated by the mode of its growth in cultivations. As to the supposed transformation of hay bacilli into anthrax bacilli, see page 241 .

\section{Bacillus aerophilus.}

Aerobio

bacillus.

This organism was found by Liborius in the hygienic laboratory at Göttingen as an accidental impurity. It Morphological presents the appearance of thin rods, $\frac{2}{3}$ rds of the thickness characters. of bacillus subtilis; these vary in length and frequently hang together, forming straight or zig-zag pseudo-threads. In the unstained preparations we can at times see a delicate sheath around the bacillus. They form on agar Cultivations. oval, highly refracting spores.-On gelatinc plates fine punctiform colonies appear after 40 hours, which under a low power show sharply defined borders, are of an oval or pcar shape, and have a yellowish green colour. Energetic liquefaction of the gclatine soon commences; while the colonies have only slightly increased in size, and have otherwise remained unaltered, the surface of the gelatine is liqueficd over the whole plate.- In puncture cultivations a broad sac-like liquefied arca is formed, the upper part of which is greyish-rcllow and. 
opaque, while the lower part is clearer, and is only reudered somewhat turbid by the presence of a few flakes.-On potatoes the bacilli form yellowish layers witl a flat surface and a dull paraffin-like appearance; later on the surface at the margin becomes drier, faintly granular, and assumes a striped appearance as the result of unevenness of the surface. - The bacillus requires the Necessity or presence of oxygen to a greater degree than any of the oxygen. other organisms as yet examined; it only grows on the surface, and ceases to form visible colonies, even when there is a relatively trivial interference with the supply of oxygen.

Among the so-called potato bacilli, which readily grow on the surface of potatoes, and which are often observed as accidental contaminations, we have-

\section{Bacillus mesentericus fuscus.*}

This organism occurs in the dust of hay, in the air, Brown potato on the surface of potatoes, \&c: ; it is very widely distri- bacillus buted. The bacilli are small and short, often occurring in chains of two to four members, and actively mobile; they form irregularly arranged, small, refracting spores.-On gelatine plates roundish, whitish colonies appear witl sharp contour under a low power, and later with delicate processes of a yellowish brown colour, and finely granular surface; liquefaction of the gelatine rapidly occurs. In puncture cultivations a whitish opacity is formed at first along the track of the needle, and at the same time there is a funnel-shaped area of liquefaction at the point of entrance of the needle, this area extending within 4 to 6 days till it reaches the wall of the glass; in this way an upper layer of fluid is formed, in which whitish grey flakes are floating.-On potatoes smooth yellowish deposits appear on the first day, the surface of which, however, become very quickly wrinkled and brown ; this

* Göttinger hyg. Institut. 
membrane is relatively thin, and docs not cxtcnd decply into the substance of the potato. The growth rapidly spreads over the whole surface of the potato.

\section{Bacillus mesentericus vulgatus.*}

Potato bacillus.

This organism is vcry widely distributed in nature; it is usually, though badly, described under the name "potato bacillus." The bacilli are thick and large, often forming pseudo-threads and spherical spores; they have an oscillating movement. On gelatine plates the colonies present a bluish-white appearance, thcy are almost transparent, but later the centre acquires an opaque white colour; the superficial colonics can attain the diameter of almost $1 \mathrm{~cm}$. These colonies sink to some extent into the liquefied gelatine; under a low power they present the appcarance of dark, distinctly granular discs, with rough borders. The gelatine is energctically liquefied. In puncture cultivations a funnel-shaped area of liquefaction is formed at first, but later the whole of the upper part of the gelatine becomes fluid; in the fluid there arc numerous grey flakes, and on it there is a delicate greyish-white wrinkled skin. At the bottom of the area of liquefaction a thicker flocculent mass is present; from that point downwards we still see, for the next few days, the remains of the line of puncture, clothed with a thick whitish deposit.-On potatoes a whitish thick growth is formed which is almost from the first markedly wrinkled, and which spreads rapidly over the whole surfacc; if we attempt to pick up a portion of this skin it is secn that the colonies have grown deeply into the substance of the potato; the raised portions of the skin remain in connection with the substance of the potato by a tough mucous mass, so that long threads may be drawn out. According to Hucppe the bacilli are not able to form any ropy substances from sugar, but they liare an encrgetic diastatic action; they also causc congulation of cascin

\footnotetext{
* Göttinger hyg. Institut.
} 
in milk in a similar manner to rennet, and cover the coagula, which are again gradually but almost entirely dissolved, with a thick tenacious envelope.

\section{Bacillus liodcrmos.*}

These are small, short bacilli, with rounded ends, and Potato with very active movement. They form on gelatine ing a smooth plates colonies with irregular outlines which float on skin. the surface of the liquefied gelatine in the form of small white flakes. In puncture cultivations liquefaction occur's in the whole of the upper zone, and at the bottom of the fluid greyish-Jellow flocks are deposited; in the lower part of the track of the needle there is a greyish growth.-On potatoes a smooth, shining layer is formed, which spreads rapidly over the whole surface, and gives to it an appearance as if it had been painted over with yellowish-white syrup. It is not till after several days that the smooth surface becomes opaque and slightly wrinkled, but in any case the wrinkles which are formed are never so marked as in the foregoing species.

\section{Bacillus multipediculus. $\dagger$}

These are long thin non-motile bacilli. The colonies Bacillus with on gelatine plates present under a low power the appear- insect-like ance of round or oral, sharply outlined, dark discs, from the periphery of which small, relatively broad processes shoot out in various places; these processes are jointed, consisting of round balls arranged in rows, and gradually becoming smaller, and they have usually a radinting direction; at times, however, they curve, and present a concentric arrangement. After 2 or 3 days these processes are visible to the nalied eye in the superficial oval white colonies; as these processes only occur here and there, and are usually only in considerable numbers at one of the pointed ends, the colony recalls the form of an insect with numerous feet and antennæ.-In puncture

* Göttingor hyg. Institut.

$\dagger$ Göttinger hyg. Institut. 
cultivations the growth is not so characteristic, but there also a row of short isolated processes is very gradually formed, these processes passing out from the whitish layer which appears along the track of the nccdle. On potatoes a dirty ycllow layer of moderate extent, and with a smooth surface, is produced, and the portions of the potato around the borders of this laycr show a dark colour.- It occurs not uncommonly as an accidental impurity on potatoes.

Of other bacilli not unfrequently met with in Göttingen the following may be mentioned :-

\section{Bacillus ramosus liquefaciens.}

Branched funnelforming bacillus.
These are fairly large, slowly moving bacilli with blunt cnds. They form on gelatine plates very characteristic colonies ; the youngest, when lying deeply in the material, present under a low power the appearance of roundish dark discs, the borders of which seem as if surrounded by hairs; the same appearance can also be seen in the superficial colonies, which are for the most part oval or pear-shaped. With the naked eye we also observe that a sharply defined funnel-shaped depression has been formed by a limited liquefaction of the gelatine. Even after several days this liquefnction has not extended any further, but the sharply defined, deep circular funnel, 2 to $3 \mathrm{~mm}$. in breadth, is surrounded by several concentric zones of varying breadth and distinguished from one another to some extent by their colour, these zones having on the whole a greyish-white ground glass appearance. On a black base these various zones can be particularly well seen.-In puncture cultivations a slight funnel-shaped depression, accompanied by liquefaction, forms at the entrance of thc ncedle; beneath this funnel the track of the needle shows a number of branches which pass off at right anglcs, the uppermost cxtending furthest into the gelntine; as we pass deeper thcse branches becomo shorter. At a later period the lique- 
faction extends very gradually over tho whole surface, and affects an upper zone of constnntly increasing depth.This organism was found by Praussnitz as an accidental contamination; it is rare.

\section{Bacillus mycoides.}

\section{(Earth bacillus.)}

These are fairly thick mobile bacilli approaching in Earth bacillus size the anthrax bacilli, and often forming long pseudo- $\begin{gathered}\text { growing like } \\ \text { mycelium. }\end{gathered}$ threads. In the threads oval, highly refracting spores appear at regular intervals, and this is also the case in the individual bacilli; the spore lies about the middle of the bacillus.-In gelatine plates a whitish turbidity is formod in which fine whitish threads of irregular interworen and branched appearnnce are scen. This network of threads attains, even after 12 to 20 hours, an extent of about $10 \mathrm{~mm}$., and resembles the mycelium of a fungus so much that one may be in doubt whether it is that, or whether it is a colony of bacteria. The threads remain delicate and fine so long as they lie in the depth of the gelatine, but they increase markedly in broadth and lose their sharp outlines when they reach the surface. The individual colonies soon run together as the rosult of the growth of this network of threads. Under a low power the threads are seen to be composed of bundles of bacilli, which usually lie loosely beside each other, but are at times densely matted together, and havo on the whole a very curved and convoluted course. Whon the threads reach the surface liquefaction of the gelatine occurs in the uppermost layer, which has already becomo diffusely opaque as tho result of the growth of tho colonies.-In puncture cultivations minuto lanirs spread in the first place from tho line of puncture into tho gelatine in denso rows; later the accompanying liquefaction obscures the charactoristic growth. On potatoes a whitish tenncious layor is formed which slowly extonds over the surface. - Theso bacilli aro almost always prosent in spocimens of earth talicn from the surface of 
fields or gardens, if these specimens are either directly dusted over gelatine plates, or if a watery extract of the earth is made and mixed with the gelatine.

The following bacilli hare also been more or less accurately described :-

Bienstock's bacilli from faces.

Bienstock's freces bacilli.

These organisms were constantly found in the frees by Bienstock. They resemble bacillus subtilis in sizo and general appearance, but they do not possess spontaneous movement; they often form longish threads. The spores appear in these threads, or even in the individual rods, usually one in each rod, rarely two, the spore being generally somewhat nearer one end than the Morphological other. The size of the spore is about the same as that characters. of the spores of subtilis; the whole substance of the spore can be stained with warm aniline fuchsine, and is not decolourised by nitric acid; with methylene blue only a fuint staining of the periphery takes place. When the spore sprouts the ellipsoid form becomes gradually cylindrical, and the substance of the rod which commences to form at each end gradually extends towards the middle of the spore, and there becomes united Cultiration. together.-One of this species of bacilli groms out from the line of puncture in the nutrient gelatine like a mesentery; main branches of a whitish-yellow colour run out into the gelatine in all directions, these branches being united together by smaller anastomoses.-The second species grows in the form of white glistening colonies, at first smooth, but later somewhat uneven on the surface, the margins of these colonies showing projections like bunches of grapes; in the course of 10 or 12 hours it extends orer the whole surface of the nutrient substratum. 


\section{Bacterium Zopfii.}

This organism was isolated by Kurth from the intestine Kurth's ballof fowls. It presents the form of bacilli $\frac{3}{4}$ to $1 \mu$. in forming breadth, and 2 to $5 \mu$. in length, usually in active movement. These bacilli form long threads, which, when growing in gelatine, show numerous bends; in fact regular spiral forms may occur, or in some cases felted structures or circular patches; all sorts of other bendings and twistings may also be seen. In fluids bacterium
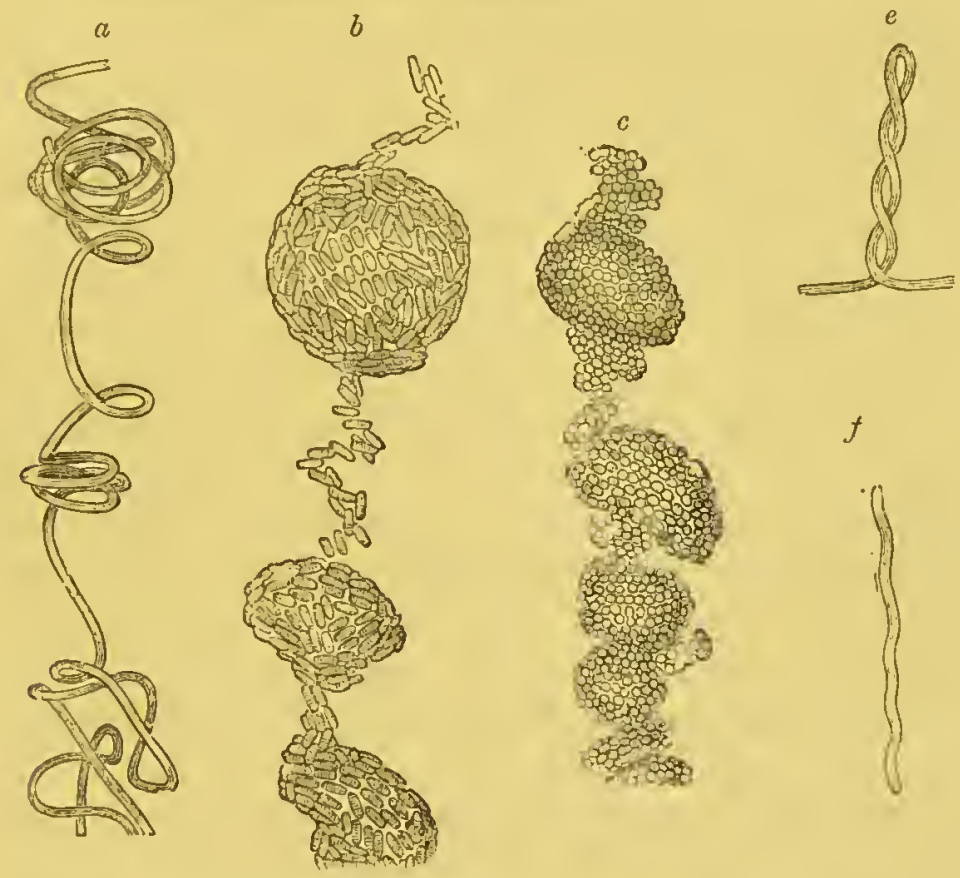

Fig. 114.-Bacterium Zopfii (after Kurth) $\times 740$.

a, threads with commencing formation of balls.

$b$, breaking up into rods.

$c$, breaking up into round segments.

$e$ and $f$, spirilla and spirulina threads.

Zopfii always forms straight threads, and this has led Kurth to the conclusion that the origin of the bendings in the gelatine cultivations is a mechanical effect, and he supposes that, given a certain length of thread, and a corresponding rapidity of growth, the resistance which the gelatine offers to the penetration of the thread is greater than the rigidity of the rod. After some time Ball form. 
dense balls are formed; in these balls the threads become broken up into short or long pieces, varying from 5 to $50 \mu$. in length; the short portions grow and bend almost always laterally from the original direction of the thread.

Formation of After some time growth ceases, and the organism bespherieal bodies. comes broken up into spherical individuals, described by Kurth as cocci. The rows of cocci remain in the gelatine united in the form of balls; when sown on new gelatine, rods and threads are again formed within 16 hours. The round forms appenr when the nutrient materials are becoming exhausted; they are not able to multiply by fission, but they can under favourable circumstances sprout out in the form of short rods. Biscuit-shaped pairs of cocci also occur, which are, however, regarded by Kurth only as a more or less advanced stage of the subdivision of a rod into two cocci. These biscuit-shaped pairs at times show swarming movcment. The behaviour of the cocci when dried appears to be especially important; while the rods die in the dry state after 52 to 108 hours these

A.e these sp'ierical wodies spores? coccus forms live for 17 to 26 days. The cocci also retain their vitality for a very long time, for eren more than 82 days, in the exhausted nutrient solution. From the biological characters mentioned above, and in correspondence with our previous definition of micrococci and spores respcctively, Kurth looks on thesc spherical forms as spores. On the other hand, we have the fact that the round cells of this bacterium are not much more highly refracting than the bacilli, that they stain intensely with aniline brown, and that there is no difference betreen them and the bacilli in their resisting power to high temperatures. Nevertheless a higher refracting power, difficulty in staining, and resistance against heat have not as yet been looked on as indispensable for the assumption that any given cell is a spore, and as a matter of fact such all assumption camnot be made so long as the general characters have been studied ou only a very small proportion of the cxisting spores. The only two important critcria which must be required on the part of a sporc are a certain resistance against external 
influences which favours the maintenance of the species, and more especially a resistance against the effect of drying; and secondly, the fact that these cells do not multiply, but can give rise to an organism resembling the mother organism. These two requirements are completely fulfilled in the case of the round cells of bacterium Zopfii, and hence we have in this case undoubtedly a spore formation which only differs from the other spore forms as yet known in that the resistant properties depend less on a thickening of the cell contents than, probably, on an alteration of the cell membrane.

These bacilli grow well on nutrient jelly ( 2 per cent. Cultivations. meat extract and $2 \frac{1}{2}$ per cent. gelatine). After 24 hours a thick, whitish-yellow layer is formed along the line of inoculation, and in the course of the following 24 hours white anastomosing lines develop, and project from the original line in radiating directions, so that the appearance of the colony when looked at superficially is that of the mycelium of a fungus. The growth, however, only occurs on or under the surface, and never extends above it; on the other hand the organism requires a large amount of oxygen, and does not grow therefore in the deeper layers of the grelatine. No growth occurs on blood serum; a diffuse turbidity occurs at first in a 2 per cent. solution of meat extract, and later a thick, whitish deposit is formed at the bottom. The optimum of temperature seems to be about $20^{\circ} \mathrm{C}$.; the swarming movements of the rods cease at from $33^{\circ}$ to $37^{\circ} \mathrm{C}$; from $37^{\circ}$ to $40^{\circ} \mathrm{C}$. involution forms appear, and when this temperature is continued for some time the bacilli lose their vitality.-Experiments on animals show that the bacilli are harmless saprophytes.

\section{Bacillus megaterium (de Bary).}

This organism was first observed by do Bary on Morphological boiled cabbage leaves. It presents the form of rods chnricters. $2.5 \mu$. in thickness, and cylindrical in form, with rounded 
Spore formation.

ends; it elongates till it is four to six times as long as broad, and then divides transversely into two halves; when acted on by alcohol or tincture of iocline the rods are seen to be composed of short segments. They are slightly bent; at times they form chains, which, howerer, rarely consist of many segments. The rods are in constant, though relatively slow, movement; flagella have not been observed. At a later period it can be seen that each rod is composed of four to six isodiametric cells, separated from each other by delicate transverse divisions; a small, round, highly refracting body soon appears in the cell, this body increasing in sizc while the surrounding protoplasm gradually disappears;

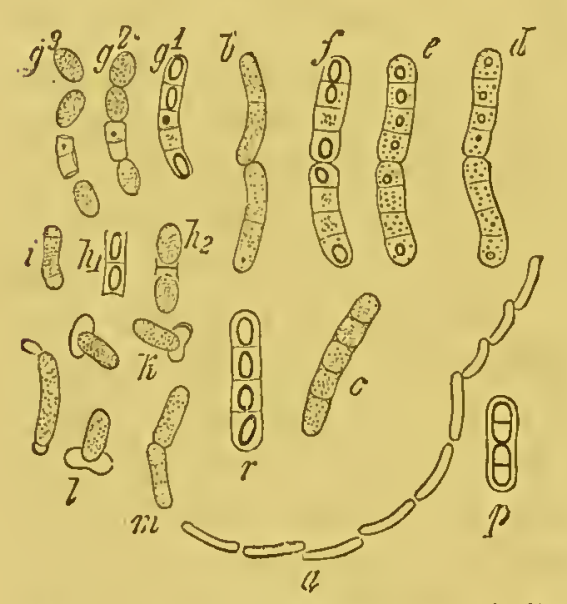
Fig. 115.-Bacillus megatorium. (After rods becomes slower, but de Bary.)

Germination of the spores.

$a$, chain of rods $\times 250$.

$i$, short rods $\times 600$.

$p$, their appearance after the action of iodine solution.

$e-f$, spore formation.

$g-m$, germination of spores $\times 600$. after a few hours it becomes converted into a longish cylindrical spore. The latter is very highly refracting, of a bluish appearance; the membrane of the mother cell gradually disappears; and the spore becomes free. During the process of formation of the spores the movement of the does not entirely cease. When the spore germinates its dark outline and its highly refracting character disappear, and it gradually increases in size till it has attained the normal breadth of the rod. When this has occurred a delicate membrane, which is torn transversely or obliquely, is suddenly separated from the surface, and the rod passes out of this membrane.-The bacilli grow at $20^{\circ} \mathrm{C}$. in solutions of grape sugar and meat extract, or in meat extract alone with or without gelatine. The gelatine is liquefied as the result of the growth of the bacilli. 


\section{Bacillus tumescons (Zopf).}

This organism was observed by Zopf on boiled carrots kept fairly moist; it forms there n tough, wrinkled whitish skin, which conisists of small disc-like gelatinous masses. The skin contains narrow rods arranged in zooglæa forms, these rods forming at a later period shorter joirts, and in these shorter. joints spores. Its other character's are not as yet known.

\section{Bacillus ulna (Cohn).}

This organism was first observed by Cohn, and then by Prazmowski, in decoctions of boiled egg albumen, and also under the shell of an egg. They are rods 1.5 to $2 \cdot 2 \mu$. in breadth and of varying length, attaining at least $3 \mu$.; they are mobile. As regards the formation of threads and spores, they resemble bacillus subtilis; the spores are 2.5 to $2.8 \mu$. in length, and over $1 \mu$. in breadth. This organism only grows on soil which is rich in albumen, for example, in decoctions of boiled egg albumen. These fluids become turbid on the day after inoculation, and cloudy masses are formed, which after some time collect on the surface of the fluid, and there run together to form a thick, but dry skin; the latter consists of very long matted bundles and balls of pseudo-threads. There is no formation of any gelatinous material. Fructification occurs in the skin on the third or fourth day. The pieces of albumen are not attacked to any marked degree by the growth of the bacilli; they retain their consistence and do not give rise to any putrefactive odour.

\section{Bacillus Hansenii (Rasmussen).}

Motile rods $2 \cdot 8$ to $6 \mu$. in length, and 6 to $8 \mu$. in breadth. They form spores $1.7 \mu$. in length and $1.1 \mu$. in breadth. They give rise to a whitish-yellow skin on meat infusion, malt decoction, \&c., at a temperature of $31^{\circ}$ to $33^{\circ} \mathrm{C}$. On potatoes the growth is of a chrome-yellow colour; at a later. period it becomes drier and orange-yellow, or yellowish-brown in colour, and gives off a fruity odour. The pigment is insolublc in all the ordinary media (water, alcohol, chloroform, lyes, acids).

\section{Bacillus tremulus.}

Shorter and thinner than bacillus subtilis, with a flagellum at each end. It has a peculiar tremulous or rotatory movement. The spore is thicker than the body of the bacillus, and it projects from the bacillus like a bladder'; the completely formerl spore usually appear's on one sidc of the rod. When the growtl 
is Iuxuriant, there arc usually two or three completely formed spores and some imperfect ones.-This organism was found by Koch on putrefying vegetable infusions, on which it forms a thick gelatinous skin.

\section{Bacterium merismopedioïdes (Zopf).}

This organism was found by Zopf in a decoction of stinking mud from the Panke river. "It forms threads which are not constant as regards thickness, but vary between 1 and $1.5 \mu$. They divide in the first instance into long rods, then into short rods, and finally into cocci. It is clear that as the threads have varying diameters so the cocci must vary correspondingly in size. The latter become free, and then show active movement. When they come to rest they form on the surface of the water masses or superficial scums, as the result of continued division in one direction; and later, as the result of division in two directions, the very characteristic ' tafel' colonies are produced, which are morphologically quite similar to the little tablets of the merismopedic state of the phycochromaceæ. These colonies consist of $64 \times 64$ cells or more. 'Their walls become gelatinous as time goes on. Then the colonies are numerous, and in close contact with each other, their gelatinous sheaths run together, and thus we hare a continuous zooglæa which always forms a thin scum ou the surface of the water.-The cocci swarm under suitable nutrient conditions (in fresh mud decoction) out of the tablet zooglæa, and again develop to rods and threads." The description given by $Z$ opf, and the fact that the cultivations were exclusively carried on in fluid media, gire risc to the suspicion that the observations depend on the presence of a misture of rarious kinds of bacteria. 


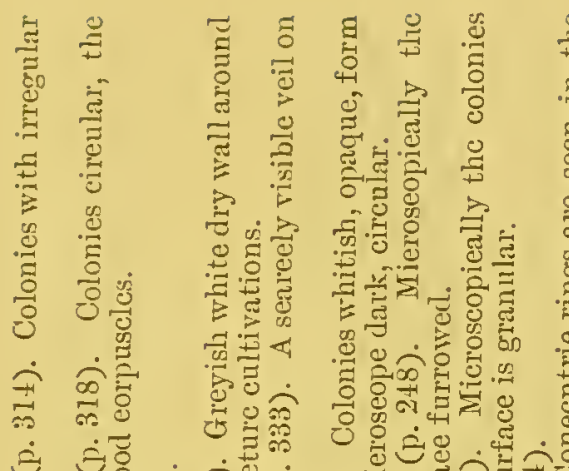

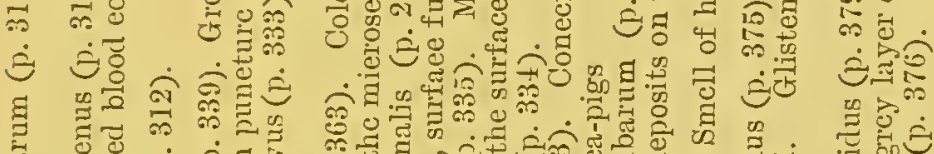

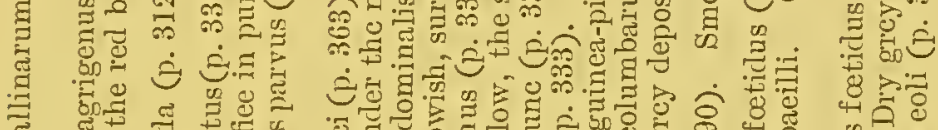
क्ञ

EI

.

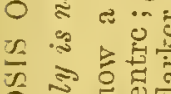

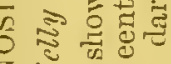

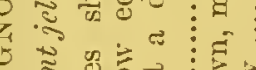

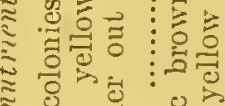

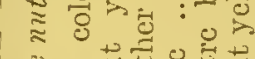

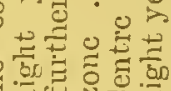

要
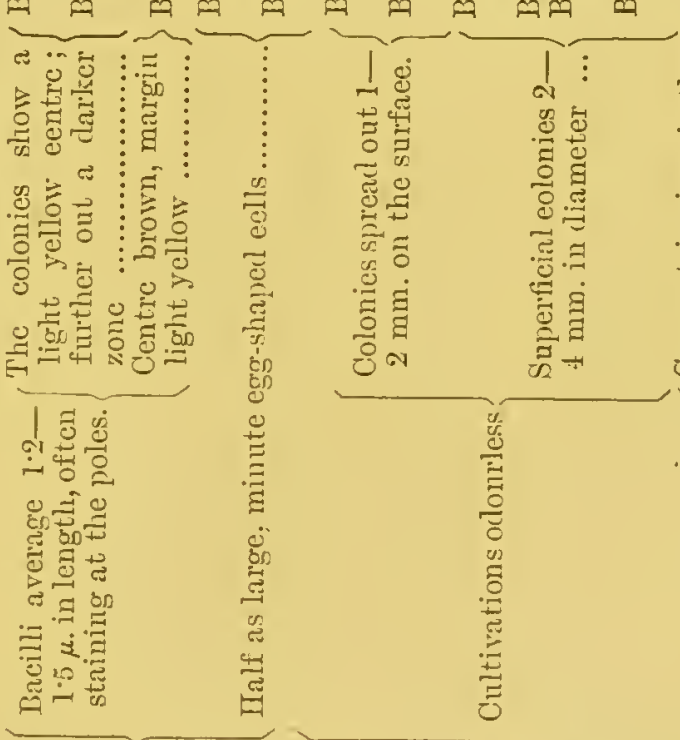

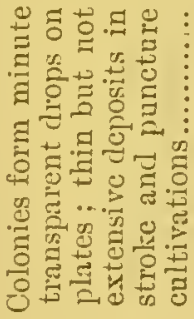

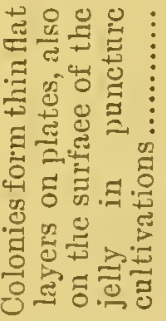




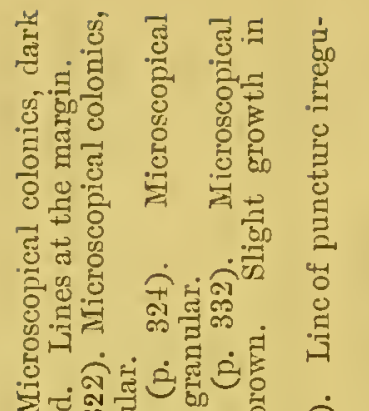

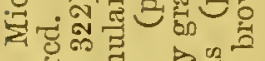

คิ

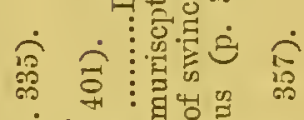

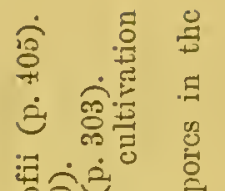

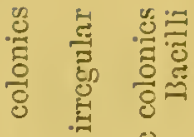
ơ

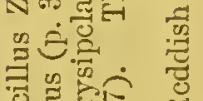

न्नु

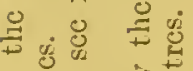

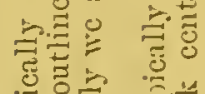

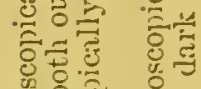

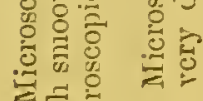

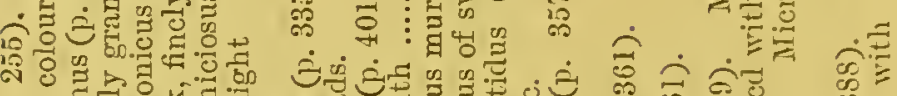

च사 3.

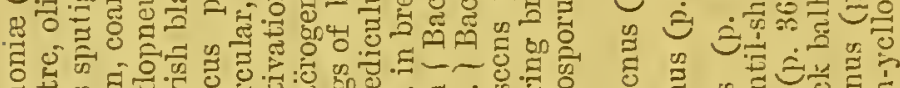

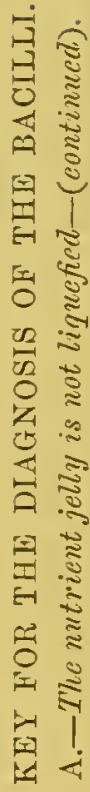

萠

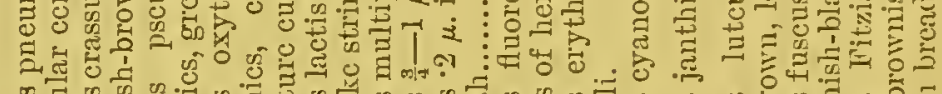

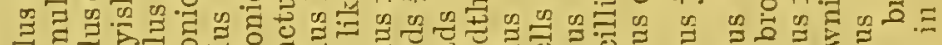

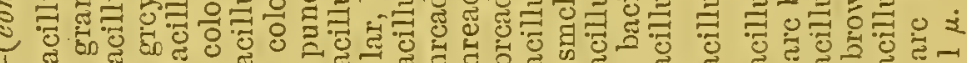

I

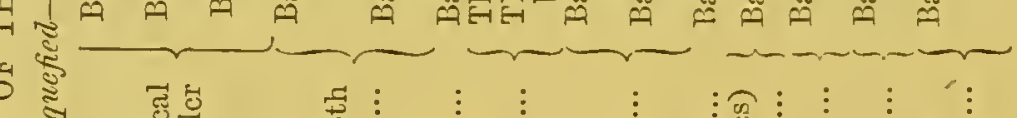

退

尊这

$8:$

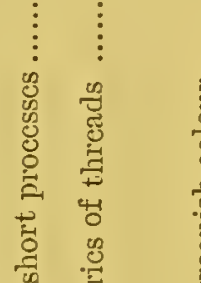

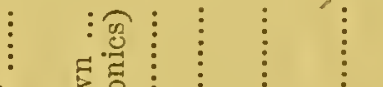

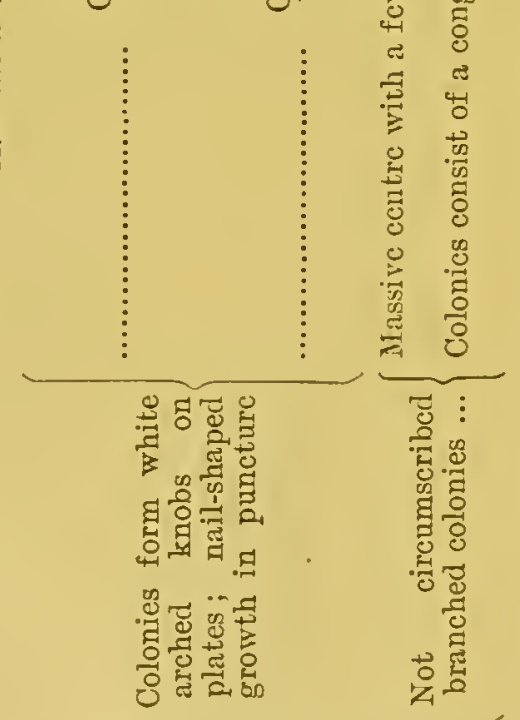

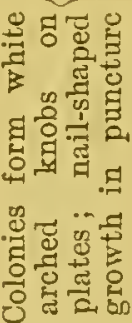

焉

है है

ํํㄹ

苟

ق

零䢍

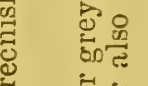

है के क्ष

4

4.

घ

密密苟

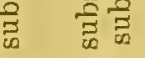

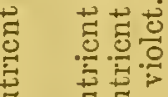

新

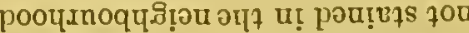

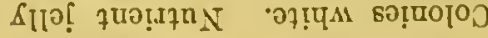




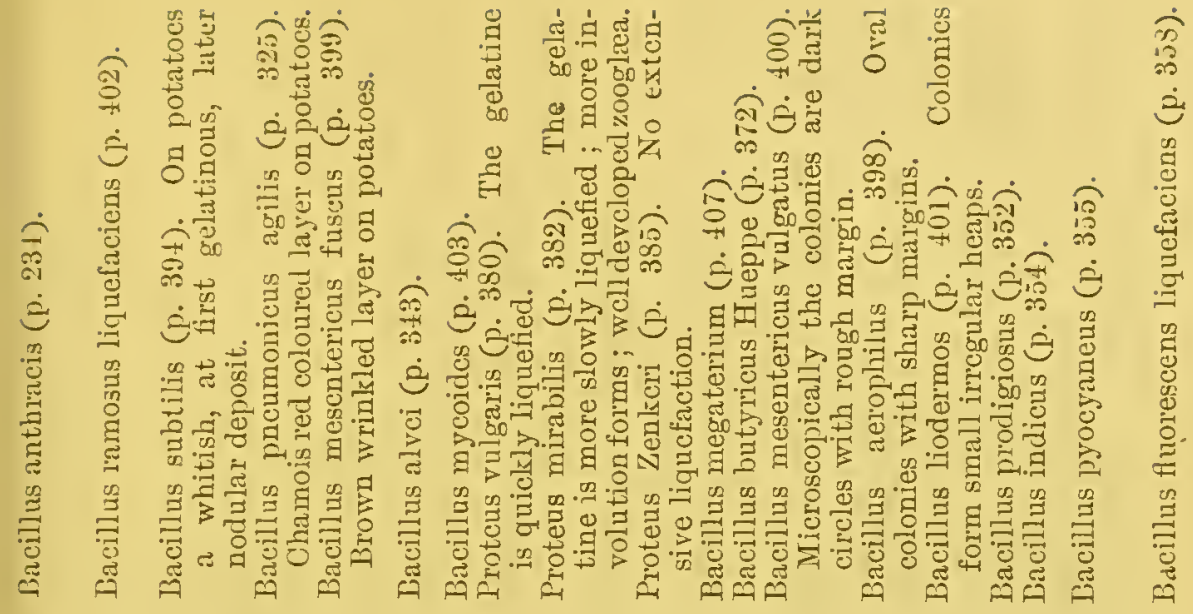

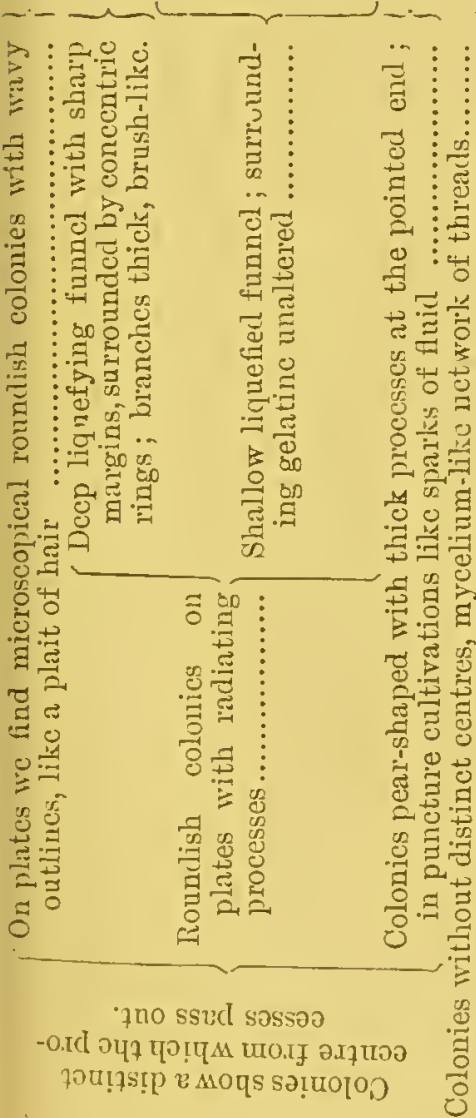




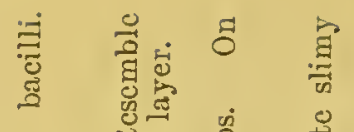

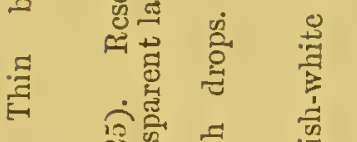

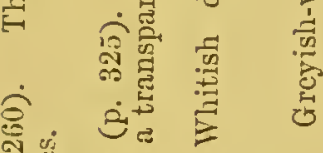

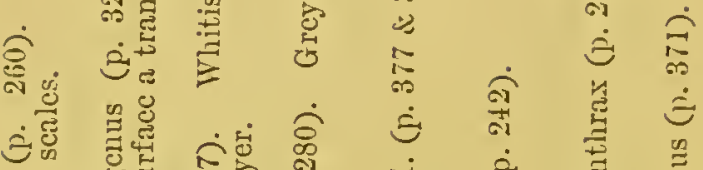

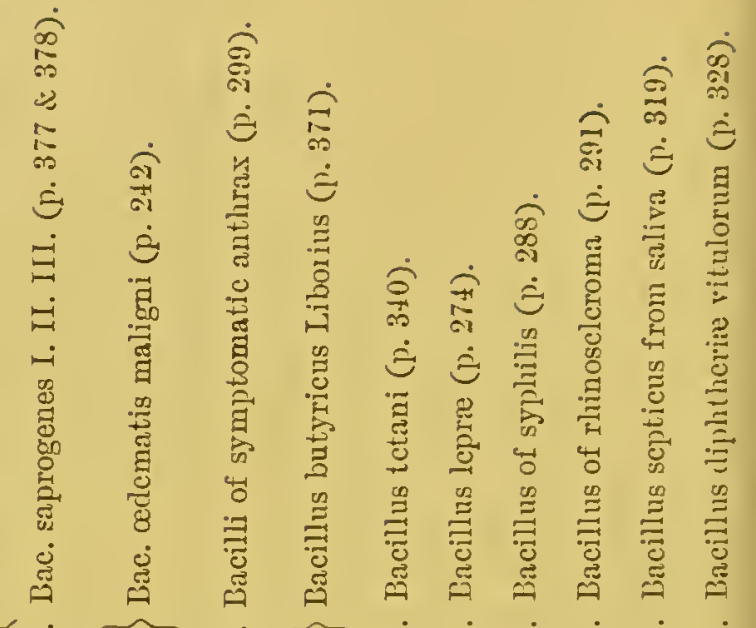

음

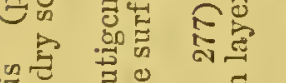

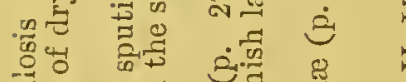

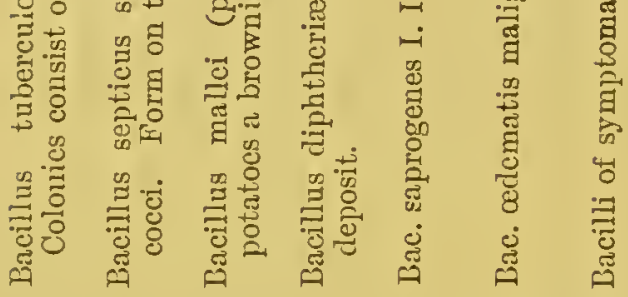

ב⿱
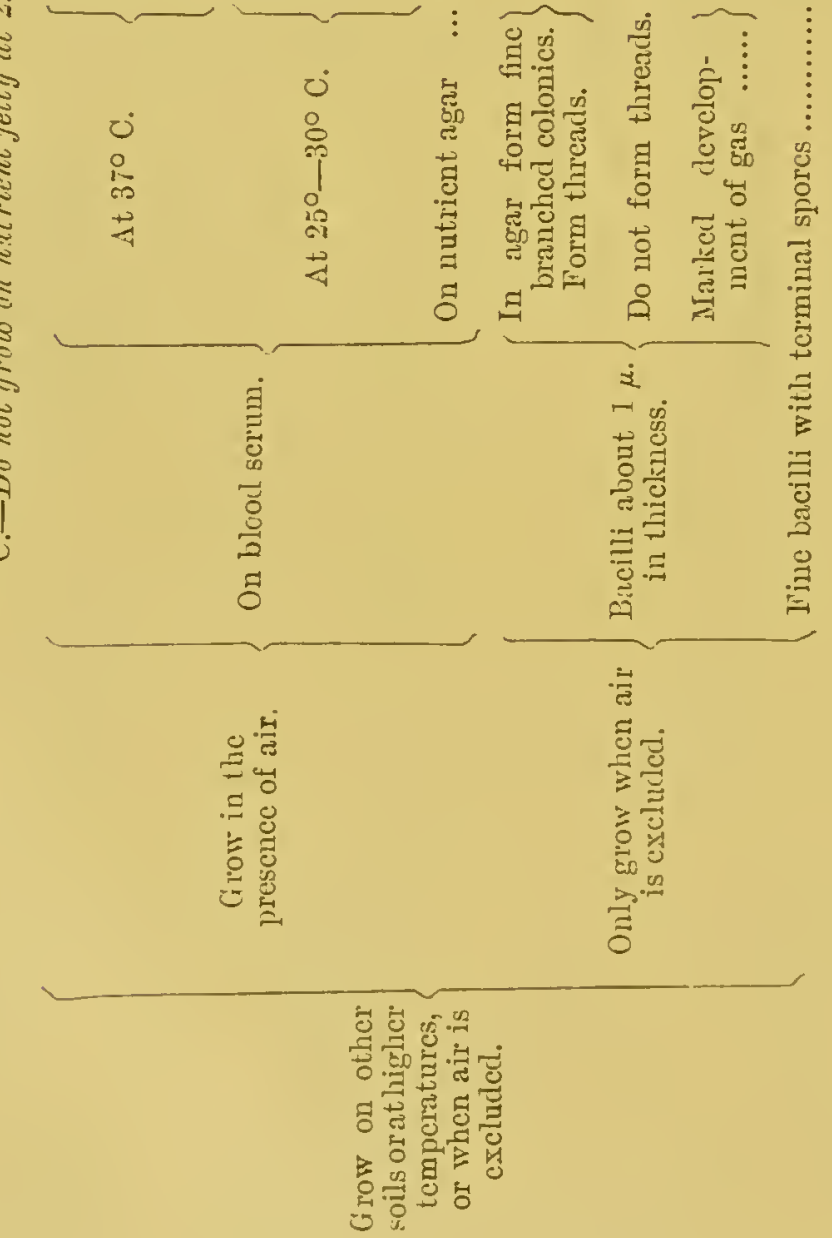

$5 \%$

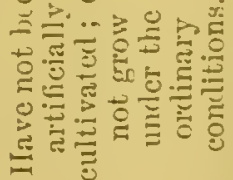




\section{SPIRILLA.}

\section{Spirilluar Choler Asiatice.}

\section{(Kommabacillus, Bacille-virgule cholérigène.)}

Numerous investigations formerly made with the view of finding the causal organism of cholera, which was long suspected to exist, led to no certain results; the discovery of micro-organisms by Pacini in 1854, and by Klob in 1867, were of no value. It was not till 1884 Koch's dis. that Koch succeeded in discovering as the causal agent covery of the of Asiatic cholera a peculiar species of bacteria which bacilli. can be constantly demonstrated in the intestinal contents and in the dejecta of those suffering from cholera, and which is never found in the intestinal contents in herlthy persons, nor in those suffering from other diseases; it is exclusively limited to the cholera intestine, and is present there in largest numbers the more violent the disease. These bacteria are very small, generally bent like a "comma," but at times forming long screw-like threads, and they grow in nutrient gelatine, on plates and in puncture cultivations, in the form of characteristic colonies which slowly liquefy the gelatine.

On examination of numerous cases of cholera, Koch Condition of was unable to find, in the blood or organs, in the intestinc spite of the most careful investigations, any bacteria which could be suspected as taking part in the infection; this result might have been expected, as the important pathological alterations only occur in the intestine, and not at all, or only to a subordinate degree, in the liver, spleen, kidneys, \&c. (Virchow*). In the intestine Koch found various alterations according to

* Verhandl. d. Chol.Conforenz, 2 Jahr, 1885. 
In acute uncomplicatod cases of cholera.

In morc protracted cascs.

In typhoid cases.

Mothods employed for the demonstration of the choleria bacilli. the intensity and duration of the process. In some cascs running a very aeute eourse there was only slight swelling and rosy red eoloration of the mucous membrine of the small intestine; and the contents of the intestine werc eolourless like riee-watcr, or bettcr, like gruel. In these eascs the eomma bacilli wcre usually prescnt in very large numbers in the intcstinal eontents, often almost in pure cultivation. If the morbid process had lasted longer the mucous membrane showed somewhat more marked alterations; more espccially therc was a patehy redness, whieh was partieularly notieeablc at the margins of the follielcs and of Peyer's patches. At the same time it was found that the eomma baeilli had penetrated into the mucous membrane; in seetions the eomma baeilli wcre found in the tube-like glands, and had to some extent pcnetrated between the epithelium and the basal mcmbrane. Nearer the surface other bacteria were also frequently present, usually thicker or finer bacilli whieh had passed morc or less dceply into the mucous membrane; but this had eridently occurred after the entrance of the eomma baeilli, which always lay most deeply, and whieh had, as it were, prepared the way for the other bactcria. - In a third category of the eases all sorts of secondary alterations liad oecurred in consequence of the longer duration of the clisease; the lower portion of the small intestinc was of a dark brownish red colour, the mucous membrane shorred superficial hrmorrhages, and at timcs it had undergonc a superficial neerosis, and was corered with diphtheritic deposits. In corrcspondenee with this, the intestinal contcnts were no longer colourless, but consisted of a bloody stinking fluid, and in it the comma bacilli were often diffieult to recognise on account of the presence of numcrous other linds of bacteria.In all these cases Koch found that the following was the best method for diseovcring the bacilli. For their demonstration he cmployed either fresh dejeeta, where possible those of a soupy character; or the contents of the ileum obtained on post-mortcm examination; or clothes which had been soiled with dejeeta. Koch has 
observed that the comma bacilli usually multiply rapidly on moist linen or moist earth, and that it is not till after 2 or 3 days that other forms of bacteria have gained the upper hand. Hence shirts and bed-clothes, even when they have been liept for some time, are as a rule still suitable for the discovery of the comma bacilli.The microscopical investigation was made by spreading Microscopical out on cover glasses a drop of the dejecta, or, better, one investigation. of the small mucous flakes which are usually present in large numbers in the turbid fluid, and which contain the largest numbers of the comma bacilli; these cover glasses were then dried, heated, and stained for 1 to 5 minutes with warm methylene blue or fuchsine solutions. It is often difficult to recognise the comma bacilli with Modification certainty among the large number of other bacteria; of the method according to Schottelius it is of advantage in these cases, after mixing the dejecta with double the quantity of faintly alkaline meat infusion, to let it stand in an open vessel for 12 hours in a warm place $\left(30^{\circ}\right.$ to $40^{\circ} \mathrm{C}$.). Under these circumstances the comma bacilli multiply chiefly at the surface of the fluid, and by taking a specimen from the surface, preparations are obtained which contain almost exclusively comma bacilli in such numbers as are only otherwise found in the typical soupy dejecta.It is more difficult to demonstrate the comma bacilli in sections of the intestinal mucous membrane. In cases which follow a very acute course the bacilli scarcely seem to penetrate into the mucous membrane at all; in old cases the bacilli which have passed into the membrane have long since died, and only other bacteria which entered afterwards are found. The comma bacilli are best demonstrated in sections of intestinal mucous membrane which is in the state of patchy redness described above; under these circumstances they can be almost always found in sections through the red border of the follicles. They are best stained with allaline methylene blue; a suitable method of double staining has not as yet been found, and this is so much the more to be regretted as it is by no means easy to see the comma bacilli in the midst of the cells and nuclei 
Difticultics of which are stained in a similar manner. An additional theil demonstration in sections.

Demonstration by cultivation.
Constant presence of comma baeilli in all cases of cholera. difficulty is caused by the fact that the bacilli only rarely lie in the same plane, and scldom show the "comma" form distinctly; as a rule the curve is directed morc or less upwards or downwards, or the comma may stand almost vertical; in all these cases a form results which differs markedly from that of the comma bacilli in cover glass preparations, where they are as a rule lying horizontally in one plane. Hence isolated comma bacilli cannot be recognised in the tissue with certainty; but where small groups are present there are usually some which show a distinct comma form, and which thus lead us to a correct conclusion as to the other individuals which are less favourably placed. If these difficulties are borne in mind, the comma bacilli can be demonstrated in the intestinal mucous membrane with complete certainty.

Much better than the microscopical examination for the demonstration of the comma bacilli is the method by cultivation, which, in fact, never fails for the discovery of other bacteria also, such as typhoid bacilli, even when a large number of microscopical specimens have failed to show any organisms. The cultivation is made in the usual manner by introducing a small mucous flake from the dejecta, or from the soiled linen, into a vessel containing liquefied gelatime $(5$ or 10 per cent.); from the original vessel two dilutions are usually made; the contents of all the three vessels are then poured out on glass plates, and after 24 , or at most 48 hours, characteristic colonies appear, which are so trpical that the diagnosis of the presence or absence of the comma bacilli can be made with certainty.

By the aid of these methods it has bcen dcmonstraterl that the comma bacilli are constantly prcsent in every distinct case of Asiatic cholcra, and also that they are only found in this disease, and never under normal conditions nor in the case of any other disense. Koch has investigated the dejecta or the intestinal contents in about 100 cases of cholera in Egypt, India, and Toulon; Nicati and Rietscli have investigated 31 cases 
in Marseilles, Pfeiffer 12 cases in Paris; cholera patients have also been examined by Babès and Watson Cheyne in Paris, by van Ermengem in Marseilles, by Armanni and Fede in Naples, by Schottelius in Turin, by Ceci in Genoa, and also by Klein, Buchner, \&c. In all these cases comma bacilli have been demonstrated in the dejecta, or in the intestinal contents. In microscopical A fewnegative observations the inm hesili from observations the comma bacill were distinctly recognised microscopical in by far the greatest majority of the cases. Some observations. observers never failed to find them by this method of investigation; the majority have, however, here and there obtained negative results. The number of these negative results will probably be still further reduced by the general use of Schottelius' method.-On the other Constant dishand plate cultivations have never failed in the hands of covery by the observers mentioned above. It is true that the comma cultivation. bacilli were not found in every specimen of the dejecta, more especially in old or complicated cases; but the examination of several specimens of dejecta cluring the course of the disease, or of the intestinal contents after death, always yielded positive results. It is probable that greater difficulties will be experienced in demonstrating the bacilli in very mild cases, such as frequently appear to occur during cholera epidemics in individuals but slightly predisposed to the disease. It may be that in these cases the number of the bacilli is so small, and their presence in the dejecta so temporary, that a certain diagnosis will not be always possible. Hence in this direction the capabilities of the method have as yet to be determined.

Comma bacilli have only been found in the vomit in Occurrenco of small numbers, on two occasions by Koch, and on three comma bacilli occasions by Nicati and Rietsch, but in these cases it is \&c. possible that the material vomited was the intestinal contents which had passed into the stomach. Nicati and Rietsch also found comma bacilli in a few instances in the bile duct and in the gall bladder.-The blood and the other organs, even the mesenteric glands and liver, were always free from comma bacilli. 
Emmerieh's denial of the constant presence of comma baeilli. limitation of the comma bacilli to the cess.
Wixclusive cholera pro-

It is neeessary for the demonstration of the eomma lacilli that the observer must be thoroughly aequainted with the methods employed by Koch, and where the first experiments of an observer give negative results, they by no means prore the absence of the comma bacilli. Thus Emmerich in his investigations failed at first in two cases to find the comma bacilli, while in eighteen further cases he was able to demonstrate their presence; as the result of this fact, whielievidently quite harmonises with the above-mentioned positive results, Emmerich * raises one of his fundamental objections to Koch's riews, by stating that the eomma baeilli are not constantly found in cholera patients. In further eonfirmation of this assertion Emmerich brings forward erroneously the eridenee of Schottelius, who, like all other authors, and like Koch himself, was not able to demonstrate the comma bacilli in all cases by mieroscopieal examination, but who distinctly states, in the very paper cited by Emmerieh, "that aeeording to his experience the plate method always gives a positive result even in those cases in which, as the result of microscopieal examination of numerous specimens, no comma bacilli could be found with certainty in the dejecta." +

- In order to demonstrate that the comma bacilli were exclusively limited to the cholera process, Koch has made very numerous control investigations. He has, however, never been able to find these organisms in normal intestinal contents, in diarrhœic stools, or in patients who had recovered from cholera. In like manner the very numerous investigations made by other observers in this direction have given without exception a negative result; nowhere except in the dejecta of Asiatic cholera, or on objects which had been soiled with these dejecta (clothes, the water of a tank), have the characteristic comma bacilli described by Koch been found.

Similarbacilli. On several occasions similar comma-shaped bacilli have been seen, and at first these were erroneously identified with Koch's comma bacilli; but on more accurate study, although morphological differences could not be made out, biological distinctions were nerertheless found betrreen these various species and the true cholera bacilli, these distinctions being sufticient to allow of * Arch.f. Hygiene, vol. iii., p. 298 .

† Deutsche mcd. Woch., Nr. 14, 1835. 
their differentiation from each other. 'This was the case, for example, with the spirilla observed by Finkler and Prior in dejecta, by Deneke in cheese, and by Lewis and Miller in the deposit on teeth. (See below.)

Even Koch's oppononts have had to admit that their efforts to find Koch's comma bacilli elsewhcre than in the dejecta of cholcra patients liave complctely failed. Klein was compelled by Watson Cheyne's objections to makc such an admission; and Buchner says in his most recent publication, "Koch's assertion that the ribrio found by him in the cholera process is exclusively limited to that process has as yct been unshaken." ** In peculiar contrast to this statcment of Buchner's is one Admission of made by his fellow-worker Emmerich in the same number of the limitation the Archiv fiur Ingiene, p. 358. "The markedly alkaline exu- of these bacill dation, rich in oxygen, washes out the intestine and removes the numerous micro-organisms which live there, while, on the other hand, it forms an admirable nutrient medium for Koch's vibrios, which also occur in limited numbers in the normal intestine, and which multiply enormously in cholera, and in many cases awake the suspicion that they are causally connected with the alterations." In support of this assertion, Unfounded which is of such cxtrcme importance with regard to the objection by ctiology of cholera, Emmerich has brought forward no proof, either from those portions of his experiments as yet published, or from those of any other investigator, and hence the statement is simply incorrect.

Hence we can no longer doubt that Koch's comma Deductious bacilli occur constantly and exclusively in Asiatic from the con. cholera; further, that they are found in the intestine in stancy of the numbers which are larger according as the cholera runs bacilli, and a purer and more typical course, and they are present thcir limitain the intestine in largest numbers at those parts where cholera the cholera process has set up the most marlied altera- process. tions, namely, in the lower portion of the small intestine. This coincidence cannot be an accidental one; on the contrary, the two phenomena, the cholera process on the one hand, and the appearance of the comma bacilli on the other, must stand to each other in the relation of cause and effect. In cxplanation of this constant concurrence we have only two Necessity for possibilities. Either the cholera process is the cause connoction of the presence of the large numbers of the comma botwocen the

* Arch.f. Irygiene, vol. iii., 1885, p. 438. and cholerin. 
bacilli, or the comma bacilli causc the cholcra process. On the first assumption there are again two explanations of the appearance of the comma bacilli : cither these organisms multiply to a great cxtent as the result of the cholera process from a few comma bacilli

Cholera cannot be the canse of the the comma the com constantly present in the normal intestine; against this, however, we have the constant negative results of numerous investigations of normal intestinal contents, along with the other necessary assumption that if this vicw is correct the comma bacilli must be distributed in a very remarkable manner, and must bc constantly present in the normal intestine of Indians and Egyptians, as well as in that of Europeans; and further, that as the result of any disease we have never as yet observed a similar constant and exclusive development of a definite form of bacteria under the favouring influence of the disease. It is evidently quite erroneous to bring forward as an analogous case the constant presence of oidium lactis in sour mill, * in which from the constancy of its presence (though as a matter of fact it is not constantly present) one might come to an erroneous conclusion as to the etiological rôle of the oildium, for in this example the second condition neccssary to prore an etiological connection between the comma bacilli and the cholera process is absent, namely, the exclusire limitation of the occurrence of these organisms to cases of cholera ; on the contrary, in the case of oiddium lactis we have to do with an organism which is extremely widely distributed everywhere, and which can be demonstrated in other places than in sour milk, and without any production of acid, and hence it is rery casy to see that it does not stand in any etiological relation to the formation of acid. There is cxactly the same objection to the other organisms, such as the aspergilli, which have likewise becn brought forward by Buchucr as evidence agrinst the ctiological significance of the comma bacilli. On the other hand, we do not know a single example in the whole range of mycology where the constant and exclusirc occurrence of a definite specics

* Buchncr, Mïnchner ärztl. Int. Bl., 1585, Nir. 50. 
of bacterium in any process does not at the same tirue imply an etiological relation between the two.

The second hypothesis of the occurrence of comma bacilli in cholera is still more unlikely, namely, that Koch's comma bacilli have been developed as the result of the influence of the cholera disease from other species of vibrio which are normally present in the intestine. Such a transformation of one species of bacteria into another which is well characterised, and which has remained unaltered in its properties for years when cultivated under a great variety of conditions, has as yet never been observed, and certainly not in such a regularly recurring and exclusive manner, under the influence of a definite morbid process. Such an hypothesis is without any fouldation, and directly contradicts all the facts which have been obtained as the result of observation and experiment.

Hence in the present state of our knowledge we can As a consecome to no other logical conclusion than that Koch's $\underset{\text { must look }}{\text { quen }}$ comma bacilli are the cause of cholera. With the same the comina right with which we infer the etiological significan of bacilli as the the spirilla of relapsing fever, of the leprosy bacilli, of cholera. typhoid bacilli, \&c., from their constant and exclusive occurrence in these diseases; with the same right with which we must look on the syphilis bacilli as the cause of the disease as soon as their constant and exclusive occurrence in syphilitic new formations has been certainly proved, we must also recognise that the comma bacilli, on account of the proof of their constant and exclusive presence, are the only and sufficient cause of Asiatic cholera.

The following facts have up to the present time been Morphological ascertained with regard to the morphological and bio- characters of logical characters of Koch's comma bacilli :-

The comma bacilli usually present the appearance of short curved rods, which, under certain circumstances remain in connection with each other, and form long 
screw-like twisted threads, and therefore in their simplest form may bo looked on as fragments of spirilla. The average length of the individual curved bacillus is about $1.5 \mu$, varying between $8 \mu$. and $2 \mu$.; the average thickness is from $\frac{1}{8}$ to $\frac{1}{3}$ of the length. The youngest. individuals either show a very slight curve or no curve at all; the more fully formed ones generally show in fresh unstained specimens a distinct curve, sometimes only a slight bend, sometimes a full half circle; in the dried and stained specimens a larger number show a less curve or are even straight, the difference being due to the method of preparation. After division the two individuals often remain united together, and thus,

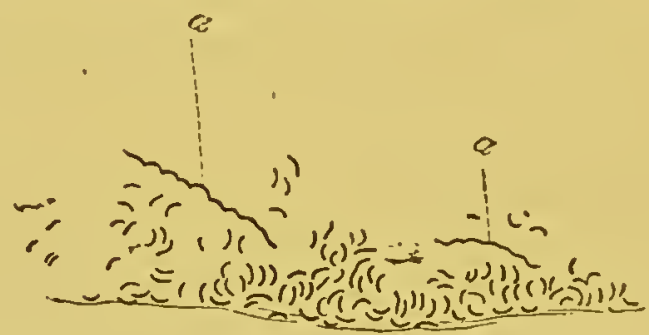

Fig. 116.-(After Koch.) Cover glass preparation from the border of a drop of meat infusion containing a purc cultivation of the comma bacilli.

Long screw-like threads $(a) \times 600$.

according to the age and degree of development, they form short and slight, or longer and more markedly bent and S-shaped figures; when examined in drop cultivations it may be seen that the two component parts of the " $\mathrm{S}$ " do not lie in one plane, but represent the commencement of a screw. As the result of the preparation we not uncommonly find in stained preparations $\epsilon$-shaped forms; it is probable that in this case the rods have become bent and displaced in the middle, so that the concavities, which were originally opposed to Spirilla. each other, now look in the same direction.-In drop cultivations there is almost always a formation of long screw-like threads or true spirilla, which may consist of 10, 20, or 30 narrow turns; this continued adhesion of the newly developed individuals, to which the spirilla 
owe their origin, is only observed in cultivations which are kept moderately warm. It is only relatively seldom that these spirilla can be well demonstrated in stained

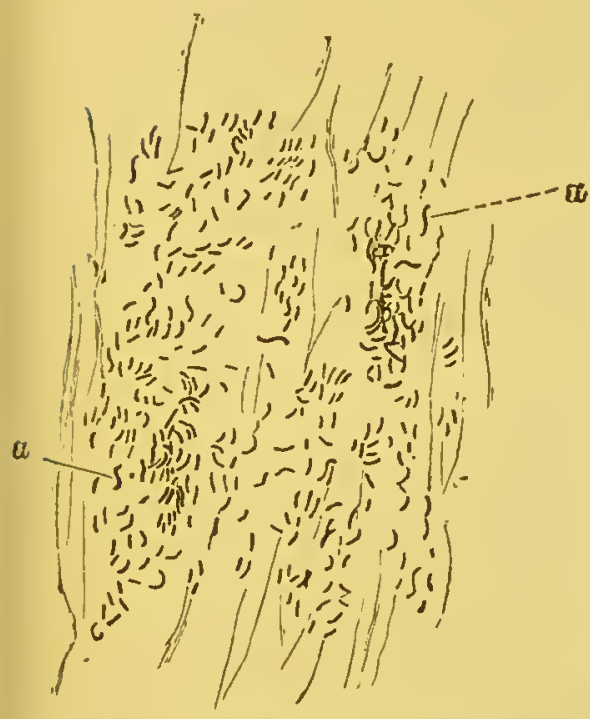

Fig. 117.-(After Koch.) Cover glass preparation.

Cholera dejecta on moist linen (two (lays old). Marked multiplication of the comma bacilli among which are S-shaped forms $(a) \times 600$.

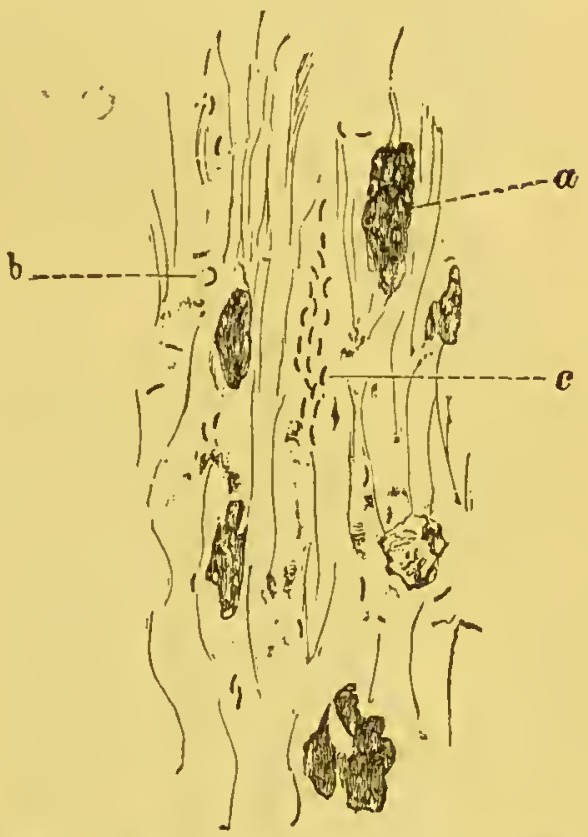

Fig. 118.-(After Koch.) Cover glass preparation from the contents of the intestine in a case of cholera.

Nuclei of the dead epithelial cells $(a)$. Semicircular comma bacillus (b).

Very characteristic arrangement of the comma bacillus $(c) \times 600$.

cover glass preparations; as a rule the turns appear more or less opened out, so that we find almost straight threads; or the threads become torn, and we only obtain short fragments.-Hence the morphological characters of the comma bucilli are best studied in drop cultivations; in order to prepare these cultivations a drop of allaline meat infusion (for the method, see the last chapter) is placed on a cover glass infected with a minute quantity of a cultivation of comma bacilli, and then so fixed on a hollow slide by the aid of vaseline that the drop hangs into the depression in the slide. The preparation is now liept at from $25^{\circ}$ to $30^{\circ} \mathrm{C}$, and the further development of the spirilla is watched from time to time by means of a high power (oil immersion). 
Morement of the comma bacilli.
Involntion forms.
By the employment of this method we also see that the comma bacilli are motile. The movement is as a rule very active, either turning round their axis or shooting forwards; in the case of the longer spirilla it is slower, and more of an oscillating character. The movement is, as a rule, most active at the margin of the drop, in the neighbourhood of the air.

The comma bacilli multiply very rapidly. - When the maximum of development has occurred in a drop culti-

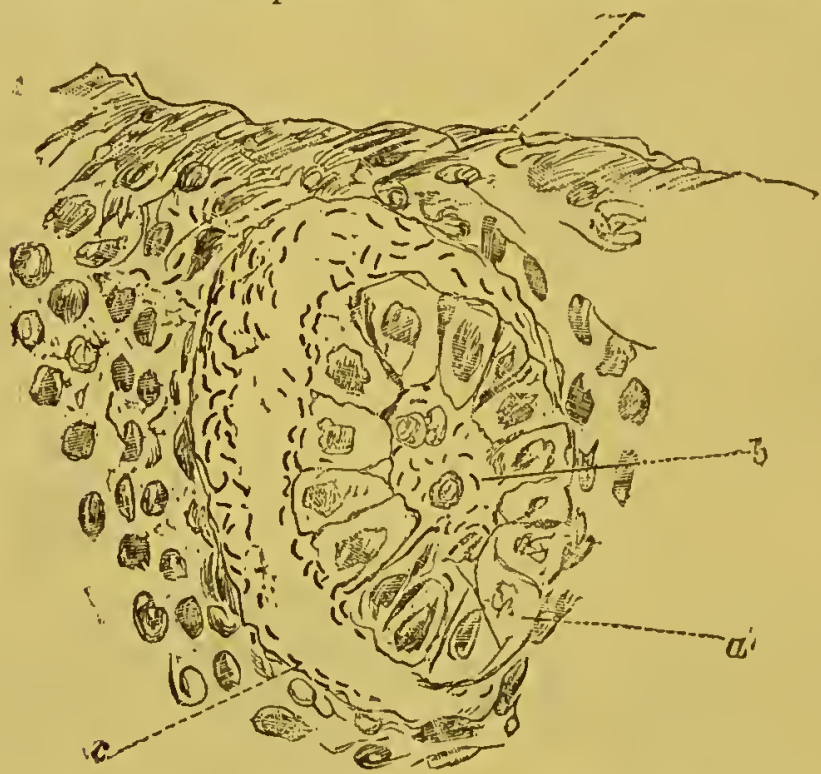

Fig. 119.-(After Koch.) Section of the intestinal mucous membrane from a case of cholera.

A Brunner's gland $(a)$ cut transversely.

In the interior $(b)$ and between the epithelium and the basal membrane $(c)$ are numerous comma bacilli $x$ 600.

vation involution appearances generally commence, at first in a few, and later in numerous individuals. The dying bacilli lose their characteristic form, shrivel up or swell out, and in such a state take up the colouring matter only slightly or not at all. In the swollen plumper rod there is often such a subdivision of that portion of the plasma which talies on the strin that, on treatment with aniline colours, an unstained spot remains in the middle of the rod which recalls the appearance of tho spores of other bacteria, and has in fact been erroneously looked on as spores. Further, according to 
Babés, longer and broader spirilla are formed in nutrient media containing alcohol, and at the end of these spirilla large round bladder-like dilatations appear ; the latter then become detached, and may remain visible for a considerable time while the thread breaks up. These spheres, as well as the spindle and flask-shaped forms which also occur, are in reality sterile involution structures.

As yet no multiplication of the comma bacilli by means of undoubted spores has been observed. Against the probability of spore formation we have the observa-

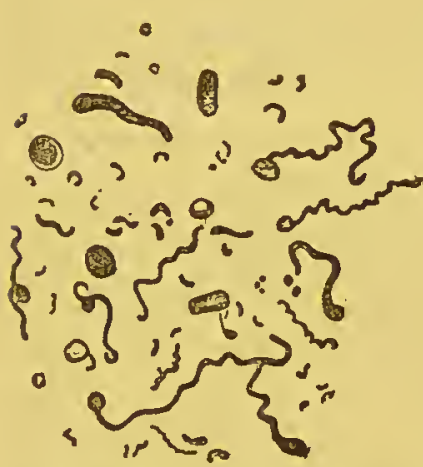

Fig. 120.-Involution forms of the cholera spirilla (after Ermengem) $\times 700$.

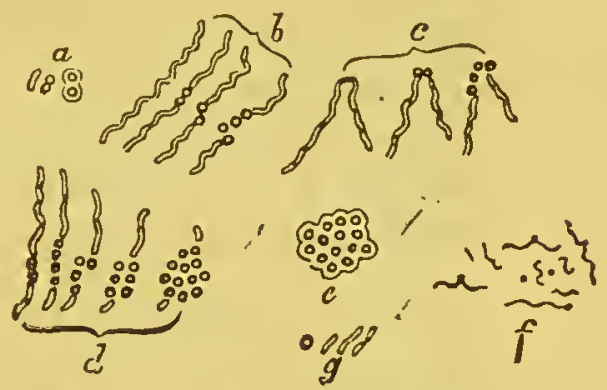

Fig. 121.-Resting forms of the cholera spirilla according to Hueppe.

$a$, breaking up of a comma bacillus into two spheres.

$b$ and $c$, formation of spheres in spirilla.

$d$ and $e$, groups of spheres.

$f$, spirilla with spheres from an old cultivation.

$g$, germination of the spheres.

tion made by Koch that in dejecta, linen, soil, \&c., impregnated with cultivations no living comma bacilli can be demonstrated if the objects have been thoroughly dried for a short time.

The involution forms just described, and the peculiar Apparent distribution of the colouring matter as the result of tion formadegeneration of the rods, have frequently led to the erroneous assumption that spores were formed. Thus Carillon* and Ferrant liave described the spherical dilatations, and Cecif the formation of the unstained portions as processes of fructification; Ferran, in fact,

* Semaine médicale, 1884 , Nov.

† Gazeta medica Calalana, 1885, Jan.

¥ Semaine médicale, 1885, March. 
thinks that he has proved that the comma bacilli form part of the cycle of development of a mould fungus (Peronospora).-Recently Hueppe * has described a resting form of the comma bacilli. As the nutrient soil becomes exhausted long twisted threads are in the first place formed; then at one part of such a thread we have the production of two spheres which are only slightly larger than the diameter of the thread, and are more highly refracting. After a little two or four other spheres appear along the thread, and at times actual zonglæa heaps, composed of numbers of spheres, are observed. These spheres, which are immobile, do not multiply by subdivision, but, according to Hueppe's direct observations, they gradually lose their refracting power and elongate to form a short rod, which then after further growth assumes the comma form, and subdivides when it has attained the " $\mathrm{S}$ " shape.

Even if this observation of the sprouting of these bodics were correct, - and Hucppe has only succeeded in observing it three times, and it is not impossible that in these cases he was deceived on account of the great difficulties of the investigation,-it would not necessarily follow that we have here to do with a spore or with a resting form. It is quite conceivable that in the course of the inrolution of the spirilla a portion of the plasma retains its power of development, althongh this portion cannot be looked on as a spore; such an idea would only be justified when it was clearly shown that this body was distinctly more resistant, and hence of service for the maintenance of the species, and that it conld resist drying and concurrence with saprophytes

Absence of any proof of greater resist ing power. better than the comma bacilli. Such qualities hare, however. not been demonstrated, either in the case of Hueppe's spheres, or in the case of the rcsting forms of the authors previously mentioned. Hueppe, it is true, says shortly that the spheres observed by him are more resistant against drying than the bacilli; but on account of the great importance of such a fact this asscrtion ought to hare been accompanicd by detailed proof, and this was so much the more required as Koch and his pupils have made very numerous experiments by drying a great varicty of cholcra cnltivations, and among these, doubtless, some which contained Hueppc's spheres. without having met with any exception to the slight resisting power of the bacilli.

* Fortschr. der Mcdicin, 1885, Nr. 19. 
The comma bacilli can be readily cultivated in very Beliaviour of various nutriont media. On gelatine plates they form bacilli in after 24 hours at $22^{\circ} \mathrm{C}$. very minute white points which cultivations. under a low power present the appearance of small round whitish-yellow refracting dises, without any sharp outline, and with an irregular and wary margin. These dises become gradually larger, they retain their faint yellow colour, which only becomes a little darker at the central part, but without any formation of zones, and the irregu-

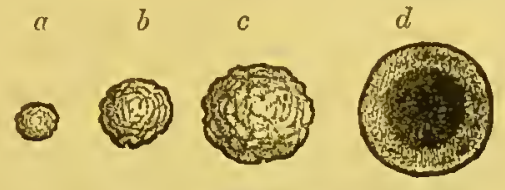

Fig. 122.-Colonies of cholera spirilla $\times 100$. a, after 20 hours.$$
\begin{array}{llll}
b, & 30 & & \\
c, & 36 & &
\end{array}
$$

At $c$ there is commencing liquefaction of the gelatine; at $d$ the colony has sunk to the bottom of the fumnelshaped liquefied area. lar outline becomes

more distinct; the same irregularity and roughness extends over the whole surface of the spherical colony, and as a consequence it presents a distinctly granular or furrowed appearance. The highly refracting character of these colonies gives them a clear shiny appearance, and the surface of the plate looks as if it had been sprinkled over with small bits of glass. The gelatine now begins to undergo gradual liquefaction; even with the maked eye the gelatine on the plates appears somewhat clepress ed at the parts where the colonies lie; a small, sharply-defined funnel, containing fluid,
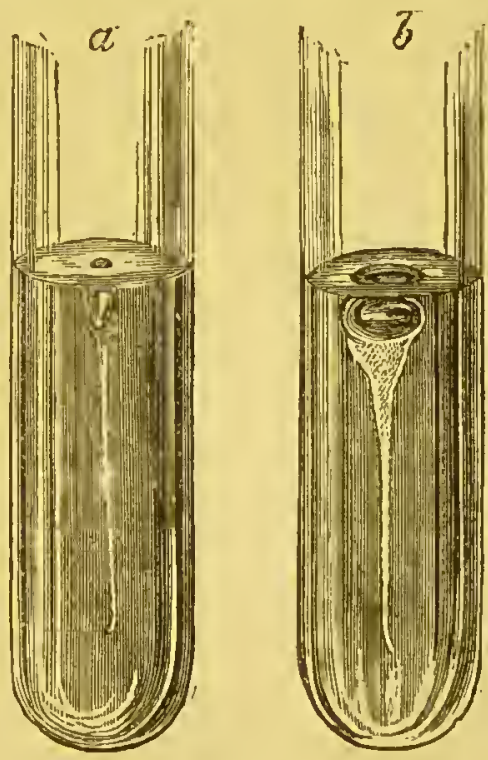

Fig. 123.-Puncture cultivation of Koch's comma bacillus.

$a$, two days old. $b$, four days old. is gradually formed at this place, the colony lying at the bottom of the funnel. The liquefaction only extends

Microscopical appearince of the colonies in nutrient jelly. 
slowly. Where there is sufficient space between the individual colonies the funnels measure at their surface scarcely $1 \mathrm{~mm}$. in diameter after 48 hours growth at $22^{\circ} \mathrm{C}$, and even after 72 hours their extent is not markedly greater.-Under the microscope the appearance is less characteristic after the commencement of the liquefaction. The margin of the area of liquefaction is circular, and has, for the most part, a sharp outline; further inwards a grey circular zone is formed which contains fluid and small fragments of the colony; in the centre the latter appears as a yellowish-brown, dull, irregularly granular disc with indistinct outline.

l'uncture cultivations.

Puncture cultivations in gelatine show, after 24 to 48 hours, a whitish turbidity along the track of the needle, and around this a slight amount of liquefaction. In this way a thin tube is formed, which contains at its peripheral part almost clear fluid, and at its central part the original whitish thread. Towards the surface of the gelatine this tube dilates in a funnel shape, the upper diameter of which has attained the extent of about $\frac{1}{2} \mathrm{~cm}$. after 48 hours. This funnel is also filled with fluid, the level of which is often markedly lower than the surface of the gelatine, so that the upper por* tion of the funnel only contains air ; this gives rise to the impression, on cursory examination, as if an air bubble filled the uppermost portion of the funnel.-This appearance, however, is not observed in every tube; slight variations from the above description are found according to the concentration of the gelatine, the temperature at which it is lept, the mode in which the puncture is made, and the amount of material introduced. In like manner the one or the other culture characteristic is found in other species of bacterin, and it is only the sum total of the characters mentioned which enables us to differentiate with certrinty the comma bacilli from other species.

After three or four clays the puncture cultiration shows a moderate extension of the funnel and of the tube, and thus a slow increase of the liquefaction; it is not till after 4 to 6 dnys that the liquefaction has occurred 
to such an extent that it has reached, at the surface, the margin of the glass; after 8 to 14 days the upper two-thirds of the gelatine is liquefied throughout its whole extent.

On nutrient agar the comma bacilli form a superficial Growth ou greyish-yellow, folded gelatinous layer, without any substrata. liquefaction of the substratum. These agar cultivations etain their vitality for a considerable length of time.On potatoes kept at the ordinary temperature no growth can be observed, but at from $30^{\circ}$ to $35^{\circ} \mathrm{C}$. a light brown, and later a more greyish-brown, mucous layer is formed.

The comma bacilli grow very luxuriantly in neutralised meat infusion, in blood serum, and in milk, the latter medium not undergoing any noticeable alteration. In none of these cultivations is there any development of putrefactive gases, nor any disagreeable odour; there is at most a peculiar aromatic and sweetish smell. (Buchner alone has observed a development of foul smell in his cultivations of comma bacilli in meat infusion.)

On the whole the comma bacilli are not very fastidious Behaviour in as regards the composition of the nutrient substrata. dilute solnIt is not till the nutrient solutions become very dilute water. that the growth ceases. As a rule no multiplication of comma bacilli takes place in infusions of the strength ordinarily employed for cultivations if diluted with 40 parts of water, while with somewhat greater concentration active growth occurs; in the former case there is a gradual diminution in the number of the organisms introduced. In water, ${ }^{*}$ even when it contains a relatively large amount of organic and inorganic material in solution, there is never any multiplication of the comma bacilli. It is only where, at the margin of stagnant water, there is a local accumulation of nutrient materials from the presence of a variety of solid particles in suspension and of pieces of mud that development occurs, and this takes place especially on the floating solid pieces, and thus for example we have the explana-

* Aceording to experiments by Bolton, Zcitschr f. Hygiene, vol. iv. 
tion of the observation made by Koch, which will be referred to again, as to the multiplication of comma bacilli in a tank in India.--The comma bacilli are also sensitive as regards any acid reaction of the nutrient medium; the meat infusion, nutrient jelly, \&c., employed for cultivations must be accurately neutralised, or, better, slightly alkaline.

Relation to oxygen.

Influence of tcmperature.
The comma bacilli belong to the acrobes in so far as they only develop with great activity at the surface of fluid or solid nutrient substrata, where they are in contact with the oxygen of the air; it also appears as if they only moved actively in the presence of a certain amount of oxygen. Nevertheless their necessity for oxygen is by no means so great that they cease entirely to multiply where that gas is limited in amount or entirely absent; on the contrary, in that case the colonies only grow somewhat more slowly and to a less extent than those which have developed in the presence of air. Thus in gelatine plates which are covered with thin plates of mica, and in gelatine tubes from which the oxygen has been expelled by means of hydrogen, a delayed growth of the comma bacilli occurs, though ultimately one quite visible to the naked eye; ${ }^{*}$ and it is this slight sensitiveness with regard to oxygen that enables the comma bacilli to multiply to a great degrce under all circumstances, and even in the varying and often relatively slight amount of oxygen which they find in the intestinal canal.

The temperature has an important influence on the growth of the cultivations. According to Koch's experiments no growth occurs below $16^{\circ} \mathrm{C}$; ; at $16^{\circ}$ or $17^{\circ} \mathrm{C}$. growth is slight, and it does not begin to be actire till about $17^{\circ}$ or $18^{\circ} \mathrm{C}$; much better culture results are obtained, however, with temperatures between $22^{\circ}$ and $25^{\circ} \mathrm{C}$, and this is the temperature at which the gelatine cultivations should be liept if possible; the optimum of temperature is considerably higher, namely, between $30^{\circ}$ and $40^{\circ} \mathrm{C}$., a temperature at which the gelatine becomes completely fluid.

* Liborius, Zeitschr.f. Iygiene, rol. i. 
Koch has also made numerous observations with Conditions regard to the action of various inhibiting and destructive death. agents on the comma bacilli. As regards those hurtful finctors, which most frequently cause the death of pathogenic bacteria in nature, namely, drying and overgrowth by saprophytes, it has already been mentioned, when discussing the question of spore formation, that the comma bacilli in all their stages of development die with extraordinary rapidity when dried. If a culti-Drying vation is spread out on a cover glass and exposed to the action of the air at the ordinary temperature the bacilli are found to be dead after 2 to 3 hours, so that no development occurs when such a glass is placed in nutrient jelly. If care is taken to have the culture fluid in a thicker layer it may be somewhat longer, but never more than 24 hours before all the comma bacilli are found to be dead. It follows from the fact of this great sensitiveness with regard to drying, which is present in all the stages of development of the comma bacilli, even in cultures which have been made under the most varying conditions, that no true resting spores are formed.Further, as the result of these experiments, we must draw the important conclusion that no living comma bacilli can be contained in any material which is in a dried or dust-like state; and as it is only from completely dry surfaces that particles of dust can be detached and carried to other localities by currents of air, it follows that a transport of living comma bacilli by the air, and the production of infection in this way, is impossible.Comma bacilli which are capable of development can Conclusionsas only be transported through tho air for short distances to transport when infective fluids are agitated and bubbles are air. detached, as for instance when waves strike against a quay or on the wheels of a water-mill, or in washing cholera linen; in these cases small bubbles of the fluid contrining bacteria may be brought by currents of air into contact with predisposed individuals.

The comma bacilli are also very easily injured by the Destruction of second factor, namely, the overgrowth by saprophytes. the comma When mixed with other bacteria they can, if they aro saprophytcs. 
present at first in considerable excess, and if the conditions as regards nutrition, temperature, reaction, and presence of oxygen, are especially favourable, gain the upper hand in the first instance, and thus form those pure cultivations which have been observed on the clothes of cholera patients, on moist soil impregnated with dejecta, and in the culture vessels prepared by Schottelius' method; but after two or three days a complete alteration in the character of the cultivation occur's in these cases; the comma bacilli die, and other bacteria gradually occupy the whole of the nutrient substrata. If the saprophytes are in excess in the first instance, or if the sum total of the conditions of life are not very favourable to the comma bacilli, the latter do not multiply at all, but the saprophytic bacteria lead rapidly to the death of the comma bacilli present, either by using up the nutrient material, or by producing poisonous products. According to Koch's experiments, comma bacilli when added to sewage could no longer be demonstrated after 24 hours; in the water in the Berlin Canal they died at the latest after 6 to 7 days. In impure water also they do not retain their vitality as a rule for a longer time, except when they are introduced in very large quantities.

Length of life If the two hurtful influences above mentioned are bacilli in pure absent the vitality of the comma bacilli may be of cultivations. long duration. They can be kept alive for months in fluid, or, at any rate, moist, pure cultivations; in gelatine cultivations they have been found living after 3 to 5 months, in agar cultivations after about 6 months (in one case mentioned by Hueppe after almost 10 months). It is evidently not impossible that an equally long preservation of living comma bacilli may at times occur in linen which is kept moist, on various parts of the soil, or on some object which is protected from drying and from the entranco of other bacteria. But under normal conditions cases of this kind must be of extreme rarity, for the comma bacilli aro almost always destroyed either by drying or by the presence of such a large quantity of water that the substratum is overgrow by other bacteria. 
Among other noxious influences the following have Relation to been investigated by Koch, and by Nicati and Rietscl other noxious been investigated by Koch, and by Nicati and Rietscls. influences. Low temperntures did not interfere with the vitality of the comma bacilli, (even- $10^{\circ} \mathrm{C}$., ) the cultivation having been completely frozen. On the other hand, high temperatures were very active; exposure for half an hour to a temperature of $60^{\circ} \mathrm{C}$. cansed death with certainty, as did also boiling of the fluid for a short time. Their growth is also hindered when, for example, 10 per cent. of alcohol is added to the nutrient substratum; or 2 per cent. of sulphate of iron; or $\frac{1}{4}$ per cent. of carbolic acid; or $\frac{1}{20}$ per cent. of hydrochloric acid; or 50 per cent. of quinine; or $\frac{1}{2000}$ per cent. of bichloride of mercury; the presence of 2 per cent. of common salt does not interfere with development. With the exception of bichloride of mercury, these organisms are most certainly killed by carbolic acid, which renders the comma bacilli incapable of development when employed in $\frac{1}{2}$ per cent. concentration for a few minutes.

In order to demonstrate with certainty the etiological Experiments significance of the comma bacilli it was desirable, if on animals. possible, to set up the choleraic process in animals by inoculation of pure cultivations. Nevertheless from the first there was but little expectation that this mode of direct experimentation could be employed with success. For it has been distinctly demonstrated that no animal of any species is ever naturally attacked with symptoms similar to those of human cholera, even although they live in intimate association with mankind and come in contact with the infective material of cholera in all sorts of ways and in places where the disease is endemic or epidemic.

Numerous experiments on animals made formerly and also in recent times with tho dejecta and romit of cholera patients, with the intestinal contents of clioler' bodies, \&c., led to no noteworthy result. On some 
occasions it seemed as if a positive result had been obtrined, but this was due to error in the experiments; thus in Thiersch's experiments white mice became ill after having been ferl on filter paper impregnated witl decomposing cholera dejecta, but they also became ill in the same manner if the cholera dejecta were omitted from the experiments; in like manner in tle experiments made quite recently by Richards in which swine were fed with very large quantities of cholera dejecta and died in from $\frac{1}{4}$ to $2 \frac{1}{2}$ hours, we may assume witl certainty, from the suddenness of the action, as well as from the circumstance that the resulting disease could not be transmitted in any way to other animals, that in these experiments he had to do with poisoning from poisonous products contained in the dejecta, and not with an infection.

Notwithstanding this slight prospect of success the experiments on animals have been again taken up by Nicati and Rietsch, Van Ermengem, Koch, \&c., since, the discovery and cultivation of the comma bacilli; and, as a matter of fact, these authors have succeeded in finding a mode of infection by which a process at any rate similar to cholera can be set up in animals by means of pure cultivations of these organisms. According to the facts mentioned above as to the immunity of these animals to every sort of natural infection, it conld hardly be expected that more than a similarity in the symptoms would be obtained, and even this result could only be looked for by the employment of an artificial mode of infection. In view of these unfarourable prospects of experiments on animals it is more correct to lay the greatest stress in the proof of the etiological rofle of comma bacilli on the demonstration of their constant and exclusive occurrence in cholera, and not on the experiments on animals; their constancy has been so completely shown that as a matter of fact the experiments on animals can be dispensed with.

Injection of cultivations in to the dnodenum.
Starting from the supposition that the seat of the action of the comma bacilli is the small intestine, but that infection by the mouth must be a difficult matter, 
because the acid in the gastric juice can kill the bacilli introduced, Nicati and Rietsch tried in the first instance to inject dejecta of cholera patients and pure cultivations of comma bacilli directly into the duodenum of guineapigs. In order to exclude the possible influence of the bile they also tied the bile duct; it was, howover, soon evident that this was an unnecessary precaution, for the bile did not in any way interfere with the growth of the comma bacilli, even when the half of the nutrient substratum consisted of bile.

On the other hand it has been made out as the result of Koch's experiments that the result depends very much on the mode in which the operation is carried out, and on the greater or less irritation and maltreatment of the intestine. If the abdominal cavity of guinen-pigs is only opened to a small extent, and if the injections are made into the nearest part of the small intestine instead of into the deeply lying duodenum, so as to avoid disturbance of the intestine, the guinea-pigs die only very exceptionally (of six animals only one died). If, on the other hand, the duodenum is drawn forward and fixed for a considerable time with forceps; if in short the intestine is treated in such a manner that hyperæmia and alteration of the peristaltic action results, and if then $\frac{1}{2}$ to 1 drop of a pure cultivation of comma bacilli is injected into the intestinal canal, by far the greater number of the animals die after from 12 to 48 hours with symptoms resembling those of cholera. After death, which occurs with great depression of the body vemperature, hyperæmic swelling of the mucous membrane of the intestine is found, and the intestimal contents are transformed into a very plentiful thin mucous fluid, which contains enormous numbers of comma bacilli almost in a pure cultiration.-Other Control linds of bacteria injected in a similar manner into the experiments. intestine did not cause death in any case, even though numerous control experiments were made, with the exception of the organisms isolated by Finkler and Prior, which caused three fatal results amoug ten guinealigs treated in this way. 'The large number of negative 
Infection of the animals by the mouth.

Preparation of the animals

control experiments shows at once that the operation per se, when properly carried out, does not place the animals in any serious danger.

Koch has however attempted to avoid this opcration, which is by no means insignificant, and to obtain infection of guinea-pigs by the mouth, and he has succeeded by neutralising the gastric juice in the first instance by means of soda solution, and subsequently administering substances which cause slowing of the peristaltic action, and thus enable the comma bacilli to remain for a longer time in the small intestinc. The following is the mode in which an experiment of this kind is performed. In the first place 5 cc. of a 5 per cent. soda solution are introduced into the stomach of the guinea-pigs by means of a catheter passed downwards from the mouth (it has been shown that as a result the intestinal contents hare an alkaline reaction for several hours), and some time afterwards $10 \mathrm{ccm}$. of fluid, to which one or several drops of a pure cultivation of comma bacilli have been added, are introduced; if only a rery little of the cultivation, one-third of a drop or less, is employed the result is uncertain. After the injection a dose of opium is administered to the animals; if the opium is introduced into the stomach of guinea-pigs it scricely produces any effect, and hence it is better to inject it directly into the abdominal cavity by means of a syringe, the dose being $1 \mathrm{ccm}$. of tincture of opium to every 200 grammes of the body weight; the back of the animal is grasped with the left land in such a manner that the abdomen is projected forwards, and then the syringe is rapidly pushed into the middle of the abdominal wall; when the operation is performed in this manner the intestines are pushed to one side so completcly that they have almost nerer been injured, nor have any other bad consequences been obscrved.

Results. After the administration of the opium narcosis occurs, lasting from $\frac{1}{2}$ to 1 hour, after which the animals seem quite well. On the evening of the same day, or on the following day, the animals lose their appetite and secm ill; a paralytic weakness of the hinder cxtremitics 
gradually develops, the respirations become weak and slow, and death occurs with symptoms of serere collapse and with marked coldness, more especially of the head and extremities. On post-mortem examination the small intestine is seen to be much reddened, and filled with a watery colourless fluid contrining flakes; the stomach and cacum also contain a large quantity of fluid, and not, as is normally the case, solid masses. The contents of the small intestine wre found in these cases, both by microscopic examination and by cultivation, to contain almost a pure cultivation of comma bacilli.-Infective experiments of this kind were made by Koch on about 100 guinea-pigs. He also succeeded in setting up the same fatal disease by employing, insterd of cholera cultivations, the intestinal contents of an animal which had been infected and bad died.

The force of these experiments is somewhat diminished Control by the observation made by Koch that some other species experiments. of bacteria, as, for example, the vibriones which morphologically resemble the comma bacilli, and were isolated by Finkler, Deneke, and Miller, when introduced into the small intestine in the same way at times set up a fatal disease; as a matter of fact, however, only 12 out of 51 animals infected with these bacteria died, while in the experiments with cholera bacteria the mortality was almost 90 per cent., and when the dose was larger all the animals were killed. Employed in the same manner the anthrax bacilli and the bacteria isolated by Brieger, as well as a number of other organisms, showed a distinct pathogenic action, while in the case of a large number of other species, for example the pyogenic cocci, the bacilli of rabbit septicæmia and of chicken cholera, \&c., no bad effect resulted. - The opium could be almost completely replaced by alcohol; other substances gave less satislactory results.

In considering how far the attompts made in these experi- Differences ments to sot up a disease similar to human eholora hare been botween he successful, it is necossary to boar in mind that in any ease in pholorn exguinea-pigs, which scem to be the most susceptible animals, produeod and romiting and profuse diarrhom are rery seldom or norow human choler:i. 
Toxic effects of cholera cultivations in large doses

observed, while in these animals after infection with comma bacilli the enormous distension of the stomach and intestinc with fluid material shows a great transudation into the intestine similar to that which occurs in man, and which leads to excessive diarrhœa aud vomiting. It must further be expressly. pointed out that the pathological anatomical alterations in the organs, and more especially in the intestines of the animals. correspond entircly with the appearances found in rapid and uncomplicated cases of cholera; extensive alterations, uleerations, and losses of substance are, according to the best anthors, not characteristic so much for pure acutc cholcra cases as for cases in which the course is protracted and complicated.-It is perhaps possible that in the course of further investigations means will be found to obtain a simpler and more natural mode of infection in these or in more susceptible animals. In any case it is right, bearing in mind the abore facts as to the immunity of animals from cholera, not to place our expectations too high, but rather in the case of cholera to assign a subordinate importance in the etiological proof to the experiments on animals.

Where large quantities of cholera cultivations are employed toxic effects are produced in the animals. If pure cultivations of the comma bacilli are injected into the peritoneal cavity of rabbits or into the veins, or in very large doses into the subcutaneous tissue, paralytic weakness of the hinder extremities, slowing of the respiration, and gastro-enteritis set in, and as a rule death occur's after 1 to 3 hours; where the material is applied subcutaneously these results are inconstant; at times the animals recover after a few hours and then remain well; in the case of starring guinea-pigs a similar intoxication occurs when the material is introduced into the stomach, and in this case the toxic products seem to be absorbed with especial rapidity. Mice also die after the injection of large doses into the peritoneal cavity. Nicati and Rietsch* were able to demonstrate that cholera cultivations when at least $\mathrm{S}$ days old cansed toxic effects even after filtration through a Pasteur's filter; in no case did fresh cultirations produce any effect. It must also be determined by further experiments whether, and to what degree, this production of poison is influenced by differences in the nutrient 
substrata, and by the other conditions of life, and also what is the nature of the toxic substance.

Some expcriments have been made on man with Expcriments cholera dejecta or cultivations, partly intentionally and on man. partly unintentionally. Thus during the last cholera Experiment. cpidemic in Paris Bochefontaine swallowed pills con-by Bochefontrining cholera dejecta, and Klein in Bombay drank a Klein. fluid said to contrin comma bacilli. In ncither case did illness follow; but in neither was there any proof that living comma bacilli were present in the material taken. And besides, the negative, like the positive, result of these two experiments was of no value in reference to the etiology of the discase, as it is well known that by no means every man who swallows the infective material suffer's from cholera, but only those who are predisposed to infection; and, on the other hand, had illness followed these infective experiments it might quite well have been objected that it was due to some other cause, for the experiments were madc in a place where cholera was prevalent.

On the other hand, another experiment unintentionally Infection of made on man furnishes a further support for the etio- man by cullogical significance of the comma bacilli. One of those comma bacilli. who took part in the courses on cholera, which werc held in Berlin in November, 1884, under Koch's direction, became ill with somewhat severe symptoms of cholera. At this time there was no case of cholcra either in Berlin or in Germany; the only possible source of the infection was the pure cultivations of comma bacilli with which the physician in question was working; and this physician was more predisposed to infection by these cultivations than any of the other students, because for some days he had suffered from gastric disturbances and slight diarrhoa. After the appcarance of the symptoms of cholera the watery dejecta of the paticnt were examined, and were found to contain very large numbers of comma bacilli which coincided in all respects with tlose obtained by Koch from cholera dejecta in India.

There is, as yet, no definite proof that the virulcut 
properties of these comma bacilli can be artificially attenuated, a thing which is by no means improbable, when we take into consideration the results obtained in the case of other pathogenic bacteria. According to a preliminary communication by Nicati and Rietsch, the virulence of cultivations of comma bacilli is diminished to a certain extent when the cultivation is carried on for a long time in meat infusion or mutrient jelly kept at $20^{\circ}$ to $25^{\circ} \mathrm{C}$. The protective inoculations which were made in Spain by Ferran with supposed attenuated choleri bacilli are so entirely wanting in the necessary experimental and statistical support (as is evident from the description given by Ferran himself, as well as from the reports of others,) that they require no serious discussion. As regards the bacilli found by Emmerich in the bodies of patients who died of cholera, see page 335 .

Jode in which the cholera infection occurs:

Distribution of the cholera bacilli in the patient.
In accordance with the facts made out by Koch as to the biological characters of the infective agents of cholera, we may suppose that the infection takes place somewhat in the following manner:-

The cholera process arises when living bacteria gain admission to the small intestine, remain there for a considerable time, and multiply actively. As the result of their growth toxic materials are formed, which in the first place cause the death of the epithelium, and ultimately of the superficial layers of the intestinal mucous membrane. If they multiply rapidly, aud if large quantities of toxic materials are produced, the latter are absorbed in large amount and set up general symptoms, and ultimately paralysis of the organs of circulation. If in this way deatlo occur's at an early period there are no deep alterations of the iutestinal mucous membrane, and the appearances on post-mortenl examination correspond to what has been described above in typical cases, viz., there is a pure cultiration of comma bacilli in the intestinnl contents but no other 
noticeable morbid appearances. If, however, the formation and absorption of the toxic products of the comma bacilli do not take place so rapidly, and if the paticnt survives this stage, the results of the local poisoning, the necrosis of the mucous membrane, become more marked; bleeding occurs, there is enormous multiplication of jutrefactive organisms which grow to the exclusion of wny comma bacilli not yet expelled; the absorption of putrefactive poisons sets up typhoid symptoms which are not a necessary part of the cholera process itself, and post-mortem examinations made at this stage show those deep alterations of the mucous membrane which hare been often erroneously looked upon as characteristic of cholera.-As can be readily demonstrated, the comma bacilli do not spread into the organs of the body, nor are they excreted in the secretions at any stage of the process. Further, direct experiments on animals show most distinctly that comma bacilli, when they enter the blood stream, unless when they are in enormous numbers, and unless toxic materials are injected at the same time, die very rapidly and do not pass from the blood in a living state into any organ, or into the intestinal canal or the urine.*

From these facts, as well as from what has been Sources previously pointed ont as to the vital properties of the infection. comma bacilli, we may draw some important conclusions as to the mode in which cholera is transmitted. In the first place the comma bacilli leave the body of the patient eridently only in the dejecta of the first few days of tho disease (quite exceptionally in tlie material vomited, sec page 419), and hence it is only these dejecta, and the objects infected by them, as for eximple the bed and body linen, vessels, soil, water-closets, earth on which these dejecta aro doposited, well-water into which the dejecta may pass, \&c., tliat can serve as sources of infection. The greatcr the number of things contaminated the more numerous will be the sources of infection, and the greater the danger of contagion.-These sources

* Wygsolowitsch, Zeitschr. I. IIy., vol. i. Sce chapter on the production of discrso. 
of infection are more especially limited by the fact that the comma bacilli so readily die, either as the result of

Duration of virulence.

Points of entrance into the body. transport.

We nay exclude currents of air and lespiration. drying or of overgrowth by saprophytes. As a consequence it is, as a rule, only fresh dejecta, and objects which have been recently soiled, that are dangerous; all materials which are completely dry, such as dry linen, rags, letters, various kinds of wares, \&c., may be excluded at once as possible carriers of infection. Where the materials are moist, and in the case of fluids, the duration of the vitality of the comma bacilli which have reached them depends upon their number, upon the number and lind of saprophytic bacteria present at the same time, and on various other external conditions; but in any case it is only rarely that it lasts for more than a few days. But it is always possible that some materials, if liept moist and in which the comma bacilli are preserved in a state of almost pure cultivation, may act for some weeks as sources of infection; for example, this is conceivable in the case of moist cholera linen which is tightly packed, of moist earth, \&c., more especially when the temperature is low.

From the mode of distribution of the comma bacilli in the body, and from the experiments as to their fate when they are injected into the veins or subcutaneously, we must draw the inference that natural infection occurs as a rule only by the mouth.

In infection, therefore, we have to deal with two factors: on the one hand the sources of infection, which, as we have seen, vary grently in number and are limited as regards resisting power' and on the other hand this one point of entrance. All the conceivable ways are evidently, however, not equally suitable for infection; on the contrary one or other mode of communication may be completely excluded, while other modes vary as regards their power under the influence of external conditions. Currents of air are entirely unsuitable for the transport of the infective agents, as by them only dry particles are detached and carried away, while the comma bacilli do not retain their vitality in the dry condition. The only exceptions in this respect are bubbles of water, which may be carried through the air.- Hence a mode 
of infection which is evidently of great importance in other contagious diserses, namely, by the respired air, may bc left out of account in cholera, and in this fact we hare i further reason for limiting the point of entrance to the commencement of the alimentary canal.

As connecting links between the sources of infection 1. Dircet first place, contact between the dejecta or between objects soiled by dejecta, such as linen, soil, furniture, \&c., on the one hand, and the mouth on the other. This mode of infection is by no means so uncommon as would at first sight appear to be the case; where cholera patients are nursed by attendants who are inexperienced, and who are not very cleanly in their habits, it must very frequently happen in handling the soiled bed and bodylinen, \&c., that infective material adheres to the hands, under the finger nails, clothing, \&c., and that in the course of the next few hours, before it has become completely dry, it is brought into contact with the mouth by unintentional and often unconscious movements.

In the second place, the infective organisms may pass 2 . Infection of from some of the sources of infection mentioned to food. articles of food, and may then reach the point of entrance along with these. The transmission to articles of food By contret. happens by contact with soiled fingers or with other objects containing dejecta; further, it will not uncom-By insect. monly take place by the intervention of insects, more especially flies. The infective material will frequently multiply to a great extent on these nutrient substrnces, and thus the sources of infection may be increased to a dangerous extent.

A third mode of infection, which is especially worthy 3. Infection of of notice, is by means of water employed for drinking drinking and purposes, for the preparation of food, for cleansing plates, ¿c. This water may be contaminated by comma bacilli, either because dejecta are intentionally or unintentionally poured out in the courts of the house and reach the wells by gutters, which are not unfrequently present, or by the water employed for rinsing the cholera linen taking the same course. In contrast to the other articles of food 
we must, however, assume that in the case of the water ordinarily used for drinking and other purposes multiplication of the comma bacilli never occurs, and that therefore they can only be present in wells for a relatively short time. (Compare the investigations by Bolton in the Zeitschrift fiir IIygiene, vol. i.) In the case of stagnant water, however, in the bilge water of ships, in the water in harbours, which is often so extremely dirty, \&c., it is probable that the comma bacilli may retain their vitality for a much longer time, and in the case of a tank in India, where the small amount of stagnant water was not only employed for bathing, drinking, and cooking, but also for washing the linen and for the reception of the contents of the water-closets, Koch was able to demonstrate such a large number of comma bacilli that it seemed likely that they had multiplied to a great extent in the tank, and that their presence was in all probability the source of infection of a number of cases of cholera which occurred at a later period among those persons who lived in the neighbourhood.

Influence of

But the factors which are concerned in infection by the individual cholera are not exhausted by the varying capabilities of predisposition. the modes of transport. We are also compelled to assume that cholera does not by any means constantly occur on every occasion when the comma bacilli have passed the point of entrance and have reached the commencement of the alimentary canal; on the contrary, a further condition comes into play, namely, the so-called

Protective arrangements in the healthy body. indivictual predisposition. In a perfectly healthy person it is erident from what we have learned from experiments as to the destruction of the comma bacilli, and from experiments on animals, that the comma bacilli may be destroyed in the stomach, more especially by the hydrochloric acid present in the gastric juice; it is also conceivable that the food may pass too rapidly through the small intestine, and that also the digestive fluids or the products of digestion may interfere with the growtl and development of the comma bacilli; and finally the energy of the cells and their resisting power towrds the toxic products of the bacilli come into play. According 
to the greater or less perfection of the protecting and regulating arrangements of the body the same infective material will in one caso cause no disturbance, in another only slight diarrhœa, which leads to rapid removal of the multiplying bacilli, and the rapid victory of the body, and in a third to serious illness. - We Acquired duces immunity for a considerable period of time. The milder or severer course of the disease does not in this instance appear to make any difference; the cases also where the regulating arrangements of the body are in such good condition that the reaction to the infection is so slight as scarcely to be designated as disease, apparently acquire this immunity. It has not as yet been definitely ascertrined how long this immunity lasts; it is probable that it may last on an average for 3 or 4 years, at any rate it usually lasts for several months, so that an individual is seldom attacked twice during the same epidemic.

On the other hand we must assume that the body is Predisposing more susceptible to infection when dyspeptic conditions factors. and slight gastric disturbances or overloading of the stomach are present, also when the digestive process has arrived at the stage where the acid reaction of the intestinal contents is slight; and likewise when large quantities of food can pass into the small intestine after a relatively short delny in the stomach, and when, on the other hand, the onward progress of the food in the small intestine is abnormally slow. The exact value of these and other assisting factors cannot as yct be accurately determined, but that as a rule factors of this kind come into play is clear from the fact that most cases of cholera occur on Mondays and Tuesdays, after there have been excosses in eating and drinking on the Sunday; and also from the observation made by Virchow that on post-mortem examination of very acute cases of cholera there are always signs that digestion has been going on actively.-Another predisposing factor seems to consist in the general weakening of the bedy, such as is occasioned by poverty, hunger, and 
disease, whether it be that in this case there is a want of resistance on the part of the whole body, or some weakening of the digestive organs.

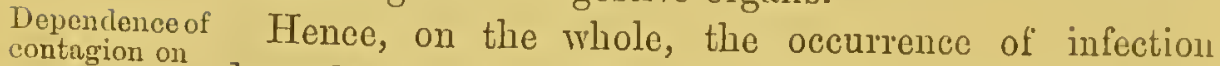
external influences.

Puesults of liactical cxpcriencc.

Contagious cases of cholcra.

depends to a great extent on external influences, which either favour its development or the reverse. The number of sources of infection is sometimes larger, sometimes smaller, the modes of transport are sometimes numerous, sometimes fow, and may ultimately be entirely absent; and it is possible that if the infectire material enter's the body it may pass through it without setting up disease, thanks to the protective arrangements present.

The question arises whether these views deduced from the chief facts which have been ascertained as to the biological characters of the comma bacillus coincide with the results which have been made out empyrically as to the mode of spread of cholera. Numerous facts have rendered it absolutely certain that eholera can be carried by contagion, the virus being transmitted from the sick to the healthy. Typical cases of contagion occur in almost every epidemic; they are most definite when the epidemic is only commencing and has not yet spread widely, while at the height of the epidemic, or in an endemic area, it is impossible to trace the origin of the individual cases.-As a classical example of undoubted transmission in this way we may mention the case observed by Virchow in the department of the Charité Hospital in Berlin, set apart for prisoners, where three individuals to whom the nursing of a cholera patient was entrusted became ill of cholera after a ferr days, while no case of cholera occurred among any of the other healthy or sick inhabitants of the hospital.* Many well-observed epidemics in ships and houses, in which the reproduction and the transmission of the disease may be distinctly followed through a number of patients one after the other, can also only be explained by contagion.-But for a long time the conclusion drawn

* Weissbach, Virchow's Arch, vol. 55, P. 249.-Virchow in th Verhandlungen der Choleraconferenz., 1885. 
from the facts as to the mode of spread of cholera has Differences in becn that the mode of infection in this disease is the contagicsscntially different from, and more dependent on, ex- cholera and termal influences than in the case of other infectious diseases, for example in small-pox. And this experience is quite intelligible if we bear in mind that in small-pox there are none of those marked limitations in the mode of spread of the virus which are seen in cholera. In the case of small-pox we have a much greater multiplicity of the sources of infection on account of the fact that the virus is given off from the whole slin in the remains of the pustules, and that it is contrined in the various secreta; we have also to do there with much more resistant infective agents, which evidently withstand drying, and can be carried by currents of air and dry objects; hence the facilities for the penetration of the contagium into the body are very great; apparently also the protective arrangements in the body which render the poison inactive even after its entrance have much less power. Hence the spread of small-pox by contagion is so very different from that of cholera, and the mode of spread of cholera acquires a special character from the fact that so many external influences render its diffusion difficult in certain cases.

In the dependence of cholera infection on external value of influences we have the explanation of the fact that in- prophylactic dividuals can be so easily and completely protected against against this disease, much more easily than against choleri. scarlatina and small-pox. While in the latter cascs all the numerous and permanent sources of infection can scarcely be attended to, and while the usual mode in which the virus enters, namely, by the respired air, cannot be controlled or influenced, it is by no means so difficult to exclude completely the possibility of the transmission of cholera. If the dejecta and the objects soiled by them are cleansed and disinfected all the sources of infection are got rid of ; if the hands, food, and drinling water arc kept quite clean the most important contaminated sources are shut off; if all gastric disturbances are 
avoided the most dangerous cause of predisposition on the part of the patient is avoided. In correspondence with these facts we learn from experience that those individuals who are in a better position of life, who are the most cleanly and moderate in their habits, are attacked by cholera in much smaller numbers than those who pay no attention to cleanliness, moderation, or the digestibility of their nutriment. Hence the English who are resident in India, and who are able to bestow great attention on the selection and preparation of their food, are almost entirely protected against cholera even in tlee regions where it is endemic. The immunity In harmony with this we have also the fact that nurses.

doctors and nurses are very seldom attacked by cholera; they are accustomed, by having to deal with other contagious diseases, to habits of precaution and cleanliness in handling the patients on the one hand, and in their mode of feeding on the other. Here and there, it is true, there are incautious or dirty nurses, or the arrangements of the hospital in question are such that the number of sources of infection is multiplied, and contagion rendered more easy; and as a result we hare in some epidemics a greater number of cases of the disease among the attendants. Experience has also shown that it is on the whole a rare occurrence for other patients and convalescent persons to be attrcked in the same hospital; and this is easily intelligible, because these individuals are usually kept clean, and their food is prepared with a care such as they do not usually employ in

Cholera on their own homes. In like manner in the case of ships, ships. where as a matter of experience it is relatively seldom that severe cholera epidemics occur, there is decidedlyless opportunity for the transmission of the contagium than in private houses; on board ship the passengers between decks are compelled to be cleanly, at least to a certain extent, and as they do not talie part in the preparation of the food there is never such a close relation between the sources of infection, the modes of contagion, and the predisposed individuals, as is seen in the houses of the poor. Nevertheless, there are naturally certain 
possible modes of transmission in large institutions and ill ships.

Hence it is undoubtedly possible, by rigid and properly applied cleanliness, to exclude a very important portion of the modes of transmission of the cholera contagium. And I may refer to the marked influence-an influence which will be discussed more in detail afterwardswhich is exerciser on the spread of the disease by the introduction of a good and plentiful supply of water, and by proper arrangements for the prompt removal of dejecta.

Having thus arrived at certain definite ideas as to the mode of transmission of cholera to the individual, and The epiclemi as to the factors which come into play, ideas founded partly on the study of the biological characters of the comma bacilli and partly on the results of experience with regard to cholera, we may attempt by the aid of the same factors to explain also the mode of the peculiar epidemic distribution of cholera.

Cholera epidemics present a series of very striking Endemic phenomena, and phenomena very difficult to explain. We see that cholera is constantly present in an endemic manner only in Lower Bengal; in the rest of India, and more especially in Europe, it occurs only at intervals in the form of devastating epidemics, and then again completely disappear's from these regions. The starting point of these epidemics must always be sought in $T_{\text {sower }}$ Bengal; from thence the disease is evidently carried into other regions. From what has been said above, Transmission it is evident that this transmission seldom occurs by any of clolera by other materials than tho fresh dejecta of the patients, whether the disease be mild or severe. Hence the disease can ouly be carried over long distances when a patient passes over the whole distance very quickly, and at the end of his journey still furnishes dejecta containing bacilli, or when a continuous chain is formed, 
of which the individual patients who reeeive the infective material from one another, reproduce it, aud pass it on, represent the links. The whole distance from Indir to Europe could not in former times be traversed by one and the same cholera patient; a chain of patients was always necessary, this chain stretching without interruption along the overland route; or the disease was carried by ships sailing from India to Europe, the ehain being in that case shorter, corresponding to the shorter time required for the journey. 'These two ehains were evidently not easily established; eren the shorter one which suffiees for the sea journey was difficult to obtain, because on ships the opportunities for the propagation of the disease are relatively unfarourable. It is, moreover, evident that any interruption of the chain, any failure in the transmission of the contagium to a new individual, must lead to failure of the spread of

Present moilc of spread of cholera.

the disease. At the present time the spread of eholera is rendered very much easier, seeing that the network of railways in Lower Bengal communieates with the rarious ports of India, so that one and the same patient ean be transported to any of the eities on the eoast; and further, because a very small number of patients is suffieient to carry on the disease during the journey from Bombay to Egypt, and the actire contagium may be earried from Egypt to the nearest European ports by one and the same patient.-In Europe also cholera ean be distributed by travellers, and we must remember that even a slight attaek of cholera which scarcely causes any notieenble disturbance of the general health, but in which nerertheless there is multiplication of the comma bacilli and their deposit in the dejeeta, is quite suffieient to transmit the disease. Striking examples, shoring to what distanees the cholera contagium may be carried at the present time by means of the railway, are furnished by the case observed by Ton Pettenkofer, where a ehild suffering from cholera carried the disease direct from Odessa to Altenburg, and the ease published by Biermer, where the eholera contagium was brought directly from liome to Zurich. 
Terertheless we motice the very striking fact that Irregularity Terertheless we notice the very striking fact th cholera does not necessarily develop in an epidemic form bution of in the region to which it gains access; that all the regions cholcra which lie along the main chanmels of trade, and to which, epidenics. in the case of cholera spreading orer Europe, there is no loubt that cholera patients and cholera dejecta frequently gain access, are not attacked by an epidemic; but that, on the contrary, large tracts of teritory and number's of towns remain completely free, while neighbouring provinces and cities are violently attacked. Even within the same town similar local differences may be found. There are also a number of places where trade is great, Local prodiswhich even during the repeated epidemics which have position. come into Europe have always remained immune, for' example Lyons, Stuttgart, Hanover, \&c. These facts give rise to the impression that in addition to the introduction of the contagium there are some other local conditions necessary for the epidemic spread of the lisease - in fact a local predisposition.

In like manner there is a peculiar seasomal distribu-Seasonal tion of the choler epidemics. As the result of careful predisposition. statistical calculations it has been shown that the choler epidemics which bave attacked the northern part of Germany always attain their highest point in the latter part of summer and harvest, while during the spring months-from February to May-the number of cases is very few.* In other regions the maxima and minima as regards season are different: thus in Calcutta the constant minimum is from June to October, and the maximum in April ; in Bombay also the cases diminish in number from Jume to November, and rise again from November to June; in Lahore there is a marlied rise from July to October, which attains its height in August, and an almost complete absence of cholera during the rest of the year. These numbers give rise to the im-

* Of the 167,000 fatal cases of cholcra which occurred in Prussia between 1848 and 1859 , tho following was tho relation to tho various months:-January, $1^{\circ} 4 \mathrm{pcr}^{\circ}$ cont. ; Fobruary, March, $\Lambda_{1}$ ril, and May together 1 per cont.; Juno, 2.6 por cont.; July, 5 per cont.; August, 20 per cont.; September, 34 per cont.; October, 21 per cent.; November, 10 per cent.; Decomber, 5 per cent. 
pression that the epidemics are dependent on some factors which vary according to the season-on a seasonal predisposition.

Extinction of the opidemies.

A third striking fact with regard to the mode of spread of cholera is that in one place the epidemic is often extinguished, while in other and neighbouring situations it continues, and that this extinction is observed botl after a short and moderate amount of disease, and after a long continued and violent outbreak of the plague.

The question arises whether these puzzling facts as regards the epidemic spread of the disease, which have excited the greatest interest during the last few years, may not possibly be solved by a more accurate analysis of the mode of infection on the same lines as that abore given in explanation of the transmission of cholera from individual to inclividual.

What are the external tactor's which influence the distribution of cholcra epirlcmies?

It. is it priori probable that the peculiar local and seasonal distribution of cholera epidemics is brought about by the action of several factors varying according to local and seasonal conditions, and depending partly on the sources of infection available for the spread of the epidemic, partly on the paths of transport from these sources to the exposed individual, and partly on the susceptibility of the latter. In studying the infection of an individual we become acquainted with a number of influences by which the sources of infection could be multiplied or reduced in number, the paths of distribution enlarged or narrowed, and the individnal susceptibility increased or diminished. These factors are also undoubtedly of equal importance in the epidemic distribution of the disease; for we must remember that an epidemic only originates and spreads when a chain of new cases follows the first in a continuous series, and that it disappears when this chain is broken. Just as the inoculation of the individual requires certain favourable chances, just as all those infections which serve for the continuance of the chains are influenced by chances of all kinds, so the epidemic will come to an end, chiefly because, orring to external circumstances, the sources of infection become less 
numerous or are entirely removed, or because the usual paths of transport have become too few, or because the exposed individuals are immune against the infection.

Accordingly those external factors which can act to a great extent on the sources of infection, on the paths of distribution, or on the exposed individuals, will probably furnish an explanation of the local and seasonal differences in the spread of cholera; and hence we must study more closely these external factors. We find these factors partly in meteorological conditions, partly in the soil, and partly in the habits and customs of different races. The most important are the following:-

1. Meteorological influences. High temperatures 1. Meteoroapproashing the optimum of the temperature of the influences. comma bacilli might favour the spread of the disease by enabling the comma bacilli to multiply as saprophytes, and by thus multiplying the sources of infection. And Temperature. the less energy of tissue change, and the less resisting power of the body by which excessively high temperatures are apt to be accompanied, appear to increase the indiridual predisposition to a certain degree.-On the other hand, epidemics are by no means absent in winter, because these favouring influences of temperature are not so important that they cannot be completely replaced by other predisposing factors. It must also be remembered that in winter we usually employ in our immediate surroundings artificial heating, and thus produco temperatures which are quite sufficient to enable the comma bacilli to multiply; and that on the other hand, in summer and in warm climates sources of infection which may be preserved for a long time at a low temperature are more readily rendered inert by drying, or by the quicker growth of saprophytic bacteria. On the whole, therefore, it is only rarely that temperature has a decisive influence on the spread of cholera.

Very great dryness of the air must render the trans-Moistnre of mission of the disease more difficult, in that it occasions the :ir. rapid deatl of the comma bacilli in the sources of infection. Cholera linen, soil contaminated with dejecta, \&c., are under these circumstances only infective for a very 
short time, and the chances of spread of the discase arc correspondingly smaller. Further, the nutricnt media arc rendered unsuitable for the multiplication of the comma bacilli by drying of the surface, as well as for the development of other bactcria which might possibly influence the individual predisposition. Finally, insects, which are of such assistance in transporting the infection, are absent. This result howcver will only occur where there is a very great deficiency in the saturation of the air with moisture, for examplc in a desert; moderate differences in the degree of moisturc of the air can only with difficulty exert a noticeablc action. Diminution of the moisture of the air, such as occurs, for example, in Calcutta during the so-called "dry season" of the year" (Novcmber to April), can coincide vely well eren with an increase of cholera if the paths of transport and the individual predisposition are at the same time farourably influenced by other factors. On the other hand, it is conceirable that in a desert climate, such as is present in Multan and Lahore during the greater part of the year, and where everything dries up, as it were, under one's eyes, the conditions farourable for the spread of the cholera may only be prescnt at most during the somewhat moister or" so-called "rainy" season (July to October).

Rrin.

Very cxcessive and constant rains will, as a whole, cause a diminution in the number of the sources of infection and of the paths of distribution. Where, as in certain parts of India, and also in many villages and habitations of the poor in European cities, all sorts of filth and all infective dejecta are collected in the courts and in the immediatc neighbourhood of the houscs, and where attempts are ncver made to cleanse these surroundings, hcavy rainfalls, which arc powerful cleansers of the surface of the carth, must lead to diminution and removal of the sources of infcetion. Where, on the other hand, the rainfall is slight and of short duration it can hardly cxert any direct action, and will at all crents occupy a sccondary position as compared with other important factors. 
2. The nature of the soil is in the first place of im-2. Influence portance in so far as, according to the declivity and of the nature porosity of the soil, the rain, the house, and the washingwater, the outflow from water-closets, \&c., can be readily carried off, or is retrined in stagnant superficial collections, or in the uppermost lnyers of the soil. Where, as in the suburbs of Calcutta, we have the presenco of tanks, and the artificial elevation of the foundations of the houses, the conditions are very fuvourable for the collection and preservation of infective material during the dry season of the year. A similar accumulation of filth and of sources of infection also occurs not uncommonly with us in narrow streets and courts.-The influence of the soil may also vary according to the season. The chances are evidently favourable for the spread of Dryness of cholera when a so-called "drying zone" exists in the the uppermost uppermost parts of the soil, so that all fluids and rain soil. which reach the soil remain in the uppermost dry layer (see Part VI.); whore there is no drying zone the impurities and any infective agents present are as a rule carried to such a depth that they are no longer present at the surface, and thus many chances of transport to man and dwellings are removed; when however a drying zone is present all infective organisms, which usually reach the soil in considerable numbers with the dejecta, with tho contents of the night-stools, with the water from washing clothes, \&c., remain for a considerable time in this upper layer. There the conditions are favourable for the preservation of the comma bacilli as well as other bacteria; and hence a source of infection is furnished from which the infective material may be carried either directly to man or to articles of food and other things in a great variety of ways, e.g. by man, animals and objects, and also by insects; and this source of infection is so much the more dangerous the longer it continues to exist.-The presence of a drying zone, which is best indicated in our neighbourhood by lowering of the level of the ground-water, is therefore under certain conditions an important seasonal predisposing factor for the sprend of cholera, while under other circumstances, such as an 
unsuitable character of the soil, cleansing of the surfuce of the soil, \&c., it is much less important than many other factors.

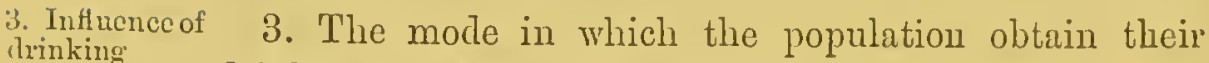
water. drinking and household water is at times of great importance. If the water has in the first instance becone contaminated with comma bacilli it forms for a short time a dangerous source of infection, which leads in the simplest and most direct manner to the exposed individuals.--The establishment of this source of infection may be greatly faroured by the situation of the well, and its mode of formation; especially where water is carried to it from the surface of the soil, or where canals or gutter's from cesspools, \&c., lead to the well. 'The more of these badly constructed wells there are in a town the more readily will cholera be spread by the water. Open and stagnant collections of water are naturally the most dangerous; in Lower Bengal such collections form the source of the water supply, and appear, as a matter of fact, to be one of the most frequent and dangerous sources of infection. Where the wells are deep and well constructed, so that they cannot be contaminated from the surface of the soil; or where the water is carried by well-constructed pipes, this mode of spread of the infective material is practically absent.

Insects. 4. Insects deserve especial mention, as they rary extremely in numbers according to place and season, and form in all probability a by no means unimportant mode of conveyance of the poison, a mode which increases or diminishes according to the number and rarieties of the insects. No quantitative estimate can be formed with regard to this factor.

5. Habits of 5. Certain habits of life can in the case of one nation life. furnish greater opportunities for the spread of cholera than in that of another. 'The arerage cleanliness of the population has the greatest influence in this respect.

('leminess. The more cleanly the method of handling the sick and the infected clothes, the more carefully contamination of the soil, of the water, and of rarious other objects with the dejecta is avoided, the fewer will be the sources of 
infection. The more carefully the hands are cleansed and the articles of food prepared, the more will the paths of spread from existing sources of infection be diminished. It is evident that in this respect marked differences must exist between more or less civilised countries; between new and well-built, and old and narrow cities; between poor and wealthy neighbourhoods; between the portion of a city inhabited by the poor and that in which the better class dwell.

As a special example of the action of general clean-Arrangement. liness we have the effect, often confirmed, of a good of water anly supply of water and drainage. Formerly these arrange- removal of ments were supposed to produce their good hygienic results chiefly by keeping the soil and ground water free from all putrescible materials, and thus withdrawing the necessary nutrient substrata from any infective germs which may have reached them. This interpretation is no longer sufficient in accordance with our present knowledge as to the conditions of life of the pathogenic fungi, but the good effects of these arrangements for cleanliness still exist as they did formerly, for they lead to marked diminution of the sources of infection and to a limitation of the paths of spread. They act by remoring as quickly and completely as possibie all the dejectic and the water employed for cleansing linen, utensils, Sc., without allowing them to come in contact with the surface of the soil, with wells, \&c. ; and further, by providing an ample and conrenient supply of water, so that cleanliness in every form is favoured, and thus infection is limited to contact, nutrient materials, and so on. But eren with these arrangements we must not under all circumstances expect a complete protection against the spread of cholera, for at certain places and at given times it is evident that other sources and paths of infection may develop, and thus the disease may spread quickly and over a wide area in spite of these sanitary arrangements.

The mode in which linen is cleansed may be especially Clenusing of referred to as another of the habits of life which has and clothes, linen. important influence on the spread of this disease. Kocl 
has pointed out that in Lyons, for example, the custom is not to wash the linen in the house, but on boats in the quickly-flowing water of the Rhone, or further down the stream, for example, in the village of Craponne. Clothes are soiled with dejecta in almost every case of cholera; the infective material retains its vitality under these circumstances for a relatively long period; the linen is a valuable material, which is treated with care and subjected to many manipulations; it is handled the more incautiously in that the cholera dejecta do not betray their presence by stink, or by any other disagreeable character. Hence linen is evidently one of the most dangerous sources of infection, and thus a very great part of the chances in favour of the distribution of cholera is removed when, as in Lyons, the linen is without exception cleansed outside the house; while on the other hand the greatest chance of infection is furnished when the linen is kept in the house, washed in leaky wells, or, as in India, in stagnant tanks.

6. Influence of 6. An important factor which hinders or farours the individual predisposition. local and seasonal spread of cholera is, finally, the indiridual predisposition of the population. Such a predisposition can in the first place be based on the habits of the population with regard to food, habits which show marked differences in different places and at different seasons. Mode of In one country the people live relatively sparingly, in nourishment.

other countries or towns, or in certain classes of the population, a very large amount of food, and more especially of fluid food, is swallowed. It is further worthy of notice that in our countries the food is almost alrays cooked during winter and spring, while in summer and harvest raw fruits and vegetables often form a considerable portion of the daily nourishment; these raw materials often set up mild gastric disturbances, and are also very suitable for the transport of bacterin. In other countries a much larger proportion of the food is constantly used without any preparatiou. It can casily be understood that by employing raw food the paths of infection are in the first place increased in number; that also is the result of the gastric disturbances, as well as of the 
labit of overloading the stomach, any comma bacilli which may have entered can the more readily obtain a footing and multiply in the alimentary canal.

The general nutritive condition, and the energy and resisting power of a whole population may also show marked differences, and may under certain circumstances influence the seasonal or local spread of cholera. Starvation as well as great assemblages of human beings, feasts, pilgrim festivals, \&c., favour an epidemic outbreak, partly on account of the slight amount of care employed in the selection and preparation of the food, partly by the frequent excesses, and partly by the weakening of the whole body.

A population is apparently in especial danger in Predisposing which at the time of the first cholera cases gastric dis- gastric disturbances. turbances are prevalent. Such seasonal prevalence of mild or severe gastric disturbances, as shown by diarrhœeas, dysenteric or even choleraic attaclss, \&c., are observed in Germany almost exclusively during late summer and harrest. It is unfortunately as yet not possible to understand thoroughly the etiology of this great increase of gastric disturbances at particular seasons; it is conceivable, for example, that the use of raw fruits or the low temperature so frequent during the night at this period of the year, and the consequent liability to cold, are of causal importance : or it may be due to some forms of micro-organisms for the preservation, distribution, and reception of which the circumstances during these months are particularly favourable; for example, these are the months during which in our country a dry zone is present in the upper layers of the soil, in which numerous bacteria may remain, and may be carried as dust by the winds, and further during these months bacteria are most frequentiy taken in by articles of food. Whatever may be the ultimate explanation, we may assume as certain that these autumnal gastric disturbances, in whatever way they have arisen, have a special favouring influence on the epidemic spread of cholera.

Lastly, the individual predisposition of a population Influence of epidemics. 
may be inflienced by the fact that a larger or smaller proportion of the individuals have been rendered immune for a time by a previous attack of cholera. As has been previously stated, we must assume that eren the mildest attack can produce this immunity, so that after a considerable epidemic a relatively high percentage of the population has been attacked. This circumstance must diminish to a great degree the chances in favour of the spread of a second epidemic; and in India, where there are almost always insusceptible districts which have been recently attacked alongside of the susceptible ones, the mode of spread of the epidemics must consequently show peculiar interruptions and leaps. Koch has called attention to the fact that by this acquired immunity of certain tracts we can understand the remarkable distribution of cholera when it spreads from one of the large pilgrim resorts as a centre; the line which the disease takes does not correspond to all the radii, although all have undoubtedly been brought in contact with cholera patients; the cholera spreads only in those directions where this acquired immunity is wanting.

Inerease of the effect of these influences as the result of continued infection.

As the result of these numerous influences, varying according to place and season, variations in the epidemic spread of cholera are the more readily produced becanse the disease is not always carried from one individual to another, but often attacks a large number of individuals at the same time. Hence the differences in the effect in cases where the chances in favour of its spread are plentiful, and in those where they are few, are still Differences in more strikingly manifested. We have only to colssider the effect of the first case of cholera. how completely different the mode of spread is according to the circumstances under which the first case of cholera is introduced into a town. In the one place the patient may be nursed in a well-to-do family, or in a suitably arranged hospital with trained nurses; in the other place the first case may occur in a marrow, poor 
quarter of the town where numerous individuals come in contact with the patient and with the dejectr, where the methods of cleanliness are by no means sufficicnt, where the food is prepared and eaten in the same room, where there are numbers of flies which aid in the transport of the germs, and where consequently it is only rarely that direct contrmination does not take place. It is evident that in the latter case the chances of a sudden and great extension of the disease are present, and hence the effect is so very different from that of the former case, in which at most only an isolated further infection occurs.

If now the disease has attacked several individuals Differencedue If now the discase has attacked several individuals to the succeedthese unequal chances continue to act in an increasing ing enses. degree, because from every new case where the chances continue favourable there is a marked multiplication of the number of individuals affected, and along with this an enormous increase in the number of sources of infection. In the one town the primitive arrangements for the removal of fæces, badly constructed wells, small dwellings, poverty of the population, bad nutritive conditions, \&c., can readily so act that almost every new case forms a source of infection and a means of transport, and that susceptible individuals are constantly present in the neighbourhood of the sick. In other towns or at other seasons, on the contrary, a very much smaller number of cases may occur, on account of the presence of a drainage system, a good supply of water, well-built houses, well-to-do, cleanly population, or on account of the fact that the individuals in contact with the sick are in great part insusceptible or immune; in this way the chances are against the further spread of the disease, and favour the interruption in the chain.

Circumstances which are apparently trivial and Influcnec of accidental, and which readily escape observation, may apparently often exert such an influence on the spread of a cholcra accidents. epidemic that the presence of local and seasonal predisposing conditions may bo of absolutely no importance. 'Thus to mention some examples of theso 
accidental conditions we not uncommonly find in the smaller towns in Mid and North Germany that the relatively pure water flows through the streets of the town in open gutters, and that this water is not only employed for household purposes but also-per nefas, but nevertheless very frequently-for carrying away the refuse from houses. If a case of cholera occurs in the higher portion of such a town, and if dejecta or water employed for washing the linen gain entrance to this running water a sudden extensive spread, a sort of explosive epidemic, may be the result, whatever be the state of matters as regards the other factors which are of importance in the production of an epidemic. Kocl obscrved another example in Marseilles; in that town the market women who offered vegetables for sale were ront to sprinkle their wares from time to time with water in order to keep them fresh, this water being taken by means of a broom from a gutter which ran past the market. The comma bacilli could very readily enter this gutter water ; and hence, by means of the infected vegetables and fruit, the germs might be distributed to such an extent that a violent epidemic could result. $-\mathrm{A}$ similar occurrence can take piace when one of the first cholera cases occurs in a dairy, and when comma bacilli, though only in very small numbers, enter the mill by one of the modes described, for milk is a very excellent soil for the growth of the cholera bacilli.

Such accidents may now and then exert an important influence on the course of the epidemic, and as it mar be very difficult to trace them subsequently, we may have the occurrence of a number of so-called "inexplicable" cases.

If we review the whole series of factors which are here mentioned, and which can influence, both as regards place and season, the commencement and the course of a cholera epidemic, we must admit that a local and seasonal distribution of cholera, rarying much at different places and times, undoubtedly exists. 
But even ns regards the peculiar laws which seem to gorern the local and seasonal spread of the disease, we may easily find, among the important factors mentioned above, some which completely explain the repeated or permanent insusceptibility of some places, or the constant preference for a definite season of the year.

Thus the occurrence of cholera in Germany in late Explanation summer and harvest can be explained by the presence of predisposition rarious predisposing factors during these months. It is in Germany. during this season, as Pettenkofer has pointed out, that the level of the ground-water is lowest, and that consequently the upper layers of the soil are driest; the existence of a definite drying zone has, as was pointed out above, a markedly favourable influence on the preservation and increase of the sources of infection. The cholera months are also those in which the largest numbers of insects are present, and these undoubtedly take part in the transport of the germs; they are also the months in which people eat the greatest quantity of raw food, which is also well suited for the transport; but above all in those months there is a marked individual predisposition on the part of a relatively large portion of the population on account of the frequent gastric disturbances, the causes of which have been previously referred to. It is easy to understand that where this dry zone is absent and with it a number of sources of infection, where the various means of transport referred to are wanting, and where there is no wide-spread individual predisposition, the chances for the spread of cholera are very unfavourable, and that therefore in our climate it does not usually spread at all during winter and spring, or at most only a few indiriduals are affected. At times, lowever, in spite of the unfavourable season of the year, some of the other predisposing factors may be so markedly developed that an exceptional epiclemic may occur even in the middle of winter or in spring.

There are also a number of factors which explain the Explanation extinction of an epidemic after its longer or shorter dura- of the extinc:tion. In this respect one important point is, that soon epidemice. 
after the first appearance of the epidemic the treatment of the individual cases is better carried out, that those who are in contact with the sick take greater care as regards cleanliness and other precautions, that the majority of the inhabitants take less raw food, that greater care is employed in providling pure water, that the individual predisposition is diminished as far as possible, partly by the avoidance of excesses, partly by early treatment of gastric disturbances, and partly, in the case of another portion of the population, by recovery from a previous mild or sercre attack; and finally, that at times, with the change of the season of the year, one or other of the external influences are removed, and thus the sources of infection, and the ease with which the germs are transported, are diminished.-The more completely and quickly all those factors which tend to the extinction of the epidemic come into play the earlier will further infection cease; the longer the one or the otler favouring condition continues the further will the epidemic spread. It is evident that in order that cholera should become permanent or endemic in the neighbourhood other very favourable conditions must be present, especially as regards the climate, and probably still more as regards the habits of life of the population.

It would lead us too far to explain the various striling phenomena which occur in the epidemic spread of cholera by the factors which come into play, and which hare already been mentioned in detail. This much is erident, that the sum of the external factors furnishes a sufficient explanation of numerous epidemiological laws, and also of numerous exceptions; whether it be that in the one case several of these factors act together, and thus increasc the effect, or whether it be that one or other are in opposition to, and thus neutralise ench other, there are a number of possible explauntions which may correspond to as many variations in the occurrence of cholern. For many persons the extraordinary multiplicity of the factors which furnish the explanation of the local and seasonal distribution of cholern is self-evident; this is more especially the case since Virchow drew attention so 
markedly to this point in the proceedings of the last cholera conference. But during the last decade the tendency to draw up a scheme of cholera epidemics, and the desire to find a single causal factor in explanation of the peculiarity of its course, has come to the front so exclusively that it seemed necessary to draw especial attention to the multiplicity of the factors which come into play, and to point out in detail what factors can produce regular local and seasonal variations in cholera epidemics, and what factors may lead to irregular and accidental rariations.

These deductions are chiefly based on the biological peculiarities of the comma bacilli as we have learned them from Koch's investigations, and on the assumption that cholera is contagious, and that the contagium is contained in the comma bacilli.

These views are, however, not as yet accepted by all Views of the cholera investigators; on the conturary, the "localistic" localists. view brought forward by von Pettenkofer, Cuningham, and their followers, is opposed to this "contagionistic" standpoint. Cuningham assumes that in order to origi- Cuninghan's nate a cholera epidemic it is not at all necessary that a view. patient suffering from cholera should enter the place where it begins, but on the contrary that cholera occurs everywhere sporadically, and that favourable local conditions are alone necessary to lead to the outbreak of an epidemic. This peculiar view is only a possible one on the arbitrary assumption that every case of violcnt diarrhoe is a case of true Asiatic cholera. This view was not easy to upset in any individual case so long as we had only symptomatic and pathological anatomical differences to enable us to distinguish between cholera asiatica and cholera nostras; it is, however, quite untenable, since we have found a marked difference between the two diseases, in that the characteristic cholera bacilli are always present in the one and never occur in the other. 
Von Pettenkofer's view.

Von Pettenkofer admits that in the case of clolera we have to do witl a virus which is carried from place to place, but he lays chief stress on the facts as to the peculiar local and seasonal distribution of cholera, and he assumes that in addition to the virus introduced, other factors, dependent on the locality, must come into play in order that an epidemic should occur. If we call the virus which proceeds from the patients " $x$," and the something due to the locality " $y$," cholera only spreads when $x$ and $y$ occur together ; $x$ alone can only" quite exceptionally cause a single case of the disease, but never an epidemic. On the contrary, in a place where $y$ is absent we may swallow cholera dejecta without any harm; while an infection would follow under these circumstances if $y$ was present in the same locality.

Pettenliofer has attempted to ascertain the nature of "y by an accurate investigation of the local and seasonal distribution of a large number of cholera epidemics, and lie has come to the conclusion that the nature of $y$ is a certain character of the upper layers of the soil. A soil which predisposes to the disease must be porous and penetrable by air and water, it must be contaminated with dejecta, organic substances, dc., and it must be to a certain extent moist. The moisture of the soil is the factor which chiefly varies with the season; too great moisture diminishes the predisposition in the same manner as too great drought. The degree of moisture of the soil is in the majority of cases most accurately shown by the variations. in the level of the ground-water, in other cases it is better determined by the amount of rainfall.

Hence those localities are permanently immune where the ground is composed of rock or dense clay, also those where the soil is quite clean, and those where the surface of the soil is always either very dry or very moist. A temporary immunity is occasioned cliefly by too great or too little moisture of the soil.

According to Pettenkofer's riow the relation between the virus $x$ and the fuctor $y$, which depends on the pre- 
disposition of the soil, is either that $y$ so propares man that he becomes susceptible for $x$, or that $x$ is altercel under the influence of the $y$ properties of the soil, and is only then capable of producing infection in man. Pettenkofer looks on the latter alternative as the most probable, and he is also of opinion that $x$ is a species of brctcrium, the development or distribution of which is much influenced by these $y$ properties of the soil.

Pettenkofer holds that Koch's comma bacillus is not Pettenliofer'; the proper $x$, because its characters show that it cannot opposition to be favourably influenced by the $y$ properties of the soil ; bacillus. the comma bacillus dies as the result of drying, while a relatively dry soil furmishes the best seasonal predisposition for cholera. The comma bacillus further rapidly dies in putrefying substrata, while a soil contaminated with dejecta is one of the predisposing factor's in favour of cholera.-Neither of these objections are, however, ralid. Where the moisture of the soil diminishes the degree of dryness is almost never such that the comma bacilli which reach the soil must at once die. On the contrary, the conditions for the spread of the infection are, as was shown on p. 457, more favourable under these circumstances. In like manner the rapid destruction of comma bacilli in putrefying substrata has reference to their behaviour in fluids where there is active multiplication of saprophytes, but does not apply to the soil in which the multiplication and hurtful influence of the saprophytes are practically of no moment.-It is, therefore, evident that Pettenkofer's opposition to the comma bacillus is in reality not at all justified; while the fact of the constant and exclusive occurrence of the commi bacilli in cholera has led him to the assumption, which certainly does not seem by any means probable, that the virus of cholera is an organism as yet unknorvn, that this virus becomes altered in an as yet unlinown manner under the influence of a porous, impurc, and somewhat moist soil, and call then cause the infection, and that after the occurrence of infection the vibriones, which are present in small numbers in tho intostine, 
become transformed into the enormously multiplying comma bacilli.

The peculiarities of the local and seasonal distribution of cholera are undoubtedly facts whicl we must all recognise. Pettenkofer's observation that the condition of the superficial layers of the soil frequently plays a causal part in these peculiarities is likewise undoubtedly correct; but it has been previously shown that this condition of the soil can exert an important influence, even though we aclmit the etiological significance of the comma bacillus. But also to an unbiased mind it is erident that the nature of the soil, to which Pettenliofer gives such prominence, is by no means of itself sufficient to explain all the peculiarities in the spread of the epidemics. There is no doubt that Pettenkofer's explanation is not applicable in many cases; that, for example, cholera epidemics in the eastern part of Prussia have occurred on dense clayey soil, and in Bombay on non-porous rock, while, on the other hand, porous soils have been passed over. We must at all events regard Pettenkofer's views only as hypotheses, and must not ascribe to them the value of a firmly established theory, which must be used as a basis on which to test the results of present and future investigations. We must, on the contrary, admit the possibility that numerous other causes come into play in the peculiar mode of spread of the epidemics, and we can only talie the proper course if we also talie into account the other possible explanations. If we base our investigations on the linown biological characters of the comma bacillus, we are at all events on firmer ground, and are more likely to find out the truth than if we stubbornly hold to the view of an unknown $x$, and $a$ still more unlinown $y$.

Prophylactic regulations against cholern.
The practical prophylactic measures to be taken against cholera differ also in an important manner according as the localistic or the contagionistic vier is 
the one held. The localists throw aside all quarantine regulations, all arrangements in order to afford protection against infection, and all disinfection; on the other land they pay special attention to the diminution of the $y$ properties of the soil, of which the contamination of the soil is that which is most easily avoided and altered; drainage, or a proper method of removing the serrage, is supposed to lead to such a condition of the soil that it is no longer suitable for the epidemic spread of cholerr.

From the standpoint of the contagionists all the measures discussed above which can protect the individual from infection are of the first importance. Hence the prevention of the introduction of the disease is the first protection against an epidemic of cholera. As cholera is generally brought to us over the sea from India by patients suffering from the disease a strict medical inspection of ships coming from India in the Suez Canal is of immense importance. It is only in sen-port towns that any good result can be hoped from qurrantine. If cholera has once broken out on the Continent nothing more can be expected from quarantine regulations. In that case each town must take care above all that the first case of cholera is quickly brought to the notice of the authorities, and is diagnosed with certainty. The latter can be almost always done by means of plate cultivations, and the sanitary authorities must therefore know how to make them. A great deal also depends on proper treatment of the first case or cases. These should be nursed wherever possible in hospitals, or at any rate by trained nurses; the linen and clothes of the patient should be disinfected with sterm in an institution for the purpose which should bo present in every town; the dejecta should be rendered innocuous, and all other suspicious substances should be disinfected with carbolic acid, sublimate, or concentrated hydrochloric acid; the sick-rooms are most readily freed from infective germs by opening the window, and shutting up and heating the room for some days; in this way the comma bacilli will be 
lilled by drying. The population should also be instructed as to the circumstances which favour or hinder infection, more especially as to the influence of careful cleanliness, as to care in preparation of the food and in the selection of drinking water, and as to the hurtful influence of excesses and of even the mildest gastric disturbances. Drainage, proper removal of waste materials, and a good water supply, are also, from the contagionistic point of view, excellent prophylactic measures for a town, the basis of these regulations being, however, somewhat different from that of the localists; the chief advantage of these arrangements is not that they lead to cleansing of the soil from putrefying materials, or freeing of it from materials which could nourish the lower organisms, but it is the prompt removal of the infective agents, and the diminution of the opportunities for infection.

\section{Spirillum Finkler and Prior.}

\section{(Vibrio proteus.)}

Finkler and Prior's pirilla.

Morphological ehriacters.
From the dejecta of patients suffering from cholera nostras which had been kept for some time, Finkler and Prior isolated a spirillum which resembles the comma bacillus of Asiatic cholcra, but can nevertheless be very readily distinguished from it, more especially by neans of a number of differences in its mode of growth.

As a rule the individual curved bacilli, which when united together form the spirilla, are the chief forms present. The curved bacilli are somewhat longer and thicker than Koch's comma bacilli; their thickness is not so regular as the latter; but on the contrary they appear oftener somewhat pointed at the ends, and thicker in the middle. Not uncommonly 
we find " $\mathrm{S}$ " forms similar to those of the cholera bacillus, and also longer screw-like threads, which, however, do not occur so frequently in gelatine cultivations, and do not show so many twists as in similar cultivations of the cholera bacilli. When examined in drop cultivations they show active movement.

According to Buchner, Finliler's bacilli have a great Involution tendency to alter their form when the state of the nutrient medium is unfavourable (Buchner has therefore proposed to give the bacillus the name Vibrio proteus). Under these circumstances they form sometimes spheres, sometimes spindles, and sometimes monad-like bodies; the latter may present an oval form as much as $4 \mu$. in breadth, or may appear as large spheres, or as very broad and fat portions of twisted threads, and they are obtained very easily by the addition of 5 per cent. of sugar, or 2 per cent. of glycerine, to the gelatine. These structures can only be looked on as pathological or involution forms.

On gelatine plates Finkler's bacilli form after 24 Cultivations hours white points, which under a low power present the appearance of circular yellow or yellowish-brown discs; in contrast to the young colonies of Koch's comma bacilli the outline of Finkler's colonies is very sharp, dark, and almost absolutely circular, while in the case of the cholera bacilli a wavy irregular outline is observed; the colour is also distinctly darker, and the surface does not present such a highly refracting, granular appearance as in the case of the true cholera colonies. Liquefaction of the gelatine begins very early; as soon as this occurs the outline of the colonies loses its sliarp-

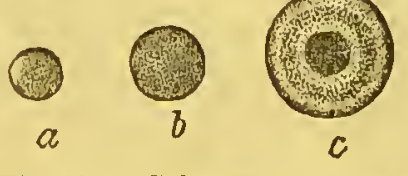

Fig. 125.-Colonies of Finkler and Prior's spirilla $\times 80$.

a, after 16 hours.
l, . 24 ,
i, ., 36 ", ness, the periphery oftell appears dentate or as if eaten awray, while, on the other hand, the external zone of liquefaction has a sharp border. One can often observe at this stage zones of different colonr in the colony; a darker central zone, then a lightier, 
and then again a darker marginal zone. The young colonies can be distinguished from those of choleru bacilli without any difficulty by means of the above mentioned characters ; at a later stage, more especially when the cholera colonies are older than Finkler's, the diagnosis is not so easy, but it can always be made when a considerable number of colonies are examiner. -At it still later period Finkler's bacilli liquefy the gelatine very energetically; a funnel, $1 \mathrm{~cm}$. in diameter or more, is formed, and as a rule the whole plate very soon becomes entirely liquid.

Puncture cultivations.

In puncture cultivations in gelatine Finkler's bacilli are also characterised by the greater energy with which
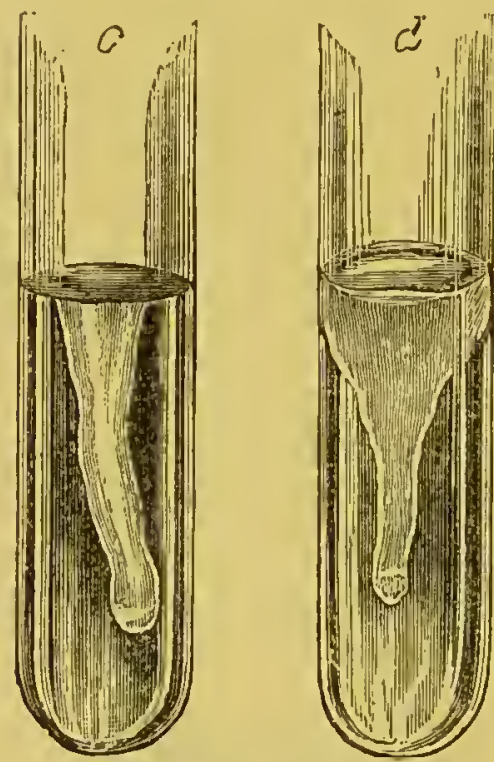

Fig. 126.-Cultivation of Finkler. and Prior's comma bacillas.

$c, 2$ days old. $d, 4$ days o? $d$. they liquefy the gelatine. When cultivated under the same conditions as Koch's bacilli they lead, even within 48 hours, to the formation of a comparatively wide sac-like tube which is filled with muddy fluid; after $2 \frac{1}{x}$ hours more the liquefaction has usually reached the rall of the test-tube and has inrolred the uppermost portion of the gelatine, while the lower end of the sac has correspondingly increased in breadtl. - Wheu cultirated on nutrient agar the bucilli form yellowish-white deposits without liquefaction, and without any definite characters. Blood serum

Growth on potatoes. is rapidly liquefied.-O (On potatoes liept at the temperature of the room they form within 48 lours a greyish-yellow gelatinous conting, which is marked oft from the substance of the potito by a white burder. This growth on potatoes forms the most striking contrast to the beliariour of Foch's comma bacilli, which do not grow at all on potatoes at the ordinary tempera- 
ture, and at higher temperatures only give rise to a thin brown conting.

In all the cultivations of Finliler's spirilla a somewhat foul smell is developed. In nutrient substrati contrining sugar, fermentation and the formation of acid take place, according to Buchner.-Finkler's bacilli seem, according to the experiments made by Finkler and Prior, to be much more resistant towards drying and overgrowth by other saprophytes than the cholera bacilli. A cultivation which had been dried and kept for two months over phosphoric acid free from water grew when planted on fresh nutrient substrata.

If a pure cultivation of Finkler's bacilli is injected Experiment. directly into the duodenum of guinea-pigs a certain on animals. proportion (3 out of 10) die according to Finkler and Prior and numerous bacilli are found in the intestinal contents, having apparently multiplied there; Kocli's control experiments also showed that about 30 per cent. of the guinen-pigs which had previously received soda solution and tincture of opium, as in the experiments with cholera cultivations mentioned above, died after the administration of cultivations of Finkler's bacilli by the mouth. - Injection of considerable quantities of cultivations, either subcutaneously, into the veins, or into the stomach, set up no disease in the animals experimented on. Pathogenic action seemed only to occur under such complex conditions, and then only so rarely that, as the result of the experiments on animals alone, Finkler's spirilla must be reckoned amollg the saprophytes.

It is still doubtful, however, whether these organisms Habitat of play a pathogenic rôle in man (this would be quite con- Finkler's ceivable when we bear in mind the similar though much more aggressive behaviour of Koch's bacilli on aninnals), and whetler they stand in any etiological relation to cholera nostras. Finkler and Prior state that they found the same spirilla on microscopical examination in five cases of cholera nostras; nevertheless these organisms could not be recognised witl certainty by other observers, and more especially by Koch, in Finkler and Prior's preparations. Finkler and Prior have only isolated 
theso organisms by cultivation (a plan that is necessary in order to render their identity certain) in the case of dejecta from cholera nostras which had been kept for a long time, and which had undergone putrefaction.-

Relation to uholern nostrins.

Other authors have, however, sought in vain for Finkler's bacilli in a largo number of cases of choler'x nostris. Thus Koch examined a considerable number of cases, and among them several which ended fatally, with negative results; and investigations by Ermengem, Watson Cheyne, Biedert, and others, have in like manner yielded negative results.

On the other hand, Miller has found curved bacilli in a hollow tooth, and these must be looked on as identical with Finkler's, from their microscopic characters, and their behaviour on cultivation and on animals; and Kuisl* has obtained Finkler's spirilla in a nutrient solution contrining peptone, meat infusion, and 2 per cent. of potash soap, from the contents of the crecum of a patient who had committed suicide.

Hence from the mode of distribution of these bacilli we cannot find any evidence of pathogenic properties, nor any relation to cholera nostras, and they must therefore be reckoned among the saprophytes till better evidence of their pathogenic character has been furnished.

From Finkler and Prior's first publications, in which they held that their bacilli were identical with Koch's comma bacilli, it is evident that they made their experiments at that time in complete ignorance of the usual and necessary methods of cultivating and isolating bacteria; and in their paper they also speak of a mode of development of their bacilli in which "alternation of generation," "mother cells" which burst at a later period, "sporc bearers," \&c.. play a part, and which has no analogy in the derelopmental history of other bacteria. In their last communication, t it is truc. these authors give a very detailed description of Koch's method of investigation, with which they have apparently become acquainted subsequently; but they attempt to bolster up their former standpoint witl only slight modifications, and

* .Münch. äratl. Intelligenzbl., 1885, 36.

+ Centralbl.f. allg. Ges. Ergänzungshefte, rol. i., Parts 5 and (i. 
to defend, withont any new and bettor reason, those original expressions which they havo introduced into the science of bacteriology.

\section{Spirillum tyrogenum.}

(Cheese spirilla.)

These organisms were isolated by Deneke in the Cheese author's laboratory from cheese which had been kept for spirilla. a long time; morphologically and on cultivation they show a greater resemblance to Koch's comma bacilli than do Finkler's spirilla, but like the latter they can be definitely distinguished from the cholera bacilli by certain culture characteristics.

The individual bacilli are somewhat smalier than Morphologica Koch's bacilli, and often show very long spirillar threads with somewhat narrower twists and smaller screws. In drop cultivations they show active movements.

On gelatine plates the youngest colonies form small Cultivations. white points after 24 hours, and under a low power they present the form of circular dises with sharp outlines,

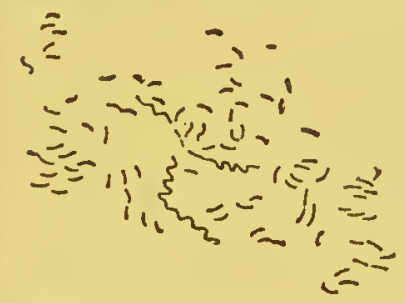

Fig. 127.-Cheese spirilla $\times 700$.

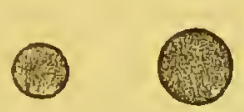

$b$

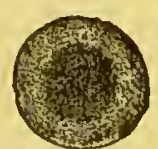

c

Fig. 128.-Colonies of cheese spirilla $\times 80$.

(", after 16 hours.

$b,, 24$,

and of a dark, greenish-brown colour. At a later period the margin appears somewhat lighter, the centre of a dark yellow colour; at the same time liquefaction of the gelatine commences, and the sharp outline of the colony not uncormmonly clisappears. The liquefaction of the grelatine is more energetic than in the case of the cholera bacilli, but does not oceur so quickly as in Finkler's. 'This fact is seen also in puncture cultivations, where a sac-like liquefied tube is formed within 24 lours, and at a later period there is complete liquefaction of the 
gelatine. On agar the cheese spirilla form a yellowishwhite layer; they liquefy blood serum energetically. No growth takes place on potatoes, eitler at the ordinary temperature or at higher temperatures.

Expeliments on animals.

By the ordinary modes of application no pathogenic action is exerted on animals. In two experiments in which the cheese spirilla were injected directly into the duodenum of guinea-pigs Deneke observed no morbid phenomena. Of fifteen guinea-pigs which were treated by Koch in the same manner as in his experiments with cholera bacilli, by previous introduction of soda solution and tincture of opium, and then of pure cultivations of these spirilla, three died.-From these results, as well as from the habitat of the spirilla, we must regard this species of bacterium as a pure saprophyte.

Deneke's experiments on animals were limited to one experiment on six guinea-pigs; into two of these eholera spirilla, into two Finkler's spirilla, and into two the eheese spirilla were injeeted into the duodenum. The two first animals died, the other four remained alive. It may be remarked here, in answer to an objeetion by Finkler, that these experiments on animals were not done on a larger seale beeause the author knew that the same experiments were being earried out at the same time in larger numbers in Koeh's laboratory, and beeause in the ease of the eholern baeilli more espeeially the results of Nieati and Rietseh and of Ermengem had already been published. The result of this eomparative experiment permitted a judgment as to the pathogenie or saprophytie nature of Finkler's and Deneke's spirilla, so mueh the more readily beeause all attempts to injure animals by these baeteria by the ordinary modes of infeetion failed, and beeause in this ease the habitat and mode of spread of the organisms did not, as in the ease of the cholera organisms, point to a pathogenie rôle whieh required to be still further confirmed by experiments on animals.

\section{Spirillum sputigenum.}

Cinred bacilli In the deposit on the teeth and in the saliva of man from the mouth.

.curved bacilli not uncommonly occur which hare a certrin resemblance to the cholera bacilli, but are somewhat larger, thinner, and more pointed at the ends. Where the staining with aniline dyes is not too dark, it can also 
be seen that the colouring matter is irregularly distributed in the rod, being less plentiful at the ends. Lewis* has nevertheless licld that these organisms are idcntical with cholera bacilli; but they differ very distinctly from these, in that the spirilla of the saliva cannot be cultivated by any of the ordinary metlods of cultivation. Hence

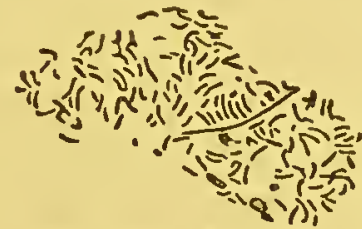

Fig. 129.-Spirillum sputigenum (after Ermengem) $\times 700$.
They grow on none of the ordinary nutrient sub. strata. the isolation of these bacteria and the study of their characters has not as yet been possible.

\section{Spirillum (Spirochete) Obermeieri.}

These organisms were first observed by Obermeier in Spirilla of the blood of patients suffering from relapsing fever. rever. They have the form of long, wary, flexile threads, with 10 to 20 convolutions; their length varies between 16 and $40 \mu$, their breadth is from $\frac{1}{4}$ to $\frac{1}{2}$ that of the comma bacilli. In fresh preparations the spirilla are seen to be motile; they move quickly, and also show undulatory movements, which pass in a wavy manner through the whole length of the thread. Colouring matters, more especially fuchsine, alkaline methylene blue, and Bismarck brown, are comparatively readily taken up; nevertheless, on account of their fineness, it is only possible to dis-

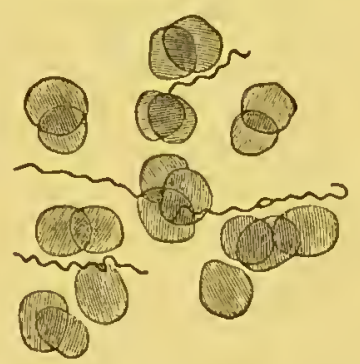

Fig. 130.-Spirilla of relapsing fever in blood $\times 500$.

cover these spirilla, when present in small numbers, with high powers, and good illumination. Larger numbers of the bacilli, which in many cases fill the blood, are on the other hand readily recognised, both in fresh and in stained preparations.

The spirilla are found exclusively in the blood of the Occurrence. patients, never in the secreta; further, they are only present during the febrile attack, but not in the interval between the attacks, or at most only for two days after 
the attack of fover. 'Their numbers vary very greatly. Outside the body, when lept in blood serum or in $\frac{1}{2}$ per cent. salt solution, the spirilla retain thcir movement. for a considerable time; but as yet we have not succeeded in obtaining any decided multiplication in any sort of mutrient substratum, nor can a cultivation be carried on through several generations.

Inoculation of On the other hand the disease, charncterised by its the disense on attacks of fever aud by the appearance of the spirilli, can
monkeys. be inoculated on monlicys, by mcans of luman blood containing spirilla. Koch and Carter were able, in the casc of long-tailed macaques, to sct up a typical attack of fever by. subcutaneous injection of a small quantity of defibrinated blood, containing spirill $\Omega$, after an incubation period of several days; during the attack of ferer the blood showed large numbers of spirilla, while the organisms were never found either before or after the appearance of the ferer. Numerous spirilla could also be demonstrated in the organs of the animals lilled at the heiglit of the febrile attack. True relapses, such as are characteristic in man, did not occur in monlieys; the most that took place was that, a few days after the crisis, the temperature was again for a short time elerated, but without any appearance of the spirochete in the bloocl.The disease can be inoculated from one monliey to another, but only by means of blood containing spirilla. Relinses. Monkeys are not protected from recurrence by one attack of the disease; Koch and Carter rere able to set up the same typical attack of fever when the monkeys which bad recovered from the first attack were inoculated again, after some days or wcelis, with blood containing the spirilla.

From the constant and exclusive occurrence of these peculiarly-shaped bacteria in relapsing fcrer, and from the fact that the disease can only be set up in licaltly monkeys by blood which contains these spirilla in the living condition, we may with certainty conclucle that the spirilla are the causal agents of this discase, even although we have not as yet succeded in cultivating the organisms, and in studying their charactcrs more minutely. 
All the other spirilla are as yet very incompletely Incompletoly known, and we do not possess methods of cultivating known specices them in a state of purity, and of observing their mode of development. They appear to grow by preference on fluid substrata, and to accumulate more especially at the surface; a situation in which they are usually found in enormous numbers is in the ordinary cesspools (Mühlhäuser). Resting forms have not as yet been described with certainty in the majority of the species which have been observed, the only exception being spirillum rugula; but it is possible that at a future period spore-like structures will be found in other of the bacteria belonging to this almost unknown class.

Geddes and Ewart* state that they have observed the following facts as regards the mode of devclopment and sporc formation of spirilla; the spirilla have alternately a motile and a resting stage; they ultimately grow in the form of $\varepsilon$ small thread without any definite coils; this thrcad bocomes longer and thicker, and spores appear in it. These spores divide rapidly and become glistening and brown, while the threads become again motile and break up sooner or later. The spores thus libcrated become encysted, and divide into it number of capsules which become motile after a period of rcst; the "sporulæ" contained in the capsules escape, sprout in a comma form, and soon grow to the ordinary spirillum.These observations have evidently not been made on pure cultivations, and arc of no valuc.

The following are the spirilla which have as yet been distinguished from one another, but which require moreaccurate study:-

Spirochcete plicatilis. - Threads thin with numerous narrow turns, 110 to $225 \mu$. in length. As a rule the threads form a double wavy line; the primary turns are of the same size in all the examples; the secondary turns are often unequal in size.

$B$, Spirochæto from tho toeth $\times 500$.

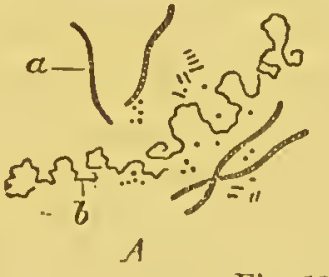

Fig. 131.

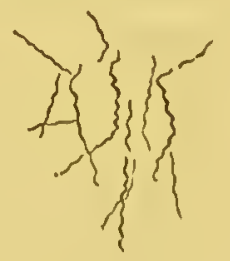

l)

1, Spirochreto plicatilis $(b)$, in its noighbourhood vibrio rugula $(a)$ and oshe: bacteria.

The organism moves with extreme

* Proc. of the Roy. Soc., vol. 27, p. 481. 
rapidity.-It occurs frequently during the summer in marsh water in which algæ are putrefying, in gutters, \&c.*

Spirochete denticola (Spirochæte of the saliva).These organisms are much shorter than the foregoing, as a rule 10 to $20 \mu$. in length; the threads have a simple wary outline, and are pointed at both ends. It occurs very frequently in the deposit on the teeth, and along with Leptothrix buccalis in the contents of carious teeth. $†$

Spirillum rugula (Vibrio rugula).-Cells 6 to $8 \mu$. in length, 5 to $2.5 \mu$. in thickness, with a single bend, or at most with flat spiral turns; at times united in longer chains, often matted together in considerable numbers (fig. 55A). They are motile, with actire rotation around their long axis. Koch has observed listinct flagella. Before spore formation takes place

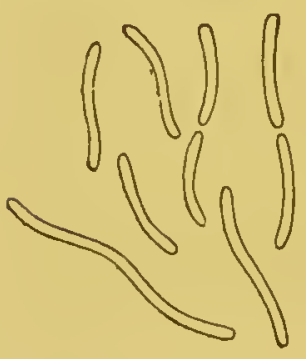

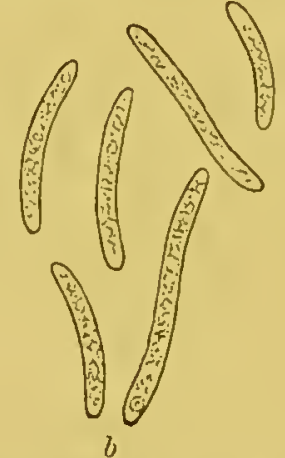

b

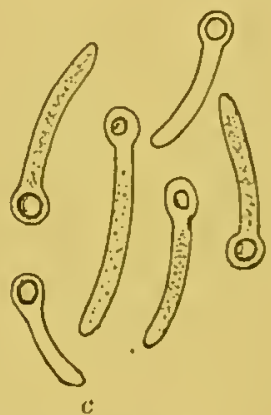

Fig. 132.-Vibrio rugula (after Prazmowski) $\times 1020$.

$a$, young rods. $\quad b$, thicker rods. c, spore-bearing rods.

the threads become thickened throughout their whole length; a spherical swelling then occurs at one end, so that the rod has the appearance of a comma; this swelling ultimately becomes a spherical spore.-The organism occurs in marsh water, in the deposit on the teeth, in fieces, \&c. It is often associated with bacillus butyricus, and is hence in all probability an anaerobe. According to Prazmowslit Vibrio rugula occasions energetic decomposition of cellulose. In decoctious

* Koch, Cohn's Beitr. z. Biol. d. Pflanzen, ii.. p. 420.

+ Ibid., p. 432.

¿Untersuchungen, \&e., Leipzig, 1S80, p. 14. 
made from regetable tissues (portions of potato, \&c.), Prazmowski was able to observe that the rods of Vibrio rugula collected around the cell walls of the tissue, and that they broke up in a short time (3 or 4 days) into swarms of Vibrio rugula. The intimate nature of the fermentative action has not as jet been ascertained.

Spirillum serpens (Vibrio serpens). - Threads thinner, 3 to 4 regular and permanent bends, 11 to $28 \mu$. in length, $\cdot 8$ to $1 \cdot 1 \mu$. in thickness; at times united in chains. Actively motile; often in dense masses.-Occurs frequently in various stagnant fluids.
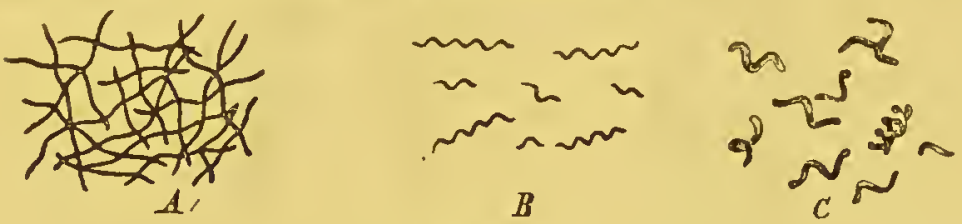

Fig. 133.

$A$, Spirillum (vibrio) serpens. $B$, Spirillum tenue.

$C$, Spirillnm undula $\times 650$.

Spirillum tenue.-Threads very thin, at least $1 \frac{1}{2}$ turns of a screw, at most, however, 2 to 5 ; the space between the individual turns is from 2 to $3 \mu$., the length of the spirilla being therefore 4 to $15 \mu$.; they move with lightning rapidity. It often occurs in dense masses in decoctions of plants.

Spirillum undula.-Threads $1 \cdot 1$ to $1 \cdot 4 \mu$. in thickness, 8 to $12 \mu$. in length, turns wider, 4 to $5 \mu$. in height. Each thread has $1 \frac{1}{2}$ to 3 turns. Rapid simultaneously turning and shooting movements; a flagellum can be distinctly seen at each end in the form of a long, slightly arched, and powerful thread, becoming thimner towards its end.-It occurs in the most various linds of putrefying fluids.

Spirillum volutans-Threads, 1.5 to $2 \mu$. in thickness, 25 to $30 \mu$. in length, somewhat thinner and rounded at the ends, with thick, dark, granular contents. Each thread has $2 \frac{1}{2}$ to $3 \frac{1}{2}$ turns, the interval being thus from 9 to $13 \mu$. Sometimes motile, sometimes nonmotile; a distinct flagellum at eacl end.-It occurs in marsh water, and it has been foun $\mathrm{I}$ in a decoction of dead fresh-water snails. 
Spirillnm sanguineum (Ophidomonas sanguinea) (according to Zopf belongs to the Beggiatoa, see page 4.88).-Threads $3 \mu$. or more in thickness, with 2 to $2 \frac{1}{2}$ turns, 9 to $12 \mu$. in width. A flagellum at each end. The spirals, which have it reddish shimmer, present a dark granular appearanee, owing to the presence of numerous lighly refracting reddish granules. Found by Warming and Colm in putrefying brackish water. In such water, which occurs in larrest in
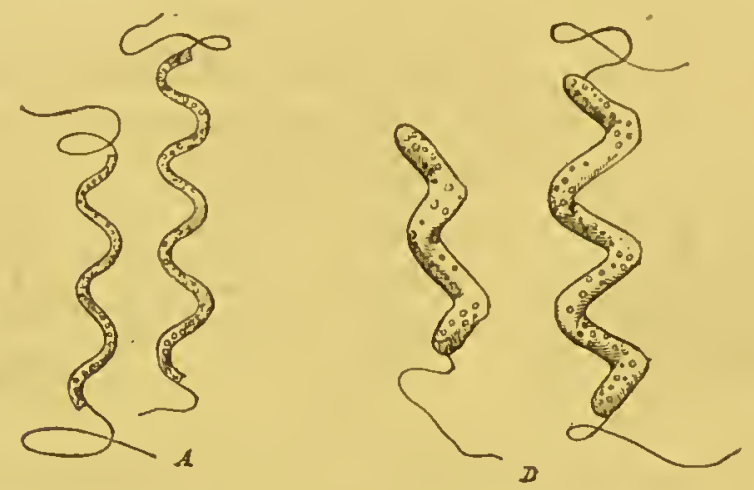

Fig. 134.-(After Cohn.)

$A$, Spirillum volutans $\times 650$.

$B$, Spirillum sangaineum (Ophidomonas sang.) $\times 600$.

many lakes on the Danish coast, and in which many algæe aud salt water phanerogams deeompose with the simultaneous appearance of red patches and masses, Warming found some other forms of spirilla, which as a rule contained granules of sulphur in their eell eontents, and which he distinguished under the names Spirillum riolacenm, Rosenbergii, attenuatum, \&e.*

Spivillum leucomelænum.-A form of rare occurrence (observed in water on the top of decomposing algæ), but which is noteworthy from the fact that alternate black and elear spaces occur in the spirillum, oceasioned by the accumulation in the interior of the rod of dark granular substances at regular intervals. $\dagger$

\section{Fission Fungi with Tariable Tegetative Forus.}

A considerable rariation in form has been recently demonstrated by Zopf's inrestigations in the case of the

* Warming, Videnskabelige Vieddedelser fia den naturhist. Forening $i$ Kjöbenhrvn, 1875, p. 398.-Coln1, Beilrüge, rol. i., Part 3, S. 169.

† Kooh, Mitth. a. d. Ges. Amt., i., p. 4 S. 
485

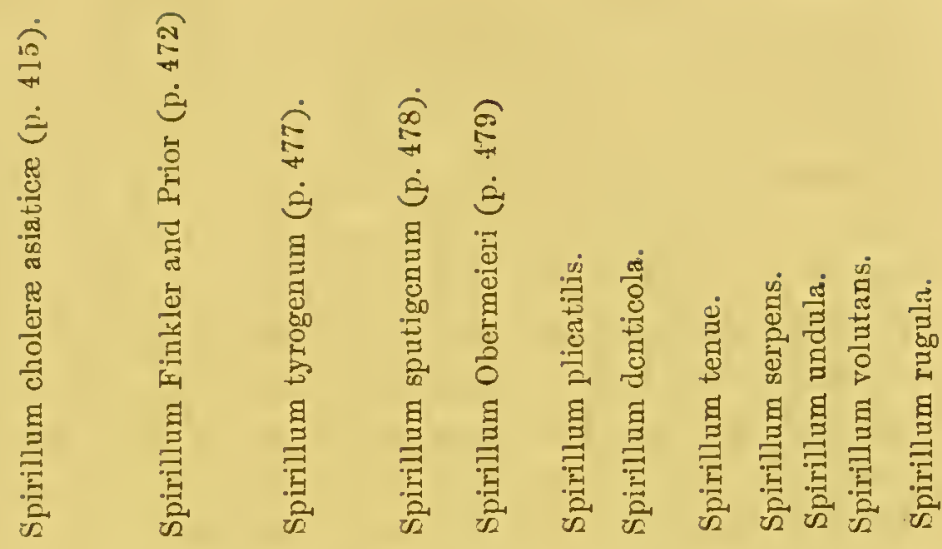

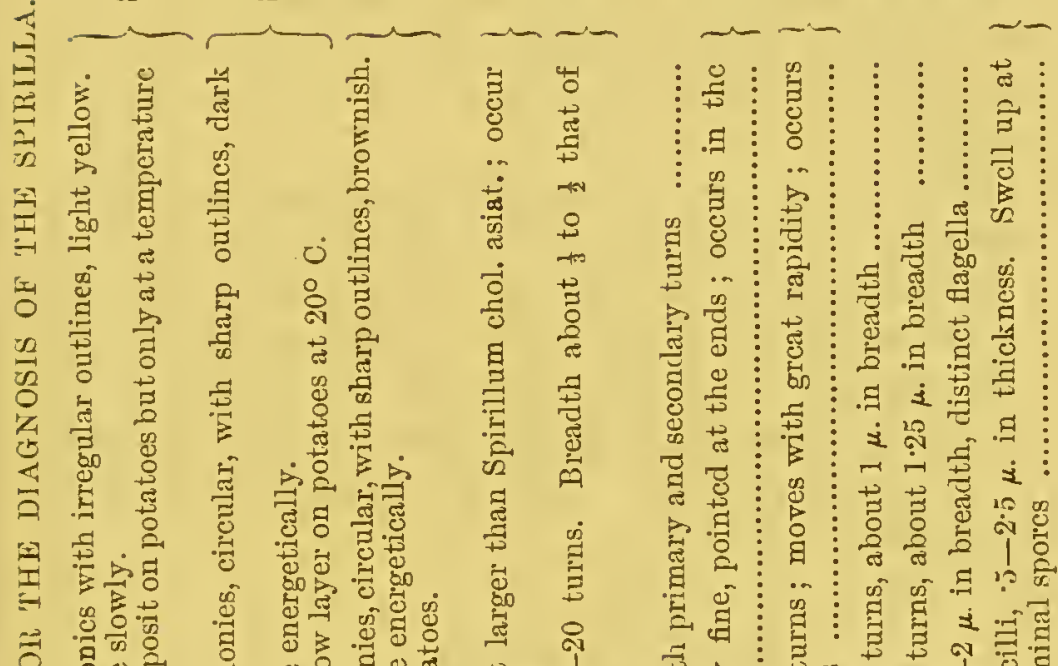
क

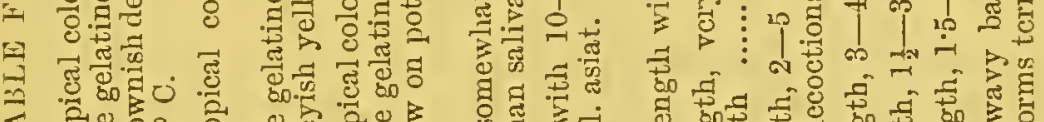

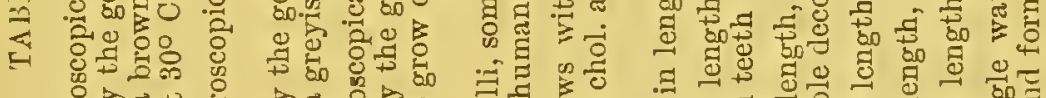

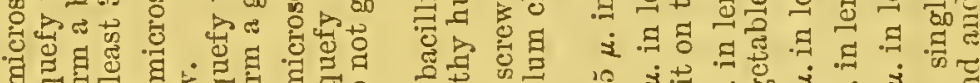

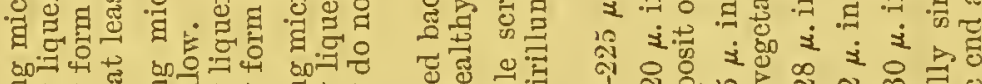

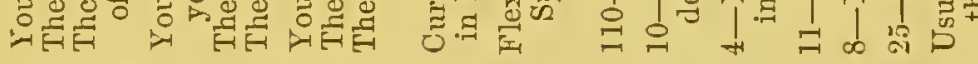
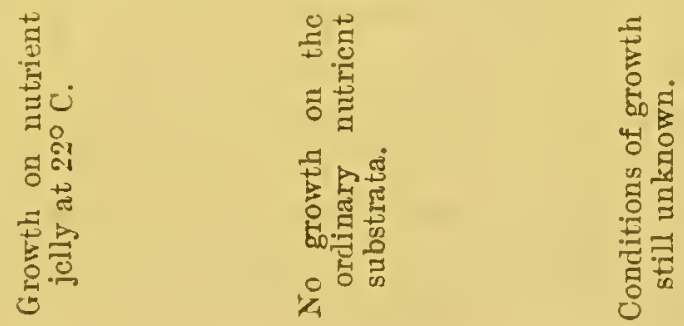
organisms arranged together in the following pages, these organisms differing from the bacteria as yet described in their natural habitat, in their size, in their morphological characters, and in many biological characters; these organisms were, up till a few year's ago, reckoned by most author's among the algæ. Zopf's results are reproduced here without any commentary, although they have not as yet been confirmed by control investigations. A repetition of his observations is, however, so much the more desirable, as the methods employed offer no sort of guarantee that he was dealing with trustworthy pure cultivations, and also as the mode in which the various vegetative forms of each variety are designated does not always appear to be sufficiently well founded.

To this group belong the organisms included in groups 3 and 4 of Zopf's classification, the leptothrix and the cladothrix forms. In the series of leptothrix varieties, the genus leptothrix has been omitted here for the reasons mentioned on page 180 , so that the genera crenothrix, beggiatoa, phragmidiothrix, and cladothrix are alone described. For the generic characters see page 180 .

\section{Crenothrix Kühniana.}

Crenothrix. This organism was discovered by Kühn, and has been investigated by Cohn, and later by Zopf. It is one of the most frequent aquatic fungi, and occurs in stagnant and flowing water; it is sometimes present in such large quantities in the water pipes in many places (Berlin, Lille) that the water is quite unfit for use. It can be artificially cultivated in decoctions of dead algre, or in decoctions of animal substances, such as swine's bladder.

Morphological According to Zopf the fungus shows coccus, rod, and characters. thread forms. The cocci are spheres 1 to $6 \mu$. in diameter; their membrane becomes gelatinous, and they multiply by fission. By this mode of multiplication, and by the gelatinous character of their membrane, 
irregular masses of zooglæa of very various sizes are formed; these masses often form very large clumps, and may have a red, green, or brownish-black colour, from the deposit in them of oxide of iron. When cultivated in marsh water the cocci grow to form rods, which again form threads by continued fission, these threads projecting from the surface of the zooglæa mass in all directions. At a certain stage they show a distinet formation of sheaths, and the oxide of iron is often deposited in these sheaths. Within the sheaths the rods continue to divide transversely, and isodiametric pieces are formed which become rounded at the ends and then represent the cocci, which are, as a rule, fairly large (ma-

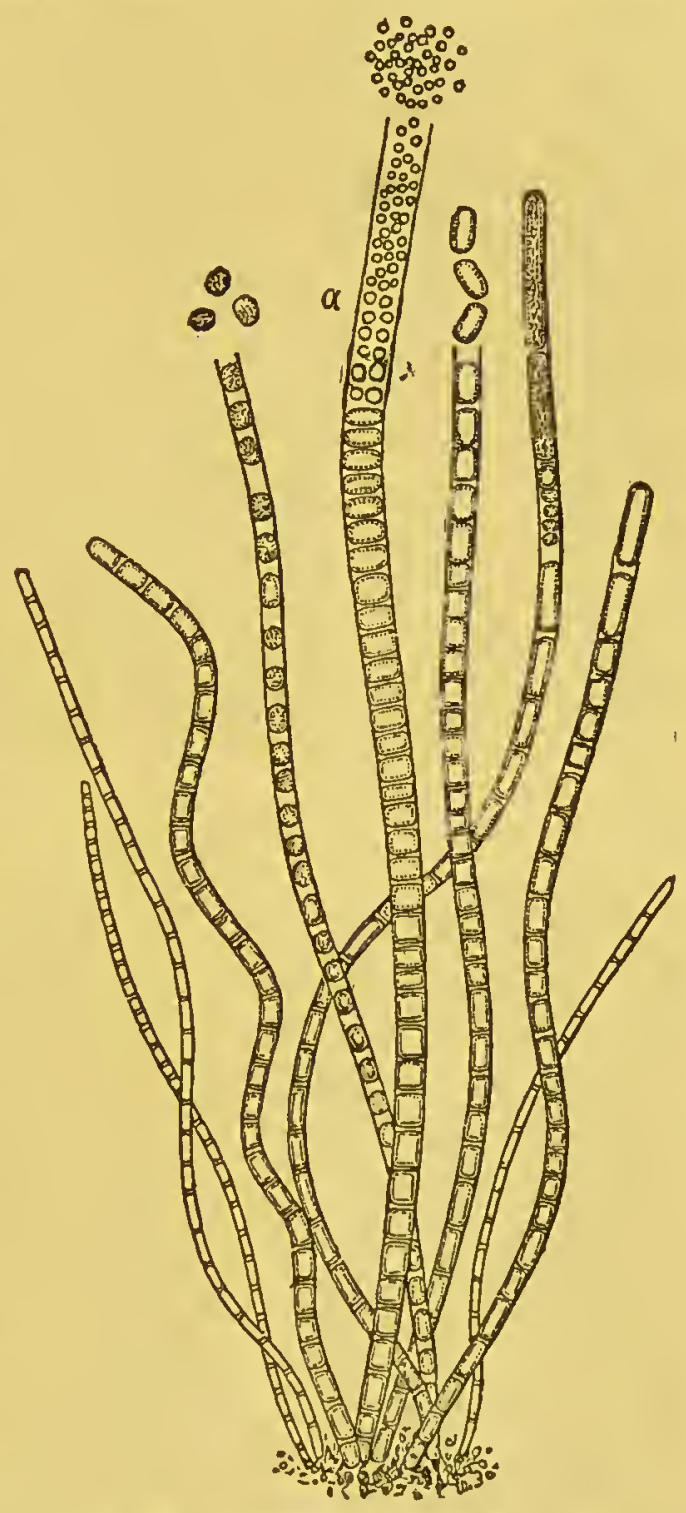

Fig. 135.-Crenothrix Kühniana $\times 600$. Thread forms with cylindrical dises and (a) cocci. (After Zopf.) crococci). In the broad threads, however, tho transverse division may go still further, so that the isodiametric portions are split up into quite small cyliudrical 
plates. In the latter longitudinal divisions appear usually parallel to the axis of the thread, and thus each cylindrical plate becomes broken up into two or four small cocci. In these crenothrix threads, therefore, the individual joints divide in two or three planes.

By continued elongation and division of the segment within the sheath so much pressure is brought to bear on the apex of the sheath that it opens at that point and permits the escape of the rods or cocci. It sometimes happens that the sheath becomes gelatinous at an early stage, and the cocci and rods remain in this gelatinous substance. In that case they sprout and burst through the gelatinous sheath, forming rods and threads, and thus the original thread has numerous secondary threads projecting from it like a brush.

Biology. Very little is known as to the physiological characters of the fungus; it requires oxygen for its vegetation, and, as the result of the presence of the gelatinous sheath, it is very resistant to variations of temperature.

\section{Beggiatoa.}

Beggiatoa. These organisms occur everywhere in stagnant and flowing impure waters, in sulphur springs, and in a part of the bay at Kiel; the organism forms milkHabitat. white, grey, red, or violet deposits on the mud, or on animal and vegetable bodies. It may be artificially cultivated in infusions of animal tissues, or of algæ, with marsh water. The fully formed threads (the free threads only represent fragments of complete threads) show a distinct contrast between their base and apex, in that they gradually increase in breadth towards the apex, and at the lower part show a distinct transverse segmentation. Spiral threads and fragments are also formed under certain nutrient conditions; the latter pass, under certain circumstances, into a swarmPresence of ing stage. In the cells of beggiaton sulphur is present Sulphur. in the form of highly refracting granules with dark outlines. The fungus is able to break up sulphur compounds, more especially sulphate of soda, and to cause 
the development of sulphuretted hydrogen; as a result, water in which these fungi are developing readily becomes uninhabitable by fish. The beggiator are but little sensitive to the influence of temperature, and they can develop luxuriantly even at $55^{\circ}$ C.Zopf distinguishes the following varieties :-

Beggiatoc alba.-This is the most widely distributed rariety. It occurs more especiallyin the waste water of sugar factories, of tauneries, and in sulphur wells (barégine or glairine). The threads grow on putrefying plants, dead insects, \&c.; they vary in thickness between 1 and $5 \mu$. Sulphur particles are not always present. On examining the threads, with or without the action of reagents, it can be seen that they are segmented into long or short rods or cocci. In the thicker threads a further subdivision of the cocci can be observed. Under certain conditions of nutrition the cocci pass into a swarming stage. After some time they again come to rest, and become attached to alga, \&c., multiply by continued fission, and form irregular zooglæa. Under certain conditions they grow and form lods which may likewisc have at swarming stagc; when these rods come to rest they grow to form threads. Further, the

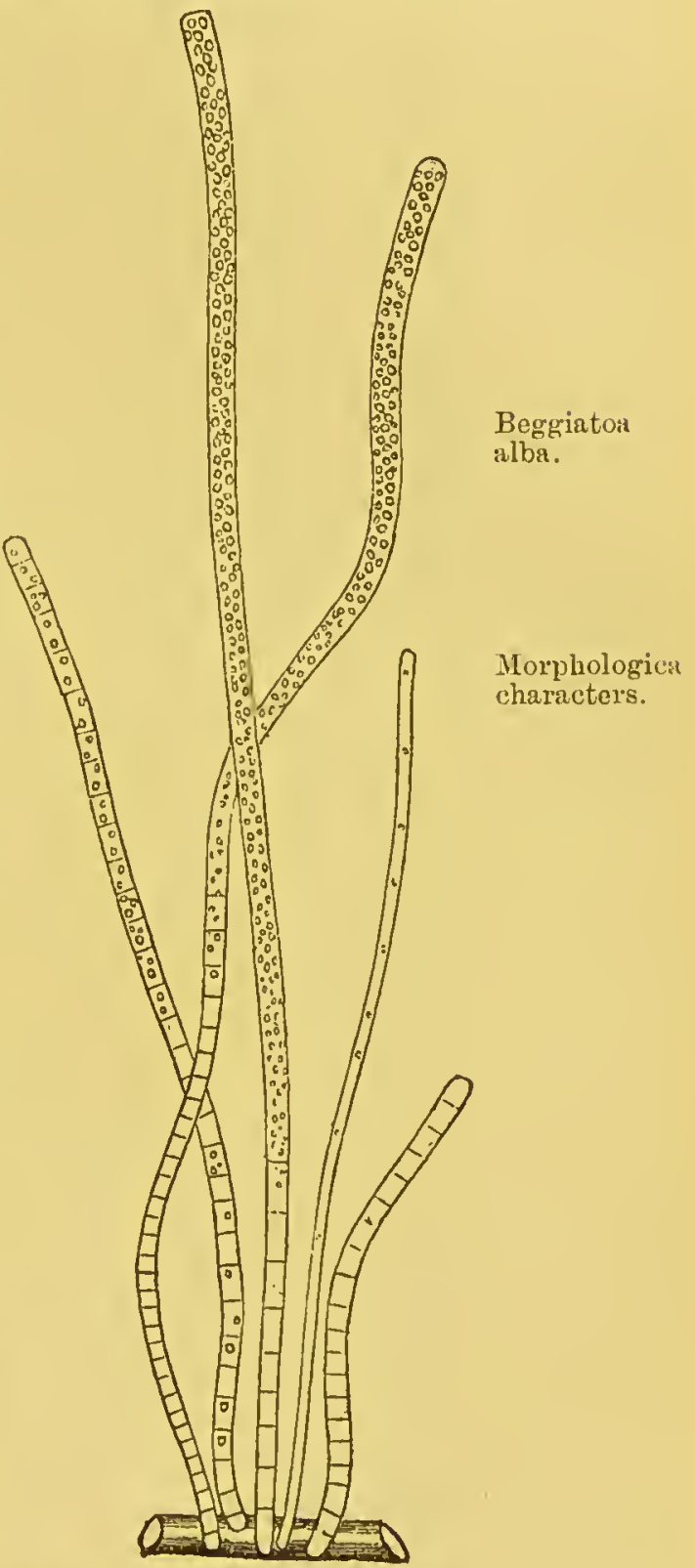

Fig. 136.-Beggiatoa alba $\times 540$.

Group of attached threads. (After Zopf.)

Beggiatoa alba.

Morphologics character's. threads may partially or wholly assume a spirnl form ond (Ophidono. spiral form, and the nas). ditions, swarn, their morcment loing cansed low cortain con(Ophid
nas). ditions, swarn, thcir morcment being caused by the presence 
Beggiaton roseopersicina.

of eilia at cach end. 'These swarming spirals werc forncrly described as ophidomonas (sce page 484). The spiral threads slow the same division into rods and cocci as the straight threads, but this is more difficult to demonstrate, and call only be done by the aid of r'cagents.

Beggiatoa roseo-persicina.-Frequent in impure ditches and ponds, covering the substratmm with a red or violet deposit. Often observed on the Danish sea-coast. In the thrcad stage it can only be distinguished from $\mathrm{B}$. alba by the reddish-riolet colour. The cocci formed in the threads develop by continuous subdivision into peculiar zooglra, which are lobulated, branched, or in the form of a network. Rods develop under ccrtain circumstances from the cocci in these colonies, and after solution of the gelatinous sheath the rods and cocci can swarm. The rods form threads, and these may show a partial or' a total spiral formation like B. alba.

Identical with The retiform zooglæa formation of B. persicina was formerly the species formerly described as Clathrocystis roseopersicina,

Beggiatoa mirrabilis. described as Clathrocystis or Cohnia roseo-pcrsicina, and by Lankester as "peach-colourcd bacterium." * The cells are spherical or oval, of a reddish colour, and as much as $2.5 \mu$. in diamcter ; they form at first solid families bound together by gelatinous material; at a later period hollow bodies appear, filled with watery fluid, and as much as $660 \mu$. in diameter'; in these bodies the cells form a single peripheral layer. The bladders are often torn or riddled with holes, and then they have the form of a delicate network, which ultimately brcaks up into irregular bunches.

The red colouring matter which is present in the cells differs from other colouring materials and is tcrmed bacteriopurpurine; the same pigment is also contained in some of the species of monas mentioned below, but it is quitc different from the colouring mattcr of micrococcus prodigiosus. Bacterio-purpurine is of a peach-red colour, is insoluble in water, alcohol, \&c., and shows under the spectroscope great absorption in the sellow and less in the grecn and blue, and also cloudiness in the more highly refracting half of the spectrum. No chlorophyll substratum is contained in the colouring matter. In the cells, espccially in old cells, dark granules can be obscrved which consist of regulinc sulphur.

Beggiatoa mirabilis.-This organism occur's in sen-watcr. forming whitish deposits on decomposing algæ, sen-wced, \&c. It is distinguished from the other beggiatoa by its large transverse diametcr $-30 \mu$. The threads slow scgmentation, at first into almost isodianctric picces, and then into short

* Rabenhorst-Winter, Lit., p. 1.-Cohn, Beitrüge, i., Part 3, 1. 157.Lankester, Quart. Journ. of Micr. Sc., 1873, rol. 13, p. 408. 
cylindrical plates. Its mode of derelopment is as yet otherwise unknown.

Phragmidiothria multiseptata.

Found by Engler in the salt water of the bay at Kiel. The Phragmidic. threads are 3 to $6 \mu$. in thickness, and are subdivided by transverse divisions into very short cylinders; in thesc cylinders longitudinal division then occurs in two or more direetions. From the minutc eoccus-like portions threads, at first very thin but constantly becoming broader, are formed.

\section{Cladothrix dichotoma.}

Very common in impure waters, in the waste water's Cladothrix. from manufacturing places, \&c. It may be artificially Occurrenoc. cultivated in decoctions of decomposing algæ, mud,

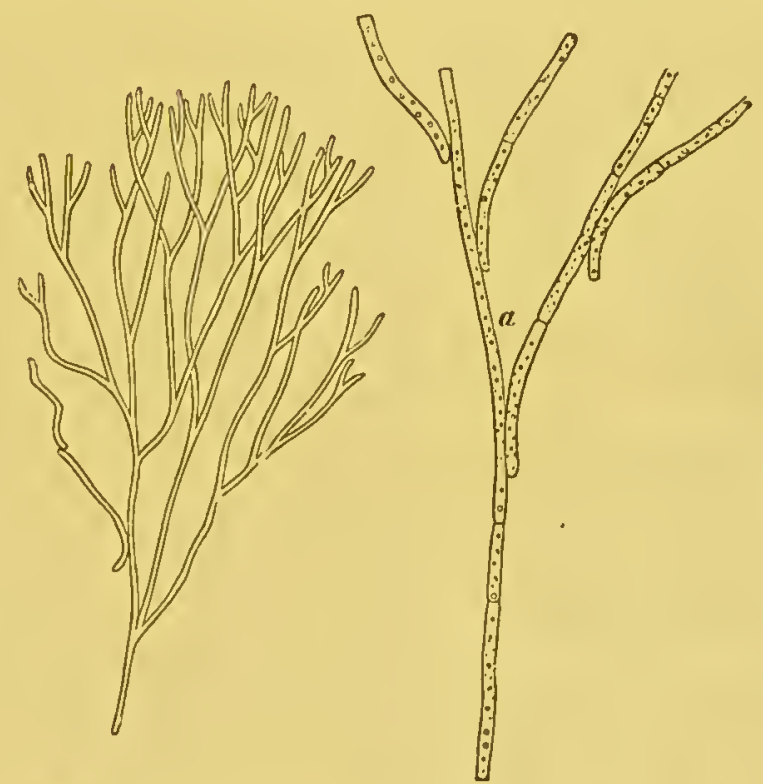

Fig. 137.-Cladothrix dichotoma. (After Cohn.)

Apparent dichotomous thrcads $\times 100$. At $a$ these are more highly magnified $(\times 600)$, and the false dichotomous divisions are distinctly seen.

flesh, \&c. It forms floating flakes and deposits on solid substrata 1 to $2 \mathrm{~mm}$. in height. The threads were ormerly described as a species of leptothrix; they form pseudo-branches, some of the rods bending to one side and elongating to form threads by continued sub-

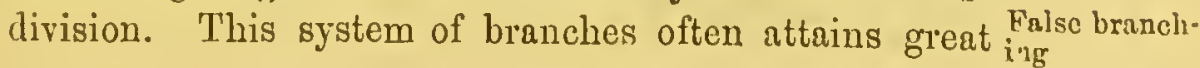


dimensions. The threads become segmented into long rods, later into short rods, and finally into cocci; but this structure is at times only visible after the employment of means which kill the organism. The segments of the threads as a rule pass out of the sheath; at times, however, the cocci grow to rods and threads in the interior of the sheath. Under certain conditions broken off portions of the branches are able to swarm, and show cilia. At times the fungus forms branches with regular spiral turns; from these also portions may be separated, and ultimately take on swarming movements. According to Billet,* spores are formed in the interior of the threads which compose the false branches.

Zooglæa ramigera

Myeonostoe.

Zopf reckons the Zooglaa ramigerat to the cycle of development of the cladothrix; this is a zooglæa branched like a trec, containing in the first place cocci, later short rods, then long rods, then lcptothrix-like threads, which at times become spirally twisted, and by the branching of which the typical cladothrix structure is ultimately formed.

According to Zopf also, the fungus described by Lankester and Cohn, $\neq$ under the name $M y$ conostoc gregarium, represents

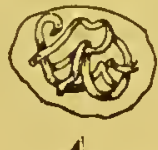

Fig, 138. - Myeonostoc gregarium (after Cohn) $\times 600$.

$A$, gelatinous ball containing a roll of threads.

$B$, individual threads. portions of the thrcads of cladothrix. Myconostoc consists of thin, colourless threads which are grouped together in the form of knot-likc, loose turns, and are surrounded by a transparent gelatinous sheath 10 to $17 \mu$. in diameter. Multiplication occurs, as in the case of ascoccus, by transrerse division of the gelatinous capsule. A zooglæa is often formed by the adhesion of gelatinous capsules. According to Zopf the spiral forms bccome broken up at a later pcriod into rods, and ultimately into coccus-likc fragments. As the result of the swclling of the jelly, the enclosed rods become morc and morc separated from cach other, and ultimately escape from the jclly, and pass into a swarming condition.

Appendix Doubtful varieties
In the casc of the following lower organisms, which may bc

* Billet, Compt. rend., vol. 100, p. 1251.

+ Itzigsohn, Sitzungsber. der naturf. Ges., Berlin, 1867.-Koch, Cohn's Beitr., ii., Part 3, p. 414.

$\ddagger$ Cohn, Beilräge, i., Part 3, p. 183. 
added here in the form of an appendix, their cycle of devolopment is quite unknown, and it is donbtful whether they should be classed among the fission fungi.

Streptothrix Foersteri is the name given by Cohn to a thread- Streptothrix like fungus which he found in the concretions in the teardncts of the human cye. This organism consists of fine colourless threads, usually straight, bnt also sometimes twisted, these threads showing at times, though seldom, distinct branching. The threads of leptothrix bnccalis arc thicker, straighter, stiffer, and mbranched, and thus differ from streptothrix. Nothing is as yet known as to the position and the mode of clevelopment of this organism.

Sphrrotilus natans.-Cells 4 to $9 \mu$. in length, $3 \mu$. in thick- Sphærotilus. ness, roundish or elongated; they occm united in rows in large numbers in the interior of colourless gelatinous sheaths, forming long threads which appear as floating flakes, densely felted like a tress of hair. Mnltiplication occnrs by isolated vegetative cells which develop new threads by continued subdivision. They reproduce themselves by means of sporcs which are formed endogenously in the vegetative cells. It occurs in stagnant and flowing water; the yonnger flakes are colonrless, the older yellowish-brown; when spore formation is taking place they are sometimes milk-white in colour, and sometimes red.*

Spiromonas.-Cells flat like a leaf, twisted around an ideal Species of long axis. Multiplication by transverse division. monas.

Spiromonas volubilis.-Colourless, transparent ; rapid movements and rapid tmrning aronnd the long axis; length, 15 to $18 \mu$.

Spiromonas Cohnii.-Colourless cells very pointed at each end, with a flagellum, and with $1 \frac{1}{4}$ turns. Breadth of the cells 1.2 to $4 \mu$. It occur's in very pntrid water.

In very foul watery fluids a number of minnte organisms Red putrefacfrequently develop in addition to the Clathrocystis roseo- tive organisms. persicina described above, these organisms being also characterised by their reddish colour, and possibly belonging to the cycle of development of that fungus. They form red flakes on all sorts of detritus at the bottom of the water, but they swim at times on the snrfacc; cren in the most marked putrid condition of the water they do not die, but on the contrary apparently take part in the putrefactive process. They are grouped together under the general name of the "pcachred putrefactive organisms." Nn chlorophyll substratmm can be recognised in the colourng matter, and hence these organisms are more properly classcd with the fission fungi

* Aftor Rabenhorst-Winter, Lit., p. 1.

+ Beilvaige z. Biol. d. P/lanzen, vol. i., Part 3. 
than with the lower monads, with whieh they have, lowevel, certain inorphologieal resemblanees. Common to them are also the dark gramules whieh are present in the pale red eell substanee, and whieh probably eonsists of sulphur (eompare Beggiatoa); and also their aetive movement eaused by flagella. Cohn has distinguished the following varieties: *

Monas vinosa.-Spherieal or oval eells about $2.5 \mu$. in diameter, often united in pairs. Cell substanee pale red with clark granules. Aetive swarming movement; flagella not olserved.

Monas Okenii._-Short eylindrieal eells, $5 \mu$. in breadth, 8 to $15 \mu$. in length, rounded at the ends, slightly eurved. Aetively mobile; a flagellum at one end twiee as long as the eell. Pale led eell substanee with dark granules.

Rhabdomonas rosea. - Spindle-shaped eells 3.8 to $5 \mu$. in breadth, 20 to $30 \mu$. in length; slow trembling movement; a Hagellum at one end. Very pale-eoloured eell substanee with clark granules.
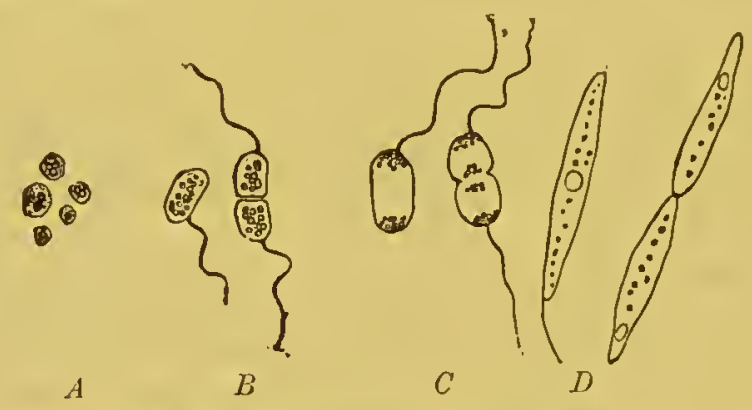

Fig. 139.-Monads. (After Cohn.)

$A$, Monas vinosa.

$B$, Monas Okenii.

$C$, Monas Warmingii.

$D$, Rhabdomonas rosea.

Monas Warmingii.-Similar to Monas Okenii, but more robust; 15 to $10 \mu$. in length, $8 \mu$. in breadth; tumbling movements; a flagellum at one end. The pale red eell substanee only eontains dark red granules at eaeh end; the ends are rounded.

* Beiträge z. Biol. d. Pfanzen, vol. i., Part 3. 


\section{PART III.}

Biology of the Micro-organisms.

Even at an early period, when elaborate experimental investigations on the subject of the vital peculiarities of the fungi were wanting, and when the attempt was made mainly by philosophical speculations to satisfy the already existing active interest in the signifcance and mode of life of the fermentative organisms, a definite and very important rôle in the economy of nature was ascribed to the class of the fungi, and efforts were made to bring the vital phenomena of the fungi, in so far as they had been observed, into unison with this róle. These earlier views have latterly been confirmed in their essential points by recent investigations and experiments ; but in certain details marked differences have been found.

The view as to the teleological function and signi- Former views ficance of the fungi rests chiefly on the absence of biological rechlorophyll; and this at once brings the fungi into lutionbetween marke plants characterised by plants and marked contrast with all other plants characterised by the fungi. the presence of chlorophyll. While the latter, including the algæ, which are so closely allied to the fungi, obtain the necessary carbon and nitrogen from the carbonic acid, ammonia, and nitric acid which surround them, and build up from these simple compounds with the aid of the chlorophyll, the complex nitrogenous and carbonaceous materials which they contain; and while these plants are consequently able to assimilate their nutrient materials from water, for example, which contains the necessary mineral substances, and from the air, which contains carbonic acid and ammonia; the fungi, on account of their want of chlorophyll, cannot live in the same manner, but require previously formed organic substances in order to replace the waste products, and 
Teloological róle of the lower fungi.

to build up new tissue. Hence they cannot exist in pure water containing only mincral substances; they grow, on the contrary, only on dead organic matter, rich in carbon and nitrogen, especially on dead plants and animals; or they live as parasites, withdrawing from their vegetable or animal hosts the organic substances necessary for their life and growth.

From these facts we can at once understand the significance of the fungi in the economy of nature. In order to supply the necessary simple nutrient materials to the chlorophyllous plants, it is cssential that the substance of dead plants should be continually broken up and reduced to these simple compounds.

The whole of the vegetation, which is yearly produced and again dies, must be so alterced in a relatively short time that water, carbonic acid, and ammonia may be again formed from albumen, carbo-hydrates, ccllulose, \&c.; and it is only under these circumstances that a constant and increasing renewal of vegetation is conceivable.

A portion of this destructive work is performed by the animal organism; the animal cells split up the vegetable materials which have been taken in, and prepares them for oxidation. The energy which had become stored up in the complcx chemical compounds of the plant, from the conversion of the energy of the light rays into a chemical energy by the aid of the chlorophyll, is used up by the animal organism, and employed for the production of heat, and for the various functions of the body. This consumption of regetable matcrials by animals is, however, by no means sufficicnt to equalise the production of regetable substances and to keep the amount of the simple nutrient materials of plants at such a level as to suffice for the constant nutrition and growth of new vegetrtion. It is evident that some other factor must come into play in the cconomy of nature by which a much more extcnsive destruction of dead regctable substances and a much greater formation of carbonic acid and ammonia is brouglit about than by the rital processes of animals; and this necessity has become 
more apparent sinee we have learned that a seareely notiecable oxidation oecurs when organie materials and the oxygen of the air are simply in eontret with eaeh other at the ordinary temperature, and that on the eontrary it is the living eells which furnish the necessary conditions for a rapid destruetion and oxidation of or'ganic materials. . Furtler, it must be pointed out that the substance of the dead animal body must also be exposed to destructive influenees in the same manner as dead regetable materials; for we also see in the ease of animal organic materials that the atmospherie oxygen alone is relatively powerless to eonvert these eompounds into earbonie aeid, ammoniu, and water.

This dangerous gap in the eonstant process of re- The fungi 1his dan break up dead generation in nature is macle good by the action of the organic lower fungi. They form the neeessary factor which materials, and renders a rapid destruetion and oxidation of dead organie them of use materials, whether of animal or vogeto the and which reproduce the simple carbon and nitrogen compounds which are neeessary for the nutrition of living and growing plants. The fungi are able to perform this rôle beeause they do not, like the chlorophyllous plants, utilise the energy of the sun, nor obtain their nutriment from carbonic aeid and ammonia, but, like animals, feed on the eomplex elemical compounds, and utilise the energy so liberated for the performance of their functions. They are the better able to do this on aeeount of the wide limits within whieh their external conditions of existence ean vary without injury; also on aceount of their extraordinarily rapid multiplication, for which they use up a eonsiderable amount of nutrient materials in a short time; and further, beeause under such circumstances they only utilise a relatively small proportion of the nutrient materials for their own growth, while a much larger proportion is deeomposed by their peculiar fermentative aetions, and thus prepared for further oxidation. Lastly, it is as it were only a slight alteration of their funetion when they at times settle as parasites on living plants and animals, and load to their. destruetion by breaking up rery rapidly the organic eon- 

vestigations as to the nutritive of the fungi.
Pasteur's in requirements

stituents of their host and converting them into simple chemical compounds.

In correspondence with this view of the function and the significance of the fungi, we must look for thcir most important physiological peculiarities in the fact that they obtain their nutrimont from complex organic substances, and are unable to assimilate the carbon and nitrogen from carbonic acid and ammonia. This characteristic therefore formed the basis of former investigations.

Pasteur was the first who made exact experimental investigations as to the biology of the fungi; these experiments led to results which differed in many respects from the views which had been held up till that time. Pasteur showed more especially that yeast and mould fungi were in so far able to live in a similar manner to the higher plants in that they could assimilate the nitrogen from ammoniacal salts, and even from nitrates, and thus, like the chlorophyllous plants, could build up the complex albuminous materials of their body from simple substances. It was also found that different fungi showed great differences in their conditions of life; that one required oxygen and led to rapid oxidation, that another could live without oxygen, and then often caused extensive though superficial decomposition of the nutrient material; that only certain fungi could tolerate an acid reaction and great concentration of the nutrient medium; that different organisms grew most luxuriantly at very different temperatures; that one preferred this, and the other that kind of nutrient material, and that they were not all equally capable of utilising the nitrogen of ammonia, or of nitric acid; that, lastly, even one and the same organism behaved very differently as regards their tissue change and encrgy under varying cxtcrnal conditions.

Fingi do not reccssinily requile colnilex organic untritive untelials.
It is true that the former views as to the significance of the fungi in nature were not completely upset by thesc certain that all the lower fungi werc able to live on complex chomical materials-that, in fact, these matcrials results of experimental investigation. For it was still 
were preferred as nutricut substances, and that therefore the destruction of dead organic substances was chiefly caused by fungi; further, that carbonic acid could not in any way be utilised either for assimilation or for growth. But the physiological characters by means of which they were able to play their peculiar rôle no longer appeared to be so simple, and could no longer be defined in a few words, but were made up of a number of processes which required separate consideration, and which varied markedly according to the species of the fungus and the external conditions which surrounded it. Hence we can no longer content ourselves with a general formula if we would obtain an insight into the vital manifestations of the fungi; but we must proceed by the inductive method, and seek to understand the life of the lower organisms from a large number of individual observations and experiments. In this place we must therefore enter into a minute and detailed discussion as to the biology of the fungi, and we must do this the more thoroughly because this side of mycological investigation is of very great importance for hygiene.

The various biological phenomena which we observe in the fungi can be subjected to experimental study in the same manner as the vital phenomena of more complex living beings, e.g., of animals or of the higher plants. If we take the latter as our basis, we must proceed from the more complex to the simpler, but it is probable that many biological problems which have proved insoluble in the case of the more complex organisms, in spite of rery numerous investigations, will be much more readily solved in these simple beings, and that thus at a later period the biology of the fungi will throw light on the biology of ligher plants, more especially when we employ the methods of investigation which have been found good in the case of the former.

If we wish to study the tissue change of any of the more complex organisms we generally attempt in the first place, by a number of variations in our experiments 
on nutrition and tissue ehange, to determine the lind and quantity of material which is taken up by them, and to aseertain the normal relation of the other external conditions which are necessary for the regular progress of life; further, we investigate the fate of the materials taken up, and how they are used in the body, also the excretory products, and finally the functions of the organs; and we are thus in a position to form an approximate idea as to the alterations of the tissue and of the energy which form the basis of the life of that organism.

We must stucly the biology of the lower fungi in a similar manner. In the ease of these also we must in the first place ascertain experimentally the necessary conditions of life; we must learn what solid nutrient materials must be supplied to the fungi, what rôle is played by oxygen, and whether temperatnre, atmospheric pressure, light, \&c., exereise any noticeable influence on the growth and the multiplication of the fungi. Where multiplication occurs by means of spores, we must ascertain what are the conditions nccessary for this act, and also on what external circumstanees the germination of these spores depends.

In the second place, it is necessary to study the results of the life of the lower fungi. Among these we learn, in the first place, the assimilation of the nutrient materials, the tissue change in the cells, and at the same time the various manifestations of energy-for example, growth, multiplication, and fructification; further, we find that the fungi exerete various produets of tissue change which are of special interest; and finally, that they exert under certain cireumstances two peculiar actions which require more minute study, viz., fermentative action and the production of disease.

The study of the conditions of life also implies a diseussion of the influences which are hurtful and clestructire to life. It is, however, advisable to consider the phenomena of involution and of the death of the lower fungi in a separate chapter, as well as the deseription of those means by which we ean interfere with the growth or life 
of the fungi. These means are identical with the disinfueting agcnts which have recently become of so much importance.

Finally, the investigatious as to the biology of the lower fungi must not be limited to the individual; the behaviour of a continued series of individuals must be talien into consideration. More especially we must direct our attention to the occurrence of modifications--to the formation of varieties, races, and species.

The discussions in the following pages are limited to those fungi which are of importance from a hygienic point of view (mould fungi, yeast fungi, and fission fungi); with regard to the other fungi and microorganisms which were mentioned in studying the molphological characters, we must refer to de Bary's excellent description of the morphology and biology of the fungi.

\section{Conditions of Life of the Lower Fungi.}

In order to understand the nutritive processes, it is in Conditions of the first place necessary to take a short survey of the chemical composition of the fungi. We must then ascertain the importance of the individual nutrient materials, in the first place of the nitrogen, and then of the carbon, hydrogen, and combined oxygen, of the mineral substances, of the water, and, finally, of the free oxygen. Special attention must also be paid to the concentration and reaction of the nutrient mixture. Of less importance is the influence of atmospheric pressure, light, electricity, and mechanical movement; while the action of various temperatures, the fermentative action, and the concurrent growth with other fungi are of res:y great importance in the development and growth of the individual micro-organisms.

In almost all these points the mould fungi, yeast fungi, and fission fungi show such differeness that each must be separately stuclied. 
(a) Monld

fungi- -

chemical consititution.

(a) Conditions of Life of the Mould Fungi.

1. Chemical Composition of the Mould Fungi.-Until recently we had no complete analysis of the mould fungi; nevertheless it was assumed that their composition was similar to that of the higher fungi. In the case of the latter, the following numbers represent the average result of various analyses:-

88 per cent. water, 3 per cent. nitrogenous and 5 per cent. non-nitrogenous organic materials, 1 per cent. ashes; when dried in the air-17 per cent. water, 25 per cent. nitrogenous and 45 per cent. non-nitrogenous substances, 8 per cent. ashes.

Sieber* * has recently made some analyses of the mould fungi, but, as it appears, without sufficient precautions as to the purity of the materials used. The following was the result-(1) of a cultivation of penicillium and mucor in a nutrient solution of gelatine and sugar:-

Soluble in Ether..... 18.7 per cent. of the dry substance.

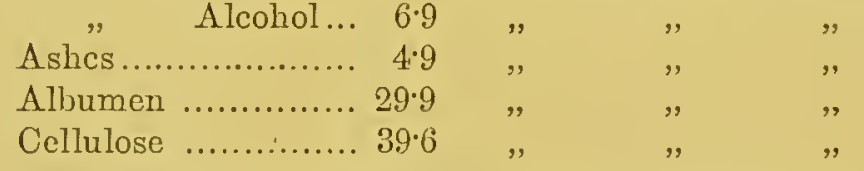

(2) Of a cultivation in a saccharine ammoniacal solution, consisting mainly of Aspergillus glaucus:-

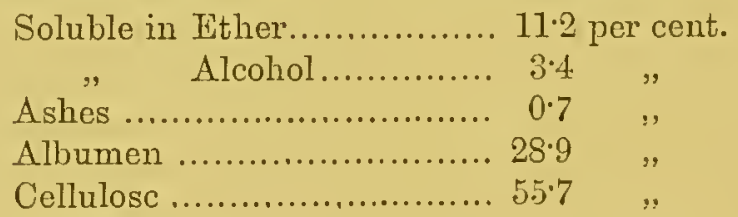

As compared with the analysis of the yeast and fission fungi (as given below), the marlied excess of non-nitrogenous substances is specially noticeable; this in the main depends on the fact that in the case of the mould fungi a large amount of cellulose is present, and that it is only in the contents of the cells that albuminous substances exist; and also on the fact that soluble saccharine matter's are present in recognisable quantity.

* Journ.f. pratt. Chemie (2), 23. 412. 
The mineral constituents in the case of the higher fungi have the following average composition:-

50 per cent. potash, 1.5 per cent. soda, 1 per cent. lime, 2 per cent. magnesia, 1 per cent. oxide of iron, 30 per cent. phosphoric acid, small quantities of silicic acid and hydrochloric acid, and very varying quantities of sulphuric acid.

According to this analysis, potash and phosphoric acid seem to be of most importance.

Stutzer* has found that mould fungi washed in water, and clried over sulphuric acid, showed a total of 3.776 per cent. of nitrogenous materials, consisting of 3.026 per cent. of proteids, and 1.539 per cent. of nuclein.

2. The Nutrient Materials of the Mould Fungi.-Cor- Nutrient responding to the chemical composition, a large amount materials. of water is necessary for building up and maintaining the constituents of the mould fungi; also organic substances containing carbon and nitrogen, and of the mineral constituents, chiefly potash and phosphoric acid. The chemical compounds which these nutrient materials furnish, and the relative amount in which the latter must be present, can however only be ascertained by special experiments.

A series of experiments in this dircetion were formerly Raulin's made by Pasteur, and have been earried out in a very thorough experiments. manner by Raulin, $\uparrow$ who proceeded as follows:-He eultivated Aspergillus niger in a nutrient solution which, as the result of numerous experiments, he had reason to believe was particnlarly suitable for the nourishment of the fungus, and wlich may be regarded as the normal solution. It was eomposed of-

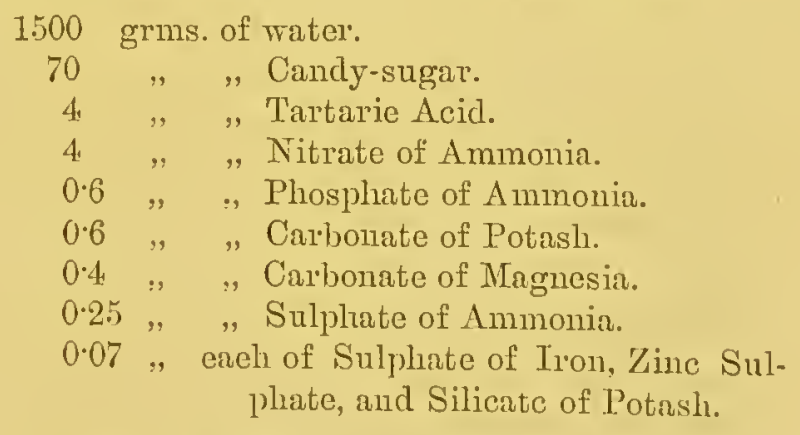

* Zeitschr. f.physiol. Chen., vol, vi., 573.

† Raulin, Compt.rend, T. 56, p. 229. 
If Raulin sowed spores of Aspergillus niger in this fluid, which was kept at a temperature of about $35^{\circ} \mathrm{C}$. in shallow eovered vessels in a layer 2 to 3 ctm. in depth, a fructifying myeelium was formed after three days; this was removed, and from the remaining fluid a new erop was obtained after three days more. After the removal of this second crop the nutrient materials of the fluid seemed to be almost entirely exhausted. The weight of the total growth when dry was determined, and was found to amount to about $25 \mathrm{grms}$. This result was compared with that obtained when one or other of the constituents of the normal nutrient solution was omitted. Raulin found that the absenee of phosphorie aeid had the greatest influcnee, the resulting growth being reduced to $\frac{1}{200}$ part of the normal; that the absenee of ammonia diminished the growth to $\frac{1}{150}$; and of potash to $\frac{x}{25}$. No eonstituent of Raulin's fluid eould be omitted without harm; even the omission of the zine had a marked influenee on the result.

Nägeli's experiments.

More complete experiments of a similar character have recently been made by Nägeli. He showed that thcre were certain sources of error in the former experiments; that, for example, sufficient care had not bec1 taken to secure pure cultivations and to exclude all other organisms ; that, further, the access of air, the reaction, the most favourable concentration of each of the nutrient materials (the so-called "optimum of concentration"): and, finally, the alteration of the nutrient solution by the growth of the fungus itsclf, were not sufficiently taken into account. Nigeli's* numerous and exact experiments led to the following results :-

Substances suitable for supplying the necessary nitrogen.

The necessary nitrogen cannot be obtaincd from frce nitrogen, nor from the nitrogen which is in combination with carbon in cyanogen; in like manner nitrogen in combination with oxygen seems to be unsuitable, at any rate nitro-compounds, such as picric acid and nitrobenzoic acid, were very bad nutricnt materials. On the other hand, the best forms seemed to be the $\mathrm{NH}_{\text {. }}$ groups; the $\mathrm{NH}$ group was less suitable. In correspondence with this, the best materials for the nourishment of the fungi wcre : ammoniacal salts (sal ammoniac, phosphate of ammonia, nitratc of ammonia; acetate, oxalate, succinate, and tartratc of ammonia, (fc.) ; also

* Nügcli, Untersuchungen ü̈ser nicdere Pilze, Munich, 1882. 
lyydrochlorate of methylamine and xthylamine, trimethylamine; leucine, asparagine; acetamide, oxamide ; and urea. The best nitrogenous nutrient materials were the soluble albuminates and peptone. Nitrogen can also be assimilated by the mould fungi from nitrates; probably in this case there is a gradual reduction of the nitric acid to nitrous acid, and ultimately to ammonia; but these reduction products have not yet been demonstrated. In comparative experiments no marked difference was found between the nutrient value of the nitrates and the salts of ammonia; urea was better than either, and peptone was better than urea.

The necessary carbon can be obtained from the For the supply groups $\mathrm{CH}_{3}$ or $\mathrm{CH}_{2}$, and in that case it is of advantage, and under certain circumstances necessary, that several carbon atoms should be united in one molecule. No carbon can be assimilated if in any given chemical combination there is only a union of carbon with nitrogen, oxygen, or carbon. Hence the following substances are not suitable for yielding carbon : carbonic acid, cyanogen, formic acid, urea, oxalic acid, and oxamicle. Of course, also, those combinations which are not soluble in water are unsuitable as food, such as the higher fatty acids and the insoluble humine substances. Apart from the number of the carbon atoms, the ease with which the compounds can be decomposed seems to be of importance; the more readily the compound can be broken up by other agents, such as by oxidising substances, the more easily can it be assimilated. Nägeli has formed the following empirical table of the nutrient value of various organic compounds witl regard to carbon: 1 . Various linds of sugar. 2. Mamnite, glyccrine; the carbon group in leucine. 3. Tartaric acid; citric acid ; succinic acid; the carbon group in asparagine. 4. Acetic acid; athylic alcohol; quinic acid. 5. Benzoic acid; salicylic acid; the carbon group in propylamine. 6 . The carbon group in methylamine; phenol. Pyrogallic acid and tamnic acid were also fairly good sources of carbon; and finally we may mention the observa- 
Nutritive raluc of the combined carbou and mitrogen sources.
Supply of hydrogen, oxygen, and sulphur. tion made by Pasten in 1858, that racemic acid, which is a combination of two forms of tartaric acid, the one rotating to the right, and the other to the left, was able to nourish the mould fungi, in the form of racimate of ammonia, but that it was only the form which rotated to the right which is taken up by the fungi, while the other is left in the nutrient fluid.

It is very difficult to compare the nutrient value of the various sources of carbon, because they evidently vary in their action in accordance with variations in the sources of nitrogen; and again, if we take care that the nitrogenous materials are the same it becomes a question whether they may not be assimilated in another way when the carbon sources are clifferent. Hence we would apparently obtain a more exact mode of comparison if we combined the sources of carbon and nitrogen, and then subjected some of these combinations to comparative experiments. In this way Nägeli has constructed the following scale, proceeding from the best to the worst nutritive materials: 1. Albumen (peptone) and sugar. 2. Leucine and sugar. 3. Tartrate of ammonia, or sal ammoniac and sugar. 4. Albumen (peptone). 5. Leucine. 6. Tartrate of ammonia; succinate of ammonia ; asparagine. 7. Acetate of ammonia.

Thus albuminous materials, and those belonging to the group of carbo-hydrates, seem to be the normal nutritive sources of the mould fungi, and it is chiefly these materials on which they feed under normal circumstances. But, on the other hand, it is noteworthy how widely the nutrient materials may vary, the fungi subsisting with ease on very different chemical substances, and also how the mould fungi seem to be able to maintain their existence as the result of their ability to obtain nutriment from the most different sorts of chemical substances.

The supply of hydrogen and of combined oxygen is partly provided for by the above-mentioned carbon and nitrogen compounds, and partly by water and free oxygen.-Sulphur also takes part in the composition of the organic constituents of the mould fungi, and is 
probably contained in all true albuminous materials. According to Nägeli's experiments, it can be taken from the albuminates, and as well, or better, from sulpliates, sulphites, or hyposulphites; sulpho-acids may also act as substitutes, but not sulpho-urea compounds or the sulpho-cyanides. Exact experiments, however, as to the supply of sulphur are very difficult to carry out, because the small quantities necessary for suitable nourishment commonly adhere as impurities to the other nutrient materials, as for example, to the sugar.

Water and mineral substances are of great importance supply of for the mourishment of the mould fungi. A large quantity of water is necessary for the nutriment of the mould fungi; in part it enter's into the complex substances which are built up by the fungi, in part it forms the chief constituent of the newly formed tissue of the fungus, and in part it acts as a dissolving and transporting medium, and thus enables the materials to move in the cell, just as in the case of the higher organisms. It is of special interest, as regards the necessity for water, to ascertain the smallest quantity necessary for the mould fungi to obtain sufficient nourishment. As regards this question we shall enter into further details when considering the subject of nutrient materials with reference to their concentration.-According to Nägeli's more recent researches, Need of a relatively small quantity of mineral substances are mineral necessary. While the chlorophyllous plants require, besides phosphoric acid, sulphuric acid, and alkalies, also calcium and magnesium, and in addition iron, silicic acid, and chlorine, the mould fungi are satisfied with sulphuric acid, phosphoric acid, potash, and calcium or magnesia. The potash, however, cannot be replaced by sodium, although it may by cæsium and rubidium. In the place of calcium we may have, besides magnesium, also barium or strontium. One element from the group of the alkalies, and ono from the allialine earths, must, however, always be present; each of these representatives of the two groups appear to havo different functions, which are probably the following: tho eartly com- 
pounds in part in the form of earthy phosphates, only form deposits in plasma and in the cell membrane, while the allaline salts are chiefly present in solution in the free fluid of the cell in the form of primary and secondary phosphates of potash $\left(\mathrm{KH}_{2} \mathrm{PO}_{4}\right.$ and $\mathrm{K}_{2} \mathrm{H} \mathrm{PO} \mathrm{P}_{4}$, the first having an acid, and the second an alkaline reaction).

Free oxygen. In addition to the solid and fluid nutrient materials which have been already mentioned, the mould fungi require for their normal development and growth the presence of free, gaseous oxygen. Pastemr found that like the higher plants, the mould fungi (penicillium) take oxygen from the surrounding atmosphere. The need of the mould fungi for oxygen is also shown by the places in which they occur; they are limited to those situations which are in immediate contact with free oxygen. Hence they grow cnly on the surface of fluids (in like manner on the external surface of animal or human bodies, in the air-passages, sc.), and then only in so far as they can obtain the oxygen dissolved in the fluids. The quantity of oxygen necessary is, however, small; and, according to Brefeld, the mould fungi which do not cause fermentation will grow when placed in an atmosphere of carbonic acid, unless it contains less than 500 of its volume of air.

Behaviour when oxygen is absent.

If the mould fungi are immersed in fluids free from oxygen their normal growth ceases; and some fungi (such as mucor) can only form yeast-like buds, and in this way, according to Brefeld, provide for the maintenance of the species. Under these circumstances, however, the yeast-like cells set up fermentation, with plentiful development of carbonic acid and the stream of bubbles of carbonic acid again brings the elements of the fungi to the surface where they are able to grow and Growth in the fructify in a normal manner.-The growth of the mould mimal body. fungi in the animal body apparently forms an exception to the above rules. It has been recently proved, as a result of numerous experiments, that the spores of aspergillus and mucor can sprout in the lidneys and in the internal organs of the living body, and grow to form a mycelium. As yet howerer, only a limited formation of mycelium bas been 
obtained under these circumstances, and the production of fruit-benring mycelium and spores las never been observed; hence the relation of the fungi to oxygen may be stated by saying that normal growth with fructification can only occur in an atmosphere containing free oxygen, while on the other hand, only a formation of mycelium occurs where (as in many animal bodies) there is no free oxygen at their disposal. This view corresponds also on the whole with the facts as to the occurrence of the parasitic mould fungi in the lower animals; the pathogenic species of empusa, cordyceps, botrytis, and isaria form in the bodies of the caterpillar's aur insects which they attack well-developed mycelium, and ultimately the so-called cylindrical gonidia; true fructification, however, only takes place by means of fruit-bearing hyphæ, which have burst through the surface and come in contact with the air.

Thus far we have discussed the question of the quality Quantity of of the nutrient materials which are required by the mould the nutrient fungi. In addition to the quality we must now allude to their quantity. It is evident that either too small or too large a quantity of any of the nutrient materials will have an unfavourable effect, and that there must bo an optinum of quantity as regards each individual component at which nutrition goes on best; this optimum, however, will depend on the general composition of the nutrient mixture, and will vary according to the amount of the other substances which are present at the same time. On this subject very little is as yet known, and only as regards two points are the experiments sufficiently numerous and precise to admit of their discussion ut the present time-namely, in the first place, the amount of water which is necessary for a suitable nutritive mixture, or, in other words, the concentration of the mixture; and, in the second place, the quantity of free alkali or free acid, i.e., the reaction of the nutrient mixture.

As regards the concentration or the amount of water Limits within in the nutriment, it may vary very considerably without which tho completely preventing the growth of the mould fungi; the wator of
mould fungi are in this respect much mould fungi are in this respect much less sensitive than 
the yenst or the fission fungi. Some mould fungi can grow in extremely dilute nutrient mixtures which only contain traces of the necessary nutrient materials. (This has been especially observed with regard to penicillium.) While, however, in this respect the vital activity of the yeast and fission fungi is almost the same, the mould fungi, on the other hand, have the advantage when we come to deal with a small amount of water and marlied concentration of the material. Under such circumstances they are by no means sensitive; nutrient mixtures from which a great part of the water has been removed by evaporation, or by the addition of salt or sugar, and which have therefore become unsuitable for the mutrition both of the budding and fission fungi, will still be available for the growth of various mould fungi. We have not yet gained exact information regarding the upper and lower limits of the amount of water, and such information is very difficult to obtain, because the quantity varies according to the other constituents of the nutrient medium, and according to the varying species of the mould fungi. In preserving articles of food, we have learnt by experience that salted or smoked meat, for example, which contains 50 per cent. of water, is no longer a suitable soil for fission fungi, but it may, nevertheless, become mouldy; in order to prevent the formation of mould, the amount of water must be reduced to only 10 to 12 per cent.; if, horever, sugar is present at the same time in large quantities, mould formation is prevented, eren with as much as 30 per cent. of water.-These numbers indicate the lowest limit as regards the amount of water; the optimum is much higher, perhaps 80 per cent., so far as the dependence of the optimum on the quantity of the other nutrient materials permits us to give definite numbers.-All the mould fungi, however, are not in like manner indifferent with regard to great, concentration of the material on which they grow. Certain fungi appear to be much more sensitive, especially somo which lend a parasitic life, and which only occur in moist seasons and in moist localities. 
The reaction of the nutrient mixture has a most im- Influence of portant influence on the growth of the mould fungi. the reaction They secm to bo most sensitive to an excess of alkali, material. although some forms occur on substrata which have a warked alkaline reaction; an cxcess of acid is not nearly so hurtful. Free tartaric acid may be present in the nutrient mixture up to 5 per cent., and free phosphoric acid up to 1 per cent., or more, without preventing the development of mould fungi. This point is of great importance, because in this respect, also, there is a difference between the mould fungi and the majority of the fission fungi, which are vory sensitive to excess of acid, and because by the reaction of the nutrient material alone the linds of fungi which obtain the mastery when growing together can be influenced.-But on this point also we can give no definite figures which take into account the differences in the nutrient solution, and the specific properties of the various forms of fungi.

As has been mentioned, there must be a most favourable proportion for all the other nutrient materials, and increase or diminution of the quantity will exercise an unfavourable action. Further, any admixture of foreign materials which are not nutritious must render the mutrient mixture to a certain extent unsuitable, even when such materials are not poisonous for the fungi, and do not hinder their growth even when present in great concentration. Finally, poisonous materials which have a specific noxious action on the growth of the mould fungi may be present in the nutrient substratum or in the surrounding air. The action of these substancos will bo discussed in the chapter on "Disinfection."

At times the mould fungi can convert insoluble mate- Fermentative lials into soluble, substances which can be absorbed, action of the and this is done by the formation of suitable forments. For instance, in the case of penicillium and aspergillus niger, the production of a forment which inverts cane-sugar and maltose* has been demonstrated, and Van Tieghem showed that penicillium and aspergillus niger were able to split up tannin into gallic acid and glucose; the

\footnotetext{
* Bourquelot, Compt. rend., vol. 97, p. 1322.
} 
Influence of external factors.

solution of cellulose, also, has been frequently noticed as a result of the penetrution of mould fungi into tlie tissues of plants, and is only explicable by the agency of ferments.

The parasitic existence of the mould fungi, in which they take the necessary nutrient materials from the host on which they grow, will be considered at greater length further on.

\section{Other Conditions of Life of the Mould Fungi.--} Increased and diminislied atmospheric pressure, light and electricity, have not yet been exhaustively studied as regards their influence on the growth of the mould fungi; in so far as existing observations enable us to draw conclusions on this subject, they appear to have no marked effect. Nothing is known as regards either a disturbing or favourable influence of movement of the nutrient mixture; and with regard to a favourable or inhibitory action of fermentation on the growth of the mould fungi there can be no question whatever, for with the abovementioned exceptions they do not cause fermentation. There remain, however, some conditions of life which may influence the growth of the fungi, more especially temperature, and concurrent growth with other fungi.

Temperature. Temperature only requires consideration in so far as it varies within medium limits. The extremes of cold or heat will be considered among those conditions which may cause the death of the fungi. In the case of those temperatures which come into play under normal conditions, the same points are of importance as were mentioned vitl regard to the concentration of the mutrient materials. In the case of the mould fungi there exists an optimum of temperature at whicl they grow most quickly and Hourish best; but this optimum differs according to the species of fungus, and also according to the other conditions of life and nutriment, in any given case. The optimum for penicillium is quite different from that for aspergillus, and they both differ from that of mucor. Penicillium glaucum appears to grow best at a temperature of about $20^{\circ} \mathrm{C}$; it grows 
also, however, at relatively low temperatures (at $+2 \cdot 5^{\circ}$ C.), which are but little above the freezing point; as the temperature rises, so does tho energy of their growth increase, till the optimum is reached; it then again diminishes and ceases entirely at about $43^{\circ} \mathrm{C}$.

In the case of Aspergillus glaucus the optimum of temperature lies between $10^{\circ}$ and $12^{\circ} \mathrm{C}$; of Aspergillus flavus about $28^{\circ} \mathrm{C}$.; of Aspergillus niger from $34^{\circ}$ to $35^{\circ} \mathrm{C}$; ; of Aspergillus fumigatus between $37^{\circ}$ and $40^{\circ}$ C. (Siebenmann); of Oidium lactis between $19^{\circ}$ and $30^{\circ}$ C., \&c.-From these figures we may draw the important conclusion, as regards the spread and the artificial cultivation of the mould fungi, that the temperature must often determine what species develops and obtains the mastery in any given nutrient material.

The simultaneous occurrence of other kinds of fungi Concurrence in the same solution exerts a very important influence with other on the growth of a cultivation of mould fungi. While it is easy to obtain a luxuriant growth of the mould fungi in solutions in which they alone have been sown, and which are protected against the entrance of other organisms, there may be no growth of mould fungi in such a solution if bacteria have entered at the same time, and if the nutrient solution in question permits the latter organisms to multiply most rapidly. Under these circumstances, those conditions of life which differ in the case of the mould fungi, the budding fungi, and the fission fungi are of special importance; of these conditions the chief are the concentration and reaction of the nutrient material. In a mixture which contains only a small quantity of water, and which has a marlied acid reaction, but few kinds of fission fungi can develop; where, therefore, these conditions are present, the soil belongs exclusively to the mould fungi and the yeast fungi. 'Thus, the mould fungi can obtain the mastery in a soil where, if it were less acid and contained more water, the fission fungi would certainly gain the upper hand, because they could assimilate the nutrient materials more onergetically and take thom away from the mould fungi. This concurrence between 
different clnsses of fungi is important, and must be noted under various other circumstances. A similar concurrence naturally occurs also among the species of one and the same class; in that case, however, other factors come into play, and lead to one or other species gaining the upper hand. Temperature has a very marked influence; if, for example, we employ a nutrient medium at $15^{\circ} \mathrm{C}$., in which the spores of Aspergillus fumigatus and of penicillium have been sown, only the latter fungi will develop well, and they will grow to such an extent that growth of the aspergilli cannot occur, although this would have taken place had there been no penicillium spores in the material in the first instance; and conversely, where both species are sown together in a medium lept at $35^{\circ} \mathrm{C}$. only the aspergilli ultimately develop. Other nutrient conditions also act in a similar manner, and hence the resulting cultivation and also the presence of any giren mould fungus in nature does not rest alone on the various conditions of life which are present, but also depends in a very important manner on the other species of fungi which may have reached the nutrient soil at the same time and may be growing in concurrence with it.

Conditions of spole formation.

Conditions of spore formation.
4. Conditions of Spore Formation and Spore Germination.-In the case of the mould fungi, the formation of spores is such an essential part of the life of the fungus that we camnot regard the formation of mycelium without fructification as a normal and complete development. The conditions of life described above hold good not only for the growth of the mycelium, but also for fructification and the formation of spores; it has already becu pointed out how necessary the presence of oxygen is for the latter process, and in this place we need only mention the few facts that are known with special reference to the act of the germination of spores. For this process we do not as a rule absolutely require the presence of any particular nutrient material, with the exception of a large quantity of water. The formation of the germinating tube talies place at the expense of the nutrient materials which have been stored up in the spore, and it 
is not till development has reaclied a certain stage that the above-mentioned nutrient materials become necessary. Hence the sprouting of moistened spores can be observed eren on glass plates. In the case of some fungi however, for example Nucor mucedo, it is true that the first sprouting can only occur on suitable soil.-Besides water the presence of oxygen and a suitable temperature are also necessary for the process of germination. Here also the minimum, optimum, and maximum of the temperature differ in the case of different species of fungi. In the case of penicillium spores the former is about $+0.5^{\circ} \mathrm{C}$., the latter about $+43^{\circ} \mathrm{C}$, and the optimum about $+22^{\circ} \mathrm{C}$; in the case of Aspergillus fumigatus, on the other hand, the minimum, according to Lichtheim, is $15^{\circ} \mathrm{C}$.- The presence of light is not necessary for the germination of the spores of the fungi.

Between the point when the conditions necessary for germination come into play and the formation of a germillating tube a certain period of time is necessary, the length of which is dependent on the species of spore, and probably, abore all, on the thickness of the spore membrane, and varies from a few hours to several days. Similar variations also exist with regard to the duration of the ritality of the spores. In the case of the uredo and Duration of recidium spores of the rust fungi, as well as in the the vitality of case of peronosporex, the duration of vitality is only a few weeks, while the spores of Penicillium glaucum are able to sprout after a year and a half, those of Aspergillus niger after more than a year, those of Nucor stolonifer after a year, of Aspergillus flavus after six years, of Aspergillus fumigatus after ten years, and of Tilletia caries and Ustilngo carbo after about eight years.* 'There is a further peculiarity in connection with the spores, namely, that they are only able to sprout after a considerable period of rest.

* Quoted from de Bars. 


\section{b. Conditions of Life of the Budding Fungi.}

\section{Chemical Composition of the Budding Fungi.}

Buckling fungi, chemical composition.

As regards the budding fungi, very numcrous experiments have becn made, which cnable us to obtain a fairly accurate idea of their chemical composition and of their tissue change. These experiments have almost cntirely becn limited to the ordinary yeast of bcer, which on account of its valuc in the preparation of food has always excited special intcrest. It is seldom that other species of these fungi, such as Mycoderma vini (A. Schultze, in Mayer's Chemistry of Fermentation), have been choscn for investigation.

Complete analyses of yeast have been published by the following authors: Schlossberger, Mulder and Wagner, Mitscherlich, Payen, Liebig.* The following was the average result in washed and dried jcast, freed as much as possible from ashes:-

48 per cent. C, $9-1,2$ per cent. N, $6-7$ per cent. $\mathrm{H}, 0.6$ per cent. S.

More recent analyses by Nigelit have led to the following r'csults in the case of yeast used for low fermentation :-

Cellulose and mucous material of cell wall 37 per cent.

Albuminous materials

Peptone

Fat

Extractires (glycerine, lcucine, \&c.)

Ashes

Yeast which has bcen carrying on fcrmentation for a considerable time contains, according to Pasteur aud others, a markedly less amount of nitrogen (only $5^{\circ} 0$ to 5.5 per cent.).- Schlossberger and MLulder hare attempted to isolate the albuminoid materials, cither by treatment with potash lye or with acetic acid; and they made out that the isolated matcrials had a composition closcly

* Sco Mayer, Lehrbuch der Gührungschenie, 1879, p. 110.-Schützenberger, Gährungserscheinungen, p. 58 .

† Silzungsber, d. bayr. Acad. d. II iss. 1878, MIay. 
allied to that of the proteids. More recently an albuminoid material has been obtained from the yeast cells by boiling with dilute hydrochloric acid and precipitating with rock salt; this material is termed mycoprotein, and plays an important rôle in the composition of the fission fungi. The amount of myco-protein has not as yet, however, been ascertained in the case of yeast (Nencki*). If the material remaining after the nction of potash lye is treated with acetic acid and water, a substance is obtained, which, on analysis, gives 44.9 per cent. C, 6.7 per cent. $H, 0.5$ per cent. $N$ (according to later analyses by Nägeli and Löw $41 \cdot 4$ per cent. $\mathrm{C}$, and 6.6 per cent. $\mathrm{H} \dagger$ ), and thus it seems to be fairly pure cellulose. These substances can be transformed, by boiling with sulphuric acid, into fermentescible sugar, and do not dissolve in ammoniacal oxide of copper, being therefore somewhat different from ordinary cellulose.-Stutzer + found in yeast which had been extracted with alcohol and then dried by means of sulphuric acid, 8.648 per cent. of total nitrogen, 5.519 per cent. of proteid nitrogen and 2.257 per cent. of nuclein nitrogen.

The amount of water in fresh yeast which is able to grow is 40 to 80 per cent. If there is a greater or less quantity of water the yeast is no longer intact or capable of multiplication.

The mode in which the relation between non-nitro- Relation begenous cellulose-like constituents and the proteid sub- twcen carbon stances undergoes alteration, as compared with the mould fungi, is worthy of note; in yeast we find 37 per cent. of cellulose, and 47 per cent. of albuminons materials; in the mould fungi there is about 50 per. cent. of cellulose, and 29 per cent. of albuminous materials.-However, it is not quite correct to reckon the quantity of nitrogen found as belonging entirely to albumen; part of it belongs to other substances, such as lencine and tyrosine, which can be obtained in

* Nencki, Beitrage zur Biologie cler Spaltpilze, 1880, S. 48.

† Journ. Sür prakt. Chem., No. 5, vol. 17.

I Stutzcr, Zeitschr. f: physiol. Chemie, vol, vi., p. 572. 
ccrtain quantities from yeast by cxtraction with icewater (with regard to this point see below). In like manner, besides ccllulose, we find gum-like bodies, glyceriue, succinic acid, \&c., which are also carbonaceous and non-nitrogenous materials; usually, howerer, these substances occur in too small quantities to exert any marked influence on the relation between proteid and cellulose.

Yerstashes, Of the several analyses of the ashes of yeast, the following results scem the most trustrorthy (Mitsc.herlich) :-

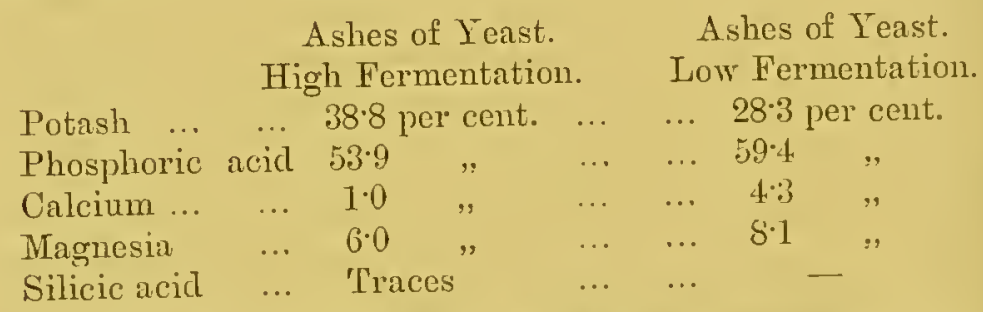

The ashes are thercfore chiefly distinguished from those of the mould fungi by the much larger quantity of phosphoric acid present, this difference corresponding entirely to the larger amount of albumen.

\section{The Nutrient Materials of the Budding Fungi.}

Nutrient materials.

In investigating the mode of nutrition and the nutrient materials of the yeast fungi, it is necessary to note that these terms are not identical with fermentation and fermentescible materials. Fermentation runs its course to a certain extent independently of the nutrition of the yeast; it is not a necessary part of the tissue change of the cells, but only forms an extension and complication of the same, which it is better to disregard for the present in attempting to ascertain the nature of the necessary nutricnt materials, and the mode in which they are used up by the yeast cells. This separation of the tro processes has only been properly carried out in the more recent experinients, while on the other hand former investigators always linked fermentation and the growth of yeast together. The more recent inrestigations made 
by Niigeli, and more especially by Hansen, are also more free from objection becuuse they have paid great attention to the purity of the cultivations of the yeast.*

As regards the nutrient materials required, the yeast Sources of fungi agree very closely with the mould fungi, so that nitrogen. what was mentioned with regard to the latter applies almost entirely to the former. A larger amount of nitrogen is requisite for the yeast fungi in correspondence with the larger quantity which they contain. The most favourable source of nitrogen is the soluble and easily diffusible albuminoid materials, and more especially peptone; but the place of the proteid substances may be taken by ammoniacal salts, substituted ammonia, and the other nitrogenous compounds mentioned in the case of the mould fungi; if, however, ammoniacal salts are the only source of nitrogen the yeast cells appear to undergo degeneration, their substance becoming richer in fat and poorer in nitrogen; and this degeneration occur's still more readily if other conditions of life, such as the presence of free oxygen, are also wanting (Nägeli). Under circumstances otherwise equal peptone is about four times better as a source of nitrogen than, for example, tartrate of ammonia. With regard to the nitrates there is an important difference between the mould fungi and the yeast cells; the nitrates are quite unsuitable for the nutrition of the yeast, and cannot serve as sources of nitrogen.

Carbon has the same relation to yeast fungi as to Necessity of mould fungi ; the best source is sugar, and then mannite, carbon. glycerine, tartaric acid, \&c. In the case of mycoderma viui, alcohol appears to be an almost necessary nutrient material, and can at most be replaced by malic acid (Schultz + ). - With regard to the hydrogen, combined oxygen, and sulphur there are no marked differences

* Comparo Pasteur, Ann. de Chim. et de Phys., (3) vol. 58.-Duclaux, Thises présent. it la fuc. de sc. de Paris, 1865.-Dubrunfaut, Compr. rend., vol. 73. - Schützenborger, Compt. vend, vol. 78.--Mayer, Untersuchungon ihter die alkoholische Galurung, \&c., 1869.-Landwirhsch. I'ersuchsstat. vol. 14.-Mach, Anal. de Oenologie, vol. 4.-Nägeli, Theorie dev Gührung, 1879.-Untcrsuchungen iiber niedere l'ilze, 1882.-Hansen, Meddedelser fin C'arlsberg Laboratoriet: Kopenhagen, 1879-1S84.

$\dagger$ Cit. in Mayer, Gührungschemie. 
between the yeast and mould fungi. Of mineral substances, potash, phosphoric acid, and calcium are indispensable; the presence of a considerable quantity of acid phosphato of potash (about 20 per cent.) has a markedly favourable influence on growth.

Neessity for free oxygen.

The mould fungi and yeast fungi behave very differently as regards oxygen. On the whole the presence of free oxygen exerts a very farourable influence on the growth and multiplication of the yeast-cells; when brought into contact with water containing oxygen or with oxy-hæmoglobin the yeast, as Schützenberger has shown, takes up the oxygen very greedily; and under otherwise similar circumstances the largest quantity of yeast is obtained when a continuous stream of air is passed through the nutrient fluid. Multiplication of the yeast can, however, occur without the access of oxygen, but only when the other nutrient materials are furnished in a suitable form, and when the yeast-cells are able at the same time to cause fermentation. Thus ycast grows actively without the presence of air in a solution of peptone, or in a decoction of yeast containing 1 to 10 per cent. of sugar, and 5 per cent. of phosphoric acid; its growth is less energetic when, instead of peptone, meat extract, urea, or ammoniacal salts are mixed with sugar; and growth does not occur, or only to a very slight extent, when no sugar is present, or when its place is taken by other bodies, such as glycerine or mannite, which do not so readily undergo fermentation. In all cases the multiplication of the yeast in the absence of oxygen goes hand in hand with fermentation of the sugar, and the fermentatire activity seems to replace the action of the free oxygen. This possibility of living without oxygen maturally influences also the occurrence and the habitat of the jeast: thus it can vegetate in the interior of fruits, provided only that these contain fermentescible sugar, and that the other conditions necessary for a development of its fermentative activity are present.

Influenee of

With regard to the concentration and reaction of the the coneontra- material there are also some differences between mould tion of the material. 
and Jerst fungi. The latter do not bear such marked concentration of the nutrient mixture as do the mould fungi ; tho optimum of the amount of water is, however, equally dependent on the nature of the other nutricnt materials. Nutrient materials which are not very suitable require as a rule a great dilution (salts of ammonia must llot be present in more than 1 per cent.), while sugar, for example, may be present in the nutrient mixture up to 35 per cent. without leading to cessation of the growth.

With regard to the reaction, the yeast fungi resemble the mould fungi in that they can bear a fairly markedly of the nutreicut acid reaction without harm; but the upper limit of the excess of acid is lower than in the case of the mould fungi, so that by increasing the acidity of the material (the addition of 5 per cent. of tartaric acid, or 1 pcr cent. of phosphoric acid) the growth of the mould fungi, as compared with that of the yeast fungi, is favoured. Yeast seems to be very sensitive to an exccss of alliali, so that even traces of alkali can hinder growth. (Dumas, Mayer.)

\section{Other Conditions of Life of the Yeast Fungi.}

Some of the other factors which can influence the energy of growth of the fungi have also been investigated in the case of yeast.-Light and electricity are, so far as ex-Action of high periments have gone, without influcnce on the growth pressurc. of the yeast: in like manner, according to expcriments by Certes and Cochin,* a pressure of 300 to 400 atmospheres maintained for several days did not injure yeast; under thesc circumstances, in fact, it was still ablo to break up sugar into alcohol and carbonic acid. Hoppc- Action of Scyler has observed that mechanical movement of the mechanical nutrient solution acts in an unfavourable manner on yeast; but this investigation was limited to the question of the fcrmentative activity of yeast, and besides, the cultivations wcre much contaminated with bacteria. On the other hand, Hansent has demoustrated, in a scries of

* Compt. rend. soc. biol, 1884.

† Medldedelser fia Carlsberg I.ab., vol, i., part 2. 
Influr nee of tempreature.

Influence of fermentation

Conc urrence with other fungi. experiments which are much less open to objection, that the beer yeast multiplies more readily when constantly shaken than when liept at rest. 'The temperature has an important influence on the development of the yeast. The optimum appears to lie between $25^{\circ}$ and $30^{\circ} \mathrm{C}$.; but it depends to a certain extent on the composition of the nutrient solution. Above the optimum the rapidity of growth rapidly diminishes, and ultimately ceases at about $53^{\circ} \mathrm{C}$.; below the optimum the diminution of the growth occurs more slowly, and even slight veretation may take place a little above the freezing point.

The fermentative activity of those yeast fungi which are able to excite fermentation forms a special factor of considerable importance. It is a matter of experience that the development of the yeast cells runs parallel with the energy of the fermentation; further, yeast appears to multiply much more rapidly when sugar is present in the nutrient solution than when materials, such as glycerine, which cannot be broken up by the yeast, are present. On the other hand, the latter substance is quite as good a nutrient material as sugar in the case of other species which cannot excite fermentation; and hence we may draw the conclusion that the fermentative activity itself is able to supply a certain amount of energy to the yeast cells which can be utilised for their vegetative life (Nägeli.)

The simultaneous presence of other fungi, and the concurrent growth with these, plays an important part in the cultivation of the yeast fungi. The bacteria more especially can, as the result of their more rapid multiplication, very readily limit the derelopment of the yeast fungi; here, however, the result is also dependent on the sum total of the conditions of life which may be more favourable for the yeast fungi, and may thus form it substitute for the less energy of their grorth. The concentration and reaction of the nutrient medium is here also of the greatest importance; at times also the temperature, higher degrees of which, for example, may protect the yeast against many mould fungi, sucl as penicillium. Fermentative actirity also seems to exert 
a special influence on the concurrent growtl of the yeast. For example, if a very minute quantity of jeast is introduced into a neutral saccharine nutrient solution, and if no care is taken to exclude bacteria, the latter generally multiply readily, and a very impure cultiration of yeast is obtained, or one in which the bacteria are in greatest numbers. If, however, we increase the amount of yeast introduced up to a certain point-1.7 grammes of dry yeast, or $10 \mathrm{ccm}$. of thick yeast, for every litre of nutrient solution-the yeast alone multiplies, and the bacteria scarcely develop at all. It can be shown that this phenomenon does not depend on the excretion of materials hurtful to the bacteria by the yeast, and we must therefore suppose that it is the fermentative movement which hinder's the multiplication of the bacteria. In accordance with this we have the observation that we are the more likely to obtain a relatively pure cultivation of yeast the quiclier and more completely the fermentation occur's after the organisms are introduced, and that it is thus independent of the number of the fission fungi which have obtained admission at the same time. Thus we have tho explanation why the ordinary beer yeast is usually fairly (but never quite) free from bacteria, and why, when the brewing process is properly carried out, we need not fear disturbance by the development of bacteria (Nügeli).*

4. Conditions of Spore Formation and Spore Germina-Conditions of tion. - In contrast to the higher plants, and also to the spore formmould fungi, the yeast and fission fungi are distinguished by the possession of a very great tendency to utilise the nutrient materials for the continuous production of purely vegetative cells without the formation of any truc fructification. In suitable nutrient media the yeast fungi constantly form new cclls by budding, and the bacteria divide continuously like an enormously developed tree without fruit. It is only when the nutrient conditions become markedly unfavourable, and when one of the most important nutrient substances begins to disappear, that there is an interruption in the ordinary mode of

* Niigoli, Theorie der Gührung, 1879, p. 77. 
multiplication; the fungus then converts the remains of the nutrient material at its disposal into a more durable cell, which can survive after the exhaustion of the nutrient material, and can grow again in new nutrient soil even after a long interval.

In the case of the yeast, the conditions necessary for the formation of spores are furnished when the nutrient substratum is very poor in nutritive materials, more especially in sugar, or is very dilute, while at the same time (as in the case of the mould fungi) free access of the oxygen of the air is permitted, and evaporation is limited. If yeast is spread out on thin slices of boiled carrot, or on moistened plaster, and then liept in a moist chamber, the formation of spores in the cells, as described on page 147, occurs in the course of a few clays; the same result is obtained if a solution of sugar containing yeast is more and more diluted by the daily addition of water. According to Hansen, " spore formation is readily observed on microscopic slides covered with a layer of nutrient jelly, if the temperature is not too high; in likc manner yenst water containing air is also a favourable nutrient medium.-The minimum of temperature at which spore formation has been observed is betreen $+{ }_{2}^{\circ}$ and $3^{\circ} \mathrm{C}$., the maximum at $37 \frac{1}{2}^{\circ} \mathrm{C}$.- The spores can be kept for a long time, and can be dried without losing their power of sprouting.

Germination of spores.

The conditions of the germination of these spores are similar to those mentioned in the case of the spores of the mould fungi. The presence of nutrient materials is not necessary for the commencement of germination; on the other hand, moisture and free oxygen are absolutely essential, so that in respect of the latter there is a marked difference between the regetation and the fructification of yeast. Further, the temperature has an important influence, but this has not as yet been quantitatively determined. $\dagger$

* l. c., rol. ii., part 2.

+ Russ. Annalen der Oenologie, rol. ii,-Butan. Zeil., 1 S73. 


\section{(c) Conclitions of Life of the Fission Fungi.}

\section{Chenical Composition of the Fission Fungi.}

In order to isolate the fission fungi from the nutrient Chemical comfluid, it is well to follow Nencki's* method, by render- pesition of the ing the fluid acid by the addition of 2 to 3 per cent. of free liydrochloric acid, and then boiling it. The bacterial masses are thus coagulated, and may be easily obtained by filtration; we must, however, avoid nutrient solutions, from which albumen might be precipitated by this method. In a 2 per cent. solution of gelatine (and also in a solution of mucate of ammonia) Nencki found the following composition, in the case of the bacteria, corresponding to the different stages of their development, beginning with the formation of a rery gelatinous zooglea :-

\begin{tabular}{|c|c|c|c|}
\hline \multirow[t]{2}{*}{ Water. } & $\begin{array}{l}\text { Pure zooglea } \\
\text { mass, } \\
84: 81 \text { per cent. }\end{array}$ & $\begin{array}{l}\text { Zooglea mass } \\
\text { with bacteria, } \\
84: 26 \text { per cent. }\end{array}$ & $\begin{array}{l}\text { Adultbacteria } \\
83.42 \text { per cent. }\end{array}$ \\
\hline & \multicolumn{2}{|c|}{ In the substance free from water. } & \\
\hline $\begin{array}{l}\text { Albumen ...... } \\
\text { Fat ............ } \\
\text { Ashes ......... } \\
\text { Undetermined }\end{array}$ & $\begin{array}{c}85 \cdot 76 \text { per cent. } \\
7.89 \quad \text { ", } \\
4.20 \quad ", \\
2 \cdot 15 \quad \text { ", }\end{array}$ & $\begin{array}{c}87.46 \text { per cent. } \\
6.41 \quad, \\
3.04 \quad, \\
3.09 \quad,\end{array}$ & $\begin{array}{c}84.20 \text { per cent. } \\
6.04 \quad, \\
4.72 \quad, \\
5.04 \quad,\end{array}$ \\
\hline
\end{tabular}

The albuminous material is to a great extent formed of a body which differs from other proteid substances in some of its reactions-for example, it is not precipitated by alcohol-and especially in its elementary contposition; it has been called by Nencki myco-protein. This substance contains 52.32 per cent. C., 7.55 per Tonciis cent. H., 14.75 per cent. N.; no sulphur, and no phos- myco-protein. plorus. On heating it with caustic potash, the following substances were obtained: plenol, skatol, indol, large quantities of fatty acids especially valerianic acid, and leucine. $\dagger$

* Nencki, Beiträge zur Biologie der Spaltpitze, 1850.

+ Noncki's Journ.fïr praht. Chem., N:F., vol. 23. 
In the case of some pathogenic organisms, numbers have been obtained which differ considerably from the above. Spores of the antlurax bacilli cultivated in nutrient gelatine in large ressels, containing 1 to 2 litres, and collected after three weels growth, showed, according to Nägeli, no myco-protein, but a peculiar albuminoid body, which he has called anthrax-protein, readily soluble in alkalies, but quite insoluble in water, acetic acid, and dilute mineral acids; it contains no sulphur.**

Brieger t has obtained the following results with regard to Friedlaender's pneumonia bacilli, which he cultivated on nutrient gelatine. He found 84.2 per cent. of water; 1.74 per cent. of fat in the dry substance; in the dry substance free from fat $30 \cdot 13$ per cent. of ashes; and in the dry substance free from fat and ashes 9.75 per cent. of nitrogen.-The organic substances gave on the whole the reactions characteristic of protein, but they were not identical with Nencli's myco-protein. -Vandevelde $f$ found on analysis of bacillus subtilis no cellulose, but nuclein.

Relation between nitregen and carlocn.

According to these results the relation between the albuminoid substances and the material resembling cellulose, which in the case of the yeast fungi was in favour of the former, is still more altered in the sume direction in the case of the fission fungi, so that the non-nitrogenous materials pass completely into the background, and albuminoid substances form almost the whole substance of the fission fungi. There are, it is true, anulyses of other fungi by Nägeli and Löw, which differ markedly in part from the above results. A growth of micrococei Contradictory in part fultes.
analyses. nitrogen and 6.94 per cent. of ashes; on the other hand, the vinegar plant, which consists of a tough jelly, in which short rods are cmbedded, yielded $98 \cdot 3$ per cent. water, and in the dry substance only 1.82 per cent. N. and 3.37 per cent. ashes, so that in this case also

* Chem. ber., rol. xvii., p. 2605.

† Zeitschr.f. physiol. Chem., vicl. ix.

†lbid., rol. viii. 
the chief body present must be the non-nitrogenous cellulose material.

Durin and Scheibler* also observed that the membrane of Leuconostoc mesenterioides chicfly consisted of a livclrocarbon closely allied to cellulose. Further analyses must show us in what way we are to explain these marked analytical differences, and what their value is.

The ashes of the fission fungi have not as yet been Ashes. accurately analysed. Brieger found in the ashes of the pneumonia bacilli phosphate of lime, phosphate of magnesia, sulphate of sodium, and chloride of sodium. As a whole, the ashes of the fission fungi have probably an analogous composition to those of the yeast.

In some species of fission fungi chemical substances are always, or at times, present which do not belong to the ordinary constituents of the bodies of these organisms. For example, substances resembling gran- Rarer

ulose occur in bacillus butyricus and in Vibrio rugula constitnents. before the formation of spores, also in bacillus Pastcur. ianus (Hansen) and in Leptothrix buccalis, and these may be demonstrated by their blue colouration by iodine. To this class of substances belongs the ruguline sulphur. sulphur found in some species of beggiatoa; further, some specific dyes, the majority of which, however, do not appear to be deposited in the wall or cell contents of the organisms.

\section{The Nutrient Materials of the Fission Fungi.}

As a whole, the nutrient materials and conditions of Nutrient life of the fission fungi resemble those of the mould materials. lungi; the different species, however, differ in their requirements so much, that much more detailed investigations are necessary. Wc must therefore await further researches before wa can write a complete account of this subject.

As a rule thesc fungi obtain nitrogen best from diffu- Sourecs of

* Quoted from de Bary. nitrogen. 
sible albuminoid materials.* Ammoniacal salts are not so suitable, but are better borne than in the case of the yeast fungi. The remaining nitrogenous compounds appear to have the same relative value as in the case of the monld fungi ; according to Nägeli, the nitrogen can also be obtrined from nitrates, and in the experiments in question it was possible to follow the gradual reduction of the nitric acid to nitrous acid, and finally to ammonia. Reduction of This reduction of nitrates by bacteria has been recently nitrates.

Sources of curbon. observed by Gayon and. Dupetit, Déhérain, Maquenne, and Springer. Anaërobic organisms similar to or identical with bacillus butyricus when they set up a fermentation, combined with the development of hydrogen, seem to cause reduction of nitrates with formation of oxide of nitrogen. This was also the case with certain aërobes, and to a less extent with the bacilli of chicken cholera, anthrax, \&c.t In all these experiments, however, it is probable that the nitrates did not suffice to provide the necessary oxygen for the fission fungi, but that reduction was a secondary phenomenon, caused by other products of the tissue change or fermentation, and only accompanying the true tissue change of the bacteria.

The supply of carbon is obtained not only from sugar but also from bodies similar to it, from glycerine, and especially from the various salts of fatty acids, such as the allialine salts of tartaric acid, citric acid, malic acid, mucic acid, lactic acid, acetic acid, \&c.; even those compounds which act, when markedly concentrated, in a decidedly poisonous manner on the bacteria can be utilised in a very dilute state as sources of carbon supply, for example, carbolic acid, salicylic acid ; further, aethylic alcohol, which forms the most favourable nutrient medium for the vinegar fungus, and which can be present in the nutrient solution up to 10 per cent. It is remarkable that, according to Pasteur's obserrations, it is ouly

* Sec more especially Nïgeli, l.c.-Cohn, Beitrïge, rol. i., Heft 2.Bucholtz, Arch.f. Exper. Pach., B. 7, S. 81.-Mayer u. Külicrim, Landw. Versuchssint., vol. 16 (Essigpilz).-v. Jaeksch (Harnstoffpilz), Zeitschr. f. physiol. Chemie, vol. 5.

+ Grayon and Dupetit, rompt. Rend., vol. 95.-Doherain and Maquenne, ibid., and vol. 97.-Bull soc. chim, 2, 35.-Springer, Chem., Ber., vol. 16. 
that form of tartaric acid which turns the polarisation to the right which can be taken up by bacteria.

In the case of some bacteria, the most favourable nutrient conditions liave been more accurately determined; for example, by von Jacksch* for micrococcus urea, and by Hueppe+ for the lactic acid bacilli. Micro- Nutrient coccus ureæ can, for example, obtain the necessary materials nitrogen and carbon from nutrient solutions containing micrococeus succinate, lactate, malate, tartrate, or citrate of ammonia, from glycocoll, leucine, asparagine, salts of asparagine, crentine, benzoate of ammonia, hippurates, and peptone. On the other hand, the following were useless as sources of nitrogen and carbon: formate, acetate, butyrate, oxalate, and salicylate of ammonia, and acetamide.

In the case of bacterium lactis, carbon is best obtained For bacterium from milk sugar, cane sugar, mannite, and dextran; the best source of nitrogen was peptone, or among the salts, tartrate of ammonia. Nitrates were quite unsuitable as sources of nitrogen. The most favourable proportion of the nutrient salts was $0.2-0.5$ per cent. of acid phosphate of potash, +0.05 to 0.1 per cent. of sulphate of magnesium $+0.015-0.025$ per cent. of chloride of calcium; this mixture could be replaced by 1. per cent. of extract of meat.

These numbers are, however, only applicable to these Difference as special cases. The more accurately the various species regards the of bacteria have been studied during the last few years, quirements of the more have differences in the different the more have differences in the nutrient requirements species of of the different species been observed. Some require bacteria. large quantities of certain albuminoid substances, and only permit a variation in the composition of the nutrient material within very narrow limits; others permit a greater variation in the nutrient materials, which, however, must be fairly concenirated and composed of complex molecules. Others, finally, prefer very dilute and simple solutions in which one can scarcely recognise anything of nutrient value. Among the bacteria contrast which are most sensitive in this respect are chiefly the betwoon the

* Zeitschr.f. physiol. Chem., vol. 5. bacteria nuld

† Mitt. a. d. Kris. Ges., vol. ii. those which multiply in water. 
Formation of ferments by bacteria.

Necessity for frce oxygen.

Pasteur's livision into wërobes and anä̈robes.

pathogenic forms, which can only grow on certain hosts, and which refuse to live on any other livingr or dead substratum (such as the spirilla of relapsing fever, or the bacilli of leprosy), or which, at any rate, require blood serum, or mixtures containing soluble albumen, peptone, and salts. The greatest contrast to these bacteria is formed by those which have been described by Bolton* (bacillus erythrosporus, microcaccus aquatilis, \&c.), which find sufficient nutrient material to enable them to grow in enormous numbers even in pure distilled water. As in all their other vital functions, so here, the bacteria present conditions which render it impossible to treat them in a schematic manner.

The number of suitable nutrient materials is increased in the case of many species of bacteria by the fact that they produce ferments which can transform insoluble substances into soluble and diffusible ones. Coagulated albumen, solidified gelatine, starch, and di-saccharates can be transformed by means of peptonising, diastatic, and inverting ferments into soluble and assimilable nutrient materials. As regards this production of ferment also the various species of bacteria show great differences both qualitatively and quantitatively.

The bacteria also behave very differently with regard to oxygen. Pasteur was the first to observe that there were bacteria which did not require free oxygen for their life and multiplication, but, on the contrary, could carry on their vital functions in the absence of oxrgen, and, indeed, the presence of that gas might interfere with their multiplication and their vital phenomena. Pasteur gare effect to this distinction by his division of the bacteria into "aërobes" and "anaërobes." The surprising fact that life could occur without oxygen was also soon confirmed by other observers, such as Nencli, Prazmowski, Rosenbach, \&c., and though Gunning asserted that in none of these experiments was the oxygen sufficiently removed, and thus no complete anaërobiosis existed, nevertheless these objections cannot hold ground against the recent experiments by Nencki and Lachewicz;

* Gütt. hyg. Institut. Mitgetheilt in Keitschr.f. IIygiene, rol, i. 
Nencli convinced himself that in the cultivation apparatus ferrocyanide of iron and reduced hæmoglobin remained unaltered, and that thus we had to do with complete absence of oxygen so far as this can be confirmed by chemical means.

Nïgeli has drawn especial attention to the great im- Replacement portance of the fermentative activity in reference to the by the oxygen need for oxygen on the part of the fission fungi; if fermentative fermentative action is going on the access of oxygen becomes unnecessary; if the bacteria in question are unable to excite fermentation, or if it so happens that they live under conditions in which no active fermentation can occur, free oxygen becomes absolutely essential for their development.

Engelmann has further shown that the motility of the bacteria is influenced to a ver'y great degree by the oxygen on tension of oxygen in the nutrient medium. Spirilla are in this respect much more sensitive than any other" species of motile bacilli; the latter assemble at the margin of any air bubble which may be present within a drop of nutrient fluid; spirilla, on the other hand, remain at some distance from the margin of the air bubble, and only approach it when the amount of oxygen in the nutrient solution has become diminished. In this species of bacteria too great a quantity of oxygen has also a similar effect in causing the cessation of movement. The lower limit of necessary oxygen was very low in this species of spirilla; if they were placed, along with micro-organisms containing chlorophyll, in a medium which was free from oxygen but illuminated with white, red, or yellow light, the spirilla at once collected at those parts where traces of oxygen were developed by the chlorophyllous cells.

More recent investigations by Liborius* have added to onr knowledge as regards the need for oxygen by the bucteria, and have more especially showl that the anaërobic organisms can live and multiply without exercising any simultaneous fermentative activity. According to Liborius' investigations we may divide the

* Gütt. lygg. Inst. See Zeilschr. S. Irygiene, vol. i. 
Obligatory anaërobes.

Facultative anaërobes. bacteria into three groups, which differ in an important manner as regards their necessity for oxygen. In the first place, we have a group of what may be termed "obligatory anaërobes," which only grow when the oxygen is removed as completely as possible from the nutrient medium, at any rate when it can be no longer demonstrated by the ordinary chemical means. To this group belong, for example, the bacilli of malignant œdema, bacillus butyricus, bacillus muscoïdes, bacillus polypiformis, \&c. Some of these organisms have the property of exciting fermentation in certain fermentescible materials, and then they are able to multiply in large numbers in correspondence with the intensity of the fermentation. In the case of other species no fermentative activity has as yet been made out. The fermentations set up by these anaërobic organisms can he arrested by the admission of oxygen, just as is the case with the growth of the same organisms in non-fermentescible substrata.

A second group is formed by what we may term the "facultative anaërobes." These bacteria grow best and most quickly when the entrance of air is permitted, but they are also capable of developing slowly when air is excluded. The degree to which the growth is influenced by the exclusion of oxygen varies very much in the different species. On the whole an artificial increase in the tension of the oxygen is injurious to the bacteria belonging to this group; but here also the degree of sensitiveness varies in the different species. Among the very numerous organisms which belong to this group we may mention more especially the various pathogenic organisms, for example, staphylococcus, streptococcus, bacillus septicus cunic., bacillus sept. crassus, bacillus antliracis, bacillus typhi. abdom., bacillus pneumonix, spirillum choleræ asiatice. In this group also the majority of the bacterin do not require to exercise fermentative activity in order to live without oxygen. In many of them their behaviour, when fermentescible materials are absent, has not as yet been tested; nerertheless simultaneous fermentative activity farours the 
anaërobric growth of these bacteria to a marked degree. In the case of some organisms, for example, bacillus lactis aërogenes (Escherich), it las been demonstrated that they can only exist without air when fermentescible material is present, and fermentation is going on.The fermentations set up by these organisms are apparently not injuriously affected by the access of oxygen, but on the contrary are favoured.

In contrast to these groups we have a third, which is obligatory composer of "obligatory aërobes"; these organisms can- aërobcs. not grow when air is excluded, even though they could otherwise excite fermentation. Their growth is interfered with by any marked diminution in the amount of air, and under these circumstances one or other of their functions may cease (for example, the production of colouring materials, of ferments, \&c.); on the other hand, their life and growth is much favoured by artificial increase in the tension of the oxygen. To this group belong, for example, bacillus subtilis, bacillus aërophilus, \&c. Nevertheless, within this group there are marked diflerences as regards the quantity of oxygen necessary, so that we can only lay down a general law, viz., that each of these species of bacteria requires a definite amount of oxygen. The fermentative action of the bacteria belonging to the group of obligatory aërobes is without exception favoured by the access of air ; for example, the lactic, and more especially the acetic, fermentation. According to Hoppe-Seyler," a continued and marked impregnation of the nutrient medium with air has a favourable action on the development of many putrefactive bacteria, as well as on the course of the putrefactive fermentations set up by them, and hence we may conclude that some of the bacteria which can excite fermentation belong to the group of aërobes, while, on the other hand, many obligatory aërobes also take' part in this process.

We can say very little which is of general appli- Concentration cability as regards the most favourable proportions of of the nntricnt the individual nutrient materials, on account of the medium.

* Zeitschr. f: physiol. Chem., vol. 8, n. 214. 
very great differences in the requirements of the different species of bacteria. On the whole, the amount of water in the nutrient material must be very great, and the concentration slight. Fermentescible substances can be protected against the invasion of bacteria by the removal of a relatively small quantity of water, while they still remain a favourable soil for the growth of the yeast fungi, and more especially of the mould fungi. Very little has been ascertained as to the limits of concentration, for this must vary according to the nature of the nutrient materials; quite as little is known as regards the optimum of the amount of water. That the latter can as a rule vary within wide limits is evident from the fact that bacteria can be cultivated equally well on semi-solid nutrient soils containing about 80 per cent. of water, in concentrated fluids containing 5 to 10 per cent. of solid constituents, and in very dilute solutions containing scarcely more than traces of nutrient substances.

Reretion.

Excess of acid or alkali may be either injurious or favourable to the development of the bacteria; the first, however, interferes most readily with the growth. In this respect there is an important difference between many of the bacteria and the mould and yeast fungi; and hence in the acid reaction of the nutrient medium we have an excellent means of protecting the cultivations of the latter organisms against the entrance of numerous species of bacteria. Many bacteria, for example, bacillus subtilis, anthrax bacilli, \&c., are very sensitive to slight excess of acid; but on the other hand there are bacteria, such as bacillus butyricus or the acetic bacterium, which can bear a very marked acid reaction without injury; indeed, many only grow when there is a certain excess of acid in the nutrient medinm (for example the bacillus of blue milk, and the bacterium of acetic acid which only grows when at least 2 per cent. of acetic acid is present). Hence an excess of alkali is hurtful to these particular bacilli, while as a rule it has by no means such an injurious effect on bacteria as the free acids; indeed, some organisms, for example tlie 
micrococcus urew, can bear an extremely high degree of alkalinity. Some bacteria show such indifference with regard to the reaction of the nutrient medium that they may commence their development on a markedly acid soil, then convert the reaction by the products of their growth into an alkaline one, and continue to grow in the presence of a marked excess of alkali.

\section{Other Vital Conditions of the Bacteria.}

According to the experiments which have as yet Influence of been made light does not appear to be one of the light. general conditions of life of the bacteria; the observation made by Engelmann that in the case of one species of bacterium (brcterium photometricum) the swarming: movements were dependent on the light does not with certainty refer to a bacterium but more probably to a fission alga.* With regard to the injurious action of sunlight, see Part 5. In like manner elec- Electricity. tricity, so far as it comes into play under normal conditions, is without any influence; strong currents, however, interfere with the development of the cultivations.t Alterations in the pressure are borne by Highpressure. many bacteria in a remarliable manner, as has been shown, for example, in the case of the bacillus butyricus ; Certes has also observed that putrefactive processes go on even under a pressure of 350 to 500 atmospheres, and that anthrax bacilli retrin their virulence after exposure for 24 hours to 600 atmospheres.

To a certain extent rest and the absence of mechanical Mechanical movement appear to be of some importance for the movement. fission fungi, although the experiments made in this respect have not given entirely uniform results. A continuous, gentle, flowing movement of the nutrient media does not appear to hinder the development of the fission fungif; on the other hand, it was observed that continuous and marked shaking of the fluid, such as is set

* Pflüger's Arch., vol. 26, p. 537.-Botan. Zeilg., 1882.

† Cohn and Mendelssoln, Cohn's Beitrïge, vol. iii., part 1.

\# Hoppe-Seyler, Festschrift u. s. u. "Ueber die Einwirkung dos Saucrstoft's auf Gährungen," 1881 . 
Influence of temperature.

up by a speeial motor,* or by sounds of suffieient intensity eondueted through the nutrient solution, $t$ have a distinct disturbing influence on development. More reeently, however, somewhat different results have been obtained in a fresh series of experiments. $f$

Further, a certain medium temperature is a necessary eondition for the development of the baeteria. Nevertheless, the optimum of temperature, as well as the upper and lower limits, are quite different in different species of bacteria, and are also dependent on the other conditions of life, more espeeially on the composition of the nutrient material. According to Eidam's experiments, with regard to the development of bacterium termo in Cohn's nutrient solution, growth begins at $+5 \frac{1}{2}{ }^{\circ} \mathrm{C}$., increasing at first slowly as the temperature rises, and then quickly from $10^{\circ} \mathrm{C}$. upwards, attains the optimum between $30^{\circ}$ and $35^{\circ}$ C., and rery rapidly diminishes, and ultimately entirely ceases at $40^{\circ}$ C. $\$$ In the case of the reetic brcterium the optimum lies between $20^{\circ}$ and $30^{\circ} \mathrm{C}$; ; below $10^{\circ} \mathrm{C}$. growth goes on extremely slowly, and it diminishes rapidly above $35^{\circ} \mathrm{C}$, and ultimately ceases a few degrees higher.\| The tubercle bacillus grows, on the other hand, only between $30^{\circ}$ and $41^{\circ} \mathrm{C}$., best at $37^{\circ}$ to $38^{\circ} \mathrm{C}$. In the case of the baeillus subtilis Brefeld found that the growth was very slow at $6^{\circ} \mathrm{C}$.; at $12.5^{\circ} \mathrm{C}$. 4 to 5 hours elapsed between each new sub-division of the rods; at $25^{\circ} \mathrm{C}$, $\frac{3}{4}$-hour; at $30^{\circ} \mathrm{C}$., $\frac{1}{2}$-hour. From these examples it is suffieiently evident that the rarious species of bacteria rary markedly with regard to their relation to temperature, and it can only be said with regard to the relation of temperature to the mould and yeast fungi, that as a rule the most farourable temperature is less than in the ease of the bacteria, in which the optimum lies nearer the temperature of the human body.

\footnotetext{
* Horvath, Pflïger's Arch.f. Physiol., vol. 17.

† Reinke, Ebcnda, vol. 23.

† Tumas, Petersunger med. Woch., 1881.

§idam, Cohn's Beiträge, i., 3, p. 209.

I| Maycr, Gülurungschemie, p. 178.
} 
The fermentative activity in all probability plays the Influence of same part with regard to the life of the bacteria as it the formentadoes in the case of the yeast fungi. In the case of the bacteria which can set up fermentation, the fermentative activity appears to farour the growth of the organisms as soon as a certain intensity of the fermentative action las been attrined, while the development of other bacteria which may be present at the same time is hindered. Hence a certain intensity of fermentative activity exerts a marked influence on the concurrent growth of various species of bacteria, and on the production of pure cultivations.

As a rule, in concurrent growth with mould and yeast Coneurrent fungi, the bacteria have an advantage in their ex-growth with tremely rapid multiplication, and in the very energetic manner in which they use up the nutrient materials. It is only when some of the conditions as regards the nutrient substratum are selected in such a manner that they exert an unfavourable influence on the development of the bacteria, while they at the same time permit the unhindered growth of the other classes of fungi, that it is possible for the latter to take possession of the nutrient medium and to exclude the bacteria. As lias been mentioned, the concentration and reaction of the wutrient material are the clief means by which the growth of the yenst and mould fungi, as compared with that of the bacteria, may be favoured.-Among the bacteria themselves rarious factors, more especially reaction, temperature, relalive amount of the individual nutrient materials, and more especially of the nitrogenous compounds, the tension of the oxygen, \&c., are the chief means by which one or other species may succeed in growing in excess, and ultimately in almost entirely gaining the upper hand.

\section{Conditions of Spore Formation and Spore Germination.}

To a still higher degree than the yeast fungi the Spore bacteria appear able to utilise suitable nutrient materials formation. 
for the simple multiplication of cells. What the conditions are which must be present in order to set up the phenomena of spore formation, a process on the whole of rare occurrence, have not as yet been fully worked out. From analogy we may suppose that the exhaustion or vitiation of the nutrient medium forms the necessary condition for the commencement of this act; and as a matter of fact this seems to be the case in many species. Apparent exceptions have as yet been observed in bacillus butyricus, bacillus subtilis, anthrax bacilli, \&c. ; neтertheless, in the spore-bearing cultivations of these bacteria it is possible that one or other of the nutrient materials has become diminished to such an extent as to suffice for the introcluction of the process of spore formation, or the nutrient substrata may have become sufficiently saturated with the noxious products of tissue change of the bacteria to render them imperfect as nutrient media. It is possible that further observations will enable us to formulate the conditions of spore formation in the bacteria in a similar manner to those of the yeast fungi; in that case, however, the marked differences between the individual species of bacteria must of course be taken into account. The oxygen exerts a peculiar effect on the spore formation of the bacteria. While in the case of the mould and yeast fungi oxygen must have free access, the bacteria are divided in this respect into two groups. The majority also appear to require oxygen for the formation of spores, and Prazmowsli pointed out that it is characteristic of these forms that they are non-motile during the stage of fructification. The true anaërobes, however-this has been clemonstrated with certainty as regards bacillus butyricus-can only fructify in the absence of oxygen, and continue to more cluring the stage of fructification.

The temperature exerts a marked influence on the process. Koch* has shown, in the case of anthrax bacilli, that a temperature of at least $16^{\circ} \mathrm{C}$. is necessary for the formation of spores; and under these circumstances limited formation of spores did not occur till after seren

* Mittheilungen a. d, Kais. Ges. Amt., p. 65. 
days. At $21^{\circ} \mathrm{C}$. spores had formed after 72 hours, at $25^{\circ} \mathrm{C}$. after 35 to 40 hours, and betrreen $30^{\circ}$ and $40^{\circ} \mathrm{C}$. after about 24 hours; the best and strongest cultivations were obtained between $20^{\circ}$ and $25^{\circ} \mathrm{C}$. In the case of bacillus subtilis spore formation did not occur below $6^{\circ} \mathrm{C}$, at $18.75^{\circ} \mathrm{C}$. it required two days, at $22.5^{\circ} \mathrm{C}$. one day, and at $30^{\circ}$ C. 12 hours.

As regards the germination of spores, and the neces- Germination sar'y conditions for that act, we have as yet no detailed of spores. observations. A certain amount of water and a fairly high temperature, differing, however, according to the species, must be reckoned as absolutely essential conditions. In the case of bacillus subtilis, the optimum of the temperature for germination lies between $30^{\circ}$ and $35^{\circ} \mathrm{C}$, and in the case of anthrax bacilli at about $35^{\circ} \mathrm{C}$.

As regards oxygen it has been made out in the case of the spores of some bacteria, for example of bacillus butyricus, that it may actually hinder the occurrence of germination; while, as a rule, the entrance of oxygen is just as necessary for the sprouting of the great majority of the spores of bacteria as it is for those of yeast and mould fungi, and as it is for the other functions of the same bacteria. 


\section{PART IV.}

VITAL ACTIONS OF THE LOWER FUNGI.

The vital actions.

Proposed plan of treating the subject.
Having discussed the conditions necessary for the life of the fungi with special reference to the nutrient materials which must always be present in their surroundings, it is the object of this part of the work to show how the nutrient materials are taken up, the transformations which they undergo in the body of the organisms, in what manner growth takes place, and how the energy, which is necessary in order to enable the fungi to carry out their other functions, is obtained from transformation of the material. It is evident that this subject, which has also to do with, and to explain as far as possible, the special activity of the fungi in exciting fermentation and disease, forms one of the most important chapters on the subject of the fungi.

The tissue change and development of energy of the mould, yeast, and fission fungi agree in their essential points to such an extent that it has not appeared necessary to treat of the three classes separately in this chapter. The behaviour of the fission fungi, as being the most important group from a hygienic point of view, is taken as a groundwork, and it is only at certain places that attention is specially directed to differences in the behaviour of the other chief groups.

In the first place, we shall make a short general review of the tissue change and development of energy of the lower fungi, closely following what is known as to the biology of the higher plants. We must then discuss the individual phases of the vital activity of the fungi, the assimilation of nutrient materials, and the changes which they undergo in the body, the derelopment of 
energy, and the products of tissue change and the excretr. Among the latter the isolated ferments and the ptomaines require a more detailed consideration. Closely allied to these we have those two peculiar, and for hygienic purposes important, phases of the vital activity of the fungi, viz., the fermentative activity and the development of disease.

\section{Review of the Tissue Change and Development of Energy in the Lower Fungi.}

For the development of those movements and alterations of material particles, which make up the life of the regetable cell, a certain amount of energy must in the first place be set free; without this these movements, and therewith the life of the plant, would cease. A small fraction of the necessary energy is obtained by osmosis; by far the greatest portion is, however, supplied to the plant by the splitting up of complex chemical compounds, and by regrouping of the atoms in more stable compounds, in other words by similar transformations to those which occur in the animal body, and which then give rise to the energy which is necessary for the various functions of the animal economy. The vital processes in vegetables Tissue elange and animals differ only in the fact that the compounds and developto be broken up are taken up by the animal bodies in in the higher an unaltered condition, while in the case of regetables plants. they must first be built up from more simple materials by means of the chlorophyll apparatus ; in the lowest forms of plants, viz., in the fungi, however, this preparative apparatus is absent, and the materials are taken up in the form of relatively complex molecules. What, however, is absolutely necessary, and common to the life of the cells of animals, vegetables, and fungi, is the deconposition of complex organic compounds accompanied with the liberation of energy.

These decompositions are carried out by means of the Decomposi. living protoplasm. The latter can apparently, like a tions in the 
ferment, gradually split up large quantities of suitable complex compounds. We do not yet know accurately the nature of the chemical bodies directly concerned in this action of the protoplasm, nor in what way decomposition takes place; it is probable that the compounds are nearly allied to the proteid materials, but are more complex. As products of decomposition we constantly observe carbonic acid, and also some other materials which will be mentioned below. We may, however, conclude from the amount of heat which becomes free at the same time, although it is trivinl, that the transformation chiefly takes place in such a way that a mole complete union of the atoms and greater saturation of the affinities, with consequent liberation of energy, results.

Intra-molecu. lar respiration.

Decomposition when oxygen is admitted.

This whole process, which is evidently the primary and true cause of life, is usually spoken of as "intramolecular respiration." For this process the access of oxygen is unnecessary, on the contrary it is characteristic of it that all vegetable cells can continue to live and breathe for a time without oxygen, and split up carbonic acid and produce heat. If substances capable of undergoing decomposition are still present in the living protoplasm, their decomposition is sufficient to furnish the necessary energy for the other processes which take place in the protoplasm, and it is only after a considerable time that there is such a deficiency of energy as to lead to the cessation of morement and life. e.

Although, therefore, the intra-molecular respiration is the chief and primary cause of development of energy in the plant, the energy so obtained does not suffice permanently to supply the whole amount required. This is usually only obtained when oxygen has free access, and when it takes part in the respiratory process. The compounds broken up in the protoplasm furnish, in addition to carbonic acid, a series of other products which readily enter into combination with oxygen. Thus extensive oxidations occur, and accordingly a more marked development of vital energy which completely 
and permanently suffices for the vital processes. The umount of energy is, however, regulated much less by the amount of oxygen present than by those processes of decomposition in the protoplasm by the intramolecular respiration, which sets up and governs the respiration by means of free oxygen.

The whole respiratory process, whether occurring Destructive with or without oxyoen, is evidently of a destructive and assimila character, and it is absolutely necessary that a constant change. supply of new material should repair the deficiencies which occur as the result of the decomposing activity of the protoplasm and the oxidising action of the oxygen, processes which furnish for the most part gaseous and combustible products. As, however, those materials which can be broken up in the protoplasm never exist nor are taken up as nutrient materials, it is evident that there must be a special process of assimilation, which consists in the absorption of the nutrient materials present, and their transformation into compounds suitable for decomposition, and which thus stands in marked contrast to the destructive respiratory process. As a rule the part played by the assimilatory process is in excess of the destruction, and thus leads to the deposit of new protoplasm, and the growth and multiplication of the cells. This is the portion of the tissue change which usually alone strikes the eye, and leads us very readily to overlook the firct that, apart from the new formed material, large quantities of the nutrient substances taken up undergo decomposition in the protoplasm, and are burned up by the oxygen.

The tissue change of the lower fungi must evidently go on in an exactly analogous manner to that of the higher plants. Here also we have a continuous destruction of organic materials, usually in the presence of oxygen, and in that case presenting the claracter of a complete combustion. Here also an assimilation of the new nutrient substances must provide the destructible material, and at the same time must supply the requirements as regards growth and multiplication, and it is a 
totally secondary matter that the assimilatory process in this case ruus its course without the aid of a chlorophyll apparatus, and that thus certain simple materials, such as carbonic acid, cannot be utilised as nutrient Tissue change materials.- As in the case of the higher plants, so also in of the lower the lower fungi, a certain amount of energy is set free by
fnngi.

Differences as these tissue changes, and this energy is employed for the functions of these minute organisms, for their processes of growth and movement, for the changes in their tissue, and for the molecular processes.

It is true that by the recognition of these essential agreements between the tissue change and the development of energy in the higher and lower plants the whole of our insight into the biological processes of the lower fungi are pretty nearly exhausted. More especially we can scarcely at the present time form any quantitative idea as to the relation between the destructive and the assimilatory tissue change, how far the assimilation and the formation of new protoplasm is as a rule in excess, or what amount of the nutrient material is taken up to serve for the destructive tissue change. Hence in most matter's provisional hypotheses as to the tissue change and development of energy in the lower fungi must take the place of facts and certain results.

compared with the higher plants in respect to the necessity for oxygen.

There is only one difference between the bacteria and the higher plants to which we need draw attention. While the activity of the protoplasm, the intra-molecular respiration, and the respiration by means of oxygen, with their development of energy and the assimilation of very various linds of nutrient materials, are common not only to the higher plants but also to the fungi, there is a marked difference with regard to their relation to oxygens. As has been mentioned, the higher plants cannot be deprived of oxygen for lengthy periods without injury, because it is only by means of the process of oxidation that a sufficient amount of energy is produced; many of the lower plants, however, can live and multiply for a long time without the presence of oxygen. In this case the small amount of energy which is furnished by the intramolecular respiration eitler suftices for the whole of the 
vital functions, and this is the more intelligible the source of more correct are our conclusions as to the absolute energy in the relations of wcight and energy in these minute beings; anaërobes. or these organisms can take oxygen from certain nutrient materials and employ it for the oxidation of other complex substances. In the majority of cases the intramolecular respiration does not permanently suffice to supply the necessary amount of energy for the bacteria, on the contrary they can only bear the loss of oxygen if a suitable substitute is present in its place. This sub-Substitution stitute is furnished by the fermentative process, in which of oxygen by a large amount of material present in the nutrient medium tive proeess. is broken up superficially, but nevertheless in such a manner that a quantity of energy is set free which is about equal to that obtained by the process of oxidation. Thus fermentation may take the place of the oxygen, and the respiration by means of oxygen and the fermentative activity may be looked on as of equal significance as regards their relation to the vital processes in the fungi.

The little that is known as regards this peculiar mode of tissue change and development of energy in the lower fungi, may be put together in the following imperfect description, in which the outlines of the picture which will ultimately be constructed as the result of future investigations are probably scarcely recognisable.

\section{The Absorption and Assimilation of the Nutrient Materials by the Lower Fungi.}

As the penctration of the nutrient materials must take place in the case of the fungi, just as in that of every vegetable cell, by mcans of diosmose through the cell Absorption of the nutrient wall and the plasma, it is evident that only those substances can be taken up which are diffusible and present in a watery solution; where the fungi apparently feed on solid matcrials, these substances are previously dissolved by the secretions of the organisms. In these preparatory processes the chemical ferments produced by the fungi take part; for example, those which peptonise solid 
albumen, or which hydrate the saccharine material and make them available for the use of the fungi, or which dissolve cellulose, and thus enable those organisms which live as parasites on vegetables to obtain an entrance.

The chemical nature of the materials taken up may, as has been above mentioned, be very various. That a transformation of these materials, a process of assimilation, must occur on their entrance into the cells of the fungi is probable, because it is not at all likely that these different compounds are of equal value as regards the different operations which occur within the cell. It is true that the assimilation of the carbon is not so marked as in the case of the chlorophyllons plants, anã moré especially that carbonic acid cannot be utilised. Nevertheless methylamine, acetic acid, alcohol, benzoic acid, tartaric acid, leucine, \&c., can without doubt be converted into more complex substances if they are offered as the only source of carbon; and this first product of assimilation must be built up with a certain expenditure of energy, which is, it is true, not so great as in the case of the assimilation of carbon from carbonic acid by green plants, but which is net replaced by energy obtained from the sun's rays, but by energy which must be set free as the result of other transformations occurring in the interior

Assimilation of carbon. of the cells. For the present we can only form hypotheses as to the nature of the first carbon assimilation product. In the case of the higher chlorophyllous plants starch is frequently one of the first products; in the case of the lower fungi, however, this substance is apparently with few exceptions entirely absent (only in some species of bacilli and in leptothrix, seo prge 370 ). From the varying nutritive value of the carboll compounds we may perhaps come to the conclusion with Nïgeli that the first produci of assimilation consists of three carbon atoms, with which hydrogen and oxygen atoms are combined, and which ean then unite with a similar complex of three carbon atoms to form a larger molecule of six carbon atoms; the more nearly the nutrient materials approach this hypotbetical body the less are the difficul- 
ties in their assimilation, and the more suitable are they for the nutrition of the plaut.

Without donbt also the nitrogenous bodies are built Assimilation up to a very large extent in the cells; and not only of nitrogen. those which constitute the protoplasm, but also those which are broken up in the intra-molecular respiration are probably always of more complex structure than the nutrient materials. Even the peptones undergo a transformation during assimilation, and where ammoniacal salts and amides are the only sources of nitrogen a complex process must result, and more especially a union with assimilation products rich in carbon. The varying expenditure of energy which is necessary for building up the assimilation products according as the material offered as food is closely allied to these products in composition, or differs much from it and is much simpler, explains in part the varying nutritive value of these compounds. The more active the growth and the new formation of protoplasm, and the more heterogeneous the nutrient materials, the greater is the amount of energy which must be set free by the respiratory processes.

The salts, likewise, do not always appear to be taken Rote of the up from the nutrient mixture in the same form in which nincral they are present within the cells. Here and there substintces, transformation and decomposition must occur under the influence of the organic acids which are formed ; further, sulphur, phosphorus, and magnesium, and possibly also calcium and potash, enter into combination with the complex molecules of the proteid materials of the protoplasm. For the production of the phosphorus, phosphoric acid secms to be alone suitable; the mion of the phosphorus with proteid bodies must occur within the oell. These transformations of the inorganic materials, however, are mucli less extensive, and require much less energy, than those of the organic substances.

In the case of the higher plants the composition of the salts may vary very greatly. Often excessive quantities of tho necessary nutrient salts are taken np, so that the relation of the individual constituents 
to the ashes raries very greatly; elements are also often absorbed which do not in reality possess the significance of necessary nutrient materials, and thcy can pass through the plant or be deposited in rarious parts of it without exercising any function (for example silicon, aluminium, manganese, \&c.; silicic acid may at times form 50 per cent. of the ashes). It is still uncertain whether anything similar occurs in the case of the fungi ; the analyses which have been as yot made are not sufficiently elaborate to enable us to draw conclusions as regards this point.

As, according to Nïgeli's experiments, potash cannot be replaced by calcium or magnesium, it is probable that the alkalies and the alkaline earths play very different parts; the latter only appear to form deposits in plasma and in the cell wall, while the alkaline salts are in part dissolved in the free cell fluid. That the potash compounds cannot be replaced by sodium or lithium is probably not due to diosmotic differences, but to the less affinity of potash for water; we may perLaps assume that the salts of sodium and lithium when in a state of solution are surrounded by firmly united molecules of water, which render them unsuitable for contact (Nägeli).

3. Alterations which the Nutrient Mutcrials undergo, and the Functional Activity of the Lower Fungi.

Relation between the plastic materials and the products of the destruc tivo tissue. cliange.
The materials assimilated undergo within the cell a series of transformations, in that ther are either employed in the manner described above for the formation of plastic material, and thus for building up new cell substance; or they undergo the destructive tissue change in which they are destroyed by the respiration, and in part converted into materials which can no longer serve as nutrieut material, and which must be got rid of as excreta. Just as in the tissue change of animals, it is not by any means necossary to assume that all the assimilated materials form in the first place cell substance and afterwards undergo destruction; it is, on the contrarr, probable that 
only a small fraction is employed to replace the cell substance which has been destroyed, and that the greater part remains in the juices of the ccll, and is subjected to the decomposing action of the protoplasm while it is in contact with it in a soluble form; finally, a very varying por-tion is employed for the formation of new cell material, and thus meets the demand for growth and multiplication.

A more accurate insight into the quantitative division of these respective rofles is however impossible at the present time. It is, indeed, frequently doubtful whether a body which is found by analysis to be a constituent part of the organism should be looked on as a plastic material suitable for its future functions, or only as an excretory product. It sometimes happens that substances which are split up from more complex compounds by intramolecular respiration and excreted by the cells, can still act as nutrient materials, and can be employed by otheror it may be the same-cells for the formation of plastic material; and in this case it is more or less a matter of choice whether these bodies are reckoned among the excreta or among the plastic materials. This difficulty, however, is present to a much lcss degree in the lower. fungi than in the higher plants; for in the former we may look on the gaseous bodies, such as carbonic acid, with certainty as excreta, whilst the higher plants can assimilate them again.

As nitrogenous plastic materials, we have chiefly the Nitrogenous whole group of proteid bodies; these are present in materials. solution in the juices of the cell, and then either undergo decomposition in the protoplasm, forming for example new cell substance, or are deposited in an insoluble condition in the cell protoplasm. Nägeli was able to make out the surprising fact that yeast cclls excrete albumen and peprone; the peptone being produced in non-fermenting neutral or acid nutrient media, and albumen in fcrmenting or non-fermenting fluids with an alkaline rcaction. In addition to the protcid substances numerous amides and amido-acids, espocially asparagine and glutaminc, arc found in the higher plants. These may be looked on partly as forerunners, and partly as the 
products of the decomposition of the proteid materials. In the same manner amides, such as leucine and tyrosin, ulso guanine, xanthinc, and sarcine, are found in the yeast and fission fungi. More especially in the so-called selffermentation of the yeast numerous combinations of this lind occur, while asparagine and glutamine have not as yct been demonstrated in the lower fungi.

These amido bodies are for the most part good nutrient substances; there is no doubt that in the case of the lower fungi the necessary nitrogen can be obtained from them alone, and that they suffice for building up the proteid material of the protoplasm; while, on the other hand, where the nutriment is exclusively albuminous, or in the self-fcrmentation of the yeast, it has been shown that they arise from the splitting up of proteid-like bodies. These serve at the same time as plastic material and as excreta; and it is typical of the economical manner in which as regards nitrogen the functions of the fungi are performed, that in the decomposition of these substances portions as a rule remain, which can again be utilised.

Abseuce of nitrogenou: excrementitious materialk.
Those nitrogenous substances which readily appear in a gaseous for'm, such as trimethylamine and various compounds of ammonia-e.g., carbonate of ammonia, sulphate of ammonia, \&c.-cannot on that account be looked on as excreta. These also can, under conditions otherwise favourable, act as satisfactory nitrogenous nutrient materials: and it appears not improbable that they may be again employed as plastic substances. Accordingly, it is only free nitrogen, nitro bodies, and, in the case of some classes of fungi, the nitrates, whicl can be reckoned as under all circumstances excretory products; and as these apparently only occur under special circumstances, there is almost nerer a separation of undoubted excrementitious nitrogenous products. Hence it follows that a colony of fingi may exist and multiply for an extremely long time on a very small quantity of nitrogenous matcrial, because the products of the decomposition of the proteid materials constantly recombine with non-nitrogenous compounds, and thus form new proteid substances which may again be utilised. 
It has, however, been shown, more especially in the case of yeast, by the investigations of Pasteur, Schützenberger, Mayer, and others, * that the amount of nitrogen gradually diminishes when yeast is cultivated in a pure saccharine solution; and this is true not only as regards the percentage quantity of nitrogen, but also as regards its absolnte amount; it therefore follows that nitrogenous materials are separated as excreta, and disappear in a gaseous form. Such a loss of nitrogen often occurs, when there is a relatively quick and copious formation of volatile nitiogenous substances which is not compensated for by the assimilation of nitrogen by the cells. Further, if those nutrient materials which can furmish carbon to the cells are absent, all those nitrogenous products of decomposition which do not at the same time contain utilisable carbon in their molecules (for example, ammonium salts, urea, oxamide), must remain as useless excreta; and in such a case, the diminution of the nitrogenous material is rery readily noticeable, but in reality only because the carbon is not used up in such a sparing manner, and because the continuous loss of the carbonaceous gases leads to the exhaustion of this element. Finally, the amount of other nitrogenous substances in the nutrient material cxerts an influence; if numerous highly nutritious nitrogenous bodies are present, nitrogenous molecules of an excrementitious character will appear much sooner, and, being less suitable as nutrient materials, will not be further used up. In cases of necessity, however, part of the nitrogenous decomposition products may probably again form nutrient material, and in this way there is a very parsimonious circulation of the material.

These facts enable us to some extent to under- Peculiar eirtand Bolton's experiments, referred to above, in which eulation of the some forms of bacteria can live and multiply rapidly in pure distilled water, i.e., where an extremely minute quantity of nutrient material is present. These experi-

* Pasteur, Ann.Chim.phys., (3) 58, 507.-Sehützonbergor, Compt.rend.. 1874, vol. 78.-Mayer, Unters. über die alkohol. Giahmung: Hoidelberg, 1869. 
Non-nitroger. ons plastic materials. monts showed an equally marked multiplication of the organisms if the growth was allowed in the first place to attain its maximum, and if the water was then sterilised and agrin sown with individuals of the same species of bacteria; this occurred on several repetitions of the process. In this case it is evident that the products of tissue change numst have been to a great extent excreted in a form which could again be utilised, and that the dead individuals could in like manner serve as mutrient material. It is only by some supposition of this kind that we can conceive the continuation of the life of these fungi with such a slight diminution of the organic materials, and the repeated development of new generntions on the same substrata.

Non-pitrogenous plastic materials seem to play a much less important part in the life of the fungi than in that of the higher plants. Starch is only found in exceptional cases, and of the other carbo-hydrates we find, in the case of mould fungi, trehalose and glucose, and in some cases also the alcohol mannite, which is usually reckoned among the carbo-hydrates. Of organic acids, tartaric acid, malic acid, and citric acid are usually reckoned as plastic materials, but as regards their destiny in the fungi nothing is as yet known; fatty oil seems, however, to be a frequent constituent of the cells of the fungi. Along with these mobile matters, corresponding in so far to soluble albumen, we have also cellulose, which is deposited in the cells and constitutes in the case of the mould and yeast fungi almost the whole of the cell membrane, but in the fission fungi only a small portion (see p. 526).-These materials are taken up from the nutrient substrata only to a slight extent in a prepared and utilisable form. As a rule, they arise in two ways, which very probably are often combined. We either find that they are built up of more simple compounds, as is, for example, certainly the case when relatively simple compounds (acetic acid, alcohol, leucine) are the sole source of carbon, or the non-nitrogenous plastic materials arise by the splitting up of more complex molecules, and more especially of 
the proteid substances, and this is, in fact, tho only mode of origin when tho fungi are fed, for example, only on peptone or albumen.

We must imagine, then, that the further fate of the non-nitrogenous substances is that they are in part employed for building up portions of the organisms (cellulose, fat); in part they combine with the nitrogenous molecules, and thus furnish the proteid-like materials; in part, lastly, they are split up in the protoplasm, chiefly in the form of carbo-hydrates, and further destroyed by the oxygen, thus furnishing true excretory prorlucts. Some of them can, like the nitro- Non-nitrogengenous materials, act on the one hand as plastic material, produetetory and on the other hand as excreta; for example, the organic acids (which are scarcely utilised when better carbowaceous nutrient materials are present at the same time) are made use of and given off if the nutrient material be poor in carbon, but otherwise suitable. Among the non-nitrogenous constituents of the fungi there are, however, some which must be looked on as true excreta, and which always act as such. Thus, oxalic acid, formic acid, \&c., cannot again play a part as nutritive compounds; and carbonic acid more especially cannot be utilised by the fungi, and hence must in all cases be looked on as excrementitious matter. As, however, carbonic acid is always produced by all the fungi, we have in its separation the chief reason for the gradual imporerishment of a nutrient mixture. Some aromatic products appear also to be formed to a slight extent in the tissue change of the fungi; for example, phenol, skatol, indol, ic. As a rule, these bodies are bad nutrient materials, and indeed, at a certain degree of concentration, can act as poisons, and hinder the derelopment of the fungi, even when other nutrient compounds are prosent; thus they for the most part behave as true excretory products.

Oxygen is the element which, in addition to the Tirsue change materials mentioned, takes the most active part in the is pen oxygen changes which occur in the bodies of the fungi. As 
the result of its aetion there is at first a eomplete combustion, and therewith a production of active energy which suffices for the functional activity of the organism. The most various groups of atoms fall a prey to the oxidising action of the oxygen, nevertheless it is chiefly those which have been formed in the protoplasm as the result of the intra-moleeular respiration, and which are more casily attacked by the oxygen than the materials which are taken up by the food and formed by the process of assimilation. 'The absorption of oxygen, and the respiration by means of oxygen, go hand in hand with the energy of the deeomposition which takes place in the protoplasm, and therefore with the activity of assimilation and growth, and thus they render a large amount of energy available for the active tissue ehange.-External influenees, espeeially the pressure of oxygen in the surrounding medium, appear relatively indifferent as eompared with the powerful influenee of the protoplasm; it is only the temperature of the nutrient materials which seems to exert a more marked influence on the amount of respiration, but it acts only by influencing the protoplasm and the decomposition occurring in it. In the case of the higher plants; it has been found that as the temperature rises, the extent of the respiratory process continually increases in sueh a manner that its curve rises from zero until the temperature at whieh death oeeurs is almost reaehed, and then it suddenly falls to zero. Whether a similar law holds good in the ease of the micro-organisms is not yet linown, but it is, $\grave{a}$ priori, probable.

'lissue change when oxygen is absent.
If oxygen is absent, decomposition in the protoplasm still eontinues for some time, as has been asecrtained by investigations on higher plants, and more espeeially on fruits, but the tissue ehange differs both as regards its products and its energy. Atomie combinations which would otherwise at once enter into uniou with oxygen, either remain unaltered after they are onee formed, or enter into combinatious with other bodies, so that all sorts of produets result, which are not obserred when plenty of oxygen is present. Carbonie aeid and 
water are chiefly formed when oxygen is present, and beyond this only slight quantities of compounds which are not so completcly oxidised; where oxygen is excluded we still find a production of carbonic acid, which is by no means insignificant in amount, but, nevertheless, is much less than that produced by the respiratory process (282 grammes of pears furnished, for example, in 5 months $1762 \mathrm{ccm}$. of carbonic acid); in addition, alcohol, organic acids, and at times hydrogen, are formed.* Only a very minute quantity of energy is set frec by the formation of these products from the more complex molecules; so that on the whole it is only for a short time, and under otherwise favourable circumstances, that the requirements of the living cells as regards energy can be supplied.

Although this intra-molecular respiration, as has been mentioned above, suffices for the complete supply of the energy required in the case of the anaerrobic fission fungi, we have no facts with regard to the more intimate processes in these cases, nor with regard to the products formed. The tissue change of these organisms is more easily analysed when they can at the same time excite fermentation in the nutrient materials. In this case they are under particularly favourable circumstances as regards life, in that they have a substitute for the supply of the necessary energy in the absence of oxygen. Under these circumstances they are able to supplement the decompositions which take place in their protoplasm in such a way that a very large quantity of fermentescible substances-much more than the cells are usually able to decompose in their interior-is superficially broken up with the liberation of energy; and the latter is then utilised by the living and growing cells to supply the energy they require. At the same time, the substancos which undergo this decomposition cannot be completcly lnurned up; on the contrary, relatively complex products result, which differ much according to the for-

* Lechartier and Bollamy, Compt. rend., 1869, T'. $69 ; 1872$, T. 75 ; 1874, T. 79,-Brefeld, Landwirthschaf. Jahrb., 1876.-ML̈̈ntz, Ann.
Chim. Phys, 1876 . 
Quantitative estimation of the tissue change. mentescible material, and are in part similar to those which usually arise when the respiration is exclusively intra-molecular.

If we attempt to estimatc quantitatively the tissue change of the fungi in the manner usually cmployed in the case of othcr organisms, viz., by placing on the one side the quantity of material taken in, and on the other side the amount which is destroyed, and also that employed for building up new tissue, wc soon find that we are not as yet in a position to make any such estimation. If fungi settle in a nutrient medium the nutrient materials are consumed very quickly, the fungi multiply rapidly, and a large portion of the nutrient materials consumed is contained in the newly formed colonies of cells which are distinctly visible to the naked eye. Another portion has, however, been used up in the respiration and in the destructive tissue change, volatile products escaping and other excretory substances being dissolved in the nutrient medium. It often happens that the elementary constitution of the latter is completely altered, because the products of the tissue change have set up changes which destroy the nutrient qualities of the remainder of the nutrient solution (formation of excess of acid or of an alkaline reaction with precipitation of earthy phosphates, \&c.). Hence it is very difficult by analysis of the nutrient substratum to estimate the relative results of assimilation and of destruction, and we require more numerous investigations before we can obtain an insight into the quantitativc relations of the tissue change of the fungi.

If we only pay attention to the process of assimilation, and if we take into account the enormously rapid multiplication of the fungi, we can understand as the result of this process alone the remarkably rapid consumption of a nutrient medium (especially wherc fission fungi are concerned). As above stated, we may assume that the complete growth and the division of a bacterium into two organisms occurs on an average within one hour; a single bacterium introduced into a nutrient solution furnishes 
after 48 Tiours (where there is no inlerference with growth) a colony consisting of two hundred and fiftysix billions of individuals; and this colony will, according to Nägeli's estimation, represent a weight when Estimation of dry of about eight grammes, which consist chiefly of the amount of albuminoid substances. During the next hour sixteen required. grammes, and after a second hour thirty-two grammes of the nutrient solution will be transformed into fungus tissue; and in the course of the third day, more especially where we commence with a number instend of a single individual, we have truly colossal numbers whicl as a matter of fact are only not usually met with, because the close aggregation of the fungi and the production of noxious materials as the result of their growth hinders their free development.

Finally, as regards the interchange of energy, which Interohange accompanies the tissue change of the fungi, we do not as of energy in yet know anything directly, but can only draw conclusions fungi.

from analogies with the higher plants. As regards the amount of energy taken in, the state of matters in the lower fungi differs somewhat in that it is practically only the chemical transformations of which we spolio above which furnish the necessary energy. In the case of the higher plants the rays of light supply the energy necessary for the assimilation of carbon; but the fungi which do not contain chlorophyll are unable to utilise this source of energy, and the whole assimilatory process takes place at the expense of the energy which has becn liberated by chemical decomposition.

The energy which has been obtained by the respiratory process is used up partly in the process of assimilation and partly in the further combinations of the materials; also in the process of growth and germination; in locomotion; and finully in the production of heat and light.As regards the consumption of energy in the processes first referred to, we have no precise linowledge. In the process of growtl, more especially in the case of the fission fungi, a large quantity of encrgy is often used up; rapid growth will therefore always go hand in hand with free respiration and the production of carbonic acid. A 
considerable expenditure of energy is also necessary for the process of the germination of spores, and this energy is only obtained in the case of most of the fission fungi by the respiration with oxygen, $01^{\circ}$ by a vicarious intense fermentation. The movements of the fission fungi are swimming movements in fluid media, and are generally or always produced by cilia. The mode of movement varies much (see p. 159), and it is usually associated with simultaneous rotation around the long axis. The energy of the movement seems to be dependent especially on the temperature and on the supply of oxygen.

Influence of temperature on movement.

Too low a temperature, like too great heat, leads to a condition of arrest of movement, and the intermediate temperatures which favour movement most, vary very Of oxygeu.

Of nutrient miterials.

of light.

Production of heat. markedly in the different species of bacteria. According to Engelmanu's experiments cited above the tension of the oxygen also influences the individual species in very varying degrees, and very slight alterations in it often interfere with locomotion.--Pfeffer" ${ }^{*}$ has further indicated the presence of suitable soluble nutrient materials as an exciting cause of movement; where the nutrient material is introduced into the fluid containing the bacteria at one side, the bacteria move towards this part; and if a capillary glass tube containing nutrient solution is placed in the fluid, the bacteria more towards the orifice of the tube and pass into its interior. If the nutrient materials are inadequate these morements do not occur.-Whether, finally, light exerts an influence on the mobility of the fission fungi, in a similar manner as it does in the case of certain swarming spores, must remain for the present undecided, because too few species have as yet been tested in this direction. $t$

Another form of movement is presented by alterations of shape in the protoplasm without any true locomotion; the dancing movement of the micrococci may be ascribed to changes of this kind.

A distinctly noticerble production of heat, similar to

* Unters. des Zotan. Instituts zu Tïlingen, i., 3 Heft.

$\dagger$ See Strasbnrger, Wirkung des Lichts und der. Wärme anf Schwörmsporen, 1878.-Engelmann, Botan. Zeitg., 1882. 
that scen in the higher plants, call also be observed in the lower fungi. This is minimal in amount if the intramolecular respiration alone is going on, and if there is neither access of oxygen nor the occurrence of fermentation; under these conditions an elevation of temperature of $\cdot 2^{\circ} \mathrm{C}$. over the surrounding temperature was found in yeast (growing in hydrogen); when air was admitted the elevation of temperature increased to $1.2^{\circ} \mathrm{C}$., and when fermentation occurred, to $3.9^{\circ} \mathrm{C}$.* These numbers, of course, only apply to the particular circumstances under which they were obtained. Elevation of the temperature of the nutrient medium has also been observed in the case of the fission fungi, though chiefly during the fermentative action. $\dagger$

Lastly, a development of light sometimes accompanies Development the vital processes of the fungi. In the case of some of of light. the higher fungi, especially of species of Agaricus, this phenomenon has been known for a long time; quite recently the phosphorescence which putrefying fish or: pieces of flesh at times show has been ascribed to lower. fungi, especially to micrococci, which, however, only occasion this phenomenon when a free access of oxygen and a temperature not too low, permit an energetic respiration.

\section{The Products of the Tissue Change of the Lower Fungi.}

The number of the products of tissue change which Products of are from time to time observed in cultivations of fungi tissue change. is extremely great; gases, such as carbonic acid, hyclrogen, marsh gas, sulphuretted hydrogen, ammonia ; nitrates; water; sulplur ; also volatile bodies, such as trimethylamine, alcohol, formic acid, acetic acid, propionic acid, butyric acid; fixed acids, such as lactic acid, malic acid, succinic acid, oxalic acid, tartaric acid; sulpho-acids, such as taurin, amides of the fatty acids, especially leucine, alanine, \&c. ; bodies of the aromatic

* Eriksson, Unters. b. dem butan. Institut. in Tübingen, 1881, Hoft 1.

† Popoff, Butan. Jahresb., 1875. - Wernieh, Organisirte Krunkheitsgifle. 
series, such as tyrosine, phenol, cresol ; reduction products, such as inclol, hydro-parncumaric acid; complex molecules, such as carbo-hydratcs, peptone, hydrolytic ferments; finally, colouring materials and alkaloid-like poisonous substances. According to the specics of the chief fungus present, and according to the external conditions of the nutrient medium, sometimes the one, sometimes the other of these products appear, and a particularly large number of thcm is observed when we have to do with fermenting or putrefying substrata.

Among these products of tissue change we can separate a group which generally occurs in the vital processes of all, or at aly rate of numerous fungi; and we can place in opposition to this the group of the rarer and more specific products, the occurrence of which is limited to one or a few species. It is also of special interest to ascertain in how far the number and the quality of the products of each individual species of fungus undergo rariations according to differences in the composition of the nutrient substratum, and whether, on the other hand, when the nutrient substratum is the same, the same products arc always furnished by the same species of bacteria; in other words, whether the power of each species of breaking up a given nutrient substratum in a particular manner is constant and special. It is clear that the answer to these questions is of extreme significance for the diagnostic value of the products of the tissue cliange.

Carbonic acid. Carbonic acid alone is of constant occurrence; water and a nitrogenous body also undoubtedly always appear as products of decomposition, but they do not, like the carbonic acid, come under observation as excreta. The life of the lower fungi seems nerer to go on without separation of carbonic acid; hence it is always present, although in very varying quantities, whcther it arises only as the result of intra-molecular respiration, or whether oxygen has been present, or fermentation has occurred.

Fatty acids and amide compounds.

A production of fatty acids and oxy-acids (acetic acid, propionic acid, butyric acid, lactic acid, succinic acid, 
Sc.), as well as of their amide compounds, occurs very ofter. We find one or other, or it may be a mixture of them, in most of the cultivatious of fission fungi even when there lins been no fcrmentation, but merely simple consumption of the mutricnt material and the multiplieation of the fungi; they are present, howerer, in much larger quantities when fermentation has occurred.

More sellom, but perhaps also equally widely distri- Aromatic. buted, we find aromatic bodies (phenol, paracresol, \&c.) products. as products of the tissue change of the fission fungi; these have as yet becu found chiefly or only in fermenting and putrefying mixtures.

Further, numerous fission fungi produce ferments, Ptomaine:, others produce substances which act like poisons and ferments. resemble alkaloids, and are commonly grouped together. under the term ptomainos. These two products of tissue change require, on account of their special importance in hygiene, a special discussion in the following pages.

Colouring materials are in some cases very common, Colonring in others they are among the rarer products of the materials. tissue change. Red pigment is, for example, formed by the pink yeast, by micrococcus cinnabareus, by bacillits prodigiosus, by bacillus indicus; green colouring matter by bacillus pyocyaneus, bacillus fluorescens putidus, bacillus erythrosporus, bacillus fluorescens liqucfac., \&c.; blue colouring matter by bacillus cyanogenus, and in putrefying mixtures (Brieger, Rohmann); riolet by bacillus janthinus; brown by bacillus fuscus; yellow by very numerous micrococci and bacilli.-These pigments are rery rarely present in the cells or in the cell walls, (these are usually colourless), and it is only the substratum on which the fungi grow that is impregnated with the pigment. It lias been further obscrved, and has recently becn ascertained by Liborius in the case of a largo number of pigment bacteria, that the colouring matters are only formed when free access of air is allowed, while if the access of air is even only moderatcly hindered (by covering with oil, sc.), the substrata and the colonies remain completely colomless, 
althongh otherwise the growtl of the fungi is not

Depencleueo of the formation of the colouring mattel's on the entrance of air.

Influenee of the nutrient smbstratum on the forma. tion of vigment.

Chemical nature of the pigments.

Produets of fermentation affected. Hence the probability is that these pigments are not produced as such by the fungi, but that the latter for'm a chromogenic substance which becomes converted into the colouring matter only as the result of the action of oxygen. Not uncommonly we notice different shades of the pigment, and at times even marked differences in the colour when the organisms are grown on different nutrient substrata ; this is evidently due to the influence of the different substrata, and of their reaction on the chromogenic substance. Such variations in the pigment are well seen in connection with the bacilli of blue milk. Very often a difference in the colour of a cultivation is due to contamination with other fungi; and this point must always be carefully tested before we refer the difference to the influence of the nutrient substratum.

But little has been ascertained as to the precise nature of these pigments; with regard to most of them re only linow a few reactions which have already been referred to in the systematic part of this work. The colouring matter, which has been most completely inrestigated, is that of greenish blue pus, pyocyanine; Gessard ascertained that chemically this substance was a base which was closely related to the ptomaines; the sulphate and chloride salts crystallise in the form of reddish needles, a crystalline precipitate is also deposited from their solutions by chloride of gold, chloride of platinum, iodide of potash, and mercury, further by tannin, chloride of mercury, and phosphoric molybdic acid. From a mixture of ferro-cyanide of potash and chluride of iron pyocyanine gradually throms domil a precipitate of Berlin blue, but more slorrly than morphine.

We have further to consider the specific products of fermentation which are limited to certain bacteria. Many of these, such as lactic acid, butyric acid, athylic alcohol, dsc., occur, it is true, very frequently as products of tissue change and of fermentation, but nerertheless, when we take into account the quantity of these products and their relation to each other, we must look on them 
as specific products of the action of certain species of bacteria; they are only formed in large quantities under the influence of a few fungi, and they then go hand in hand with the best development and growth of these species. It is more seldom that we meet with other alcohols containing more carbon, such as mannite, viscose, \&c.; these appear almost entirely to be specific fermentative products of a few species of fission fungi.In like manner we have, as rare and limited products of the tissue change of the bacteria, the granulose of the fungi, which become blue on the addition of iodine, and the sulphur of the species of beggiatoa.

These various products of tissue change are not, how- Variations in ever, so limited to the species of fungi which produces the products them that each species only produce one of the products change as the belonging to the same group; on the contrar. frequently observe that the same species of bacteria can tho nutrient
conditions. at the same time produce carbonic acid, fatty acids, ferments, ptomaines, and colouring matters ; that they can also excite fermentation, and eventually can, as the result of their parasitic growth, set up clisease in animals or vegetables attacked by them. We have already, on page 351, referred to this matter in the case of many fission fungi.

As regards the answer to the questions as to the constrncy and specific nature of the products of the tissue change, it becomes clear from numerous observations that the individual species of bacteria calnot on every nutrient soil furnish all the materials which it is capable of producing, but that, on the contrary, many products require the presence of special constituents in the substratum, these constituents not, however, being necessary for the life of the fungus.

The variation in the shades of the pigment according to the nutrient substratum points to some such infiuence of external conditions; and this influence is still more marked, for example, in the case of the bacilli of glanders and cholern, which only produce a brown colouring matter on potatoes and not on iny of tle other ordinary nutrient substrata; and it is ulso sliow. 
by the fact that the occurrence of definite products of fermentation is absolutely dependent on the presence of definite fermentescible substances, without which, however, the life of the bacteria in question can go on very well. We have also to bear in mind the marked influence exerted by the presence or absenee of oxygen on the nature of the materials formed ; further, that the composition of the nutrient medium and the excess of nitrogenous or non-nitrogenous substances determine the relative quantity in which the various produets usually appear. Finally, in some eases abnormal alterations in or mere accidental admixtures with the nutrient medium lead to the transitory appearance of musual products. In the same way we can observe in the higher plants the formation of large quantities of amides when there is no assimilation of earbon ; further, the formation of benzoic acid when hippuric acid is given to the plants as the nitrogenous nutrient material. In like manner, the mould fungi, for example, are able to form gallie acid and glucose from tannie acid, and it is probable that the above-mentioned (p. 528) splitting up of the nitrates oecurs in the same way. More elaborate researches will, without doubt, lead to the discorery of many of these more or less accidental products of tissue ehange occasioned only by deviations in the nutrient medium, and disappearing again with alteration in the nature of the soil.

Coustancy of the produets of the tissue ehange where the nutrient conditions lemain the same.
These differenees in the excreta do not in the least prevent us from utilising eertrin characteristic products of tissue change as a means of recognising the different species of bacteria. For so long as the external conditions remain the same, the same products of tissue change constantly accompany the specific form. Te do not find that other fungi suddenly acquire the porrer of yielding produets which are characteristic of a certain speeies of bacteria; and where normal conditions are to sonie extent maintained, it happens just as seldom that this species of baeteria loses its elaracteristic properties, and furnishes other products of tissue change instead. Thus we find that the production of colouring matter, 
the formation of peptonising forments, or the specific fermentations, so constantly accompany the same species of organism that we can employ these facts as diagnostic means for distingnishing and recognising the species. In the diagnostic key given above the possibility of peptonising gelatine and the production of pigment form a basis for the differentiation of bacteria otherwise rery difficult to distinguish from each other.

Even when, under the influence of abnormal external conditions, these characteristic products, and along with them the most important means of recognising the species of bacterium, have disappeared, the property of the fungus in question can still be always regained as soon as it is cultivated under those conditions under which this property is usually observed. For even when Retention of the temporary unfavourable conditions were so abnormal this constancy that some of the individuals died, or were pathologi-action of hure cally altered, it usually happens that if any individuals retain their power of development, the same products of tissue change which are normally observer constantly reappear under the same normal conditions. The bacteria evidently behave in this respect as a whole like the higher plants, which do not acquire or lose the power of producing this or that specific product of tissue change; the hemlock, indeed, loses its power of producing conium, and the plants which furnish indigo cease to prepare indigo, when they lead a morbir existence under abnormal conditions, but both these functions are resumed when more favourable conditions permit the surviving examples or their offspring to exercise fully their vital functions, and thus onder all circumstances this power remains as a specific property of each specific species.-It is only with regard to some with regarrl of the properties of the lower fungi, viz., the production to the produc. of fermentation or disease, that there is a peculiar tation and deviation from the behavionr of the linglier plants; the fission fungi may permanently lose these properties nnder the action of abnormal external conditions, and this loss may then be transmitted to the offspring through a number of generations even when the con- 
ditions of existence have again become normal. This matter of attenuation is more fully entered into in the following chapter on the conditions affecting the death of the organisms.

Injury of the baeteria by the products of their own tissue change.

The products of the tissue change of many of the fission fungi appear to exercise a remarkable inhibitory action on the growth and multiplication of the same organisms. This has been definitely ascertained in the crse of certain fermentations; thus, as is well known, in the alcoholic fermentation, alcohol when present in the nutrient substratum in the proportion of 14 per cent. interferes with the vital activity of the jeast cells; similarly, the ammoniacal fermentation of urine ceases when the amount of carbonate of ammonium In fermenting has risen to about 13 per cent.; in like manner the mixtures. lactic acid and the butyric acid, which are formed in the corresponding fermentations, must be neutralised by the addition of carbonate of lime or of oxide of zinc, because otherwise the constantly increasing amount of free acid is injurious to the life and the fermentatire activity of the bacilli which are at work (lactic acid is inIn growths jurious even in the amount of 0.8 per cent.).-Analogous without fermentation. actions have also been often suspected with regard to the products of the tissue change of many bacteria where no fermentation is going on, but in these instances it has not been demonstrated with complete certainty. The relatively rapid death of these bacteria in nutrient substrata which still contain a large amount of good nutrient materials is usually explained by the hurtful action of the accumulated products of their own tissue change. Suppositions have also been frequently made as to the more precise nature of the materials which come into play in this action; attention has been chiefly paid to the aromatic products (phenol, paracresol, \&c.), which are found in numerous putrefactive processes, for these as a matter of fact exert an encrgetic inhibitory action Nature of the even in very small quantities. But eren for these riews injurious products. proof is still wanting, becanse from the occurrence of 
aromatic substances in certain fermentations we cannot without further ovidence draw conclusions as to their gencral presence in the tissue change of other fungi, and because perhaps in this direction also the individual species of bacteria have a different and specific behaviour. -Buchner thinks that lic has recently observed a totally different influcnce of the products of tissue change in the case of the cholera spirilla; these organisms are thought to develop particularly well, and better than other forms of fission fungi, in a nutrient solution which contains the products of the cholera spirilla obtained from a previous cholera cultivation.**

A further effect of the products of tissue change is Injurious thcir supposed action on the development of other influence of species of fission fungi. The observation that some of tissue species, more especially the sensitive pathogenic forms, otherbacteria. rapidly die, when, at the same time, saprophytic fungi have established themselves in the same nutrient medium-death occurring much too quickly for any hurtful action by the withdrawal of nutrient materialcan scarcely be explained otherwise than by supposing that the products of the tissue change of the saprophytic fungi have exerted a poisonous action on the other organisms. Here, however, we also require more precise facts, and more especially with regard to whether the group of aromatic products which is common to many saprophytic fungi is the important one, or whether in the case of different fungi different products tale.part in the action against the concurrent organisms.

\section{The Ptomaines.}

In investigating putrefying mixtures the discovery Ptomaine. wins first made that, under the influence of bacteria, nitrogenous bases arise which arc, in many respects, similar to the vegetable alkaloids; somo of those bodies are innoctous to the higher organisms, other's, howeror, like the alkaloids, exert a poisonous action. These basic bodies ivere found when putrefaction liad gone on for some

* Mrïnch. aratl. Intell, Bl., 1855, Nr. 50. 
Fxtension of the ter'm ptomaines to all the nitrogenous basos produced by bacteria.

First demonstration of toxic putrefactive mo. rlucts.

First demonstration of chomically pure ptomaines.

time in human dead bodies, and the whole group of these materials was consequently included by Selmi under the designation "cadaveric alkaloids or ptomaines" (from the Greek word $\pi \tau \hat{\omega} \mu a$, a dead body). It is well to retain this term still, although recent investigations have shown that nitrogenous bases with specific action appear not only in the putrefactive process but also among the products of tissue change of pathogenic bacteria.

It would lead us too far to give here an accurate historical statement of the investigations which have been devoted during the last few years to the demonstration and analysis of the ptomaines.* The credit of having first drawn attention to the occurrence of poisonous putrefactive bases belongs to Panum; at a subsequent period Bergmann and Schmiedeberg, Zuelzer and Sonnenschein, Hager, Otto, Selmi, dc., obtained from putrefying substrata poisonous extracts, which usually resembled conium in their poisonous action or in their chemical reactions, but at times also atropine, curare, delphinine, or morphine. None of these investigations, however, led to the isolation of definite chemical substances from the toxic extracts.

Nencki $t$ was the first to succeed in separating and in ascertaining the elementary composition and the constitution of a putrefactive alkaloid. He obtained from putrefying gelatine a crystallisable body which had the composition $\mathrm{C}_{8} \mathrm{H}_{11} \mathrm{~N}$, and perhaps the structure $\mathrm{C}_{6} \mathrm{H}_{4}<\mathrm{CH}_{3}-\mathrm{NH}_{2}$. This base is isomeric with collidine, but differs from it by its behaviour on heating, \&.e. Gautier and Etard, at a later period, isolated from putrefying fish two substances, of which the one appears to be identical with that obtained by Nencki, while the other had the composition $\mathrm{C}_{9} \mathrm{H}_{13} \mathrm{~N}$; further, Guareschi

* Sce Husemann's Reports in Arcli. f. Pharmacie, 3 R., Bd. 16-22: Otto, Anleitung zur Ausmittlung der Gifle, 6 Anfl. Branschweig, 1S55.Brieger, Ueber Ptomaïne, Berlin, 1885, und Heitere Untersuchungen äber Ptomaine, Berlin, 1885. See the rest of the literature there, and in Maly's Jahresber. f. Thierehmie.

+ Noncki, Ueber die Zersetzung der Gelatine und des Eiucisscs, Bern, $: 876$ 
and Mosso obtained, from putrefying fibrine, an oil of the composition $\mathrm{C}_{10} \mathrm{H}_{1:} \mathrm{N}$, which has a similar action to curare; and E. and H. Sallowsli obtained by the putrefaction of flesh and fibrine a crystallisable base, which on analysis seemed to differ a little in its composition, $\mathrm{C}_{5} \mathrm{H}_{11} \mathrm{NO}_{2}$ or $\mathrm{C}_{7} \mathrm{H}_{15} \mathrm{NO}_{2}$, and hence probably was not quite pure.

Brieger has, during the last few years, talien up the Bricger's study of the ptomaines with great success; to his ininvestigations. restigations we already owe a number of rery important results.

Brieger isolated numerous nitrogenous bases, partly 1. Putrefacfrom putrefying fibrine, meat, fish, cheese, gelatine, and ptomaines. ycast; partly from putrefying human bodies ; and partly from pure cultivations of pathogenic fungi; some of these proved to be non-poisonous, others were distinctly poisonous.

To the non-poisonous, or, at any rate, to bases which only act in a poisonous manner in large doses, belong:

1. Neuridine, very widely distributed; obtained from Non-poisonthe putrefaction of meat, cheese, gelatine (in very large quantities), and from decomposing human organs from the third day onwards. Composition, $\mathrm{C}_{5} \mathrm{H}_{14} \mathrm{~N}_{2}$, a diamine which breaks up into dimothylamine and tri-methylamine. Characterised by the formation of a compound with picris acid, which is not readily soluble.

2. Gadinine, obtained from putrefying torsk, has the formula $\mathrm{C}_{7} \mathrm{H}_{1} \mathrm{NO}_{2}$; constitution still unknown.

3. Cadaverine, from decomposing bodies, found in traces from the fourth day upwards, plentifully from the tenth to the twelfth days. $\mathrm{C}_{5} \mathrm{H}_{16} \mathrm{~N}_{2}$; has a disagreeable odour, recalling that of conium.

4. Putrescine occur's along with the former, $\mathrm{C}_{4} \mathrm{H}_{12} \mathrm{~N}_{2}$.

5. Saprine, likewise a cadaveric alkaloid; it lats the same percentage composition as cadaverine, but it is distinguished from it by the characters of its compound with hydrochloric acid, and of its gold salt.

6. Brieger also found cholin during the first few days of the putrefaction of dead bodies, and after the 
disappearance of the cholin, trimethylamine, also dimethylamine and triæthylamine.

'The formula of cholin is, $\mathrm{C}_{5} \mathrm{H}_{15} \mathrm{NO}_{2}$, and it must be looked on as trimethyloxæthylammonium oxyhydrate $\left(\mathrm{CH}_{3}\right)_{3}, \mathrm{~N}, \mathrm{OH}, \mathrm{C}_{2} \mathrm{H}_{4}, \mathrm{PH}$. It occur's very widely distributed in the body, united in lecithin with distearylglycerinephosphoric acid, and appears at the commencement of the putrefaction of dead bodies, probably by the splitting up of lecithine. Cholin only acts in a poisonous manner in very large doses.

To the poisonous bases belong:

Poisonous

1. Peptotoxine, the poisonous constituent of many Peptotoxine. peptones ; it is formed, for example, in the digestion of fibrine by artificial gastric juice. It can be in part extracted from peptone by xthyl- and amyl-alcohol ; composition as yet unknown. Frogs and rabbits are killed with symptoms of paralysis and insensibility.-This first poisonous product of the splitting up of albuminous bodies can probably be also obtained as the result of the peptonising action of bacteria, although this has not yet been directly proved.

Neurin.

2. Neurin, obtained from flesh which had putrefied for five or six days, was formerly frequently confused with cholin, but is distinguished from it by the absence of one molecule of water. It has the composition $\mathrm{C}_{5} \mathrm{H}_{13} \mathrm{NO}$, and must be looked upon as the oxihydrate of trimethylvinylammonium $\left(\mathrm{CH}_{3}\right)_{3}, \mathrm{C}_{2} \mathrm{H}_{3}, \mathrm{~N}, \mathrm{OH}$ (the vinyl group $\left.=\underset{\mathrm{CH}-}{\mathrm{CH}_{2}}\right)$ - Neurin is poisonous in small closes to frogs and mammals; for cats fire milligrams per kilo-weight is the poisonous dose. The symptoms observed are, salivation, dyspnoa, in the first place quickening, then lowering, of the heart's action; also violent peristalsis of the intestine, with diarrhea; finally, conrulsions and collapse. The group of symptoms most resembles those produced by muscarine; atropine appears to be the most active antidote.

Neurin is probably formed from the cliolin of the lecithin by the withdrawal of water, and this scparation 
of water seems to occur under the influence of many putrefactive bacteria. It is possible that it occur's also under many other circumstances, and especially as the result of the action of chemical agents.

3. A base similar to, and isomeric with, rthylendiamine, of the formula $\mathrm{C}_{2} \mathrm{H}_{4}\left(\mathrm{NH}_{2}\right)_{2}$. It has been recently shown to be distinct from xthylendiamine; obtained in the putrefaction of fish.

4. Muscarin, long known as the poison of the fungus of flies (muscardine), an oxidation product of cholin; $\mathrm{C}_{5} \mathrm{H}_{25} \mathrm{NO}_{3}$; was likewise found by Brieger in putrefying fish.

5. In the putrefaction of human bodies Brieger obtained, after seven days, the first traces of toxic bases, and they were got more plentifully after two to three weeks. Two ptomaines could be recognised, of which, however, the quantities obtained did not suffice for more accurate analysis. One of them set up marked diarrhœa in rabbits; the other, called mydalein, caused in the first place dilatation of the pupils, injection of the vessels of the ear, elevation of the temperature of the body, marked flow of saliva and diarrhœa, and finally death, with panting respiration and depression of temperature.

From pure cultivations of specific pathogenic bacteria 2. Ptomaine: Brieger was able to isolate the following bases :from purc cultivations:

The bacilli of typhoid fever, when grown in meat in- of pathogenic: fusion, gave rise to no putrefaction, no development of From typhoid sulphuretted hydrogen, indol, or phenol; on repeated occasions, however, a new ptomaine was obtained from these cultivations, the gold salt of which was most oasily purified; but a more exact analysis of this substance has not yet been published. This ptomaine caused, in guinea-pigs, flow of saliva, frequent respiration, dilatation of the pupils, and diarrhoea. On postmortem examination the henrt was fonnd in a state of systolic contraction.

Cultivations of Staphylococcus aureus in meat in- From fusion which was kept at a temperature of $30^{\circ}$ to $50^{\circ} \mathrm{C}$. staplyylorecei. for about four weoks, gave a non-poisonous base which did not onter into combination with chloride of gold, 
Prodnotion of ptomaines by cholera spirilla.

By other hacilli.

Absence of ptomaines in muthrax cultirations.
Hygicnic

importance of the ptomaines.

but formed, with chloride of platinum, a crystalline compound which could be analysed. More accurate detrils are still wanting with regard to this base.

The toxic action of pure cultivations has further been observed in various kinds of bacteria, without any attempt having been made to isolate the poisonous substances. For example, in the case of the spirilla of Asiatic cholera (sec page 440); furtlier, in a whole group of bacilli which cause a similar toxic effect with special involvement of the intestine, such as bacillus crassus sputigenus, bacillus oxytocus perniciosus, \&c. (see page 331). Other pathogenic bacteria have been investigated for similar products of tissue change, but as yet with negative results; thus, Nencki has in vain examined cultivations of antlurax bacilli for nitrogenous bases, and Marmé has arrived at the same result with cultivations of anthrax bacilli made in the author's laboratory.

The facts which have as yet been made out with refard to the occurrence of ptomaines are evidently of very grent importance. In the first place, they are of importance in medical jurisprudence, for medical jurists must, in investigating cases of poisoning, proceed in a totally new direction, and with the most extreme care. Hygiene also has an interest not less intense in the accurate investigation of these peculiar products of the tissue change of bacteria. It appears that the wholesale poisoning of people so often obserred, and which resembles severe epidemics of contagious diseases in its mode of appearance, is commonly caused by decomposing nutrient materials in the early stage

Poisoning by food containing ptomaines (cheese, fish, meat, ice.).

of putrefaction. In cheese, sausages, meat, or fish, to which these cases of poisoning are usually referred, the bases described above, or others as yet unlinown. lave probably been formed under the action of bacteria from the albumen of the nutrient materials in question, and have occasioned these toxic symptoms. A circumstance which fuvours the occurrence of these accidents, 
the bases occur in the commencing stage of putrefaction, before any disagrcenble smell is noticeable (only: in the slow putrefaction of human tissues was Brieger unable to discover any poisonous ptomaines during the first few drys), and that, on the other hand, a more advanced stage of putrefaction seems to destroy them; at any rate, Brieger failed to find, on the eighth day of the putrefaction of meat, bases which were present at an earlier period.**

The ptomaines also play an important part in certain infective diseases of wounds. For a long time surgeons have held the view that "putrid intoxication" arises as the result of the growth of certain saprophytic fungi on the surfaces of wounds; these form ptomaines, which are absorbed and then set up their poisonous action in the body. Similar phenomena occur, in all probability, on the wounded surface of the puerperal uterus as the result of the growth of saprophytic fungi. Further, intoxication can also occur from the intestine, where it is not uncommon to find putrefaction of the intestinal contents and production of poisonous bases; here, however, absorption is on the whole slower, and occur's in smaller doses, so that the intoxication is not so intense. It is also of importance for the production of these ptomaine actions that the formation of the poisonous bases may begin in a very early stage of the decomposition of albumen by bacteria, even before true putrefaction.

Further, the discovery of specific ptomaines in the cultivations of pathogenic fungi evidently gives us the key to the mode of action of these bacteria in the human body; we have every reason for believing that the most important morbid symptoms of typhoid fever, cholera, and many other infective diseases are due to the producThe ptomaines
as a cause of putrid intoxication.

\footnotetext{
* In a case of poisoning with mussels, which recently occurred in Wilhelmshafen, Brieger's investigations have showu (Deutsche med. Woch., 1885, No. 53) that ptomaincs, and, among them, a poisonous base which has boen already analysod $\left(\mathrm{C}_{6} \mathrm{H}_{15} \mathrm{NO}_{2}\right)$ and called mytilotoxin, were the cause of the disease. The mussels wore not in a puntrid condition, but even in the fresh state exerted their poisonous action. In this case, thorefore, there must have been oither a production of ptomaines by the mussels themselves, or elso they must have taken up from the surrounding wator poisons produced by bactcria.
}

Specific ptomaines as the active agents of the cholera and typhoid bacilli. 
Inflinence of various materials on the formation of ptomaines.

Varying reelation of the saprophytic bacteria to the production of ptomaines.

tion of specific poisons by the bacteria which are the causc of the diseasc, and as the result of this knowledge, we may entertain the hope that important indications for a rational treatment of these diseascs may result from the discovery of the specific ptomaines.

A number of important questions with regard to this matter still require solution. Thus it would evidently bc of great importance to learn whether the putrefactirc alkaloids are formed in the same quantity and with the same poisonous qualities by different bacteria in the same material, and conversely by the same bacteria but under varying composition of the putrefying material and under varying external conditions. As regards the latter point, a larger amount of lecithin and cholin may, for example, favour the formation of the poisonous neurin; and as regards the various species of bacteria which set up putrefaction, researches, which are as yet incomplete, but which are being carried out in the author's laboratory by Henrigan, have already shown that certain anaërobes can, in the course of putrefaction without the presence of oxygen, furnish poisonous products much more quickly and energetically than any of the other putrefactive fungi which have been as yet tested.

It seems in fact as if, as in the case of the higher fungi, the production of poisonous substances by different kinds of bacteria can show very marlied qualitative and quantitative differences, so that an early and detailed lnowledge of their vital actions is the more desirable in the case of the individual species of bacteria.

\section{Chemical Ferments.}

Ferments. Definition.

By "ferments" or "cnzymes" wo understand complex organic materials which readily undergo alteration, and have the power, within ccrtain limits of tempcrature, of transforming relatively large quantities of other organic materials in such a way that bodies arise with, on the whole, less heat-producing powcr than the materials from whicl thcy were formed. 
Such ferments play an important rôle in plyysiological processes, especially in the nutrition of the body. Stated generally, they have the power of so transforming materials which, as such, cannot enter an organism, nor perfor'm any function in it, that they become soluble, diffusible, and capable of being utilised as nutrient substances. Insoluble albumen is converted into peptone; starch and cellulose into soluble dextrose; fat is broken Importance for the proup; cane-sugar, which cannot be decomposed in proto- nutrition. plasm, is converted into glucose, which is readily acted on. The most highly organised animals require these ferments just as much as the most lowly organisms; the former prepare them in special glandular organs, but even in the lower fungi, in which no organs can be distinguished, ferments are nevertheless a very common product of tissue change, and one necessary for nutrition.

As regards the mode of action of these ferments, the most striking point is that a relatively small quantity suffices to transform a large quantity of the body which is being broken up; the whole chemical action, therefore, seems to run its course without the ferment itself playing an active part or becoming altered. This circumstance led to the use of the term "ferment," as applied to the chemical bodies of which we are speaking, and to the inclusion of the processes set up by them in the same class with the fermentative and putrefactive processes. Indeed, many investigators look on it as probable that all the fermentative processes may be referred to such chemical ferments, and believe that it is only by sucle a view that it is possible to understand aright the processes of fermentation.

Nevertheless the investigations which have been made as yet, compel us to take the view that the true fermentations, and the action of isolated chemical ferments, differ so much from each otlier that they must both be treated separately. As a rule, however, the chemical ferments play a part, and, in fact, set agoing many complex fermentative and putrefactive changes; and they play an important role in the nourishment of many 
Diastatic ferments.

As procluets of the tirsue cliange of the bilcteris.

of the exciting agents of fermentation. For these reasons the chemical ferments require to be considered more in detail in this place.

We distinguish the following kinds of chemical ferments :-

1. Dinstatic ferments. These convert starch into forms of glucose (maltose, clextrose, \&c.), and, as a rule, they only act where the reaction is neutral or slightly acid, but not where it is alkaline. They occur frequently in animals and plants. Of animal ferments we hare, belonging to this group, the ptyalin of the salira; the ferment of the pancreatic juice, which, when the reaction is allaline, converts starch into glucose; the ferment contained in the liver, which acts on glyocogen; two ferments present in the urine (Selmi, * Béchamp and Baltust), \&c. We find the diastatic ferments rery widely distributed in plants; they occur in specially large quantities in germinating wheat, in malt, and also in the most various organs of plants, in young seeds, leares, \&c. (Brasset:).

Diastatic ferment has been frequently demonstrated during the last few years as a product of the tissue change of bacteria. Marcanos found a ferment of this lind in bacteria which frequently occur in the external sheath of maize; Hueppe\| demonstrated a diastatic action in connection with the bacterium lactis; Niller isolated a species of bacteria from human intestinal contents which was able to dissolve starch. Wortmann**** was also able to demonstrate energetic diastatic action in a mixture of bacteria which he obtained from decomposing beans or potatoes, and which he cultivated in a mixture of nutrient salts and wheat stnrch.-That the solution of the starch in these cases really depends on the production of a ferment can, howerer, only be re-

* Selmi, Atti dei Lincei, vol. v.

† Béchamp und Baltus, Compt.rend., rol. 92.

\pm Brasse, lbirl., vol. 99.

$\$$ Marcano, llid., vol. 95

il Hueppe, llith. a. d. Kutis. Ges. A., rol. ii.

- Miller, Deutsch. med. Woch., 1885, Nr. 49.

** Wortmann, 7.f. pliysiol. Chem., vol, vi. 
garded as proved when we have succeeded in separating the active ferment from the bacteria. As a matter of Isolation of fact, the experiments which have been made in this the ferment. direction by Marcano and by Wortmann, have led to an imperfect isolation of the ferment; the former found that the cultivating fluid filtered through porcelain, or treated with chloroform, still showed a diastatic action; and Wortmann was able to demonstrate an isolated ferment by extraction of the mixture of bacteria and precipitation with alcohol; this ferment was soluble in water, converted starch energetically into glucose, acted better in faintly acid solutions, and also exerted its diastatic action when oxygen was excluded. Wortmann found that this ferment was only produced by the bacteria in question when they had at their command neither albumen nor any other source of carbon; usually they furnished a peptonising ferment, but instead of this they produced a diastatic ferment when they were in a starving condition, and were unable to obtain the necessary nutriment in any other way than by solution of starch; further, the ferment was only formed when the bacteria had plenty of oxygen.-Wortmann's observations are, however, not completely convincing, because he worked with an unknown mixture of bacteria, and also because the possible action of the living bacteria, in addition to that of the supposed isolated ferment, is not entirely excluded in the researches, especially as the activity of the solution of the ferment only appeared after a longish incubation period. Nevertheless, taking into consideration all these experiments, it is very probable that renewed experiments free from these objections will lead to similar results as regards the diastatic ferments of bacteria.

2. Inverting ferments. These convert cane-sugar, Invertin. milli-sugar, and maltose into forms of glucose (dextrose, lævulose, galactose). They occur in the digestive track of animals, but they have not yet been demonstrated in the higher plants. A similar ferment has, however, been demonstrated by Gayon* in species of ponicil-

* Gayon, Bull. soc. clim., 35, 58. 
lium and aspergillus (not in mucor); and Bourquelot* found in Aspergillus niger, a ferment which he was able to extract, and which inverted maltose and cane-sugar. The same ferment is also constantly, and in large quantities, produced by the ordinary yeast, which can onlyr cause fermentation of cane-sugar by virtue of this ferment. According to Kjeldahl the invertin of yeast extract does not act on maltose. The action on cane-sugar occurs best between $53^{\circ}$ and $56^{\circ} \mathrm{C}$., and when the reaction of the fluid is slightly acid. All the species of yeast do not produce invertin; thus, Roux + found a small round torula, which caused intense fermentation in solutions of glucose, but which was without action on Oecrryence in cane and milk sugar.-Bacteria also not uncommonly haeteria.

Cellulose forment. appear to have the power of inverting these substances; this is asserted to be the case by Hueppe, for example, in the case of the bacillus of the lactic fermentation; this organism causes fermentation of cane and milk sugar only after an alteration of the fluid-as regards the inverting property-has occurred, which alteration is probably caused by hydratisation. Bourquelot, on the other hand, concludes from his experiments that the bacteria of the lactic fermentation can cause the fermentation of maltose and cane-sugar directly and without preliminary inversion. This contradiction is perhaps explained by the circumstance that the two authors were not working: with the same species of bacteria. In the case of the butyric acid bacilli, it is manimously agreed that it does not possess any inverting power; on the other hand, in the case of some other species of bacteria Miller has. made positive statements.

3. A ferment which dissolves cellulose is producec presumably by the bacillus butyricus and by ribrio rugula, probably also by various other bacterin. Accurate investigations on this matter are wanting.

Peptonising 4. Peptonising ferments, which convert albuminous ferments. materials into soluble diffusible forms. In addition to

* Bourquelot, Compt. rend., vol. 97.

+ Kjeldahl, Meddedelser fra Curlsberg Labor., rol. i., Parts 2 and 3.

+ Soux, Bull. soc. chim., vol. xxxy. 
the ferments of the gastric juice and of the pancreatic secretions which belong to this group, bodies possessing a similar action also occur fairly widcly distributed in plants. 'Thus, from Carica papaya we have papain, which acts like the pancreatic juice in alkaline solutions; then we have a ferment similar to pepsin, which acts when the reaction is acid, and occurs in those plants which feed on flesh, and in Ethalium septicum.-Ferments of this class are evidently extremely common in the lowcr fungi. The large number of species of bacteria now Occurrence in known which cause liquefaction of the nutrient gelabactcria. tine, appear to cause this liquefaction only by the production of a ferment which dissolves albumen and gelatine. As the liquefaction usually occurs when the reaction is alkaline, these bacterial ferments approach the pancreatic ferment, trypsin and papain, rathcr than pepsin. Attempts at isolating these ferments, and accurate investigations as to the action of the peptonising bacterial ferments on various albuminous materials, are as yet wanting. The fact that many bacteria liquefy gelatine, but not solidified blood serum, seems to show that the various albuminous bodies are not all rendered fit for assimilation in the same manner, viz., by means of this production of ferment.-Many bacteria do not produce peptonising ferment under all circumstances; this production seems especially to ccase when oxygen is excluded, just as was obserred by Wortmann in the case of the diastatic ferment of the bacteria.**

5. Rennet ferment. This causcs an altcration of Ferment the albuminoid materials of mill, which shows itsclf in rescmbling the coagulation of the cascin. A similar ferment is, as is well known, present in the stomachs of calios; and we may further assume that it is at times produced by the mill glands, for Meissner $\dagger$ found that the mill of goats, even when bacteria werc completely cxcluded, became coagulated, evidently from a fcrmont which had

* For further details with regard to this subject sec tho Paper by Liborius (Zeitschrift $f$. Hygiene, i., Part 1) which has appored while this book was passing through the press.

i Mcissner, Deutsche Zeitschr.f. Chir., vol. 13, p. 334. 
already appeared in the milk glands. Then Duclaux, and, later, Hueppe, + have pointed out that numerous bacteria show a fermentative action by means of which they cause the coagulation of the casein of the milk, where the reaction is amphoteric, i.e., slightly acid, and slightly alkaline; afterwards they usually peptonise the precipitated casein by means of a ferment similar to trypsin, and ultimately break it up still furtler. To this group belong, for example, the butyric acid bacilli; and also, according to Hueppe's observations, bacillus pyocyaneus, bacillus mesentericus vulgatus, sarcina aurantiaca, \&c.

Ferments of glucosides.

Decomposition of fat.

Urea fernient.

6. Fcrments which break up glucosides. These act on bodics which have ariscu by the ether-like combination of two compouent clements, in other words, by the loss of water. ouc of these componcnts being glucosc. By the fcrmentative actiou water is taken up, and the moleculc is split up into its original component clements, hcnce glucose, and also auother body of very varyiug composition are formed. The best known crample of this process is the action of the fermcnt emulsine on amygdaline, andalso that of myrosine on myrouate of potash; a similar decomposition is also known iu the case of salicinc, of arbutine, of couifcriue, of tamnic acid, aud various other glucosides. With regard to these, it has not jet been with certainty madc out whether screral glucosides can be split up by the same ferment, for example by emulsin, or whether here also we must assume the action of specific ferments; and nothing is accurately kuown as rcgards the occurrence of such ferments in the lower fuugi.

7. A ferment which splits up fat into fatty acids and glycerine is probably prescnt in pancrcatic secretion, presumably also in mauy plauts and lower fungi.

8. The ferment of urea, which breaks up certain amide combinations in urine with the absorption of water ; urea is converted into carbonate of ammonium, hippuric acid into glycocoll and benzoic acid. Formerly this action was exclusively ascribed to the micrococcus urex, and Musculus isolated, as he supposed, from these bacteria the active enzyme which was soluble in water. According to Ladureau, $\ddagger$ this ferment is actire in ressels

* Duclaux, Compr. rend., vol. 91.

$\dagger$ Hucppo, Deutsche med. Hoch., 1881, Nr. 48 and 49.

† Ladureau, Compt. rend., rol. 99. 
from which the air has been exhausted, also under the pressure of three atmospheres, and also when oxygen, hydrogen, or nitrogen are present. According to the more recent investigations made by Leube, the property of splitting up urea belongs to various other bacteria; and prre cultivations of the micrococcus urea proved to be inactive when they were froed from living micro-organisms by filtration through plaster. It is possible, therefore, that the ferment isolated by Musculus did not come from bacteria at all (see page 214).

All the ferments which have been mentioned here are Method of produced by the organs of higher animals, or by lowly separating the organisms, but are not so intimately connected with the life of the producer that it is impossible to isolate and separate the ferments from the living cells; when this is done the products so separated show the same activity. In the case of numerous ferments such a separation has been already successfully effected, and we may draw the conclusion from analogy that, as regards the separation of the ferments which have not yet been isolated, the difficulties are chiefly technical, and not insurmountable. They are usually obtained by precipitation from their solutions by such means as alcohol, or by carrying them down with precipitates, and then extracting them from the precipitate thus obtained by means of solvents (glycerine, water). The results of chemical analysis have given the following numbers :-

Carbon. Hydrogen. Nitrogen. Sulphur. Ashes. Chemical

$\begin{array}{lllllllllll}\text { Diastase } & \ldots & 45 \cdot 7 & \ldots & 6 \cdot 9 & \ldots & 4 \cdot 6 & \ldots & - & \ldots & 6.1 \\ \text { Tnvertin } & \ldots & 40 \cdot 5 & \ldots & 6 \cdot 9 & \ldots & 9 \cdot 5 & \ldots & - & \ldots & - \\ \text { Emulsin } & \ldots & 48 \cdot 8 & \ldots & 7 \cdot 1 & \ldots & 14 \cdot 2 & \ldots & 1 \cdot 3 & \ldots & - \\ \text { Papain } & \ldots & 52 \cdot 2 & \ldots & 7 \cdot 1 & \ldots & 16 \cdot 4 & \ldots & - & \ldots & -\end{array}$

As regards the analyses as yet made, however, it is probable. that the ferments were far from pure; by cleansing them as far as possible, more especially from dextrine and gum-like bodies, Loew *btained ferments which approach albuminoid bodies in their composition much more than thoso which had been previously

* Loew, l'flüger's Arch., vol. 27. 
Analysis of purified terment:

Mode of aetion of the ferments. analysed. Thus Loew found in the case of the pancreatic ferment, which in a pure condition occurs as a snow-white powder, carbon $=52.75$ per cent.; hydrogen $=7 \cdot 51$ per cent.; nitrogen $=16.55$ per cent.; oxygen + sulphur $=28 \cdot 19$ per cent. ; ashes $=1.77$ per cent.

Selmi* states that he has obtained from urine two crystalline diastatic ferments, the one crystallising in the form of microscopic dice, the other like a fern leaf.

The mode of action of these ferments may be generally characterised, by saying that they produce hydrolytic decompositions; that is to say, every molecule of the substance which is being split up breaks up into two or more molecules by taling up one or several molecules of water. In correspondence with this, the decomposition in the case of some of the ferments mentioned abore rould occur in the following manner:-

(1) Diastase: $\mathrm{C}_{24} \mathrm{H}_{40} \mathrm{O}_{20}+3 \mathrm{H}_{20} \mathrm{O}=\mathrm{C}_{6} \mathrm{H}_{1,} \mathrm{O}_{5}+3 \mathrm{C}_{6} \mathrm{H}_{12} \mathrm{O}_{6}$.

$$
\text { Stareh. Dextrine. Dextrose. }
$$

or, according to more recent views:

$$
\begin{gathered}
\mathrm{C}_{36} \mathrm{H}_{62} \mathrm{O}_{31} \\
\text { Stareh. }
\end{gathered}
$$

(2) Invertin: $\mathrm{C}_{12} \mathrm{H}_{22} \mathrm{O}_{11}+\mathrm{H}_{22} \mathrm{O}=\mathrm{C}_{6} \mathrm{H}_{12} \mathrm{O}_{6}+\mathrm{C}_{6} \mathrm{H}_{12} \mathrm{O}_{4}$.

$$
\text { Cane-sngar. Dextroso Lrevulose. }
$$

(3) Eraulsin : $\mathrm{C}_{20} \mathrm{H}_{27} \mathrm{NO}_{11}+2 \mathrm{H}_{2} \mathrm{O}=2 \mathrm{C}_{6} \mathrm{H}_{12} \mathrm{O}_{0}+\mathrm{C}_{6} \mathrm{H}_{3} \cdot \mathrm{COH}+\mathrm{CNH}$. Amygdalin. Dextrose. Oil of bitter Hydroalmonds. cyanie

$$
\begin{aligned}
& \mathrm{C}_{13} \mathrm{H}_{16} \mathrm{O}_{7}+\mathrm{H}_{22} \mathrm{O}=\mathrm{C}_{6} \mathrm{H}_{12} \mathrm{O}_{6}+\mathrm{C}_{6} \mathrm{H}_{4} \mathrm{OH}, \mathrm{CH}_{2} \mathrm{OH} \text {. } \\
& \text { Salieine. Dextrose. Saligenine. } \\
& \mathrm{C}_{16} \mathrm{H}_{22} \mathrm{O}_{3}+\mathrm{H}_{2} \mathrm{O}=\mathrm{C}_{6} \mathrm{H}_{12} \mathrm{O}_{6}+\mathrm{C}_{6} \mathrm{H}_{3}\left\{\begin{array}{l}
\mathrm{O} \cdot \mathrm{CH}_{3} \\
\mathrm{OH}
\end{array}\right\} \mathrm{C}_{3} \mathrm{H}_{49} \mathrm{OH} \text {. } \\
& \text { Coniferin. Dextrose. Coniferyl aleohol. }
\end{aligned}
$$

(4) Ferment of urea : $\mathrm{CO}, \mathrm{NH}_{2}, \mathrm{NH}_{2}+2 \mathrm{H}_{2} \mathrm{O}=\mathrm{CO}_{3}\left(\mathrm{NH}_{4}\right) 2$.

$$
\text { Urea. Carbonate of ammonia. }
$$

In the case of some of the other ferments, for example, the peptonising one, we camnot make anything like an accurate formula for the transformation; but it is probable that in all, the decomposition takes place in a similar manner by the taking up of water.

Similar aetion Numerous other chemical agents are also capable of of chemienI agents. ferments. When boiled with dilute sulphuric acid, 
starch undergoes a similar transformation to that caused by the action of diastase; canc-sugar, the same transformation into dextrose and levulose as by invertin; superheated stean splits up fat; continuous boiling with water peptonises albumen. As a difference between the action of these chemical agents and that of ferments, it bas been suggested that the latter take such a slight part in the decomposition that thcy can split up unlimited quantities of the fermentescible bodies; but as a matter of fact such an unlimited action does not, by any means, appear to be the case. On the contrary, in the case of pepsin, ptyalin, diastase, \&c., there are distinct limits to the action; thus, diastase can, at most, act on two thousand times its quantity of starch. Under ordingry circumstances it is scarcely likely that all of this power will be employed, because the ferment becomes injured by the alteration of the substratum, or is partially precipitated in most fluids by the occurrence of precipitates.

The sensitiveness of the ferments towards external Dependenee influences is comparatively great. As regards the tem- of the fermenperature, in the first place every ferment has an optimum, on external which, however, is not constrnt in all cases, but depends on other circumstances simultaneously present. In the Temperature. case of diastase, the optimum is about $63^{\circ} \mathrm{C}$. (Kjeldahl, loc. cit.); in the case of emulsin about $50^{\circ} \mathrm{C}$.; in the case of ptyalin about $46^{\circ} \mathrm{C}$. Diastatic action has been observed even at $+5^{\circ} \mathrm{C}$.; from that point it increases with increasing temperature till it reaches the optimum. Between $65^{\circ}$ and $75^{\circ} \mathrm{C}$. we usually observe a complete cessation of the fermentative action, and a permanent loss of the fermentative power; the longer the heat is continued, so much the lower degrees of tempcrature suffice for this action. The addition of glycerine raises the degrec of the hurtful temperature; the addition of alcohol acts in a convcrse manner. These numbers, however, are only valid as regards moist preparations; in the dry state the isolated ferments can be heated from $120^{\circ}$ to $160^{\circ} \mathrm{C}$. before they are injured.Among other circumstances which influence them may 
Action of acids.

be mentioned the reaction of the medium. Excess of alkali is injurious to most of the ferments. A slight degree of acidity is very well borne by some fermentsdiastase, invertin-and their action is, in fact, increased by a slightly acid reaction; the pepsin-like ferments absolutely require a certain excess of acid for the development of their action. Other ferments, such as emulsin, are hindered in their action even by 15 per thousand of hydrochloric acid (Falk*). Larger amounts of acid are always injurious.-The salts of the heavy metals, and other substances which precipitate albumen, act of course Carbolic acid. after the manner of poisons. Carbolic acid interferes with the fermentative action of emulsin and ptyalin; other ferments, and more especially diastase, are, on the contrary, scarcely affected; according to Kjeldahl (loc. cit.) the addition of $\cdot 2$ and $\cdot 4$ per cent. causes a scarcely noticeable diminution. On the contrary, on the addition of $\cdot 03$ per cent. of salicylic acid a marked diminution of the diastatic effect is observed, and on the adition of $\cdot 1$ per cent. the action entirely ceases.-Peroxide of hydrogen, which hinders all the fermentations dependent on the presence of living organisms (Bert and Regnard $\dagger$ ), and also hydrocyanic acid, chloroform, ether, benzole, and oil of turpentine, scarcely injure the isolated ferment at all; and, for example, by the salts of ammonia (up to 10 per cent.) and by alkaloids, such as veratrin and curare, the inversion of cane-sugar is much favoured.

Most of the ferments act only on a certain class of chemical bodies; it is only combinations which are closely allied to each other which are, as a rule, broken up by the same ferments. Thus emulsin splits up several glucosides; but, on the other hand, invertin, for example, does not act on dextrine, maltose, or starch; nor does diastase act on cane-sugar, or on glucosides. If several chemical ferments are present in the same solution they may destroy each other; thus pepsin digests trypsin and ptyalin. This, howerer, does not hold good in the case of all ferments, for diastase

* Falk, Virchow's Arch, rol. 93.

† P. Bert und Regnard, Compt.rend., vol. nt. 
and remnet, for example, do not interfere with cach other at all.

As to the mode in which the soluble ferments act, we Attempts to can make no definite hypothesis. We may perhaps explain the suppose that the ferment acts as a carrier of the water ferments. to be taken up; that it, in the first place, takes up the water itself, and then hands it on to the molecules which are breaking up. Or, according to Bunsen-Hüfner we may picture the contact and fermentative action by supposing that the ferment, like sulphuric acid in the formation of ether, has a greater affinity for certain atoms or groups of atoms of the molecule which is being broken up than the remainder has, and thus brings about a new grouping of the atoms, after the completion of which it is again regenerated. Both these hypotheses want the support of any actual demonstration that water is taken up, or that any such combinations of the ferment occur. A third view, put forward by Nägeli, is closely allied to that last mentioned, but also harmonises with the hypothesis put forward by Nägeli as to the process of fermentation, which will be referred to below; according to this view the ferments do not themselves enter into combinations, but only act on definite groups of atoms by the condition of movement of their molecules, and thus cause a transformation and new grouping of the elements.

In whatever way the action of ferments may bo Distinetion ultimately explained, it is clcar that we have here to between the do with another kind of process than that which occurs ferments and in the true fermentations. The ferments are soluble chemical bodies, not necossarily united with living organisms which are only able to set up hydrolytic decompositions, while in the true fermentation complex alterations of groups of atoms occur which require the constant presence and the immediate action of living organisms. The great difforence in both these processes is most clcarly evident from a conlparison of the external conditions which favour or injure them; the soluble forments act best at a 
temperature of about $60^{\circ} \mathrm{C}$, and when the reaction is acid and comparatively large quantitios of peroxide of hydrogen, carbolic acid, oil of turpentine, \&c., liardly weaken their action, while under the same conditions we constantly observe a eomplete cessation of the life, or, at any rate, of the fermentative actirity of all micro-organisms.

\section{Fermentation.}

Definition of fermentation.

Under certain circumstances wo find a deriation in the biological behaviour of micro-organisms, which is accompanied by a very thorough decomposition and consumption of the nutrient material, and the formation of special products, characterised by their quality and quantity. Among these products, volatile gases usually take a prominent place; and in addition bodies are constantly formed of less heat-producing power than those matcrials from which they are dcrived, and thus in the process of decomposition there is constantly a liberation of vital encrgy. The sum total of these phenomena is usually designated by the term "fermentation."

Fermentation must also, at any rate ultimately, be referred to decompositions in the protoplasm, to the intramolecular respiration. We may suppose that the act of fermentation was evolved from this respiration, and that it originally only represented an act of self-preservation due to the continued absence of oxygen. Tithout active combustion by the aid of oxygen, the internal respiration alone is not able to furnish sufficient cnergy for the purposes of the organism. When oxygen is absent, the nutrient material is split up superficially, it is true, but so much the more extensircly, and thus the cnergy which is requisite for the complete life of the micro-organisms is obtained. In the course of their further crolution the organisms become divided into two great groups : in the one, the fermentative action only occurs when there is neccssity for it owing to the absence of oxygen ; in the other, the fermentative action which corresponds to those special conditions has been gradually dereloped 
into a constant property, and these organisms excite fermentation even when the presence of a plentiful supply of oxygen does away with the necessity for tho act, the fermentation occurring whenever they are provided with fermentescible materials.

A sine qua non for the occurrence of fermentative Classification action is the presence of fermentescible material. of the fermenOnly a limited number of chemical bodies form suit- cording to the able materials, and it is not every one of the substances bu which are capable of undergoing fermentation which can be broken up by all of the fermentative agents; on the contrary, each substance is only decomposed by one or a few organisms, and every species of bacteria is limited to a few suitable substances. In the case of many micro-organisms no body is as yet known which they are able to split up by fermentation. It is possible that the functions of these organisms are always limited to the ordinary respiratory tissue changes; but it is possible that, in the case of one or other of these bacteria, the necessary fermentescible substance will yet be found.

It is only by the consideration of individual cases that we can recognise and understand the nature and properties of the material suitable for fermentation, as well as the mode in which it is split up by the fermentative action. We differentiate a large number of specific fermentations, which receive their names either from one or a few characteristic products, or from the nature of the fermentescible material, or, finally, from the fermenting agent. In what follows we shall describe, in the first place, fermentation by the yeast fungi; then the various fermentations caused by bacteria, which may be divided into five groups, viz., a. Fermentation of carbo-hydrates; $\beta$. Fermentation of the higher alcohols (glycerine, erythrite, mannite); $\gamma$. Fermentation of the fatty acids; $\delta$. Putrefaction; $\epsilon$. The formation of acetic acid from alcohol. 


\section{A. Alcoholic Fermentation of Sugar by Yeast.}

Fermentescible material.

The fermentescible material is furnished by the glucoses of the formula $\mathrm{C}_{6} \mathrm{H}_{12} \mathrm{O}_{6}$, namely, dextrose, lævulose, lactose, or galactose; further, by maltose, to which the formula $\mathrm{C}_{18} \mathrm{H}_{34} \mathrm{O}_{17}$ is given, and which, therefore, only acquires the same composition as glucose by taking up water. Dextrose forms the most favourable material; if it is exposed to fermentative action in a mixture along with other forms of glucose, for example, lævulose, the dextrose is the first to undergo fermentation.-Cane-sugar and mills-sugar only undergo fermentation when they are converted into glucose; the former can be converted into dextrose and lrvulose by means of invertin (therefore by yeast), the latter is transformed into galactose and dextrose by means of a ferment produced by some fungi ; further, they can both be converted into these glucoses by boiling with dilute mineral acids. -Other carbo-hydrates also, such as starch, gum, and cellulose, can be converted into glucose by ferments, or by treatment with acids; starch is transformed into dextrose by means of ptyalin and also by acids, and into maltose by diastase (malt). - All the carbo-hydrates last mentioned can therefore, in like manner, serve for fermentation, if only ferments which transform them into glucose are at the same time present in the fermenting mixture; and as these ferments are usually produced in large quantities by the same organisms which cause the fermentation (invertin by yeast, the ferment which transforms milk-sugar by bacteria), the incapacity of canesugar, starch, \&c., to undergo fermentation directly is practically of little account, and fermentation frequently occur's when these substances are present, and when the directly fermentescible glucoses are absent, being at most somewhat delayed in its commencement. By being provided with ferments which form glucose, the area of the vital and fermentative activity of the fermentative agents is markedly enlarged.

Forms of

The specific decomposition of glucose into alcohol yeast eapable and carbonic acid is limited to yeast, but all the species of exeiting fermation. of saccharomyces are not able to set up an equally 
energetic fermentation. Two species, becr and wine yeast, act most powerfully. Tho former is constantly cultivated in beer wort; fresh fermentation is set up by the addition of the yeast from fermenting wort to fresl fermentescible fluid. According to the more or less violent progress of the fermentation, high or low jeast is obtained; in the former the budding takes place more rapidly, and we thus obtain groups of cells which are readily taken up by the stream of carbonic acid and carried to the surface. The wine yeast-S. ellipsoideus -is the form which is most widely distributed in nature; it establishes itself spontaneously in the most various saccharine solutions when exposed to the entrance of air, or it is introduced into these, for example, by the skins of the grapes, on which it is constantly found. The other forms of yeast, S. apiculatus, exiguus, \&c., appear to possess a less degree of vegetative energy and fermentative action. In the case of some, as, for example, pink yeast ( rosa hefe), no fermentative action has, as yet, been noted; mycoderma only excites a temporary and trivial fermentation when it is artificially compelled to grow at the bottom of fluids.

The yeast-like growths of some of the mould fungi Fermentative have a more powerful fermentative action than the forms mould and of yeast last mentioned, in that, when immersed in sugar fission fungi. solution, they set up a fairly energetic decomposition of the sugar, with the formation of alcohol and carbonic acid; at the same time they approach true yeast in their conditions as regards form and growth. These properties are most marked in Mucor racemosus, M. cercinelloides, M. spinosus; they are less developed in Mucor mucedo, and hardly at all in Mucor stolonifer.Other mould fungi are also able to produce traces of alcohol and carbonic acid when they grow in saccharine solutions in the absence of oxygen; but the amount produced cannot be at all compared with that formed by the species of mucor and by the true ycasts, and only depends on the intramolecular respiration, by means of which also the cells of any of the higher plants can form alcohol and carbonic acid.-Further, in the for- 
Chemical processes in this felmentation.

mentation of carbo-hydrates by bacteria, we have not uncommonly a plentiful formation of alcohol and carbonic acid (sce below); but, in this casc, numerous other products constantly arise, so that the amount of alcohol is relatively unimportant. Hence the production of alcohol and carbonic acid is not of itself claracteristic for the fermentation by yeast. What is characteristic is the enormous and almost cxclusire formation of these bodies from definite kinds of sugar, and, in contrast to the organisms which only have a similar action when air is excluded, the circumstance that the presence of oxygen does not hinder the formation of these substances, but rather favour's it.

The mode in which glucose is broken up in the fermentation by yeast was formerly represented by a rery simple chemical formula. It was believed that the glucose molecule was split up into two molecules of alcohol, and two molecules of carbonic acid: $\mathrm{C}_{6} \mathrm{H}_{12} \mathrm{O}_{6}$ (glucose) $=2 \mathrm{C}_{2} \mathrm{H}_{5}, \quad \mathrm{OH}$ (iethyl-alcohol) $+2 \quad \mathrm{CO}_{2}$. Pasteur, however, showed that a number of other substances constantly appeared, even when the fermentescible materials and the yeast were, as far as possible, pure; on an average $2 \cdot 5$ to 3.6 per cent. of the fermenting sugar appeared in the form of glycerine $\left(\mathrm{C}_{3} \mathrm{H}_{5}\right.$ $\left.(\mathrm{OH})_{3}\right)$, and $\cdot 4$ to 7 per cent. in the form of succinic acid $\left(\mathrm{C}_{2} \mathrm{H}_{4}(\mathrm{COOH})_{2}\right)$; and further, there were constantly traces of acetic acid, and often of other alcohols, such as amyl-alcohol. The attempt has been made to include these side products by the formula 49 $\left(\mathrm{C}_{6} \mathrm{H}_{12} \mathrm{O}_{6}\right.$ ) (glucose), +30 $\mathrm{H}_{2} \mathrm{O}=12 \quad \mathrm{C}_{4} \mathrm{H}_{6} \mathrm{O}_{4}$ (succinic acid), $+72 \quad \mathrm{C}_{3} \mathrm{H}_{8} \mathrm{O}_{3}$ (glycerine), $+30 \quad \mathrm{CO}_{2}$ (Pasteur'), or by the formula $4 \mathrm{C}_{6} \mathrm{H}_{12} \mathrm{O}_{6}+3 \mathrm{H}_{2} \mathrm{O}=\mathrm{C}_{4} \mathrm{H}_{6} \mathrm{O}_{4}$ $+6 \mathrm{C}_{3} \mathrm{H}_{8} \mathrm{O}_{3}+2 \mathrm{CO}_{2}+\mathrm{O}$ (Monoycr); but this attempt has not been successful in giving a correct view of the quantitative conditions. - The same bye-products are also found in the fermentation by the joast forms of mucor; at any rate Fitz was able, in this case, to demonstrate succinic acid with certainty. Further, Brefeld found that the bye-products were the more plentiful the more unfarourable were the mutrient con- 
ditions for the fermentativo agents. Towards the end of the fermontation these materials seem to accumulate, and those fermentative agents which are only able to sct up the fermentation with difficulty, and which in reality require other conditions of existence, furnish bye-products in especinlly large quantities; for example, Mucor mucedo furnishes more than Mucor racemosus, and Mucor stolonifer more than Mucor mucedo.

We may, perhaps, suppose that in succinic acid, Significance glycerine, \&c., we have represented the special products of the lyodeof the tissue change of the yeast. As a matter of fact we must assume that, in addition to the splitting up of the sugar, there also occur decompositions, and, whore oxygen is present, oxidations of the complex molecules of the protoplasm of the yeast, which are composed of nitrogenous and non-nitrogenous groups of atoms; as a consequence the ordinary products of the destructive tissue change appear in the nutrient mixture. It is, however, difficult to identify these products with those bye-products which appear in fermentation; the quantity of the latter is much too great, and their quality also is too peculiar. Further, in this case, the amount of the bye-products must be proportional to the amount of the active jeast cells which are present, and must also, in the first place, depend on the quantity which has been sown. But as yet nothing has becn obserred as regards any such relation. We must therefore either assume that the decomposition of the sugar in the fermentative action in reality occurs, at any rate as regards the largest amount, according to a more complicated formula, in which there is a constant formation of glycerine and succinic acid; or that the appenrance of these bye-products is caused by impure fermentescible material, by the admixture of bacteria, and by thoir decomposition of the nutrient materials. 'Wlie possibility of such impurities must be admitted in the case of the expcriments which have been as jet made, in spite of the great precautions which have been taken by various author's since the time of Pasteur, because it was not possible, in the carlier methods, to isolate purc 
Employment of impure yeast in previous experiments.

Self formentation of yeast.

species of yeast. It is only within the last few years that Hansen has been able to obtain a completely pure material, by using Koch's solid nutrient media, and we must await the results obtained by chemical analysis, in the experiments made with this yeast.

Very special attention has been paid by many investigator's to the so-called "self-fermentation" of yeast. This occur's when large quantities of frcsh, active yeast is left to itself in the presence of a plentiful supply of water, insufficient eutrauce of air, and a favourable temperature $\left(25^{\circ}\right.$ to $30^{\circ} \mathrm{C}$.). Under these circumstances a large amount of carbonic acid and alcohol are formed, the yeast becomes soft, and gires with war'm water an extract containing numerous substances, which must be looked ou as products of tissue change aud of decay. According to the investigations of Béchamp and Schützeuberger the water contains albuminoid substances, gum, a ferment rotating to the left, a substance called zymasc. pscudo-leucin (with which a rarying quantity of sulphur is mixed), tyrosin, butalaniu, carnin, xanthin, guanin, sarkin.The substances last named are evidently derived from the decomposition of albuminoid materials; the production of carbonic acid and alcohol, however, can only be explaiued either by the presence of fermentescible sugar in the yeast, or by the ready conversion of some constituents of the yeast cell into sugar; in that case the substance from which the sugar is derived will belong either to the group of carbo-hydrates, such as cellulose or gum, or to the group of proteid substances. According to Pasteur, material resembling sugar is always present in yeast, this material beiug very difficult to extract as such, but becoming couverted into sugar by mineral acids, for example; and it is this, along with the cellulose of the cell wall, which furnishes, according to Pasteur's riew, the fermentative products which arise iu the self-fermentation. Auother important view was, however, advocated by Liebig: he found, in some experiments on the self-fermentation of yeast, such large quantities of alcohol and carbonic acid ( 8 to 13.5 per cent. of alcohol, of the total weight of the dry yeast), that the whole amount of cellulose and other carbohydrates contaiued in the yeast was not sufficient to furuish this amount of fermeutative products; hence in order to explain the amount of these substances it was necessary to assume the occurrence, to a large extent, of a decomposition of albuminoid substances. Liebig laid the grcatest stress on this decomposition of albuminoid substances becausc he saw in it the really essential and constant process which took place in fermentation; according to his riew; the essence of the 
fermcntative process is that a complcx proteid substance, when in a statc of decomposition, transmits its chemical movements to other molccules, such as sugar.

Nägcli's more recent researches, however, show most distinctly that, in the sclf-fermentation of yeast, thc process which takes place is not limited to, and only dependent on, the yeast; but that, in the former expcriments, withont doubt bacteria also actcd and took part in the decomposition of the substance of the yeast. In fact the very circumstances under which the self-fermentation was obscrved were such that of nccessity an active development of bacteria must occur ; these lived and multiplied at the expense of the dead yeast cells, and probably also sct up fermentative processes in ccrtain of the constituents of the yeast substance which had been rendered soluble by ferments given off by them. A portion of the nitrogenous derivatives found in the extract may result from the activity of these bacteria, which can probably also take part in the production of carbonic acid and alcohol. Nägeli so arranged the experiments that when, for cxample, by the addition of citric acid, the development of bacteria was rendered difficult, only minimal traces of alcohol were found, probably derived from the small quantities of saccharine sub)stances which are contained in the yeast cells, and. which underwent fermentation when no saccharine nutrient material was at the disposal of the yeast. This process would be quitc analogous to the decompositions which occur in starving animals. But we have no grounds for bclieving that the protcid substance of thc exhausted yeast cells can be utilised by other living ycast cells; because the ferments necessary for the solution of these substances are not found in yeast. Further experiments, in which attention is paid to the purity of the cultivation, arc therefore rcquired to give definite information as to the rcal cxtent of the self-fermentation of the yeast, and as to the products of tissue changc.

Coclin * has attempted to aseertain the time required The tim for fermentation, by continuous measurement of the requirer for amount of earbonic acid developed. He found that in the first instance ten to twenty minutes always elapsed before active fermentation eommenced; and the time was still longer in dilute solutions. From that timo onwards the course of the fermentation may be expressed by a steeply ascending line, which finally ends in the form of a parabola. 'This period of ineubarion does not mean that the saccharine solution must first penetrate

* Cochin, Cumpt. rend., vol. 90. formentation. 
into the interior of the yeast cells, and that for this a certain time is required; for the same plenomenon is observed when the yeast is implanted in a new solution directly from a solution in active fermentatiou.

Influence of various conditions on the qunntitative result.

A mount of sugar.

Quantity of yeast.

The quantitative result of the fermentation undergoes murked variations according to the composition of the fermentiug material, accordiug to the quality of the yeast, according to the length of time, and according to various external influences.

The amount of sugar in the solution must not exceed 35 per cent., for otherwise the yeast cells suffer for want of the proper quantity of water; the best proportion of sugar seems to be 2 to 4 per cent., and then 20 to 25 per cent. (Wiesner), but this striking fact of two optima requires confirmation. The quantity of yeast added is, within certain limits, irrelevant for the progress of the fermentations. Dumas found that one gramme of sugar was completely broken up at $24^{\circ} \mathrm{C}$. by 20 grammes of yeast within twenty-four minutes; the addition of 100 grammes of yeast did not alter this result in the slightest. Where a large amount of yeast is added intense fermentation occurs, even in pure solutions of sugar, which ultimately ceases, learing behind a yeast which is exhausted and poor in nitrogen; if it is desired to keep up a permanent fermentation with relatively small quantities of yeast, the addition of other nutrient materials, more especially of nitrogenous Accumulation materials, is necessary.-Further, the contiuuation of of alcohol. the fermentatiou is limited by the accumulatiou of the alcohol; the presence of 12 per cent. of alcohol hinders the growth of the yeast, and when more than 14 per cent. is present fermentation cerses entirely. In the case of the mucor yeast this limit is much lorerabout $3 \frac{1}{4}$ to 4 per cent. (iu the case of $\mathrm{Nucol}$ stolonifer even 1.3 per cent.); this form of yeast is also mucl more sensitive to great concentration of the sugar solutiou, for a satisfactory fermentatiou only occurs in solutions contrining less than 7 per cent. of sugar

Temperature. (Fitz).-Of the external influcnces the temperature is of chief importance; as a rule $25^{\circ} \mathrm{C}$. seems to be 
the most favourable temperature, but this optimum raries under the influence of rarious factors. Further, the influence of the rëration of the fermenting mixture, its impreguntion with oxygen, is of importance. Accord- Oxygen. ing to Nägeli, the access of oxygen fivour's fermentation in all cases; chiefly when, at the same time, materials which offer good nutriment for the yeast are present in the fermenting mixture, because in that case a much more active multiplication of the cells can occur. In investigations recently made by Hansen,* it was found that the same quantitative results require a longer time when air is absent, and that, at the same time, fewer yeast cells are formed and take part in the fermentation; on the other hand, by continued aëration the same result is reached in a shorter time, and there is a much more extensive multiplication of the cells. Therefore, under the influence of the presence of oxygen the formation of the cells and the occurrence of fermentation takes place more quickly, but the action of the individual cells is not, on an average, so great as when air is absent.-Of chemical agents which disturb or hinder fermentation may be mentioned free alkalies, also sulphurous acid, sublimate, chloroform; while sulphuretted hydrogen, arsenious acid, carbolic acid, salicylic acid, strychnine, hydrocyanic acid, only hinder the fermentation of yeast when markedly concentrated, or do not affect it at all.

As regards the fermentation of bread, liephyr, koumiss, see page 607.

\section{B. Fermentation by Bacteria.}

\section{(a). Fermentation of Carbo-hydrates.}

The carbo-hydrates furnish, under the influence of Fermentation varions bacteria, a lactic fermentation, a mucous or of carbomannite fermentation, a butyric fermentation, a dextran fermentation, and, fiually, some fermentations in which acthylic alcohol and various other products are formed.

* Hanson, Mredelelelser-fra Carlsbcrg Lab., vol. i., Part 2. 


\section{Lactic Fermentation.}

Lactic fermentation.

The materials necessary are grape-sugar, canc-sugar, milk-sugar, mannite, sorbite, inosite. Cane-sugar and milk-sugar are probably in the first place converted into glucose. Spontaneous fermentation is most frequently observed in milk; it probably also plays a part in the preparation of bread and leaven, and frequently occurs in the fabrication of starch, and in the saccharine juice of beet-root. We can artificially obtain a lactic fermentation either by leaving milk to stand at about $30^{\circ} \mathrm{C}$. for three or four days, or by mixing a weak sugar solution with somewhat old cheese and with purified chalk, and kecping the mixture for several days at $30^{\circ}$ to $35^{\circ} \mathrm{C}$; ; in the lattcr case the lactate of lime which is formed can be easily obtained (see Schützenberger, page 172).

Fermentative The bacillus acidi lactici is in most cases the exciting agents.

agent of the fermentation. But the lactic fermentation is by no means confined to this one species of bacterium, but, on the contrary, a large number of cocci and bacilli which have been montioned above, share with it the fermentative power, and are only distinguished from it by the fact that the quantitative result of their action is much less, and that they are by no means so widely distributed as the ordinary lactic acid bacillus. Hence in all spontaneous fermentations we find that the lactic bacilli usually take part, and generally in much the largest numbers.

Nature of the The nature of the chemical decomposition has not ret decomposition. been completely explained. Formerly the attempt was made to explain the decomposition of sugar in the lactic fermentation by the simple formula, $\mathrm{C}_{6} \mathrm{H}_{12} \mathrm{O}_{6}$ (glucose) $=$ $2\left(\mathrm{C}_{2} \mathrm{H}_{4}, \mathrm{OH}, \mathrm{COOH}\right)$ (Inctic acid), and Miller also states that he has observed in the casc of some bacteria this simple decomposition of the molccules of sugar. Such a process, without any development of gas, and without any more marked altcration in the molecule, could not be regarded as formentution according to the 
definition given both in this work and also by various other author's.

As a matter of fact, development of carbonic acid is always observed in the ordinary lactic fermentation; and Boutroux, as well as Hueppe, has obscrved the development of carbonic acid in fermentation set up by purc cultivations of lactic acid bacteria. Former observers Incompletehave also found, besicles carbonic acid, other fermentative ness of the products (alcohol, butyric acid, mannite, gum). It is formula. probable that these substances often owe their origin only to the simultaneous presence of adrentitious organisms which stand in no relation to the lactic fermentation; nevertheless, it is not by any means à priori impossible that the various bacteria which are capable of setting up lactic fermentation can occasion decompositions which are dissimilar, and combined with a larger number of bye-products. In any case, howerer, the above formula is incorrect for the lactic fermentation by the bacillus acidi lactici, because no account is taken in it of the carbonic acid which is constantly observed.

The course of the fermontation and its dependence on various external conditions has been already cliscussed on page 365 .

\section{Butyric Acid Fermentation.}

The materials for this fermentation are furmished by Butyric acid starch, dextrine, inuline, cane-sugar, and dextrose; and fermentation. also by milk-sugar, but only after hydration. The butyric acid fermentation occurs spontaneously, and is very widely distributed; thus it is found in milk which has stood for a long time, in "sauer-kraut," in checse, in the ripening of which it probably plays a part, \&c. In order to obtrin it artificially it is well, according to Fitz, to mix together 100 grammes of potato starch (or dextriue), one gramme of sal ammouiac and the ordinary nutrient salis, with two litres of water, and to add 50 grammes of carboute of lime, in order to neutralise the butyric acid as it is formed. According 
Fermentatire agents.

to Déhérain* and Maquenne the exciting agents of the butyric acid fermentation are found in large numbers in the earth of ficlds and gardens; hence it is best to infect the fermentescible mixture with this, or with old cheese, or' with cow dung. The ressels are then liept at $40^{\circ} \mathrm{C}$.

While formerly it was only supposed that one species of bacterium had the power of exciting the butyric fermentation, it has been recently demonstrated that several species of bacteria are capable of this act, and that the fermentation with one or with some forms of bacteria can occur in the presence of air, while for the actirity of other's the exclusion of air is a necessary condition. Besides the species mentioned on page 367 , it seems, according to Fitz, $\uparrow$ that a short cylindrical bacillus, described by him, is capable of setting up butyric fermentation, this bacillus possessing a moderate amount of spontaneous morement, not forming spores, and not becoming blue on the addition of iodine. It belongs to the class of aërobes, and causes fermentation of all carboNature of the hydrates except starch and cellulose.-The formula for decomposition.

the decomposition is probably different for the rarious different species; in any case, carbonic acid and hydrogen seem to be constantly formed in large quantities. Fitz has also found on analysis of the products obtained from a hundred grammes of starch, 34.7 grammes of butyric acid, $5 \cdot 1$ grammes of acetic acid, and 1 gramme of rthylic alcohol. As, however, it has, as yet, been scarcely possible to cultivate the butyric acid bacilli perfectly pure, no experiment with absolutely pure cultivations has been subjected to accurate analysis, and therefore we must not lay too great reight on these numbers. See page 369 .

\section{Viscous or Munnite Fermentation.}

Viscous formentation of winc.
The materials which furnish this fermentation are dextrose and invert sugar ; as regards the ferment, the micrococcus viscosus, see p. 216. The fermentation

* Déhérain et Mrqueme, Bull. soc. chem. (2) rol. 29-Comp?. rend., vol. 97 .

$\dagger$ Fitz, Chem. Ber., vol. xrii., P. 1188. 
often occur's in certain kinds of wine, more especially in white wine, also in the saccharine juices of turnips, carrots, onions, \&c.; the fluids attacked become viscous and can be drawn out in threads. The fermentation is best obtained artificially by using a decoction of beer yeast, which is filtered and mixed with sugar, or by employing starch, rice, or barley-water containing sugar; the optimum of temperature is about $30^{\circ} \mathrm{C}$. Among the products of fermentation is always a lind of gum, which is closely related to dextrine, and has been recently termed by Béchamp "viscose"; mannite and carbonic acid are also formed. Viscose is soluble in cold water, Viscose. is precipitated by alcohol, does not reduce Fehling's solution, shows the same composition as starch, and rotates in the same manner as soluble starch.-At times, and probably owing to the action of other ferments, lactic acid, butyric acid, acetic acid, and hydrogen are formed. Under the most favourable circumstances 100 parts of sugar yield $51 \cdot 1$ parts of mannite, $45 \cdot 5$ parts of gum, and 6.2 parts of carbonic acid; hence the fermentation can be expressed by the formula, $50\left(\mathrm{C}_{6} \mathrm{H}_{12} \mathrm{O}_{6}\right)$ $($ dextrose $)=12\left(\mathrm{C}_{12} \mathrm{H}_{20} \mathrm{O}_{10}\right)(\mathrm{gmm})+24\left(\mathrm{C}_{6} \mathrm{H}_{14} \mathrm{O}_{6}\right)$ (mannite) $+12 \mathrm{CO}_{2}+12 \mathrm{H}_{2} \mathrm{O}$. Schmidt-Mülheim supposes that, in this fermentation of wine, there are, in fact, two fermentations taking place together ; the one which produces mannite and carbonic acid, and the other as the result of which the gum-like substance arises. - SchmidtMülheim observed the formation of the latter substance alone without simultaneous production of carbonic acid and mannite in the so-called tenacious milk as the result Viscous ferof the growth of the micrococcus described on page 216 . millk. This fermentation is not a fermentation of the albuminoid materials of milk, but is due to splitting up the milksugar, or it may be also cane-sugar, grape-sugar, or mannite. The viscous substance formed is precipitated by alcohol as a white sticky precipitate, which only swells up slightly in water, much more freely in potash lye, readily reduces Fehling's solution, and is stained brown by iodine and iodide of potash. - The optimum of temperature for this fermentation lies between $30^{\circ}$ and $40^{\circ} \mathrm{C}$. 


\section{Dextran Fermentation.}

Jextran The only directly suitable material is grape-sugar; cane-sugar does not ferment directly, but, as the fermenting agents furnish large quantities of invertin, the decomposition of the cane-sugar is only slightly delayed. It not uncommonly occurs spontaneously in the juice of beet-root, and hence is much dreaded in sugar factories. The fungus which causes the fermentation is leuconostoc mesenterioides. The decomposition results mainly in the formation of large quantities of a jelly-like substance-the dextran. We have no accurate knowledge as to the process of the fermentation; as to the molphological character's of the fungus, see page 214 .

\section{Cellulose Fermentation (Marsh Gas Fermentation).}

Cellulose

fermentation.

Cellulose, in the form of dead plants, straw, paper, or cotton-wool, frequently undergoes solution and fermenMaterials and tation by bacteria. Hoppe-Seyler* was able to set up this fermenting ngents.

Course.

First kind. fields, meadows, and woods; according to Déhérain $\uparrow$ and Gayon $\ddagger$ it often occurs in dung; on the whole, it seems shown that cellulose is dissolved and broken up by the same fermentation in the intestinal canal of the ruminants. - The bacteria which set up this fermentation have not, as yet, been cultivated pure. As to the chemical processes, Tappeiner has made several investigations, and found that there are two kinds of fermentation of cellulose; the first occurs in neutral extract of fermentation by all kinds of mud, and also by earth from to be extremely widely distributed. Tappeiner has meat solution containing 1 per cent. of extract of meat, in which purified cotton-wool or paper pulp is suspended; under these circumstances, carbonic acid and marsh gas escape (in the first few days the marsh gas is in much greater excess than at a later period); further, small

* Hoppe-Seyler, Chem. Ber., vol. xvi.

† Déhírain, Compt. vend., vol. 98.

\pm Gayon, ibid. 
quantitics of sulphuretted hydrogen, aldelıyde, isobutyric acid, acetic acid. The second f'crmentation occurs when Second kind. an alkaline extract of meat solution is employed; in that case only carbonic acid and hydrogen are formed, alongr with the same bye-products as in the former fermentrtion.-Tappeiner* has rentured to conclude from lis researches that the solution and decomposition of cellulose in the intestinc of ruminants only occurs as the result of this fermentation, and that therefore the cellulose is of no nutrient ralue for the orgunism. Accordingr to the experiments and calculations of Wilsingt and Henneberg and Stohmann, thowercr, this view does not seem to be accurate, and only a part of the cellulose which disappears in the intestine is lost by fermentation.

\section{Other Fermenlations.}

In the case of various carbo-hydrates, Fitz observed a fer- Varions other mentation in which athylic alcohol was formed as the chicf fermentutions. product. From 500 grammes of starch he obtained 10 grammes of athylic alcohol; from the same quantity of dextrine 22 grammes; milk-sugar also furnished chicfly the same alcohol.

Bontroux found a transformation of milk sugar into gluconic acid by a species of bacterium similar to the mycoderma accti.

'To Bricger' we owe the knowledge of a number of fermenta- Fermentations of carbo-hydrates caused by pathogenic bacteria. Ac- tions by cording to this author bacillus cavicida splits up solutions of pathogenic grape-sugar in such a way that propionic acid is the chief product. Bacillus pneumonia causes a marked development of gas in five per cent. sugar solutions to which a little nutrient gelatine has been added, and in the fluid there is acctic acid as the chicf product of the fermentation, and, in addition, small quantitics of formic acid and athylic alcohol. Typhoid bacilli formed from grapo sugar or starch wthylic aleohol, acctic acid, and lactic acicl. A non-pathogenic: coccus, obtained from faces, which forms on gelatine flat pyramids of a glistening white colour, decomposes three pes' cent. grape-sugar or canc-sugar solution in such a way that whylic alcohol along with traces of acetic acid is formed.

* 'Tappeiner, Chem. Ber.. rol. 16.-Zcilschr. f. Biol., rol. 20.

+Wilsing, ilid. $\quad \neq$ Henneberg und Stohmann, ibid., vol. 21. 


\section{(3). Fermentation of the Higher Alcohols.}

Fermentation of the higher alcohols.

Glycerine.
While no fermentations have been with certainty observed in the case of the diatomic glycol, rarious fermentations caused by bacteria have been demonstrated in the triatomic alcohol, glycerine, the tetratomic alcolıol, erythrite, the pentatomic alcohol, quercite, and the hexatomic alcohols mannite and clulcite.

In the case of glycerine, Fitz observed four fermentations. Under the influcnce of the bacillus Fitzianus-the morphology and source of which we hare discussed on page 388-glycerine furnishes considerable quantities of rthylic alcohol (for example, 29 grammes from 100 grammes of glycerine), and, as bye-products, capronic acid, bntyric acid, and a little acetic acid.

In order to set up the second fermentation, which chiefly furnishes butylic alcohol, solutions of hay-water and glycerine are mixed and kept at $40^{\circ} \mathrm{C}$. without being previonsly boiled. A bacillus is found in the fermenting mixture which is $2 \mu$. broad, and 5 to $6 \mu$. long, and which is actively motile while the fermentation is going on. In stronger solutions of glycerine (above 10 per cent.) the fermentation soon ceases, and the bacillus forms spores. If fresh cow-dung is somn in the glycerine nutrient solution, æthylic and butylic alcohols are formed in about equal (quantities (also a little propylic alcohol), and, in correspondence with this, the nutrient solution is peopled by two forms of bacilli.

Thirdly, Fitz was able to set up a fermentation in glycerine by means of the bacillus pyocyaneus in which large quantities of butyric acid, along with athylic alcohol and succinic acid, were obtained.

Fourthly, as the result of the growth of small thin rods. often united together in pairs, which are also able to set up fermentation in malate of lime, æthylic alcohol (21 grammes from 100 grammes of glycerine), and also formic acid and succinic acid were obtained.-A fermentation of glycerine was also caused by other bacteria; thus, as the result of the growth of microcooci, alcohol, butyric acid, formic acid, and fucetic acid were found; Hoppe-Seyler fonnd, on the addition of putrefying fibrine to a glycerine solution, chictly butyric acid, acetic acid, and succinic acid as products of fermentation. Vigna* olsserred the formation of athylic and butylic alcohol

* Vigna, Chem. Ber., rol. xvi. 
from glyecrine, and was dealing therefore probably with the combination of the two fermentations first mentioned.-In all these decompositions of glyeerine, with the exception, perhaps, of the fermentation by bacillus Fitzianus, which has been more accurately studied by Bucluner, the methods employed do not furnish a sufficient guarantee for a thoroughly pure growth, and the morphological characteristics of the fermenting agents hare not been sufficiently attended to, and thns the value of these careful chemical investigations is diminished.

In the case of erythrite Fitz also found a number of fer- Erythritc. mentations; one bacterium caused a decomposition in which two molecules of erythrite were split up into one molecule of butyric acid, and one molecule of snccinic acid, with a loss of $2 \mathrm{H}_{2} \mathrm{O}$ and $1 \mathrm{H}$; another bacterinm eaused a fermentation with only slight traces of suecinie aeid.

Mammite, in the first place, gives rise to the lactic fermenta- Mannite. tion abore mentioned. According to Fitz also, a bacterium causes in a three per cent. solution of mannite the formation of nol'mal butylic alcohol, æthylic alcohol, succinie acid, and lactic acid; and a elub-shaped bacillus obtained from boiled hay infusion furnished æthylic alcohol (26 per cent.), formic acid (5.6 per cent.), and a little suecinie aeicl.

Dulcite behaves very similarly to the earbo-hydrates as Dulcite. regards the lactic fermentation. According to Fitz, dnlcite also gives rise to a fermentation with a little alcohol and mnch butyric acid. Quercite gives rise to a fermentation with the almost exclusire formation of normal butyric acid.

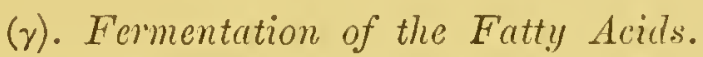

Numerous acids belonging to the group of fatty bodies Fermentation form a suitable fermentescible material when they are of the fatty given to bacteria in the form of neutral salts. The lime salt of these acids seems to be the most suitable, and with it almost all the experiments on fermentation have been made. The following are capable of undergoing. fermentation : formic acid $(\mathrm{HCOOH})$, acetic acid $\left(\mathrm{CH}_{3}\right.$, $\mathrm{COOH})$; further, a number of oxy-acids, namely: lactic acid $\left(\mathrm{C}_{2} \mathrm{H}_{4}, \mathrm{OH}, \mathrm{COOH}\right)$, glycerinic acid $\left(\mathrm{C}_{2} \mathrm{H}_{3}\right.$, $\left.(\mathrm{OH})_{2}, \mathrm{COOH}\right)$, malic acid $\left(\mathrm{C}_{2} \mathrm{H}_{3}, \mathrm{OH},(\mathrm{COOH})_{2}\right)$, tartrric acid $\left(\mathrm{C}_{2} \mathrm{H}_{2},(\mathrm{OH})_{2},(\mathrm{COOH})_{2}\right)$, citric acid $\left(\mathrm{C}_{3} \mathrm{H}_{4}, \mathrm{OH}\right.$, $\left.(\mathrm{COOH})_{3}\right)$.

Formate of lime furnishes, aceording to Hoppe-Sey-ler, 
when mixed with sewcr-mud, carbonate of lime, carbonic acid, and hydrogen; acctate of lime, treated in a similur manncr, gives carbonatc of lime, carlonic acid, and marsh gas.

Lactatc of lime undcrgocs, according to Fitz, four differcnt kinds of fermentation; in the first place, under the influcnce of a thin bacillus, which often forms long chains, it gives rise to the propionic acid fermentation, in which acetic acid, succinic acid, and alcoliol appear as bye-products; the process may probably be expresscd by the formula $3 \mathrm{C}_{2} \mathrm{H}_{4} \mathrm{OH} \mathrm{COOH}$ (lactic acid) $=2 \mathrm{C}_{2} \mathrm{H}_{5} \mathrm{COOH}$ (propionic acid) $+\mathrm{CH}_{3} \mathrm{COOH}$ (acetic acid) $+\mathrm{CO}_{2}+\mathrm{H}_{2} \mathrm{O}$. - In the second place, the acctate of lime under other conditions furnishes, along with propionic acid, large quantities of normal valerianic acid; from 3 kilogrammes, 126 grammes of propionic acid and 101 grammes of valcrianic acid werc obtained.-Thirdly, as the result of the action of the short aërobic butyric acid bacilli discovered by Fitz, butyric acid and propionic acid were chiefly formed.Fourthly, Pastcur (Comptes rendus, 1861) long ago obserred the butyric acid fcrmcntation of lactate of lime; Fitz obtained in this fcrmentation, from 500 grammes of lactate of limc, about 34 grammes of butyratc of lime, and also 36 grammes of athylic and butylic alcohol. This fermentation may bc representcd by the formula $2\left(\mathrm{C}_{2} \mathrm{H}_{4} \mathrm{OH} \mathrm{COO}\right)_{2} \mathrm{Ca}$ (lactate of lime) $=\mathrm{CO}_{3} \mathrm{Ca}$ (carbonate of lime) $+3 \mathrm{CO}_{2}+4 \mathrm{H}_{2}+\left(\mathrm{C}_{3} \mathrm{H}_{5}\right.$ $\mathrm{COO})_{2} \mathrm{Ca}$ (butyrate of lime).

Glycerinate of lime gives, when fermented by longish micrococci, chiefly acctatc of lime, along with a little succinic acid and athylic alcohol; the pure fermentation probably occurs according to the formula $\left(\mathrm{C}_{2} \mathrm{H}_{3}(\mathrm{OH})_{2} \mathrm{COO}\right)_{2} \mathrm{Ca}$ (glycerinate of lime) $=\left(\mathrm{CH}_{3} \mathrm{COO}\right)_{2} \mathrm{Ca}$ (acetate of lime) $+2 \mathrm{CO}_{2}+2 \mathrm{H}_{2}$. The same material can also be fermented, by means of fairly large bacilli, to formic acid, with a littlc methylic alcohol and acctic acid as bye-products.

Nalate of lime can likcwisc undcrgo screral fermentations. Under the influcnce of thin bacilli-the same which causcd the fermentation of glyccrine-succinic acid (about 60 per cent. of the matcrial) and a littlc acetic acid are formed; with othcr shorter bacilli propionic acid is the chief product, along with a littlc acetic acid.-In the third placc, there is, at times, a formation of butyric acid, with the development of hydrogen; and finally, according to Schützcubcrger, the malate of lime is split up with the formation of lactic acid and carbonic acid.

Turtrate of lime gives rise cither to the propionic acid fermentation found by Pastcur, and also obtained by Fitz, which probably takes place according to the formula $3 \mathrm{C}_{4} \mathrm{H}_{6} \mathrm{O}_{6}$ (tartaric acid) $=\mathrm{C}_{2} \mathrm{H}_{5} \mathrm{COOH}$ (propionic acid) $+2 \mathrm{CH}_{3} \mathrm{COOH}$ (acetic acid) $+5 \mathrm{CO}_{2}+2 \mathrm{H}_{2} \mathrm{O}$; or butyric acid fcrmentation 
results; or, in the third place, a dccomposition occurs, in which acctic acid is chiefly formed (from 100 grammes of tartrate of lime Fitz obtained 45 grammes of acetate of lime), and, in addition, rethylic alcohol, butyric acid, and succinic acid.

According to Kocnig* thcre is obtained from a solution of tartrate of ammonia together with nutrient salts, on the addition of a drop of putrid fluid, a slight development of gas (carbonic acid and hydrogen), a large quantity of succinic acid, and a little formic acid and acetic acid. From tartrate of lime infected with the samc material (which, however, forms an unknown mixture of bacteria) there results no succinic acid, but carbonic acid, acetic acid, formic acid, propionic acid, and a little butyric acid.

According to Fitz's experiments, citrate of lime furnishes large quantities of acetic acid, under the influence of small, thin bacilli (from hay-water), while as bye-products we have æthylic alcohol and succinic acid.-Mucic acid also is, according to Schützenberger, readily split up into acetic acid, carbonic acid, and hydrogen.

Finally, we may mention here the fermentation of quinate of lime, which has been obserred by Loew, from which, when air is present, there results protocatechic acid; but when oxygen is absent, acetic acid and propionic acid.

Althougl the progress which has been made during Incompletethe last few years, as regards the method of performing ness of these these experiments on fermentation, in that attention on fermenta. has been paid to the purity of the organisms sown, is very marked, we must accept with a certain reserve all the decompositions which have been referred to in the foregoing paragraphs, because in almost all the experiments the purity of the cultivations is not absolutely free from question. In order to obtain a really trustworthy result, it is evidently not only necessary to cultivate the fermentative agents pure, and to sterilisc the fermentescible substratum carefully, but it is also well, after the termination of the fermentation, to examine the remaining fluid with the aid of the recent bacteriological methods in order to ascertain that no other bacterin than those that were sown are present, and have taken part in the decomposition observed. It is absolutely necessary to require these precautions on account of the danger, never completely avoidable, of the accidental entrance

* Kosnig, Chem. Ber., vol, 14. 
Fermentations employed in the preparation of food.

Fermentation manufactures, \&c. Even as regards the cause, the
of bread.

of saprophytes. This test, however, has almost never' been employed.

Thus on the whole we have very few certain facts as to the mode in which the decompositions are brouglit about by certain species of bacteria. Hence it is that we are, as yet, very imperfectly informed as to many of the most frequent fermentative processes which spontaneously occur, or are artificially set up in our surroundings, for example, in the preparation of food, in many course, and the products of the fermentation of bread, we know very little that is trustworthy. It is very probable that the rising of the leaven is not caused by a pure yeast fermentation, for, especially in leaven, bacteria are present in preponderating numbers. According to the more recent investigations of Chicandard,* yeast does not play any part, or only a very secondary one, in the fermentation of bread, and the true agent seems to be rather a species of bacterium. Marcanot also sees in the mobile bacteria the true cause of the fermentation of bread, while Bontroux+ is of opinion that in this process several kinds of organisms, varieties of yeast, and bacteria play an active part.-It would be very desirable to obtain information as to this daily fermentative phenomenon by means of accurate experiments made with the aid of the more recent bacteriological methods. $\S$

In some cases combinations of fermentations are employed in the preparation of nutrient materials, especially in order to obtain the formation of xthylic alcohol by means of yeast from materials which are not in reality fermentescible, for example, from starch, dextrine, milk-

* Chicandard, Compt. rend., vols. 96, 97.

‡ Bontroux, ibid., vol. 97.-Moussettc, ibicl., vol. 96.

§ Duclaux has made minute investigations as to the bacteria which grow in milk and in cheese, and which take part in the decompositions which occur; he designates them under the generic name tyrothrix, and distinguishes T. scnber, T. tenuis, 'I' filiformis, \&c.-Unfortnnately the paper's in which these results arc given in detail (Annals de l'Instit. agron., and Duclaux's Chimie biologique) could not bc obtaincd in the librarics in Göttingen and Berlin, and only becanc known to the author at too late a period to be ntiliscd in this work. 
sugar. Such combined fermentations probably occur in the preparation of chicha from maize, as well as of the Japanese kösi from rice (Marcano*); further, in the two kinds of milk wine which have been already mentioned on page 372 -koumiss and kephyr.

Kephyr is, without doubt, the most important of these pre- Kephyr. parations as an article of diet.t The method ordinarily Native mode employed in its preparation by the inhabitants of the of manufasCaucasus is very simple; the fresh cow or goat milk is eollected in a flask, a small quantity of the kephyr bodies is introduced, the flask is closed and placed, in summer in a shady place and during the coolcr part of the day in the sun, in winter in the dwelling rooms, and frequently thoroughly shaken. The drink is ready after one or two days; it is then poured off; over the remains of the kephyr bodics left in the flask new milk is poured.-Elsewhere, two methods are employed in its preparation. According to the first, the dry, Preparation brownish kephyr bodies, which are sold in this eondition, are from dry placed for five or six hours in lukewarm water, till they swell ture.

up. 'They are then carefully washed, and introduced into fresh milk, which is changed once or twice daily till the kephyr bodies become of a pure white colour, and in fresh milk rapidly rise to the surface (after twenty to thirty minutes). On a table-spoonful of granules so prepared abont a litre of milk is then poured, and the whole introduced into a flask which is allowed to stand open for five or six hours, then tightly closed and kept at abont $18^{\circ} \mathrm{C}$, being shaken up about every two hours. After cight to twenty-four hours the fluid is passed through a fine sieve into another flask (this must not be more than four-fifths full); it is then corked and shaken from time to time. After twenty-four hours the socalled one-day-old kephyr is obtained, which contains only little carbonic acid and aleohol; as a rule it is the two-day-old which is drunk, and which, after standing at rest for some time, divides into two layers-a lower, whey-like and transparent; and an upper, formed of cxtremcly fine flakes of casein; when it is shaken up it has a cream-like consistence. Three-day-old kephyr is still thinner and very sour.-What remains after filtration through the sieve can be added to fresh milk after being thoroughly washed with water.

The second and more simple method can be employed where Preparation a good trro or threc-rlays-old kephyr is obtainable. Of this, from active

* Marcano, Compt. vend., vol. 95.

+ After Krannhalls.-Kephyr was introduced into Germany at the establishment of $\mathrm{Dl}$. Stern in Kissingen. 
onc part is added to threc or four parts of fresh cow milk, it is then introduced into flasks and allowed to stand for about forty-eight hours, being shaken from time to time. Of the drink so prepared, from one-fifth to onc-third is left lochind in the flask, as a ferment for new milk which is added to it.'The temperature must, as a lule, be about $18^{\circ} \mathrm{C}$.; it is only at the commencement that a higher temperature is desirable. -The kephyr granules which are being employed must lue cleansed carefully from time to time, and broken down till they are about the sizc of a pea. 'The cleanscd granules cau then be dried on blotting paper in the sun or in the neighbonrhood of an oren; in the dry state they retain their power of growth for a very long time-for several months, and even years.

Chemical eomposition of kephyr.

The chemical investigations hare as yet added as little knowledge as to the conrse of the kephyr fermentation as have the cultivation experiments. It is certain that the most important products of fermentation are æthylic alcohol, lactic acid, and carbonic acid; small ģuantities of glycerine, succinic acid, acetic acid, and butyric acid are also formed. The amount of lactic acid in prepared kephyr is usually about 1.5 per cent.; the amount of alcohol $1^{\circ} \mathrm{Tr}$.; both have been shown to arise only from the milk-sugar. During the first twenty-four hours the greater proportion of the milk-sugar is utilised for the formation of lactic acid, while during the following days the formation of alcohol is greater. When the temperature is high $\left(25^{\circ}\right.$ to $30^{\circ} \mathrm{C}$.) the lactic fermentation is too greatly favoured as comparcel with the alcoholic fermentation, and it is only at a definite low tempcrature that the two fermentations follow a normal course.- The amount of albumen in the milk is, nccording to the analyses as yet made, apparently not altered in the kephyr fermentation; but the casein undergoes an alteration in that it becomes suspended in the milk in extremely finc flakes, so that the whole fluid assumes an almost cream-like consistence. It is probable that the dietetic value of the preparation is largcly due to this alteration in form of the casein. Peptone cannot be demonstrated.

\section{(8). Putrefaction.}

Putrefaction. Under the term putrefaction, or putrefuctive fermentation, we understand the rapid and intense decomposition of nitrogenous and chiefly albuminoid substauces by certain bacteria in which gaseous, foul-smelling products are formed in large quantities. 
The material for this fermentation is, in the first Material. place, furnished by the albuminous substances themselves; these never seem to undergo the decomposition directly, but first become converted into peptone ; as, however, a peptonising ferment is usually produced, by putrefactive and many other bacteria, there is practically only a difference as regards time between the putrefaction of soluble and insoluble albuminous materials; by the addition of peptonising pancreatic ferment the putrefactive process is, horever, hastened. Further, gelatinous materials, and materials which give rise to gelatine, are liable to undergo putrefactive fermentation; then the peptones; finally, some nitrogenous bodies, which are, however, more removed from the proteid materials in their composition and in their characters, but which are closely allied to them in that they must be looked on as components of the albuminous molecule; more especially leucine, perhaps also tyrosin, indol, \&c.

In accordance with our present views as to the com- Nature of the position of the albuminoid boclies, and in accordance decomposiwith the analogies with the decomposition which these bodies undergo as the result of the action of acids and alkalies, we must, as a whole, assume that in the decomposition of the albuminoid molecule as the result of putrefaction, amido derivatives of the fatty acids (amido acids), nitrogenous bodies of the aromatic series, sulphoacids (taurin), and perhaps also peptone-like bodies are formed. As a rule, however, the products which first appear are rapidly broken up further, so that they scarcely attract attention ; for example, the amido acids are broken up into ammonia and fatty acids, of which the latter are still further decomposed according to the formulæ given above, usually with the liberation of curbonic acid, hydrogen, and marsh gas. Thus, in the case of leucine a fermentation has been found which seems to take place according to the formula $\mathrm{C}_{5} \mathrm{H}_{10}$ $\mathrm{NH}_{2} \mathrm{COOH}$ (leucine) $+2 \mathrm{H}_{2} \mathrm{O}=\mathrm{C}_{4} \mathrm{H}_{9} \mathrm{COOH}$ (valerianic acid) $+\mathrm{NH}_{3}+\mathrm{CO}_{2}+2 \mathrm{H}_{2}$. Glycocol and other amido acids probably also undergo a similar decomposition. 
In the case of tyrosin also we must assume that a further rapid decomposition takes place, because it is only found in considerable quantities at the commencement of putrefaction; according to Nencki this fermentation can occur according to the formula: $\mathrm{C}_{6} \mathrm{H}_{4} \mathrm{OH}$ $\mathrm{C}_{2} \mathrm{H}_{3} \quad \mathrm{NH}_{2} \mathrm{COOH}$ (tyrosin) $=\mathrm{C}_{6} \mathrm{H}_{4}<\mathrm{NH}=\mathrm{CH}$ (indol) $+\mathrm{CO}_{2}+\mathrm{H}_{2} \mathrm{O}+\mathrm{H}_{2}$. According to Baumann, in the putrefaction of tyrosin, when the entrance of oxygen is not completely hindered, hydroparacumaric acid, paroxy phenylacetic acid, parncresol, and phenol are formed in that order; in this decomposition paraëthyl, phenol, and paroxybenzoic acid probably form intermediate stages, carbonic acid, water, and ammonia being set free. Other observers have demonstrated the formation of hydrocinnamic acid from tyrosine.-Among the transitory products we have also succinic acid, which brealis up into carbonic acid and propionic acid, likewise phenylamido-propionic acid, which furnishes phenylacetic acid, and phenylamidoacetic acid, which gives rise to small quantities of amygdalic acid, along with other products of decomposition.

Products.

The following are the numerous bodies which arise in putrefactive processes: carbonic acid, hydrogen, free nitrogen, sulphuretted hydrogen, phosphuretted hydrogen, methane; formic acid, acetic acid, butyric acid, valerianic acid, palmitic acid; acrylic acid, crotonic acid ; glycollic acid, lactic acid, valerolactamic acid ; oxalic acid, succinic acid; leucin, glycocoll, glutaminic acid, aspartic acid, amidostearic acid; ammonia, carbonate of ammonia, sulphide of ammonia; numerous amine bases, propylamine, trimethylamine, \&c. ; indol, scatol-carbonic acid, scatol; tyrosin, and the bodies belonging to the aromatic series which have been above mentioned as originating from it; finally, the ptomaines referred to on p. 569.

The number and multiplicity of these products lead to the conclusion that their formation does not always occur to the same extent in every putrefactive fermentation. As a matter of fact we by no means always find all the products mentioned; on the contrary, the decom- 
position of the albuminous molecule runs its course in a varying manner, and leads to the production, sometimes of these, sometimes of those, products in largest amount. This varying course of putrefactive processes Varying can be in part occasioned by differences in the fermen- course of the tescible material, in part, also, by differences in the processes. external conditions; but the cause of the greatest and most important variations is differences in the kinds of bacteria which set up putrefaction. According as one or other species of bacteria, or a varying mixture of them, gain the upper hand in the putrefying mixture we have a qualitative or quantitative difference in the nature of the products.

Since we have been able to employ the methods of Multiplicity pure cultivation for the organisms which excite putre- of the exciting fuction, we have good grounds for believing that we shall patrefaction. be able to obtain definite proof of the fact that various kinds of bacteria are capable of splitting up albumen, and, at the same time, obtain an insight into the mode of action of each of these linds. Even now we know a large number of species of bacteriu which can, in pure cultivation, occrsion a rapid decomposition of the albuminous molecule, with the formation of foul-smelling gases, but the action of these is very various, whether we look at the nature of the products, or at their quantity. In the case of the majority of these products we require a more accurate knowledge of their chemical nature; in the case of many it is only the development of foulsmelling gases, the chemical composition of which is not more accurately known, which leads us to assume that a putrefactive decomposition of the albuminous molecule has occurred. The following are examples of these linds of bacteria :-

\begin{tabular}{c|c} 
Species of bactcrium. & $\begin{array}{c}\text { Putrcfactive products as yet } \\
\text { demonstrated. }\end{array}$ \\
\hline Bacillus putrificus coli ......... & $\begin{array}{l}\text { peptone, ammonia, fitty acids, } \\
\text { tyrosinc, phenol, indol, sci- } \\
\text { tol, dc. (sec p. 377). } \\
\text { Bacillus saprogencs, I, II, III. }\end{array}$ \\
foul-sinclling gases.
\end{tabular}




\begin{tabular}{|c|c|}
\hline Species of bacterium. & $\begin{array}{l}\text { Putrcfactive products as yot } \\
\text { demonstrated. }\end{array}$ \\
\hline $\begin{array}{l}\text { Breillus coprogenus foctidus } \\
\text { Proteus vulgaris, mirabilis, } \\
\text { Zenkeri }\end{array}$ & $\begin{array}{l}\text { foul-smelling gases. } \\
\text { peptone, foul-smelling gases. }\end{array}$ \\
\hline $\begin{array}{l}\text { Bacillus pyogenes fœtidus ... } \\
\text { Micrococcus fœtidus } \ldots \ldots \ldots \text {..... } \\
\text { Miller's Bacillus (p. } 375 \text { ) ...... }\end{array}$ & $\begin{array}{l}\text { foul-smelling gases. } \\
\text { foul-smelling gases. } \\
\text { sulphuretted hydrogon, am- } \\
\text { monia. }\end{array}$ \\
\hline $\begin{array}{l}\text { Bacillus fluorescens lique- } \\
\text { faciens (bacterium termo?) }\end{array}$ & $\begin{array}{l}\text { peptone, volatile fatty acids, } \\
\text { green colouring matter. }\end{array}$ \\
\hline Bacillus butyricus, Hueppe... & $\begin{array}{l}\text { peptonc, leucin, tyrosine, am- } \\
\text { monia, substauces with } \\
\text { bitter taste. }\end{array}$ \\
\hline Bacillus urea ................. & trimethylamine. \\
\hline Bacillus prodigiosus ...... & trimethylamine. \\
\hline Bacillus pyocyaneus ........... & peptone, ammonia. \\
\hline Bacillus fluorescens putidus & trimethylamine. \\
\hline Bacillas janthinus ............. & peptone, ammonia. \\
\hline Various anac̈robes.............. & foul-smelling gases. \\
\hline $\begin{array}{l}\text { Bacteria from mud or the in- } \\
\text { testinal contents of lumi- } \\
\text { nants (Tappeiner) }\end{array}$ & $\begin{array}{l}\text { earbonic acid, marsh gas, sul- } \\
\text { pliuretted hydrogen, \&c. }\end{array}$ \\
\hline
\end{tabular}

It must be further mentioned that Salkowski has found very various quantities of indol and scatol in his analyses of putrefying mixtures, and that he refers these variations to differences in the prevailing lind of bacteria; Tappeiner's observation must also probably be interpreted in the same manner. He has found that, in the paunch of cattle, scatol only occurs, and not indol, which is otherwise very widely distributed in the intestines of the herbirora.

Different lesults of the action of different putrefactivc organisms.
Hence we must come to the conclusion that numerous kinds of bacteria are capable of splitting up albumen, but that they are not all able to furnish representatires of the various groups of putrefactive products in such a completo manner as Bienstock's bacillus putrificus coli, for example; but that many can only break up certain parts of the molecule, leaving considerable portions unaltered. Hence we cannot attempt to form general formulæ for the decomposition of albuminoid 
materials as the result of putrefaction. We can only employ definite cliemical formulæ for each kind of putrefaction occasioned by a definite micro-organism.

The putrefaction which occurs spontaneously shows Spontaneous very great differences, according to the bacteria which putrefaction. are accidentally present, and according as the conditions of existence are at the time more favourable for one or other species. The kind of organisms which gain the upper hand at the commencement of the process depend on the concentration, the chemical composition, the reaction, and the temperature of the putrescible materials; in the course of time, and under the influence of gradually extending putrefaction, these external conditions alter completely; from neutral bodies others can arise which cause an acid reaction; by the decomposition chiefly of nitrogenous molecules and the formation of ammonia the alkalinity of the material may be increased; the relation of the individual chemical materials alters, because one kind is broken up to a greater extent than another. Thereby the most favourable conditions of existence are agnin provided for other kinds of bacteria; and thus the spontaneous putrefaction consists of a series of decompositions, not as a rule following any definite order, but dependent on individual conditions which cannot be controlled, these decompositions being caused by various different kinds of bacteria, and kinds which act in the most various ways. At the commencement of putrefaction we usually observe several kinds of micrococci and also large bacilli; in the later stages we find in addition masses of short bacteria; on the surface of the mixture forms scem to predominate which were formerly described under the name of bacterium termo, and of these it appears from plate cultivations that bacilIus fluorescens liquefaciens forms the largest numbers. Nor must we forget that numerous forms of bacteria which have no fermentative action, or which do not find a suitable material for the development of their fermentative activity, establish themselves in putrefying mixtures, though it is true that at a later period, when energetic fermentation is present, the organisms which 
Influence of oxygen on the eourse of the putrefaetive process.

Pasteur's view.

The true putrefactive organisms axe anaërobos. play an active part in it usually hinder the development of other forms. All these accompanying micro-organisms must complicate the putrefactive process, in that the specific products of their tissue change become mixed with the products of the fermentation.

Oxygen exerts the greatest influence on the course of the putrefactive process. [t lias been long known that true putrefaction, with foul-smelling gaseous products, occurs only when the amount of air is limited. When air is freely admitted these odours are absent, and a rapid and very complete oxidation of the putrescible materials takes place, this form of putrefaction being therefore designated under the special name decay. Pasteur was the first to indicate more clearly the difference between putrefaction in the presence of oxygen, and putrefaction without oxygen; according to Pasteur, when air is excluded, the oxygen contained in the fluid is, in the first place, used up completely by certain microorganisms (monas crepusculum and bacterium termo). As soon as the oxygen is remored these bacteria die, and fall to the bottom of the vessel in the form of a deposit. After this has occurred the true putrefactive bacteria appear; they can only exist where oxygen is absent; they set up the putrefactive fermentation, and absolutely require the preparatory action of these aërobes. If, on the other hand, the fluid is freely exposed to air, the aërobic bacteria develop continuously at the surface and form a scum, which at times falls to the bottom in masses, but is constantly regenerated. This scum prevents the access of the oxygen to the fluid, and thus it is possible that vibriones, which can only live when oxygen is absent, but which cause the fermentations, can develop in the fluid, as it were under the protection of the bacterial cover. The somewhat complex fermentative products thus formed serve as nutriment to the aërobes at the surface, and the latter then break them up into the simplest compounds, water, carbonic acid, ammonia, and thus the products which are ordinarily characteristic of putrefaction are not found.

In this way Pasteur sought to explain the difference 
between putrefaction in the presence and in the absence Putrefaction of oxycu, in correspondence with his theory of fer- also occurs in of oxygen, in correspondence with his theory of fer- the presence mentation based on the absence of this gas. This riew of oxygen. is, however, evidently not quite correct. As the result of more recent investigations, it has been shown beyond doubt that, as well in the presence as in the absence of oxygen, certain linds of bacteria are able to split up the albuminoid molecule and furnish the products characteristic of putrefaction. Further also, we have in the chemical processes which occur in putrefaction a partial explanation of the influence of oxygen.

When oxygen is absent extensive reduction processes occur, which, for the most part, arise directly in the process of fermentation; fatty acids are formed from oxyacids; marsh gas, sulphuretted hydrogen, sulphur (for example in the beggiatoa) appear; above all, however, hydrogen is formed in the various fermentations. As is Various evident from the formulæ given above, hydrogen is processes liberated in the fermentation of formic acid, lactic acid according as (butyric acid fermentation), glycerinic acid, malic acid, present. tartaric acid, erythrite, leucin, \&c. ; this hydrogen must at times lead to further reduction effects. Nitrates must be converted by this hydrogen into nitrites, indigo blue into indigo white, invert sugar into mannite; sulphates can also probably be reduced by it. On the whole, however, the alteration of the fermentescible material and of the products of fermentation, as the result of the action of the hydrogen, is only slight, and it is characteristic of the course of fermentation without oxygen that the true fermentative products appear in the main in an unaltered condition without having undergone further destruction and oxidation; and also we can understand that in this process of putrefaction only those bacteria can exist which are able to act without the presence of oxygen, so long as they liave fermentescible material at their. disposal.

The casc is otherwise when there is frce access of Rote of the oxygen. In this case the same hydrogen which in the nascent former instance ouly performed a secondary function, probably now plays a much more important part. 
Hoppe-Seyler has tried to show that when oxygen is present the nascent hydrogen breaks up the molecule of oxygen and thus renders the latter active; the nature of the process being that, as the hydrogen is gradually formed, two atoms of it constantly take up one atom of the oxygen molecule and thus form water, while the other atom of oxygen is capable in the free state of causing the most powerful oxidations. Hoppe-Seyler* has recently shown that hydrogen arising in other ways also possesses this power of rendering oxygen active; thus it is possible to set up energetic oxidation processes by means of palladium hydrate by gradual dissociation of the hydrogen in the presence of oxygen; and the action of phosphorus on oxygen has a similar explanation.

On this view we can understand how it is that in the presence of oxygen putrefaction runs such a completely

Inodorous decry.

Spontaneous occurrence of putrefnction and decay. different course than when oxygen is excluded. It is not only that the true reduction products, such as hydrogen, or sulphuretted hydrogen, do not appear, having undergone oxidation, but also that a number of other substances, which at the ordinary temperatures are quite resistant to the closed oxygen molecule, are attacked by the active oxygen and converted into the most simple compounds. Thus the destruction of the putrescible material occurs in as complete a manner as when it is broken up in the living animal body, or in that of bacteria which normally oxidise the nutrient materials when oxygen is present. Further, it is not uncommons that, both on and under the surface of the fluid, bacteriaor, when the circumstances are favourable, yeast, or mould fungi-obtain their nutriment from the products of the fermentation and burn these up to the most simple compounds; and we must regard it as at present undetermined whether the products of putrefaction can be more frequently and in larger quantities destroyed in this way, or as the result of the nascent hydrogen, and its action on tho oxygen.

In our normal surroundings, both putrefaction and

* Zcilschr.f. physiol. Chenic, ii., 22.-See also Baumann, ibid., r. 244. 
decay constantly occur. Where fluids putrefy for a long time-in cesspools, canals, gutters, \&c.-fermentation and putrefaction ordinarily occur at first as the result of the action of aërobic bacteria; as the oxygen is gradually used up, and as carbonic acid, hydrogen, and other gases fill the fluid, a condition arises so favourable for anaërobic bacteria as can scarcely ever be procured by artificial means in purc cultivations. The anaërobes then continue the putrefactive process, and more especially occasion the formation of large quantities of stinking gases; and, in addition to these putrefactive anaërobes, other bacteria, which stand in no sort of relation to the putrefactive process itself, such as the bacilli of malignant œdema and of tetanus, utilise the favourable conditions of complete exclusion of oxygen, multiply, and form spores.

A true decay, that is to say a putrefaction without Deeny in the the development of odorous gases and of reduction products, implies an extremely intimate contact of the putrescible material with the air. The most favourable conditions for this process seem to exist in soil which is very porous, and is moistened from time to time; under such circumstances mineralisation of organic substances occurs in such a complete manner that in a short time neither ammonia nor sulphuretted hydrogen, nor more complex carbon compounds are present, but on the contrary only nitrates, sulphates, and carbonic acid. For further remarks as to nitrification see the chapter on "Soil." -We very frequently meet with a mixture of putrefaction and decay in dead organic materials. In the upper layers of a fluid, or on the surface of a dead body, decay can occur, while in the deeper layers putrefactive processes of such extent and intensity take place that the products of true putrefaction appear side by side with the products of decay.

In the decomposition in the soil we frequently obscre Mouldiness products which can not as yet be satisfactorily defined; (Vermoderthesc are more cspecially seen in the destruction of portions of plants which chicfly consist of ccllulose. In this casc there is a formation of humin substnnces, and when oxygen 
is absent there is a plentiful formation of marsh gas in marshcs. 'This deeomposition of vegetable sulsstances, poor' in nitrogen, is specially designated by the term mouldiness (Temoderung); but the ehemical meaning of this term is not yet quite elear. The term decay (Terwesung) is also at present employed for several different processes; thus Nägeli uses it for the destruction of organie substances by mould fungri. In this, however, we lave no really marked fermentative action, but only a gradual consumption of the nutrient materials, and hence it is better to rcstriet the term to putrefaction in the presence of oxygen in which-when the eoncentration and reaetion of the medium are favourable-the mould fungi naturally help in the complete deeomposition of the material. Under speeial circumstances where suitable baeteria, or a fermentescible material, or other conditions for the fermentative processes are absent, the eonsmmption of the organie substances by mould, yeast, and fission fungi plays the ehief part; the destruetion must then, howerer, go on eorrespondingly slowly, and furnish the ordinary produets of tissue change of the lower fungi. It would be incorreet to reekon such a process among the processes of fermentation or putrefaction.

\section{(є). Acetic Fermentation.}

Acetic fermentation. rthylic alcohol is converted into acetic acid, and is expressed by the formula, $\mathrm{CH}_{3}, \mathrm{CH}_{2}, \mathrm{OH}$ (xthylic

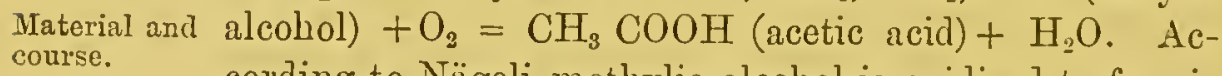
cording to Nügeli methylic alcohol is oxidised to formic acid in a similar manmer. The oxygen is taken up to a very much less degree when alcohol is exposed to the air, and spread out over a large surface on filtered paper, wood shavings, \&c.; it occurs to a greater extent when spongy platinum, charconl, and similar porous Fermentative bodies aid the conveyance of the oxygen. It is paragents. - ticularly energetic, howerer, when the derelopment of a defunite fungus occurs in the alcoholic material, especially when it is spread over a large surface. As to the morphological characters of this fungus see $p$. 389. Along with it there are usually found other fungi; saccharomyces mycoderma often derelops at the commencement in greatest numbers, so that this fungus 
was formerly looked on as the exciting agent of the acetic fermentation. According tu Nägeli, however, this form of yeast only prepares the soil for the acetic fungus by using up the fruit acids when they are present in large amount in the fermentescible material, and the presence of which would hinder the development of the bacteria; in this way it neutralises the medium. But this explanation of the peculiar concurrence of these two species of fungi, which is so often observed, is not completely satisfactory, because the acetic bacterium can bear the presence of acetic acid in the nutrient fluid in much larger amount than other bacteria.

The development of the acetic fungus only occurs Conditions of when the ordinary nutrient materials, nitrogenous sub-fermentation. stances, and salts, are present. The fermentescible material (the alcohol) must not be present in too great concentration (at most $10 \mathrm{per}$ cent.). The development of the acetic fungus occurs best when a certrin quantity of acetic acid ( 1 to 2 per cent.) is already present. The formation of acetic acid ceases below $10^{\circ} \mathrm{C}$. and above $35^{\circ} \mathrm{C}$.; the optimum lies between $20^{\circ}$ and $30^{\circ} \mathrm{C}$.; by heating the fermenting fluid to $60^{\circ} \mathrm{C}$. for twenty minutes, the fermentative action is permanently stopped unless new bacteria obtain access to it. As to the other products which appear in the fermenting mixture nothing is known; according to Nägeli, the acetic fungus forms extremely minute quantities of carbonic acid and water.

According to the few ccrtain observations which have bcen Doubtful rôle made as to the acetic fermentation, this process scems to be of the organvery different from that of the other fermentations. Marked isms in the decomposition of the alcohol molecule and marked formation mentation. of carbonic acid docs not occur'; the formation of acctic acid runs its course much less riolently than the other fermentative processes; the same effect is obtained by spongy platinum and by charcoal. All this las led Pastcur to the view that the formation of acctic acid is not really a physiological action of the fungus, but that the organisms only act in a similar manner as spongy platimm, as carrice's of oxygen. Maycr has, however, pointed out, as against this riew, that the optimum of the action of the acctic frmgus is quite 
different to that where the acetic acid is formed by means of spongy platinum; the latter process is increased by an elevation of tempcratmre which is destructive to the fungus. Nevertheless, it is cvident that the action as oxygen-carricrs must be bound up with a large number of intact fungus-cells, and that this action mnst, to a certain extent, run parallel with the active development of the fungus. And further, the fact that specific forms are fonnd in association with the formation of acetic acid can not alter Pasteur's vicw; for the conditions of existence of the fungi which take part in the formation of acetic acid are so peculiar both as regards the amount of alcohol and the amount of acetic acid in the medinm, that only few forms call enter into concurrence with them. Whether, however, as a matter of fact, only one or several forms are involved in the action mnst be determined by fnrther pure cnltivations.

If, on the othcr hand, the formation of acetic acid is a physiological act of certain fungi, we wonld expect that the mnltiplication of the fungi would be intimately connected with their function, that other products of tissuc change wonld also be formed, that, at all erents, there must be in part a further oxidation of the acetic acid. And further, it is a qnestion whether we onght in reality to look on the formation of acetic acid as a fermentative process, or whether we mnst not simply regard it in this way that the fungi, among other nutrient matcrials, also take up alcohol, when it is present in particularly large amount, and oxidise it only to acetic acid. In the lattcr case Pasteur's carrying of the oxygen takcs place in the cells; the alcohol acts as nutrient material, which, when present in smaller quantity in the nutrient mixture, is destroyed and burned up by rery rarious kinds of fnngi; which, however, when in a more concentrated form only permits the growth of a few fungi, and is then no longer burned up to the nsnal end products. This oxidation of the alcohol can only be designated as fcrmentation in the ordinary acceptation of the term, when it has been demonstrated that relatively very large quantitics of the matcrial can be acted on in a short time, that almost the whole of the fermentescible material undergoes this incomplete oxidation, and that this metamorphosis of the material is sufficiently different from the ordinary physiological processes to be looked on as a special fnnction, as compared with the assimilatory and destructive tissue change.-The solution of these questions must be given by further inrestigations. If, in reality, we have to do with $\Omega$ fermentation, then the whole process of the acctic fermentation can be best miderstood on Nägeli's theory, to be mentioned immediately. 
However different the chemical process is in each of General view the fermentations described, we can find some general of the chemipoints of resemblance in all the true fermentations. fermentation, We everywhere observe a marked splitting up of the fermentescible molecule, and an extensive re-arrangement of the atoms. In all cases carbonic acid is formed, and for this it is evident that new combinations between carbon and oxygen are necessary, and these are rendered possible by the solution of combinations between oxygen and hydrogen, carbon and hydrogen, carbon and carbon.* In the fermentation of formic acid $\mathrm{H}-\mathrm{C}<\mathrm{O}-\mathrm{O}$ Wandering of the oxygen

the union of the oxygen and hydrogen atoms in the atom. hydroxyl group, and also that of the hydrogen and carbon atoms, is broken up. The liberated hand of the oxygen atom unites with the hand of the carbon atom liberated at the same time; the two hydrogen atoms which are freed unite with one another, and thus $\mathrm{CO}_{2}$ and $\mathrm{H}_{2}$ are formed. In a similar manner, in all fermentations there occurs a wandering of the oxygen atom from the hydlogen to the carbon; while, on the other hand, by the separation of the $\mathrm{C}-\mathrm{H}$ and $\mathrm{C}-\mathrm{C}$ union room is procured for the new attachment of the oxygen to the carbon. In short, the group carboxyl is formed while, on the other hand, reducing atomic groups, $\mathrm{H}-$ $\mathrm{H}$ or $\mathrm{C}-\mathrm{H}$ compounds, appear. In the whole movement stronger affinities are grouped together, and energy becomes free. Nevertheless, the wandering of the oxygen atom which leads to the breaking up of the molecule only occurs when the molecule is not too large in relation to the number of the displaceable oxygen atoms. If, as in the case of many benzole dcrivatives, and in the higher fatty acids, numerous carbon atoms are united with each other, while only one $\mathrm{C}-\mathrm{H}$ group is present which can form carboxyl, no such wandering occurs in a molecule; on the other hand, this wandering is possible when several $O$ atoms can enter into new $\mathrm{C}$ combinations, as in the fer-

* Hoppe-Seyler, Physiolog. Chem., p. 124.-Arch. f. d. ges. physiol., vol, sii. 1. 
mentation of the glucoses, where three carboxyl combinations are present in the six $C$ atoms, and lead to the breaking up of the relatively large molecule. For the same reason fermentation of acetic acid is very difficult, and of propionic acid still more difficult; for here, as in the case of formic acid, there is only one $\mathrm{O}$ atom which can be utilised for the formation of carboxyl, while the molecule itself is much larger. On the other hand, fermentation can occur more readily in the oxy-acids (glycollic acid, lactic acid, \&c.), because in these there exists a second hydroxyl group, and thus a second displaceable $O$ atom. Accordingly, the following substances are not at all capable of fermentation: carburetted hydrogen, amines which do not contain any oxygen; further, the large molecules of the higher fatty acids, and of the benzole derivatives which are poor in oxygen (the latter only in regard to the benzole portion, while, naturally, in the side groups, splitting up and wandering of oxygen can occur). On the other hand the following, among other substances, must be capable of fermentation: the higher alcohols, the lower uni-basic fatty acids, up to propionic acid, the oxy-acids, and the multi-basic acids of the fatty series, the carbo-hydrates, and the albuminoid materials.

The decompo- Hence without extensive displacement of the atoms, sition of the molecule in this case is different from the action of enzymes.

no fermentation is conceivable, and it is by this intense alteration of the fermentescible molecules that the true fermentations are chiefly distinguished from the hydrolytic decompositions caused by isolated ferments. All fermentations are direct results of the functional activity of micro-organisms, and it is not only absolutely certain, from the experiments preriously described, that fermentation never occurs without living organisms, but we must also free ourselves from the idea that the fermentative action results from the production of a ferment which cannot be separated from the micro-organism without interfering with its life. The intimate process of fermentation shows so much that is different from that of the action of enzymes, and shows, on the other hand, such an intimate connection 
with the other direct vital actions of the micro-organisms, The fermentawith the othcr hirect vital actions of tho micro-organ a that we must of necessity look on the fermentation as a physiological physiological function of the living cells.

We must further assumc that the mode in which fermentescible substances are split up differs very much according to the species of micro-organism which excites it. It is true that the former view, that one organism exclusively possesses the power of setting up a definite fermentation, is not confirmed by more recent investigations, but the functional action of the individual fungi which set up fermentation is none the less a specific one, and the same fungus always splits up the same material in the same manner. This specific property Specific also remains constant for the same species, and is activity of the developed whenever the other conditions suitable for individual the fermentation in question, such as material, tempera- bacteria. ture, \&c., are present. It is only as the result of Constancy of certain noxious influences which will be discussed under this property. the conditions of death of the lower fungi that there can be a loss or a weakening of this property of exciting fermentation. (Facts of this kind have, at any rate, Weakening of been observed by Fitz in the case of two butyric acid the property fungi.) But these attenuated bacteria cannot occasion fcrmentation. some other fermentation; on the contrary, they retain their specific character, and they have only lost, as the result of noxious influences, that peculiar specific physiological function which is expressed in the excitation of fermentation.

Although it is thus clear that we must look on the fermentations as the physiological functional acts of certain micro-organisms, there still remains great uncertainty with rcgard to the mode in which we should define this function, and with regard to its relation to the other vital actions of the organisms.

In the organisms which are capable of setting up The tissuc fermentation tissuc change can run its course in various change of the ways; either the organisms are present in a nutrient, cxeite fermonbut not fcrmentesciblc, mcdium (such as ycast in a solution of mills-sugar), and in that case they do not behave like organisms which can cause fermentation; tation. 
they assimilate their nutriment, grow and multiply, break up the nutriment in their protoplasm, and taking up oxygen form the products of tissue change formerly described. Or oxygen only may be wanting in the medium; in that case the intramolecular respiration, with its insignificant destructive tissue change, can for some time maintain the life of the organisms. Or, in the third place, a fermentescible material, suitable for the organism in question, is present; in that case extensive decomposition of the material occurs, nlong with active multiplication of the organisms; this takes place as regards the majority of organisms in every case where the other conditions of life are favourable, in the case of some (bacillus butyricus) it only occurs so long as oxygen is at the same time absent.

The fermenta-

The splitting up of the material, as the result of tive action. fermentation, differs in many respects from the ordinary tissue change. In the fermentation very much larger quantities of material are acted on than are otherwise necessary for the nourishment of the same number of organisms. Further, the decomposition is a relatirely incomplete one; in the respiratory tissue change the nutrient substances are oxidised to simple compounds, but in the fermentation the materials of the nutrient medium remain, for the most part, in the form of complex molecules, and it is only some of the more simple groups that are broken up. Finally, in the fermentations the oxygen does not take an important part in the breaking up of the materials, and more especially in their conversion into the end products, as is the case in respiration, but the whole decomposition often talies place without any aid from oxygen, which only acts secondarily and then causes oxidation.

In correspondence with these differences betreen the ordinary tissue change and fermentation we hare the fact that many chemical materials act as nutriment without being able to act as fermentescible materials, and vice versa $\vec{a}$; thus formic acid cannot serre as nutriment but is broken up by fermentation, while, on the other hand, the benzole derivatives and the higher fatty 
acids resist fermentation, but are to a certain extent good nutrient media.

The splitting up of the fermentescible substances never forms the only physiological act of the organisms which take part in it. 'It is evident that nutrition, growth, and multiplication of the cells must go on at the same time, and for this purpose the fermentescible materials do not, as a rule, suffice, but salts, nitrogenous substances, and at times also carbon substances, must also be at the disposition of the fungi; when oxygen is excluded, the presence of a particularly good nitrogenous nutrient material is an absolute necessity for continued growth. Further, the protoplasm, as the result of its action, must always be to a certain extent used up, and thus the products of the destructive tissue change must appear, only, in this case, the want of oxygen must bring about a conformity of these products with those of the intramolecular respiration. It is for the progress of this assimilating and destructive tissue change that the necessary energy is obtained as the result of the fermentation, although the sum of the material which is directly utilised for this tissue change appears to be very small in relation to the amount of fermentescible substance which is broken up; according to Pasteur, the amount of the sugar employed for nourishment, for example in an energetic fermentation of sugar by means of yeast, amounts only to 1 per cent. of the fermented mass.

As, in this way, the fermentative processes, up to a Is the fercertain point, go on alongside of the ordinary tissue mentesciblo change, the further question arises whether it is neces- broken up in sary for the occurrence of the fermentations that the fermentescible material, like the nutrient material, must not only come in immediate contact, but also enter in a loose combination with the protoplasm, and must pass into the interior of the cells, or whether the decomposition can take place outside the cells, and whether less intimate contact of the protoplasm with the fermentescible materials is sufficient for their decomposition? According to experiments made by Cochin* it can be

\footnotetext{
* Cochin, l'ompt, rend, vol. 96 .
} 
demonstrated that a part of the sugar from a saccharine solution in which yeast liept without oxygen is sown, passes into the yeast cells and is there rapidly broken up; but this only takes place with regard to a small fraction of the sugar, and it does not occur in every yeast capable of setting up fermentation. Hence the question as regards the seat of the decomposition cannot as yet be decided witl cortainty; the great quantity of the material broker up in a short space of time leads at any rate to the presumption, that in fermentation a chemical combination between the protoplasm and fermentescible materials does not occur, but that that process is limited to the ordinary nutritive and respiratory processes of the cells.

Nägeli's theory of fermentation. Nägeli has in fact put forward some very definite reasons for believing that fermentescible molecules lying outside the cells (but it is true in their immediate neighbourhood) can be brokell up by the movements in the protoplasm. This is shown, for example, in the formation of acetic ether, which frequently accompanies the alcoholic fermentation; acetic ether is not formed when acetic acid is present in the fermenting mixture; acetic acid and alcohol must, on the contrary, meet in the nascent state; if both were produced by the same organisms it would be conceivable that they arose and combined within the cells; but the alcoliol is formed by yeast cells, the acetic acid by bacteria, and thus their combination is only possible if both the components arise outside the cells. Nägeli also observed that bacteria were able to reduce and decolourise litmus colouring-matter, although it could be shown that the colouring material could not penetrate into the living plasma of the cells. Further, numerous observations indicate that the alcoholic fermentation which occurs in the interior of minijured fruits is brought about by yeast cells, which have their seat on the skin; lastly, Nägeli explains the fact that in a sugar solution containing large numbers of reast cells bacteria which may lave been present gradually die, by supposing that the movements which are communicated from the plasma of the yeast cells to the sugar molecule ultimately pass on to the bacteria and thus weaken these 
organisms, which require another kind of movement. This fact can be utilised for obtaining, to some extent, pure cultivations of yeast and of other fermentative organisms.

Nevertheless, the observations made by Nïgeli do not lead us to any certain conclusion as to the occurrence of the fermentative action. With regard to the formation of acetic ether, it is always conceivable that the same bacteria produce both components, because re know that the formation of alcohol is not limited to the yeast fungi, and that glycerine, for example-a body always present in fermentation by yeast-is split up, according to Fitz's experiments, by bacteria with the formation of alcohol and acetic acid. Objections may also be made to the other facts brought forward by Nägeli, but, on the whole, Nägeli's view appears, at any rate for the present, to be the best grounded, and hence the most probable, hypothesis as to the act of fermentation. According to him the fermentative act occurs in this way, that as the result of the intramolecular activity in the protoplasm intense conditions of movement are brought about, and that, on the other hand, chemical molecules are present outside the cells, which are set into active morement as the result of these motions, so that the breaking up of the molecule results. Those organisms are not capable of setting up fermentation, in the plasma of which unsuitable and insufficient movements arise; only those chemical substances can be broken up by the fermentation, to which the movements can be readily communicated.

\section{The Parasitic Existence of the Lower Fungi.}

The extension of the vital activity of the lower fungi Purnsitismus which is of the greatest importance to us, is that they and symbiosis. can under certain circumstances grow as parasites on or in the higher living organisms. It does not of necessity follow that injury to the host is the consequence of such 
a parasitismus; on the contrary, there are certain parasites which can live in a plant or an animal for a long time without in any way influencing its normal existence, and indeed in many cases the parasitismus can form an advantageous symbiosis for the host, as, for example, in the lichens, which consist of a combination of algate and fungi, in which the chlorophyl-bearing algre proride carbon compounds which can be utilised by the fungus, while the latter takes up mineral nutrient materials from the substratum, and thus supplies them for the common nourishment.

As a rule, homever, the advent of parasites, and more especially of the parasitic fungi, is accompanied by more or less severe injury to the organisms which they attack. A number of the most devastating diseases of plants, animals, and man, have been proved with complete certainty to be due to parasitic fungi, and our chief motire and real aim in studying the morphology and biology of the lower fungi is the fact that they can excite disease.

Classification of the parasitic fungi.

Obligatory parasites.
Among the large number of the fungi which are capable of leading a parasitic life, we notice, when we study them accurately, differences as regards the mode of the parasitismus which render it easier to understand this peculiar phenomenon. Many of the parasitic fungi are only able to lead this kind of existence, and these can carry on their vital functions, either not at all, or only in a very limited manner, on dead substrata; other fungi, on the coutrary, also flourish as saprophytes, and their parasitic existence is in fact only a continuous extension of the wide limits within which they can carry on their life and action.

De Bary has sharply defined these differences, and lias based on them the following classification of the parasitic fungi :-

1. Obligatory parasites. These require a parasitic life in order to attain their full derelopment. They may be divided into two classes, namely, (a) Strictly obligatory purasites, which only occur in nature as parasites, and can be cultivated on dead substrata ouly under conditions artificially produced in the laboratory; and (b) 
Facultative saprophytes, which as a rule complete thoir cycle of development as parasites, but which can exist under certain circumstances as saprophytes, and can pass through some portion of their developmental cycle as such.

2. Facultative parasites. These are species which Facultative usually grow as saprophytes, but which, however, at times find the conditions necessary for their existence in living organisms, and can then multiply there.

3. Obligatory saprophytes, which cannot obtain any foothold in the living vegetable or animal organism, but can only grow on dead substrata.

The mould, yeast, and fission fungi bchave so differently in their rôles as exciting agents of clisease that they must be discnssed separately. It is not the purpose of thc present work to give an accurate description of the parasitic discases caused by the mould fungi; they will only bc noticed in so far as they furnish facts for some gencral conclusions. For a more detailed description of the diseascs of plants we must refer to the works of de Bary, Hartig, and Frank.**

The natural mode of origin and spread of the diseases caused by the bacteria will be discussed in detail in the sixth and seventh chapters, while in this place we shall only speak of the action and fate of bactcria which havc already ponetrated into the body.

\section{A. The Mould Fungi as Exciting Agents of Discase.}

(a) Parasitic mould fungi.

The monld fungi are dangerous chiefly to the higher Mould fungi plants. They are able to spread in the tissue of the phinnts. plant, their germinating tubes and mycelial threads penetrating into ratural openings or through accidental injuries of the epidermis, and then running between the cells; they frequently also bore through the walls of the cells, and in that case have probably the power of secreting a ferment which dissolves the cellulose.

The mode of action of the parasitic moulds is rery Mode of

* De Bary, Vgl. Morph. u. Biol. der Pilze, Lcipzig, 1884, P. 384, ff. - and action. Hartig, l.ehrb. d. Baumkrankheiten-Iortrïge im ïrzll. ver. zu Jü̈chen, 1881.-Frank, Die Fflankenkrankikeilen, Schenk's IFandb. d. Botanik. Breslan. 
various. At times they gradually destroy the whole of the surrounding tissue, so that a mass of fungi, consisting of mycelium and spores, occupies the place of the original vegetable substances (ustilaginer, exoascus); or alterations of a more local character arise, for example, marked growth of the parenchyma, which leads to all sorts of swellings and alterations in form (chytricliacere, cystopus, \&c.); or, finally, local alterations are less noticeable, but instead a gradual degeneration of the surrounding tissue occurs, which shows itself in discolouration and browning of the cells attacked. In by far the greatest number of cases the infection leads to death of the plant, or to death and degeneration of the fruit.

Individual predisposition

Among the large number of mould fungi there are relaof the plant.

tively few species which possess this pathogenic power, and we must assume that these species are prorided with particularly powerful means of penetrating the cell membrane. Further, each of the pathogenic forms can only attack one or a few species of plants, and among plants which are apparently similar there are often only a few individuals which are specially predisposed to the action of the parasitic fungus. Minute differences in the structure of the epidermis and of the cell walls, slight variations in the chemical composition of the cell juice, greater or less energy of growth and of tissue change, are the conditions to which must be referred the connection between certain parasitic fungi and certain plants, the immunity of other plants, and, in short, the individual predisposition to the infective diseases. The epidermis of the plants seems to oppose an especially great resistance against the fungi, and hence infection can often only occur while the parts attacked are in a young condition and still possess a delicate slin. Thus the ustilaginex and peronospora inf. only attack young plants or young seed; hypoderma macrosporon only penetrates into young pine cones. An injury of tho epidermis is often requisite to enable the mycelium threads to penetrate it; species of fumago only derelop on parts which are attaclied by aphis; in the case of 
a species of nectria, which occasions the so-called cancer of the pine bark, the necessary condition for the penetration of the germinating tube is only furnished where the bark has been eroded by moths; the spores of trametes pini sprout only on freshly broken surfaces of branches, and from that point send their mycelial threads into the wood. Frequently also it is only certain parts of the plants which are suitable for the attack and development of the fungi. Thus claviceps attacks the flowers, exoascus the fruit, and byssothecium the roots of the plants which are infected by these fungi. De Bary gives an interesting example in the parasite of the white rust of cresses, cystopus candidus, the germinating tube of which can only develop in the cotyledons, and can hence only infect those plants which have just formed cotyledons at the time at which the spores are being distributed and are germinating.

While these peculiarities in the spread of the parasitic Scasonal and diseases of plants may be satisfactorily explained by local differ-differences in inclividual predisposition, we often observe distribution another series of phenomena which cannot be referrect of epidemics to the same cause. For instance, we often see in particular localities an epidemic spread of a parasitic disease, while in other places plants of the same species are only attacked in a sporadic manner; and in like manner there are years in which the disease only spreads to a slight degree, while at other times severe epidemics occur in the same places.

These differences have their explanation in part in certain external influences which vary with locality and season, and which form the so-called local and seasonal predisposition. A factor belonging to this class which favours most of the infections caused by mould fungi is, for example, a continuous and marked degree of moisture in the air and in the soil, which of itself permits the sprouting of the fungus spores. The ustilagines, claviceps, and many otliers, require such a continuous moisture; peziza willk., which occasions the cancer of larches, only forms fruit-bearing hypha when the air is 
Factors which moist. The duration of the period of moisture is often influence the the important point; thus epidemics of rosellinia quer-
spread. cina develop only when there is continuous rain; the fruit carrier's of hypoderma macrosp. swell up and burst only when rain has lasted for several days. At times also the temperature must be specially favourable for the sprouting of the spores, and they call only cause infection when suitable temperature and suitable moisture happen to be present together:-The conditions for a successful infection are still further complicated, in that the above-mentioned factors which predispose to the penetration of the fungus mycelium into the plant must coincide with a certain stage of development of the fungus, and with external conditions which are farourable to this development. A moist warm season is often a predisposing factor which favours the growth of the parasite when young plants are present, or when, at the same time, insects have caused injuries of the epidermis, or when, as the result of storm, \&c., fresh fractures of the branches have been produced. If these predisposing factors are absent during the moist period, or if the latter occurs when the plants in question are older and provided with firmer epidermis, no infection occurs.-Here and there other more remote factors, which often seem to be a matter of chance, play a part in the development, and more especially in the epidemic, spread of the parasitic disenses of plants. Thus the development of the urediner depends upon the condition of their second host, which they require as the result of their alternation of generation, and if the barberry bushes are accidentally or intentionally remored the rust of grain ceases; in many species of fungi suitable means of transport must aid the spread of the spores, as in the case of phytophtorn fagi, where men and animals in passing transport the spores. Lastly, in some cases where infection can only occur in the immediate neighbourhood from the furtler spread of the mycelium, everything depends on the grouping of the plants which can be attacked; it is only when these occur in close contret with eacl other that an epidemic 
spread can take place, while the latter is impossible as soon as other species of plants, which are not liable to the infection, are mixed with the individuals of the kind that are threatened.- It is evident that by taking into consideration all these numerous factors which exercise an influence on the occurrence of epidemics, the rise and fall of the parasitic diseases of plants can be explained, and that at the same time these observations, which can be made ou plants with great certainty, must be of great advantage in enabling us to understand the epidemics of animals and man with which they offer numerous analogies.

Among animals it is chiefly the invertebrata, and, Mould fungi among these, the insects, which are attacked by para- as parasites sitic mould fungi. The infection always occurs by the penetration of the mycelial threads into the external uninjured skin; in the case of empusa radicans it has been demonstrated, as the result of experiments, that infection never occur's from the intestine. In some In insects. cases the fungus may enter almost anywhere; for example, laboulbenia can penetrate through the back, head, legs, or wings of flies. In other cases the place of entrance is limited; empusa muscre, for example, can only enter at the abdomen of the fly, and in the case of isariæ the infection of the caterpillars occurs through the stigmata of the tracher.-In some cases the parasitic fungi cause very little inconvenience to their host; thus laboulbenia muscæ may exert no injurious action, but the insects attacked usually die. The mycelium threads, when they have penetrated into the body, grow througli the muscle and fatty tissue, and usually give off conidir in the blood, which grow to form an extensive mycelium; during this process there is an almost entire consumption of the structures of the animal attacked. Such an energetic growth is only conceivable when the nutrient conditions which the animal body offers are particularly favourable to the fungus, when the animal cells assimilate with very little energy, and when there is a more or less complete absence of reaction. These conditions appear to be present in the insects which are 
In fish and bircls.

In mall. attacked. Here, however, we can also recognise certain predisposing factors; thus it has been observed that botrytis bassiana does not attack all silk-worms equally, but chiefly young individuals, and mole especially those which are in a weak state as the result of imperfect nourishment, \&c. It is only by careful selection in the culture of the silk-worms that this disease can be combated.

An infection by saprolegnia has been observed in fish; the fungus occasions, in the first place and very gradually, a disturbance of the function of the skin, and an affection of the gills, and, according to de Bary, the disease develops only in fish which are already ill from other causes. In the case of birds, mould fungi occur comparatively frequently in the respiratory organs; Bollinger* and Schütz (see p. 124) have shown that these fungi do not occur secondarily in organs previously diseased, but that they are the primary causes of the disease; they develop partly in the trachea and in the bronchi, partly also in the tissue of the lungs and in the cavities of the lung, and they cause severe disturbance of the respiration, and ultimately lead to the death of the animal. The forms which have as yet been found are species of aspergillus and mucor; possibly the same which grow also in mammals and in man.

In man epiphytic development of pathogenic mould fungi is frequently met with on the external surface of the skin, where they set up diseases of the skin (favus, tinea tonsurans, \&c.). Certain species of aspergillus and mucor also frequently develop on collections of dend portions of tissue, for example, on the coating of the tongue, in the contents of a dilated stomach, in carities of the lungs, \&c.; also in the external auditory canal and on the cornea, where they set up inflammation.- If spores of saprophytic mould fungi (penicillium) are injected into the circulation of dogs or rabbits, they stick on the walls of the capillaries, or in the endothelial cells, especially in the liver, spleen, and medulla of bone, and they may remain there for a long time without

* Vortrüge im ärall. Vevein au Mrünchen, 1881. 
sprouting, and without causing any disturbance. Wyssokowitsch* was able to demonstrate their presence in these organs in large numbers even after seven days. If, on the other hand, the spores of certain species of aspergillus and mucor were injected into the reins, the sprouting of the spores occurred at various parts of the body, and masses of mycelium were formed, which were visible to the naked eye. If very numerous spores were injected, and if very large numbers of these mycelium masses developed, the animals died. As has been above described (see p. 123), the largest number of the deposits after injection of aspergillus and mucor occurred in certain organs. This apparent choice of certain parts of the body does not depend only on variation in the distribution of the spores and on greater deposit of the spores in certain organs differing according to the species of fungus injected; but the sprouting of the spores and the derelopment of the mycelium in the organs is also more or less favoured by certain other conditions, so that, for example, spores of aspergillus glaucus form the most luxuriant mycelium in the kidneys and in the liver, and the spores of mucor the most distinct and numerous deposits in the kidneys, mesenteric glands, and Peyer's patches, while in other parts the spores either do not sprout at all or only to a very imperfect degree.

That only a few species of mould fungi occur in the Limited bodies of warm-blooded animals seems to be chiefly, but development not exclusively, due to the fact that only these forms fungi in the can, at the high temperature of warm-blooded animals, animal borly develop a sufficient amount of energy to enable them to live in concurrence with the cells of the animal body (see p. 136). The limitation of their fructification to the surfaces of the animal body is explained by the necessity for contact with free air.

On the whole, among the infective agents of higher animals the mould fungi play only an insignificant part, the nutrient conditions which they find there are unsuitable, the temperature being liigl, the juices of the body being highly albuminous and weakly alkaline, and

\footnotetext{
* Zeitschr.S. Ilygiene, vol, i., Part 1.
} 
further they are completely surrounded by fluid media, so that an extensive formation of mycelium or fructification can nerer occur. On the other hand, the chemical composition as well as the temperature of the juices of plants furnish better conditions of existence for the mould fungi, and here, as in the case of insects, they find an opportunity of quickly penetrating through the whole mass of the body attacked, and of thus bringing the mycelial threads into contact with the free air.

\section{B. The Budding Fungi as Infective Agents.}

Parasitic yeast fungi.
Parasitic bacteria.

In plants.
Parasitic budding fungi have never as jet been observed in plants, and in animals they occur extremely rarely, and then only as epiphytic parasites. The only known case of the latter kind is that of the fungus of thrush, which for a time was looked on as a species of mycoderma. Large numbers of yeast cells also at times occur in the stomach and intestines of man, and probably on account of the plentiful supply of saccharine nutriment, can keep up fermentation for some time, and can thus occasion certain disturbances.

\section{Fission Fungi as Causes of Disease.}

In contrast to the mould fungi, the bacteria almost never attack higher plants, while warm-blooded animals very frequently serve as their hosts. In the affection known as the yellow disease of hyacinths in Holland, we have however, according to Wakker, * an exception to this rule in that an accumulation of yellow gelatinous bacterial masses occasions the disense of these plants. The low temperature and the chemical composition of the regetable juices is evidently very unfavourable for the development of bacteria, more especially as the cell juices are almost always distinctly acid, and thus protect the plants against the bacteria, which are so sensitire in this respect. Further, the cellulose which surrounds ench indiridual

* Botan, Centralbl., rol, xir. 
cell cannot be dissolved or penetrated by the majority of bacteria; some forms, it is true, can convert the dead cellulose into sugar, or can cause it to ferment, but even these organisms appear to be unable, under the otherwise unfavourable conditions, to live in concurrence with the living vegetable cells. On the other hand, in the warm-blooded animals the bacteria find a substratum, rich in albumen, faintly allialine, and at a temperature of about $37^{\circ} \mathrm{C}$., and thus they have the most favourable conditions for their derelopment and multiplication; hence the bacteria threaten the living animal with much more serious danger's.

Nevertheless, it is by no means all bacteria which are In animals. able to live in the living animal; on the contrary, we can here also employ the classification given by de Bary, of obligatory parasites, facultative parasites, and true saprophytes. The species belonging to the group of the saprophytes are much more numerous than the others; bacteria, such as bacillus subtilis, micrococcus flavus, bacillus erythrosporus, micrococcus aquatilis, and innumerable other forms, can be introduced in enormous quantities into the veins, subcutaneously by the mouth, or by inhalation into living warm-blooded animals without causing any injury to the body.

Among the facultative and obligatory parasites, the Various different species show the most various degrees of patho- pathogenic genic action.-In considering this question it must be action. remembered that the parasitic bacteria are often limited to definite species or races of animals as their hosts, and that not uncommonly the same species of bacterium which in one class of animals excites a severe disease, behaves in regard to another class as a pure saprophyte. We shall enter more minutely into these important differences in the chapter on "Predisposition" ; we need only point out here that we are accustomed to reckon a species of bacterium among the group of prasites if it exerts pathogenic action on any" one species of animal.

The least amount of parnsitic energy is shown by those Bacteria bacteria which almost never multiply in the interior of which causc the living body, but vegetate only on the surface, on the menus of their 
ptomaines when they grow over a larere extent of surface.

Bactcria which act as poisons in smaller number's, and which ultimatcly penetrate into the body. which readily penetrate into the body, and multiply in its interior. skill, on the mucous membranes, on wounds, in the intestine, \&c., and cause injury to the body by producing ptomaines which, being soluble, penetrate from the surface into the body and there act as poisons. Many of the bacteria belonging to this class live as a rule as saprophytes. Some of them excite fermentation and putrefaction; they do not injure the living animal at all so long as they occur in small numbers on the surface, and it is only when they can develop in large numbers, and when they are not removed from time to time, as occur's under normal conditions, that the production of ptomaines is so marked that injury to the host ensues.

Some bacteria have a more marked pathogenic character, in that they produce very poisonous ptomaines, to which the bodies of warm-blooded animals have not become gradually adapted. Hence these injure the organism, even when they are growing only over a slight extent of surface. It not uncommonly happens in this case that the ptomaine action is only the precursor of the invasion of the bacteria into the interior of the body; the latter is so wealiened by the poisoning that the bacteria find less resistance, and can develop in the blood and in the organs, which previously could easily have resisted their invasion.

A further stage in the development of parasitismus is represented by those bacteria which, without further assistance, and in relatively small numbers, can establish themselves in the interior of the living body and multiply there. These either lead to local morbid processes (tuberculosis, pneumonia) at the place of entrance, ol they spread through the whole body with the circulation, and grow in the whole of the capillary vascular system. The bacteria then occasion either morbid growth of tissue or necrotic destruction of tissue, or the mechanical disturbances of the tissue change and of the cell life which results from the distribution and multiplication of the bacteria leads to grave injury to the animal by means again of specific ptomaines.

Growth in the The gradual spreading necrosis of the tissue, and the body accompanied with necrosis of the spread of the bacterial growth into new territory killed tissuc 
by the action of the products, is very claracteristically seen in the progressive necrosis of tissue observed by Koch in the case of mice (see p. 209), also in connection with the bacilli of pigeon diphtheria, \&c. (sce p. 326). It is probable that such bacteria do not always lead to a progressive destruction of the tissue; at times it is evident that such a violent reaction and such a great new formation of cells occurs that the development of the bacteria and the production of the injurious materials cannot lieep pace with it; in that case the inflammation indicates the limit and the end of the bacterial development.

Another mode of development within the living body Development is illustrated for example by the bacilli of malignant parasites. nedema, and of symptomatic anthrax. These bacilli, belonging to the class of anaërobes, are not able to multiply in the living blood, nor in open wounds, nor can they grow when introduced in minute quantities; on the contrary, they require the previous occurrence of an injury which must furnish at least a certain amount of dead tissue, and further they must be present in large numbers from the beginning; or if a wound is present oxygen must to a certain extent be excluded from it; further, the bacilli do not penetrate in all directions in the various tissues of the body, they only grow where the smallest amount of interchange of gases renders their existence easier, for example in the subcutaneous cellular tissue, or in the serous coverings of the organs; and it is only when the whole body has become cxtremely poor in oxygen-as a rule only after death-that they are able to develop in the blood and in the various internal organs.

Another mode of spread and penetration is shown by Penetration the micrococci of erysipelas. These also do not multiply into the in the blood-vessels, nor, when injected into the reins, vessels. do they cause any disease of internal organs; on the contrary, they only grow in the lympli chamels of the skin, exciting here a locally limited inflammation, and furnishing also, in all probability, toxic materials, by the absorption of which the marked general symptoms 
are produced. They do not show any very great parasitic energy, because, as a rule, they are only found in a living state at the margin of the crysipclas, and apparently very readily succumb to the influence of the living tissue cells which accumulate there.

Penetration Lastly, those species of bacteria which cause the
into, and within, the blood-vessels. numerous forms of septicrmia and pyæmia which have been closely studied in animals, live and act chiefly in the blood-vessels. They multiply most readily and rapidly in the free blood current; they arc found especially in the smaller vessels and in the capillaries in such numbers that the ressels are here and there completely filled with them, or the blood corpuscles appear embedded in a large mass of bacteria. They form a thick layer on the walls of the ressels, and their distribution is so extensive that, on making sections from any internal organ, almost all the capillaries in every preparation are found completely lined by them. Many bacteria also attack the colourless blood corpuscles; in preparations of such blood large plasma cells are found, which are quite filled with bacteria, others are met with in the stage of decay, which has evidently been caused by the entrance of the bacteria (as in the so-called mouse septicæmia, p. 310). As the result of this extensive ristribution of the bacteria serious alterations must occur in the tissue change of all the tissues involved; the energy of the nutrient stream which passes into the tissues from the capillaries, the removal of the waste products formed in the tissue cclls, and the exchange of gases in the tissue, must all undergo a marked alteration; in correspondence with the altered nutrition of the cells there is an alteration in their functional activity, in the first place, in that more extensive decomposition of the material which is present occurs, for which, ou the other hand, there is no corresponding substitute; in like manner the new formation of cells, in place of those which are exhausted or dead, does not occur in a mormal manner. Finally, in addition, we have perhaps also the production of specific moxious materials on the part of the growing bacteria, and thus there results a complete 
disturbance of the tissue change and of the arrangements which regulate the functions of the body, and this disturbance goes on till severe general morbid symptoms occur, which usually lead to death.-Some of the micro- Embolism. organisms which belong to this class may very readily lead to blocking of the smaller blood-vessels, either by their accumulation in large numbers, or by the heaping up of materials which have arisen from the breaking up of the plasma cells; in such cases there very readily occurs, in parts, necrosis of the surrounding tissue, and subsequent development of the bacteria in this tissue, which still further degenerates under the direct action of the organisms. At times the most active multiplication of the bacteria in the capillary system only occurs in one or some organs which are particularly predisposed, and thus the emboli often show a predilection for certain organs. Thus it happens that the local symptoms are often the most striking, and that the type of the disease varies markedly, according as in the one case the general phenomena, in the other, these or those local symptoms are prominent.

The power possessed by a limited number of bacteria Biological of leading a parasitic existence in the body of warm- peculiarities blooded animals raises the question to what biological genic bacteria. peculiarities of these bacteria this power is due; what differences exist between their properties and those of the saprophytic bacteria; what are the protective arrangements of the living body which render the multiplication and development of the latter impossible, but which, on the other hand, are powerless against these patlogenic bacteria?

'The attempt was formerly made to explain this rela- Resistance tion by the aid of some one active factor in the living against the organism. Thus, it has been pointed out that it is tho fluids of possible that some bacteria can only grow in a quiescent medium and not in the fluids of the body which are in active movement, and it has been supposed that 
Resistance against oxygen?
Resistance against excretion from the body?
Horvath's experiments give some support to this view. But these experiments, and the control experiments which have been since made, do not, as has been mentioned above (p. 535), yield any satisfactory results applicable to the continuous flowing movement of the: fluids of the body.

The supposition has also been frequently expressed that the bacteria which are able to live in the living body are only those which find there a sufficient supplyof oxygen, and as Szpilmann had shown that anthrax bacilli are not destroyed by the action of ozone, while putrefactive bacilli are rapidly killed, there seemed to be some ground for this view.-But more accurate experiments which have been made by Liborius, * as to the requirement of oxygen by the pathogenic bacteria, have shown that these are obligatory or facultative anaërobes, and require much less oxygen than a large number of saprophytes. On the contrary, a certain indifference with regard to oxygen seems to be a necessary condition for the parasitic existence of the bacteria; it is only thus that they are able to develop a large amount of vegetative energy in parts of the body in which the tension of the oxygen is very low.

Further, the view has been frequently expressed that the living body tries to prevent the development of bacteria by continually eliminating any organisms which get into the blood stream by the lidneys, and ultimately by other secretory organs, from which it would follow that only those bacteria are capable of growing in the boly which can multiply in the material present in it and at that temperature with such an amount of energy that the continued elimination of a large number of the bacteria is provided for.-But by the researches of Wyssoliowitsch* it has been definitely shown that the normal living body does not excrete saprophytic and pathogenic bacterin. This only takes place when pathogenic bacteria have become deposited and liave grown in a secretory organ, and when, in consequence of this growtli, injury to the tissue of the

* Zeitschr.f. Ifygiene, vol. i., Part 1. 
organ has occurred.-Besides, it may be easily seen that Preference the mutrient materal present in the blooded animals, and the temperature of the body, are ditions in tho not specinlly favourable for the pathogenic organisms, and do not enable them to multiply more rapidly than the saprophytes; for in a dead body, kept at $37^{\circ} \mathrm{C}$., the saprophytes obtain the mastery in a short time, even when they have been introduced in smaller numbers than the pathogenic bacteria.

This want of influence of the movements of the Resistance $t$, fluid, of the tension of the oxygen, of the secretory the living functions, of the temperature, and of the chemical composition of the body on the one hand, and on the other hand the fundamental alteration of the conditions of existence of bacteria when death of the body occurs, shows us that it is in the protoplasm of the living cells that the most important factor, and that which regulates the differences in the behaviour of saprophytes and parasites, lies. Only those bacteria can be reckoned in the latter class which are able to obtain the mastery, and to multiply in concurrence with the living cells, while the saprophytes are not able to grow when subjected to the influence of the living cells, but on the contrary die. Thus the living cells would form the seat where the body carries on the battle with the invading bacteria, where the saprophytes are destroyed, and where the parasitic bacteria gain the victory.

This view of a battle between the cells and bacteria, for a time only obtained by deduction, seems to have gained a definite support from the experiments of Metschnikoff. He was able in experiments with a Metschnikof : yeast parasite of daphnis, as well as in experiments with phagocytes. anthrax bacilli, which he introduced under the skin of frogs, to observe that bacteria are taken up by leucocytes; the bacteria were gradually destroyed in the substance of the leucocytes, being as it were, digested. Metschnikoff at a later period mado similar obserrations in rabbits and guinea-pigs which he had inoculated with attenuated anthrax bacilli. Nevertheless, Metschnikoff's experiments are by no means free from 
objection, and a large number of control investigatious which were made in the author's laboratory by Wyssoliowitsch lecl to a totally different result, and showed that after introduction of large quantities of saprophytic and pathogenic bacteria into the blood stream of warmblooded animals the leucocytes did not take them up. They play no It is only some specific forms of bacteria which are part in warmblooded animals.

Wyssoliowitsch's investigations.
Fixation of tho bacteria on the walls of the capillaries. found constantly in large numbers within the colourless blood corpuscles, such as the bacilli of Koch's mouse septicæmia, or of swine erysipelas. In these cases, however, the leucocytes which occur in all stages of degeneration give much more the impression as if they were the attacked and decaying part, and the bacteria, on the other hand, of which large numbers are found in the dying cells, as if they were the victorious agents.

Certain other cellular elements of the body seem, however, as a matter of fact, to play an important part in the battle with the invading bacteria. According to the more recent investigations by WJssokowitsch, bacteria, botl saprophytic and pathogenic, when introduced into the blood of warm-blooded animals are in the first place very rapidly eliminated from the circulating blood, in a similar manner as has formerly been shown in the case of particles of colouring matter. This disappearance from the blood stream is not occasioned by excretion of the bacteria in any of the secretions, nor by their destruction in the circulating blood; but the bacteria are fixed in the capillaries of rarious organs, chiefly of those where the current of blood is slow; the adhere to the walls of the capillaries, or are taken up into the interior of the endothelial cells. These bacteria are found in largest numbers in the liver, spleen, and medulla of bone. The fight with the parasites seems to occur at the seat of deposit chiefly in the endothelial Death of non-cells, which results either in death of the bacteria or in pathogenic the destruction of the cells which are immediately conendothelial cerned, and the multiplication of the bacteria. It can
colls. be observed that typical saprophytes die at the seat of deposit in a relatively short time - within a few hoursand bacteria which are pathogenic for other species of 
animals, within twenty-four to forty-eight hour's. It is only the spores of sapropliytes, for example of bacillus subtilis, which evidently play the part of completely indifferent foreign elements, that were found alive and capable of development after about three months in the endothelial cells of the capillaries of the spleen and liver.

When the bacteria do not enter in large numbers nor directly into the blood, but in small numbers through slight injuries of the skin or of the mucous membrane, a similar battle between the bacteria and the tissue and endothelial cells of the immediate neighbourhood, probably also occurs in the first instance, and thus all those bacteria are pathogenic for a definite species of animal which, after their contact with these cells, are able to grow and multiply, while the cells, on the contrary, undergo pathological alterations or die.

We obtain, also, a further insight into the causes of the pathogenic action of bacteria by some experiments, which will shortly be published by Wyssokowitsch, in which he succeeded, by artificially lowering the energy of the cells of the body, in enabling bacteria which, under ordinary circumstances, are not pathogenic for the animals employed, to multiply rapidly and occupy the whole of the living body. Such a weakening of the Nox-pathobody resulted, for example, by the employment of high genie bacteria temperatures approaching closely the body temperature genic when by which the tissue change was as much as possible artificially reduced; further, by certain mineral poisons, such as weakened. chromate of ammonia; by far the most completely and rapidly, however, by some of the ptomaines furnished by bacteria. The products furnished by bacillus crassus Infineuee of sputigenus, by bacillus Neapolitanus, \&c., act apparently ptomaines. on the walls of the capillary vessols, and alter the endothelial cells in such a manner that small quantities of micrococcus totrageuus, Finkler's spirillum, bacillus prenmonixe, and other species of bacteria, not at all injurious to normal rabbits, can multiply in enormous numbers after the injection of these products, are not completely removed from the blood stream, and do not tie in the cndothelial cells. 
It is probable that we must explain in an analogous manner the former experiments by Salomonsen as to the action of jequirity on frogs (p. 348); further, the influence of papayotin on the number of bacteria in the blood, as observed by Rossbach. The investigations in this direction must be still more extended and varied before we can draw general conclusions from them; we may, however, expect that they will ultimately enable us to obtain definite views as to the more intimate details of the battle which occurs between cells and bacteria. 


\section{PART Y.}

CONDITIONS AFFECTINa THE DEATH OF THE LOWER

FUNGI.

Tarious external influences cause injury to the lower Disinfection. fungi, and affect their vital activity more or less profoundly. All these injurious factors are evidently of great interest, because we must search among them for the meaus to enable us to oppose the grave dangers which threaten us on the part of the fungi, namely, the infective diseases; and the whole of the influences which alter the normal life of the lower fungi are asually considered together under the heading "Modes of Disinfection."

Very numerous experiments have been already made Difference in with regard to the mode and the degree of action of the action of disinfecting means; these means acdisinfecting means; these must, nevertheless, be still cording to greatly expanded. For just as in the study of the fungus. biological character's of the fungi, so in this case it has been found that the various species do not behave in the same manuer, but that the one is most markedly afficted by this influence, the other by that; and that, further, the sum total of the other conditions of life which are present influences the action of the individual disinfecting means. High temperatures injure the fungi According to more readily when bad nutrient materials are present at ditions of life. the same time; the active dose of specific poisons varies according as the external conditions represent the optimum or vary from the optimum. The stage of development of the bacteria las also a marked influence on their resisting power; young individuals as a rule are more resisting, while older individuals which are approaching the stage of iuvolution can be destroyed 
Aeeording to the stage of development.

by trivial and transiont injuries. The effect of the formation of spores is of very special importance. If we have to deal with organisms which form thesc extremely resisting bodies, means which would greatly injure, or cven destroy, other fungi may be entirely without effect. Hence in disinfection experiments spore-bearing and non-spore-bearing organisms must not be mixed together, each must be tested separately.

Among the means of disinfection we reckon not only those which kill and destroy the organisms, but also those influences which only cause a permanent loss or a diminution in activity of some of their vital phenomena, and even those which only occasion a temporary delay in their growth and multiplication. These different degrees of degeneration and death require a separate discussion.

\section{I.-Inhibitory Means.}

Inhibition of development.

Inhibitian of individual vital phenomena.
The smallest degree of injury which micro-organisms can experience, as the result of external influences, consists in a disturbance of their complete development, which only lasts so long as the injurious factors are present, while afterwards under normal conditions the ordinary vital phenomena can again go on undisturbed.

Minute departures from the normal conditions of cxistence often lead to cessation of some one biological function. Thus by alterations in the nutrient substrata, by diminution in the amount of oxygen, by a temperature somewhat too low or too high, we may hare cessation of the swarming power, of the secretion of peptonising ferments, of the fermentative action, of the production of colouring matter, or of the spore formation; while otherwise growth, multiplication, and all other vital phenomena remain unaltered. Their power in producing disease also may be influenced by similar trivial alterations in the conditions of life, and may eren be temporarily removed; and it would be a matter of great interest to learn more accurately the various means-for example, small doses of specific poisons, alterntions in 
temperature, \&c.- by the employment of which we might be able for a certain time to neutralise the superiority of the pathogenic bacteria over the cells of the animal body.

The cessation of all vital phenomena, and also of Complete growth and multiplication, is only brought about by inhibition of marked abnormalities in the external conditions. A partial interference with growth is produced by all those alterations in the conditions of existence which lead to a departure from the optimum. These most favourable conditions of existence have been referred to already in detail, and it has also been pointed out in what way every variation of temperature, concentration, \&c., beyond a certain limit results in interference with the vital energy of the fungi.

Complete cessation of growth frequently occur's as the Withdrawal result of gradual exhaustion of the nutrient materials. of necessary In every nutrient medium it ultimately happens, as the materials. result of continued multiplication of the fungi, that some or all of the colonies no longer find the nutrient materials necessary for their further development. In fluids the yeast or fission fungi which have already formed are deposited in the form of a powdery precipitate on the bottom of the vessel. It depends chiefly on the species of the fungus in question how long they can retain their vitality under such conditions without a fresh supply of nutriment. Some only exist in a latent condition for a short time, they soon degenerate and break up; others are much more resisting. To the first group belong the majority of the micrococci, to the latter the spore-forming bacilli, the spores of which can retain their vitality for years; but many micrococci also-for example, Staphylococcus aureus-show a similar resisting power. It is not necessary that all the nutrient materials should be exhausted; on the contrary, the loss of a single necessary material is sufficient to lead to a period of rest.

A very fiequent cause of cessation of the growth of withdrawal bacteria is the diminution of the necessary amount of of witer. water in the nutrient medium. Growth ceases on the most varions nutrient media on the surface of the soil, 
\&c., whenever the amount of water has fallen below 60 to 70 per cent.; more accurate determination of these limits is, however, wanting.

Light: and pressure. electricity,

Among other influenees light and pressure seem scarcoly to exert any notieeable cffect on the development of the lower fungi. Certes and Cochin found that yeast could break up sugar under a pressure of 300 to 400 atmospheres; in like manner putrefactive phenomena occurred in fluids which were kept under a pressure of 350 to 500 atmospheres.Flectrieity, in the form of the constant galvanie eurrent, eauses cessation of the multiplieation of the bacteria; this effect is due to the electrolytie action of the current, which leads to the production at the positive pole of a distinctly acid reaction, and at the negative pole of a distinctly alkaline one. No influence is notieenble when the eurrent is weak; the effect is not produced till at least two powerful elements arc employed.

Temperaturc. Of much greater practical importance is the temperature of the nutrient medium. At a low temperature as well as at a high temperature multiplication of bacteria (and also of mould fungi) ceases; but in almost all species the limit of the low and high temperature appears to be different. In the case of many organisms these limits liare not yet been accurately determined. In the case of many saprophytes (the water bacteria, the organisms formerly grouped under the term "bacterium termo," \&c.) slight growth may occur at a temperature of $+6^{\circ}$ C., and development only ceases at a temperature of from $4^{\circ}$ to $5^{\circ} \mathrm{C}$. On the other hand, the lowest limit of growth for the spirillum of Asiatic cholera is from $15^{\circ}$ to $16^{\circ} \mathrm{C}$; for the bacilli of glanders, about $22^{\circ} \mathrm{C}$.; and for the tubercle bacilli, $33^{\circ} \mathrm{C}$. Cessation of multiplication as the result of higher temperatures occurs: in the case of the lactic acid bacillus, above $45 \cdot 3^{\circ} \mathrm{C}$; in the case of bacterium termo, from $40^{\circ}$ to $43^{\circ} \mathrm{C}$; in the case of bacillus subtilis, at $50^{\circ}$ to $55^{\circ} \mathrm{C}$. The higher limit is difficult to ascertain, because the temperature which only leads to temporary cessation of vital activity, and that which-more especially when it acts for a considerable time-causes permanent loss of certain properties, usually lie very close to each other. 
Of great practical importance also is the cessation of Chemical development as the result of the addition of small quan- poisons tities of active chemical and specifically poisonous materials to the nutrient substrata. Here also it is not easy to ascertain precisely the value of these means, because they behave very differently according to the composition of the nutrient substrata. This difference chiefly depends on Difference iu the fact that when these chemical materials are added the action to the nutrient substrata, chemical decompositions fre- the nature of disinty occur, as the result of which a portion of the substratum. Hence it is clear that definite values of the inhibitory means can only be laid down in the case of one and the same nutrient solution, while the values will differ where the composition of the nutrient substratum varies. For example, Boillat* ascertained that in albuminous substrata chloride of zinc and other metallic salts only produced a disinfecting action after all the albumen was precipitated by them, and when a sufficient excess remained in the solution for purposes of disinfection. Further, as mentioned above, various species of fungi behave differently towards noxious agencies, and in the same species the degree of the action always depends on the other conditions of life which may be present at the same time. Hence a generally applicable scale of the value of disinfecting substances cannot be given; and in like manner trustworthy results are only obtained from those experiments which have been made with known and well-characterised species of bacteria.

Of the figures which have been as yet published we Experiment.: may mention here only a few, some of which, however, by Dela Croix have not been obtained by the employment of all the in meat inabove-mentioned precautions. De la Croix tested the bacteria of meat infusion (that is to say, not a pure cultivation of a single species), and found that their development in meat infusion ceased when the following substances were present in the degree of concentration mentioned below :-

* Journ.f. prakt. Chem., N.F., vol. xxy. 
By Ratimoff sion aseptic, the following concentrations were necessary:-

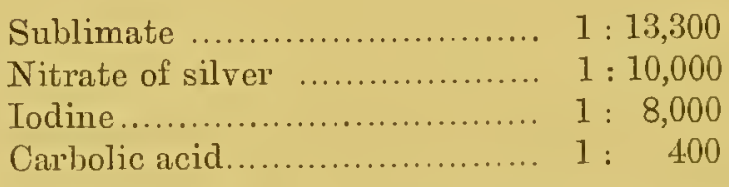

In order to prevent the development of bacteria ou meat, about 30 times the amount given above was necessary.

By Mignel. According to Miguel's experiments, development of bacteria in meat infusion is prevented by-

\begin{tabular}{|c|c|}
\hline & $1: 40$ \\
\hline xide of hydrogen & $1: 20,000$ \\
\hline ic chloride...... & $1: 14,300$ \\
\hline Nitratc of silver & $1: 12,500$ \\
\hline Iodine .............. & $1: 4,000$ \\
\hline rorme & $1: 4,000$ \\
\hline & $1: 1,66 \overline{7}$ \\
\hline & $1: 1,100$ \\
\hline & $1: 1,000$ \\
\hline $1: 500$ to & $1: \quad 333$ \\
\hline .................... & 1: \\
\hline of potash ... & 1: \\
\hline Arse & 1: \\
\hline Borncic acid .... & 1: \\
\hline fi iron. & 1: \\
\hline & \\
\hline & \\
\hline odide of & \\
\hline
\end{tabular}


Koch has tested the inhibitory action of various poisons Experiments on non-spore-bearing anthrax bacilli. The results were baithili. obtained by filling small vessels with $10 \mathrm{ccm}$. of blood serum or of peptonised meat infusion ( 1 per cent. peptone, $\frac{1}{2}$ per cent. meat extract and water), and then adding the disinfecting substances. A number of these vessels, and among them some without any disinfecting substances, were placed side by side under a bell-jar in the presence of moisture. A silk thread, impregnated with anthrax spores, was then placed in each vessel; in the control ressels growths of long anthrax threads were always present after twenty-four hours, and presented a very characteristic appearance, and one not easily mistaken. In a similar manner the other vessels were examined under the microscope in the course of the next few days, and thus absence of growth or the appearance of threads indicated the activity or inactivity of the disinfecting means. (In the case of other species of bacteria nutrient gelatine is often preferable for these experiments, the chemical substance to be tested, and also a small quantity of the bacteria, being added to it, and then the liquefied jelly poured out on glass plates.) The following are the most important figures obtained by Koch :-

Distinct hindering of Complete cessagrowth tion of growth

Occurred when the concentration reached

\begin{tabular}{|c|c|c|}
\hline & $1,600,000$ & .. $1: 300,000$ \\
\hline & $1: \quad 330,000$ & $1: 33,000$ \\
\hline Allyl-alcohol & 167,000 & - \\
\hline Arseniate of potash & 100,000 & 10,000 \\
\hline Thymol ................... & 80,000 & - \\
\hline בין & 75, & - \\
\hline$H_{y} \mathrm{~d} x$ & $4: 0,000$ & $1: \quad 8,000$ \\
\hline Oil of pep & $\begin{array}{r}33,000 \\
5,000\end{array}$ & … \\
\hline Potash soap & $\begin{array}{l}5,000 \\
5,000\end{array}$ & $1:-1,000$ \\
\hline Iodine .......... & 5,000 & - \\
\hline Hydr & 2,500 & $1: 1,700$ \\
\hline Bolacic acid .. & 1,250 & $1:$ \\
\hline $\left.\begin{array}{l}\text { Brominc } \\
\text { Chlorine }\end{array}\right\}$................ & 1,500 & - \\
\hline Permanganate of potash... & 1,400 & - \\
\hline
\end{tabular}


Letion of various metallie salts
Distinet hindering of Complete eessa-
growth

Oeeurred when the eoncentration reached

\begin{tabular}{|c|c|c|c|}
\hline Salicylic acid & 1: & $8,300 \ldots \ldots .1$ & 1,500 \\
\hline Benzoic " . & $1:$ & 2,000 & - \\
\hline Carbolic & $1:$ & 1,250 & 8.50 \\
\hline Benzoate of soda .... & 1: & $200 \ldots \ldots$ & - \\
\hline Camphor.............. & 1: & 2,500 , over 1 & 1,250 \\
\hline Quinine ..... & $1:$ & $830 \quad \ldots \ldots .1$ & 625 \\
\hline Alcohol ........ & 1: & 100 & $12 \cdot v$ \\
\hline Common salt. & 1: & 64 & 一 \\
\hline
\end{tabular}

A series of expcriments by Richet* may also be montioned where the fluid employed was a mixture of 900 grammes of sea-water, 100 grammcs of neutralised urine, and 1 gramme of peptone, the attempt being made to ascertain how much of the various metallic salts it was necessary to add to this solution to prevent the development of bacteria. In the following table the amount of the pure metal has been calculated from the amount of the metallic salt which it was neccssary to add to each litre of fluid, and also for comparison those figures are given which correspond to the quantity of metal per litre which was necessary to kill salt water fish. From this comparison we see at once the much grcatcr resisting power of the bacteria, and also the unequal behariour of certain metallic poisons in reference to the animal and vegctable ccll.

\section{Amount of metal per litre of fluid}

To hinder the development To kill fish. of bacteria.

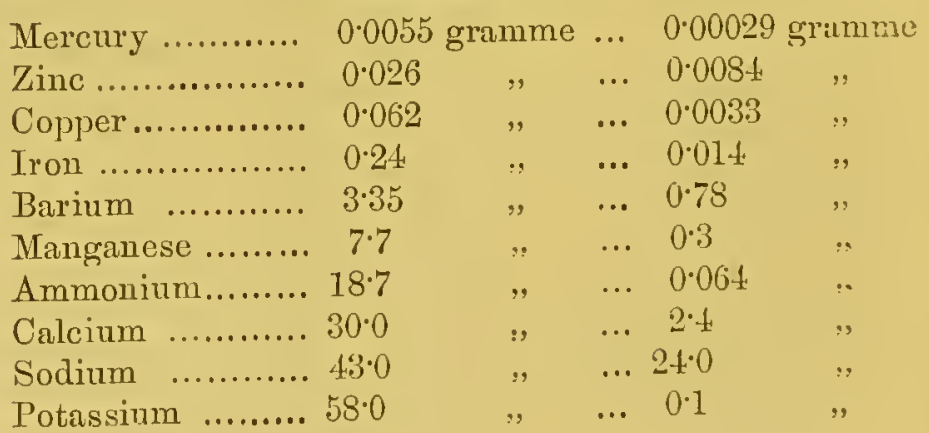

Of the inhibitory substances not included in the foregoing tables, but which have becn tested and recommended, we may mention the following :-

Other

disinfeeting substanees.

According to the experiments of Wassileff $f$ calomel has an

* Compt. rend., vol. 97.

+ Zeitschr.f.physiol. C'hem., rol. ri. 
encrgetic action in preventing putrefnction, whilst it docs not interfere with the activity of the digestive ferments.According to Schulz and Hoffmann organic acids of the fatty series, citric acid, formic acid, \&c., are powerful antiputretactive substances; formic acid in the amount of 25 per cent. is able to preserve Bucholtz's nutrient fluid for months. According to Donath* chinolin is antiputrefactive in the percentage of $\cdot 2$, and according to Vigier torthophenolsulphoacid is actire in a percentage of 5 to 1 .-Bert and Regnard + have made experiments as to the antiseptic and disinfecting properties of peroxide of hydrogen, and Chappuis $\S$ on ozone, lut without paying sufficient attention to the dose of the substance and the species of the bacterium.-Kolbe drawn attention to the fact that when kept in vesscls fillcd with carbonic acid fresh ox flesh can be preservod against putrefaction for four to fire weeks; mutton cannot, however, be similarly preserved. More accurate examination of the antiseptic properties of carbonic acid is desirable.

According to experiments by Kuisl potash soap is not such a good inhibitory substance for other bacteria as for. anthrax bacilli. Even when present in a concentration of 10 per cent. it was not able to prevent putrefaction in meat.

\section{II.-Attennation of Pathogenic and Fermentative Organisms.}

By noxious influences of definite but closely limited At'cunation intensity we may so alter many bacteria that they losc certain of their vital functions, this loss lasting for a long time and even when the cultivation is continued under completely normal conditions. The noxious factors which are suitable for this action are less encrgetic than those which cause complete death of tho bacteria; on the other hand, the effects are more marked than in the case of the inhibitory means, which only exert their action so long as they are present in the nutrient substratum. At times, however, the greater offect necessary for attenuation can also be produced by sufficiently long-continued action of the milder meaus. When properly regulated, high temperatures and various

* Chem. Ber., vol. 14.

‡ Compl. rend., vol. 94.

|| Journ.f.pralit. Chem., (2) vol. 26.

† Mém. soc. biolog., 1884.

$\S$ Bull. soc. Chim., vol. 35.

- Nünch. ürztl. Intelligenzbl., 1885. 
The more intimate nature of attenuation.

Attenuation of the agents of fermentation.

Attenuation of pathogenie baeteria.

Anthrax bacilli. Attenuation by high temiperatures. chemical poisons are able to produce a permanent attenuation.

The vital phenomena which are in this way lost are, as far as has yet been ascertained, only the power of producing fermentation and that of exciting disease. A similar occurrence has not been observed in the case of the other functions and products of the tissue change (pigment, ferments, \&c.). The loss of the fermentative or pathogenic properties is usually designated shortly under the term "attenuation of the bacteria." Whether at the same time there is diminished energy of growth and of the whole phenomena of tissue change in the pathogenic bacteria, thus explaining the victory of the cells of the body, or whether it is only one of the vital phenomena which is of importance in the warfare with the cells of the body, namely, the production of a poison, \&c., which is acted on by the noxious agent and destroyed for a considerable time, can only be decided as the result of further investigations.

Attenuation of the pathogenic mould fungi has not as yet been observed; see the above-mentioned experiments by Fränkel, p 126.

As regards the attenuation of the fermentative bacteria we have observations by Fitz. The anaërobic bacillus butyricus could be so altered by heating it for five hours at a temperature of $90^{\circ} \mathrm{C}$., or for seven homrs at $84^{\circ} \mathrm{C}$., that it no longer furnished the characteristic fermentative products in suitable materials although it multiplied actively. In like manner the agent of butyric fermentation isolated by Fitz at a later period (p. 388), as well as the bacillns Fitzianus, lost readily the power of producing fermentation, but also readily regained it.

The attenuation of pathogenic bacteria has as yet been successful in the case of bacillus anthracis, the bacillus of symptomatic anthrax, the bacillus of fowl cholera, the bacillus of swine erysipelas, and the as yet unlinown exciting agent of hydrophobia.

The phenomenon of attenuation has been most accurately studied in the case of the anthrax bacilli. The employment of ligh degrees of temperature has prored 
to be a very suitable means ; the temperature may vary between $42^{\circ}$ and $55^{\circ} \mathrm{C}$, and the organisms must be exposed to it for a longer time the lower the temperature employed. Thus according to Toussaint a temperature of $55^{\circ} \mathrm{C}$. was able to attenuate the bacilli of an anthrax cultivation in ten minutes; according to Chauveau a temperature of $52^{\circ} \mathrm{C}$. must be employed for fifteen minutes, of $50^{\circ} \mathrm{C}$. for twenty minutes, of $47^{\circ} \mathrm{C}$. for one to four hours after previous exposure to $42^{\circ}$ to $43^{\circ} \mathrm{C}$. for twenty hours ; according to Pasteur and Koch a temperature of $43^{\circ} \mathrm{C}$. must be employed for six days, a temperature of $42^{\circ} \mathrm{C}$. for about twenty-eight to thirty days, in order to obtain a complete loss of the pathogenic action; where the action is continued above thirty days death of the bacilli occurs.

According to Pasteur's recommendations, which have Most suitable been more precisely worked out by Koch, the following is the method best suited for obtaining attenuated anthrax bacilli: the cultivations are made in neutralised chicken broth, which is placed in a moderately deep layer in Erlenmeyer's flasks. These flasks are then placed in a D'Arsonval's thermostat liept at $42^{\circ} \mathrm{C}$. In spite of careful regulation the temperature varies somewhat in the interior; and hence the individual vessels frequently show a somewhat varying degree of attenuation. At times, also, spore formation may take place, though as a rule this does not occur at $42^{\circ} \mathrm{C}$; if it does talie place the attempt at attenuation fails. Hence it must always be borne in mind that some of the cultivations may not have succeeded. From eight days onwards the vessels must be tested daily; and the degree of attenuation of each specimen is ascertained either by sowing the material in a vessel containing chicken-broth and kept at $37^{\circ} \mathrm{C}$., so that spores are soon formed; or by inoculating a mouse with the specimen, and after its death making cultivations from the spleen, and thus obtaining spores. The cultivations or spores so obtrined preserve for a long time that degree of virulence at which the material had arrived.

After exposure to a temperature of $42^{\circ} \mathrm{C}$. for ten days Various the anthrax bacilli are so attenuated that rabbits and dogrees of 
guinea-pigs show almost no reaction when inoculated; at a somewhat earlicr period, guinea-pigs, but not rabbits, are killed. From the tenth to the twenty-fourth day we obtain the so-called "mouse anthrax," that is to say, a cultivation of bacilli which is only able to kill mice. These attenuated bacilli behave, according to Koch, somewhat differently in the body of the mouse than the virulent bacilli, the capillaries of the lung becoming filled with extremely long pseudo-threads in a manner which is not observed in the case of ordinary anthrax.

The first and second vaccines prepared by Pasteur for the protective inoculation of sheep are treated for twelve and twenty-four days respectively in the manner above described.

According to Pasteur's vicr the oxygen of the air is the chief active agent in this process of attenuation; while Koch regards the temperature as the most important factor, its effect being perhaps also aided by certain products of tissue change of the bacilli. The results of attenuation experiments at varying high temperatures show most distinctly that the effect depends almost exclusively on the temperature, and is in fact the result of the action of a certain temperature, as well as of the length of time to which the material is exposed to it.

Return of attenuated bacilli to virulent bacilli.

In the case of anthrax bacilli attenuated in this manner, researches have been made as to whether they regain their former virulence whell cultivated under normal conditions, or whether they permanently retrin the attenuated virulence when once it is acquired. On the whole the experiments have not given an uniform result, and are as yet too few in number to enable us to deduce any law which accounts for the return of the rirulence in some cases, and the absence of such return in others. The virulence appears to be regained most readily and most regularly whcro the attenuation has been brought about, according to Toussaint's method, by the short action of high temperatures; the bacilli which hare been attenuated by ten minutes' cxposure to $55^{\circ} \mathrm{C}$. regain 
their virulence, according to Chaureau, in the first normal cultivation, and this is also the case where a temperature of $47^{\circ} \mathrm{C}$. Las been employed; on the other hand, where, in Pasteur's method, a temperature of only $42^{\circ}$ to $43^{\circ} \mathrm{C}$. is employed, there is as a rule no return of virulence. Thus Koch cultivated completely attenuated anthrax bacilli which had been kept for twenty-nine days at $42^{\circ} \mathrm{C}$. for two year's under the most favourable conditions without the last cultivations being able even to infect mice; at the same time, however, the morphological characters of the bacilli and the appearance of the colonies did not show any difference from those of the virulent bacilli.-According to Pasteur the virulence can be regained if anthrax bacilli attenuated according to his method are in the first place inoculated on a newly-born guinea-pig; this animal succumbs to the infection, and then an animal one day old is inoculated from the first, then an animal two days old from the second, and so on; and thus ultimately a gradual increase of virulence is obtained, till even adult animals are killed. Koch, however, on repeating this experiment was unable to confirm these results.

Among other means of attenuating anthrax bacilli we Attenuation may mention the action of chemical substances which of anthrax are poisonous to bacteria, a method first employed by carbolic acid Toussaint, and later by Chamberland and Roux. According to the latter author's carbolic acid of the strength of 1 to 600 causes complete attenuation of a cultivation kept for twenty-four days at $35^{\circ} \mathrm{C}$.; if examined after twelve days the cultivation still possesses its full virulence. Solutions of bichromate of potash of the strength of 1 By chromic to 1700 kill anthrax bacilli; where the dilution is greater ( 1 to 2,000 to 1 to 5,000), it only causes such an attenuation that sheep are no longer affected by inoculation, while guinea-pigs and rabbits still die. If a 2 per cent. Bysulphurons solution of sulphurous acid acts for eight to ten days on acid. anthrax spores at a temperature of $35^{\circ} \mathrm{C}$, and if the spores are then cultivated on normal nutrient jelly, a growth is obtained which is still able to kill guineapigs, but does not kill rabbits. 
By cultivation in an apparatus kept constantly in motion.

By long. continued cultivation.

By light and pressure.

Attenuation of the bacilli of fowl cholera.

Of symptomatic anthrax.

Of swine erysipelas.

Attenuation of the virus of rabies.

Buchner obtained loss of virulence in the anthrax bacilli if he cultivated them outside the body for a number of generations in certain nutrient substrata, such as in extract of meat solution, with or without peptone, to which a very plentiful supply of air was added by the employment of an apparatus which lept the solution in constant motion. There werc many objections to this method as first described by Buchner (p. 240); but protective inoculations which have been made by Frank with Buchner's attenuated anthrax bacilli show that, as a matter of fact, a gradual loss of virulence can be obtained by this method.

A diminution of virulence also appears to occur when the anthrax bacilli are lept for a long time in the same culture fluid (Koch).

Lastly, according to Arloing, ${ }^{*}$ exposure for three hours to sunlight, and, according to Chaureau and Wossnessenski, $\uparrow$ increased atmospheric pressure, cause an attenuation of the anthrax bacilli.

Among other pathogenic bacteria the bacilli of fow] cholera, of symptomatic anthrax, and of swine erysipelas show a similar behaviour. In the casc of the firstmentioned bacillus the mode of the attenuation has not as yet been accurately ascertained (p. 317); in the case of symptomatic anthrax the attenuation is best obtained by the employment of high temperatures (p. 301). A special and new principle has been followed by Pasteur in the case of the bacilli of swine erysipelas; he found that their virulence was increased by repeated transmission of the infective agents through pigeons, while, on the other hand, it was diminished by their acclimatisation in the bodies of rabbits (p. 307).

Another plan, and onc not as yet completely cxplained, has been recently employed by Pastcur" for the attenuation of the virulence of the poison of rabies. Pasteur's method is shortly as follows:-As the infective agents of rabies are as yet completcly unknown, and hare not been cultivated artificially, a purc rabic poison, and

* Compt. rend., rol. 99. † Ibid., rcl. 93.

\pm Compt. rend., 1885, 26th October. 
one which is practically uniform in its virulence, must be procured for the attenuation experiments. This is obtained by continued inoculation of the poison on rabbits. If one starts from a rabid dog, and inoculates from this animal a rabbit under the dura mater into the brain substance, rabies appears in the latter animal aftcr an incubation period of about fourteen days; if the inoculations are carried on from rabbit to rabbit the period of incubation becomes gradually shorter ; after 40 to 50 inoculations it has fallen to seven clays, and up till the ninetieth transmission there is scarcely any further alteration to be observed; hence the poison has become acclimatised in the body of the rabbit, and has attained an almost constant degree of virulence.-It has been further proved that the spinal cord of these rabbits contains the rabic poison throughout its whole extent.

If now the cord is cut up into fragments a few ctm. in length, and if these are hung up in dry air, the virulence gradually disappears; the length of time which elapses before complete disappearance of the virulence varies with the thickness of the fragments, and above all with the external temperature; the lower the temperature, the longer is the virulence retained. If the pieces are preserved in a vessel from which air is excluded, or in carbonic acid gas, or in a moist condition, the virulence is retained for months, always provided that the access of saprophytic bacteria is prevented.-In order to obtain rabic poison of varying virulence suitable for protective inoculations a number of pieces of cord are placed at the same time in a corresponding number of vessels, the air of which is kept dry by pieces of potash. The portions of cord which are kept in this manner for onc to two days set up, like the fresl material, rabics in rabbits after seven days' incubation; when the pieces are preserved for six days the length of the incubation period is increased to fourteen days; when the pieces are kept for seven days in the dry air rabbits inoculated no longer become ill.

Definite facts as to the active agents are as yet wanting, nor do we jet possess a sufficicnt explanation of the 
mode of action. Pasteur has only been able to give a series of hypotheses, which at the most show how, witlı the help of vague speculations, this ingenious inrestigator is able to obtain great experimental results.

\section{III.-Means for Killing Bacteria.}

Means for killing bacteria.

Continued withdrawal of nutriment.

Withdrawal of water.
The means which are suitable for the destruction of the lower fungi have a special interest, because in the practical work of disinfection the problem is usually how to injure the infective agents so that they can no longer grow and multiply even under the most favourable conditions of existence.

Death of the bacteria occurs in the first place when the exhaustion of the nutrient materials, or the withdrawal of some material important for life and the consequent state of latent life, are continued for too long a time. The death of the individuals ultimately follows the prevention of their development, but the period of time at which this effect is produced varies greatly according to the resisting power of the individual species of bacteria. The spores of bacilli are the most resistant, and may probably survive in a latent state for hundreds of years; non-spore-bearing bacilli and micrococci, and more especially numerous parasitic fungi, are the most sensitive in this respect.

The withdrawal of water plays a particularly important part. This mode of destruction occurs rery widely in nature, and all those bacteria which do not form resting spores die in a relatively short period of time. The marked difference in the length of time during which non-spore-bearing bacteria, and those provided with spores, can resist the action of drying is a very useful criterion as to whether any doubtful morphological structure is, or is not, a spore (pp. 428 and 406). Spirilla and some species of cocci (streptococci) appear to be the most sensitive to drying. Differences also exist between the resting forms of rarious species, but these differences have not as jet been accurately made out. 
The other conditions of life of the bacteria do not produce any such marked effect. Pressure and electricity only appear to destroy bacteria when carried to extremes (p. 535); intense sunlight is said to have a comparatively energetic action, but these expcriments must be repeated with more careful attention to the possibility of other hurtful factors coming into play.

A very active agent for the destruction of the lower Hightemperafungi is high temperature, while, on the other hand, low tures. temperatures, even carried to an extreme degree, only prevent development, but never cause the death of the organism. The effect of heat depends on the degree of temperature, and on its duration; continued action of relatively low temperatures produces the same result as a short action of high temperatures. The temperature necessary to cause the death of the Varying organisms varies also very greatly according to the other power of nonconditions of life, and more especially according to the spore-bearing resisting power of the species in question. The chief of spores. difference is found between bacteria which do not form spores and those which are spore-bearing.-The former are, as a rule, killed when in a moist state or in fluids by exposure for one to two hours to a temperature of $48^{\circ}$ to $60^{\circ} \mathrm{C}$.; where they are $d r y$ the temperature must as a rule be continued for a longer time. Even spore-forming bacteria may be killed by these relatively low degrees of temperature if the heat is applied on repeated occasions, and if in the intervals between its application the organisms are placed under the most favourable conditions of existence, so that any spores that are present may sprout and form bacilli.-If the latter are killed by the subsequent application of heat beforc new spores are formed, we may be certain that after the heat has been applied five or six times no living spores exist, and all the adult organisms are destroyed. For cxamplc, blood serum may be freed from all organisms, although the heat employed has not bcen sufficiont to cause coagulation of the albumen; the material is placed for an hour daily for five or six days in succession at a temperature of about $56^{\circ} \mathrm{C}$., and is in this way com- 
pletely freed from all living organisms.-It is much more difficult to kill quickly the spores of the mould fungi. Hot air at a temperature of $120^{\circ} \mathrm{C}$. does not completely destroy them after half an hour's exposure; they are not certainly killed unless they are exposed to a temperature of $110^{\circ}$ to $115^{\circ} \mathrm{C}$. for an hour and a half. The spores of penicillium appear to be less resistant than the spores of Aspergillus niger.- - The most difficult to kill are the spores of bacilli, although among these great differences exist. Thus anthrax spores are less resistant than the spores of tubercle bacilli, and these again are less resistant than those of bacillus subtilis, and more especially of the bacilli contained in garden earth.

Influence of moisture.

In the process of disinfection it is very important to remember that dry spores always require much longer exposure to hent than spores in a moist state. It appears as if that total alteration of the protoplasm which leads to death occurs much more readily when there is a certain amount of water in it than when it is completely dry. Hence it is very difficult to destroy the spores of bacilli by hot air ; even when a considerable amount of watery vapour is added to air kept at a temperature of $100^{\circ}$ to $140^{\circ} \mathrm{C}$. it acts to a large extent as a drying medium, and objects exposed to it rapidly pass into such a state of dryness that it is only with great difficulty that alterations of the protoplasm occur. Thus the dry spores of bacilli are only killed by exposure for three hours to a temperature of $140^{\circ} \mathrm{C}$. If it is desired to disinfect the interior of large masses which are bad conductors of heat, a much longer duration of the heat is necessary in order to obtain the desired effect. But even an exposure for three hours to $140^{\circ} \mathrm{C}$. irreparably spoils all sorts of clothing.

Action of heat It is much more easy to destroy the spores of bacilli in fluids. in fluids. Antlirax spores are destroyed in boiling water "ithin two minutes; the spores of the hay bacillus resist this temperature for about ten or fifteen minutes (according to Buchner for sixty minutes); after fifteen minutes the majority of spores are destroyed. It is, however, often difficult to raise the temperature 
of the whole mass of fluid to be disinfected to $100^{\circ} \mathrm{C}$.; on the other hand it is easy, as Koch has shown, by means of a current of steam to obtain the necessary temperature of $100^{\circ} \mathrm{C}$. in all sorts of materials. At the Action of a bottom of the apparatus necessary for this purpose ste $\mathrm{m}$. there is a large vessel, on the top of which a tube of sheet zinc, 1 to 2 metres in height, is fixed; this tube is gradually narrowed at the top, and finally runs out in the form of a short tube, only $1 \mathrm{~cm}$. in diameter. The zinc tube is fixed tightly on the top of the boiler, and its outer surface is enveloped in some substance which conducts heat badly. If the water in the boiler is boiled, the steam passes out of the narrow upper opening in a strong current, and from that opening downwards the steam has a temperature of $100^{\circ} \mathrm{C}$. If now the objects to be disinfected are placed inside the vertical tube they are rapidly penetrated by the steam and raised to a temperature of $100^{\circ}$, and even in a few minutes the majority of the spores of bacilli are destroyed. The duration of the heat must of course be somewhat varied according to the nature of the materials. Fresh tubercular sputum is disinfected with certainty in about fifteen minutes, dried sputum in thirty to sixty minutes. A duration of sixty minutes is sufficient to lill the most resistant spores as yet known, even when surrounded by a relatively dense mass of material.-The rapidity of the effect is increased by employing a salt solution, and thus obtaining steam at a higher temperature than $100^{\circ} \mathrm{C}$.

A number of chemical poisons are also suitable for the Chemical destruction of bacteria. With regard to these, we have poisons. to note the concentration of the poison, the duration of its action, the nature of the nutrient substrata and the other conditions of life, and the specific resisting power of the species, more especially the presence of resting forms. -Bacteria free from spores are on tho whole destroyed by very small proportions; thus carbolic acid lills anthrax bacilli when in a concentration of 25 to .5 per cent.; 1 per cent. sulphurous acid kills them within five to fifteen minutes. - In the practical work of disinfection 
Trustworthy disinfecting mcans must destroy spores.
Experiments with anthrax spores. a knowledge of the proportions necessary for destroying bacteria free from spores is of comparatively little importance; in many cases we have to do with infective agents which undoubtedly form spores, in other cases the infective agents are not accurately known, and the possibility of the formation of resting forms is doubtful. Complete trust can therefore only be placed in those methods which can destroy any spores which may possibly be present. It is therefore of chief practical importance to test the disinfecting media with regard to their action on spores.

In this respect a series of experiments made by Koch is worthy of note, these experiments having been made by the comparison of various chemical poisons as regards their action on the same object-for example, on anthrax spores. The following are the most important results of these experiments :-

1. The following substances had no action on anthrax spores, even after acting for several months:-

Distilled water

Absolute alcohol

Chloroform

Glycerine

Benzole

Benzoic acid (concentrated watery solution)

Salicylic acid ( 5 per cent. in alcohol, 2 per cent. in oil) Thymol (5 per cent. in alcohol)

Ammonia

Salt solution (concentrated)

Chloride of calcium solution (concentrated)

Clilorate of potash ( 5 per cent. in water)

Alum (4 per cent. in water)

Borax (5 per cent. in water)

Potash soap (2 per cent. in water).

2. The following showed incomplete or slow action on anthrax spores:-

Ether (incomplete action after cight days, complete action after thirty days)

Acetone (incomplete after fire days)

Iodine, 1 per cent. in alcohol (incomplete after one day) 
Sulphuric acid, 1 per cent. in water (incomplete after ten days)

Sulphate of copper, 5 per cent. in water (incomplete after five days)

Boracic acid, saturated watery solution (incomplete after six days)

Hydrochloric acid, 2 per cent. in water (complete after ten days)

Arsenious acid, 1 per thousand in water (complete after ten days)

Sulphuretted hydrogen in water (incomplete after five days)

Ammonium sulphide (complete after five days)

Formic acid, 1.12 specific gravity (complete on the fourth day)

Quinine, 2 per cent. in water $\left(\begin{array}{l}2 \\ 5\end{array}\right)$ and alcohol $\left(\begin{array}{l}3 \\ 5\end{array}\right)$ (incomplete on the first day)

Quinine, 1 per cent. in water with hydrochloric acid (complete on the tenth day)

Oil of turpentine (incomplete on the first day, complete after five days)

Chloride of lime, 5 per cent. in water (incomplete on the first and second day, complete after five days)

Chloride of iron, 5 per cent. in water (incomplete on the second day, complete after six days)

3. The following showed rapid and complete action, all of them destroying the organisms on the first day :-

Chlorine water freshly prepared

Bromine, 2 per cent. in water

Iodine water

Osmic acid, 1 per cent. in water.

Permanganate of potash, 5 per cent. in water

Bichloride of mercury, 1 to 20,000 in water

A 5 per cent. watery solution of carbolic acid caused complete destruction of spores between the first and second day; a 5 per cent. solution in oil or alcohol had no action on antlirax spores.

We may also mention a series of experiments by Effect of a Gïrtner and Plagge* which aro more especially of shortaction of

* Verhandl. der Deutschen Gesellsch.f. Chirurgie, 1885. or sublimate 
practical interest to the surgeon. Gürtner and Plagge employed carbolic acid in the strength of 1 per cent., 2 per cent., and 3 per cent, and also 1 to 1,000 sublimate solution. The materials used for the research were pure cultivations in meat infusion of the following organisms: 1. Non-spore-bearing anthrax bacilli; 2 . Glanders bacilli; 3. Streptococci from a case of puerperal fever; 4. Pyogenic streptococci; 5. Erysipelas cocci; 6. Micrococcus tetragenus; 7. The bacilli of diphtheria ; 8. Staphylococcus albus ; 9. Staphylococcus aureus; 10 . The cocci of osteomyelitis; 11 . Bacillus prodigiosus; 12. Bacillus of typhoid fever free from spores ; 13. Micro-organisms from a case of spontaneous meningitis. The cultivations were mixed with the disinfecting fluids for only a very short time-as a rule eight to sixty seconds-and a small quantity was then introduced into nutrient jelly or blood serum.- It was found that the sublimate solution lilled all these organisms even in eight seconds, with the single exception of the meningitis organisms, which were still living after sixty seconds. The 3 per cent. carbolic acid liilled all the organisms without exception in eight seconds. In the case of the 2 per cent. carbolic acid the osteomyelitis and the meningitis bacteria required thirty to fortyfive seconds; with the 1 per cent. carbolic acid rapid disinfection was only obtained in the case of the anthrax and glanders bacilli.

As regards the disinfecting action of certain chemical poisons a large number of experiments hare been made which we need not here refer to in detail, but the following materials which are much employed may bc mentioned :-

Action of sulphurous acid.
Sulphurous acid was formerly recommended as a good and cheap means of disinfection for dwelling-rooms. 20 grammes of roll sulphur were burned per cubic centimetre of space; in order to render the burning of the sulphur easier $100 \mathrm{ctm}$. of sulphur matches and $40 \mathrm{ctm}$. of spirit were added to every kilo of sulphur. In this way an amount of sulphurous acid was obtaincd representing $1.4 \mathrm{per}$ cent. in volume. The duration of 
the action was at least eight hours.-More recent investigations by Koch and Wolffhuigel have however shown that sulphurous acid, even when as concentrated as possible - $a$ degree of concentration which cannot be attained in practice-only kills spores imperfectly; even with regard to non-spore-bearing bacteria the action is uncertain when present in 10 per cent. by volume if the layers to be disinfected are at all thick.-Further', sulphurons acid penetrates with considerable difficulty into the deeper layers of masses of clothing, \&c., and only has a certain amount of disinfecting action when the objects have been previously moistened, while at the same time it causes considerable injury to them.Dujardin-Beaumetz has recently again recommended sulphurous acid, and asserts, as the result of practical experience and of experiments with cultivations of bacteria in infusions, that the burning of 20 grammes of sulphur per cubic metre is sufficient for complete disinfection. The experimental proofs brought forward by Dujardin are, however, quite insufficient.

Chlorine and bromine have, on the whole, a very Action of marked action, more especially when the objects have chlorine been moistened, or when the air is saturated with moisture. In dry air, and where the material is dry, even several parts per 100 of these vapours in the air do not cause complete disinfection. Where, however, the materials have been previonsly artificially moistened the presence of 3 per cent. by volume of chlorine and 21 per cent. of bromine when acting for three hours is sufficient to kill all spores; $\cdot 03$ to $\cdot 04$ per' cent. by volume also suffices when it acts for twenty-four hours. This favourable effect has, however, only been obtrined in experiments in laboratories, and not where the experiments were carried on on a larger scale, e.g., in dwellingrooms. In the latter case it is very difficult to keep up the necessary concentration, and to have the vapour equally divided throngh the whole room.

In disinfection with chlorine it is best to employ for every cubic metre of space 25 kilo of chloride of lime $+\cdot 35$ kilo of crude hydrochloric acid. The material is 
divided into portions of at most half a kilo in each vessel, and these vessels are placed at as great a height as possible, and at regular intervals. In order to protect the individual engaged in the experiment care must be taken that the chief mass of the hydrochloric acid does not gain access to the chloride of lime till the room has been closed. In this way 1 per cent. per volume of chlorine is obtained at first, but the proportion very rapidly diminishes. Spores which are exposed on free surfaces are killed pretty certainly, but if they are surrounded by various layers of material the result is doubtful. By this method, however, all sorts of materials are irreparably damaged.

Bromine is best employed in the form of masses of silex, impregnated with definite quantities of bromine, as recommended by Frank. These masses are placed at the highest points of the room to be disinfected. According to Frank, 4 grammes of bromine per cubic metre are sufficient for complete disinfection, if the temperature is kept uniformly at at least $18^{\circ} \mathrm{C}$. According to Fischer and Proskauer, the distribution of the bromine in the room is still more unequal than that of chlorine, and hence the disinfection is correspondingly more uncertain. These experiments were, however, made at a low temperature, and this probably favoured an unequal distribution. Sufficient proof is still wanting that at higher temperatures a really trustworthy disinfection is obtained at all parts of the room. The injury to the materials by bromine is at least as great as by chlorine.

Action of corrosive sublimate.
Corrosive sublimate is, as is evident from the preceding figures, the most active bacterial poison. A solution of 1 to 5,000 kills all spores in the course of some hours; a solution of 1 to 1,000 has the same effect in a few minutes. As such a solution can be scarcely called poisonous to man, it is the best means for the disinfection of tho hands and of numerous articles in common use. It must be noted, however, that in the case of many substrata, for example albuminous fluids, the action may not occur, because the sublimate is precipitated, and a sufficient quantity does not remain in solu- 
tion; for example, the addition of sublimate to tubercular sputum has proved to be quite insufficiont for disinfection. Sublimate has been recommended by König* for the disinfection of dwelling-rooms in the form of vapour, obtained by heating about 60 grammes of sublimate for a room of about 60 cubic metre space. It has, however, been shown by Lübbert, + Heraeus, $\ddagger$ and Kreibohm $\$$ that it is only the bacteria which are superficially placed that are reached and killed by the sublimate, while on the other hand the very slightest covering of the objects hinders disinfection.

Carbolic acid is likewise a certain means of disinfec- Action of tion when in strong solution, and when allowed to act carbolic acicl. for a considerable time; 5 per cent. watery solutions destroy resistant spores in a few days. Non-sporebearing bacteria are killed by 3 per cent. solutions in a very short time (see the experiments by Gärtner and Schotte, mentioned above). Carbolic acid often acts better than sublimate for the disinfection of albuminous fluids, more especially of fresh tubercular sputum which is disinfected with certainty in twenty-four hours by the addition of an equal quantity of 5 per cent. carbolic acid. As regards the methods of disinfection which should be employed in practice, see Part VII.

* Centralbl.f. Chirurg., 1855, Nr. 12.

† München ärztl. Intelligenzbl., 1885, Nr. 49.

I Zeitschr. f. Hyg., vol. i., Part 2. 
APPENDIX.

CONSTANCY AND MUTABILITY OF THE SPECIES OF FUNGI.

Arc there constant and physio- fungi, which have as yet been looked on as distinct, are logical specific
characters for really of constantly distinct form and possess constant the various
species of physiological characters, or whether the morphological bactcria? and biological characteristics which are employed for distinguishing the species are varying and inconstant attributes, which readily undergo permanent alteration under the influence of the external conditions of existence.

For the solution of this question we may possibly obtain information from comparison with the higher plants, which form useful analogies as regards the constancy or variability of species and their characteristics. Behaviour of We cannot, however, come to a true decision by such higher organisms. comparison: this can only be arrived at by direct inrestigation.

As a matter of fact, it has long been known that a number of morphological and biological alterations can be observed in all plants. In the first place, certain alterations are constantly seen in all normal plants of the same species; these belong to the characteristics of the species, and only complete its special characters. To this class of alterations belong those which the plants show at various stages of their growth and derelopment; further, the alternation of generation of the fungi, with its enormous differences in form and plyysiological chaDifferences in racters. Where the developmental cycle of a species

has not yet been completely ascertained, it may readily happen that various developmental forms of the same species may for a time be looked on as independent 
species, till more accurate knowledge of the relations between them has been obtained.

Further, some plants show differences in their beliaviour at times, which may be designated as modifications, and usually as abnormalities of lesser or greater degree. These changes are set up by some unusual extermal influence; injuries and mechanical insults, abnormal nutriment, unfavourable situation, and many other causes act in this way, either singly or together. The conse- Nonquences are degenerative and involution changes of the hereditary most rarious kinds visible to the eye, and abnormalities in their physiological behaviour. The variations in the percentage of ash in the plants, the ofttimes enormous accumulation of silicic acid, the pallor of plants when the nutriment is free from iron, the accumulation of amides in starving flowering plants, the paler colours of many flowers, and so on, are alterations of this lind set up by external conditions. But it is characteristic with regard to these alterations that they are inconstant and non-hereditary attributes of the plants; they only last so long as the external conditions which produce them are in action, and they disappear after a few generations if completely normal conditions have been present. These modifications are thus so variable that they cannot serve for the formation of new species, for which, on the contrary, constant characters, which are transmissible through a long series of generations, are necessary.

In the third place, however, it must be admitted that the characters of the species which appear to us as constant may undergo a change after the lapse of a considerable period of time. Among many similar plants exposed to the same external conditions some individuals at times show slight differences; the subsequent generntions of these plants retain these differences; after a considerable time fresh differences may be observed among some of the descendants, and in this way we lave a gradual formation of new rarieties and species. This ultimate result is attained either when the varia- Mode of origin tions are of such a lind that the plants affected by them of hereditay grow more strongly and more quickly under the ordiuary 
The rarietics we not produeed by cxternal conditions.
Conclusions from analogy applied to tho lower fungi. external conditions than the other more normal examples, or when the cultirator intentionally selects the indiridnals which show a certain kind of abnormality, and only employs these for further cultivation.

In this way, Darwin's hypothesis seeks to explain the origin of varieties, species, and genera. But it is important and necessary for the definition of a well-marlied species that the new properties should be relatively constant, and not undergo alteration, under the influence of varying external conditions. As a matter of fact it seems to be impossible, by selecting the exterual conditions, to produce other species at will; in experiments performed with this aim the plants always remain the same, they at most undergo modifications and degenerate, but they do not acquire any constant and hereditary abnormalities, provided that there is no tendency to abnormal growth in the plants themselves. The origin of all varieties may be referred to a tendency in the plants towards variation which is peculiar to them and cannot as yet be explained. This tendency is of rer. varying intensity according to the species of plant; some for'm varieties extremely readily, others extremely seldom, and the variations occur quite as well when the plunts are all kept under conditions which are as much as possible the same as when they are subjected to different influences. It is only the vital power and the power of development of the varying plants that depends on the sum total of the external conditions.-Of the most marked influence on the tendency to variation is the sexual union of different individuals; where such a union occurs variations are usually formed rery plentifully. But even withont sexual processes the tendency of many plants to form new varieties is rery great.

If now we attempt from these riews as to the origin and charncteristics of the species of the higher plants, which have been put forward more especially by Nïgeli, to obtain a standpoint to explain corresponding variations in the lower fungi, we must assume that in these the formation of modifications, varieties, and species must as a whole occur in a similar manner. Certain altera- 
tions in form ean only be looked on as stages in the development of the same species, and belong within the boundaries of the speeies ; further, temporary modifieations will arise under the aetion of definite external influences; finally, varieties and new speeies with constant hereditary charaeteristies may be formed from existing species. To what extent the formation of varieties occurs will probably depend on the tendeney of the lower fungi to undergo rariation; whether this is great or small can only be decided by direct observations. As in the case of the lower fungi, and more espeeially in the bacteria, sexual processes are absent, and thus one of the most important factors in the formation of varieties is wanting, we must a priori expect a greater constaney in the species, and a slower variation. On the other hand, the rapid growth and the quick succession of new generations can lead to more rapid occurrence of variations than in the higher plants, and to their formation within measurable periods of time, and, as it were, before our eyes. Nevertheless, it is a question how we should define the individual generations of the fungi. Is every bacteric cell to be regarded as an individual, and does each individual colony represent an innumerable number of generations, or are the cells of such a colony analogous to those of higher plants, and is it only when fructification and spore formation oeeurs that a new generation is formed?

We thus obtain only a number of open questions, and Results of arrive at the conviction that from the analogy with the direct obserhigher plants we cannot gain any definite conclusions as to the behaviour of the lower fungi; hence it is only by aetual observations and experiments that we ean hope for a definite result.

In so far as observations have gone, we have in the 1. Morpho. first place observed all sorts of morphologieal differences logical differin the lower fungi. Some of these differences undoubtedly belong to those which only help to characterise the species. In this sense the processes of growth and development oeeasion eertain alterations in form which are always the same in the same species. We observe 
that from the most simple spore-cells rods and threads proceed, and that spores again form in these threads;

Stages of development. we observe, further, in the mould fungi, such as aspergillus or penicillium, a transition into a completely different form of fructification - we see the ordinary yeast pass into spore-benring cells of a totally different form. External influences often lead to the formation of the one or the other form of derelopment; but under these circumstances there always arise only the definite forms which are characteristic of the species, and not all sorts of rariations differing according to the external conditions which have been at work. According to Zopf's riers there is in the case of many bacteria a particularly wide cycle of vegetative forms; but in spite of all these differences in form definite species can nevertheless be made. We have only, in this lespect, to learn all the stages of development, and to arrange them among the characteristics of the species.

Degenerative conditions and modifications seeording to nutriment.
In the second place, in the lorrer fungi modifications of form also occur under the influence of external agencies. To a certain degree the nutrient conditions, for example, can influence the form in a similar manner as in the case of higher beings. Slight increase or diminution in length and thickness, a more marked swelling of the cells and threads, is not uncommonly observed (Buchuer); and according to the external conditions of existence, now the one, now the other stage of derelopment may be most prominent, and may be obserred in a particularly complete form. But on more careful examination we can ascertain that these rariations scarcely ever go far enough to alter the types of form which are looked on as characteristic of the indiridual species. 'The relation of the length of the rod-shaped bacteria to the breadth. the form of the ends of the rods, the charncter of the thread form, the mode in which the individuals are grouped together, remain, as a whole, untouched by such variations. Under the practically abnormal exterual conditions more marked alterations in form, nnd the production of pathological and involution forms, often occur. These variations in form render it difficult to 
differentiate the bacteria on the basis of their morphological characters, more especially as in the case of the bacteria we havo to deal with extremely slight and delicate differences in form; and hence we must give up the former classifications based essentially on such differences. But as a matter of fact these various alterations in form do not lead to the disappearance of the species, but only serve, by the use of more complete means of observation, for a more accurate differentiation of the individual species.

After the lapse of long periods of time it is probable that a third kind of morphological alteration may occur in the lower fungi, and lead to the formation of varieties and new species; these alterations, however, appear as a rule to occur in a similarly slow and inappreciable manner as in the higher plants. Very distinct evidence has recently been produced which shows that the form of certain bacteria has undergone extraordinarily little variation even in the course of hundreds and thousands of years. In thin sections of the petrified roots of conifers from the coal period, van Tieghem* was able to demonstrate the characteristic butyric acid bacillus; and Zopf and Miller t found in the tartar on the teeth of Egyptian mummies the same forms of bacteria which can at the present time be demonstrated as the ordinary inhabitants of the mouth. These examples, however, are only of value for the species in question, and we cannot without further information draw the conclusion that all fungi have a similarly slight tendency to undergo variation.

Nägeli, Buehner, Wernich, and others have formerly Difforences in asserted that under the influenee of external eonditions a the views as very marked variation in form occurs, and that one species to tho variean be eonverted by variations in the conditions of its form. existenee into another specics, eharaeterised by other morphological eharaeters and other modes of growth (thus the anthrax baeilli were converted into a so-called transition form, and then into true hay breilli, see p. 24:1).-The 
more, however, the mcthods of pure eultivation have ljeen perfected, the more has the conviction gained ground that such variations in their characters probably occurs to as slight an extent in the case of the bneteria ns in that of higher organisms, and that the former observations on which these statements were founded were not made by methods which wcre free from objeetion. Buehner himself has in his more recent investigations pointed out numerous speeifie morphologieal charaeters. It is no doubt not impossible that many of the species which have as yet been looked on as definite forms from examination by ineomplete means, and at an early period of our knowledge, may, when the modes of investigation have become more perfeet, be recognised as related to each other, and that thus from two species whieh have as yet been looked on as morphologically distinet we may have to form a single speeies with a somewhat great variability in vegetative form. But as yet no facts of this kind have been demonstrated, and if they should be demonstrated in any individual ease they would not afford any ground for doubting the ralue of the morphologieal eharaeters in distinguishing the spccies of other bacteria.*

2. Physiological differences.

In view of the difficulty of the morphological distinction of species, we must, as has already been mentioned above, in many cases employ marked and specific physiological characters as means of diagnosis and of classification. The character's so employed must naturally be constant and hereditary; it is only then

* Buchner has recently (Arch.f. IIyg., vol. iii., p. 380) implied that I confound variability in vegetative form with that of species, and that I fight against the former, while in reality I mean the latter. But from various portions of my criticisms of Zopf's hypothcsis, as well as in the first edition of this book, it is very evident that I am by no means guilty of any such mistake. As a proof I cite the following passage from p. 276 of the first edition of this work:-

"In spite of the view that cocci, bacteria, bacilli, spirilla, only represent developmental forms which rendily pass into each otler, it might nevertheless be still possible to form distinct morplologically characterised species. We obsorve in the cocci, bacilli, and spirilla, many other peculiarities of form which might serre to charncterise a species, and if the chief weight were laid on these peculinrities we would obtain a clnssification founded on morploological characters, and could ultimately attempt to make a diagnosis of the species accordiug to the cxternal form, even though the same fungus occurred in a coccal, bacteric, or spirillar form."

According to the view which Buchner and Wernich support, such a differentiation of constant forms would not, howerer, be trustwortly: those morplological characters would, as a rule, only be the product of tho oxternal conditions of life. 
that they can be of use for the formation of distinct varieties. Characters which readily undergo alteration under the influence of all sorts of external conditions, which are readily lost and acquired, are as little suitable for characterising varieties as varying differences in form.

As a matter of fact we have, in the production of ferments, in the formation of pigment, in the setting up of fermentation and disease, and in the whole mode in which the nutrient substrata are assimilated and broken up by the bacteria, such hereditary and characteristic physiological attributes of the species of bacteria.

It has been already mentioned above (p. 563) that Variability the sum total of the external conditions of existence of the resing cxerts a very marked influence on the quality of the pro- external ducts of tissue change, and that by abnormal external conditions every individual phase of the characteristic vital phenomena may be abolished; but, nevertheless, these variations in physiological characters follow definite lines and clo not go beyond the characters of the species in question. In correspondence with this fact those vital phenomena which are constant under certain nutrient conditions can be very readily employed as means of distinction; and the loss of the individual characters as the result of definite external conditions only serves as a means of increasing the number of characteristics of the species.

Further, as in the case of other organisms, so also Alteration ly probably in the case of bacteria, they may become accli- accli tion. matised to abnormal conditions of existence; for example, to an excess of salts, to a different reaction of the nutrient medium, to temperature, \&c. It is conceivable tliat the same abnormal conditions when suddenly employed cause cessation of development, while when gradually introduced they still permit the exercise of the vital functions. More accurate facts, however, are still wanting as to the behaviour of bacteria under such conditions, but it is " priori probable, from what we know of the behaviour of the ligher organisms, that even under 
suitable acclimatisation of bacteria the result will be not a loss or diminution, but a multiplication of their specific characters, and that the properties thus acquired will again be lost after a few generations when the abnormal external conditions are replaced by normal ones.

Nägeli's views as to the mutability of the bacteria.

Nägeli, Buchner, Wernich, and others have formerly assumer the existence of a very rapid and limitless alteration of the characters of species of bacteria which had up to that time been distinguished from each other. "According to my view each of the species of bacteria could occasion the formation of lactic acid, pntrefaction, and various forms of disease. Each species has the power of accommodating itself to unequal external conditions, and consequently of appearing in various forms morphologically and pliysiologically peculiar. The adaptation or acclimatisation may be more or less complete and more or less permanent, according to the time and the other factors which are at work. . . Thus forms of an nuequal degree of development and of unequal constancywould be produced in accordance with the various extermal conditions. The same bacterium would at one time live in milk and form lactic acid; at another on meat and canse putrefaction; again in wine, and lead to the formation of a. gummy substance; subsequently in the earth withont setting up any fermentation; and finally in the human body, and take part in some form of disease. . . . It would on a soil which was equally disposed for various fermentations occasion those changes which most correspond to the physiological stage at which it has arrived by its previous made of life. Bacteria which frequently change their habitat would of course retain an indefinite character, and be equally well disposed to assume diflerent forms and to excite different fermentations ". (Nägeli*).

Nägeli and Bnchner found an experimental support for these views in the observation that bacteria which caused milk to become sour lost this property in a saccharine solntion of ment extract, and caused there an ammoniacal fermentation, and it was only after a huudred or more gencrations in milk that the property of forming acid slowly recurred.

Hueppe, howerer, tested this question accurately, and was unable to makc out any such rariability in the helatriour of the lactic acid bacilli, but he showed that an ammoniacal fermentation could be caused in the milk by butyric acid bacilli, whioh, in the form of resistant spores, could readily

* Nilgeli die niederen Pilie, München, 18тT, p. 22. 
remain unnoticed in a living condition in milk which had been insufficicntly sterilised; and thus he showed that it was probable that in these experiments we did not have to do with variation in the character's of the same specics, but with the effect of different species of bacteria.

The more the methods of pure cultivation of bacteria have been improved, and the morc complete our knowledge as to the biology of the bacteria has become, so much the more certainly do all other experiments lead us to the conviction that the specific vital characters of the lower fungi can be r'ctained in a similar manner as in the higher organisms, and we not subject to any cxtensive variation.-Even Buchncr in his more recent investigations recognises the physiological attributes of the bacteria as sufficiently constant to enable him to base on them a distinction between the individual species.

It is true that during a long period of time, just Formation of as in the case of the higher plants, a real formation of varictics. varieties may occur in the lower fungi, the physiological character's being chiefly affected. This rariation does not, however, arise as the direct result of definite external conditions, but is due originally to a certain tendency to variation which often only leads to an ephemeral existence of the somewhat abnormal examples, and thus to no important consequences; at times, however, when by chance the external conditions are such that these abnormal examples are, as the result of the abnormality in their physiological characters, especially able to grow concurrently with other organisms, and are not weaker than individuals which have not these properties, we may have a continuation of these abnormalities through a series of generations, and thus the formation of a new variety. In many of the lower fungi, however, the tendency to this form of variation is extremely slight; more especially we must accept it as undoubted with regard to most of the exciting agents of fermentation that they have retained the same physiological characters and the same morle of breaking up the fermenting materials for thousands of years.

In one respect, it is true, a cliaracter of the bacteria has been observed which does not apparently follow the 
The loss of the power of bacteria to excite disenso and fermenta. tion.

It would be necessary to regard attennation as a degenerative process if it were not hereditary. laws which have been made out with regard to the higher organisms. The power possessed by nany bacteria of multiplying in the body of living warm-blooded animals, as well as the property of others of exciting fermentation in suitable substrata, have, as has been above mentioned (p. 656), proved extremely labile in many species of bacteria, and can be destroyed by numerous influences, such as high temperatures, chemical poisons, \&c., which cause degeneration of the organisms. Indeed, the repeated passage of certain parasitic bacteria through more or less suitable hosts appears, according to Pasteur's experiments, to lead to increase or diminution in their virulence, ${ }^{*}$ and in the case of glanders, for example, a cultivation for a certain length of time on potatoes, which is otherwise the most suitable dead mutrient material for their growth, suffices to lead to complete disappearance of their virulence (Loeffler).

This "attenuation" of the lower fungi would not be of much importance if we had only to do with a degenerative process which had arisen under the inftuence of the alnormal conditions of life employed, and which was only retained so long as these conditions acted, and was not hereditary through a long series of generations under normal conditions, but was rapidly lost.

* A similar alteration of pathogenie properties of the lower organisms was formerly stated to oceur by Davaine as the result of his experiments on progressive virulence. Davnine thought that he lad observed that the virulenee of septicemia breilli constantly inereases the of tener they are inoenlated from one animal to another; thus, while of an infective fluid found accidentally several drops are necessary to insure infection in the first instance, yet, when it has been inocnlated from animal to animal for a considerable time it is ultimately found that the minutest fraction of a drop is sufficient to cause the fatal discase. Koeh and Gaffky (Mitheil. a. d. Kais. Ges. Amt, rol i.) were able to demonstrate that in the ease of several bacteria whieh oecasioned soptieæmia no such progressive inerease in virnlenee existed; that it was only neeessary to employ larger doses at first, when the material used for inoenlation was very impure and only contained a few of the pathogenie organisms; that, on tho other hand, when the material was pure the same dilution was as active at the commeneement of the scrics of exporiments as at tho end. More reecut experiments of Pasteur as regards swino erysipelas, hydrophobia, \&e., point, however, to the faet that some speeies of baeteria undergo marked alterations in virulenee as the result of their passage through the bodies of eertain warmblooded animals. 
In this case the attenuation would be analogous to the numerous dcgenerativc processes which have beell observed in higher organisms; the diminution in the amount of quinine in the species of cinchona, the loss of the production of conium in hemlock when the plants are cultivated in unsuitable soil, the diminution in the amount of chlorophyll, or the imperfect and slower growth of the various organisms under unfavourable external conditions, would then furnish analogous examples.

But it is remarkible that the attenuated condition of An attenuated pathogenic and fermentative bacteria carmot as a matter condition is, of fact be removed, as in the case of these degenerated transmissible plants, by subsequent cultivation under normal condi-generations. tions. On the contrary, undoubted facts have been made out which show that this attenuated condition can last for a long time, and through a long series of generations, more especially when it was set up by milder means, employed for a long time.

Thus in the case of many bacteria a character has been made out which must be regarded as a biological curiosity, and which does not in any way harmonise with the other biological characters of the bacteria. For thus a on the whole we undoubtedly observe, as has been stated charagieal above, a constancy in the hereditary properties of the been proved bacteria similar to that of the higher plants, and even the bacteria the virulence of the parasitic bacteria appear's to corre- which differs sperre- entirely from spond in its laws with those of the other characters, in that of the that in spite of numerous variations in the cultivation, no isms. alteration occurs, or only appears under certain abnormal conditions, and then affects the one gencration alone.

There can, howcver, be no longcr any doubt as to the rcmarkable fact of the artificial development of a hereditary attenuated condition in some bacterin, and as the result of this most recent development of our knowledge, we must come to the conclusion that we ought to be extremcly cautious in our judgment when we attempt to apply laws which concern other organisms to bacteria, or when we would draw general conclusions with regard to bacteria from single observations. 
More than in any other scientific department is it necessary to limit our judgment in the case of the lower fungi to the particular species in question, and we are just as little justified in declaring that a hereditary attenuated condition of the bacteria is impossible, as the result of theoretical considerations, as we would be in deducing from a few instances in which such attenuation has been proved that there is an extensive alteration of virulence as the result of other influences, and in the case of other species of bacteria, which have not been tested, or that there is a similar variable condition of all the other properties of the bacteria. 


\section{PART VI. \\ DISTRIBUTION AND HABITAT OF THE BACTERIA.}

Numerous forms of bacteria grow in the most various General surroundings of mankind, whenever they mect with distribution sufficient moisture, nutritive material, and a temperature bacteria. of at least $6^{\circ}$ to $10^{\circ} \mathrm{C}$, and they multiply the more quickly the nearer the temperature approaches the arerage optimum of $20^{\circ}$ to $30^{\circ} \mathrm{C}$, and the better and more plentiful the nutritive material. Wherever dead organic materials, excreta of man and animals, dead bodies, dead plants, household refuse, \&c., accumulate on the surface of the ground, in stagnant or rumning water, or within dwelling-houses, in the presence of sufficicnt moisture and temperature, bacterial growth occurs, and ultimately occasions the complete destruction of these materials, the place of which is taken by an enormous number of newly-formed individuals.

In view of the distribution, the enormons capacity for multiplication, and the relatively great resisting porrer of the bacteria, one involuntarily inquires as to the means which come into play in mature in order to destroy the masses of bacteria which are being constantly formed, and to provide against their accumulation in too great numbers. The cold of winter is not the active agent, for, as is well known, it only occasions an arrest of development, and appears to preserve all the bacteria in a living state. The natural means of disinfection is in The natural the first place drying of the bacteria; then exhaustion of means of the nutritive substrata; at times also high temperatures, more especially on the surface of the soil from the solar heat. These various agents in truth only lill the less resistant vegetative forms, while the majority of the permanent forms retain their vitality in a dry state, aud 
Frate of parasitic bacteria.

also in solutions in which the mutriment is exhausted, and at the lighest tcmperature reached by insolation at the surface of the soil.

Nevertheless, the cffcet of thesc means may be grcat, and incleed sufficient for the purposc, because opportunities for the sprouting of the spores often present themselves in nature, and they thus assume a vulnerable form; and hence it is chiefly by a constant variation bctween good nutritive conditions on the one hand, and the absence of water and nutritive materials on the other, that destruction of the various kinds of bacteria and regulation of the bacterial life arc brought about.

In the case of those forms of bacteria which excite our special interest by the fact that they can at times develop in the bodics of the higher living animals, their continued existence in our natural surroundings is rendered more cspecially difficult, because they are for the most part very particular as to the quality of their nutriment, require a farourable temperature, and are often extremely sensitive to alterations in the nutritive substrata, and to the amount of water present. Further, all the facultative parasites are very readily overgrown by saprophytes, which grow much more quickly under the conditions of life present in our surroundings; the latter thercfore withdraw from the former the necessary uutritire materials and also injure them by the products of their tissue change. If, therefore, it is necessary for infective agents to grow for a considcrable time under the ordinary conditions, they must evidently have the opportunity of growing in a sort of pure cultiration; and such an exclusive occupation of the substratum by pathogenic bacteria sometimes occurs on semi-solid nutritive materials, on floating portions of regetable or animal tissue, \&c.-In fact the prescrvation of facultative and obligatory parasites which harc grown in this way outside the human body, or which have grown in the human body, and passed from it into the surrounding world, is a matter of considerable difficulty. They are most easily preserved when spore forms are present, which can persist unaltercd for a long time in a dry condition, or in 
exhausted nutrient material. Where spore forms are absent, preservation can possibly still occur if the existing conditions are such that the sensitive parasitic bacteria are not destroyed or overgrown by saprophytes. Conditions of this kind are furnished, for example, where the temperature is under $+5^{\circ} \mathrm{C}$; and also (as will be described more fully afterwards) in porous and moderately moist soil.

For the distribution of bacterial life on the surface of T'ransport of the soil, it is also of importance that they should not be bacteria. restricted to the original place where they developed, but should be transported over greater or less distances. Currents of air and flowing water are the most important means of transport; to a less extent, but in a great variety of ways, they may also be carried by animals and by the trade and intercommunication of mankind.

When we examine our various surroundings as to the Occurrence presence of bacteria, we find them, in the first place, in of bacteria in the air in very varying numbers. By the methods as the air. yet employed for these investigations, from 100 to 500 living bacteria have been found in every cubic metre of the layers of the air which lie immediately above the ground; in the air of dwelling-rooms they have been found in very small numbers when all movement of the air has been as much avoided as possible for some time, while they are present in large numbers when the dust has been raised by movements and other disturbances. Direct microscopical examination of the collected air germs, as well as the experiments on filtration of the air (Hesse), have shown that the micro-organisms floating in the air do not occur as isolated individuals, but that numerous individuals of the same kind are as a rule united together in chains and groups, or adhere to coarse particles and visible pieces of dust.

The origin of the air germs must almost always be Origin of air sought in the bacterial colonies on the surface of the germs. earth, for there is not sufficient moisture to permit 
f) inly

thoroughly diry bacteria 1)ass into the ilir.
Difference in weight of air gerins. multiplication during their transport through the air. Furtler, bacteria as a rule only pass into the air from bacterial colonies which are thoroughly dry and are broken into fragments by external force. Nägeli lias shown that even strong currents of air are unable to detach bacteria from moist surfaces; it is only when there is at the same time a spurting up of the fluid by waves, or by violent agitation (mill wheels, washing, \&c.), or by the formation of bubbles, that particles of water, and with them bacteria, can be carried by currents of air over short distances. Even when a colony of bacteria dries up it cannot at once become loose, so that portions could pass into the air ; on the contrary, the dried bacteria generally adhere very firmly to the substance beneath, and it is only by brealiage due to external violence, or to the effect of temperature, that small light particles are loosened and can be carried away by currents of air.

Former observer's had, it is true, at times obtained evidence of detachment of bacteria by feeble currents of air, and eren from moist surfaces, but thosc experiments were not made with pure cultivations of bacteria, nor by the help of solid nutrient substrata, and hence bacteria entering through insufficicnt joints might easily cause deception and lead to the idea that they had become detached from the surfaces of the fluids inrestigatcd. At the present time the experiments can be readily repcated with completely uniform results if we work with pure cultivations of the rarer forms of bacteria and are thus able to distinguish organisms which hare come accidentally from without, from those which werc present on the surface of the nutrient substrata.

The bacteria, once they have passed into the air, float or are carried about by currents of air for a varying time. In addition to differences in the strength of the currents, the size and weight of the floating particles is of especial influence in this respect. Gross particles of dust, such as one sees with the naked eye by any mode of illumination, soon full in quiescent air along with the bacteria aclhering to them; the smaller or so-called solar specks float more easily, and are carried about by slight currents. Finally, the minute collections of bacteria or individual bacteria which are never visible to the naked 
eye, and of which the weight represents the billionth of a gramme or less, do not become deposited to any great extent even in quiescent air. We must also suppose that these minute bodies are surrounded by a condensed conting of air consisting chiefly of the vapour of water, and forming as it were a parnchute and mantle which renders floating ensier (Nïgeli).

From these observations and considerations we at Local differonce arrive at some laws as to the local and seasonal ences in the distribution of bacteria in the air. Everywhere where germs. there is a plentiful development of bacteria on the surface of the soil, and where complete dessication of superficial colonies takes place, there will be a considerable number of bacteria in the air. Where there is no opportunity for the growth of bacteria (in deserts, on high mountains, \&c.), or where the surface is always moist (over the sea), the air will be almost or entirely free from bacteria. Nothing certain is known as to the distances to which dry but living bacteria can be carried by the wind; from the extraordinary distances orer which other particles of dust can be carried, we may conclude that when opportunity offer's the bacteria may be carried over very considerable areas. This circumstance naturally tends to destroy to a considerable extent local differences in the amount of bacteria in the air; nevertheless, by far the greater number of the air germs will always originate from local sources.

It cannot be lecided, and it is also of subordinate importance, whether the few bacteria which have been found on high mountains have their origin in winds or in the body, the elothes and utensils of the observers, or in insignificant local sources; and of equally slight importance is the hunt for bacteria in the air of the highest mountains and on the most distant seas, which has been carricd on for the last few years, has been entirely wanting in proper aim and has more referenee to the sensational public than to seicntifie interest.

Variations at different timos in the number of air Variations at germs are, apart from the varying quantity of available different tires bacterial colonies, dependent in the first place upon the germs. conditions which favour the passage of now bacteria 
Infinenco of dry winds.

Effect of the distribution of the germs over a great extent of air.

Deposit of air grerms by the condensation of water vipour.

Orer estiman tion of the into the air; and in the secund place upon the factors which influence the deposit of floating germs from the air. Dry winds more especially lead to an increase in the number of bacteria in the air. Even when the deficiency of moisture in the air is not great, and when the air is moist, drying of the most superficial layer's may occur at the exposed parts of the surface of the earth, and dust may be carried into the air along with a certain number of bacteria; great drought lasting for some time (as in the case of the east winds in our neighbourhood) leads, however, to a much greater degree of drying; every corner of the streets, courts, and houses, the deeper layers of the soil, \&c., gradually become dry, and many more, and also greater varieties of, bacteria,-ultimately also pathogenic bacteria,-pass into the air in these places.

In spite of this markedly favourable influence of dry winds in increasing the number and kinds of air germs, it is nevertheless possible that a cubic metre of the air in our neighbourhood may scarcely show more germs than in still, damp weather. For the dry winds will possibly distribute the germs which are taken up over a much greater area, and more especially carry them to a considerable altitude. A greater amount of water in the atmosphere, on the contrary, more especially, however, the occurrence of descending currents of moist air, and in particular a great condensation of water vapour, must lead to sinking of the particles of dust, and thus occasion, in the first place, an increase in the number of germs in the layers of air close to the surface of the earth, until continued condensation and rains have eventually brought back the greater number of the bacteria to the soil. - In the investigations made up to the present time, but little attention has been paid to these conditions affecting the distribution of the germs in the air, and especially to the possibility of their deposition by condensation of water vapour, although it is probable that a more intimate knowledge of the modo of distribution of the air germs will give us enlightenment as to the mode in which many infections (e.g., malaria) occur.

On the whole too great a rôle was formerly ascribed to 
the air in the spread of saproplytic and infective germs. dangcr of air By the experience obtrined in bacteriological work and in surgical practice, it has become evident that bacteria but seldom enter nutrient substrata from quiescent air, that even a simple cover which keeps off the vertically falling particles of dust forms even in impure air all extremely efficient protection, and that the entrance of bacteria occurs far more frequently from unclean objects, unintentional contaminations, \&c., than from air germs. On the other hand, dusty air in active movement offers an excellent opportunity for the spread of bacteria; and it is remarkable in what numbers they may be deposited on a cool object-on nutrient materials, \&c., placed in ice-along with the water vapour condensed at the same time. But even then the pathogenic bacteria form only a minute fraction as compared with the saprophytes. In fact in the open air the dilution of the pathogenic germs soon becomes so very great that a direct infection is a rare occurrence; it is only from the air within dwellings and in the neighbourhood of the sick that infection occurs at all frequently.

Neither the points of view nor the methods for the in- Defects in the vestigation of the air are at the present time so precise that recent it is possible to make definite statements as to the investigations and seasonal differences in the number of the air germs, or that well-founded conclusions can be drawn as to the part played by the air in the spread of one or other of the infective diseases. Miquel's attempts to draw a parallel between the results which he has obtained in his air investigations, and the mortality from the various infective diseases, are at least premature, and only show how long-suffering the statistical method is, and how easily it can be misused in order to prove a deceptive causal connection.

'The distribution and behnviour of bacteria in the soil Occurrence is of very special hygienic interest, because for a long and bchaviom. time, and especially since Pettenkofer's convincing de- the soil ductions, the soil has been regarded as a very important 
factor in the occurrence of epidemic diseases. The connection proved by statistics to exist between the variations in the mortality from typhoid fever in Munich and the variations in the level of the ground water furnished the chief argument for the view that something took place in the soil which exercised an important influence on

Petteukofer's views as to the relation between the soil and infeetive baeteria.
View as to a speeifie influenee of the soil on the development and spread of the infective germs. interesting results of that statistical observation leave it however, in the first place, doubtful whether the alteration in the soil, as shown by rariations in the ground water, exercise any influence on the development of the infective germs; or whether it is only of special importance for the transport of the germs present in soil to man; or whether, in the third place, there is a direct connection between the conditions of the soil and the infective germs, or an indirect one in this way, that the apparently predisposing condition of the soil and the spread of the epidemics must be referred to a third causal factor common to both.-Further, the question arises, supposing that the soil exerts some direct influence on one or several of the infective agents, whether this influence must be regarded as absolutely necessary for the epidemic spread of the diseases in question, so that a necessary and specific rôle must be assigned to the soil; or whether the spread of the same disease may not frequently occur in other ways without any connection with the soil?

The decision of these questions is evidently only possible when we obtain a more accurate knowledge of the pathogenic agents, of their vital characters, and of their mode of spread; before we possessed any knowledge of this kind we could only form hypotheses as to the more intimate connection between the soil and infective diseases.

Pettenkofer and his followers formerly sought to show that it was probable that the soil exercised a peculiar and definite influence on the development of the infective germs as well as on their transport to man; a porous soil infiltrated with waste organic materials and moistened from time to time was supposed to be indispensable for the development, and, so to spenk, ripening of the 
infective agents; and tlie same soil was supposed, perhaps at a definite stage of dryness, to enable the infective germs to be transported by currents of air.

This view was undoubtedly completely justified by the state of our knowledge at that time as to the nature of the pathogenic agents. But since we are now able to set on foot direct obserration and experimental investigations as to the mode of development and the conditions of existence of the infective agents, we must subject our former views as to the occurrence of infective diseases, and more especially as to the influence of the soil on the pathogenic bacteria, to revision and criticism. In fact as to the behaviour of bacteria in the various media in our surroundings many thorough investigations are necessary, and we are far from seeing clearly the relations between the soil and the pathogenic bacteria. But in many directions the more recent bacteriological investigations have given us valuable facts which compel us to alter our former views.

If we shortly summarise what we have learned during Results of the last few year's by direct observation and experiment direct ns to the general behaviour of the most various kinds of bacteria in the soil, we obtain in the first place the unanimous result that, as a matter of fact, the bacterial life in the soil is extremely active, that the soil is evidently the chief reservoir for bacteria, into which the greatest part of all fluids containing bacteria, almost all refuse water, excreta, \&c., pass, and on the surface of which the germs which have passed into the air are again in great part deposited. Enormous numbers of bacteria have always been Richness of found in the soil by the most various observers. Infusions various kinds made from manured field and garden earth, even though of bacteria. diluted 100 times, still contain thousands of bacteria in every drop, and the ordinary soil of streets and courts also shows the presence of large numbers. Bacilli are present in much the largest numbers; but in the most superficial layers and in moist ground there are also numerous forms of micrococci. Some species are markedly prominent, and are found in the most varied places and at the most various times in the soil, while they occur in other 
Pathogenic bacteria in the soil.

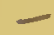
Frequency of
an infective action of the soil.

Vital powers of the bactoria of the soil. substrata muclı less commonly; such are, for example, the bac. mycoïdes (p. 403), and some other forms which have not as yet been more minutely described. Various kinds of bacilli must also be very often present in the soil in the form of resting spores, as can be concluded with certainty from disinfection experiments.

Pathogenic forms are also not uncommonly found. Well-known iuhabitants of the soil are the bacilli of malignant odema, of infective tetanus, the bac. septicus agrigenus, \&c., which are commonly and almost exclusively found in garden or field earth. Pathogenic bacteria occur with such frequency in the soil that no material found in nature so easily produces infection as earth. If mice, guinea-pigs, or rabbits are inoculated with a quantity (not too small) of earth from the surface of the ground a much higher percentage of cases of disease is obtained than when the inoculation is made with some fluid containing bacteria. If large quantities of the latter are injected a large number, or it may be all of the animals die of ptomaine poisoning; but an infective disease only results in rare cases. We have also reason to assume that the infective diseases caused by the soil would be more numerous, and would lead to the isolation of other species of pathogenic fungi, were it not that these odema and tetanus bacilli are so widely distributed that they obscure the other infective agents and cause the death of the animal before other more slowly growing bacteria have had time to multiply.This marked infective property of the soil must evidently' make us a priori inclined to accept the riew that the soil is of special importance in the occurrence of human infective diseases.

We have also obtained some information as to certain cffects produced by the bacteria on the soil. Thus Schlösing and Müntz, and at a later period Warington, showed that the formation of nitric acid from the ammonia of organic substances is chiefly caused by lowly organisms; when soil has been heated or treated with disinfecting means it loses almost entirely this power, which is otherwise constantly observed. In like mnmer Wollny and Fodor 
were able to show that the formation of carbonic acid in Production of the soil was entirely the result of the life of lower organ-carbonic acid. isms. Further, Gayon and Dupetit, as well as Déhérain and Maquenne, have furnished proof that when oxygen is deficient a reduction of the nitrates to nitrites, ammonia and nitrogen can be brought about by the bacteria of the soil. According to investigations made by Reducing Heraeus (Zeitschrift f. Hyg., vol. i.), many forms of bacteria (such as bac. prodigiosus, cheese spirilla, Finkler's spirilla, typhoid bacilli, anthrax bacilli, staphylococci) are able to oxidise ammonia to nitric acid; while other' species (for example, two kinds of bacilli cultivated from watcr) cause the reduction of the nitrates in a marlied manner. Schlösing and Müntz held that nitrification was Nitrificatiou caused exclusively by one species of bacteria which was is not caused isolated by them from the soil; but their description of the the bacteria of bacteria does not at all indicate that they worked with a really pure cultivation, and the investigations of Heraeus compel us to adopt the view that a large number of bacteria are capable of causing nitrification either by simple assimilation and oxidation, or by a sort of fermentation. In soil the conditions are especially favour- But the most able for some of these bacteria which act by oxidation conditions for because concentrated solutions and large quantities of nitrification organic material further the multiplication of the re-by tho soil. ducing bacteria, while in more dilute nutrient substrata, which is usually the condition even of unclean soil, the oxidising bacteria gain the upper hand. Hence in by far the greatest number of cases we obscrve oxidation processes in the soil, which on account of the marked subdivision of the material in thin layer's, the intimate contact of air, and the simultaneous surface attraction of the soil, lead to an extremely rapid and complcte destruction of organic matcrial. - As to the individual phases of the decomposition of the soil, and as to the various influences which act on it, wo must await the results of continued investigation with pure cultivations of bacteria from the soil under various conditions.

We also possess some observations, although on the Transport of whole unsatisfactory ones, as to the distribution and bactoria witl- 
transport of bacteria in the soil. The bacteria in the first place generally reach the most superficial layers with refuse fluids, from the air, sc. ; and hence in these layers we find by far the greatest number of bacteria. Many bacteria also pass at once from cesspools, \&c., into somewhat deeper layers of the ground, $1-3$ metres mndcr the surface, and impregnate these especially strongly in the immodiate neighbourhood of the cesspool. The question is whether bacteria can spread from these points over considerable distances of the soil in a horizontal and vertical direction. Currents of water or air suggest themselves as the chief means of transport. The former, when they soak through the soil from the surface as far as the ground water, ultimately carry the bacteria into the deeper layers and into the ground water; or again, where thcre is great craporation from the surface, the water rising by capillàry action carries bacteria which have collected beneath By downward into the upper layers. But on experimental investiga-
currents of water. tion neither mode of transport has proved to be practicable. Numerous filtration experiments on a large and small scale have shown most distinctly that a lajer of earth $\frac{1}{2}$ to 1 metre in thiclness is an excellent filter for bacteria, and hence the purification of fluids from bacteria must be still more complete in cultivated and especially in clay soil, and where the fluid mores with extreme slowness. In harmony with this we have the fact, first ascertained by Koch and latcr on repeated occasions in the author's laboratory, that the deeper. layers of soil contain very much fewer or indeed no bacteria in contrast to the superficial layers which are almost always rich in them (apart naturally from soil which has been artificially disturbed). Further, it has been repeatedly observed that wells which are well protected against contamination with bacteria from the surface and from the sides of the well furnish a water almost cntirely frce from bacteria; that, further, wells of water containing bacteria become the purer the more water is pumped up, and the more ground water comes in from the deeper layers of the soil.-Hence we can only assume 
that bacteria penetrate to a very limited degree into the deeper layer's of the soil, more especially as it has been shown from Hofmann's investigations that the passage even of fluids and of substances in solution only takes place with extreme slowness, and usually months and years elapse before the layers in the neighbourhood of the ground water are reached.

That a current of fluid passing upwards by capillary By upward attraction can carry bacteria from the deeper layers of the capillary soil to the more superficial has been recently asserted water. by Soyka* as the result of a series of experiments. Similar experiments, however, when repeated by Pfeiffer + and also in Koch's laboratory, have led to entirely contrary results. However, even if such a transport of bacteria by capillary currents were possible to a slight degree, we could hardly regard this mode of transport for bacteria as of any value under normal conditions, for we have evidence that the deeper layers of the soil are the poorest in bacteria, while the most superficial layers have the largest numbers; and, further, with regard to man, the capillary current as a means of transport for germs from the soil is scarcely of any importance, because, as we shall see, it is only the composition of the actual surface of the ground which has to be taken into consideration.

Whether currents of air passing through the soil can By currents of carry bacteria along with them was first experimentally air. tested by Niigeli, and then by Renk, Soyka, Pfeiffer, and others; all these observers obtained the uniform result that even strong currents of air were unable to carry a single bacterial germ through a layer of earth a few centimetres in thickness; the layer of earth even in the completely dry state acts perfectly as a filter, and in ordinary soil, which is always slightly moist, and in which the movement of the ground air is very slight, there is so much less possibility of detachment and transport of bacterin.-Lastly, we might also think that By continued bacteria might spread by continued growth. The giowth.

* Prager merl. Wochenschir., 1885, No. 28.

† Repert, d. anal. Ch., 1886, No. 1.-Zeitschrif f. Irygicne, vol. 1, Part 3. 


\section{(i98 DISTRIBUTION AND HABITAT OF THE BACTERIA.}

cuergetic processes of oxidation in the soil show us that active life, and in correspondence with that, marked multiplication of bacteria, occur's in it; but even were the growth very active, the vegetation could only spread extremely slowly over the enormously large surfaces which a porous soil offers, and this mode of spread would not come at all into consideration in the case of pathogenic bacteria.-Finally, transport of bacteria can occur in many instances by all sorts of animals which live and move in the soil, for example, by worms, but this can only take place to a very limited extent. On the whole, then, we must regard the bacteria in the soil as more or less fixed in a particular place, and only altering their position slowly and over short distances.

Behaviour of the pathogenic bacteria in the soil.

1. Do the pathogenic bacteria mul. tiply in the soil?

The results of the recent investigations as to the behaviour of pathogenic bacteria in the soil are thus of great importance. We have to ascertain whether the soil can in reality exert a specific influence on pathoyenic bacteria, whether such an influence is shown in favouring the growth and the multiplication of the pathogenic bacteria, or whether it affects their preserration and spore formation, or whether, in the third place, it is only the spread of the infective agents from the soil to man which depends on definite conditions of the soil.

From our present knowledge as to the conditions of life of the pathogenic bacteria, it scems very improbable that they are able to multiply in the soil. T'he low temperature in the deeper layers is of itself sufficient to prevent entirely the multiplication of this class of bacteria. In those upper layers, which always or at times show a temperature of at least $16^{\circ} \mathrm{C}$., growth of pathogenic bacteria could occur if suitable nutritive substances were present, if there were nothing to hinder the development, and if none of the more rapidly growing saprophytes were present. These conditions, however, are almost never fulfilled under ordinary circumUnfarourable stances. Numerous experiments by Bolton, Heraeus,

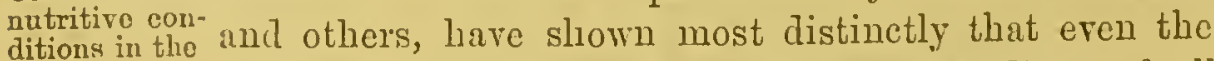
soil. tylloid bacilli, which are the least fastidious of all 
the pathogenic organisms, absolutely require a small quantity of the best nutritive materials for their growth and multiplication. In this respect the pathogonic bacteria show a marked contrast to some of the saprophytic forms, which can maintain life with nutritive matcrials of almost any quality, and can, therefore, grow actively in the soil. Better nutritive materials may, however, be occasionally found in certain localities in the most superficial layers of the soil, but at the most only temporarily, because rapid destruction and decomposition is always being brought about by saprophytic bacteria, and by the surface action of the elements of the soil. Various pathogenic bacteria can, it is true, be cultivated in pure diluted urine, and Schrakamp has also observed a development of anthrax bacilli in soil which was previously sterilised, and to which urine, blood serum, nutritive jelly, \&c., were added. From this, however, we cannot draw any conclusions as to the conditions of the normal soil. The excreta, \&c., reach it usually Direct exprerin a markedly altered condition, and containing nume- ments with rous saprophytic bacteria. As a rule they become vory results. much diluted in the soil by rain, and the layers in which they are in the first place retained are likewise full of saprophytes and formentative agents, and in a suitable state for rapid decomposition of the material. Hence manured soil presents very different nutritive conditions to those of pure fluids, and conclusions as to the bchaviour of the natural soil can only be drawn from experiments with real manured field and garden earth. Experiments of this kind have already becn made by Koch. Ho attempted to grow anthrax bacilli in garden earth, in very rich mould from the banks of rivers, in the mud of the same rivers, and also in the mud of strects, a little water boing added to these substances. Neverthcless no growth occurred.-Praussnitz las also made investigations in this direction in the author's laboratory, but has not as yet obtained any marked or permanent multiplication of patlogenic bacteria in any kind of soil, or by any mode of manuring. Ihese experiments are boing continued, and it is very possible 
that here and there degrees of uncleanness of the soil may be found which permit a short-lived and local multiplication; but on the whole such a property of the soil is exceptional, even under the conditions employed in laboratory work. And these conditions are in so far very much more favourable for the multiplication of the pathogenic bacteria than are the natural ones, because in them earth which has been previously sterilised at $100^{\circ} \mathrm{C}$., and freed from other bacteria, and air not containing carbonic acid, are always employed. In reality the concurrence of the saprophytes which find their most favourable conditions for existence in the soil, and also the accumulation of carbonic acid, are in a very marked degree unfarourable for multiplication of the pathogenic bacteria.

Multiplication Hence it appears to be of relatively little importance only occurs very exceptionally even in impure soil. for the question of the multiplication of pathogenic bacteria in the soil, whether the latter is more or less contaminated, that is to say, impreguated with excreta. Possibly greater or less contamination may lead to a certain fluctuation in the prevalent species of bacteria, but all of these belong to the category of the obligatory saprophytes, and leave no room for the facultative parasites which are much more particular as to the conditions of their life. Without doubt it will at times happen that a pure cultivation of pathogenic bacteria (for example blood from animals suffering from anthrax) reaches the upper layers of the soil along with good nutritive material, and then multiplication of the anthrax bacilli will occur in the soil so impregnated. But this is evidently no special action of the soil, for the same thing might happen on any other substratum. In a similar manner typhoid and cholera bacilli, which pass along with the fresh dejecta into a soil containing bad nutritive materials and numbers of saprophytes. may multiply to a certain extent for a short time at the expense of the nutritive materials contained in the dejecta, in the same manner as would happen under other very different conditions witlout contact with the soil. Here there is no sort of favouring and specific 
influence of the soil, and of the impurities of the soil, but on the contrary ratleer an unfavourable action.

If, however, we ask whether the soil favours the pre- 2. Are pathoservation of pathogenic bacteria, our answer must perhaps genic bacterin be somewhat different. This might occur if circum-the soil? stances were present which favoured spore formation or long preservation of preformed spores, or of those formed in the soil, or retention of vitality by non-sporebearing bacteria. Soyla* has recently observed, in a series of experiments with anthrax bacilli, that spores are formed more quickly when the fluid containing them is mixed with soil than when they are liept in the original fluid under conditions other'vise similar (at the same temperature, \&c.). Now spore formation in the No important case of anthrax bacilli occurs chiefly at the surface of furtherance of fluids, and hence spores are the more numerous, and formation. the earlier formed in a fluid the thinner the layer in which it is spread out. In soil which is not saturated with moisture, any fluids poured on it are quickly distributed in rery thin layers, and thus offer the best conditions for spore formation. But these conditions are also furnished on any substratum when the fluids are spread ont in thin layers on the surface.

According to Soylia, acceleration of the spore formation is most marked when the soil contains such an amount of moisture that from 25 to 75 per cent. of the pores are filled with fluid. This gives a very large margin, which besides was never sharply defined in his series of experiments, for numerous spores were found, and the delay in their formation was only trivial when a hundred per cent. of the pores were filled, while where the proportion was under 25 per cent. the spores were so widely distributed that comparison was impossible.

Soyla was unable to observe spore formation in the anthrax bacilli when the temperature of the soil was below $18^{\circ} \mathrm{C}$., or under conditions which would hinder spore formation in fluids.

From these results it is evident that the soil exercises no marked or specific iufluence on the formation of

\footnotetext{
* Fortschritte d. med., 1886, Nr. 9 .
} 
On the other hand spores once formed are well preserved.
Preservation of non-sporebearing baeteria. spores in the case of anthrax bacilli; on the contrary, the bacilli form spores in the superficial and somewhat dry layers of the soil in the same manner-perhaps here and there somewhat quicker, but certainly not to any marked degree-as in portions of the bodies of animals which have died of anthrax and which are lying on the surface, in the dejecta of anthracic animals, on nutrient vegetable materials, in marshy flats, \&c.

It is conceivable that in the case of some other pathogenic bacilli, which are less disposed to the formation of spores than the anthrax bacilli, spore formation may occur in a more exclusive manner and much more favourably under the conditions peculiar to the soil; as yet, however, we have no evidence in favour of such a view.

On the other hand, pre-existing spores, or those formed in the soil, are perhaps better preserved there than in any other superficial substrata. In the latter, as the result of rains, or of currents of water and air, which may bring new nutrient materials, may again moisten the dried masses, or may carry the spores to other parts rich in nutriment, the spores may very readily sprout and form bacilli, which then succumb to the saprophytes present. In the soil, on the other hand, the unfavourable nutrient conditions, and the unfarourable conditions of temperature, can almost always prevent the sprouting of the spores, and thus we have an explanation of the fact that existing spores can remain there for a long time, and that we so often find in the soil large numbers of resisting spores.

But even without previous spore formation the soil may possibly preserve various kinds of bacteria, including pathogenic ones. We saw previously that the chief reason why non-spore-bearing bacteria so readily died under natural conditions, was either because they were present in fluid media, and were then exposed to the danger of being overgrown by other bacteria, or because the loss of water and the drying of the nutrient substratum led to their death.

We can readily conceive that such complete drying of 
bacteria as to lead to their destruction does not readily occur in the soil, not even in the so-called dry soil, because the air in it is saturated with moisture, and a layer of vapour surrounds the elements of the soil; but that, on the contrary, as Soyka has suggested, the arrangement of the fluid in the soil in thin capillary layer's surrounding the particles produces a sort of fixation of the bacteria, and hinder's such free circulation of the organisms as occurs in thicker layers of fluid, and thus both their overgrowth by other bacteria and their destruction by drying are avoided; and these two factors, which are present in the soil in a very exceptional manner, lead to preservation of non-spore-bearing pathogenic bacteria to an extent which occur's much more rarely in other substrata.

The result that the soil may possibly be a particularly good Explanation preserving medinm for bacteria, but does not permit their of the marked mnltiplication, seems opposed to the experience mentioned infectivity of ahove that a soil impregnated with putrid fluids sets up infective diseases in animals much more readily than the pntrid fluids themselves. But this fact is casily explained without assuming a multiplication of these bacteria. In putrid fluids parasitic bacteria are present in very much smaller numbers than the saprophytic forms, among which some are always present which furnish very poisonons ptomaincs. On account of these ptomaines we cannot employ large doses of the putrid fluid if we wish to obtain an infection; after the injection of large quantities the animals only die of intoxication, and when on the other hand small doses are injected the chances of an infection are vory slight on account of the relatively small number of the pathogenic bacteria.-If now the putrid fluids reach a porous soil the individual bacteria are fixed and preserved, while there is rapid destruction of the ptomaines. Numerous experiments formerly performed, and also those carried on of late by Falk and Soyka, have shown that the soil by its capillary attraction splits np poisonous organic hases, and also ptomaines, in a very short time. Hence we car introduce subcutanconsly into animals large quantities of an impure soil without in any case causing intoxication, and henco with such a soil infoctire discases we much more casily produced than with tho fluids themselves. Very small quantities of the soil are usually
without any effoct.

The question now arises whether this supposed, but 
Local and seasomal differences in the power of the soil to preserve bacteria.

as yet by no means proved, power of the soil of preserving pathogenic bacteria is subject to local and seasonal variations; and whether these variations might suffice to explain the local and seasonal differences in the distribution of epidemic diseases as understood by Pettenliofer?

Although we have as yet no experimental proof of such a view, it is probable that certain local and seasonal differences in the preserving power of the soil do in fact exist. Thus compact rock, which does not permit the entrance of fluids and bacteria, would be out of the question as a means of preservation. Further, the rarious forms of porous soil would show quantitative differences according to the size of the particles and the degree of porosity. Possibly also the greater or less contamination of the soil is of influence, but only in so far that if the soil contains a large quantity of saprophytes and of nutritive materials, it will be less suitable for the preservation of pathogenic bacteria.

As regards time also, certain variations may occur; more especially it is conceivable that a very moist soil presents more the conditions of a fluid, and prevents the rapid distribution and fixation of the bacterial masses which are necessary for their preservation, while the action of the air which is present in the pores of a soil only partially moistened does not occur, and thus preservation is prevented. As excessive moistening of the npper layers of the soil is generally accompanied by a ligh level of the ground water, the sinking of the ground water may frequently indicate increased suitability of the soil for the preservation of pathogenic bacteria.

The preservation of bacteria in the soil is, howerer, not necessnry for the spread of discasc.

But in spite of the possible existence of these local and seasonal variations, the preserving power of the soil would not be in the slightest degree sufficient to exert an exclusive influence on the spread of epidemic diseases. For wo cannot assume with regard to any species of bacterium that the condition of preservation in which it is prescnt in the soil is at all necessary to fit it for being transmitted to other individuals ; on the contrary, all infective ngents are without doubt capable of causing 
further infection without and before coming in contact with the soil. And further, the preservation of the pathogenic bacteria is certainly not an exclusive property of soil ; on the contrary, sufficient preservation can occur in very various substrata, especially when the bacteria in question can readily form spores, as in the case of the anthrax bacilli, or are already spore-bearing when they leave the body, as in the case of the typhoid bacilli. Many kinds of soil may perhaps in this respect be of more than average value, and the preservation of the spores in them may be remarkably long and complete. But there are always so many other possible modes of distribution of the pathogenic bacteria that the action or want of action of the soil in their preservation cannot in very many cases exercise any marked influence on the spread of the epidemic.

A third question arises, in what way bacteria preserved 3 . How do the in the soil can spread to man, and whether a definite preserved oondition of the soil, varying according to time and place, spread from has much influence on this spread? The following man? modes of transport may come into play in the case of the bacteria of the soil :-

1. Winds, which carry up the dust, and with it the Winds. bacteria, from the most superficial layer's of the soil, and transport them through the air. From what has been said above as to the organisms of the air and as to the movement of bacteria within the soil, it is evident that such a detachment of bacteria is only possible in completely dry soil, and only from the superficial layers, which are converted into dust. A thoroughly moist soil does not permit the detachment of bacteria, nor docs a soil which possesses a superficial dry layer, but the outermost surface of which is moistened from time to time by
slight rains.

2. The ground water, and the water taken from it for drinking and other purposes. Where there is a for Ground water. layer of cultivated soil above the ground water this mode of transport cannot come into play; but where the ground water is only separated by thin layers of loose soil from the surface, and where it can ultimately reach the sur- 
Food.

By animals.

Digging.

Sensonal influences on their spread due to the moisture of the ground.

Behaviour of the water in the soil. face if it inereases in amount, and also when fissures and eraeks open a communieation between the contents of cesspools and the ground water used in houses, it will oeeasionally happen that the bacteria poured into the soil again return to man and to dwellings.

3. Articles of food which grow in the soil (potatoes, turnips, roots, \&c.) carry particles of earth adhering to them, and large numbers of bacteria from the upper layers of the soil, into dwellings, kitehens, kitehen utensils, towels, \&c., and thus ultimately to other limds of food.

4. Men and animals who come in any way in contact with the soil, implements whieh are employed in eultivation, \&c., can in a similar manner aid in the transport of the baeteria from the soil to the domestie economy.

5. By digging the soil and laying bare the decper layer's which may eontain bacteria, while at the same time dry winds prevail, numbers of pathogenic bacteria may be detached whieh have reached the soil from defective eesspools, or at a former time from the surface, but which have been withdrawn from contact with the outer air by being corered with nerr layers of soil. It is possible that we may in this way explain the frequently suggested connection between typhoid epidemies and digging up the soil of streets.

As a matter of fact it is evident that these rarions modes of transport of the pathogenic baeteria of the soil do not come equally into action in every soil and at every season, but that local and seasonal causes of rariation exist, and favour or hinder one or other mode of transport.

The seasonal influenees are most distinctly seen in the first and most widespread mode of transport, viz., the spread through the air; and this is due to the varying degrees of moisture of the upper layers of the soil.

$\Lambda$ s to the important conditions of the moisture of the soil in relation to this point we have obtained clearer information by Hofmann's investigations.* In porous soil we hare to 
listinguisl, in the first place, a superficial zone of evaporation in which the degrce of moisture of the soil is very variable, and oscillates between complete saturation and marked dryness; in this zone, when of great breadth as the result of the summer heat, the whole of the rain in late summer and harvest often finds a pliace, and the filling of the capillary pores does not reach to its lower border; in this case there is therefore always a dry layer between the most external part which is temporavily wetted by the rains, and the deeper layel's of the soil in which the water lies. And under these conditions all the impurities which reach tle soil remain in the upper dry zone.

Under this layer lies a zone which never dries, but in which the capillary pores are always full of water. If this zone receives water from above (when the upper dry layer las been completely filled with rain water) the amount of water in it remains the same, for the excess runs downwards into the third zone, that of the ground water.

It is evident that, when a drying zone exists, the con- Favouring ditions are the most favourable for the detachment and aetion of a carrying away of the bacteria of the soil by currents of air. It is only in that case that this most important mode of transport comes into play. During the whole of the winter and a great part of the spring there is usually no dry zone in our climate, and hence no possibility for such a passage of germs into the air. In the latter ond of summer and in antumn, on the other hand, this possibility is prescnt, and is only absent from time to time when the occurrence of rain renders the outer
surface moist.

As the existence of a dry zone always results in the The variations cessation of addition to the ground water from above, and in the ground thus leads to sinking of the level of the ground water, index of an we have in the variations in the lerel of the ground water of the soil a fairly useful index of the ground water of the soil. the bacteria of the soil by the wind. however, quite correct, because the temporary moisture not, the surface of the soil (sometimes lasting ory moisture of and months) and the cossation in the cren for wcels occasioned find no the transport thus level of the gromel water.

The existence of a dry zone has a further farourable 
Furtheraction effect on the number and variety of the bacteria transof the ilying ported by the wind, because all impure fluids, dejecta,
zone. \&c., and with them all bacteria, remain in the most superficial dry zones. In this way the accumulation of the most various kinds of saprophytes, and also of pathogenic bacteria, talies place to a much greater cxtent than in the case of a thoroughly moist soil where there is no drying zone, because the continuous stream of water in the latter case carries the bacteria to a certain though moderate depth and remores them from the action of the wind.

The other modes of transport are only to a slight degree subject to influences varying according to season. Formerly a variation in infective power was ascribed to the ground water according as its level was high or low; usually, however, the number of bacteria present in it is but little influenced by alterations of the level.

The spread by food, man, and various materials can perhaps be favoured by the presence of a drying zone, in that when such a zone exists a large accumulation of bactcria occurs in the most superficial layers of the soil from which the transport takes place; nevertheless a constant difference of this kind can only be made out in the case of those soils which are exposed to continual contamination, as in the soil of streets, courts, \&c. ; while the soil of fields, for example, which are only impregnated at considerable intervals with fluid containing bacteria, can only show seasonal variations in the action of the mode of transport as the result of a conjunction of accidents.

On the whole, therefore, it is practically only the drying of the surface of the soil which increases the danger of distribution of pathogenic germs from the soil.

fulluence of the local (i) nstitution of the soil on the spread of the bacteria.

The existence of any influence on the transport of the bacteria of the soil as the result of the character of the soil in any given locality is not so evictent. Here again it is only a porous soil, and one which can talie up large numbers of bacteria, which could excrt an influence on their distribution. Further, we may suppose that where the pores are large the bacteria do not on the whole accumulate in such numbers, but are more readily clistributed orer con- 
siderable distanees than in finely porous soil; and this must be the result, more especially when copious rains thoroughly soak the soil, and when there is no drying zonc. In such a grossly porous soil the drying zone assumes a special importance; for it is only while it exists that there is any chanee of the bacteria being transported by winds, or by men or things. Finely porous soil, on the other hand, keeps back the baeteria in the superficial layer to a much greater extent, and even possibly when the dry zone is absent; in this case the baeteria may be distributed, not indeed by winds, but in other ways, for example, by contaet with man, \&e., even when the surface is moist, and henee the differenee between the dry and the moist stage is not so sharply marked in finely polous soil.

We must, however, for the present leave it to experimental investigations made with baeteria to confirm or to eorreet these ideas, and to give us definite information as to the speeial disposition of the individual kinds of soil for the spread of infective germs.

From what has gone before we ean at all events eome Risunc. to the definite eonelusion that the soil does not lead to any special ripening, or even to active multiplieation of the pathogenic baeteria, but on the other hand, that it possibly aids in their preservation, and in the distribution of the bacteria so preserved. Both preservation and distribution are probably subject to local and seasonal variations; for it is only a porous soil, and only at a time when a superficial dry zone exists, and where the ground water is as a rule sinking, that a preservation and more especially a distribution of the infective germs ean take place.

By this property of preserving the pathogenic agènts Influmec of in an unaltered condition, and allowing their return of the soil on again under eertain eonditions in large numbers to the of the spreil on surroundings of man, the soil probably takes part in the dircenses. spread of many infective diseases; and the dependenee of these properties of the soil on local and seasonal influences will ultimately find its expression in the loeal and seasonal variations of many epidemies. The most 
E'requent dis tribution of the typhoid bacilli from the soil.

'l'hoil' distribution, howcrel, does not occur only by means of the soil.

The pathonenic agents io not acquilc infective properties as the result of the influenee of the soil. important mode of spreact, more especially of such pathogenic bacteria as reach the soil directly or in a roundabout way along with the dejecta of the sick (e.I., typhoid bacilli), and which either contain resistant spore forms in the dejecta as passed, or form these in the soil, is that in one or other of the ways mentioned they are again carried into the houselold from the uppermost layers of the soil. And this distribution only occurs from a porous soil, and at a time when a dry zone exists (in other words when the level of the ground water is low), that is to say, it depends markedly on local and seasonal predisposition.

But even the typhoid bacilli are not always restricted to this mode of spread. We must assume that they can cause infection in other ways, and this assumption is still more necessary in the case of those pathogenic bacteria which do not reach the soil to the same extent, or which (like the cholera bacilli) cannot be distributed from the soil in the most common manner, viz., by currents of air, for the reason that they cannot withstand the necessary degree of drying. In the case of the majority of the facultative parasites, therefore, their preservation in and distribution from the soil forms in reality a rare exception.

The important difference between our views and those of Pettenkofer is, therefore, that we (basing our opinions on our present knowledge of the biology of the pathogenic bacteria and their behariour in the soil) can find nothing in the soil which must of necessity act on the pathogenic bacteria in order to make them capable of producing infection. The idea formerly held as to a sort of ripening of the infective agents under the influence of certain mysterious properties of the soil cannot be brought into accord with the reccutly ascertained facts as to the biological properties of the bacteria, and must now be definitely abandoned. Nor can we assume that the multiplication of pathogenic bacteria takes place exclusively in the soil (perhaps with the exception of the as yet completely unknown cause of malaria), because other superficial substrata are as a whole 
much more suitable for such a multiplication; what the soil really effects in a marked manner, viz., the preservation and the distribution of the preserved pathogenic agents, is, however, not an exclusive privilege of the soil ; on the contrary, the distribution of these infective agents can also take place by other means and in otler ways, which are for the most part more arailable than the roundabout way through the soil.

Further, the occurrence of local and seasonal varia- The local and tions in the distribution of the infective diseases, which, seasonal according to Pettenkofer, are only explicable on the as- is not only sumption that the soil exerts an influence, does not by means of the any means necessitate the idea of a constant connection soil, but also between soil and epidemics. We see, on the contrary, that the other modes of spread in which the soil does not come into question, c.g., the spread by the food, by contact, \&c., are subject to local and seasonal variations which are quite sufficient to explain the corresponding oscillations of the epidemics (see the following part).

Bacteria are almost always present in very varying Occurrence of numbers in water. The varieties observed are almost bacteria in without exception saprophytes. Among these there are some which are of special interest, because they are able to multiply markedly in the presence of imponderable quantities of the most simple nutritive materials, and at it tcmperature of $\mathrm{S}^{\circ}$ to $10^{\circ} \mathrm{C}$., and hence they are present in large numbers in the most various kinds of water. These "water bacteria" of which Bolton" has isolated six Bucterii varieties, which are very widely distributed, influence the total number of bacteria in any particular water: for which where they are present they multiply with such extreme rapidity, that very soon the number of all the other hacteria becomes insignificant compared with them. The quality of the water is quite indifferent for these typical inhahitants of the water; they multiply quite as markedly

" buiton, Zeitschr. f. Ilygiene, vol. i., Part 1.-See Cramer, Nie Wasse rver:sorgung von Zïrich. Zïrich, 1885. -Wolffhügel, Arb. a. d. Kais. Ges. Aml, 1885, vol. i.-Wolffhügel and Riedel, ibid., 1886, vol. 2.I. rne, Alli della R. Acad. dei Iincei. Ser. 1, vol, i. 
Behaviour of pathogenic bacteria in watex. in distilled water which is as pure as possible, as in the so-called bad well water which is contaminated witl sewage.-Besides these special bacteria we have as inhabitants of the water those forms which are clalacterised by their more advanced morphological development, and by the variability of their vegetative forms insisted upon by Zopf, viz., crenothrix, cladothrix, beggiatoa. We require more accurate investigations as to the character of the water which is necessary for the development of these fungi.

Many of the other saprophytic forms apparently either do not multiply at all in water, or only to a very limited extent. Nor can any of the pathogenic bacteria multiply in water even where the temperature is favourable, because they absolutely require a certain even though a small quantity of the best nutritive materials. Typhoid bacilli require, according to Bolton's experiments, at least 67 milligrammes of organic nutritive materials per litre of water, cholera bacilli require 400 milligrammes per litre. Such an amount of organic materials ouly occurs extremely rarely in water which is employed for household and drinking purposes; and besides, in the case of the pathogenic bacteria very much depends on the quality of the nutritive materials, and even the presence of a considerable quantity of the less nutritious organic materials which are usually present in water is unable to replace the necessary but small amount of peptone and albumen.

On the other hand, the pathogenic bacteria retain their vitality for a comparatively long time in water. Nonspore-bearing anthrax bacilli and micrococcus tetragenus live for about six days, typhoid bacilli free from spores for fourteen to twenty days, spore-bearing bacilli from thirty to ninety days or longer. In the case of cholera bacilli Wolffhügel and Riedel have made out a duration of vitality of about eighty days, and frequently also a multiplication; however, in some of their experiments, the results of which are not completely in unison, they have probably sown too many organisms, and have carried over a small amount of nutritive material from 
the cultivation, which has been able to exert a decided influence on their multiplication and preservation. In numerous experiments which have been made in the author's laboratory multiplication of cholera bacilli has never been observed in any water when only small numbers of the organisms were sown; on the contrary, they have always died within eight to fourteen days.

In these laboratory experiments the conditions are particularly favourable for the development and preservation of the pathogenic bacteria, because sterilised water has always been employed for the cultivation experiments. Under ordinary circumstances the saprophytes, which are always present in large numbers in water, must render the conditions much more unfavourable for the existence of the pathogenic bacteria. This has in fact been directly proved by experiments macle by Wolffhügel and Riedel, who have found that cholera bacilli disappear in unsterilised water even after two days, although large quantities are introduced.

The entrance of the bacteria into the rater does not Mode of occur to any great extent through layers of intact soil, entrance of or through the ground water. The unanimous results wells. of the experiments made by Roth, * Bolton, + Heracus + + and others show that in the majority of wells the number of bacteria constantly decreases the more fresh ground water is drawn into them by continuous pumping. Further, after the pumping has been continued for some time there are unusually few bacteria in the wells if they are well covered on the surface and protected, as far is possible, from fresh contamination from the well wall ancl from the pumping tube; e.g., where we have tubular iroll wells and conducting pipes. Hence we must conclute that the bacteria reach the drinking and houselold water chiefly by currents from the surface, and also by cracks and passages which run through the soil from cesspools, \&c., towards the wall of the well. It is evident that pathogenic bacteria can also reach wells in

* Vierteli.f. ger. med., N. F., Bul. 43, Heft 2.

$\dagger$ 'eitschrift I. Mygiene, Bd, 1 , Heft 1.

\pm llikl., Heft 2. 


\section{DISTRIBUTION AND MABITAT OF THE BACTERIA.}

the same manner. Hence wo luve the best opportunity for the infection of drinking water where an imperfectly covered well stands in the middle of the ordinary dirty court; as a rule all dejecta and waste water are poured out on the soil of these courts, aud further, the arrangements are frequently such that the superfluous water employed for washing clothes, for example, flows back again into the well.-At times, also, the ground water which supplies the well contains numerous bacteria; this is the ease, for example, when the distance from the surface is slight, or when cesspools in the neighbourhoods of the wells reach as deep as the ground water, or when the soil is exceptionally porous.

Factors which The number of bacteria in a water chiefly depends on influence the number of bacteria in water. whether varietics are present which are able to multiply in the water, and whether the eonditions are favourable for their multiplication. These conditions are the more favourable the higher the temperature and the lougrer the water is stagnant and able to maintain the newly formed bacteria. Hence we find the greatest numbers of bacteria in stagnant water and during the summer months, and the smallest numbers in wells which are much used and during the cold scason of the year. The other conditions of the water, the amount of organic material and salts present in it, are not of importance for the multiplication of these special linds of bacteria, nor for the number of bacterial in any giren water. It is only when the true water bacteria are absent, and saprophytes are present, which require a large quantity of nutritive materials, that the differences in the chemical constitution find an expression also in the number of the bacteria.-We cannot, therefore, draw any conclusion from the number of living bacteria in a given specimen of water as to its infective porrer, or eren as to the degree of eontamination; such couclusions can only be come to when we asecrtain at the same time whether aquatic bacteria are present, and whether the conditions, such as the season of the year or the frequency with which the well is used, are farourable for their inultiplieation before the specimen was taken. 
It is always very difficult to pick out the pathogenic Demonstrabacteria from among the large number of saprophytes. presenee of And in attempting to ascertain their presence we have pathogenic also to remember that they do not as a rule live long in well water; that as they never multiply in the water, every withdrawal of water, and every addition of pure ground water diminishes their numbers; and it is only in those cases where there is repeated contamination by pathogenic bacteria that the chances of demonstrating them by cultivation are at all favourable.-It is probably owing to these difficulties that pathogenic bacteria have never as yet becn demonstrated witl absolnte certainty in any water.

In addition to the ground water which is chiefly Running employed for drinking and lousehold purposes, the water as a water which flows on the surface of the ground often transport of serres as a means of transport of saprophytic, and at times of pathogenic bacteria. In fact the water in gutters, streams, and rivers is particularly clangerous, because it not unfrequently serves the double purpose of taking up and removing waste water of the most rarious kinds, and at the same time of supplying water for household purposes.

Further, stagnant and superficial collections of water, Banks of the muddy banks of rivers, and fields which are at times rivers, pords. submerged, are probably of special importance for the andsubmcrged etiolo special importance for the regions as etiology of many infective diseases. These act not only babitats as means of transport for all sorts of disease germs, but they also in all probability facilitate the growth and multiplication of the facnltative parisites. It las been slown that anthrax, typhoid, and cholera bacilli can grow well on moist, dead portions of plants, snch as often occlir in enormous quanities on the hanlis of rivers, in regions which are flooded, ice. In these places the bacteria mentioned find a farourable temperature, as well as the necessury moisture and nourishment, during a great part of the year, and if a saprophytic existence of parasites is possible anywhere in the natural surroundings of man, it must be here. Such a saprophytic growth is most likely to occur in tropical clima!es; it 


\section{DISTRIBUTION AND HABITAT OF THE BACTERIA.}

was there that Koch succeded in demonstrating the presence of cholera bacilli in one of the Indian tanks, and proving that a marked saproplytic multiplication of the bacilli had occurred on the banlis of the tank.

Facteria in urticles of foorl. l) evelomment of facultativo parnsites on urtivles of foner.
We daily talie into our bodies rery large numbers of living bacteria, not only with water, but also with our food. To some articles of food-for example, beer, cheese, \&c.-numerous bacteria are intentionally added in their preparation. In the case of other articles of food, of which the edible portions are formed beneath the surface of the soil, large numbers of bacteria adhere to the particles of earth surrounding them. Other's again, such as fruits, are covered with numerous bacteria from the air, which are either fixed on their sticky surface, or are deposited there by the condensation of watery rapour. Further, it very frequently happens that articles of food which were originally free from bacteria, or which were sterilised in their preparation (milk, meat, rarious kinds of cooked food), are infected either by contact or from the air, and according to their nutrient conditions and the prevailing temperature, smaller or larger colonies of bacteria derelop on them.

In all these cases the colonies may consist of completely harmless saprophytes; or, on the other hand, bacteria may be present which are able to set up fermentation, and which are not altogether indifferent, for if taken into the body in very large numbers they may exert their energies in too marlied a manner in the human digestive tract; or, again, the bacteria may belong to a class which usually grow as saprophytes, but which produce very active ptomaines, some of which may cause morbid changes in the intestinal mucous membrane; or, finally, pathogenic bacteria may be at times present in the food.

Those bncterin which develop on food liept in the liouse seem to be especially worthy of attention. Under these circunstances the temperature is often very 
favourable for a multiplication of facultative parasites; further, the nutricnt substrata could scarcely bo better even if they were prepared for the artificial cultivations of the pathogenic bactcria; again, many articles of food are solid, and thus it is not so easy for the saprophytes to overgrow these bacteria. Milk, broth, and meat aro excellent nutrient substrata for typhoid and cholcra bacilli, and we cannot but suppose that these and similar pathogenic agents, when they once reach the food, the vessels, or washing-cloths, \&c., either through the air, or from the carth, or by contact, very readily multiply to such a markcd extent that the greatest dangers may lesult from the use of such food.

Not only the facultative parasites, which find here obligatory conditions particularly favourable for their development, parasites. but also the obligatory parasites can be carried to man by the food, and especially those which (like the tubercle bacilli) are infective for animals as well as for man, and are at times introduced by the use of meat.

The dangers on the side of articles of food can be almost completely aroided by the mode of preparationby sufficient boiling and roasting - and by aroiding the use of food which has been liept for a considerable time after being cooked. But as we know, in all nations and in all classes of the people part of the food is eaten in a raw state, or after it has been kept for a long time, and thus it contains numerous bacteria. The proportion of Local differthe whole food which is employed in such a dangerous ences in the condition is very variable, and differs according to the bacteria in customs and manners of each people. Thus while in Southern lands thcre is the greatest carclessness as rogards the food, cven the larger portion of it being used in a raw or half decayed condition, in other regions there is such great care in the selection, treatment, and proparation of articles of food that the danger of this mode of infection is reduced to a minimum.

Honce the number of bacteria in articles of food, and the dangor of infection resulting therefrom, is evidently subject to marked local differences, and seasomal variations can also occur with equal frequency. 'Tluus, in 
Sensoual differences.

our country the summer is naturally the time of the year' during which those purasites which require a ligh temperature ean most readily establish themselves on artieles of food; furthcr, on iccount of the presenee of raw deeaying fruits antumn is a particularly favourable time for contamination with numerous and different linds of bacteria, and it so happens that, at the same time of the year, the rarious articles of food arc exposed to greater danger of contamination by the bacteria preserved in the soil, becausc the latter are at that time readily distributed owing to the formation of dust on the surfaee of the ground. This dust formation is in our climate almost exclusively limited to the end of summer and to autumn, because it is only then that a superficial dry zone is constuntly and for a considerable time present.- Henee we lave various reasons for believing that at a partieular time of the year exeeptionally large numbers of bacteria are taken into the intestine with the food, some of which perhaps produce ptomaines, and thus possibly propare the intestine for more serere diseases, while others may penetrate as infective agents into the predisposed intestinal traet.

From what has been said, it is evident that artieles of food probably form such a marked faetor in the spread of the infective diseases that we must in future attempt to gain a more aeeurate knowledge of this mode of infection.

Bacteria in clothing.
Numerous bacteria of all linds are also frequently present in the artifieial surroundings of eivilised man; thus the elothing is for the most part very rich in living miero-organisms, whieh have roaehed it partly from the surfaee of the body and the exereta, and partly from without by the dust and rain. Washing elothing is not uneommonly the means of transport of faeultative and obligatory parasites; such a rôle on the part of elothes is well known in the ease of those infeetive diseases whieh are loealised in the skin (c.g., small-pox), 
also in the case of cholcra, where, owing to the fact that Infoction by the linen becomes soaked with the nutrient substances clothing. contained in the dejecta, multiplication of the pathogenic agents may occur on it, so long as drying does not take place. Infective disenses of wounds, diphtheria, puerperal ferer, tuberculosis, \&c., are also without doubt frequently carried by linen and dressings. Unfortumately we do not as yet lnow, and must still ascertain by cxact researches, how far the usual methods of cleausing linen destroys the infective agents, or how long they may retain their vitality in linen which has been washed and put away.

The dwelling offers many opportunities for the pre- Occurrence of servation and distribution of bacteria, and especially of bacteria in tlee facultative and obligatory parasites; a multiplication within the materials, which in a narrow sense belong to the dwelling, does not seem to occur. The soil under the In the soil floors forms, according to Emmerich's investigations, a under floors. particularly favourable reservoir, and often contains enormous numbers of saprophytic, and not uncommonly also of pathogenic bactcria. These are present partly in the original and for the most part very impure material, and in part they reach it through the medium of the water used for scouring, which carries with it sputa, remains of dejecta, \&c., and passes through the numerous joints and seams of the floor into the porous material beneath. In this way the hacteria of pneumonia, spores of tubercle bacilli, \&c., can readily reach the soil. It is probably quite exceptionally that a multiplication of bacteria occur's here, because as a rulc the material contains very little water. But it is probable that varions forms of bacteria can be preserved in the porous mass in a manner similar to that which oceurs in the natural soil. The bacteria can be extremely roadily detached aud distributed from this reservoir by tlie mechanical disturbances to which the floor of a dwelling-room is exposed; the large masses of dust which rise from the seams at every step can be rcadily secn in a beam of sunlight.-Where the flooring is close aud covered with oil colours, more especially, 
lowever, where it is waxed and polished, this reservoir of bacteria with its danger of infection need not be taken into consideration.

Further, the furniture, curtains, and corners of the rooms, which are usually insufficiently cleaned, form places on which bacteria may be deposited and preserved for a considerable time.

Bacteria in refuse.

Not a good nutritive sulbstratrm for patiogenic baeteria.

The refuse of louses and of cattle stalls forms also a favourable place for the accumulation of bacteria. The intestinal cxcreta contain at times infective agents mixed with the large numbers of saprophytes; for cxample, typhoid bacilli, cholera bacilli, tubercle bacilli, anthrax bacilli, the bacilli of swine fever, of chicken cholera, \&c.; further, probably the infective agents of dysentery and of the epidemic diarrhœa of children. Fresh urine scldom contains micro-organisms, but it is a suitable nutritive substratum for the most various hinds of bacteria; we must further bear in mind the kitchen refuse, kitchen water and washing water, which are for the most part laden from the first with numerous bacteria, and can also serve as a settling place for others when it stands for a long time. All these wastc materials have up to the present bee! looked on as the chicf nutritive materials for pathogenic bacteria, and in this respect have as a rule been much over-estimated; on the contrary, they usually offer such excellent nutrient conditions for the saprophytes that they are totally unsuitable for the growth of infectivo agents. We see in all waste waters, in putrid fluids, \&c., that the facultative parasites, even when they are sorn in them in enormous quantities, die in a few hours, or at most days; and it is only in the spore form that they can be preserved (without multiplication) for a longer time.

Dangerous on Hence these waste materials are only of importance wcreunt of the for the spread of the infective disenses in so far as they dejecta which may at times contain obligatory or facultative parasites contain patho- which come from the bodies of discased individuals ; and
genicbacteria. hence the most important hygionic point with regard to the remoral of the waste materials is that the whole mass, with the infectire agents which may be prescut in 
it, should be remored as quickly and completely as possible from the dwellings and from the neighbourhood of susceptible individuals. This aim will be best fulfilled Their prompt by a system of drainage which is at the same time com- removal by bined with a constant and sufficient supply of pure water, thus rendering the carrying out of cleanliness easier. The system of removal of refuse by means of pails seems less satisfactory, especially when by this means the excrement and the infective agents in it are thrown on gardens or fields in the neighbourhood of dwellings, thus leading to the preservation of the germs, and therefore probably to their re-introduction into the dwellings. The system of cesspools, by storing up the masses for a longer time, affords a better guarantee than the pail system for the cleath of the infective bacteria before they reach the ground. A decided disadvantage of the two Disadvanlast-mentioned methods as compared with the drainage tages of the system is, that there is always a danger of infective germs methods. spreading in some way or other to the surroundings of man, from dried masses in the exit-tube; while in the former system the water-closets and pipes leading therefrom can be readily kept in a clean and moist condition. And further, stagnant gutters, dirty courts, \&c., with their multifarious dangers of infection, can only be effectively dealt with by flushing with water and by drainage.The question as to the hygienic value of the methods of cleansing towns must therefore be reconsidered from the points of view shortly indicated above; we must also trace out more accurately the fate of the pathogenic agents in each of the systems employed, and of course we must also carefully weigh other interests before coming to a final conclusion as to the value of any given system. At all events the most important hygienic Necessity for points of view from which these matters have up to the fresh contpresent been consiclered are incorrect, because tho viow lias been acted on that especially good nutrient matcrials for pathogenic bacteria aro prosent in the refuse materials, and that it is necessary to keep the soil free from these substances, and to remove them from human dwellings, in order to prevent a development of disease germs in 


\section{DISTRIBUTION AND HABITAT OF THE BACTERIA.}

Significance of contamina. tion of the soil.

Infection as the result of professionand occupation.

Infection by rloctors, midwives, \&c.

them or in the eontaminated soil. We must undoubtedly give up this view, sinee we have become better aequainted with the conditions of life of the pathogenie bacteria; and we cannot now see in a contamination of the soil such a great and immediate danger of infection as formerly, especially when the water required for household purposes is not taken from this soil, but is condueted from a distanee by a system of pipes. Of eourse, however, it is very desirable for other reasons to lieep the soil pure, and this is attained at the same time and in the most complete manner by those methods which keep prominently in view as rapid a removal of all pathogenic agents as possible from the dwelling-house. The neeessity for and the sanitary effect of drainage thus remain the same, and it is only the basis on whieh the precantions are taken which is altered in accordanee with the more reeent views.

The profession and business of the individuals also in many ways aid the spread or the reception of pathogenic bacteria. In former times, for example, the infeetive diseases of wounds were undoubtedly often carried by physieians who did not at that time hesitate to examine the infeeted wounds of one patient and the fresh wounds of another with the same imperfectly cleansed finger. Even now infection is frequently earried by the clothes and hands of those medieal men who do not rightly estimate the dangers of infection. In like manner midwives, to whom is almost entirely to be ascribed the transmission of puerperal fever, nurses, washerwomen. old clothes men, rag-eollectors, \&c., very often lead to opportunitics the further spread of infective agents.- We only require for infection to speciaily mention further the manifold possibilities of
in children. infeetion to which children are wont to expose themselves; how they eover their hands now with the soil of dirty courts, now with the water of gutters, and the most various objeets rich in baeteria, and then the next moment plaee them in their mouths, or ent their food with their dirty hands. It is difficult to understand how when a ehild beeomes ill from typhoid ferer, diphtheria. \&e., the majority of doetors, in spite of these tangers of 
infection which are constantly present and very evident, always scarcl for the ominous glass of "impure " water" which lias in their opinion caused the disease.

Large numbers of bacteria are also present on the Bacteria on surface of the human body. The most various forms of the surface of bacteria have alroady been demonstrated on the skin, in the sweat from the feet and axilla, \&c. It is evident on the skin. from the researches of Forster, * that in spite of apparently careful washing, bactcria still adhere to and retain their vitality in the folds of the skin of the finger and under the finger nails; he found that, even after cleaning the hands with brushes, water, and soap, if the fingers were pushed into nutrient jelly a varying number of bacterial colonies constantly developed.

On the internal surfaces of the body still greater In the mouth. numbers of bacteria are found. For a long time saprophytes have been known to exist in the month, which excite fermentations, and bear a distinct relation to caries of the teeth (p.391); various forms of pathogenic bacteria have also been observed there. Thus Kreibohm in a relatively small number of cultivations from the secretions of the mouth has isolated four different forms. which cause septicrmia in animals (see p. 319); and also the bacillus crassus sputigenus, which occurs comparatively frequently in man, which likewise causes septic infection in some animals, and which produces in its cultivations a violent poison, lilling those animals which are not susceptible to infection by intoxication if introduced in large doses. This state of matters is readily intelligible when one considers that in the cavity of the mouth there exists a very suitable tempcrature, and in the dead cpitholium, \&c., a good nutritive material for the development of pathogenic bacteria. Hence it is readily conceivable that parasitic bncteria, which require a special point for thcir invasion of the body, can live for a time as epiphytes, till they find an opportunity of entering the body, and thus the occurrence of an infec-

* C'entralb. f. klin. méd., 1855, Nr. 18. 
tion need not be immediately preceded by the reception of the infective agent. Possibly this is the meaning of the observation made by Loeffler on the presence of the diphtheritic bacilli in the secretions of the mouth of a healthy child (see p. 287).

Un the respi- Various bacteria (e.g., Micrococcus tetragenus) are ratory mucous also found in the laryngeal mucus, and in that of the
membrine. trachea and bronchi ; these have been carried in by the respired air, and have in part multiplied to a considerable extent in the mucus.

In the Enormous numbers of bacteria are also met with in stomacl. the intestinal tract. Numerous forms are found even in the contents of the stomach. It has been erroneously assumed that the acid contents of the stomach kill most forms of bacteria; this is, however, not the case. Feeble aetion Experiments which have been made by Mac Fadyan of the gastrie in the author's laboratory have shown that even the
juiee strongly acid gastric juice of the dog can kill only cholera and anthrax bacilli with anything like constancy, that, however, most other bacteria are not so susceptible to the action of the gastric juice, and can pass in a living state through the stomach even when conditions are as farourable as possible for an energetic action of the gastric juice; among bacteria which behave in this way may be mentioned micrococcus tetragenus, staphylococcus aureus, bacillus cuniculicida, \&c.

In the intestine.

Hence there is for the most part only a temporary hindrance to development in the stomach, and regetative forms such as spores reach the small intestine in a living condition in large numbers. There they find a good opportunity for development so long as the reaction Some prevail- of the chyme remains neutral or faintly alkaline; it is ing rarieties. true that this multiplication appears to be limited chiefly to certain definite forms of bacteria, so that in spite of the multiplicity of forms and varieties which strikes one at first, there are some whicl evidently find in the intestinal contents a particularly farourable soil for multiplication, and occur there almost constantly. These prevailing varieties seem to rary according to the 
composition of the food as well as the course and stage of digestion.-The occurrence of an acid reaction in the intestinal contents must cause marked alteration in the bacterial life in the intestine. More especially do organic rcids, such as occur in the later decompositions of the chyme, exert a particularly marked inhibitory action on many bacteria; it is only some forms which are exceptionally insensitive, such as lactic acid and butyric acid bacilli, which still remain capable of development, and thus gain the mastery the sooner.-Anaërobes are also Anarrobes. constantly found in the intestines, and often in such large numbers that there can be no doubt that they have multiplied there. This is easily intelligible, because in certain sections of the intestine, and in certain layers of the intestinal contents, there is always a deficiency of oxygen sufficient to permit the development of anaërobes.

Among the large numbers of intestinal bacteria the Pathogenic saprophytes are most numerous, nevertheless those bacteria in tho bacteria which do not grow so quickly as the saprophytes, and are hence as a rule hardly adapted for concurrent growth with them, not uncommonly multiply to a marked extent, and possibly grow in the folds of the intestinal wall which are more removed from the action of the saprophytes of the chyme. In this way bacteria may develop in the intestine which are dangerous to the body, partly by means of their ptomaines, and partly by penetrating into the intestinal wall and causing infection.

We must await future investigations for a more accurate knowledge of the intestinal bacteria, for an isolation of the varieties which occur most frequently or regularly, and also of those which only occur now and then, and for facts as to their functions and their effects.*-This study is to some extent rendered difficult by the fact, that in microscopical preparations made

* While these shects were passing throngh the press, an extensive rescurch, which has just been published by Esehorieh (Die Darmbakterien res Siüulings, Stnttgart, 1886), forms an importunt beginning to the
investigations in this department. 
some of the intestinal bacteria do not grow in the ordinary i:nltures.

Absence of bacterin in the interior of the healthy body.

the interior of the body under normal conditions (see p. 83). It is only when parasitic organisms hare penetrated into the body, and have set up clisease there, that we have the presence of specific bactcria cither in wxecpitions. the blood or in rarious organs. Further, Wyssokowitsch has shown that bacteria may be temporarily; present in an apparently quite normal body when bacteria, either saprophytes or at any rato species not infective for the animal in question, lare penctrated into the blood through a wound. Such bacteria are deposited chicfly in the lirer, spleen, and medulla of bone, and remain there in a living condition for a length of time varying from a few hours to davs, while 
spores, e.g., those of bacillus subtilis, may live for several months (compare p. 644).

The secretions of the body also, more especially the Absence of urine, are according to the inrestigations of Wyssolio- of pathogenie witsch * free from bacteria, eren when infective bacteria ones, in the are present in the body and circulate in the blood. It is only in the cases whcre there is plugging of the ressels of the kidneys by masses of bacteria, and in consequence necrotic patches with marked lesion of the tissue, that we have an excretion of bacteria in the urine. such a state of matters is almost always seen after the injection of staph. aureus into the blood, but these bacteria do not appear in the urine soon after the injection even when large numbers were introduced, but only after deposits have been formed in the kidney and have opened up artificial passages.

Gunning thas examined the air expired by man for Absence of bacteria. He found that when the air was expired bacteria in the through a nutrient solution there was no infection of the latter if only the entrance of saliva, \&c., was prevented. As a matter of fact we must, from what we have learnt as to the detachment of bacteria from moist surfaces (see p. 688), regard it as very improbable that bacteria would be detached from the constantly moist unucous membranes and carried with the current of expired air which is constantly saturated with moisture. -Hence the only way in which we can conceive that organisms present on the mucous surface of the respiratory tract can spread through the air, is that in speaking and coughing small particles of fluids are detached, expelled, and remain mixed for short distances with the expired current of air, or that sputa dry up after their. expulsion, and are converted into dust.

* Zeitschr.f. IIygiene, Bd. I, Heft 1.

+ Klin. Monatbl.f. Angenheilh., Juhrgr. 20, 1852. 
PART VII.

THE MODE OF SPREAD OF THE INFECTIVE DISEASES.

The principal IN the following paragraphs we shall slietch shortly mode of spread the mode of spread of the human infective diseases, but of the infec- only in so far as it bears an intimate relation to the tive diseases.

biological facts mentioned in the preceding pages, to the distribution of the pathogenic bacteria, and to the conclusions already drawn. And even within these limits we shall by no means attempt to give a complete description in view of the large number of these diseases which never completely coincide in their mode of spread, of the number of the problems to be solved, of the numerous isolated facts obtained by investigation and observation, and of the manifold hypotheses and theories which have been promulgated. This limitation will be the more permissible, because in a former chapter on "Cholera" a detailed description of the mode of spread of at least one kind of infective agent has been given, and to this we must refer the reader as an example which may be extended on the fundamental lines to be mentioned below.

In considering the mode of spread of the infective diseases we have in the first place to take into consideration the sources of infection, the modes of transport to man, and the points of invasion at which the penetration of the infective agents into the healthy body occurs. Then we have to pay special attention to the individual predisposition and immunity, for these points influence the mode of spreal of many infective disenses in a high degree. Finally, we must shortly consider the meaning and the causes of the local and seasonal variations in the epidemic distribution of the infectirc diserses. 


\section{The Sources of Infection.}

At the present time we only reckon as infective All infective diseases those affections which are caused by the discases aro penetration of a pathogenic agent from without into ngents which the body of the patient, and its multiplication there multiply in Hence a relatively insignificant quantity of the virus is patient. always sufficient for the infection, but a certain time usually elapses before the development of the action, this time being necessary for the multiplication of the virus.

If a noxious agent must be employed in a certain and large dose, if it does not multiply in the body of the patient, and if the action sets in relatively quickly, the process is comprehended under the term "intoxication." And in like manner when disease is produced by a so-called miasma, that ter'm implying a gaseous chemical substance or a mixture of unorganisert substances not capable of reproduction in the body, we regard it not as infection but as intoxication.

From the fact that reproduction is necessary, it follows Hence the that the infective agents are all organised beings. It pathogenie has been further ascertained by the researches of the ing organisus. last ten years that these organisms-quite apart from the animal parasites - chiefly belong to the class of bacteria; it is possible, however, that the exciting agents of certain human infective diseases belong also to other as yet imperfectly known classes of micro-organisms, e.g., the mycetozoa.

It follows also, from the reproduction of the infective All infective agents in the body of the patient, that all true infective disenses ear diseases can be transmitted continuously from sick to from thic sick liealthy individuals, although it is possible tlat for to the healthy". reasons to be discussed later this transmission is at times accomplished only under marlied difficulties, ant at certain stages of the disease, and in one particular way. Quite recently the malarial virus has been tramsmitted to healthy individuals by inoculation of the blood of sick people, and henco the infective character of this disease has been demonstrated with certainty.

Althongh this power of multiplication and trams- 
mission is common to all infective agrents, we have still to ascertain their natural mode of spread in each individual case, and especially whether and to what extcrit the infective agents are transmitted from the sick to tho lealthy under the ordinary conditious met with in practice.

With reforence to the naturial mode of spread, the uncstion is whether agents capablc of producing infection are given off by the sick.

Contagiousnon-contagious infective riseases.

'The natural mode of transmission evidently depends on whether the infective agents can leave the body of the sick in a state capable of producing infection. If they are given off' from some diseased surface of the body in sufficient quantity, in a living state and sufficiently resistant, then the disease may be transmitted directly from the sick to the healtly, and spreads under certain circumstances by contagion.

If, on the other hand, the infective agents which are reproduced in the body of the sick do not leave it at all, or only in a state incapable of causing infection, the infective disease in question is non-contagions. The infective agents which cause these diseases must be located somewhcre in the surroundings of man, from whence they can penetrate into healthy individuals, and where they can also probably continue to multiply. Hence all the non-contagious infective agents are capable of a saprophytic existence, and belong to the group of facultative parasites (see p. 629). The most important representatives of this group are the infective agents of malaria.

In the group of the contagious infective agents we are at once struck by a remarkable rariety in the clegree of contagiousness. This undoubtedly depends in part on the unequal resisting power of the healthy body against the various pathogenic agents, an intluence which will be dwelt on presently; in part also, however, on the quantity and the resisting power of the infective agents which are given off from the diseased body. Contagion by Some of these are very vulnerable and quickly die after direct contact. they leave the body, and therefore can only pass from the sick to the liealthy by direct contact. Other's retain their vitality in the surroundings of the sick for some time after they are giren off from the body; they 
can therefore be transmitted not only by direct.contact Contagion by but sorts of objects which play the rôle of surrounding transporting agents; some are characterised by a particularly lengthened resisting power, and in the case of these, the number of modes of transport is marliedly greater. In effecting the transport, and in preserving the infective agents, surrounding objects are not all of equal value, some act better, others worse. Porous substances, soil, articles of clothing, \&c., appear to be particularly well fitted for these purposes.

In the preceding paragraph we have only referred to the case where the objects in human surloundings act merely as indifferent means of transport for the contagious infective agents, and where the latter do not grow or multiply on them; these infective agents are only able to multiply in the human body, and therefore belong to the obligatory parasites.

But there are also contagious infective agents which can lead a saprophytic existence on the dead materials in our surroundings, and must therefore be classified as facultative parasites. In this case there is a multipli-Multipliention cation of the sources of infection outside the body of the of the infoccation of the sources of infection outsicle the body of the tive agents $\mathrm{c}$ patient, and this may go on to such an extent in our sur- surrounding roundings, that there are in fact more chances of infection by the infective agents produced outside the body than by direct or indirect transmission by indifferent objects of the infective agents given off from the patient. On the whole, however, the simple transport of resistant infective agents by various objects is in many respects of as great importance for the spread of a disease as when a certain degree of multiplication is possible outside the body; where the obligatory parasites are preserved for a long time, and are very lesisting, the important influence of the surrounding's is often as nrarked as when multiplication of the possibly less resistant facultative parasites has here and there taken place. In recent times special slight importstress has been laid on the distinction between the infective ance of saproagents according as they belong to the facultative or to for the sprcart the obligatory parasites, or accol'ding as they multiply of discases. in the surroundings, or pass through them unchanged; 
but this, (listinction is not of great importance from the point of view of the mode of spread of human infectirc diseases. 1. Contagious To mention some examples, we have in the group parasites with of the contagious obligatory parasites infective agents slight resist- which are distinguished by slight resisting power and
ing power.

With grenter resisting power. require direct inoculation; for example, the agents of syphilis, gonorrhœa, and hydrophobia. To those diseases which can also be carried by various objects on account of the greater resisting power of their causal agents belong small-pox, measles, scarlatina, tuberculosis, glanders, diphtheria, and the majority of the infective diseases of wounds. Differences in the contagiousness of these disenses are either due to the degree of resisting power of the infective agents, or to the fact that the situation of the points of invasion and the special protective arrangements of the healthy body only permit their entrance in rare cases.

2. Contagious facultative parnsites.

Spread of anthrax.
To the group of the contagions facultative parasites belong the exciting agents of typhoid fever, cholera, and anthrax. Here also the chief mode of spread is hy. means of surrounding objects, which only act as transporting agents, viz., clothing, water, soil, \&c.; at times. however, multiplication or fructification also occurs on articles of food, in regions which are marshy, or wherc vegetable remains are plentiful, \&c. This occurrence may exert a special influence on the mode of spread of the disease, because the maintenance of the species is thereby rendered certain for a considerable time, and also because, as in the case of anthrax, the formation of resisting spores occurs at times only ontside the body.

Anthrax bchaves very differently according as it pursnes: the course of a septicamia as a result of at cutancous inocul:1tion, or of an intestinal anthrax from swallowing food containing spores. In the first case, bacilli are not usually giveu off from the affected body; the surface of the wound is occupied by other lacteria, and it is ouly at times thar anthrax bacilli are exereter in the urine; after death the cadaver may become in prey to putrefnetive bacteria withou the passage of virulent antlurax bacilli into the surroundings. In such cases-for cxample, in animals artificially inoculater 
with anthrax-it is crident that healthy animals do not casily beeome affected, even whon they live in close eontaet with the disensed ones. On the other hand, in intestinal anthrax 'fuantities of dejecta containing anthrax spores are poured out on the meadows from whieh healthy animals obtain their food, and thus it is easy to understand how the disease spreads by the spores whieh are preserved in the grass. In like manner in burying the bodies of animals which have clied of anthrax, and which have been opened, blood, \&c., may be left on the surface of the soil, and spores subscquently form there and ultimately get into the fodder:-While, howcrer, in this mode of spread the pathogenie agents are as a rule ultimately killed or interfered with by some metcorological influenee, it is probable that there are some natural abodes of the anthrax bacilli where they multiply outside the hody and eonstantly form new spores, these abocles being therefore dangerons and permanent reservoirs; situations of this kind are present in the ncighbourhood of rivers and marshes, where suffieient moisture, fivourable temperature, and a plentiful supply of dead regctable substanees are present, and thus in exceptional eases a saprophytic growth of anthrax baeilli ean take placc. From these situations the spores may be transported to meadows by means of floods, and there give rise for a series of years to outbreaks of disease, although the multiplication of the infective agcnts may be limited to the body of the diseased animal.- In the case of man, as is well known, infection with anthrax occurs almost exelusively by means of the bacilli and spores developed in the discased animal, and adbering to the skin, hairs, dc., and the faet that the formation of the spores oeeur for the most part after the death of the animal docs not in any way detract from the contagious character of this mode of spread.

Various other infective agents may show a certain amount of saprophytic growth, which, however, is of less importance as regards their spread than in the case of typhoid fever, cholcra, and anthrax. The staphylococci Parasites which have only slight are very widely distributed; but it is relatively unimportant whcther their number increases only as the result of constant reproduction in pus, or also as the result of siproplyytic growth. The streptococci, erysipelas cocci, i'c., are able to multiply on dead nutrient substrata under favourable conditions; but the usual mode of spread to healthy individuals is neverthcless either in the fresh statc by contact, instruments, ifc., or in the 
preserved state by clotlies, dressings, furniture, or from the surface of the body.

Unequal l'csisting powe of the facultative parasites.
Non-contagious facultative parasites.

Also among the so-called facultative parasites we find very varying degrees of resisting power, and this influences the mode of spread to a much greater degree than the temporary saprophytic multiplication. Anthrax spores show, for example, a very marked resisting power, and hence can be carried by the most various objects, and can act after a very long interval of time; the spores of the typhoid bacilli which are possibly present in large numbers in the dejecta of the sick do not, it is true, possess such great resisting power, but they can nevertheless retain their vitality for several months in various substances, in fluids, and in the dry state; the cholera bacilli, on the other hand, as mentioned above (p. 444), die in a few days under the conditions normally present in our surroundings.

In the third group of the non-contagious facultative parasites we must include the exciting agents of malaria, which, however, are as yet completely unknown; these organisms possibly belong to the mycetozoa, and probably multiply in water which is rich in vegetable materials, and especially on marshy ground, and are carried when drying occurs into the air immediately over the surface.

For a long time it has been the fashion to employ the term non-contagious for all those infective diseases in the spread of which our surroundings play a distinct rôle, and in these cases-for example, in malaria-it has been assumed that the infective agents are transmitted, Pettenkofer's not by the sick, but by the surroundings. This incorvicw that typhoid fever and cholera bclong to the last group. rect view as to the sources of infection has even been applied to the obligatory parasites; but it is the facultative parasites, more especially such as the exciting agents of typhoid fover and cholera, that liave been designated by a large number of epidemiologists as non-contagious, and placed in the same category as malaria.

Undoubtor

Apart, however, from undoubted practical experienco contagious- ness thphoid cholera and typhoid fever are contagious, the view fever and cholera. just referred to, and which is now held chiefly by Petten- 
lofer, is irreconcilable with the results of the more recent experimental investigations with regard to the specific exciting agents of typhoid fever and cholora. We sec that both in typhoid fever and cholera the living infective agents of these discases are given off in large numbers in the dejecta of the sick, and there is absoIntely no reason why they should not transmit the disease to a healthy predisposed individual, either by immediate contact, or through the intervention of some objoct. Pettenkofer assumes that these agents as they Exeretion of come from the sick are not ripe, and are not able to agents capable cause infection: ond he holds that they must first ac or eausing quire their infective properties in a suitable soil outside the sick. the body. This idea of a specific transformation of the infective agents in the soil could, however, only be held so long as we were completely in the dark as to the nature of the infective agents; it is no longer admissible in the present state of our linowledge as to the biology of the infective agents of typhoid ferer and cholera. And besides, we have definitely ascertained from experiments on animals, as well as from involuntary experiments on man, that there is no necessity for a transformation of the infective agents after they are given off by the sick in order to enable them to cause infection.

The possibility of the spread of these diseases by Role of the contagion, and its occasional occurrence, must there- surroundingfore be looked upon as undoubted facts. It is true that of both the surroundings play a very marked part in the natural disenses. distribution of these diseases, but they do so chiefly by preserving unaltered the infective agents given off by the sick, and bringing them in contact with predisposed individuals. Among the numerous substrata and objects in our surroundings, the soil appears particularly well adapted for such a preservation, and therefore in many cases it plays a prominent part as a means of transport. To a less degree the spread of these discases is also influenced by a multiplication of the infective agents outside the body-on nutritive materials, on the surface of the soil, \&c.; but in our climate this ectogenous development and multiplication of the typhoid 
Local ind scasonal predisposition may be explained without assuming any specific influence of the soil.

and cholera bacilli is of little inportance, and las but little influence on the mode of spread of the disease, while on the other hand it plays a more important role in tropical countries.

The chief fact which Pettenkofer has brought forward in support of his views is the peculiar local and sersonal distribution of cholera and typhoid fever, which according to him can only be explained as a result of some influence of the soil. It has been already shown in the chapter on cholera, and will be further discussed below, that such local and seasonal variations in the distribution of these diseases can be very well explained, cren though we hold to the opinion of the contagiousness of both diseases, and only ascribe to the soil the róle of a part of our surroundings, in that like other substrata it harbours the infective agents given off by the sick for a considerable time, and then again brings them into contact with man.

In accordance with the foregoing views we have to consider the following sources of infection.

Having thus arrived at definite views as to the various modes of spread of the infective diseases, it is easy to group together and characterise the sources of infection in the case of each individual disease. The following is the result in the case of the more important infective diseases, omitting those whose mode of transmission is as yet too imperfectly linown (viz., leprosy, recurrent fever, dysentery, yellow ferer, dre.) :-

\section{a. Contagious Obligatory Parasites.}

(a) With slight resisting power.

Syphilis and gonorrhea: sources of infection, the fresh secretions.

Rabies: fresh salira, blood, spinal cord, and brain. 
(ß) With greater resisting power (also transmissible by various objects).

The acute cxanthemata (small-pox, scrrlatina, measles, \&c.) : typhus ferer. Sources of infection, the morbid products of the skin and mucous membranes. The exciting agents are probably cast off in large quantities; they can withstand drying, they adhere to rags, wash linen, beds, furniture, \&c.

Diphtheria: the sputa, membranes expelled by coughing, secretions of the mouth, secretions from other mucous membranes attacked by the disease. The pathogenic agents can probably retain their vitality in the dry state for a certain time, for how long is as yet unknown; they can adhere to the linen, bedding, floors, soil, \&c. We do ņot as yet possess more accurate knowledge as to the nature of the sources of infection.

Tuberculosis: chiefly the sputa. The spores cast off in the sputum retain their vitality in the dry state for about six months. They can adhere to the linen, clothes, furniture, \&c.; they are also present in the soil under the flooring in a living condition, in the dust of the streets, \&c. In consequence of the large number of phthisical patients, the number of the infective agents in the sputa, and their resisting power, the sources of infection are almost everywhere present.

Glanders: the secretions of the diseased mucous membranes, and of the ulcers of the skin, furnish the infective agents in large quantities. According to Loeffler's recent investigations spores are probably not formed, for the dry cultivations usually die after some days or weels (it was only exceptionally that they were found alive after three months), and a temperature of $55^{\circ} \mathrm{C}$. kills the infective agents in five minutes. The most important sources of infection are therefore the fresh secretions and, for some days or weelis, the various objects to which they adhere.-According to Loefller a saprophytic growtl of the bacilli does not occur in the nutrient materials present in the stalls. 
Erysipclas and other human infective diseases of wounds (puerperal fever, ic.): secretions of wounds either in the fresh state or dried on linen, dressings, bedding, ultimately beneath the floors. In the majority of cases we do not as yet know low long the infective agents retain their vitality in the dry state. The ordinary pyogenic organisms are present in dust, on clothing, on the surface of the human body, dc.

\section{b. Contagious Fucultative Parasites.}

Anthrax: 1. The fresh secretions of wounds or of the diseased mucous membranes, also dressings, clotles, Sc. 2. Fæces of animals suffering from intestinal anthrax, soil and grass impregnated with such dejecta. 3. Preserved portions of anthrax cadarers. (slin, hair), earth (or portions of the dwelling, clothing, \&c.) which has come in contact with the blood, organs, sc., during the post-mortem examination. - In all cases the duration of the infective power depends on whether or not spores are forned. There are plenty of opportumities for their formation outside the living body in a great rariety of substrata, provided the temperature is sufficient. 4. Saprophytic colonies of bacilli growing on the banks of rivers, \&c.

'Typhoid firer: dejecta of patients. For the most part the infective agents are present in the spore form ; they retain their vitality for a considerable time in a dry state, at all events up to three months (Gaftiy); they also live for screral months in watery fluids, and in drinking water. Hence various objects (linen, bedding) which come in contact with the dejecta may retain infective properties for a long time. It is probable also that the spores may be preserved for a long time in the soil (in garden and field earth on which dejecta has been deposited). -Multiplication can ultimately occur in nutrient materials, especially in milk, in broth, on meat, s.e.

Cholera: dejecta of the sick. They only retain their 
vitality for a few days under ordinary conditions; they die as the result of drying or from over-growth by saprophytes. Hence the most frequent sources of infection are the fresh dejecta, and the objects contaminated with them : linen, bedding, water, food, superficial layers of the soil.-Multiplication can occur on various nutrient materials, as in the case of typhoid bacilli.

\section{c. Non-contagious Facultatice Parasites.}

Malaria: probably in marsh water, on the banks of rivers, on the surface of marshy soil. Nothing more precise is known.

\section{The Modes of Transport.}

According to the description given in the preceding Modes of chapter, the sources of infection are as a rule repre- transport sented by the fresh or dry secretions of wounds, of the sonrees of diseased mucous membranes, or of the skin; further, healthy and by objects and materials in our surroundings contamiindivicunls. nated by them, especially dressings, linen, clothing, bedding, the soil under the flooring, drinking water and articles of food, the most superficial layers of the soil.

From these sources the infective agents may be carried to individuals capable of taking the infection.

1. By contact between the healthy and sick. The 1. Contact surface of the body of healthy inclividuals is brought between into direct contact with the morbic secretions or the sick indiobjects harbouring them, by handling the infected persons, or even through a third person. Almost all the infective diseases can be transported in this way. This mode of transport is on the whole extremely frequent, and in the case of many diseases it is the only, or at least the most important, mode of infection (syphilis, gonorrhca, infective tiseases of wounds, sc.).

2. By contact with infective animals. The transmis-2. Contact sion of the most important zoonotic diseases occurs by between 
diseased animals and man.

3. Trausport by insects.

4. Transport by water and tood.

ร. Transport by currents of air.

Influence of the transport by air on the contagious. ness contact with the fresh or dried morbid excretu, or with objects contaminated therewith, the contact being brought about by intentionally handling these materials, by bites, sc.

3. By insects which transport fresh or dried excreta, or objects contaminated with them, to individuals capable of taking the infection.

4. By swallowing food or water which contain infective germs. This is the most important mode of trans port for those infective diseases in which the invasion only begins from the intestine (typhoid fever, cholera). Water and food may be directly contaminated by the infected excreta, or the contamination in the case of the food may be occasioned by contact, insects, adhering portions of soil, or infective air germs, in the case of water by the wash linen, \&c.

5. By aërial germs. As has been pointed out abore, the trunsport by currents of air only occurs in the case of those infective agents which can withstand drying. Accordingly it does not come into play in cholera; it is, further, almost excluded or occurs very rarely in glanders and some infective diseases of wounds; on the other hand it plays an important rile in the acute exanthemata, typhus, typhoid fever, tuberculosis.

It is apparent that the last-mentioned mode of transport has an important influence on the mode of contagion. In cases where it camnot occur the other modes of transpurt are much more easy of recognition and avoidance. We can comparatively readily protect ourselves against infection by contact by means of careful cleanliness, and against the introduction of the infective agents by food and water, by careful selection and preparation of the nutriment, and direct transport by infected animals or insects occurs on the whole rery seldom. On the other hand, transmission ly currents of air occur's in an unnoticeable manner and one against which no protection exists, and it may extend orer considerable distances; the infective agents which are transportable in this way may also infect individuals who do not come into immediate contact with the sick 
or with infectious objects. The number of infections caused by them is under certain circumstances much greater and more widely distributed. That all the diseases belonging to this group do not in practice show an equaliy liigh degree of contagiousncss, - that, for example, the acute exanthemata and typhus fever are extremely contagious, while in typhoid fever and tuberculosis the dangcr of contagion is much less, - is explained by the other conditions necessary for infection; for example, by the situation of the seats of invasion and by the individual predisposition. These two conditions are referred to more in detail in the following pages.

The detachment of the infective agents from their Conditions for substrata and their passage into the air occurs from the transport by dried excreta and the various objects to which they adhere-from clothing, from the flooring, from the surface of the soil. In all cases complete dryness of the surface is a necessary condition for the detachment of the infective germs; hence in the soil this only occurs wlen a drying zone is present, and when the most superficial layer is in a state of dust.

It frequently happens that the same mode of transport Indirect transdoes not carry the infective agents directly from the source port. of infection to the point of invasion, but that it carries them in the first place to another means of transport. Thus, for cxample, the detached infective agents may be carried by currents of air to articles of food, and from thence reach the exposed individual.

\section{The Seats of Invasion.}

Before we cun arrive at definite idens as to the in- Do the skin portance of the seats of invasion for the spread of the and mucous infective discases, we must decide the question whether the henlthy the bacteria call penetrate the various surfaces of the the entrauce body, the skin, and especially the mucous membranes, of hacteria? when these are in a normal condition? 
'This question was formerly answored in the affirmative in the ease of the intestine and lungs.

'The saprophytes are supposed to die in the hloorl.

'This assumption is incorrect.
This question has or the most part been answercd in the affirmative. The passage of oil globules through the walls of the intestine, and the cnormous surface and delicate epithelial corering of the lung, las been prominently pointed out; and the constant entrance of saprophytic bactcria, and the occasional passage of infective agents into the interior of the body, especially into the circulating blood, has been assumed. Pettenkofer has indicated the lungs as the chief organ through which the pathogenic bacteria pass into the blood; according to the view generally hcld, they are then carried from the lungs to those parts of the body in which the local affections characteristic of the disease in question usually appear. Thus the infective agents of cholera and typhoid fever, when they are inhaled, are supposed to pass through the lungs into the blood, and from thence into the mucous membrane of the intestine, where they multiply and set up the specific alterations.

The fact that no bacteria have been found in the interior of the healthy body in rarious careful investigations is opposed to the riew that saprophytic bacteria are constantly penetrating into the normal body from the lungs and intestine. Von Fodor and others have, however, sought to explain this contradiction by the assumption that the saprophytic organisms which pass into the body are rapidly destroyed in the blood.

Such an explanation is, however, no longer admissible after the researches of Wyssoliowitsch, to which we hare previously alluded. These investigations have shomn that a great variety of bucteria are not dcstroyed in the circulating blood, but retain their vitality in the interior of certain organs for several hours, days, or eren months. If, therefore, there were a constant passage of bacteria from the lungs and intestines into the blood, we must undoubtedly frequently find them in considerable numhers in the interior of the body, and the resistant subtilis spores which are always present on the surface of the body wonld gradually accumulate in the bady.

As the result of these experiments it is very improhable that bactcria can pass through the mucons mem- 
branes and lymphatic glands, and ultimately reach the blood. It is probable also that patlogenic bacteria behave in this respect in the same manner as the ordinary intants of the surface of the body; for the excreting membranes of the animal body (kidneys) are just as impassable for the numerous linds of pathogenic bacteria as for the saprophytic organisms.

Nevertheless it was desirable to make direct experi- Direct experiments as to the passability of the walls of the lungs and ments as to of the intestine by bacteria; and experiments of this of the lunilit kind have been carried out in large numbers by Wysso- tine by kowitsch during the course of last year in the author's bacteria. laboratory. From these experiments, which will be shortly published in the Zcitschrift für Hygiene, it follows with complete certainty that neither the surface of the lung nor of the intestine permits the direct passage of bacteria into the blood, so long as the mucous membrane is intact; even if small lesions of the mucous membrane are present, the bacteria do not as a rule reach the blood, but remain in the neighbouring lymphatic glands. - In the Intestine. experiments on the intestine, staphylococcus aureus, bacillus indicus, and spores of subtilis were employed; the cultivations were given in large quantities as food, and it was found that the bacteria did not suffer any injury from the gastric juice; but in order to be more certain as to this point, they were in some cases injected into loops of intestine isolated by ligatures. In no case, however, were the bacteria found in the organs which, as had been previously ascertained, always preserved any germs which had really reached the blood; while, on the other liand, they were always found when even only very small quantities of the same bacteria were introduced into the blood or into the peritomeal cavity. In the experiments with loops of intestine, small injuries of the intestinal membrane were mavoidable; and then the bacteria in question could be found in limited numbers in the corresponding mesenteric glands, but did not pass beyond them.*

" Ruibbert (Deutsch Med.Woch., 1885, Nr. 13) and Bizzozero (Centralbl. $f . d$ med. 11 och., 1885, $\mathrm{Nr}$. 45) found various kincls of baeteria in heulthy. 
l.nugs.

Experiments as to the passability of the surfaces of the lungs were made by causing the animals to inhale either the dried cultivation in the form of dust, or a fluid cultivation in the form of spray; or the material was injected into the trachea in small and repeated quantities. Here also no passage of the bacteria into the blood was observed, even when the lung tissue had undergone pathological changes as the result of the injections.These results harmonise entirely ivith those obtained by Arnold, who found by very numerous and careful investigations that minute bodies (soot, ultramarine, \&c.), when inhaled do not pass into the blood or organs of the body, but at most only reach the neigh bouring bronchial glands. Arnold has ascertained by accurate microscopical investigations that the human lung does not behave differently to that of animals as regards its passability to minute elements; soot does not pass into the internal human organs by normal preformed paths, but only by abnormal ways.

'I'here is no ja-sage of haceria tlirutigh the lunga and intestiue.

Invision of the borly either by direct int.induction of bacteria into lise lliood.

Hence we have given up the former view that bacteria can pass reaclily into the blood, and from thencs into the organs of the body through the intact lungs or the normal intestine; on the contrary, the body of warmhlooded animals nowhere offer's a surfice permeable by infective agents, so far as is as yet known, unless important alterations of the normal tissue hare preriously occurred.

One mode in which an infective agent can enter the blood and the internal organs of the body is when a large opening is present which permits its direct passage into the blood; for example, $n$ wound of the skin or mucous membrane communicating witlı a blood ressel.

animals in the follicles of tho processus vermiformis and of the sacculus rot. at tho cutrance to the cecum, which had evidently penetrated from the lumen of the intestine; they did not appenr to be alive in the deeper layers of tho follicles, and eould not be traced beyond tho follicles. This oecurrence of bacteria at one special part of the intestinal mueous membrano, together with the constantly negative results obtrined in other parts of the intestinc. and with the evident. death of theso baeteria in the decper liyers, quite corresponds with the results of WyEsokowitsch's experiments. 
This is a mode of infection which we frequently produce artificially in our experiments on animals, but which seldom occurs under natural conditions. 'The experiments Even then inon animals, however, teach us further that in many infec- $\begin{aligned} & \text { fection does } \\ & \text { not always }\end{aligned}$ tive diseases the penetration of the infective agents into ocenr. the blood is not sufficient for the production of infection; we see that the bacilli of pneumonia, of malignant $œ$ dema, of cholera, the micrococci of erysipelas, \&s., do not cause disease when injected into the blood, with suitable precautious against the entrance of other bacteria, such as disinfection of the wound in the skin, while they are virulent in the same animals when introduced into other parts, such as into a wound of the lung, into a wound of the skin, into an altered intestine, \&c. This is explained in part by the fact demonstrated by Wyssokowitsch that bacteria circulating in the blood are not excreted through certain surfaces of the body, such as the wall of the intestine, and cannot pass into the lumen of the intestine, for example, except when hremorrhages occur in the mucous membrane; and that therefore cholera and typhoid bacilli, even when they have penetrated into the blood, do not always reach their proper seat of action. Wyssokowitsch's experiments also give a partial explanation, these experiments showing that the endothelial cells of the capillaries have the power of fixing and destroying bacteria circulating in the blood; hence only those bacteria which are able to overcome this protective arrangement can set up disease from the blood. In the case of those resistant infective agents which can penetrate with the blood into various organs, and multiply there or in the blood itself, injection into the blood is a rery active mode of infection, e. $\%$, in the case of the exciting agents of septicrmia, anthrax, and tuberculosis.

Besides this infection through the blood, which occurs or the infeecompratively seldom, infection evidently occurs in many tive agents dieases by the primary establishment and development special points of the infective agents at those parts of the body in wards beeme which the specific process occurs or begins; so that the the seat of the seat of the alterations characteristic of the infective 
disease in question coincides with the specific seat of invasion. Erysipelas develops in the lymphatic channels of the skin; wounds of the skin which open an entrance to these channels form the points of invasion of the erysipelas cocei : gonorrhœa cstablishes itself only on the urethral and conjunctival mucous membrane, and these are likewise the seats of invasion of the gonococci: pneumonia is limited to the lungs, and there the invasion of the infective agents must begin: typhoid and cholera localise themselves in the first place in the intestine (leaving out of account the secondary deposits of the typhoid bacilli), and here we must look for the seats of invasion of the infective agents. If typhoid bacilli are introduced into the lnngs, pneumoria bacteria into wounds in the skin, gonococci on the intestinal mucous membrane, there is no result even when small wounds and injnries are preseut.

Some infective agents can set up a primary specific disease in several different organs of the body; for example, anthrax in wounds of the skin, in the intestine, in the luings; tuberculosis likewise in the lungs, intestine, genito-urinary system, \&c.; diphtheria on various mucous membranes. In the case of these diseases the points at which the infective agents can enter are therefore correspondingly more numerous.

In the case of the acute exanthemata it is probable that the skin or the surface of the mucous membranes are the parts which are specially predisposed for the development of the infective agents, and it is also probable that these parts are the seats of invasion of other as yet nnlnown infective agents.

'llicse points of invasion permit the batrance of when in a normal conditions:

We must next inquire whether these points of invasion peculiar to the various linds of infectire agents permit the establishment and development of these agents when the tissues are in the normal condition, or whether solutions of continuity of the slin or mucous membranes must be present to cmable the infective agents to penctrate. It is eonceivablo that some infective agents do not require any preparation of the seat of invasion, but only that they should be protected while 
developing in folds and recesses of the mucous membrane, and not be readily removed with the mucus or overgrown by saprophytes. In such situations the parasites might be able to multiply to a certain extent, and then lead to a production of toxic materials which would be sufficient to destroy the neighbouring cells, and thus allow them to penetrate more deeply into the tissue. Such penetration through normal skin and mucous membrane must be assumed, more especially in the case of the infective agents of the acute exanthemata, whicl often attack very numerous individuals.

Other infective agents, on the contrary, probably require $\mathrm{Or}_{\mathrm{r}}$ the infecminute lesions or solutions of continuity of the mucous tive agents membrane in order to obtain a firm footing in the tissue, lesions at the and multiply at first at the cost of the dead cell material, sion. and spreading from that point carry on the struggle against the living cells. In all cases, however, the presence of such minute injuries farours the entrance of all infective agents and increases the individual predisposition (see below).

The fact that a specific and exclusive seat of invasion Importance of is necessary for each infective agent evidently is of great the speeifie importance as regards the mode of spread of the infective sion for the diseases. For the transmission of this group of diseases of the diseasc. it is evidently not sufficient that the means of transport should carry the infective agents from the source of infection to some part or other of the body, but it is also necessary that they should be brought to a particular situation. In the case of cholera and typhoid the disease must therefore occur chiefly as the result of swallowing infected water and infected food; it is possible that the germs may also reach the mouth by contact or by the inspired air, but it is only in relatively few cases that a sufficient number of the infective agents will pass in this way in a living state through the stomach into the intestine.

It is further evident that the position and other con- Infuence of ditions of the specific points of inrasion must have a the position of great influence on the danger of infection. Althougl invasion. the spores of the typhoid bacilli are probably more 
lesistant than the infective agents of the acute exanthemata, and although both are produced in large quantities and distributed in the surrounding world by the patient, the latter are, nevertheless, incomparably more contagious, because the unprotected surfaces of the body can be readily invaded by them, and these surfaces are very easily infected by contact or by currents of air; on the other hand, in the case of typhoid fever we usually have to do with a limited mode of transport by means of imperfectly prepared food and of impure water, and the seats of invasion are difficult of attack and provided with a protective arrangement; in this case also currents of air can only exercise an influence as a means of transport in so far as they curry the specific infective agents, in the first place to the food, and under favourable conditions by means of the food to the intestine.

In the case of some infective agents which are as yet but little known (malaria, relapsing ferer, \&c.), we can scarcely put forward any hypotheses as to whether specific points of invasion are present at all, or where they should be looked for.

\section{Individual Predisposition.}

Uneqnal pre- Experience has long ago taught us that the different ilisposition of infective agents are not equally dangerous to all kinds
different different
speies and of of warm-blooded animals, but that the one can affect only
lifferent in. diviturals. this, the other only that species. Closely allied species and races of animals often show in this respect the most striling differences; thus the bacillus murisepticus kills without exception every house-mouse inoculated even with the most minute quantity, while field-mice are not at all affected even by large doses; and the micrococcus tetragenus is only infective for the white variety of house-mice, while it is not infectire for the grey variety.-But eren among the individuals of one and the same species sinilar differences exist; and the infective organisms which are peculiar to man attack for the most part only a certain number of predisposed in- 
dividuals, while others equally exposed to the attack of the infective agents are not affected, in other words are immune.

As to the causes and the meaning of this indiridual predisposition and immunity we know as yet rery little, but the lesults of a large number of experiments on animals give us some insight into the behariour of the infective agents in the body. Further investigations must, however, be made on these points before we can come to any very definite conclusions. The factors Factors which which influence the predisposition of the body lie partly are of in. in the body itself, in the constitution of its cells, secretions, \&c., and come partly from without, these external factors aiding the infective agents in that they render the body abnormally susceptible to attack.

In the first place it may happen that the access of Protective certain infective agents to their specific points of invasion is rendered difficult by the natural protective arrangements of the body; thus the gastric juice canl, according to its degree of acidity, and according to its quantity, injure those infectire agents which must derelop in the intesline; and this injurious action may be present to a greater degree in one species of animal, or in one individual than in other individuals, where the infective agents more easily pass this protective arrangement.Further, as regards those infective agents which have their seat in the lungs, the more or less narrow and convoluted entrance to the respiratory tract, the ciliated epithelium, and the sensitive mucous membrane form a protective arrangement of varying efficacy, and according to the development of these arrangements the one species or the one individual will have an advantage orer the other as regards the easo with which parasitic bacteria can enter the lungs.

Further differences in the constitution of the points of invasion even of an apparently trivial character must the characters excreise a very important influence. Thus according to of invasionts species and race, according to the age and stato of thenselves. nutrition of the individual, sc., there are probably differonces in the skin, in the mucous mombrane, and 
especially in the epithelium, which, although scarcely noticeable, have nevertheless a marked effect, and permit or prevent the growth of the infective agents. Loeffler, in his investigntions on diphtheria, has brought forward a very beautiful experimental proof of the importance of the character of the epithelium; he showed that young guinea-pigs could be infected in the vagina by cultivations of the bacilli of diphtheria, evidently because the epithelium of the mucous membrane is extremely delicate and easily injured; older animals, whose vagina is protected by tough epithelium, were, on the contrary, quite insusceptible to this mode of inoculation.-The variation in predisposition in accordance with age which is seen in various human infective diseases, must probably be in part referred to a similar influence of the epithelium at the point of invasion. Further, many facts point to the view that even the very slightest pathological alterations or loosening of the epithelium, such as usually occurs in catarrhs for example, also render infection easier.

Inflience of

Further, the condition of the other more deeply thic othcr cells. placed cells of the affected organ is also of importance for the occurrence of the disease. The endothelial cells of the capillaries, and to a very marked extent in some organs the cells of the lymphoid tissue, appear to play an important part in the battle with the attacking bacteria, and on the vitnl energy of these cells the result of the battle-its rapid termination before genernl infection occurs, or its continuation in ever-increasing dimensions-will depend to a very marked degree. In the case of the endothelial cells of the blood vessels it can be experimentally shown how a general depression of the cell energy by poisons, and especially by ptomaines, leads to a totally different ending to the battle in which in the normal condition these cells are, in the case of certain species of bacteria, always victorious; it can be shown that, under the influence of ptomaine poisoning, the same bacteria which formerly quickly died in the endothclial cells, and never caused disense in the animals, are now able to multiply extremely rapidly in 
the blood and cause the death of the animals which were previously immune (Wyssoliowitsch).

Not uncommonly small iujuries due to the most External invarious causes seem to prepare the points of invasion jurics at the for the reception of the infective acents, and to pave the points of invaway for their growth. Experimental proof of this mode of predisposition has been recently brought forward by Orth and Wyssokowitsch ; these investigators were able to set up typical endocarditis in rabbits by first causing trivial lesions of the cardiac valves, and then injecting cultivations of staplyylococci; on the other hand, the infection did not succeed when the cultivation was injected without simultaneous injury of a valve.

In the intestinal mucous membrane predisposing injuries of this kind may at times be caused by animal parasites, by sharp and pointed constituents of the food, \&c. It is possible also that other, though not truly infective, bacteria, which, however, when they multiply to a marked extent in the intestine produce considerable quantities of ptomaines, and by means of these cause irritation of the intestinal mucous membrane with loosening of the epithelium, may be able to prepare the soil for the true infective agents, and thus give rise to predisposition.

It is evident that the various factors just mentioned Importance of present such manifold though shight differences that the different behaviour of individuals and species is rery diseases tho easily intelligible. It is true that these-and especially the individual differences-do not play an equally prominent. part in the case of all the infective agents; the more exposed the points of invasion, the more extensive and numerous they are, and the more energetically the infective agents in question are able to orercome the resisting power of the cells, so mucl the less will individual predisposition come into play. These con-slighter insiderations seem to be especially applicable in the case frence of the of the acute exanthemata of man, and hence the danger in the acurc of infection in these diseases is much more general thum in other cases where the exciting agents, althongh they possess the same or even a grcater degree of resisting 
power, and can be distributed by the most various modes of transport, establish themselves, however, chiefly in the lungs or in the intestine, -in other words, in places which are protected by special arrangements against the entrance of infective agents in a manner varying in individual cases; and the danger of contagion is still less when the energy of the infective agents is so slight as compared with that of the cells of the body that they can only reach the place of their development when the epithelium has been specially prepared and weakened. Influence of The influence of individual predisposition is most the predisposi- strikingly seen in the case of tuberculosis; in this
tion in the spread of tubereulosis. disease we learn from experience that the greater or less accumulation of resistant infective agents in human surroundings plays a relatively subordinate part in the spread of the disease; on the other hand, the state of the protective arrangements at the points of entrance, and especially the state of nutrition of the mucous membrane, lias such a definite and important influence that it has become the rule to pay the greatest attention to the removal of the individual predisposing factors (by good nourishment, increased respiratory movements, Sc.), and not to attempt the careful removal of the infective agents, as is done in the case of other infectire diseases.

\section{Acquired Immunity and Protective Inoculation.}

Of special importance is the immunity acquired as the result of recovery from the same disease, or from one caused by similar or attenuated exciting agents.

Relapsing riseases.

Such immunity is not acquired in the case of all infective diseases. Erysipelas, pyimin, gonorrhœu, relapsing fever, pneumonia, and malaria, frequently. show relapses eren within a short time after recovery from the first attack. Other disenses are followed by immunity for some time, but nerer without exception, nor to a similar degree, in the different species of animals; for example, anthrax may occur repeatcdly in 
man and horses, while sheep and cattle seem to be protected by one attack of the disease. Cholera, as a rule, gives protection for some years against a second attack; nevertheless even in this cuse exceptions not uncommonly occur. A marked immunity, lasting for a Varying long time, follows a single attack of the acute exanthe- degrees of mata, and of typhoid fever.

In the case of those disenses which produce immunity, even though for a short time, it almost always happens that the second attack runs a milder course, and often occasions only a very trivial disturbance of the general condition. Nevertheless the length of time between the two attacks may, according to the nature of the infective agent, completely neutralise this effect.

Further, it is important to note that in the case of many diseases the severity of the attack seems to be almost of no importance for the production of immunity. In the case of the acute exanthemata, typhoid fever, cholera, \&c., we often observe remarkably mild cases, in which there is only a trivial local development of the infective agents at the seat of invasion, and yet recovery from such affections, which can scarcely be called diseases, may lead to immunity against the infective agent in question.- Nevertheless, in other diseases we are able not unfrequently to trace a relation between the degree of the immunity and the severity of the disease.

An explanation of the peculiar phenomenon of acquired Former immunity cannot at present be given on the basis of experi-attempts to ments. Numerous attempts have been made to furnish an acquin thed explanation. Thus Klebs and Pasteur assume that in the immunity. first attack of the discase some material that is necessary for the life of the pathogenic fungi has been removed from the body, and that the body thus acted on no longer offers a suitable soil for the development of the organism at a subsequent period. But the results of our eultivation experiments and all our biological expericnce contradict, on the one hand, the idea of such a sensitiveness of pathogenic bacteria towards minute quantitios of an unknown nutrient material, and on the other the probability that sich a state of matters should be kept up for year's in the living body.-Chiuvean, Wernich, aud others have assumed that those products of the life of the bacteria which are noxious to the organisms them- 
Assumption of H. reactionary alteration at the spat of invation.

selves may remain for a long time in the body, and thus afford a proteetion against subsequent invasions. But this disinfecting power of the produets of the bacteria, which has been often insisted upon, appears, aeeording to the accurate experiments of Sirotinin, to be in most cases a fable, or at any rate to be much exaggerated; and, on the other hand, such a stubborn retention of minute quantities of this hacterial poison in the living body does not at all correspond to our ordinary physiologieal ideas.-Grawitz sought to cxplain immunity by supposing that as the result of the battle between the cells of the body and the pathogenie organisms, the vital energy and the assimilating power of the animal cells is inereased as eompared with that of the parasites; and that the duration of the immunity is oceasioned by the transmission of this inereased physiologieal energy from one cell generation to another. But in this ease it would be very difficult to understand why it is always only the same or similar infective agents which oecasion a suffieient incrcase of the cell energy.

A better view, and one more in correspondence with the views developed in the preceding pages, as to the mode of entrance of the infective agents, is that put forward by Buchner, viz., that that organ which is associated with the development of the specific infectire agents undergoes a reactionary alteration of its tissue uncler the influence of the bacteric development, and that this lasts for a long time, and does not permit a second derelopment. Wolff berg bas put forward a similar hypothesis with regard to the origin of the immunity against smallpox after vaccination. Wolff berg asserts that the alterntions which lead to the immunity must occur in the shin, as being that organ which forms the first and most important point of attack for the infective agents; and he tries to point ont the probability that the causes of the immunity are chiefly the destruction of the weak cells of the rete, and the retention and development of the more resistant elements.

On the assumption of a reactionary alteration of the specific seats of invasion, we can understand that it is only the infective agents of the sume disease, or of one similar to it (or only weakened agents), whicle are nble to give immunity against a later attack by the same 
organisms. Only those parasitos which have exactly the same seats of invasion can come into play in causing a reactionary alteration of these seats. - It further becomes intelligible that complete immunity against later invasions is at times obtained by locally limited affections which have caused an almost unnoticeable disturbance of the whole body, for it is only a certain local affection of the seats of invasion which seems to be of importance for the production of the immunity.-It is to be hoped that experimental investigations will soon afford a more sure basis for the attempt to explain immunity; as yet the explanations are quite hypothetical, and do not meet all cases, but only apply to that group of infective diseases which have specific points of invasion.

The experience as to the action of pestilences, and Protective inmore especially the knowledge of the protective effect of oculation. vaccinia against small-pox, which has been gained by experiments on millions of men for almost 100 years, have demonstrated that the acquired immunity is in many respects the most important factor in preventing the devastating action of the infective diseases. In vaccination we artificially transmit organisms which are remarkably like the infective agents of small-pox, but which excite in man only a mild and local disease. By this In variola. inoculation we can prevent the invasion of virulent infective agents of the same lind; and such a vacciuation is of great value, especially for variola, because, as we know, one attack of this disease gives a very long continued and certain immunity; because, further, the attenuated vaccine material preserves its slight degree of virulence with great constancy; and because as a result we need neither fear injury from the inoculation, nor uncertainty in the result.

During recent years only few, and at the same time crude and uncertain attempts liave been made to extend protective inoculation to other infectire discases, especially in the case of domestic animals, bui since the roar 
In chicken cholera.

1880 there has becn a rery actire movement in this direction with the aim of providing an extensive application of protective inoculation.**

The starting point of this movement was Pasteur's discovery that the microbes of chicken cholera could be artificially attenuated, and that the inoculation of these attenuated bacteria caused a local affection in forls, after recovery from which they were found to be immune against inoculation with the virulent infective agents of fowl cholera. On page 317 a more mimute description of Pasteur's experiments is given; we need only add here that two vaccines have been employed in practice, of which the first is more, and the second less attenuated; the first vaccine is injected by means of a Pravaz syringe at the tip of the wing of fowls, and the second vaccine is employed twelve to fifteen days later. As a result the animals are said to be protected against the virulent bacteria. Kitt was, however, unable to confirm Pasteur's results as regards the protective action of these inoculations. And even if the action of the raccine were prompt, it is very seldom that it could be of practical value in view of the usually very rapid spread of the disease in the hen-houses which are attacked, and of the length of time which must elapse till the protectire inoculation is completed. The ralue of the inoculation is also correspondingly less, because by proper disinfection of the hen-houses a much more reliable prophylaxis can be obtained.

In sympitum. atic anthrax.

The method of protective inoculation with the artificially aitenuated infectire agents was then attempted in the case of anthrax, sjmptomatic anthrax, and swine Inswineferer. fever. The methods employed in the two last diseases lave been already described on pages 300 and $30 T$; it was there shown that the practical ralue of the inoculations against swine fever is as yet extremely doubtful, while the results in symptomatic anthrax are more

* While these pages were passing through the pross a very raluable paper has been published by Kitt under tho title IVert und. Untert der Schutimpfungen gegen Thiersenchen, Berlin, 18S6, to which wo mnst refer the render for all the detuils with legind to protectiro inoculations. 
favourable; but here also we cannot yet come to a final judgment on account of our ignorance of the leugth of duration of the protection, the absence of a calculation as to the cost, and the neglect up to the present time of other prophylactic measures in the infected districts.

The inoculations for anthrax have excited special In anthrax. interest. They were carried out in the first place with bacilli attenuated by Toussaint's method (p. 657); a practically useful vaccine was later produced by Pasteur. and Chaureau, each by a different method. Pasteur Pastenr's employed as his first vaccine a cultivation in meat method. infusion which had been lept at a temperature of $42^{\circ}$ to $43^{\circ} \mathrm{C}$. till it no longer killed guinea-pigs and rabbits, but was still fatal to mice (see page 657). One division of a Pravaz syringe of this vaccine is injected on the inner side of the hind thigh of sheep; in the case of cattle two divisions are injected behind the shoulder: After the lapse of twelve to fourteen days a similar injection is made with the second vaccine, which has been lept at $42^{\circ}$ to $43^{\circ} \mathrm{C}$. till rabbits are not killed by it, while mice and guinea-pigs still die. It was, not till Koch introduced the method of testing the cultivations on these. three linds of animals that it was possible to know exactly the degree of virulence of the organisms.Chauveau makes his vaccine by heating the organisms Chaurean': for a shorter time at, higher temperatures; he em.method. ploys fresh anthracic blood and not cultivations, and in order that it may be warmed as quickly as possible, be collects it in very small glass tubes. More recently Chauveau, in conjunction with Wosnessenksi, has also utilised for the purpose of attenuation the simultaneous action of ligh pressure (page 660). The virulence of his vaccine lies somewhat between that of the two vaccine materials employed by Pastour ; it is chiefly intended for cattle, and they are inoculated in the ear by means of a syringe.-The other methods of attenuation and protective inoculation for anthrax bave not as yet been introduced into practice.

In judging of the results obtained wo must, in the first place, note that the effect of the protective inocu- 
Valne of the protective in. oculation for anthrux.

Protective in. oevlation for rabies. Method. lation differs in different species of animals; for example, guinea-pigs and rabbits cannot be made immune by the attenuated anthrax bacilli; rats often resist inoculation with the virulent material, but do not thereby acquire immunity. In like manner the effect is different in sheep and cattle, the two species of animals chiefly inoculated in practice. In the case of sheep the protective inoculation appears to be particularly uncertain in its results; too weak raceines do not give the necessary guarantee for immunity; too strong materials, on the other hand, readily cause the death of the animal; further, the duration of the protection is very short, probably not lasting more than a year; and it has also been shorw by Koch that sheep inoculated with strong vaccines are not able to resist natural infection produced by feeding them with anthrax spores. - In the case of cattle the result is probably more favourable, because stronger vaccines can be borne, the losses by the inoculations themselres are less, and the chances of immunity are better. Nevertheless even here we cannot make any definite statements as to the duration of the protection, nor as to its potency against the natural modes of infection. In any case the strong vaccines present a certain amount of danger for the people who have to attend on the animals, and without doubt these protective inoculations can only be looked on as a temporary means to be employed till rational means of prophylaxis, proper modes of disinfection, change in the pasture, care in burying the dead bodies, \&c., have been generally introduced.

The protective inoculation which has most recently attracted attention is that employed by Pasteur against rabies. When the method of attennating the rabic virus described on page 660 had been ascertained, Pasteur attempted to rencer dogs immune by first inoculating them with virus which had been dried for the longest time, and which was the weakest; then two days later less virulent material ras used, and so on till finally the virulent virus was employed.--When these experiments had led to uniform results. Pasteur made pro- 
tectire inoculations on persons who had been bitten by dogs which were stated to be rabid. His method collsisted in injecting into the patient on the first day a Pravaz syringeful of an emulsion prepared by the aid of sterilised infusion from a portion of the spinal cord of a rabbit which had died of rabies, the cord haring been dried for furrteen days; on the following day a mixture from a piece of spinal cord dried for twelve days was injected; on the third day a cord eleven days old was used, and so on, till on the twelfth day a virulent material which had been preserved for only one day was employed.

By this method hundreds of people have been treated Results of the in Pasteur's laboratory, and the number is still increas- proteetive ining. However, of these some have died of rabies shortly after the treatment, and others at a later period. It is difficult to decide with certainty whether the percentage of those who have died after inoculation is smaller than of those who die when no protective inoculation is used, as among those who have been treated by Pasteur there is a large number who were, it is true, bitten by dogs, but in which there was no certainty that the dogs were mad. It is nevertheless probable that a much smaller percentage of those persons who have been inoculated have died as the result of the bite than of those not inoculated, and, therefore, that the protective inoculation has had the desired effect in a large number of cases. But this result is far from being a certain and constrnt one, and in addition to the uncertainty of the effect, we have on the other hand the danger that persons who were not infected by the bite, and who would not therefore have died of rabies, may have been infected by the inoculation itself. In some of the fatal cases which have followed the preventive treatment, the suspicion of such an unintentional production of the disease cannot be entirely put aside.

On the whole an unbiased person will receive the Differences impression that Pasteur's discovery, which is of un- betwcen the impression that Pastenr's discovery doubted scientific value, has been introdnced into prac- oeulation for tice too hurriedly. As contrasted with the preparation other modes of of other vaccines, the method of attenuation is difficult protectivn 
to control, and does not sufficiently guarantee the degree of virulence. Further, the whole process of protective inoculation against rabies completely differ's from former protective inoculations for small-pox, antlirax, symptomatic anthrax, and swine fover, and also from the experiments made on dogs with the rabic virus, and which scrved as a proof of the utility of the method, for the pcople which were inoculated by Pasteur were already infected by the virulent discase. In all the former protective inoculations which might be thought to be analogous, the preventive means were employed before the infection, and experience has taught us that inoculation with raccine lymph, for example, has no effect if infection with variola has occurred before the vaccination was performed. In like manner the dogs experimented on by Pasteur, with regard to which accurate numbers have been published, were not infected before the protective inoculation. Pasteur mentions, however, that he has attempted subsequent protectire inoculation on dogs which liad been previously bitten or infected with virulent matcrial; but accurate numerical details of these most important experiments have not been given, and hence the suspicion arises that in these' experiments the result obtained has been as little constant and cortain as those which have followed the inoculations on infected individuals.

A more thorough scientific study of the matter in various directions would, therefore, have been at all cvents desirable before the method was introduced into practice. It is very possible that the method in its present form, being so difficult of control, may, if employed extensively and by less experienced hands than those of Pasteur and his assistants, leitd to many serious mishaps.

cencral value (if protective inoculations.
In conclusion, neither the inoculation for rabies, nor the other modern protectire vaccinations, represent the ideal of a satisfactory prophylaxis against the infectirc diseases. Even the valuable vaccination for small-pox has not been generally introduced without difficulties, and yet in the case of rariola we have to do with a disease which, on account of the number and resisting 
power of the sources of infection, on account of the easy transportation of the infective agents, and on account. of tho readiness with which the body is attacked, can be influenced with extreme difficulty by other prophylactic means. It is further a disease which is very specially suitable for a protective inoculation on account of the peculiar certainty and persistence of the immunity. On Advantages of the other hand, in the case of the majority of other in- phylanatic fective diseases, it is decidedly more rational to aim at means. the destruction of the infective agents, and the prevention of their spread or invasion, than to rely on an uncertain protective inoculation. That in the case of rabies suitable prophylactic rules deserve by far the greatest confidence is shown most distinctly by the condition of those countries in which a high tax on dogs, stringent rules against stray or possibly rabic animals, and under certain circumstances compulsory muzzling, have been already introduced; statistics show that in these countries (Prussia, Bavaria, \&c.) the deaths from rabies in dogs have diminished to a marked degree, and in man have practically disappeared.

\section{The Local and Seasonal Predisposition to Infectice. Diseases.}

From the foregoing considerations as to the mode of Irrogular disspread of the infective diseases, we may draw the con- tribntion of clusion that this distribution cannot occur either equaily diserses. over a large area or in an unbroken course as regards time, but that seasonal and local variations must apperr. and exert an influence on the occurrence of these diseases.

In none of the infective disenses is the spread of the: infective agents lilic that of a gas which diffuses itself equally in all directions, and over grent distances; on the contrary, the effective agents, eren in the inost: favourable cases, only sprend equally from one centre. over a small distance. Even the mosi typical contagia, vir., the exciting agents of tho acute exanthe- 
Multiplicity of the local and seasonal variations.

mata, are not distributed over a wide area by means of currents of air; on the contrary, with the distance from the patient and the progressive dilution by pure air there is eridently such a rapid diminution of the chances of infection that they are no longer sufticient for a natural spread of the disease; on the other hand, where the transport is by the air the chances of infection only exist in the immediate neighbourhood of the sources of infection, and when the infective agents pass over greater distances they are usually carried by means of man or by surrounding objects.

The patient may therefore form the centre of a small infectious area; from this new centres may then be established in all possible directions, these contres having their origin in infected patients, or in any other suitable source of infection. The immediate neighbourhood of such a centre is always specially dangerous; whether, howerer, a number of infections will occur in the sume house, or whether the danger will disappenr there without the occurrence of any new infection while infective agents may possibly have been carried to other streets or places, and give rise to fresh areas of infection, depends in every individual case on a great rariety of circumstances-on the number and resisting power of the sources of infection, on the number of modes of transport, on the individual susceptibility-and may vary to a great extent. We must, therefore, after what has been said in the foregoing chapters as to the multiplicity of all the factors which come into play in infection, look on the whole essence of distribution as something so direrse and varying, and we must realise that the paths are so tortuous and the results so mexpected, that we need not be surprised either by a persistent localisation, or by an apparently causeless leap of the disease over a considerable distance.

It is only where a community is overtaken by a new and very contagious disease, where total ignorance of the danger of infection renders every mode of transmission easier, and where erery individual prescuts a predisposed body not yet protected by recovery from similar 
affections, that there can be a general distribution of the disease without distinction of person. In every other case we meet with a great number of variations.

In the great majority of these variations it is unavoid- Laws as able that we here and there come across apparent natural local and lars ; one locality will be more frequently attacked than $\begin{gathered}\text { seasonal } \\ \text { vuriations. }\end{gathered}$ another, one season of the year will cause an increase in the number of cases of the disease, another will cause a diminution, and so on. Such recurring local and seasonal variations are in their essence only a further result of the numerous concomitant accidents, and one cannot from small numbers deduce laws which justify the assumption of a special local or seasonal influence.

Here and there, however, the variations apparently follow more distinct laws, and these point to external influences, varying with place and season. This is a priori intelligible if we consider in how marked a degree the number and resisting power of the sources of infection, the facility of transport, and the state of the seats of invasion are dependent on causes varying with place and time. Even in those diseases which are ex-In obligatory tremely easily transmitted, $c . g$.s the acute exantlemata, we can at times, though by no means always, recognise regularly recurring seasonal or marked local variations. Thus the statistics of small-pox epidemics show that the Seasonal lisease usually increases markedly in the cold months variations in and diminishes in summer; and that, further, in warm parasites. climates there is a marked increase in the dry season, and. an almost complete disappearance in the wet months.* Ono can scarcely go wrong in attributing the regular increase of small-pox in winter to the greater amount of time spent at home, to the more intimate association of individuals, to the wearing of the same clothing for some time, and to the diminished cleansing of the skin, thus rendering the transport of the infective agents and their preservation at the seats of invasion much easier than in summer when all these favouring factors are absent. These differences are of course more or less marked in different countries, according to the climate and the

* Hirsch, Itenduch tler histor, geogr. Puth, 2 Aufl, i., p. 10 s. 
Locil variations in scallatinal epirtemics.

mode of life. In tropical climates the remarkable diminution of small-pox in the rainy season may be due to the easier cleansing of the body and to the increased difficulty in the transport of the infective agents by currents of air, perhaps also to certain habits of life which cannot be thoroughly appreciated.

The mode of spread of scarlet fever forms a very striking example of the effect of locality. While epidemics of scarlet fever have constantly occurred in Europe during the present century, and many of them have spread from place to place, some towns have re-: mained entirely free from the disease for years, although they have been in communication with the infected: places. Thus Münster has been free from scarlatina for 50 years, Tuttlingen for 35 years, and Ulm for 17 year's, while long intervals have occurred between the epidemics in Lyons and also in the whole department of Indre-etLoire.* Experiences of this kind might very readily mislead us into supposing that there was some special influence, proceeding from the nature of the soil or from some other part in the surroundings of man, which favoured the development of scarlatinal epidemics in the one case and hindered it in the other; and yet we have. overwhelming proof that scarlet fever only spreads by contagion. Nevertheless, in spite of the purely contagious character of the disease, differences in its local, distribution may quite well occur. Thus it may happen. that all sorts of accidents, which can scarcely be gauged, may prevent the infective agent, although repeatedly: introduced, from causing infection; for example, these agents may only come in contact with individuals which have been previously attacked, and are therefore immune; or again, the infective agents may find a difficulty in obtaining a foothold in these individuals, owing to their: cleanly habits, and so on. In a similar manner it is possible that a particular city may present better opportunities for a long continued immunity than another, in that the population may have been largely attacked during a former epidemic, or in that the spread of the

$$
\text { * Hirsch, l. c., 1) } 128 .
$$


disense from tho first case may be rendered difficult on 1:account of certrin habits of the population, such as the mode of treatment of the sick (inunction of fat), ispecial attention to cleanliness, \&c.- - It is, howerer, evident that even when a place has remained free from the disease for sereral years, although repeated epidemics have occurred in its neighbourhood, we are - not justified in asserting that this placc possesses a permanent immunity, due to a direct influence of the :nature of the place on the infective agents; on the contrary, all these places have ultimately been found to be susceptible as soon as the effect of the previous epidemic has disappeared, and the chances against the attack of the infective agents hare become less favourabie.

A priori we may, howerer, expect that these local and Grcater local seasonal rariations will be more marked in the case of variations in those infective diseases which are not so extremely con- the less cont tagious as the acute exanthemata, but in which the discases. distribution is much more depeudent on external acci- dents. This will evidently be the case where the sources of infection, the modes of transport, and the seats of invasion are limited, and where a marked spread of the infection can only result when there is a certain concurrence of these circumstances. The chief of these diseases In cholera. arc those which are occasioned by the contagious facultative parasites, in which the number of the sources of infection increases or diminishes under the influence of. - external conditions, the modes of transport vary in their - value, and the seats of invasion become accossible or inaccessible. The numerous influences which come into play in these cases have been subjected to a more accurate analysis in the chapter on cholera (page 443), and from the description which has been given there we may -readily understand the manifold character of thesc influences and the applicability of the facts to other disenses which show a similar mode of distribution.

In many towns a regularly recurring seasonal varia- In typhoiul tion is still more marked in the case of typhoid ferer fever. than in cholern: thus during the dry harvest months, and when the level of the ground water is low, tho 
number of cases of typhoid fever increases, while it Inflnouco of a diminishes as the ground water rises. In explanation drying zone of of this phemomenon the same factors must be taken spread of into account as afforded to some extent an explanation typhoid fever. of the corresponding rariation in the cholera epidemics, but in the case of typhoid fever the drying of the superficial layers of the soil at the time when the frequency of typhoid fever increases comes more markedly into play than in the case of cholera. As the typhoid bacilli undoubtedly often reach the soil with the dejecta, either when fresh or after being retained for some time in cesspools, and as they are present partly in the spore form, and can thus be preserved for a long time and carried by currents of air, the drying of the surface of the soil or the sinking of the ground water must exert a mucl greater influence on the spread of this disease than in the case of cholera. The typhoid spores can, when a dry zone is present, be very readily carried by currents of air from the surface of the soil along with the dust to dwellings and to various materials on which they can develop, and thus the chances of infection are much increased at these times.

It is true that there is no absolute necessity for assuming an exclusive influence of the soil as an explanation of the coincidence between the frequency of typhoid fever and the dryness of the soil at the end of Other faotork.summer and during harvest. It is quite possible that, as in the case of cholera, other factors which come more markedly'into play at these periods-such as the character of the food, the large numbers of insects, factors which influence the individual predisposition, \&c.have an influence on the seasonal distribution of typhoid epidemics. In those cities where there is a constant and immediate connection between the dryness of the soil and typhoid fever we call scarcely go wrong in ascribing the sudden increase of cases chiefly to the

Thoir multi. drying of the surface of the soil. Where, howerer, the picicity. seasonal relation is less marked, and where we have also to explain a local distribution, we must not without very strcng reason refer the cxplanation only to alterations 
in the soil ; on the contrary, the whole series of factors which influence the local and seasonal occurrence, and which have been referred to above, must be taken into consideration just as much as in the case of those affections which are only contagious and which are in no wise influenced by the soil, but which nevertheless also show local and seasonal variations (scarlet fever, smallpox). Among these factors the chief are certain habits of life, selection and preparation of food, water supply, cleanliness of the person and of the dwelling, and the previous occurrence of epidemics with the consequent immunity.

There are a number of factors which we can with Drinking more or less certainty refer to as affording a certain water as an amount of explanation of the smaller epidemics of local onttyphoid fever which often show a marked local and typhoid ferer. seasonal occurrence. At present there is a tendency among physicians to find something remarkable and only explicable by the assumption of a special and specific mode of spread in almost all cases of typhoid fever, whether they are limited to a single house, or occur in neighbouring houses, or pass over streets; the usual explanation has been the presence of wells containing so-called impure water.

It is no doubt quite true that the typhoid bacilli are carried by the water in many large and in numerous small epidemics, but it is equally certain that in a large number of cases this mode of transport has been assumed without sufficient justification. The view is also generally held that it is only by means of the drinking water that we can explain those cases where a small circle of people become affected around the small central epidemic, some of the persons in this circle being passed over (these usually not having partaken of the water), and where in addition a few individuals outsicle this immediate circle become affected, these being shown to have also consumed this water. On examining sucl, cases, however, we very often find that the statistical facts were insufficient and incorrect, because they only take into account a small portion of the population 
Influcnce of various accidents on the distribution of the bacteria.
It is often impossible to discover the cause of the local distribation of (1)idemics. surrounding the wells, and that the observer has paid but little attention to this defect, on the assumption that in no other way could such a peculiar distribution of the disease have occurred.

To obtain an idea of the inuumerable small accidents 'which may influence the spread of the infective agents in one or other direction, and that without the intervention of drinking water, we only require to follow the fate of a cultivation of some readily recognisable form of bacterinm, e.g., bacillus prodigiosus, when placed anywhere in a house. We can often observe how small red colonies appear on various nutrient substrata and articies of food, with regard to which it is evident, from the place where they have developed or from the grouping of the colonies, that they have been carried by the fingers, sleeves, table, or flies without intentional or even conscious contact with the exposed cultivation. It may further be observed that at one time the epidemic is limited to the room in which the culture is; at another it suddenly appears in another and distant room; again it rapidly spreads over the whole house; or again it appear's in neighbouring houses without any affection of the immediate neighbourhood; and lastly, although the conditions are apparently the same, no epidemic may occur. The result is so dependent in each individual case on the most trivial accidents, that in laboratories where much work is done with bacteria one soon ceases to wonder at the peculiar and varying mode of spread of this or that readily recognisable impurity.

Exactly analogous are the sources of infection of typhoid epidemics, whether originating from a patient suffering from the disease, or from infected earth, or from spores which have been carried to suitable nutrient substrata, or from any materials which have been contaminated with typhoid dejecta. The mode, the direction, and the cxtent of the spread of the epidemic from these sources depends on a great variety of accidents. As in the case of the prodigiosus cultivation, the transport by man and various objects will play a very important rôle; the result in each case will, howerer, 
depend on whetlier the germs can live in the place to which they are transported, whether they find sufficient mutrient materials to permit their growth, \&c.

Thus it is only seldom that we are able to pick out the true mode of transport from the many possible ones. This want of knowledge, and our open acknowledgment of it, does not, however, render it more difficult to take prophylactic measures against a typhoid epidemic. In whaterer way the spores lave been transported they arc in all probability introduced into the body by water and food; and they only leave the body by the dejecta. If the latter are thoroughly disinfected or remorcd by a good system of drainage, if the water is taken from proper wells, and if the selection and preparation of food is attended to, a typhoid epidemic can be satisfactorily coped with even though the exact mode of transport in each individual case remains unknown. The closure of suspected wells is also a perfectly proper procedure, though the reason for doing so is not now the same as formerly; the former practice led to insufficient and probably erroneous views as to the etiological importance of the water, and to too great onesidedness in the prophylactic measures.

It is evident that the great multiplicity of the factors which play a part in the local and seasonal distribution of all infective diseases makes it extremely difficult to draw conclusions as to the nature and the infective properties of the causal agents from these local and seasonal variations and from the laws which appear to govern them. At the prescnt time, when we can study the behaviour of the infective agents themsclves, and can solve the question of their mode of distribution expcrimentally, it would help us but little to cmploy the sensonal preformer circuitous method by which we drew conclusions as to the characters of the infective agents from the phenomena of thcir local and scasonal distribution; it is much better to attempt to gain a solid basis from experiments with the isolated infective agents themsclves, and thus to obtain an cxplanation of the results of cpidemiological statistics. 


\section{The most Important Prophylactic Measures against} the Spread of the Infective Discases.

We can very easily deduce the prophylactic measures against infective diseases from the facts as to the mode of spread of these diseases which have been referred to in the foregoing paragraphs.

Proplhylaxis by influencing the individual predisposition.

Prophylaxis byclestruction or removal of the jufective agents.

(iencral pro. phylactic incasures.
In some cases it seems best to direct our precuutionary methods rather torvards the individual predisposition of the body than towards the infective agents, and in fact to neglect the latter more or less completely. The most marked example of this is tuberculosis (see p. 752). It is possible also that other infective diseases will be best held in check by such a method of prophylaxis, and probably there is a great field for investigation and for practical work in this direction.

Among the means of lessening the individual predisposition we have also protective vaccination, the practical value of which-with the single exception of vaccination for small-pox-must, however, for the reasons given above (p. 760), be judged on the whole unfavourably.

In the great majority of cases, however, our prophylactic measures deal with the infective agents themselves, and seek to destroy them, or to hinder their derelopment or spread.

The reporting of cases, quarantine, and the isolation of the sick are precautions which do not require any special discussion, nor do the points which would hare to be discussed in conncction with them specially concern the matter of this work, and we may therefore pass them over. We have here to do with the measures for the destruction and removal of the sonrces of infection mentioned on p. 736, and for interfering with the modes of transport (sec p. 739). The folloming are the most important precautions in this direction :-

a. Measures uhich are generally applicable. - In cases of disease it is of the first importance to destroy or disinfect all the excreta of the sick which may contain the effectire agrents, and all the objects contaminated with them, 
more especially linen, beds, \&c.; it is further necessary to keep all these sources of infection in a moist statc till they can be disinfected, so that the infective agents may not become detached and carried away by currents of air. (This is unnecessary in cholera.) All surrounding objects which might retain the infoctive agents, and which are difficult to cleanse, should be removed as far as possible, and protected from contamination (for cxample, soil, \&c., the iloors and walls of sick-rooms should be closely covered with some impermeable material). Those who come in contact with the sick should be particularly cleanly, and should also wash with sublimate or carbolic lotions ; similar cleanliness is also necessary with regard to the clothing, the dwclling, the kitchen, \&c. It is also desirable that those who are particularly predisposed to one or other disease on account of the presence of abnormal points of invasion (as in the case of wounds, catarihs, gastric disturbances, \&c.) should avoid the danger of infection, and should observe the necessary precautions even when no evident sources of infection are present.

b. Special precautions in indiridual discascs.-In the casc of the acutc exanthemata we must attempt by cautions ire rubbing oil over the skin of the patient to prevent, or at diseases. any rate to limit, the detachment of the infective agents from the surface of the body, and their transport through the air. Thorough ventilation of the sick-room, which is much recommended for prophylactic purposes, can, it is true, lead to a dilution of the germs, but it is difficult cren by the best methods of rentilation to diminish the chanccs of infection to such an extent as occurs in the open air, and as is requisite if we are to place ventilation on the same footing as the other prophylactic measures.

In those discases in which the seat of invasion and the seat of the disease lie in the intestinal tract, such as cholcra and typhoid fever, we must, when there is a great danger of infection, pay the greatest attention to the preparation of the food, and we must also sec that the drinking water comes from pipes or from grood wells, 
and this is done by insisting that all food must be cooked, and that all water must be filtered through a proper apparatus. Where sources of infection are present we must also employ the general precautions referred to above. An extremely important measure consists in making arrangements to remove dejecta and waste water rapidly and to get rid of gutters, and thus to render it impossible for the surface of the surrounding soil, the wells, and the watercourses to become contaminated with dejecta.

Disinfection.

The prevention of fresh sources of infection by means of a rational method of disinfection, forms the most important part of the prophylactic measures in the rnajority of the infective diseases. This method applies to the following materials, and is carried out by the following means :-

Disinfection of excreta.

Disinfection of linen, beds, de. carrying out this method of disinfection, and of these
Apparatus for three have been tested and found satisfactory. These disinfecting $a$ are the apparatus made by Schimmel \& Co.in Chemnitz, the stationary and portable apparatuses made by $\mathrm{T}$. current of stcrm. pus, dc.) should be mixed with 5 per cent. carbolic acid (or if necessary with commercial fuming hydrochloric acid), and allowed to stand for twenty-four hours, each motion being disinfected at once. The receptacles must be repeatedly washed with similar solutions. Infective material on the body of the patient must also be removed by means of carbolic acid, or sublimate solutions.

2. The linen and bed linen of the patient, dressings, feather beds, woollen blankets, mattresses, straw beds,* handkerchiefs, curtains, carpets, dc., should be disinfected by a current of steam at $100^{\circ} \mathrm{C}$. Trrious apparatuses have been constructed in recent years for

1. The infective excreta of the patient (sputa, dejecta, T. Bacon in Berlin, and lastly that by Rietschel is Henneberg. - So far as possible these various machines

* It is usually best to burn straw beds and other worthless matcrials. In practice, howcver, this camnot always be done without risk of infection, and in that casc it is simplest to disinfect these materials also in tho storm apparatus. 
should be round, or nearly round, in order to avoid the presence of corners in which the disinfection may very readily be imperfect. It must also be borne in mind that hot air containing a ccrtain amount of steam does not by any means have the same effect as a good current of stenm without any air ( $\sec$ p. 665); those forms of apparatus are untrustworthy in which steam is present even under high pressure, but not in such quantity that after filling the apparatus $\Omega$ good current of steam escapes from it. It does not seem to be necessary to raise the temperature of the stenm by employing saline solutions; it has becn definitely proved by numerous experiments in Koch's laboratory, and by comparative tests by Wolff which were made on a number of machines and in a trustworthy manner, that even very large objects (balls composed of 22 woollen blankets) are completely disinfected by exposure for one to tro hours to a current of stcam at $100^{\circ} \mathrm{C}$. One hour suffices for smaller objects, and half an hour for linen and clothing, the time being reckoned from the moment when the steam which escapes shows a temperature of $100^{\circ} \mathrm{C}$.

By this plan the injury done to the materials is rery slight. Linen, feather beds, mattresses, clothing, printed matter, \&c., are quite unhurt, but sensitive colours are somewhat altcred. Disinfection by heat cannot be cmployed for objects made of leather (boots), gum, or caoutchouc, and bound books.

No definite statement can be made as to the special advantages of one or othcr of the disinfecting apparatuses mentioned above; at all events, they are all trustworthy and useful. They are prepared in various sizes and at various prices, and one ought tó be in use in every town.

In Göttingon a very simple and cheap apparatus has been Special introduced provisionally, and acts extremely well. It is con- description of structed on the same principles as the sterilising apparatus ratus for discommonly used in laboratorios and described on page 665 , infection. being merely correspondingly larger. It is desirable to have two of these machines of different sizes, the one being 7 metres in height and $50 \mathrm{~cm}$. in diumeter, the other $1 \%$ metres 
Construction high and $80 \mathrm{~cm}$. wide. The smaller, which costs with acces-

of the machines.

Wethod of herting.

nents have not, however, acted well, and they lengthen the Prevention of process too much; they are besides quite superfluous if care wetting of the is taken to prevent the materials from coming in contact
materials. materinls.

sory apparatus abont $£ 710$ s., is employed when portions of clothing or linen are to be disinfected (as in tuberculosis); the larger, which costs about $£ 13$, scrves for the disinfection of beds, mattresses, \&e-l'he apparatus is made of tin, with the exception of the bottom, which is copper, and has a conical shape, enlarging at the lower part so as to increase the hoating surface. The receptacle for the water is prorided with a tube projecting outwards, through which it is filled, with a pressure gauge tube, and with a stop cock to empty it. To provide air-tight fittings for the lid, and also at the at tachment of the body of the machine to the boiler, these parts fit into grooves which are filled with watcr. To prevent cooling, the body and the lid are protected by a thick layer of clay, which is fixed on by means of gange bandages, and an external arrangement of wire netting. In the lid there is a tube for a thermomcter, and another for the steam, with which a long leaden tube is connected so as to conduct the stcam out of the house.

The apparatus is heated by gas. In the case of the larger apparatus twelve large Bunsen burners are necessary to raise the temperature of the thermometer in the lid to $100^{\circ} \mathrm{C}$. within half an hour; for the smaller apparatus five burners are sufficient. This method of heating has the advantage that it can be very cheaply fitted up, that the temperature remains constant, that the heat is very completely utilised, and that the disinfection is completed in a rery short time (within two hours). The cost of the gas for the larger apparatris is about sixpence per hour, that for the smaller about $2 \frac{1}{2} d$. Where larger machines are employed boilers and fires are of course indispensable.

Attempts have been made to add arrangements to warm the clothing, \&c., preriously, and to pass a current of dry hot air through them subsequently to the disinfection in order to dry them as quickly as possible. These arrangements have not, however, acted well, and they lengthen the current of steam they dry in a very short time, within half an hour; and it is only at those places where the water has soaked in that the moisture remains longer and that the colours are more readily destroyed. Hence in the apparntus described above special carc has been taken that the witer condensing on the walls or top of the apparatus shall not rum on to the matcrials which are heing disinfected. Beds anrl similar bodies are placed in a cylindrical basket of strong 
wire, the sides of whieh are at least $1 \mathrm{em}$. from the wall of the vessel, and are lined with wire netting and inside that with waxed eloth, whieh is the only material impermeable to water" which stancls heating well. Further, to protect the artieles lrom water dropping from above without preventing the passage of the steam they are eovered with sevoral layers of cloth. By means of these simple arrangements the artieles can be clried in half an hour if they are laid out on a dry frame arranged around an ordinary iron stove, and thus only two to three hours elapse from the begimning to the end of clisinfection.-Above the apparatus an arrangement is fixed hy means of whieh the eover ean be raised and turned aside. the basket introduced or removed, and the eover replaeed in a very few minutes.

Spring mattresses can be sufficiently disinfected by scrubbing them with sublimate solution $(1: 2000)$; it is most conrenient to combine this procedure with the disinfection of the dwelling. Boots, indiarubber materials, \&c., should also be washed with sublimate solution.

3. In the house, the bedstead (and the other furni-Disinfection ture if necessary) and the floor should be scrubbed with dwelling. sublimate solution, and afterwards washed with soap and water. In the water-closets, the seat, the pan, and the drain should be scrubbed or sluiced with 5 per cent. carbolic lotion. The contents of cesspools, \&c., should be mixed with commercial hydrochloride acid till the reaction of the contents after being well stirred is markedly acid. Where the cesspools are very large we cannot attempt disinfection. - As to the defects and the methods of disinfection of the air see p. 669. In most cases no attempt is made to disinfect the air, but reliance is placed in thorough ventilation. We may, however, before disinfecting the floor, furniture, \&c., attempt to cause deposition and fixation of the air germs by loading the air with moisture by means of steam or spray.

To carry out thorough disinfection it is essential that Necessity for there should be a staff of educated persons, indeed this an educated is quite as necessary as the possession of a proper apparatus. In a small town three trustworthy persons are sufficient; these should be thoroughly instructed and examined by tho medical officer; in larger cities the staff must be correspondingly more numerous. 
Regulations for disinfec. tion in Gottingen.
In Güttingen the following regulations have been drawn u, by Dr. Schütte. - Families in which a ease of infective disease has occurred, and who desire disinfection, must send an intimation to the court-house, stating also the nature of the disease. In this way the staff can judge as to the extent of the disinfection and the method to be employed; the following are their instruetions aceording to the nature of the ease :-

Small-pox, scarlet fever, typhus fever, diphtheria, \&c.; linen, beds, eurtains, \&c., are to be disinfected with a current of steam; bedsteads and floors to be scrubbed with sublimate solution; upholstery, \&c., to be moistened with sponges. dipped in sublimate solution, and at once dried.

Cholera, typhoid fever, dysentery: disiufection of linen, \&c., by steam. Water-elosets disiufected with 5 per eent. carbolic aeid; eesspools, \&c. with eommercial hydroehloric acid. In cholera warm and ventilate the room, in typhoid fever and dysentery cleanse the bedsteads, floor, \&c., with sublimate solution.

'Tubereulosis : disinfeetion of the linen and beds.

The persons who are to earry out the disinfeetiou take with them all the solutions, vessels, brushes, \&c., also some indiarubber garments, and a number of moistened cloths of various sizes; also the wire basket from the sterilising apparatus. These are transported in asuitable hand barrow. When they reach the house they put on the indiarubber garments, and take the utensils and cloths into the room, wrap) the beds, mattrasses, elothes, \&c., in the moist cloths, cleanse their hands aud mackintoshes with sublimate solution, and plaee the parcels in the wire eage. One of the disinfectors. takes these baek to the apparatus, which has been in the meantime heated by the third, while the first remains behiud aud disinfeets the room. After two to three hours the beds, \&c., are brought baek, and in the meantime the room lias been disinfected.

The detailed instructions may be obtained from the magistrate of Göttiugeu, or from Dr. Schütte, the medieal officer of health.

It is a fact which cannot be overloolied that it is as a result of the recent bacteriological investigations that we ale in a position to employ trustworthy proplylactic measures agrinst the infective diseases, and more especially to carry out the disinfection so thoronglyly that it has become one of the most potent means of opposing the spread of these aftections. 


\section{PART VIII.}

METHODS OF INVESTIGATING BACTERIA.

I do not propose in the present work to give at all a complete description of the various methods of bacteriological investigation; such an attempt would very much increase its size, and is so much the less necessary as very thorough descriptions of bacteriological methods have been given by Hucppe, and also in a recent work by Huber and Becker (Leipzig, Vogel, 1886).

In the following pages I shall only put together the most important methods for the microscopical examination of bacteria, for their cultivation, and for their demonstration in air, water, and soil.

\section{Mieroseopical Examination of the Lower Fungi.}

We can examine microscopically a great variety of Mcthods of materials, such as fluid and solid substances, nutritive microscopical materials, such as fluid and solid substances, nutritive cxamination materials, dust, earth, animal and vegetable organs and of bactoria. juices, fungus colonies, \&c. In doing this we must always remember that these lowly organisms are constantly present in all our surroundings, and that in order to demonstrate the presence of the fungi in any one of these materials care must be taken to prevent the accidental introduction of fungi into the preparation frem the surroundings. All instruments, glasses, re- Apparatus. agents, \&c., must therefore be free from organisms, and this is best attained in the case of the instruments and glasses by exposing them for a short time to a temperature of at least $150^{\circ} \mathrm{C}$, or, still better in many cases, by placing them in a solution of corrosive sublimate 1 to 2,000 . 
If we are investigating pathogenic organisms we must remember that numerous fungi are constantly growing on the surface of healthy living animals, on the skin, in

Mode of obtaining the specimons.

Staining of bacteria.

Cover glass preparations. the cavity of the mouth, \&c. After death these organisms rapidly spread, in the first place, into all the superficial parts of the body; spccimens taken witl the view of investigating the presence of pathogenic organisms must therefore never be taken from the irnpure surface, even in the case of living animals; and after death we must always try, if possible, to obtain the specimens from the intcrior of the organs by making a scries of fresh cuts with a heated knife.

The direct microscopical observation (sometimes after the addition of a half per cent. soda solution, a mixture of glycerine and water, or a solution of acetate of potash 1 to 10 ) without further aids only gives results at all satisfactory in the case of the larger fungi, or of cultirations of bacteria ; if other objects, such as cells, nuclei, or fragments of nuclei, crystals, and amorphous inorganic materials, arc present in the preparation we may not be able to recognise the bacteria, even under very high powers of the microscope. Hence in almost all cases where it is important to examine the preparation accurately it becomes necessary to stain the microorganisms. The bacteria talic up certain colouring materials with extraordinary energy, and we can usually so manage the staining that the micro-organisms alone are coloured, or at lcast these alone are markedly stained, while all the other objects in the preparation are but faintly, or not at all, tinged. And where we wish to demonstratc the absence of micro-organisms from some material it is only possible to do so with any degree of certainty by the aid of mcthods of staining.The treatment of the preparations with the riew of staining them differs according as we hare to do with fluids or with animal orgms.

Fluids are in the first place dried on a corer glass in a rery thin layer, a small drop being placed on the glass by means of a recently licated platinum wire, and spread out over it by a few circular movements, or still 
better by laying a second cover glass on the top of the first, so that the drop is spread out, and the layer of fluid extends to the border of the cover glass; these glasses are then slid asunder, and thus we obtain two thinly-spread layers; these layers dry in a few minutes. If now the cover glass is at once brought into contact with the staining solution the layer again becomes detached, and is washed away; hence the organisms must first be fixed on the glass as far as possible. This can be done either by prolonged immersion of the glasses in absolute alcohol, or by exposing them for a short time to a temperature of from $110^{\circ}$ to $130^{\circ} \mathrm{C}$. (for two to ten minutes), but the exact degree of heat differs somewhat in the case of different objects, and must be ascertained by experiment. This heating can be conveniently and sufficiently done by passing the cover glass two or three times slowly ("about as quickly as we cut bread ") through the flame of a Bunsen burner or a spirit lamp. After this treatment the organisms adhere so firmly to the glasses that these can be liept for a long time in watery fluids without any bad result.

The cover glass being prepared in this way a drop of one of the staining solutions mentioned below is placed on it; it usually suffices to allow the solution to act for from fifteen to twenty minutes; if we wisl to prolong the action it is advisable to float the cover glasses on the staining: material contained in a flat vessel. The cover glass is then seized with forceps, freed from the stain by filter paper, washed in distilled water, or at times in very dilute acetic acid ( 5 to 10 drops to $100 \mathrm{ccm}$. of water), and then placed on the slicle with a drop of water, or else dried and mounted in oil of cloves or Canada balsam.

Organs must in the first instance be hardened in Treatment of absolute alcoliol for some time (several days); in doing this plenty of alcohol must be used, and it is well to cut the organs into small pieces. A number of fine sections are then made, if possible by means of a microtome, and are placed in tho first instance in absolute alcoliol, and from thence transforred to the staining solution. The 
sections remain in this solution for from a half to five hours, in some cases even for twenty-four hours. By warming the solution to $30^{\circ}$ to $40^{\circ} \mathrm{C}$. the duration of the staining can be considerably shortened. When the sections are taken out of the stain the whole tissue is strongly coloured, and hence we must attempt to produce a differentiation between the organisms and the tissue by placing the sections in alcohol, or in dilute acetic acid, which has the effect of withdrawing the colouring matter from the cells, and leaving only the organisms and at most the nuclei of the cells stained (in addition also certain forms of mucine, horny tissue, at times fat, and the axis cylinder of nerves retain the stain). In most cases the best method of decolourising tissue is to leave the sections in alcohol for fifteen to thirty minutes, then to transfer them to oil of cloves, from this again to pure alcohol, and then again to oil of clores. It is well at times to employ dilute acetic acid before the alcohol. The sections can be at once examined in the oil of cloves; or they can be transferred to slides, the oil removed carefully by blotting paper, and the sections then mounted in balsam. Some colouring matters are dissolved out by the oil of cloves, and in these cases the sections are transferred from alcohol to oil of bergamot or xylol, in some cases after a previous short immersion in oil of cloves.-If we have a freezing microtome at hand the fresh organ can be at once frozen and cut. The sections are then in the first instance placed in salt solution, from which they are carefully removed to absolute alcohol, and then treated as above described.

Staining materials.

Carmine or hæmatoxylin are only rarely employed as staining materials, the chief dyes used being the aniline colours, to which the lower fungi show a great affinity.

According to Ehrlich* we have to distinguish tro great groups of aniliue dyes which are sharply defined from each other by their chemical and histological peculiarities; these are the acid and the basic colouring materials.

* Westphal, Schwarze, Spilling (Lit.), Weigert.-See also Virchow's Arch., vol. 84. 
Among the acid dyes we reckon all those colouring mattcrs in which the strining substance is an acid; the dye is not nccessarily, howerer, a frec acid, nor nced it even have an acid renction, it may be in combination with bases forming salts, such as picrate of ammonia. There are four classes of acid colouring materials, viz.: 1. Fluorescine; to this group belong fluorescin, pyrosin, cosin (tetrabromfluorescin), and several others. 2. Nitro bodies-for example, Martin's yellow (a salt of binitronaphthol), picric acid, aurantia (the ammonia salt of hexanitrodiphenylamine). 3. Sulpho acids-for example, tropæolin, bordeaux, ponceau ; derivatives of the form of aniline blue which is soluble in spirit; aniline black, \&c. 4. Primary acid dyes-for example, rosolic acid, alizarine, nitroalizarine, purpurine, cœruleine, possibly hæmatoxyline, \&c.

To the basic dyes belong fuchsine (rosauiline), inethyl violet, methyl green (both of them methyl derivatives of rosaniline, the latter being usually contaminated with methyl violet), triphenylrosaniline (impure aniline blue) and its derivatives, cyanine, safranine, magdala; further, the stains which are more especially employed for colouring bacteria, viz., Bismarck brown, dahlia, and gentian violet.

The basic colouring matters arc not usually sold as free bases, but as salts; thus luchsine is sold as hydrochlorate or acetate of rosaniline.

The basic aniline dyes are almost alone suitable for staining bacteria; they, however, also stain the nuclei. In order to prevent the occurrence of a diffuse stain of the whole tissue we must treat the stained preparations with solutions which have a greater affinity with the staining material than the tissue, but less affinity than the micro-organisms (and nuclei of cells); such solutious are alcohol and dilute acetic acid.

Many bacteria only talie up few stains well; and hence in searching for unknown micro-organisms all the various staining materials must be employed with or without the addition of acetic acid, or in faintly alkaline solution; the spores of bacilli do not take up the colouring matter unless when they are specially treated. In the case of most forms of micrococci all the nuclear stains (carmine, hæmatoxyline, basic aniline dyes) are suitable. These organisms can be stained red with the various forms of carmino which stain the nuclei, and also with purpurine, 
Most useful strining solutions.

fuchsine, magdala, and magenta; brown, with Bismarck brown, or vesuvine; green, with methyl green; blue or violet, with hæmatoxyline, methylene blue, iodine violet, methyl violet, dahlia, and gentian violet. Many of the bacilli, however, can only be stained by those aniline dyes which stain nuclei. The following are the materials which are most used.

Methylene blue, more especially in faintly alkaline solution (Loeffler's universal staining fluid). This fluid is prepared by mixing $1 \mathrm{ccm}$. of concentrated alcoholic solution of methylene blue, which can be kept for a long time, with $200 \mathrm{ccm}$. of distilled water, and then adding two to four drops of a 10 per cent. solution of caustic potash. The mixture must be refiltererl every day, and must be freshly prepared about every eight days.

Gentian violet (B.R. in the catalogue of the Berlin company for the manufacture of aniline dyes) in about 1 per cent. watery solution.

Fuchsine is liept at hand in the form of a concentrated alcoholic solution, and is diluted with about five times the amount of water when required.

Methyl violet, gentian violet, and dahlia show in a special degree the property of metachromatic staining, i.e., they stain various elements of a shade somewhat different from the primary colour, reddish to red, \&c. Methyl green, which is usually contaminated with methyl violet, often gives blue, and at times rose tints.

Donble stain- In order to differentiate better between nuclei and ingr. bacteria double staining is at times very suitable; we may mention, for example, double staining with picrocarmine and gentian violet, which depends on the fact that the carnine can drive out the violet from the nuclei, but not from the bacilli. The sections are placed in the first instance in a solution of gentian violet, then in alcohol, then for a moment in water $j n$ order to remore the alcohol, and then in Weigert's picro-carmine solution. After remaining in this solution for a half to one hour they are passed through water, alcohol, oil of cloves, and Camada balsam. The result is that the nuclei of the cells have a red colour, while the bacilli 
are stained blue. The clubs of actinomyces can be stained reddish-blue by treatment first with Wedl's orseille (Virchow's Archiv, vol. 74), and then with gentian violet.

T'ubercle bacilli are best stained by the following To stain method (see p. 261) : aniline oil and water are well bacilli. shaken up together, and then filtered through moistened thick filter paper; concentrated alcoholic fuchsine or gcntian violet solutions are then cautiously dropped into the filtered aniline water till a slight cloudiness is noted, which later again disappears (about 10 to 20 drops of the stain to $10 \mathrm{ccm}$. of aniline watcr). The cover glasses, prepared with sputum in the manner above-mentioned, are then floated on this colouring matcrial for from twelve to twenty-four hours, or, if the solution is kept at a temperature of $30^{\circ}$ to $35^{\circ} \mathrm{C}$., for one to two hours ; in the case of sections, it is best to stain them for twenty-four hours, and then to warm the solution for one to two hours. The cover glasses and sections arc then washed in the first instance in acidulated alcohol $(100 \mathrm{ccm}$. alcohol, $20 \mathrm{ccm}$. water, and 20 drops of concentrated hyclrochloric acid); after a short time (a half to two minutes) the red or violet colour is removed from all the thinner parts of the preparations, which are now carefully washed in water, the cover glasses clried, and then stained in dilute watcry solution of methylene blue if fuchsine lias been employed $j_{11}$ the first instance, or with a solution of vesuvine if gentian violet has been used. After five to fifteen mirutes they are washed in water, dried, and mounted in Canadi balsam. Sections are placed for half an hour in the methylene blue or vesuvine solution, and then treated in the usual manner; if the preparations are to be preserved we must employ oil of bergamot instead of oil of cloves.In this way we obtain preparations in which the tubercle bacilli are stained red or violet, and the cells and cell nuclei blue or brown. The only other organisms which show the same staining reactions as tuberele bacilli are, so far as we know at present, the leprosy bacilli. Some other materials also retain the stain in this method, sucl as the epiclemic structures, the spores of the mould fungi, 
the spores of bacilli under certriu conditions, and also at times fat crystals, which are sometimes present iu sputum; the fat crystals are, however, readily soluble in ether and chloroform (Celli and Guarncri).-The pure solutions of the dyes, and also the mixture of aniline and water, can be liept for a long time, but the latter must always be freshly filtered before use, and the mixture with the colouring material must always be freshly prepared.-The following solutiou will, however, keep for from ten to twelve days: $100 \mathrm{ccm}$. saturated aniliuc water, $+11 \mathrm{ccm}$. coucentrated alcoholic solution of methyl violet or fuchsine, $+10 \mathrm{ccm}$. absolute alcohol.-With regard to the uumerous other methods of staining bacteria, see tho papers by Plaut* and Kaatzer. $中$

As regards the staiuing of the bacilli of syphilis and smegma, see p. 289.

Gram's method.
Gram's method is admirably adapted for the differential staining of bacteria in the tissue, and also as a means for the diaguostic separation of many species of bacteria. It cousists of, 1, aniline geutian violet solution, Ehrlich's formula (as for staining tubercle bacilli); 2 , solutiou of iodine and iodide of potassium, composed of 2 grammes of iodide of potassium, 300 grammes of water, and 1 gramme of iodiue. The sectious are trausferred from absolute alcohol to the strining solution, aud remain there for from one to threc minutes (in the case of tubercle bacilli for twelve to twenty-four hours), then aftcr a short immersion iu alcohol they are placed in theiodiue solution. After one to three minutes the sections are agaiu placed iu alcohol till they are completcly decolourised, then iu oil of cloves, \&c. As a result the tissuc aud nuclei hare a faint yellow colour; the bacteria, ou the other haud, are intensely blue or black. Cover glass preparations are treatcd in a similar manuer.-The following organisms retain the stain in this method: the bacteria of pneumonia, the cocci of pyauia and crysipelas, staphylococci, tubcrcle bacilli, autlirax bacilli, and rarious saprophytes;

* Plaut, Fürbungsmethorlen u. s. 20., 2 Aufl., 1885.

+ Kantzer, Dic technik der Sputumuntersuchung auf Tuberkelbacillen 2 Aufl., 1885. 
on the other hand, typhoid bacilli and cholera spirilla are dccolourised by the iodine solution.

Buchner, * and subscquently Hueppe, was the first Staining of who was successful in staining the spores of various the spores of bacilli. In order to stain the spores the cover glass preparations are raised to a higher temperature than in strining the bacteria, thus they are not passed three times but from six to ten times through the flame, or they are lieptfor a quarter to half an hour in a dry chamber at a temperature of $180^{\circ}$ to $200^{\circ} \mathrm{C}$. After this treatment the spores take up the ordinary aniline dyes.-Neisser, however, succeeded in strining spores by the use of the solutions employed to stain tuberele bacilli when they were at the same time warmed. Cover glass preparations, prepared in the ordinary manner, are floated on the aniline fuchsine solution at a temperature of $80^{\circ}$ to $90^{\circ} \mathrm{C}$. for ten, twenty, or even forty minutes, and are subsequently treated like preparations of tubercle bacilli. By this method the spores are stained red and the bacilli blue.

In order to preserve the preparations we can employ Preservation Canada balsam, dammal, a concentrated solution of paration. acetate of potash or glycerine; the latter, however, is only suitable for preparations stained with solutions of aniline brown which contain glycerine. - The best mounting matcrial for mould and yeast fungi is glycerine gelatine (one part of gelatine, six parts of water, seven parts of glycerine, and one part of carbolic acid, warmed and filtered).

For the examination of the preparations only the best Microscopical microscopes are suitable. In the case of the larger forms of bacteria-for example, anthrax bacilli-dry lenses are sufficient, in the case of all the smaller forms it is necessary to use the best oil immersion lenses. $\dagger$ In order to be able to recognise the stained bactcria in the tissue a special mode of illumination is necessary.

* Miïnchener ärzll. Intelligenzbl., 1884, p. 370.

$\dagger$ Excellent oil immersion lenses and apparatus for illumination are furnished by Zoiss of Jena, Seibert and Kraft, Leitz and R. Winkel in Göttingen. Winkel's lenses are excellent, and, according to the author's experience, are most worth the money.-Colouring materinls and other apparatus can be obtained from Dr. Grübler in Leipzig. 
It would of course be best if we could obtain a pure colour picture, i.e., if the Cunada balsam and the tissue had an identical refractive index, and as a consequence the tissue were not at all visible, and only the bacterin could be seen by virtue of the stain that is in them. But usually the various portions of the tissue lave a different refractive index to the Canada balsam, and gire rise by diffraction of the transmitted rays of light to the structure picture, which consists of lines and shadows, and which obscures the colour picture. We must therefore try, as far as possible, to obliterate these diffraction appearances and the structure picture, and this can be done by the employment of a suitable illumination apparatus.

Abbé's sub. stage condev $=\mathrm{er}$.

If we examine a microscopical preparation illuminated at first with a narrow, and then with a constantly but slowly inereasing conc of light, we find that the diffraction appearances and the strueture pieture, which were most intense with the narrow diaphragm, gradually disappear; and to the same degree as the strueture picture diminishes, so the colour pieture becomes more intense and sharper. Hence where possible a eondenser must be employed with so large an angle that the diffraetion appearanees are completely obliterated. An instrument which attains this object completely is the condenser devised by Abbé, and prepared by Zciss. This consists of a combination of lenses, the focal point of which is only a few millimetres distant from the front lens. When this lens is plaeed in the opening of the stage of the mieroscope at a somewhat lower level than that of the stage the foeal point falls on the objeet under cramination, and the latter is consequently best illuminated in this position. The angle of aperture of the rays is so great that the most external of them are bent in a laycr of water almost $16^{\circ}$ towards the axis, and hcnee the total active eone has an aperture of $120^{\circ}$, a broader aperture than that of any other condenser. The rays of light are sent into the system of lenses by means of a mirror which can only rotate around a fixed point in the axis of the mieroscope. Between the mirror and the lons, and near the foeal point of the former, we lave the arrangement for diaphragms which can be moved laterally and circularly. so that the cone of rays may be altered in any manner desired. By means of a greater or less dinphragm the aperture of the lens is modified from the smallest to the largest. 
The appearances observed under the microscope are Photography best reproduced by means of photography. The cover of baeteria. glass preparations prepared in the manner abore described permit the employment of high power inmersion lenses. It is best to stain the organisms brown. Photography also possesses a special advantage in that the photographic plate reproduces the microscopic picture better, or rather with greater accuracy, than does the retina of the eye.

The scnsitive plate is to a ccrtain cxtent an eye which is not blinded by bright light, and which does not bccome tired by the attempt to distinguish between minnte differcnces in light, \&c. We often find on the ncgatire, when the picture has been sharply focusscd, finc objects, for example, minute flagella, which can only lse seen with the greatest difficulty, and under the most favourable conditions of illumination.

As regards the methods of photography sce the works mentioned below.*

Bacteria, more especially micrococci, may be con-Differential founded with detritus, but the latter shows granules of diagriosis of irregular size and grouping; we also at times find small drops or little spheres, which become stained with the dyes, and the nature of which is as yet doubtful. Confusion is most likely to occur with the cells described by Ehrlich under the name of "Mastzellen" (plasma cells, granular cells), which are very widely distributed, and increase in number in various pathological processes. The uniform round granules of these cells are usually stained in a similar manner, and with a similar shade, to the bacteria; and the two forms can often be only distinguished by the position which they occupy, and more especially by the fact that the granules in the plasma cells are always grouped in the form of cell-like structures. If it is necessary to make certain that we are studying bacteria the following method may be employed: after staining with aniline the sections are

* Gerlaeb, Die Phntoyraphie als Mïl/smittel mikiosknpischer Forschung Leipzig, 1863.-Beneke, Die Photographie als Hïl smittel u. s. wo., Brannehwoig, 1868.-Reiehardt n. Stllronburg, Lehrbuch der mikroskopischen Photographie, Leipzig, 1868.-Vogel, Lehvbuch der Photographie, Berlin, 1874. Soo also the exeellent photographs by R. Koeh in Cohn's Beirr., vol. 2 , and in the Mitheilungen $a, d$. Kris. Gesundheits-Amt, rol. 1. 
treated, not with acetic acid or alcohol, but with a weak solution of carbonate of potasll, and under these circumstances the nuclei and plasma cells, and in fact all animal tissues, lose the stain, and the bacteria alone retain it (Koch).

Methods of cultivation.

Vossels.

II. The Artificial Cultivation of the Louer Organisms.

Artificial cultivation is absolutely essential for the minute study of the properties of the various microorganisms.

The vessels most commonly employed for this purpose are thick-walled test tubes; or vessels $5 \mathrm{~cm}$. in diameter with narrow necks; or flasks of various sizes, the best of which are the so-called Erlenmeyer's flasks with flat

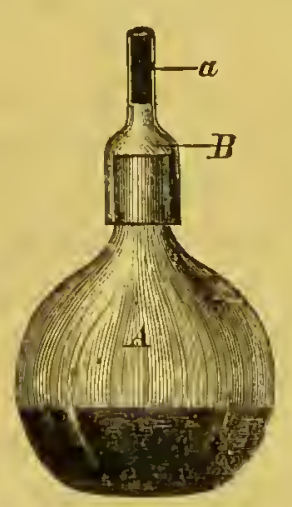

Fig. 140.-Pasteur's culture vessels. bottoms. In order to exclude the organisms plugs of cotton wool are employed, which extend for about $3 \mathrm{~cm}$. into the neck of the ressels, and project about $1 \mathrm{~cm}$. above it; this must not press too closely on the walls lest channels be left on the surface of the compact mass. Pasteur employs small flasks (matras), on the neck of which a small helmet fits $(B)$, which contains the plug of wool $(n)$. These vessels are more especially suitable for culture fluids where one wishes to re-inoculate frequently; in this case it is not necessary to take out the cotton wool plug with the particles of dust adhering to it- the helmet itself is lifted. Fol* employs a complicated plan consisting of an external cotton wool plug which remains untouched, in the interior of which is a glass tube which becomes narrower at the lower part. This tube contains at the lower part an asbestos, and at the upper part a cotton wool plug, and when a specimen is required only the latter is removed, while the asbestos plug is perforated by a heated canula.-As a rule, how-

\footnotetext{
* Arch. des sc. phys. el natur., Gúnire, 1884, t. 11.
} 
erer, these precautious are quite unnecessary; when the ressels are opened it is sufficient to burn the outer part of the cotton wool, which contains the dust, in the flame of the Bunsen burner in order to remove almost entirely the danger of the introduction of germs.

In many cases where we wish to have a larger surface of nutrient material we may employ, besides Erlenmeyer's flasks, small flat glass capsules with vertical walls 1 to $2 \mathrm{~cm}$. in height, and with a diameter of 4 to $6 \mathrm{~cm}$. - the so-called crystallisation capsules. These are preserved in a wider cylindrical vessel, 15 to $20 \mathrm{~cm}$. in height, in which the capsule can be readily raised and lowered by means of a bent strip of metal ; the cylinder is plugged with cotton wool in the usual manner. If microscopic slides or glass plates are employed for cultivation it is sufficient to preserve them in glass dishes which are well closed, and it is best for the cover to orerlap the lower part* of the dish.

The uutrient substrata. These must, in correspcinlence The nutrient with what has been said above with regard to the conditions of life of the lower fungi and of the necessary mutrient materials, consist of carbonaceous, nitrogenous, and mineral substances; the excellence of the nutrient solution depends on the nutritive value of the materials employed, and also on whether the quantities present approach as nearly as possible the optimum of concentration, on whether the reaction is that which is best for the organism in question, on whether, and in what quantity, oxygen is present, \&c.

If we wish to cultivate mould fungi, and to aroid as fal as Formould and we can the entrance of bacteria, wc raust cmploy a substratum yeast fungi. which is solid, which contains a small amount of water, and of which the reaction is markedly acid; in the case of the ycast fungi the best conditions are obtained by the cmployment of fluids which are not so markedly acid, but are still distinctly so, and which contain a considerable amount of

* A more precise description of the apparatus and the utcnsils necessury for tho cultivation of bacteria will be found in the special catalogues of the firms from which all these articlos can bo obtained. The following may be rocommended: R. Mucncke, Berlin, N.W.; I. Robrbcck, Berlin, N.W. 
sugar; for bactelia the most suitalle substrata are those which contaiu a large amount of water, and of which the reaction is neutral or alkaline.

As mutrient soil for mould fungi we employ decoctions of dried plums and other fruits; deeoctions of the fresh dung of herbivorous animals; decoctions of yeast containing is large amount of sugar; spread ont dung of herbivorous animals; pieces of bread which may be impregnated with various decoctions; a paste made of bread, \&c. If the sul,strata are not sufficiently acid they may be made so by ueans of tartaric acid ( 2 to 5 per cent., according to the concentratiou of the nutrient solution) or phosphoric acid ( $\frac{1}{2}$ to 1 per cent.).-Iu the case of yeast fungi we select a decoction of malt, wort, or one of the above-mentioned decoctions, to which grape sugar is added; in the case of bacteria, urine, hay infusiou, meat infusion, \&c., to which may be added the ashes of yeast, cigars, \&c., and of which the reaction should be as far as possible neutral, or at the most very slightly acid or alkaline.

For saprophy- Pasteur formerly recommended the following as a pure tic bacteria. artificial nutrieut solution: 100 parts of water, 10 parts of candy sugar, 1 part of tartrate of ammonia, and the ashes from 1 part of yeast, the weight of the latter beiug about $\cdot 075$ of that of the whole mixture. Bucholtz replaced the yeast ashes in this solution by 5 grm. of phosphate of potash. Cohn selected the following mixture: ' $1 \mathrm{gr} m$. of phosphate of potash, 1 grm. of crystallised sulphate of magnesia, 01 grm. of tribasic phosphate of lime, $20 \mathrm{~g}$ ' $\mathrm{m}$. of distilled water, and 2 grm. of tartrate of ammonia.-These and similar nutrient solutious were, howerer, inuperfect in various ways, as has receutly beeu discovered by Nägeli. As the result of numerous experiments as to the uutriment of the lower fungi, Nägeli recommends the following solutions as normal fluids for bacteria (from these, solutions suitable for mould and yeast fungi can be readily prepared by the addition of sugar and acid) :-

1. Water 100 ccm., tartrate of ammonia 1 grm., bipliospliate of potash $\left(\mathrm{K}_{2} \mathrm{HPO}_{4}\right) \cdot 1 \mathrm{grm}$., sulphate of magnesia $02 \mathrm{grm}$. and chloride of calcium $.01 \mathrm{gr} \cdot \mathrm{m}$.

Instend of the tartrate of ammonia we may employ acetate or lactate of ammonia, \&c., or even asparagine or lcucine:

2. Water 100 cem., peptone or soluble albumen 1 grim., biphosphate of potash (K.2HPO, $\cdot 2$ grm., sulphate of magnesia 04 grm., chloride of calcimm 02 grm.

3. Water $100 \mathrm{ccm}$, cane sugar $3 \mathrm{grm}$, tartrate of ammonia 1 gr'm., and inineral salts as in No. 2. 
These various nutrient substrata are more or less un- For patho. suitable for the cultivation of the pathogenic bacteria. genicbucteria. These organisms evidently require a certain quantity of albumen aud peptone, and sometimes also sugar, and are very sensitive to variations in the composition of the nutrient substratum. In the case of the majority of the pathogenic bacteria, the most favourable medium must be specially ascertained by experiment.

T'he following nutrient solutions are the best: meat infusion (prepared in the same manner as in the preparation of the nutrient jelly); meat infusion, with 1 per cent. peptone and 2 per cent. dextrose; solution of meat extract (Licbig's meat extract, 1 per thousand), with peptone and dextrose; milk; blood serum. We have also a series of soft but solid nutrient substrata, more especially boiled potatoes ; mixtures of the nutrient solutions with solidifying agents, such as gelatine or agar; solidified blood serum. All these nutrient substrata must be neutralised till the reaction becomes faintly alkaline; where the reaction is at first markedly acid, this is done by the addition of concentrated soda solution, where the excess of acid is slight it is best to employ a solution of the acid phosphate of soda.

All the vessels and nutrient substrata must be Sterilisation thoroughly sterilised before their employment, i.e., of the ressels they must be deprived of all living germs. This is done substratı. by heating the ressels (test tubes, with their cotton wool plug, \&c.) in copper or iron cases liept at a temperature of $150^{\circ}$ to $180^{\circ} \mathrm{C}$. for an hour ; at this temperature the wool is slightly burned; as a rule the temperature differs at various parts of the oven, and we must therefcre ascertain in what part the proper temperature is present.-Larger dishes are washed out with a solution of corrosive sublimate ( 1 to 2000 ), and then thoy are repeatedly rinsed with distilled water which has been sterilised by boiling, or with absoluto alcohol.-The nutrient substrata as soon as they have beon introduced into the sterilised vessels aro freed from their germs by boiling them in a steaming apparatus; according to the amount of material they remain for fifteen to 
sixty minutes in the current of steam. The mixtures containing gelatine often lose their power of solidification if the heat has been continued for too loug a timc; hence for these mixtures we employ discontinuous heating, i.e., the gelatine mixture is placed on the first day in the steam for only five minutes; it is then kcpt till next day at a temperature of $20^{\circ}$ to $30^{\circ} \mathrm{C}$., so that any living spores which have remained behind may germinatc; it is then exposed to the steam for five minutes on the second day, and this is repeated on the third day. -In the case of blood serum, which must be obtained clear and transparent, temperatures of only $55^{\circ}$ to $60^{\circ} \mathrm{C}$. are employed, and for five or six days in succession the material is exposed to this temperature for several hours (see p. 663).

Special

Methods of Preparing some of the Nutrient Substrata. Nutrient sub- - Potatoes are immersed for half-an-hour in a solution strata.

Potatocs. of corrosive sublimate in order to kill the resisting spores present in the particles of earth which adhere to the outside of the potato; they are then washed with sterilised water, ind cooked for thirty to forty minutes in the steaming apparatus. They are then placed to cool in a sterilised and covered vessel, and when they are cold they are cut by means of a knife which has been previously heated, and is still warm; the cultivation is then spread over the freshly cut surface.

Meatinfusion. Meat infusion and nutrient jelly. One kilo of good beef, free from fat, is minced and placed in two litres of water; after it has been kept for twenty-four hours at $15^{\circ}$ to $20^{\circ} \mathrm{C}$., the fluid is drained off, and the solid material is well squeezed; the infusion is then placed in flasks and boiled for one hour in the steaming apparatus, and then filtered. One per cent. of peptone and half per cent. of common salt is then added to the filtrate, which is neutralised with soda solution; the mixturc is again boiled and filtered, and then introduced into the cultivation vessels; these vessels are again sterilised in

Nutrient jelly. the stcaming apparatus for twenty to thirty minutes. - If a solid substratum is requircd re add, in addition to the peptone and common salt, 5 to 10 per ccnt. of gelatine, 
or 1 per cent. of agar-agar. The gelatine is dissolved by heat; the mixture is then neutralised, boiled for ten minutes in the sterming apparatus, and filtered through a warm filter. If the filtrate is not clear it must be again boiled, either with or without the addition of white of ego. The clear filtrate is introduced into the test tubes or flasks, and sterilised in the steaming apparatus for five minutes on three successive days. - The agar Nutrientagar. mixture must be kept for a long time (ten to twelve hours) in a state of constant simmering over a small flame, the water being replaced as it evaporates; it is then filtered through a warm funnel, or it is poured into a tall cylinder which is kept in warm water till the muddy portion is deposited; it is then allowed to solidify, the upper clear portion is cut off, dissolved by boiling, and placed in the various vessels; these are then again sterilised by exposure for half hour to the steam.

If possible sheep's blood should be received with anti- Blood serum. septic precantions in a sterilised vessel and covered with a sterilised glass platc; after forty-eight hours the clear serum is removed by a pipette, transferred directly to the ressels to be employed for cultivation, and kept at a temperature of $68^{\circ}$ to $70^{\circ} \mathrm{C}$. till the serum is solidified. The ressels are then placed in an incubator, and it is generally found that the great majority are sterile.-If it is found impossible to obtain the blood with antiseptic precautions, it must in the first place be sterilised as above described at $55^{\circ} \mathrm{C}$. on several successive day's. - Instead of killing the germs we may sometimes try to get rid of them by filtcring the nutrient material through plaster or porcelain (Chamberland's filter).

All the nutrient substrata which are to be employed for cultivation must be tested before use to see whether they are sterile; for this purpose they are kept for some time, and generally at a high temperature $\left(30^{\circ}\right.$ to $35^{\circ} \mathrm{C}$.) ; where the nutrient material is completely sterile no alterations ought to occur. The substrata are protected against drying by means of a caoutchouc cap placed over the wool plug.-Nutrient materials prepared with gelatine must not be placed at a higher temperature than $20^{\circ}$ to 
Re-inoculation.

$25^{\circ} \mathrm{C}$., otherwise they will become liquid; on the other hand, agar mixtures and solidified blood serum may be liept at a temperature of $35^{\circ}$ to $39^{\circ} \mathrm{C}$.

The inoculation of these sterilised media must be performed with great care; a small quantity of material containing the organisms is taken by means of a heated platinum wire, or of a fine glass tube, and the cotton wool plug being removed for the moment the wire is introduced into the nutrient material. In this method the entrance of organisms from the air is never quite excluded, but as the danger of contamination from the air is much less than from the instruments employed, this source of error is not of any great importance in practice. However, it is advisable in all cases where we wish to be certain as to the purity of the cultivations, to aroid draughts in the room, shaking of the room, \&c., and if necessary to moisten the floor and the walls.- It is well for the experimenter to wash his hands in sublimate solution before proceeding to the inoculation.

\section{Special Methods of Cultivation.}

Some speeial methods of cultivation.
Small cultivations, such as those on hollow microscopic slides, or in the so-called "gluss chambers," are

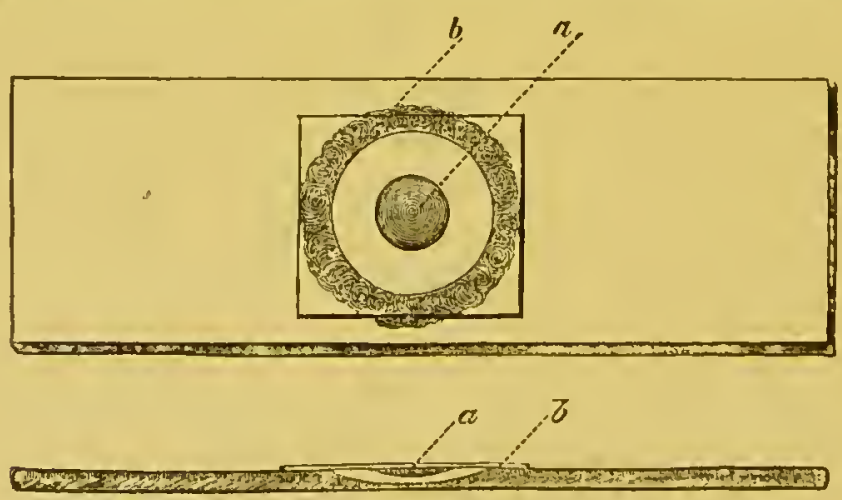

Fig. 141.-Drep eultivations. $a$, the hanging drop. $b$, the layer of vaseline.

of use for studying the stages of development of a species Drop eultiva. tions. of bacteria which has already been cultivated pure. The most simple mode of carrying on these cultivations is by 
placing a small drop of the nutrient solution on the centre of a sterilised cover glass; the latter is then seized with heated forceps, turned over, and placed orer the hollow in a sterilised excavated slide. Before doing this it is well to place a layer of vaseline around the carity in the slide, and the corer glass is pressed on this layer, and thus air is excluded (see fig. 141; $a$, the hanging drop; $b$, the vaseline layer, which must not touch the border of the drop). The development of the bacteria in the drop can then be watched with high powers of the microscope, either by the use of a warm slide, or by Watson Cheyne's method (see p. 344).

Access of air is necessary for the development of many fungi, and the arrangement just described does not permit it. In these cases Prazmowsli has devised an arrangement by which a small channel leads from the moist chamber to the outer air, and is not closed by the vaseline. These moist chamber's do not permit a long observation, because the closure is imperfect, and impurities, more especially mould fungi, are generally found after a few days.

The glass cells employed by von Recklinghausen and Glass cells. Brefeld are more perfect arrangements. Brefeld's apparatus, which has been specially constructed for the cultivation of mould fungi and for their observation with high powers, consists of a narrow glass tube which dilates in the middle and forms a flattened sphere. The walls of the chamber are only of the thickness of cover glasses, and are so flat that an uniformly thin layer of fluid may be readily obtained in their interior. These vessels are thoroughly cleaned and freed from fat by immersion in ether and subsequently in boiling water, and then the fluid containing the fungus to be examined is sucked in, so that the inner wall of the chamber is only covered by a thin layer, and thus an individual spore can be watched for days with a high power.

Where larger cultivations are required we employ Advantages of either fluid or solid nutrient substrata. The latter are solid nutrient most suitable for obtaining and maintaining a pure cultivation, and they also form the best means for isolating 
individual species of bacteria from a mixture of organisms. Solid nutrient media had been formerly frequently employed, but Koch was the first to use them with the definite view of obtaining thereby pure cultivations. - While in the case of fluids the organisms which are introduced, and any which may have accidentally entered, become mixed with each other, so that those that are few in number are scarccly recognisable among the larger number of rapidly growing organisms, in the case of solid substrata the individual species are much more easily isolated. If we inoculate a species of bacterium at various parts of the solid nutrient substratum, small colonies, soon distinctly visible to the naked eye, develop at each of the points of inoculation; if extraneous organisms accidentally fall on the same nutrient soil, they on their part form isolated colonies which do not usually mix with those inoculated, and which are readily distinguishable from them by their colour, form, and consistence; should, however, the extraneous germ fall on one of the colonies inoculated, and multiply at the same part, they usually cause an alteration in the external appearance of this colony; and we can ascertain by simple microscopical observation whether at any part which we wish to choose for the inoculation of fresh soil impurities are present. For the second inoculation we only employ those parts which are found to be quite pure, and it is in the certainty with which we can find the material for each further inoculation that we have one of the greatest advantages of solid as compared with fluid nutrient substrata. If in the latter extraneous organisms once enter they spread through the whole medium, and it is pure chance if we succeed in aroiding one of these extraneous organisms when we inoculate fresh soil; the previous examination of a drop under the microscope is not sufficient; for if we find on examination that other organisms are present it is very difficult to obtain a pure cultivation. In the case of the solid nutrient substrata, on the other hand, it is not necessary to avoid altogether the entrance of other organisms, for in this case, as we can constantly control the selection of the part for re-inocu- 
lation, we have a guarantec for the purity of the second cultivation.

Among these solid nutrient substrata potatoes are Transparent more especially convenient. Nevertheless, it is better substrata. if we can obtain a transparent soil, as, for example, by the admixture of gelatine or agar with the fluid; on these transparent soils the majority of the bacteria grow in a very characteristic manner, and we can distinguish the colonies very easily, not only with the nalied eye, but also by the aid of the microscope. I have already, on p. 167, pointed out the most important differences of the strolse and puncture cultivations on these nutrient substrata.

It is, however, difficult to isolate the individual species Isolation of bacteria from a mixture by means of strolie and bacteria. puncture cultivations on solid nutrient substrata. If after the gelatine has been allowed to solidify on a glass slide we draw several long strokes over the surface with the infected needle we observe that discrete colonies appear at various parts of the track, and we can then reinoculate from these before they have coalesced with the other colonics. The more we dilute the material to be investigated, the more readily do we succeed in obtaining these discrete colonies. But where numerous species are present it may very readily happen that the organisms are carried along the stroke, and that several species develop at the same place.

On the other hand, the organisms can be very readily Plate cultiraisolated by means of plate cultivations. In this method the material to be investigated is in the first place mixed with the fluid jelly in various degrees of dilution, and this jelly, containing the subdivided germs, is then poured out on a cold glass plate, on which it rapidly solidifies. It is evident that in this method cach of the suspended germs will be fixed at a particular spot, and if they are not too numerous, isolated colonies will develop from each organism, and these can be recognised by their charactcristic appearance under the microscope, and may bo inoculated into test tubes.

For this purpose wo employ square, or, better, oblong 
plates of about 8 to $12 \mathrm{~cm}$. in length, and 6 to $8 \mathrm{~cm}$. in breadth. A number of these are sterilised at $180^{\circ} \mathrm{C}$., and kept in a covered vessel; the uppermost plate is always taken, and the gelatine is placed on its lower surface. We usually employ three plates, of which each is laid on a large sheet of glass, which is kept lerel. If the room is warm it is well to place a vessel containing cold water or ice beneath this glass plate. A mixture of nutrient jelly and bacteria is then poured out on its surface. This mixture is prepared in the following manner: we take three test tubes each containing 8 to 10 ccm. of nutrient jelly, and the gelatine in each is liquefied by dipping them in water at $40^{\circ} \mathrm{C}$. A small quantity of the material to be investigated is then introduced into the first glass and slowly but carefully mixed with the jelly; from this mixture three to five loopfuls are introduced into the second glass; this is again thoroughly shaken up, and from this glass three to five loopfuls are introduced into the third. The contents of these three glasses are then poured out on separate glass plates, the gelatine being equally divided cver the plate by means of a previously heated glass rod. A strip about $1 \frac{1}{2} \mathrm{~cm}$. in breadth is left free all round the margin; on these free places sterilised glass supports are placed and fixed with a few drops of gelatine, and thus several plates may be piled one above the other. The plates are liept covered with a bell-jar till the gelatine is quite firm; after ten to fifteen minutes they can be placed in a glass vessel and set on one side. The vessel and its cover are lined with moistened filter paper, and sterilised in the steaming apparatus. These ressels may be placed in incubators kept at a temperature of about $22^{\circ} \mathrm{C}$, and are examined every twelve or twentyfour hours, at first without removing the cover, and later by examining the plates under the microscope at a mngnification of 80 to 100 diameters.

By employing three degrees of dilution as above described, we almost always find that one of the plates is good, i.c., it contains a few isolated colonies which can be counted, and on the other hand not too few 
colonies to make it doubtful whether or not they have arisen from accidental impurities, air germs, \&c. If at least 10 , or at most 500 colonies grow on a plate, it is in most cases a useful plate; if we only wish to count the colonies, and not to investigate them further, the number on the plate may be as great as 5,000. If in all three plates the numbers are greater or less than those given it is well to repeat the experiment.

In investigating various questions it is of great importance that we should be able, by counting the colonies which have grown on the plate, to estimate the number of bacteria which are present in a mixture of organisms. In order to do this we must add a measured quantity of the material to the jelly, and afterwards count the number of colonies accurately. This is most easily done, when the colonies are numerous, by means of a glass plate divided into squares. In such a case we only count a few of the squares, strike an average from the figures so obtained, and calculate the number in the whole plate.

Similar plates can also be made with nutrient agar. Agar plates. This material is first liquefied in the tubes by boiling, and then cooled to $40^{\circ} \mathrm{C}$. in a water bath; the material is then added to the liquid agar, and the mixture poured out on the plates. We must employ agar, which becomes fluid at $40^{\circ} \mathrm{C}$, but solid at $38^{\circ}$ or $39^{\circ} \mathrm{C}$. The agar afterwards often expresses water, and as a result the whole mass may subsequently glide over the glass plate. It is therefore of importance to line the vessels in which the agar plates are to be kept only with dry filter paper; and thus the water as it is expelled from the agar evaporates so quickly that it cannot collect between the material and the glass plate.

A modification of the plate cultivations which has Esmarch's been made by Esmarch* is very useful for many prac- method. tical purposes. Instead of flat glass plates lie employs wide test tubes, and the surface of the glass plate is replaced by the equally large internal wall of the test tube; while the gelatine is still fluid, and after it las been mixed with the material under investigation, the

* Zeitsclir.f. IIyyiene, rol. i., Part 2. 
tube is continually rotatcd in a horizontal position, and thus as the material cools it solidifies in the form of an equally thin layer over the whole wall of the tube. The best way of doing this is to close the tube by mcans of a caoutchouc cap, let it swim on cold water, and give it a slight rotatory motion with the right hand, holding the orifice of the tube loosely in the left, and lreeping it in the horizontal position.-In order to count the colonies the outer surface of the tube may be divided into larger or smaller portions by ink lines. One great advantage of this method is, that in the case of bacteria which grow very slowly an opportunity is afforded for their growth in these tubes, in which contamination cannot occur. It is more difficult to examine accurately the individual colonies, and to inoculate from them, than in the case of the plate cultivations, and it is only in special crses that this method would be employed when further cultivations were required.

Where it is important to obtain as complete knowledge as possible of all the species of bacteria which are present, we must vary the nutrient conditions as far as we can, more especially we must vary the amount of sugar, the degree of alkalinity, the temperature, and the amount of oxygen; in the case of numerous bacteria the conditious necessary for their artificial cultiration are not as yet known, and hence it is desirable to rary the Cultivation of conditions as much as possible.-For cultivating the unaërobic bacteria. anaërobic bacteria Liborius recommends deep layers of nutrient agar containing 2 per cent. of dextrose. For this purpose test tubes are filled to a height of about 10 $\mathrm{cm}$. with the nutrient material, and the bacteria to be investigated are mixed with this material while still fluid and at a tempcraturc of $40^{\circ} \mathrm{C}$.; the result is that isolated colonies of the anaërobes grow in the deeper laycrs. Instead of this method we may employ ressels containing nutrient substrata from which all the air has bcen expelled by means of hydrogen. Vessels of the form shown in fig. 142 are best suited for this purposc, and these are filled with the nutrient agar up to the lercl of the lateral tube; the material to be tested is then introduced 
through the upper opening, while a continuous stream of hydrogen is sent through the lateral tube, and when it has passed for a sufficiont length of time the tubos are sealed at $a$ and $b$. In vessels of this kind we obtain luxuriant growth of the most typical anaerrobes. If we wish to obtain the colonies of the anaërobes in such a way that they may be examined under the microscope, we employ little vessels containing a layer of the nutrient material at least $1.5 \mathrm{~cm}$. in depth, and these ressels are placed in an iron case with a tight fitting cover and provided with stopcocks, by means of which hydrogen can be passed through the vessel and all the air driven out. For further details, see Liborius, Zeitschr.f. Hygiene, rol. i., part 1.

If we have to do with bacteria which will not grow on solid nutrient substrata but only in fluids, the difficulty of isolating them is much greater. This was formerly done by Klebs' method-the so-called method of fractional cultivation; in this method a vessel is in the first place inoculated

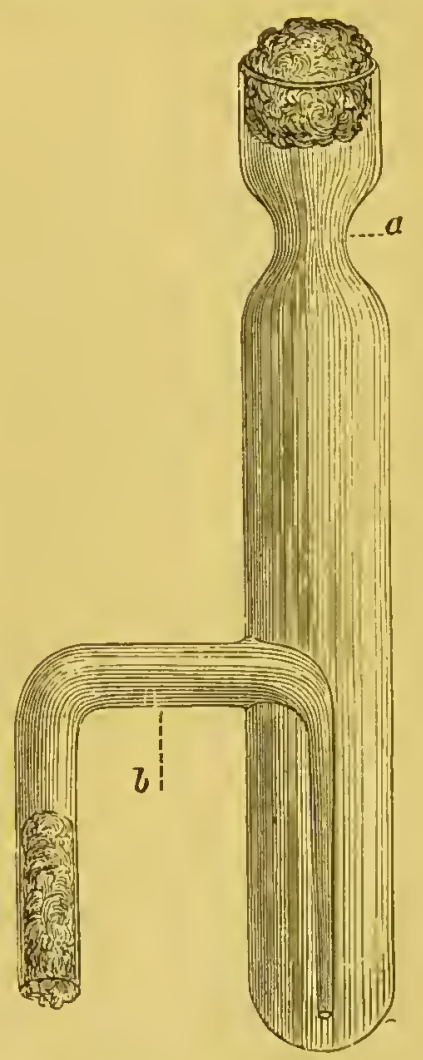

Fig. 142.-Apparatus for the cultivation of anaërobes. and the bacteria are allowed to grow; a small quantity is then taken from the first vossel and introduced into a new nutrient material; this is again allowed to develop, and the process repeated througl a series of cultivations. In this method the cultivations gradually become purer and contain only those organisms which grow most quickly mder the conditions present, whle the chances of the presence of the more slowly growing organisms become constantly less. This method is, however, not as a rule of much use, because it is not 
Dilution method.

always the most quickly growing organisms which interest us; it is true that by varying the external conditions, more especially the temperature, we may vary the species of organism which grows most quickly in the mixture; but the method is alwrys uncertain and tedious, more especially as we know very little as regards the most favourable conditions for the growth of the rarious linds of organisms.

A much better plan is that of diluting the material to a great degree. This principle was first recommended by Brefeld, and then by Nägeli and Buchner, and Brefeld employed it more especially for the purpose of inoculating the moist chambers described above. According to Brefeld a small quantity of the material is taken and mixed thoroughly with pure sterilised water; the dilution is carried to such a degree that in the quantity contained on the point of $\Omega$ lancet-shaped needle only one germ should be present. When we have convinced ourselres by microscopical examination that this condition has been complied with, we then introduce this amount into each of a series of ressels, and if we employ a large number of vessels, and if in these the same organisms develop which are most numerous in the material employed, the chances are that only one germ was present in each drop. In some of the ressels we will find examples of the other organisms which are present in smaller numbers in the material. If we are isolating mould fungi, the spores of which are difficult to see, it is well to employ a nutrient solution instead of water, in order that the spores may sprout, and thus become larger and more easily visible, and then to dilute the material in the manner above described.

In the case of the bacteria the microscopical examination is, as a rule, of but litlle value, because the spores, and even the fully grown organisms, are so small that it is practically impossible to ascertain the presence of a single germ in one drop. In this case we can only get an npproximate ider as to the amount of dilution from the microscopical appearances. The whole process rests on the assumption that the organisms in which we are interested 
were present in relatively large numbers in the material employed, and in many cases, even where we have to do with pathogenic organisms, this condition is probably fulfilled; where, however, saprophytes of various linds are present in great excess, it is hardly feasible to hope for complete separation by this method.

In some cases it is well to combine the plate method and the dilution method in order to obtain good results.

The whole method of pure cultivation must of cour'se be practised in the first instance with some typical examples. As good specimens for this purpose I would recommend the cultivation of bacillus prodigiosus on potatoes, gelatine, \&c., at various temperatures; the cultivation of anthrax bacilli on potatoes, mutrient jelly, blood serum, and in fluid substrata, likewise at various temperatures; the cultivation of Aspergillus flavescens on slices of potato at a low temperature $\left(15^{\circ}\right.$ to $20^{\circ} \mathrm{C}$., \&c.). If every one who attempts the cultivation of fungi, and especially the isolation of pathogenic organisms, would first test their knowledge with these typical examples, a great many imperfect papers would remain nupublished.

Having succeeded in obtaining a pure cultivation of A further an organism, we have next to determine its morpho- tion of the logical and biological character's. We have to ascertain specie: what are the nutrient materials, and what the temperisture which most favour its growth, and whether, and in what degree, it requires the presence of oxygen; we have to test whether it is able to excite fermentation, and for this purpose we have to add the most important of the fermentescible substances (carbo-hyclrates, the higher alcohols, fatty acids, albuminous materials, sc.) to the ordinary nutrient materials, and under the other conditions necessary for the growth of the organisms. We have further to ascertain whether the organism isolated lias any pathogenic action; inoculation experiments must be made on a variety of animals, more especially on mice, which are so very susceptiblo to infective diseases, and also on guinea-pigs, rabbits, monkeys, \&e. 'These experiments must be carried out 
with smaller and larger doses, and the organisms must be introduced either by superficial inoculation, or by injection into the subcutaneous tissue, or by direct injection into the blood stream. If the animals become ill or die similar attempts at cultivation and inoculation must be made with their blood or organs, and the identity of the organisms inoculated with those found must be ascertained. All thesc experiments must be frequently repeated.-Lastly, we must malie experiments as to the conditions of death of the organisms, and more especially as to the loss of their pathogenic properties, and we must ascertain what external conditions and what disinfecting means can most readily cause their destruction (see p. 653).

3. Bactcriological Investigation of Air, Water, and Soil.

Examination of air.

Miquel's method.
Fig. 143.-Miquel's apparntus for the investigation of air. a. Air.-Attempts were formerly made to ascertain the number, species, and vitality of the organisms present in the air by fixing the germs on sticky surfaces, and by subsequent microscopical examination. These attempts were, however, failures, but in recent times fresl methods have been derised, the essential aim of which is to obtain a derelopment of the indiridual germs, and then to count the colonies. Miquel employed for this purpose a fluid nutrient substratum, a broth prepared somewhat after the method described on p. 792 ; this material was introduccd iuto a large number of small glass ressels of the form
sterilised ressels were fixed in a shown in fig. 143. These sterilised ressels were fixed in a stand, the end $f$ was comnected with an aspirator, and the 
point a was heated and then broken off. A small quantity, 1 to 3 litres, of air was drawn through the Hinid and the point $a$ was sealed, the plug $c$, composed of spun glass, and which might have taken up some of the germs, was blown back into the fluid, and the apparatus was placed in an incubator. In each of these experiments 20 to 50 vessels were employed; after some time it was ascertained in how many of these muddiness had occurred as the result of the development of bacteria, and if this did not occur in all the resscls, but only in a small proportion of them, it was assumed that in each of the muddy vessels only one germ had entered. Hence the number of the vessels in which dovelopment occurred gave also the number of the germs which were present in the quantity of air aspirated through all the ressels. If none of the tubes became muddy, or if, on the contrary, they all became turbid, the experiment was repeated with larger or smaller quantities of air; if all the tubes had become turbid it was only possible to obtain the approximate minimal number of the organisms present, for in each case the muddiness might have been clue not only to one but even to tro, or ten, or more germs.

As is quite evident, the utility of this method rests on Sources of the assumption that the germs are very equally dis- error in this tributed in the air, and that they do not exist in masses. All other observations, however, show that this assumption is incorrect. Direct microscopical observations demonstrate that there are numerous collections of bacteria among the germs present in the air, and that they are by no means equally distributed throughout the air.-Besides, the whole method is extremely troublesome, and does not permit any sufficient variation of the nutrient media.

Hesse has attempted to utilise the solid nutrient sub- Hesse's strata for the investigation of air. A glass tube, $70 \mathrm{~cm}$. method. in length and $3.5 \mathrm{ccm}$. in width, is filled with $50 \mathrm{ccm}$. of nutrient jelly in such a way that the inner wall is lined with the material, and that a thiclicr layer of it is present at the lower part of the tube. One end of the tube is closed 
with an india-rubber cork, the centre of which is perforated, and contains a glass tubo plugged with cotton wool; this glass tube is connected with the aspirator, the other end is corered with a caoutchouc cap, in which there is a central hole through which the air enters. The whole tube is placed on a stand in a horizontal position.

The germs present in the air fall-usually shortly after the entrance of the air into the tube-on the gelatine, and develop there to form isolated colonies. By this method we often obtain very instructive appearances, but even this method does not give accurate comparative results. For one thing, it is difficult to ascertain the proper rapidity of the current of air, so that $n o$ germs shall pass through the tube, and yet that they shall not be too numerous near the entrance of the tube; again, the dry surface of the gelatine is not a suitable place for the commencement of dcrelopment; and, lastly, a mass of organisms gires rise to colonies which are equally well isolated as those which develop from a single individual.

Other methods.

Other attempts to determine quantitatively the germs of the air have also as yet failed in giving entirely satisfactory results. Von Sehlen's attempts to employ agar mutrient solutions are open to the error that rapidly growing saprophytes may enter these nutrient materials while the air is being slowly drawn through them; and further, that it is difficult to retain the germs in the fluid, and

Faults of the methods as yet employed, ard suggesalso to vary the composition of the nutrient substratum. tions for their - It seems best to employ indifferent substrata for the reception of the germs of the air. This can be best done by the use of cotton wool, glass wool, and similar substances. The material employed for the filtration of the air, and laden with the air germs, is then put into mutrient jelly, and after this has been shaken up for about half an hour (in order to break up any colonies that may be present) it is poured out on plates. If we wisl to employ a variety of nutrient substrata the material used for the filtration is in the first place slraken up with salt solution, and equal known quantitics of this solution are 
alded to the various nutricut substrata.-Attempts carried out on those principles seem to promise useful results, but as yet this method lias not been sufficiently tested.

b. Wuter.-The specimens to be investigated must be Investigation taken in sterilised vessels with glass stoppers, or, in order of water. How to avoid contamination which is very apt to occur during speeimens. the transport, in small glass bulbs devoid of air and subsequently sealed. These glass bulbs have a diametcr of about $1 \frac{1}{2} \mathrm{~cm}$., and are provided at one side witl a glass tube almost of capillary thickness, and 10 to $15 \mathrm{~cm}$. in length.* By warming the bulb, and subsequently immersing it in distilled water it is about half filled with water; it is then placed on a stand, the glass tube being directed obliquely upwards, and surrounded with filter paper; the water in the bulb is thon brought to the boil, the steam streams out of the capillary tube, and any drops of fluid which may be carried with it are soaked up by the filter paper. When all the water, with the exception of half a drop, has been volatilised the capillary tube is sealed while the stream of sterm is still passing.

These tubes are carried in this state,

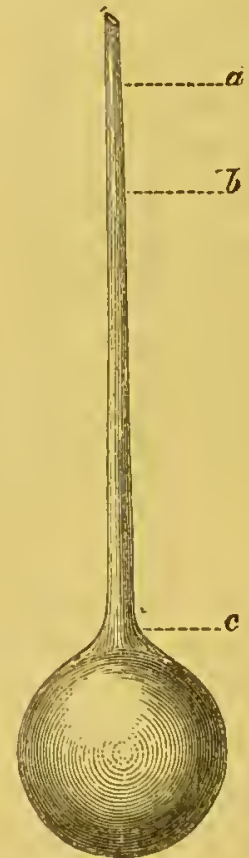

Fig. 144.-Apparatus for colleeting watcr. and can be readily sent over considerable distances in tin vessels witl a wooden bottom in which two hollows are present. - In taking the specimen to be tester a solution of sublimate $(1$ to 2,000$)$ is poured over the bulb and the lands of the experimenter, and then the sublimate is remored by a portion of the water to be tested. When it lias been quite removed, the capillary tube is broken near the point (at a) under water, which then rushes into and fills the bulb. The tube is then sealed (at $b$ ) in tire flame

* These glass bulos are roadily prepared by means of a blow-pipe, or they can be obtained from any glass manufuctory at a priee of from 3 l. to $7 d$. per dozen. 
of a spirit lamp. - When these bulbs are brought back to the laboratory they are again disinfected and washed with sterilised water. A mark is made with a file close to the junction of the tube with the bulb (at $c$ ), and the tube broken off at this point. The resulting opening is sufficient to enable one to remove the clesired amount of water-a drop to a cubic centimetre or more-by means of a sterilised pipette.

Investigation. The best method of ascertaining the number and species of the germs present is by means of gelatine plates, or by Esmarch's method. In order to obtain useful plates (containing 10 to 5,000 colonies), it is well to make the first experiment with from 1 to 10 drops of water ; according to the result of this experiment we can employ in the subsequent attempts either larger quantities, or we can dilute the water with sterilised distilled water. If, however, we cannot again obtain a fresh specimen of the water to be tested we must at first malie a large number of plates containing varying amounts of the water.

Error as the

It is of importance to examine the water as soon result of keepof water.

as possible, at any rate within one to three hours after it has been obtained. This precaution is essential, in view of the fact that has now been confirmed by many investigator's that the bacteria in the water multiply rapidly if it is kept in a warm place (see p. 711). In transporting the water it should be packed in ice; Wolffhügel has indeed ascertained that when water is preserved in ice the number of living germs present gradually diminishes; but the diminution is not so marked during the first twenty-four or forty-eight hours as to malie any essential difference in the result. The great point is to avoid as far as possible any delay in the investigation.

Fol and Dunant have described a method of analysing water which is closely similar to Miguel's method of examining air, but it also possesses all the errors of this method, and is not of any practical use.*

In judging the results of the investigntion we hare to bear in mind the points which liare been referred to on p. 714 .

* See Bo:ton, Ztitschr.f. IIys ie"e, rol. 1, Part 1. 
c. Soil.-As yet no accurate methods of investigating Investigation the bacteria of the soil have been published. The of soil. author has found that the best method is to talie a small lnown quantity of the soil and mix it with a known quantity of sterilised distilled water; the mixture is thoroughly shaken up for a half to one hour; and then various quantities of the fluid are taken and employed, as in the case of the examination of water, for a number of plate cultivations. - In the case of the soil, also, it is of importance to examine the specimen as soon as possible after it has been taken, because the saprophytes multiply rapidly in the laboratory as the result of the higher temperature. No trustworthy method has been published with regard to taking specimens of the soil at various depths in such a way that all contamination from without and from the adjacent layers of soil is avoided.

It is of extreme importance in the interest of hygienic investigation that the methods of the bacteriological investigation of air, water, and soil should be improved. 



\section{N D E T.}

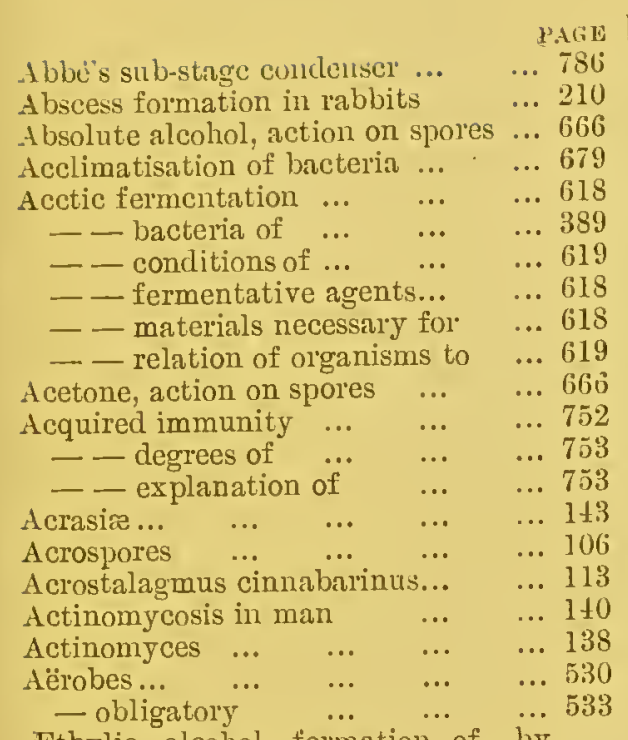

Ethylic alcohol, formation of, by fermentation ... ... ...6 601

Agar plate cultivations $\quad \ldots \quad$... 799

- preparation of, for cultivations 793

Air. bacteriological investigation of $80 \pm$

- occurrence and behaviour of $\begin{array}{lllll}\text { bacteria in } \quad \ldots & \ldots & \ldots & 687\end{array}$

— transport by currents of $\quad \ldots \quad 7+0$

Air germs, deposit of, by condcnsation of watcr vapour ... ... 690

- - crrors in the recent investigations on $\quad \ldots \quad \ldots 6 \quad \ldots 691$

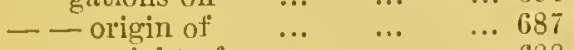

—— weight of $\quad \ldots \quad \ldots 6 \quad \ldots 68$

Alcohol as an iuhibitory ngent ... 65. - influence of amount of, on fermentation $\quad \ldots \quad \ldots \quad \ldots \quad 59 t$

Alcoholic fermentation of sugn by $\begin{array}{lllllll}\text { y cast } & \ldots & \ldots & \ldots & \ldots & 588\end{array}$ Alcohols, fermentation of the higher 1302 Allyl-alcohol as an inhibitory agent ... (i.j) Alum, action on spores $\quad$... ... libiti Alvarez and 'Tavel on smegma bacilli 2!) 1 A mitlo bodiesas nutriment for bacteria 550 Ainmonia, netion on spores ... ... 666 A nunonium sulphicle, action on spores 667

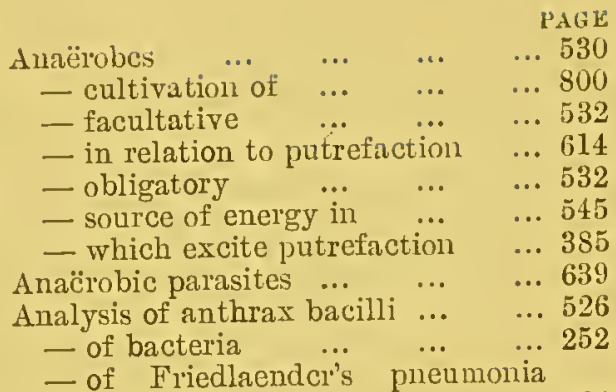
$\begin{array}{llllll}\text { bacilli } & . . . & \ldots & \ldots & \ldots & 526\end{array}$

一 of micrococci $\quad \ldots \quad$... $\quad$.. 526

- of the ashes of the fission fungi 527

— of the budding fungi ... $\quad . .516$

— of the mould fungi $\quad \ldots \quad \ldots 502$

— of the vinegar plant $\quad \ldots . \quad \ldots \quad 526$

Aniline dyes, Ehrlich on $\quad$... $\quad$... 780

$\begin{array}{llllll}\text { Antheridium } & \ldots & \ldots & \ldots & \ldots & 107\end{array}$

Anthrax bacilli, analysis of ... $\quad \ldots 526$

- - attenuation of $\quad \ldots . \quad \ldots 657$

—- degrees of attenuation $\quad \ldots 6.57$

- Koch on spore formation in 538

- - Pastcur's views on the attenuation of $\quad \ldots \quad \ldots \quad \ldots 658$

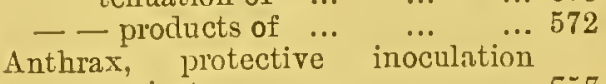
$\begin{array}{lllll}\text { against } & \ldots & \ldots & \ldots & 557\end{array}$

— source of infection of ... $\quad \ldots$ 73s

$\begin{array}{lllll}- \text { spread of } . . . & \ldots & \ldots & \ldots & 732\end{array}$

$\begin{array}{lllll}\text { Anthrax-protcin } & \ldots & \ldots & \ldots & 526\end{array}$ Apparatus for disinfection by steam 772 Aquatic bacteria $\quad \ldots \quad \ldots \quad$.. 711 Area Celsi, micrococci in $\quad \ldots \quad \ldots 203$ Arloing, Cornevin, and 'Thomas, on the bacillns of Rauschbrinicl ... 29!

Aromatic bodies, production of, by the lower fungi $\quad \ldots \quad \ldots \quad \ldots \quad$... 61

Arscniate of potash as an inhibitory $\begin{array}{llllll}\text { agent } & \ldots & \ldots & \ldots & \ldots & 653\end{array}$

Arsenious acid, action on spores $\quad \ldots 667$ $\begin{array}{lllllll}\text { Asci } & \ldots & \ldots & \ldots & \ldots & \ldots & 106\end{array}$ Ascococcus Billiothii ... $\quad \ldots . \quad \ldots 231$

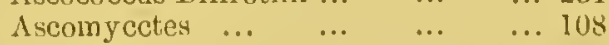
Ascosporcs $\quad \ldots \quad \ldots \quad \ldots \quad \ldots l 06$ Ashes of fission fungi, antulysis of $\ldots 527$ $\Lambda$ shes of yeast, analysis of $\ldots \quad \ldots 518$ 
Aspereilli, patlioge crili, patlogenic properties of... 123 Aspergillus $\quad \ldots . \quad \ldots . \quad \ldots . \quad \ldots \quad 119$

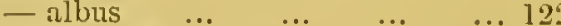

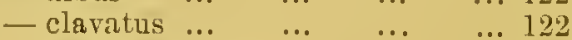

- distribution of $\ldots . \quad \ldots \quad \ldots 126$

- flavus $\quad \ldots \quad \ldots . \quad \ldots \quad \ldots 121$

- fumigatus $\quad \ldots . \quad \ldots \quad \ldots 121$

- infective, tcmperaturc optimum of $\quad \ldots \quad \ldots \quad \ldots . \quad \ldots 12$ \% $\begin{array}{llllll}\text { niger } & \ldots & \ldots & \ldots & \ldots & 121\end{array}$ - ochraccus $\quad \ldots . \quad \ldots \quad \ldots 122$

- parasitic, occurrence of, in bircls 124

- - — - in mammals ... ... 125

$-\ldots-$ in $\operatorname{man} . . . \quad \ldots \quad \ldots 125$

Assimilation by the bacteria... $5+3,545$ Atmospheric pressure, influencc of, on bactcria..

... 535

— - in relation to yeast... $\quad \ldots .521$

Attcnuatcd anthrax bacilli, return of virulence of $\quad \ldots \quad \ldots . \quad \ldots 658$

Attenuation of anthrax bacilli $\quad$.. 239

— - - by carbolic acid _.. 659

- - - by chromic acid _.. 659

- - - by heat $\quad . .6 \quad \ldots 656$

- - - by sulphurous acil $\ldots 659$

— chicken cholera bacilli ... 317

- pathogenic and fermentativc organisms

... 655

- - Rauschbrand bacilli... $\quad \ldots 300$

- - the bacilli of chicken cholera 660

— the virus of rabies ... ... 660

Author's suggestions as to the best methor of examining air for bacteria

806

B.

Babes on red sweat ... ... ... 22:

Bacillary necrosis of the liver ...350

Bacilli, character's of tle $\quad \ldots \quad \ldots 172$

Bacilli in malaria $\quad \ldots \quad$... ... 294

— in smegma $\quad$... ... ... 291

- key for the diagnosis of $\quad \ldots+11$

- of saliva ... $\quad \ldots \quad$... $\quad \ldots 319$

- pathogenic in animals ... ... 299

- pathogenic in man ... ... 234

- with no known pathogenic properties ... ... ... ... 351

Bacillus... $\quad \ldots \quad \ldots \quad \ldots \quad \ldots \quad \ldots 156$

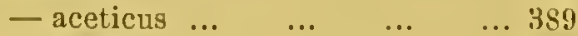

- acidi lactici $\quad \ldots \quad$... $\quad \ldots .363$

$\begin{array}{llll}\text { - aerophilus } \quad \ldots & \ldots & \ldots & \ldots 98\end{array}$

$\begin{array}{llllll}\text { - alvei } & \ldots & \ldots & \ldots & \ldots & 343\end{array}$

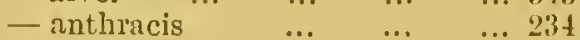

\begin{tabular}{lllll} 
- butyricus & $\ldots$ & $\ldots$ & $\ldots$ & \\
\hline & $\ldots$ & $\ldots$ & $\ldots$ & 366
\end{tabular}

- butyricus (Hueppe) ... .. 372

- butyricus (Liborius) ... $\quad \ldots .371$

- butyricus (Prazmowski) $\quad \ldots 367$

- butyricus, products of ... ... 612

- caucasicus $\quad . . \quad$... $\quad . .372$

- causing erysipclas in the cnr of rabbits ...

... $\quad$... 3.50
Bacillus cavicila

- - fermentation of carbo-liydrates by $\quad \ldots \quad$... ... 601

- choleræ gallinarum $\quad . . \quad \ldots 314$

- coprogenes fotidus $\quad$... $\quad \ldots 379$

— - - products of $\quad \ldots \quad \ldots 612$

- - parvus... $\quad . . \quad \ldots \quad \ldots \quad \ldots 33$

- crassus sputigenus (K reibohm) 322

- cuniculicida (Koch) ... ... 312

- cyanogenus $\quad . . \quad$... ... 361

— diphtherix (Loeffler) ... ... 280

— - columbarum (Loeffler) ... 326

- - vitulorum (Loeffler)... ... 328

— dysodes ... $\quad . . \quad \quad \ldots \quad$... 374

- erythrosporus ... $\quad \ldots \quad \ldots 357$

\begin{tabular}{llll} 
- Fitzianus & $\ldots$ & $\ldots$ & $\ldots$ \\
\hline
\end{tabular}

— - as a ferment of glycerine ... 602

- fluorcscens liquefacicns _.. 358

- - - products of $\quad \ldots \quad \ldots 612$

- - putidus $\quad \ldots \quad \ldots . \quad \ldots 357$

- - products of $\quad \ldots \quad \ldots 612$

- fuscus $\quad \ldots \quad \quad \ldots \quad \ldots . \quad \ldots 360$

- Hansenii ... $\quad \ldots . \quad \ldots . \quad \ldots \quad \ldots 409$

- janthinus... $\quad \ldots \quad \ldots \quad \ldots 361$

- - products of $\ldots . \quad \ldots \quad$... 612

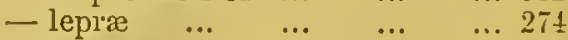

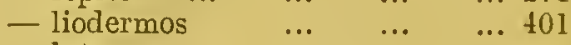

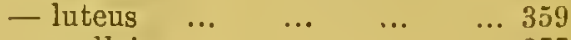

- mallei $\quad \ldots \quad \ldots . \quad \ldots \quad \ldots 277$

- megaterium $\quad \ldots \quad$... $\quad \ldots 407$

- mesentericus fuscus $\quad \ldots \quad$... 399

- - vulgatus $\quad \ldots \quad$... ... 400

— multipediculus ... $\quad . . \quad$... 401

- murisepticus (Koch) ... ... 310

- mycoides... $\quad . . \quad$... ... 403

- neapolitanus $\quad \ldots \quad \ldots . \quad \ldots 335$

- necrophorus $\quad \ldots \quad$... $\quad . .338$

— œdematis maligni _.. $\quad$... 242

— of jequirity ophthalmia _.. 346

— of Rauschurand ... ... ... 299

— of rhinoscleroma $\quad$... ... 291

— of swine crysipclas _.. $\quad$... 302

— of syphilis $\quad \ldots \quad \ldots . \quad \ldots 28 s$

— oxytocus perniciosus $\quad . . \quad$... 332

- parvus ovatus ... $\quad \ldots \quad \ldots 339$

- Pasteurianus ... ... ... 390

— pneumonire (Friedländer) ... 255

- - fermentation of carbo-hydrates by $\quad \ldots \quad$... $\quad \ldots 601$

— pncumonicus agilis $\quad \ldots \quad$... 325

- polymyxa $\quad$... ... ... Bjt

— prodigiosus $\quad \ldots \quad \ldots \quad \ldots \quad \ldots 3,2$

— - products of $\ldots \quad$... ... bil?

- pseudopneumonicus ... ... 324

— putrificus coli ... $\quad . . \quad$... 37 it

- - - prorlucts of $\quad \ldots . \quad \ldots$ ill

- pyocyaneus, as a ferment of glycerinc $\quad \ldots . \quad \ldots \quad \ldots 602$

— - products of ... $\quad \ldots \quad$... 612

- pyogenes foetidus $\quad \ldots \quad \ldots 37$...

— - - products of $\quad \ldots . \quad \ldots 612$

- rimosus liquefaciens ... ... $\$ 02$ 
PAGE

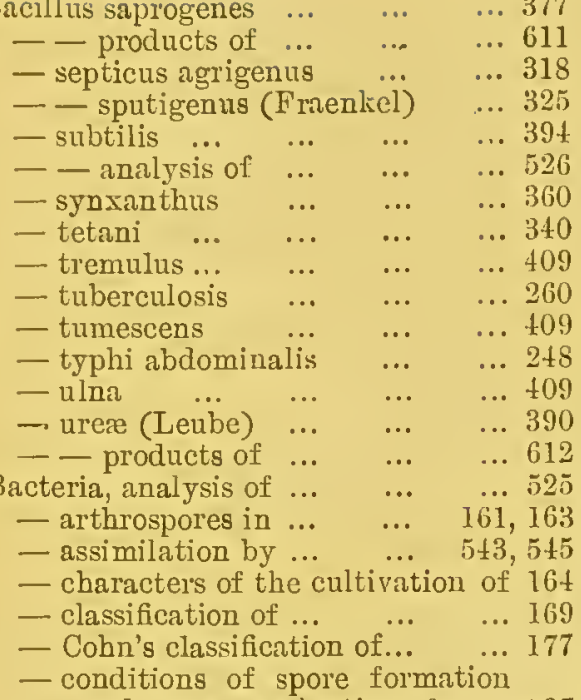
and spore germination of $\quad . .537$

- de Bary's classification of $\quad . .179$

- destruction of, in the body ... 643

- diagnosis of, from tissue elements ... $\quad . . \quad \ldots . \quad \ldots 787$

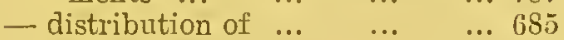

- endospores in $\quad \ldots \quad \ldots \quad \ldots \quad \ldots l 61$

— fermentation by $\quad \ldots . \quad \ldots 595$

— fermentation of sugar by $\quad \ldots 590$

- from mud, or the intestinal contents of ruminants, products of $\quad \ldots \quad \ldots \quad \ldots 612$

- germination of spores of $\quad \ldots \quad 163$

— growth in meat jelly $\quad . . \quad \ldots 165$

— habitat of $\quad \ldots . \quad \ldots \quad$... 685

— in articles of food $\quad \ldots . \quad \ldots 716$

— in dwelling houses $\quad \ldots \quad \ldots 719$

— in clothing $\quad \ldots \quad \ldots \quad \ldots 718$

- influence of atmosphcric pressure on ... $\quad \ldots \quad$... $\quad \ldots 535$

—influence of concurrent $\ldots$ growth on 537

- influence of electricity on $\quad . .553$.

- influence of fermentative activity on the life of $\ldots . \quad \ldots \quad 536$

— influence of light on $\ldots . \quad \ldots$ 53.5

- influence of mcchanical movement our

... 535

- influchee of temperature on $\quad \ldots \quad 536$

$\begin{array}{lllll}\text { - in refuse ... } & \ldots & \ldots & \ldots & 720\end{array}$

— in the intestine ... $\quad \ldots . \quad \ldots .724$

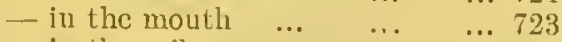

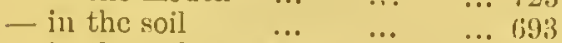

— in the soil under floors... $\quad \ldots \quad$... 119

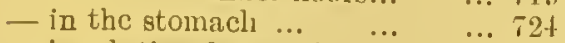

— involution forms of $\quad \ldots . \quad \ldots l$ inf

- means for the destruction of $\ldots .6662$

- methorl of diagnosing ... $\quad \ldots .7 \overline{i f i}$

— methods of investigating $\quad \ldots \quad$ i

- movement of $\quad \ldots \quad \ldots . \quad \ldots \quad$ 15!

- multiplication of $\quad \ldots . \quad \ldots$... 160

- on the respiratory mucous mem-

brane ... $\quad \ldots \quad \ldots \quad \ldots 72 t$

$\begin{array}{lllll}- \text { on the skin } & \ldots & \ldots & \ldots & \\ & & \ldots 23\end{array}$

— on the surface of the body $\quad \ldots 723$

- parasitic, in plants ... ..6 636

- propagation of, by sporcs ... 161

- reaction of the nutrient medium in relation to ... $\quad . . \quad$... 534

- rclation of concentration of the nutrient medium to $\ldots \quad \ldots \quad$... 533

— relation of, to oxygen ... ... 530

- spores of ... $\quad \ldots \quad \quad \ldots \quad 156,162$

$\begin{array}{lllll}\text { — staining of } & \ldots & \ldots & \ldots & 778\end{array}$

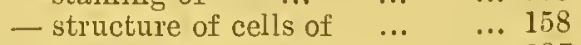

— transport of $\quad \ldots \quad \ldots \quad \ldots 687$

— vegetative forms of $\quad \ldots \quad \ldots \quad$... 155

-with variable vegetative forms 175 ,

— Zopf's classification of ... ... 180

Bacteriological investigation of air, water, and soil... ... ... $80 t$

Bacterio-purpurine $\quad \ldots \quad \ldots \quad \ldots \quad \ldots 490$

$\begin{array}{llllll}\text { Bacterium } & \ldots & \ldots & \ldots & \ldots & 156\end{array}$

- brunneum $\quad$... $\quad \ldots . \quad \ldots 360$

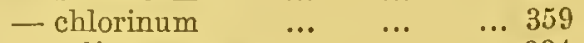

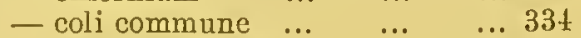

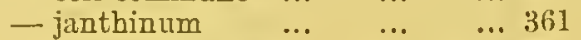

- lactis ac̈rogenes ... ... ... 33 3

- lactis, nutrient materials neces$\begin{array}{lllll}\text { sary for... } & \ldots & \ldots & \ldots & 529\end{array}$

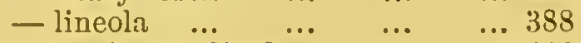

- merismopedioïdes $\quad \ldots \quad \ldots 410$

— syncyanum $\quad$... $\quad$.. $\quad \ldots 361$

— synxanthum $\quad \ldots \quad \ldots \quad \ldots \quad \ldots 360$

$\begin{array}{llllll}\text { - termo } & \ldots & \ldots & \ldots & \ldots & 387\end{array}$

- - rclation of temperature to ... 536

$\begin{array}{llllll}- \text { Zopfii } & \ldots & \ldots & \ldots & \ldots & 40 \text {; }\end{array}$

$\begin{array}{llllll}\text { Basidia } \ldots & \ldots & \ldots & \ldots & \ldots & 105\end{array}$

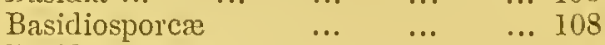

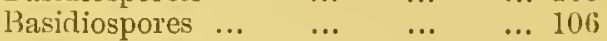

$\begin{array}{lllll}\text { Bassi on muscardinc } & \ldots & \ldots & \ldots & \end{array}$

$\begin{array}{lllllll}\text { Beer yeast } & \ldots & \ldots & \ldots & \ldots & \text { i๘ } 9\end{array}$

Bces, bacillus of foul broocl of $\quad \ldots 343$

$\begin{array}{lllll}\text { Beggiatoa } & \ldots & \ldots & \ldots & 17 t, 488\end{array}$

$\begin{array}{llllll}\text { 一 alba } & \ldots & \ldots & \ldots & \ldots & 489\end{array}$

- mirabilis ... $\quad \ldots . \quad \ldots \quad$... 490

— roseo-pcrsicina $\quad \ldots \quad \ldots \quad \ldots \quad \ldots 40$

- sulphur in $\quad \ldots \quad . . . \quad \ldots \quad 526$

Behaviour of bacteria in the air ... 6857

- of bactcria in the soil ... ... $69 . \mathrm{I}$

Benzoate of sola as an in libitory agent $6.5 \mathrm{t}$

Benzoic acid, netion on spores ... 666

- - as anl nllhibitory agent ... 653

Benzole, action on spores $\quad \ldots \quad \ldots 666$

Bichloride of mercury, action on

spores $\quad \ldots \quad$... $\quad \ldots \quad$... 667

_ - as an inhibitory agent ...6 653

Bicnstock's bicilli from faecs 333,404

- putrefactive bacillus from frecs 376

Billrutl's objections to the parasitic

$\begin{array}{lllll}\text { theory ... } & \ldots & \ldots & \ldots & 97\end{array}$ 
Biological relations between thate higher plants and the fungi, former views as to $\quad . . \quad \ldots 495$

Biology of the micro-organisms $\quad \ldots \quad 495$ Birds, mould fungi as parasites in ... 634 $\begin{array}{llllll}\text { Black yeast } & \ldots & \ldots & \ldots & \ldots & 154\end{array}$ $\begin{array}{llllll}\text { Blight fungi } & \ldots & \ldots & \ldots & \ldots & 109\end{array}$ Blood serum, preparation of, for cul-

Blue milk, bacillus of $\quad \ldots . \quad \ldots .3(i)$

Boracic acid, action on spores $\quad \ldots 6667$ - - as an inhibitory agent $\ldots 653$

Borax, action on spores $\quad . . \quad \ldots 666$

Bostroem on cultivation of actinomyecs $\ldots \quad \ldots \quad \ldots \quad \ldots 1+1$

$\begin{array}{llllll}\text { Botrytis... } & \ldots & \ldots & \ldots & \ldots & 11 \text { i) }\end{array}$

Bread, fermentation of $\quad \ldots \quad \ldots$... 606

Brefeld's glass cells $\ldots \quad \ldots \quad \ldots \quad \ldots 795$

Brefeld on temperature in relation to bacillus subtilis ... $\quad \ldots 536$

Bricger's analysis of Friedlaender's pneumonia bacilli $\quad \ldots \quad$... 526

Brieger on ptomaines... $\quad . . \quad \ldots 56$

Bromine as a disinfectant $\quad \ldots \quad$... 6699

— as an inhibitory agent ... $\quad . .653$

Bromine water, action on spores ... 667

Buchner on the staining of spores ... 785

- on the variability of anthrax

bacilli... $\quad \ldots \quad \ldots \quad \ldots 240$

Buldling fungi as infective agents ... (i36

— — chemical composition of $\ldots$ islo

- - conditions of life of... ... 516

- - conditions of spore formation and spore germination of $\quad \ldots 523$

- - nutrient materials of $\quad \ldots \quad 518$

Bumm on the coccus of gonorrhœa... 199

Butyric acid fermentation ... ... 597

- _ - fermentative agents of the 598

— — - materials necessary for ... 597

- - nature of the decomposition of ...

... 508

Bye products in the alcoholic fermentation of sugar ... ... 590

\section{C.}

Cadaverine

.. 569

Calomel as a disinfectant $\quad \ldots . \quad \ldots 654$

Camphor as an inhibitory agent $\quad . .654$

Carbo-hydrates, bacilli causing fermentation of ...

- fermentation of, by bacteria ... 59\%

Carbolic acid, action on bacteria $\quad \ldots \quad 6677$

- - action on spores $\quad \ldots \quad \ldots$ libi7

- - as a disinfectant ... ... 671

- - as an iuhibitory agerit ... 6.5.

Carbon, assimilation of, by the lower fungi ... ... ... ... 540

— sources of, for the fission fungi... 52S

— — nf, for the mould linngi $\quad . . .50 .1$

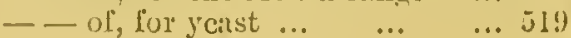

Carbonic acid as a product of the lower fungi $\quad \ldots \quad \ldots \quad \ldots .560$ Cellulose fermentation $\quad \ldots \quad \ldots 600$ - solution of, by the butyric acid bacillus... $\quad \ldots \quad$... $\quad \ldots 578$

Ccrebrospinal meningitis, microcoeci in

Charbon symptomatique, bacillus of 299 Charrin's septicémic consécutive au cliarbon...

Chavcau on protective inoenlation in anthrax...

Checse spirilla... $\quad \ldots \quad \ldots \quad \ldots \quad 477$

Chemical composition of the budding fungi $\quad \ldots \quad \ldots \quad \ldots \quad \ldots . \mathrm{II} 1$;

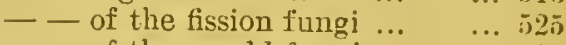

$\begin{array}{llll}- & \text { of the mould fungi ... } \quad \ldots & 502\end{array}$

Chemical ferments $\ldots \quad \ldots . \quad \ldots \quad$...

$\begin{array}{lllll}- \text { rôle of } \ldots & \ldots & \ldots & \ldots & 575\end{array}$

- poisons as inhibitory agents of bacterial growth

Cheyne's method of studying spore formation and the sprouting of spores

Chicken cholera, attenuation of the bacilli of $\quad \ldots \quad \ldots \quad \ldots 660$

- - bacillus of $\quad \ldots \quad \ldots \quad \ldots 314$

- - protective inoculation against $75 . ;$

Chinolin as an antiputrefactirc agent 65.5

Chlorate of potash, action on spores 666 Chloride of calcium, action on spores 666 Chloride of iron, action on spores ... 667 Chloride of lime, action on spores ... 667

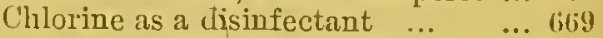
— as an inhibitory agent ... $\quad \ldots 653$ - water, action on spores... $\quad . .6667$ Chloroform, action on spores $\quad$... 666 Cholera, acquired immunity ... $\quad \ldots \quad 447$

- artificial production in animals 438

- bacillus $\ldots \quad \ldots \quad$... $\quad . .+4 i$

— contagiousness of $\quad \ldots \quad \ldots .734$

— Emmerich's bacillus of... $\quad \ldots .33 .5$

— endemic occurrencc $\quad . . \quad$... 4.1

— factors predisposing to ... ... 447

- influence of individual predisposition on $\quad \ldots \quad \ldots \quad 446,460$

— influenee of the soil on $\quad \ldots 45 \overline{5}$

- local and seasonal rariations $\begin{array}{llllll}\text { in } & \ldots & \ldots & \ldots & \ldots & \end{array}$

- localistic ricw $\ldots \quad \ldots \quad \ldots+467$

- local preclisposition $\quad . . \quad$... 453

— metcorological influences $\quad \ldots 4$ 45.

- modes of trinsport of the infective agents of ... $\quad \ldots \quad \quad \ldots$ tt4

— naturil modc of infection $\quad \ldots+22$

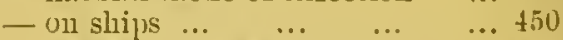

- Pettenkofer's vicws on ... ... 468

- points of cutrance of the infective agents into the body ... fft

- present mode of spread of ... 4.i2

- proplyylactic mensures igaillst $4 f 9$

- prophylactic regulations : igninst 40 
Cholera, protcctivc ariangements in the healthy body $\quad . . \quad \ldots 446$ — seasonal predisposition ... ... 453 — sources of infection $\quad \ldots \quad 443,738$ - transmission by the sick ... 451 Cholera nostras, relation of Finklcr and Prior's spirillum to $\ldots 476$

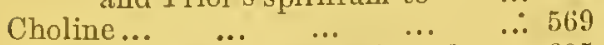

Citrate of lime, fermcntation of $\ldots 605$

Cladothrix $\quad \ldots . \quad \ldots . \quad \ldots . \quad \ldots 174$

$\begin{array}{lllll}\text { - dichotoma } & \ldots & \ldots & \ldots & 491\end{array}$

Clathrocystis roseo-persicina $\quad$... 490

Claviceps purpurea $\quad . . \quad \ldots . \quad \ldots 113$

$\begin{array}{llllll}\text { Cleospora } & \ldots & \ldots & \ldots & \ldots & 115\end{array}$

$\begin{array}{llllll}\text { Clostridium } & \ldots & \ldots & \ldots & \ldots & \ldots\end{array}$

Clothing, bacteria in ... ... ... 718

Clou de Bislira... $\quad . . \quad \ldots \quad \ldots \quad \ldots 188$

Cochin on the time required for fermentation $\quad . . \quad \ldots . \quad \ldots 593$

Cohn's nutrient solution $\quad$... $\quad \ldots 790$

Comma bacillus $\quad \ldots \quad \ldots \quad \ldots 415$

Common salt as an inhibitory agent 654

Concentration of the nutrient medium in rclation to the bacteria $\quad . .533$

Concurrent growth of bacteria $\quad \ldots \quad 537$ - - of mould fungi with other organisms $\quad \ldots \quad$... $\quad \ldots .513$ _ — of yeast with other fungi $\quad . . .522$ Conditions of life of the budding fungi 516 - - - of the fission fungi ... 525 _ _ of the lower fungi ... 501 - - - of the mould fungi _.. 502 $\begin{array}{llllll}\text { Conidia ... } & \ldots & \ldots & \ldots & \ldots & 106\end{array}$

Constancy of the character's of the fungi $\quad . . \quad \ldots \quad$... $\quad . .672$ - of the products of tissue change 564 Contact, transport by $\quad$... $\quad \ldots 739$ Contagion by dircet contact $\quad$.. 730 - by surrounding objects... ... 731 Contagious facultative parasites $\quad \ldots 732$ - - - sources of ... ... ... 738 — infective cliscascs $\quad \ldots . \quad \ldots 730$ - obligatory parasitcs $\quad \ldots \quad$... 732 - - sources of infection by ... 736

Contamination of the soil $\quad . . \quad \ldots 722$ Cordua on zoonotic finger crysipeloid 201 Cordiceps isaria $\quad \ldots . \quad \ldots \quad \ldots 115$ Corrosive sublimatc as a disinfectant 670 Cover glass preparations $\quad \ldots \quad \ldots 778$ Cienothrix $\quad \ldots \quad \ldots . \quad \ldots \quad \ldots 17 t$ $\begin{array}{lllll}\text { - Kühniana } \quad \ldots & \ldots & \ldots & 486\end{array}$ Cryptococcus xanthogenicus $\quad \ldots 20213$ Cultivation of armërobic bacteria $\ldots 800$ — of micro-orgallisms _.. ...788 - spccial methods of $\quad \ldots \quad \ldots 794$

D.

Dahlia... Death of the lower fungi, collditions affecting the
Dc Bary on bacillus megatcrium ... 407 - classification of the parasitic $\begin{array}{lllll}\text { fungi } \quad . . & \ldots & \ldots & \ldots & 628\end{array}$

$\begin{array}{cccccc}\text { Decny } & \ldots & \ldots & \ldots & \ldots & \ldots\end{array}$ Degcucrative changes in the fungi, variations as the result of $\ldots 676$

Dc la Croix on the action of chemical agcnts on bacteria ... ...651

Denclie on chccse spirilla $\quad \ldots \quad \ldots 477$

Dental carics, bacilli in $\quad$... $\quad$.. 298

Destruction of bactcria by cluemical 391 poisons ... $\quad \ldots \quad \ldots 6 \quad \ldots 655$

$$
\begin{array}{cccc}
\text { poisons } \ldots & \ldots & \ldots & \ldots 6 \\
\hline
\end{array}
$$

_ - in the blood $\ldots . \quad \ldots 7+2$

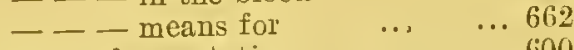

Dextran fcrmentation $\quad \ldots \quad \ldots 600$

Dcxtran fcrmentation of sugar ... 215

Diagnosis of bacteria from tissuc $\begin{array}{lllll}\text { elements } & \ldots & \ldots & \ldots & 787\end{array}$

— of the bacilli, kcy for ... $\quad \ldots 411$

— of the micrococci, kcy for $\quad$... 232

- of the spirilli, licy for ... ... 485

Diastase, chcmical composition of ... 581

Diastatic ferments $\quad . . \quad \ldots . \quad \ldots \quad 576$

Dilution, scparation of bacteria by... 802

Diphtheria in calves, bacillus of $\quad . .328$

— in pigeons, bacillus of ... ... 326

- Locftler's bacillus of ... ... 280

- micrococci in ... $\quad$... $\quad$... 202

- sources of infection of ... $\quad \ldots 737$

Diplococcus albicans tardissimus $\quad \ldots 230$

Disinfection $\quad . . \quad \ldots . \quad \ldots \quad \ldots 647$

$\begin{array}{llllll}\text { - by steam ... } & \ldots & \ldots & \ldots & 772\end{array}$

— experiments, conditions of $\quad \ldots 647$

- natural means of $\quad . . \quad \ldots 685$

— of dwelling-houses $\quad . . \quad \ldots 775$

一 of excretn $\quad$... $\quad$.. $\quad$... 772

— of linen, beds, \&c. ... ... 772

— Schiitte's regulations for $\quad$... 776

Dispora caucasica $\quad . . \quad \ldots . \quad \ldots 372$

Distilled water, action on sporcs $\quad$.. 666

Distribution of bacteria $\quad . . \quad \ldots 655$

$\begin{array}{lllll}\text { Double staining } & \ldots & \ldots & \ldots & 752\end{array}$

Diainagc, advantages of $\quad \ldots \quad \ldots 721$

Drinking water in relation to typhoid fever ... ... ... 767

Drop cultivations $\quad \ldots \quad \ldots \quad \ldots \quad \ldots 794$

Drying, influcnce of on cholcra bacilli $\$ 33$

Dry zone in relation to the spread of bactclia from the soil $\ldots 707$

Duclaux, on tlic coagulation of cascine by bacteria $\quad . . \quad \ldots . \quad \ldots .5 s 0$

Dujardin-Benumetz on sulphurous acid as a disinfectant... ... 66!)

Dulcitc, fermentation of $\quad . . \quad \ldots 603$

Duodelum, injcction of cholera bacilli into $\quad . . \quad \quad \ldots \quad \ldots 436$

Durin and Sclicbler on the analysis of bactcria... $\quad . . \quad \ldots \quad \ldots 527$

Dwelling-houscs, disinfection of $\ldots 775$ 
E.

PAGF

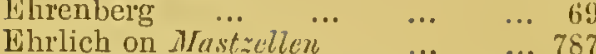
—on the aniline dyes $\quad \ldots . \quad \ldots 780$ Eidam on temperature in relation to bacterium termo ... ... 536 Eleetricity, influence of, on bacteria 535 Embolism by baeteria $\quad \ldots \quad \ldots 641$ Emmerieh's bacillus of cholera $\quad . .335$ Emmerich on bacteria in diphtheria 287 - on cholera baeilli ... ... +20

- on pneumonia bacteria outside the body ... $\quad \ldots \quad \ldots \quad 259$

$\begin{array}{lllll}\text { Empusa muser } & \ldots & \ldots & \ldots & 2511\end{array}$

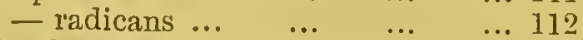

Emulsine, chemical composition of... 581 Endocarditis ulcerosa $\quad \ldots \quad \ldots . .67$

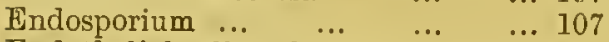
Endothelial eells, relation to bacteria 644 Endothelium, importance of, in regard to infection $\ldots, \quad \ldots, \quad \ldots$

Energy, development of, by the lower $\begin{array}{lllll}\text { fungi } \ldots & \ldots & \ldots & \ldots & 544\end{array}$

— interchange of, in the lowerf ungi 557

- source of, in the case of the anaërobcs

Engelmann on the ${ }^{\cdots}$ inflienee $\ldots 545$ oxygen on the movement of the baeteria

$\begin{array}{lllll}\text { Entomophtorex } & \ldots & \ldots & \ldots & 531 \\ & & \ldots & \ldots & 111\end{array}$

$\begin{array}{llllll}\text { Enzymes } & \ldots & \ldots & \ldots & \ldots & 177 \\ & & \end{array}$

Epidemic anthrax, mode of oecurrence of...

Epidemic diseases of plants, factors which influenee their spread... 632

- - of plants, relation to season and locality $\quad \ldots \quad \ldots \quad \ldots 631$

$\begin{array}{llllll}\text { Episporium } & \ldots & \ldots & \ldots & \ldots & 107\end{array}$

Epithelium, importanee of, in regard $\begin{array}{lllll}\text { to infection } & \ldots & \ldots & \ldots & 750\end{array}$

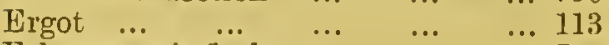

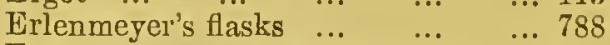

Erysipelas, sources of infection of ... 738

$\begin{array}{lllll}\text { Erysiphæ oiddium } \quad \ldots & \ldots & \ldots & 126\end{array}$

Erythrite, fermentation of $\ldots . \quad \ldots 603$

Escherieh on bacilli in the fæces of infants... $\quad . . \quad \ldots \quad \ldots 334$

Esmarch's method of separating bac$\begin{array}{llllll}\text { teria } & \ldots & \ldots & \ldots & \ldots & 790\end{array}$

Ether, action on spores $\quad \ldots . \quad \ldots$... 6660

Etiology of cholera $\quad \ldots \quad \ldots . \quad \ldots \quad$... 421

$\begin{array}{llllll}\text { Eurotium } & \ldots & \ldots & \ldots & \ldots & \text { 119 }\end{array}$

- aspcrgillus glaucus $\quad \ldots \quad \ldots \quad$... 123

$\begin{array}{lllllll}\text { - repens } & \ldots & \ldots & \ldots & \ldots & 123\end{array}$

IExanthemata, sources of infection of 737 Excrementitious nitrogenous produets of the lower fungi $\quad . .550$

$\begin{array}{llll}\text { Excreta, disinfection of } \quad \ldots & \ldots & 772\end{array}$ Excretion of infective agents by the sick $\quad \ldots \quad \ldots \quad \ldots \quad \ldots$ 73.

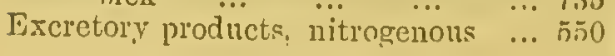

Excretory produets, non-nitrogenous PAs

-nitrogenous 553

lixpired air, absenee of bacteria in $\ldots$ 1 146

Extcrual conditions, variations in, as influencing the prorlucts of time change $\quad \ldots \quad \ldots \quad \ldots 679$

\section{F.}

Facultative anaërobes $\quad$.. $\quad \ldots \quad 532$

$\begin{array}{lllll}- \text { parasites ... } & \ldots & \ldots & \ldots & 532 \\ & \end{array}$

$\begin{array}{lllll}\text { — saprophytes } & \ldots & \ldots & \ldots & \ldots 29 \\ & \ldots & \ldots & \ldots & \end{array}$

Freces, Bienstock's bacilli of $\quad \ldots 404$

Falken heim on sareina ventriculi $\ldots 326$

Fate of non-nitrogenous materials in the lower fungi $\quad . . \quad \ldots .553$

— of the parasitic bacteria outside the body $\quad \ldots \quad \ldots \quad \ldots 686$

Fatty acids as anti-putrefaetive substances... $\quad \ldots \quad \ldots . \quad \ldots 655$

- - fermentation of $\ldots .6063$

- - produetion of, by the lower fungi $\quad . \quad$... $\quad \ldots \quad \ldots 560$

$\begin{array}{ccccc}\text { Favus, fungus of } & \ldots & \ldots & \ldots & 560 \\ \end{array}$

— of miee, fungus of $\quad \ldots . \quad \ldots .130$

Fermentation ... $\quad \ldots \quad \ldots \quad \ldots \quad \ldots 586$

$\begin{array}{llllll}- \text { aeetic } & \ldots & \ldots & \ldots & \ldots & 618\end{array}$

— and tissue ehange $\quad \ldots \quad$... 623

- a physiological act of living $\begin{array}{lllll}\text { organisms } & \ldots & \ldots & \ldots & 623\end{array}$

— as a substitute for oxygen in supplying energy $\quad$... $\quad \ldots \quad 545$

— by bacteria $\quad \ldots \quad \ldots \quad \ldots \quad \ldots 595$

— butyrie aeid $\quad \ldots \quad \ldots \quad \ldots 597$

— of eellulose $\quad \ldots \quad$... $\quad \ldots 600$

- chemical ehanges in ... ... 621

— classification of ... $\quad \ldots \quad \ldots \quad \ldots 587$

— clefinition of $\quad \ldots \quad \ldots . \quad \ldots \quad 586$

- dextran ... $\quad . . \quad \ldots \quad \ldots 600$

— influenee of oxygen on... ... 595

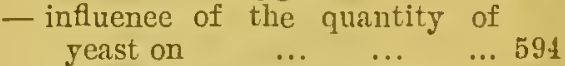

— influenee of temperature on $\quad \ldots .594$

- influence of the amount of alcohol on $\quad \ldots \quad \ldots \quad \ldots \quad \ldots 594$

- influenee of the amount of $\begin{array}{lllll}\text { sugar on } & \ldots & \ldots & \ldots & 594\end{array}$

$\begin{array}{lllll}\text { - lactie acid } & \ldots & \ldots & \ldots & \ldots 966\end{array}$

— of bread ... $\quad \ldots . \quad \ldots . \quad \ldots 606$

— of carbo-hydrates br bacteria ... 593

- of glucose, chemical process of 590

... of the fatty acils _.. $\quad \ldots 603$

— of the ligher alcohols ... ... 60?

— products of $\quad \ldots \quad \ldots \quad$... 562

— time required for $\quad \ldots \quad \ldots \quad \ldots 93$

$\begin{array}{llllll}\text { - viseous } & \ldots & \ldots & \ldots & \ldots & \ldots 98\end{array}$

Fermentatirc action of the mould $\begin{array}{llllll}\text { fungi } & \ldots & \ldots & \ldots & \ldots & 511\end{array}$

— - relation to acids $\ldots . \quad \ldots .554$

- - relation to temperature ... 583

Fcrmentative activity as a substitute for oxygen $\quad \ldots \quad \ldots \quad \ldots \quad$... 
Fermentativeactivity, infuence of, ou the life of the bactcria

- - of ycast

Fermentative olganisms, attcumation of $\quad \ldots \quad \ldots \quad \ldots \quad \ldots 656$

Fermented fluids, scums on ... ... 151 Felments and true felmentatious; distinction between ... ... 585

— chemical ... $\quad . . \quad \ldots . \quad \ldots 574$

— chcmical composition of $\quad \ldots 581$

- formation of, by bacteria $\quad$... 530

- method of scparating ...

- mode of action of

... 581

- relations to carbolic acio

582,585

relations to carbolic acid ... 584

— relations to salicylic acid ... 584

— which break up glucosides ... 580

— which decompose fat ... ... 580

Finkler and Prior's spirillum $\quad$... 472

F'ission fungi as causes of disease $\ldots 636$

— - chemical conditions of $\quad \ldots \quad 525$

— conditions of life of... ... 525

- - granulose in ... $\quad . . \quad \ldots \quad \ldots 27$

— nutrient materials of $\quad \ldots 527$

— - sources of carbon of $\quad \ldots .528$

— - sources of nitrogen of $\quad \ldots \quad 527$

Fish, mould fungi as parasites in ... 634

Fitz on the fermentation of dulcite... 603

- on the fcrmentation of elythrite 603

- on the fermentations of glycerine 602

- on the fermentation of mannite 603

Flacherie, micro-organisms in $\quad$.. 207

Flics, parasitic mould fungi in $\quad \ldots 633$

Fol's method of cultivation ... ... 788

Food, bacteria in $\quad . . \quad \ldots . \quad \ldots 716$

— ptomaines in $\quad . . \quad \ldots \quad \ldots \quad \ldots 572$

— transport by $\quad \ldots \quad$... $\quad . .770$

Form of the fungi, valiations in, as the result of degenerative changes 676

Form of the lower fungi, variations in, during development $\quad . .675$

Formate of lime, fermentation of ... 603

Formic acid, action on spores $\quad$... 667

Foul brood, bacillus of $\quad \ldots \quad \ldots 343$

Fowl scab, fungus of ... $\quad \ldots . \quad \ldots 129$

Flactional cultivation $\quad \ldots$... 801

Frank on disinfection with bromine 670

A. Fraenkel's bacillus of puetumonia 325

E. Fraenkel on a diplococcus from vaginal secretion

... 230

Frcire on micro-organisms in yellow fever $\quad \ldots \quad \ldots \quad \ldots \quad \ldots 203$

Friedländer's pncumonia bacteria ... 255

Fuchsinc $\quad \ldots \quad \ldots . \quad \ldots \quad \ldots 782$

Fumago $\quad \ldots \quad \ldots . \quad \ldots \quad \ldots 115$

Function of the lowcr fungi in naturc 497

Functional activity of the lower fungi 518

Fungi, absorption and assimilation of nutriment by $\ldots$.... ...

- alterations which the nutrient materials undergo ... ... 548

— assimilation of carbon by ... 5t(j

- assimilation of nitrogen br ... $5+7$
Fungi, condilions aflecting the death

PAGE

— functional aetivity of ... ... 548

- morphology of ... $\quad . . . \quad \ldots 103$

- placc of, in the vegctable lingdlom $\quad . . \quad \ldots \quad \ldots \quad \ldots 101$

— products of tissuc change of ... 559

— spore formation in $\quad . . \quad$... 105

- tissue change and development of cnelgy in ... ... ... $5+1$

— vital actions of ... $\quad \ldots \quad \ldots 540$

Fusisporium solani $\ldots . \quad \ldots \quad \ldots 113$

G.

Gadinine $\quad \ldots \quad \ldots \quad \ldots \quad \ldots 569$

Gaffliy on micrococcus tetragenus ... 205

— on typhoid bacilli ... ... 248

Gäitner and Plagge on the action of carbolic acid on bacteria ... 668

Gastric juicc, action of, on bacteria... 724

Gastro-enteritis, bacteria of ... ... 330

$\begin{array}{llllll}\text { Gemma } & \ldots & \ldots & \ldots & \ldots & 105\end{array}$

General prophylactic measuies $\quad \ldots 770$

Gentian violet... $\quad \ldots \quad \ldots . \quad \ldots 782$

Germ theory, development of $\quad \ldots 70$

- - objections to... ... $\quad \ldots \quad 81$

Germination of spores of bactcria $\ldots 163$

- - of yeast ... ... ... 524

Giant cells and tubercle bacilli $\quad \ldots 263$

Glanders, bacillus of ... $\quad . . \quad \ldots 277$

- sources of infection of ... $\quad \ldots 737$

Glucose, forms of, suitable for alcuholic fermentation ... ... 588

Glucosides, ferments of $\quad \ldots \quad \ldots 580$

Glycerinate of lime, fermentation of 604

Glycerine, action on spoles ... ... 666

Glycerine, fermentations of ... ... 602

Gonor"hcea, micrococcus of ... ... 198

- sources of infection of ... $\quad \ldots \quad 736$

Goodsir on sarcina ventriculi $\ldots 226$

Göttingen, regulation for disinfection in ... $\quad . . \quad \ldots \quad \ldots 776$

Gram's method of staining ... ... 781

Granulowa fungoides, streptococei in 204

Granulose in the fission fungi ... 527

Grawitz oul the development of pathogenic properties in mould $\begin{array}{llllll}\text { fungi } & \ldots & \ldots & \ldots & \ldots & 138\end{array}$

Ground water as an index of the moisture of the soil ... ... 70 \%

H.

Habilat of baetcria $\quad . . \quad \ldots 6 \quad \ldots 68.5$

Habitats for bacteria in water $\quad \ldots 775$

Hrmoplilia neonatorum, micrococci in ... ... $\quad \ldots \quad$... 203

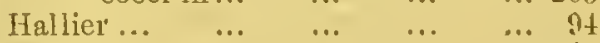

Haplococcus reticulatus $\quad$... $\quad$... 14

Hauscr's putrefuctire bacilli _.. 380

Fanstoria $\quad \ldots \quad \quad \therefore \quad \ldots \quad \ldots$ lit 
Hay bacillus ....... PE

Healtly body, absence of bacteria in the $\quad \ldots \quad \ldots \quad \ldots \quad \ldots 726$

Heat, production of, by the lower fungi 558 Henle's views on contagia ... $\quad \ldots \quad 91$ Hereditary variations in the lower fungi, mode of origin of $\quad \ldots 673$

Hesse's method of examining air for' bacteria

Hoppe-Seyler on the influencc of oxygen on putrefaction

Hueppe on spores in comma bacilli... 428 - on the production of invertine ferment by the bacillus lactis 578

— on the staining of sporcs ...785 - on variability in the lactic acid bacilli ... $\quad \ldots \quad \ldots 6 \quad \ldots 680$

Hyacinths, yellow disease of... $\quad \ldots 6836$ Hydrochloric acid, action on spores 6677 - - as an inhibitory agent $\quad . .663$

Hydrocyanic acid as an inhibitory agent $\quad . .6 \quad \ldots \quad \ldots 6 \quad \ldots 653$

Hydrogen, rốte of nasecnt, $\ldots$ in putrefaction ... $\quad \ldots \quad \ldots \quad \ldots 615$

Нурһж ... ... . .

\section{I.}

Illumination of specimens, method of 786 Immunity

... 752 Indirect transport of infective agents 741 lndividual predisposition $\quad \ldots \quad \ldots 748$ Infants, bacilli in fæces of $\ldots . \quad \ldots .334$ Infection as the result of profession and occupation

\begin{tabular}{lllll} 
— by clothing & $\ldots$ & $\ldots$ & $\ldots$ & 729 \\
\hline
\end{tabular}

— by doctors, \&c. ... $\quad \ldots . \quad \ldots 7722$

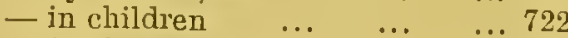

— in cholera $\quad \ldots \quad \ldots . \quad \ldots 442$

- sources of $\quad \ldots \quad \ldots . \quad \ldots 729$

Infective agents, accidents influcucing the spread of $\quad \ldots \quad \ldots 768$

- - mode of transport of $\quad \ldots 739$

- multiplication of, on surrounding objects

... 731

$\begin{array}{llll}- \text { seats of invasion of ... } & \ldots & 7+1\end{array}$

— slight importance of saprophytic growth of, for the spread of diseasc

Infectivc diseases, local and seasonal predisposition to $\quad \ldots \quad \ldots 761$

— - mode of spread of $\quad \ldots . \quad \ldots 728$

- - prophylactic measurcs agrainst 770

Infcctive nature of soil $\quad \ldots \quad \ldots 694$

Influenza, micrococci in $\quad \ldots . \quad \ldots 203$

$\begin{array}{llll}\text { Inhibition of growth of bacteria } \quad \ldots & 648\end{array}$

Inhibitory action of the products of tissue changc ... $\quad . . \quad \ldots \quad 566$

Injury in relation to infection $\quad \ldots$ Tó

Iodine, action nn spores $\quad . .6 \quad \ldots .666$

- as an inhibitory agent ... $\quad \ldots 6$... 65

indine water, action on spores $\quad \ldots 667$
Inscets, parasitic mould fungi PAt: - transport by Intcstine, bactcria in the $\ldots 4 \quad 417,724$ Intestinal mucous membranc, [rassage of bacteria through $\quad$.. $7 \notin 2$ Intramolecular respiration in the lower fungi $\quad \ldots \quad \ldots \quad \ldots \quad \ldots+2$ - - relation of oxygen to ... $5+2$ Invasion, differences in the charactcrs of the points of ... ... 74 ?

Invasion of infective agents, seats of $7+1$ $\begin{array}{llllll}\text { Invertine } \quad \ldots & \ldots & \ldots & \ldots & 577\end{array}$ - chemical composition of $\quad \ldots .581$ - production of, by bacillus lactis 578 Involution forms of cholcra bacilli... $\$ 26$

J.

Jequirity ophthalmia, bacilli of $\ldots 346$

I.

Kicpbyr, chemical composition of ... 608

— ferment of $\quad \ldots \quad$... $\quad$... 372

- preparation of ... $\quad \ldots \quad \ldots 607$

Key for the diagnosis of the bacilli... 411

- for the diagnosis of micrococci 232

- for the diagnosis of the spirilla 485

Kitt on protcctive inoculation A. 756

Klebs on fractional cultivation ... 801

Klcbs and Tommasi-Crudeli on bacilli in malaria $\quad \ldots \quad$... ... 294

Koch, cxperiments on the inhibitory action of various poisons $\quad . .605$

— on cholera bacilli $\quad \ldots \quad \ldots+15$

- on protective inoculation in $\begin{array}{lllll}\text { anthrax... } & \ldots & \ldots & \ldots & 758\end{array}$

- on spore formation in anthrax bacilli ... $\quad \ldots \quad$... $\quad . .538$ - on the advantages of solicl nutrient substrata $\quad . . \quad$... 796

- on tubercle bacilli ... ... 260

Koch and Wolffhiggel on sulphurous acid as a disinfectant... ... 66 ?

König on disinfection with sublimate $6 i 1$ Kreibohm's bacilli of saliva ... ... 31! Kurth on bacterium Zopfii ... ... 40.

\section{L.}

$\begin{array}{llllll}\text { Laboulbenia } & \ldots & \ldots & \ldots & \ldots & 11 .\end{array}$ Lactate of lime, fermentation of ... b0t Lactic acid bacteria ... $\quad . . \quad$... $\left.366_{3}\right)$ Lactic fermentation ... $\quad \ldots \quad \ldots \quad$... 96 — - fermentative agents of $\ldots 596$ — - matcrials nccessary for $\quad \ldots 596$

- - nature of the decomposition 596 Lankestcr on a peach-coloured bacterium $\ldots \quad \ldots \quad \ldots \quad \ldots \quad \ldots 40$

Laveran on organisms in malaris $\ldots$ 20.5

Lcprosy, bacillus of ... $\quad . . \quad \ldots .27 t$

$\begin{array}{llllll}\text { Leptothrix } & \ldots & \ldots & \ldots & \ldots & \text { l.ji }\end{array}$

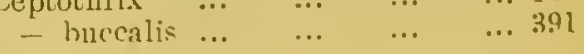


$\begin{array}{llll} & & & \text { PAGE } \\ \text { Leptothrix giganten } & \ldots & \ldots & 392 \\ \text { Leubc's bacillus urere } & \ldots & \ldots & 390 \\ \text { - micrococcus ureac } & \ldots & \ldots & 212 \\ \text { Leuconostoc mescnterioides ... } & \ldots & 214 \\ \text { Liborius on bactcria in relation } & \text { to }\end{array}$

$$
\text { oxygen ... } \quad \ldots \quad \ldots . \quad \ldots 531
$$

Lichen ruber, olganisms in ... ... 297

Liebig's views on fermentation $\ldots 86$

Light, development of, by the fungi 559 - influence of, on bacteria ... 535

- influence of, on the motility of bacteria... $\quad . . \quad \ldots \quad \ldots 558$

Linen, disinfection of $\quad \ldots . \quad \ldots 772$ Liver, acute yellow atrophy of micrococci in ... $\quad . . \quad$... ... 203

Local differences in the number of air germs $\quad \ldots \quad \ldots \quad \ldots \quad \ldots 689$

- - in the number of bacteria in food ... ... ... 717

Local predisposition to infective diseases... $\quad . . \quad \ldots . \quad \ldots 761$

Localistic vicw of cholera $\quad \ldots \quad \ldots 467$

I,ochia, cocci in $\quad . . \quad \ldots . \quad \ldots 200$

Loeffler on diphtheria in calves ... 328 —on streptococci in diphtheria ... 283 - on streptococcus articulorum ... 194 Loeffler's bacillus of diphtheria $\quad . .280$

— bacillus of pigeon diphtheria ... 326

— universal staining fluid _.. 782

Loeffler and Schitz on glanders bacilli 277 Loss of fermentative and pathogenic properties

.. 565

Lower fungi, conditions of life of ... 501

Lungs, passage of bacteria through... 742

Lustgarten on the bacilli of syphilis 259

\section{M.}

Malaria, bacteria in ... .. 292 - sources of infection of ...

... 739

Malate of lime, fermentation of ... 604

Malignant œdema, bacillus of $\quad$... 242

- — in man $\quad . . . \quad \ldots . \quad \ldots 247$

Mannite fermentation-see viscons.

- fermentation of ... ... ... 603

Marchiafava on bacilli in malaria ... 294

Marchiafava and Celli on organisms in malaria $\quad . . \quad$... ... 295

Marsh gas fermentation-see cellulose.

Mastzclicn $\quad \ldots \quad \ldots . \quad \ldots \quad \ldots 787$ Mcasles, micrococei in $\quad$... ... 202

Meat infusion, preparation of, for cultivations $\quad \ldots \quad \ldots \quad \ldots 792$

Mechanical movemcnt, influence of, on bacteria $\quad . . \quad \ldots \quad \ldots 535$

Merismopedia ... $\quad \ldots \quad \ldots . \quad \ldots \quad 160$

Meteorological influcnces in cholera 455

Methor of isolating bactcria $\quad . .797$ - of staining spores _.. ... 785

Mcthods of investigating bacteria ... 777

Methods of the microscopical exanination of the lnwer fungi 777
Methylene bluc $\quad \ldots \quad$... $\quad \ldots 782$

Mcthyl greel ... $\quad \ldots . \quad \ldots . \quad \ldots 782$

$\begin{array}{llllll}\text { - violet } & . . & \ldots & \ldots & \ldots & \\ \end{array}$

Metschnikoff on phago-cytosis _..6 643

Mice, progressive necrosis of tissuc in 209

Micrococci, characters of $\quad \ldots \quad \ldots 171$

- analysis of $\quad \ldots \quad \ldots \quad$... 526

- key for the diagnosis of $\quad$... 232

— of putrefaction ... ... ... 217

- pathogenic in mall ... ... 183

$\begin{array}{lllll}\text { Micrococcus } \quad \ldots & \ldots & \ldots & \ldots & 155\end{array}$

— albicans amplus $\quad$.. $\quad$... 229

- aurantiacus $\quad . . \quad \ldots . \quad \ldots 224$

$\begin{array}{llll}\text { - candicans } & \ldots & \ldots & \ldots 218\end{array}$

— cereus albus $\quad \ldots . \quad \ldots \quad \ldots 228$

— - flavus $\quad \ldots . \quad \ldots \quad$... 228

- chlorinus... $\quad \ldots . \quad \ldots \quad \ldots 24$

- cinnabareus ... ... ... 218

- citreus conglomeratus ... ... 228

- coronatus $\quad \ldots \quad \ldots . \quad \ldots 220$

— cyaneus ... $\quad \ldots \quad$... ... 221

— flavus desidens ... ... ... 222

- - liquefaciens ... $\quad \ldots . \quad \ldots 219$

- - tardigradus $\ldots . \quad \ldots . \quad \ldots 219$

— fcetidus ... $\quad \ldots \quad$... $\quad \ldots 216$

— - products of $\ldots . \quad \ldots \quad \ldots 612$

$\begin{array}{lllll}\text { fulvus } \quad \ldots & \ldots & \ldots & \ldots & 225\end{array}$

— gonorrhœea $\quad \ldots \quad \ldots \quad \ldots 198$

- hrematodes $\quad \ldots \quad$... ... 225

- lacteus faviformis $\quad \ldots \quad$... 229

$\begin{array}{lllll}\text { - luteus } \quad \ldots & \ldots & \ldots & \ldots 21\end{array}$

\begin{tabular}{lllll} 
- Pflugeri & $\ldots$ & $\ldots$ & $\ldots$ & $\ldots$ \\
\hline
\end{tabular}

— prodigiosus $\quad \ldots \quad \ldots . \quad \ldots 352$

- pyogenes tenuis ... $\quad \ldots \quad \ldots 189$

一 radiatus $\ldots . \quad \ldots \quad$... $\quad \ldots 221$

\begin{tabular}{lllll} 
- joseus & $\ldots$ & $\ldots$ & $\ldots$ & $\ldots$ \\
\hline
\end{tabular}

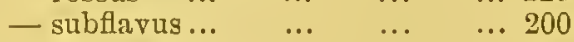

- tetragenus $\quad \ldots \quad$... $\quad$... 205

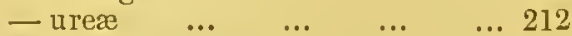

- - liquefacicns ... $\quad \ldots . \quad \ldots 213$

— - nutrient materials necessary for $\quad \ldots \quad \ldots \quad \ldots \quad \ldots 529$

$\begin{array}{lllll}\text { versicolor } & \ldots & \ldots & \ldots & 222\end{array}$

— violaceus... $\quad \ldots \quad$... $\quad \ldots 224$

- viscosus ... $\quad \ldots \quad \ldots . \quad \ldots 216$

— viticulosus $\quad \ldots \quad \ldots . \quad \ldots \quad \ldots 23$

Micro-organisms as parasitic exciting agents of discasc $\quad \ldots \quad \ldots . \quad \ldots 0$

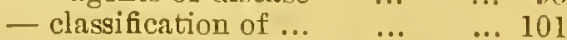

Microscopical examination, mocle of obtaining the specimens ... 778

Microscopical examination of specimeris $\ldots . \quad \ldots \quad \ldots . \quad \ldots \quad 78.1$

Microscopical examination of the lower fungi, methods of $\quad \ldots 777$

Milk, viscous fermentation of $\quad \ldots$ n.)y

Miller on curved bacilli in carious tectl $\quad \ldots \quad \ldots \quad \ldots \quad \ldots+76$

Miller's bacillus, products of $\quad \ldots 6612$

- bacteria from the deposit on teeth

- coccus from com $\ldots \ldots 393$ 
Mincral substances, assimilation of, by the lower fungi $\quad . . \quad \ldots 5.77$

Miquel's cxperiments on clisinfection 652 - methor of cxamining air for bacteria...

Mitscherlich's analysis of the ashes of Jcast... … … ... 518

Mode of sprenl of the infective discascs... $\quad . . \quad \ldots \quad \ldots 728$

Modc of entrance of bacteria into wclls 713 Monadina $\quad \ldots \quad \ldots \quad \ldots \quad \ldots \quad \ldots 1+3$ Monas Okenii ... $\quad \ldots \quad \ldots \quad \ldots \quad \ldots 494$

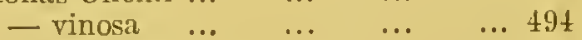
- Warmingii $\quad \ldots \quad \ldots . \quad \ldots 4494$ Morphological differences in the lowcl fungi $\quad \ldots \quad \ldots \quad \ldots 675$

Morphology of micro-organisms ... 101 Motility of bacteria, influence of

light on... $\quad \cdots$ of $\quad$ mutrient materials on $\quad . . \quad \quad \ldots \quad$... 5.58 - _ - influcnce of oxygen on 531, 558 - — - influence of temperature on 558 Mould fungi as cxciting agents of

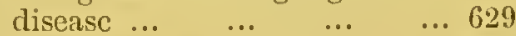
- - as parasites in birds _..63t - - - - in tish ... ... .. 634 - - - in insects $\quad \ldots \quad \ldots 633$ - - - - in man... ... .. 631 — - - on animals ... $\quad \ldots 633$ — - chemical composition of ... 502

- - concurrence with other ol'ganisms $\quad \ldots \quad \ldots \quad \ldots 513$

— Conditions of life of... $\quad \ldots .502$

- conditions of spore formation and spore gcrmination ... 514

- - duration of the vitality of the spores ... 515

— - fermentation of sugar by ... 589

— - fermentative action of ... 511

- - growth in the animal body... 508

- mode of penetration into plants ... $\quad$... $\quad . . \quad \ldots 629$

— - nutrient materials of $\quad \ldots 503$

— - lelation of, to oxygen ...508

- relation to concentration of mutrient material ... ... 509

— - relation to temperature ... 512

- - relation to the reaction of the nutrient material

Mouldincss $\quad \ldots \quad$... $\quad \ldots \quad \ldots 617$

Mouse septicæmia, baeillus of $\quad \ldots 310$

Mouth, bacteria in $\quad . . \quad \ldots \quad \ldots 723$

Mucor colymbifcl $\quad \ldots \quad \ldots . \quad \ldots \quad \ldots 134$

— melittophtor us ... $\quad \ldots \quad$... 133

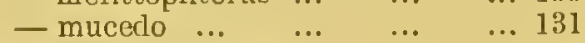

\begin{tabular}{lllll} 
raccmosus & $\ldots$ & $\ldots$ & $\ldots$ & $\ldots$ \\
\hline
\end{tabular}

— rhizopodiformis ... ... .. 133

$\begin{array}{lllll}\text { - stolonifer } & \ldots & \ldots & \ldots & 132\end{array}$

$\begin{array}{llllll}\text { Mucorince } & \ldots & \ldots & \ldots & \ldots & 138\end{array}$

Iultiplication of pathogenic bacteria in the snil.
PAGE

Muscardinc $\quad \ldots \quad$.. $\quad \ldots \quad$... 1] Muscalinc $\quad \ldots \quad \quad \ldots \quad \ldots . \quad \ldots 571$ Musculus's ferment of urine $21 \%, 580$ Mussels, poisoning by $\quad$... $\quad . .573$ Mutability of bactcria, Nägcli's views on $\quad . . \quad \ldots \quad \ldots \quad \ldots \quad(; 80$

- of the characters of the fungi... 672

Mycclium $\quad \ldots \quad$... $\quad \ldots \quad \ldots 104$ \begin{tabular}{llllll} 
Mycetozoa & $\ldots$ & $\ldots$ & $\ldots$ & $\ldots$ & \\
\hline
\end{tabular} — parasitic ... $\quad \ldots . \quad \ldots . \quad \ldots 144$

Mycoderma accti $\quad \ldots \quad$... $\quad \ldots 389$ Myconostoc gregarium $\quad$... $\quad \ldots \quad \downarrow 92$ Mycosis fungoides, streptococci in ... 204

Myco-protein ... $\quad \ldots \quad$... $\quad \ldots 525$ Myco-protein in yeast $\quad \ldots . \quad \ldots 517$ Mydalein $\quad \ldots \quad$... $\quad \ldots . \quad \ldots 571$

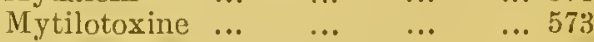
Myxomycetes ... $\quad \ldots \quad \ldots \quad \ldots 1 \neq 2$

N.

Nägeli on mineral substances in relation to the lower fungi ... $5 \pm 8$

- on the assimilation of carbon by the lower fungi $\quad \ldots . \quad \ldots 546$

— on the sclf-fermentation of yeast 593

Nägcli's analysis of anthrax bacilli... 526

- analysis of ycast... $\quad \ldots \quad \quad \ldots 516$

- experimcnts on the nutrient materials of the mould fungi 504

— normal nutricut solutions ... 790

— thcory of fermentation... ... 626

- views as to the mutability of bacteria... $\quad . . \quad \quad \ldots \quad \quad \ldots 680$

Natural means of disinfection ... 685

Neisscr on the coccus of gonorlicea 198

Nencki on ptomaines $\quad . . \quad$... 568

Nencki's analysis of bacteria $\quad . .525$

— myco-protein ... ... ... 525

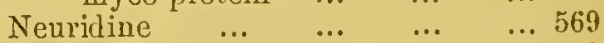

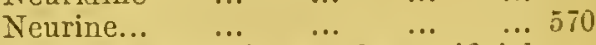

Nicati \& Rietsch on the artificial production of cholern in animals ... $\quad . . \quad \quad \ldots \quad \quad \ldots \quad 436$

Nicolaier on the tetanus bacillus ... $3 \pm 0$

Nitrates, rcduetion of, by bacteria ... $52 \mathrm{~s}$

Nitrification ... $\quad . . \quad \ldots . \quad \ldots 695$

Nitrogen, assimilation of, by the lower fungi $\quad . . \quad \ldots \quad \ldots \quad \ldots 5 \pm 1$ - sources of, for the fission fungi 527

— sources of, for ycast ... $\quad . .519$

- source of supply for the mould fungi ... ... ... ... 万ot

Nitrogenous plastie materials, alterations in by the lower fungi ... i 1 ? Non-contagious facultative parasites 734 - infeetive disenses $\quad . . \quad \ldots . \quad \ldots$ Non-hereditary rariations in the lower fungi f... ... ... 673

Non-nitrogenous plastic matcrials ... 552

Nosema hambycis. ... . .. ... 20 
INDEX.

Number of air germs, local differences in the $\ldots \quad \ldots \quad \ldots 689$

Nutrient jelly, preparation of, for cultivations $\quad \ldots \quad \ldots . \quad \ldots 792$

- materials of the budding fungi 518

— - of the fission fungi ... $\quad . .527$

- - of the lower fungi, alterations which they undergo $\quad . .5+8$

— - of the mould fungi ... $\quad . .503$

$\begin{array}{lllll}\text { - } \text { substrata ... }_{1} & \ldots & \ldots & \ldots & 789\end{array}$

Nutriment of the lower fungi, amount $\begin{array}{lllll}\text { required } & \ldots & \ldots & \ldots & 557\end{array}$

Nutritive requirements of the fungi, Pasteur on $\quad \ldots \quad \ldots \quad \ldots 498$

o.

Obermeier's spirillum $\quad \ldots \quad \ldots \quad \ldots 79$

Obligatory aërobcs $\quad \ldots \quad \ldots \quad \ldots \quad \ldots 533$

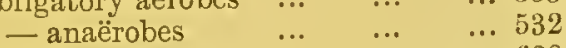

$\begin{array}{lllll}\text { — parasites ... } & \ldots & \ldots & \ldots & 628\end{array}$

— saprophytes $\quad \ldots \quad$... $\quad$... 629

Occurrence of bacteria in the air ...687

_ - - in the soil... $\quad . . \quad \ldots 691$

- - - in water $. . . \quad \ldots . \quad \ldots 711$

Oidium albicans $\quad \ldots \quad \ldots \quad \ldots 131$

$\begin{array}{llllll}- \text { lactis } & \ldots & \ldots & \ldots & \ldots & 127\end{array}$

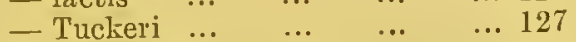

Oil immersion lenses ... $\quad \ldots \quad \ldots 785$

— of cloves as an inbibitory agent 653

- of mustard as an inhibitoly $\begin{array}{llllll}\text { agent } & \ldots & \ldots & \ldots & \ldots & 653\end{array}$

- of peppermint as an inhibitory $\begin{array}{llllll}\text { agent } & . . & \ldots & . . & \ldots & 653\end{array}$

- of turpentinc as an inlibitory $\begin{array}{llllll}\text { agent } & \ldots & \ldots & \ldots & \ldots & 653\end{array}$

$\begin{array}{llllll}\text { Oogonium } & \ldots & \ldots & \ldots & \ldots & 107\end{array}$

Oospores $\quad \ldots \quad \ldots \quad \ldots \quad \ldots l 07$

Ophidomonas sanguinea $\quad \ldots \quad \ldots$ t8t

Origin of air germs $\quad . . \quad \ldots \quad \ldots \quad \ldots 687$

Osmic acid, action on spores $\quad \ldots 667$

Oxygen, influence of, on fermentation 595

- influence of, on the motility of

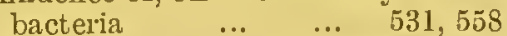

- influence of, on the putrefactive process ... $\quad \ldots \quad \ldots . \quad \ldots 614$

— influence of, on yeast cells ... 520

- in relation to intramolecular respiration $\quad \ldots \quad \ldots \quad \ldots 5 \pm 2$

— in relation to the mould fungi... 508

- in relation to the tissue change of the lower fungi $\quad \ldots \quad \ldots \quad \ldots 53$

- rclation of, to bactcria... $\quad$... 530

Ozæena, micrococci in... $\quad$.. $\quad$... 203

$$
\text { P. }
$$

Pancrcatic ferment, chemical compo$\begin{array}{lllll}\text { sition of } & \ldots & \ldots & \ldots & 582\end{array}$

l'arasitic bacteria $\quad \ldots . \quad \ldots . \quad \ldots 636^{\circ}$ - - degrees of pathogenic action 637 - - fate of... $\quad \ldots \quad \ldots \quad \ldots 686$ - - modes of aetion of $\ldots \quad \ldots$... 6338
Parasitie bacleria, morles of devclop-

PAGE

ment in the body ... ... 638

$\begin{array}{llllll}\text { 一 fungi } & \ldots & \ldots & \ldots & \ldots & 109\end{array}$

— — classification of $\quad \ldots . \quad \ldots 628$

— moulel fungi $\quad . . \quad \ldots \quad \ldots 629$

— rôle of micro-organisms, proof of 98

- yeast fungi $\quad \ldots \quad \ldots \quad \ldots 636$

Parasitismus of the lower fungi $\ldots 627$

Parrots, disease of $\quad \ldots \quad \ldots \quad \ldots 207$

Passet's pseudopneumonia bacteria... 321

Pasteur on acetic fcrmentation ... 619

— on aërobes and anaërobes ... 530

- on attenuation of chicken cholera bacilli ... $\quad$... $\quad$.. 317

— on fermentation by yeast ... 77

- on protective inoculation against anthrax $\quad \ldots \quad \ldots \quad \ldots 756$

- on protective inoculation for rabies $\quad . . \quad \ldots \quad \ldots \quad \ldots \quad \ldots 758$

— on silk-worm disease $\ldots . \quad \ldots 209$

- on the attenuation of the virus $\begin{array}{lllll}\text { of rabies } & \ldots & \ldots & \ldots & 660\end{array}$

- on the fermentation of glucose 590

- on the nutritive requirements $\begin{array}{lllll}\text { of the fungi } & \ldots & \ldots & \ldots & 498\end{array}$

Pasteur's bacillus of saliva ... $\quad$.. 321

— flasks for cultivations ... $\quad$... 788

— nutrient solution $\quad$.. $\quad \ldots \quad 790$

— views on putrefaction ... ... $61 t$

- views on the attcnuation of anthrax bacilli $\quad . .6 \quad \ldots 658$

Pathogenic bacteria, behaviour of, in $\begin{array}{llllll}\text { water } & \ldots & \ldots & \ldots & \ldots & 712\end{array}$

— - biological peculiarities of $\ldots 641$

_ - in the soil. behaviour of ... 698

_ - resistance against excretion 642

_ - resistance against oxygen ... 642

- - resistance to the living cclls. $6 \pm 3$

Pathogenic organisms, attenuation of 656

- - fermentation of carbo-hydrates by $\quad$... $\quad \ldots \quad \ldots 601$

Peach-coloured bacterium, Lankestel on $\quad \ldots \quad$... $\quad \ldots \quad \ldots \quad 490$

Pebrine, micro-organisms in... $\quad \ldots 208$

$\begin{array}{llllll}\text { Penicillium } \quad \ldots & \ldots & \ldots & \ldots & 136^{\circ}\end{array}$

$\begin{array}{llllll}- \text { glaucum } & \ldots & \ldots & \ldots & \ldots & 137\end{array}$

Pepsinc, chemieal composition of ... 581

Peptone, production of, by ycast $\quad . .5 \quad 519$

Peptonising ferments... $\quad . . \quad \ldots \quad 578$

$\begin{array}{llllll}\text { Peptotoxinc } & \ldots & \ldots & \ldots & \ldots & 570\end{array}$

$\begin{array}{lllll}\text { Perisporiacer } & . . & \ldots & \ldots & \ldots\end{array}$

$\begin{array}{llllll}\text { Perithecia } & \ldots & \ldots & \ldots & \ldots & 106\end{array}$

Permanganatc of potash, action on spores $\quad . .6 \quad \ldots \quad$... $\quad \ldots 667$

_ - — as an inlibitory agent ... 65 ;

Peronospora infestans $\quad \ldots \quad$... 112

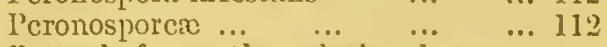

Pettcnkofer on the relation between the soil and infective bacteria 692

Pfeffer on certain nutricnt materials in relation to the movement of bacteria... $\quad . . \quad \ldots \quad \ldots 558$

$\begin{array}{lllll}\text { Phago-cytosis ... } & \ldots & \ldots & \ldots & \ldots \\ & & & & \end{array}$ 
PAGE

Phosphorus, source of, in the fungi... 547

Photography of baeteria $\quad . . \quad \quad \ldots 787$

Phragmidiothrix multiseptata ... 491

Phthisical sputa, distribution of the baeilli by means of ... ... 271

$\begin{array}{lllll}\text { Phycomyeetes... } & \text {.. } & \text {... } & \text {... } 109\end{array}$

Physiological differenees between the lower fungi $\quad . .6 \quad$... $\quad$... 678

Pig typhoid, bacillus of $\quad$... $\quad \ldots 302$

Pigeon diphtheria, baeillus of $\quad$.. 326

Pigment, chemieal nature of $\quad$... 562

- formation, relation of oxygen to 562

- - relation of the nutrient sub-

... 562

- production of, by the lower fungi $56 i$

Pink yeast $\quad . . . \quad \ldots . \quad \ldots \quad \ldots 154$

Pityriasis versieolor $\ldots . \quad \ldots . \quad \ldots 127$

Plants, epidemie discase of ... $\quad . .6631$

— parasitie baeteria in ... ...636

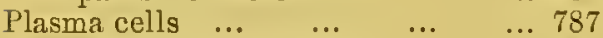

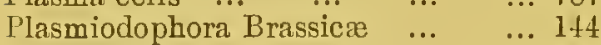

$\begin{array}{lllll}\text { Plasmodia } \quad . . & \ldots & \ldots & \ldots & 142\end{array}$

Plate cultivations $\quad \ldots . \quad \ldots . \quad \ldots 7797$

Pleuropneumonia in eattle, miero-

$$
\text { organisms in ... ... ... } 204
$$

Pneumonia, bacillus of (Friedländer) 255

- bacilli (Friedlaender) analysis of 526

— baeteria, baeilli resembling ... 322

- Fraenkel's bacillus of ... ... 325

Potash soap, action on sporcs $\quad$... 666

— - as an inhibitory agent ... 653

Potato baeilli ... $\quad$... $\quad$... .. 399

- disease $\quad . . \quad$... $\quad \ldots \quad$... 112

Potatoes,preparationof,foreultivations 792

Predisposition, rôle of, in tubereulosis 273

- to infeetion in different speeies and individuals $\quad \ldots \quad \ldots 748$

Preservation of pathogenic baeteria in the soil $\quad \ldots \quad$... ... 701

- _ - - in the soil not neecssary for the spread of discase ... $70 \pm$

Products of the putrefactive fermentation $\ldots . \quad \ldots \quad \ldots . \quad \ldots$

- of the tissue change of the lowcr fungi $\ldots$... ... ...

Progrcssive abseess formation in rabbits, mieroeoeeus of

... 210

- ganglenous emphysema in man 247

- necrosis of tissue in miee, mieroeoceus of

209

Promycelium ... $\quad . . \quad \ldots \quad \ldots \quad \ldots 110$

Prophylaetic measures against the spread of infective discases ... 770

- regulations against eholera ... 470

Protective inoeulation $\quad$... $\quad \ldots 752$

- - gencral value of $\quad \ldots \quad \ldots 760$

- $\begin{array}{llll}\text { in anthrax } \quad . . & \ldots & \ldots & 210\end{array}$

- - in Rausehbrand ... ... 300

— - in swinc erysipclas ... ... 306

$\begin{array}{lllll}\text { Proteus mirabilis } & \ldots & \ldots & \ldots & 352\end{array}$

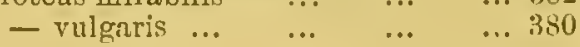

Proteus vulgaris and mirabilis, ploduets of

.. 612

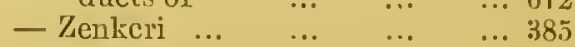

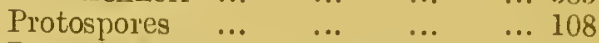

Ptomaincs $\quad \ldots \quad \ldots . \quad \ldots \quad \ldots 567$

- aetion of ... $\quad \ldots \quad \ldots \quad \ldots 638$

- hygienic importanee of $\quad \ldots 572$

- in food $\quad . . \quad \ldots \quad \ldots \quad \ldots 572$

- influence of nutriment on the formation of $\quad . . \quad \ldots \quad \ldots 57 t$

— influence of, on parasitismus ... 645

- of putrcfaetion ... $\quad$... $\quad \ldots .569$

- of typhoid bacilli _.. ... 571

- production of, by the lower fungi 561

Pueeinia graminis $\quad \ldots \quad$... $\quad \ldots 116$

Putrefaetion $\quad$.. $\quad \ldots . \quad \ldots . \quad \ldots 608$

— mieroeoeei of $\quad \ldots \quad \ldots . \quad \ldots 217$

— spontaneous $\quad \ldots \quad$... $\quad \ldots 613$

Putrefactive anaërobes $\quad$... $\quad$... 385

- bacteria ... ... $\quad . . \quad \ldots 375$

- fermentation, materials for ... 609

- multiplicity of the exciting agents of $\quad \ldots \quad \ldots . \quad \ldots 611$

- - nature of the deeomposition 609

- - products of ... $\quad . .6 \quad \ldots 610$

- - variations in ... ... ... 611

- proeess, influenee of oxygen on $61 t$

- ptomaines $\quad$... $\quad$... $\quad$... 569

Putreseine $\quad . . \quad \quad \ldots . \quad \ldots . \quad \ldots 569$

Putrid intoxication, ptomaines as the

eause of... $\quad . . \quad \quad \ldots \quad \ldots 573$

Pyæmia in rabbits, microeoeeus of ... 210

$\begin{array}{llllll}\text { Pycnida } \quad \ldots & \ldots & \ldots & \ldots & 106\end{array}$

$\begin{array}{llllll}\text { Pyocyanine } & \ldots & \ldots & \ldots & \ldots & \ldots\end{array}$

- ehemieal eomposition of $\quad \ldots 562$

Pyrenomyeetes $\quad$... $\quad \ldots \quad$... 113

Q.

Quantitative estimation of the tissue change ... $\quad . . \quad \quad \ldots \quad \ldots . \quad 056$

Quereite, fermentation of $\quad \ldots . \quad \ldots 606$

Quinate of lime, fermentation of ... 60.3

Quinine, action on spores $\quad . .6 \quad \ldots 667$

- as an inhibitory agent ... $\quad$... 651

R.

Rabbits, progressirc ab-eess formation in ... $\quad . . \quad \ldots \quad \ldots .210$

- pyæmia in $\quad \ldots \quad \ldots .210$

- septieremia in $\quad \ldots \quad \ldots . \quad \ldots 211$

— septiexinia, baeillus of ... $\quad$... 312

Rabies, attenuation of the virus of... 660

- protective inoculation for $\quad$... 758

- sources of infection of ... ... 736

Rasinussen's speeies of lcptotlirix ... 392

liatimoff on disinfection $\quad \ldots \quad \ldots \quad(\mathbf{6}) 2$

Raulin's experiments on the nutrient matcrials of the mould fungi 503

Rauschbrand, baeillus of $\quad$.. $\quad$.. $29 ! 9$

Reation of the nutricnt material in relation to the yenst fungi ... $5: 21$ 
Reaction of the nutrient material in relation to bacteria $\quad . . \quad$... 534

Relapsing diseases $\quad \ldots \quad \ldots \quad \ldots 752$

Relapsing fever, spirillum of $\quad . .479$ !

Rennet, ferment of $\ldots \quad \ldots \quad \ldots \quad 79$

Respiratory mucous membrane, bac... ... ... 724

Rhabdomonas rosca $\ldots . . \quad \ldots \quad \ldots 444$

Rhinoscleroma, bacillus of ... ...291

Ribbert on bactcria in healthy intestinal mucous membrine ... 743

Richet's experiments on disinfection 654

Rinderpest, micro-01'ganisms in ... 204

Rindfleiscli on streptococci in mycosis $\begin{array}{lllll}\text { fungoides } & \ldots & \ldots & \ldots & 209\end{array}$

Rouget du porc, bacillus of ... ... 302

$\begin{array}{llllll}\text { Rust } \quad \ldots & \ldots & \ldots & \ldots & \ldots & 116\end{array}$

$i$.

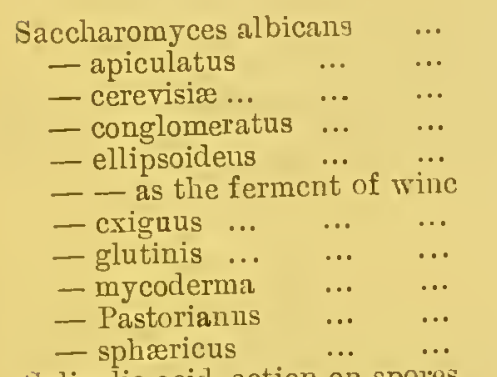

Salicylic acid, action on spores

_ _ as an inhibitory agent

Saliva, spirochæte of ... ...

Salt solution, action on spores

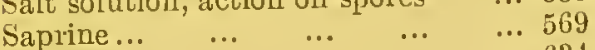

$\begin{array}{llllll}\text { Saprolegnia } & \ldots & \ldots & \ldots & \ldots & 634\end{array}$

$\begin{array}{ccccc}\text { Saprophytic bacilli } & \ldots & \ldots & \ldots & 351 \\ \text { _ micrococci } & \ldots & \ldots & \ldots & 212\end{array}$

- mould fungi, rcsults of injcction

in animals $\quad \ldots \quad \ldots \quad \ldots 634$

$\begin{array}{llllll}\text { Sarcina ... } & \ldots & \ldots & \ldots & \ldots & 160\end{array}$

- aurantiaca $\quad \ldots \quad \ldots . \quad \ldots 226$

- intestinalis $\quad \ldots \quad \ldots \quad \ldots 227$

- litoralis Rcitenbachii hyalina... 228

$\begin{array}{llllll}\text { - lutea } & \ldots & \ldots & \ldots & \ldots & 225 \\ \end{array}$

- ventriculi $\quad \ldots . \quad \ldots . \quad \ldots 226$

Sattler on jequirity bacilli $\ldots \ldots \ldots$

- on micro-organisms iu trachoma 203

Scarlatina, micrococci in ... ... 202

- epidemics, local variations in ... 7 tit

$\begin{array}{lllll}\text { Schizomycetes ... } & \ldots & \ldots & \ldots & 15.5\end{array}$

Schou's bacillus pncumonicus agilis... 325

Schroeder aud Dusch... $\quad \ldots \quad \ldots .72$

$\begin{array}{llllll}\text { Schulze... } & \ldots & \ldots & \ldots & \ldots & 71\end{array}$

Schütte, regulations for disinfection in Göttingen ... ... ... 776

$\begin{array}{llllll}\text { Schwan! } & \ldots & \ldots & \ldots & \ldots & 70\end{array}$

$\begin{array}{llllll}\text { Sclerotium } & \ldots & \ldots & \ldots & \ldots & \\ & \ldots & \ldots & \ldots & \end{array}$

Scason and locality in relation to the cpidemic discrses of plants ... $6: 31$

Scason, influcnce of, in cholera $\quad \ldots \quad+153$
Seasonal differences in the number of bacteria in food ... ... T18

Seasonal predisposition to infective diserses... $\quad \ldots \quad \ldots \quad \ldots 761$

Scats of illvasion of infective agents $7+1$

Sections, methorl of preparation and staining of $\quad \ldots \quad$... $\quad \ldots \quad 779$

Scparation of bacteria by dilintion ... 802

_

Septicamia in micc, bacillus of $\quad$.. 310

- in rabbits, bacillus of ... ... 312

_ - - micrococcus of $\quad \ldots \quad$... 211

Ships, cholera on ...

Sieber's analysis of the moulil inngi 502

Significance of micro-organisms $\quad . .666$

Silk-worms, lethargy of $\quad \ldots \quad \ldots 207$

Skin, bacteria on $\quad . .6 \quad \ldots . \quad \ldots 723$

Small-pox cpidemics, scasonal variations in ... $\quad . . \quad \ldots \quad \ldots 763$

Smut $\quad \ldots \quad \ldots . \quad \ldots \quad \ldots \quad \ldots 110$

Soil, bactcriological investigation of

693,809

- influencc of, in cholera... ... 457

- occurrence and behaviour of bacteria in ... $\quad . . \quad \ldots 691$

- preservation of pathogenic bacteria in ... $\quad . .6 \quad \ldots \quad \ldots 701$

- relation to infective bactcria ... 69.

- transport of bacteria within the 69 \%

Solid nutrient substrata, advantages of $\ldots \quad \ldots \quad \ldots \quad \ldots 79$

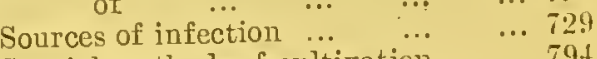

Special methods of cultivation $\quad . .794$

Special prophylactic measures in individual discases... ... ... 77 l

Specific points of invasion, importance of, for the mode of spread of the disease $\ldots \quad \ldots \quad \ldots \quad \ldots 747$

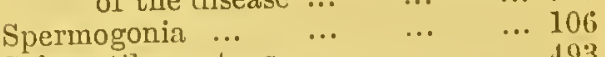

Spharotilus natans $\ldots . \quad \ldots \quad \ldots 493$

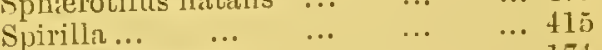

— characters of $\ldots . \quad \ldots . \quad \ldots \quad 174$

- key for the diagnosis of $\quad \ldots 485$

Spirillum $\quad \ldots \quad \ldots \quad \ldots . \quad \ldots 15 t i$

— cholerx Asiaticre $\quad \ldots . \quad \ldots 415$

- Finkler and l'rior $\quad \ldots \quad \ldots 472$

- leucomelrenum ... $\quad . . \quad \ldots .444$

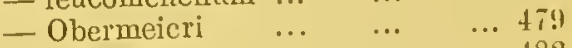

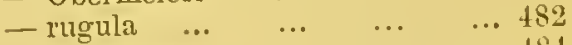

- sanguincum $\quad \ldots \quad \ldots \quad \ldots \quad \ldots 84$

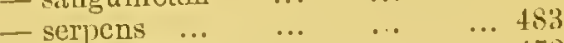

- sputigenum $\quad \ldots \quad \ldots . \quad \ldots+48$

$\begin{array}{llllll}\text { - telluc } & \ldots & \ldots & \ldots & \ldots & 483\end{array}$

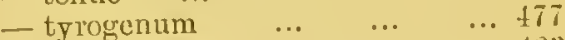

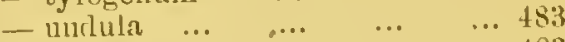

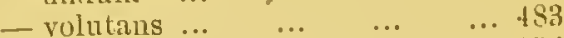

$\begin{array}{llllll}\text { Spirochate } & \ldots & \ldots & \ldots & \ldots & 15 i\end{array}$

- denticola... $\quad \ldots \quad \ldots . \quad \ldots$ ts:

- Obcrmeicri $\quad \ldots . \quad \ldots \quad \ldots+49$

- plicatilis ... $\quad \ldots \quad \ldots \quad \ldots \quad \ldots$ fil

\begin{tabular}{llllll} 
Spiromonas & $\ldots$ & $\ldots$ & $\ldots$ & $\ldots$ & $\ldots$ \\
\hline
\end{tabular}

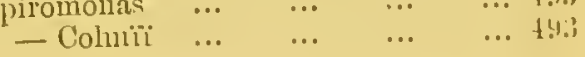


Spiromonas volubilis ... _.. _.. 493

Spirulina $\quad \ldots \quad \quad \ldots \quad \quad \ldots \quad 156,380$

Spontaneous puticfaction $\quad$... $\quad$... 613

Sporangium $\quad$... $\quad$.. $\quad \ldots . \quad \ldots 106$

Spore formation in bacteria, conditions of ... $\quad \ldots \quad \ldots . \quad \ldots \quad 537$

— - in the mould fungi ... $\quad \ldots .514$

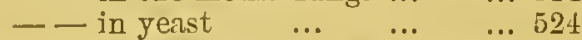

Spore germination in baeteria, conditions of ... $\quad . . \quad \quad \ldots . \quad \ldots .539$

— — in the mould fungi ... ... 514

- - in ycast $\quad . . . \quad \ldots . \quad \ldots 524$

Spores, formation of ... $\quad \ldots . \quad \ldots \quad \ldots 342$

- method of staining $\quad \ldots \quad$... 785

— of bacteria, destruction of ... 663

- of fungi, acrogcnous segmenta-

tion of ... $\quad \ldots \quad \ldots . \quad \ldots 105$

— - endogenous; formation of 106

- - - intercalary, formation of 105

- - - sexual fructification of ... 106

Spores of mould fungi, duration of the vitality of

... 515

Spores, resistance of, to high temperatures

... 663

Staining materials for bacteria $\quad \ldots 780$

- of bacteria $\quad \ldots \quad$... $\quad \ldots 778$

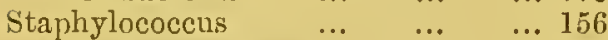

- pyogenes albus ... $\quad \ldots \quad \ldots 187$

- - - characters of $\quad \ldots \quad \ldots 187$

— - c cffect on animals... ... 188

— pyogenes aureus _.. ... 183

- - - action on animals _.. $18 \tilde{0}$

— - mode of growth ... ... 184

- - morphology of $\ldots . \quad \ldots 183$

- - - occurrence in man ... 186

- - - produets of growth 185,571

- citreus

Steam, apparatus for disinfection by 772

— as a disinfccting agent... ... 665

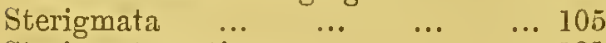

$\begin{array}{lllll}\text { Sterigmatocystis } & \ldots & \ldots & \ldots & 121\end{array}$

Sterilisation of ressels and nutrient $\begin{array}{llll}\text { substrata } \quad \ldots & \ldots & \ldots & 791\end{array}$

Stomach, bacteria in ... $\quad . . . \quad \ldots .724$

Streptococci in diphtheria. Lneffler on 283

- distinction betwcen the ... 196

Streptococcus ... $\quad \ldots \quad \quad \ldots \quad \quad \ldots 155$

- articulornm $\quad \ldots \quad$... $\quad \ldots .194$

— bombycis... $\quad \ldots . \quad \ldots \quad \ldots 207$

$\begin{array}{lllll}\text { Charrin } & \ldots & \ldots & \ldots & \ldots 207\end{array}$

— erysipclatosus $\ldots . \quad \ldots \quad \ldots 191$

— - action on animals ... $\quad \ldots \quad 192$

- - mode of growth $\quad \ldots \quad \ldots 191$

- - occurrchce in man ... ... 192

— malignus ... $\quad \ldots \quad \quad \ldots \quad \ldots 193$

- perniciosus psittrcorum $\quad \ldots 207$

- pyogenes ... $\quad . . \quad \ldots \quad \ldots \quad \ldots 189$

— - action on animals ... ... 190

- - mode of growth $\quad$... $\quad$... 189

— moxphology of $\quad \ldots . \quad \ldots l 189$

- - occurrence in man ... $\quad$... 191

$\begin{array}{llll}\text { Streptococcus scpticus } & \ldots & \ldots & 195\end{array}$
PAGE

Streptothrix Focrsteri $\quad$... $\quad . .4 \$ 93$

Stutzcr's analysis of yeast ... $\quad \ldots \quad 517$

— analysis of the mould fungi ... 503

Sugar, aleoholic felmentation of, by yeast

... 588

- influenee of the amount of, on fermentation ... ... ... $59 t$

Sulphatc of copper, action on spores 667

Sulphur in the beggiatoa ... $\quad . .5527$ Sulphuretted hydrogen, action on sporcs ... $\quad . . \quad \ldots \quad \ldots 667$

Sulphuric acid, action on spores $\quad . .667$

Sulphurous acid as a disinfectant ... 668

Sweat, red $\quad . . \quad \ldots . \quad \ldots \quad \ldots 225$

Swinc erysipclas, attenuation of the bacilli of $\quad \ldots . \quad \ldots \quad$... 660

- - bacillus of $\quad \ldots \quad \ldots \quad \ldots 302$

- - micrococci in... ... ... 205

Swine fever, protective inoculation against... $\quad . . . \quad \ldots . \quad \ldots 756$

Symptomatic anthrax, attenuation of the bacilli of ... ... ... 660

- - protective inoculation against 756

Syphilis, bacillus of ... ... $\quad$... 288

- sources of infection of .... $\quad \ldots 736$

\section{T.}

Tappeincr on cellulose fermentation 600 Tartratc of lime, fermentation of ... 604 Teeth, caries of, bacilli in ... ... 298 — Miller's eurved bacilli in _.. 476 Teleological rôle of thc lower fungi $\$ 96$ Temperature in relation to the growth of bacteria $\quad . . \quad \ldots . \quad \ldots 650$ — in relation to the mould fungi 512 - influence of, on fermentation ... 594

- influence of, on the motility of bacteria $\quad . . \quad \ldots . \quad \ldots 508$

— relation of, to bacteria ... $\quad$... 536

— relation to yeast $\quad$.. $\quad \ldots \quad 522$

- resistance of bacteria to $\quad \ldots 663$

Test for trustworthy disinfecting

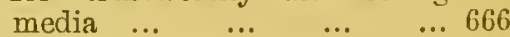

Tetanus bacillus $\quad \ldots . \quad \ldots . \quad \ldots 340$

Thallus ... $\quad$.. $\quad \ldots \quad$... $\quad \ldots 10 t$

Thrush, fungus of $\quad \ldots \quad \ldots \quad 131,152$

Thymol, action on spores $\quad . .6 \quad$... 666

— as an inhibitory agent ... ... 653

Tilletia caries ... $\quad$... $\quad \ldots . \quad \ldots 110$

Tinea tollsurans, fungus of ... ... 127

'lissue change in prescnec of oxygen 558

— - in the lower fungi ... ... $\overline{5}+1$

— - of the lower fungi, products of

- wlicn oxygen is absent ... 5.5t

Toxic effects of cholera cultirations $t+0$

Traclioma, micrococci in ... ... 203

Transmission of infective disenses

from the sick to the healtiy... $72 ?$

Trausport by air, conditions for ... itl

— - imfluenec of, on contrgiousuess $i t 0$ 
PAGE Transport of bacteria... ... ... 687 currents of watcr $\quad \ldots \quad \ldots 696$ — of infective agents to incli- 695 viduals, mode of $\quad \ldots \quad$... 739 - of pleserved bacteria fiom the soil to the man $\quad \ldots \quad \ldots 705$

True fungi, classification of ... $\quad \ldots .108$

Tubercle bacillus $\quad \ldots \quad$... $\quad \ldots 260$ — - method of staining of $\quad \ldots 783$

- mode of entrance into the body $\quad \ldots \quad$... $\quad \ldots \quad$... 272

Tuberculosis, mocte of spread of $\quad \ldots 271$ — sources of infection of ... $\quad \ldots 737$ Turpentine, oil of, action on spores ... $\quad \ldots \quad \ldots \quad \ldots 667$

Typhoid bacilli, distribution from the soil ... $\quad \ldots \quad$... $\quad \ldots 710$

- - fermentation of carbo-hydrates by $\quad$... $\quad \ldots \quad \ldots 601$

_ - modes of distribution of $\quad \ldots 253$

_ points of entrance of $\quad \ldots 253$

Typhoid fercr, bacillus of ... ... 248

- contagiousness of ... ... 734

- local and seasonal variations

- in $\quad . . \quad$.. $\quad . . \quad \ldots 765$ - - sources of infection of $\ldots 738$ $\begin{array}{llllll}\text { Tyrothrix } & \ldots & \ldots & \ldots & \ldots & 606\end{array}$

Unboiled tissues, preservation of $\quad \ldots 74$

Urea ferment ... $\quad$... $\quad$... $\quad \ldots 580$

$\begin{array}{llllll}\text { Urediner } & \ldots & \ldots & \ldots & \ldots & \\ \text { Urea } & \ldots & \ldots & \ldots & \ldots & 116\end{array}$

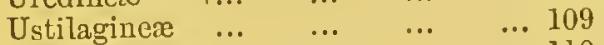

Ustilago carbo... $\quad \ldots \quad \ldots \quad \ldots \quad \ldots 110$

$$
\text { V. }
$$

Vaccination $\quad \ldots \quad \ldots \quad \ldots \quad \ldots 755$

Vaccinia, micrococci in $\quad \ldots . \quad \ldots 202$ Vandeveldc's analysis of bacillus subtilis ... $\quad \ldots \quad \ldots \quad \ldots \quad \ldots 526$

Variations in the lower fungi $\quad$... 681

- in the form of the fungi as the result of degenerative changes 676

- in the form of the lower fungi during development ... ... 675

- in the lower fungi, relation to cxternal conditions ... ...667

- in the products of tissuc change as the result of varying extermal conditions $\quad$... ... 679

Variola, micrococci in $\quad \ldots . \quad \ldots 202$

Various anaërobes, products of $\quad \ldots 612$

Vesscls for the cultivation of orgarisms $\quad \ldots \quad \ldots \quad \ldots \quad \ldots \quad \ldots 788$

$\begin{array}{llllll}\text { Vibrio } \ldots & \ldots & \ldots & \ldots & \ldots & \\ \end{array}$

- rugula $\quad . . \quad \ldots \quad \ldots \quad \ldots 482$

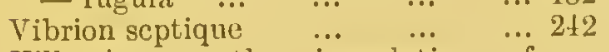

Villcmin on the inoculation of tubercle $\quad \ldots \quad$... $\quad \ldots .260$
Vilucgar ulant, analysis of $\ldots . \quad \ldots 526$

Violet bacillus... $\quad \ldots \quad$... $\quad \ldots 361$

Viscose ... $\quad . . \quad \ldots \quad \ldots \quad \ldots \quad 216,599$

Viscous fermentation... ... ... 598

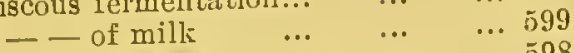

Vital actions of the lower fungi $\quad \ldots .510$

Von Pettenkofer's views on cholera... 468

Von Sehlen on organisms in malaria 295

W.

Water, bacteriological investigation of $\mathrm{S07}$

— influence of, in cholera... ... 458

- occurrence of bacteria in $\quad \ldots 711$

- transport by $\quad . . \quad$... ... $7 t 0$

Weight of air germs ... $\quad \ldots \quad \ldots 688$

Whooping-cough, organisms in ... 297

Winds, influence of dry winds on the number of air germs ... ... 690

Wine, viscous fermcntation of $\quad$... 598

Wortmann on diastatic ferment $\quad . .577$

Wyssokowitsch on the destruction of bacteria in the body ... ... 611

- on the passability of the walls of the lungs and intestine by bacteria... $\quad . . \quad \ldots . \quad \ldots 743$

X.

Xerosis conjunctiva, organisms in ... $29 \pi$

\section{I.}

Teast, alcoholic fermentation of sugn' $\begin{array}{llllll}\text { by } \quad \ldots & \ldots & \ldots & \ldots & 588\end{array}$

- concurrent growth with other $\begin{array}{llllll}\text { fungi } \quad \ldots & \ldots & \ldots & \ldots & 522\end{array}$

— discovery by Caignard-Latour . 69

- folms of, capable of exciting fermentation ... ... ... 588

- influence of fermentative activity on the growth of $\quad \ldots \quad 522$

- influencc of quantity of, on fermentatioll $\quad \ldots \quad \quad \ldots . \quad \ldots \quad \overline{0.94}$

- myco-protcin in ... $\quad \ldots . \quad \ldots 517$

— necessity for oxygen $\ldots . \quad \ldots \quad 520$

Yenst of beer ... $\quad$... $\quad$... $\quad \ldots .119$

- relation of tempcrature to $\ldots 522$

- relation of, to the fermentative process ... $\quad . . \quad \ldots \quad \ldots 76$

— relation to atmosplicric pressure 521

- sclf-fermentation of $\quad \ldots \quad$... 592

— spore germination $\quad \ldots \quad$... 524

$\begin{array}{lllll}\text { - sporcs of ... } & \ldots & \ldots & \ldots & \ldots 2.4\end{array}$

- the only causc of alcoholic fermentation $\quad . . \quad \ldots . \quad \ldots \quad$ il

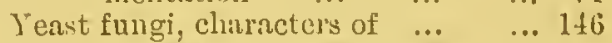

- - formation of mycclimm by ... 147

— - formation of spores in $\quad . . .147$

- multiplication of $\ldots . \quad \ldots .1+7$

- - lelation to concentration of nutriment $\quad \ldots \quad \quad \ldots \quad$... 


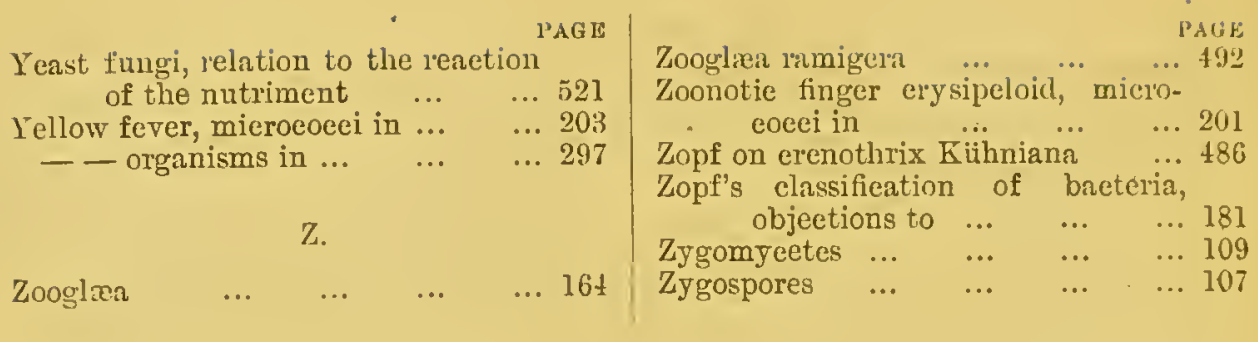







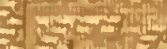
$5-24 x-5 x^{2}$

$3 y-57525$

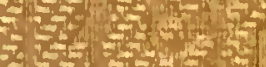

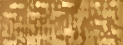

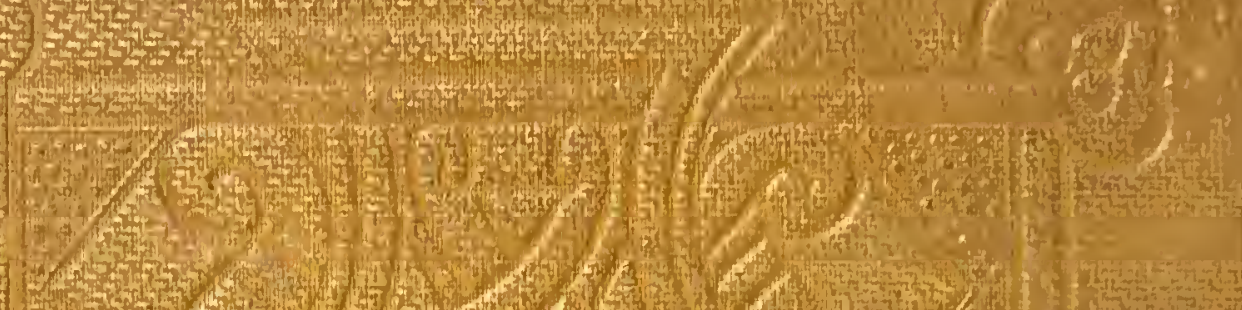

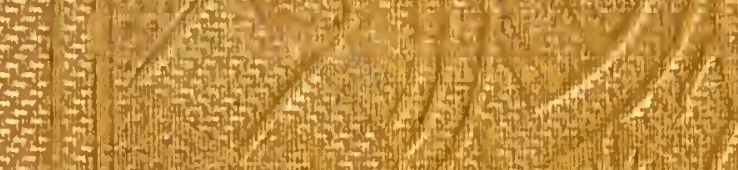

\section{1.}
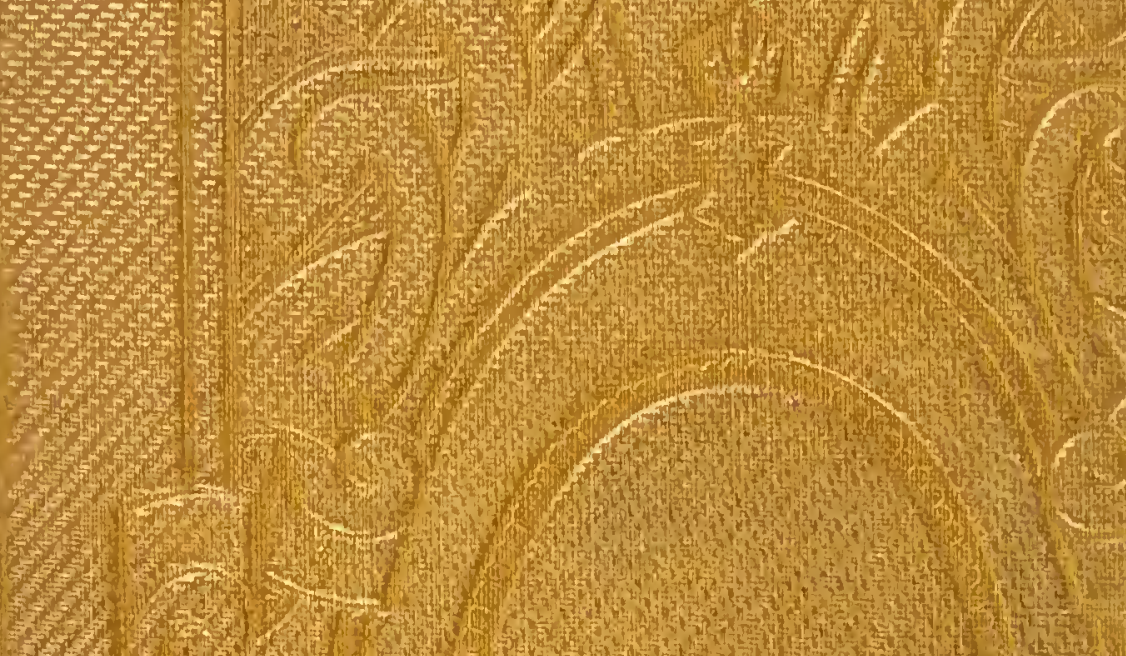

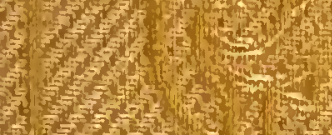

t.

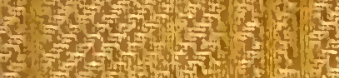

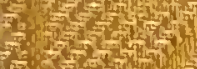

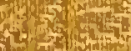

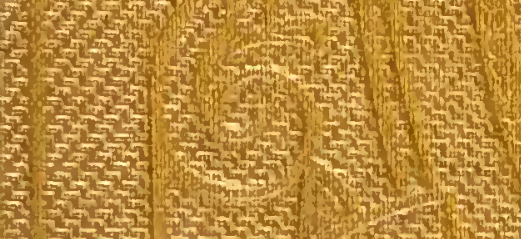

$x^{2}+\frac{1}{2}$

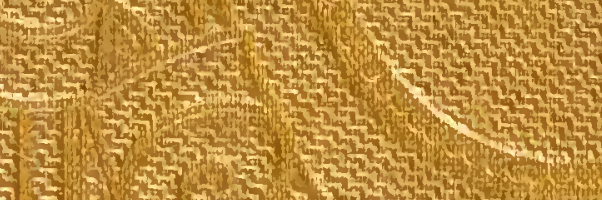

(1)
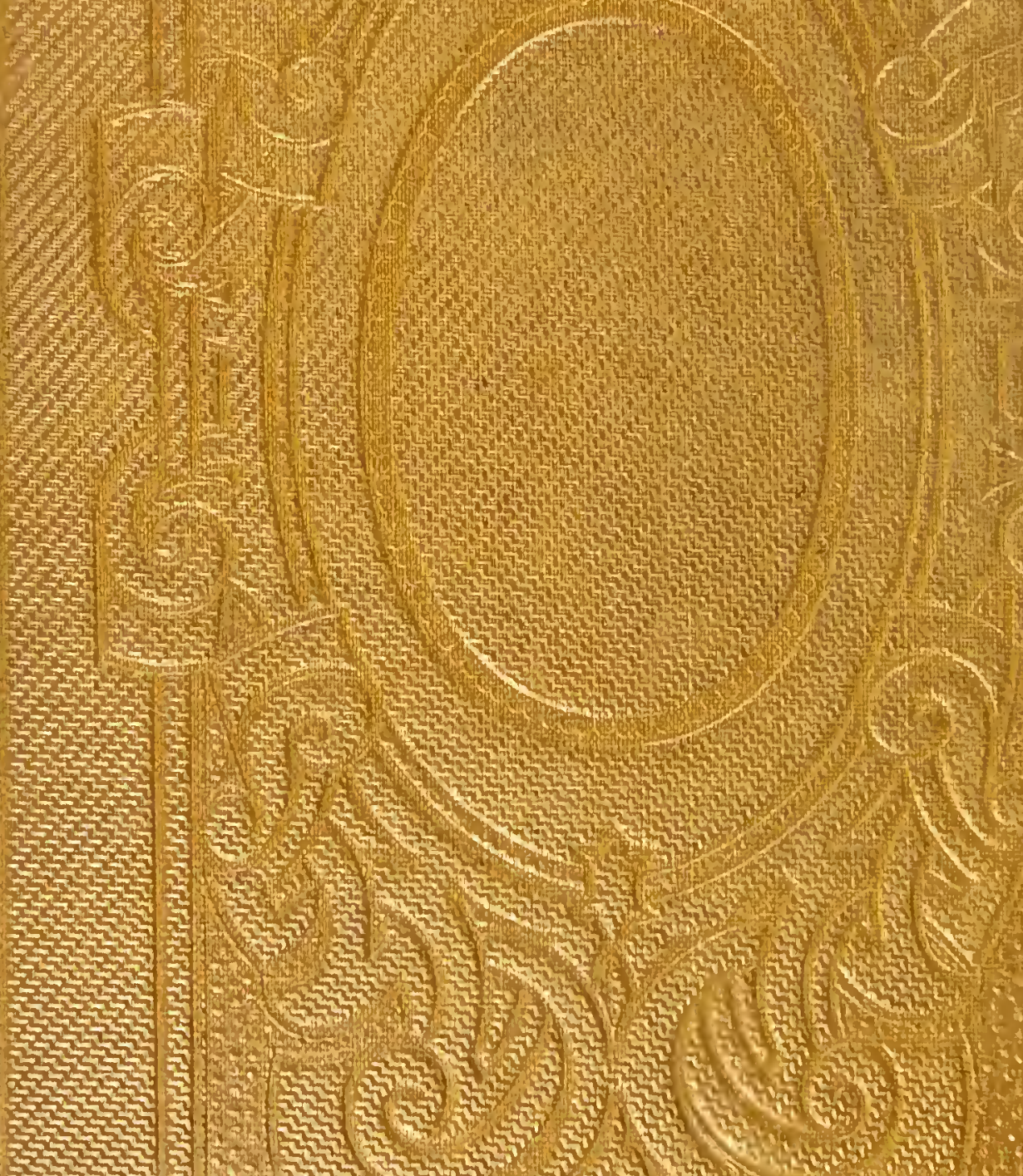

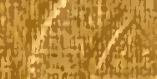

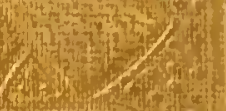

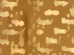

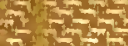

$\frac{2}{3}$

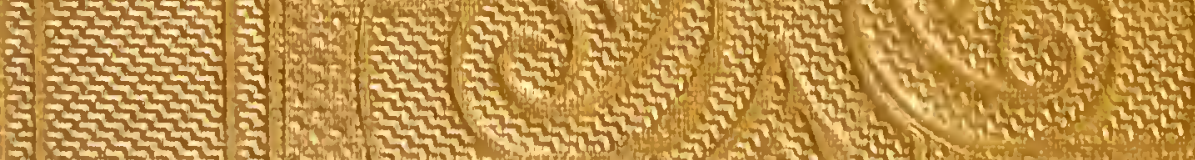

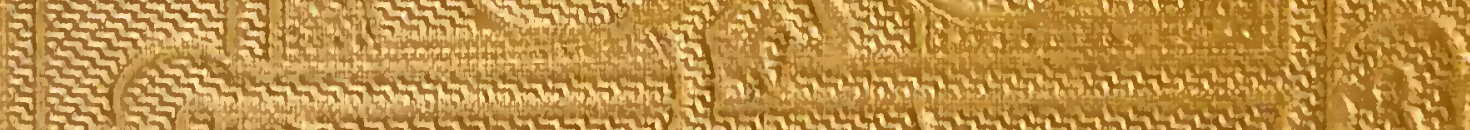

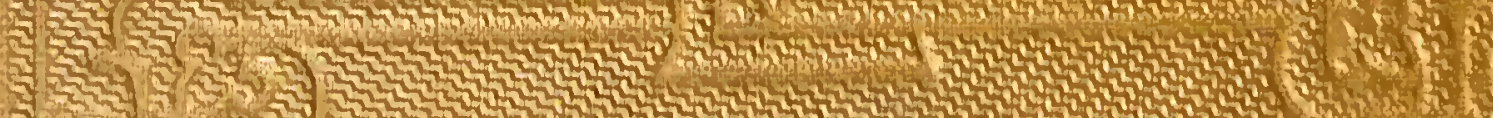

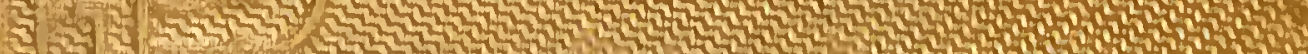

